

\section{REVISTA BRASILEIRA DE POLÍTICAS PÚBLICAS}

\section{BRAZILIAN JOURNAL OF PUBLIC POLICY}

\section{Editores responsáveis por essa edição:}

Editores gerais

Marcelo Dias Varella, Priscila Pereira de Andrade

Editor especial

Paulo Afonso Cavichioli Carmona e Jefferson Carús Guedes 


\section{REVISTA BRASILEIRA DE POLÍTICAS PÚBLICAS \\ Brazilian Journal of Public Policy}

Programa de Mestrado e Doutorado em Direito do UniCEUB

Centro Universitário de Brasília

Reitor

Getúlio Américo Moreira Lopes

Presidente do Conselho Editorial do UniCEUB

Elizabeth Regina Lopes Manzur

Diretor do ICPD

João Herculino de Souza Lopes Filho

Coordenador do Programa de Mestrado e Doutorado e Editor

Marcelo Dias Varella

\section{Linha editorial}

"A Revista Brasileira de Políticas Públicas é um periódico acadêmico da área jurídica que tem como finalidade constituir instrumento de veiculação de trabalhos científicos e doutrinários que abordem questões jurídicas da contemporaneidade e, ainda, aspectos da interação entre Direito e Políticas Públicas. Direciona, portanto, seu objeto de interesse a questões referentes a governabilidade, integração, participação cidadã, desenvolvimento e outros temas envolvendo o Estado, a Sociedade e o Direito.

Sendo assim, a proposta de linha editorial a ser seguida pela Revista Brasileira de Políticas Públicas é apresentada a partir de duas áreas fundamentais, que se subdividem:

I) Democracia, Políticas de Estado e de Governo e seus aspectos jurídicos: tendências do Direito Constitucional e do Direito Administrativo; teoria das políticas públicas; sistema de governo; sistema eleitoral e cidadania; sistema de partidos e reforma constitucional

II) Políticas Públicas de desenvolvimento econômico e social e suas interfaces com o Direito: políticas de desenvolvimento econômico e produção local/regional, desenvolvimento sustentável e meio-ambiente, desenvolvimento humano e planejamento da ação governamental".

\section{CONSELHO EDITORIAL}

Marie-Pierre Lafranchi, Université d'Aix-en-Provence, Faculté de droit et de science politique, Provence-Alpes-Côte d'Azur, França Frederico Augusto Barbosa, Centro Universitário de Brasília, Programa de Mestrado e Doutorado em Direito, Brasília/DF, Brasil Gilberto Bercovici, Universidade de São Paulo, Faculdade de Direito, Departamento de Direito Econômico-Financeiro, São Paulo/SP, Brasil João Maurício Adeodato, Universidade Federal de Pernambuco, Centro de Ciências Jurídicas, Departamento de Teoria Geral do Direito e do Direito Privado, Recife/PE, Brasil

José Adercio Leite Sampaio, Escola Superior Dom Helder Câmara, Escola de Direito, Belo Horizonte/MG, Brasil

José Heder Benatti, Universidade Federal do Pará, Instituto de Ciências Jurídicas, Belém/PA, Brasil

\section{EDITOR}

Marcelo D. Varella, Centro Universitário de Brasília, Programa de Mestrado e Doutorado em Direito, Brasília/DF, Brasil

\section{EDITORA ADJUNTA}

Priscila Pereira de Andrade, Centro Universitário de Brasília, Revista Brasileira de Políticas Públicas, Brasília/DF, Brasil

\section{EQUIPE TÉCNICA}

Yuri Valente do Nascimento, Centro Universitário de Brasília, Revista Brasileira de Políticas Públicas, Brasília/DF, Brasil

Aline Assunção Santos, Centro Universitário de Brasília, Revista Brasileira de Políticas Públicas, Brasília/DF, Brasil

\section{Layout capa}

Departamento de Comunicação / ACC UniCEUB

\section{Diagramação}

S2 Books

\section{Disponível em:}

http://www.rbpp.uniceub.br

\section{Circulação}

Acesso aberto e gratuito

Matérias assinadas são de exclusiva responsabilidade dos autores.

Citação parcial permitida com referência à fonte. 
Revista Brasileira de Políticas Públicas / Programa de Mestrado e Doutorado em Direito do UniCEUB. - vol. 7, n. 1 (ago. 2017) - . Brasília : UniCEUB, 2011

Quadrimestral.

ISSN 2236-1677

Disponível também on-line: www.rbpp.uniceub.br

1. Direito. 2. Políticas Públicas. I. Programa de Mestrado e Doutorado em Direito do UniCEUB

CDU $34+338.26$

Ficha catalográfica elaborada pela Biblioteca Reitor João Herculino 
Metodologia do direito, teorias da posse e a posse na NOVA LEI DE REgularização FUNDIÁRIA ................................................................................................15

Helton Junio Da Silva, Rafhael Frattari Bonito e Renata Aparecida de Oliveira Dias

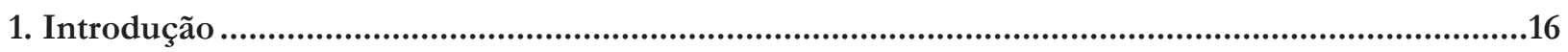

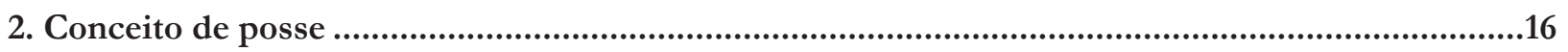

2.1. Breves considerações sobre a posse no Código Civil Brasileiro ………………………………………….... 17

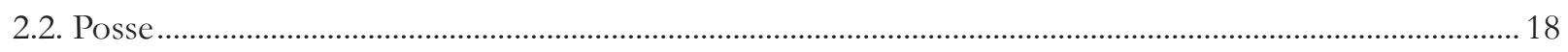

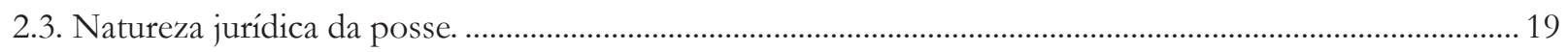

3. considerações sobre metodologia do direito e as teorias da posse ...............................................20

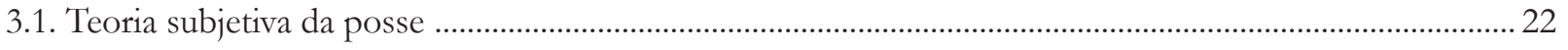

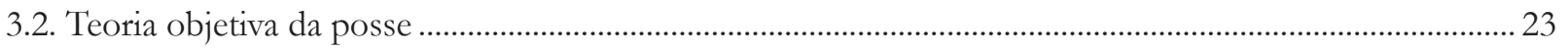

4. A posse na regularização fundiária e posse ad usucapionem .........................................................25

4.1. A posse na regularização fundiária ............................................................................................................. 26

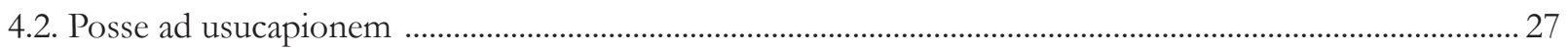

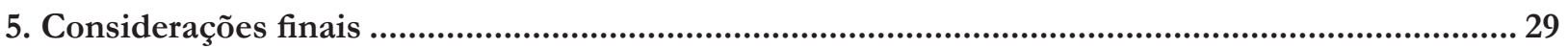

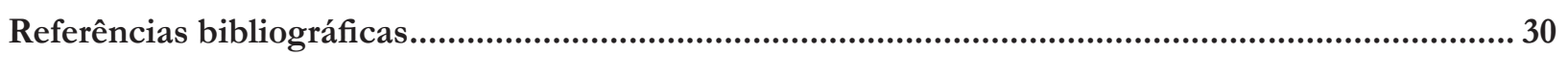

A PRoteÇão Positiva do domínio PÚBliCo ............................................................33

Maria Edelvacy Pinto Marinho

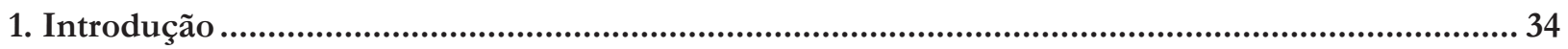

2. A relação entre propriedade intelectual e domínio público. ......................................................... 34

3. A proteção do domínio público como meio de assegurar o equilíbrio entre proteção e acesso. ... 37

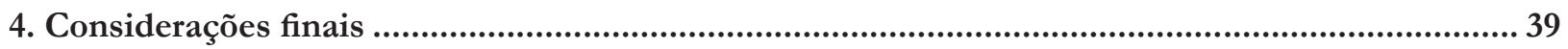

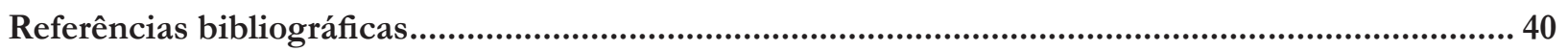

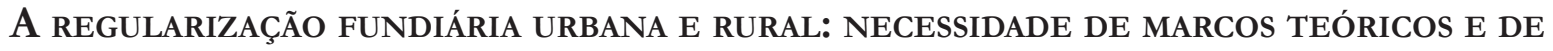

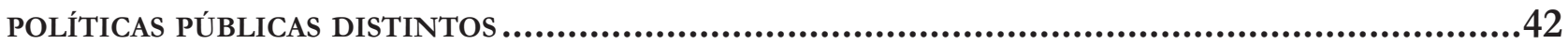

Émilien Vilas Boas Reis e Márcio Luís de Oliveira

1. Introdução.

2. Regularização fundiária: a propriedade e a posse imobiliárias como elementos do direito de moradia urbana ou rural 
3. A regularização fundiária e a conjugação da função social com a função ambiental da propriedade e da posse 46

4. Dimensões urbanas e rurais do processo de regularização fundiária: marco regulatório e implementação de política pública próprios 48

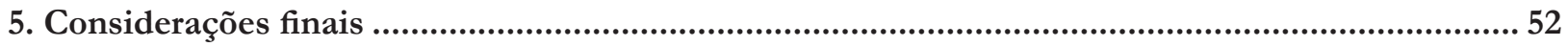

Referências bibliográficas...................................................................................................................... 52

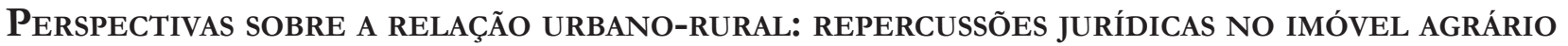
APÓS A EDIÇÃO DA LEI N. 13.465/2017 ..................................................................55

Luana Nunes Bandeira Alves e Luly Rodrigues da Cunha Fischer

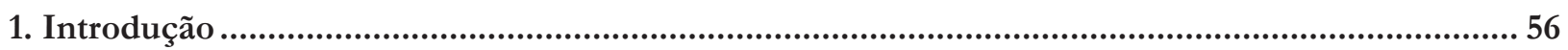

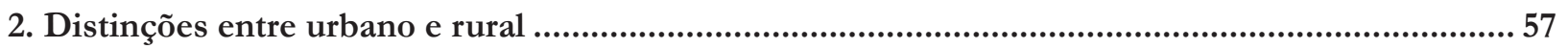

3. Imóvel agrário: definição, classificações e regras de parcelamento ............................................61

4. Hipóteses de incidência do imposto predial e territorial urbano e do imposto territorial rural:

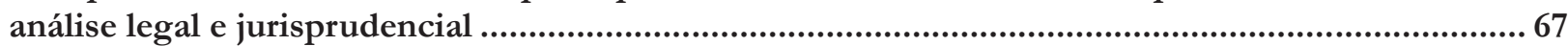

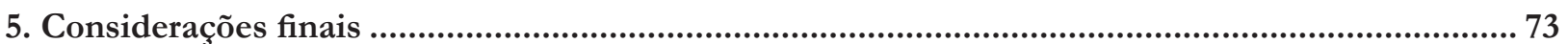

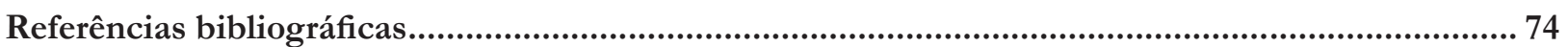

A FunÇão urbanística do REgistro de IMÓveis NA INSCRiÇão de CONSTRUÇÕes ................81 Paulo Afonso Cavichioli Carmona e Fernanda Loures de Oliveira

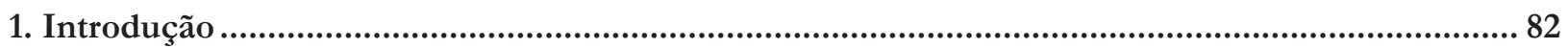

2. A importância do controle urbanístico das construções ........................................................... 82

3. O papel do registro de imóveis na tutela urbanística das construções .......................................... 86

4. Crítica aos artigos 60 e 63 da Lei 13.465 de 11 de julho de 2017 .................................................. 89

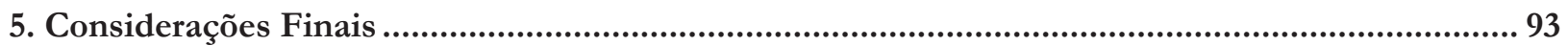

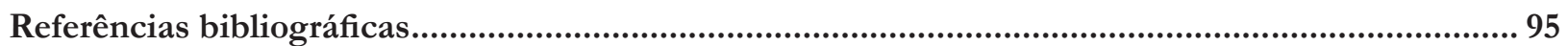

Direitos De Propriedade E Instrumentos Econômicos De Regulação Ambiental: Uma Análise Das Atribuições Implícitas ..................................................................................98 Laura Meneghel dos Santos, Antônio José Maristrello Porto e Rômulo Silveira da Rocha Sampaio

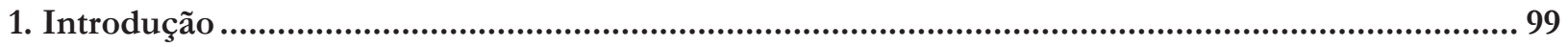

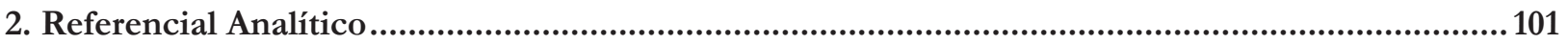

3. Instrumentos econômicos de gestão ambiental..............................................................................104

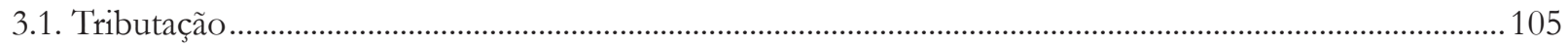

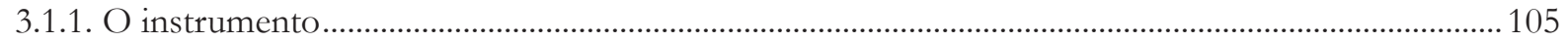

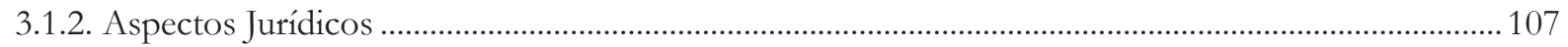

3.1.3. Um exemplo: O ICMS Ecológico.................................................................................................... 108

3.2. Sistemas de Certificados Negociáveis .......................................................................................................... 110 
3.2.1. O instrumento 110

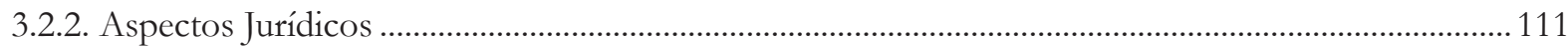

3.2.3. Um exemplo: as Cotas de Reserva Ambiental no Novo Código Florestal........................................... 112

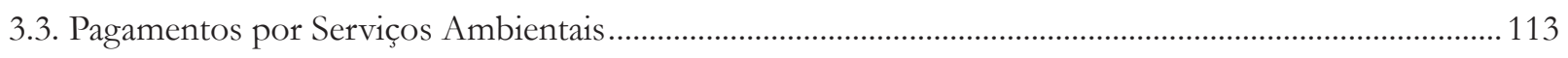

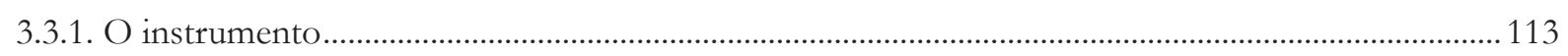

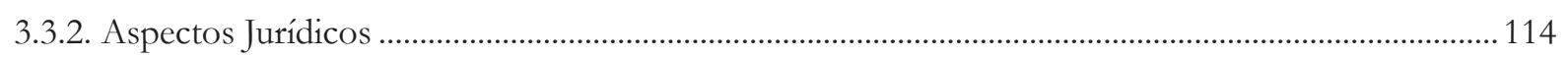

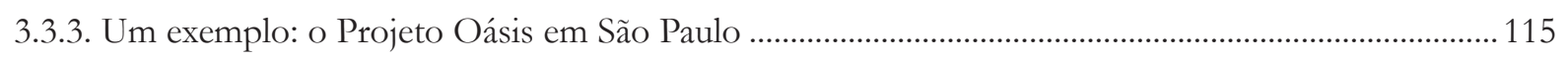

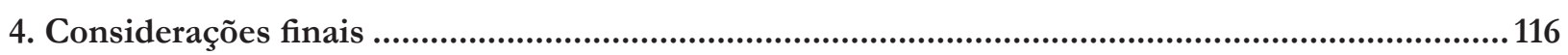

Referências bibliográficas...................................................................................................117

Aspectos Urbanísticos, Civis e Registrais do Direito Real de Laje ............................. 122

Paulo Afonso Cavichioli Carmona e Fernanda Loures de Oliveira

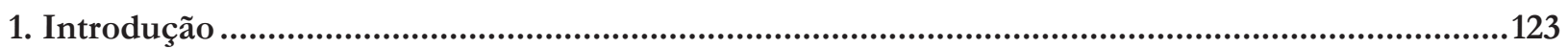

2. O Direito De Laje Na Lei 13.465 De 11 Julho De 2017 ............................................................123

3. Comparação Do Direito De Laje Com Institutos Similares............................................................127

3.1. Direito De Laje Vs. Instituição De Condomínio Edilício ............................................................................... 127

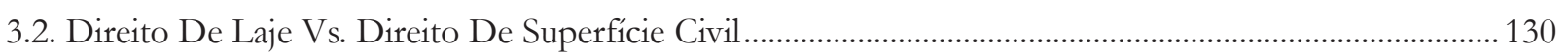

3.3. Direito De Laje Vs. Direito De Superfície Urbanístico ………………………………………................... 133

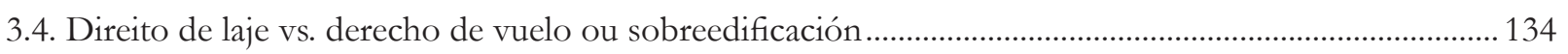

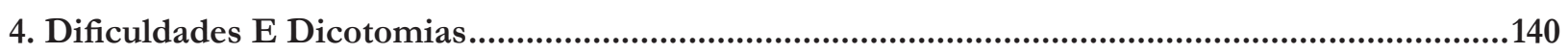

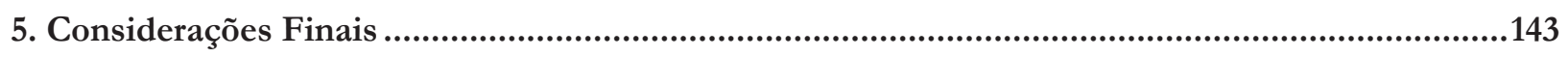

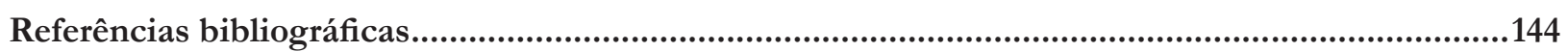

INTERAÇÃO ENTRE A ACESSIBILIDADE URBANÍSTICA E O DIREITO À CIDADE: POSSIBILIDADE DE INCLUSÃO SOCIAL DAS PESSOAS COM DEFICIÊNCIA ................................................... 148

Daniella Maria dos Santos Dias, Domingos do Nascimento Nonato e Raimundo Wilson Gama Raiol

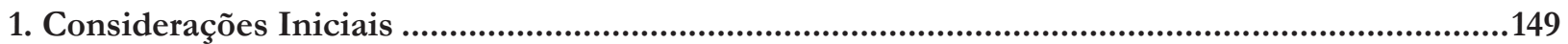

3. A concepção de direito à cidade: o que a acessibilidade arquitetônica tem a ver com isso? .........154

4. Acessibilidade urbanística como direito fundamental ....................................................................158

5. Evidências Empíricas ....................................................................................................................... 161

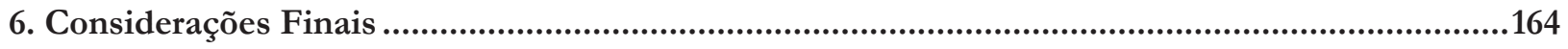

Referências bibliográficas................................................................................................................164

LONGEVIDADE E CIDADE: DO DANO URBANÍSTICO À GARANTIA DO DIREITO À MORADIA ADEQUADA PARA IDOSOS DE BAIXA RENDA.......................................................................... 169

Luzia Cristina Antoniossi Monteiro, Nayara Mendes Silva e Vania Aparecida Gurian Varoto

1. Introdução. 
2. Envelhecimento populacional nas cidades: enfoque na moradia ................................................. 171

3. O Ministério Público e mecanismos em defesa de direitos da pessoa idosa.................................173

4. O Termo de Ajustamento de Conduta - TAC ..................................................................................174

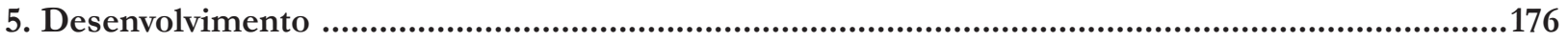

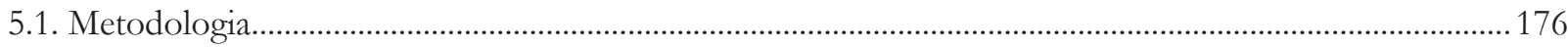

5.2. O Condomínio Exclusivo para Idosos de baixa renda e a aplicação do TAC para a efetivação da moradia

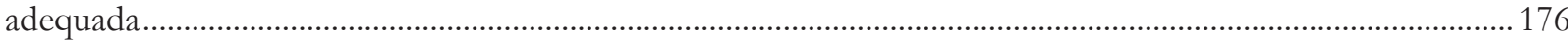

5.3. O muro de arrimo: assegurando a moradia e contendo os riscos ................................................................ 179

5.4. Um novo TAC reforça as condições de moradia digna................................................................................... 180

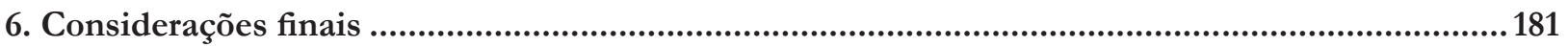

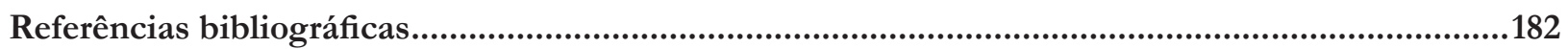

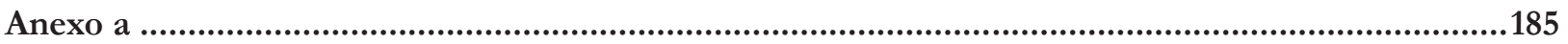

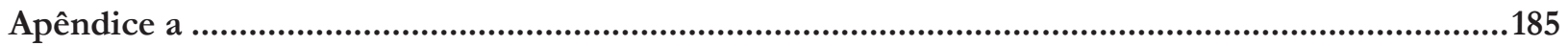

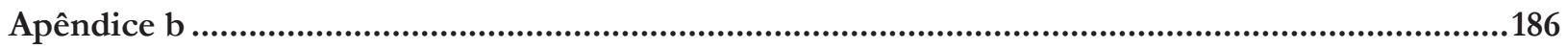

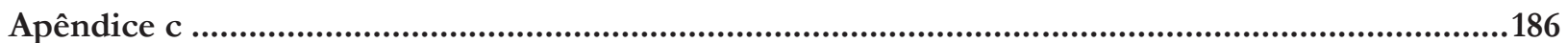

Regularização Fundiária e Política Ambiental: Incongruências do Cadastro Ambiental Rural no Estado do Pará ............................................................. 188

Lise Tupiassu, Jean-Raphael Gros-Desormaux e Gisleno Augusto Costa da Cruz

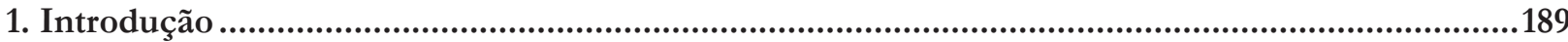

2. O Car Como Indutor De Equívocos Na Regularização Fundiária ...............................................190

3. As Inconsistências Nos Registros Do Car .....................................................................................195

4. Impacto Fundiário Da Utiização Do Car Na Política Do Icms Verde No Estado Do Pará..........198

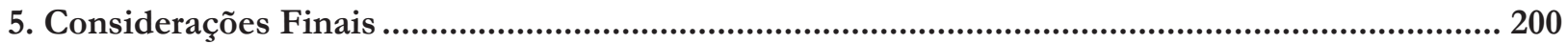

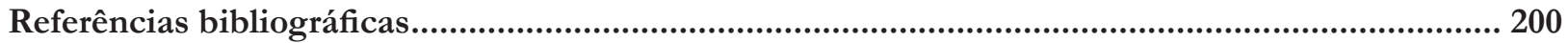

A Regularização do Parcelamento do Solo de Loteamentos Públicos: Um Estudo Baseado no Projeto do Loteamento de Interesse Social Vila Betinho em Chapecó/

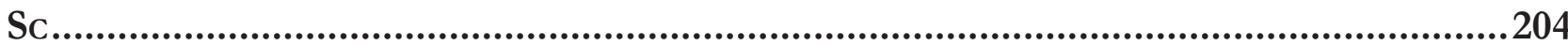

Reginaldo Pereira e Karen Bissani

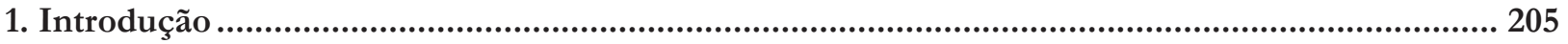

2. A Regularização Fundiária No Contexto Da Política De Desenvolvimento Urbano .................. 206

3. O Programa Municipal De Regularização Bairro Legal ...............................................................210

4. O Caso Do Loteamento De Interesse Social Vila Betinho ..........................................................212

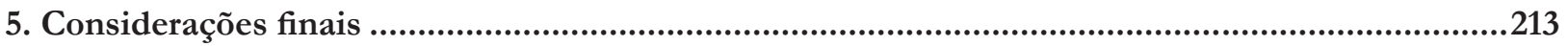

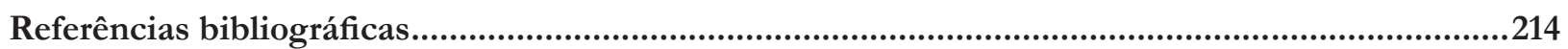


João Aparecido Bazolli, Olivia Campos Maia Pereirae e Mariela Cristina Ayres Oliveira

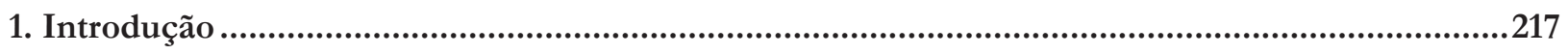

2. Araguaína: Modelo De Ocupação (Des)Ordenada ............................................................... 220

3. Os Setores E As Características Das Ocupações Irregulares .................................................. 222

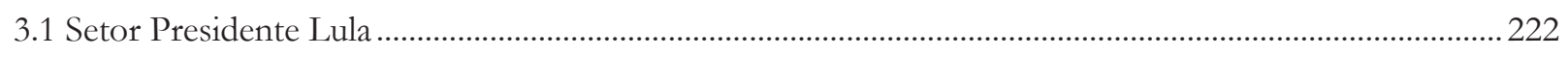

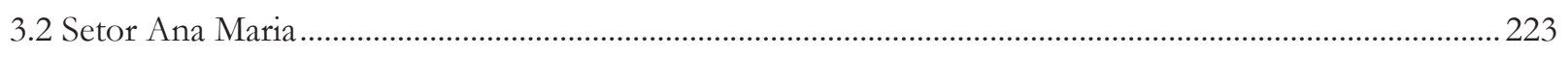

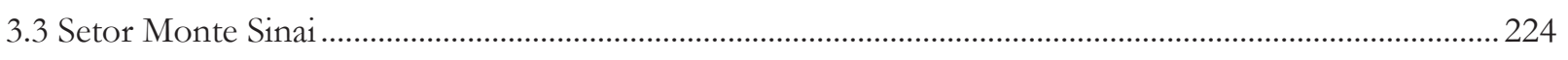

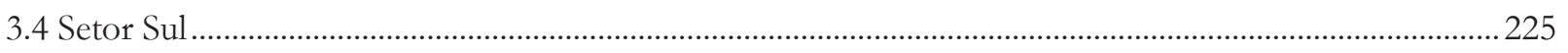

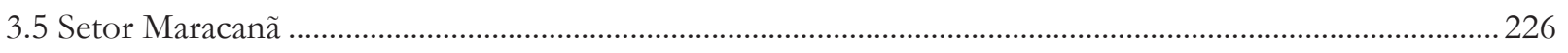

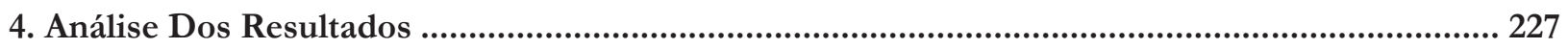

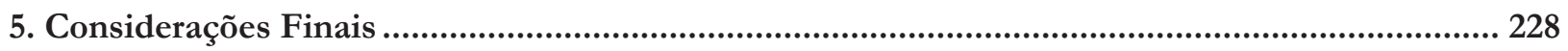

Referências bibliográficas............................................................................................................... 229

RegularizaÇão fundiáRia de ComUnidades Quilombolas em Mato Grosso do

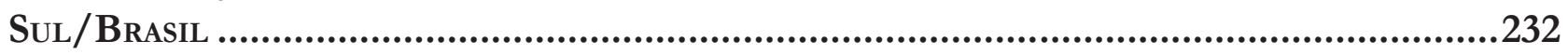

Antonio Hilario Aguilera Urquiza e Lourival dos Santos

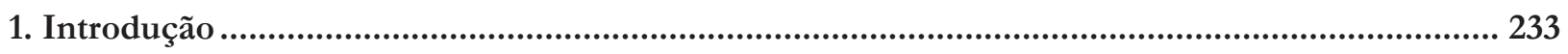

2. Comunidades quilombolas a regularização fundiária ................................................................. 235

3. Comunidades, territórios e políticas públicas ............................................................................... 237

4. As comunidades quilombolas e a regularização fundiária........................................................... 239

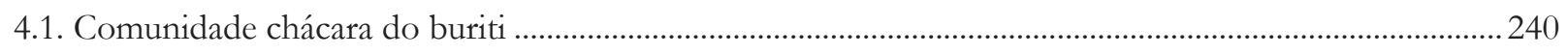

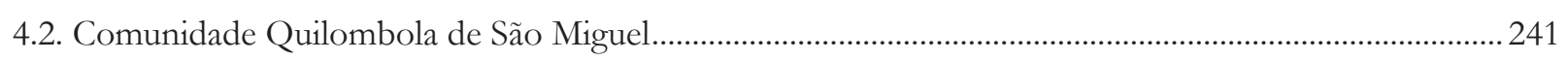

4.3. Comunidade Quilombola de Furnas da Boa Sorte ........................................................................................ 241

4.4. Comunidade Quilombola Furnas do Dionísio ...........................................................................................242

4.5. Comunidade Quilombola Desidério Felipe de Oliveira …………………...................................................... 242

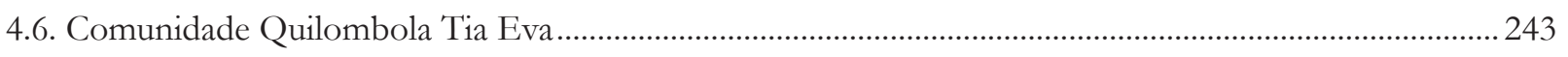

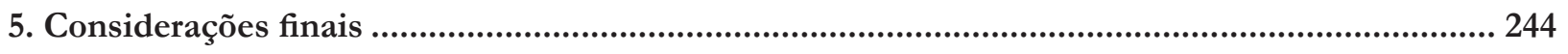

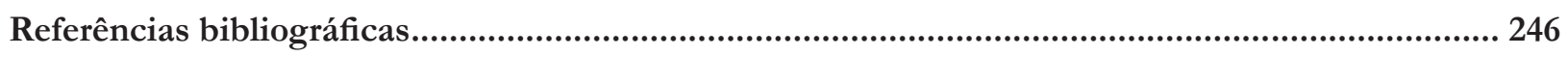

Políticas públicas e escolha racional: o caso do Centro Urbano de Cultura, Arte, Ciência e Esporte de Fortaleza, Estado do Ceará ................................................249 Mariana Dionísio de Andrade e Rodrigo Ferraz de Castro Remígio

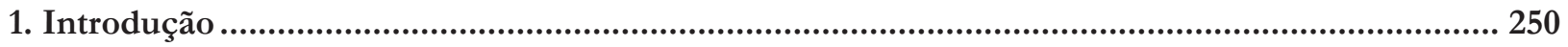

2. O lugar das políticas públicas no neoinstitucionalismo de escolha racional ...............................251 
3. Definindo prioridades na agenda governamental

4. Análise do caso: Centro Urbano de Cultura, Arte, Ciência e Esporte de Fortaleza -

Rede CUCA 255

5. Políticas públicas e novos diálogos com a cidade de Recife ......................................................... 258

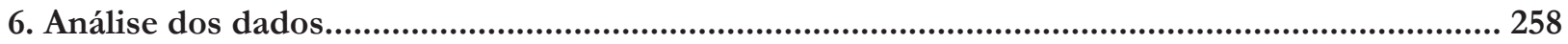

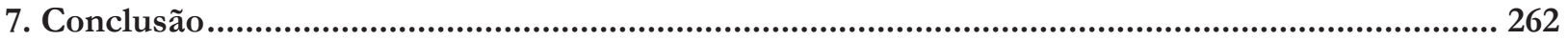

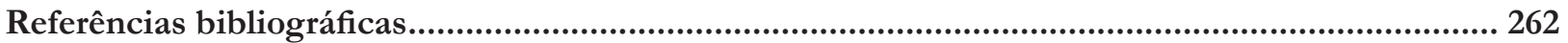

O ACESSO À ÁGUA POTÁVEL COMO PARCELA DO MÍNIMO EXISTENCIAL: REFLEXõES SOBRE A INTERRUPÇÃO DO SERVIÇO PÚBLICO DE ABASTECIMENTO DE ÁGUA POR INADIMPLEMENTO DO USUÁRIO .....................................................................................................266

Augusto César Leite de Resende

1. Introdução

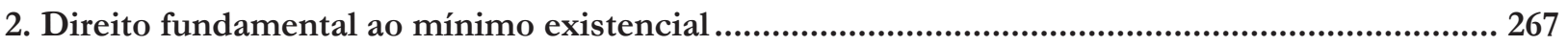

3. Mínimo existencial: o acesso à água potável.................................................................................271

4. A prestação do serviço público de abastecimento de água .......................................................... 275

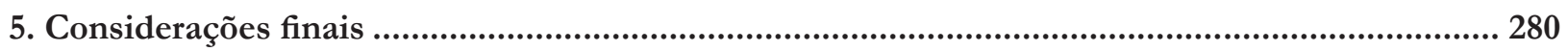

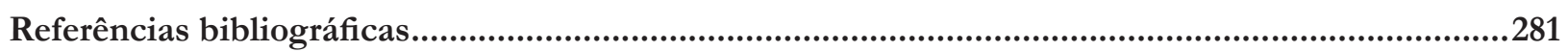

II. Outros temas ............................................................................................2284

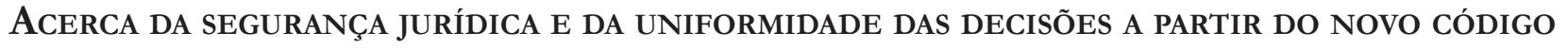
DE PROCESSO CIVIL À LUZ DO MODELO CONSTITUCIONAL DO PROCESSO BRASILEIRO ...............286 Cintia Garabini Lages e Lúcio Antônio Chamon Junior

1. Introdução.

2. Pressupostos interpretativos em torno da Exposição de Motivos do Código de Processo

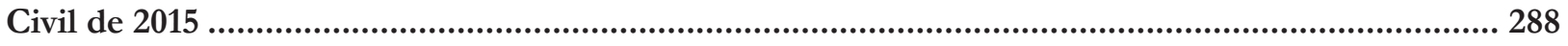

3. Da compreensão procedimental do modelo constitucional do processo brasileiro ...................... 294

4. Traços reconstrutivos do Modelo Constitucional Processual brasileiro ....................................... 298

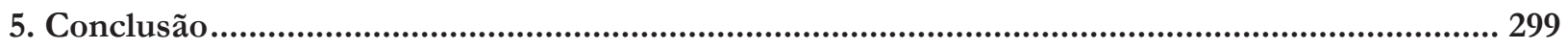

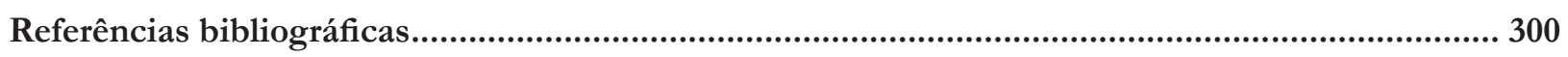

O IMPACTO DO FEDERALISMO SANITÁRIO BRASILEIRO NA EFETIVIDADE DO DIREITO À SAÚDE ...303 Renato Braz Mehanna Khamis e Ivan Ricardo Garisio Sartori

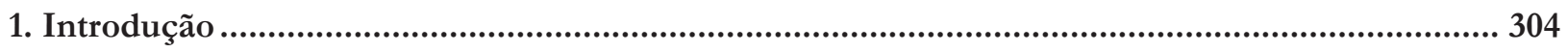

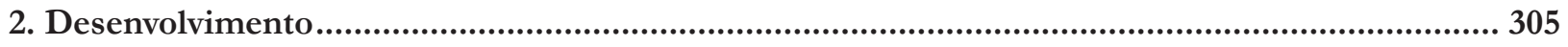

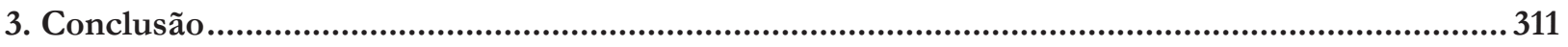

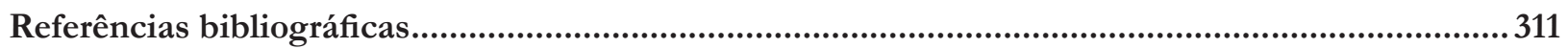




\section{A Evolução Histórica dos Direitos da Criança e do Adolescente: da insignificância}

JURÍDICA E SOCIAL AO RECONHECIMENTO DE DIREITOS E GARANTIAS FUNDAMENTAIS.............. 314 Renata Mantovani de Lima, Leonardo Macedo Poli e Fernanda São José

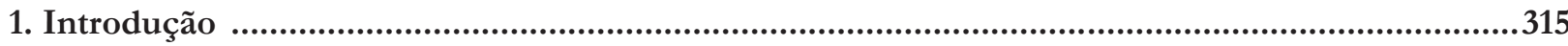

2. A criança e o adolescente como seres insignificantes: "Adultos" em corpos infantis....................315

3. A criança e o adolescente como seres "imperfeitos"; como "objetos" de tutela estatal ................318

4. A criança e o adolescente como sujeitos de direitos, detentores de direitos e garantias

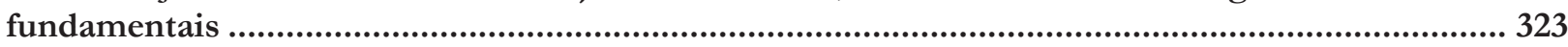

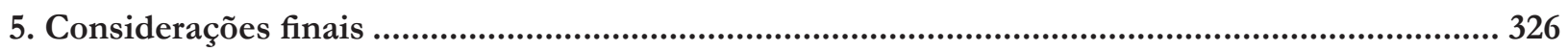

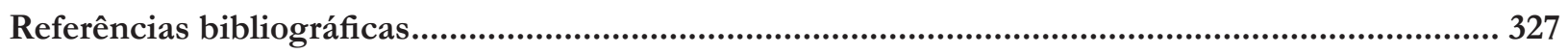

\section{A INTERVENÇÃo DiRETA E INDIRETA NA ATIVIDADE ECONÔMICA EM FACE DA ORDEM JURÍdiCA}

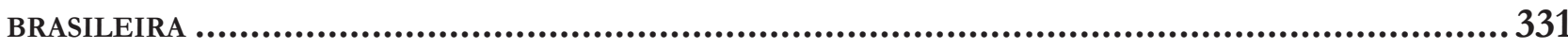

Antônio Francisco Frota Neves e Hector Valverde Santana

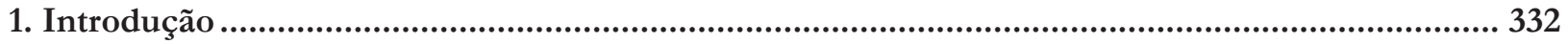

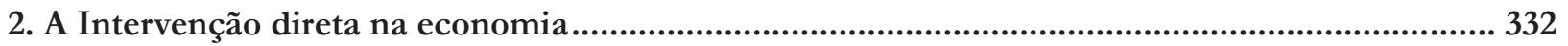

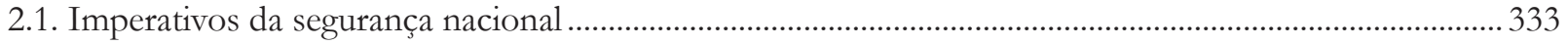

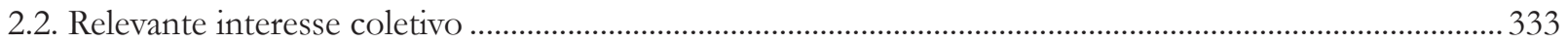

3. Instrumentos de exploração da atividade econômica ....................................................................... 334

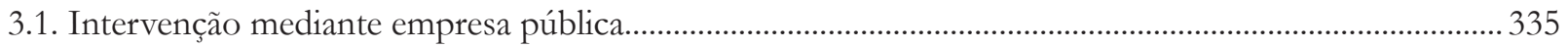

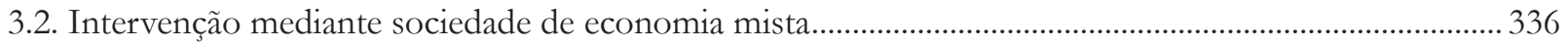

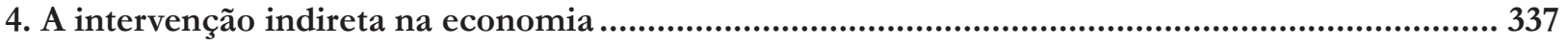

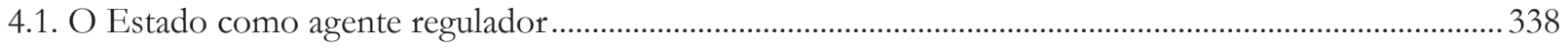

4.2. O Estado como agente regulador por indução ………………………………………............................... 339

4.3. A planificação da atividade econômica no marco regulatório ....................................................................... 340

5. A prestação de serviços públicos por terceiros................................................................................. 342

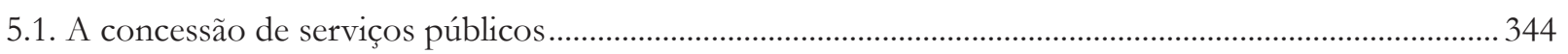

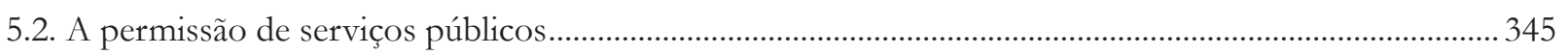

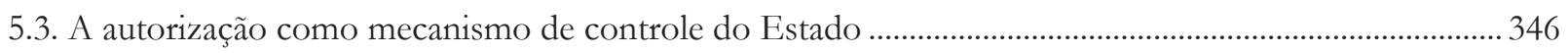

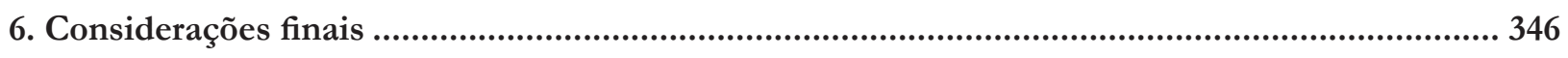

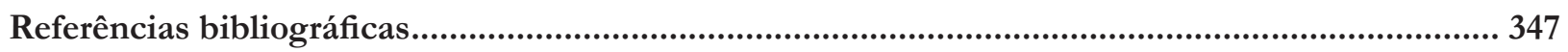

Conflitos AGRÁRIOS: DESOBEDIÊNCIA CIVIL OU CRIME?...................................................350

Edilene Lôbo e Paulo Henrique Brant Vieira

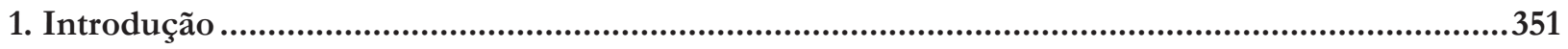

2. O processo de colonização como marco fático dos conflitos agrários no Brasil......................... 352

3. A construção normativa da criminalização da luta pela terra ................................................. 357 
4. A proteção constitucional à propriedade e a (im)possibilidade de criminalização das ocupações de

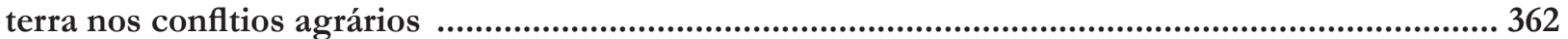

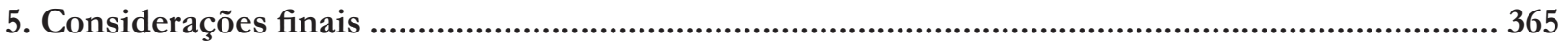

Referências bibliográficas.................................................................................................................... 366

O PODER POLÍTICO E A MÍdIA DE MASSA: A PERSPECTIVA DA FISCALIZAÇÃo DE CONCESSÕES E OUTORGAS DE RADIODIFUSÃO NO BRASIL...................................................................369

Bruno Mello Correa de Barros e Rafael Santos de Oliveira

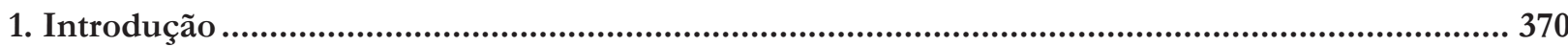

2. A comunicação e a concentração de mídias e meios no panorama da sociedade informacional 371

3. As mídias e o controle da informação na perspectiva brasileira ................................................. 374

4. Outorgas e concessões: a atuação ficalizatória e a pressão política na radiodifusão do Brasil.... 377

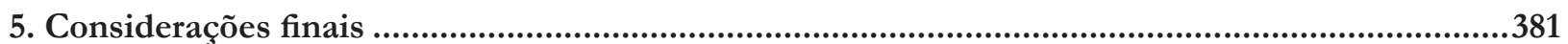

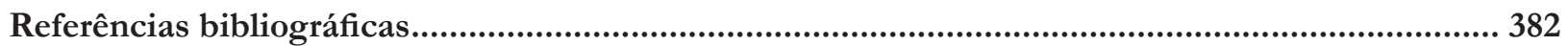

Os IMIGRANTES No BrASIL, SUA VULNERABILIDADE E O PRINCÍPIO DA IGUALDADE...................385

Leda Maria Messias da Silva e Sarah Somensi Lima

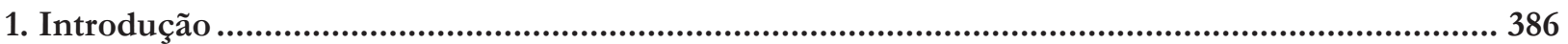

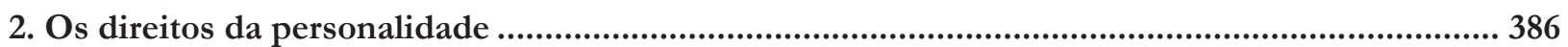

2.1. Proteção dos vulneráveis e o Princípio da Igualdade ................................................................................... 388

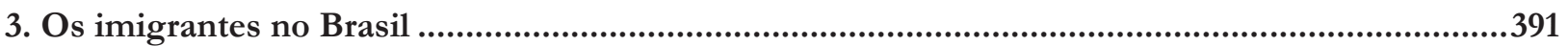

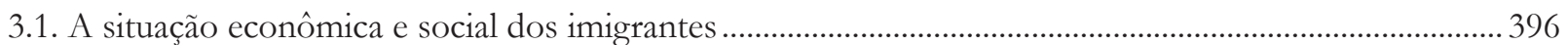

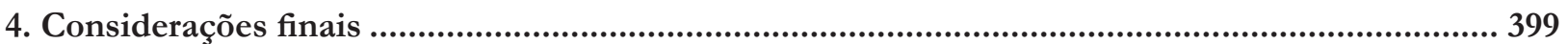

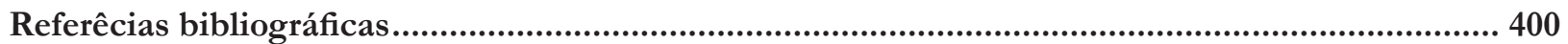

Normas Editoriais..............................................................................................404

Envio dos trabalhos: 


\section{DOSSIÊ TEMÁTICO}




\section{REVISTA BRASILEIRA DE POLÍTICAS PÚBLICAS BRAZILIAN JOURNAL OF PUBLIC POLICY}
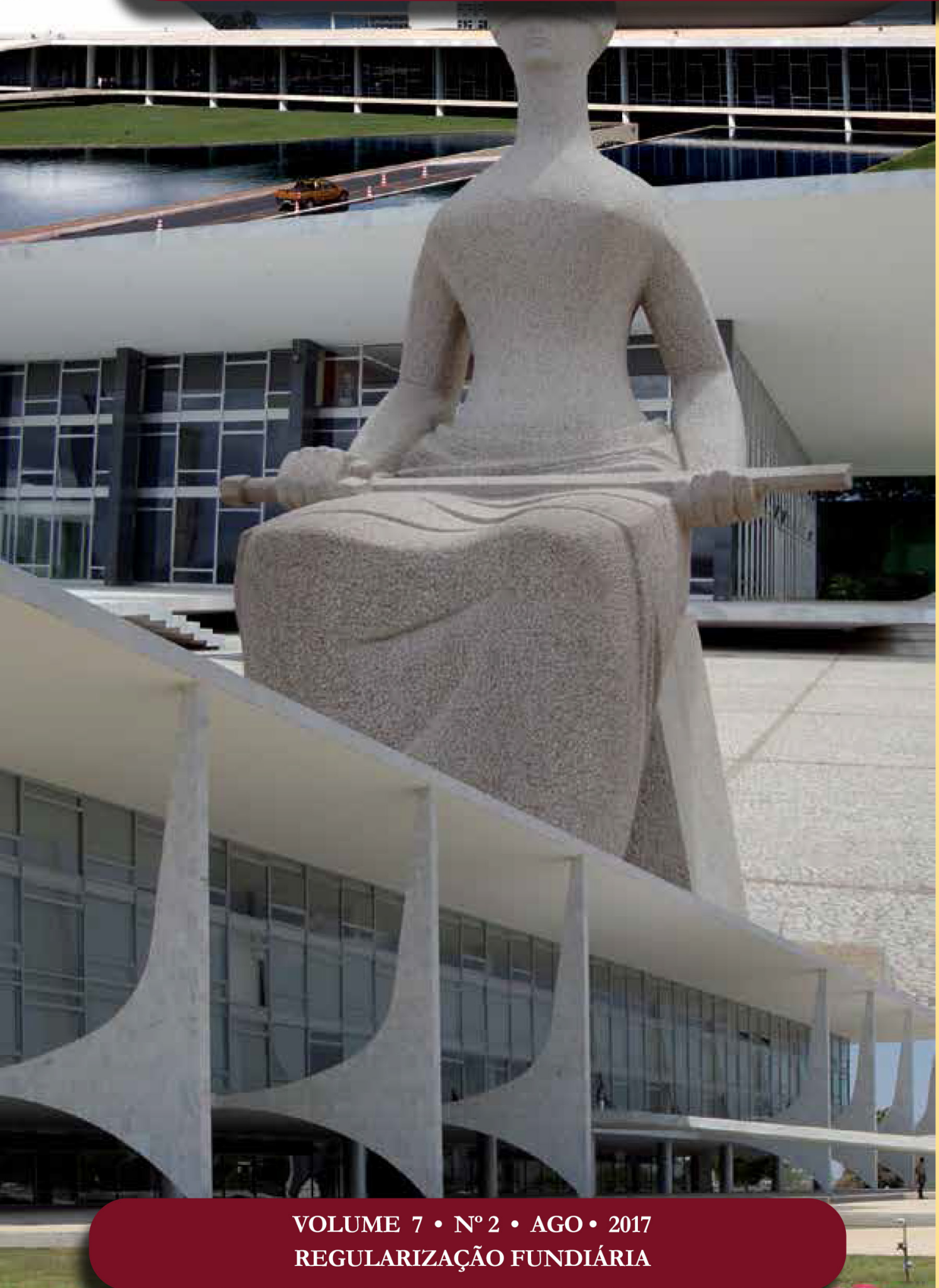

Metodologia do direito, teorias da posse e a posse na nova lei de regularização fundiária

Legal method, theories of land property and possession and the the law of land regularization

Helton Junio Da Silva

Rafhael Frattari Bonito

Renata Aparecida de Oliveira Dias 


\section{Metodologia do direito, teorias da posse e a posse na nova lei de regularização fundiária*}

\section{Legal method, theories of land property and possession and the the law of land regularization}

\author{
Helton Junio Da Silva** \\ Rafhael Frattari Bonito*** \\ Renata Aparecida de Oliveira Dias****
}

* Recebido em 30/07/2017 Aprovado em 25/09/2017

** Mestrando em Direito Privado pela FUMEC, Advogado. Membro da Comissão de Direito Notarial e Registral da OAB Seção Minas Gerais. Email: heltonjunio@yahoo.com.br

*** Sócio Responsável pela área Tributária do VLF Advogados. Doutor e mestre pela Faculdade de Direito da Universidade Federal de Minas Gerais Professor dos cursos de graduação e de mestrado em Direito na Universidade FUMEC/MG. Email: frattari@vlf.adv.br

**** Prefeitura de Belo Horizonte Servidora Pública Municipal na Prefeitura de Belo Horizonte na Secretária Municipal de Finanças. Advogada especialista em Direito Público pela Universidade Cândido Mendes. Email: renata. aod@gmail.com

\section{Abstract}

This article aims to analyze the possession institute with reflections on the methodology of law and to make considerations regarding the possession of Law 13.465 / 2017, which deals with land regularization in Brazil. For the development of the study was carried out the doctrinal and legal research on the proposed theme, seeking in such sources the theoretical and historical basis for its foundation. In this way, the concept of tenure will be presented, as well as its legal nature. In the sequence, some problematizations are made regarding the methodology of the law together with the presentation of the subjective and objective theories of possession. Next, a brief study is carried out on land tenure regularization in Brazil and on possession ad usucapionem. The originality of the article is attributed to the recent legal modification and the systematics made feasible by the reflections 
about the methodology of the law. After considering the related topics, it was possible to conclude that the ownership function changes with socio-historical, cultural, and economic reality.

Keywords: possession - methodology of law - land regularization.

\section{INTRODUÇÃo}

O estudo e tratamento do instituto da posse remonta àquele dado pelo Direito Romano desde a elaboração do Código Civil Romano, o Codex Juris Civilis. E, embora pouca coisa tenha evoluído desde esta época, vários autores, após a formulação das teorias da posse de Ihering e Savigny, buscam sistematizar tal instituto, tornando-o assim um grande e desafiador objeto de estudo.

A palavra POSSE deriva do latim possessio que provém de potis, prefixo potestas, que significa poder; e sessio, sufixo da mesma origem de sedere, que quer dizer, estar firme, assentado. Indica, portanto, um poder que se prende a uma coisa.

Vários autores buscaram ao longo do tempo definir com mais precisão o termo "Posse", dando para este o exato significado técnico desse instituto. Esta busca da conceituação de posse é bem complexa e desafiadora seja por provocar muitas divergências doutrinárias quanto à origem, os elementos essenciais, seja quanto a definir sua natureza jurídica. Diante dessas dificuldades surgiram várias teorias, entre elas a teoria Objetiva e a Teoria Subjetiva da Posse, defendidas por Ihering e Savigny, respectivamente.

É a partir desse conflito de entendimentos e da dificuldade de se estabelecer um conceito mais exato do termo posse que se fundamenta o objeto de estudo deste artigo.

Para tanto no primeiro capítulo irá se apresentado as tentativas de se conceituar a instituto da posse, tanto na legislação brasileira quanto na doutrina especializada no Direito Civil.

Já o segundo capítulo abordará as visões existentes sobre a natureza jurídica da posse e sua estreita relação com a dificuldade de se conceituá-la. Será ainda exposto algumas considerações sobre as maiores teorias do estudo da posse até os dias atuais, as teorias de Ihering e Savigny.

No terceiro capítulo são apresentadas breves reflexões sobre metodologia do direito e as teorias da posse. No último capítulo é abordado a posse ad usucapionem e frente as teorias da posse.

\section{Conceito de POSSE}

Trata-se a posse de um fenômeno que ocupa um lugar importante nas discussões sociais e jurídicas desde os tempos da Roma antiga, tornando assim seu estudo imprescindível para delimitar direitos, efeitos e consequências, já que esta atingia e ainda atinge as mais diversas relações humanas, principalmente no que ser refere ao âmbito jurídico e econômico. Nas palavras de Fachin ${ }^{1}$

A partir do momento em que uma regra de conduta passou a se ocupar do fenômeno possessório, já apanhou a relação possessória como uma relação de poder, de senhorio. Essa tradução do fato para o universo jurídico foi incorporada pelo direito romano, e de certo modo, remanesce até os dias que correm(...) Daí se vê que o nascimento da posse encontra-se ligado à determinação de um conteúdo econômico privado, porque dotada do caráter de exclusividade e de pessoalidade, contrapondo-se aos caracteres de socialidade ou comunidade do uso.

1 FACHIN, Luiz Edson. A função social da posse e a propriedade contemporânea: uma perspectiva da usucapião imobiliária rural. Porto Alegre: Fabris, 1988. p.24 
Assim, o primeiro passo ao se pretender estudar a posse trata-se de apresentar o seu conceito. Porém, conceituar a posse sempre foi uma tarefa de extrema complexidade. Desde que apresentada as teorias objetiva e subjetiva da posse, defendidas por Ihering e Savigny respectivamente, vários autores procuram apresentar um conceito mais amplo do que podemos vir a entender a posse.

Contudo, antes de apresentar os conceitos e considerações doutrinárias, é importante mencionar como a posse é tratada no Código Civil Brasileiro.

\subsection{Breves considerações sobre a posse no Código Civil Brasileiro}

Embora a expressão posse seja utilizada em muitos dispositivos legais, nossa legislação civil não apresenta um conceito fechado. O Código Civil Brasileiro² apresenta, contudo, o que chama "Da posse e sua classificação", como se pode observar em seus artigos 1.196 a 1.203.

Art. 1.196. Considera-se possuidor todo aquele que tem de fato o exercício, pleno ou não, de algum dos poderes inerentes à propriedade.

Art. 1.197. A posse direta, de pessoa que tem a coisa em seu poder, temporariamente, em virtude de direito pessoal, ou real, não anula a indireta, de quem aquela foi havida, podendo o possuidor direto defender a sua posse contra o indireto.

Art. 1.198. Considera-se detentor aquele que, achando-se em relação de dependência para com outro, conserva a posse em nome deste e em cumprimento de ordens ou instruções suas.

Parágrafo único. Aquele que começou a comportar-se do modo como prescreve este artigo, em relação ao bem e à outra pessoa, presume-se detentor, até que prove o contrário.

Art. 1.199. Se duas ou mais pessoas possuírem coisa indivisa, poderá cada uma exercer sobre ela atos possessórios, contanto que não excluam os dos outros compossuidores.

Art. 1.200. É justa a posse que não for violenta, clandestina ou precária.

Art. 1.201. É de boa-fé a posse, se o possuidor ignora o vício, ou o obstáculo que impede a aquisição da coisa.

Parágrafo único. O possuidor com justo título tem por si a presunção de boa-fé, salvo prova em contrário, ou quando a lei expressamente não admite esta presunção.

Art. 1.202. A posse de boa-fé só perde este caráter no caso e desde o momento em que as circunstâncias façam presumir que o possuidor não ignora que possui indevidamente.

Art. 1.203. Salvo prova em contrário, entende-se manter a posse o mesmo caráter com que foi adquirida.

Percebe-se assim, que nossa legislação apresentou apenas o conceito de possuidor, ou seja, aquele que detém a posse. Observa-se ainda que este conceito está intrinsicamente ligado a outro conceito tão importante quanto: a propriedade.

O Código Civil ainda apresenta outros elementos da posse, que embora, a princípio não seja relevante para o estudo aqui proposto, vale a pena ser ressaltado.

Nos artigos que seguem aqueles citados anteriormente, encontram-se os artigos 1.204 a 1.209 que trata das formas de aquisição da posse (em nome próprio ou te terceiros). Na sequência, os artigos 1.210 a 1.222 tratam dos efeitos da posse, mais especificamente de seu alcance de suas limitações.

Esses dois Capítulos apresentados no Código Civil configuram-se como pontos de destaque quando do estudo de alguns outros institutos fundados exatamente na forma de aquisição e efeitos da posse, como é o caso do Usucapião (Direito Real adquirido através da posse). Sendo a forma de aquisição da posse de

2 BRASIL. Lei N ${ }^{\circ}$ 10.406, de 10 de Janeiro de 2002. Institui o Código Civil. Disponível em < https://www.planalto.gov.br/ ccivil_03/LEIS/2002/L10406.htm > Acesso em: 23 jul 2017 
fundamental importância, no que diz respeito aos requisitos de mansidão e pacificidade e os efeitos no que diz respeito à boa fé e ao próprio direito ad usucapionem. Por fim, destacamos o os artigos 1.223 e 1.224 que tratam da perda da posse.

\subsection{Posse}

Passa-se agora a apresentar alguns conceitos doutrinários da posse. Como já apontado definir a posse é um exercício hercúleo para qualquer doutrinador que pretenda sem conciso e direto, sem adentrar nas teorias objetivas e subjetivas da posse, principalmente quando nossa legislação também se escusou de assim defini-la. Apresentemos, porém, algumas dessas tentativas.

Para Souza ${ }^{3}$ a definição pode ser extraída de forma reflexiva do já citado art. 1.196 do Código Civil:

O Nosso Código Civil, em seu art. 1.196, usa do conceito de propriedade para, de forma reflexiva, conceituar o que seja possuidor para que, dessa conceituação, o leitor possa inferir o que seja posse. (...)

Assim, pelo que dispõe o artigo 1.196 de nosso Código Civil, a posse é um fato. É o simples exercício de qualquer dos poderes inerentes ao direito de propriedade, a saber: usar, gozar e dispor.

Farias e Rosenvald ${ }^{4}$, apoiam seu entendimento sobre a posse nas palavras do historiador Paolo Grossi.

Para o historiador Paolo Grossi, além da propriedade, são outros os vínculos entre sujeitos e bens que emergem a um nível jurídico e com os quais se constroem as relações que os juristas chamam reais, isto é, radicadas in re. Na posse o problema central não é o vínculo formal e exclusivo sancionado pelos livros fundiários, o pertencimento de um bem a alguém; é a efetividades sobre o bem prescindindo das suas formalizações. Podemos dizer que a posse do bem se refere a uma dimensão da factualidade contraposta a um reino estático de formas oficiais.

Gagliano $^{5}$, por sua vez assim define a posse de forma bem direta: "A posse é uma circunstância fática tutelada pelo Direito. Vale dizer, é um fato, do qual derivam efeitos de imensa importância jurídica e social."

Fiúza ${ }^{6}$, por sua vez, apresenta o seguinte conceito de posse, após discutir sobre sua natureza jurídica:

Posse é a situação, em que uma pessoa tem um bem em seu poder, ou seja um bem se acha subordinado à esfera de atuação de uma pessoa. A essa situação de coisas, denomina-se posse. É evidente que, uma vez que o ordenamento jurídico incida sobre essa situação, transforma-a em situação de direito ou situação jurídica.

Embora apresentados como conceitos fechados e próprios, todos eles decorrem das idéias que se tem sobre a natureza jurídica da posse: a posse passa pela situação de fato ou pelo direito subjetivo. Percebe-se que a dificuldade de apresentar tal conceito, surge da controvérsia que cercam a matéria, principalmente quando se trata de definir sua natureza jurídica, assim como informa Fachin ${ }^{7}$

Não há autor contemporâneo que tratando do assunto não tenha analisado as teorias subjetivas e objetivas da posse, ora para evidenciar o acerto da primeira, ora para demonstrar a sua superioridade, ora para constatar que entre tais concepções as diferenças são vem menos substanciais do que se apregoa.

Assim, em uma tentativa de melhor elucidar o conceito da posse necessário se faz um estudo sobre a natureza jurídica da posse e consequentemente análise sobre as teorias de Ihering e Savigny.

3 SOUZA, Adriano Stanley Rocha.Direito das coisas. 4. ed. Belo Horizonte: Del Rey, 2015. p.8

4 FARIAS, Cristiano Chaves de; ROSENVALD, Nelson. Curso de direito civil: volume 5 : direitos reais. 13. ed. rev., ampl. e atual. Salvador: Juspodivm, 2017. p.60

5 Gagliano, Pablo Stolze; FILHO, Rodrigo Pamplona. Manual de direito civil. São Paulo: Saraiva, 2017.p. 991

6 FIUZA, César. Direito civil: curso completo. 18. ed. rev., atual. e ampl. São Paulo: Revista dos Tribunais, 2015.p.1085.

7 FACHIN, Luiz Edson. A função social da posse e a propriedade contemporânea: uma perspectiva da usucapião imobiliária rural. Porto Alegre: Fabris, 1988.p.25 


\subsection{Natureza jurídica da posse.}

Intrinsecamente ligada ao conceito encontra-se o estudo da natureza jurídica da posse e por isso é tão relevante seu estudo. Para Farias e Rosenvald ${ }^{8}$ :

Compreender a sua natureza significa entender se a posse é protegida pelo ordenamento por seu próprio significado, ou como uma extensão da tutela da propriedade, ou mesmo, da necessidade do sistema de evitar qualquer forma de violência e proteger a personalidade do ser humano.

De fato, muitos conceitos de posse apresentados no item anterior partem da definição da sua natureza, que nas palavras de Fiúza ${ }^{9}$ pode ser duas: a situação de fato ou o direito subjetivo.

Assim, embora resuma em duas possibilidades, o autor apresenta três teorias sobre a natureza jurídica da posse, sendo a terceira um misto entre as duas primeiras.

A primeira, defendida por Windscheid, Trabuscchi, Silvio Rodrigues, Washington de Barros, Clovis Bevilaqua, entre outros, defende que a natureza jurídica da posse é fática, ressaltando que "por situação de fato, neste caso, não se entenda situação não acolhida pelo Direito Positivo, mas situação oriunda de conjunto dinâmico de fatos jurídicos que irá consistir numa relação jurídica"10.

Para a segunda corrente a natureza jurídica da posse seria o direito subjetivo. Tal tese é defendida por Ihering, Teixeira de Freitas e Caio Mário. Nesta perspectiva Cezár Fiúza ${ }^{11}$ esclarece:

(...) posse é direito do titular sobre a coisa. Logicamente esse direito nasce de um fato. Mas a posse difere dos outros direitos reais. Enquanto nestes o fato é apenas sua origem, desaparecendo com o nascimento do direito, na posse, o direito só existe enquanto existir o fato.

Já a terceira corrente destacada por Fiúza, é aquela defendida por Savigny, Lafayette, Merlin e outros. Para estes autores a posse possui natureza de fato e direito, simultaneamente. "Num primeiro momento, a posse é situação de fato, como descrito acima. Ocorre que dessa situação fática se originam direitos, como interditos e a usucapião. Assim, por suas consequências, posse é direito. "12

Após discorrer sobre a as teorias da natureza jurídica da posse, Fiúza apresenta seu ponto de vista sobre a posição mais adequada ao direito brasileiro. Para ele a segunda corrente, defendida por Ihering, é a mais pertinente: a natureza jurídica da posse seria a situação fática. $\mathrm{O}$ autor ${ }^{13}$ justifica seu posicionamento fundamentando em dois elementos da posse: corpus e animus.

Podemos asseverar que, em princípio, posse é a situação jurídica caracterizada por dois elementos: corpus e animus. Inerente a ela, acha-se relação possessória básica, entre possuidor e não possuidores, dela emergindo o direito real à proteção possessória.

O corpus, neste sentido representa o elemento objetivo, a atitude externa do possuidor. É no ponto de vista do autor ${ }^{14}$ a visibilidade do domínio, a conduta do possuidor em relação à coisa. Já o animus é representado pelo elemento subjetivo, ou seja, corresponde a vontade de ter a coisa para si, como se dono fosse.

Para Fiúza ${ }^{15}$ as outras duas correntes apresentadas possuem uma falha ao relacionar a natureza jurídica da posse ao direito subjetivo, pois ao assim tratar a posse incorreriam no risco de excluir da sociedade seus direitos e deveres, prejudicando assim a função social da posse.

8 FARIAS, Cristiano Chaves de; ROSENVALD, Nelson. Curso de direito civil: volume 5 : direitos reais. 13. ed. rev., ampl. e atual. Salvador: Juspodivm, 2017.p.66-67

9 FIUZA, César. Direito civil: curso completo. 18. ed. rev., atual. e ampl. São Paulo: Revista dos Tribunais, 2015.p. 1084

10 FIUZA, César. Direito civil: curso completo. 18. ed. rev., atual. e ampl. São Paulo: Revista dos Tribunais, 2015.p. 1084

11 FIUZA, César. Direito civil: curso completo. 18. ed. rev., atual. e ampl. São Paulo: Revista dos Tribunais, 2015.p. 1084

12 FIUZA, César. Direito civil: curso completo. 18. ed. rev., atual. e ampl. São Paulo: Revista dos Tribunais, 2015.p. 1084

13 FIUZA, César. Direito civil: curso completo. 18. ed. rev., atual. e ampl. São Paulo: Revista dos Tribunais, 2015.p. 1085

14 FIUZA, César. Direito civil: curso completo. 18. ed. rev., atual. e ampl. São Paulo: Revista dos Tribunais, 2015.p. 1085

15 FIUZA, César. Direito civil: curso completo. 18. ed. rev., atual. e ampl. São Paulo: Revista dos Tribunais, 2015.p. 1085 
Há quem defenda ainda que não é possível admitir a natureza jurídica da posse defendida do Savigny, pois o Código Civil Brasileiro não elencou a posse como um direito real no rol numerus clausus do artigo 1.225 do Código Civil. Desta forma, o direito a posse não seria um direito real, mas sim um direito especial. Flávio Tartuce $^{16}$ simplifica: trata-se de direito de natureza especial, sui generis.

Feitas as considerações sobre conceito e natureza jurídica da posse, é de extrema importância destacar de forma mais aprofundada as teorias da posse desenvolvidas por Ihering e Savigny, na medida de que, como vimos parte todo o pressuposto e estudos sobre este instituto no direito atual.

\section{CONSIDERAÇÕES SOBRE METODOLOGIA DO DIREITO E AS TEORIAS DA POSSE}

Friedrich Carl Von Savigny foi talvez o maior estudioso do direito romano, ela dominava os pandectas, ou seja, as coletâneas de leis compiladas por Justiniano. Pode se afirmar que os alemães usaram as pandectas para construir seu sistema jurídico como forma de consolidar a Alemanha como um só Estado.

A escola histórica do direito alemão apelava para o costume como fonte do direito. Savigny afirmava que a principal fonte do direito era o costume e que o costume servia de base para reinterpretar o direito romano. É possível afirmar que Savigny foi o percussor da expressão "relações jurídicas". O professor Lúcio Antônio Chamon Júnior ${ }^{17}$ ao correlacionar direitos e deveres no discurso jurídico moderno lembra obra Direito Romano Atual de Savigny:

Savigny entende que o direito subjetivo enquanto um poder em cujos limites reina a vontade do indivíduo que, para tanto, conta com o consentimento de todos. A manifestação mais clara, ao mesmo tempo que acidental, do direito se daria quando, em sendo negado e atacado, fosse jurisdicialmente reconhecido tanto em sua existência, quanto em sua extensão. Savigny afirma como sendo acidental tal reconhecimento porque, na verdade, a existência desse limite à vontade reinante do indivíduo haveria que ser derivada do conceito de relação jurídica: e há o julgador que se atentar a todas as partes de tal relação para chegar a uma decisão adequada.

O objetivo nesse momento seria de uma sistematização do direito, por isso é que se defende que o positivismo começa com a escola histórica.

Savigny acreditava que o direito é como uma "linha invisível de separação", que se desenvolvem nas relações espontâneas, algo vivo, que se experimenta no dia a dia e resulta da convivência para que os indivíduos possam encontrar segurança e independência. Savigny, chama de direito, servo da moral, enquanto garantidor de um espaço de livre arbítrio. Implicando numa distinção em termos de conteúdo entre Direito e Moral, pois a relação do direito se desenvolveria de forma particular e determinada individualmente. ${ }^{18}$

Não é da observação do costume que se compreende o direito, tem algo em comum, que subjaz, os costumes diferentes. Esse algo que é comum só se acha no espírito do povo. Conforme ensina o ilustre professor André Cordeiro Leal, o espírito do povo alemão (Volksgeist) na época de Savigny deveria se seguir de interpretação a todo o direito romano que ele resgatava. Questiona-se então o que o povo alemão queria, o que estava por traz dos costumes dos quais se alimentava o direito? Para Savigny o que o povo queria era autonomia ${ }^{19}$.

Nesse sentido, o espírito alemão era empreendedor, que deveria dar vazão à vontade, que deixa o sujeito

16 TARTUCE, Flávio. Manual de Direito Civil: volume único. São Paulo: Método, 2011.p.715

17 CHAMON JUNIOR, Lúcio Antônio. Teoria Geral do Direito Moderno. Por uma Reconstrução Crítico-Discursiva na Alta Modernidade. Lumen Juris, Rio de Janeiro. 2007.p.79

18 CHAMON JUNIOR, Lúcio Antônio. Teoria Geral do Direito Moderno. Por uma Reconstrução Crítico-Discursiva na Alta Modernidade. Lumen Juris, Rio de Janeiro. 2007.p.79

19 LEAL, André Cordeiro. Notas de Aula. FUMEC. Belo Horizonte, 18 de abril de 2017. 
existir, nos remetendo a um enfoque moral do direito. Nas palavras do professor Lúcio Antônio Chamon Júnior ${ }^{20}$ :

A autonomia privada, como assevera Habermans, justificada a partir da idéia de inviolabilidade da pessoa e garantia, em contrapartida, da liberdade de arbítrio, reclusa-se, sobretudo, na liberdade de firmar contratos além de adquirir propriedade, bem como aliená-la ou transmiti-la - os direitos subjetivos são antes interpretados, em face daquilo que os justifica, como direitos negativos de não intromissão na esfera pessoal de reino absoluto de vontade.

Nesse aspecto é possível reconhecer o costume como pretensão de autonomia. O povo produziria o direito, mas quem é responsável pela interpretação do direito é a doutrina.

Sem aprofundar numa perspectiva investigativa da metodologia do direito, cabe ainda entender a relação do pensamento de Savigny com a lógica o fundamento moralizante da didática Kantiana. Segundo a professora Ingueborg Maus ${ }^{21}$ ao discorrer sobre soberania popular e autônima dos processos jurídicos-estatais:

O próprio Kant aparece como expert da autonomia e antecipa o que a autonomia de todo procedimento democrático poderia apresentar como resultado, tornando-se culpado da pior das transgressões da qual ele acusou o próprio absolutismo não esclarecido: ele cerra o horizonte do futuro do qual dependem processos sociais de aprendizado.

Posterior a essa leitura, a conhecida "jurisprudência dos interesses" pretendeu romper com esse pensamento, pois como o Estado protege a vontade de alguém que não gera benefícios para a coletividade. A jurisprudência dos interesses protege o direito subjetivo, que é o interesse juridicamente tutelado. A jurisprudência nesse sentido não se restringe a coletânea de decisões, mas sim uma metodologia, uma escola do direito, segundo a qual a interpretação do direito deve se dar num determinado sentido. A escola dos interesses nos diz que o Estado deve proteger o direito subjetivo.

Rudolf Von Thering foi um dos precursores da chamada "jurisprudência dos interesses". Possivelmente a Jurisprudência dos interesses foi o estudo que mais buscou conciliar a segurança e justiça. Essa posição foi fortalecida na Alemanha na primeira metade do século XX. Após a unificação da Alemanha, o positivismo científico baseado nas pandectas foi aos poucos cedendo espaço a um positivismo legalista, estabelecido no estudo das leis nacionais elaboradas nas últimas décadas do século XIX.

$\mathrm{Na}$ escola dos interesses há, portanto, uma postura utilitarista. A supremacia do interesse privado sobre o direito público remete à autonomia de Savigny e a supremacia do interesse público sobre o privado remete à ética utilitarista. Nessa lógica, a função social seria benefício aos excluídos.

Possivelmente Savigny e Ihering buscaram no digesto para entender o que os romanos chamavam de posse, porque em sua época não havia um poder legislativo que editava regras vinculativas a todos. Para os romanos a posse tinha muitos significados, assim como a detenção, e Savigny escolheu um dos sentidos que mais se harmonizava com o espírito alemão. Ele formulou um conceito de posse adequado para a sua época.

Na obra Metodologia da Ciência e do Direito, o autor Karl Larenz, ao abordar a transposição da jurisprudência dos interesses à jurisprudência da valoração, resgata o inusitado êxito da defesa de Philipp Heck, ao menos no direito privado a respeito da jurisprudência dos interesses.

Entre as críticas feitas por Philipp Heck, destaca-que o argumento de que era preciso suprir as insuficiências do pensamento lógico dedutivo puro com elementos intuitivos. Nesse aspecto, seria preciso reconhecer a realidade social concreta. Dessa forma, apenas com aprofundamento na esfera sociológica da gênese dos interesses que poderia levar o legislador a desenvolver leis com a devida ponderação que merecesse.

Nessa reflexão, foi criada uma nova perspectiva metodológica que voltará a aparecer na chamada Juris-

20 CHAMON JUNIOR, Lúcio Antônio. Teoria Geral do Direito Moderno. Por uma Reconstrução Crítico-Discursiva na Alta Mocdernidade. Lumen Juris, Rio de Janeiro. 2007.p.81

21 MAUS, Ingeborg. Direito e política: teoria da democracia. Tradução Elisete Antoniuk. Belo Horizonte; Del Rey, 2009. p. 170. 
prudência dos valores. Nas palavras de Karl Larenz ${ }^{22}$

O modo como valora esses distintos interesses e necessidades nos respectivos nexos de regulação e como confere prevalência a qual quer um deles plasma-se na regulação por ele encontrada e decorre desta, bem como das manifestações dos participantes no processo legislativo. As valorações do legislador assim identificadas permitem extrair resultados, quer para a interpretação da lei, quer como, em certas circunstâncias, para a resolução de casos por ele não diretamente regulados, mas a tratar analogamente à luz de critérios de valoração.

É possível considerar que jurisprudência dos valores, dessa forma, representa mais uma continuidade do que uma verdadeira ruptura com a jurisprudência dos interesses.

A justificativa das considerações a respeito da metodologia do direito é que a leitura de Savigny e Ihering são refletidas das teorias da posse. Para tanto, se faz necessária a análise das teorias subjetiva e objetiva da posse.

\subsection{Teoria subjetiva da posse}

A teoria subjetiva, desenvolvida pelo jurista Carl Von Savigny, foi a primeira capaz de tratar a posse atribuindo-lhe elementos e efeitos. Segundo Souza ${ }^{23}$ :

(...) a posse entre os romanos era mais sentida que conceituada. O romano sabia dizer quem exercia a posse sobre algo. No entanto, não sabia conceituar o que fosse posse. Desde a Roma antiga muito foi falado, escrito e teorizado. No entanto, a primeira teoria capaz de dissecar o fato 'posse', atribuindo-lhe elementos e efeitos, foi a Teoria Subjetiva de Savigny.

Savigny eleborou sua teoria com base na observação de como, até então, os romanos reconheciam a posse, como assim destacou Souza ${ }^{24}$.

$\mathrm{Na}$ formulação de sua teoria acerca da posse Savigny partiu do ponto mais elementar de uma pesquisa científica: a observação. Savigny observou que apesar de ninguém conseguir definir o que fosse posse, todos eram capazes de reconhecer quem era possuidor. Ele percebeu que as pessoas atribuíam a qualidade de possuidor àquele que demonstrasse poder físico sobre a coisa.

Assim, Savigny pôde, nas palavras de Farias e Rosenvald ${ }^{25}$, definir a posse como "o poder que a pessoa tem de dispor materialmente de uma coisa, com intenção de tê-la para si e defende-la contra a intervenção de terceiros. A partir deste conceito, Savigny ainda estabeleceu que para haver a posse seria necessário a junção de dois elementos: corpus e animuns domini.

O animus domini é caracterizado pela vontade de ser proprietário, de ter a coisa como sua. Para Savigny, uma vez ausente essa intenção de ter a coisa como sua, não há o que se suscitar a posse. Já o corpus está relacionado com o contrato entre o possuidor e a coisa e mais tarde passou a ser a mera possibilidade de contar com a coisa, estando ela a sua disposição.

Para resumir tal entendimento, Corrêia ${ }^{26}$ assim define o conceito de posse na teoria de Savigny:

A posse é o poder de dispor fisicamente da coisa, com ânimo de considera-la sua e defende-la contra a intervenção de outrem. Encontram-se, assim na posse dois elementos: um elemento material, o corpus, que é representado pelo poder físico sobre a coisa; e um elemento intelectual, o animus, ou seja, o propósito de ter a coisa como sua, isto é, o animus rem sib babendi.

\footnotetext{
22 LARENZ, Karl. Metodologia da ciência do direito. 3. ed. Lisboa: Fundação Calouste Gulbenkian, 1997. P.164.

23 SOUZA, Adriano Stanley Rocha. Direito das coisas. 4. ed. Belo Horizonte: Del Rey, 2015.p.9

24 SOUZA, Adriano Stanley Rocha. Direito das coisas. 4. ed. Belo Horizonte: Del Rey, 2015.p.10

25 FARIAS, Cristiano Chaves de; ROSENVALD, Nelson. Curso de direito civil: volume 5 : direitos reais. 13. ed. rev., ampl. e atual. Salvador: Juspodivm, 2017.p.60

26 CORREIA, Jonas Ricardo. Usucapião no novo CPC: teoria, pratica e legislação pertinente. 2. Ed. Campo Grande: Contemplar, 2016.p. 25
} 
O entendimento recebe a denominação de teoria subjetiva justamente pela valorização do animus domini um elemento subjetivo, a vontade do sujeito em relação à coisa possuída.

Porém, embora ressaltasse a importância do animus domini, de acordo com esta teoria se faltasse um dos dois elementos hão poderia se falar de posse. Salles $^{27}$ assim define o posicionamento de Savgny diante da necessidade de tais elementos:

Para ele, portanto, a posse constituir-se-ia de dois elementos: o poder físico sobre a coisa (corpus) e a intenção de tê-la como sua (animus), ou seja, o ânimo de ter sobre a coisa o direito de propriedade. Separadamente, nenhum desses elementos seria suficiente para consubstanciar a posse. Animus sem corpus representaria mero fenômeno psíquico, sem qualquer repercussão no mundo do direito. Por outro lado, corpus sem animus equivaleria a simples detenção, consubstanciadora de posse natural mas não de posse jurídica.

Por ser caracterizada pelo elemento interno da pessoa (possuidor) a teria de Savigny é chamada de Teoria Subjetiva e suas falhas estão conforme desta Farias e Rosenvald ${ }^{28}$ justamente na exacerbação do papel da autonomia da vontade.

Critica-se na teoria subjetiva, a exacerbação do papel da autonomia da vontade pela incondicionada ligação da posse ao animus domini. Segundo Savigny, refletindo o ideário liberal e individualista vigente na época, a pessoa era o indivíduo abstrato que ocupava um dos polos da relação jurídica, possuindo autodeterminação nas relações econômicas. Esta visão restrita e unitarista camufla o ser humano concreto, capaz de se manifestar em uma pluralidade de relações possessórias, nas quais não releva o exame do animus domini, mas sim a proteção à moradia, ao trabalho e a defesa incondicional dos direitos da personalidade e da dignidade da pessoa humana.

É importante ressaltar, porém que tal teoria também teve seus méritos no estudo da posse do direito civil, de modo geral. Foi a partir de seus apontamentos que foi possível "projetar autonomia à posse por explicar que o uso dos bens adquire relevância jurídica forma da estrutura da propriedade privada e que a titularidade formal desse direito subjetivo não encerra todas as possibilidades do amparo jurídico. "29 É partir de seus estudos que a posse deve ser protegida e amparada pelo direito.

Outro destaque que deve ser apontado na teoria de Savigny é que embora tenha suas falhas e não seja a teoria adotada pelo Código Civil, utiliza-se de algumas ponderações da teoria de Savigny na fundamentação e exigências de alguns direitos. É a partir dessa teoria que no Brasil se fundamenta a usucapião. A posse usucapiendo tem como suporte e elemento essencial o exercício da posse, sendo essa exercida através do contato do possuidor com a coisa (ou bem) como se dono fosse. Do contrário, quando se tem o contato do possuidor sem a intenção de dono, ocorre a mera detenção da coisa, nestes casos apontamos a relação locatícia, de comodato, empréstimo, etc.

\subsection{Teoria objetiva da posse}

A teoria objetiva da posse foi desenvolvida pelo jurista Rudolph Von Ihering. Para ele, em contraposição ao que dizia Savigny, basta a experiência do corpus para que restasse caracterizada a posse. O contato físico significa, para ele uma exteriorização do direito de propriedade. Segundo Correia ${ }^{30}$ :

A posse é a exteriorização da propriedade, estabelecida entre a pessoa e a coisa com uma finalidade econômica, bastando apenas o corpus para existência dessa relação, dispensando-se o animus. Sendo

27 SALLES, José Carlos de Moraes. Usucapião de bens imóveis e móveis. 7. ed. rev. atual. e ampl. São Paulo: Revista dos Tribunais, 2010.p.61-62

28 FARIAS, Cristiano Chaves de; ROSENVALD, Nelson. Curso de direito civil: volume 5 : direitos reais. 13. ed. rev., ampl. e atual. Salvador: Juspodivm, 2017.p.61

29 FARIAS, Cristiano Chaves de; ROSENVALD, Nelson. Curso de direito civil: volume 5 : direitos reais. 13. ed. rev., ampl. e atual. Salvador: Juspodivm, 2017.p.61

30 CORREIA, Jonas Ricardo. Usucapião no novo CPC: teoria, pratica e legislação pertinente. 2. Ed. Campo Grande: Contemplar, 2016.p.25 
assim, são considerados possuidores, todos que vierem a ter poder físico sobre determinado bem através, por exemplo, de contrato.

Importante aqui salientar que o momento em que Ihering propôs sua teoria era uma época de transição em que a Europa vivia o início da fase positivista, em que predominava o liberalismo e, sobretudo o individualismo. Desta forma afirma Fachin ${ }^{31}$ :

Jhering viveu no período de transição entre o método histórico natural e o positivismo, predominando, no início, a chamada jurisprudência dos conceitos, e, posteriormente, instaurou-se a fase positivista. Nessa época o mundo europeu vivia o triunfo do liberalismo, do individualismo e também o início das codificações. Confrontou-se Jhering com os representantes da Escola Histórica, da qual Friedrich Carl Savigny (1779-1861) foi expoente.

Nos estudos de Ihering sobre a posse percebe-se que, embora reconhecesse e valorizasse a obra de Savigny sobre a matéria, Thering foi um grande opositor em relação aos fundamentos da teoria subjetivista de Savigny, senão vejamos nas palavras do próprio autor ${ }^{32}$.

A posse é o exercício da propriedade, é a propriedade resumida, possível, em começo; está em relação constante com a propriedade: o próprio Savigny, que afinal não perfilha esta doutrina, lhe reconheceu um certo grau de verdade; talvez mesmo não tenha ela deixado de influir sobre a sua descoberta do animus domini.

No primeiro capítulo de sua obra Fundamentos dos Interditos Possessórios, Ihering ${ }^{33}$ já inicia demonstrando tal reconhecimento e oposição em relação à posição de Savigny:

Alguns autores, especialmente os antigos, evitam completamente o problema, conformam-se, como acontece sempre, com o fato consumado. Mas se algum fato existe que tenha necessidade de explicação sê-lo-á este, sem dúvida. Assim compreendeu-o Savigny e por essa razão procurou explica-lo.

A sua solução, porém, não obstante o aplauso que logo mereceu, não se conseguiu manter e inúmeras tentativas fizeram-se para ver a questão de outra maneira, e por minha vez, faço a tentativa de uma nova solução.

Uma das tentativas de Ihering demonstrar que a Teoria de Savigny era falha é a obra Teoria Simplificada da Posse, conforme se demonstra a seguir ${ }^{34}$ :

Segundo a teoria reinante, esta vontade deve tentar possuir a coisa como ou à maneira de uma coisa própria (animus domini). A falta de semelhante vontade é que, em certos casos, ao que parece, deve-se conceituar como posse não no sentido jurídico, mas no natural (detenção, mera posse). Essa doutrina é falsa - a verdadeira explicação da diferença está não na natureza particular da vontade de possuir, a qual não tende nunca à apreensão da coisa, mas na disposição legal que, conforme a diversidade da relação (causa possessionis), faz nascer ora a detenção ou a apreensão.

Dessa forma, entre os pensamentos de Ihering e Savigny se estabeleceu "a base da controvérsia possessória no direito romano. " 35

Como se verificou no subtítulo anterior, Savigny defendeu que para haver a posse era necessário a junção de dois elementos: corpus e animus domini. Sem a presença de um dos dois não era possível estabelecer a relação de posse entre a pessoa e o bem.

Foi justamente nessa "obrigatoriedade" que discordou Ihering. Para ele a posse é composta de apenas um elemento: o corpus. No seu entender o animus domini estaria inserido corpus, concluindo assim que a

31 FACHIN, Luiz Edson. A função social da posse e a propriedade contemporânea: uma perspectiva da usucapião imobiliária rural. Porto Alegre: Fabris, 1988.p.26

32 IHERING, Rudolf von. Fundamento dos interditos possessórios. Tradução De Adherbal de Carvalho. Bauru: Edipro, 2007.p.59

33 IHERING, Rudolf von. Fundamento dos interditos possessórios. Tradução De Adherbal de Carvalho. Bauru: Edipro, 2007.p.19-20

34 IHERING, Rudolf von. Teoria simplificada da posse. Belo Horizonte: Editora Lider, 2009.p.41

35 FARIAS, Cristiano Chaves de; ROSENVALD, Nelson. Curso de direito civil: volume 5 : direitos reais. 13. ed. rev., ampl. e atual. Salvador: Juspodivm, 2017.p.62 
posse seria um direito, uma exteriorização do domínio ou da propriedade ${ }^{36}$, sendo dispensável a análise de qualquer elemento subjetivo. "Não é difícil conectar a concepção de posse como exteriorização do domínio e a exacerbação do individualismo vigente naquele momento histórico. " 37

Para uma melhor compreensão deste conceito, vamos apresentar o entendimento desses dois elementos para Ihering. Nas palavras de Farias e Rosenvald ${ }^{38}$, Ihering assim percebe o animus domini e o corpus:

Ihering entende que o animus não pode ser compreendido como a "intenção de dono", mas como a affectio tenendi, ou seja, a vontade do possuidor de se conduzir perante o bem como se conduziria o proprietário. (...)

Ademais, corpus, para Ihering, não estaria na possibilidade física de dispor da coisa, tal qual argumentava Savigny, mas na simples visibilidade da propriedade em seus elementos caracterizadores.

Assim, é possível perceber que na teoria objetiva da posse o animus é apenas a vontade de se tornar visível como proprietário da coisa e o corpus seria a exteriorização da propriedade em que se cumpre o destino econômico do bem. Para Ihering nada é mais importante que o corpus ou seja, a conduta que o dono se liga ao bem, à maneira como age o sujeito sobre a coisa, expondo o seu poder fático sobre a essa. Por esse poder se estabelece a posse.

Apresentados os aspectos fundamentais da teoria objetiva da posse de Ihering e Savigny é possível apontar que o Código Civil Brasileiro adotou a teoria objetiva da Posse. Embora não apresente um conceito fechado para posse, ao conceituar o possuidor (art. 1196) o referido diploma legal não fez qualquer referência ao animus domini e por isso "claro está, pois, que a teoria adotada é a de Ihering, muito mais adequada ao tráfego negocial contemporâneo.

Cabe ressaltar, porém, que nossa legislação não abandonou de todo a idéia da posse associada ao animus domini. Conforme destacada anteriormente o animus domini corresponde a elemento essencial a ser inclusive demonstrado, nas ações de usucapião em todas as suas modalidades, como assim será abordado no capitulo a seguir.

\section{A POSSE NA REGULARIZAÇão FUNDIÁRIA E POSSE AD USUCAPIONEM}

A lei 13.465/2017 publicada no dia 12 de julho de 2017, proveniente da medida provisória 759/2016, que por sua vez havia sido aprovada no Senado na forma do projeto de lei (PLV) 12/2017, do relator senador Romero Jucá, dispõe sobre a regularização fundiária rural e urbana, sobre a liquidação de créditos concedidos aos assentados da reforma agrária e até a respeito da regularização fundiária no âmbito da Amazônia Legal; institui mecanismos para alterar a eficiência dos procedimentos de alienação de imóveis da União ${ }^{39}$,

36 La teoría de Savigny, si quiere ser sincera, no puede ver en la cuasi posesión más que una singularidad sin motivo alguno, una de las más terribles confusiones de ideas que haya habido nunca en el derecho, y en verdad, el abismo que separa el poder físico y la cosa de una parte, y de la otra el ejercicio de los innumerables derechos que pueden en el derecho moderno ser objeto de una cuasi posesión, abstracción hecha de esos dos elementos, es infranqueable. Este abismo no podrá salvarse sino mediante la idea de que esas dos formas de la posesión contienen ambas el ejercicio de un derecho, y cuanto Savigny se vale de este expediente, inevitable por lo demás, no lo hace sino a costa de una infidelidad con su teoría. Desde el instante en que recurre a la noción del ejercicio del derecho, confiesa que la idea del poder físico sobre a la cosa no es una ideal primordial y no tiene una importancia independiente para la posesión, que, por tanto, no puede servir de fundamento a toda la teoría posesoria, sino que no tiene más que la importancia secundaria de ser la forma bajo la cual se manifiesta la idea del ejercicio del derecho en la propiedad. (IHERING, Rudolf von. La posesión. Versión Española de ADOLFO POSADA. Madrid: Editorial Reus, 1926).

37 FACHIN, Luiz Edson. A função social da posse e a propriedade contemporânea: uma perspectiva da usucapião imobiliária rural. Porto Alegre: Fabris, 1988.p.26-27

38 FARIAS, Cristiano Chaves de; ROSENVALD, Nelson. Curso de direito civil: volume 5 : direitos reais. 13. ed. rev., ampl. e atual. Salvador: Juspodivm, 2017.p.63

39 BRASIL. Lei n ${ }^{\circ} 13.465$ de 12 de julho de 2017. Dispõe sobre a regularização fundiária rural e urbana, sobre a liquidação de créditos concedidos aos assentados da reforma agrária e sobre a regularização fundiária no âmbito da Amazônia Legal; institui mecanismos para aprimorar a eficiência dos procedimentos de alienação de imóveis da União; altera as Leis $\mathrm{n}^{\circ \mathrm{s}} 8.629$, de 25 de fevereiro de 1993,13.001, de 20 de junho de 2014, 11.952, de 25 de junho de 2009, 13.340, de 28 de setembro de 2016, 8.666, de 21 
direito real de lage e legitimação da posse.

A referida Lei 13.465/2017 apresenta muitas alterações na legislação brasileira. As modificações alcançam mais de 25 textos legais, dentre eles o Código Civil, Processo Civil, Lei de Registros Públicos entre outras leis e estranhamente ainda revoga dispositivos da Lei Complementar 76/1993.

Cabe mencionar, ainda, a natureza programática da referida Lei de Regularização Fundiária, pois muitos dos procedimentos e medidas, para implementação, dependem de portarias e regulamentos a serem elaborados por autoridades do governo federal, de seus órgãos e autarquias, como por exemplo: INCRA, SPU, e Prefeituras Municipais.

As alterações promovidas impactam o direito imobiliário, o instituído da propriedade, o direito real de laje, o condomínio fechado de casas, o sistema único de matrícula nos cartórios de imóveis. O art. 101 altera a Lei no 6.015, de 31 de dezembro de 1973, passa a vigorar acrescida do seguinte art. 235-A: onde fica instituído o Código Nacional de Matrícula (CNM) que corresponde à numeração única de matrículas imobiliárias em âmbito nacional ${ }^{40}$.

A referida sem dúvida será motivo de grandes debates, questionamentos e mudanças. Entretanto, para o presente estudo será esboçado as informações sobre a posse.

\subsection{A posse na regularização fundiária}

É possível afirmar que o termo posse é uma expressão de destaque na Lei 13.465/2017, tanto de pela natureza e finalidade da lei quanto nas alterações que ela propõe.

Ao abordar Regularização Fundiária, no Título I, a lei altera dispositivos da lei no 8.629/1993, que disciplina disposições relativas à reforma agrária. Inicialmente ao citar a posse inclui no art. $5^{\circ}$, que incidirão juros compensatórios a contar da imissão de posse, quando houver imissão prévia na posse e, posteriormente, for verificada divergência entre o preço ofertado em juízo e o valor do bem fixado na sentença definitiva. No art.19, parágrafos $3^{\circ}$ e $4^{\circ}$ do inciso VI, ao referenciar os ocupantes de áreas inferiores à fração mínima de parcelamento, nos casos em que a capacidade do projeto de assentamento não atenda todos os candidatos selecionados, será observada de forma prioritária quando houver substituição dos beneficiários originários dos lotes, nas hipóteses de desistência, abandono ou reintegração de posse.

Na parte conceitual da Lei 13.465/2017 $7^{41}$ no art.11, considera-se nos incisos V e VI que:

V - Certidão de Regularização Fundiária (CRF): documento expedido pelo Município ao final do procedimento da Reurb, constituído do projeto de regularização fundiária aprovado, do termo de compromisso relativo a sua execução e, no caso da legitimação fundiária e da legitimação de posse, da listagem dos ocupantes do núcleo urbano informal regularizado, da devida qualificação destes e dos direitos reais que lhes foram conferidos;

VI - Legitimação de posse: ato do poder público destinado a conferir título, por meio do qual fica reconhecida a posse de imóvel objeto da Reurb, conversivel em aquisição de direito real de propriedade na forma desta Lei,

de junho de 1993, 6.015, de 31 de dezembro de 1973, 12.512, de 14 de outubro de 2011,10.406, de 10 de janeiro de 2002 (Código Civil), 13.105, de 16 de março de 2015 (Código de Processo Civil), 11.977, de 7 de julho de 2009, 9.514, de 20 de novembro de 1997, 11.124, de 16 de junho de 2005, 6.766, de 19 de dezembro de 1979, 10.257, de 10 de julho de 2001, 12.651, de 25 de maio de 2012, 13.240, de 30 de dezembro de 2015, 9.636, de 15 de maio de 1998, 8.036, de 11 de maio de 1990, 13.139, de 26 de junho de 2015, 11.483, de 31 de maio de 2007, e a 12.712, de 30 de agosto de 2012, a Medida Provisória no 2.220, de 4 de setembro de 2001, e os Decretos-Leis $\mathrm{n}^{\text {os }} 2.398$, de 21 de dezembro de 1987, 1.876, de 15 de julho de 1981, 9.760, de 5 de setembro de 1946, e 3.365 , de 21 de junho de 1941; revoga dispositivos da Lei Complementar no 76, de 6 de julho de 1993, e da Lei no 13.347, de 10 de outubro de 2016; e dá outras providências. Disponível em < http://www.planalto.gov.br/ccivil_03/_ato2015-2018/2017/lei/L13465.htm $>$ acesso em 30 de jul 2017.

40 BRASIL. Lei n ${ }^{\circ} 6.015$ de 31 de dezembro de 1973. Dispõe sobre os registros públicos, e dá outras providências. Disponível em <http://www.planalto.gov.br/ccivil_03/leis/L6015compilada.htm > acesso em 30 de jul 2017.

41 BRASIL. Lei 13.465 de 11 de julho de 2017. Op.Cit. 
com a identificação de seus ocupantes, do tempo da ocupação e da natureza da posse; (grifo nosso)

O aspecto da Legitimação da Posse, assim como na revogada Lei 11.977/09 ao tratar da legitimação de posse, a Lei 13.465/17 apresenta também o novo direito real, a legitimação fundiária, conceituada como o mecanismo de reconhecimento da aquisição originária do direito real de propriedade sobre unidade imobiliária objeto da Reurb, o que pode ser considerado uma agressão ao patrimônio público. Porém, essa análise não será observada no presente estudo.

No que se a legitimação de posse, voltada para as áreas de domínio privado, sendo conceituada como instrumento de uso exclusivo para fins de regularização fundiária, é considerada como ato do poder público com o objetivo de conferir título, para reconhecimento da posse de imóvel objeto da Reurb. Nesse caso, com a qualificação dos ocupantes, do tempo da ocupação e da natureza da posse. Para a qual poderá ser convertida em direito real de propriedade. Ainda versa a lei que a legitimação de posse poderá ser transferida por causa mortis ou por ato inter vivos e não se aplica aos imóveis urbanos situados em área de titularidade do poder público.

Mantendo a lógica da lei revogada, a nova lei ${ }^{42}$ apresenta a prescrição aquisitiva com conversão automática ao título de propriedade, livre de ônus, como um título originário:

Art. 26. Sem prejuízo dos direitos decorrentes do exercício da posse mansa e pacífica no tempo, aquele em cujo favor for expedido título de legitimação de posse, decorrido o prazo de cinco anos de seu registro, terá a conversão automática dele em título de propriedade, desde que atendidos os termos e as condições do art. 183 da Constituição Federal, independentemente de prévia provocação ou prática de ato registral.

$\int 10$ Nos casos não contemplados pelo art. 183 da Constituição Federal, o título de legitimação de posse poderá ser convertido em título de propriedade, desde que satisfeitos os requisitos de usucapião estabelecidos na legislação em vigor, a requerimento do interessado, perante o registro de imóveis competente.

\2o A legitimação de posse, após convertida em propriedade, constitui forma originária de aquisição de direito real, de modo que a unidade imobiliária com destinação urbana regularizada restará livre e desembaraçada de quaisquer ônus, direitos reais, gravames ou inscrições, eventualmente existentes em sua matrícula de origem, exceto quando disserem respeito ao próprio beneficiário. (Grifo nosso)

Por fim, outro ponto que merece destaque da referida é a alteração promovida na Lei de Registros Públicos, que já havia sido alterada pela Lei 13.105 de 16 de março de 2015, com a introdução na ordem jurídica brasileira da usucapião extrajudicial. Para esse instituto, a posse passou a ser reconhecida mediante a ata notarial lavrada pelo tabelião, atestando o tempo de posse do requerente e de seus antecessores. O uso da ata notarial passou a ser um instrumento de formalização da posse através de um documento público.

Cabe mencionar também que um dos grandes entraves da usucapião extrajudicial era a exigência de que se a planta não contivesse a assinatura de qualquer um dos titulares de direitos reais, confinantes e de outros direitos registrados, o silencio era tido como discordância. Isso comprometia profundamente o objetivo da desjudicialização do instituto.

A Lei 13.465/17 modificou o dispositivo que tratava do tema dispondo que os titulares de direitos registrados ou averbados e os confinantes, serão notificados para manifestar consentimento expresso em quinze dias, sob pena de ser interpretado o silêncio como concordância.

\subsection{Posse ad usucapionem}

Dentre as diversas modalidades e espécies de posse enumeradas pelos estudos jurídicos a este respeito, toma destaque neste trabalho a posse ad usucapionem.

42 BRASIL. Lei 13.465 de 11 de julho de 2017. Op.Cit. 
A posse "ad usucapionem" é aquela exercida por um possuidor que adquire as condições obter a propriedade ou outro direito real pela usucapião. Nas palavras de Fachin ${ }^{43}$ "um dos efeitos fundamentais da posse é consumar a usucapiãoDessa forma, a usucapião ocorre, quando o possuidor, após posse mansa e ininterrupta durante determinado lapso de tempo, tem a possibilidade de se tornar proprietário de um bem.

Nas palavras de Fiúza ${ }^{44}$ :

A posse será ad usucapionem quando o possuidor puder adquirir a propriedade do bem possuído por usucapião. (...) Dessarte, para que a posse se repute ad usucapionem, serão essenciais a relação externa entre possuidor e a coisa, ainda que indireta (corpus), e a vontade de se dono, de se assenhorear da coisa (animus). Esta vontade deve estar presente desde o primeiro momento da posse. (...) Assim, para que enseje usucapião, a posse deverá se caracterizar pelo animus domini desde o início; o possuidor deverá possuir em seu nome desde o primeiro instante.

O termo “usucapião" significa "aquisição pelo uso", mas não por qualquer uso, e sim pelo uso prolongado, o que comprova a relevância do tempo nessa forma de aquisição. Pela perspectiva histórica, a usucapião se converte, ao mesmo tempo, como forma de perda e aquisição da propriedade, considerada como prescrição aquisitiva. Desde a Roma Antiga, essa forma de constituição se fez a partir de uma ação prolongada no tempo.

Conceitualmente, a usucapião é uma forma originária de aquisição da propriedade pela posse contínua da coisa, acrescida dos demais requisitos legais. O Código Civil, no art. $1.238^{45}$, reafirma a usucapião como modo de aquisição da propriedade imobiliária.

Sendo assim, pode-se inferir que o fundamento da usucapião é dar uma função social ao bem, ou seja, se o dono se descuida no tocante à utilização, deixando-a sem destinação, proporcionará a outro a oportunidade de se apossar da coisa. José Carlos de Moraes Salle ${ }^{46}$ s, ao tratar do tema, afirma que:

Interessa à paz social a consolidação daquela situação de fato na pessoa do possuidor, convertendo-a em situação de direito, evitando-se, assim, que a instabilidade do possuidor possa eternizar-se, gerando discórdias e conflitos que afetam perigosamente a harmonia da coletividade. Assim, o proprietário desidioso, que não tenha a intenção de abandoná-lo, perde sua propriedade em favor daquele que, havendo se apossado da coisa, mansa e pacificamente, durante o tempo previsto em lei, da mesma cuidou e lhe deu destinação, utilizando-a como se fosse sua.

Para Savigny ${ }^{47}$

La adquisicion de la propiedad por usucapion se distingue esencialmente de la adquisicion por tradicion en cuanto que la tradicion es um acto instantáneo, mientras que la usucapion resulta de uma serie de hechos continuados durante um largo espacio de tiempo.

Percebe-se assim como a abordagem da posse, principalmente quanto à posse ad usucapionem, se torna de extrema importância quando se trata de entender o instituto da usucapião.

Neste contexto, percebe-se que o animus domini, elemento defendido por Savigny em sua teoria subjetiva como fundamental para se caracterizar a ocorrência da posse, ganha destaque em nossa legislação. Assim,

43 FACHIN, Luiz Edson. A função social da posse e a propriedade contemporânea: uma perspectiva da usucapião imobiliária rural. Porto Alegre: Fabris, 1988.p.23

44 FIUZA, César. Direito civil: curso completo. 18. ed. rev., atual. e ampl. São Paulo: Revista dos Tribunais, 2015.p. 1090

45 Art. 1.238. Aquele que, por quinze anos, sem interrupção, nem oposição, possuir como seu um imóvel, adquire-lhe a propriedade, independentemente de título e boa-fé; podendo requerer ao juiz que assim o declare por sentença, a qual servirá de título para o registro no Cartório de Registro de Imóveis. Parágrafo único. O prazo estabelecido neste artigo reduzir-se-á a dez anos se o possuidor houver estabelecido no imóvel a sua moradia habitual, ou nele realizado obras ou serviços de caráter produtivo.

46 SALLES, José Carlos de Moraes. Usucapião de bens imóveis e móveis. 7. ed. rev. atual. e ampl. São Paulo: Revista dos Tribunais, 2010.p.49

47 SALLES, José Carlos de Moraes. Usucapião de bens imóveis e móveis. 7. ed. rev. atual. e ampl. São Paulo: Revista dos Tribunais, 2010.p.49 
embora, haja um certo consenso na nossa literatura jurídica que o direito brasileiro tenha adotado a teoria objetiva da posse de Ihering, a teoria de Savigny é sem dúvida um ponto de importante observação no estudo das teorias da posse.

No caso de usucapião o ordenamento jurídico brasileiro "parece" fazer uma exceção à teoria objetiva de Ihering adotada pelo Código Civil Brasileiro, pois exige a intenção de possuir a coisa como dono para que haja a aquisição, tornando-se necessário a existência obrigatória do animus domini do possuidor em sua análise.

Percebe-se assim que, o instituto da usucapião no Brasil envolve a noção do animus domini daquele que possui a coisa, como defendia Savigny, não bastando o corpus. Tal situação leva ao entendimento que, talvez esta seja uma importante concessão feita pela legislação brasileira à teoria subjetiva, da qual o legislador do Código de 2002 não conseguiu desvincular-se.

Fiúza ${ }^{48}$, porém se opõe a esta possibilidade defendendo que, embora, haja a exigência do animus domini, a teoria de Ihering é a única adotada pelo ordenamento jurídico brasileiro.

... talvez por exigir a posse ad usucapionem o animus domini, muitos dizem ser para ela adotadas a teoria subjetivista de Savigny. A tese não convence, simplesmente porque na teoria de Ihering o elemento animus, embora secundário, existe, podendo ser caracterizado como animus domini (convicção de dono) ou como affectio tenendi (agir como dono, mesmo sabendo não o ser). A questão é importante, uma vez que Savigny não admite o usucapião baseado na posse indireta, enquanto Ihering admite.

\section{Considerações finais}

Não há dúvidas de que as discussões a respeito do estudo de Savigny e Ihering vão muito além do que as teorias da posse. O posicionamento político defendido no que se refere à escola histórica e as reflexões a respeito da jurisprudência dos interesses certamente extrapolam os estudos até o momento desenvolvidos por muitos autores.

No que se refere ao escopo do modesto trabalho, pode-se mencionar que para Ihenring o interesse a ser protegido é aquele benéfico a todos e isso é provado com a normalidade no uso da coisa. Para Savigny alguém tem a posse e recebe proteção do Estado quando ele é autônomo, quando não reconhece poder alheio superior ao seu, ou seja, projeta a sua vontade sobre a coisa, não precisa levar benefício à sociedade, Pacta sunt servanda. Já para Ihering, para ter proteção do Estado não basta que seja dono, tem que dar destinação utilitária ao bem. A destinação utilitária do bem é o uso normal daquele bem, que é feito conforme sua finalidade. O código civil veda o uso anormal da propriedade, sendo vedados os atos que não tragam utilidade ao proprietário e sejam animados pela intenção de prejudicar os outros.

O que é o direito para Ihering então? Seria a violência estatal? É a violência que assegura a normalidade, é o legislador que escolhe qual interesse irá prevalecer? $\mathrm{O}$ Estado assegura o uso econômico das coisas dentro de uma ordem de prioridade. $\mathrm{O}$ direito então seria o poder do Estado de fazer valer o interesse que ele, o Estado, escolher.

Para Ihering as cláusulas gerais conferem elasticidade às normas para que elas não fiquem desatualizadas, mas na verdade elas impedem uma metodologia objetiva sobre a aplicabilidade da norma, pois é o juiz quem vai aplicar a norma no caso concreto.

A jurisprudência dos interesses evolui para jurisprudência dos valores, que confunde norma com valor, pretensão descritiva com pretensão normativa. Ihering estabeleceu a interpretação teleológica da norma, ou seja, as suas finalidades política, social, econômica e política; Savigny porém jamais a admitiria isso.

48 FIUZA, César. Direito civil: curso completo. 18. ed. rev., atual. e ampl. São Paulo: Revista dos Tribunais, 2015.p. 1091 
O que se pode concluir com o presente estudo é posse, assim como demais conceitos adotados no direito, sofre modificações conforme o contexto sócio, histórico e cultural. A Lei 13.465/2017 é uma demonstração dessa mutabilidade do uso do instituto, a referida lei ainda comprova que além do contexto sócio, histórico e cultural acrescenta o aspecto político e econômico.

Será que a referida Lei 13.465/2017 realmente promove a proteção de interesses que, se opostos, devem ser conciliados com a predominância dos interesses sociais, conforme defendia Ihering ou considera que caso a intenção do legislador conflite com a consciência coletiva o interprete deverá optar por essa última, conforme argumenta Savigny? Lembra-se que a lei teve sua motivação instigada por uma medida provisória, o que por sua vez já renderia vários questionamentos, uma vez, que pela matéria e a complexidade dos assuntos deveria observar o trâmite convencional.

Quais seriam os bens tutelados nessa lei? Não resta dúvida que a regularização de bens imóveis no Brasil é um tema relevante e é preciso instrumentos para regulamentar as propriedades no país. A quantidade de obrigações, cadastros, tributos, emolumentos torna cada dia mais distante a possibilidade de manter os títulos registras de forma fidedigna com a realidade. A insegurança jurídica em muitas cidades está instaurada. A mencionada lei teria então como principal substrato a legitimação de ocupações irregulares de lotes de assentamento, de terras públicas federais e de áreas urbanas. São todos esses e outros pontos que devem ser incansavelmente discutidos. Como o presente estudo teve como eixo central as discussões a respeito da posse, nesse sentido, pode-se mencionar que a mesma adquiriu atribuições e funções que não haviam sido reconhecidas no passado. A possibilidade de conversão em direito real, com a forma de aquisição originária, ou seja, isenta e livre de ônus de qualquer natureza, gravames ou inscrições.

\section{REFERÊNCIAS BIBLIOGRÁfICAS}

ALVES, José Carlos Moreira. Posse. Rio de Janeiro: Forense, 1985

ANDRADE, Adriano de Azevedo. O fundamento da protecao possessoria. Belo Horizonte: UFMG, 1964

BESSONE, Darcy. Da posse. São Paulo: Saraiva, 1996

BRANDELLI, Leonardo. Usucapião Administrativa. De acordo com o novo Código de Processo Civil. São Paulo: Saraiva, 2016.

BRASIL. Lei no 6.015 de 31 de dezembro de 1973. Dispõe sobre os registros públicos, e dá outras providências. Disponível em <http://www.planalto.gov.br/ccivil_03/leis/L6015compilada.htm > acesso em 30 de jul 2017.

BRASIL. Lei No 10.406, de 10 de Janeiro de 2002. Institui o Código Civil. Disponível em < https://www. planalto.gov.br/ccivil_03/LEIS/2002/L10406.htm > Acesso em: 23 jul 2017

BRASIL. Lei no 13.465 de 12 de julho de 2017. Dispõe sobre a regularização fundiária rural e urbana, sobre a liquidação de créditos concedidos aos assentados da reforma agrária e sobre a regularização fundiária no âmbito da Amazônia Legal; institui mecanismos para aprimorar a eficiência dos procedimentos de alienação de imóveis da União; altera as Leis $n^{\text {os }}$ 8.629, de 25 de fevereiro de 1993,13.001, de 20 de junho de 2014, 11.952, de 25 de junho de 2009, 13.340, de 28 de setembro de 2016, 8.666, de 21 de junho de 1993, 6.015, de 31 de dezembro de 1973, 12.512, de 14 de outubro de 2011,10.406, de 10 de janeiro de 2002 (Código Civil), 13.105, de 16 de março de 2015 (Código de Processo Civil), 11.977, de 7 de julho de 2009, 9.514, de 20 de novembro de 1997, 11.124, de 16 de junho de 2005, 6.766, de 19 de dezembro de 1979, 10.257, de 10 de julho de 2001, 12.651, de 25 de maio de 2012, 13.240, de 30 de dezembro de 2015, 9.636, de 15 de maio de 1998, 8.036, de 11 de maio de 1990,13.139, de 26 de junho de 2015, 11.483, de 31 de maio de 2007, 
e a 12.712, de 30 de agosto de 2012, a Medida Provisória no 2.220, de 4 de setembro de 2001, e os DecretosLeis $\mathrm{n}^{\text {os }}$ 2.398, de 21 de dezembro de 1987, 1.876, de 15 de julho de 1981, 9.760, de 5 de setembro de 1946, e 3.365, de 21 de junho de 1941; revoga dispositivos da Lei Complementar no 76, de 6 de julho de 1993, e da Lei no 13.347, de 10 de outubro de 2016; e dá outras providências. Disponível em < http://www.planalto. gov.br/ccivil_03/_ato2015-2018/2017/lei/L13465.htm > acesso em 30 de jul 2017.

CORREIA, Jonas Ricardo. Usucapião no novo CPC: teoria, pratica e legislação pertinente. 2. Ed. Campo Grande: Contemplar, 2016.

CHAMON JÚNIOR, Lúcio Antônio. Teoria Geral do Direito Moderno. Por uma Reconstrução CríticoDiscursiva na Alta Mocdernidade. Lumen Juris, Rio de Janeiro. 2007.

FACHIN, Luiz Edson. A função social da posse e a propriedade contemporânea: uma perspectiva da usucapião imobiliária rural. Porto Alegre: Fabris, 1988.

FARIAS, Cristiano Chaves de; ROSENVALD, Nelson. Curso de direito civil: volume 5 : direitos reais. 13. ed. rev., ampl. e atual. Salvador: Juspodivm, 2017

FIUZA, César. Direito civil: curso completo. 18. ed. rev., atual. e ampl. São Paulo: Revista dos Tribunais, 2015.

GAGLIANO, Pablo Stolze; FILHO, Rodrigo Pamplona. Manual de direito civil. São Paulo: Saraiva, 2017.

IHERING, Rudolf von. La posesión. Versión Española de ADOLFO POSADA.. Madrid: Editorial Reus, 1926.

IHERING, Rudolf von. Fundamento dos interditos possessórios. Tradução De Adherbal de Carvalho. Bauru: Edipro, 2007.

IHERING, Rudolf von. Teoria simplificada da posse. Belo Horizonte: Editora Lider, 2009.

LARENZ, Karl. Metodologia da ciência do direito. 3. ed. Lisboa: Fundação Calouste Gulbenkian, 1997.

MELLO, Henrique Ferraz Corrêa de. Usucapião Extrajudicial. São Paulo: Yk Editora, 2016.

REZENDE, Astolpho. A posse e a sua proteção. São Paulo: Saraiva, 1937.2v

SAVIGNY. M.F.C de. Sistema del Derecho Romano Actual. Traducido del aleman por M.CH. GUENOUX. Madrid: F. Gongora Y Compania, Editores, 1879.

SAVIGNY, Friedrich Karl Von. Sistema do direito romano atual: volume VIII. Ijui: Ed. Unijui, 2004.

SALLES, José Carlos de Moraes. Usucapião de bens imóveis e móveis. 7. ed. rev. atual. e ampl. São Paulo: Revista dos Tribunais, 2010.

SOUZA, Adriano Stanley Rocha. Direito das coisas. 4. ed. Belo Horizonte: Del Rey, 2015

TARTUCE, Flávio. Manual de Direito Civil: volume único. São Paulo: Método, 2011. 


\section{REVISTA BRASILEIRA DE POLÍTICAS PÚBLICAS BRAZILIAN JOURNAL OF PUBLIC POLICY}

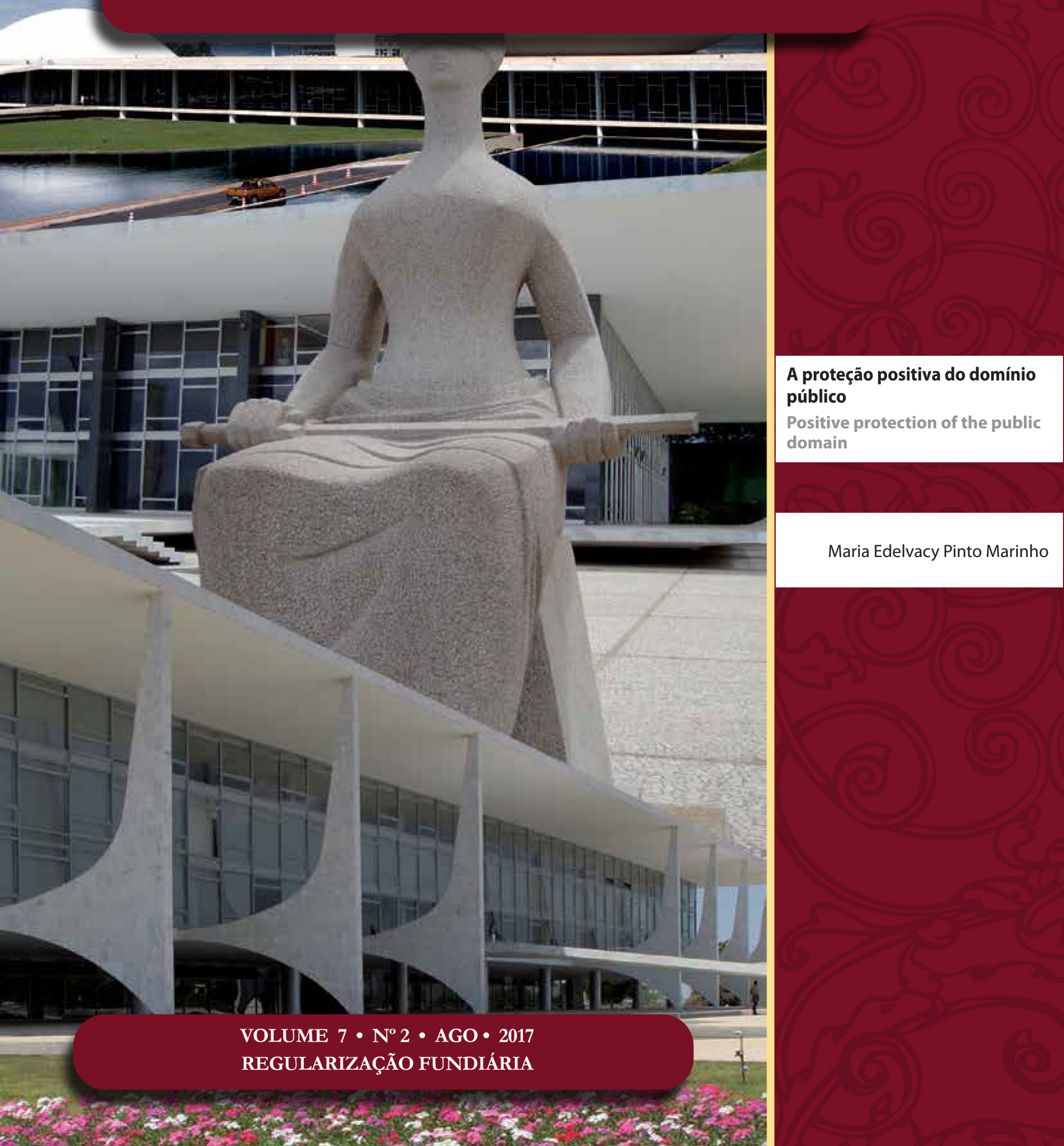




\title{
A proteção positiva do domínio público*
}

\section{Positive protection of the public domain}

\author{
Maria Edelvacy Pinto Marinho**
}

\section{Resumo}

A expansão da proteção dos bens intelectuais não se dirige, apenas, à natureza do objeto passível de proteção, mas também aos direitos de exploração concedidos aos seus titulares. $\mathrm{O}$ artigo analisa, a partir dos instrumentos jurídicos internacionais, o espaço destinado à proteção do domínio público. Parte-se do pressuposto de que um ambiente favorável ao desenvolvimento da inovação consiste na busca do equilíbrio entre proteção e acesso aos bens intelectuais. O exame realizado nesse artigo é feito tendo como referência o direito de patentes e com base em pesquisa documental e bibliográfica. Conclui-se que o foco demasiado na proteção dos bens intelectuais das últimas décadas tem alterado o equilíbrio necessário para o estímulo a inovação e que é necessário discutir mecanismos eficientes de proteção positiva do domínio público e não apenas a proteção por exclusão do sistema de patentes, como tem sido feito até então.

Palavras-chaves: Propriedade intelectual. Domínio público. Proteção positiva. TRIPS.

\section{Abstract}

The expansion of the protection of intellectual property is not only directed towards the nature of the object to be protected, but also to the exploitation rights granted to its owners. This paper article analyzes, from international legal instruments, the space destined to the protection of the public domain. It is assumed that an environment favorable for the development of innovation comprises the search for a balance between protection and access to intellectual property. The examination carried out herein is performed with reference to patent law and based on a documental and bibliographic research. It is concluded that too much focus on intellectual property protection in recent decades has altered the balance needed to stimulate innovation, and that it is necessary to discuss efficient mechanisms of positive public domain protection, and not only protection by exclusion from the patent system, as has been done so far.

Key-words: Intellectual property. Public domain. Positive protection. TRIPS.

** Professora do Programa de Mestrado e Doutorado em Direito do Centro Universitário de Brasília e Professora de direito da universidade Presbiteriana Mackenzie, Doutora em direito pela Universidade Paris 1- Panthéon Sorbonne, Advogada. Contato: mariaedelvacy@ gmail.com
Recebido em 29/06/2017 Aprovado em 25/07/2017 


\section{INTRODUÇÃo}

Os direitos de propriedade intelectual são objeto de uma forte expansão nas últimas décadas. No campo das patentes, reconheceu-se a proteção para inovações dos setores biotecnológico e software. Novas formas de propriedade intelectual foram criadas para proteger bancos de dados e a topografia de circuitos integrados. Os direitos autorais têm ampliado as plataformas por meio das quais as obras devem ser protegidas e restringidas as possibilidades de uso autorizado por aqueles que adquirem a obra. A exclusividade do uso dos dados apresentados como condição para entrada de medicamento do mercado via sistema de propriedade intelectual põe em dúvida seu real objetivo: se a função é proteger a obra/invento ou o investimento para seu desenvolvimento.

No âmbito nacional, observam-se duas estratégias, uma pautada no reconhecimento desses novos direitos e outra centrada no encorajamento da utilização dos direitos de propriedade intelectual entre os produtores conhecimento científico. Foi o caso do Bay-Dole Act nos EUA, criado para incentivar o uso de patentes nas universidades ${ }^{1}$, e do Brasil com as leis 10.973/2004 (lei de incentivo à inovação) e marco legal da ciência e tecnologia, lei 13.243/2016.

Como resultado, muito se tem dito sobre os efeitos negativos da expansão da apropriação dos bens intelectuais. Entre eles, o fenômeno da "tragédia dos anticommons", segundo a qual o excesso de direitos exclusivos gera a subutilização do conhecimento protegido. Em direitos de patente, essa questão tem sido estudada principalmente em relação às patentes na área biotecnológica ${ }^{3}$. Trata-se de um setor caracterizado por pedidos de reivindicações redigidos de maneira ampla, dirigidos a um objeto cujo potencial ainda não é conhecido pela comunidade científica. Em áreas novas, há o risco de se conceder patentes cuja amplitude venha frear o interesse e a pesquisa de outros investidores e acadêmicos. Outro setor atingido com o excesso de patentes é a indústria eletrônica. Em ambos os casos, a necessidade de coordenação entre os vários direitos de propriedade intelectual pré-existentes relativos a um mesmo objeto dificulta seu desenvolvimento. O excesso de direitos exclusivos pode constituir um obstáculo para a promoção da inovação. Sendo esta uma função que confere legitimidade à lei de patentes, não é de estranhar que o modelo jurídico, atualmente aplicado às patentes, esteja sujeito a questionamentos.

O objetivo desse artigo é analisar, a partir do sistema jurídico internacional de propriedade intelectual, o quanto este reforça ou dificulta a livre circulação de conhecimentos técnicos e científicos por não reconhecer diretamente a necessidade de proteção dos bens intelectuais integrantes do domínio público. $\mathrm{O}$ artigo foi dividido em dois tópicos: a relação entre propriedade intelectual e domínio público e a proteção do domínio público como meio de assegurar o equilíbrio entre proteção e acesso.

\section{A ReLAÇão entre PROPRIEDADE INTELECTUAL E domíNIO PÚBLICO.}

Em conjunto, o domínio público e do direito de patentes foram imaginados como um sistema de duas faces e em dois tempos que agiriam como mecanismo de incentivo à produção e acesso à inovação. $\mathrm{O}$ direito

1 EUA. University and Small Business Patent Procedures Act (Bay-Dole Act.), 35 U.S.C \$200.

2 Esse termo foi introduzido por Michael Heller no artigo "The tragedy of anticommons: property in the transition from Marx to Markets", a fim de estabelecer um contraponto com o fenômeno descrito por Garrett Hardin em seu artigo "the tradegy on the commons", no qual ele aprofunda a ideia de que o livre acesso e a demanda ilimitada a recurso finito, provoca a degradação desse recurso pela exploração excessiva e defende como uma solução possível a restrição acesso, que muitos interpretaram como uma proibição de apropriação. Veja mais sobre: HELLER, M. A "The Tragedy of the Anticommons: Property in the Transition from Marx to Markets". Harvard Law Review, v. 111, p. 621-688, 1998 e HARDIN, G. "The Tragedy of the Commons". Science, v. 162, n. 3859, p. 1243-1248, Dec. 1968.

3 HELlER, M. A; EISENBERG, R. S “Can Patents Deter Innovation? The Anticommons in Biomedical Research". Science, v. 280, 1998. Disponível em: <http://ssrn.com/abstract=121288>. 
de propriedade intelectual seria uma proteção temporária para determinados tipos de produtos intelectuais que, graças ao incentivo dado pela exclusividade de sua exploração, garantiria a produção de novos conhecimentos. O domínio público asseguraria o fornecimento de informações em livre acesso, de modo que as empresas, universidades e particulares pudessem desenvolver novos inventos/obras a partir daqueles gerados em função do incentivo da exclusividade.

O sistema de proteção aos inventos é composto de dois acordos que versam, diretamente, sobre a matéria patenteável e que tem impactos no domínio público. A Convenção União de Paris e o Acordo sobre aspectos dos direitos de propriedade intelectual relacionados ao comércio (conhecido por sua sigla em inglês, TRIPS). Cada Acordo é gerenciado por uma organização internacional diferente. A Organização Mundial da Propriedade Intelectual (OMPI) administra a Convenção União de Paris. Trata-se de uma organização integrante das Nações Unidas e que declara ter por objetivo "liderar o desenvolvimento de um sistema internacional de propriedade intelectual equilibrado e eficaz que permita a inovação e a criatividade para o benefício de todos." 4 A convenção União de Paris foi criada em 1883 e já foi objeto de seis revisões ${ }^{5}$. O texto da Convenção de Paris de 1883 foi ratificado por 174 Estados e a última revisão de Estocolmo por 194 Estados. O Acordo TRIPS é administrado pela Organização Mundial do Comercio (OMC) e passou a integrar o conjunto de acordos constitutivos da organização, a partir da última rodada de negociações. O ingresso tardio se deveu ao fracasso na negociação de um acordo que garantisse uma maior proteção aos direitos dos titulares de propriedade intelectual na OMPI. Por ser um acordo constitutivo, todos os integrantes da OMC devem ratificar o TRIPS como condição para seu ingresso. A OMC conta com 164 Estados-membros.

O sistema internacional de propriedade intelectual é pautado, entre outros, pelos princípios do tratamento nacional e da nação mais favorecida. Como consequência desse último, os acordos firmados entre os Estados-membros bilateralmente devem permitir que os direitos, ali concedidos entre as partes, sejam estendidos para os demais Estados membros do TRIPS. E o tratamento (direitos e deveres) acordado aos nacionais daqueles países deve ser aplicado, também, aos demais nacionais dos países integrantes do TRIPS.

A Convenção de Paris e suas posteriores revisões não tratam, diretamente, do domínio público. Permite aos Estados-membros um espaço amplo de definição do que seria a matéria patenteável, sendo possível a exclusão de setores da proteção e a inclusão no domínio público de objetos protegidos por patente, caso o titular do direito não o produza o invento no país que concedeu o título.

A análise preliminar do Acordo TRIPS para a proteção do domínio público sugere que o Acordo permitiu a expansão da matéria patenteável e a expansão da proteção territorial. O TRIPS aborda, apenas, uma vez, diretamente, a questão do domínio público no artigo 70. 3: "Não haverá obrigação de restabelecer proteção da matéria, que, na data de aplicação desse Acordo para o Membro em questão, tenha caído no domínio público." Esse artigo reconheceu que as invenções que já integrassem o domínio público dos Estados-membros poderiam assim permanecer. Trata-se de uma regra de transição, uma cláusula que visa garantir àqueles que já faziam uso de uma obra ou invento protegido em outros países, mas que não contavam com a proteção naquele país, a continuidade de sua exploração. É uma regra que reconhece direitos adquiridos. Tem por função garantir a segurança jurídica, a estabilidade das relações contratuais realizadas na vigência das normas anteriores que não previam a proteção para aqueles bens.

Constata-se que, exceto essa referência direta no artigo 70.3, o Acordo TRIPS estabeleceu uma proteção residual ao domínio público. Em outras palavras, é a partir das definições de condições de patenteabilidade e da matéria de patenteável, dos direitos e obrigações dos titulares, que o Acordo TRIPS define, indiretamente, o conteúdo de domínio público. Trata-se de uma técnica de redação comum na área de patentes. O que deveria significar que a regra é o acesso e a exceção é o uso de direitos exclusivos.

4 OMPI. What is Wipo? Disponível em: <http://www.wipo.int/about-wipo/en/>

5 A CUP foi revisada em Bruxelas em 1900, Washington em 1911, Haia em 1925, Londres em 1934, Lisboa em 1958 e Estocolmo em 1967, e esta versão foi modificada em 1979. 
Séverine Dusollier identifica quatro subdomínios definidores indiretos do domínio público nas legislações nacionais e nos tratados sobre patentes: ontológico, temporal, regulamentar e consentido. ${ }^{6}$

O domínio público “ontológico" envolve inovações que, por natureza, não podem ser capazes de apropriação, pois não cumprem os requisitos de patenteabilidade. Se a proteção dos direitos de propriedade intelectual conforme definidos no TRIPS “ deve contribuir para a promoção da inovação tecnológica e para a transferência e difusão de tecnologia, em benefício mútuo de produtores e usuários de conhecimento tecnológico ", nada mais lógico que o legislador tenha excluído do âmbito da patenteabilidade "invenções", que impeçam a circulação do conhecimento e, consequentemente, o desenvolvimento de outras "invenções". Daí a necessidade de cumprir as condições de patenteabilidade. Essa ideia de domínio público ontológica é alvo de críticas.

A definição de matéria patenteável depende dos valores de cada sociedade em um dado momento e não há relação necessária com a natureza do objeto. É mais uma questão política que ontológica. A proteção dos métodos cirúrgicos e de negócios são passíveis de proteção em determinados sistemas, a exemplo do americano, e excluída do rol de proteção de outros, como é o caso da lei brasileira.

Nas legislações de tradição romano-germânica, é comum a descrição de objetos não suscetíveis de proteção pelo direito de patentes. Este é o caso das teorias científicas, princípios, métodos matemáticos e ideais abstratas. Em tese, esses objetos nem sequer exigiriam exclusão explícita, dado o fato de que eles não cumprem os critérios de patenteabilidade devido sua natureza abstrata. ${ }^{7}$ O objetivo dessa exclusão explícita da lei é destacar a necessidade de livre acesso aos instrumentos de desenvolvimento da pesquisa de base ${ }^{8}$, bem como a relação concreta que deve existir entre a invenção e sua exploração exclusiva.

No que concerne ao critério temporal, sabe-se que por atribuir direitos exclusivos por um período pré-definido de tempo, o direito de patentes estabelece um prazo para que o invento integre o domínio público. Esse período de vigência da patente já se encontra harmonizado via tratado. O período mínimo de proteção é de vinte anos contados da data de depósito do pedido. ${ }^{9}$ Passada a duração de exclusividade acordada por lei, a invenção "cai em domínio público".

No entanto, a precisão do método temporal na definição do domínio público foi relativizada em razão da possibilidade concedida por algumas legislações em prolongar o período de exclusividade. Uma dessas possibilidades de prolongação da exclusividade está atrelada aos pedidos de autorização para ingresso de um novo medicamento no mercado. O período pode variar entre cinco anos, como a legislação americana, e dez anos, a exemplo da legislação europeia. A extensão do prazo de exclusividade interfere no ingresso de medicamentos genéricos no mercado, reduzindo, por conseguinte, o acesso da população a medicamentos mais baratos.

Séverine Dusollier chama de domínio público regulamentar as exceções previstas no artigo 27.3 do Acordo TRIPS, ou seja, as áreas em que os Estados-Membros podem excluir da patenteabilidade: seja porque não se deseja encorajar o desenvolvimento da invenção em um determinado campo, seja porque as invenções não deveriam ser susceptíveis de apropriação. No primeiro caso, têm-se como exemplos as invenções prejudiciais para a saúde ou para o ambiente; no segundo, métodos cirúrgicos e terapêuticos.

A exclusão da patenteabilidade em caso de contrariedade à ordem pública e a moralidade é justificada pela falta de interesse por parte do Estado em incentivar esse tipo de invenção. ${ }^{10}$ Este seria o caso das inven-

6 DUSOLLIER, S. « Le domaine public en droit d'auteur et en droit des brevets ». In : MIREILLE BUYDENS, Séverine Dusollier. (Dir.). L'intérêt général et l'accès à l'information en propriété intellectuelle. Bruxelles: Bruylant, 2008. p. 136

7 AZEMA, J.; GALLOUX, J-Ch. Droit de la propriété industrielle. Paris : Dalloz, 2006. p. 109.

8 SCHMIDT-SZALEWSKI, J.-L. PIERRE. Droit de la Propriété industrielle. Paris: Litec, 2007. p. 38.

9 OMC, TRIPS, artigo 33.

10 DUSOLLIER, S. «Le domaine public en droit d'auteur et en droit des brevets ». In : MIREILLE BUYDENS, Séverine Dusollier. (Dir.). L'intérêt général et l'accès à l'information en propriété intellectuelle. Bruxelles: Bruylant, 2008. p. 130. 
ções que tem por objeto a clonagem humana.

A partir do fundamento da utilidade, o legislador mantém a validade do título de patente condicionado ao pagamento de uma retribuição anual ao escritório de patentes que defiriu o pedido. Não havendo o pagamento, presume-se que o titular não teria mais interesse em manter a exclusividade na exploração do invento e este poderia integrar o domínio público.

Esse seria o caso do domínio público consentido. Ele "inclui as invenções para as quais foram solicitadas patentes ou para os quais as patentes não tenham sido mantidas notadamente pela falta de pagamento das taxas exigidas."

No contexto internacional, o domínio público consentido é o resultado da aplicação do princípio da territorialidade e independência da lei de patentes. A patente é concedida por cada país e sua aplicação é limitada ao seu próprio território. Os tratados existentes contem mecanismos que facilitam a apresentação de pedidos de patentes em vários países simultaneamente. É o caso da regra da prioridade, que concede ao titular do pedido o reconhecimento da primeira data de apresentação deste como uma referência para a identificação do requisito da novidade em outros escritórios de patentes. Outro mecanismo relevante consiste na possibilidade de realizar o depósito até um ano depois da solicitação do primeiro pedido sem que haja a perda do cumprimento do requisito da novidade.

É possível que o titular mantenha válido o título em um país e não renove em outros. No país onde o título não foi renovado, se permite a exploração do invento livremente. Do mesmo modo, o titular da patente que não tenha mostrado interesse em buscar sua proteção em outros países, permite aos interessados nesses países a exploração livre desse invento no seus territórios. Pode, por conseguinte, coexistir países em que o objeto da patente esteja protegido e outros em que ele se encontre em domínio público.

O tratamento dado ao domínio público nos tratados é feito de maneira residual, indireta. Essa aferição é feita a partir de três critérios: campos de proteção, duração da exclusividade e interesse do titular na manutenção da exclusividade.

\section{A PROTEÇÃo do domínIO PÚbliCo COMO MEIO de ASSEGURAR O EQUILÍbRIO ENTRE PROTEÇÃO E ACESSO.}

Há quem defenda que o tratamento por exclusão dado ao domínio público o torne incapaz de responder a expansão dos objetos patenteáveis e ao aumento dos direitos acordados aos titulares da patente ${ }^{11}$. Isto provocaria um desequilíbrio entre a proteção de invenções patenteadas e a preservação de um espaço para a produção e acesso à inovação, o que finalmente representaria um obstáculo a concretização do direito de patentes em si.

Sugere-se que o domínio público seja tratado não mais a partir da lógica residual dos direitos de patente, mas de acordo com uma lógica de proteção positiva que lhe seja própria. A partir da lógica atual, o domínio público tem sido tratado como um depósito de invenções e inovações que não têm a capacidade ou não podem ser protegidas por patentes, em vez de ser entendido como um conjunto de conhecimentos que devem permanecer em modo de livre acesso e uso da sociedade. A existência de um espaço de livre acesso garantiria a função do domínio público de estímulo à inovação. Espaço esse preenchido por bens insuscetíveis de apropriação ou por já terem esgotado o período em que deveriam ser mantidos em modo de uso exclusivo do titular.

11 É o caso de Sévérine Dusouliier no artigo «Le domaine public en droit d'auteur et en droit des brevets ». DUSOLLIER, S. «Le domaine public en droit d'auteur et en droit des brevets ». In : MIREILLE BUYDENS, Séverine Dusollier. (Dir.). L'intérêt général et l'accès à l'information en propriété intellectuelle. Bruxelles: Bruylant, 2008. p. 122. 
É nessa perspectiva de complementaridade que se insere a proteção positiva do domínio público. O modelo atual foi pensado para um mercado baseado na inovação, em que as empresas poderiam cumprir o papel de protetor do domínio público porque sua proteção favoreceria seus próprios interesses. Ao questionar a nulidade de uma patente por falta de novidade, ou atividade inventiva, as empresas poderiam explorar o produto apresentado pela concorrente. Entretanto, os custos com o processo, as incertezas e o risco de os concorrentes fazerem o mesmo tem levado a uma proteção do domínio público muito aquém do potencial imaginado. Se a proteção da propriedade intelectual vem a resolver uma falha do mercado em estimular a inovação e coibir a ação de free riders, a proteção positiva do domínio público pelo mercado tem se revelado falha e, também, necessita da intervenção estatal para corrigi-la.

De fato, tal correção começa pela melhoria da qualidade do exame realizado pelos escritórios de patentes. Observa-se um aumento dos pedidos depositados que tem sido acompanhado do respectivo aumento da estrutura e mecanismos de exame.

No espaço internacional, algumas iniciativas nesse sentido podem ser mencionadas e, entre eles, a Agenda de Desenvolvimento adotada pela OMPI em 2007 ${ }^{12}$. O grupo B da agenda reagrupa as recomendações destinadas “ao estabelecimento de normas, flexibilidades, políticas públicas e domínio público”. No parágrafo 16, se recomenda que se leve em consideração "a preservação do domínio público na elaboração de normas da OMPI "e que se aprofunde "a análise das consequências e vantagens de um domínio público rico e acessível. ”

O parágrafo 20 recomenda o desenvolvimento de diretrizes para auxiliar os Estados-membros a identificar os objetos integrantes do domínio público em seus territórios. É esse espaço de dúvida que é utilizado para coibir o uso de bens que já integram o domínio público. O receio de um processo por uso indevido inibe a ação e investimentos dos concorrentes. A prática de ameaça ou uso de processos judiciais sem respaldo no direito de propriedade intelectual, apenas tendo por razão frear a entrada de concorrentes no mercado, tem sido chamada pela jurisprudência de sham litigation. Essa prática de abuso do direito de ação e do uso indevido do sistema de propriedade intelectual foi objeto de um inquérito setorial pela Comissão Europeia em março de 2008. O setor analisado, nesse caso, foi o farmacêutico. Identificou-se uma série de práticas anticoncorrenciais, ou de uso indevido do sistema de proteção de patentes, como estratégias defensivas de patenteamento, estratégias de evergreeening e acordos entre empresas inovadoras e de medicamentos genéricos para evitar a entrada destes no mercado. Tais dados demonstram a necessidade de intervenção estatal como meio de proteger o domínio público e evitar o abuso, por parte de empresas inovadoras, da exclusividade ofertada pelo sistema de propriedade intelectual. ${ }^{13}$

Apesar das recomendações da OMPI datarem o ano de 2007, o desenvolvimento dessas normas, ainda, se encontra no campo das sugestões. Entre estas, distinguem-se propostas mais concretas sobre a criação de um registo internacional de domínio público ${ }^{14}$, o reconhecimento expresso de que as limitações e exceções aos direitos de patente devam ser tão importantes como o direito patentear; o desenvolvimento de modelos de licenciamento adaptados às necessidades de acesso, bem como a adoção de uma interpretação do artigo 30 do Acordo TRIPS — sobre as exceções aos direitos dos titulares de patentes — que vise à promoção de soluções para o equilíbrio entre a proteção e acesso.

Entre os modelos de licenciamento, merecem destaque os movimentos do software livre e do creative commons. Ambos apresentam modelos de licenças em que o autor pode optar pela adoção de alguns di-

12 OMC. TRIPS-Acordo sobre direitos de propriedade relacionados ao comercio, OMPI. Agenda do Desenvolvimento, 2007. Disponível em: <http://www.wipo.int/ip-development/en/agenda/>

13 Sobre o inquérito e suas repercussões, ver o site da União Europeia destinado a divulgação inquérito e dos relatórios de monitoramento realizado após a identificação das práticas de sham litigation. Disponível em: <http://ec.europa.eu/competition/sectors/ pharmaceuticals/inquiry/index.html >.

14 U. SUTHERSANEN. "Time for a declaration of the 'public domain' A2K and the Wipo development agenda. Acces to knowledge (A2K3)" Conference. Geneve, 8-10 septembre. Dispoível em : http://a2k3.org/ 
reitos reservados ao invés da política de todos os direitos reservados. Esses modelos nasceram do interesse privado, não tiveram por origem o legislador estatal, foram fruto da necessidade trazida principalmente pela plataforma de acesso a conteúdo que é a internet. A velocidade com que se tem acesso a conteúdo e sua difusão gerou a necessidade de licenças que pudessem comportar essas peculiaridades.

O princípio de continuidade do livre acesso é um dos deveres daqueles que desejem utilizar o conteúdo disponibilizado por meio de licenças do creative commons ou, GNU. O projeto "creative commons" teve por objetivo oferecer uma alternativa para a proteção tradicional dos direitos do autor cujas obras são disponibilizadas em um ambiente virtual. A licença consiste na permissão para que os usuários possam baixar e distribuir os trabalhos por ela protegidos, desde que observe as regras previamente estabelecidas pelo autor da obra. Há seis tipos de licenças na plataforma que aqui serão apresentadas do modelo mais permissivo ao modelo mais restritivo respectivamente: Atribuição, Atribuição-compartilha igual, Atribuição sem derivações, Atribuição-não comercial, Atribuição-NãoComercial-CompartilhaIgual, Atribuição-SemDerivações-SemDerivados. ${ }^{15}$

Em resposta a esse fenômeno, algumas iniciativas já podem ser observadas na área de patentes, principalmente no campo da biotecnologia e da investigação biomédica. Entre essas iniciativas, a Biological Innovation for Open Society (BIOS) ${ }^{16}$ se distingue pelo seu objetivo de partilha dos resultados da investigação no campo da biotecnologia (principalmente agrícola) para reduzir a dependência dos cientistas quanto ao uso de ferramentas tecnológicas protegidas por grandes empresas. Essas tecnologias se referem a inserção de genes modificados em plantas, de modo que eles possam expressar novas funcionalidades, bem como métodos relacionados com a decodificação genética. Ao dispor de tecnologias-chave no domínio da biotecnologia, o BIOS o faz com base na cláusula de licença “copylefft', de modo que qualquer melhoria na invenção obriga aquele que fez uso da licença gratuitamente deve disponibilizar o seu acesso a qualquer um dos participantes do projeto. O BIOS criou uma plataforma em que as tecnologias protegidas são de livre acesso e utilização, uma vez que, como contrapartida ao licenciado, invenções e melhorias feitas a partir da tecnologia de base são disponibilizados, livremente, nessa plataforma. Ou seja, o inventor da melhoria pode patentear sua invenção, mas é obrigado a assegurar o livre acesso aos usuários do fundo comum.

Não se trata, contudo, de uma modalidade de domínio público. Trata-se do exercício do direito de propriedade intelectual. Esse tipo de licença reflete a necessidade de modelos adaptados a uma era que tem no acesso sua própria razão de existência. Evidencia, também, os excessos observados quando se trata de direitos do autor: ampliação do período de proteção de cinquenta para até setenta anos após a morte do autor, proibições de cópia, inclusive para uso próprio, restrições de uso que dificultem a adaptação e exploração do produto protegido adquirido pelo consumidor.

Apesar dessas inciativas não versarem sobre o domínio público propriamente dito, elas fornecem uma solução para a ampliação do acesso em um momento em que as leis e tratados aumentam a possibilidade dos titulares dos direitos de propriedade intelectual de restringirem ainda mais o acesso a bens protegidos. Mas, não são suficientes. É tempo de os Estados adotarem normas específicas para a proteção do domínio público e desenvolverem ferramentas para a que a sociedade possa proteger um espaço de livre acesso e uso.

\section{Considerações finais}

A discussão em torno de uma proteção positiva do domínio público evidencia, também, o baixo grau de novidade e atividade inventiva de certas invenções já protegidas, e o elevado grau de exclusividade acordada aos detentores de patentes sobre os inventos. A utilidade da discussão sobre a proteção positiva do domínio

15 Ver o conteúdo de cada uma dessas licenças no site: https://creativecommons.org/licenses/?lang=pt_BR

16 Ver mais sobre a iniciativa no site da organização. Disponível em: <http://www.bios.net/daisy/bios/bios.html>. 
público reside na análise de soluções que assegurem a livre circulação e utilização do conhecimento científico e técnico.

Os dados aqui apresentados revelam a necessidade dos Estados de ajustar o direito de propriedade intelectual aos novos desafios e de desenvolver normas que levem a uma proteção positiva do domínio público. Desse modo, o domínio público pode agir como contrapeso ao processo de ampliação do conteúdo dos objetos protegidos por patentes de tal sorte que se possa desenvolver mecanismos eficientes na busca do equilíbrio entre proteção e acesso.

O que se observa, contudo, é o uso de tratados, principalmente os bilaterais, para ampliar o conteúdo patenteável e os direitos dos titulares de patentes. O tratamento residual do domínio público favorece essa ampliação. $\mathrm{O}$ fortalecimento do domínio público passa pelo seu reconhecimento jurídico como instituto próprio, e não apenas consequência residual da ausência de proteção ou de sua expiração.

\section{REFERÊNCIAS BIBLIOGRÁFICAS}

AZEMA, J.; GALLOUX , J-Ch. Droit de la propriété industrielle. Paris : Dalloz, 2006.

DUSOLLIER, S. «Le domaine public en droit d'auteur et en droit des brevets ». In : MIREILLE BUYDENS, Séverine Dusollier. (Dir.). L'intérêt général et l'accès à l'information en propriété intellectuelle. Bruxelles: Bruylant, 2008. p. 136

EUA. University and Small Business Patent Procedures Act ( Bay-Dole Act.), 35 U.S.C \$200.

HARDIN, G. “The Tragedy of the Commons”. Science, v. 162, n. 3859, p. 1243-1248, Dec. 1968.

HELLER, M. A; EISENBERG, R. S "Can Patents Deter Innovation? The Anticommons in Biomedical Research”. Science, v. 280, 1998. Disponível em: <http://ssrn.com/abstract=121288>.

HELLER, M. A “The Tragedy of the Anticommons: Property in the Transition from Marx to Markets". Harvard Law Review, v. 111, p. 621-688, 1998.

OMC. TRIPS-Acordo sobre direitos de propriedade relacionados ao comercio, OMPI. Agenda do Desenvolvimento. 2007. Disponível em: < http://www.wipo.int/ip-development/en/agenda/>.

SCHMIDT-SZALEWSKI, J.-L. PIERRE. Droit de la Propriété industrielle. Paris: Litec, 2007.

SUTHERSANEN, U. "Time for a declaration of the 'public domain' A2K and the Wipo development agenda. Acces to knowledge (A2K3)" Conference. Geneve, 8-10 septembre. Disponible sur: <http://a2k3. org/>. 


\section{REVISTA BRASILEIRA DE POLÍTICAS PÚBLICAS BRAZILIAN JOURNAL OF PUBLIC POLICY}

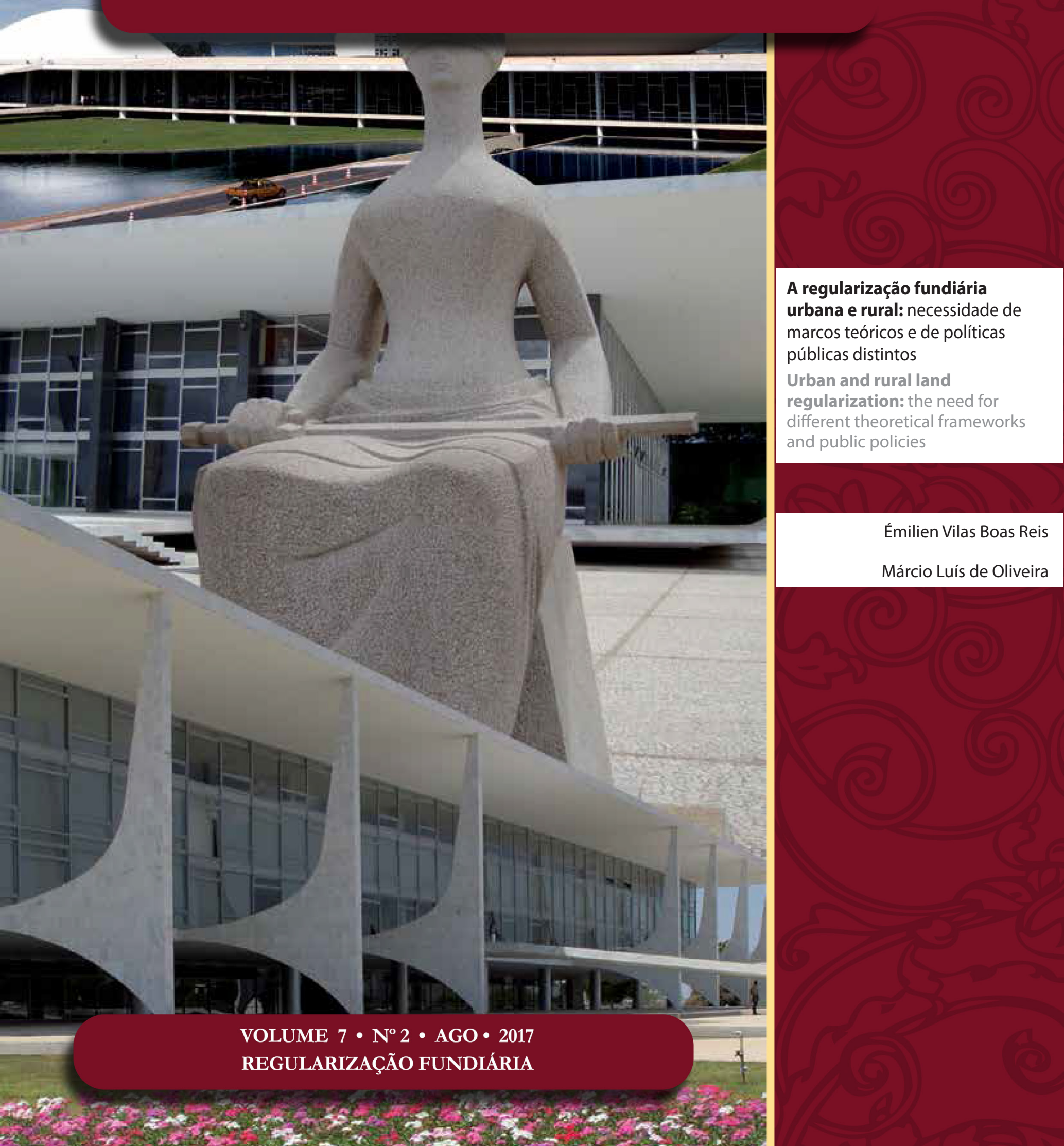




\title{
A regularização fundiária urbana e rural: necessidade de marcos teóricos e de políticas públicas distintos*
}

\section{Urban and rural land regularization: the need for different theoretical frameworks and public policies}

\author{
Émilien Vilas Boas Reis** \\ Márcio Luís de Oliveira***
}

\section{Resumo}

Independentemente das concepções liberais ou comunitárias, que justificam tanto a propriedade e a posse públicas e/ou privadas, a ocupação imobiliária urbana ou rural irregulares necessitam de regularização fundiária para viabilizar o direito fundamental e o direito humano de acesso à moradia e ao uso social da terra produtiva, respectivamente. Como se tratam de realidades e problemas distintos (o urbano e o rural), o artigo teve por objetivo fazer uma abordagem conceitual da regularização fundiária e de demonstrar que seria mais adequada a adoção de marcos legais e de políticas públicas específicas para a regularização fundiária urbana e a rural. O texto conclui que a regularização fundiária urbana tem por foco a legalização e a inserção da propriedade e da posse na estrutura regular das cidades, ao passo que a segunda tem por objetivo a legalização e a inserção da propriedade e da posse na estrutura de produção no campo. Ambas as regularizações visam à efetividade do direito à moradia social e ambientalmente sustentáveis. No caso da regularização fundiária rural, acresce-se, ainda, o direito de uso da terra como política de equidade socioeconômica e de produção sustentável. $\mathrm{Na}$ elaboração do artigo, foi adotada a metodologia conceitual-analítica, em vez da dogmática jurídica, para tratar da regularização fundiária urbana e rural em suas premissas conceituais e procedimentais. Nesse sentido, e em razão do viés analítico a que foi dado ao tema-problema, não se adotou um referencial teórico específico.

Palavras-chave: Ocupação Urbana; Ocupação Rural; Regularização Fundiária.

** Pós-doutor em Filosofia pela Faculdade de Letras da Universidade do Porto (Portugal); Doutor e Mestre em Filosofia pela PUCRS; Graduado em Filosofia pela UFMG; Professor de Filosofia e Filosofia do Direito da Graduação e da Pós-graduação em Direito Ambiental e Desenvolvimento Sustentável da Escola Superior Dom Helder Câmara, BH/MG. E-mail: mboasr@yahoo.com.br

*** Doutor e Mestre em Direito. Professor da Universidade Federal de Minas Gerais (UFMG), da Escola Superior Dom Helder Câmara (ESDHC) e da Faculdade Milton Campos (FMC); Advogado e Consultor Jurídico. E-mail: marcio.luis@uol.com.br

\section{Abstract}

Regardless of the liberal or community conceptions that justify both public and / or private ownership and possession, irregular urban or rural real estate occupation need land regularization to enable the fundamental right and human right of access to housing and social use of land, respectively. As they deal with different realities and problems (urban and rural), 
the article aimed to make a conceptual approach to land regularization and to demonstrate that it would be more appropriate to adopt legal frameworks and specific public policies for urban land regularization and the rural one. The text concludes that urban land regularization is focused on the legalization and insertion of ownership and possession into the regular structure of cities, while the second one has the objective of legalizing and inserting ownership and possession into the production structure in the countryside. Both regularizations aim at the effectiveness of the right to social housing and environmentally sustainable. In the case of rural land regularization, there is also the right to use land as a policy of socioeconomic equity and sustainable production. In the elaboration of the article the conceptual-analytical methodology was adopted, instead of legal dogmatics, to deal with the urban and rural land regularization in its conceptual and procedural premises. In this sense, and due to the analytical bias given to the problem theme, a specific theoretical framework was not adopted.

Keywords: Urban Occupation. Rural Occupation. Land Regularization.

\section{INTRODUÇÃo}

A propriedade e a posse, bem como a ocupação imobiliária irregular urbana e rural, remontam a uma longa discussão filosófica, científica e dogmática. Tratando-se de tema que é objeto de constante regramento jurídico e de adoção de diversas políticas públicas, a questão da regularização fundiária assume especial importância no Brasil, cuja estruturação social, ainda, se caracteriza pela iniquidade socioeconômica e por impactos ambientais provenientes das ocupações irregulares e potencialmente conflitivas no campo e nas cidades.

Tendo em vista a relevância dessa matéria, o texto assenta-se no seguinte tema-problema: a propriedade e a posse, independentemente de suas concepções filosóficas de natureza pública ou privada, e, como objetos de ocupação irregular, podem demandar a necessidade de regularização fundiária de modo a se promover o direito fundamental e o direito humano à moradia e à produção sustentáveis?

De modo a responder ao tema-problema, o presente artigo apresenta as seguintes hipóteses: a) a concepção de propriedade e posse revela, tanto sob o seu paradigma público ou privado, motivos para que a ocupação irregular justifique a ação estatal para a necessidade de sua regularização fundiária; b) se sim, a regularização fundiária da propriedade e da posse imobiliárias urbana e rural mostra-se em conformidade com o direito fundamental e o direito humano de moradia e de acesso à terra, como políticas públicas de implementação de equidade socioeconômica e ambientalmente sustentáveis; c) a regularização fundiária urbana e rural, em razão de suas distinções, necessita de marcos regulatórios e de políticas públicas próprios.

$\mathrm{Na}$ elaboração do artigo, foi adotada a metodologia conceitual-analítica para tratar da regularização fundiária urbana e rural em suas premissas conceituais e procedimentais. Não se fez, neste trabalho, o uso da dogmática jurídica de modo mais específico, uma vez que seu objetivo principal consistiu na abordagem conceitual do instituto da regularização fundiária. Nesse sentido, e em razão do viés analítico a que foi dado ao tema-problema, não se adotou um referencial teórico específico.

São, por conseguinte, objetivos do artigo demonstrar os problemas da ocupação irregular da propriedade e da posse imobiliária urbana e rural, bem como a necessidade de sua regularização fundiária sob marcos regulatórios e políticas públicas distintos, de modo a se promover o acesso sustentável do direito à moradia e ao cultivo da terra.

Para tanto, o artigo foi organizado em três seções, além da introdução e das considerações finais. $\mathrm{Na}$ primeira delas, abordou-se o tema da propriedade e da posse como elementos do direito de moradia urbana e rural. No item dois, discutiu-se a questão da ocupação irregular e a necessidade da regularização fundiária com a conjugação da função social e da função ambiental da propriedade e da posse. No terceiro ponto, 
relataram-se as dimensões urbanas e rurais do processo de regularização fundiária e a necessidade da adoção de marco regulatório e de implementação de política pública próprios para melhor atender às suas particularidades.

\section{REGULARIZAÇÃo FUNDIÁRIA: A PROPRIEDADE E A POSSE IMOBILIÁRIAS COMO ELEMENTOS DO DIREITO DE MORADIA URBANA OU RURAL}

A propriedade e a posse, há muito, são temas de reflexão no âmbito da doutrina político-jurídica. Certo, porém, que a propriedade e a posse, especificamente sobre imóveis — desdobramento temático deste trabalho (regularização fundiária) —, são objetos de regramento pelos sistemas jurídicos, tanto de matriz liberal quanto comunitarista. Apesar das distintas fundamentações quanto à origem da propriedade e da posse, e às suas consequências positivas e negativas no processo civilizatório, a real diferença entre as duas tradições jurídicas ocidentais - liberalismo e comunitarismo - assenta-se, sobretudo, em critérios de normatização da extensão da titularidade e do exercício da propriedade ou da posse.

$\mathrm{Na}$ vertente liberal, reconhece-se à pessoa natural ou jurídica o amplo direito à titularidade e ao exercício da propriedade ou da posse. Nesse sistema, os direitos de propriedade e de posse não são, por óbvio, absolutos, pois estão sujeitos a limitações de direito público e privado por diversas justificativas e em múltiplas dimensões (direito civil, direito empresarial, direito administrativo, direito penal, direito tributário etc.). Já no modelo comunitarista ideal, a titularidade e o exercício da propriedade ou da posse não constituem, por si, direitos atribuíveis à pessoa natural ou jurídica, mas espécies de concessões estatais para utilização individual ou coletiva, a título precário. Por óbvio, a história registrou diversas gradações de comunitarismo, mas, mesmo em relação ao socialismo histórico, houve algum grau, ainda que mínimo, de tolerância à propriedade e à posse imobiliária com finalidade residencial.

Entretanto, numa ou noutra matriz, a propriedade e a posse imobiliárias são objetos de uma determinada abordagem político-jurídica que merece especial atenção da sociedade, dos agentes econômicos privados (dependendo do sistema econômico) e do Estado, qual seja: o regramento, a elaboração e a implementação de políticas públicas de habitação e de produção rural (agricultura, pecuária, piscicultura e extrativismo). Enquanto a questão do acesso à habitação é tema mais afeto às políticas públicas de urbanização, o chamado "acesso ao campo" está correlacionado às políticas públicas que tentam viabilizar e conciliar as necessidades e as tendências da produtividade no setor primário da economia (mais especificamente na agropecuária) com a garantia da efetiva subsistência socioeconômica sustentável de núcleos familiares e segmentos sociais com tradições campesinas ou opção pela vida rural.

Por outro lado, a ocupação de terras urbanas ou rurais resulta da dinâmica antropológica de sedentarização dos agrupamentos humanos ${ }^{1}$. A sociabilidade da condição humana e o instituto de sobrevivência do grupo tendem ao assentamento ou à fixação na localidade com potencialidades para lhes proporcionar habitação, ou seja, que lhes forneça condições de adaptação socioambiental, sustento, abrigo permanente e possibilidade de constituir identidade indivíduo-localidade. Aliás,

É o cultivo da terra que permite ao Homem sedentarizar-se. Apropria-se do espaço, que passa a assumir como o seu espaço de conforto, onde habita e cultiva os víveres necessários à sobrevivência. Acreditava controlar o caos natural ao domesticar as plantas, assim como os animais e, com este controlo, iniciou um processo que acompanha a humanidade desde então: o processo de apropriação do espaço e, consequentemente, de identificação com o espaço. ${ }^{2}$

\footnotetext{
1 Sobre o processo de sedentarização do ser humano e seus desdobramentos, recomenda-se a leitura de: CÂMARA CASCUDO, Luís da. Civilização e cultura: pesquisas e notas de etnografia geral. São Paulo: Global, 2004.

2 CORREIA, Rui Sá. No man's land. No man's time: contributo epistemológico para o conceito de paisagem. p. 21. Disponível em: <http://dspace.uevora.pt/rdpc/bitstream/10174/11838/1/NO\%20MAN\%27S\%20LAND\%20.\%20NO\%20MAN\%27S\%20
} 
Ou seja, a sedentarização é um fato do processo histórico-civilizacional. Assim, alguns segmentos sociais ocuparão os espaços que, por circunstâncias ou conveniências, lhes fornecerão condições de subsistência e de identidade ou lhes aumentarão a capacidade econômica, ainda que sem planejamento ou adequação ao sistema jurídico. Como dito, a sedentarização como construção da habitação é tema que remonta ao passado civilizatório.

A sedentarização é, portanto, um dos fatores antropológico-sociológicos que justifica a importância da habitação como um dos elementos constitutivos da identidade e da solidariedade social e, por conseguinte, da paz pública. Logo, o acesso à habitação é um direito social fundamental, alçado à categoria de direito constitucional, independentemente da matriz liberal ou comunitarista da propriedade e da posse, conforme apresentado na primeira parte deste texto. Nesse sentido, o efetivo acesso à habitação é medida de política pública implementadora de equidade social que, se não resolvida a contento, desvela alto potencial de conflito urbano ou rural. E, por habitação, há que se entender o sítio que forneça ao indivíduo e aos seus familiares condições de adaptação socioambiental, identidade, sustento e abrigo permanente.

Por conseguinte, na concepção contemporânea de habitação, se incluem a residência (a segurança jurídica do "asilo inviolável" da identidade e da intimidade da pessoa ou do núcleo familiar ou afetivo, bem como a proteção da permanência ou estabilidade) e a infraestrutura material de moradia (elementos que viabilizam o abrigo e a adaptabilidade socioambiental: a construção e seu entorno material). Consequentemente, parte relevante da infraestrutura da habitação se expressa na propriedade ou na posse da localidade onde ela (a habitação) se desvela. Eventualmente, essa propriedade ou posse pode estender-se para além da habitação, como a moradia rural, pois o seu titular é dependente do manejo da terra circundante para sobreviver com a atividade agropecuária ou congênere.

Assim, desde a formação do constitucionalismo social —, o que remonta à primeira metade do século XX —, o acesso à habitação nas cidades ou no campo é direito fundamental, cuja efetivação é matéria concernente ao Estado, o que não dispensa a possibilidade de a iniciativa privada e a sociedade civil organizada atuarem como agentes colaboradores na sua implementação. Nesse contexto, e ao discorrer sobre as bases jurídicas do constitucionalismo social, Oliveira afirma que

Aquela nova dimensão de direitos, garantias e deveres fundamentais passava a incluir dois grandes segmentos de conquistas jurídicas na modernidade ocidental: a) a proteção legislativa e fiscalizadora do trabalhador e das associações (sindicatos) dos trabalhadores contra o abuso das práticas liberais da época; b) a universalização progressiva do acesso à educação, ao sistema de tratamento de doenças, à infraestrutura sanitária e habitacional, à assistência social e à previdência social. Logo, a proteção do trabalhador e dos sindicatos gerava ônus (deveres) tanto para a iniciativa privada (patrões) quanto para o Estado (dever de fiscalização e execução das normas trabalhistas). Mas parcela significativa dos direitos e garantias sociais de segunda dimensão (educação, saúde, previdência etc.) impunha deveres imediatos ao próprio Estado, que assumia o encargo histórico-civilizacional de sua efetiva regulação e implementação material. ${ }^{3}$

É, também, fato notório que os direitos sociais foram alçados à condição de direitos humanos em foro internacional, sobretudo a partir da adoção do Pacto Internacional de Direitos Econômicos, Sociais e Culturais, em 1966, pela Organização das Nações Unidas. Após esse Tratado, várias normas internacionais de naturezas jurídicas distintas foram expedidas por inúmeras organizações internacionais de âmbito global ou regional, como a União Europeia e a Organização dos Estados Americanos. Mas, todas essas normas do Direito Internacional impõem, primordialmente, aos Estados o dever jurídico, político e fiscal de implementação dos direitos sociais, ainda que os Estados possam contar, para tal, com a colaboração da inciativa privada e da sociedade civil organizada tanto nacionais quanto internacional. Sobre este dever dos Estados, Carvalho menciona que

TIME.pdf>. Acesso em: 21 jul. 2017.

3 OLIVEIRA, Márcio Luís de. A constituição juridicamente adequada. 2. ed. Belo Horizonte: D’Plácido, 2016. p. 205. 
Levando-se em conta o que se encontra expresso no Pacto Internacional de Direitos Econômicos, Sociais e Culturais (Parte II, art. 2.1, em especial), deve-se compreender que os Estados se obrigaram a adotar medidas até o máximo de seus recursos disponíveis para alcançar progressivamente por todos os meios apropriados, inclusive e, sobretudo, a adoção de medidas legislativas, a fim de que os direitos reconhecidos naquele instrumento internacional alcancem a sua plena efetividade. Por conseguinte, os Estados assumiram encargos e se vincularam ao cumprimento daqueles objetivos, nomeadamente ao se absterem de adotar medidas que impliquem retrocesso social. ${ }^{4}$

E continua o autor, em nota:

Conforme magistério de Miguel Carbonell, a partir do texto do artigo 2.1 pode-se afirmar que o Pacto Internacional de Direitos Econômicos, Sociais e Culturais gera para os Estados-Partes tanto obrigações de comportamento como obrigações de resultado, isto é, não se trata de que os Estados devam se conduzir de certa maneira, senão também que logrem certos objetivos, que proponham metas e as realizem. ${ }^{5}$

Entretanto, em todos os países há algum nível de ilegalidade em certas ocupações urbanas e rurais, que alcançam, inclusive, patamares muito acentuados nos Estados com baixa equidade socioeconômica, como o Brasil. Nessas sociedades, o alto índice de ocupações urbanas e rurais sem nenhum planejamento e à margem da legalidade conduzem a diversos fenômenos de desagregação social, tais como a baixa qualidade de vida dos seus moradores, o maior risco de ocorrência de acidentes e calamidades nessas áreas, o aumento da violência local, a inacessibilidade a serviços e bens públicos e privados relevantes (saúde, educação, saneamento, segurança, defesa social, energia elétrica, mobilidade, comércio, lazer), incertezas e instabilidades nas relações e situações jurídicas relacionadas à propriedade e à posse (sobretudo no caso de acesso a crédito, realização de negócios e sucessão), a formação de bolsões de extrema pobreza, a baixa produtividade agropecuária (em se tratando de habitação campesina), a potencialização de impactos ambientais, o descontrole de processos migratórios.

Constata-se, pois, que ocupações urbanas e rurais irregulares (ilegais e sem planejamento público) são causadoras e potencializadoras de diversos problemas, como os listados acima. Contudo, elas precisam ser regularizadas de modo a eliminar ou reduzir os efeitos da desagregação e da iniquidade social da qual resultam e para a qual, também, concorrem numa relação consubstanciada de causa-efeito. Para tanto, faz-se necessária a elaboração e implementação da chamada regularização fundiária.

\section{A REGULARIZAÇÃo FUNDIÁRIA E A CONJUGAÇÃo dA FUNÇÃo SOCIAL COM A FUNÇÃo AMBIENTAL DA PROPRIEDADE E DA POSSE}

A regularização fundiária torna-se necessária, útil e adequada nas hipóteses em que a ilegalidade da propriedade ou da posse apresenta-se como problema social com potencialidade para gerar grandes conflitos urbanos ou rurais, ou colocar em risco a integridade física e patrimonial das pessoas, além de gerar ou agravar a iniquidade social e os impactos ambientais. Tanto por questões de melhoria da produtividade agropecuária (no âmbito rural) quanto por razões ambientais ou de equidade social (nos dois casos, urbana e rural), a regularização fundiária revela-se como elemento importante para o desenvolvimento sustentável, que deve conciliar o uso produtivo da propriedade (geração de riqueza), promover a equidade social e assegurar a proteção do meio ambiente.

Por isso mesmo, a regularização fundiária, ao ser elaborada e implementada como opção constitucional-legislativa e como planejamento de política pública, deve conjugar tanto a "função social" quanto a "fun-

4 CARVALHO, Osvaldo Ferreira de. Direitos humanos sociais: dever estatal de promoção e garantia dos direitos sociais e sua concretização judicial. Direito \& Justiça, Porto Alegre, v. 38, n. 1, p. 77-90, jan./jun. 2012.

5 CARVALHO, Osvaldo Ferreira de. Direitos humanos sociais: dever estatal de promoção e garantia dos direitos sociais e sua concretização judicial. Direito \& Justiça, Porto Alegre, v. 38, n. 1, p. 77-90, jan./jun. 2012. 
ção ambiental" da propriedade e da posse, como distingue Araújo, ao tecer crítica acadêmica a julgado do Supremo Tribunal Federal:

Com efeito, enquanto a função social preocupa-se com as condições sociais e econômicas da pessoa humana e da coletividade, a função ambiental está voltada à proteção do meio ambiente. Ambas são importantes e imprescindíveis, constituindo-se em ideais a serem construídos e alcançados pelo poder público e por toda a coletividade, a partir da ação dos governos, das organizações da sociedade civil e de cada indivíduo.

Não se pode concordar, portanto, com a visão defendida de forma corriqueira pela doutrina e contida em algumas decisões do STF, acima analisadas, no sentido de que a função social é gênero do qual a função ambiental é espécie. Neste artigo foram apresentados alguns contraexemplos a esta afirmativa, evidenciando-se que há inúmeras situações fáticas nas quais o interesse ambiental entrará em choque com o interesse social. Nessas hipóteses, função social e função ambiental apresentar-se-ão com conteúdos distintos, revelando que a função ambiental implica o direcionamento do exercício do direito de propriedade voltado à conservação do meio ambiente como objetivo primeiro.

Assim, a utilização da expressão "função socioambiental da propriedade" nem sempre estará correta, podendo ser aplicada apenas nas hipóteses em que o interesse social e o ambiental coincidam. Há situações em que tais interesses estarão em confronto; daí porque, sob o aspecto conceitual, melhor será compreender a "função ambiental da propriedade" como desempenho ou cumprimento da finalidade de conservação do meio ambiente como categoria que carrega valor em si próprio, independentemente de deveres outros ligados aos interesses humanos. ${ }^{6}$

É, pois, fato que a qualidade da habitação na cidade ou no campo tem alta relevância na efetividade dos direitos sociais, com implicações políticas, econômicas e ambientais.

No que concerne à irregularidade da propriedade e da posse em âmbito urbano, o problema ganha maior impacto nas metrópoles, como sintetiza Grostein:

O padrão de urbanização brasileiro imprimiu às metrópoles pelo menos duas fortes características associadas ao modo predominante de "fazer cidade": apresentam componentes de "insustentabilidade" vinculados aos processos de expansão e transformação urbana e proporcionam baixa qualidade de vida a parcelas significativas da população. Esse padrão cria um espaço dual: de um lado, a cidade formal, que concentra os investimentos públicos e, de outro, seu contraponto absoluto, a cidade informal, que cresce exponencialmente na ilegalidade urbana, sem atributos de urbanidade, exacerbando as diferenças socioambientais. A transformação urbana desses espaços implica processos amplos que extrapolam as práticas correntes de regularização de parcelamentos ou urbanização de favelas. ${ }^{\top}$

Já no meio rural, o problema da irregularidade da propriedade e da posse é crônico no Brasil. Além de ser altamente concentrador da propriedade e da produção rural, o sistema brasileiro nunca conseguiu promover justiça social no campo, quer pela secular prática da grilagem de terras (fraudes na documentação do título de propriedade ou de posse), quer pela precariedade da atividade agropecuária de subsistência em relação ao domínio e à reserva de mercado de grandes empreendimentos nesse setor, como relatado por Hespanhol, ao tratar da chamada agricultura familiar:

Com o agravamento dos problemas enfrentados por esses produtores (exaustão dos solos, baixa produtividade das culturas, baixos preços para os produtos agrícolas, dificuldades de acesso ao crédito rural etc.) associado a intensificação da concentração fundiária resultante da expansão das áreas de pastagens, levaram a descapitalização crescente dessas explorações familiares, resultando numa menor capacidade de absorção de força de trabalho e a consequente (sic) expulsão de um expressivo contingente populacional. ${ }^{8}$

6 ARAÚJO, Giselle Marques de. Função Ambiental da Propriedade: uma proposta conceitual. Revista Veredas do Direito, Belo Horizonte, v. 14, n. 28, p. 251-276, jan./abr. 2017. Disponível em: <http://www.domhelder.edu.br/revista/index.php/veredas/article/ view/985/546>. Acesso em: 25 jul. 2017.

7 GROSTEIN, Marta Dora. Metrópole expansão urbana: a persistência de processos “insustentáveis”, resumo. São Paulo em Perspectiva, São Paulo, v. 15, n. 1, jan./mar. 2001. Disponível em: <http://dx.doi.org/10.1590/S0102-88392001000100003>. Acesso em: 19 jul. 2017.

8 HESPANHOL, Rosângela Aparecida de Medeiros. A produção familiar: perspectivas de análise e inserção na microrregião ge- 
Ademais de a realidade rural brasileira ser altamente conflitiva e iníqua, os modos de ocupação irregular do campo e as práticas agropecuárias sem controle e padronização sustentáveis são causadoras de impactos ambientais extremante negativos, sobretudo em áreas que demandam maior proteção, a exemplo da Amazônia, da Mata Atlântica e do Pantanal, como ressaltado por Brito e Barreto, com base em estudos feitos por Fearnside:

As ações de regularização fundiária da Amazônia precisam estar acompanhadas de medidas de combate à falsificação de títulos de terra, conhecida como grilagem de terras. Do contrário, muitas posses que estão sendo cadastradas e georreferenciadas não poderão ser tituladas, devido à existência de títulos falsos incidindo no mesmo território. Além disso, a grilagem também contribui com a degradação ambiental na região, já que parte das áreas griladas é geralmente desmatada para sinalizar a sua ocupação.

Logo, as soluções para os problemas rurais demandariam por várias políticas públicas que implementassem, simultaneamente, a regularização fundiária e a reforma agrária de reestruturação do modelo de ocupação e de produção no campo. Um modelo que pudesse conjugar os interesses da grande produção agropecuária em escala industrial com a produção de pequenos e médios fazendeiros. Nessa reconfiguração da ocupação e da produção rural, haveria a necessidade de fomento ao cooperativismo de emancipação, de modo a gerar maior qualidade de vida e autonomia financeira para os núcleos familiares dependentes da agropecuária de subsistência ou de pequena escala.

As irregularidades quanto à propriedade e a posse urbana e rural assumem escalas desmedidas em todo o território brasileiro. Por essa razão, legislações e programas nacionais, regionais e locais de regularização fundiária são indispensáveis para a promoção do desenvolvimento sustentável no país, observadas as competências dos entes federativos, e realizados de modo coordenado e sincrônico. Desenvolvimento que consiga ser indutor da produção de riqueza nas cidades e no campo, seguido de equidade social e de proteção ambiental.

Logo, e independentemente das conceituações legais, pode-se dizer que a regularização fundiária é o processo realizado pelo Estado, com ou sem a coparticipação da iniciativa privada ou da sociedade civil organizada, para legalizar a propriedade e a posse de assentamentos irregulares e para integrá-los ao contexto jurídico e à infraestrutura urbana ou rural, por meio de medidas jurídicas e de políticas públicas com alcance social, econômico e ambiental.

\section{Dimensões URBANAS E RURAIS do PROCESSO dE REGULARIZAÇÃo FUNDIÁRIA: MARCO REGULATÓRIO E IMPLEMENTAÇÃO DE POLÍTICA PÚBLICA PRÓPRIOS}

A regularização fundiária, como processo complexo e potencialmente conflitivo que é, assenta-se na interseção das funções básicas do Estado: a atividade legislativa, a promoção de políticas públicas e os atos de jurisdição, com o acompanhamento dos entes fiscalizadores (Ministério Público e Tribunais de Contas), exigindo-se, ainda, a atuação das Defensorias Públicas, já que muitos casos envolvem situações de pessoas hipossuficientes. No Brasil, em razão de suas dimensões continentais e pela adoção do modelo federativo como forma de organização do Estado, faz-se necessária a coordenação e a sincronização dos processos de regularização fundiária em âmbito federal, estaduais, distrital e municipais, observadas, como dito, as competências constitucionais dos entes da Federação.

Primeiramente, porém, há que se ter um marco regulatório claro e objetivo do ponto de vista conceitual dos institutos, procedimentos e instituições jurídicas que serão referenciais para o processo. Por óbvio, esse

ográfica de Presidente Prudente. 2000. Tese (Doutorado em Geografia) - Programa de Pós-Graduação em Geografia do Instituto de Geociências e Ciências Exatas da Universidade Estadual Paulista, Rio Claro, 2000.

9 BRITO, Brenda; BARRETO, Paulo. A regulariz̧ação fundiária avançou na Amaz̧ônia?: os dois anos do Programa Terra-Legal. Belém: Instituto do Homem e Meio Ambiente da Amazônia - IMAZON, 2011. p. 39. 
marco há que ser federal e preferencialmente distinto para os setores urbano e rural, em razão de suas inúmeras diferenças conceituais, pragmáticas, finalísticas e consequenciais. Não se pode olvidar, como já mencionado, que a regularização fundiária no campo deve ser acompanhada de reforma agrária emancipatória dos pequenos e médios produtores rurais. Caso contrário, a regularização fundiária rural pode revelar-se ineficiente no todo ou em parte em determinada localidade onde houver sido implementada.

Devido a dimensão continental do Estado brasileiro e pelas inúmeras distinções ambientais, sociais e econômicas, a regularização fundiária, como marco legal federal, deve propiciar adequações regionais e locais sem perder, contudo, o aspecto integrador e coordenador. Daí a necessidade de institucionalização de um sistema federalizado regulador, fiscalizador e coordenador que possa atuar em conjugação com os inúmeros ministérios e secretarias estaduais e municipais vinculados ao tema, além de órgãos de fomento socioeconômico e de amparo científico e tecnológico.

Torna-se, pois, indispensável a institucionalização de um órgão gestor federal, com a efetiva representação da União, dos Estados, dos Municípios, da sociedade civil organizada, da iniciativa privada, além de membros dos Ministérios Públicos, das Defensorias Públicas e dos Conselhos Nacionais de Justiça e do Ministério Público. E, repita-se, com a distinção entre a regularização fundiária urbana e a rural. Por esses mesmos motivos, a adoção do marco relatório matriz da federalização da regularização fundiária há que contar, na sua elaboração, com a atuação democrática dos diversos segmentos públicos e sociais interessados, além da comunidade científica. Nenhum marco regulatório em relação a essa temática será bem-sucedido se seus fundamentos não forem postos a efetivo debate com a sociedade e se não se mantiver, com esta, um permanente diálogo durante sua implementação ou revisão.

Instituído um marco regulatório, a regularização fundiária, como política pública de grande complexidade, requer planejamento adequado em sua elaboração, implementação, avaliação e revisão, além da disponibilização de recursos, patrimônio e agentes públicos qualificados.

Os processos de regularização fundiária serão, ainda, distintos de acordo com as áreas de sua abrangência e as finalidades a serem alcançadas. Mas há, pelo menos, dois modelos distintos de regularização fundiária: a urbana e a rural.

A finalidade precípua da regularização fundiária urbana consiste em, além da legalização da propriedade e da posse dos locais de moradia, adaptar e fazer integrar a área regularizada ao espaço urbano social, econômico e ambientalmente sustentável, demandando, para tanto, da implementação de uma infraestrutura que permita aos moradores a acessibilidade a bens e a serviços públicos e privados próprios das cidades. Logo, o processo não visa, meramente, legalizar a propriedade e a posse ilícitas, mas viabilizar o direito fundamental de moradia, assegurando a boa qualidade de vida habitacional:

Trata-se de um conjunto de ações multidisciplinares, onde atuam profissionais dos segmentos jurídico, urbanístico, ambiental e social, com a finalidade de integrar os assentamentos irregulares ao contexto legal das cidades. As ações necessárias à promoção da regularização de um parcelamento incluem desde o levantamento de dados e informações acerca da situação física, ambiental, social, dominial e jurídica da área a ser regularizada, passando pelas etapas de diagnóstico multidisciplinar, estudos técnicos e fundiários, elaboração de pareceres, proposituras para compatibilização à legislação e outras assessorias específicas, de modo a assegurar o cumprimento de todos os procedimentos formais e certificar a condição de conformidade legal e viabilidade da regularização. A partir daí, são produzidos o projeto de regularização e outras peças técnicas necessárias para formalizar a legalização do parcelamento perante os órgãos públicos e o cartório de registro de imóveis.

Além do procedimento de regularização documental, que garante o título de propriedade em benefício dos ocupantes, o processo de regularização fundiária deverá contemplar a análise das condicionantes sociais e ambientais, bem como a identificação das intervenções físicas que serão necessárias para assegurar as condições dignas de ocupação e consolidação da área no contexto de uma cidade sustentável, 
de modo a garantir a função social da propriedade e o bem-estar da população. ${ }^{10}$

Por sua vez, os objetivos a serem alcançados pela regularização fundiária rural poderão variar muito, de acordo com a política de desenvolvimento a ser implementada no campo. Não bastará, nesse caso, legalizar a propriedade e a posse da terra rural, apenas, com a finalidade de garantir acesso à moradia, mas inserir a pequena, a média e, eventualmente, a grande propriedade ao contexto da produção agropecuária recomendável como política pública de desenvolvimento não apenas sob o viés social, como também econômico e ambiental.

Assim, há um aspecto peculiar da regularização fundiária rural que é a inserção da propriedade e da posse na estrutura de produção agropecuária. Obviamente, o foco prioritário é o assentamento de pequenos e médios agricultores e seus respectivos núcleos familiares, mas a adequada colocação da propriedade rural na estrutura de produção socioeconômica e ambientalmente sustentáveis é elemento integrador da regularização fundiária campesina, sob pena de inefetividade da política pública. Por esse motivo, muitas vezes, a regularização fundiária rural é acompanhada de reforma agrária que implica não apenas a intervenção do Estado na propriedade privada como também a outorga de terras públicas (bens dominicais), acompanhada (a regularização fundiária) de um conjunto de medidas próprias para viabilizar a produção rural sustentável. Não se pode perder de vista o fato de que o êxodo rural é, em parte, consequência de políticas públicas inadequadas de assentamento rural.

Nesse ponto, vale ressaltar as preocupações acerca da regularização fundiária de zonas territoriais limítrofes entre os setores urbano e rural, que são apresentadas por Santoro, com base em estudos feitos no Estado de São Paulo:

Graziano da Silva (1997) defende que há que se repensar o espaço rural, que hoje não está apenas vinculado à evolução do mundo agrário, mas é palco de mudanças multimensionais, ou seja, não apenas mudanças da ordem econômica ou social, nem apenas mudanças do ponto de vista estrito da produção e/ou do consumo, mas também mudanças culturais, nas relações com emprego urbano, nas possibilidades de ir-e-vir cotidianamente. $\mathrm{O}$ rural vive a possibilidade de combinar atividades agrícolas com não-agrícolas a partir de mudanças no trabalho tanto na agricultura moderna como na indústria de base fordista, esta é a base do conceito hoje de pluriatividade rural. No campo econômico, é preciso incorporar a esfera da circulação como parte das "novas formas", mais especificamente, o capital financeiro agindo sobre o rural, as commodities e seus reflexos na organização do espaço rural; e, principalmente, o significa do atual processo que o autor chama de "commodotization", ou seja, o fato das áreas rurais estarem crescentemente associadas com atividades voltadas para o consumo, tais como lazer, turismo, residência, preservação do meio ambiente, etc. (1997, p.4). Esta última mudança é sentida a partir destas novas ocupações sobre o espaço rural e trarão novos desafios para o planejamento deste espaço (Santoro, 2012; Zuquim, 2007).

$\mathrm{Na}$ sua tese, Graziano da Silva resume as atividades não-agrícolas com importância crescente no meio rural brasileiro como sendo:

(1) a proliferação de indústrias, em particular, agroindústrias, no meio rural. Este exemplo é presente no estudo de caso de Catanduva, mas também em algumas normas municipais observadas, através de zoneamentos industriais próximos às rodovias;

(2) as atividades relacionais à crescente urbanização do meio rural, com moradia, turismo, lazer e outros serviços, e a preservação do meio ambiente. Neste caso, assistimos a proliferação de loteamentos fechados, parques temáticos, shoppings, etc. que aparecem nas normas identificadas, geralmente através de zoneamentos específicos ou leis buscando a regularização destas tipologias; e,

(3) não menos importante, a proliferação dos sítios de recreio, ou simplesmente

chácaras, como são chamadas no interior do Estado de São Paulo, cujo regramento sobre este padrão de

10 INSTITUTO SOMA. Regularização fundiária. Disponível em: < http://institutosoma.org.br/areas-de-atuacao/regularizacaofundiaria/. Acesso em: 21 jul. 2017. 
ocupação também mostrou-se frequente a partir dos municípios estudados nesta tese. ${ }^{11}$

Essas áreas limítrofes entre as zonas urbanas e rurais estão muitas vezes localizadas em espaços territoriais até mesmo amparados pela legislação civil, mas que contrastam com as regras ambientais e urbanísticas, não sendo, porém, de natureza propriamente urbana, tampouco tecnicamente rural, do ponto de vista clássico. Por conseguinte, a regularização fundiária nesses espaços indefinidos necessita de marco regulatório próprio e de políticas públicas específicas, como conclui Santoro:

Não parece ser o zoneamento que contém uma gradação de densidades de ocupação, o garantidor da preservação do meio ambiente, pois ele impõe às áreas da fronteira entre o rural e o urbano, usos dispersos e pouco densos, que não tem se mostrado não poluidores. A admissão de densidades menores de ocupação e de menos infraestruturas urbanas tem em conta que o próprio terreno daria conta de absorver os impactos de uma ocupação pouco adensada e dispersa. Mas os exemplos citados sinalizam que estas áreas estão ameaçadas pela expansão dos usos urbanos, uma vez que, para serem regulares em termos de parâmetros —, tamanho mínimo de lote —, devem estar contidas em áreas urbanas. Ainda que, para estarem regulares em relação à infraestrutura e doação de áreas públicas, deveriam estar contidas em áreas rurais. Isso sem falar nas flexibilizações de parâmetros de preservação ambiental —, permissão da ocupação de áreas de preservação permanente, redução da reserva legal, entre outros já citados - já encontradas.

Esta lacuna do planejamento para os usos dispersos ou de urbanização rarefeita —, neste artigo tratado a partir do exemplo das chácaras, sítios de recreio ou ranchos —,, torna este uso ameaçador ao meio ambiente preservado. Ainda que, seja potencialmente, uma forma de uso e ocupação com potencial muito positivo para a preservação, como sinaliza Graziano da Silva (1997).

Há que se pesquisar qual seria a infraestrutura necessária para qualificar estas ocupações que não se definem como rurais, nem como urbanas. Há também que se considerar que estas podem (ou devem) ser as próximas áreas a sofrerem adensamentos, ou seja, também é necessário prever, na definição de infraestrutura necessária, os impactos de adensamento futuro destas áreas. Há de se considerar também a relação entre produtividade agrícola e a forma de ocupação urbana, estimulando a pluriatividade rural e seu desenvolvimento econômico com usos rurais e urbanos que garantam a sobrevivência das famílias que habitam estes espaços e que, ao mesmo tempo, garantam a preservação do meio ambiente natural. ${ }^{12}$

Resta, por fim, lembrar que a regularização fundiária, ainda, necessita considerar aspectos relacionados aos grupos humanos que ocupam a terra sob condições histórico-culturais, como as etnias indígenas e os quilombolas. Nesses casos, tanto o marco regulatório quanto as políticas públicas precisam considerar diversos outros aspectos a não ser, apenas, o da moradia e o do assentamento rural. E muitas dessas áreas, além de serem regidas por normas específicas, são objeto de grandes conflitos. É ainda fato que as terras tradicionalmente ocupadas por etnias indígenas e grupos quilombolas resultam da chamada "posse efetiva" pela moradia e pelo uso e produção, com a constituição de cultura e identidade próprias. E é nesse aspecto que se pode tecer uma crítica acerca da alteração do padrão legitimador do direito consuetudinário de ocupação da terra pela posse efetiva, relegado a segundo plano pela legitimação decorrente da titularização cartorial da propriedade, o que, muitas vezes, fomenta a prática da grilagem de terras, em detrimento de posseiros historicamente efetivos:

Não obstante esta integração das formas mais ou menos autônomas de atividades produtivas empreendidas pelos escravos à economia geral, é preciso ressaltar que o trabalho livre sobre a terra não

11 SANTORO, Paula Freire. Entre o rural e o urbano: zonas de chácaras, sítios de recreio ou ranchos e a preservação do meio ambiente. In: SEMINÁRIO NACIONAL SOBRE O TRATAMENTO DE ÁREAS DE PRESERVAÇÃO PERMANENTE EM MEIO URBANO E RESTRIÇÕES AMBIENTAIS AO PARCELAMENTO DO SOLO. 3., Painel "A Dimensão Ambiental da Cidade"; Belém, Universidade Federal do Pará (UFPA), 10 a 13 de setembro de 2014. Disponível em: <http://anpur.org.br/appurbana2014/anais/ARQUIVOS/GT31803520140518153453.pdf> Acesso em 20 jul. 2017.

12 SANTORO, Paula Freire. Entre o rural e o urbano: zonas de chácaras, sítios de recreio ou ranchos e a preservação do meio ambiente. In: SEMINÁRIO NACIONAL SOBRE O TRATAMENTO DE ÁREAS DE PRESERVAÇÃO PERMANENTE EM MEIO URBANO E RESTRIÇÕES AMBIENTAIS AO PARCELAMENTO DO SOLO. 3., Painel "A Dimensão Ambiental da Cidade"; Belém, Universidade Federal do Pará (UFPA), 10 a 13 de setembro de 2014. Disponível em: <http://anpur.org.br/appurbana2014/anais/ARQUIVOS/GT31803520140518153453.pdf> Acesso em 20 jul. 2017. 
garantiu, de forma alguma, o acesso dos ex cativos a ela no momento posterior à Abolição. Ao contrário, a exclusão do segmento populacional negro em relação à propriedade da terra foi peremptoriamente estabelecida por meio de uma série de atos do poder legislativo ao longo do tempo. Ainda durante a escravidão, a Lei de Terras de 1850 veio substituir o direito à terra calcado na posse por um direito auferido via registros cartoriais que comprovassem o domínio de uma dada porção de terra. O direito legítimo adquirido através da posse efetiva é uma noção do 'direito costumeiro', que até hoje regeu a relação do campesinato tradicional com a terra, incluindo os grupos camponeses negros. ${ }^{13}$

Vê-se, pois, que, guardadas as distinções, a posse efetiva pela ocupação originária do território justifica, do ponto de vista jusfilosófico e dogmático, a proteção constitucional e dos direitos humanos dada às etnias indígenas no que tange à obrigatoriedade da demarcação e da preservação de suas terras pelos Estados. Assim, o tema das terras indígenas merece tratamento próprio até mesmo para se evitar a regularização fundiária de áreas rurais tradicionalmente ocupadas por essas etnias e que, por isso mesmo, não podem ser objeto de eventual regularização quando indevidamente ocupadas por terceiros.

\section{Considerações finais}

Independentemente das vertentes liberais ou comunitaristas da propriedade e da posse, os sistemas jurídicos nacionais e internacional reconhecem o direito fundamental e direito humano de moradia (a propriedade e a posse imobiliária urbana e rural), e o de uso da terra como possibilidade de sustento e de produção agropecuária (a propriedade e a posse imobiliária rural). Em ambos os casos, a propriedade e a posse são consideradas elementos indispensáveis ao desenvolvimento sustentável capaz de conciliar a produção da riqueza, a equidade socioeconômica e a proteção ambiental, quer nas cidades, quer no campo. Assim, são abordadas as temáticas da irregularidade da ocupação imobiliária urbana e rural e os diversos problemas que dela decorrem, tornando-se necessária a regularização fundiária, amparada em marcos legais e implementação de políticas públicas adequadas às suas distinções.

Em síntese, as hipóteses apresentadas na introdução foram comprovadas. Ou seja, à parte das concepções liberais ou comunitárias, que justificam tanto a propriedade e a posse públicas e/ou privadas, a ocupação imobiliária urbana ou rural irregulares necessita de regularização fundiária para viabilizar o direito fundamental e direito humano de acesso à moradia e ao uso social da terra produtiva, respectivamente. Como se tratam de realidades e problemas distintos, seria, porém, adequada a adoção de marcos legais e de políticas públicas específicas para a regularização fundiária urbana e a rural. A primeira tem por foco a legalização e a inserção da propriedade e da posse na estrutura regular das cidades. A segunda tem por objetivo a legalização e a inserção da propriedade e da posse na estrutura de produção no campo. Ambas as regularizações visam à efetividade do direito à moradia social e ambientalmente sustentáveis. No caso da regularização fundiária rural, acresce-se, ainda, o direito de uso da terra como política de equidade socioeconômica e de produção sustentável.

\section{REFERÊNCIAS BIBLIOGRÁFICAS}

Sobre o processo de sedentarização do ser humano e seus desdobramentos, recomenda-se a leitura de: CÂMARA CASCUDO, Luís da. Civilização e cultura; pesquisas e notas de etnografia geral. São Paulo: Global, 2004.

13 SCHMITT, Alessandra; TURATTI, Maria Cecília Manzoli; CARVALHO, Maria Celina Pereira de. A atualização do conceito de quilombo: identidade e território nas definições teóricas. Comunicação de Resultados de Pesquisa. Ambiente \& Sociedade, ano 5 , n. 10, semestral, 2002. Disponível em: <http://www.scielo.br/pdf/asoc/n10/16889.pdf>. Acesso em 21 jul. 2017. 
CORREIA, Rui Sá. No man's land. No man's time: contributo epistemológico para o conceito de paisagem, p. 21. Disponível em: <http://dspace.uevora.pt/rdpc/bitstream/10174/11838/1/NO\%20MAN\%27S\%20 LAND\%20.\%20NO\%20MAN\%27S\%20TIME.pdf>. Acesso em 21 jul. 2017.

OLIVEIRA, Márcio Luís de. A constituição juridicamente adequada. $2^{a}$ ed. Belo Horizonte: D’Plácido, 2016, p. 205.

CARVALHO, Osvaldo Ferreira de. Direitos humanos sociais: dever estatal de promoção e garantia dos direitos sociais e sua concretização judicial, p. 85, In: Direito \& Justiça, Porto Alegre, v. 38, n. 1, p. 77-90, jan./jun. 2012.

CARVALHO, Osvaldo Ferreira de. Direitos humanos sociais: dever estatal de promoção e garantia dos direitos sociais e sua concretização judicial, nota 80, p. 90, In: Direito \& Justiça, Porto Alegre, v. 38, n. 1, p. 77-90, jan./jun. 2012.

ARAÚJO, Giselle Marques de. Função Ambiental da Propriedade: uma proposta conceitual, p. 271, In: Revista Veredas do Direito, Belo Horizonte, v. 14, n. 28, p. 251-276, jan./abr. 2017. Disponível em: <http:// www.domhelder.edu.br/revista/index.php/veredas/article/view/985/546>. Acesso em 25 jul. 2017.

GROSTEIN, Marta Dora. Metrópole e expansão urbana: a persistência de processos “insustentáveis", resumo, In: São Paulo em Perspectiva. São Paulo, vol.15 no.1, Jan./Mar. 2001, versão online, disponível em: <http://dx.doi.org/10.1590/S0102-88392001000100003> Acesso em 19 jul. 2017

HESPANHOL, Rosângela Aparecida de Medeiros. A produção familiar: perspectivas de análise e inserção na microrregião geográfica de Presidente Prudente. Rio Claro, 2000, p. 322. Tese (Doutorado em Geografia). Programa de Pós-Graduação em Geografia do Instituto de Geociências e Ciências Exatas da Universidade Estadual Paulista.

BRITO, Brenda; BARRETO, Paulo. A regularização fundiária avançou na Amazônia?: os dois anos do Programa Terra-Legal. Belém, PA: Instituto do Homem e Meio Ambiente da Amazônia - IMAZON, 2011, p. 39.

Instituto Soma - Organização da Sociedade Civil de Interesse Público (OSCIP) reconhecida pelo Ministério da Justiça. Disponível em: <http://institutosoma.org.br/areas-de-atuacao/regularizacao-fundiaria/>. Acesso em 28 jul. 2017.

SANTORO, Paula Freire. Entre o rural e o urbano: zonas de chácaras, sítios de recreio ou ranchos e a preservação do meio ambiente, p. 11. Trabalho apresentado no APPURBANA 2014 - III Seminário Nacional sobre o Tratamento de Áreas de Preservação Permanente em Meio Urbano e Restrições Ambientais ao Parcelamento do Solo. Painel “A Dimensão Ambiental da Cidade”; Belém, Estado do Pará, Universidade Federal do Pará (UFPA), 10 a 13 de setembro de 2014. Disponível em: <http://anpur.org.br/app-urbana-2014/ anais/ARQUIVOS/GT3-180-35-20140518153453.pdf>. Acesso em 20 jul. 2017.

SANTORO, Paula Freire. Entre o rural e o urbano: zonas de chácaras, sítios de recreio ou ranchos e a preservação do meio ambiente, p. 19. Trabalho apresentado no APPURBANA 2014 - III Seminário Nacional sobre o Tratamento de Áreas de Preservação Permanente em Meio Urbano e Restrições Ambientais ao Parcelamento do Solo. Painel "A Dimensão Ambiental da Cidade"; Belém, Estado do Pará, Universidade Federal do Pará (UFPA), 10 a 13 de setembro de 2014. Disponível em: <http://anpur.org.br/app-urbana-2014/ anais/ARQUIVOS/GT3-180-35-20140518153453.pdf>. Acesso em 20 jul. 2017.

SCHMITT, Alessandra; TURATTI, Maria Cecília Manzoli; CARVALHO, Maria Celina Pereira de. A atualização do conceito de quilombo: identidade e território nas definições teóricas. Comunicação de Resultados de Pesquisa. Ambiente \& Sociedade, ano V, n 10, $1^{\circ}$ Semestre de 2002, p. 3. Disponível em: <http://www. scielo.br/pdf/asoc/n10/16889.pdf>. Acesso em 21 jul. 2017. 


\section{REVISTA BRASILEIRA DE POLÍTICAS PÚBLICAS BRAZILIAN JOURNAL OF PUBLIC POLICY}
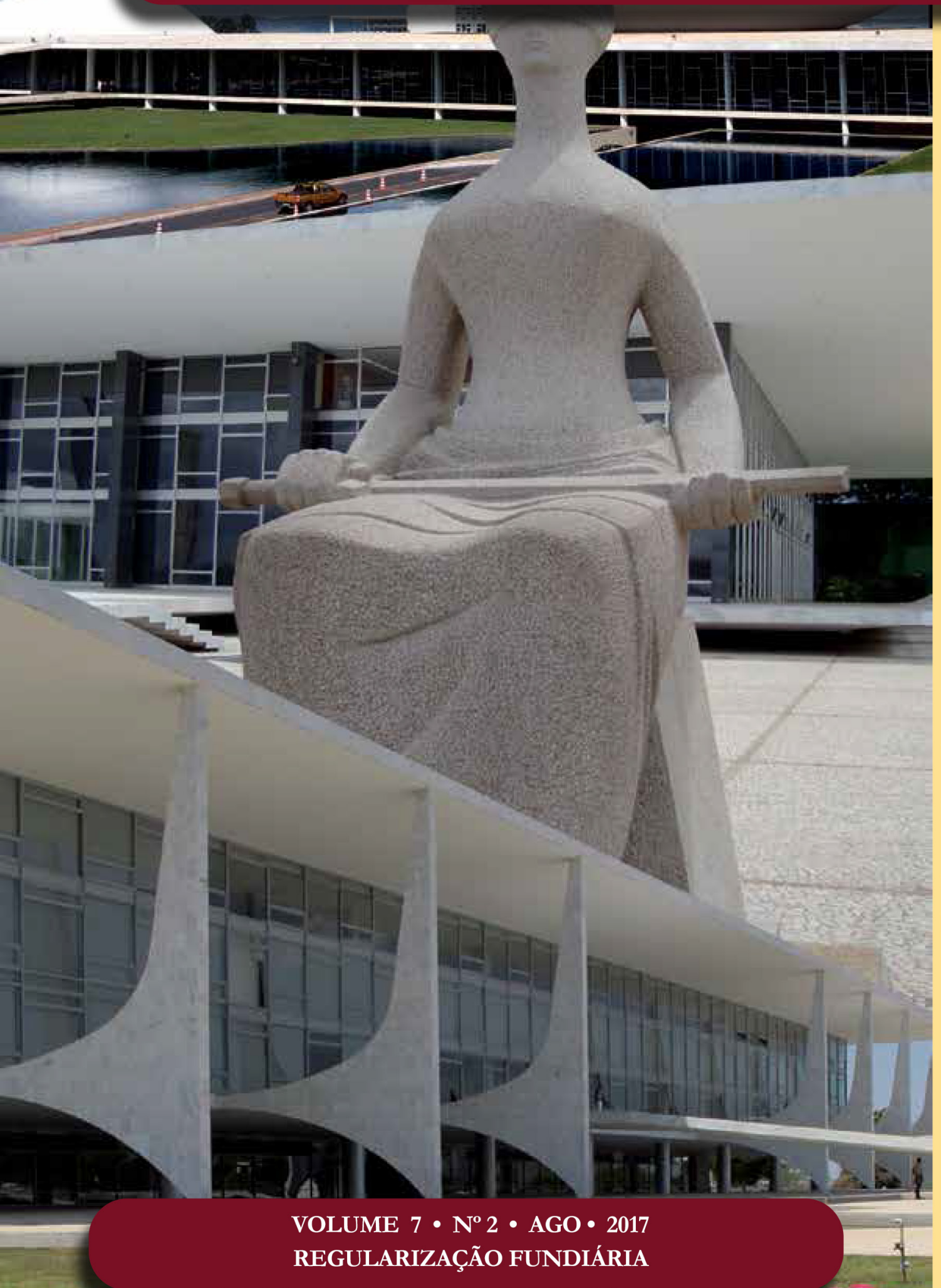

Perspectivas sobre a relação urbano-rural: repercussões jurídicas no imóvel agrário após a edição da lei n. 13.465/2017

Perspectives concerning the urban-rural relation: legal repercussions in the agrarian property after law n. 13.465/2017

Luana Nunes Bandeira Alves Luly Rodrigues da Cunha Fischer 


\section{Perspectivas sobre a relação urbano-rural: repercussões jurídicas no imóvel agrário após a edição da lei n. 13.465/2017*}

\author{
Perspectives concerning the urban-rural \\ relation: legal repercussions in the agrarian \\ property after law n. 13.465/2017
}

\author{
Luana Nunes Bandeira Alves** \\ Luly Rodrigues da Cunha Fischer***
}

* Recebido em 30/07/2017 Aprovado em 31/08/2017

** Mestre em Direito pela Universidade Federal do Pará. Advogada Residente da Clínica de Direitos Humanos da Amazônia. E-mail: luanabandeiraalves@gmail.com.

*** Doutora em Direito pela Universidade Federal do Pará e Universidade de Paris XIII em regime de co-tutela. Mestre em Direito pela Universidade Federal do Pará. Professora adjunta 1 nas disciplinas de Direito Agrário e Direito Ambiental da Universidade Federal do Pará. E-mail: lulyfischer@yahoo.com.

\section{Resumo}

Este trabalho analisa a definição do imóvel agrário com base em aporte teórico-jurisprudencial, objetivando formular considerações sobre qual regime jurídico de tributação e parcelamento a que ele está submetido após a edição da Lei Federal n. 13.465/2017. O processo metodológico foi a análise qualitativa a respeito da distinção entre os espaços urbanos e rurais, das definições e classificações do imóvel agrário, da incidência do Imposto Predial e Territorial Urbano e do Imposto sobre Propriedade Territorial Rural, bem como é discutido o regime de parcelamento do solo. Em um segundo momento, com base no método do caso americano, é feita uma análise jurisprudencial em sequência cronológica de decisões do Supremo Tribunal Federal, do Superior Tribunal de Justiça e dos Tribunais Regionais Federais sobre o tema. Verificou-se que, majoritariamente, a jurisprudência tem entendido que o imóvel agrário, localizado em área urbana, se submete à incidência do Imposto sobre Propriedade Territorial Rural, o que reflete tanto em questões propriamente agrárias quanto tributárias, envolvendo essa espécie de imóvel. Contudo, as recentes alterações legislativas modificaram, parcialmente, a primazia da legislação agrária sobre a urbanística nos casos de regularização fundiária de núcleos urbanos informais para fins de parcelamento do uso do solo. O artigo versa sobre tema de grande relevância prática e aborda a temática de forma inédita, em razão da recente edição do novo marco de regularização fundiária urbana no país.

Palavras-chave: Imóvel agrário. Destinação. Zona Urbana. Tributação. Regularização Fundiária. Parcelamento.

\section{Abstract}

This paper analyses the definition of agrarian property based in a theoretical and jurisprudential support to formulate considerations about the legal regime of taxation and land use of agrarian property after Law $\mathrm{n}$. 13.465/2017. At first, the methodological process was based on a qualitative analysis about the distinction between urban and rural areas, the incidence 
of Rural and Urban Land Taxes and criteria applied to land use. Secondly, it is presented a legal analysis using case method, using the Supreme Federal Court, Regional Federal Courts and Superior Justice Courts' rulings concerning this matter. The article concludes that in the Courts rulings prevails the understanding that the rural property located in urban areas is subject to rural taxation and rural land use laws. However, recent legislative modifications modified the primacy of the agrarian legislation over urban law in the cases of land tenure regularization in informal urban settlements for land use purposes. This article presents a theme of great practical relevance and brings an original approach to subject due the novelty of the New Federal Urban Land Tenure Regularization Policy in the country.

Keywords: Agrarian property. Destination. Urban Zone. Taxation. Land Tenure Regularization. Land Use.

\section{INTRODUÇÃo}

A relação entre urbano e rural tem sido discutida em diversos momentos históricos a partir de diferentes perspectivas e que resultam, consequentemente, no estabelecimento de distintos critérios para definir esses espaços. No entanto, com o desenvolvimento técnico-científico e o processo de globalização, essas diferenças espaciais têm sido, gradativamente, reduzidas, fortalecendo a noção de um "novo rural", sendo essa expressão utilizada para se referir ao cenário de desenvolvimento de atividades terciárias, como turismo e prestação de serviços nos espaços rurais.

Apesar de haver uma maior indiferenciação entre o urbano e o rural na contemporaneidade, essa dicotomia persiste na área jurídica, especialmente para fins tributários e de parcelamento e uso do solo. Ainda que desde 2001, em razão do advento da Lei do Estatuto da Cidade, o planejamento local deva considerar a totalidade do território municipal, a questão agrária é uma competência privativa da União, com pouca ou nenhuma ingerência estadual e local. Já a questão urbanística é uma competência comum, havendo sua execução sido tradicionalmente tratada no âmbito local. Portanto, a dicotomia entre a regulação do solo urbano e rural, na prática, persiste no Direito brasileiro, gerando diversos conflitos para o planejamento municipal.

Em razão do conflito de normas posto, o presente trabalho tem por objetivo investigar quais são as normas jurídicas que incidem sobre o imóvel agrário em áreas urbanas, bem como quais são as repercussões da Lei n. 13.465/2017 para essa discussão.

A metodologia empregada no presente artigo foi a análise qualitativa, utilizando as técnicas de revisão bibliográfica, documental e análise jurisprudencial.

A apresentação dos resultados foi organizada em três tópicos. Inicialmente, é realizada a discussão sobre essas diferentes vertentes relacionadas à distinção entre as áreas urbanas e rurais. Em seguida, apresentarmos a definição, as classificações e as regras de parcelamento do denominado imóvel agrário, sendo importante esclarecer que, embora a expressão utilizada pela legislação seja imóvel rural, neste trabalho, adota-se, preferencialmente, o uso do termo imóvel agrário com base em apontamentos doutrinários de classificação deste imóvel².

Destaca-se que essa questão, também, envolve a discussão sobre a distinção entre agrariedade e ruralidade no contexto da empresa agrária ${ }^{3}$. Assim, para o entendimento da discussão realizada neste artigo, considera-se mais adequada a utilização da terminologia imóvel agrário, uma vez que a agrariedade ${ }^{4}$ diz respeito à atividade agrícola a partir do ciclo agrobiológico e está consequentemente relacionada à destinação e uso do imóvel.

1 ENDLICH, Ângela Maria. Perspectivas sobre o urbano e o rural. In: SPOSITO, Maria Encarnação Beltrão; WHITACKER, Arthur Magon. (Org.). Cidade e campo: relações e contradições entre rural e urbano. São Paulo: Expressão Popular, 2006. p. 17.

2 REZEK, Gustavo Elias Kallás. Imóvel rural: agrariedade, ruralidade e rusticidade. Curitiba: Juruá, 2007. p. 71.

3 TRENTINI, Flavia. Teoria do direito agrário contemporâneo. São Paulo: Atlas, 2012. p. 26-28.

4 REZEK, Gustavo Elias Kallás. Imóvel rural: agrariedade, ruralidade e rusticidade. Curitiba: Juruá, 2007. p. 61-80. 
O termo rural está estritamente voltado à questão da localização, da espacialidade de forma restrita, o que o torna insuficiente para a discussão dos imóveis com destinação agrária localizados em espaços urbanos. Dessa forma, a expressão imóvel rural, somente, será empregada nos momentos em que for discutida a legislação que adota sua utilização.

Nesse contexto, discutem-se quais as implicações para o regime jurídico de tributação e de uso e parcelamento do solo aplicável nos casos em que esse imóvel esteja localizado em áreas urbanas, bem como qual regulação deverá prevalecer nos casos de conflito entre o planejamento federal e local segundo a jurisprudência do Supremo Tribunal Federal (STF), do Superior Tribunal de Justiça (STJ) e dos Tribunais Regionais Federais (TRFs) acerca dos aspectos teóricos discutidos sobre esse conflito normativo.

A pesquisa das decisões foi realizada a partir dos sítios eletrônicos de cada tribunal tendo por base as seguintes palavras-chave: imóvel rural IPTU, imóvel rural ITR, imóvel rural tributário e imóvel rural urbano. Esse método consiste na análise da jurisprudência a partir dos seguintes elementos: resumo dos fatos (facts), objeto da ação (issue), fundamentação (reasoning) e a decisão do Tribunal (bolding).

Segundo Luciana de Oliveira Ramos e Vivian Cristina Schorscher ${ }^{5}$, a ferramenta acadêmica acima descrita enfatiza mais a fundamentação e os argumentos que embasam a solução do que a resolução do caso em si.

Contudo, em cada uma das seções acima, discutiremos quais as inovações trazidas à discussão com a edição da Lei Federal n. 13.465/2017, que instituiu o novo marco da política de regularização fundiária urbana no país.

\section{Distinções ENTRE URBANo E RURAL}

A ideia de contraposição entre o urbano e o rural vem sendo superada por diversas razões que devem ser levadas em consideração. De acordo com Ângela Maria Endlich ${ }^{6}$, existem diferentes critérios de definição sobre o urbano e o rural a serem analisados complementarmente, são eles: limites oficiais ou delimitação administrativa, delimitação de um patamar demográfico, densidade demográfica e ocupação econômica da população.

O critério estabelecido a partir da delimitação administrativa remete à ideia de rural e urbano como adjetivos espaciais, pois se fundamenta nos limites estabelecidos oficialmente pelo Estado, sendo esta a concepção adotada pelo Brasil. Segundo Luly Rodrigues da Cunha Fischer ${ }^{7}$, a definição do perímetro urbano é uma das competências local a partir da qual o Município delimita o seu espaço para o exercício do poder de polícia de controle do parcelamento e uso do solo. Para essa definição, é utilizado o critério jurídico em consonância com o art. $3^{\circ}$ do Decreto-Lei n. $311 / 1938^{8}$.

Ainda a respeito do critério administrativo, é interessante notar que, de acordo com as lições de José Eli da Veiga ${ }^{9}$, em outros países, é comum a combinação entre critérios estruturais, como: número de habitantes

5 RAMOS, Luciana de Oliveira; SCHORSCHER, Vivian Cristina. Método do caso. In: GHIRARDI, José Garcez (Org.). Métodos de ensino em Direito: conceitos para um debate. São Paulo: Saraiva, 2009. p. 53.

6 ENDLICH, Angela Maria. Perspectivas sobre o urbano e o rural. In: SPOSITO, Maria Encarnação Beltrão; WHITACKER, Arthur Magon. (Org.). Cidade e campo: relações e contradições entre rural e urbano. São Paulo: Expressão Popular, 2006. p. 13.

7 FISCHER, Luly Rodrigues da Cunha. Ordenamento territorial e planejamento municipal: estudo de caso das limitações supralocais à aplicação do art. 30, VIII da Constituição de 1988 pelo município de Parauapebas, Pará. 2014. Tese (Doutorado em Direito) - Instituto de Ciências Jurídicas, Universidade Federal do Pará, Belém, 2014. p. 145-148.

8 BRASIL. Decreto-Lei $n$. 311, de 2 de março de 1938. Dispõe sobre a divisão territorial do país. Disponível em: <http://www2. camara.leg.br/legin/fed/declei/1930-1939/decreto-lei-311-2-marco-1938-351501-publicacaooriginal-1-pe.html>. Acesso em: 05 maio 2015.

9 VEIGA, José Eli da. Nem tudo é urbano. Cienc. Cult., São Paulo, v. 56, n. 2, p. 26-29, Apr. 2004. Disponível em: < http://cienciaecultura.bvs.br/scielo.php?script=sci_arttext\&pid=S0009-67252004000200016\&lng=en\&nrm=iso>. Acesso em: 26 jul. 2017. 
ou densidade; e funcionais, a exemplo dos serviços indispensáveis aos cidadãos, sendo que o Brasil se distingue mundialmente por considerar como cidades locais tão precários, nos quais não há sequer escolas ou transporte coletivo.

Segundo Ângela Maria Endlich ${ }^{10}$, as definições de caráter demográfico remetem à ideia de um rural como dispersão e o urbano enquanto aglomeração, porém, essa concepção mostra-se insuficiente para avaliar questões importantes, como, por exemplo: a riqueza ou a pobreza; e o nível de educação dos habitantes.

Atualmente, a vinculação à ocupação econômica se encontra superada, já que se fortalece o posicionamento de que diversas atividades vêm sendo desenvolvidas no campo, o que constitui o novo rural. Nesse sentido, José Eli da Veiga ${ }^{11}$ destaca que, nos territórios rurais mais dinâmicos, predominam as atividades terciárias, principalmente serviços que geram fluxo de capital, a exemplo do turismo e da recreação.

O Brasil tem passado por várias modificações socioeconômicas e em virtude dessas mudanças é que, de acordo com Ângela Maria Endlich ${ }^{12}$, os critérios analisados se mostram insuficientes para contemplar as complexidades entre urbano e rural. Por esse motivo, considera que a concepção de centralidade é aquela que se mostra mais adequada a esse novo contexto, pois não pressupõe limites fixos entre urbano e rural; ou seja, o urbano pode se estender para além das cidades, se relacionando, diretamente, com o rural e, consequentemente, superando a ideia de compartimentação entre essas áreas.

A partir de 2001, houve alterações jurídicas no ordenamento na regulação dos espaços urbanos, afetando, consequentemente a definição de rural. A primeira delas está contida no art. 39, \ $2^{\circ}$ da Lei n. 10.257/2001, determinando que "o plano diretor deverá englobar o território do Município como um todo"13. No entanto, tal determinação não superou a dicotomia entre o emprego do critério de urbano e rural na legislação brasileira.

Em 2009 foram editadas duas leis que trouxeram critérios de definição de área urbana. A primeira, a Lei n. 11.952/2009, dispõe sobre a regularização fundiária das ocupações incidentes em terras situadas em áreas da União, no âmbito da Amazônia Legal, que estabelece que "são passíveis de regularização fundiária as ocupações incidentes em terras públicas da União, [...] situadas em áreas urbanas, de expansão urbana ou de urbanização específica" (art. 21) ${ }^{14}$.

Essas doações ocorreriam nas áreas previstas no perímetro indicado na Lei Municipal de Ordenamento Territorial Urbano (plano diretor, em lei municipal específica para a área ou áreas objeto de regularização ou em outra lei municipal), sendo tal exigência dispensada, apenas, nos casos de áreas urbanas consolidadas $(\operatorname{art.~22})^{15}$.

O Decreto n. 7.341/2010, que regulamentou as disposições acima, define áreas urbanas consolidadas como aquelas que possuam: a) sistema viário implantado com vias de circulação pavimentadas ou não, que

10 ENDLICH, Ângela Maria. Perspectivas sobre o urbano e o rural. In: SPOSITO, Maria Encarnação Beltrão; WHITACKER, Arthur Magon. (Org.). Cidade e campo: relações e contradições entre rural e urbano. São Paulo: Expressão Popular, 2006. p. 14-15. 11 VEIGA, José Eli da. Mudanças nas relações entre espaços rurais e urbanos. In: PIQUET, Rosélia; OLIVEIRA, Elzira de. Economia e território no Brasil contemporâneo. 2007. Disponível em: < http://www.zeeli.pro.br/wp-content/uploads/2012/06/Mudancas_nas_relacoes_entre_espacos.pdf $>$. Acesso em: 10 jun. 2015.

12 ENDLICH, Ângela Maria. Perspectivas sobre o urbano e o rural. In: SPOSITO, Maria Encarnação Beltrão; WHITACKER, Arthur Magon. (Org.). Cidade e campo: relações e contradições entre rural e urbano. São Paulo: Expressão Popular, 2006. p. 19.

13 BRASIL. Lei n. 10.257, de 10 de julbo de 2001. Regulamenta os arts. 182 e 183 da Constituição Federal e estabelece diretrizes gerais da política urbana. Disponível em: < http://www.planalto.gov.br/ccivil_03/leis/LEIS_2001/L10257.htm>. Acesso em: 23 jun. 2015.

14 BRASIL. Lei n. 11.952, de 25 de junho de 2009. Dispõe sobre a regularização fundiária das ocupações incidentes em terras situadas em áreas da União, no âmbito da Amazônia Legal; altera as Leis nos 8.666, de 21 de junho de 1993, e 6.015, de 31 de dezembro de 1973; e dá outras providências. Disponível em: < http://www.planalto.gov.br/ccivil_03/_ato2007-2010/2009/lei/111952.htm>. Acesso em: 17 jun. 2017.

15 BRASIL. Lei n. 11.952, de 25 de junho de 2009. Dispõe sobre a regularização fundiária das ocupações incidentes em terras situadas em áreas da União, no âmbito da Amazônia Legal; altera as Leis nos 8.666, de 21 de junho de 1993, e 6.015, de 31 de dezembro de 1973; e dá outras providências. Disponível em: <http://www.planalto.gov.br/ccivil_03/_ato2007-2010/2010/Decreto/D7341. htm>. Acesso em: 17 jun. 2017. 
configuram a área urbana por meio de quadras e lotes; b) uso predominantemente urbano, caracterizado pela existência de instalações e edificações residenciais, comerciais, voltadas à prestação de serviços, industriais, institucionais ou mistas, bem como demais equipamentos públicos urbanos e comunitários $\left(\operatorname{art} .2^{0}\right)^{16}$.

Assim, percebe-se que, além do tradicional critério administrativo, passou o ordenamento jurídico a considerar o elemento da destinação efetiva, isto é, a função urbana, independentemente da localização urbana ou rural para fins de regularização fundiária. Esse critério, no entanto, aplica-se, somente, aos municípios localizados na Amazônia Legal.

A segunda norma editada foi a Lei n. 11.977/2009 ${ }^{17}$ que dispunha sobre a regularização fundiária de assentamentos localizados em área urbana cabendo ao município a competência para executar esse procedimento, de acordo com Andreza Aparecida Franco Câmara ${ }^{18}$. Atualmente, se encontra revogada e definia a área urbana como "parcela do território, contínua ou não, incluída no perímetro urbano pelo Plano Diretor ou por lei municipal específica" e área urbana consolidada como "parcela da área urbana com densidade demográfica superior a cinquenta habitantes por hectare e malha viária implantada e que tenha, no mínimo, dois dos seguintes equipamentos de infraestrutura urbana implantados: a) drenagem de águas pluviais urbana; b) esgotamento sanitário; c) abastecimento de água potável; d) distribuição de energia elétrica; ou e) limpeza urbana, coleta e manejo de resíduos sólidos” (art. 47) ${ }^{19}$.

Nessa lei, diferentemente do que ocorre com a legislação voltada à regularização urbana na Amazônia legal, que não autorizava, expressamente, a regularização fundiária urbana fora dos limites administrativos estabelecidos pela legislação municipal, prevalecendo, em nível nacional, o critério administrativo. O uso do conceito de área urbana, consolidada no caso da lei em comento, tinha finalidade de criar critérios objetivos para autorizar ou não a intervenção em áreas de preservação permanente situadas em núcleos urbanos contínuos ou descontínuos, assim definidos por legislação municipal.

É por essa razão que a Lei n. 12.651/2012, conhecida como Novo Código Florestal, incorporou a definição de área urbana consolidada da Lei n. 11.977/2009, utilizando, cumulativamente, o critério demográfico e administrativo para autorizar a regularização fundiária de interesse social em áreas de preservação permanente, realização de obras habitacionais e de urbanização $\left(\operatorname{art.} 7^{\circ}, \$ 2^{\circ}\right)^{20}$, não havendo qualquer inovação sobre a matéria.

A Lei n. 13.465/2017, que dispõe sobre a regularização fundiária rural e urbana, sobre a liquidação de créditos concedidos aos assentados da reforma agrária e sobre a regularização fundiária no âmbito da Amazônia Legal, alterou as disposições acima descritas, introduzindo uma nova definição de urbano para fins de

16 BRASIL. Decreto n. 7.341, de 22 de outubro de 2010. Regulamenta a Lei n. 11.952, de 25 de junho de 2009, para dispor sobre a regularização fundiária das áreas urbanas situadas em terras da União no âmbito da Amazônia Legal, definida pela Lei Complemen$\operatorname{tar} n^{\circ} 124$, de 3 de janeiro de 2007, e dá outras providências. Disponível em: < http://www.planalto.gov.br/ccivil_03/_ato20072010/2009/lei/111952.htm>. Acesso em: 17 jun. 2017.

17 BRASIL. Lei n. 11.977, de 7 de julho de 2009. Dispõe sobre o Programa Minha Casa, Minha Vida - PMCMV e a regularização fundiária de assentamentos localizados em áreas urbanas; altera o Decreto-Lei n³.365, de 21 de junho de 1941, as Leis $\mathrm{n}^{\text {os }} 4.380$, de 21 de agosto de 1964, 6.015, de 31 de dezembro de 1973, 8.036, de 11 de maio de 1990, e 10.257, de 10 de julho de 2001, e a Medida Provisória no 2.197-43, de 24 de agosto de 2001; e dá outras providências. Disponível em: <http://www.planalto.gov.br/ ccivil_03/_ato2007-2010/2009/lei/111977.htm>. Acesso em: 11 jun. 2017.

18 CÂMARA, Andreza Aparecida. Políticas Públicas de Habitação e o programa de aceleração do crescimento: análise das intervenções no estado do Rio de Janeiro. Revista Brasileira de Políticas Públicas, Brasilia, v. 1, n. 3 - número especial, p. 145-178, dez. 2011. p. 167.

19 BRASIL. Lei n. 11.977, de 7 de julho de 2009. Dispõe sobre o Programa Minha Casa, Minha Vida - PMCMV e a regularização fundiária de assentamentos localizados em áreas urbanas; altera o Decreto-Lei n³.365, de 21 de junho de 1941, as Leis $n^{\circ 5} 4.380$, de 21 de agosto de 1964, 6.015, de 31 de dezembro de 1973, 8.036, de 11 de maio de 1990, e 10.257, de 10 de julho de 2001 , e a Medida Provisória no 2.197-43, de 24 de agosto de 2001; e dá outras providências. Disponível em: <http://www.planalto.gov.br/ ccivil_03/_ato2007-2010/2009/lei/111977.htm>. Acesso em: 11 jun. 2017.

20 BRASIL. Lei n. 12.651, de 25 de maio de 2012. Dispõe sobre a proteção vegetal nativa. Disponível em: < http://www.planalto. gov.br/ccivil_03/_ato2011-2014/2012/lei/112651.htm>. Acesso em: 23 jun. 2015. 
regularização, que é a de núcleos urbanos informais $\left(\operatorname{art.} 9^{\circ}, \int 1^{\circ}\right)^{21}$. Segundo a nova lei, um núcleo urbano é definido como um:

Assentamento humano, com uso e características urbanas, constituído por unidades imobiliárias de área inferior à fração mínima de parcelamento prevista na Lei no 5.868, de 12 de dezembro de 1972, independentemente da propriedade do solo, ainda que situado em área qualificada ou inscrita como rural.

Essa definição é aplicável mesmo aos imóveis localizados em área rural, ou seja, em áreas não previstas no plano diretor como urbanas, de expansão urbana ou de urbanização específica, sendo interessante destacar que ficaram excluídas dessa lei os núcleos urbanos informais situados em áreas indispensáveis à segurança nacional ou de interesse da defesa, assim reconhecidas em decreto do Poder Executivo federal.

Nesse contexto, a única exigência é de que o espaço ocupado pelo núcleo urbano informal tenha área inferior à fração mínima de parcelamento na região, sendo caracterizado pela legislação agrária como um minifúndio.

Já o núcleo urbano informal é aquele classificado como "clandestino, irregular ou no qual não foi possível realizar, por qualquer modo, a titulação de seus ocupantes, ainda que atendida a legislação vigente à época

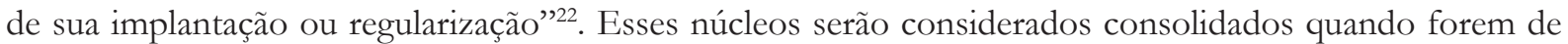
difícil reversão, identificado o tempo da ocupação, a natureza das edificações, a localização das vias de circulação e a presença de equipamentos públicos, entre outras circunstâncias a serem avaliadas pelo Município.

Se esses núcleos urbanos informais estiverem situados, total ou parcialmente, em área de preservação permanente, em área de unidade de conservação de uso sustentável ou de proteção de mananciais se torna obrigatória a elaboração de estudos técnicos que justifiquem as melhorias ambientais em relação à situação de ocupação informal anterior, inclusive por meio de compensações ambientais, quando for o caso.

Nota-se que, quando a regularização fundiária abranger área de unidade de conservação de uso sustentável que admita regularização, será exigida, também, a anuência do órgão gestor da unidade, desde que estudo técnico comprove que essas intervenções de regularização fundiária implicam a melhoria das condições ambientais em relação à situação de ocupação informal anterior.

21 BRASIL. Lei n. 13.465, de 11 de julho de 2017. Dispõe sobre a regularização fundiária rural e urbana, sobre a liquidação de créditos concedidos aos assentados da reforma agrária e sobre a regularização fundiária no âmbito da Amazônia Legal; institui mecanismos para aprimorar a eficiência dos procedimentos de alienação de imóveis da União; altera as Leis nos 8.629 , de 25 de fevereiro de 1993, 13.001, de 20 de junho de 2014, 11.952, de 25 de junho de 2009, 13.340, de 28 de setembro de 2016, 8.666, de 21 de junho de 1993, 6.015, de 31 de dezembro de 1973, 12.512, de 14 de outubro de 2011, 10.406, de 10 de janeiro de 2002 (Código Civil), 13.105, de 16 de março de 2015 (Código de Processo Civil), 11.977, de 7 de julho de 2009, 9.514, de 20 de novembro de 1997, 11.124, de 16 de junho de 2005, 6.766, de 19 de dezembro de 1979, 10.257, de 10 de julho de 2001, 12.651, de 25 de maio de 2012, 13.240, de 30 de dezembro de 2015, 9.636, de 15 de maio de 1998, 8.036, de 11 de maio de 1990, 13.139, de 26 de junho de 2015, 11.483, de 31 de maio de 2007, e a 12.712, de 30 de agosto de 2012, a Medida Provisória no 2.220, de 4 de setembro de 2001, e os Decretos-Leis nos 2.398, de 21 de dezembro de 1987, 1.876, de 15 de julho de 1981, 9.760, de 5 de setembro de 1946, e 3.365, de 21 de junho de 1941; revoga dispositivos da Lei Complementar no 76, de 6 de julho de 1993, e da Lei no 13.347, de 10 de outubro de 2016; e dá outras providências. Disponível em: <http://www.planalto.gov.br/ccivil_03/_ato2015-2018/2017/lei/ L13465.htm>. Acesso em: 25 jul. 2017.

22 BRASIL. Lei n. 13.465, de 11 de julho de 2017. Dispõe sobre a regularização fundiária rural e urbana, sobre a liquidação de créditos concedidos aos assentados da reforma agrária e sobre a regularização fundiária no âmbito da Amazônia Legal; institui mecanismos para aprimorar a eficiência dos procedimentos de alienação de imóveis da União; altera as Leis nos 8.629 , de 25 de fevereiro de 1993, 13.001, de 20 de junho de 2014, 11.952, de 25 de junho de 2009, 13.340, de 28 de setembro de 2016, 8.666, de 21 de junho de 1993, 6.015, de 31 de dezembro de 1973, 12.512, de 14 de outubro de 2011, 10.406, de 10 de janeiro de 2002 (Código Civil), 13.105, de 16 de março de 2015 (Código de Processo Civil), 11.977, de 7 de julho de 2009, 9.514, de 20 de novembro de 1997, 11.124, de 16 de junho de 2005, 6.766, de 19 de dezembro de 1979, 10.257, de 10 de julho de 2001, 12.651, de 25 de maio de 2012, 13.240, de 30 de dezembro de 2015, 9.636, de 15 de maio de 1998, 8.036, de 11 de maio de 1990, 13.139, de 26 de junho de 2015, 11.483, de 31 de maio de 2007, e a 12.712, de 30 de agosto de 2012, a Medida Provisória n ${ }^{\circ} 2.220$, de 4 de setembro de 2001, e os Decretos-Leis $\mathrm{n}^{\mathrm{os}} 2.398$, de 21 de dezembro de 1987, 1.876, de 15 de julho de 1981, 9.760, de 5 de setembro de 1946, e 3.365, de 21 de junho de 1941; revoga dispositivos da Lei Complementar $n^{\circ} 76$, de 6 de julho de 1993, e da Lei no 13.347 , de 10 de outubro de 2016; e dá outras providências. Disponível em: <http://www.planalto.gov.br/ccivil_03/_ato2015-2018/2017/lei/L13465.htm>. Acesso em: 25 jul. 2017. 
Destaca-se que casos em que ocupação tenha ocorrido às margens de reservatórios artificiais de água destinados à geração de energia ou ao abastecimento público, a faixa da área de preservação permanente consistirá na distância entre o nível máximo operativo normal e a cota máxima maximorum.

Nesse contexto, pode-se afirmar que a nova legislação abandona o critério administrativo para fins de regularização fundiária, considerando apenas a destinação efetiva da área ocupada para funções urbanas. A prévia definição da área como urbana, tradicional no ordenamento jurídico brasileiro, foi superada, sendo compatível com a noção de planejamento territorial municipal único, prevista no Estatuto da Cidade. No caso da Amazônia Legal, mesmo após as modificações ocorridas no ano de 2017, a regra da destinação permanece válida, apenas, para as áreas urbanas consolidadas.

Contudo, o critério da destinação efetiva pode afetar tanto o planejamento das cidades, gerando descontrole da expansão da mancha urbana, como prejudicar a segurança alimentar do território, pois a conversão do solo rural em urbano é altamente rentável para fins de especulação imobiliária. Para limitar esse possível efeito adverso, essa regularização limita-se aos imóveis rurais classificados como minifúndios, ou seja, que perderam de fato sua capacidade produtiva.

\section{IMÓVEL AGRÁRIO: DEFINIÇÃO, CLASSIFICAÇÕES E REGRAS DE PARCELAMENTO}

A definição de imóvel rural foi unificada na legislação agrária e tributária, aplicando-se também o critério da destinação efetiva. O conceito legal no citado inciso I do art. $4^{\circ}$ do Estatuto da Terra (Lei n. 4.504/64) ${ }^{23}$, atualizado, após a Constituição Federal de 1988 (CF/1988) ${ }^{24}$, pelo coincidente inc. I do art. $4^{\circ}$ da Lei n. $8.629 / 1993^{25}$, o define como o prédio rústico de área contínua, qualquer que seja a sua localização, que se destine ou possa se destinar à atividade agrária.

O conceito de rústico está ligado à noção de não edificado. No entanto, com o desenvolvimento técnico-científico, esse elemento deixa de ser uma característica essencial para a definição ${ }^{26}$ ocorrendo predominantemente em meio rural ${ }^{27}$. Nesse sentido, é esclarecedor o precedente do STJ sobre o tema, ao estabelecer que “[o] critério para a aferição da natureza do imóvel, para sua classificação, se urbano ou rural, para fins de desapropriação, leva em consideração não apenas sua localização geográfica, mas também a destinação do bem"28.

Este, também, é o entendimento que se depreende da leitura do art. $4^{\circ}$, I, do Estatuto da Terra ${ }^{29}$, que deixa em segundo o plano o critério da localização para definir imóvel rural, colocando em evidência a forma de exploração extrativa agrícola, pecuária ou agroindustrial.

A expressão área contínua está ligada à continuidade econômica da atividade agrária, e não à mera continuidade física. Por essa razão, a existência de estrada, cerca ou rio, desde que não atrapalhe o exercício da atividade e a circulação, não descaracteriza o elemento da área contínua. Nesse sentido dispõe o Ato Declaratório n. 9/1998 da Secretaria da Receita Federal ${ }^{30}$, que dispõe que:

23 BRASIL. Lei n. 4.504, de 30 de novembro de 1964. Dispõe sobre o Estatuto da Terra. Disponível em: <http://www.planalto.gov. br/ccivil_03/leis/L4504.htm>. Acesso em: 05 maio 2015.

24 BRASIL. Constituição (1998). Constituição da República Federativa do Brasil. Disponível em: <www.planalto.gov.br/ccivil_03/ constituicao/constituicao.htm>. Acesso em: 05 maio 2015.

25 BRASIL. Lei $n$. 8.629, de 25 de fevereiro de 1993. Regulamenta os dispositivos constitucionais relativos à reforma agrária. Disponível em: <http://www.planalto.gov.br/ccivil_03/leis/L8629.htm>. Acesso em: 5 maio 2015.

26 ROCHA, Olavo Acyr de Lima. A desapropriação no direito agrário. São Paulo: Atlas, 1992. p. 80.

27 REZEK, Gustavo Elias Kallás. Imóvel Agrário: agrariedade, ruralidade e rusticidade. Curitiba: Juruá, 2008. p. 48.

28 BRASIL. Supremo Tribunal de Justiça. RESP 1170055/TO, Rel. Min. Eliana Calmon, publicação DJ de DJ de 24/6/2010.

29 BRASIL. Lei n. 4.504, de 30 de novembro de 1964. Dispõe sobre o Estatuto da Terra. Disponível em: <http://www.planalto.gov. br/ccivil_03/leis/L4504.htm>. Acesso em: 05 maio 2015.

30 BRASIL. Secretaria da Receita Federal. Ato Declaratório Normativo COSIT n. 9, de 31 de julho de 1998. Entendimento da expressão 
I - a expressão "área contínua" de que trata o $\$ 2^{\circ}$ do art. $1^{\circ}$ da Lei 9.393, de 19.12.1996, tem o sentido de continuidade econômica, de utilidade econômica e de aproveitamento da propriedade rural;

II - considera-se imóvel rural de área contínua a área do prédio rústico seja ela um todo único, indivisível, seja ela dividida fisicamente por estrada, rodovia, ferrovia ou por um rio.

É oportuno destacar que, de acordo com as lições de Gustavo Elias Kallás Rezek ${ }^{31}$, a continuidade econômica deve ser seguida pela proximidade física das áreas. Assim, a lei agrária ameniza o conceito da continuidade física do direito civil, mas não o despreza por completo. Deve-se analisar caso a caso, razão pela qual adota a expressão continuidade físico-econômica, que reflete a necessidade de continuidade econômica agregada à proximidade física entre as áreas passíveis de exploração.

Cumpre observar que a possibilidade de descontinuidade não é, apenas, espacial, mas registral. O imóvel rural contínuo, assim, poderá ser constituído por uma ou mais propriedades rurais, inclusive de proprietários diferentes. Nesse sentido destacamos precedente do STF, que estabelece que "[a] existência de condomínio sobre o imóvel rural não impede a desapropriação-sanção do art. 184 da Constituição do Brasil, cujo alvo é o imóvel rural que não esteja cumprindo sua função social" 32 .

Por fim, cumpre destacar a questão da afetação potencial dos imóveis agrários contida na definição. A Instrução Normativa (IN) n. 17-B, de 22 de dezembro de $1980^{33}$, que dispõe sobre o parcelamento de imóveis rurais, estabelece as hipóteses de necessidade de prévia anuência do Instituto Nacional de Colonização e Reforma Agrária (INCRA). Nos casos de parcelamento para fins urbanos de imóvel rural localizado em zona urbana ou de expansão urbana, cabe ao INCRA apenas realizar a atualização do cadastro rural, contanto que o parcelamento esteja previamente aprovado pela Prefeitura e registrado no Cartório de Registro de Imóveis.

Já nos casos de parcelamentos urbanos localizados fora da zona urbana ou na zona de expansão urbana, o ato normativo do INCRA determina que é de sua competência exclusiva, a requerimento do interessado, autorizar a conversão de solo rural em urbano. Assim, a alteração de uso será autorizada nos casos em que: a) por suas características e situação, seja própria para a localização de serviços comunitários das áreas rurais circunvizinhas; b) seja oficialmente declarada zona de turismo ou caracterizada como de estância hidromineral ou balneária; e c) comprovadamente tenha perdido suas características produtivas, tornando antieconômico o seu aproveitamento.

Essas medidas têm por objetivo assegurar a disponibilidade de terras para o uso agrário, garantindo a segurança alimentar. No entanto, essa restrição para Municípios cujo crescimento urbano é rápido, como no caso dos que estão sujeitos a elevado fluxo migratório na Amazônia Legal, o poder local tem pouca capacidade de interferir no processo de parcelamento do solo nas áreas de expansão urbana e de urbanização específica.

A Lei n. 13.465/2017 $7^{34}$ conferiu maior poder ao Município para promover a regularização fundiária em

\footnotetext{
“área contínua” constante do $\$ 2^{\circ}$ do art. $1^{\circ}$ da Lei n. 9.393/1996. Disponível em: < http:// normas.receita.fazenda.gov.br/sijut2consulta/link.action?visao $=$ anotado\&idAto $=5843>$. Acesso em: 25 jul. 2017.

31 REZEK, Gustavo Elias Kallás. Imóvel Agrário: agrariedade, ruralidade e rusticidade. Curitiba: Juruá, 2008. p. 53.

32 BRASIL. Supremo Tribunal Federal. MS 24.503, Rel. Min. Marco Aurélio, publicação DJ de 05/09/2003.

33 BRASIL. Instrução Normativa n. 17-B, de 22 de dezembro, de 1980. Dispõe sobre o parcelamento de imóveis rurais. Disponível em: < http:// www.incra.gov.br/media/institucional/legislacao/atos_internos/instrucoes/instrucao/I17b_221280.pdf>. Acesso em: 23 jun. 2015.

34 BRASIL. Lei n. 13.465, de 11 de julho de 2017. Dispõe sobre a regularização fundiária rural e urbana, sobre a liquidação de créditos concedidos aos assentados da reforma agrária e sobre a regularização fundiária no âmbito da Amazônia Legal; institui mecanismos para aprimorar a eficiência dos procedimentos de alienação de imóveis da União; altera as Leis nos 8.629 , de 25 de fevereiro de 1993, 13.001, de 20 de junho de 2014, 11.952, de 25 de junho de 2009, 13.340, de 28 de setembro de 2016, 8.666, de 21 de junho de 1993, 6.015, de 31 de dezembro de 1973, 12.512, de 14 de outubro de 2011, 10.406, de 10 de janeiro de 2002 (Código Civil), 13.105, de 16 de março de 2015 (Código de Processo Civil), 11.977, de 7 de julho de 2009, 9.514, de 20 de novembro de 1997, 11.124, de 16 de junho de 2005, 6.766, de 19 de dezembro de 1979, 10.257, de 10 de julho de 2001, 12.651, de 25 de maio de 2012, 13.240, de 30 de dezembro de 2015, 9.636, de 15 de maio de 1998, 8.036, de 11 de maio de 1990, 13.139, de 26 de junho de 2015, 11.483, de 31 de maio de 2007, e a 12.712, de 30 de agosto de 2012, a Medida Provisória no 2.220, de 4 de setembro de 2001, e os Decretos-Leis $n^{\text {os }} 2.398$, de 21 de dezembro de 1987, 1.876, de 15 de julho de 1981, 9.760, de 5 de setembro de 1946, e 3.365 ,
} 
áreas de expansão urbana e de urbanização específica. Com a mudança do conceito de núcleo urbano, a regra da Instrução Normativa do INCRA n. $17-B / 1980^{35}$ foi parcialmente afastada pela nova lei federal. Com base nas novas regras de regularização fundiária, compete, exclusivamente, aos Municípios, que estejam situados os núcleos urbanos informais a serem regularizados, classificar a modalidade de regularização; processar análises, aprovar os projetos propostos e emitir a Certidão de Regularização Fundiária (CRF) (art. $30)^{36}$.

A CRF é definida como ato administrativo de aprovação da regularização que deverá acompanhar o projeto aprovado (art. 41) 37 $^{37}$ apresentando no mínimo: a) o nome do núcleo urbano regularizado; b) a localização; c) a modalidade da regularização; d) as responsabilidades das obras e serviços constantes do cronograma; e) a indicação numérica de cada unidade regularizada, quando houver; e f) a listagem com nomes dos ocupantes que tiverem adquirido a respectiva unidade, por título de legitimação fundiária ou mediante ato único de registro, bem como o estado civil, a profissão, o número de inscrição no cadastro das pessoas físicas do Ministério da Fazenda e do registro geral da cédula de identidade e a filiação.

A referida certidão de regularização fundiária substitui a exigência anterior do licenciamento urbanístico-ambiental integrado prevista na Lei n. 11.977/200938 no processo de aprovação dos projetos de regularização fundiária urbana. Esse ato, também, substitui os processos individuais de titulação da área regularizada, pois nela, também, está contida a listagem com nomes dos ocupantes que tenham adquirido a respectiva unidade por título de legitimação fundiária ou mediante ato único de registro.

de 21 de junho de 1941; revoga dispositivos da Lei Complementar n ${ }^{\circ}$ 76, de 6 de julho de 1993, e da Lei n 13.347 , de 10 de outubro de 2016; e dá outras providências. Disponível em: <http://www.planalto.gov.br/ccivil_03/_ato2015-2018/2017/lei/L13465.htm>. Acesso em: 25 jul. 2017.

35 BRASIL. Instrução Normativa n. 17-B, de 22 de dezembro, de 1980. Dispõe sobre o parcelamento de imóveis rurais. Disponível em: <http://www.incra.gov.br/media/institucional/legislacao/atos_internos/instrucoes/instrucao/I17b_221280.pdf>. Acesso em: 23 jun. 2015.

36 BRASIL. Lei n. 13.465, de 11 de julho de 2017. Dispõe sobre a regularização fundiária rural e urbana, sobre a liquidação de créditos concedidos aos assentados da reforma agrária e sobre a regularização fundiária no âmbito da Amazônia Legal; institui mecanismos para aprimorar a eficiência dos procedimentos de alienação de imóveis da União; altera as Leis nos 8.629 , de 25 de fevereiro de 1993, 13.001, de 20 de junho de 2014, 11.952, de 25 de junho de 2009, 13.340, de 28 de setembro de 2016, 8.666, de 21 de junho de 1993, 6.015, de 31 de dezembro de 1973, 12.512, de 14 de outubro de 2011, 10.406, de 10 de janeiro de 2002 (Código Civil), 13.105, de 16 de março de 2015 (Código de Processo Civil), 11.977, de 7 de julho de 2009, 9.514, de 20 de novembro de 1997, 11.124, de 16 de junho de 2005, 6.766, de 19 de dezembro de 1979, 10.257, de 10 de julho de 2001, 12.651, de 25 de maio de 2012, 13.240, de 30 de dezembro de 2015, 9.636, de 15 de maio de 1998, 8.036, de 11 de maio de 1990, 13.139, de 26 de junho de 2015, 11.483, de 31 de maio de 2007, e a 12.712, de 30 de agosto de 2012, a Medida Provisória no 2.220, de 4 de setembro de 2001, e os Decretos-Leis $\mathrm{n}^{\text {os }} 2.398$, de 21 de dezembro de 1987, 1.876, de 15 de julho de 1981, 9.760, de 5 de setembro de 1946, e 3.365, de 21 de junho de 1941; revoga dispositivos da Lei Complementar $n^{\circ} 76$, de 6 de julho de 1993, e da Lei no 13.347 , de 10 de outubro de 2016; e dá outras providências. Disponível em: <http://www.planalto.gov.br/ccivil_03/_ato2015-2018/2017/lei/L13465.htm>. Acesso em: 25 jul. 2017.

37 BRASIL. Lei n. 13.465, de 11 de julho de 2017. Dispõe sobre a regularização fundiária rural e urbana, sobre a liquidação de créditos concedidos aos assentados da reforma agrária e sobre a regularização fundiária no âmbito da Amazônia Legal; institui mecanismos para aprimorar a eficiência dos procedimentos de alienação de imóveis da União; altera as Leis nos 8.629 , de 25 de fevereiro de 1993, 13.001, de 20 de junho de 2014, 11.952, de 25 de junho de 2009, 13.340, de 28 de setembro de 2016, 8.666 , de 21 de junho de 1993, 6.015, de 31 de dezembro de 1973, 12.512, de 14 de outubro de 2011, 10.406, de 10 de janeiro de 2002 (Código Civil), 13.105, de 16 de março de 2015 (Código de Processo Civil), 11.977, de 7 de julho de 2009, 9.514, de 20 de novembro de 1997, 11.124, de 16 de junho de 2005, 6.766, de 19 de dezembro de 1979, 10.257, de 10 de julho de 2001, 12.651, de 25 de maio de 2012, 13.240, de 30 de dezembro de 2015, 9.636, de 15 de maio de 1998, 8.036, de 11 de maio de 1990, 13.139, de 26 de junho de 2015, 11.483, de 31 de maio de 2007, e a 12.712, de 30 de agosto de 2012, a Medida Provisória no 2.220, de 4 de setembro de 2001, e os Decretos-Leis nos 2.398, de 21 de dezembro de 1987, 1.876, de 15 de julho de 1981, 9.760, de 5 de setembro de 1946, e 3.365, de 21 de junho de 1941; revoga dispositivos da Lei Complementar no 76, de 6 de julho de 1993, e da Lei no 13.347, de 10 de outubro de 2016; e dá outras providências. Disponível em: <http://www.planalto.gov.br/ccivil_03/_ato2015-2018/2017/lei/L13465.htm>. Acesso em: 25 jul. 2017.

38 BRASIL. Lei n. 11.977, de 7 de julho de 2009. Dispõe sobre o Programa Minha Casa, Minha Vida - PMCMV e a regularização fundiária de assentamentos localizados em áreas urbanas; altera o Decreto-Lei n³.365, de 21 de junho de 1941, as Leis $\mathrm{n}^{\circ \mathrm{s}} 4.380$, de 21 de agosto de 1964, 6.015, de 31 de dezembro de 1973, 8.036, de 11 de maio de 1990, e 10.257, de 10 de julho de 2001 , e a Medida Provisória n 2.197-43, de 24 de agosto de 2001; e dá outras providências. Disponível em: <http://www.planalto.gov.br/ ccivil_03/_ato2007-2010/2009/lei/111977.htm>. Acesso em: 11 jun. 2017. 
Esse ato administrativo é igualmente responsável por suprir o processo de desafetação do INCRA dos imóveis rurais com parcela inferior ao menor módulo rural, ou seja, das propriedades rurais classificadas

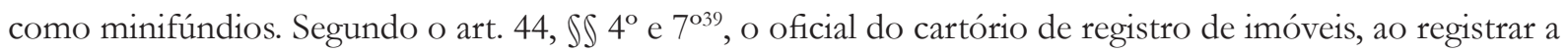
CRF, não necessita da averbação prévia do cancelamento do cadastro de imóvel rural no INCRA.

Em verdade, como a desafetação nessas hipóteses se dá com a expedição da CRF, o oficial do cartório de registro de imóveis notificará o INCRA, o Ministério do Meio Ambiente e a Secretaria da Receita Federal do Brasil apenas após o registro da CRF, para que esses órgãos cancelem os respectivos registros existentes no Cadastro Ambiental Rural (CAR) e nos demais cadastros relacionados a imóvel rural, relativamente às unidades imobiliárias regularizadas.

É importante esclarecer que o Estatuto da Terra, em seu artigo $4^{040}$; e o Decreto n. $55.891 / 1965^{41}$, no artigo $6^{\circ}$, classificam o imóvel agrário a partir das seguintes modalidades: minifúndio, propriedade familiar, empresa rural, latifúndio por exploração e latifúndio por dimensão. Todas as referidas modalidades se relacionam ao conceito de módulo rural que - de acordo com o art. $5^{\circ}$ do Estatuto da Terra ${ }^{42}$; e o art. 14 do Decreto $^{43}$ acima citado — diz respeito à área mínima de parcelamento do solo, economicamente aproveitável em cada localidade.

O minifúndio, previsto no art. $4^{\circ}$, inc. IV, é conceituado como o imóvel agrário com área agricultável inferior ao módulo mínimo para a região em que se localiza e o tipo de exploração a qual se destina. Por ser inferior ao mínimo necessário para obter rentabilidade com a exploração econômica da terra, o minifúndio resulta em pobreza e prática predatória dos recursos naturais, sendo, portanto, proibido pelo art. 65 do Estatuto da Terra, conforme salienta Gustavo Elias Kallás Rezek ${ }^{44}$. É somente nesses casos que a Lei n. 13.465/2017 $7^{45}$ atribuiu competência aos Municípios para a desafetação automática do imóvel rural.

39 BRASIL. Lei n. 13.465, de 11 de julho de 2017. Dispõe sobre a regularização fundiária rural e urbana, sobre a liquidação de créditos concedidos aos assentados da reforma agrária e sobre a regularização fundiária no âmbito da Amazônia Legal; institui mecanismos para aprimorar a eficiência dos procedimentos de alienação de imóveis da União; altera as Leis nos 8.629 , de 25 de fevereiro de 1993, 13.001, de 20 de junho de 2014, 11.952, de 25 de junho de 2009, 13.340, de 28 de setembro de 2016, 8.666, de 21 de junho de 1993, 6.015, de 31 de dezembro de 1973, 12.512, de 14 de outubro de 2011, 10.406, de 10 de janeiro de 2002 (Código Civil), 13.105, de 16 de março de 2015 (Código de Processo Civil), 11.977, de 7 de julho de 2009, 9.514, de 20 de novembro de 1997, 11.124, de 16 de junho de 2005, 6.766, de 19 de dezembro de 1979, 10.257, de 10 de julho de 2001, 12.651, de 25 de maio de 2012, 13.240, de 30 de dezembro de 2015, 9.636, de 15 de maio de 1998, 8.036, de 11 de maio de 1990, 13.139, de 26 de junho de 2015, 11.483, de 31 de maio de 2007, e a 12.712, de 30 de agosto de 2012, a Medida Provisória no 2.220, de 4 de setembro de 2001, e os Decretos-Leis $n^{\text {os }} 2.398$, de 21 de dezembro de 1987, 1.876, de 15 de julho de 1981, 9.760, de 5 de setembro de 1946, e 3.365, de 21 de junho de 1941; revoga dispositivos da Lei Complementar no 76, de 6 de julho de 1993, e da Lei no 13.347, de 10 de outubro de 2016; e dá outras providências. Disponível em: <http://www.planalto.gov.br/ccivil_03/_ato2015-2018/2017/lei/L13465.htm>. Acesso em: 25 jul. 2017.

40 BRASIL. Lei n. 4.504, de 30 de novembro de 1964. Dispõe sobre o Estatuto da Terra. Disponível em: <http://www.planalto.gov. br/ccivil_03/leis/L4504.htm>. Acesso em: 05 maio 2015.

41 BRASIL. Decreto n. 55.981, de 31 de marco de 1965. Regulamenta dispositivos do Estatuto da Terra. Disponível em: <http:// www.planalto.gov.br/ccivil_03/decreto/1950-1969/D55891.htm>. Acesso em: 05 maio 2015.

42 BRASIL. Lei n. 4.504, de 30 de novembro de 1964. Dispõe sobre o Estatuto da Terra. Disponível em: <http://www.planalto.gov. br/ccivil_03/leis/L4504.htm>. Acesso em: 05 maio 2015.

43 BRASIL. Decreto n. 55.981, de 31 de marco de 1965. Regulamenta dispositivos do Estatuto da Terra. Disponível em: < http:// www.planalto.gov.br/ccivil_03/decreto/1950-1969/D55891.htm>. Acesso em: 05 maio 2015.

44 REZEK, Gustavo Elias Kallás. Imóvel rural: agrariedade, ruralidade e rusticidade. Curitiba: Juruá, 2007. p. 63.

45 BRASIL. Lei n. 13.465, de 11 de julho de 2017. Dispõe sobre a regularização fundiária rural e urbana, sobre a liquidação de créditos concedidos aos assentados da reforma agrária e sobre a regularização fundiária no âmbito da Amazônia Legal; institui mecanismos para aprimorar a eficiência dos procedimentos de alienação de imóveis da União; altera as Leis nos 8.629, de 25 de fevereiro de 1993, 13.001, de 20 de junho de 2014, 11.952, de 25 de junho de 2009, 13.340, de 28 de setembro de 2016, 8.666, de 21 de junho de 1993, 6.015, de 31 de dezembro de 1973, 12.512, de 14 de outubro de 2011, 10.406, de 10 de janeiro de 2002 (Código Civil), 13.105 , de 16 de março de 2015 (Código de Processo Civil), 11.977, de 7 de julho de 2009, 9.514, de 20 de novembro de 1997, 11.124, de 16 de junho de 2005 , 6.766, de 19 de dezembro de 1979, 10.257, de 10 de julbo de 2001, 12.651, de 25 de maio de 2012, 13.240, de 30 de dezembro de 2015, 9.636, de 15 de maio de 1998, 8.036, de 11 de maio de 1990, 13.139, de 26 de junbo de 2015, 11.483, de 31 de maio de 2007, e a 12.712, de 30 de agosto de 2012, a Medida Provisória no 2.220, de 4 de setembro de 2001, e os Decretos-Leis nos 2.398, de 21 de dezembro de 1987, 1.876, de 15 de julho de 1981, 9.760, de 5 de setembro de 1946, e 3.365, de 21 de junbo de 1941; revoga dispositivos da Lei Complementar no 76, de 6 de julbo de 1993, e da Lei no 13.347, de 10 de outubro de 2016; e dá outras providências. Disponível em: <http://www.planalto.gov.br/ccivil_03/_ato2015- 
A propriedade familiar, disposta no art. $4^{\circ}$, inc. II, da Lei n. 4.504/1964, é necessariamente explorada pelo agricultor e sua família, sendo, excepcionalmente, constatado o auxílio de terceiros. Essa espécie representa a área suficiente à garantia da subsistência e rentabilidade econômica daqueles que a exploram, podendo ser, pelo menos, igual a um módulo rural ou superá-lo, desde que não configure a empresa rural, conforme pontuam Luá Cristina Siqueira Reis e João da Cruz Gonçalves Neto ${ }^{46}$.

No que tange à empresa rural, essa espécie é prevista pelo art. $4^{\circ}$, inc. VI, do Estatuto da Terra, sendo definida como imóvel destinado ao empreendimento de pessoa física ou jurídica, de direito público ou privado, com objetivo econômico.

O latifúndio por exploração, definido pelo art. $4^{\circ}$, inc. V, alínea b, da legislação acima citada, diz respeito à extensão que não excede a área referente ao latifúndio por dimensão. Mas, sua principal característica é o fato de ser inexplorado ou explorado de forma ineficiente.

A modalidade latifúndio por dimensão está extinta, pois, embora tenha sido prevista pela legislação infraconstitucional, não foi recepcionada pela CF/1988 em seu art. 185, inciso I ${ }^{47}$, o qual prevê as hipóteses de configuração do imóvel rural quanto à sua extensão ${ }^{48}$.

Além da classificação prevista pelo Estatuto da Terra, há, também, aquela que se encontra no texto da CF/1988, mais precisamente em seu art. 185, incisos I e II ${ }^{49}$, sendo esse dispositivo posteriormente regulamentado pela Lei n. 8.629/1993 $3^{50}$.

A classificação constitucional analisa o imóvel agrário quanto à sua extensão, como pequena, média ou grande propriedade (art. 185, inc. I); e quanto à sua exploração, como propriedade produtiva ou improdutiva (art. 185, inciso II) $)^{51}$.

É importante ressaltar o posicionamento Plenário do STF no julgamento do Mandado de Segurança n. 24719-DF ${ }^{52}$, relatado pelo Ministro Carlos Velloso, ao consolidar que a classificação da propriedade rural em pequena, média ou grande se apreende estritamente da extensão do lote, sem exclusão do espaço considerado não aproveitável da área total do imóvel. Contudo, esse entendimento aplica-se, apenas, para fins de classificação do imóvel agrário, conforme a interpretação do art. 185 da CF/1988 53 .

Dessa forma, posterior à Constituição, o art. $4^{\text {o }}$ da Lei n. 8.629/1993 $3^{54}$ determina que a pequena propriedade compreende de um a quatro módulos fiscais; a média propriedade é superior a quatro e inferior a quinze módulos fiscais; e, por fim, a grande propriedade representa as áreas superiores a quinze módulos fiscais.

Ao analisar, de forma crítica, a legislação exposta, contata-se que o Estatuto da Terra ${ }^{55}$ se mostra insufi-

2018/2017/lei/L13465.htm>. Acesso em: 25 jul. 2017.

46 REIS, Luá Cristine Siqueira; GONÇALVES NETO, João da Cruz. Produção de alimentos: agricultura familiar x cultura de exportação no Brasil sob a perspectiva da sustentabilidade. Revista Brasileira de Políticas Públicas, Brasília, v. 4, n. 1, p. $91,2014$.

47 BRASIL. Constituição (1998). Constituição da República Federativa do Brasil. Disponível em: <www.planalto.gov.br/ccivil_03/ constituicao/constituicao.htm>. Acesso em: 05 maio 2015.

48 Essa espécie de imóvel agrário era aquela que não excedia 600 vezes a dimensão do módulo médio da área ou que excedia 600 vezes a média dos imóveis rurais de determinada localidade.

49 BRASIL. Constituição (1998). Constituição da República Federativa do Brasil. Disponível em: <www.planalto.gov.br/ccivil_03/ constituicao/constituicao.htm>. Acesso em: 05 maio 2015.

50 BRASIL. Lei n. 8.629, de 25 de fevereiro de 1993. Regulamenta os dispositivos constitucionais relativos à reforma agrária. Disponível em: <http://www.planalto.gov.br/ccivil_03/leis/L8629.htm>. Acesso em: 5 maio 2015.

51 BRASIL. Constituição (1998). Constituição da República Federativa do Brasil. Disponível em: <www.planalto.gov.br/ccivil_03/ constituicao/constituicao.htm>. Acesso em: 05 maio 2015.

52 BRASIL. Supremo Tribunal Federal. Mandado de Segurança 24719-DF, Rel. Min.Carlos Velloso, publicado em: 14/05/2004.

53 BRASIL. Constituição (1998). Constituição da República Federativa do Brasil. Disponível em: <www.planalto.gov.br/ccivil_03/ constituicao/constituicao.htm>. Acesso em: 05 maio 2015.

54 BRASIL. Lei n. 8.629, de 25 de fevereiro de 1993. Regulamenta os dispositivos constitucionais relativos à reforma agrária. Disponível em: <http://www.planalto.gov.br/ccivil_03/leis/L8629.htm>. Acesso em: 5 maio 2015.

55 BRASIL. Lei n. 4.504, de 30 de novembro de 1964. Dispõe sobre o Estatuto da Terra. Disponível em: <http://www.planalto.gov. br/ccivil_03/leis/L4504.htm>. Acesso em: 05 maio 2015. 
ciente para abranger a complexidade de situações existentes atualmente envolvendo áreas urbanas e rurais. Isso ocorre, principalmente, em virtude do tempo de existência dessa lei que foi promulgada na década de 1960, cabendo, também, compreender que, apesar de a Constituição Federal de 1988 ser mais recente que o Estatuto da Terra, esta se mostra incompleta por não tratar de espécies como: o minifúndio que, também, deve ser discutido.

Sendo assim, se mostra mais adequada e atualizada a classificação doutrinária proposta por Gustavo Elias Kallás Rezek ${ }^{56}$, segundo a qual o imóvel agrário poderá ser definido: a) quanto à sua localização, como a.1) rural ou a.2) urbano; b) quanto à qualificação do meio para o exercício da atividade agrária, como b.1) rústico ou b.2) edificado; e c) quanto à sua política governamental, como c.1) empresa agrária, c.2) latifúndio e c.3) imóvel devoluto.

Antes de detalharmos cada uma dessas espécies, é importante destacar que essa classificação pode ser considerada: mais recente, pois foi desenvolvida em uma obra datada no ano de 2006; completa por envolver tanto as modalidades já previstas na legislação, quanto outras espécies que não foram tratadas constitucional e infraconstitucionalmente; e, mais adequada à complexidade das novas situações que surgem em razão da inexistência de limites rígidos entre o urbano e o rural, tal como o caso do imóvel agrário urbano, objeto deste estudo.

Assim, o imóvel rústico é aquele cuja atividade agrária é necessariamente desenvolvida a partir do contato direto com a terra fértil para o desenvolvimento de plantas ou criação de animais, enquanto o imóvel edificado é aquele em que estas mesmas atividades podem ser desenvolvidas por meio de maquinários e construções que substituam a presença direta da terra fértil. Nesse sentido, Flavia Trentini ${ }^{57}$ dispõe que, modernamente, muitos produtos de origem agrícola não dependem de uma relação direta com a utilização da terra.

No que tange à concepção de empresa rural, Gustavo Elias Kallás Rezek ${ }^{58}$ defende a ideia do imóvel de empresa agrária, e não de empresa rural aos moldes do Estatuto da Terra ${ }^{59}$, porque o primeiro possui um sentido mais amplo, enquanto o segundo se mostra ultrapassado e restrito.

A referida classificação adota os conceitos estabelecidos pela legislação vigente com relação às espécies de latifúndio por exploração, a partir do qual aquela propriedade que for considerada improdutiva deverá ser objeto de desapropriação para fins de reforma agrária.

Quanto ao imóvel devoluto este é propriedade do Estado, sendo constituído pelas chamadas terras devolutas — as quais o Poder Público não incumbiu uma destinação — que seriam imóveis agrários por sua potencialidade, aguardando a correta destinação pelo Estado.

Essa classificação, no entanto, não foi ainda totalmente incorporada pela legislação agrária, possuindo ainda a questão tratamento fragmentário, especialmente no que concerne à relação entre regulação do uso do solo urbano e rural.

A partir da análise da legislação e da doutrina sobre o tema é possível afirmar que diferentemente, do que ocorreu com a definição de imóvel rural, em que o critério da afetação foi parcialmente alterado em prol de uma maior autonomia dos municípios para promover a regularização fundiária de assentamentos urbanos informais, os critérios de classificação do imóvel rural permanecem inalterados.

O que definirá se o imóvel urbano previamente ocupado será urbano ou rural em áreas de expansão urbana ou de urbanização específica será sua destinação efetiva e não mais o critério formal da desafetação.

56 REZEK, Gustavo Elias Kallás. Imóvel rural: agrariedade, ruralidade e rusticidade. Curitiba: Juruá, 2007. p. 74.

57 TRENTINI, Flavia. Teoria do direito agrário contemporâneo. São Paulo: Atlas, 2012. p. 27-28.

58 REZEK, Gustavo Elias Kallás. Imóvel rural: agrariedade, ruralidade e rusticidade. Curitiba: Juruá, 2007. p. 75

59 BRASIL. Lei n. 4.504, de 30 de novembro de 1964. Dispõe sobre o Estatuto da Terra. Disponível em: <http://www.planalto.gov. br/ccivil_03/leis/L4504.htm>. Acesso em: 05 maio 2015. 
Essa medida não coloca em risco, ao menos teoricamente, a necessidade de primazia da destinação de áreas rurais à atividade agrária, pois a autonomia dos municípios para concretizar a intervenção sem a necessidade de prévia anuência do INCRA ocorre apenas em áreas de pequena dimensão, que são os minifúndios já previamente ocupados.

Entretanto, é necessário ressaltar que essa medida poderá gerar conflitos entre o órgão agrário federal e os Municípios, pois como tradicionalmente não há controle preventivo pelo Município das ocupações espontâneas, atividades agrícolas como a horticultura poderão desaparecer em razão da pressão decorrente da especulação fundiária em zonas periféricas, podendo colocar em xeque a segurança alimentar dos centros urbanos. Esse controle permanece apenas para os parcelamentos do solo para fins urbanos formais, para os quais ainda são válidas as exigências da IN INCRA n. 17-B/19806.

\section{HiPÓTESES DE INCIDÊNCIA DO IMPOSTO PREDIAL E TERRITORIAL URBANO E DO IMPOSTO TERRITORIAL RURAL: ANÁLISE LEGAL E JURISPRUDENCIAL}

A incidência do IPTU, de acordo com o art. 156, inc. I, da CF $/ 1988^{61}$, é definida pelo ente municipal e Distrito Federal sobre os imóveis localizados na zona urbana. Para efeitos de incidência desse imposto, o art. 32 da Lei n. 5.172/1966, o Código Tributário Nacional (CTN) ${ }^{62}$, dispõe que se entende por zona urbana aquela que for definida pela lei municipal, devendo existir concomitante nessa área pelo menos dois melhoramentos dentre os que estão elencados na legislação. As alíquotas desse imposto progridem de acordo com o valor da propriedade que varia em razão da localização e do uso do imóvel, conforme o art. $4^{\circ}$, inc. II, da CF $/ 1988^{63}$.

Diferentemente do IPTU, a cobrança do ITR é competência da União, e, conforme o art. 153, $\$ 4^{\circ}$, inc. III, da CF $/ 1988^{64}$, este incide com base de cálculo, apenas, sobre o valor da terra nua, considerando toda a extensão do lote e o seu grau de utilização, conforme a incidência de alíquotas aplicadas progressivamente, como determina o art. 11 da Lei n. 9.393/1996 $6^{65}$.

A progressividade da alíquota cobrada depende diretamente da relação entre a extensão da propriedade e o seu grau de utilização, sendo este um ponto importante para a análise do ITR, em virtude da questão central sobre a destinação agrária desses imóveis. De acordo com Flavia Trentini ${ }^{66}$, com relação à doutrina agrária, o imóvel será compreendido como agrário independentemente de sua localização, sendo considerada principalmente a sua destinação. O Estatuto da Terra, também, é taxativo quanto a esse ponto em seu $\operatorname{art.} 4^{\circ}$, inc. ${ }^{67}$, ao dispor que será considerado imóvel rural qualquer que seja a sua localização, desde que se

60 BRASIL. Instrução Normativa n. 17-B, de 22 de dezembro, de 1980. Dispõe sobre o parcelamento de imóveis rurais. Disponível em: <http://www.incra.gov.br/media/institucional/legislacao/atos_internos/instrucoes/instrucao/I17b_221280.pdf>.Acesso em: 23 jun. 2015.

61 BRASIL. Constituição (1998). Constituição da República Federativa do Brasil. Disponível em: <www.planalto.gov.br/ccivil_03/ constituicao/constituicao.htm>. Acesso em: 05 maio 2015.

62 BRASIL. Lei n. 5.172, de 25 de outubro de 1966. Dispõe sobre o Sistema Tributário Nacional. Disponível em: <http://www. planalto.gov.br/ccivil_03/leis/L5172.htm>. Acesso em: 07 jun. 2015.

63 BRASIL. Constituição (1998). Constituição da República Federativa do Brasil. Disponível em: <www.planalto.gov.br/ccivil_03/ constituicao/constituicao.htm>. Acesso em: 05 maio 2015.

64 BRASIL. Constituição (1998). Constituição da República Federativa do Brasil. Disponível em: <www.planalto.gov.br/ccivil_03/ constituicao/constituicao.htm>. Acesso em: 05 maio 2015.

65 BRASIL. Lei n. 9.393, de 19 de dezembro de 1996. Disponível em: <http://www.planalto.gov.br/ccivil_03/leis/L9393.htm>. Acesso em: 25 jul. 2017.

66 TRENTINI, Flavia. Teoria do direito agrário contemporâneo. São Paulo: Atlas, 2012. p. 26.

67 BRASIL. Lei n. 4.504, de 30 de novembro de 1964. Dispõe sobre o Estatuto da Terra. Disponível em: <http://www.planalto.gov. br/ccivil_03/leis/L4504.htm>. Acesso em: 05 maio 2015. 
destine às atividades dispostas no art. 15 do Decreto-Lei n. 57/1966 ${ }^{68}$.

Nesse sentido, quanto maior for a propriedade, tendo em vista a classificação constitucional; e menor for o grau de utilização, previsto pela legislação infraconstitucional, maior será a alíquota incidente sobre o ITR. Isso acontece por conta de um esforço legislativo para desestimular as propriedades improdutivas.

A partir da presente discussão, verifica-se o descompasso entre o critério da localização para incidência tributária, a partir do CTN; e as disposições da legislação agrária que considera também o critério da destinação do imóvel. Assim, em virtude dessa dissonância são verificados determinados problemas quanto à tributação dos imóveis agrários localizados em áreas urbanas. Em razão da complexidade que envolve o imóvel agrário localizado em área urbana, seja em matéria de Direito Agrário ou Direito Tributário é importante buscar verificar qual tem sido o entendimento jurisprudencial do STF, STJ e dos TRFs.

Como resultando da pesquisa de jurisprudência foram analisadas 30 decisões, sendo: 4 julgados do STF, 7 decisões do STJ, 2 julgamentos do TRF da $1^{a}$ Região, 2 decisões do TRF da $2^{\text {a }}$ Região, 4 julgados do TRF da $3^{a}$ Região, 2 decisões do TRF da $4^{a}$ Região e 9 julgamentos do TRF da $5^{a}$ Região. A seleção das decisões se baseou no critério de utilização de determinadas palavras-chave no sítio eletrônico de cada um desses tribunais, as referidas palavras-chave são: imóvel rural IPTU, imóvel rural ITR, imóvel rural tributário e imóvel rural urbano. Por fim, esclarece-se que a pesquisa jurisprudencial foi realizada no período de maio a julho de 2015.

Em 1982, o STF ${ }^{69}$ declarou inconstitucional o art. $6^{\circ}$ da Lei n. 5.868/1972 $2^{70}$, porque não se tratava de lei complementar para poder estabelecer critérios de natureza tributária, sendo, então, aplicáveis os arts. 29 e 32 do $\mathrm{CTN}^{71}$ que se fundamentam no critério da localização do imóvel, ressalvando a discussão sobre o critério da destinação. Em 1986, o STF foi novamente instado a se manifestar acerca a incidência do IPTU com fundamento no art. 32 do CTN, porém, não foi conhecido o respectivo recurso extradionário ${ }^{72}$.

No ano de 1999, o Tribunal Pleno do STF ${ }^{73}$, em votação unânime, declarou inconstitucional o art. 12 da Lei n. 5.868/1972 $2^{74}$ no tocante à revogação do art. 15 do Decreto-Lei n. 57/1966

Sendo assim, ao analisar a questão de bitributação relacionada ao IPTU e ao ITR, o Tribunal Regional Federal da $2^{a}$ Região (TRF da $2^{a}$ Região) $)^{76}$, em uma das primeiras decisões dos TRFs encontradas na pesquisa jurisprudencial a partir do critério cronológico, considerou que estando o imóvel situado em zona urbana caberia a cobrança do IPTU fundamentando que diante do conflito de natureza tributária: 1. estando o imóvel localizado em área urbana, urbanizável ou de expansão urbana; e 2. não tendo exploração agrícola, pastoril ou extrativa vegetal, este será sujeito ao IPTU, afastando a incidência do ITR, declarando não provida a referida apelação.

Em decisão publicada no ano de 2004, o Tribunal Regional Federal da $5^{\mathrm{a}}$ Região (TRF da $5^{\mathrm{a}}$ Região) ${ }^{77}$

68 BRASIL. Decreto-Lei n. 57, de 18 de novembro de 1966. Dispõe sobre o Imposto sobre a Propriedade Territorial Rural. Disponível em: <http://www.planalto.gov.br/ccivil_03/decreto-lei/Del0057.htm>. Acesso em: 07 maio 2015.

69 BRASIL. Supremo Tribunal Federal. Recurso Extraordinário 93850-MG, Rel. Min. Moreira Alves, publicado em: 27/08/1982.

70 BRASIL. Lei n. 5.868, de 12 de dezembro de 1972. Cria o Sistema Nacional de Cadastro Rural. Disponível em: <http://www. planalto.gov.br/ccivil_03/leis/L5868.htm>. Acesso em: 05 maio 2015.

71 BRASIL. Lei n. 5.172, de 25 de outubro de 1966. Dispõe sobre o Sistema Tributário Nacional. Disponível em: <http://www. planalto.gov.br/ccivil_03/leis/L5172.htm>. Acesso em: 07 jun. 2015.

72 BRASIL. Supremo Tribunal Federal. Recurso Extraordinário 100427-DF, Rel. Min. Carlos Madeira, publicado em: 07/03/1986. 73 BRASIL. Supremo Tribunal Federal. Recurso Extraordinário 1407735-SP, Rel. Min. Sydney Sanchers, publicado em: 04/06/1999.

74 BRASIL. Lei n. 5.868, de 12 de dezembro de 1972. Cria o Sistema Nacional de Cadastro Rural. Disponível em: <http://www. planalto.gov.br/ccivil_03/leis/L5868.htm>. Acesso em: 05 maio 2015.

75 BRASIL. Decreto-Lei n. 57, de 18 de novembro de 1966. Dispõe sobre o Imposto sobre a Propriedade Territorial Rural. Disponível em: <http://www.planalto.gov.br/ccivil_03/decreto-lei/Del0057.htm>. Acesso em: 07 maio 2015.

76 RIO DE JANEIRO. Tribunal Regional Federal $2^{a}$ Região. Apelação Civel 147640-RJ, Rel. Des. Castro Aguiar, publicada em: 08/03/2001.

77 PERNAMBUCO. Tribunal Regional Federal $5^{\text {a }}$ Região. Embargos de Declaração na Apelação Cível 294568-SE, Rel. Des. Hélio Silvio Ourem Campos, publicados em: 19/03/2004. 
analisou os Embargos de Declaração opostos pela Fazenda Nacional, em razão de suposta contradição a respeito da incidência de IPTU em imóvel incluído na área de expansão do Município de Aracajú. Nesse caso o Tribunal, com base nas disposições dos arts. 29 e 32 do CTN $^{78}$, negou provimento aos Embargos por não haver contradição na decisão que julgou que independentemente do uso dado à propriedade, incide a cobrança do IPTU sobre imóvel situado em área urbanizável ou de expansão urbana, conforme lei municipal, mesmo que não sejam constatados os melhoramentos dispostos no art. 32, \$1 ${ }^{\circ}$, do CTN. Assim, observa-se que essa decisão teve por fundamento preponderante as disposições do Código Tributário Nacional.

É interessante destacar que ainda em 2004, o TRF da $5^{\text {a }}$ Região ${ }^{79}$ julgou uma apelação cível em que a União suscitou o art. 15 do Decreto-Lei n. $57 / 1986^{80}$, o qual expressa a não incidência do art. 32 do CTN nos casos em que o imóvel seja utilizado para exploração extrativa vegetal, agrícola, pecuária ou agroindustrial, incidindo o ITR. Como no caso em tela não foi comprovada essa hipótese, foi determinada a incidência do IPTU, conforme disposto no art. 32 do $\mathrm{CTN}^{81}$. Nessa decisão se verifica, expressamente, a discussão sobre a destinação do imóvel em favor da incidência do ITR.

Outro posicionamento é o do Tribunal Regional Federal da $3^{a}$ Região (TRF da $3^{a}$ Região) ${ }^{82}$ em decisão referente a Embargos à Execução, onde a embargada promoveu uma execução fiscal com fundamento em uma certidão de inscrição em dívida ativa de débito de ITR referente ao exercício tributário do ano de 1986. Ocorre que o imóvel agrário foi integrado à área urbana, fato este devidamente comprovado. Sendo assim, o Tribunal entendeu que a área situada em zona urbana só pode ser submetida ao IPTU, sendo totalmente afastado o ITR. Nota-se, nessa decisão, um descompasso com o entendimento majoritário dos TRF's e do STJ, conforme a análise sistemática das decisões estudadas, uma vez que esse entendimento foi expressamente genérico ao afirmar que aos imóveis situados em zona urbana somente cabe a cobrança de IPTU.

No ano de 2004, o STj ${ }^{83}$, também, se manifestou a respeito da matéria, assentando o entendimento de que ao dispor a respeito do IPTU, o legislador optou, a prima facie, pela adoção do critério da localização do imóvel em área urbana, mas, ainda assim, o Tribunal assevera que no caso do ITR, este não incide somente nos imóveis localizados em área rural, podendo também recair sobre aqueles que se encontram em zona urbana quando se voltam à atividade agrária. A decisão esclarece, ainda, que essa fundamentação se encontra em consonância com o entendimento do $\mathrm{STF}^{84}$.

Nesse mesmo sentido, foi o posicionamento expresso pelo STJ ${ }^{85}$ em 2009 na decisão cujo relator foi o Ministro Herman Benjamin em que foi ratificada a não incidência do IPTU, mas do ITR sobre imóvel localizado em área urbana do município quando comprovada a destinação agrária. A referida decisão é recorrentemente mencionada em julgamentos posteriores tanto do STJ ${ }^{86}$ quanto dos TRF's ${ }^{87}$.

78 BRASIL. Lei n. 5.172, de 25 de outubro de 1966. Dispõe sobre o Sistema Tributário Nacional. Disponível em: <http://www. planalto.gov.br/ccivil_03/leis/L5172.htm>. Acesso em: 07 jun. 2015.

79 PERNAMBUCO. Tribunal Regional Federal 5 Região. Apelação Cível 325790-SE, Rel. Des. Francisco Cavalcanti, publicada em: 19/04/2004.

80 BRASIL. Decreto-Lei n. 57, de 18 de novembro de 1966. Dispõe sobre o Imposto sobre a Propriedade Territorial Rural. Disponível em: <http://www.planalto.gov.br/ccivil_03/decreto-lei/Del0057.htm>. Acesso em: 07 maio 2015.

81 BRASIL. Lei n. 5.172, de 25 de outubro de 1966. Dispõe sobre o Sistema Tributário Nacional. Disponível em: <http://www. planalto.gov.br/ccivil_03/leis/L5172.htm>. Acesso em: 07 jun. 2015.

82 SÃO PAULO. Tribunal Regional Federal $3^{a}$ Região. Reexame Necessário Cível 438884, Rel. Des. Fábio Pietro, publicado em: 26/05/2004.

83 BRASIL. Superior Tribunal de Justiça. Recurso Especial 472628-RS, Rel. Min. Castro Moreira, publicado em: 20/06/2005.

84 BRASIL. Supremo Tribunal Federal. Recurso Especial 492869-PR, Rel. Min. Teori Albino Zavascki, publicado em: 20/06/2005; e Agravo Regimental no Recurso Especial 679173-SC, Rel. Min. Denise Arruda, publicado em: 18/10/2007.

85 Recurso Especial 1112646-SP, Rel. Min. Herman Benjamin, publicado em: 28/08/2009.

86 BRASIL. Superior Tribunal de Justiça. Recurso Especial 1150408-SP, Rel. Min. Castro Meira, publicado em: 19/10/2010; Recurso Especial 1207093-SP, Rel. Min. Benedito Gonçalves, publicado em: 26/11/2010; Agravo Regimental no Agravo em Recurso Especial 259607-SC, Rel. Min. Benedito Gonçalves, publicado em: 17/06/2013.

87 PERNAMBUCO. Tribunal Regional Federal 5a Região. Apelação Civel 54795-SE, Rel. Des. Geraldo Apoliano, publicada em: 08/04/2014. 
De forma indireta, em 2005, o TRF da $1^{a}$ Região ${ }^{88}$ externou o posicionamento de que a classificação do imóvel em urbano ou rural ocorre conforme sua destinação, e não sua localização com fundamento na aplicação analógica do art. $4^{\circ}$, inc. I, da Lei n. 8.629/1993 ${ }^{89}$. Destaca-se que este entendimento se encontra em consonância com decisões anteriores desse mesmo Tribunal ${ }^{90}$.

Em 2010, o TRF da $3^{\text {a }}$ Região ${ }^{91}$, com base nos precedentes da jurisprudência do STJ ${ }^{92}$, afirmou que, uma vez comprovado o critério da natureza da atividade empresarial de cunho agrário, considera-se o imóvel sujeito à cobrança do ITR, pela União; e não do IPTU, pelo Município. Assim, este julgado diferiu, substancialmente, em relação à decisão analisada referente ao ano de 2004 emitida pelo mesmo órgão jurisdicional ${ }^{93}$.

É interessante, também, notar que, em 2011, o TRF da $5^{\text {a }}$ Região94, além de manter o posicionamento dominante na jurisprudência que considera o critério topográfico em conjunto com a destinação do imóvel, destacou que compete ao ente municipal delimitar a zona urbana por meio do Plano Diretor Municipal que é um importante instrumento da política urbana e, por consequência, do ordenamento territorial. Esse instrumento se encontra previsto tanto no plano constitucional, por meio do art. $182, \$ 1^{\circ}$, da Constituição Federal; quanto na legislação infraconstitucional, como é o caso da Lei n. 10.257/2001 ${ }^{95}$, conhecida como Estatuto da Cidade, que regulamenta os arts. 182 e 183 da Constituição ${ }^{96}$, estabelecendo as diretrizes gerais da política urbana.

Nesse sentido, também no ano de 2011, o TRF da $3^{a}$ Região ${ }^{97}$ em sede de Apelação Cível em que o autor defendia a configuração da relação jurídico-tributária com a União, em razão da incidência de ITR em imóvel com destinação agrária, o Tribunal entendeu que o critério da localização, em determinados casos, é insuficiente tanto para determinar a incidência tributária quanto para verificar as repercussões desta. A referida decisão destacou um ponto muito importante dentro do regime jurídico de tributação nos casos em discussão que se reporta justamente à necessidade de analisar em conjunto os critérios topográfico e de uso do imóvel ${ }^{98}$.

Em 2014, o TRF da $2^{a}$ Região $0^{99}$ em sede de Apelação Cível ressaltou que, com relação ao alargamento do

88 BRASÍLIA. Tribunal Regional Federal 1ª Região. Apelação Civel 200143000013530-TO, Rel. Des. Carlos Olvavo, publicada em: $02 / 06 / 2005$.

89 BRASIL. Lei n. 8.629, de 25 de fevereiro de 1993. Regulamenta os dispositivos constitucionais relativos à reforma agrária. Disponível em: <http://www.planalto.gov.br/ccivil_03/leis/L8629.htm>. Acesso em: 5 maio 2015.

90 BRASÍLIA. Tribunal Regional Federal 1ª Região. Apelação Cível 200143000010655-TO, Rel. Des. Carlos Olvavo, publicada em: $31 / 05 / 2005$.

91 SÃO PAULO. Tribunal Regional Federal 3a Região. Apelação Civel 1319113, Relator Juiz Federal Convocado Silva Neto, publicada em: 24/01/2011.

92 BRASIL. Superior Tribunal de Justiça. Recurso Especial 1112646-SP, Rel. Min. Herman Benjamin, publicado em: 28/08/2009; e Agravo Regimental no Recurso Especial 679173-SC, Rel. Min. Denise Arruda, publicado em: 18/10/2007.

93 SÃO PAULO. Tribunal Regional Federal $3^{\text {a }}$ Região. Reexame Necessário Cível 438884, Rel. Des. Fabio Pietro, publicado em 26/05/2004.

94 PERNAMBUCO. Tribunal Regional Federal 5a Região: Apelação Cível 429176-CE, Rel. Des. Geraldo Apoliano, publicada em: 24/02/2011.

95 BRASIL. Lei n. 10.257, de 10 de julho de 2001. Regulamenta os arts. 182 e 183 da Constituição Federal e estabelece diretrizes gerais da política urbana. Disponível em: < http://www.planalto.gov.br/ccivil_03/leis/LEIS_2001/L10257.htm>. Acesso em: 23 jun. 2015.

96 BRASIL. Constituição (1998). Constituição da República Federativa do Brasil. Disponível em: <www.planalto.gov.br/ccivil_03/ constituicao/constituicao.htm>. Acesso em: 05 maio 2015.

97 SÃO PAULO. Tribunal Regional Federal $3^{a}$ Região: Apelação Cível 1346598-SP, Rel. Juiz Federal Convocado Leonel Ferreira, publicada em: 18/04/2011.

98 Nesse mesmo sentido destacam-se decisões de outros TRFs, tais como: Tribunal Regional da $5^{a}$ Região, Apelação Cível 446665-SE, Juiz Federal Convocado Frederico Pinto de Azevedo, publicada em: 10/05/2011; Tribunal Regional da $5^{a}$ Região, Apelação Cível 522906-SE, Rel. Des. Luiz Alberto Gurgel de Faria, publicada em: 07/10/2011; Tribunal Regional da $5^{a}$ Região, Apelação Cível 98345-SE, Rel. Des. Élio Wanderley de Siqueira Filho, publicada em: 20/10/2011; Tribunal Regional da $5^{a}$ Região, Apelação Cível 548781-SE, Rel. Des. Francisco Cavalcanti, publicada em: 16/11/2012; Tribunal Regional da $3^{a}$ Região, Reexame Necessário Cível 872104, Rel. Juiz Federal Convocado Roberto Lemos, publicado em: 03/08/2012; e Tribunal Regional da $4^{a}$ Região, Reexame Necessário Cível Processo 500354203201240472, Rel. Des. Rômulo Pizzolatti, publicado em: 13/11/2013.

99 RIO DE JANEIRO. Tribunal Regional Federal 2 2a Região. Apelação Cível 597137-RJ, Rel. Des. Aluisio Gonçalves de Castro 
perímetro urbano resultante do crescimento das cidades, é competência do município delimitar essas áreas para que sejam devidamente aplicadas as normas urbanísticas de caráter específico voltadas ao ordenamento territorial. A decisão trata de uma questão importante que diz respeito ao ordenamento territorial incluído no planejamento e voltado à melhor organização do território em compatibilidade com a atração de recursos e o desenvolvimento regional.

Ainda no ano de 2014, o Tribunal Regional Federal da $4^{a}$ Região (TRF da $4^{a}$ Região) ${ }^{100}$, em análise a uma Apelação Cível em Ação Anulatória de Débito Fiscal, afirmou que a simples cobrança indevida de tributos não configura dano moral em favor do contribuinte. Ressalta-se que esta foi a única decisão analisada durante a pesquisa que suscitou a questão a respeito da ocorrência de dano moral em caso de cobrança tributária indevida.

No início de 2015, o TRF da $5^{a}$ Região ${ }^{101}$ condenou, em razão de cobrança indevida e em consonância com as normas de Direito Civil, a União à restituição devida à autora pelos valores pagos a título de ITR quando o imóvel, além de estar localizado em zona urbana, não era destinado à atividade agrária. É importante destacar que nesta decisão o Tribunal assentou o entendimento de que a atividade agrária pode ser presumida, por exemplo, a partir de notificações emitidas pela Secretaria do Estado do Desenvolvimento da Agropecuária e Pesca Estadual acerca da necessidade de inscrição do imóvel no Cadastro Estadual de Estabelecimentos Pecuários.

Dessa forma, as decisões analisaram a questão acerca da incidência do IPTU ou ITR nos casos em que o imóvel agrário está localizado em área urbana, matéria esta que tem sido discutida nos tribunais desde 1982 quando o STF considerou inconstitucional o art. $6^{\circ}$ da Lei n. 5.868/1972, tendo também declarado a inconstitucionalidade do art. 12 da Lei n. 5.868/1972 ${ }^{102}$ no tocante à revogação do art. 15 do Decreto-Lei ก. $57 / 1966^{103}$.

O STJ tem se manifestado desde 2004 no sentido de que, em matéria tributária, a priori o legislador optou pelo critério da localização quanto ao IPTU, porém, quando se trata do ITR, este não incidirá somente nos imóveis localizados em zona rural, sendo também analisada, nesses casos, a atividade desenvolvida nos referidos imóveis. Em 2009, esse mesmo tribunal publicou uma decisão paradigmática que é citada em vários julgados posteriores dos tribunais regionais, a referida decisão teve como relator o Ministro Herman Benjamin, sendo ratificada a incidência do ITR e afastada a aplicabilidade do IPTU quando comprovada a atividade agrária do imóvel em áreas definidas como urbanas pelo município.

No que tange aos tribunais regionais, pode-se, então, afirmar que o TRF da $1^{\text {a }}$ Região desde 2005 tem entendido que a classificação do imóvel e as repercussões desta ocorrem com base na destinação dada ao referido imóvel. O TRF da $2^{a}$ Região ressaltou em 2014 que o alargamento do perímetro urbano deverá ser devidamente delimitado pelo município, o qual é o ente federado competente para realizar tal delimitação.

O TRF da $3^{a}$ Região primeiro emitiu uma decisão, no ano de 2003, em descompasso com o entendimento dado pelo STF e STJ, porém em 2010 mudou o seu posicionamento, afirmando, então, a incidência do ITR quanto ao imóvel agrário urbano. Nesse sentido, o TRF $5^{a}$ Região, em 2004, já discutia a extensão quanto à aplicabilidade do IPTU, sendo que em 2011 considerou expressamente que o critério da localização deve ser analisado em conjunto com a destinação do imóvel, sendo importante ressaltar a competência do

Mendes, publicada em: 23/05/2014

100 PORTO ALEGRE. Tribunal Regional Federal 4ª Região. Apelação Cível 50226126920134047200, Rel. Des. Rômulo Pizzolatti, publicada em: 14/10/2014.

101 PERNAMBUCO. Tribunal Regional Federal 5a Região. Apelação Civel 31409-PB, Rel. Des. Roberto Machado, publicada em: 05/03/2015.

102 BRASIL. Lei n. 5.172, de 25 de outubro de 1966. Dispõe sobre o Sistema Tributário Nacional. Disponível em: <http://www. planalto.gov.br/ccivil_03/leis/L5172.htm>. Acesso em: 07 jun. 2015.

103 BRASIL. Decreto-Lei n. 57, de 18 de novembro de 1966. Dispõe sobre o Imposto sobre a Propriedade Territorial Rural. Disponível em: <http://www.planalto.gov.br/ccivil_03/decreto-lei/Del0057.htm>. Acesso em: 07 maio 2015. 
município quanto à delimitação da zona urbana por meio do Plano Diretor Municipal.

Com base nas decisões analisadas acerca do imóvel agrário localizado em área urbana, uma realidade que se intensifica em razão da globalização, pode-se afirmar que, do ponto de vista do STF, STJ e dos TRFs, esses imóveis devem ser submetidos ao regime jurídico de tributação do ITR, uma vez que, em conjunto com o critério topográfico, se analisa o critério da destinação do imóvel referente às atividades de exploração agrícola, pastoril, extrativa vegetal ou agroindustrial, atentando-se, também, às devidas regulamentações do regime de parcelamento de uso do solo rural.

É possível, ainda, afirmar que em caso de conflito entre o regime de tributação municipal e federal, prevalecerá o regime da propriedade rural, independentemente se localizado em área urbana, de expansão urbana ou de urbanização específica. Na prática, a existência desses imóveis rurais em áreas que o município deseje influenciar no parcelamento do solo causa grandes empecilhos para o Poder Público Municipal, uma vez que não há no ordenamento jurídico instrumento que permitisse ao ente local forçar a conversão de imóvel rural em urbano. Essa opção estava adstrita ao interesse do loteador, sendo o único legitimado a solicitar a desafetação do imóvel de rural para urbano.

Portanto, os principais instrumentos disponíveis para esse fim na Constituição de $1988^{104}$ e na Lei Federal n. $10257 / 2001^{105}$, que são o parcelamento compulsório, a tributação progressiva e a desapropriação por descumprimento da função social da propriedade urbana são inaplicáveis a esses imóveis, independentemente de sua localização, uma vez que prevalece o princípio da destinação agrária sobre o princípio da localização do IPTU. Assim, caso não haja interesse do proprietário em parcelar seu imóvel, a única alternativa que resta aos Municípios seria a desapropriação por utilidade pública ou interesse social do imóvel rural, solução em regra pouco viável devido ao elevado valor que esses imóveis rurais possuem quando próximos a centros urbanos.

A Lei n. 13.465/2017, nesse ponto, não trouxe uma solução para a questão. A única menção que a nova lei faz à questão tributária está ligada à impossibilidade do cartorário obstar o registro da regularização fundiária nos casos de falta da comprovação do pagamento de tributos ou penalidades tributárias (art. $13, \sqrt{ } 2^{\circ}$ e $\left.44, \int 3^{\circ}\right)^{106}$.

Vale destacar que a referida lei disciplinou o uso da arrecadação de bens abandonados (art. 64) ${ }^{107}$, mas

104 BRASIL. Constituição (1998). Constituição da República Federativa do Brasil. Disponível em: <www.planalto.gov.br/ccivil_03/ constituicao/constituicao.htm>. Acesso em: 05 maio 2015.

105 BRASIL. Lei n. 10.257, de 10 de julho de 2001. Regulamenta os arts. 182 e 183 da Constituição Federal e estabelece diretrizes gerais da política urbana. Disponível em: <http://www.planalto.gov.br/ccivil_03/leis/LEIS_2001/L10257.htm>. Acesso em: 23 jun. 2015.

106 BRASIL. Lei n. 13.465, de 11 de julho de 2017. Dispõe sobre a regularização fundiária rural e urbana, sobre a liquidação de créditos concedidos aos assentados da reforma agrária e sobre a regularização fundiária no âmbito da Amazônia Legal; institui mecanismos para aprimorar a eficiência dos procedimentos de alienação de imóveis da União; altera as Leis nos 8.629, de 25 de fevereiro de 1993, 13.001, de 20 de junho de 2014, 11.952, de 25 de junho de 2009, 13.340, de 28 de setembro de 2016, 8.666, de 21 de junho de 1993, 6.015, de 31 de dezembro de 1973, 12.512, de 14 de outubro de 2011, 10.406, de 10 de janeiro de 2002 (Código Civil), 13.105, de 16 de marco de 2015 (Código de Processo Civil), 11.977, de 7 de julbo de 2009, 9.514, de 20 de novembro de 1997, 11.124, de 16 de junho de 2005 , 6.766, de 19 de dezembro de 1979, 10.257, de 10 de julbo de 2001, 12.651, de 25 de maio de 2012, 13.240, de 30 de dezembro de 2015, 9.636, de 15 de maio de 1998, 8.036, de 11 de maio de 1990, 13.139, de 26 de junho de 2015, 11.483, de 31 de maio de 2007, e a 12.712, de 30 de agosto de 2012, a Medida Provisória no 2.220, de 4 de setembro de 2001, e os Decretos-Leis nos 2.398, de 21 de dezembro de 1987, 1.876, de 15 de julbo de 1981, 9.760, de 5 de setembro de 1946, e 3.365, de 21 de junho de 1941; revoga dispositivos da Lei Complementar no 76, de 6 de julho de 1993, e da Lei $n^{\circ}$ 13.347, de 10 de outubro de 2016; e dá outras providências. Disponível em: <http://www.planalto.gov.br/ccivil_03/_ato20152018/2017/lei/L13465.htm>. Acesso em: 25 jul. 2017.

107 BRASIL. Lei n. 13.465, de 11 de julho de 2017. Dispõe sobre a regularização fundiária rural e urbana, sobre a liquidação de créditos concedidos aos assentados da reforma agrária e sobre a regularização fundiária no âmbito da Amazônia Legal; institui mecanismos para aprimorar a eficiência dos procedimentos de alienação de imóveis da União; altera as Leis nos 8.629 , de 25 de fevereiro de 1993, 13.001, de 20 de junho de 2014, 11.952, de 25 de junho de 2009, 13.340, de 28 de setembro de 2016, 8.666, de 21 de junho de 1993, 6.015, de 31 de dezembro de 1973, 12.512, de 14 de outubro de 2011, 10.406, de 10 de janeiro de 2002 (Código Civil), 13.105, de 16 de março de 2015 (Código de Processo Civil), 11.977, de 7 de julho de 2009, 9.514, de 20 de novembro de 1997, 11.124, de 16 de junho de 2005, 6.766, de 19 de dezembro de 1979, 10.257, de 10 de julho de 2001, 12.651, de 25 de maio de 
a competência municipal está restrita aos imóveis urbanos, não alcançando, no caso imóveis rurais desocupados em áreas urbanas, de expansão urbana ou de urbanização específica. A competência nesses casos, conforme dispõe o Código Civil em vigor, é da União (art. 1276, $\left.\int 1^{\circ}\right)^{108}$.

A falta de instrumentos preventivos de controle do uso do solo de imóveis rurais, mesmo quando localizados em zonas urbanas definidas em lei municipal, faz com que a pressão pelo uso da terra gere ocupações e conflitos fundiários urbanos. Nesses casos restará apenas aos Municípios convalidar situações de ocupações consumadas, sem a possibilidade de planejar o uso do solo por meio da aplicação do princípio da destinação efetiva assegurado pelo novo marco legal. No entanto, ainda que tal modificação legislativa tenha dado maior autonomia aos municípios em garantir o direito à moradia da população, tal medida não contribui para o pleno desenvolvimento das funções sociais da cidade, considerado um princípio da política urbana brasileira.

\section{Considerações finais}

O presente artigo teve por objetivo investigar quais são as normas jurídicas que incidem sobre o imóvel agrário em áreas urbanas, bem como quais são as repercussões da Lei n. 13.465/2017 para essa discussão.

A nova lei introduziu a aplicação do princípio da destinação efetiva para fins de regularização fundiária urbana, bem como uma nova terminologia: o núcleo urbano. Essa nova definição permite a intervenção do município mesmo nos imóveis localizados em área rural, ou seja, em áreas não previstas no plano diretor como urbanas, de expansão urbana ou de urbanização específica. A única exigência é de que a área ocupada seja inferior à fração mínima de parcelamento na região. Essa abordagem é compatível com a noção de planejamento territorial municipal único, prevista no Estatuto da Cidade.

Contudo, o critério da destinação efetiva pode afetar tanto o planejamento das cidades, gerando descontrole da expansão da mancha urbana, como prejudicar a segurança alimentar do território, pois a conversão do solo rural em urbano é altamente rentável para fins de especulação imobiliária. Para tentar limitar esse efeito, a autonomia do município para desafetar o solo rural está limitada aos casos em que a área perdeu sua capacidade produtiva, não tendo sido revogada totalmente a norma disciplinada na Instrução Normativa do INCRA n. 17-B/1980.

Quanto ao aspecto tributário, a partir da análise jurisprudencial, pode-se concluir que em caso de conflito entre o regime de tributação municipal e federal, prevalecerá o regime da propriedade rural, independentemente se localizado em área urbana, de expansão urbana ou de urbanização específica. Os principais instrumentos disponíveis para esse fim na Constituição de 1988 e na Lei Federal n. 10.257/2001, que são o parcelamento compulsório, a tributação progressiva e a desapropriação por descumprimento da função social da propriedade urbana não são inaplicáveis a esses imóveis, independentemente de sua localização, uma vez que prevalece o princípio da destinação agrária sobre o princípio da localização do IPTU. A Lei n. 13.465/2017. Nesse ponto, não trouxe uma solução para a questão.

A falta de instrumentos preventivos de controle do uso do solo de imóveis rurais, mesmo quando localizados em zonas urbanas definidas em lei Municipal, faz com que a pressão pelo uso da terra gere ocu-

2012, 13.240, de 30 de dezembro de 2015, 9.636, de 15 de maio de 1998, 8.036, de 11 de maio de 1990, 13.139, de 26 de junho de 2015, 11.483, de 31 de maio de 2007, e a 12.712, de 30 de agosto de 2012, a Medida Provisória no 2.220, de 4 de setembro de 2001, e os Decretos-Leis $n^{\text {os }} 2.398$, de 21 de dezembro de 1987, 1.876, de 15 de julho de 1981, 9.760, de 5 de setembro de 1946, e 3.365, de 21 de junho de 1941; revoga dispositivos da Lei Complementar $n^{\circ} 76$, de 6 de julho de 1993, e da Lei no 13.347 , de 10 de outubro de 2016; e dá outras providências. Disponível em: <http://www.planalto.gov.br/ccivil_03/_ato2015-2018/2017/lei/L13465.htm>. Acesso em: 25 jul. 2017.

108 BRASIL. Lei n. 10.406, de 10 de janeiro de 2002. Institui o Código Civil. Disponível em: < http://www.planalto.gov.br/ ccivil_03/leis/2002/L10406.htm>. Acesso em: 25 jul. 2017. 
pações e conflitos fundiários urbanos. Nesses casos restará apenas aos Municípios convalidar situações de ocupações consumadas, sem a possibilidade de planejar o uso do solo por meio da aplicação do princípio da destinação efetiva assegurado pelo novo marco legal. No entanto, tal medida não contribui para o pleno desenvolvimento das funções sociais da cidade, considerado um princípio da política urbana brasileira.

\section{REFERÊNCIAS BIBLIOGRÁFICAS}

BRASIL. Constituição (1998). Constituição da República Federativa do Brasil. Disponível em: <www.planalto.gov. br/ccivil_03/constituicao/constituicao.htm>. Acesso em: 05 maio 2015.

BRASIL. Decreto n. 55.981, de 31 de março de 1965. Regulamenta dispositivos do Estatuto da Terra. Disponível em: <http://www.planalto.gov.br/ccivil_03/decreto/1950-1969/D55891.htm>. Acesso em: 05 maios 2015.

BRASIL. Decreto n. 58, de 10 de dezembro de 1937. Dispõe sobre loteamento e venda de terrenos. Disponível em: <http://www.planalto.gov.br/ccivil_03/decreto-lei/1937-1946/Del058.htm>. Acesso em: 05 maio 2015.

BRASIL. Decreto n. 59.428, de 27 de outubro de 1966. Regulamenta dispositivos do Estatuto da Terra. Disponível em: < http://www.planalto.gov.br/ccivil_03/decreto/antigos/d59428.htm>. Acesso em: 05 maio 2015.

BRASIL. Decreto n. 62.594, de 8 de abril de 1968. Regulamenta o art. 65 do Estatuto da Terra. Disponível em: <http://www.planalto.gov.br/ccivil_03/decreto/antigos/d62504.htm>. Acesso em: 23 jun. 2015.

BRASIL. Decreto n. 7.341, de 22 de outubro de 2010. Regulamenta a Lei n. 11.952, de 25 de junho de 2009, para dispor sobre a regularização fundiária das áreas urbanas situadas em terras da União no âmbito da Amazônia Legal, definida pela Lei Complementar no 124, de 3 de janeiro de 2007, e dá outras providências. Disponível em: <http://www.planalto.gov.br/ccivil_03/_ato2007-2010/2010/Decreto/D7341.htm>. Acesso em: 17 jun. 2017.

BRASIL. Decreto n. 7.830, de 17 de outubro de 2012. Dispõe sobre o Sistema de Cadastro Ambiental Rural. Disponível em: <http://www.planalto.gov.br/ccivil_03/_Ato2011-2014/2012/Decreto/D7830.htm>. Acesso em: 05 maio 2015.

BRASIL. Decreto-Lei n. 311, de 2 de março de 1938. Dispõe sobre a divisão territorial do país. Disponível em: <http://www2.camara.leg.br/legin/fed/declei/1930-1939/decreto-lei-311-2-marco-1938-351501-publicacaooriginal-1-pe.html>. Acesso em: 05 maio 2015.

BRASIL. Decreto-Lei n. 57, de 18 de novembro de 1966. Dispõe sobre o Imposto sobre a Propriedade Territorial Rural. Disponível em: <http://www.planalto.gov.br/ccivil_03/decreto-lei/Del0057.htm>. Acesso em: 07 maio 2015.

BRASIL. Instrução Normativa n. 17-B, de 22 de dezembro, de 1980. Dispõe sobre o parcelamento de imóveis rurais. Disponível em: < http://www.incra.gov.br/media/institucional/legislacao/atos_internos/instrucoes/ instrucao/I17b_221280.pdf>. Acesso em: 23 jun. 2015.

BRASIL. Lei Complementar n. 76, de 6 de julho de 1993. Dispõe sobre procedimentos do processo de desapropriação de imóvel rural. Disponível em: <http://www.planalto.gov.br/ccivil_03/leis/LCP/Lcp76.htm>. Acesso em: 05 maio 2015.

BRASIL. Lei n. 10.257, de 10 de julho de 2001. Regulamenta os arts. 182 e 183 da Constituição Federal e estabelece diretrizes gerais da política urbana. Disponível em: < http://www.planalto.gov.br/ccivil_03/leis/ LEIS_2001/L10257.htm>. Acesso em: 23 jun. 2015. 
BRASIL. Lei n. 10.406, de 10 de janeiro de 2002. Institui o Código Civil. Disponível em: < http://www.planalto.gov.br/ccivil_03/leis/2002/L10406.htm>. Acesso em: 25 jul. 2017.

BRASIL. Lei n. 11.952, de 25 de junho de 2009. Dispõe sobre a regularização fundiária das ocupações incidentes em terras situadas em áreas da União, no âmbito da Amazônia Legal; altera as Leis nos 8.666, de 21 de junho de 1993, e 6.015, de 31 de dezembro de 1973; e dá outras providências. Disponível em: < http:// www.planalto.gov.br/ccivil_03/_ato2007-2010/2009/lei/111952.htm>. Acesso em: 17 jun. 2017.

BRASIL. Lei n. 11.977, de 7 de julho de 2009. Dispõe sobre o Programa Minha Casa, Minha Vida - PMCMV e a regularização fundiária de assentamentos localizados em áreas urbanas; altera o Decreto-Lei no3.365, de 21 de junho de 1941, as Leis nos 4.380, de 21 de agosto de 1964, 6.015, de 31 de dezembro de 1973, 8.036, de 11 de maio de 1990, e 10.257, de 10 de julho de 2001, e a Medida Provisória no 2.197-43, de 24 de agosto de 2001; e dá outras providências. Disponível em: <http://www.planalto.gov.br/ccivil_03/_ato20072010/2009/lei/111977.htm>. Acesso em: 11 jun. 2017.

BRASIL. Lein. 12.651, de 25 de maio de 2012. Dispõe sobre a proteção vegetal nativa. Disponível em: < http:// www.planalto.gov.br/ccivil_03/_ato2011-2014/2012/lei/112651.htm>. Acesso em: 23 jun. 2015.

BRASIL. Lei n. 13.465, de 11 de julho de 2017. Dispõe sobre a regularização fundiária rural e urbana, sobre a liquidação de créditos concedidos aos assentados da reforma agrária e sobre a regularização fundiária no âmbito da Amazônia Legal; institui mecanismos para aprimorar a eficiência dos procedimentos de alienação de imóveis da União; altera as Leis nos 8.629, de 25 de fevereiro de 1993, 13.001, de 20 de junho de 2014, 11.952, de 25 de junho de 2009, 13.340, de 28 de setembro de 2016, 8.666, de 21 de junho de 1993, 6.015, de 31 de dezembro de 1973, 12.512, de 14 de outubro de 2011, 10.406, de 10 de janeiro de 2002 (Código Civil), 13.105, de 16 de março de 2015 (Código de Processo Civil), 11.977, de 7 de julho de 2009, 9.514, de 20 de novembro de 1997, 11.124, de 16 de junho de 2005, 6.766, de 19 de dezembro de 1979, 10.257, de 10 de julho de 2001, 12.651, de 25 de maio de 2012, 13.240, de 30 de dezembro de 2015, 9.636, de 15 de maio de 1998, 8.036, de 11 de maio de 1990,13.139, de 26 de junho de 2015, 11.483, de 31 de maio de 2007, e a 12.712, de 30 de agosto de 2012, a Medida Provisória no 2.220, de 4 de setembro de 2001, e os Decretos-Leis nos 2.398, de 21 de dezembro de 1987, 1.876, de 15 de julho de 1981, 9.760, de 5 de setembro de 1946, e 3.365, de 21 de junho de 1941; revoga dispositivos da Lei Complementar no 76, de 6 de julho de 1993, e da Lei no 13.347, de 10 de outubro de 2016; e dá outras providências. Disponível em: <http:/ /www. planalto.gov.br/ccivil_03/_ato2015-2018/2017/lei/L13465.htm>. Acesso em: 25 jul. 2017.

BRASIL. Lei n. 4.504, de 30 de novembro de 1964. Dispõe sobre o Estatuto da Terra. Disponível em: < http:// www.planalto.gov.br/ccivil_03/leis/L4504.htm>. Acesso em: 05 maio 2015.

BRASIL. Lei n. 4.947, de 6 de abril de 1966. Fixa normas de Direito Agrário. Disponível em: < http://www. planalto.gov.br/ccivil_03/leis/L4947.htm>. Acesso em: 05 maio 2015.

BRASIL. Lei n. 5.172, de 25 de outubro de 1966. Dispõe sobre o Sistema Tributário Nacional. Disponível em: <http://www.planalto.gov.br/ccivil_03/leis/L5172.htm>. Acesso em: 07 jun. 2015.

BRASIL. Lei n. 5.868, de 12 de dezembro de 1972. Cria o Sistema Nacional de Cadastro Rural. Disponível em: <http://www.planalto.gov.br/ccivil_03/leis/L5868.htm>. Acesso em: 05 maio 2015.

BRASIL. Lei n. 8.629, de 25 de fevereiro de 1993. Regulamenta os dispositivos constitucionais relativos à reforma agrária. Disponível em: <http://www.planalto.gov.br/ccivil_03/leis/L8629.htm>. Acesso em: 5 maio 2015.

BRASIL. Lei n. 9.393, de 19 de dezembro de 1996. Dispõe sobre o Imposto sobre a Propriedade Territorial Rural. Disponível em: <http://www.planalto.gov.br/ccivil_03/leis/L9393.htm>. Acesso em: 23 maio 2015.

BRASIL. Secretaria da Receita Federal. Ato Declaratório Normativo COSIT n. 9, de 31 de julho de 1998. Entendimento da expressão "área contínua" constante do $\$ 2^{\circ}$ do art. $1^{\circ}$ da Lei n. 9.393/1996. Disponível em: 
$<$ http://normas.receita.fazenda.gov.br/sijut2consulta/link.action?visao=anotado\&idAto $=5843>$. Acesso em: 25 jul. 2017.

BRASIL. Superior Tribunal de Justiça. Agravo Regimental no Agravo em Recurso Especial n. 259607. Classificação e definição do imóvel a partir da localização e destinação. Relator: Ministro Benedito Gonçalves. $1^{a}$ Turma. Julgado em: 11/06/2013. Publicado em: 17/06/2013. Disponível em: <https://ww2.stj.jus.br/processo/ revista $/$ documento $/$ mediado $/$ ?componente $=$ ATC\&sequencial $=29416376 \&$ num_registro $=201202454057$ $\&$ data $=20130617 \&$ tipo $=5 \&$ formato $=$ PDF $>$. Acesso em: 20 jun. 2015.

BRASIL. Superior Tribunal de Justiça. Recurso Especial n. 1112646 (Processo n. 200900510886). Imóvel em área urbana com destinação rural. Relator: Ministro Herman Benjamin. $1^{\text {a }}$ Turma. Julgado em: 26/08/2009. Publicado em: 28/08/2009. Disponível em: <https://ww2.stj.jus.br/processo/revista/documento/media $\mathrm{do} /$ ?componente $=$ ATC $\&$ sequencial $=5927728 \&$ num_registro $=200900510886 \&$ data $=20090828 \&$ tipo $=5 \&$ formato=PDF $>$. Acesso em: 19 jun. 2015.

BRASIL. Superior Tribunal de Justiça. Recurso Especial n. 1150408 (Processo n. 200900743331). Não incidência do IPTU em imóvel localizado em área urbana com atividades rurais. Relator: Ministro Castro Meira. $2^{a}$ Turma. Julgado em: 28/09/2010. Publicado em: 19/10/2010. Disponível em: <https://ww2.stj.jus.br/ processo $/$ revista $/$ documento $/$ mediado $/$ ?componente $=$ ATC\&sequencial $=12272382 \&$ num_registro=2009 00743331\&data $=20101019 \&$ tipo $=5 \&$ formato $=$ PDF $>$. Acesso em: 20 jun. 2015.

BRASIL. Superior Tribunal de Justiça. Recurso Especial n. 1207093 - SP (Processo n. 201001279449). Imóvel localizado em área urbana com exercício de atividade agropastoril. Relator: Ministro Benedito Gonçalves. $1^{\text {a }}$ Turma. Julgado em: 23/11/2010. Publicado em: 26/11/2010. Disponível em: <https://ww2.stj.jus.br/ processo $/$ revista $/$ documento $/$ mediado $/$ ?componente $=I T A \&$ sequencial $=1024712$ \&num_registro $=20100$ 1279449\&data $=20101126 \&$ formato $=$ PDF $>$. Acesso em: 20 jun. 2015.

BRASIL. Superior Tribunal de Justiça. Recurso Especial n. 472628 - RS (Processo n. 200201353268). Critério a serem observados: localização e destinação. Relator: Ministro Castro Meira. $2^{a}$ Turma. Julgado em: 12/05/2005. Publicado em: 20/06/2005. Disponível em: <https://ww2.stj.jus.br/processo/revista/documento $/$ mediado $/$ ?componente $=$ ATC\&sequencial $=1403234 \&$ num_registro $=200201353268 \&$ data $=20040$ 927\&tipo $=5 \&$ formato $=$ PDF $>$. Acesso em: 19 jun. 2015.

BRASIL. Superior Tribunal de Justiça. Recurso Especial n. 492869 - PR (Processo n. 200300116193). Imóvel situado em zona urbana: localização e destinação. Relator: Ministro Teori Albino Zavascki. $1^{\text {a }}$ Turma. Julgado em: 15/02/2005. Publicado em: 07/03/2005. Disponível em: <https://ww2.stj.jus.br/processo/revista/ documento $/$ mediado $/$ ?componente $=$ ATC $\&$ sequencial $=1621850 \&$ num_registro $=200300116193 \&$ data $=2$ 0050307\&tipo $=5 \&$ formato $=$ PDF $>$. Acesso em: 19 jun. 2015.

BRASIL. Superior Tribunal de Justiça. Recurso Especial n. 679173 - SC. Imóvel situado em zona urbana e a necessidade de comprovação da destinação econômica. Relatora: Ministra Denise Arruda. $1^{\text {a }}$ Turma. Julgado em: 11/09/2007. Publicado em: 18/10/2007. Disponível em: <https://ww2.stj.jus.br/processo/revista/ documento $/$ mediado $/$ ?componente $=$ ATC $\&$ sequencial $=3361918 \&$ num_registro $=200400998596 \&$ data $=2$ 0071018\&tipo $=5 \&$ formato $=$ PDF $>$. Acesso em: 19 jun. 2015.

BRASIL. Supremo Tribunal Federal. Mandado de Segurança n. 24719. Classificação da propriedade rural. Relator: Ministro Carlos Velloso. Tribunal Pleno. Julgado em: 22/04/2004. Publicado em: 14/05/2004. Disponível em: <www.stf.gov.br>. Acesso em: 25 jun. 2015.

BRASIL. Supremo Tribunal Federal. Recurso Extraordinário n. 100427 - DF. Imposto Predial e Territorial Urbano. Relator: Ministro Carlos Madeira. $2^{a}$ Turma. Julgado em 04/02/1986. Publicado em: 07/03/1986. Disponível em: <www.stf.gov.br>. Acesso em: 13 jun. 2015.

BRASIL. Supremo Tribunal Federal. Recurso Extraordinário n. 1407735 - SP. Direito constitucional, tributário e processual civil. Relator: Ministro Sydney Sanches. Tribunal Pleno. Julgado em: 08/10/1998. Publicado 
em: 04/06/1999. Disponível em: <www.stf.gov.br> Acesso em: 13 jun. 2015.

BRASIL. Supremo Tribunal Federal. Recurso Extraordinário n. 93850 - MG. Critério para a caracterização do imóvel como rural ou urbano. Relator: Ministro Moreira Alves. Tribunal Pleno. Julgado em: 20/05/1982. Publicado em: 27/08/1982. Disponível em: <http://redir.stf.jus.br/paginadorpub/paginador. jsp?docTP=AC\&docID=187342>. Acesso em: 13 jun. 2015.

BRASÍLIA. Tribunal Regional Federal (1ª Região). Apelação Cível n. 200143000010655 - TO. Imóvel rural em área urbana. Relator: Desembargador Carlos Olavo. $4^{a}$ Turma. Julgado em: 16/05/2005. Publicado em: 31/05/2005. Disponível em: <www.trf1.jus.br>. Acesso em: 19 jun. 2015.

BRASÍLIA. Tribunal Regional Federal (1ª Região). Apelação Civel n. 200143000013530 - TO. Imóvel rural em área urbana. Relator: Desembargador Carlos Olavo. $4^{a}$ Turma. Julgado em: 16/05/2005. Publicado em: 02/06/2005. Disponível em: <www.trf1.jus.br>. Acesso em: 19 jun. 2015.

CÂMARA, Andreza Aparecida. Políticas Públicas de Habitação e o programa de aceleração do crescimento: análise das intervenções no estado do Rio de Janeiro. Revista Brasileira de Políticas Públicas, Brasília, v. 1, n. 3 número especial, p. 145-178, dez. 2011.

ENDLICH, Ângela Maria. Perspectivas sobre o urbano e o rural. In: SPOSITO, Maria Encarnação Beltrão; WHITACKER, Arthur Magon. (Org.). Cidade e campo: relações e contradições entre rural e urbano. São Paulo: Expressão Popular, 2006. p. 11-32.

FISCHER, Luly Rodrigues da Cunha. Ordenamento territorial e planejamento municipal: estudo de caso das limitações supralocais à aplicação do art. 30, VIII da Constituição de 1988 pelo município de Parauapebas, Pará. 2014. Tese (Doutorado em Direito) - Instituto de Ciências Jurídicas, Universidade Federal do Pará, Belém, 2014.

JARDIM, Eduardo Marcial Ferreira. Manual de direito financeiro e tributário. 12. ed. São Paulo: Saraiva, 2011.

PERNAMBUCO. Tribunal Regional Federal (5a Região). Apelação Cível n. 294568 - SE (Processo $n$. 200205000173537). Distinção entre imóvel rural e urbano. Relator: Desembargador Hélio Silvio Ourem Campos. $1^{a}$ Turma. Julgado em: 11/12/2003. Publicado em: 19/04/2004. Disponível em: <www.trf4.jus. br>. Acesso em: 13 jun. 2015.

PERNAMBUCO. Tribunal Regional Federal (5 $5^{\mathrm{a}}$ Região). Apelação Cível $n .31409$ (Processo $n$. 00033218520124058200). Imóvel localizado em área urbana com destinação rural e a incidência de ITR. Relator: Desembargador Roberto Machado. $1^{\text {a }}$ Turma. Julgado em: 26/02/2015. Publicado em: 05/03/2015. Disponível em: <www.trf5.jus.br>. Acesso em: 23 jun. 2015.

PERNAMBUCO. Tribunal Regional Federal (5a Região). Apelação Cível n. 325790 - SE (Processo n. 200185000027695). Imóvel que preencher as condições para se enquadrar como urbano. Relator: Desembargador Francisco Cavalcanti. $2^{a}$ Turma. Julgado em: 02/03/2004. Publicado em: 19/04/2004. Disponível em: <www.trf5.jus.br>. Acesso em: 13 jun. 2015.

PERNAMBUCO. Tribunal Regional Federal (5 Região). Apelação Cível n. 429176 - CE. (Processo n. 200581000202817). Imóvel situado em zona urbana. Relator: Desembargador Geraldo Apoliano. $3^{\text {a }}$ Turma. Julgado em: 17/02/2011. Publicado em: 24/02/2011. Disponível em:<www.trf5.jus.br>. Acesso em: 23 jun. 2015.

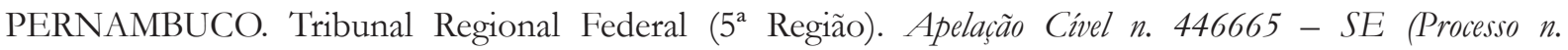
20018500002760). Imóvel situado em zona urbana com destinação rural. Relator: Juiz Federal Convocado Frederico Pinto de Azevedo. $3^{a}$ Turma. Julgado em: 28/04/2011. Publicado em: 10/05/2011. Disponível em: <www. trf5.jus.br>. Acesso em: 23 jun. 2015.

PERNAMBUCO. Tribunal Regional Federal (5a Região). Apelação Civel n. 522906 - SE (Processo n. 
200785000038166). Critério topográfico e destinação do imóvel. Relator: Desembargador Luiz Alberto Gurgel de Faria. $3^{a}$ Turma. Julgado em: 29/09/2011. Publicado em: 07/10/2011. Disponível em: <www. trf5.jus.br>. Acesso em: 23 jun. 2015.

PERNAMBUCO. Tribunal Regional Federal (5a Região). Apelação Civel n. 54795 - SE (Processo $n$. 00013861720114058500). Imóvel localizada em zona urbana e critério da destinação. Relator: Desembargador Geraldo Apoliano. $3^{a}$ Turma. Julgado em: 03/04/2014. Publicado em: 08/04/2014. Disponível em: $<$ www.trf5.jus.br>. Acesso em: 23 jun. 2015.

PERNAMBUCO. Tribunal Regional Federal (5 Região). Apelação Civel n. 548781 (Processo n. 548781). Imóvel localizado em área urbana com destinação rural. Relator: Desembargador Francisco Cavalcanti. $1^{a}$ Turma. Julgado em: 08/11/2012. Publicado em: 16/11/2012. Disponível em: <www.trf5.jus.br>. Acesso em: 23 jun. 2015.

PERNAMBUCO. Tribunal Regional Federal (5a Região). Apelação Cível n. 98345 - SE (Processo $n$. 200485000050724). Imposto Predial e Territorial Urbano e destinação do imóvel. Relator: Desembargador Élio Wanderley de Siqueira Filho. 2a Turma. Julgado em: 11/10/2011. Publicado em: 20/10/2011. Disponível em: <www.trf5.jus.br>. Acesso em: 23 jun. 2015.

PORTO ALEGRE. Tribunal Regional Federal (4a Região). Apelação Civel n. 50226126920134047200. Anulação de débito fiscal. Relator: Desembargador Rômulo Pizzolatti. 2a Turma. Julgado em: 10/10/2014. Publicado em: 14/10/2014. Disponível em: <www.trf4.jus.br>. Acesso em: 24 jun. 2015.

PORTO ALEGRE. Tribunal Regional Federal (4a Região). Reexame Necessário Civel Processo $n$. 500354203201240472. Imposto Predial e Territorial Urbano e Imposto sobre a Propriedade Territorial Rural. Relator: Desembargador Rômulo Pizzolatti. $2^{a}$ Turma. Julgado em: 12/11/2013. Publicado em: 13/11/2013. Disponível em:<www.trf4.jus.br>. Acesso em: 24 jun. 2015.

RAMOS, Luciana de Oliveira; SCHORSCHER, Vivian Cristina. Método do caso. In: GHIRARDI, José Garcez (Org.). Métodos de ensino em Direito: conceitos para um debate. São Paulo: Saraiva, 2009. p. 49-60.

REIS, Luá Cristine Siqueira; GONÇALVES NETO, João da Cruz. Produção de alimentos: agricultura familiar x cultura de exportação no Brasil sob a perspectiva da sustentabilidade. Revista Brasileira de Políticas Públicas, Brasília, v. 4, n. 1, p. 89-98, 2014.

REZEK, Gustavo Elias Kallás. Imóvel rural: agrariedade, ruralidade e rusticidade. Curitiba: Juruá, 2007.

RIO DE JANEIRO. Tribunal Regional Federal (2 Região). Apelação Civel n. 597137 (Processo $n$. 200550010120901). Competência para definição do perímetro urbano. Relator: Desembargador Aluisio Gonçalves de Castro Mendes. 5a Turma. Disponível em: <www.trf2.jus.br>. Acesso em: 13 jun. 2015.

RIO DEJANEIRO. Tribunal Regional Federal (2a Região). Apelação cíveln. 147640 - RJ (Processo n. 9702294614). Imposto Territorial Rural e Imposto sobre a Propriedade Predial Urbana. Relator: Desembargador Castro Aguiar. $2^{a}$ Turma. Julgado em: 14/02/2001. Publicado em: 08/01/2001. Disponível em: <www.trf2.jus.br>. Acesso em: 13 jun. 2015.

ROCHA, Olavo Acyr de Lima. A desapropriação no direito agrário. São Paulo: Atlas, 1992.

SÃO PAULO. Tribunal Regional Federal (3 Região). Apelação Cível n. 1319113 (Processo n. 000144857.2003.4.03.6119). Sujeição ao ITR, art. 15 do Decreto-Lei 57/1966. Relator: Juiz Federal Convocado Silva Neto. Julgado em: 26/11/2010. Publicado em: 24/01/2011. Disponível em:<www.trf3.jus.br>Acesso em: 23 jun. 2015.

SÃO PAULO. Tribunal Regional Federal (3 $3^{a}$ Região). Apelação Cível n. 1346598 - SP (Processo $n$. 000851619964036100). Insuficiência do critério da localização do imóvel. Relator: Juiz Federal Convocado Leonel Ferreira. Julgado em: 30/03/2011. Publicado em: 18/04/2011. Disponível em:<www.trf3.jus.br>. Acesso 
em: 23 jun. 2015.

SÃO PAULO. Tribunal Regional Federal (3ª Região). Reexame Necessário Cível n. 438884. (Processo n. 0505273 40.1992.4.03.6182). Imóvel situado em área de expansão urbana. Relator: Desembargador Fabio Pietro. $4^{a}$ Turma. Julgado em: 28/04/2004. Publicado em: 26/05/2004. Disponível em: <www.trf3.jus.br>. Acesso em: 13 jun. 2015.

SÃO PAULO. Tribunal Regional Federal (3ª Região). Reexame Necessário Civel n. 872104 (Processo n. 01257809619794036100). Imóvel situado em área de expansão urbana. Relator: Juiz Federal Convocado Roberto Lemos. $3^{\text {a }}$ Turma. Julgado em: 19/07/2012, publicado em: 03/08/2012. Disponível em: <www.trf3.jus.br>. Acesso em: 23 jun. 2015.

SILVA, José Afonso da. Curso de direito constitucional positivo. São Paulo: Malheiros, 2011.

SILVEIRA, Domingos Sávio Dresch da. A propriedade agrária e suas funções sociais. In: SILVEIRA, Domingos Sávio Dresch da (Org.). O Direito Agrário em debate. Porto Alegre: Livraria do Advogado. 1998. p. $11-25$.

SOUZA FILHO, Carlos Frederico Marés; SONDA, Claudia; LEMOS, Angelaine. Cadastro Ambiental Rural (CAR) e povos tradicionais. Revista da Faculdade de Direito UFG. Goiás, v. 39, n. 1, p. 77-91, jun., 2015. Disponível em: <http://www.revistas.ufg.br/index.php/revfd/article/view/36494/18729>. Acesso em: 03 jul. 2015.

SOUZA, João Bosco Medeiros de. Direito Agrário. Lições básicas. São Paulo: Saraiva, 1994. p. 27-37.

TRENTINI, Flavia. Teoria do direito agrário contemporâneo. São Paulo: Atlas, 2012.

VEIGA, José Eli da. A relação rural/ urbano no desenvolvimento regional. Brasília, 2005. Disponível em: <http:// www.nomads.usp.br/documentos/textos/modos_vida/14_veiga/elidaveiga_relacao_ruralurbano.htm>. Acesso em: 10 jun. 2015.

VEIGA, José Eli da. Mudanças nas relações entre espaços rurais e urbanos. In: PIQUET, Rosélia; OLIVEIRA, Elzira de. Economia e território no Brasil contemporâneo. 2007. Disponível em: <http://www.zeeli.pro. br/wp-content/uploads/2012/06/Mudancas_nas_relacoes_entre_espacos.pdf>. Acesso em: 10 jun. 2015.

VEIGA, José Eli da. Nem tudo é urbano. Cienc. Cult., São Paulo, v. 56, n. 2, p. 26-29, Apr. 2004. Disponível em: <http:/ / cienciaecultura.bvs.br/scielo.php?script=sci_arttext\&pid=S0009-67252004000200016\&lng=e n\&nrm=iso $>$. Acesso em: 26 jul. 2017. 


\section{REVISTA BRASILEIRA DE POLÍTICAS PÚBLICAS BRAZILIAN JOURNAL OF PUBLIC POLICY}

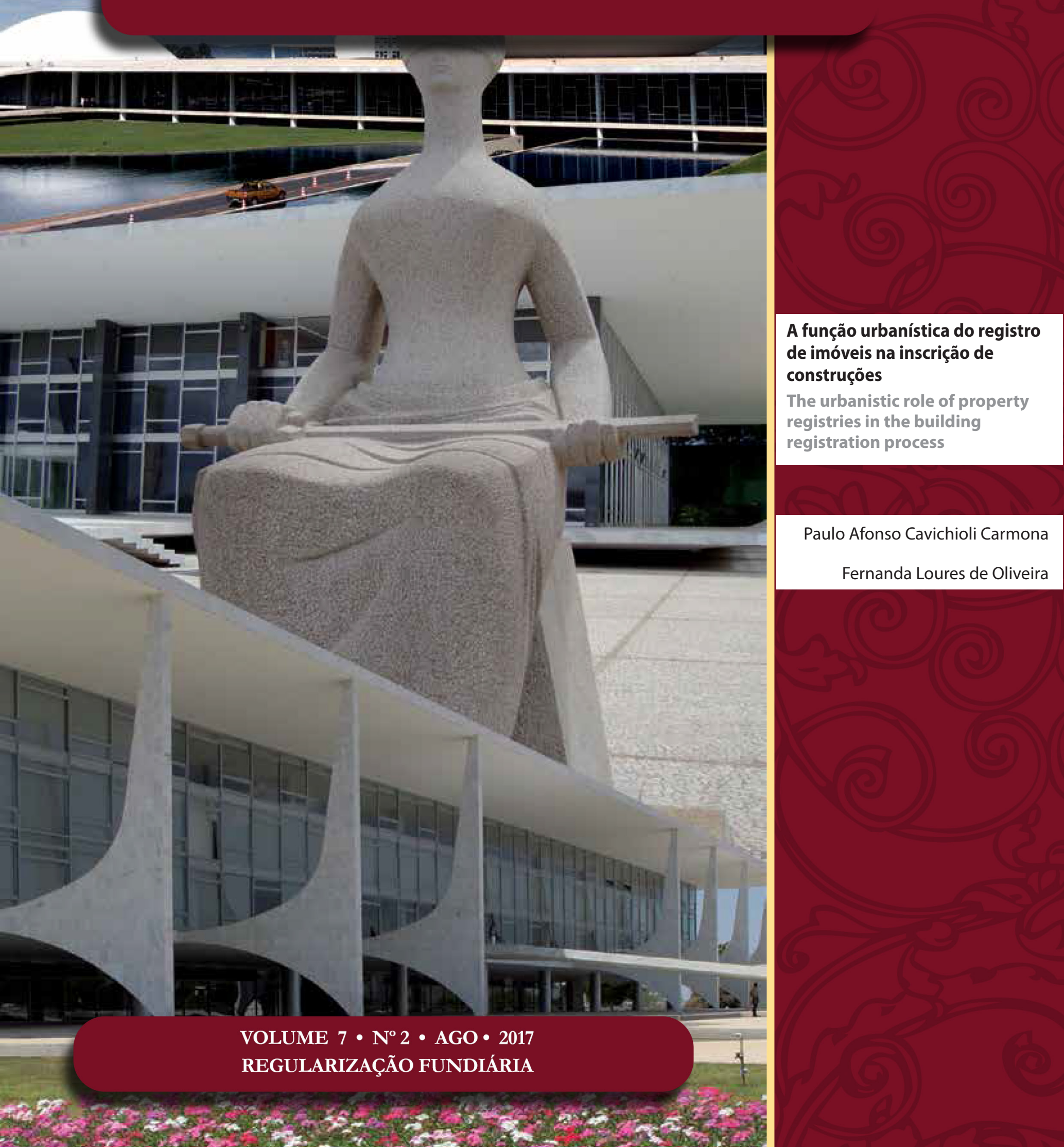




\title{
A função urbanística do registro de imóveis na inscrição de construções*
}

\section{The urbanistic role of property registries in the building registration process}

\author{
Paulo Afonso Cavichioli Carmona** \\ Fernanda Loures de Oliveira***
}

\section{Resumo}

A análise da legislação pátria denota que, ao longo do processo de construção do sistema de registro predial e com a afirmação do direito urbanístico como disciplina jurídica determinante para o desenvolvimento nacional, delineou-se, no Brasil, uma função urbanística do registro de imóveis. Essa função, de natureza preventiva e indireta, tem papel fundamental para obrigar o proprietário a respeitar os índices e determinações urbanísticas, sob pena de não ter êxito na inscrição de sua construção na serventia imobiliária. Entretanto, tomou corpo, com a edição da Lei 13.465 de 11 de julho de 2017, um questionável movimento destinado a suprimir o papel urbanístico do registro de imóveis, em clara afronta ao imperativo de ordenação das cidades. É o que se visa demonstrar por meio do presente artigo, que se vale de metodologia essencialmente dogmática, pela análise da legislação brasileira. As conclusões obtidas são no sentido da necessidade da manutenção do registro de imóveis como sentinela do direito urbanístico, em prol da afirmação de cidades organizadas. A originalidade do estudo decorre do caráter recente do normativo questionado, avaliando-se seus possíveis efeitos práticos sobre a organização do território urbano - principal ambiente de vida da população brasileira.

Palavras-chave: Controle Urbanístico. Registro de Imóveis. Averbação de Construções.

* Recebido em 20/07/2017 Aprovado em 09/08/2017

** Professor do Programa de Mestrado e Doutorado em Direito do Uniceub; mestre e doutor em Direito pela PUC-SP; Juiz de Direito (TJDFT); Professor dos cursos de especialização em Direito da FESMPDFT.

*** Doutoranda em Direito e Políticas Públicas pelo Centro Universitário de Brasília, Mestre em Direito e Políticas Públicas pelo Centro Universitário de Brasília. Registradora de Imóveis do $8^{\circ}$ Ofício de Registro de Imóveis do Distrito Federal.

\section{Abstract}

An analysis of Brazilian domestic legislation reveals that development of a building registration process over time and recognition of urban planning law as a core legal discipline for national development has had the effect of delineating a specific urban planning role for property registries in Brazil. This role, defined as preventative and indirect, is aimed principally at requiring property owners to comply with basic urban planning indices and rules, under penalty of having registration of their structures denied by the jurisdictional property registry service. However, a controversial movement designed to undermine the role of property registries in the urban planning process, in clear contravention of the imperative to ensure orderly development of cities, began to take shape with the enactment of Law No. 13,465 
of June 11, 2017. This article is intended to demonstrate the emergence of this phenomenon through application of an essentially dogmatic methodology centered on an examination of the pertinent Brazilian legislation. The study concludes that preserving the role registries as a protector of urban planning law is necessary to advocate on behalf of organized urban spaces. The study's novelty derives from the recentness of the law in question and consequent of the practical effects of urban territorial organization - the principal living environment of the Brazilian population.

Keywords: Urban Planning Controls. Property Registries.Notation of Buildings.

\section{INTRODUÇÃo}

O presente artigo tem como objetivo demonstrar que a edição da Lei 13.465 de 11 de julho de 2017, em relação à parte na qual permite a averbação de edificações por mera notícia do interessado, dispensando-se a apresentação do instrumento de habite-se, representa perigoso retrocesso legal, que reduz o controle urbanístico das construções realizado pelas serventias imobiliárias.

A metodologia de pesquisa utilizada é fundamentalmente dogmática, pautando-se na análise do normativo questionado, no entanto, utiliza-se, também, da revisão bibliográfica, por meio de pesquisa em fontes de doutrina afetas ao objeto de estudo. Toma-se como marco teórico a ideia de Vicente de Abreu Amadei, expressa em seu trabalho "o aspecto instrumental do registro imobiliário", que destaca a relevância do controle registral em matéria urbanística.

Inicia-se o trabalho verificando-se a importância do controle urbanístico das construções. Nesse contexto, apresenta-se o direito de construir não como uma prerrogativa decorrente do direito de propriedade, mas como uma atividade fortemente regulada pelo poder de polícia urbanística estatal. Em seguida, parte-se para o exame da função urbanística do registro de imóveis, destacando-se a importância e os termos em que se dá esse papel de controle, no que se refere à averbação das construções. Por fim, analisa-se o retrocesso representado pela modificação da legislação federal, defendendo-se a não aplicação dos novos dispositivos, até mesmo porque violadores da competência municipal em matéria de ordenação urbana.

A relevância do estudo é evidente, sob as óticas teórica e prática. É indispensável a adequada análise teórica da nova legislação, a fim de verificar se se amolda ao sistema jurídico pátrio, apontando-se suas eventuais incompatibilidades. Tal exame teórico possui, ainda, importante repercussão prática, pois influenciará a atuação das serventias de registro de imóveis do país, orientando sua qualificação na seara da averbação de construções.

\section{A IMPORTÂNCIA DO CONTROLE URBANÍSTICO DAS CONSTRUÇõES}

O urbanismo, temática essencial no mundo contemporâneo — marcadamente urbano — é entendido como um plexo de instrumentos estatais, que possuem como finalidade a ordenação dos espaços habitáveis e a obtenção de melhores condições de vida. Para o atingimento de seu fim, o urbanismo casa-se com o Direito para converter as necessidades urbanísticas em imposições legais, estabelecendo "normas de desenvolvimento, de funcionalidade, de conforto e de estética da cidade", racionalizando o uso do solo, ordenando o traçado urbano, coordenando o sistema viário e controlando as edificações construídas ou que se vise construir na urbe ${ }^{1}$.

1 MEIRELLES, Hely Lopes. Direito municipal brasileiro. 16. ed. São Paulo: Malheiros, 2008. p. 522-524. 
Com efeito, o "uso da propriedade urbana deve-se dar em prol do coletivo", por isso as normas urbanísticas, em sua essência, são sempre direcionadas ao bem-estar da coletividade e ao interesse público ${ }^{3}$. Os interesses sociais tutelados nesse campo são os mais diversos, e "vão desde os que asseguram a satisfação de necessidades físicas, até os que proporcionam conforto espiritual ou sensações estéticas”, estabelecendo-se coeficientes máximos de ocupação, gabaritos de altura dos edifícios, determinações de recuo e afastamento, bem como se impondo o dever de "solidez, salubridade, funcionalidade e estética às edificações", além do equilíbrio ambiental, em prol da garantia da saúde, da segurança e do conforto aos usuários e à comunidade de modo geral ${ }^{4}$.

Nessa linha, o proprietário-construtor deve ter em mente que, embora possua o domínio do imóvel, não pode dar a ele o uso e a destinação que lhe aprouver, pois o direito de construir não se submete, apenas, aos domínios do direito privado, mas, ao contrário, deve observar uma série de restrições decorrentes do direito urbanístico. A construção consiste em procedimento de urbanização secundária, após a constituição legal do lote, que deve ser controlada pelo direito urbanístico tanto no que se refere à estabilidade, segurança e salubridade do edifício, como também no que tange à compatibilidade do projeto de construção com o plano de desenvolvimento urbano ${ }^{5}$.

Não por outro motivo, a legislação nacional tanto se ocupa de disciplinar o direito de construir. O Estatuto da Cidade (Lei 10.257 de 10 de julho de 2001) é farto de exemplos nesse sentido: estabelece como diretriz geral da política urbana o estímulo à utilização de padrões construtivos que reduzam impactos ambientais e proporcionem a economia de recursos naturais (art. $2^{\circ}$, XVII); confere importância ao coeficiente de aproveitamento do solo, entendido como a relação entre a área edificável e a área do imóvel, definida a partir da proporcionalidade entre a infraestrutura existente e o aumento de densidade esperado, a qual deve ser fixada, em seus limites máximos, no plano diretor municipal ou distrital (art. 28, $\iint 1^{\circ}$ a $3^{\circ}$ ); e prevê a possibilidade de utilização, pelo ente federativo local, das operações urbanas consorciadas - conjunto de medidas coordenadas pelo Município ou Distrito Federal, com proprietários, moradores, usuários e investidores privados para obter, em área determinada, transformações urbanísticas estruturais, bem como melhorias sociais e ambientais - para a regularização de construções e para a concessão de incentivos aos projetos que comprovem o uso de tecnologias de construção e edificação que valorizem os recursos naturais

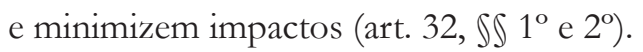

Nada obstante, é na seara das normas locais que se encontram os principais dispositivos sobre o assunto. O plano diretor é o instrumento pelo qual a Administração municipal ou distrital "poderá determinar quando, como e onde edificar" ". Há também as leis de zoneamento, com fixação do uso permitido ou predominante e os códigos de obras e de posturas, em que são fixadas as minúcias técnicas e jurídicas para aprovação de edificações na localidade.

De fato, as normas urbanísticas podem emanar de qualquer dos entes federados, no entanto, é fácil identificar a especial importância do papel dos municípios e do Distrito Federal7. É a esses entes atribuída a competência para legislar sobre normas de interesse local, podendo, pois, tecer particularidades sobre a atividade edificatória realizada em seus domínios.

Como mencionado, as citadas particularizações são expressas por meio de regulamentos sobre áreas edi-

2 CARMONA, Paulo Afonso Cavichioli. Violência x cidade: o papel do Direito Urbanístico na violência urbana. São Paulo: Marcial Pons; Brasília: Fundação Escola Superior do Ministério Público do Distrito Federal e Territórios, 2014. p. 296.

3 DI SARNO, Daniela Campos Libório. Elementos de direito urbanístico. Barueri: Manole, 2004. p. 8.

4 MEIRELLES, Hely Lopes. Direito de construir. 9. ed. São Paulo: Malheiros, 2005. p. 43-44.

5 CASTILHO, José Roberto Fernandes. Disciplina urbanística da propriedade: o lote e seu destino. 4. ed. São Paulo: Pillares, 2013. p. 179.

6 CARMONA, Paulo Afonso Cavichioli. O consórcio imobiliário como instrumento de intervenção urbanística. Belo Horizonte: Fórum, 2007. p. 57.

7 CARMONA, Paulo Afonso Cavichioli. Das normas gerais: alcance e extensão da competência legislativa concorrente. Belo Horizonte: Fórum, 2010. p. 101-102. 
ficáveis, que podem compreender determinações de altura, volume, estrutura e estilo das edificações, regras sobre "alinhamento, nivelamento, afastamento, áreas livres e espaços verdes", bem como tipos de material de construção admitidos, além dos "mínimos de insolação, iluminação, aeração e cubagem", as normas de zoneamento e o uso exclusivo ou predominante de cada zona da cidade. A regulamentação edilícia estabelece o "controle das construções, que tem, por fim, assegurar as condições mínimas de habitabilidade e funcionalidade à edificação, principalmente à moradia, que é a razão de ser de toda cidade"

São diversos os índices de contenção das edificações, envolvendo gabarito, que incide sobre a altura máxima permitida e toma por base a medida em metros lineares; o coeficiente de aproveitamento, que versa sobre densidade, sendo critério relacional que envolve medida em metros quadrados; e a quota mínima de lote, que afeta o número de unidades, sendo, também, critério relacional o qual limita o número e as dimensões das partes de propriedade exclusiva (apartamentos, flats, vagas de garagem, salas, lojas, escritórios etc.) ${ }^{9}$.

Por sua vez, o alinhamento cuida da delimitação do domínio público e particular, mediante ato unilateral da Administração local. Já o recuo refere-se à necessidade de afastamento mínimo da edificação relativamente à via pública ou ao vizinho, cuidando de área que, embora integrada ao imóvel particular, é onerada com um impedimento à edificação. De outra parte, o nivelamento é a conformação do lote e, consequentemente, da construção nele edificada, ao nível da via pública, de modo a não prejudicar seu perfil. A outro giro, a funcionalidade urbana consiste na definição de um planejamento a ser seguido pelas edificações, que não podem ensejar transtornos para a ordenação das cidades, como excessiva concentração populacional, uso desmedido do solo, localização inconveniente e desajustamento da ocupação humana ao meio ambiente. Entre os requisitos de funcionalidade, devem ser observadas as normas sobre uso e ocupação, na perspectiva do zoneamento urbano - divisão da área a partir de sua precípua destinação, em setores residenciais, comerciais, industriais, institucionais e mistos. As limitações urbanísticas também podem ser fundamentadas na tutela estética, destinada à manutenção da harmonia do conjunto, para que as edificações sejam dotadas de boa aparência, o que justificam imposições edilícias de altura e disposição, bem como de apresentação de fachada e construção de muros divisórios ${ }^{10}$.

Tudo o que foi exposto nesta seção permite examinar a bipartição do denominado poder de polícia urbanística do Estado. Em verdade, esse poder é atribuído ao Legislativo, mediante a criação de leis disciplinadoras das limitações ao exercício de liberdades; e, essencialmente, à Administração Pública, por meio da regulamentação das leis e do controle de sua aplicação. A efetivação das leis pode ser preventiva, mediante a expedição de ordens, notificações, licenças ou autorizações; ou repressiva, por meio da imposição de medidas coercitivas destinadas a cessar a atividade que desborda da lei ${ }^{11}$.

O controle preventivo da atividade de construção é realizado pela aprovação do projeto edilício, que demanda a apresentação, à repartição competente da Administração municipal ou distrital, do projeto elaborado em conformidade com as diretrizes técnicas e devidamente assinado por profissional habilitado ${ }^{12}$. A aprovação tem natureza de ato vinculado, de modo que, se o projeto atende às determinações legais, não deverá ser negada, entretanto, se o projeto apresenta desconformidades, abre-se o prazo para sua correção ${ }^{13}$. Trata-se de pressuposto para a concessão de autorizações e licenças ${ }^{14}$, que são medidas indispensáveis para

8 MEIRELLES, Hely Lopes. Direito de construir. 9. ed. São Paulo: Malheiros, 2005. p. 109-119.

9 CASTILHO, José Roberto Fernandes. Disciplina urbanística da propriedade: o lote e seu destino. 4. ed. São Paulo: Pillares, 2013. p. 182-183.

10 MEIRELLES, Hely Lopes. Direito de construir. 9. ed. São Paulo: Malheiros, 2005. p. 122-140.

11 DI PIETRO, Maria Sylvia Zanella. Poder de polícia em matéria urbanística. Temas de direito urbanístico, São Paulo, p. 23-38, 1999. p. 25.

12 SILVA, José Afonso da.Direito urbanístico brasileiro. 6. ed. São Paulo: Malheiros, ano. p. 431-432.

13 DI PIETRO, Maria Sylvia Zanella. Poder de polícia em matéria urbanística. Temas de direito urbanistico, São Paulo, p. 23-38, 1999. p. 32.

14 SILVA, José Afonso da.Direito urbanístico brasileiro. 6. ed. São Paulo: Malheiros, ano. p. 431-432. 
a deflagração regular de uma construção ${ }^{15}$.

Embora tanto a concessão da licença quanto da autorização sejam materializadas pela outorga de um alvará, ambos os instrumentos não se confundem. Nesse sentido, dispõe Hely Lopes Meirelles:

Alvará é o instrumento da licença ou da autorização para a prática de ato, realização de atividade ou exercício de direito dependente de policiamento administrativo. É o consentimento formal da Administração à pretensão do administrado, quando manifestada em forma legal. $\mathrm{O}$ alvará pode ser definitivo ou precário: será definitivo e vinculante para a Administração quando expedido diante de um direito subjetivo do requerente como é a edificação, desde que o proprietário satisfaça todas as exigências das normas edilícias; será precário e discricionário se a Administração o concede por liberalidade, desde que não haja impedimento legal para sua expedição [...]. O alvará definitivo consubstancia uma licença; o alvará precário expressa uma autorização. Ambos são meios de atuação do poder de polícia, mas com efeitos fundamentalmente diversos, porque o alvará de autorização pode ser revogado sumariamente, a qualquer tempo, sem indenização, ao passo que o alvará de licença não pode ser invalidado discricionariamente, só admitindo revogação por interesse público superveniente e justificado, mediante indenização; ou cassação por descumprimento das normas legais na sua execução; ou anulação por ilegalidade na sua expedição em todas essas hipóteses através de processo administrativo com defesa do interessado ${ }^{16}$.

Assim, a licença pode ser conceituada como um ato vinculado, pelo qual a Administração verifica o atendimento das exigências legais pelo interessado, facultando-lhe a construção pretendida. Por outro lado, a autorização é ato discricionário e precário, pelo qual se torna possível o levantamento de construção provisória. Enquanto a autorização é sempre revogável, a licença traz ínsita a presunção de definitividade ${ }^{17}$, abarcando direito de construir do proprietário, que não pode ser revogado, salvo indenização do titular pela desapropriação de seu direito ${ }^{18}$.

Pode-se, portanto, conceituar a licença para construir como "ato administrativo constitutivo-formal" que possibilita a realização de uma construção, de acordo com o projeto aprovado e observado o prazo estipulado $^{19}$. Em regra, os entes locais estabelecem o prazo de validade do alvará em seus códigos de obras, fixando período para início e para término da construção, sob pena de caducidade do alvará e necessidade de sua renovação ${ }^{20}$. Após a publicação do despacho concessivo da licença e a emissão do alvará, o particular passa a ter direito à edificação nos termos citados. Os efeitos do ato cessam uma vez executada a construção, o que determina a realização das etapas seguintes do poder de polícia ${ }^{21}$.

Com a concessão da licença, ganham relevo os instrumentos de controle concomitante da Administração, que se efetiva durante a execução da obra, por meio de comunicações, relatórios, vistorias e fiscalização. Como regra, exige-se do interessado a comunicação, com antecedência, do início da realização da obra, bem como a apresentação de relatórios construtivos complementares referentes à estrutura ou aos cálculos, além de todas as informações indispensáveis ao bom acompanhamento da execução da obra e sua pertinência à lei e à licença ${ }^{22}$. Cabe, ainda, à autoridade administrativa competente realizar vistorias e inspeções técnicas, para certificar a observância do projeto aprovado ${ }^{23}$.

Finalizada a construção, passa a ser necessária a realização do controle sucessivo, destinado a verificar a

15 DI PIETRO, Maria Sylvia Zanella. Poder de polícia em matéria urbanística. Temas de direito urbanístico, São Paulo, p. 23-38, 1999. p. 32 .

16 MEIRELLES, Hely Lopes. Direito administrativo brasileiro. 36. ed. São Paulo: Malheiros, 2010. p. 142.

17 MEIRELLES, Hely Lopes. Direito administrativo brasileiro. 36. ed. São Paulo: Malheiros, 2010. p. 191.

18 DI PIETRO, Maria Sylvia Zanella. Poder de polícia em matéria urbanística. Temas de direito urbanístico, São Paulo, p. 23-38, 1999. p. 32 .

19 FIGUEIREDO, Lúcia Valle. Disciplina urbanistica da propriedade. 2. ed. São Paulo: Malheiros, 2005. p. 128.

20 DI PIETRO, Maria Sylvia Zanella. Poder de polícia em matéria urbanística. Temas de direito urbanístico, São Paulo, p. 23-38, 1999. p. 32 .

21 FIGUEIREDO, Lúcia Valle. Disciplina urbanistica da propriedade. 2. ed. São Paulo: Malheiros, 2005. p. 129.

22 SILVA, José Afonso da. Direito urbanístico brasileiro. 6. ed. São Paulo: Malheiros, ano. p. 449.

23 DI PIETRO, Maria Sylvia Zanella. Poder de polícia em matéria urbanística. Temas de direito urbanístico, São Paulo, p. 23-38, 1999. p. 32 . 
conformidade da execução, para que possa ser expedido o "auto de conclusão" ou "habite-se", sem o qual a ocupação do prédio é ilegal e sujeita a sanções ${ }^{24}$. O "habite-se" é, pois, o documento necessário para que se proceda à ocupação de edifícios. Trata-se de denominação vulgar para o alvará de utilização do imóvel, expedido pelo município ou pelo Distrito Federal ${ }^{25}$, o qual "indica que a edificação recebeu uma atestação pública de idoneidade para o uso específico a que se destina"26.

Além da vistoria da Administração, faz-se necessário o exame pelos demais órgãos competentes, como o corpo de bombeiros, por exemplo, que verificará a segurança da construção $\mathrm{O}^{27}$ — se assim previsto na legislação local, os bombeiros devem ser chamados a aprovar o projeto, participando, desde o início, da concepção da obra, assim como as concessionárias de água e energia.

Como se pode ver, o procedimento de avaliação, acompanhamento e atestação de obras é complexo e se protrai no tempo. Todo o zelo da legislação se justifica tendo em vista a necessidade de verificação de aspectos urbanísticos, como topografia do solo, infraestrutura disponível, compatibilidade ao meio ambiente da área afetada, altura do prédio, além de aspectos relacionados à higiene (como ventilação, luminosidade, umidade) e à segurança (como peso do prédio, materiais empregados na construção, cálculos estruturais) e demais requisitos técnicos legalmente exigidos para o porte da obra projetada ${ }^{28}$.

As considerações encetadas tornam clara a importância do controle urbanístico das construções. Resta ainda analisar como o registro de imóveis auxilia na referida tutela.

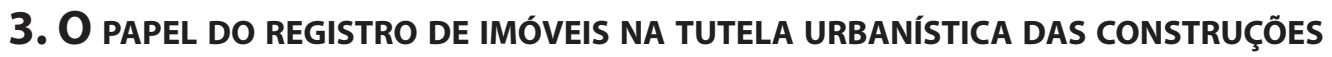

Viu-se que a tutela urbanística das construções é indispensável para a garantia da adequada ordenação das cidades, da segurança, da higiene, da estética e da funcionalidade das edificações. Trata-se de atividade que deve ser imposta e efetivamente cobrada do proprietário sempre que se queira realizar qualquer ato formal incidente sobre a obra.

No plano registral, a Lei de Registros Públicos (Lei 6.015 de 31 de dezembro de 1973) estabelece, em seu art. 167, inciso II, 4, a averbação da edificação na matrícula do imóvel a que se refira. O art. 246, $\int 1^{\circ}$, do mesmo diploma legal prevê que a citada averbação será feita "a requerimento dos interessados, com firma reconhecida [...] instruído com documento comprobatório fornecido pela autoridade competente".

Nessa linha, são necessários os seguintes documentos: requerimento do proprietário, com firma reconhecida, em que constem os dados do imóvel, como endereço, número de matrícula ou transcrição, data e valor da obra; "auto de conclusão", "habite-se", "alvará de utilização" ou documento equivalente, que ateste o término da construção e que o prédio encontra-se pronto para o uso a que se destina, mencionando-se expressamente qual é a área construída; além da citada documentação, o art. 47, inciso II, da Lei 8.212 de 24 de julho de 1991 determina a apresentação da Certidão Negativa de Débito (CND) previdenciário da obra de construção civil, para sua averbação no registro de imóveis. A CND somente é dispensada no caso de imóvel cuja construção tenha sido concluída anteriormente a 22 de novembro de 1966 (art. 47, \ $6^{\circ}$, “c"); na hipótese de averbação de construção localizada em área objeto de regularização fundiária de interesse social (art. 47, $\int 6^{\circ}$, “e"); e em se tratando de construção residencial unifamiliar, destinada ao uso próprio, de tipo econômico, executada sem mão-de-obra assalariada (art. 30, VIII). Nesse último caso, o proprietário pessoa

24 SILVA, José Afonso da. Direito urbanístico brasileiro. 6. ed. São Paulo: Malheiros, ano. p. 450.

25 MEIRELLES, Hely Lopes. Direito de construir. 9. ed. São Paulo: Malheiros, 2005. p. 148-207.

26 SILVA, José Afonso da.Direito urbanístico brasileiro. 6. ed. São Paulo: Malheiros, ano. p. 450.

27 CASTILHO, José Roberto Fernandes. Disciplina urbanística da propriedade: o lote e seu destino. 4. ed. São Paulo: Pillares, 2013. p. 37.

28 SANTOS, Flauzilino Araújo dos. Condomínios e incorporações no registro de imóveis: teoria e prática. São Paulo: Mirante, 2012 . p. 227. 
física deverá apresentar declaração de que atende os citados requisitos, bem como de que não possui outro imóvel, nos termos do art. 370, inciso I, da Instrução Normativa RFB 971 de 13 de novembro de 2009; ademais, a área total edificada não pode ser superior a setenta metros quadrados (art. 370, I, "b”).

Alguns oficiais exigem, ainda - e, a depender do Estado, tal determinação consta expressamente das normas da Corregedoria local, como ocorre, por exemplo, no Estado do Paraná29 —, o certificado de responsabilidade técnica, que poderá ser a Anotação de Responsabilidade Técnica (ART), expedida pelo Conselho Regional de Engenharia e Agronomia (CREA) ${ }^{30}$ ou o Registro de Responsabilidade Técnica (RRT), emitido pelo Conselho de Arquitetura e Urbanismo (CAU) ${ }^{31}$. Tais documentos são importantes, pois encerram a vinculação do engenheiro ou arquiteto responsável pela obra.

De fato, o zelo do registrador, em relação à exigência e conferência dos citados documentos para a averbação de uma construção, se justifica diante da força da fé pública que ele imprime nos atos inscritos em seus arquivos. Os registros de imóveis têm como função a garantia da autenticidade, segurança, publicidade e eficácia dos atos jurídicos, conforme art. $1^{\circ}$ da Lei 8.935 de 18 de novembro de 1994, motivo pelo qual sua chancela induz a crença da sociedade em geral de que o direito inscrito é regular e respeitou os passos necessários para sua realização válida.

Nessa seara, o processo pelo qual a serventia imobiliária aprova ou desaprova documentos apresentados à sua apreciação denomina-se qualificação registral. Trata-se de relevante modo de controle, pelo qual há emissão de um juízo de admissibilidade, mediante apreciação técnica e imparcial, de modo que somente tenham êxito em acessar o sistema registral os documentos cuja idoneidade for constatada pelo registrador ${ }^{32}$.

Com efeito, a atividade registral, necessariamente provocada, inicia-se com o requerimento do interessado, que apresenta seu título para lançamento no Protocolo (art. 12 da Lei 6.015 de 1973). A partir da prenotação, abre-se o prazo, normalmente, de trinta dias, para a análise e a posterior inscrição (para os títulos perfeitos) ou devolução (para os defeituosos) do documento apresentado (art. 205). Nesse intervalo, ocorre o exame da legalidade, pelo qual se avaliam a autenticidade do título, a identidade das partes e do imóvel, e a observância aos princípios da prioridade, da continuidade e da especialidade ${ }^{33}$. Igualmente, a qualificação é o momento oportuno no qual o registrador condiciona a prática do ato ao atingimento de objetivos próprios de outros ramos do Direito, a exemplo do urbanístico.

Quanto ao alcance da atuação do registrador, entende-se que não deve ser limitada ao exame de formas extrínsecas, mas abarcar verificações relacionadas à legitimidade das partes, à adequação do documento, à higidez dos atos nele inseridos e, de modo geral, ao atendimento a normas de ordem pública ${ }^{34}$. Por outro lado, devem ser reprimidos eventuais ímpetos de insistir, intolerantemente, em formalidades inúteis ${ }^{35}$.

29 Art. 565. Da matrícula ou à margem da transcrição do imóvel, os registradores farão constar da averbação a Anotação de Responsabilidade Técnica (ART), na forma do disposto no art. $1^{\circ}$ da Lei n ${ }^{\circ} 6.496$ de 07.12.1977, sempre que executadas tarefas pelos profissionais nela enquadrados, relacionadas com loteamentos, divisões, demarcações, retificações de áreas e desmembramentos, bem como quando da averbação de construções.

30 Trata-se de documento exigido com fulcro nos arts. $1^{\circ}$ e $2^{\circ}$ da Lei 6.496 de 1977, que exigem a ART para a execução de quaisquer atividades referentes à engenharia; e com base no art. 7, alíneas "b", "c", "e", "f" e "g" da Lei 5.194 de 1966, que capitulam a execução de obras e projetos como serviços de engenharia.

31 Trata-se de documento exigido com fulcro nos arts. 45, 46 e 47, bem como no art. $2^{\circ}$, incisos V e XII e respectivo parágrafo único, inciso V, da Lei 12.378 de 2010, que exigem o RRT para execução de quaisquer atividades de arquitetura e urbanismo e definem como atividade própria de arquiteto e urbanista a condução de obras; e com base nos arts. $2^{\circ}$ da Resolução do CAU/BR 91 de 2014 e $3^{\circ}$, item 2, da Resolução CAU/BR 21, que disciplinam a obrigatoriedade do RRT para a realização de atividades técnicas, obras urbanísticas e arquitetura das edificações.

32 SANTOS, Flauzilino Araújo dos. Princípio da Legalidade e Registro de Imóveis. In: DIP, Ricardo; JACOMINO, Sérgio (Org.). Doutrinas Essenciais: Direito Registral. 2. ed. São Paulo: Revista dos Tribunais, 2013. v. 2. p. 859-903. p. 313.

33 CARVALHO, Afrânio de. Registro de imóveis: comentários ao sistema de registro em face da Lei 6.015, de 1973, com as alterações da Lei 6.216, de 1975, Lei 8.009, de 1990, e Lei 8.935, de 18.11.1994. Rio de Janeiro: Forense, 1997. p. 251-252.

34 SANTOS, Flauzilino Araújo dos. Princípio da Legalidade e Registro de Imóveis. In: DIP, Ricardo; JACOMINO, Sérgio (Org.). Doutrinas Essenciais: Direito Registral. 2. ed. São Paulo: Revista dos Tribunais, 2013. v. 2. p. 859-903. p. 320-321.

35 VALLIM, João Rabelo de Aguiar. Direito imobiliário brasileiro: doutrina e prática. São Paulo: Revista dos Tribunais, 1980. p. 88-89. 
Deve-se ter clara a ideia de que a qualificação registral não se restringe a garantir segurança e oponibilidade aos direitos inscritos, não estando a serviço, apenas, das finalidades do direito privado. O registrador de imóveis é, nesse sentido, uma importante autoridade, em posição favorecida para o exercício da tutela urbanística das construções, devendo exigir a observância aos requisitos indispensáveis para a existência de uma obra regular, antes de deferir o ingresso da edificação na matrícula do imóvel.

Assim, sua tutela à ordenação urbana é formalizada por meio da exigência de que a oficialização da propriedade da obra seja precedida por sua necessária verificação urbanística. O controle exercido pelo registro de imóveis é, portanto, coadjuvante relativamente à Administração Pública, tendo caráter imperativo e não meramente dispositivo ${ }^{36}$.

Ora, nada obstante o fato de o controle urbanístico ser competência precípua dos municípios e do Distrito Federal, a lei o assegura, também, por meio dos registros de imóveis, no exercício de sua função de análise jurídica dos títulos. Destarte, o registrador atua na seara urbanística quando exige do interessado o respeito às imposições da legislação urbanística.

$\mathrm{Na}$ medida em que se faz necessária a comprovação da expedição do "habite-se" —ou documento equivalente - para a averbação de edificações, o registrador de imóveis, de modo indireto, assume papel de tutela urbanística, obstando o acesso ao registro predial da construção que não respeitou as fases urbanísticas necessárias para sua execução ${ }^{37}$. Desse modo, "aproveita-se das hipóteses de inscrição existentes para, condicionando-as à observância de requisitos urbanísticos, fazer com que o registro predial atue também, pelo juízo de qualificação, como instrumento de controle urbanístico"38.

Se, corriqueiramente, não é comum a diligência do comprador juntamente à Prefeitura Municipal ou ao Governo do Distrito Federal, muito mais frequente é a avaliação perante a serventia imobiliária, de modo que a inexistência da inscrição da obra poderá ensejar questionamentos por parte do pretenso adquirente. Por isso é oportuna a exigência do respeito à legislação urbanística, por parte do registrador, de modo a obrigar o proprietário a regularizar sua construção. Tudo isso demonstra a fundamental importância do ofício de registro predial no controle da legalidade de edificações, sendo relevantíssima contribuição registral à tutela urbanística das cidades.

Resta, pois, evidente o interesse do controle de legalidade a cargo dos registradores, como ferramenta urbanística eficaz. A qualificação registral é um bom momento para o monitoramento da observância aos regulamentos de construção e de todo o arcabouço legal urbanístico, erigindo o registro de imóveis como importante instrumento para garantia do respeito à legalidade urbana ${ }^{39}$. Garante-se, desse modo, a obtenção da visibilidade registral de suas construções, apenas, àqueles que se submetam ao crivo da autoridade municipal ou distrital competente para a análise das edificações.

Nesse ponto, cumpre salientar que a exigência legal de apresentação do documento que atesta a aptidão do imóvel para ser utilizado não é, apenas, um modo de assegurar a posição de eventuais futuros adquirentes, mas uma forma de garantir que haja efetiva tutela urbanística da construção, que, caso contrário, muito provavelmente, ficaria relegada, tornando bem mais frequentes "os casos de anomalia urbanística por falta de controle urbanístico preventivo"40.

36 ARRIETA CUEVAS, Raúl. Naturaleza de los planes de desarrollo urbano y el registro inmobiliario. Revista de Derecho Público, n. 14, p. 5-21, 1983. Disponível em: <http://www.ulpiano.org.ve/revistas/bases/ artic/texto/RDPUB/14/rdpub_1983_14_5-21. pdf>. Acesso em: 4 fev. 2017. p. 6-18.

37 AMADEI, Vicente de Abreu. O Aspecto Instrumental do Registro Imobiliário. In: DIP, Ricardo; JACOMINO, Sérgio (Org.). Doutrinas Essenciais: Direito Registral. 2. ed. São Paulo: Revista dos Tribunais, 2013. v. 2. p. 859-903. p. 885.

38 AMADEI, Vicente de Abreu. O Aspecto Instrumental do Registro Imobiliário. In: DIP, Ricardo; JACOMINO, Sérgio (Org.). Doutrinas Essenciais: Direito Registral. 2. ed. São Paulo: Revista dos Tribunais, 2013. v. 2. p. 859-903. p. 897.

39 FUERTES, Mercedes. Urbanismo y publicidad registral. 2. ed. Madrid: Marcial Pons, 2001. p. 157-158.

40 AMADEI, Vicente de Abreu. O Aspecto Instrumental do Registro Imobiliário. In: DIP, Ricardo; JACOMINO, Sérgio (Org.). Doutrinas Essenciais: Direito Registral. 2. ed. São Paulo: Revista dos Tribunais, 2013. v. 2. p. 859-903. p. 899. 
Resumindo a natureza e a relevância da tutela registral em matéria urbanística, ressalta Vicente de Abreu Amadei que, por efeito dessa previsão, a lei impõe, nesses casos, um "duplo controle preventivo do resguardo dos aspectos urbanísticos". O primeiro controle é direto e levado a efeito pelas autoridades administrativas, a quem se atribui o dever de aprovar o projeto, expedir a licença para construir, executar os instrumentos de controle concomitante (como as vistorias), exercer o controle sucessivo, pela verificação da conformidade da obra e expedir o "habite-se" ou documento equivalente. Já o segundo é indireto e executado pelos oficiais de registro de imóveis, mediante o juízo de qualificação. Trata-se de "esferas de atribuições e exercício de juízos e atos distintos, mas atuando, ambos, no controle urbanístico" ${ }^{41}$.

Pelo exposto, pode-se concluir afirmando que as principais atribuições de ordenação e controle da atividade urbanística são competência do Poder Público local, no entanto, não é excesso do legislador a utilização de outras ferramentas destinadas à promoção da legalidade urbana. Entre tais instrumentos, a lei erigiu o registro de imóveis. Nesse contexto, maior força é atribuída ao procedimento de qualificação registral, o qual deixa de ser mero exame negocial, para assumir ares de essencialidade no âmbito do desenvolvimento urbano. A função urbanística do registro de imóveis implica um segundo controle, que é indireto, mas fundamental para a afirmação de uma cidade estruturada, com aptidão ao desenvolvimento sadio.

\section{Crítica aos artigos 60 e 63 da Lei 13.465 de 11 de Julho de 2017}

Afirmou-se a importância do controle urbanístico das construções, sob os aspectos de segurança, higidez, higiene, estética e funcionalidade. Observou-se, também, que o registro de imóveis tem relevante papel para a garantia do cumprimento da legislação urbanística, na medida em que condiciona a inscrição da edificação à apresentação dos documentos exigidos pelos regulamentos edilícios.

Ocorre que todo esse sistema de proteção urbanística das construções se encontra ameaçado, no que tange às edificações relacionadas a conjuntos habitacionais que compõem a regularização fundiária urbana (Reurb), conforme art. 60 da Lei 13.465 de 2017; bem como no que se refere às construções localizadas em áreas de regularização fundiária de interesse social (Reurb-S), nos termos do art. 63 do mesmo diploma legal. O primeiro dos dispositivos mencionados determina a dispensa do "habite-se" e, no caso de Reurb-S, também das certidões negativas de tributos e contribuições previdenciárias. Do mesmo modo, o segundo dispositivo estabelece que, na hipótese de Reurb-S, o ato de averbação das edificações poderá ser ultimado "a partir de mera notícia, a requerimento do interessado, da qual constem a área construída e o número da unidade imobiliária, dispensada a apresentação de habite-se e de certidões negativas de tributos e contribuições previdenciárias".

Embora os impactos sejam aparentemente restritos, uma vez que os dispositivos são vinculados, apenas, a áreas de conjuntos habitacionais destinados à regularização fundiária urbana e a setores afetados à regularização de interesse social, uma análise mais profunda do assunto demonstra o caráter equivocado dessa primeira impressão. Ora, o último censo demográfico brasileiro, levado a efeito no ano de 2010, demonstra que o Brasil possuía, já naquele período, 15.868 setores subnormais — conjuntos de, no mínimo, cinquenta e uma unidades habitacionais carentes, dispostas de modo desordenado, caracterizadas por ocupação ilegal da terra no momento da pesquisa ou período recente; e urbanização fora dos padrões vigentes ou precariedade de serviços públicos essenciais —, totalizando uma área de 169.170 hectares ou $1.691 .700 \mathrm{~m}^{2}$ de ocupação. Em termos de adensamento, nacionalmente, a maior parte dos domicílios já se encontrava em áreas nas quais predominavam a inexistência de espaçamento entre as construções $(72,6 \%)$ e a verticalização em um pavimento $(64,6 \%)$. No entanto, a depender das características da região e, sobretudo, da oferta

41 AMADEI, Vicente de Abreu. O Aspecto Instrumental do Registro Imobiliário. In: DIP, Ricardo; JACOMINO, Sérgio (Org.). Doutrinas Essenciais: Direito Registral. 2. ed. São Paulo: Revista dos Tribunais, 2013. v. 2. p. 859-903. p. 899. 
de trabalho local, foi identificada uma real tendência de adensamento ${ }^{42}$. Entende-se que o incentivo da lei, autorizando o aval do registro de imóveis a construções sem o adequado planejamento, por mera notícia do proprietário, pode agravar esse quadro, gerando, ainda, maior adensamento em áreas carentes da necessária infraestrutura.

A propósito do adensamento populacional, comentando resolução da Direção Geral dos Registros e do Notariado, em caso de recurso contra negativa de registro, em serventia imobiliária de Madrid, de escritura declaratória de obra nova e constituição de condomínio, Gabriel Soria Martínez critica o entendimento segundo o qual seriam alheios à normativa urbanística: a configuração jurídica que seus ocupantes dão à unidade ocupada, bem como o número de famílias que poderiam se alojar em cada uma das edificações. Para Martínez, o desenvolvimento das cidades, calcado no ordenamento territorial e urbano e no princípio ambiental do desenvolvimento sustentável, estaria sujeito à observância das normas legais e regulamentares que garantem a suficiência dos serviços urbanísticos e sociais relativamente ao número de edificações, bem como ao obrigatório controle de segurança e de higiene das populações, proibindo-se a ocupação excessiva e impondo-se a vigilância das condições higiênico-sanitárias mínimas das habitações. Tudo isso justifica, no entender do autor, a intervenção administrativa sobre os atos jurídicos que podem causar aumento na densidade populacional e no número de unidades habitacionais. Em verdade, os planos urbanos fixam o número máximo de construções, levando em conta as disposições de estacionamento, áreas verdes, espaços abertos, saneamento, além de outros serviços e equipamentos indispensáveis (serviços de abastecimento e evacuação e fornecimento de energia elétrica, entre outros). Determinam, ainda, a superfície mínima exigida para a unidade habitacional, com vistas à prevenção de incêndios, a segurança e a salubridade da construção. Nesse contexto, Martínez discorda da resolução da Direção Geral, entendendo ser estaincompatível com a necessidade, imposta pelo princípio da qualificação, de se verificara legalidade dos atos destinados à inscrição no registro predial, motivo pelo qual compreende não ser possível a inscrição da instituição de condomínio edilício acompanhada de licença municipal para a construção de edificação unifamiliar, a menos que haja concessão de nova licença, autorizando a construção realizada em padrões superiores ${ }^{43}$.

No mesmo sentido, o art. 46.1 do Real Decreto espanhol 1093/1997, de 4 de julho, determina como requisito para a inscrição de um título a obtenção da licença adequada, salvo quando, legalmente, dispensada; o art. 48.1 impõe que, nas escrituras declaratórias de obra nova, inclua-se a literal menção à licença concedida; e o art. 53.a) estabelece a proibição de constituírem-se unidades suscetíveis de aproveitamento independente em número maior que o estabelecido na declaração de obra nova, a menos que se obtenha nova licença concedida de acordo com as previsões de planejamento urbanístico vigente ${ }^{44}$. Igualmente, o art. 28.1 do Real Decreto Legislativo 7/2015, de 30 de outubro, estabelece, para a declaração de obra nova, a necessidade de apresentação, na lavratura da escritura declaratória, do ato de conformidade, aprovação ou autorização administrativa exigida pela legislação de ordenação territorial e urbanística; o art. 28.1.b) prevê, para as escrituras de construção nova finalizada, a necessária exigência da concessão das autorizações administrativas destinadas a assegurar que o edifício reúna as condições indispensáveis para o uso a que se destina, salvo se a lei estipular exigência diversa; e, finalmente, o arts. 6 e 6.a) definem que a constituição de condomínio deve ser autorizada pelo órgão administrativo competente, sendo requisito indispensável à sua inscrição que o

42 INSTITUTO BRASILEIRO DE GEOGRAFIA E ESTATÍSTICA (IBGE). Censo Demográfico 2010: aglomerados subnormais informações territoriais. Rio de Janeiro, 2010. p. 1-251. Disponível em: < http://biblioteca.ibge.gov.br/visualizacao/periodicos/552/cd_2010_agsn_if.pdf>. Acesso em: 4 ago. 2017. p. 18-42.

43 MARTÍNEZ, Gabriel Soria. Declaración de obra nueva y constitución em régimen de propiedad horizontal. Reserva de ley para la exigibilidad de licencia respecto de la creación de mayor número de elementos privativos de los permitidos en la licencia de edificación. Examen del artículo 53.a) del Real Decreto 1093/1997, de 4 de julio. In: LASO MARTíNEZ, José Luis et al. El urbanismo desde la perspectiva del registro de la propiedad: comentarios sobre la jurisprudencia y la doctrina de la Dirección General de los Registros e del Notariado. Madrid: Colegio de Registradores de la Propiedad y Mercantiles de España. 2013. p. 227-241.

44 ESPANHA. Real Decreto 1093/1997, de 4 de julio. Aprueba las normas complementarias al Reglamento para la ejecución de la Ley Hipotecaria sobre Inscripción en el Registro de la Propiedad de Actos de Naturaleza Urbanística. «BOE» núm. 175, de 23 de julio de 1997, p. 22.451-22.470. Disponível em: <https://www.boe.es/diario_boe/txt.php?id=BOE-A-1997-16469>. Acesso em: 4 ago. 2017. 
título esteja acompanhado da autorização administrativa concedida ou do testemunho notarial desta, salvo quando o número e as características das unidades autônomas resultantes sejam os que resultam da licença de construção que autoriza a obra ${ }^{45}$.

Não se ignora o fato de que a nova legislação brasileira (Lei 13.465 de 2017) foi editada para facilitar a regularização rural, a fundiária urbana e a alienação de imóveis da União, sob o argumento de que o diploma anterior — Lei 11.977 de 2009 — demonstrou-se insuficiente para a resolução do problema, em razão da "desconformidade entre as normas existentes e a realidade fática dos tempos hodiernos" ${ }^{46}$. Entende-se, porém, que o objetivo de simplificação — embora válido —, não pode ir ao cúmulo de vulnerar importantes aspectos urbanísticos, como é o caso da adequada realização de construções.

De fato, a autoconstrução - entendida como o processo pelo qual os próprios interessados encarregam-se da gestão da construção de seus edifícios, por meio da aquisição de materiais, contratação de executores ou trabalho direto nas obras de edificação ou reforma, característica de assentamentos populares, muitas vezes levada a efeito em áreas de proteção ambiental ou de risco (deslizamentos e alagamentos), com recursos técnicos próprios, pelos quais se ocupa e constrói de forma precária — pode ensejar perigo à vida e à integridade de seus moradores ou ocupantes ${ }^{47}$. No caso de construção em áreas de interesse ambiental, não raro, há comprometimento de recursos fundamentais a todos os moradores da cidade, como na hipótese de edificação em áreas de mananciais; ademais, é possível que "os problemas de drenagem, risco de vida por desmoronamentos, obstáculos à instalação de rede de água e esgoto" tornem inviável ou extremamente dispendiosa a urbanização futura ${ }^{48}$. Sem mencionar possíveis problemas relacionados à instabilidade estrutural, inadequações das instalações elétricas e hidráulicas e os decorrentes da ausência de elementos de proteção contra quedas, o que torna questionável o afã governamental de consolidar precariedades.

Acrescente-se a isso o fato de que os registros de imóveis são dotados de fé pública e de grande visibilidade social. Matéria veiculada pela imprensa, a partir de dados coletados pelo Instituto Datafolha, demonstra que os cartórios estão em primeira posição em termos de confiança em instituições públicas ${ }^{49}$, o que torna preocupante a alteração legislativa citada, permitindo que construções não analisadas, sob o ponto de vista urbanístico, pelos municípios e pelo Distrito Federal, possam ganhar a chancela do oficial registrador.

Outro ponto a ser questionado refere-se à divisão constitucional de competências para o tratamento da matéria urbanística. Deveras, as normas sobre urbanismo podem advir de qualquer dos entes federados, cujo campo de atuação nem sempre é fácil de $\operatorname{precisar}^{50}$.

$\mathrm{O}$ art. 21 da Constituição Federal estabelece "a competência geral da União, que é consideravelmente ampla" e a maior parte das competências materiais exclusivas desse ente federativo ${ }^{51}$. Entre as competências elencadas, constam as seguintes, de ordem urbanística: "elaborar e executar planos nacionais e regionais de

45 ESPANHA. Real Decreto Legislativo 7/2015, de 30 de octubre. Aprueba el texto refundido de la Ley de Suelo y Rehabilitación Urbana. «BOE» núm. 261, de 31 de octubre de 2015, p. 103.232-103.290. Disponível em: <https://www.boe.es/diario_boe/txt. php?id=BOE-A-2015-11723>. Acesso em: 4 ago. 2017.

46 BRASIL. Exposição de Motivos 00020/2016 MCidades MP CCPR. Brasília, DF: 21 dez. 2016. Disponível em: <http://www.planalto.gov.br/ccivil_03/_ato2015-2018/2016/Exm/Exm-MP\%20759-16.pdf>. Acesso em: 8 jun. 2017. p. 1.

47 SÁ, Werther Lima Ferraz de. Autoconstrução na cidade informal: relações com a política habitacional e formas de financiamento. 2009. 169 f. Dissertação (Mestrado) - Programa de Pós-Graduação em Desenvolvimento Urbano, Universidade Federal de Pernambuco, Recife, 2009. p. 24-73.

48 MARICATO, Ermínia. Metrópole, legislação e desigualdade. Estudos Avançados, São Paulo, v. 17, n. 48, p. 151-166, 2003. Disponível em: <http://www.scielo.br/pdf/ea/v17n48/v17n48a13.pdf>. Acesso em: 3 jul. 2017. p. 158.

49 ASSOCIAÇÃO DOS NOTÁRIOS E REGISTRADORES DO BRASIL (ANOREG/BR). Confiança dos brasileiros nos cartórios é destaque em pesquisa do Datafolha. 2016. Disponível em: <http://www.anoreg. org.br/index.php?option=com_content\&view=articl e\&id=26641: confianca-dos-brasileiros-nos-cartorios-e-desta que-em-pesquisa-do-datafolha\&catid=19\&Itemid=180>. Acesso em: 3 jul. 2017.

50 CARMONA, Paulo Afonso Cavichioli. Das normas gerais: alcance e extensão da competência legislativa concorrente. Belo Horizonte: Fórum, 2010. p. 101.

51 BRANCO, Paulo Gustavo Gonet. Organização do Estado. In: MENDES, Gilmar Ferreira; BRANCO, Paulo Gustavo Gonet. Curso de direito constitucional. 9. ed. São Paulo: Saraiva, 2014. p. 979-1.020. p. 999. 
ordenação do território e de desenvolvimento econômico e social" (inciso IX); e "instituir diretrizes para o desenvolvimento urbano, inclusive habitação, saneamento básico e transportes urbanos" (inciso XX).

De outra parte, o art. 23 da Constituição prevê a competência material comum de todos os entes federativos, incluindo União, Estados, Distrito Federal e municípios. A regra estabelece a cooperação entre os entes, mas, em caso de conflito, é possível utilizar o denominado critério da preponderância de interesses ${ }^{52}$. Entre as competências fixadas no dispositivo, podem ser destacadas as seguintes como afetas, também, ao direito urbanístico, embora tangenciem outras disciplinas, como o direito ambiental ${ }^{53}$ :

III - proteger os documentos, as obras e outros bens de valor histórico, artístico e cultural, os monumentos, as paisagens naturais notáveis e os sítios arqueológicos;

IV - impedir a evasão, a destruição e a descaracterização de obras de arte e de outros bens de valor histórico, artístico ou cultural;

VI - proteger o meio ambiente e combater a poluição em qualquer de suas formas;

VII - preservar as florestas, a fauna e a flora;

IX - promover programas de construção de moradias e a melhoria das condições habitacionais e de saneamento básico;

$\mathrm{X}$ - combater as causas da pobreza e os fatores de marginalização, promovendo a integração social dos setores desfavorecidos;

XII - estabelecer e implantar política de educação para a segurança do trânsito.

Prosseguindo na análise da repartição constitucional de competências em matéria urbanística, o art. 24 prescreve um "condomínio legislativo", a partir da fixação da competência legislativa concorrente. Nesse âmbito, compete à União estabelecer "normas gerais" e aos Estados e ao Distrito Federal fixar normas suplementares $\left(\iint 1^{\circ}\right.$ e $\left.2^{\circ}\right)$. Ademais, compete aos municípios legislar sobre "assuntos de interesse local”, assim considerada, por exemplo, a ordenação do solo urbano, de modo que a competência suplementar municipal "se exerce para regulamentar as normas legislativas federais e estaduais, inclusive as enumeradas no art. 24 da CF, a fim de atender, com melhor precisão, aos interesses surgidos das peculiaridades locais" ${ }^{\prime 5}$.

Por "normas gerais", devem ser compreendidas as de natureza principiológica, que instituem "princípios, diretrizes, fundamentos, critérios básicos, linhas mestras", definindo um conceito limite, o qual possibilita que a "legislação concorrente estadual, distrital ou municipal (particularizadora) opte, escolha, minudencie e determine o que the parecer mais adequado para o atendimento de seu interesse no âmbito discricionário de sua competência específica" ${ }^{55}$. Nessa linha, não deve a União invadir a competência dos demais entes, por meio da regulação pormenorizada de um instituto urbanístico, mas, apenas, apresentar sua principiologia, o rumo a ser seguido.

O citado art. 24 define como competência concorrente legislar sobre direito urbanístico (inciso I), além das seguintes matérias, que possuem interface com esse ramo do Direito:

VI - florestas, caça, pesca, fauna, conservação da natureza, defesa do solo e dos recursos naturais, proteção do meio ambiente e controle da poluição;

VII - proteção ao patrimônio histórico, cultural, artístico, turístico e paisagístico;

VIII - responsabilidade por dano ao meio ambiente, ao consumidor, a bens e direitos de valor artístico, estético, histórico, turístico e paisagístico;

52 BRANCO, Paulo Gustavo Gonet. Organização do Estado. In: MENDES, Gilmar Ferreira; BRANCO, Paulo Gustavo Gonet. Curso de direito constitucional. 9. ed. São Paulo: Saraiva, 2014. p. 979-1.020. p. 1.001.

53 A enumeração apresentada está de acordo com o disposto em: CARMONA, Paulo Afonso Cavichioli. Das normas gerais: alcance e extensão da competência legislativa concorrente. Belo Horizonte: Fórum, 2010. p. 101.

54 BRANCO, Paulo Gustavo Gonet. Organização do Estado. In: MENDES, Gilmar Ferreira; BRANCO, Paulo Gustavo Gonet. Curso de direito constitucional. 9. ed. São Paulo: Saraiva, 2014. p. 979-1.020. p. 1.001-1.004.

55 CARMONA, Paulo Afonso Cavichioli. Das normas gerais: alcance e extensão da competência legislativa concorrente. Belo Horizonte: Fórum, 2010. p. 57-59. 
XIV - proteção e integração social das pessoas portadoras de deficiência;

De outra parte, o art. 25 estabelece a atribuição residual dos Estados, na medida em que lhes são reservadas as competências não vedadas pela Constituição $\left(\mathbb{S} 1^{\circ}\right.$ ); bem como duas competências expressas, uma das quais relacionada à matéria urbanística, isto é: a possibilidade de instituição, por lei complementar, de "regiões metropolitanas, aglomerações urbanas e microrregiões, constituídas por agrupamentos de municípios limítrofes, para integrar a organização, o planejamento e a execução de funções públicas de interesse comum" ( $\left(3^{\circ}\right)$.

Por sua vez, o art. 30 apresenta as competências dos municípios, a quem compete legislar sobre temáticas de interesse local (inciso I); suplementar a legislação federal e a estadual no que for cabível (inciso II); criar, organizar e suprimir distritos, nos termos da legislação estadual (inciso IV); organizar e prestar, de modo direto ou sob o regime de concessão ou permissão, os serviços públicos de interesse local, como o de transporte coletivo (inciso V); promover a adequada ordenação territorial, pelo planejamento e o controle do uso, do parcelamento e da ocupação das cidades (inciso VIII); e, por fim, promover a proteção do patrimônio histórico-cultural da localidade (inciso IX).

Igualmente, a competência municipal (e distrital) é, também, disciplinada no Capítulo II da Constituição, o qual trata da política urbana, de acordo com o qual a política de desenvolvimento urbano, destinada a desenvolver as funções sociais da cidade e garantir o bem-estar dos que nela habitam, deve ser executada pelos municípios e pelo Distrito Federal, consoante as diretrizes gerais estabelecidas em lei (art. 182).

A análise realizada sobre a competência em matéria urbanística permite verificar o papel de destaque na ordenação urbana que possuem os municípios e o Distrito Federal, pois são estes entes que executam e concretizam, de fato, os processos urbanísticos, dentro da cidade ou fora dela ${ }^{56}$. Diante disso, pode-se questionar a compatibilidade dos arts. 60 e 63 da Lei 13.4652017 relativamente à competência (precipuamente) municipal e distrital para a organização espacial e edilícia das cidades.

Com efeito, aceitar a inscrição da construção por "mera notícia” equivaleria a enfraquecer o controle preventivo, concomitante e sucessivo municipal e distrital, já que não mais contaria com o controle indireto do registrador, no sentido de obrigar o interessado a obter o documento hábil, comprobatório da aptidão da construção para o uso a que se destina. Essa inscrição é passível de ensejar, no adquirente ou usuário, a errônea percepção de que a edificação respeitou todas as fases necessárias para sua segurança, higiene e funcionalidade, quando, na verdade, o edifício pode não ter respeitado os padrões construtivos estabelecidos na legislação local.

Não se desconhece o fato de que somente à União compete legislar sobre registros públicos (art. 22, inciso XXV, da Constituição Federal). No entanto, autorizar o ingresso no mundo jurídico, por meio da visibilidade jurídico-social dos registros de imóveis, de edificações potencialmente violadoras dos regulamentos edilícios locais, parece transbordar a competência normativa federal em matéria urbanística. Por isso entende-se que a função urbanistica do registro de imóveis é indissociável do que dispõe a legislação local, não podendo o oficial registrador, ainda que com espeque em norma federal, dispensar o "babite-se" ou documento equivalente para a averbação de construções, uma vez, que estas, para serem regulares, devem necessariamente estar em conformidade com o disposto na legislação municipal on distrital sobre zoneamento, usos, obras e posturas.

\section{Considerações Finais}

Examinou-se o papel essencial do direito urbanístico para a garantia da ordenação das cidades, do bem-estar da coletividade e do interesse público. Nesse contexto, a regulamentação edilícia é essencial para

56 DI SARNO, Daniela Campos Libório. Elementos de direito urbanístico. Barueri: Manole, 2004. p. 11-41. 
assegurar saúde, segurança e conforto aos usuários e à comunidade, ao cuidar de aspectos relacionados à solidez, estabilidade, salubridade, segurança, higiene, funcionalidade, pertinência ao plano de desenvolvimento urbano da região e estética das construções.

Afirmou-se, ainda, que os municípios e o Distrito Federal são os principais agentes reguladores e fiscalizadores da atividade edificatória, podendo estabelecer minúcias técnicas sobre o assunto, determinando como e onde edificar. Seu poder de polícia não se limita, porém, à disciplina legal, mas envolve forte atuação prática da Administração Pública, para controlar preventiva, concomitante, sucessiva e repressivamente o processo de construção.

Verificou-se que o controle preventivo da atividade se inicia com a aprovação do projeto, seguindo-se da concessão da licença para construir, por meio da outorga do alvará, o que é pressuposto para a deflagração regular de uma edificação. Iniciada a construção, a Administração passa a acompanhar a realização da obra, que deverá ser desenvolvida nos limites da lei e da licença, por meio de comunicações, relatórios, vistorias e fiscalização. Ultimada a construção, abre-se espaço ao controle sucessivo, que envolve análise da conformidade da execução e expedição de "habite-se" ou documento equivalente, que atesta a possibilidade de ocupação do prédio.

Viu-se, também, que as edificações são objeto de averbação na matrícula do imóvel, desde que apresentado o respectivo atestado do término da construção e de que o prédio está pronto para ser utilizado. A necessidade de que seja exigida a referida documentação decorre do fato de que a chancela do registrador, por meio da inscrição da construção no fólio real, induz a crença de que a edificação respeitou os passos necessários para sua realização de modo válido e, especialmente, seguro.

Somente podem acessar ao fólio real os títulos cuja idoneidade foi verificada pelo registrador. Nessa mesma linha, o registro de imóveis deve exigir que sejam observados todos os requisitos indispensáveis para a existência de uma obra regular, antes de inscrevê-la no registro predial.

A função urbanística do registro de imóveis expressa-se, pois, por meio de um controle preventivo, coadjuvante ao da Administração Pública, imperativo e indireto, exigindo-se a apresentação do documento que comprova a realização de um controle direto pelos órgãos competentes do município ou do Distrito Federal. Trata-se de função importante, pois, se não é comum a diligência do comprador junto à Prefeitura, o é a análise perante a serventia imobiliária. Assim, a não averbação da construção na matrícula do imóvel pode despertar no comprador o interesse em verificar se a obra seguiu ou não os trâmites necessários para sua realização regular.

Notou-se, entretanto, que o sistema de proteção urbanística das construções, realizado de modo cooperativo, entre registro de imóveis e Administração Pública, encontra-se ameaçado com a edição dos arts. 60 e 63 da Lei 13.465 de 2017, no que tange às edificações relacionadas a conjuntos habitacionais que compõem a regularização fundiária urbana (Reurb) e às construções localizadas em áreas de regularização fundiária de interesse social (Reurb-S), em que passou a ser admitida a averbação "por mera notícia", independentemente de apresentação de "habite-se".

Examinou-se que a autoconstrução pode ensejar perigo à vida e à integridade física dos usuários do prédio, havendo risco de instabilidade estrutural, inadequação das instalações elétrica e hidráulica e inexistência de proteção contra quedas. Tudo isso a demonstrar que o objetivo de simplificação da averbação de construções pode não ser uma boa ideia, pois permite que obras sem garantia de solidez adquiram a aparência de legalidade e a força da fé pública do oficial registrador.

Analisou-se, outrossim, a questão da repartição constitucional da competência em matéria urbanística, afirmando-se o papel de destaque dos municípios e do Distrito Federal, a quem compete a execução e concretização dos instrumentos urbanísticos. Essa constatação permitiu o questionamento sobre a compatibilidade dos novos dispositivos legais frente à competência precípua municipal e distrital sobre a organização 
e disciplina edilícia das cidades.

Observou-se que, embora a União possua competência privativa para legislar sobre registros públicos, não pode autorizar o ingresso no mundo jurídico de edificações que não observaram os regulamentos locais sobre construções, sob pena de ferir a competência municipal em matéria urbanística.

Concluiu-se, assim, pela inviabilidade de averbação de construções, no registro de imóveis, a partir de "mera notícia" do interessado, sendo imperioso exigir a apresentação do "habite-se" ou documento equivalente. De fato, as construções, somente, são regulares se respeitarem a legislação local de zoneamento, uso, obras e posturas.

\section{REFERÊNCIAS BIBLIOGRÁfICAS}

AMADEI, Vicente de Abreu. O Aspecto Instrumental do Registro Imobiliário. In: DIP, Ricardo; JACOMINO, Sérgio (Org.). Doutrinas Essenciais: Direito Registral. 2. ed. São Paulo: Revista dos Tribunais, 2013. v. 2. p. 859-903.

ARRIETA CUEVAS, Raúl. Naturaleza de los planes de desarrollo urbano y el registro inmobiliario. Revista de Derecho Público, n. 14, p. 5-21, 1983. Disponível em: < http:// www.ulpiano.org.ve/revistas/bases/artic/ texto/RDPUB/14/rdpub_1983_14_5-21.pdf>. Acesso em: 4 fev. 2017.

ASSOCIAÇÃO DOS NOTÁRIOS E REGISTRADORES DO BRASIL (ANOREG/BR). Confiança dos brasileiros nos cartórios é destaque em pesquisa do Datafolha. 2016. Disponível em: <http://www.anoreg.org.br/ index.php?option $=$ com_content\&view $=$ article\&id $=26641$ :confianca-dos-brasileiros-nos-cartorios-e-destaque-em-pesquisa-do-datafolha\&catid=19\&Itemid=180>. Acesso em: 3 jul. 2017.

BRANCO, Paulo Gustavo Gonet. Organização do Estado. In: MENDES, Gilmar Ferreira; BRANCO, Paulo Gustavo Gonet. Curso de direito constitucional. 9. ed. São Paulo: Saraiva, 2014. p. 979-1.020.

BRASIL. Exposição de Motivos 00020/2016 MCidades MP CCPR. Brasília. 21 dez. 2016. Disponível em: <http://www.planalto.gov.br/ccivil_03/_ato2015-2018/2016/Exm/Exm-MP\%20759-16.pdf>. Acesso em: 8 jun. 2017.

CARMONA, Paulo Afonso Cavichioli. Das normas gerais: alcance e extensão da competência legislativa concorrente. Belo Horizonte: Fórum, 2010.

CARMONA, Paulo Afonso Cavichioli. O consórcio imobiliário como instrumento de intervenção urbanística. Belo Horizonte: Fórum, 2007.

CARMONA, Paulo Afonso Cavichioli. Violência x cidade: o papel do Direito Urbanístico na violência urbana. São Paulo: Marcial Pons; Brasília: Fundação Escola Superior do Ministério Público do Distrito Federal e Territórios, 2014.

CARVALHO, Afrânio de. Registro de imóveis: comentários ao sistema de registro em face da Lei 6.015, de 1973, com as alterações da Lei 6.216, de 1975, Lei 8.009, de 1990, e Lei 8.935, de 18.11.1994. Rio de Janeiro: Forense, 1997.

CASTILHO, José Roberto Fernandes. Disciplina urbanística da propriedade: o lote e seu destino. 4. ed. São Paulo: Pillares, 2013.

DI PIETRO, Maria Sylvia Zanella. Poder de polícia em matéria urbanística. Temas de direito urbanístico, São Paulo, p. 23-38, 1999.

DI SARNO, Daniela Campos Libório. Elementos de direito urbanístico. Barueri: Manole, 2004. 
FIGUEIREDO, Lúcia Valle. Disciplina urbanística da propriedade. 2. ed. São Paulo: Malheiros, 2005.

FUERTES, Mercedes. Urbanismo y publicidad registral. 2. ed. Madrid: Marcial Pons, 2001.

INSTITUTO BRASILEIRO DE GEOGRAFIA E ESTATÍSTICA (IBGE). Censo Demográfico 2010: aglomerados subnormais informações territoriais. Rio de Janeiro, 2010. p. 1-251. Disponível em: <http:/ / biblioteca.ibge.gov.br/visualizacao/periodicos/552/cd_2010_agsn_if.pdf>. Acesso em: 4 ago. 2017.

MARICATO, Ermínia. Metrópole, legislação e desigualdade. Estudos Avançados, São Paulo, v. 17, n. 48, p. 151-166, 2003. Disponível em: <http://www.scielo.br/pdf/ea/v17n48/v17n48a13.pdf>. Acesso em: 3 jul. 2017.

MARTÍNEZ, Gabriel Soria. Declaración de obra nueva y constitución em régimen de propiedad horizontal. Reserva de ley para la exigibilidad de licencia respecto de la creación de mayor número de elementos privativos de los permitidos en la licencia de edificación. Examen del artículo 53.a) del Real Decreto 1093/1997, de 4 de julio. In: LASO MARTÍNEZ, José Luis et al. El urbanismo desde la perspectiva del registro de la propiedad: comentarios sobre la jurisprudencia y la doctrina de la Dirección General de los Registros e del Notariado. Madrid: Colegio de Registradores de la Propiedad y Mercantiles de España. 2013. p. 227-241.

MEIRELLES, Hely Lopes. Direito administrativo brasileiro. 36. ed. São Paulo: Malheiros, 2010.

MEIRELLES, Hely Lopes. Direito de construir. 9. ed. São Paulo: Malheiros, 2005.

MEIRELLES, Hely Lopes. Direito municipal brasileiro. 16. ed. São Paulo: Malheiros, 2008.

SÁ, Werther Lima Ferraz de. Autoconstrução na cidade informal: relações com a política habitacional e formas de financiamento. 2009. 169 f. Dissertação (Mestrado) - Programa de Pós-Graduação em Desenvolvimento Urbano, Universidade Federal de Pernambuco, Recife, 2009.

SANTOS, Flauzilino Araújo dos. Condominios e incorporaçoes no registro de imóveis: teoria e prática. São Paulo: Mirante, 2012.

SANTOS, Flauzilino Araújo dos. Princípio da Legalidade e Registro de Imóveis. In: DIP, Ricardo; JACOMINO, Sérgio (Org.). Doutrinas Essenciais: Direito Registral. 2. ed. São Paulo: Revista dos Tribunais, 2013. v. 2. p. 859-903.

SILVA, José Afonso da. Direito urbanístico brasileiro. 6. ed. São Paulo: Malheiros.

VALLIM, João Rabelo de Aguiar. Direito imobiliário brasileiro: doutrina e prática. São Paulo: Revista dos Tribunais, 1980. 


\section{REVISTA BRASILEIRA DE POLÍTICAS PÚBLICAS BRAZILIAN JOURNAL OF PUBLIC POLICY}
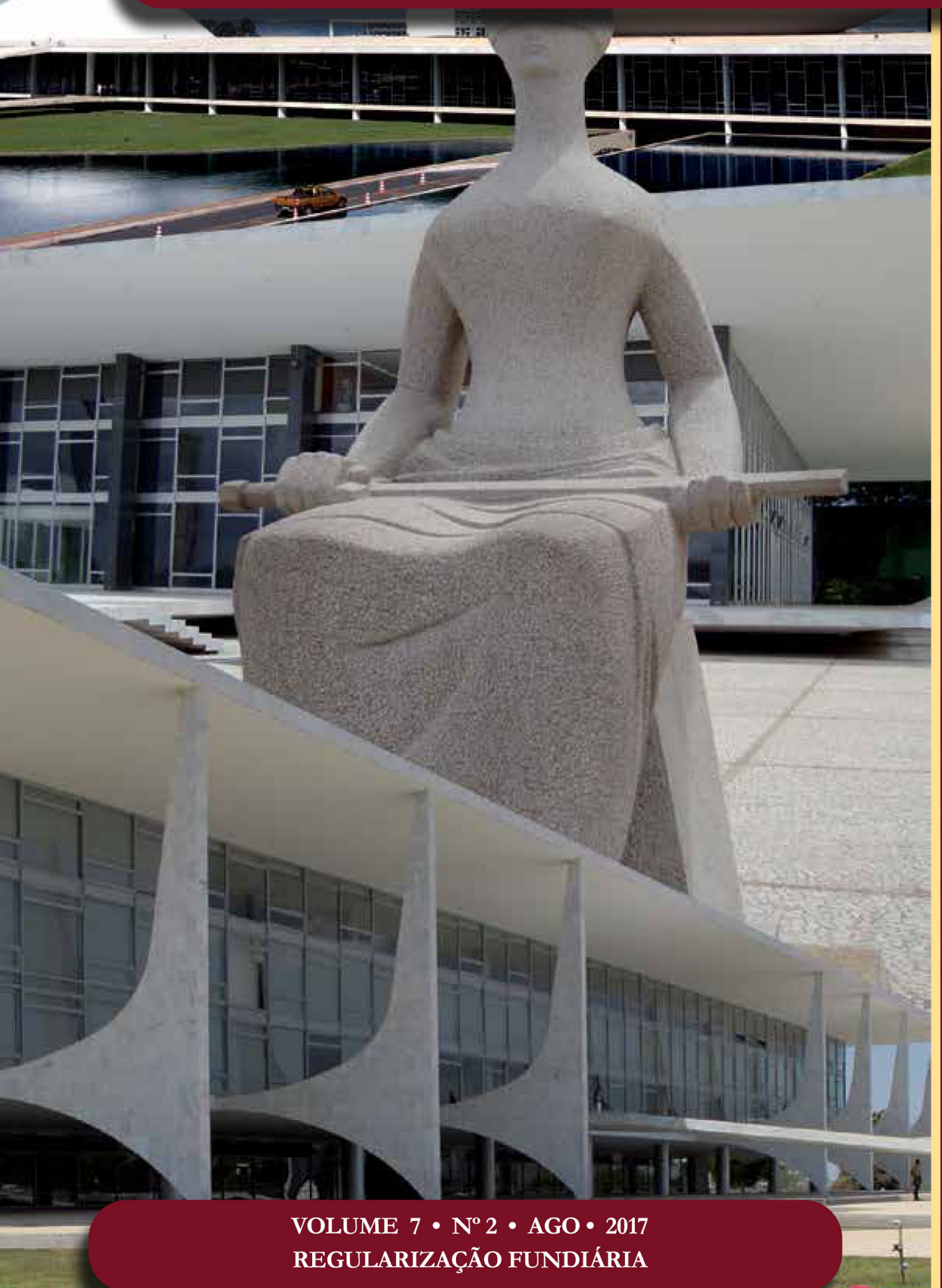

Direitos De Propriedade E Instrumentos Econômicos De Regulação Ambiental: Uma Análise Das Atribuições Implícitas Proprietary Rights And Economic Instruments Of Environmental Regulation: An Analysis Of Implicit Attributions

Laura Meneghel dos Santos

Antônio José Maristrello Porto Rômulo Silveira da Rocha Sampaio 


\title{
Direitos De Propriedade E Instrumentos Econômicos De Regulação Ambiental: Uma Análise Das Atribuições Implícitas*
}

\author{
Proprietary Rights And Economic \\ Instruments Of Environmental Regulation: \\ An Analysis Of Implicit Attributions
}

* Recebido em 09/05/2017

Aprovado em 07/07/2017

** Doutoranda e Mestra em Políticas Públicas, Estratégias e Desenvolvimento pelo Instituto de Economia da Universidade Federal do Rio de Janeiro (UFRJ). Pesquisadora do Centro de Estudos em Direito e Economia (CPDE) da Escola de Direito do Rio de Janeiro da FGV. Formada em Ciências Econômicas pela Universidade Estadual de Campinas (Unicamp). Tem experiência em pesquisa multidisciplinar nas áreas de Economia, Direito, Políticas Públicas e Meio Ambiente. E-mail: msantos.laura@gmail. com

*** Doutor em Direito (Doctor of the Science of Law - J.S.D.) pela University of Illinois. Mestre (Master of Laws - LL.M.) pela University of Illinois. Graduado em Direito pela Fundação de Ensino Octávio Bastos. Professor da Graduação e do Mestrado em Direito da Regulação da FGV Direito Rio. Coordenador do Centro de Pesquisa em Direito e Economia (CPDE) e do Centro de Pesquisa em Direito Ambiental (CDMA) da FGV Direito Rio. Representante do CPDE no Conselho de Análises Econômicas e Sociais do Estado do Rio de Janeiro. E-mail: antonio.maristrello@fgv.br

**** Doutor em Direito Ambiental pela Pace University. Mestre em LL.M. em Direito Ambiental pela Pace University. Mestre e graduado em Direito pela PUC-PR. Professor da Graduação e do Mestrado em Direito da Regulação da FGV Direito Rio. Professor adjunto na Pace University de Nova York. Professor visitante da Georgia State University College of Law em Atlanta. Lidera o Grupo de Pesquisa de Direito e Meio Ambiente do CNPq no âmbito da FGV Direito Rio e ainda atua como coordenador do curso de especialização em Direito da Regulação Ambiental. Tem experiência na área de Direito, com ênfase em Direito Ambiental, atuando principalmente nas seguintes áreas de sustentabilidade, governança ambiental, mudança climática e direito de águas. E-mail: romulo. sampaio@fgv.br

\author{
Laura Meneghel dos Santos** \\ Antônio José Maristrello Porto*** \\ Rômulo Silveira da Rocha Sampaio**** \\ Antônio José Maristrello Porto***
}

\section{Resumo}

Considerando-se que a sobre-exploração dos recursos naturais está, muitas vezes, associada à falta ou à insegurança de direitos de propriedade sobre recursos, bens e serviços que beneficiam a sociedade como um todo, este trabalho aborda o tratamento dessa problemática pelos instrumentos econômicos de gestão e regulação ambiental. Com base no referencial analítico de Direitos de Propriedade proposto nos trabalhos de Elinor Ostrom, Guido Calabresi e Douglas Melamed, foram analisados três instrumentos econômicos de gestão ambiental (tributação, sistemas de certificados negociáveis e pagamentos por serviços ambientais), assim como uma experiência brasileira de cada um deles. Observamos que, ao tentar estabelecer um sistema econômico mais eficiente e sustentável via internalização de externalidade ambientais, os instrumentos econômicos de gestão ambiental engendram uma variedade de formas de atribuição tácitas de direitos de propriedade relativos ao meio ambiente. Ou seja, para que resultados eficientes (tanto ambientalmente quanto economicamente) possam ser de fato gerados, é essencial que o Direito atue no sentido de garantir a segurança jurídica dessas atribuições, formalizando arranjos institucionais claros e impondo sanções efetivas para aqueles que não forem complacentes com a modelagem jurídica e econômica estabelecida para os instrumentos. Fica claro, portanto, que uma política ambiental eficaz não pode prescindir de um tratamento multidisciplinar que se aproprie das ciências jurídica e econômica.

Palavras-chaves: Externalidades. Direitos de propriedade. Instrumentos econômicos de gestão ambiental.

\section{Abstract}

Considering that, the overexploitation of natural resources is, many times, associated with the lack or insecurity of property rights on resources, goods and services that benefit the society as a whole, this paper sought to explain how the economic instruments of environmental management sol- 
ve this question. Based on the analytical framework of Property Rights proposed in the studies of Elinor Ostrom, Guido Calabresi and Douglas Melamed, three economic instruments of environmental management (taxation, negotiable certificate systems and payments for environmental services) were analyzed, as well as the Brazilian experience of each of them. We observed that, in trying to set a more efficient and sustainable economic system through internalization of environmental externalities, economic instruments for environmental management engender a variety of tacit property rights' attributions related to the environment. That is, to achieve efficient results (both environmentally and economically), it is essential that the Law acts in the sense of guaranteeing the legal security of these attributions, formalizing clear institutional arrangements and imposing effective sanctions for those who are not compliant with the legal and economic schemes established for the instruments. It is clear, therefore, that an effective environmental policy cannot dispense a multidisciplinary approach that combines economic and legal sciences.

Keywords: Externalities. Property rights. Economic instruments for environmental management.

\section{INTRODUÇÃo}

Os recursos, bens e serviços ambientais ${ }^{1}$ (ou ecossistêmicos) fornecidos pela natureza contribuem para o bem-estar da sociedade ${ }^{2}$. Assinalando a importância do meio ambiente, a Constituição da República Federativa do Brasil de 1988 estabelece, em seu artigo 225, que "todos têm direito ao meio ambiente ecologicamente equilibrado, bem de uso comum do povo e essencial à sadia qualidade de vida". Tal país é um dos maiores detentores de riqueza biológica do mundo, logo, a discussão e a implementação de políticas de preservação ambiental se fazem ainda mais prementes ${ }^{3}$.

Ao longo dos dois últimos séculos, os recursos, bens e serviços ambientais tornaram-se mais escassos. A perda de espécies e ecossistemas se deu em velocidade acelerada ${ }^{4}$. Crescentes pressões derivadas da urbanização desordenada, do padrão de consumo insustentável, das mudanças nas dietas alimentares, do aumento populacional e mudanças climáticas, combinadas a diversos outros fatores, desafiam a manutenção da biodiversidade e dos ecossistemas ${ }^{5}$.

O avanço de tal escassez fez do meio ambiente objeto de preocupação de todas as áreas do conhecimento com o objetivo de evitar seu desperdício e a consequente redução do bem-estar social. No campo da economia, os preços muitas vezes não refletem os efeitos negativos aos recursos ambientais. Existem, ainda, dificuldades, técnica e institucional, de definir direitos de propriedade entre contemporâneos e gerações futuras ${ }^{6}$. Como lidar com essas externalidades no tempo e no espaço é um desafio para o regulador.

Percebendo esses problemas como relevante, a proteção ambiental passa a ser buscada pelo Estado por

1 São, em última instância, fluxos de materiais, energia e informações derivados dos ecossistemas naturais e cultivados que, combinados com os demais tipos de capital (humano, manufaturado e social), produzem o bem-estar humano. ROMEIRO, Ademar Ribeiro. Economia ou economia política da sustentabilidade. In: ECONOMIA do meio ambiente. Rio de Janeiro: Elsevier Brasil, 2010. p. 14.

2 São muitos os benefícios: os alimentos, as matérias-primas, a regulação do clima na Terra, a formação dos solos, o controle contra erosão, o armazenamento de carbono, a ciclagem de nutrientes, o provimento de recursos hídricos em quantidade e qualidade, a manutenção do ciclo de chuvas, a proteção da biodiversidade, a proteção contra desastres naturais, elementos culturais, a beleza cênica, a manutenção de recursos genéticos, entre muitos outros.

3 MIGUEL, Luciano Costa. Desenvolvimento sustentável: uma visão conciliadora para a concretização de um direito fundamental e um princípio da ordem econômica. Revista Brasileira de Políticas Públicas, Brasília, v. 2, n. 2, p. 141-156, jul./dez. 2012.

4 PRATES, Ana Paula Leite; IRVING, Marta de Azevedo. Conservação da biodiversidade e políticas públicas para as áreas protegidas no Brasil: desafios e tendências da origem da CDB às metas de Aichi. Revista Brasileira de Políticas Públicas, Brasília, v. 5, n. 1, p. $27-57,2015$.

5 SEEHUSEN, Susan; PREM, Ingrid. Porque pagamentos por serviços ambientais? In: GUEDES, Fátima Becker; SEEHUSEN, Susan Edda (Org.). Pagamentos por Serviços Ambientais na Mata Atlântica: lições aprendidas e desafios. Brasília: MMA, 2011. p. 15-54.

6 MOTTA, Ronaldo Seroa da. O uso de instrumentos econômicos na gestão ambiental. Rio de Janeiro: IPEA, 2000. 
meio de políticas públicas que intervenham na ordem econômica ${ }^{7}$. Inicialmente, foram instituídos instrumentos de comando e controle que, até hoje, conformam a base das políticas ambientais de muitos países industrializados, inclusive o Brasil. Basicamente, esses instrumentos constituem um conjunto de normas, regras, procedimentos e padrões a serem obedecidos pelos agentes econômicos de modo a adequar-se a certas metas ambientais, acompanhado de um conjunto de penalidades previstas para os recalcitrantes ${ }^{8}$.

Os exemplos mais usuais de instrumentos de comando e controle são: regras de zoneamento, definição de padrões de qualidade, imposição de estudos ambientais e exigência de prévio licenciamento. Reis e Mot$\operatorname{ta}^{9}$ apontam que falhas institucionais - relativas a falta de capacidade governamental administrativa para monitorar e implementar os comandos normativos e processar e punir infratores - explicam os resultados pouco eficientes alcançados por esses tipos de intervenções. Para Lustosa, Cánepa e Young ${ }^{10}$, a deficiência informacional dos reguladores, também, contribui para essa ineficiência. Ou seja, nem sempre regimes de propriedade públicos conseguem resolver o problema de escassez dos recursos naturais.

De acordo com os autores supracitados, para solucionar esses problemas, muitos países praticam, atualmente, uma política ambiental mista que integra instrumentos de comando e controle e econômicos de gestão ambiental. Estes, com uma lógica de propriedade particular (examinada em detalhes a seguir), atuam, justamente, no sentido de alterar o preço (custo) de utilização de um recurso, internalizando as externalidades e, portanto, afetando seu nível de utilização (demanda) ${ }^{11}$.

Isso posto, parece que um olhar multidisciplinar, abrangendo as disciplinas do Direito e da Economia, pode contribuir para esclarecer as circunstâncias envolvidas na gestão ambiental, auxiliando o aprimoramento das políticas públicas. Nessa linha, com base no referencial analítico de Direitos de Propriedade proposto por Calabresi e Melamed ${ }^{12}$ e Ostrom ${ }^{13}$, este artigo esclarece de que forma alguns instrumentos econômicos de gestão ambiental atribuem direitos de propriedade relativos a recursos (bens e serviços) naturais que beneficiam a sociedade como um todo.

A seguir, apresentamos a estrutura analítica proposta por Calabresi e Melamed ${ }^{14}$ e Ostrom ${ }^{15}$ para análise dos direitos de propriedade relacionados ao meio ambiente. Em seguida, detalhamos três instrumentos econômicos de gestão ambiental: tributação; sistemas de certificados negociáveis; e pagamentos por serviços ambientais, contextualizando-os com a teoria econômica que os sustentam. A partir disso, examinamos como os direitos de propriedade são atribuídos e protegidos em cada um desses mecanismos, expondo um exemplo prático de cada deles. Por fim, tecemos as considerações finais.

\footnotetext{
7 MIGUEL, Luciano Costa. Desenvolvimento sustentável: uma visão conciliadora para a concretização de um direito fundamental e um princípio da ordem econômica. Revista Brasileira de Políticas Públicas, Brasília, v. 2, n. 2, p. 141-156, jul./dez. 2012.

8 MARGULIS, Sergio. A regulamentação ambiental: instrumentos e implementação. Rio de Janeiro: IPEA, 1996. (Texto para Discussão; n. 437).

9 REIS, Eustáquio J.; MOTTA, Ronaldo Seroa da. The application of economic instruments in environmental policy: the Brazilian case. Revista Brasileira de Economia, Rio de Janeiro, v. 48, n. 4, p. 551-576, 1994.

10 LUSTOSA, Maria Cecília Junqueira; CÁNEPA, Eugenio Miguel; YOUNG, Carlos EF. Política ambiental. Economia do meio ambiente: teoria e prática. Rio de Janeiro: Elsevier, 2010. p. 163.

11 MOTTA, Ronaldo Seroa da. O uso de instrumentos econômicos na gestão ambiental. Rio de Janeiro: IPEA, 2000.

12 CALABRESI, Guido; MELAMED, A. Douglas. Property rules, liability rules, and inalienability: one view of the cathedral. Harvard Law Review, Cambridge, MA, p. 1089-1128, 1972.

13 OSTROM, Elinor. Private and common property rights. In: BOUCKAERT, B.; GEEST G. De (Ed.). Encyclopedia of Law and Economics. Cheltenham: Edward Elgar Publishing, 2000. p. 332-379.

14 CALABRESI, Guido; MELAMED, A. Douglas. Property rules, liability rules, and inalienability: one view of the cathedral. Harvard Law Review, Cambridge, MA, p. 1089-1128, 1972.

15 OSTROM, Elinor. Private and common property rights. In: BOUCKAERT, B.; GEEST G. De (Ed.). Encyclopedia of Law and Economics. Cheltenham: Edward Elgar Publishing, 2000. p. 332-379.
} 


\section{Referencial Analítico}

É importante, em primeiro momento, assinalar as diferentes interpretações expressas pelas disciplinas do Direito e da Economia em relação aos direitos de propriedade ${ }^{16}$. De modo bastante simplificado, o Direito define a propriedade como um direito real (poder direto e imediato sobre uma coisa) que, geralmente, abrange os direitos de posse, uso, fruição e alienação (ainda que possam pertencer a pessoas diferentes) conforme estabelecido nos ditames legais. $\mathrm{Na}$ Economia, os direitos de propriedade tendem a estar relacionados com as expectativas de proveito de um ativo. Segundo Yoram Barzel:

The term 'property rights' carries two distinct meanings in the economic literature. One $[\ldots]$ is essentially the ability to enjoy a piece of property. The other [...] is essentially what the state assigns to a person. I designate the first 'economic (property) rights' and the second 'legal (property) rights ${ }^{17}$.

Mello ${ }^{18}$ ressalta que essas definições não se equiparam, uma vez que, no âmbito da análise econômica, o que importa é o que os agentes acreditam que podem fazer ou controlar, enquanto, na esfera jurídica, o que interessa é o que eles podem fazer legalmente. O Direito, então, atua para garantir maior segurança ao pleno exercício do direito de propriedade.

if economic analysis concerns itself with the effects of the allocation of rights on the behavior of agents and with the economic results thereafter, then it is important to take into account by which means the legal system guarantees - with more or less safety - such rights. ${ }^{19}$

Assim, o presente estudo da atribuição de direitos de propriedade associada aos instrumentos econômicos de gestão do meio ambiente visa esclarecer de que maneira a ordem jurídica pode contribuir para a obtenção de resultados mais eficientes em políticas que compatibilizem desenvolvimento econômico e preservação ambiental. Para tanto, utilizamos o referencial analítico proposto por Calabresi e $\mathrm{Melamed}^{20} \mathrm{e}$ Ostrom $^{21}$.

Antes de nos voltarmos para o trabalho dos autores supracitados, vale a pena lembrar que, quando as populações humanas e seus impactos eram pequenos em relação ao ecossistema que os sustentava, a utilização do capital natural era caracterizada pelo privilégio ${ }^{22}$, uma vez que fazia pouco sentido estabelecer direitos de propriedade para recursos superabundantes. No entanto, atualmente, a poluição ou extração de recursos naturais implica custos a outros indivíduos (muitas vezes àqueles das gerações futuras), consequentemente, ampliam-se as pressões para o desenvolvimento de políticas ambientais que atribuam ou modifiquem direi-

16 É necessário apontar que as interpretações não são consensuais e uniformes dentro de cada disciplina. Tal discussão, contudo, não faz parte do escopo desse estudo. Para mais detalhes ver: COLE, Daniel H.; GROSSMAN, Peter Z. The meaning of property rights: law versus economics?. Land Economics, Madison, WI, v. 78, n. 3, p. 317-330, 2002; MELLO, Maria Tereza Leopardi; ESTEVES, Heloísa Lopes Borges. Property Rights: building an interdisciplinary approach. In: COLLOQUE CHARLES GIDE, 2010, Paris. Paris, maio de 2010.

17 BARZEL, Yoram. Economic analysis of property rights. Cambridge: Cambridge university press, 1997. p. 3. Em tradução livre: “O termo direitos de propriedade carrega dois significados distintos na literatura econômica. Um é essencialmente a habilidade de desfrutar de alguma propriedade. O outro é essencialmente o que o Estado atribui a uma pessoa. Eu denomino o primeiro de direitos (de propriedade) econômicos e o segundo de direitos (de propriedade) legais".

18 MELLO, Maria Tereza Leopardi. "Property" Rights and the Ways of Protecting Entitlements - an interdisciplinary approach. 2015 (mimeo).

19 MELLO, Maria Tereza Leopardi; ESTEVES, Heloísa Lopes Borges. Property Rights: building an interdisciplinary approach. In: COLLOQUE CHARLES GIDE, 2010, Paris. Paris, maio de 2010. Em tradução livre: "Se a análise econômica se preocupa com os efeitos da alocação de direitos no comportamento dos agentes e com os resultados econômicos consequentes, então é importante levar em consideração os meios pelos quais o sistema jurídico garante - com maior ou menor segurança - tais direitos".

20 CALABRESI, Guido; MELAMED, A. Douglas. Property rules, liability rules, and inalienability: one view of the cathedral. Harvard Law Review, Cambridge, MA, p. 1089-1128, 1972.

21 OSTROM, Elinor. Private and common property rights. In: BOUCKAERT, B.; GEEST G. De (Ed.). Encyclopedia of Law and Economics. Cheltenham: Edward Elgar Publishing, 2000. p. 332-379.

22 Se alguém possui um privilégio, possui o direito de se comportar como pretenda, não possuindo os demas quaisquer direitos. DALY, Herman; FARLEY, Joshua. Economia ecológica: princípios e aplicações. Lisboa: Instituto Piaget, 2004, p.442. 
tos de propriedade ${ }^{23}$.

Em seu trabalho seminal $3 / 4$ considerado "one of the most influential essays of twentieth century legal scholarship" $243 / 4$ Calabresi e Melamed $^{25}$ desenvolveram uma estrutura analítica que eles acreditavam que serviria para integrar vários aspectos legais relacionados, mas que, tradicionalmente, eram analisados em áreas temáticas separadas, como propriedade e responsabilidade civil.

Partindo-se da constatação de que, em qualquer disputa legal, além de decidir o lado vencedor $3 / 4$ ou a quem pertence o direito $3 / 4$ o Estado deve, também, estabelecer qual o tipo de proteção que será concedida, os autores identificam três tipos de direitos: aqueles protegidos por regras de propriedade (property rules), aqueles protegidos por regras de responsabilidade (liability rules) e direitos inalienáveis. Conforme apontam, ainda que essas categorias não sejam, completamente, distintas, tal classificação é útil para explicar os motivos que nos levam a proteger certos direitos de uma dada maneira ${ }^{26}$.

Um direito protegido por uma regra de propriedade só pode ser removido de seu titular a partir de uma transação voluntária, sendo seu valor negociado entre comprador e vendedor. Ou seja, a realocação do direito é possível por meio do mercado. Esta seria a forma de proteção que demandaria menor intervenção estatal, uma vez que, após determinar a alocação do direito, o Estado não tenta determinar seu valor. As partes ficam livres para transacionar o direito caso a valor oferecido pelo comprador seja considerado suficiente pelo vendedor.

Assim, na ausência de custos significativos de transação, a solução economicamente eficiente seria alcançada, pois o direito pode migrar para o agente que mais o valoriza e tem capacidade de pagamento ${ }^{27}$. Por exemplo, o trabalho de um médico é atrapalhado pelo barulho de uma máquina de confeitaria do estabelecimento vizinho e os dois entram na justiça para verificar quem possui o direito: o médico tem direito ao silêncio ou o confeiteiro tem direito ao barulho. Suponhamos que o juiz decide que o trabalho do médico possui um valor ético maior e atribui a ele o direito, protegendo-o com uma regra de propriedade. No entanto, vamos imaginar que o bem-estar econômico do médico possa ser auferido e que o seu ganho seja de $\mathrm{R} \$ 40,00$ com o silêncio, enquanto o bem-estar econômico do confeiteiro, que depende do barulho para produzir, seja reduzido em $\mathrm{R} \$ 60,00$ (ou seja, o direito é mais valioso para esse último). Por meio do mercado, esses dois agentes podem negociar livremente e chegar em uma situação que beneficie os dois, logo, mais eficiente. Hipoteticamente, o confeiteiro pode oferecer pagar $\mathrm{R} \$ 45,00$ ao médico pelo direito de fazer barulho: o médico ganharia $\mathrm{R} \$ 5,00$ a mais do que se preservasse o direito ao silêncio e o confeiteiro poderia, então, retomar sua produção, conseguindo um saldo de $\mathrm{R} \$ 15,00(60-45)^{28}$.

A "regra da responsabilidade" (liability rule) estabelece que a parte desprovida do direito pode tomá-lo da parte a quem o direito foi atribuído, por meio do pagamento de uma quantia em dinheiro fixada pelo juiz ou por outro funcionário do governo. Não raramente, essa forma de proteção de direitos resulta no estabelecimento de uma indenização pela violação do direito do titular. Obviamente, aqui uma maior intervenção do Estado é demandada, de forma que este não define, somente, a forma de proteção do direito, mas também o valor que possibilita a transferência ou destruição desse direito. Logo, em comparação com a regra de propriedade, aqui ocorre perda do poder de barganha dos agentes e o Estado, por meio de seus órgãos, terá que se esforçar para se aproximar do resultado de mercado, estimando o valor que tornaria a parte prejudicada

23 DALY, Herman; FARLEY, Joshua. Economia ecológica: princípios e aplicações. Lisboa: Instituto Piaget, 2004.

24 KENNEDY, David; FISHER III, William W. The canon of American legal thought. Princeton, NJ: Princeton Univ. Press, 2006.

25 CALABRESI, Guido; MELAMED, A. Douglas. Property rules, liability rules, and inalienability: one view of the cathedral. Harvard Law Review, Cambridge, MA, p. 1089-1128, 1972.

26 CALABRESI, Guido; MELAMED, A. Douglas. Property rules, liability rules, and inalienability: one view of the cathedral. Harvard Law Review, Cambridge, MA, p. 1089-1128, 1972.

27 PORTO, Antônio José Maristrello; FRANCO, Paulo Fernando. Uma Análise Também Econômica do Direito de Propriedade/Also an Analysis of Economic Property Rights. Economic Analysis of Law Review, v. 7, n. 1, p. 207-232, 2016.

28 Exemplo inspirado no artigo seminal de Ronald Coase COASE, Ronald. The Problem of Social Cost. Journal of Law and Economics, Chicago, IL, v. 3, n. 1, p. 1-44, 1960. 
indiferente entre perder o direito ou receber aquela quantia em dinheiro.

Voltando ao exemplo do médico e do confeiteiro anteriormente utilizado, caso o direito atribuído ao médico fosse protegido por uma regra de responsabilidade, o confeiteiro só poderia retomar suas atividades (com a máquina barulhenta) se pagasse uma indenização ao médico pelo incômodo. O que será determinante nessa decisão (produzir ou não com tal máquina) será o valor da indenização estipulado. Para qualquer valor menor que $\mathrm{R} \$ 60,00$, será vantajoso para o confeiteiro retomar a produção pagando a indenização, no entanto, para valores menores que $\mathrm{R} \$ 40,00$, o médico não será, inteiramente, ressarcido pelos dados gerados. Caso o valor da indenização seja superior a $\mathrm{R} \$ 60,00$, é mais vantajoso para o confeiteiro parar de produzir com a máquina barulhenta.

Por fim, os direitos são inalienáveis quando sua transferência não é permitida mesmo que existam compradores e vendedores dispostos a negociá-lo. O Estado intervém proibindo a venda do direito em algumas ou todas as circunstâncias. Assim, as regras de inalienabilidade podem ser vistas como limitantes ou regulamentações da concessão do próprio direito ${ }^{29}$. Tal forma de proteção de direito é um reconhecimento da falta de racionalidade individual temporária ou permanente (parcial ou absoluta) para decidir acerca de certas situações ou titularidades. O direito à liberdade, por exemplo, é um direito inalienável. Ainda que existam vendedores e compradores para tal direito no mercado, o Estado considera que os custos sociais e morais dessa transação superam, significativamente, os possíveis benefícios individuais dos agentes e inviabiliza tal negociação por meio da inalienabilidade.

Cabe sublinhar, conforme apontado por $\mathrm{Mello}^{30}$, que, embora o direito de propriedade (no sentido jurídico, como direito real) tenha, em geral, a característica de poder ser transferido somente pela vontade de seu proprietário, o conceito utilizado pelos autores possui um escopo mais amplo, na medida em que pode acolher direitos não relacionados com uma "coisa". Ademais, as regras de responsabilidade podem ser aplicadas a algumas situações que seriam, legalmente, consideradas direitos de propriedade (tal como uma licença compulsória aplicada a uma propriedade intelectual).

Elinor Ostrom $^{31}$, ao analisar a forma de gestão dos recursos comuns ${ }^{32}, 3 / 4$ aqueles bens não exclusivos e rivais $3 / 4$ define direitos de propriedade como ações (referentes a alguma coisa) que os indivíduos podem tomar em relação a outros indivíduos. Então, considerando-se a propriedade como um feixe de direitos, a autora identifica cinco tipos de direitos de propriedade relevantes para a gestão dos recursos comuns:

Acesso: O direito de entrar em uma área física definida e desfrutar benefícios não subtrativos;

Exploração: O direito de obter unidades de recursos ou produtos de um sistema de recursos;

Administração: $\mathrm{O}$ direito de regular padrões de uso interno e transformar o sistema de recursos por meio de melhorias;

Exclusão: O direito de determinar quem terá os direitos de acesso e de exploração e como esses direitos podem ser transferidos;

Alienação: $\mathrm{O}$ direito de vender ou transferir os direitos de administração e exclusão.

Os primeiros dois direitos, acesso e exploração, são considerados direitos de propriedade operacionais e

29 CALABRESI, Guido; MELAMED, A. Douglas. Property rules, liability rules, and inalienability: one view of the cathedral. Harvard Law Review, Cambridge, MA, p. 1093, 1972.

30 MELLO, Maria Tereza Leopardi. "Property" Rights and the Ways of Protecting Entitlements - an interdisciplinary approach. 2015. (mimeo).

31 OSTROM, Elinor. Private and common property rights. In: BOUCKAERT, B.; GEEST G. De (Ed.). Encyclopedia of Law and Economics. Cheltenham: Edward Elgar Publishing, 2000. p. 332-379.

32 A autora chama esses recursos de "common-pool resources". Neles, a exclusão de indivíduos é custosa (bem não exclusivo), o consumo de um indivíduo reduz os bens disponíveis aos outros (bem rival) e podem ser geridos por diferentes regimes de propriedade (privada, comum, pública). Um lago, por exemplo, pode ser considerado um recurso comum $3 / 4$ diferentes lotes de terra podem ter acesso a ele (exclusão difícil) 3/4 e a pesca realizada por alguns indivíduos reduz o estoque de peixes disponíveis aos demais. 
os demais são denominados direitos de propriedade de escolha coletiva. É importante destacar que indivíduos (ou coletividades) podem possuir direitos de propriedade bem definidos que incluem ou não todos os direitos acima descritos. Ou seja, para Ostrom ${ }^{33}$ direitos de propriedade bem definidos não se resumem à possibilidade de alienação. Dessa forma, os diferentes regimes de propriedade (privada, comum ou pública) comportam variadas possibilidades de combinações de direitos 3/4 "multiple powers to take actions regarding a particular thing" ${ }^{34}$. Conforme assinala a autora:

Devising property regimes that effectively allow sustainable use of a common-pool resource requires rules that limit access to the resource system and other rules that limit the amount, timing, and technology used to withdraw diverse resource units from the resource system ${ }^{35}$.

De forma geral, os recursos ambientais, definidos pelo art. $3^{\circ}$, inc. V, da Lei 6.938/81, como sendo a atmosfera, as águas interiores, superficiais e subterrâneas, os estuários, o mar territorial, o solo, o subsolo, os elementos da biosfera, a fauna e a flora, podem ser considerados recursos comuns. Ainda que determinadas situações facilitem a possibilidade de exclusão, eles geram fluxos de unidades de recursos ou benefícios (como os serviços ambientais de regulação do clima e de ciclagem de nutrientes, por exemplo) que podem afetar, positivamente, (ou negativamente caso haja degradação) a qualidade de vida das populações local, regional e até global. Assim, na busca por um uso mais sustentável dos recursos ambientais, é oportuno analisar como os instrumentos econômicos de gestão ambiental orientam os cinco direitos de propriedade estabelecidos por Ostrom ${ }^{36}$.

\section{INSTRUMENTOS ECONÔMICOS DE GESTÃO AMBIENTAL}

Os instrumentos econômicos de gestão ambiental buscam estabelecer melhorias ambientais através de incentivos e desincentivos via sistema de preços. De acordo com Reis e Motta ${ }^{37}$, o princípio do poluidor/ usuário pagador é a essência dessa abordagem $3 / 4$ market based instruments approach $3 / 4$ que tenta fazer com que a escassez dos recursos naturais seja refletida nos preços de mercado. De acordo com Perman et al. ${ }^{38}$, enquanto os instrumentos de comando e controle (de gestão ambiental) operam pela imposição de obrigações ou restrições de comportamento, os instrumentos econômicos funcionam por meio da criação de incentivos para influenciar / induzir atos comissivos ou omissivos de firmas e indivíduos. Ou seja, esses instrumentos alteram estrutura de recompensas a disposição dos agentes.

Quando alteram o retorno associado ao uso ou exploração dos recursos naturais, tais instrumentos econômicos conferem direitos e deveres relativos ao meio ambiente. Entender as especificidades dessas atribuições é fundamental para a compreensão das circunstâncias envolvidas nesse tipo de política. Isso, por sua vez, possibilita que o Direito aprimore os arranjos institucionais para sua implementação, contribuindo para o alcance de melhores resultados.

33 OSTROM, Elinor. Private and common property rights. In: BOUCKAERT, B.; GEEST G. De (Ed.). Encyclopedia of Law and Economics. Cheltenham: Edward Elgar Publishing, 2000. p. 332-379.

34 MELLO, Maria Tereza Leopardi. "Property" Rights and the Ways of Protecting Entitlements - an interdisciplinary approach. 2015 (mimeo).

35 OSTROM, Elinor. Private and common property rights. In: BOUCKAERT, B.; GEEST G. De (Ed.). Encyclopedia of Law and Economics. Cheltenham: Edward Elgar Publishing, 2000. p. 332-379. Em tradução livre: "Estabelecer regimes de propriedade que permitam efetivamente o uso sustentável de um recurso comum requer regras que limitam o acesso ao sistema de recursos e outras regras que limitam o montante, o tempo e a tecnologia usados para retirar diversas unidades de recursos do sistema de recursos".

36 OSTROM, Elinor. Private and common property rights. In: BOUCKAERT, B.; GEEST G. De (Ed.). Encyclopedia of Law and Economics. Cheltenham: Edward Elgar Publishing, 2000. p. 332-379.

37 REIS, Eustáquio J.; MOTTA, Ronaldo Seroa da. The application of economic instruments in environmental policy: the Brazilian case. Revista Brasileira de Economia, Rio de Janeiro, v. 48, n. 4, p. 551-576, 1994.

38 PERMAN, Roger et al. Natural resource and environmental economics. Harlow: Pearson Education, 2003. p. 217. 
Nessa seção analisaremos três instrumentos econômicos de gestão ambiental: tributação, sistemas de certificados negociáveis e pagamentos por serviços ambientais. Primeiro, apresentamos a base teórica de cada um deles $3 / 4$ cujo ponto de partida é o aparecimento e tratamento das externalidades no âmbito da economia neoclássica ${ }^{39}$. Em seguida, refletimos e indicamos as diferentes atribuições de direitos relativos ao meio ambiente preconizadas por cada instrumento. Por fim, apontamos uma experiência brasileira com cada um deles.

\subsection{Tributação}

\subsubsection{O instrumento}

Segundo a teoria desenvolvida por Arthur Cecil Pigou, no século XX, a correção da externalidade ambiental negativa (poluição / degradação da qualidade do meio ambiente) poderia ser feita mediante a imposição, pelo Estado, de um tributo, incidente sobre cada unidade produzida, igual à diferença entre o custo marginal privado e o custo marginal social. De acordo com Perman et al. ${ }^{40}$, o imposto elimina a diferença (criada pela poluição ambiental) entre o preço privado eficiente e o preço socialmente eficiente. Esse raciocínio é ilustrado na Figura 1 e esclarecido a seguir.

Figura 1 - Imposto pigouviano: internalização de externalidade negativa em mercado competitivo ${ }^{41}$

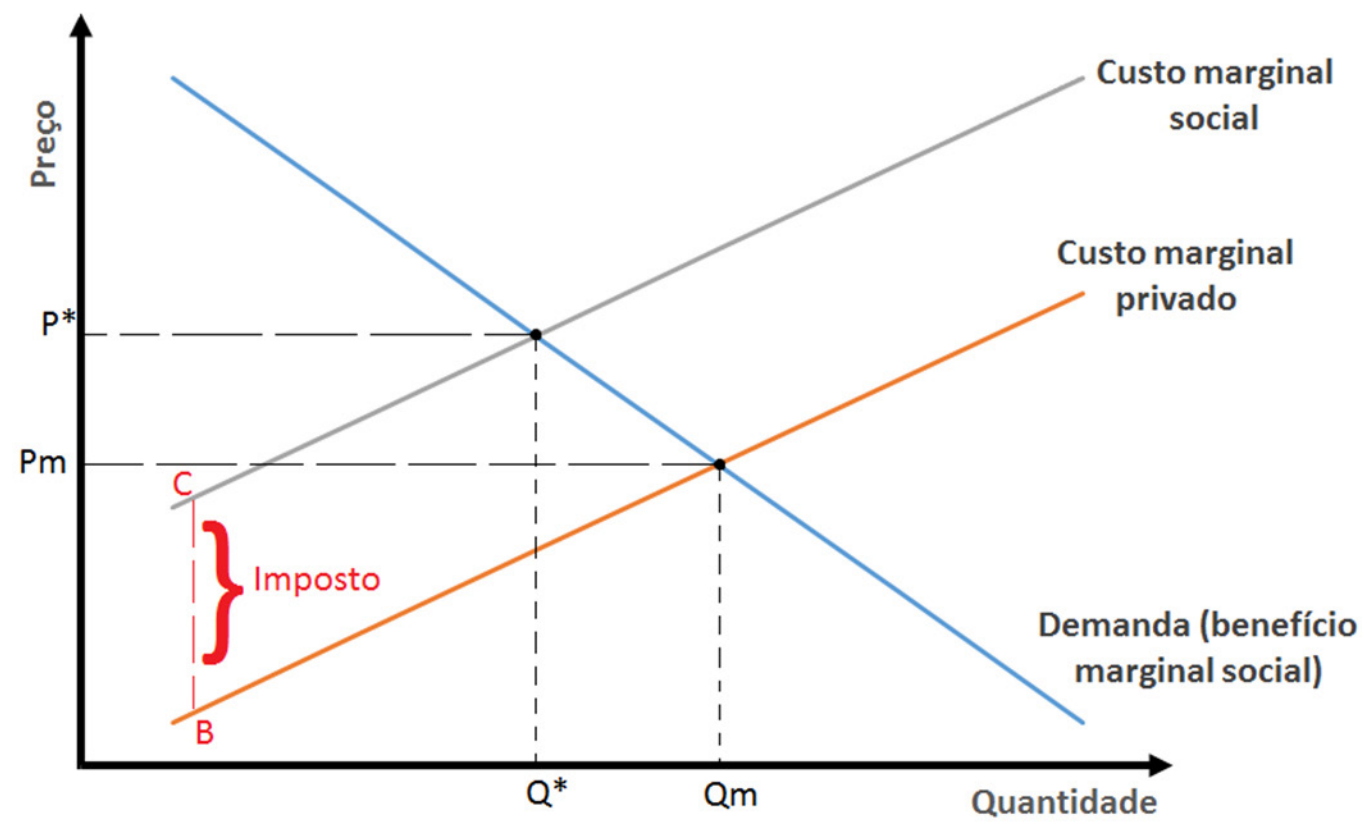

Em um mercado competitivo e sem externalidades, a curva de demanda (soma lateral de todas as demandas individuais dos consumidores) intercepta a curva de oferta de mercado (soma lateral de todas as curvas de custo marginal privado das empresas que compõem o mercado) no ponto de equilíbrio - ótimo

39 A base teórica desses instrumentos é sustentada por algumas premissas da Teoria do Equilíbrio Geral, tais como, mercado perfeitamente competitivo, agentes racionais e bem-informados. No entanto, sabe-se que a realidade dista $3 / 4$ muitas vezes substancialmente $3 / 4$ desses "modelos ideais", podendo frustrar a implementação bem-sucedida desse tipo de política. O presente trabalho não tem a pretensão de avaliar a execução dos instrumentos econômicos de gestão ambiental, mas, sim, desvelar a dinâmica de direitos de propriedade por trás dos mesmos.

40 PERMAN, Roger et al. Natural resource and environmental economics. Harlow: Pearson Education, 2003. p. 218.

41 Em que, E* é o ponto de eficiência (Custo Marginal Social se iguala ao Custo Marginal Privado); P* e Q* são, respectivamente, o preço e o nível de produção com aplicação do imposto; Pm e Qm são, respectivamente, o preço e o nível de produção sem o imposto; BC é o imposto por unidade sobre a poluição. 
de $\operatorname{Pareto}^{42}$ (Em, Qm). Entretanto, na presença de uma externalidade negativa (CB) por unidade produzida, saímos do ponto ótimo, pois o custo marginal social se torna maior que o preço. Isso quer dizer que um dado produto não tem precificado o impacto negativo no meio ambiente decorrente do processo necessário para produzi-lo. O Estado, então, pode impor um tributo (por unidade produzida) igual ao valor da externalidade para corrigir a curva de custo marginal privado global. Dessa forma, os preços aos consumidores passariam a refletir o real custo de produção do produto (cobrindo os custos sociais). Como consequência, o novo equilíbrio poderia apresentar uma redução na quantidade produzida e comercializada do produto ${ }^{43}$. Com produção reduzida, a pressão sobre o meio ambiente seria menor e, na hipótese em que todos os demais mercados estão devidamente ajustados, o Ótimo de Pareto seria recuperado ${ }^{44}$.

Segundo Perman et al..$^{45}$, esse tipo de tributo constitui instrumento de política custo-eficiente o que, frente a ele, firmas que maximizam lucro reduzirão as emissões de poluição até o ponto em que o custo marginal de abatimento se iguale a taxa imposta - como todas as firmas agem dessa maneira, a redução das emissões é alcançada com o menor custo. Contudo, essa espécie de solução demanda da autoridade ambiental estatal um "profundo conhecimento da relação entre a emissão de poluente pelo setor e o valor pelo qual outros setores produtivos e/ou consumidores são afetados por tal emissão" ${ }^{46}$. Em outras palavras, demanda do regulador o conhecimento de informações sobre o nível de poluição socialmente desejado. Essa mensuração é complexa visto que a poluição pode ter efeitos cumulativos não previstos, impactando de forma negativa bens e serviços ambientais de utilidade futura.

Além da imposição de um tributo para internalização de externalidades negativas, também é possível aplicar um subsídio para a internalização de externalidades positivas (figura 2). Nesse caso, o governo subsidia uma determinada atividade, pagando por cada unidade consumida a diferença entre o benefício marginal social e o benefício marginal privado. Apesar desse subsídio poder ser considerado uma taxação negativa, conforme lembra Perman et al. ${ }^{47}$, a distribuição de ganhos e perdas ocorre de maneira diferente da do imposto. Neste ocorrem transferências líquidas de renda dos poluidores para o governo, enquanto os subsídios levam a transferências líquidas na outra direção.

42 O economista Vilfredo Pareto especificou como condição para a alocação ótima de recursos a situação segundo a qual é impossível que todos os indivíduos ganhem como consequência de uma troca posterior, que é conhecida como condição de eficiência de Pareto. Assim, um estado da economia é eficiente no sentido de Pareto quando não há nenhuma possibilidade de se melhorar a posição de, pelo menos, um dos agentes dessa economia sem que com isso a posição de um outro agente seja piorada. Também é chamada de alocação ótima dos recursos de Pareto, otimização de Pareto, máximo de Pareto e critério de Pareto. COSTA, Simone S. Thomazi. Introdução à economia do meio ambiente. Análise - Revista de Administração da PUCRS, Porto Alegre, v. 16, n. 2, p. 305, ago./dez. 2005.

43 A ocorrência de tal redução ou não dependerá da elasticidade da curva de demanda. No nosso exemplo, na figura 1, a curva de demanda é, negativamente, inclinada e o aumento do preço leva à redução da quantidade produzida. Caso a demanda fosse inelástica, por exemplo, o aumento do preço não provocaria alteração na quantidade disponível no mercado.

44 CÁNEPA, Eugenio Miguel. Economia da poluição. In: ECONOMIA do meio ambiente: teoria e prática. Rio de Janeiro: Elsevier, 2010. p. 79-98.

45 PERMAN, Roger et al. Natural resource and environmental economics. Harlow: Pearson Education, 2003. p. 219.

46 CÁNEPA, Eugenio Miguel. Economia da poluição. In: ECONOMIA do meio ambiente: teoria e prática. Rio de Janeiro: Elsevier, 2010. p. 79-98.

47 PERMAN, Roger et al. Natural resource and environmental economics. Harlow: Pearson Education, 2003. p. 219. 
Figura 2 - Subsídio fiscal: internalização de externalidade positiva em mercado competitivo ${ }^{48}$

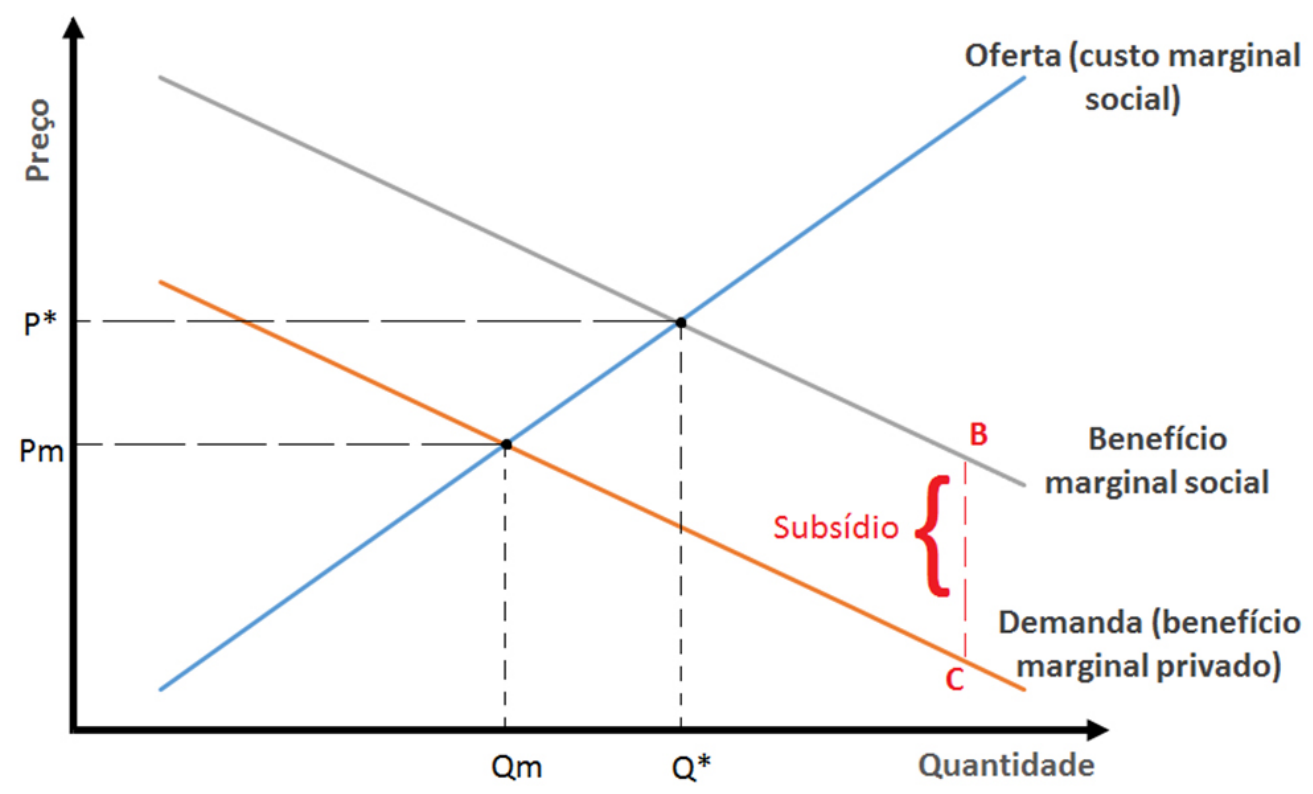

\subsubsection{Aspectos Jurídicos}

Para simplificar nossa análise, consideramos uma situação hipotética na qual um governo central impõe um tributo (por unidade de poluição) em fábricas que emitem dióxido de enxofre (SO2) na atmosfera, um bem ambiental de uso comum. Nessa situação, há que se examinar como os direitos de propriedade foram atribuídos e resguardados.

A partir do referencial analítico de Calabresi e Melamed $^{49}$, podemos considerar que a instituição desse tributo gera o mesmo efeito de um direito a uma atmosfera não poluída protegido por uma regra de responsabilidade. $\mathrm{O}$ imposto representa uma tentativa de realinhar o interesse privado ao social, transferindo para o mercado a decisão sobre a desejabilidade do produto $^{50}$. Nesse caso, as fábricas podem optar por não poluir (produzindo menos) em razão dos efeitos do aumento dos custos no preço e na demanda. A racionalidade não reside em um “direito a poluir", vedado pelo ordenamento jurídico brasileiro, mas em utilizar um instrumento econômico para viabilizar uma política pública de inibir a poluição. O pagamento do tributo, contudo, não reverte aos cidadãos individualmente considerados, mas ao Estado na qualidade de gestor do bem de uso comum.

A imperfeição de um modelo de tributação reside na potencial assimetria de informação. O regulador, dificilmente, consegue determinar com precisão o valor da cobrança necessária para que o nível de poluição atinja o ótimo social. Para diminuir esse desequilíbrio, os recursos arrecadados devem ser aplicados em tecnologias limpas e em programas de melhoria da qualidade ambiental, de forma a reverter como benefício para a sociedade.

48 Em que, E* é o ponto de eficiência (Benefício Marginal Social se iguala ao Custo Marginal Social); P* e Q* são, respectivamente, o preço e o nível de produção com aplicação do subsídio; Pm e Qm são, respectivamente, o preço e o nível de produção sem o subsídio; BC é o subsídio por unidade produzida.

49 CALABRESI, Guido; MELAMED, A. Douglas. Property rules, liability rules, and inalienability: one view of the cathedral. Harvard Law Review, Cambridge, MA, p. 1089-1128, 1972.

50 O imposto possibilita a sociedade leve em consideração os custos sociais daquela produção por meio dos efeitos de substituição e de renda decorrentes do aumento do preço. 
À luz do direito tributário, esse tipo de tributo tem natureza extrafiscal ${ }^{51}$. A arrecadação de recursos para o poder público não constitui sua finalidade primordial. Ela é decorrência do objetivo maior de inibir ou incentivar a prática de determinados comportamentos, com o objetivo de promover valores constitucionalmente consagrados, tal como a proteção ambiental. ${ }^{52}$

Voltando a análise para o feixe de direitos estabelecido por Ostrom $^{53}$, é possível considerar que o direito atribuído à sociedade, nesse caso, é somente um direito operacional de acesso a uma atmosfera limpa, sendo os direitos de escolha coletiva - especialmente o de alienação $3 / 4$ geridos pela autoridade central. Nessa perspectiva, pode ser que o Estado, por razões paternalistas, esteja melhor capacitado para determinar se o ganho total dos beneficiados é maior que a perda daqueles que foram desfavorecidos ${ }^{54}$.

\subsubsection{Um exemplo: O ICMS Ecológico}

Na legislação, da maioria dos estados da federação, sobre repartição do Imposto sobre Operações Relativas à Circulação de Mercadorias e sobre Prestação de Serviços de Transporte Interestadual e Intermunicipal e de Comunicação (ICMS) aos municípios, a expressão ICMS Ecológico é utilizada para denominar normas destinadas a compensar e estimular a conservação e o uso sustentável dos recursos ambientais. Contudo, não há um modelo único de implementação do ICMS Ecológico. Cada estado determina, de maneira particular, os requisitos da distribuição e a alíquota dos recursos arrecadados do ICMS que serão destinados para esse fim.

O artigo 158 (inciso IV) da Constituição Federal determina que 25\% do total arrecadado com ICMS nos estados seja repartido entre os respectivos municípios, da seguinte forma: i) três quartos (75\%), no mínimo, na proporção do valor adicionado nas operações relativas à circulação de mercadorias e nas prestações de serviços realizadas em seus territórios; ii) até um quarto (25\%), de acordo com o que dispuser lei estadual. Essa oportunidade legal possibilitou a adoção de critérios ambientais na distribuição destes $25 \%$

Assim, podemos interpretar o ICMS ecológico como um subsídio pigouviano, dado que ele proporciona uma contrapartida financeira pelo fornecimento de externalidades positivas tais como os serviços ecossistêmicos proporcionados pela afetação do território municipal, por exemplo, com unidades de conservação. O recebimento dos recursos varia, por município, de acordo com a redução do desmatamento, a porcentagem da área ocupada por unidades de conservação, terras indígenas e quilombolas, os índices de qualidade do meio ambiente, o controle e combate de queimadas, a conservação de solos, entre outros critérios que, repita-se, variam entre os estados. Dessa forma, proporcionando ganhos econômicos, o ICMS ecológico incentiva políticas públicas de conservação e preservação do meio ambiente.

Em 1991, o Paraná foi o primeiro estado brasileiro a adotar tais instrumentos normativos em resposta às demandas das autoridades municipais prejudicadas com as restrições ao crescimento econômico em decorrência da proteção ambiental. Em seguida vieram os estados de São Paulo (1993) e Minas Gerais (1995). Atualmente, 17 dos 26 Estados brasileiros já adotam o mecanismo ${ }^{55}$.

51 Ver: RIBEIRO, Ricardo. A extrafiscalidade ambiental no ICMS. In: CARLI, Ana Alice De; COSTA, Leonardo De; RIBEIRO, Ricardo Lodi (Org.). Tributação e sustentabilidade ambiental. Rio de Janeiro: FGV, 2015, p. 45-62; OLIVEIRA, Gustavo. A extrafiscalidade ambiental e a alíquota mínima do ISS. In: CARLI, Ana Alice De; COSTA, Leonardo De Andrade; RIBEIRO, Ricardo Lodi (Org.). Tributação e sustentabilidade ambiental. Rio de Janeiro: FGV, 2015, p. 217-222.

52 LUKIC, Melina Rocha. Instrumentos tributários para a sustentabilidade: uma análise comparativa da destinação do ICMS pelos estados segundo critérios ambientais. In: CARLI, Ana Alice De; COSTA, Leonardo De Andrade; RIBEIRO, Ricardo Lodi (Org.). Tributação e sustentabilidade ambiental. Rio de Janeiro: FGV, 2015. p. 177-198.

53 OSTROM, Elinor. Private and common property rights. In: BOUCKAERT, B.; GEEST G. De (Ed.). Encyclopedia of Law and Economics. Cheltenham: Edward Elgar Publishing, 2000. p. 332-379.

54 CALABRESI, Guido; MELAMED, A. Douglas. Property rules, liability rules, and inalienability: one view of the cathedral. Harvard Law Review, Cambridge, MA, p. 1094, 1972.

55 ICMS ECOLOGICO. [Homepage]. Disponível em: <http://www.icmsecologico.org.br/site/>. 
O funcionamento do ICMS Ecológico no Paraná se baseia em dois critérios: áreas protegidas e mananciais de abastecimento, possuindo cada um 2,5\%, inteirando os 5\% do ICMS arrecadado que é distribuído conforme o critério ecológico presente na lei. Por um lado, visando à conservação de biodiversidade, as áreas protegidas ${ }^{56}$ abrangem, além das Unidades de Conservação da Natureza, públicas e privadas, previstas no Sistema Nacional de Unidades de Conservação - SNUC, as Terras Indígenas, as Reservas Legais, Áreas de Preservação Permanente e Faxinais. Por outro, devem ser beneficiados pelo critério de mananciais de abastecimento os municípios que abrigarem em seus territórios parte ou o todo de mananciais de abastecimento para municípios vizinhos. Ademais, a composição do ICMS ecológico paranaense se baseia em duas dimensões, uma quantitativa e outra qualitativa:

A quantitativa leva em conta a superfície da área protegida na relação com a superfície total do município onde estiver contida. Esta relação é corrigida por um multiplicador que caracteriza o nível de restrição de uso da área protegida notadamente a categoria de manejo de Unidade de Conservação. A qualitativa considera, além de aspectos relacionados à existência de espécies da flora e fauna, insumos necessários disponibilizados à área protegida, visando a manutenção e melhoria do seu processo de gestão ${ }^{57}$.

Dessa maneira, quanto melhor for a qualidade da gestão das áreas protegidas, maior será a participação do município no ICMS Ecológico. Os índices percentuais definidos para cada município são calculados a partir da aplicação de fórmula que visa mensurar o Coeficiente de Conservação da Biodiversidade - CCB $^{58}$.

Entre 1997 e 2008, as áreas de preservação do Paraná registraram um crescimento superior a 10\% ${ }^{59}$. Adicionalmente, o ICMS Ecológico paranaense contempla anualmente 50 mananciais responsáveis pelo abastecimento de aproximadamente $55 \%$ da população urbana do estado. No total, são beneficiados 80 municípios situados nas áreas de mananciais, que juntos recebem mais de $\mathrm{R} \$ 70.000 .000,00$ (setenta milhões de reais ${ }^{60}$. Logo, esse instrumento se mostrou capaz de influenciar políticas públicas municipais de ampliação das áreas de unidades de conservação, de forma a incrementar a participação na distribuição de recursos. $\mathrm{O}$ instrumento provou que a instituição de critérios de desempenho ambiental na alocação orçamentária de impostos já existentes pode aumentar a eficácia de políticas de conservação sem aumentar a carga fiscal ${ }^{61}$.

Por fim, é importante ressaltar o papel fundamental do Direito na definição de regras claras para a distribuição do ICMS Ecológico. Logo, considerando-se o papel do Direito nas políticas públicas, conforme apontado por Coutinho ${ }^{62}$, podemos considerar que o ICMS Ecológico, buscando concretizar um direito previsto no capítulo VI da Constituição Federal (direito como objetivo) e aproveitando uma possibilidade de alocação existente na legislação (direito como arranjo institucional), estabelece a forma com que os recursos disponíveis serão distribuídos a partir de uma determinada distinção e valoração das iniciativas

56 Em relação às áreas particulares, o Paraná mais uma vez foi pioneiro ao criar um arranjo legal institucional que faz com que os recursos recebidos pelo município em virtude da existência de Reservas Particulares do Patrimônio Natural - RPPNs, em seu território, chegue, em parte, aos proprietários dessas Unidades de Conservação.

57 LOUREIRO, Wilson; MARTINEZ, Alexandre. ICMS Ecológico como instrumento de apoio às RPPN do Paraná. In: CASTRO, R.; BORGES, M. (Org.). RPPN: conservação em terras privadas, desafios para a sustentabilidade. Planaltina do Paraná: Edições CNRPPN, 2004. p. 8.

58 Para mais detalhes, consultar: LOUREIRO, Wilson. Contribuição do ICMS Ecológico a Conservação da Biodiversidade no Estado do Paraná. 2002. 189 f. Dissertação (Mestrado) - Programa de Pós-Graduação em Engenharia Florestal, Universidade Federal do Paraná, Curitiba, 2002.

59 ROSSI, Aldimar; MARTINEZ, Antonio Lopo; NOSSA, Valcemiro. ICMS Ecológico sob o enfoque da tributação verde como meio da sustentabilidade econômica e ecológica: experiência do Paraná. Revista de Gestão Social e Ambiental, São Paulo, v. 5, n. 3, p. 90-101, 2011.

60 Maior portal eletrônico brasileiro sobre ICMS Ecológico. Disponível em: < http://www.icmsecologico.org.br/site/>.

61 YOUNG, Carlos Eduardo; BAKKER, Leonardo. Instrumentos econômicos e pagamentos por serviços ambientais no Brasil: incentivos Econômicos para Serviços Ecossistêmicos no Brasil. Rio de Janeiro: Forest Trends, 2015. p. 33-56.

62 Esses papéis consistem em apontar fins e situar as políticas no ordenamento (direito como objetivo), criar condições de participação (direito como vocalizador de demandas), oferecer meios (direito como ferramenta) e estruturar arranjos complexos que tornem eficazes essas políticas (direito como arranjo institucional) COUTINHO, Diogo. O Direito nas Políticas Públicas. In: MARQUES, Eduardo; FARIA, Carlos Aurélio Pimenta de (Org.). Política Pública como Campo Disciplinar. Rio de Janeiro: Fiocruz; São Paulo: Unesp, 2013. p. 181-200. 
municipais de preservação ambiental (direito como ferramenta).

\subsection{Sistemas de Certificados Negociáveis}

\subsubsection{O instrumento}

A ideia dos certificados negociáveis de poluição é atribuída ao economista canadense John Dales que, na década de 1960, postulou a propriedade estatal do bem ambiental como base e, a partir daí, utilizou, amplamente, os mecanismos de mercado objetivando reduzir os custos econômicos de controle da poluição. Por meio desse instrumento, o Estado estabelece um limite para a quantidade total de poluição permitida. Ou seja, não pode haver acréscimo de emissões sem que ocorra decréscimo equivalente no sistema. $\mathrm{O}$ limite precisa ser compatível com a qualidade ambiental desejada. E é justamente por isso, também, que um sistema de certificados negociáveis não constitui "direito a poluir", repita-se, vedado pelo ordenamento jurídico brasileiro. Ao contrário, constitui-se como instrumento para viabilização do limite de impacto determinado em regulamento a um menor custo do que um sistema de responsabilidade pura (comando e controle).

A partir dessa definição regulamentar de limite de impacto ambiental, o poder público emite a quantidade correspondente de Certificados Negociáveis de Impacto e os leiloa (ou distribui) entre os empreendimentos do setor regulado ${ }^{63}$. Conforme Perman et al. ${ }^{64}$, a implantação de um sistema de certificados negociáveis (marketable emission permits scheme) envolve também:

Uma lei que estabeleça que nenhuma empresa está autorizada a emitir mais substância (do tipo designado) do que o permitido pelos certificados que possui;

Um sistema que possibilite o monitoramento das emissões reais e a aplicação de sanções $3 / 4$ com poder de dissuasão $3 / 4$ aos empreendimentos que excedem os limites permitidos;

Uma escolha (a cargo da autoridade central) sobre a forma como a quantidade total de certificados será inicialmente alocada entre os empreendimentos regulados;

Uma garantia de que os certificados poderão ser livremente negociados entre as firmas conforme o preço acordado na negociação entre as partes interessadas.

Diferentemente da tributação, nos sistemas de certificados negociáveis, o ajuste se dá em termos de quantidades em vez de preços, de maneira semelhante aos instrumentos de comando e controle que instauram quotas. Mas os certificados negociáveis podem ser mecanismos mais atrativos por possuírem a qualidade de serem transferíveis. Tal qualidade insere um custo de oportunidade na decisão de impactar o meio ambiente, nas palavras de Perman et al., "the firm incurs a cost in emitting each unit of the pollutant, that cost being the current market permit price" ${ }^{65}$.

O mercado para os certificados negociáveis se estabelece porque as firmas os valoram de forma diferente em decorrência da existência de distintos custos marginais de abatimento de emissões. Firmas com altos custos de abatimento estarão dispostas a pagar altos preços na compra de certificados, enquanto que aquelas com baixo custo de abatimento se disporiam a pagar menos. Assim, as firmas podem considerar preferível vender seus certificados (no lugar de comprá-los) se o preço de venda exceder o seu custo marginal de abatimento e vice-versa.

63 CÁNEPA, Eugenio Miguel. Economia da poluição. In: ECONOMIA do meio ambiente: teoria e prática. Rio de Janeiro: Elsevier, 2010. p. 79-98.

64 PERMAN, Roger et al. Natural resource and environmental economics. Harlow: Pearson Education, 2003. p. 223.

65 PERMAN, Roger et al. Natural resource and environmental economics. Harlow: Pearson Education, 2003. p. 223. Em tradução livre: "a firma incorre em um custo ao emitir cada unidade de poluente, sendo esse custo o corrente preço de mercado do certificado". 
Referentemente ao funcionamento do mercado, no equilíbrio, os custos marginais de abatimento das firmas se igualarão e a meta de poluição, como no caso da tributação, será alcançada ao menor custo. Segundo Perman et al.$^{66}$, um sistema de certificados negociáveis deveria ser, de alguma forma, equivalente a um sistema de impostos ou subsídios, desde que o preço dos certificados seja igual à taxa (negativa ou positiva) implementada.

Uma questão que costuma ser controversa nesse tipo de instrumento econômico de gestão ambiental é a forma inicial de alocação dos certificados negociáveis de poluição. Eles podem ser leiloados, quando ocorre, inicialmente, a transferência de recursos das firmas para o governo, ou, alternativamente, distribuídos por meio de algum critério arbitrário imposto pela autoridade ambiental, como o nível de produção, atual e histórico, por exemplo. Nesse caso, as transferências de recursos se darão, somente, entre as firmas. Em um mercado perfeitamente competitivo e sem custos de transação, o método de alocação inicial não interfere na distribuição de emissões entre as firmas no curto prazo $^{67}$, mas pode provocar efeitos significativos na distribuição de renda e riqueza entre as firmas no longo prazo $^{68}$, podendo gerar barreiras à entrada e maior concentração industrial, uma vez que a capacidade de adaptação das firmas não é homogênea.

\subsubsection{Aspectos Jurídicos}

Para simplificar, de maneira semelhante à análise dos aspectos jurídicos da tributação como instrumento de gestão ambiental, aqui também consideramos uma situação hipotética em que um governo cria um sistema de certificados de impacto ambiental negociáveis para controlar as emissões de dióxido de enxofre na atmosfera. Sem especificar o critério de alocação, estabelece-se que os certificados são distribuídos sem custos para as fábricas.

A partir da perspectiva proposta por Calabresi e Melamed ${ }^{69}$, podemos supor que dois direitos foram criados em relação ao meio ambiente. De um lado, é atribuído à sociedade um direito inalienável a uma atmosfera limpa (o nível ótimo de impacto deve ser estabelecido pela autoridade ambiental, ainda que tal determinação seja complexa). O nível de emissões não pode ultrapassar o limite estabelecido pelos certificados.

De outro lado, por meio dos certificados negociáveis, são atribuídos às fábricas direitos de impacto protegidos por uma regra de propriedade, ou seja, que podem ser transacionados, livremente, no mercado, sendo o preço resultado da barganha entre comprador e vendedor (que, conforme vimos, leva em consideração, principalmente, os custos marginais de abatimento da poluição).

Com base no feixe de direitos estabelecidos por Ostrom $^{70}$, novamente tomamos o direito atribuído à sociedade como um direito operacional de acesso a uma atmosfera limpa. À autoridade central, por sua vez, pertencem os direitos de administração e exclusão, uma vez que ela decide o nível de poluição e quem pode impactar a atmosfera ao emitir um número limitado de certificados e ao distribuí-los entre as firmas. O direito de alienação possuído pelas fábricas abrange, somente, a possibilidade de transacionar um direito de exploração, nesse caso, o direito de impactar a atmosfera dentro dos limites regulamentares.

66 PERMAN, Roger et al. Natural resource and environmental economics. Harlow: Pearson Education, 2003. p. 224.

67 Tal assunção considera que, no cenário de leilão, todos certificados são vendidos ao mesmo preço. O equilíbrio nos dois cenários dependerá do nível de poluição desejado (ou da quantidade de certificados emitidos) e dos custos de abatimento de poluição das firmas (que no agregado também é o mesmo nas duas situações). Firmas com custos de abatimento de poluição muito baixos irão abater mais, enquanto que aquelas com altos custos irão poluir mais (adquirindo mais certificados por leilão ou por negociação). Para um exemplo numérico mais detalhado, ver: PERMAN, Roger et al. Natural resource and environmental economics. Harlow: Pearson Education, 2003. p. 224-227.

68 PERMAN, Roger et al. Natural resource and environmental economics. Harlow: Pearson Education, 2003. p. 227.

69 CALABRESI, Guido; MELAMED, A. Douglas. Property rules, liability rules, and inalienability: one view of the cathedral. Harvard Law Review, Cambridge, MA, p. 1089-1128, 1972.

70 OSTROM, Elinor. Private and common property rights. In: BOUCKAERT, B.; GEEST G. De (Ed.). Encyclopedia of Law and Economics. Cheltenham: Edward Elgar Publishing, 2000. p. 332-379. 


\subsubsection{Um exemplo: as Cotas de Reserva Ambiental no Novo Código Florestal}

O antigo Código Florestal Brasileiro (CFB), instituído pela Lei Federal n 4.771/1965, determinava que cada propriedade de terra rural mantivesse parte de sua área total com vegetação nativa, denominada “Área de Reserva Legal” (“ARL”), fixando as áreas a serem protegidas de acordo com as regiões. Essa obrigação foi mantida pela atual lei florestal (Lei 12.651/12) ${ }^{71}$. Apesar da importância das ARL (e Áreas de Preservação Permanente $3 / 4$ "APP") ${ }^{72}$ para a proteção e restauração de processos ecológicos essenciais, em virtude da falta de tecnologia ou insumos para a restauração, dos custos de oportunidade e da ausência de aplicação rigorosa do antigo Código Florestal, muitos proprietários de terra optavam por descumprir a lei e acumular passivos ou multas ${ }^{73}$.

A nova lei florestal anistiou a multa por desmatamentos ilegais realizados antes de 22 de julho de 2008, mas exigiu que as propriedades superiores a quatro módulos fiscais ${ }^{74}$ regularizassem sua situação no futuro ${ }^{75}$. Para tanto, foram criados mecanismos de flexibilização que possibilitaram aos proprietários rurais "compensar" eventuais deficits de ARL em uma propriedade com excedentes de ARL de outras propriedades. O artigo 44 da Lei 12.651/12 instituiu a Cota de Reserva Ambiental ("CRA") que visa permitir "que proprietários de terras dentro do mesmo bioma negociem reservas excedentes entre si" " Cada CRA corresponde a um título nominativo e representativo de 1 hectare de área de vegetação nativa. Como lembra Packer ${ }^{77}$, títulos representativos, segundo lição clássica do Direito Empresarial, não expressariam uma operação de crédito, mas representam mercadorias ou bens que fundamentam sua existência. Para que fosse possível o estabelecimento desse sistema, a nova legislação criou o Cadastro Ambiental Rural (CAR):

que exige que todos os proprietários ou "posseiros" de propriedades rurais registrem suas terras no órgão ambiental estadual, delineando a RL e a APP georreferenciadas em imagens de satélite (...) para servir de base para o monitoramento do cumprimento.(...) Embora o CAR seja obrigatório para todos os tipos de propriedade, a emissão de CRA é aberta apenas aos proprietários de terras tituladas. ${ }^{78}$

Após 22 de julho de 2008, no entanto, todos os proprietários que suprimiram vegetação nativa acima dos limites legais permitidos deverão retornar para a legalidade pela restauração dessas áreas, sem possibilidade de comprar CRA, ou seja, "as CRA são apenas um instrumento para auxiliar o cumprimento de deficits históricos (e não de futuros) "’79.

\footnotetext{
71 Atualmente, o percentual da propriedade que deve ser registrado como Reserva Legal é: 80\% em propriedades rurais localizadas em área de floresta na Amazônia Legal; 35\% em propriedades situadas em áreas de Cerrado na Amazônia Legal; e 20\% em propriedades situadas em outras formas de vegetação nas demais regiões do país.

72 Áreas de Preservação Permanente (APPs) são definidas como áreas cobertas ou não por vegetação, situadas, por exemplo, ao longo de cursos d'água, ao redor de nascentes, encostas íngremes e áreas em altitude superior a mil e oitocentos metros. SILVA, Jessica; RANIERI, Victor. O mecanismo de compensação de reserva legal e suas implicações econômicas e ambientais. Ambiente \& Sociedade, São Paulo, v. 17, n. 1, p. 115-132, 2014.

73 MAY, Peter H. et al. Cotas de reserva ambiental no novo código florestal brasileiro: Uma avaliação ex-ante. Publicação Ocasional 146. Bogor, Indonesia: CIFOR, 2015.

74 O módulo fiscal é definido pela área de terra conceitualmente necessária para suprir as necessidades básicas de uma família rural. Tal dimensão é estabelecida pelos estados.

75 No total, a nova legislação florestal reduziu a área estimada com déficit de RL em 58\%, de $50 \pm 6$ a $21 \pm 0,6 \mathrm{Mha}$ MAY, Peter H. et al. Cotas de reserva ambiental no novo código florestal brasileiro: Uma avaliação ex-ante. Publicação Ocasional 146. Bogor, Indonesia: CIFOR, 2015. p. 2.

76 MAY, Peter H. et al. Cotas de reserva ambiental no novo código florestal brasileiro: Uma avaliação ex-ante. Publicação Ocasional 146. Bogor, Indonesia: CIFOR, 2015. p. 3.

77 PACKER, Larissa A. Novo Código Florestal e Pagamentos por Serviços Ambientais: Regime proprietário sobre os Bens Comuns. Curitiba: Juruá, 2015. p. 189.

78 MAY, Peter H. et al. Cotas de reserva ambiental no novo código florestal brasileiro: Uma avaliação ex-ante. Publicação Ocasional 146. Bogor, Indonesia: CIFOR, 2015. p. 2.

79 MAY, Peter H. et al. Cotas de reserva ambiental no novo código florestal brasileiro: Uma avaliação ex-ante. Publicação Ocasional 146. Bogor, Indonesia: CIFOR, 2015. p. 3.
} 
O instrumento de Cotas de Reserva Ambiental instituído pela nova lei florestal não funcionaria, exatamente, como um Sistema de Certificados Negociáveis de Impacto Ambiental, uma vez que o que é transacionado não é o direito de impactar, mas a obrigação de preservar. Similarmente, o poder público determina um nível ótimo de vegetação nativa, distribui as obrigações de ARL entre os proprietários dos diferentes biomas e permite que proprietários com carência de ARL comprem daqueles com excesso. O preço das cotas não será resultado das diferenças nos custos marginais de abatimento, mas dos diferentes custos de oportunidade da terra. Isso possibilitará a regularização dos deficits com menores custos, promovendo ganhos de eficiência econômica.

Ainda existem inúmeras incertezas sobre os procedimentos de registro para títulos de CRA, alguns estados aprovaram legislação complementar para realização das negociações, mas a velocidade de implementação do CAR é bastante desigual entre os entes federativos. A estrutura institucional precisará estabelecer um sistema confiável de monitoramento e aplicação da lei com baixos custos de transação para o estabelecimento de um mercado efetivo de CRA. Ademais, a possibilidade de compensação de reservas legais em outras regiões, ainda que no mesmo bioma, é contestada por muitos ambientalistas que veem a vegetação nativa como parte essencial de ecossistemas locais, contribuindo na reciclagem de nutrientes e na regulação do microclima, por exemplo. Somente a partir de desenvolvimentos futuros será possível avaliar a efetividade ecológica e eficiência econômica das CRA.

De volta ao papel do Direito na política pública tratado por Coutinho ${ }^{80}$, apesar do estabelecimento de um instrumento (direito como ferramenta) que facilita o cumprimento das obrigações instituídas pela lei florestal, cujo propósito é a promoção do desenvolvimento sustentável (direito como objetivo), ainda é necessário avançar nas normas jurídicas que estruturam seu funcionamento, regulam seus procedimentos e se encarregam de viabilizar a articulação entre atores direta e indiretamente ligados a tal política (direito como arranjo institucional).

\subsection{Pagamentos por Serviços Ambientais}

\subsubsection{O instrumento}

O economista Sven Wunder ${ }^{81}$ define o pagamento por serviço ambiental (PSA), a partir de cinco elementos, como uma transação voluntária (1), na qual, um serviço ambiental bem definido ou um uso da terra que possa assegurar este serviço (2) é comprado por, pelo menos, um comprador (3) de, pelo menos, um provedor (4), sob a condição de que o provedor garanta a provisão deste serviço (5).

Tal instrumento econômico de gestão ambiental, assim como os certificados negociáveis de impacto, tem sua origem no trabalho seminal de Ronald Coase ${ }^{82}$ que estabelece que, em uma situação de baixos custos de transação $0^{83}$ e direitos de propriedade bem definidos, a livre negociação entre indivíduos pode corrigir os problemas de externalidade, levando a resultados eficientes.

Os pagamentos por serviços ambientais são desdobramentos de externalidades positivas, nesse caso, as negociações alcançam um resultado eficiente (ou atingem o ponto de equilíbrio) quando a disposição a

80 COUTINHO, Diogo. O Direito nas Políticas Públicas. In: MARQUES, Eduardo; FARIA, Carlos Aurélio Pimenta de (Org.). Política Pública como Campo Disciplinar. Rio de Janeiro: Fiocruz; São Paulo: Unesp, 2013. p. 181-200.

81 WUNDER, Sven. Necessary conditions for ecosystem service payments. Paper apresentado na Economics and Conservation in the Tropics: A Strategic Dialogue conference, Moore Foundation/ CSF/ RFF, São Francisco, 31 Janeiro - 1 Fevereiro, 2008.

82 COASE, Ronald. The Problem of Social Cost. Journal of Law and Economics, Chicago, IL, v. 3, n. 1, p. 1-44, 1960.

83 No mundo real, os custos de transação são positivos, consequentemente, torna-se mais difícil o alcance de resultados eficientes pela livre negociação. Assim, a forma como o sistema jurídico lida com essa realidade interfere diretamente na segurança dos contratos e nos riscos associados às negociações. As garantias fornecidas pelas instituições formais impactam, então, de forma significativa nas atividades econômicas. 
pagar do comprador (beneficiário da externalidade) se iguala à disposição a fornecer do provedor que leva em consideração os custos de oportunidade perdidos com o provimento da externalidade ambiental. Em algumas situações, os lucros de usos alternativos da terra (exploração agropecuária em vez de preservação florestal, por exemplo) podem ser muito altos para competir com a conservação; em outras, os custos de transação podem ser demasiado elevados para viabilização de PSAs ${ }^{84}$.

Apesar da existência, no "mundo real", de esquemas de PSAs "puros", com os cinco elementos apontados por Wunder ${ }^{85}$, na prática, existe um número muito maior de esquemas "tipo - PSA". São similares porque satisfazem a maioria, mas não todos os critérios pontuados. Contudo, em todos eles, a autoridade central (e o Direito) tem um papel crucial na garantia da segurança jurídica das transações, atuando na definição de direitos de propriedade e na imposição de sanções aos que não cumprem os contratos ${ }^{86}$. Adicionalmente, em alguns casos, o Estado pode atuar como demandante, fornecendo a principal fonte de recursos para o mecanismo.

Isso porque, em decorrência da característica de bens públicos dos serviços ambientais, a disposição de pagamento tende a ser baixa, estando a formação da demanda intimamente associada tanto ao grau de exclusividade e rivalidade quanto à utilização do serviço ambiental. Além dos recursos governamentais, esquemas de PSA, também, são financiados por usuários e interesses voluntários. Ademais, muitas vezes o Estado, também, precisa atuar ao lado da oferta, criando políticas/programas ou legislação específica para capacitar potenciais ofertantes a se tornarem provedores efetivos ${ }^{87}$.

Um ponto importante nos esquemas de PSA é a definição do preço a ser pago pelo serviço ambiental fornecido. Dado a inexistência de preços de mercado, os métodos de valoração ${ }^{88}$ econômica dos serviços ambientais - ainda que não sejam estritamente necessários 3/4 podem ser bastante úteis para mostrar aos compradores uma estimativa dos benefícios econômicos relacionados ao provimento de cada serviço ambiental.

\subsubsection{Aspectos Jurídicos}

Para análise dos aspectos jurídicos dos PSAs, partimos de um exemplo hipotético e simplificado de uma fábrica que emite dióxido de enxofre, prejudicando a pequena comunidade em seu entorno. Como se trata de um poluidor e um grupo pequeno de prejudicados, vamos admitir baixos custos de transação.

Por meio de um esquema de PSA, a comunidade ao entorno da fábrica poderia adquirir emissões menos nocivas da fábrica (possibilitadas por uma mudança tecnológica, por exemplo). Diferentemente das situações de imposto pigouviano em que se observa o princípio do poluidor - pagador, nos esquemas de PSA,

84 WUNDER, Sven. Necessary conditions for ecosystem service payments. Paper apresentado na Economics and Conservation in the Tropics: A Strategic Dialogue conference, Moore Foundation/ CSF/ RFF, São Francisco, jan./fev. 2008. Disponível em: < http://www.rff.org/ files/sharepoint/Documents/08_Tropics_Conference/Tropics_Conference_Papers/Tropics_Conference_Wunder_PES_markets.pdf>. Acesso em: 15 fev. 2017.

85 WUNDER, Sven. Necessary conditions for ecosystem service payments. Paper apresentado na Economics and Conservation in the Tropics: A Strategic Dialogue conference, Moore Foundation/ CSF/ RFF, São Francisco, jan./fev. 2008. Disponível em: <http://www.rff.org/ files/sharepoint/Documents/08_Tropics_Conference/Tropics_Conference_Papers/Tropics_Conference_Wunder_PES_markets.pdf>. Acesso em: 15 fev. 2017

86 No entanto, a efetividade do sistema vai depender da disposição e capacidade do sistema jurídico em assumir os custos de transação do cumprimento do contrato de PSA. WUNDER, Sven. Necessary conditions for ecosystem service payments. Paper apresentado na Economics and Conservation in the Tropics: A Strategic Dialogue conference, Moore Foundation/ CSF/ RFF, São Francisco, jan./fev. 2008. Disponível em: <http://www.rff.org/files/sharepoint/Documents/08_Tropics_Conference/Tropics_Conference_Papers/Tropics_Conference_Wunder_PES_markets.pdf >. Acesso em: 15 fev. 2017.

87 SEEHUSEN, Susan; PREM, Ingrid. Porque pagamentos por serviços ambientais? In: GUEDES, Fátima Becker; SEEHUSEN, Susan Edda (Org.). Pagamentos por Serviços Ambientais na Mata Atlântica: lições aprendidas e desafios. Brasília: MMA, 2011. p. 15-54.

88 Para mais detalhes ver: MOTTA, Ronaldo Seroa da. Manual para valoração econômica de recursos ambientais. Local: IPEA/MMA/ PNUD/CNPq, 1997. 
de modo geral, temos contextos em que se faz presente o princípio do usuário/ beneficiário - pagador ${ }^{89}$, ou, de outra forma, o princípio do protetor - recebedor.

Nesse caso, à luz da estrutura analítica de Calabresi e Melamed $^{90}$, podemos interpretar um esquema de PSA como uma situação em que o direito de impactar é atribuído à fábrica, estando esse direito protegido por uma regra de propriedade, ou seja, se a comunidade prejudicada (demandante) desejar interromper a atividade nociva, terá que pagar ao poluidor (réu) dinheiro suficiente para persuadi-lo a desistir do direito.

Quando os indivíduos afetados entram em consenso e decidem pagar para a fábrica diminuir ou eliminar a emissão de SO2, a partir do feixe de direitos estabelecidos por Ostrom ${ }^{91}$, podemos considerar que o que está sendo negociado não é apenas um direito de acesso a uma atmosfera limpa, mas também um direito de administração de regular a tecnologia e os padrões de uso da fábrica. Isso se, no contrato de PSA estabelecido, o provimento de uma atmosfera limpa estiver condicionado à utilização de uma tecnologia específica. $\mathrm{Na}$ realidade, geralmente, os PSAs estão associados a um padrão de uso alternativo dos recursos naturais (ainda que em determinadas situações possam existir flexibilidades). No nordeste da França, por exemplo, a empresa engarrafadora de água Vittel (Nestlé Waters) pagou produtores rurais para que adotem técnicas agropecuárias mais sustentáveis, visando diminuir os níveis de nitrogênio na água ${ }^{92}$.

\subsubsection{Um exemplo: o Projeto Oásis em São Paulo}

O Projeto Oásis é uma iniciativa da Fundação Grupo Boticário de Proteção à Natureza (FGBPN) que tem o propósito de estimular a criação de leis municipais e estaduais de PSA, visando à conservação das áreas naturais e sua biodiversidade, à produção de água e ao incremento de renda dos proprietários de terra envolvidos.

A Fundação desenvolveu uma metodologia de PSA específica (um modelo flexível capaz de atender realidades heterógenas) e estabelece parcerias regionais para a sua implantação em diferentes municípios brasileiros. Seu papel é orientar e acompanhar o processo de implantação e desenvolvimento, dando suporte no estabelecimento de áreas prioritárias, elaboração de marco legal, valoração ambiental e articulação institucional.

A experiência pioneira do Projeto Oásis teve início em 2006 na região metropolitana de São Paulo. Por meio de recursos da Fundação Mitsubishi e do apoio da FGBPN, da prefeitura e do governo de São Paulo, proprietários de terras que mantêm remanescentes de Mata Atlântica protegidos são premiados financeiramente, contribuindo para a conservação de mananciais da região da Bacia do Guarapiranga, fundamental para o abastecimento da cidade de São Paulo e de milhões de seus habitantes.

Por meio de acordos privados, cada proprietário recebe, por ano, entre $\mathrm{R} \$ 75,00$ e $\mathrm{R} \$ 370,00$ por hectare de área natural conservada. A valoração se dá pelo custo de reposição, conforme a conservação das áreas e o Índice de Valoração de Mananciais (IVM). São utilizados três critérios: a) Produção e armazenamento de água - R\$ 99/ha/ano; b) Controle de erosão - R\$ 75/ha/ano; e c) Manutenção da qualidade da água R\$ 196/ha/ano - valor máximo R\$370,00/ha/ano. Nos primeiros 5 anos de implementação do projeto,

89 Milaré, embora reconhecendo proximidades e até certa complementaridade entre os dois princípios, entende-os diferentes, pois enquanto o primeiro impõe ao poluidor o dever de prevenir e reparar por eventuais danos, o segundo, dá azo à cobrança pela utilização de recursos ambientais, não em caráter punitivo, mas sim, pelo valor que o recurso natural representa de per si ou, ainda, em razão de sua função ecossistêmica MILARÉ, Édis. Direito do ambiente: doutrina, prática, jurisprudência, glossário. 4. ed. rev. atual. e ampl. São Paulo: Revista dos Tribunais, 2005.

90 CALABRESI, Guido; MELAMED, A. Douglas. Property rules, liability rules, and inalienability: one view of the cathedral. Harvard Law Review, Cambridge, MA, p. 1089-1128, 1972.

91 OSTROM, Elinor. Private and common property rights. In: BOUCKAERT, B.; GEEST G. De (Ed.). Encyclopedia of Law and Economics. Cheltenham: Edward Elgar Publishing, 2000. p. 332-379.

92 PERROT-MAITRE, Daniéle. The Vittel payments for ecosystem services: a "perfect" PES case. International Institute for Environment and Development, London, UK, 2006. Disponível em: <http://pubs.iied.org/pdfs/G00388.pdf>. Acesso em: 02 maio 2017. 
o investimento realizado pela Fundação Mitsubishi foi de $\mathrm{R} \$ 800.000,00$ para PSA. Outros $\mathrm{R} \$ 400.000,00$ foram financiados pela Fundação Grupo Boticário de contrapartida/administração e desenvolvimento do projeto $^{93}$.

No total, são 13 proprietários rurais ${ }^{94}$ participantes que contribuem para a preservação de cerca de 900 hectares de áreas naturais ${ }^{95}$. As propriedades beneficiadas têm em média 60 hectares de dimensão e os pagamentos mensais oscilam entre $\mathrm{R} \$ 100,00$ e $\mathrm{R} \$ 7.000,00$ por mês, dependendo das características ambientais, tais como densidade hídrica, conservação florestal e condições de saneamento ${ }^{96}$.

Posteriormente, o Projeto Oásis expandiu-se para outros municípios, chegando em Apucarana (PR) em 2009, a partir de uma parceria com a Secretaria de Meio Ambiente e Turismo (SEMATUR). Em 2011, ele foi implementado em São Bento do Sul em Santa Catarina e, em 2012, iniciou-se parceria com o Ministério Público de Minas Gerais e a Associação Mineira de Defesa Ambiental ("Amda”) para a efetivação do projeto em Brumadinho (MG). ${ }^{97}$

Como podemos observar, o Projeto Oásis em São Paulo se baseia no princípio do protetor - recebedor. A fonte financiadora (Fundação Mitsubishi), apesar de não receber vantagens diretas dos resultados esperados pelo programa em relação à quantidade e qualidade de água, se beneficia do fortalecimento de sua marca pelo seu envolvimento na questão socioambiental ${ }^{98}$.

O PSA do Projeto Oásis estabelecido em São Paulo, apesar de promover a proteção do meio ambiente, contribuindo para a efetivação de um objetivo constitucional, pode não ser considerado uma política pública per se dado que ele se desenvolveu por meio de contratos entre entes privados (proprietários de terra e a Fundação Mitsubishi). No entanto, grande parte dos PSAs implementados no Brasil (Programa Bolsa Floresta, Programa Produtor de Água, etc.) e no Mundo (PSA da Costa Rica, por exemplo) são resultados de iniciativas governamentais, sendo a atuação do Estado $3 / 4$ seja como demandante dos serviços e/ou estimulador de ofertantes $3 / 4$ ampla e fundamental para a modelagem jurídica e estruturação institucional dos programas. Logo, o Direito como ferramenta ${ }^{99}$ é imprescindível para a operacionalização dos PSAs.

\section{Considerações finais}

Reconhecendo a importância da gestão ambiental num contexto em que a escassez dos recursos naturais ameaça reduzir o bem-estar social, este artigo se propôs a analisar aspectos jurídicos de três instrumentos econômicos de gestão ambiental: tributação, sistemas de certificados negociáveis de poluição e pagamentos

93 O monitoramento realizado pela Fundação Boticário envolve a avaliação dos aspectos: vegetação, hidrografia e manejo da propriedade, que influem no cálculo dos valores a serem recebidos pelos proprietários. VEIGA, Fernando; GALVADÃO, Mariana. Iniciativas de PSA de Conservação dos Recursos Hídricos na Mata Atlântica. In: GUEDES, Fátima Becker; SEEHUSEN, Susan Edda (Org.). Pagamentos por Serviços Ambientais na Mata Atlântica: lições aprendidas e desafios. Brasília: MMA, 2011. p. $123-182$.

94 Diferentemente de outras iniciativas do projeto Oásis, em São Paulo os beneficiários não são produtores rurais convencionais: com algumas exceções, as propriedades não têm nenhuma produção que gere renda YOUNG, Carlos Eduardo; BAKKER, Leonardo. Payments for ecosystem services from watershed protection: A methodological assessment of the Oasis Project in Brazil. Revista Natureza \& Conservação, Curitiba, v. 12., n. 1., p. 71-78, 2014.

95 VEIGA, Fernando; GALVADÃO, Mariana. Iniciativas de PSA de Conservação dos Recursos Hídricos na Mata Atlântica. In: GUEDES, Fátima Becker; SEEHUSEN, Susan Edda (Org.). Pagamentos por Serviços Ambientais na Mata Atlântica: lições aprendidas e desafios. Brasília: MMA, 2011. p. 123-182. p. 123-182.

96 YOUNG, Carlos Eduardo; BAKKER, Leonardo. Payments for ecosystem services from watershed protection: A methodological assessment of the Oasis Project in Brazil. Revista Natureza \& Conservação, Curitiba, v. 12., n. 1., p. 72, 2014.

97 FUNDACAO GRUPO BOTICARIO. Disponível em: < http://www.fundacaogrupoboticario.org.br/pt/o-que-fazemos/oasis/pages/default.aspx>.

98 BERNARDES, Carolina; SOUSA JÚNIOR, Wilson. Pagamento por serviços ambientais: experiências brasileiras relacionadas à água. Encontro Nacional Da ANPPAS, v. 5, p. 4-7, 2010.

99 COUTINHO, Diogo. O Direito nas Políticas Públicas. In: MARQUES, Eduardo; FARIA, Carlos Aurélio Pimenta de (Org.). Política Pública como Campo Disciplinar. Rio de Janeiro: Fiocruz; São Paulo: Unesp, 2013. p. 181-200. 
por serviços ambientais (PSAs).

De forma que um dos maiores problemas para internalização de externalidades ambientais é a ausência de direitos de propriedade bem definidos sobre o meio ambiente, buscamos entender de que forma os instrumentos mencionados superam essa dificuldade a partir de um referencial analítico da disciplina do Direito proposto por Calabresi e Melamed ${ }^{100}$ e Ostrom ${ }^{101}$.

Como vimos, os instrumentos econômicos de gestão ambiental visam estabelecer melhorias ambientais por meio de incentivos e desincentivos via sistema de preços. Contudo, tais incentivos e desincentivos implicarão $3 / 4$ ainda que implicitamente $3 / 4$ em diferentes atribuições de direitos entre empreendimentos com impactos no meio ambiente, sociedade e Estado.

A partir do trabalho de Calabresi e Melamed ${ }^{102}$, consideramos que um imposto pigouviano corresponde à atribuição do direito a um meio ambiente não polúído à sociedade, protegido por uma regra de responsabilidade. Nos sistemas de certificados negociáveis de impacto ambiental, consideramos que um direito inalienável a um meio ambiente equilibrado é conferido à sociedade, enquanto que aos potenciais impactadores é atribuído um direito de impactar (dentro de determinados limites) protegido por uma regra de propriedade. Por fim, interpretamos os esquemas de PSAs como uma situação em que um direito de impactar (sem limites) protegido por uma regra de propriedade é atribuído aos impactadores, ou seja, a comunidade prejudicada teria que pagar para interromper a atividade nociva.

Com base no feixe de direitos de propriedade propostos por Ostrom ${ }^{103}$, observamos que, geralmente, esses instrumentos funcionam de modo a garantir à sociedade o direito de acesso a um meio ambiente equilibrado. A sociedade (ou comunidade afetada), também, possuiria o direito de administração em esquemas de PSAs. No caso da tributação, os direitos de escolha coletiva, especialmente o de alienação, seriam geridos pela autoridade central. Nos sistemas de certificados negociáveis de impacto, os direitos de administração e exclusão pertenceriam à autoridade central. O direito de alienação possuído pelos impactadores abrangeria, somente, a possibilidade de transacionar um direito de exploração, tomado como o direito de impactar.

Ou seja, ao tentar estabelecer um sistema econômico mais eficiente e sustentável via internalização de externalidades ambientais, os instrumentos econômicos de gestão ambiental engendram uma variedade de formas de atribuição tácitas de direitos de propriedade relativos ao meio ambiente.

Assim, para que resultados eficientes (tanto ambientalmente quanto economicamente) possam ser de fato gerados, é essencial que o Direito atue no sentido de garantir a segurança jurídica dessas atribuições, controlando os custos de transação, formalizando arranjos institucionais claros e impondo sanções efetivas para aqueles que não forem complacentes com a modelagem jurídica e econômica estabelecida para os instrumentos. Fica claro, portanto, que uma política ambiental eficaz não pode prescindir de um tratamento multidisciplinar que se aproprie das ciências jurídica e econômica.

\section{REFERÊNCIAS BIBLIOGRÁFICAS}

BARZEL, Yoram. Economic analysis of property rights. Cambridge: Cambridge university press, 1997.

100 CALABRESI, Guido; MELAMED, A. Douglas. Property rules, liability rules, and inalienability: one view of the cathedral. Harvard Law Review, Cambridge, MA, p. 1089-1128, 1972.

101 OSTROM, Elinor. Private and common property rights. In: BOUCKAERT, B.; GEEST G. De (Ed.). Encyclopedia of Law and Economics. Cheltenham: Edward Elgar Publishing, 2000. p. 332-379.

102 CALABRESI, Guido; MELAMED, A. Douglas. Property rules, liability rules, and inalienability: one view of the cathedral. Harvard Law Review, Cambridge, MA, p. 1089-1128, 1972.

103 OSTROM, Elinor. Private and common property rights. In: BOUCKAERT, B.; GEEST G. De (Ed.). Encyclopedia of Law and Economics. Cheltenham: Edward Elgar Publishing, 2000. p. 332-379. 
BENEVIDES, Gustavo et al. Tributação como instrumento promotor da sustentabilidade: mito ou verdade?: um estudo nos municípios componentes da Região do Grande ABC. In: CONGRESSO BRASILEIRO DE CUSTOS. 18., 2011, Rio de Janeiro. Anais... Rio de Janeiro, 2011.

BERNARDES, Carolina; SOUSA JÚNIOR, Wilson. Pagamento por serviços ambientais: experiências brasileiras relacionadas à água. Encontro Nacional Da ANPPAS, v. 5, p. 4-7, 2010.

CALABRESI, Guido; MELAMED, A. Douglas. Property rules, liability rules, and inalienability: one view of the cathedral. Harvard Law Review, Cambridge, MA, p. 1089-1128, 1972.

CÁNEPA, Eugenio Miguel. Economia da poluição. In: ECONOMIA do meio ambiente: teoria e prática. Rio de Janeiro: Elsevier, 2010.

COASE, Ronald. The Problem of Social Cost. Journal of Law and Economics, Chicago, IL, v. 3, n. 1, p. 1-44, 1960.

COLE, Daniel H.; GROSSMAN, Peter Z. The meaning of property rights: law versus economics?. Land Economics, Madison, WI, v. 78, n. 3, p. 317-330, 2002.

COSTA, Simone S. Thomazi. Introdução à economia do meio ambiente. Análise-Revista de Administração da PUCRS, Porto Alegre, v. 16, n. 2, p. 301-323, ago./dez. 2005.

COUTINHO, Diogo. O Direito nas Políticas Públicas. In: MARQUES, Eduardo; FARIA, Carlos Aurélio Pimenta de (Org.). Política Pública como Campo Disciplinar. Rio de Janeiro: Fiocruz; São Paulo: Unesp, 2013.

DALY, Herman; FARLEY, Joshua. Economia ecológica: princípios e aplicações. Lisboa: Instituto Piaget, 2004.

KENNEDY, David; FISHER III, William W. The canon of American legal thought. Princeton, NJ: Princeton Univ. Press, 2006.

LOUREIRO, Wilson. Contribuição do ICMS Ecológico a Conservação da Biodiversidade no Estado do Paraná. 2002. 189 f. Dissertação (Mestrado) - Programa de Pós-Graduação em Engenharia Florestal, Universidade Federal do Paraná, Curitiba, 2002.

LOUREIRO, Wilson; MARTINEZ, Alexandre. ICMS Ecológico como instrumento de apoio às RPPN do Paraná. In: CASTRO, R.; BORGES, M. (Org.). RPPN: conservação em terras privadas, desafios para a sustentabilidade. Planaltina do Paraná: Edições CNRPPN, 2004.

LUKIC, Melina Rocha. Instrumentos tributários para a sustentabilidade: uma análise comparativa da destinação do ICMS pelos estados segundo critérios ambientais. In: CARLI, Ana Alice de; COSTA, Leonardo de Andrade; RIBEIRO, Ricardo Lodi (Org.). Tributação e sustentabilidade ambiental. Rio de Janeiro: FGV, 2015.

LUSTOSA, Maria Cecília Junqueira; CÁNEPA, Eugenio Miguel; YOUNG, Carlos EF. Política ambiental. Economia do meio ambiente: teoria e prática. Rio de Janeiro: Elsevier, 2010.

MARGULIS, Sergio. A regulamentação ambiental: instrumentos e implementação. Rio de Janeiro: IPEA, 1996. (Texto para Discussão; n. 437).

MAY, Peter H. et al. Cotas de reserva ambiental no novo código florestal brasileiro: Uma avaliação ex-ante. Publicação Ocasional 146. Bogor, Indonesia: CIFOR, 2015.

MELLO, Maria Tereza Leopardi; ESTEVES, Heloísa Lopes Borges. Property Rights: building an interdisciplinary approach. In: COLLOQUE CHARLES GIDE, 2010, Paris. Paris, maio de 2010.

MIGUEL, Luciano Costa. Desenvolvimento sustentável: uma visão conciliadora para a concretização de um direito fundamental e um princípio da ordem econômica. Revista Brasileira de Políticas Públicas, Brasília, v. 2, n. 2, p. 141-156, jul./dez. 2012. 
MILARÉ, Édis. Direito do ambiente: doutrina, prática, jurisprudência, glossário. 4. ed. rev. atual. e ampl. São Paulo: Revista dos Tribunais, 2005.

MOTTA, Ronaldo Seroa da. Manual para valoração econômica de recursos ambientais. Local: IPEA/MMA/PNUD/ CNPq, 1997.

MOTTA, Ronaldo Seroa da. O uso de instrumentos econômicos na gestão ambiental. Rio de Janeiro: IPEA, 2000.

OLIVEIRA, Gustavo. A extrafiscalidade ambiental e a alíquota mínima do ISS. In: CARLI, Ana Alice De; COSTA, Leonardo De Andrade; RIBEIRO, Ricardo Lodi (Org.). Tributação e sustentabilidade ambiental. Rio de Janeiro: FGV, 2015.

OSTROM, Elinor. Private and common property rights. In: BOUCKAERT, B.; GEEST G. De (Ed.). Encyclopedia of Law and Economics. Cheltenham: Edward Elgar Publishing, 2000.

PACKER, Larissa A. Novo Código Florestal e Pagamentos por Serviços Ambientais: Regime proprietário sobre os Bens Comuns. Curitiba: Juruá, 2015.

PERMAN, Roger et al. Natural resource and environmental economics. Harlow: Pearson Education, 2003.

PERROT-MAITRE, Daniéle. The Vittel payments for ecosystem services: a "perfect" PES case. International Institute for Environment and Development. London, UK, 2006. Disponível em: < http://pubs.iied.org/ pdfs/G00388.pdf>. Acesso em: 02 maio 2017.

PORTO, Antônio José Maristrello; FRANCO, Paulo Fernando. Uma Análise Também Econômica do Direito de Propriedade/Also an Analysis of Economic Property Rights. Economic Analysis of Law Review, v. 7, n. 1, p. 207-232, 2016.

PRATES, Ana Paula Leite; IRVING, Marta de Azevedo. Conservação da biodiversidade e políticas públicas para as áreas protegidas no Brasil: desafios e tendências da origem da CDB às metas de Aichi. Revista Brasileira de Políticas Públicas, Brasília, v. 5, n. 1, p. 27-57, 2015.

REIS, Eustáquio J.; MOTTA, Ronaldo Seroa da. The application of economic instruments in environmental policy: the Brazilian case. Revista Brasileira de Economia, Rio de Janeiro, v. 48, n. 4, p. 551-576, 1994.

RIBEIRO, Ricardo. A extrafiscalidade ambiental no ICMS. In: CARLI, Ana Alice De; COSTA, Leonardo De; RIBEIRO, Ricardo Lodi (Org.). Tributação e sustentabilidade ambiental. Rio de Janeiro: FGV, 2015.

ROMEIRO, Ademar Ribeiro. Economia ou economia política da sustentabilidade. In: ECONOMIA do meio ambiente. Rio de Janeiro: Elsevier Brasil, 2010.

ROSSI, Aldimar; MARTINEZ, Antonio Lopo; NOSSA, Valcemiro. ICMS Ecológico sob o enfoque da tributação verde como meio da sustentabilidade econômica e ecológica: experiência do Paraná. Revista de Gestão Social e Ambiental, São Paulo, v. 5, n. 3, p. 90-101, 2011.

SEEHUSEN, Susan; PREM, Ingrid. Porque pagamentos por serviços ambientais? In: GUEDES, Fátima Becker; SEEHUSEN, Susan Edda (Org.). Pagamentos por Serviços Ambientais na Mata Atlântica: lições aprendidas e desafios. Brasília: MMA, 2011.

SILVA, Jessica; RANIERI, Victor. O mecanismo de compensação de reserva legal e suas implicações econômicas e ambientais. Ambiente \& Sociedade, São Paulo, v. 17, n. 1, p. 115-132, 2014.

VEIGA, Fernando; GALVADÃO, Mariana. Iniciativas de PSA de Conservação dos Recursos Hídricos na Mata Atlântica. In: GUEDES, Fátima Becker; SEEHUSEN, Susan Edda (Org.). Pagamentos por Serviços Ambientais na Mata Atlântica: lições aprendidas e desafios. Brasília: MMA, 2011.

WUNDER, Sven. Necessary conditions for ecosystem service payments. Paper apresentado na Economics and Conservation in the Tropics: A Strategic Dialogue conference, Moore Foundation/ CSF/ RFF, São Francisco, jan./ fev. 2008. Disponível em: <http://www.rff.org/files/sharepoint/Documents/08_Tropics_Conference/ 
Tropics_Conference_Papers/Tropics_Conference_Wunder_PES_markets.pdf>. Acesso em: 15 fev. 2017. YOUNG, Carlos Eduardo; BAKKER, Leonardo. Instrumentos econômicos e pagamentos por serviços ambientais no Brasil: incentivos Econômicos para Serviços Ecossistêmicos no Brasil. Rio de Janeiro: Forest Trends, 2015.

YOUNG, Carlos Eduardo; BAKKER, Leonardo. Payments for ecosystem services from watershed protection: A methodological assessment of the Oasis Project in Brazil. Revista Natureza \& Conservação, Curitiba, v. 12, n. 1, p. 71-78, 2014. 


\section{REVISTA BRASILEIRA DE POLÍTICAS PÚBLICAS BRAZILIAN JOURNAL OF PUBLIC POLICY}

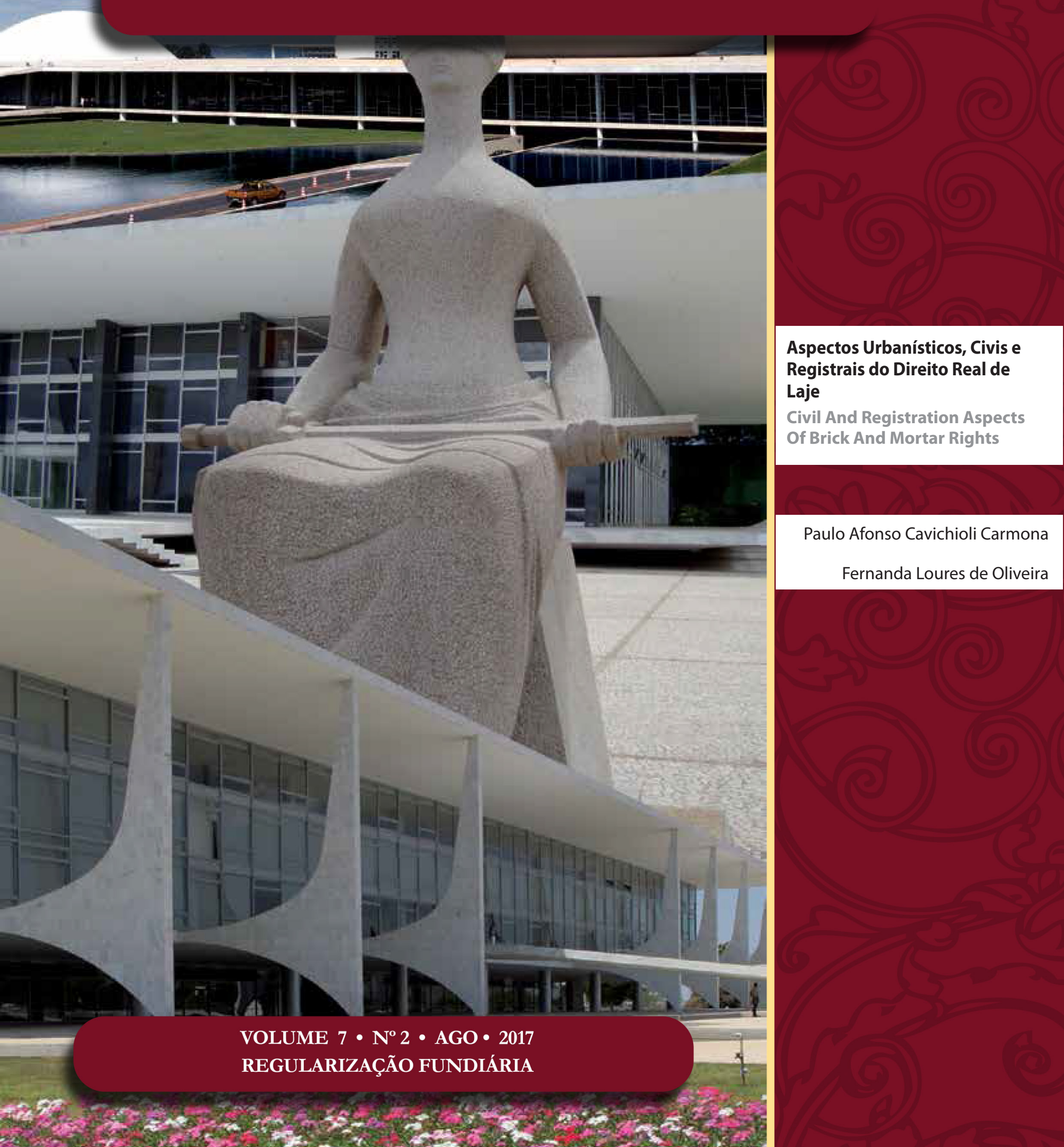




\title{
Civil And Registration Aspects Of Brick And Mortar Rights
}

\author{
Paulo Afonso Cavichioli Carmona** \\ Fernanda Loures de Oliveira***
}

\section{Resumo}

Com o advento da Lei 13.465 de 11 de julho de 2017, um novo direito real foi introduzido na ordem jurídica brasileira: o direito de laje. Em que pese a resistência inicial da doutrina, entende-se importante direcionar um olhar interessado ao novo instituto, de modo a viabilizar sua aplicação prática, diferenciando-o dos demais direitos reais já existentes. É o que se visa realizar por meio do presente artigo. Utilizando-se de metodologia marcadamente dogmática, que parte do exame do novo diploma legal em confronto com a disciplina já existente do direito de superfície e do condomínio edilício, conclui-se que o direito real de laje, embora semelhante, em certos aspectos, a esses direitos reais, possui clara autonomia normativo-conceitual, com natureza jurídica específica. Trata-se de tema de grande interesse para a doutrina urbanística, civil e registral imobiliária, que ainda não consolidaram entendimentos sobre o assunto.

Palavras-Chave: Direito Real de Laje. Dicotomias. Direito de Superfície. Condomínio Edilício.

* Artigo convidado

** Professor do Programa de Mestrado e Doutorado em Direito do Uniceub; mestre e doutor em Direito pela PUC-SP; Juiz de Direito (TJDFT); Professor dos cursos de especialização em Direito da FESMPDFT. Email: paccarmona@hotmail.com

*** Doutoranda em Direito e Políticas Públicas pelo Centro Universitário de Brasília, Mestre em Direito e Políticas Públicas pelo Centro Universitário de Brasília. Registradora de Imóveis do $8^{\circ}$ Ofício de Registro de Imóveis do Distrito Federal. Email: nandinhaloures@hotmail.com

\section{Abstract}

With enactment of Law No. 13,465 dated June 11, 2017, a new real right was introduced in the Brazilian legal system: brick and mortar rights (direito de laje). Notwithstanding initial resistance to the legal doctrine, there is now recognition on the importance of examining the new legal concept, with a view to enabling its practical application and distinguishing the concept from other applicable two real rights. The purpose of this article is to examine the new legal concept more closely. Specifically, through application of a manifestly dogmatic methodology, which begins with a comparative analysis of the new law and the existing legislation on surface rights and building condominium rights, the article concludes that brick and mortar rights, although similar in certain aspects to other real property rights, is clearly constituted by an independent normative framework of a distinct legal nature. The issue is of significant importance to civil and property registration law doctrine, neither of which has arrived at a conclusive interpretation of the issue. 
Keywords: Brick and Mortar Rights. Dichotomies. Surface Rights. Building Condominium.

\section{INTRODUÇÃo}

O escopo do presente artigo é delimitar o direito real de laje, introduzido na ordem jurídica nacional pela Lei 13.465 de 11 de julho de 2017, frente aos demais direitos reais já existentes. A distinção realizada centra-se nos carácteres dos direitos de superfície civil e urbanística e do condomínio edilício.

A metodologia de pesquisa empregada é dogmática, pois parte do exame do novo diploma legal em confronto com a disciplina de outros direitos reais consagrados.

Inicia-se o trabalho apresentando o regramento vigente para o direito de laje. Nesse ponto, apresenta-se a laje como autêntico direito de propriedade. Em seguida, parte-se para o exame das semelhanças e distinções existentes entre o regime do direito de laje e os regimes do direito de superfície e do condomínio edilício. Por fim, analisam-se as dificuldades práticas do instituto, que não pode ser interpretado pelos registradores de imóveis como forma de instituição de condomínio, sob pena de sua inutilidade, bem como suas dicotomias registrais, em termos de documentos a serem apresentados e atos de inscrição.

A relevância do estudo decorre da necessidade de afirmação prática do instituto do direito de laje, com seu potencial de regularização dos imóveis existentes nas favelas brasileiras.

\section{O Direito De Laje Na Lei 13.465 De 11 Julho De 2017}

Uma das grandes novidades trazidas com a edição da Lei 13.465 de 11 de julho de 2017 foi a inclusão de um novo direito real ao rol do art. 1.225 do Código Civil: o direito real de laje (inciso XIII). A citada lei, cuja discussão e votação foram deflagradas pela edição da Medida Provisória 759 de 22 de dezembro de 2016 e, ao final, convertida na forma do Projeto de Lei de Conversão 12 de 2017, disciplina o novo direito real em seu Capítulo V do Título II, e abarca regulamentação mais completa que a da medida provisória citada, a qual era demasiado sucinta nesse ponto.

De acordo com a medida provisória, o direito real de laje consistiria na possibilidade de coexistência de unidades imobiliárias autônomas de titularidades distintas situadas em uma mesma área, permitindo-se ao proprietário a cessão da superfície de sua construção, a fim de que terceiro edificasse unidade distinta daquela originalmente construída sobre o solo. Tal direito contemplaria o espaço aéreo ou o subsolo de terrenos públicos ou privados, tomados em projeção vertical, como unidade autônoma, desde que houvesse isolamento funcional e acesso independente, bem como respeito às posturas edilícias e urbanísticas previstas em legislação local.

Nesse sentido, o que distinguiria a existência de uma laje, para os fins da abertura de matrícula própria para cada unidade, na serventia imobiliária, seria a possibilidade de acesso independente, isto é, uma escada ou rampa de acesso que permitisse o ingresso na edificação do titular do direito real de laje, sem a necessidade de ingresso pela unidade do proprietário original do terreno. Assim constituídas, as unidades poderiam ser alienadas e gravadas livremente; a medida provisória vedava, porém, a instituição de sobrelevações sucessivas, isto é, a constituição de uma ou mais lajes sobre a primeira laje construída.

A medida deixava claro que a instituição do direito real de laje não implicaria atribuição de frações ideais de terreno ou participações em áreas já edificadas, de modo a evidenciar a autonomia do novo direito real criado. $\mathrm{Na}$ mesma linha, dispôs que o titular da laje responderia pelos encargos e tributos que incidissem sobre a sua unidade. 
Nos termos da exposição de motivos da medida provisória, a instituição do direito real de laje destinou-se a adequar a legislação à realidade brasileira, "marcada pela profusão de edificações sobrepostas", permitindo a regularização fundiária de favelas, sem que ficasse condicionada à constituição de condomínio, desde que a unidade superior apresentasse acesso exclusivo ${ }^{1}$.

A partir da edição da medida, fervoroso debate inaugurou-se na doutrina civilista. Cristiano Chaves de Farias, por exemplo, afirmou tratar-se de instituto com potencial de prestar relevantes serviços à população brasileira mais necessitada, na medida em que dirimiu histórica controvérsia sobre os encargos tributários decorrentes da laje; sem mitigar as normas municipais e distritais sobre o direito de construir, já que condicionou o direito ao respeito às "posturas públicas". Criticou, porém, o fato de a medida provisória não ter estabelecido direito de preferência recíproco para os proprietários das unidades autônomas, o que "poderia ser um mecanismo inibidor de conflitos futuros e garantidor de uma efetiva possibilidade de consolidação da titularidade plena sobre a coisa"2.

Por outro lado, Roberto Paulino de Albuquerque Júnior criticou o fato de que o direito real de laje não é novidade no Direito brasileiro, mas apenas uma modalidade de direito de superfície que, desde 2001, já tem previsão expressa na legislação nacional, a superfície por sobrelevação — afirmação que se pretende examinar no próximo item do presente trabalho. Por isso ressaltou que a permissão de abertura de matrícula registral autônoma, que é tema delicado do direito de superfície; e a permissão de constituição do direito sem submissão ao regime do condomínio edilício, embora úteis e importantes, são regras que deveriam ter sido incluídas na disciplina do direito de superfície, não havendo sentido "em inscrever como direito real autônomo no Código Civil uma modalidade de um direito real já previsto, muito menos em utilizar-se terminologia menos técnica quando já se dispõe de uma mais adequada em utilização"’3.

De outra parte, Otavio Luiz Rodrigues Junior criticou a falta de técnica na redação do novo direito real, definido como um "direito-possibilidade", e a não utilização das bases do já existente direito de superfície

Pablo Stolze endossou a crítica de que o legislador poderia, em vez de inaugurar disciplina específica, tratar do instituto no âmbito do próprio direito de superfície. No entanto, exaltou o fato de que a regulação do direito real de laje deu visibilidade a uma situação social bastante comum nas cidades brasileiras. Ressaltou, ainda, tratar-se de um direito real limitado à estrutura autônoma edificada, devendo-se interpretar com cautela, porém, o requisito do "acesso independente", pois, na realidade urbanística brasileira, uma mesma escada ou rampa de acesso pode ser utilizada simultaneamente por vizinhos que habitem unidades sobrelevadas contíguas. Exaltou, também, a autonomia registral conferida ao novo direito real, mas criticou a vedação a concessões de sobrelevações sucessivas, sob a perspectiva do princípio constitucional da função social ${ }^{5}$.

Sob o ponto de vista da segurança estrutural do edifício, severas críticas foram lançadas à falta de preocupação normativa com a segurança da construção ${ }^{6}$. Outras críticas poderiam ser levantadas, como a falta de vinculação registral entre a matrícula do terreno e a responsável por abarcar o direito real de laje, uma vez que, pelo expresso teor legal, não haveria qualquer participação do titular da laje relativamente ao solo e

1 BRASIL. Exposição de Motivos 00020/2016 MCidades MP CCPR. Brasília, DF, 21 dez. 2016. p. 12. Disponível em: <http://www. planalto.gov.br/ccivil_03/_ato2015-2018/2016/Exm/Exm-MP\%20759-16.pdf>. Acesso em: 10 jul. 2017.

2 FARIAS, Cristiano Chaves de. Direito real da laje: novidade de fim de ano no direito civil brasileiro, 2017. Disponível em: <https://www.cers.com.br/noticias-e-blogs/noticia/direito-real-da-laje-novidade-de-fim-de-ano-no-direito-civil-brasileiro->. Acesso em: 10 jul. 2017.

3 ALBUQUERQUE JÚNIOR, Roberto Paulino de. O direito de laje não é um novo direito real, mas um direito de superfície, 2017. Disponível em: <http://www.conjur.com.br/2017-jan-02/direito-laje-nao-direito-real-direito-superficie>. Acesso em: 11 jul. 2017.

4 RODRIGUES JUNIOR, Otavio Luiz. Um ano longo demais e seus impactos no Direito Civil Contemporâneo, 2016. Disponível em: <http://www.conjur.com.br/2016-dez-26/retrospectiva-2016-ano-longo-impactos-direito-civil-contemporaneo>. Acesso em: 11 jul. 2017.

5 STOLZE, Pablo. Direito real de laje: primeiras impressões, 2017. Disponível em: < https://jus.com.br/artigos/54931/direitoreal-de-laje-primeiras-impressoes>. Acesso em: 11 jul. 2017.

6 CONSELHO DE ARQUITETURA E URBANISMO (CAU/BR). Entidades denunciam inconstitucionalidade da MP 759, 2017. Disponível em: <http://www.fna.org.br/entidades-denunciam-inconstitucionalidade-da-mp-759/>. Acesso em: 12 jul. 2017. 
a outras edificações. Ademais, soa estranho deixar que um direito fosse definido, apenas, pela posição assumida pela escada ou rampa de acesso à unidade.

De modo a responder essas e outras críticas, bem como para aprimorar a disciplina do novo direito real, durante a tramitação legislativa da medida provisória, foram sugeridas diversas alterações ${ }^{7}$, motivo pelo qual a matéria passou a ser processada como projeto de lei de conversão, o qual foi aprovado na Câmara e no Senado e submetido à sanção do Presidente da República. Por fim, o referido projeto foi publicado como norma, recebendo a numeração de Lei 13.465 de 11 de julho de 2017.

A citada lei efetuou diversas alterações, especialmente, no Código Civil e na Lei de Registros Públicos, passando a prever: redação mais técnica na definição do direito, embora sua nomenclatura permaneça em linguagem popular, de modo a "aproximar o Direito do homem comum"; direito de preferência na aquisição; possibilidade de sobrelevações sucessivas; vedação a obras que prejudiquem, bem como obrigação de respeitar a segurança, a linha arquitetônica e o arranjo estético do edifício; dever de contribuir para a conservação e fruição das partes que sirvam a toda a edificação. Ademais, foi suprimida a necessidade de acesso independente e isolamento funcional, bem como foi solucionada a questão da falta de vinculação registral entre a matrícula do solo e da acessão artificial originária e a referente à construção do titular da laje.

O art. 1.510-A do Código Civil passou a prever que o proprietário da construção-base poderá ceder a superfície superior ou inferior de sua edificação para que o titular da laje mantenha unidade diversa da originalmente construída sobre o solo, a qual abrangerá o espaço aéreo ou o subsolo de terrenos públicos ou privados, tomados em projeção vertical, excluídas as demais edificações não pertencentes ao proprietário da construção-base. Nesse sentido, em relação à construção sobrelevada, o titular da laje poderá dela usar, gozar e dispor, inscrevendo seu direito em matrícula própria, do mesmo modo, responderá pelos encargos e tributos incidentes sobre sua unidade. Permanece a previsão de que o direito de laje não implica atribuição de fração ideal sobre o solo ou qualquer tipo de participação em construções já concluídas.

A lei estabelece faculdade expressa aos municípios e ao Distrito Federal, os quais poderão (e é salutar que o façam) dispor sobre posturas edilícias e urbanísticas associadas ao direito real de laje. Tais normas deverão ser respeitadas para que o titular da laje possa ceder superfície de sua construção para a instituição de direito de laje sucessivo, mediante expressa autorização dos titulares da construção-base e das demais lajes.

O normativo passou a prever algumas obrigações para as partes envolvidas: vedou ao titular da laje prejudicar com obras novas ou falta de reparação a segurança, a linha arquitetônica ou o arranjo estético do edifício; determinou a aplicação, no que couber, das normas aplicáveis aos condomínios edilícios; estabeleceu a partilha, entre o proprietário da construção-base e os titulares das lajes, das despesas necessárias à conservação e fruição das partes que sirvam a todo o edifício e dos serviços de interesse comum, na proporção que venha a ser definida em contrato; e assegurou, a qualquer interessado, o direito de promover reparações urgentes na construção.

Para os efeitos da lei, consideram-se que servem a toda a edificação: os alicerces, colunas, pilares, paredes-mestras e todas as partes restantes que constituam a estrutura do edifício, as instalações gerais de água, esgoto, eletricidade, aquecimento, gás, comunicações e semelhantes que sirvam a todo a construção; as coisas que sejam afetadas ao uso de todo o prédio; e, finalmente, os telhados ou os terraços, ainda que vinculados ao uso exclusivo do titular da laje.

\footnotetext{
7 A partir de sugestões da doutrina e, nomeadamente, dos professores Otávio Luiz Rodrigues Júnior; Roberto Paulino de Albuquerque Júnior; Hércules Alexandre da Costa Benício; Rodrigo Numeriano; Flauzilino Araújo dos Santos; Sérgio Jacomino; Frederico Henrique Viegas de Lima; e Rodrigo Reis Mazzei (OLIVEIRA, Carlos Eduardo Elias de. Direito real de laje à luz da Lei $n^{\circ}$ 13.465, de 2017: nova lei, nova hermenêutica, 2017. p. 1-3. Disponível em: <https://www12.senado.leg.br/publicacoes/estudoslegislativos/tipos-de-estudos/textos-para-discussao/td238>. Acesso em: 12 jul. 2017).

8 OLIVEIRA, Carlos Eduardo Elias de. Direito real de laje à luz da Lei nº 13.465, de 2017: nova lei, nova hermenêutica, 2017. p. 5. Disponível em: <https://www12.senado.leg.br/publicacoes/estudos-legislativos/tipos-de-estudos/textos-para-discussao/td238>. Acesso em: 12 jul. 2017.
} 
Na hipótese de alienação de qualquer das unidades sobrepostas ou sotopostas ${ }^{9}$, haverá direito de preferência, em igualdade de condições com terceiros, aos titulares da construção-base e, se não houver interesse destes, aos titulares de direito real de laje no edifício, preferindo, sucessivamente, o titular das lajes ascendentes e o das descendentes, assegurada prioridade à laje mais próxima à unidade a ser alienada. Todos os interessados deverão ser cientificados por escrito, para se manifestarem em trinta dias, ressalvada a possibilidade de estipulação diversa no contrato entabulado entre as partes. Caso não lhes seja dado conhecimento da alienação, o titular da construção-base ou da laje poderá, por meio de depósito do preço correspondente, haver para si a parte alienada a terceiros, desde que o requeira no prazo decadencial de cento e oitenta dias contados da alienação.

O art. 1.510-E do Código Civil prevê a extinção do direito real de laje, em caso de ruína da construção-base, salvo: se estiver instituído sobre o subsolo; ou se a construção-base for reconstruída no prazo de cinco anos. Não se afasta, porém, o direito a eventual reparação civil contra o responsável pela ruína.

Sob o ponto de vista registral, o art. 176, \ $9^{\circ}$, da Lei 6.015 de 1973, passou a prever que o direito de laje será objeto de matrícula própria, bem como de averbação na matrícula da construção-base e nas matrículas das lajes anteriores, com remissões recíprocas (isto é: fazendo-se, também, averbação das construções anteriores na matrícula aberta para a nova unidade).

Por fim, o art. 799 do Código de Processo Civil passou a estabelecer como incumbência do exequente o requerimento de intimação do titular da construção-base, bem como, se for o caso, do titular de lajes anteriores, quando a penhora recair sobre o direito real de laje; do mesmo modo, se incidir sobre a construção-base, solicitar a intimação dos titulares das lajes (incisos X e XI).

A redação da lei inspirou-se na disciplina do direito de construir sobre edifício alheio (art. $1526^{\circ}$ ) do Código Civil lusitano, bem como na definição das partes comuns do prédio, estabelecida na parte em que o citado código regulamenta o condomínio (art. $1421^{\circ}$ ), com algumas adaptações ${ }^{10}$. O primeiro sujeita o direito às limitações impostas à constituição da propriedade horizontal, bem como, levantado o edifício, às regras do condomínio, passando o construtor a ser condômino das partes comuns do prédio. $\mathrm{O}$ segundo define como partes comuns da edificação: o solo, os alicerces, as colunas, os pilares, as paredes mestras, bem como todas as partes componentes da estrutura do prédio; o telhado ou terraço, ainda que afeto ao uso de qualquer unidade; as entradas, as escadas e os corredores de uso ou passagem comum; e as instalações gerais de água, eletricidade, aquecimento, ar-condicionado, gás, comunicações e semelhantes. Presumem-se, ainda, como partes comuns, na lei civil portuguesa: os pátios e jardins anexos; os ascensores; as dependências destinadas ao uso e habitação do porteiro; as garagens; e, em geral, as coisas que não sejam afetadas ao uso exclusivo $^{11}$.

Em termos doutrinários, pode-se dizer que a natureza jurídica do direito de laje é de direito real sobre coisa própria, pois, tal como definido na legislação, trata-se de direito sobre todo o espaço que se expande a partir da laje ou do piso da construção-base, de modo sobreposto ou sotoposto ${ }^{12}$. De fato, o domínio é o mais amplo direito sobre a coisa, embora tenha, ele mesmo, limites determinados por lei; permite, ao titular do direito, utilizar o bem ou destruí-lo, aliená-lo, gravá-lo ou dele dispor — conforme os contornos norma-

9 CAMARGO, Marco Antonio de Oliveira. Direito de laje: explicando para quem quer entender, 2017. Disponível em: <http:// www.notariado.org.br/index.php?pG=X19leGliZV9ub3RpY2lhcw==\&in=OTA2MQ==>. Acesso em: 12 jul. 2017.

10 OLIVEIRA, Carlos Eduardo Elias de. Direito real de laje à luz da Lei no 13.465, de 2017: nova lei, nova hermenêutica, 2017. p. 4. Disponível em: <https://www12.senado.leg.br/publicacoes/estudos-legislativos/tipos-de-estudos/textos-para-discussao/td238>. Acesso em: 12 jul. 2017.

11 PORTUGAL. Código Civil, 1966. Disponível em: < http://www.pgdlisboa.pt/leis/lei_print_articulado.php?tabela=leis\&artigo_ $\mathrm{id}=\&$ nid $=775 \&$ nversao $=\&$ tabela $=$ leis $>$. Acesso em: 13 jul. 2017.

12 OLIVEIRA, Carlos Eduardo Elias de. Direito real de laje à luz da Lei nº 13.465, de 2017: nova lei, nova hermenêutica, 2017. p. 6. Disponível em: <https://www12.senado.leg.br/publicacoes/estudos-legislativos/tipos-de-estudos/textos-para-discussao/td238>. Acesso em: 12 jul. 2017. 
tivamente admitidos; bem como possibilita a exclusão de terceiros, salvo determinação legal ${ }^{13}$. O direito de propriedade é em si uno e sua condição normal é a plenitude, sendo composto de atributos ou faculdades, que compreendem os poderes de usar, gozar e dispor da coisa ${ }^{14}$. Nessa linha, o art. 1.510-A, \ $3^{\circ}$, do Código Civil, estabelece que os titulares da laje podem dela usar, gozar e dispor- o que evidencia a vontade do legislador de tratar a laje como modalidade de propriedade.

Ora, a doutrina registral imobiliária esclarece que o princípio da especialidade designa o fato de a inscrição recair sobre objeto especificamente individuado, abrangendo a forçosa individualização do "imóvel que seja objeto de direito real, a começar pelo de propriedade", pois a inscrição somente pode versar sobre imóvel preciso ${ }^{15}$. Esse princípio, aliado à ideia de unitariedade matricial, de acordo com a qual todo imóvel será dotado de matrícula própria, a qual consiste no retrato do bem de raiz ${ }^{16}$, que imprime individualidade à coisa imóvel ${ }^{17}$, endossa a tese de que tal direito é modalidade de propriedade ${ }^{18}$, uma vez que a lei, expressamente, atribui ao direito real de laje a abertura de matrícula própria (art. 176, \ 9 9 , da Lei 6.015 de 1973).

\section{Comparação Do Direito De Laje Com Institutos Similares}

Viu-se que o direito real de laje é modalidade nova de direito de propriedade, que ingressou no mundo jurídico por meio da Lei 13.465 de 2017, a qual optou por discipliná-lo de modo autônomo. Nesse sentido, se interpretar é "selecionar possibilidades comunicativas da complexidade discursiva"19 e se "toda interpretação tem que começar com o sentido literal", já que a interpretação que não se situe "no âmbito do sentido literal possivel, já não é interpretação, mas modificação de sentido" 20 , opta-se, neste trabalho, por ressaltar a vontade legislativa aparente de inaugurar um novo direito real, apartado do condomínio edilício e do direito de superfície. Sob esse móvel, procura-se apresentar semelhanças e, especialmente, distinções entre o direito real de laje e esses outros direitos reais que com ele guardam semelhança, procurando-se traçar algumas balizas - mesmo que incipientes — sobre a teorização do primeiro.

\subsection{Direito De Laje Vs. Instituição De Condomínio Edilício}

O condomínio edilício está disciplinado no Capítulo VII do Título III (da Propriedade) do Livro III (do Direito das Coisas) do Código Civil, entre os artigos 1.331 e 1.358-A. Trata-se de "fenômeno econômico e jurídico moderno", modalidade nova de condomínio, que inaugura um regime jurídico no qual há "conjugação orgânica e indissolúvel da propriedade exclusiva e da copropriedade"21. É o que decorre do art. 1.331 do Código Civil.

13 PONTES DE MIRANDA, Francisco Cavalcanti. Tratado de Direito Privado: Parte Especial - Direito das Coisas: propriedade. São Paulo: Revista dos Tribunais, 2012. v. 9. p. 69-71.

14 PEREIRA, Caio Mário da Silva. Instituições de direito civil: direitos reais. 22. ed. Rio de Janeiro: Forense, 2014. v. 4. p. 96.

15 CARVALHO, Afrânio de. Registro de imóveis: comentários ao sistema de registro em face da Lei no 6.015, de 1973, com as alterações da Lei no 6.216, de 1975, Lei no 8.009, de 29.03.1990, e Lei no 8.935, de 18.11.1994. 4. ed. Rio de Janeiro: Forense, 1997. p. 203. 16 ALVIM NETO, José Manuel de Arruda; CLÁPIS, Alexandre Laizo; CAMBLER, Everaldo Augusto (Coord.). Lei de registros públicos comentada. Rio de Janeiro: Forense, 2014. p. 1015.

17 CARVALHO, Afrânio de. Registro de imóveis: comentários ao sistema de registro em face da Lei $\mathrm{n}^{\circ}$ 6.015, de 1973, com as alterações da Lei no 6.216, de 1975, Lei no 8.009, de 29.03.1990, e Lei no 8.935, de 18.11.1994. 4. ed. Rio de Janeiro: Forense, 1997 . p. 144. 18 OLIVEIRA, Carlos Eduardo Elias de. Direito real de laje à luz da Lei no 13.465, de 2017: nova lei, nova hermenêutica, 2017. p. 6. Disponível em: <https://www12.senado.leg.br/publicacoes/estudos-legislativos/tipos-de-estudos/textos-para-discussao/td238>. Acesso em: 12 jul. 2017.

19 FERRAZ JÚNIOR, Tércio Sampaio. Introdução ao estudo do Direito: técnica, decisão, dominação. 46. ed. São Paulo: Atlas, 2003. p. 260.

20 LARENZ, Karl. Metodologia da ciência do Direito. Tradução de: José Lamego. 7. ed. Lisboa: Fundação Calouste Gulbenkian, 2014. p. $452-454$.

21 PEREIRA, Caio Mário da Silva. Instituições de direito civil: direitos reais. 22. ed. Rio de Janeiro: Forense, 2014. v. 4. p. 176. 
Várias são as características que aproximam o condomínio edilício do novo direito real de laje. Por exemplo, em ambos haverá áreas de propriedade exclusiva: as unidades imobiliárias autônomas. Em comentário sobre o tema, Flauzilino Araújo dos Santos conceitua o que se deve compreender como unidade autônoma, para fins de caracterização do condomínio edilício, levantando as seguintes características: independência, ou seja, afetação a uso independente; autonomia funcional, isto é, a unidade deve conter "os acessórios básicos para seu uso ordinário"; autonomia jurídica, decorrente da inscrição da unidade em matrícula própria; e saída ou acesso à via pública, ou seja, existência de saída ao logradouro público de modo direto ou por passagem comum, ainda que constituída por servidão de passagem, "sem ter de atravessar parte de outra propriedade exclusiva" 22 . Idênticas considerações podem ser aplicadas no âmbito do direito de laje, tendo em vista os $\llbracket \int 1^{\circ}$ e $3^{\circ}$ do art. 1.510-A do Código Civil, que disciplinam a edificação subsequente como unidade imobiliária autônoma e impõem a abertura de matrícula própria.

Em ambos os casos, a propriedade sobre a unidade autônoma é direito pleno e perpétuo ${ }^{23}$. No âmbito do condomínio edilício, o código é expresso ao dispor que as partes suscetíveis de uso independente podem ter as mais variadas formas, constituindo-se de apartamentos, escritórios, salas, lojas, sobrelojas etc. (art. 1.331, $\int 1^{\circ}$ ). Tais unidades, por efeito de sua propriedade exclusiva, podem ser alienadas e gravadas livremente, exceto, quanto aos condomínios edilícios, os abrigos para veículos, que não podem ser alienados ou alugados

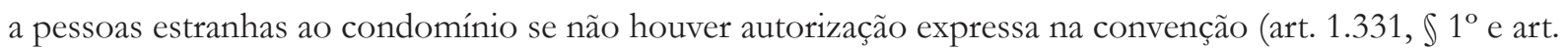
$\left.1.510-\mathrm{A}, \mathbb{\int} 3^{\circ}\right)$.

Da mesma forma, tanto no condomínio edilício como no direito de laje, há certas áreas consideradas como partes que servem a todo o edifício. No condomínio edilício, as partes comuns da edificação podem ser classificadas como partes comuns por natureza e partes comuns por destinação. As partes comuns por natureza caracterizam-se pela impossibilidade de desafetação factual, sob pena de prejuízo às finalidades precípuas das unidades autônomas. Por outro lado, as partes comuns por destinação são aquelas em que se impõe o uso comum por convenção passível de desfazimento ${ }^{24}$.

Nesse sentido, são partes comuns: o solo, a estrutura do prédio, o telhado, a rede geral de distribuição de água, esgoto, gás e eletricidade, a calefação e refrigeração centrais, o acesso ao logradouro público e demais partes utilizadas em comum pelos condôminos, que não poderão ser alienadas separadamente ou divididas $\left(\operatorname{art.} 1.331, \sqrt{ } 2^{\circ}\right)$.

Do mesmo modo, na laje, são partes que servem a todo o edifício, caracterizadas como "partes comuns por natureza": os alicerces, colunas, pilares, paredes-mestras e todas as partes restantes que constituam a estrutura do prédio (art. 1.510-C, $\sqrt{ } 1^{\circ}$, inciso I); e as instalações gerais de água, esgoto, eletricidade, aquecimento, ar-condicionado, gás, comunicações e semelhantes que sirvam a todo o edifício (art. 1.510-C, $\mathbb{S}$ $1^{\circ}$, inciso III).Além dessas, também são partes que servem a todo o edifício as que forem afetadas a uso comum, representando "partes comuns por destinação" (art. 1.510-C, $\int 1^{\circ}$, inciso IV).

Prosseguindo no exame das semelhanças, pode-se verificar que, tanto os condôminos quanto os titulares das lajes possuem direito de usar, fruir e dispor das suas unidades (art. 1.335, inciso I e art. 1.510-A, $\int 3^{\circ}$ ); possuem dever de contribuir para a conservação e fruição das partes que sirvam a todo o edifício e ao pagamento de serviços de interesse comum (art. 1.336, inciso I e art. 1.510-C), proporcionalmente e na forma estabelecida na convenção ou contrato (art. 1.334, inciso I e art. 1.510-C, in fine); e não podem realizar obras

22 SANTOS, Flauzilino Araújo dos. Condominios e incorporações no registro de imóveis: teoria e prática. São Paulo: Mirante, 2012. p. 48. 23 Em que pese o fato de, no caso das unidades do condomínio edilício, tratar-se de autêntico direito de propriedade em sentido clássico, em que existe uma "garantia jurídica sobre uma fração específica da superfície do planeta, um espaço físico delimitado no solo", ao passo que, no direito de laje, há uma importante distinção jurídica, que será mais bem examinada a seguir: a inexistência de direito ou fração sobre o solo (CAMARGO, Marco Antonio de Oliveira. Direito de laje: explicando para quem quer entender, 2017. Disponível em: <http://www.notariado.org.br/index.php?pG=X19leGliZV9ub3RpY2lhcw==\&in=OTA2MQ==>. Acesso em: 12 jul. 2017.

24 SANTOS, Flauzilino Araújo dos. Condomínios e incorporacões no registro de imóveis: teoria e prática. São Paulo: Mirante, 2012. p. $52-53$. 
que comprometam a segurança da edificação e seu arranjo estético (art. 1.336, incisos II e III, e art. 1.510-B). No condomínio edilício, as obras ou reparações necessárias poderão ser realizadas mesmo sem autorização pelo síndico ou, em caso de omissão ou impedimento deste, por qualquer condômino (art. 1.341, \ $1^{\circ}$ ). De modo análogo, qualquer interessado poderá promover reparações urgentes na construção objeto de direito de laje, conforme dispõe o art. 1.510-C, $\$ 2^{\circ}$.

Por fim, como última afinidade entre os institutos, tem-se a necessidade de consentimento unânime para ampliação do prédio. Assim, por exemplo, no condomínio edilício, a lei civil determina que a construção de outro pavimento destinado a conter novas unidades depende de aprovação da unanimidade dos condôminos (art. 1.343). Similarmente, o $\int 6^{\circ}$ do art. 1.510-A do Código Civil determina que, para ceder a superfície de sua construção para novo direito de laje, o interessado deve obter autorização expressa dos titulares da construção-base e das demais lajes, respeitadas as posturas edilícias e urbanísticas locais.

Nada obstante a existência de aproximações, o direito de laje e o condomínio edilício são institutos que muito se separam quando a análise alcança pontos específicos, mas cruciais para a delimitação de ambas as formas de propriedade. O primeiro ponto a ser enfatizado é o fato de que o condomínio edilício pode dar azo a edificações mais complexas, nas quais é possível a existência de inúmeras unidades por pavimento, bem como maior número de equipamentos e partes de uso comum.

[...] as edificações coletivas, mesmo os conjuntos habitacionais populares, são desenvolvidas dentro de critérios psicossociais de engenharia e arquitetura de vanguarda, de forma a garantir melhor qualidade de vida, proteção ao meio ambiente e sustentabilidade, segurança e progresso do espírito comunitário aos ocupantes, em razão de atividades que os aproximam. Alguns exemplos podem ser mencionados. [...] controle de entrada e saída de condôminos, trabalhadores e visitantes [...] salão social comunitário, piscinas, salas de jogos, quadras de tênis, playgrounds, churrasqueiras, fitness e outros equipamentos afins que são utilizados por todos e com observância às regras previamente estabelecidas ${ }^{25}$.

Basta pensar que, no âmbito do condomínio edilício, haverá um projeto previamente concebido para suportar a complexidade do edifício, abarcando todos os seus recursos, equipamentos e unidades autônomas por pavimento. Nesse sentido, o art. 1.332 do Código Civil determina que se institua o condomínio por ato entre vivos ou testamento, registrado na serventia imobiliária, no qual conste, além do disposto em lei especial, a discriminação e individualização das unidades, estremadas umas das outras e das partes comuns (inciso I). A lei especial aludida é a Lei 4.291 de 16 de dezembro de 1964, cujo art. 32 impõe a apresentação de variados documentos técnicos, a exemplo dos quadros da NBR 12.721/2006 - Versão Corrigida 2:2007 (art. 53). Por outro lado, na seara do direito de laje, há apenas uma construção base, sobre a qual se vislumbra a possibilidade de levantamento de mais uma (ou algumas) construções, nos termos das posturas edilícias e urbanísticas municipais e distritais (art. 1.510-A, $\sqrt{\int} 5^{\circ}$ ). Nessa linha, como o projeto original não era em si vocacionado à constituição de edificações complexas sobre aquelas fundações, ainda que se vislumbre a possibilidade de levantamento de novas construções, certamente estas terão natureza mais singela.

Outro ponto de destaque é o fato de que, no condomínio edilício, em regra, o terraço de cobertura é parte comum, ressalvada a possibilidade de disposição contrária na constituição do condomínio (art. 1.331, $\left.\llbracket 5^{\circ}\right)$. No direito de laje, ao revés, o telhado ou terraços de cobertura presumem-se destinados ao uso exclusivo do titular da laje (art. 1.510-C, $\int 1^{\circ}$, inciso II), o que decorre até mesmo da previsão da possibilidade de instituição de lajes sucessivas (art. 1.510-A, $\mathbb{\int} 6^{\circ}$ ).

Todavia, a maior diferença existente entre ambos os regimes jurídicos é a existência ou não de fração ideal no solo. Vários dispositivos do Código Civil estabelecem a necessidade de existência da fração ideal para o condomínio edilício. Nessa linha, o art. 1.331, \ $3^{\circ}$, de acordo com o qual a cada unidade caberá, de modo inseparável, uma fração ideal no solo e nas partes comuns, identificada de forma decimal; o art. 1.332, inciso II, que estabelece como cláusula obrigatória do instrumento de constituição e especificação de

25 SANTOS, Flauzilino Araújo dos. Condomínios e incorporações no registro de imóveis: teoria e prática. São Paulo: Mirante, 2012. p. 36. 
condomínio a determinação da fração ideal atribuída a cada unidade no terreno e nas partes comuns; o art. 1.336, inciso I, que estabelece a proporção das frações ideais como método de determinação da contribuição dos condôminos nas despesas do condomínio; e o art. 1.331, $\int 1^{\circ}$, que determina a necessidade de previsão das respectivas frações ideais no solo e nas outras partes comuns na descrição das partes de utilização independente. Em sentido diametralmente oposto, a instituição do direito real de laje não implica a atribuição de fração ideal de terreno ou a participação proporcional em áreas já edificadas (art. 1.510-A, $\int 4^{\circ}$ ).

Essa distinção, ao contrário do que se possa imaginar, possui relevantíssimas consequências práticas. Em razão dela, caso haja ruína da construção-base, haverá extinção do direito real de laje sobreposto, se não houver reconstrução da construção-base em cinco anos, podendo apenas o titular do direito de laje demandar eventual reparação civil contra o culpado pela ruína (art. 1.510-E). No condomínio edilício, de outra parte, como todos são titulares de uma quota sobre o terreno, havendo destruição considerável do prédio, os condôminos poderão deliberar sua reconstrução ou venda, repartindo-se o apurado, proporcionalmente, ao valor das respectivas unidades (art. 1.357).

Por fim, como última e importante distinção a ser apontada, tem-se a questão do direito de preferência. No direito de laje, em caso de alienação de qualquer das unidades sobrepostas ou sotopostas, terão direito de preferência, em igualdade de condições com terceiros, os titulares da construção-base e da laje, nessa ordem, garantida a prioridade para a laje mais próxima (art. 1.510-D). Diferentemente, no condomínio edilício, as unidades autônomas podem ser alienadas "livremente" (art. 1.331, $\sqrt{ } 1^{\circ}$ ), só havendo direito de preferência em favor dos condôminos no caso de aluguel de área para abrigo de veículos (art. 1.338) e no caso de venda do terreno após a destruição do prédio (art. $1.368, \mathbb{\$} 2^{\circ}$ )

\subsection{Direito De Laje Vs. Direito De Superfície Civil}

O direito de superfície está previsto como direito real no inciso II do art. 1.225 do Código Civil e é disciplinado no Título IV de seu Livro III, do Direito das Coisas, entre os artigos 1.369 e 1.377. De acordo com o diploma civil, ao proprietário é dado conceder a terceiro o direito de construir ou plantar em seu terreno, por tempo determinado, entretanto, o direito de superfície não autoriza obras no subsolo, salvo quando inerentes ao objeto da concessão.

São muitas as similitudes entre o direito de superfície e o direito de laje: em ambos os casos, há suspensão dos efeitos da acessão (superficies solo cedit), não se consolidando como propriedade do detentor do solo a obra erigida sobre o terreno, mas configurando direito real distinto (arts. 1.369 e 1.510-A do Código Civil); nos dois, a concessão do direito poderá ser feita de modo gratuito ou oneroso (arts. 1.370 e 1.510-A — o último é silente a respeito, interpretando-se a omissão, portanto, como possibilidade); o direito de superfície e o direito de laje são transmissíveis a terceiros (arts. 1.372 e $\int 3^{\circ}$ do art. 1.510-A); e, em caso de alienação dos direitos (propriedade sobre o terreno ou direito de superfície; e construção-base ou laje), haverá direito de preferência, em igualdade de condições (arts. 1.373 e 1.510-D).

Ademais, embora o parágrafo único do art. 1.396 do Código Civil disponha que a superfície, em regra, não alcança o subsolo, o Enunciado 568 da VI Jornada de Direito Civil destaca que o direito de superfície deve ser interpretado de modo a abranger o uso não apenas do solo, como do subsolo e do espaço aéreo correspondente ao terreno, na forma fixada no contrato, admitindo o direito de sobrelevação, nos termos da legislação urbanística. A justificativa para a edição do enunciado é conferir a máxima eficácia possível ao direito de superfície previsto no Código Civil e no Estatuto da Cidade, transformando-o em importante instrumento de aproveitamento da propriedade imóvel ${ }^{26}$.

No entanto, as semelhanças terminam aí. Ao contrário do que ocorre com o direito real de laje, o direito

26 BRASIL. Conselho da Justiça Federal. VI Jornada de Direito Civil: Enunciado 568. Disponível em: <http://www.cjf.jus.br/ enunciados/enunciado/639>. Acesso em: 13 jul. 2017. 
de superfície não enseja propriedade plena e perpétua, mas apenas resolúvel, resultando em um desdobramento, pelo qual uma construção ou plantação é considerada, separadamente, da propriedade do solo ${ }^{27}$, mas ambas as propriedades incidem sobre o mesmo bem imóvel e não sobre unidades autônomas ${ }^{28}$, entendidas como imóveis distintos, como ocorre no direito de laje. Assim, ao mesmo tempo em que o superficiário adquire a propriedade resolúvel das acessões, o fundeiro mantém a titularidade (propriedade limitada) sobre o terreno; diversamente do que acontece na laje, em que tanto o proprietário originário mantém propriedade plena sobre a construção-base, quanto o titular da laje o tem sobre sua unidade construída.

Não se nega que o direito de superfície tem a nota característica de ensejar a criação de propriedades autônomas (uma nua e a outra resolúvel) e não o desdobramento dos poderes dominiais, como os outros direitos reais limitados ${ }^{29}$. A propósito, é em razão dessa especificidade que Rodrigo Reis Mazzei defendeu a abertura de uma "submatrícula"autônoma para o direito, ainda que lançada em "livro auxiliar" 30 . Na mesma linha, Cristiano Chaves de Farias e Nelson Rosenvald defenderam a necessidade de que os ônus e gravames decorrentes da propriedade do solo e do direito de superfície fossem incorporados a bases distintas ${ }^{31}$.

No entanto, é fato que a abertura de matrícula não se presta ao lançamento de direitos reais, muito menos se destina a melhor organização de ônus e gravames, mas à correspondência a um imóvel específico (princípio da unitariedade matricial, pelo qual há uma matrícula para cada imóvel e um imóvel para cada matrícula), o que é a base do sistema brasileiro de fólio real. Nem se diga que a existência do desdobramento de propriedades ensejaria, necessariamente, a duplicidade matricial, uma vez que, no caso da alienação fiduciária, também, há desdobramento, em propriedade fiduciante e propriedade resolúvel fiduciária, e mesmo assim não se questiona o lançamento desse direito real no seio da matrícula do imóvel — em si uno.

Pelo exposto, sendo a superfície um direito real que enseja uma propriedade resolúvel e não a existência de unidades imobiliárias distintas, não há motivos para a abertura de matrícula autônoma, mas tão somente para o ato de registro, a ser lavrado na matrícula do imóvel do proprietário-concedente (art. 167, inciso I, item 39 da Lei 6.015 de 1973) e, posteriormente, encerrado, mediante averbação de sua extinção (art. 167, inciso II, item 20), momento no qual o proprietário recupera o pleno domínio do terreno ${ }^{32}$.

Exemplo dessa natureza real limitada do direito de superfície é o disposto no art. 1.374 do Código Civil, segundo o qual, mesmo antes do termo final, a superfície poderá resolver-se caso o superficiário dê ao terreno destinação diversa daquela para a qual foi concedida. Essa hipótese de extinção é incompatível com o direito de laje, em que há efetiva transferência de propriedade plena, de modo que, se o titular da laje dá à sua unidade destinação diversa da que tem a edificação, os problemas daí decorrentes serão resolvidos pelo direito de vizinhança, aplicando-se, por empréstimo, o disposto sobre o condomínio edilício, no inciso IV do art. 1.336 do Código Civil (dever do titular da laje de não utilizar sua unidade de maneira prejudicial ao sossego, salubridade e segurança dos possuidores, ou aos bons costumes) e não o disposto no art. 1.374 sobre a extinção da superfície por emprego em destinação diversa daquela para que foi concedida ${ }^{33}$.

Merece destaque o fato de que, na superfície, o legislador impõe ao superficiário a responsabilidade pelos encargos e tributos incidentes sobre o imóvel (art. 1.371) — embora a doutrina, com base na ética que nor-

27 PEREIRA, Caio Mário da Silva. Instituições de direito civil: direitos reais. 22. ed. Rio de Janeiro: Forense, 2014. v. 4. p. $219-220$.

28 CAMARGO, Estela L. Monteiro Soares de. Direito de superfície. In: TUTIKIAN, Cláudia Fonseca; TIMM, Luciano Benetti; PAIVA, João Pedro Lamana (Org.). Novo direito imobiliário e registral. 2.ed. São Paulo: Quartier Latin, 2010. p. 49-64.

29 FARIAS, Cristiano Chaves de; ROSENVALD, Nelson. Curso de direito civil: reais. 11. ed. São Paulo: Atlas, 2015. v. 5. p. 515.

30 MAZZEI, Rodrigo Reis. O direito de superfície no ordenamento jurídico brasileiro. 2007. 406 f. Dissertação (Mestrado) - Direito das Relações Sociais, Pontifícia Universidade Católica de São Paulo, São Paulo, 2007. p. 161-186.

31 FARIAS, Cristiano Chaves de; ROSENVALD, Nelson. Curso de direito civil: reais. 11. ed. São Paulo: Atlas, 2015. v. 5. p. $516-517$.

32 CENEVIVA, Walter. Lei dos registros públicos comentada. 20. ed. São Paulo: Saraiva, 2010. p. 390.

33 Discordamos, na hipótese, dos ensinamentos de Carlos Eduardo Elias de Oliveira, que defende a possibilidade de, em caso de lacuna legal no tratamento do direito de laje, recorrer-se, por analogia, às regras próprias do direito de superfície (OLIVEIRA, Carlos Eduardo Elias de. Direito real de laje à luz da Lei n 13.465, de 2017: nova lei, nova hermenêutica, 2017. p. 7. Disponível em: <https://www12.senado.leg.br/publicacoes/estudos-legislativos/tipos-de-estudos/textos-para-discussao/td238>. Acesso em: 12 jul. 2017). 
teia o Código, defenda a interpretação no sentido de que a responsabilidade se limita à própria concessão ${ }^{34}$ e o Enunciado 94 da I Jornada de Direito Civil estabeleça a plena liberdade das partes para deliberar, no respectivo contrato, a respeito do rateio dos encargos e tributos incidentes sobre a área objeto da concessão do direito de superfície ${ }^{35}$ - ao passo que, no direito de laje, há expressa determinação de que o titular da laje responde apenas pelos encargos e tributos que incidem sobre a sua unidade $\left(\mathbb{S} 2^{\circ}\right.$ do art. $\left.1.510-\mathrm{A}\right)$.

Outro aspecto que diferencia o direito de laje do direito de superfície do Código Civil é o fato de este último ser, por expressa disposição legal, temporário, fixando uma propriedade resolúvel, que, em algum momento, será extinta, com o consequente remembramento da propriedade plena nas mãos do titular do terreno $^{36}$, independentemente de indenização, salvo disposição diversa no contrato — necessariamente público — de concessão de superfície (art. 1.375).

Ponto que também merece ser lembrado é o fato de haver quem defenda a possibilidade de registro de direito de superfície sobre fração ideal do terreno, "desde que a área objeto da superfície esteja suficientemente identificada" ${ }^{37}$. Sem adentrar a discussão sobre a efetiva possibilidade de registro de fração localizada em imóvel indiviso, ainda que sob a nota da superfície, certo é que tal procedimento parece incompatível com o direito de laje. Nele, a lei é clara ao vedar a atribuição de fração ideal ao titular da laje ( $\mathbb{S} 4^{\circ}$ do art. 1.510-A do Código Civil), outrossim, entende-se que o $\int 1^{\circ}$ do art. 1.510-A da lei civil prevê a atribuição ao titular do direito de toda a laje ou o subsolo da construção-base, tomados em projeção vertical, não sendo possível a constituição de diversas unidades no mesmo pavimento, mas apenas a título de sucessivas cessões das superfícies das edificações $\left(\mathbb{S} 6^{\circ}\right)$.

Também há diferenças entre os institutos quando o assunto é a incidência do imposto de transmissão. $\mathrm{Na}$ constituição do direito de superfície, pela lógica tributária, o cálculo do imposto de transmissão não deve ser feito considerando-se a "pauta cheia", pois "o imposto não pode incidir sobre todo o imóvel, que permanece no patrimônio do proprietário”, exatamente como ocorre em relação à instituição do usufruto ${ }^{38}$. Luís Eduardo Schoueri coaduna com essa posição, entendendo que a base de cálculo deve ser menor, pois se trata de direito menor que o direito de propriedade ${ }^{39}$. No Distrito Federal, por exemplo, aplicando-se o art. $5^{\circ}$, \ $2^{\circ}$, inciso I, da Lei 3.830 de 14 de março de $2006 \mathrm{c} / \mathrm{c}$ art. $5^{\circ}$, $\ 2^{\circ}$, inciso I, do Decreto 27.576 de 28 de dezembro de 2006, a base de cálculo do direito de superfície equivaleria a setenta por cento do valor venal do imóvel ${ }^{40}$. Em sentido diametralmente oposto, no direito de laje, o cálculo do imposto de transmissão deve ter em conta o valor ("cheio") do potencial construtivo da laje negociada, caso a cessão tenha sido feita para que o titular da laje construa sua unidade; ou o valor ("cheio") do imóvel levantado sobre a construção-base, caso a cessão seja feita para que o titular da laje mantenha unidade distinta já edificada sobre a primeira construção.

34 MAZZEI, Rodrigo. Direito de superfície: breve comparativo entre o Código Civil e o Estatuto da Cidade. MPMG Jurídico, n. 20, p. 60, abr./maio/jun. 2010. Disponível em:<https://aplicacao.mpmg.mp.br/xmlui/bitstream/handle/123456789/458/Direito $\% 20$ de $\% 20$ superf\%C3\%ADcie_Mazzei.pdf?sequence=3 >. Acesso em: 17 jul. 2017.

35 BRASIL. Conselho da Justiça Federal. I Jornada de Direito Civil: Enunciado 94. Disponível em: < http://www.cjf.jus.br/enunciados/enunciado/726>. Acesso em: 16 jul. 2017.

36 PEREIRA, Caio Mário da Silva. Instituições de direito civil: direitos reais. 22. ed. Rio de Janeiro: Forense, 2014. v. 4. p. $221-222$.

37 CAMARGO, Estela L. Monteiro Soares de. Direito de superfície. In: TUTIKIAN, Cláudia Fonseca; TIMM, Luciano Benetti; PAIVA, João Pedro Lamana (Org.). Novo direito imobiliário e registral. 2. ed. São Paulo: Quartier Latin, 2010. p. 57.

38 CAMARGO, Estela L. Monteiro Soares de. Direito de superfície. In: TUTIKIAN, Cláudia Fonseca; TIMM, Luciano Benetti; PAIVA, João Pedro Lamana (Org.). Novo direito imobiliário e registral. 2. ed. São Paulo: Quartier Latin, 2010. p. 62-63.

39 INSTITUTO BRASILEIRO DE DIREITO TRIBUTÁRIO (IBDT). Mesa de debates, 1 jun. 2006. Disponível em: < http:// www.ibdt.com.br/2006/integra_01062006.htm>. Acesso em: 16 jul. 2017.

40 Sobre o tema, o Supremo Tribunal Federal afastou a existência de ofensa à Constituição, ao apreciar norma que dispunha como base de cálculo da constituição da superfície o valor venal do imóvel utilizado para o cálculo do IPTU ou o preço atribuído ao imóvel no negócio jurídico, na ementa, constou, porém, que, em relação à base de cálculo, não se configurou qualquer incorreção ao se considerar, para fins do imposto, o valor da transação (BRASIL. Supremo Tribunal Federal. Recurso Extraordinário com Agravo 982.808. Recorrente: REP Participações Ltda. Recorrido: Município de São Paulo. Relator: Gilmar Mendes. Brasília - DF, 15 de agosto de 2016. Diário de Justiça Eletrônico, n. 176, de 19 de agosto de 2016). 
Por fim, merece destaque o fato de que, no âmbito do direito real de laje, há norma expressa disciplinando as sobrelevações sucessivas ( $\$ 6^{\circ}$ do art. 1.510-A do Código Civil), o que não ocorre em relação ao direito de superfície. Nada obstante, parte da doutrina já defendia a possibilidade de concessão dos diversos planos da construção, no âmbito da superfície, abrangendo tantos planos quantas fossem "as formas possíveis e autônomas de aproveitamento econômico" ${ }^{41}$, de modo que o terceiro utilizasse o gabarito a que o superficiário tivesse direito, mas que fora subaproveitado ${ }^{42}$.

\subsection{Direito De Laje Vs. Direito De Superfície Urbanístico}

Finalmente, passa-se a examinar o direito de laje à luz do instituto que, provavelmente, é o mais próximo à sua regulamentação legal, sendo de delicada distinção.

Com efeito, a Lei 10.257 de 10 de julho de 2001 foi a primeira a introduzir o direito de superfície na legislação brasileira, como instrumento da política urbana (art. $4^{\circ}$, inciso V, "l"). Sua posterior previsão no Código Civil não resultou, porém, em revogação das normas constantes do Estatuto da Cidade, pois neste, o direito de superfície não é visualizado sob a ótica civilista, mas como mecanismo de desenvolvimento urbano (Enunciado 93 da I Jornada de Direito Civil) ${ }^{43}$. Nesse sentido, o Estatuto da Cidade pode ser considerado como norma especial relativamente ao Código $\mathrm{Civi}^{44}$.

A exemplo do que ocorre com o direito de laje, na superfície disciplinada pela Lei 10.257 de 2001, também há exceção ao princípio de que o acessório segue o principal, coexistindo direitos reais diversos em uma mesma área de terras (art. 1.510-A do Código Civil e art. 21 da Lei 10.257 de 2001); ambos podem abranger o direito de utilizar o subsolo ou o espaço aéreo, admitido o direito de sobrelevação, nos termos da legislação urbanística (art. 1.510-A do Código Civil e $\int 1^{\circ}$ do art. 21 da Lei 10.257 de 2001 c/c Enunciado 568 da VI Jornada de Direito Civil);nos dois casos, a concessão do direito poderá ser feita de modo gratuito ou oneroso ( $\left(2^{\circ}\right.$ do art. 21 da Lei 10.257 de 2001 e art. 1.510-A do Código Civil - o último é silente a respeito, interpretando-se a omissão, portanto, como possibilidade);o superficiário e o titular do direito de laje responderão integralmente pelos encargos e tributos que incidem sobre o objeto de seus respectivos direitos $(\Omega$ $3^{\circ}$ do art. 21 da Lei 10.257 de 2001 e $\$ 2^{\circ}$ do art. 1.510-A do Código Civil);o direito de superfície e o direito de laje são transmissíveis a terceiros $\left(\$ \int 3^{\circ}\right.$ e $4^{\circ}$ do art. 21 da Lei 10.257 de 2001 e $\int 3^{\circ}$ do art. 1.510-A do Código Civil);e, em caso de alienação dos direitos (propriedade sobre o terreno ou direito de superfície; e construção-base ou laje), haverá direito de preferência, em igualdade de condições (art. 22 da Lei 10.257 de 2001 e 1.510-D do Código Civil).

Ocorre, porém, que, a despeito de poder ser estipulado por tempo indeterminado, o direito de superfície do Estatuto da Cidade, também, é um direito real limitado, fixando propriedade superposta referente à construção (porém, não em sua plenitude, mas essencialmente resolúvel) executada em bem de raiz alheio ${ }^{45}$. Nesse sentido, a possibilidade de sua transferência a terceiros fica condicionada aos termos do contrato respectivo ( $\left(4^{\circ}\right.$ do art. 21 da Lei 10.257 de 2001); além disso, extingue-se o direito de superfície pelo descumprimento das obrigações contratuais assumidas pelo superficiário (art. 23, inciso II); e, uma vez extinto

41 TEPEDINO, Gustavo José Mendes. Os direitos reais no novo Código Civil: Anais do "EMERJ Debate o Novo Código Civil”, p. 175, 2002. Disponível em: < http://www.emerj.tjrj.jus.br/revistaemerj_online/edicoes/anais_onovocodigocivil/anais_especial_2/ Anais_Parte_II_revistaemerj_168.pdf>. Acesso em: 17 jul. 2017.

42 MAZZEI, Rodrigo. Direito de superfície: breve comparativo entre o Código Civil e o Estatuto da Cidade. MPMG Jurídico, n. 20, p. 59, abr./maio/jun. 2010. Disponível em:<https://aplicacao.mpmg.mp.br/xmlui/bitstream/handle/123456789/458/Direito $\% 20 \mathrm{de} \% 20$ superf\%C3\%ADcie_Mazzei.pdf?sequence=3 >. Acesso em: 17 jul. 2017.

43 BRASIL. Conselho da Justiça Federal. I Jornada de Direito Civil: Enunciado 93. Disponível em: < http://www.cjf.jus.br/enunciados/enunciado/725>. Acesso em: 14 jul. 2017.

44 DI PIETRO, Maria Sylvia Zanella. Direito de superfície. In: DALLARI, Adilson Abreu; FERRAZ, Sérgio (Coord.). Estatuto da Cidade: comentários à Lei Federal 10.257/2001. 4. ed. São Paulo: Malheiros, 2014. p. 177.

45 DI PIETRO, Maria Sylvia Zanella. Direito de superfície. In: DALLARI, Adilson Abreu; FERRAZ, Sérgio (Coord.). Estatuto da Cidade: comentários à Lei Federal 10.257/2001. 4. ed. São Paulo: Malheiros, 2014. p. 176;188;194. 
o direito, o proprietário recupera o pleno domínio do imóvel, incluindo as acessões e benfeitorias nele introduzidas, independentemente de indenização, salvo estipulação em contrário no respectivo contrato (art. 24). Igualmente, o direito de superfície pode extinguir-se pelo emprego em finalidade diversa daquela para qual recebeu a concessão o superficiário ( $\left(1^{\circ}\right.$ do art. 24), averbando-se no registro de imóveis (na matrícula do bem no qual a superfície foi constituída) a extinção do direito real ( $\$ 2^{\circ}$ do art. 24). Todas essas disposições são incompatíveis com o direito de laje, em que há efetiva transferência de propriedade (não sendo direito real limitado), quando então — não havendo inadimplemento contratual relacionado à transferência, que possa gerar o desfazimento do negócio - , a relação existente entre o titular da laje e o proprietário da construção-base será regida pelas normas de vizinhança.

A propósito, se, à primeira vista, o fato de o Estatuto da Cidade permitir a instituição da superfície por prazo indeterminado é elemento que aproxima a superfície do direito de laje, sua análise mais acurada aponta no sentido diverso. Rodrigo Mazzei destaca que, na ausência de prévio ajuste contratual quanto ao prazo da superfície, sua resolução poderá ser feita de modo unilateral, vedando-se apenas, em interpretação analógica ao parágrafo único do art. 473 do Código Civil, a resolução antes do transcurso de prazo compatível com os investimentos realizados ${ }^{46}$, pois "prazo indeterminado" não se coaduna com "perpetuidade". Por outro lado, no âmbito do direito de laje, não há que se falar em resolução unilateral do direito ou em cálculo de "tempo compatível com os investimentos efetuados", na medida em que se transfere a propriedade plena da laje, mediante direito autônomo e perene, admitindo-se, apenas, discussões relacionadas ao desfazimento do ajuste em havendo hipótese de inadimplemento (ex.: não pagamento do preço estipulado para a laje).

Outro ponto relevante para o distanciamento dos institutos é o fato de que o direito de laje não pode abranger o uso do solo, pois pressupõe a existência de uma construção-base, sobre a qual incidirá a sobrelevação ou sotoposição (art. 1.510-A do Código Civil, caput e $\int 1^{\circ}$ ). Por outro lado, a superfície abrange o direito de utilizar o solo $\left(\$ 1^{\circ}\right.$ do art. 21 da Lei 10.257 de 2001).

Por fim, o \ $3^{\circ}$ do art. 21 da Lei 10.257 de 2001 determina, em relação à superfície, que o superficiário suporte, proporcionalmente à sua parcela de ocupação efetiva, parte dos encargos e tributos sobre a área objeto da concessão, ressalvada a possibilidade de disposição em contrário no contrato firmado pelas partes. Entende-se que essa previsão não se compatibiliza com o direito de laje, relativamente ao qual a intenção legislativa foi claramente a de constituir unidades autônomas, dotadas de inscrições fiscais distintas $\left(\$ 2^{\circ}\right.$ do art. 1.510-A do Código Civil), o que fica especialmente evidente com o dispositivo que determina a não atribuição de fração ideal de terreno ao titular da laje, tampouco a participação proporcional em áreas já edificadas ( $\$ 4^{\circ}$ do mesmo dispositivo). ${ }^{47}$

\subsection{Direito de laje vs. derecho de vuelo ou sobreedificación}

Assim como no Direito brasileiro, também na Espanha, no âmbito da propriedade imóvel, tradicionalmente se considerava que o poder do proprietário era ilimitado verticalmente ou, como diziam os romanos usque ad sidera, usque ad inferos (do céu ao inferno). Nesse sentido, ainda hoje o Código Civil espanhol estabelece no art. 350 que:

O proprietário de um terreno é dono de sua superfície e do que está debaixo dela, e pode fazer nela as obras, plantações e escavações que lhe convenha, salvo as servidões, e com sujeição ao disposto nas leis sobre Minas e Águas e nos regulamentos de polícia. ${ }^{48}$

46 MAZZEI, Rodrigo. Direito de superfície: breve comparativo entre o Código Civil e o Estatuto da Cidade. MPMG Jurídico, n. 20, p. 60, abr./maio/jun. 2010. Disponível em:<https://aplicacao.mpmg.mp.br/xmlui/bitstream/handle/123456789/458/Direito $\% 20$ de $\% 20$ superf\%C3\%ADcie_Mazzei.pdf?sequence=3 >. Acesso em: 17 jul. 2017.

47 Para análise aprofundada sobre o direito de superfície urbanístico, inclusive no direito comparado, vide: LIMA, Frederico Henrique Viegas de. O direito de superfície como instrumento de planificação urbana. Rio de Janeiro: Renovar, 2005.

48 Código Civil, art. 350: El propietario de un terreno es dueño de su superficie y de lo que está debajo de ella, y puede hacer en él las obras, plantaciones y excavaciones que le convengan, salvas las servidumbres, y con sujeción a lo dispuesto en las leyes sobre 
Portanto, na Espanha, o direito do proprietário se estende não só ao solo propriamente dito, mas também alcança o espaço aéreo e ao subsolo. Outra norma geral do Direito Civil espanhol estabelece que o proprietário tem direito de fazer seu tudo aquilo que se incorpora, natural ou artificialmente, à coisa de que é titular (art. 334).

Desse modo, o derecho de vuelo ou sobreedificación é uma exceção à referidas normas gerais, pois pode ser conceituado como um direito real limitado que faculta a seu titular para edificar uma ou mais plantas sobre ou sob um edifício total ou parcialmente alheio e para executa as obras necessárias, fazendo-se proprietário da construção.

O direito de laje adotado no Código Civil brasileiro tem, portanto, inspiração e similitude com o Derecho de Vuelo ou Derecho de Sobreedificación, ${ }^{49}$ previsto no ReglamentoHipotecario espanhol, como um "direito real com vocação de domínio", dotado de uma estrutura bifásica, nos termos do art. 16.2, 'a' e 'd':

El derecho de elevar una o más plantas sobre un edificio o el de realizar construcciones bajo su suelo, haciendo suyas las edificaciones resultantes que, sin constituir derecho de superficie, se reserve el propietario en caso de enajenación de todo o parte de la finca o transmita a un tercero, será inscribible conforme a las normas del apartado $3^{\circ}$. del artículo 8 de la Ley y sus concordantes. En la inscripción se hará constar:

a) Las cuotas que hayan de corresponder a las nuevas plantas en los elementos y gastos comunes o las normas para su establecimiento.

$[\ldots]$

d) Las normas de régimen de comunidad, si se señalaren, para el caso de hacer la construcción. ${ }^{50}$

Assim, o instituto possui duas fases distintas: a) fase provisória, na qual se concede um direito de edificar sobre ou abaixo da edificação afetada; b) fase definitiva, na qual, como consequência do exercício do direito, surge um direito de propriedade pleno e definitivo sobre o objeto construído. ${ }^{51}$

O Derecho de Vueloou Sobreedificación ('Direito de Espaço Aéreo' ou 'Sobrelevação', em tradução livre para o português), é aquele que surge sob pactos reais para os quais é concedido a uma pessoa distinta dos proprietários do edifício o direito de elevá-lo ou aprofundá-lo por meio da construção de novas plantas e fazendo sua a propriedade das mesmas de modo perpétuo se bem integrado ao regime de propriedade horizontal do edifício que serve de base, sem que constitua direito de superfície.

Note-se, porém, que o derecho de vuelo tem sido entendido como um direito real limitado e, para determinar sua constituição, conteúdo e extensão, é necessária a inscrição no registro, atendendo ao princípio da especialidade ou determinação, exigível para a constituição de novos direitos reais.

O instituto, também, aparece no legislação civil e urbanística da Catalunha. No primeiro caso, no Capítulo VII do Título VI do Livro V do Código Civil da Catalunha,artigos 567.1 a 567.6, como o direito real sobre um edifício ou um teto edificável que atribui a alguém a faculdade de construir uma ou mais plantas sobre o imóvel gravado e fazer sua a propriedade das novas construções (art. 567.1). Cabe destacar o artigo

Minas y Aguas y en los reglamentos de policía.

49 É o posicionamento de Flávio Tartuce. TARTUCE, Flávio. Direito real de laje à luz da Lei no 13.465/2017: nova lei, nova hermenêutica. Disponível em: <https://flaviotartuce.jusbrasil.com.br/artigos/478460341/ direito-real-de-laje-a-luz-da-lei-n-13465-2017-nova-lei-nova-hermeneutica>. Acesso em: 24 jul. 2017. Outros autores, como Ricardo Lira, destacam que o Direito de Laje tem inspiração no Direito de Sobrelevação, uma espécie do direito de superfície que algumas legislações estrangeiras desenvolveram, como é o caso da Suíça, Itália e Portugal. LIRA, Ricardo Pereira. O Direito de Superfície e o espaço aéreo. Revista Forense, n., v., p. $365,2002$. 50 Os itens 'b' e 'c', que foram introduzidos por conta da reforma realizada pelo Real Decreto 1867/1998, de 4 de setembro, foram anulados pelas Sentenças da Sala $3^{a}$ do Tribunal Supremo (T.S.), de 31 de janeiro de 2001 e 24 de fevereiro de 2000, respectivamente, o que significa que não são mais exigíveis para a criação do direito estabelecer o número máximo de plantas a serem construídas e o prazo de vigência, mas devem respeitar as limitações do planejamento urbanístico no âmbito local, como prevê a alínea 'd'. 51 PELAZ, Jesús P. López. Derecho de Vuelo ¿Qué es y qué características tiene?, nov. 2016. Disponível em: <http://www.abogadoamigo.com/derecho-de-vuelo/>. Acesso em: 23 jul. 2017. 
567.2 que exige os requisitos para constituição do derecho de vuelo: número máximo de plantas e elementos privativos, critérios para determinar a cota de comunidade, prazo máximo de 30 anos para o exercício do direito, preço ou contraprestação. As normas estabelecem, ainda, critérios para legitimidade, transmissibilidade, exercício e extinção. A seguinte tabela apresenta acomparação do derecho de vuelocom o direito de laje:

\section{Tabela 1 - Diferenças entre Direito Real de Laje e Derecho de Vuelo}

\begin{tabular}{|c|c|}
\hline DIREIRO REAL LAJE - Brasil & DERECHO DE VUELO - Catalunha \\
\hline $\begin{array}{l}\text { Código Civil, art. 1.510-A. O proprietário de uma } \\
\text { construção-base poderá ceder a superfície superior } \\
\text { ou inferior de sua construção a fim de que o titular da } \\
\text { laje mantenha unidade distinta daquela originalmente } \\
\text { construída sobre o solo. } \\
\text { Código Civil, art. } 1.510-\mathrm{A}, \int 1^{\circ} \text { O direito real de laje } \\
\text { contempla o espaço aéreo ou o subsolo de terrenos } \\
\text { públicos ou privados, tomados em projeção vertical, } \\
\text { como unidade imobiliária autônoma, não contem- } \\
\text { plando as demais áreas edificadas ou não pertencen- } \\
\text { tes ao proprietário da construção-base. }\end{array}$ & $\begin{array}{l}\text { Artículo 567-1. Concepto. } \\
\text { 1. El vuelo es el derecho real sobre un edificio o un solar edificable que } \\
\text { atribuye a alguien la facultad de construir una o más plantas sobre el } \\
\text { inmueble gravado y hacer suya la propiedad de las nuevas construccio- } \\
\text { nes. Los preceptos del presente capitulo son de aplicación al derecho de } \\
\text { subedificación. }\end{array}$ \\
\hline $\begin{array}{l}\text { Código Civil, art. } 1.510-\mathrm{A}, \int 5^{\circ} \text { Os Municípios e } \\
\text { o Distrito Federal poderão dispor sobre posturas } \\
\text { edilícias e urbanísticas associadas ao direito real de } \\
\text { laje. }\end{array}$ & $\begin{array}{l}\text { Artículo 567-1. Concepto. } \\
\text { 2. El ejercicio del derecho de vuelo comporta la legitimación para hacer } \\
\text { construcciones, de acuerdo con el título de constitución y el planeamiento } \\
\text { urbanistico. }\end{array}$ \\
\hline $\begin{array}{l}\text { Lei no } 6.015 / 73 \text {, art. } 176 . \int 9^{\circ} \text { A instituição do di- } \\
\text { reito real de laje ocorrerá por meio da abertura de } \\
\text { uma matrícula própria no registro de imóveis e por } \\
\text { meio da averbação desse fato na matrícula da con- } \\
\text { strução-base e nas matrículas de lajes anteriores, com } \\
\text { remissão recíproca. }\end{array}$ & $\begin{array}{l}\text { Artículo 567-2. Constitución. } \\
\text { 1. El derecho de vuelo debe constar necesariamente en escritura pública, } \\
\text { que debe contener, al menos, los siguientes datos: } \\
\text { a) El número máximo de plantas, edificios, si procede, y elementos pri- } \\
\text { vativos que pueden construirse, de acuerdo con la normativa urbanistica } \\
\text { y de la propiedad horizontal vigentes en el momento de constituirse el } \\
\text { derecho. }\end{array}$ \\
\hline $\begin{array}{l}\text { Código Civil, art. 1.510-A, } \int 4^{\circ} \text { A instituição do di- } \\
\text { reito real de laje não implica a atribuição de fração } \\
\text { ideal de terreno ao titular da laje ou a participação } \\
\text { proporcional em áreas já edificadas. }\end{array}$ & $\begin{array}{l}\text { b) Los criterios que deben aplicarse en la determinación de las cuotas de } \\
\text { participación que corresponden a los elementos privativos situados en las } \\
\text { plantas o edificios nuevos y las que corresponden a los situados en las } \\
\text { plantas o edificios preexistentes, que deben garantizar la proporcionali- } \\
\text { dad adecuada entre todas. } \\
\text { c) Elplazo para ejercerlo, que no puede superar en ningún caso, sumán- } \\
\text { dole las prórrogas, los treinta años. } \\
\text { d) El precio o contraprestación que, si procede, debe satisfacer la perso- } \\
\text { na que adquiere el derecho, o bien la forma en que se valora este si se } \\
\text { reserva. }\end{array}$ \\
\hline
\end{tabular}




\begin{tabular}{|c|c|}
\hline $\begin{array}{l}\text { Código Civil, art. } 1.510-\mathrm{A}, \int 2^{\circ} \mathrm{O} \text { titular do direito } \\
\text { real de laje responderá pelos encargos e tributos que } \\
\text { incidirem sobre a sua unidade. }\end{array}$ & $\begin{array}{l}\text { Artículo 567-2. Constitución. } \\
\text { 2. El título de constitución del derecho de vuelo puede incluir los siguien- } \\
\text { tes contenidos: } \\
\text { a) Las normas de comunidad o de propiedad horizontal por las que debe } \\
\text { regirse el edificio una vez se ha ejercido. } \\
\text { b) La limitación de la disponibilidad del derecho de vuelo. } \\
\text { c) La facultad de los titulares del derecho de vuelo de establecer o modi- } \\
\text { ficar el régimen de propiedad horizontal, de modificar la descripción del } \\
\text { edificio preexistente y de fijar o redistribuir las cuotas de participación } \\
\text { sin el consentimiento de los concedentes. } \\
\text { d) Los demás pactos licitos que se consideren convenientes. }\end{array}$ \\
\hline & $\begin{array}{l}\text { Artículo 567-2. Constitución. } \\
\text { 3. La constitución del derecho de vuelo y sus modificaciones pueden opo- } \\
\text { nerse a terceras personas de buena fe desde que se efectúa su inscripción } \\
\text { en el Registro de la Propiedad en la forma y con los efectos establecidos } \\
\text { por la legislación hipotecaria o desde que las terceras personas han tenido } \\
\text { conocimiento de las mismas. }\end{array}$ \\
\hline $\begin{array}{l}\text { Código Civil, art. } 1.510-\mathrm{A}, \int 6^{\circ} \text { O titular da laje po- } \\
\text { derá ceder a superfície de sua construção para a in- } \\
\text { stituição de um sucessivo direito real de laje, desde } \\
\text { que haja autorização expressa dos titulares da con- } \\
\text { strução-base e das demais lajes, respeitadas as postu- } \\
\text { ras edilícias e urbanísticas vigentes. }\end{array}$ & $\begin{array}{l}\text { Artículo 567-3. Legitimación. } \\
\text { 1. El título de constitución del derecho de vuelo lo otorgan los propieta- } \\
\text { rios del inmueble o los usufructuarios con facultad de enajenar. } \\
\text { 2. El derecho de vuelo, si se constituye o se reserva en el titulo de consti- } \\
\text { tución de una propiedad horizontal, debe constar en cláusula separada } \\
\text { y especifica. } \\
\text { 3. Es precisa la unanimidad de todos los propietarios para constituir } \\
\text { el derecho de vuelo sobre un edificio sometido al régimen de propiedad } \\
\text { horizontal. }\end{array}$ \\
\hline $\begin{array}{l}\text { Código Civil, art. } 1.510 \text {-D. Em caso de alienação de } \\
\text { qualquer das unidades sobrepostas, terão direito de } \\
\text { preferência, em igualdade de condições com tercei- } \\
\text { ros, os titulares da construção-base e da laje, nessa } \\
\text { ordem, que serão cientificados por escrito para que } \\
\text { se manifestem no prazo de trinta dias, salvo se o con- } \\
\text { trato dispuser de modo diverso. } \\
\int 1^{\text {o }} \text { O titular da construção-base ou da laje a quem } \\
\text { não se der conhecimento da alienação poderá, me- } \\
\text { diante depósito do respectivo preço, haver para si } \\
\text { a parte alienada a terceiros, se o requerer no prazo } \\
\text { decadencial de cento e oitenta dias, contado da data } \\
\text { de alienação. } \\
\int 2^{\circ} \text { Se houver mais de uma laje, terá preferência, } \\
\text { sucessivamente, o titular das lajes ascendentes e o ti- } \\
\text { tular das lajes descendentes, assegurada a prioridade } \\
\text { para a laje mais próxima à unidade sobreposta a ser } \\
\text { alienada. }\end{array}$ & $\begin{array}{l}\text { Artículo 567-4. Transmisibilidad. } \\
\text { 1. El derecho de vuelo y la propiedad del inmueble preexistente son } \\
\text { enajenables libremente por actos entre vivos y por causa de muerte, tanto } \\
\text { gratuitos como onerosos, si no se ha pactado de otro modo. } \\
\text { 2. El derecho de vuelo y la propiedad del inmueble preexistente son } \\
\text { hipotecables y gravables en la medida en que son enajenables. }\end{array}$ \\
\hline
\end{tabular}


Código Civil, art. 1.510-B. É expressamente vedado ao titular da laje prejudicar com obras novas ou com falta de reparação a segurança, a linha arquitetônica ou o arranjo estético do edifício, observadas as posturas previstas em legislação local.

Código Civil, art. 1.510-C. Sem prejuízo, no que couber, das normas aplicáveis aos condomínios edilícios, para fins do direito real de laje, as despesas necessárias à conservação e fruição das partes que sirvam a todo o edifício e ao pagamento de serviços de interesse comum serão partilhadas entre o proprietário da construção-base e o titular da laje, na proporção que venha a ser estipulada em contrato.

$\int 1^{\circ}$ São partes que servem a todo o edifício:

I - os alicerces, colunas, pilares, paredes-mestras e todas as partes restantes que constituam a estrutura do prédio;

II - o telhado ou os terraços de cobertura, ainda que destinados ao uso exclusivo do titular da laje;

III - as instalações gerais de água, esgoto, eletricidade, aquecimento, ar-condicionado, gás, comunicações e semelhantes que sirvam a todo o edifício; e

IV - em geral, as coisas que sejam afetadas ao uso de todo o edifício.

$\int 2^{\circ}$ É assegurado, em qualquer caso, o direito de qualquer interessado em promover reparações urgentes na construção na forma do parágrafo único do art. 249 desse Código.

\section{Artículo 567-5. Ejercicio.}

1. Se faculta a los titulares del derecho de vuelo para edificar a su cargo de acuerdo con el título de constitución, con el proyecto y con las licencias administrativas que corresponden. Los titulares del derecho de vuelo deben dotar el conjunto del edificio de la seguridad y los elementos exigibles por la normativa de la edificación y, si procede, de la vivienda.

2. La construcción debe hacerse de la forma que cause menos molestias a los propietarios u ocupantes de las plantas o edificios preexistentes. Los titulares del derecho de vuelo deben indemnizar a dichos propietarios $u$ ocupantes por los perjuicios que les causen durante la construcción.

3. El titular o la titular del derecho de vuelo hace suyos, con pleno dominio, los elementos privativos situados en las plantas o edificios que resultan del mismo, puede otorgar solo y a su cargo la declaración o ampliación de obra nueva, modificando la descripción del edificio preexistente si es preciso, y, si se ha pactado, puede establecer el régimen de propiedad horizontal.

4. Los titulares del inmueble preexistente sobre el que se constituyó el derecho de vuelo mantienen la propiedad de los elementos privativos situados en las plantas o edificios que ya existian al constituirse el derecho. 
Código Civil, art. 1.510-E. A ruína da construçãobase implica extinção do direito real de laje, salvo:

I - se este tiver sido instituído sobre o subsolo;

II - se a construção-base não for reconstruída no

Parágrafo único. $\mathrm{O}$ disposto neste artigo não afasta o direito a eventual reparação civil contra o culpado pela ruína. prazo de cinco anos.

\section{Artículo 567-6. Extinción.}

1. El derecho de vuelo se extingue por las causas generales de extinción de los derechos reales y, además, por las siguientes causas:

a) Por falta de finalización de las obras de nueva construcción en el plazo fijado, en la parte no construida. Sin embargo, si al vencer el plazo la edificación se ha iniciado, el derecho se entiende prorrogado por el tiempo que la licencia de obras prevé para la finalización, siempre y cuando la escritura de declaración o de ampliación de obra nueva se haya presentado en el Registro de la Propiedad dentro del plazo.

b) Por una modificación de la normativa urbanistica que comporte la imposibilidad de edificar las plantas o edificios convenidos. Si la normativa solo impide parcialmente la construcción, el derecho se mantiene dentro de los limites posibles, y su titular puede modificar las construcciones previstas sin necesidad de consentimiento de los propietarios del inmueble si se ajusta al nuevo planeamiento urbanístico y lo acredita con las certificaciones técnicas y administrativas correspondientes.

2. El derecho de vuelo no se extingue por destrucción del edificio sobre el que recae.

3. Los titulares del derecho de vuelo, si como consecuencia del planeamiento urbanistico el edificio sobre el que recae es subrogado por un solar edificable, deben tener en el nuevo solar una parte del volumen edificable proporcional a la que les correspondía en la finca reemplazada.

\section{Fonte: os autores}

Além disso, o Código Civil catalão, que consagra, expressamente, o princípio da função social da propriedade, ${ }^{52}$ estabelece, no artigo 553.13 do Livro V, que trata do regime jurídico da propriedade horizontal, que o direito reservado para sobre-elevar ou subedificar que se constitua em favor dos constituintes ou de terceiros é válida e que se pode outorgar as sucessivas declarações de obra nova redistribuindo as cotas de participação, nos seguintes termos:

Artículo 553-13. Constitución y reserva del derecho de vuelo.

1. La constitución o la reserva expresa del derecho para sobreelevar, subedificar o edificar en el mismo solar del inmueble a favor de los constituyentes o de terceras personas es válida si la establece el título de constitución del régimen de propiedad horizontal.

2. Los titulares del derecho de vuelo están facultades para edificar a su cargo de acuerdo con el título de constitución del derecho, para hacer suyos los elementos privativos que resultan de él y para otorgar, solos y a su cargo, las correspondientes declaraciones o ampliaciones de obra nueva y, si se ha previsto al constituir el régimen o el derecho, la modificación de la división horizontal. El ejercicio sucesivo del derecho con la construcción de la nueva edificación supone la redistribución de las cuotas de participación, que llevan a cabo los titulares de los derechos reservados de acuerdo con el presente código y con el título de constitución, sin necesidad del consentimiento de la junta de propietarios.

3. La constitución o la reserva a que se refiere el apartado 1 solo es válida si consta en una cláusula específica y el derecho se constituye de acuerdo con el artículo 567-2.

52 Artículo 541-2. Función social. Las facultades que otorga el derecho de propiedad se ejercen, de acuerdo con su función social, dentro de los límites y con las restricciones establecidas por las leyes. 


\section{Dificuldades E Dicotomias}

Afirmou-se, ao longo deste artigo, a autonomia e especificidade jurídicas do direito de laje frente aos demais direitos reais com ele semelhantes. Cumpre, ainda, determinar suas distinções práticas, com destaque para os documentos e atos a serem apresentados/realizados no registro de imóveis.

Com efeito, "a propriedade deve ser analisada no seu aspecto funcional, tendo como finalidade precípua dar efetividade ao princípio da dignidade da pessoa humana", nesse sentido, deve-se garantir o acesso da população em geral a esse direito ${ }^{53}$. É preciso reverter o fato de que "grande parte da população brasileira reside à margem da lei" ${ }^{\text {. }}$. Nessa perspectiva, surge o direito de laje, diante da constatação de que "a regra na periferia é a casa crescer para acolher filhos e filhas que se casam" 55 . A implementação do direito representa "desobstrução das veias estatais no sentido de dar cumprimento e efetividade" à função social e à previsão do direito fundamental de moradia ${ }^{56}$. Para que a nova regulação tenha êxito, todavia, é indispensável um olhar acolhedor ao instituto, sobretudo, da parte dos ofícios de imóveis, para que não venham a dele exigir, em sua constituição, os mesmos documentos e formalidades do condomínio edilício - o que o tornaria incapaz de efetivar todas as suas potencialidades em termos de regularização fundiária.

Por isso entende-se que, no Brasil, pela própria configuração do direito real de laje, não se deve aplicar entendimento semelhante ao disposto no art. $1526^{\circ}$ do Código Civil português, segundo o qual o direito de construir sobre edifício alheio se sujeita às limitações impostas à constituição da propriedade horizontal. Se assim fosse, não haveria necessidade de se regular o direito de laje, que, evidentemente, consiste em forma de construção menos complexa que o condomínio edilício, desafiando, como tal, documentação menos extensa.

De fato, a instituição de condomínio edilício depende de uma série de documentos próprios, como a planta e o projeto aprovados pelo órgão administrativo responsável; o instrumento de instituição e especificação de condomínio; Anotação de Responsabilidade Técnica (ART) ou Registro de Responsabilidade Técnica (RRT) relativamente ao projeto arquitetônico como um todo e aos cálculos correspondentes; preenchimento dos quadros da ABNT relativos a toda a obra, conforme NBR 12.721/2006 - Versão Corrigida 2:2007; entre outros. Assim, a regularização de cada unidade depende, indissociavelmente, da regularização de toda a edificação, não sendo possível que um só titular regularize a sua situação, independentemente da vontade dos demais.

No direito de laje, ao revés, é possível (e mesmo pressuposta) a regularização em separado. Não resta dúvida, porém, que o novo direito foi concebido para regularizar situações de fato envolvendo população de baixa renda, não podendo nem devendo ser usado por grandes empreendedores como "válvula de escape das rigorosas regras do condomínio edilício (art. 1.331 e seguintes) ou do negócio complexo de incorporação imobiliária (L. 4.591/64) " ${ }^{57}$.

Deveras, no direito de laje, a regularização do pavimento posterior depende da averbação da construção-base, já que a própria definição do direito de laje, estabelecida no art. 1.510-A do Código Civil, pressupõe a existência jurídica da primeira edificação. Caso contrário, por certo não haveria "laje", ao menos em sentido sobreposto.

53 CARVALHO, Eusébio. Direito à propriedade. Do discurso à realidade. In: FARIAS, Cristiano Chaves de (Org.). Leituras complementares de direito civil: o direito civil-constitucional em concreto. 2. ed. Salvador: JusPodivm, 2009. p. 288-295.

54 CARMONA, Paulo Afonso Cavichioli. Curso de direito urbanístico. Salvador: Jus Podivm; Brasília: Fundação Escola Superior do Ministério Público do Distrito Federal e Territórios, 2015. p. 354.

55 NALINI, José Renato. Direitos que a cidade esqueceu. São Paulo: Revista dos Tribunais, 2011. p. 96.

56 TESHIMA, Márcia; PONA, Everton Willian. Do direito de laje: uma visão mitigada do direito de propriedade ao direito de moradia. Argumentum: Estado, Democracia Econômica e Políticas Públicas, Marília: UNIMAR, v. 12, p. 71-72, 2011.

57 LOUREIRO, Francisco Eduardo. Direito de superficie e laje, 2017. Disponível em: < http://iregistradores.org.br/direito-de-superficie-e-laje/>. Acesso em: 19 jul. 2017. 
A exemplo do que ocorre com o direito de superfície, entende-se que, também, o direito de laje possui estrutura plástica, existindo três momentos possíveis na relação de laje: o direito real de construir sobre ou sob construção alheia; a propriedade separada, efeito da concreção do direito real de construir; e a propriedade separada, efeito da alienação que o titular da construção-base faz a outrem da construção já existente, reservando-se a edificação erigida no térreo; ou ainda por efeito da alienação separada que o proprietário faz a duas pessoas, transferindo a uma a construção-base e a outra a laje sobreposta ou sotoposta — o que poderá, inclusive, efetuar por testamento, para depois de sua morte. Nesse último caso (venda com reserva da edificação térrea ou alienação separada das construções sobrepostas ou sotopostas), haverá propriedade separada por cisãa ${ }^{58}$. Pode-se, ainda, imaginar a situação de um prédio existente e objeto de condomínio civil convencional, em que os proprietários decidam pela extinção do condomínio tradicional, "pelo regime de propriedades horizontais sotopostas ou sobrepostas" $" 59$.

Nas últimas três hipóteses aventadas, em que há alienação com reserva, alienação para proprietários distintos ou extinção de condomínio, é pressuposto da lavratura do instrumento de constituição de direito de laje a averbação, também, da construção sobreposta ou sotoposta. Nesse caso, a questão da regularidade da edificação é prévia à constituição da laje. E, nos casos de alienação, será mais fácil ao município (vendas), ao Estado (doações ou transmissões causa mortis) e ao Distrito Federal determinar o elemento quantitativo da regra-matriz de incidência do imposto de transmissão.

A transferência ou atribuição das unidades (construção-base e lajes) exigirá escritura pública se o valor superar o montante de trinta salários mínimos, nos termos do art. 108 do Código Civil. No caso da instituição de condomínio edilício, a regra é a não exigência de escritura e a admissão de instrumento particular, pois não se trata de efetiva constituição, extinção ou transferência de direito real, mas apenas afetação a determinado regime jurídico ${ }^{60}$; paralelamente, todavia, a instituição de condomínio, também, exige escritura pública, quando haja atribuição de unidades em favor dos condôminos, na forma do art. 196, $\ 4^{\circ}$, do Provimento Geral da Corregedoria de Justiça do Distrito Federal ${ }^{61}$.

Os atos registrais serão, apenas, os seguintes: após a averbação da construção do segundo pavimento, na forma do art. 167, inciso II, item 4, da Lei 6.015 de 1973 —-mediante a apresentação de requerimento do proprietário, com firmas reconhecidas e "habite-se" ou documento equivalente (art. 246, \ $1^{\circ}$, do mesmo diploma legal), acompanhados de Certidão Negativa de Débito (CND) previdenciário da obra de construção civil (art. 47, inciso II, da Lei 8.212 de 24 de julho de 1991) ou de declaração de dispensa (art. 47, \ $6^{\circ}$, “c"; art. 47, \ 6" "e" da Lei 8.212 de 1991; ou art. 370, inciso I, da Instrução Normativa RFB 971 de 13 de novembro de 2009), bem como, a depender das normas da Corregedoria local, do certificado de responsabilidade técnica (ART ou RRT) —, será necessário averbar a cessão do direito de laje na matrícula do imóvel de origem - exigindo-se, para tanto, "medição e representação gráfica do terreno e da edificação", bem como esclarecimentos sobre as formas de acesso às unidades, devendo ser apresentados plantas e memorial aprovados no órgão administrativo competente, provando que "a estrutura das construções é calculada de forma a oferecer segurança para o número de pisos que se deseja registrar" ${ }^{62}$, bem como contrato em que se constitua direito de passagem com a transferência da laje (servidão sobre a construção-base, conforme art. 1.378 do Código Civil). Na averbação, deverá constar remissão ao número da nova matrícula da unidade

58 LIRA, Ricardo Pereira. Liberdade e direito à terra. Revista Direito Administrativo, Rio de Janeiro, n. 143, p. 19, jan./mar. 1981.

59 CAMArgo, Marco Antonio de Oliveira. Direito de laje: explicando para quem quer entender, 2017. Disponível em: <http:// www.notariado.org.br/index.php?pG=X19leGliZV9ub3RpY2lhcw==\&in=OTA2MQ==>. Acesso em: 12 jul. 2017.

$60{ }^{60}$ INSTITUTO DE REGISTRO IMOBILIÁRIO DO BRASIL (IRIB). Incorporação imobiliária: casas geminadas. Convenção de condomínio, 2016. Disponível em: <http://www.irib.org.br/noticias/detalhes/incorporacao-imobiliaria-casas-geminadas-convencao-de-condominio >. Acesso em: 19 jul. 2017.

61 DiSTRITO FEDERAL. Provimento Geral da Corregedoria de Justiça, de 7 de janeiro de 2014. Disponível em: < http://www. tjdft.jus.br/publicacoes/provimento-geral-da-corregedoria-aplicado-aos-servicos-notariais-e-de-registro/ProvimentoGeralNotrioseRegistradores.pdf>. Acesso em: 19 jul. 2017.

62 WEINGARTEN, Marcelo; CYMBALISTA, Renato. Direito de laje: desafios, 2017. Disponível em: < http://sites.usp.br/outrosurbanismos/direito-de-laje-2/>. Acesso em: 19 jul. 2017. 
autônoma, cuja abertura deve ser promovida (art. 176, \9 9 , da Lei 6.015 de 1973). Nessa nova matrícula, é que deverá ser registrada a transferência da nova unidade. Descreveu-se, assim, a forma de inscrição da modalidade de constituição do direito de laje por cisão — admitida, ao menos em relação ao direito de superfície, pelo Enunciado 250 da III Jornada de Direito Civil ${ }^{63}$.

De outra parte, nas duas primeiras hipóteses, de constituição do direito real de construir; e de fixação de propriedade separada, por efeito da concreção do direito de construção, torna-se imperiosa a determinação sobre quais os documentos a serem exigidos do interessado, quando de sua entrada no registro de imóveis.

Sobre o tema, Carlos Eduardo Elias de Oliveira entende não haver obstáculo ao registro do "ato constitutivo do direito real de laje sem prévia autorização do município, pois a mera instituição de um direito real de laje não significa que haverá a realização de construção efetiva”; para justificar seu posicionamento, ressalta o fato de que o registro do direito de superfície não reclama prévia autorização municipal ${ }^{64}$. Entende-se, porém, que as situações são deveras distintas para reclamar igual tratamento. No direito de superfície, ao menos em sua conformação legal, não há nada construído sobre o solo, não havendo qualquer problema em se constituir o direito, para que, mais tarde, o superficiário obtenha, do poder público, as diretrizes para o aproveitamento do terreno. Por outro lado, o direito de laje pressupõe a possibilidade de manutenção de unidade distinta daquela originalmente construída sobre o solo (art. 1.510-A), ou seja, pressupõe a construção sobre outra edificação já existente. Para a configuração dessa viabilidade de edificar, é imperioso que a autoridade administrativa competente se manifeste sobre a capacidade da estrutura construída para receber nova construção.

Por isso se entende como indispensável exigência não apenas o "habite-se" averbado para a edificação que suportará o direito de laje; como também a apresentação de alvará de construção ou certidão da Prefeitura ou Governo do Distrito Federal, que atestem a viabilidade de levantamento de nova edificação sobreposta ou sotoposta à construção-base. É, ainda, necessário apresentar o contrato referido no art. 1.510-C, caput, in fine, do Código Civil, espécie de "convenção de condomínio" que irá dispor sobre a proporção em que cada um concorrerá nas despesas de conservação e fruição das partes que sirvam a todo o edifício e no pagamento de serviços de interesse comum. Quanto a esse contrato, considera-se recomendável seu registro no Livro 3 (Registro Auxiliar) da serventia imobiliária, a exemplo do que ocorre com a convenção de condomínio (art. 178, inciso III, da Lei 6.015 de 1973), para que não venha futuro comprador alegar desconhecimento de seus termos. Para se efetuar o registro desse contrato, pode-se utilizar a previsão do art. 178, inciso VII, da Lei de Registros Públicos, que autoriza o registro, a requerimento do interessado, dos títulos que forem registrados no Livro 2 , no seu inteiro teor.

Quanto aos atos registrais exigíveis, deve ser promovida a averbação da cessão do direito de laje, mediante apresentação do alvará de construção ou certidão (art. 176, \ $9^{\circ}$, da Lei 6.015 de 1973); posteriormente, deve ser averbada a construção do segundo pavimento, com menção expressa ao número de sua nova matrícula, para fins de remissão recíproca - nesse caso, a averbação da construção dependerá de todos os documentos normalmente necessários, acompanhados das plantas e do memorial aprovados, nos quais esteja especializada a nova unidade, bem como do instrumento de constituição da servidão de passagem. Nessa hipótese, a abertura da matrícula será feita em nome do novo proprietário, constando, como registro anterior, o número da matrícula da construção-base.

Por óbvio, no âmbito das favelas, a aplicação do disposto sobre o registro do direito de laje deverá ser precedida da devida regularização fundiária urbana de interesse social (Reurb-S), promovendo-se a legitimação fundiária, pela qual se admite a aquisição originária de propriedade de área pública ou privada, na forma do art. 23 da Lei 13.465 de 2017. Isso porque, na maior parte dos casos, a construção sobre a qual a laje foi

63 BRASIL. Conselho da Justiça Federal. III Jornada de Direito Civil: Enunciado 250. Disponível em: <http://www.cjf.jus.br/ enunciados/enunciado/487>. Acesso em: 13 jul. 2017.

64 OLIVEIRA, Carlos Eduardo Elias de. Direito real de laje à luz da Lei nº 13.465, de 2017: nova lei, nova hermenêutica, 2017. p. 8-9. Disponível em: <https://www12.senado.leg.br/publicacoes/estudos-legislativos/tipos-de-estudos/textos-para-discussao/td238>. Acesso em: 12 jul. 2017. 
edificada consiste em terreno invadido ou patrimônio público ${ }^{65}$.

Todo o até aqui exposto consiste em impressões iniciais sobre as concepções civis e o sistema registral a ser desenvolvidos, a partir do exame e interpretação das novas normas. Ressalte-se que, como aqui compreendido, o direito de laje é um regime jurídico, um modo de constituição de unidades autônomas, existente ao lado da instituição de condomínio edilício.

\section{Considerações Finais}

Viu-se que o direito de laje consiste em novo direito real introduzido pela edição da Lei 13.465 de 2017. Pelas disposições normativas editadas, fica evidente a intenção legislativa de discipliná-lo como direito autônomo.

Em vista do exposto, procurou-se, ao longo do trabalho, estabelecer distinções entre o direito de laje e outros direitos reais análogos, como o direito de superfície civil, a superfície urbanística e o regime jurídico do condomínio edilício.

Afirmou-se que o direito de laje se diferencia do condomínio edilício na medida em que este pode dar azo à existência de inúmeras unidades por pavimento, bem como maior número de equipamentos e partes de uso comum, ao passo que o direito de laje somente se coaduna com edificações mais singelas, soerguidas sobre construções-base cujas fundações não foram preparadas para construções mais elaboradas.

Verificou-se, também, que, no direito de laje, o telhado ou terraços de cobertura presumem-se destinados ao uso exclusivo; e há direito de preferência na aquisição — regras que não se repetem para o condomínio edilício. No entanto, apontou-se como principal distinção o fato de que os condomínios edilícios exigem a existência de fração ideal do solo e das partes comuns, vinculada à unidade autônoma; ao passo que, na disciplina do direito de laje, há expressa vedação a atribuição de frações ideais.

Salientou-se que o direito de laje constitui propriedade plena e perpétua, ao passo que a superfície civil resulta em propriedade resolúvel, necessariamente temporária; em razão dessa distinção, o direito real de laje enseja a abertura de matrícula para a unidade autônoma, ao contrário da superfície, que é simplesmente registrada na matrícula do fundeiro.

Destacou-se, ainda, que, enquanto na superfície, poderá haver resolução do direito caso o superficiário dê ao terreno destinação diversa daquela para qual foi concedida; no direito de superfície, isso não é possível, resolvendo-se o caso por analogia às normas do condomínio edilício ou por aplicação do direito de vizinhança.

Do mesmo modo, mereceu destaque o fato de a superfície civil, pela lógica tributária, implicar base de cálculo menor, por ensejar, apenas, propriedade resolúvel; de outra parte, defendeu-se, em relação à laje, a aplicação do valor "cheio" do potencial construtivo negociado ou do imóvel levantado sobre a construção-base.

Notou-se que, enquanto na superfície urbanística, passível de ser instituída por prazo indeterminado, a possibilidade de resolução, após prazo compatível com os investimentos, é da sua natureza; no direito de laje, a propriedade tende à perpetuidade. Viu-se, também, que o $\ 3^{\circ}$ do art. 21 da Lei 10.257 de 2001 determina ao superficiário urbanístico que suporte, proporcionalmente à sua parcela de ocupação efetiva,

65 CORRÊA, Cláudia Franco; MENEZES, Juliana Barcellos da Cunha e. A regularização fundiária nas favelas nos casos de "direito de laje": construindo pontes entre o direito inoficial e o direito vigente. In: SALEME, Edson Ricardo; ARAÚJO, Ludmila Albuquerque Douettes; Ó CATÃO, Marcone do (Coord.). Direito urbanistico, cidade e alteridade. Florianópolis: CONPEDI, 2016, p. 93. Disponível em: <https://www.conpedi.org.br/publicacoes/y0ii48h0/929a805v/1P20biS8TwWoxxf8.pdf>. Acesso em: 19 jul. 2017. 
parte dos encargos e tributos sobre a área objeto da concessão, ressalvada a possibilidade de disposição em contrário no contrato firmado pelas partes; essa previsão não se compatibiliza, como visto, com o direito de laje, em que cada proprietário arca com suas próprias incidências fiscais.

Assentou-se, ainda, a inspiração e as similitudes do direito real de laje com o derecho de vuelo ou sobre edificación, previstos na legislação espanhola e catalã.

Por fim, afirmou-se a necessidade de exigências mais simples para a inscrição do direito de laje, em face do condomínio edilício, no âmbito dos registros de imóveis, sob pena de inutilidade do instituto. Nesse sentido, foram apresentadas algumas sugestões e alternativas para qualificação e inscrição no registro imobiliário.

\section{REFERÊNCIAS BIBLIOGRÁFICAS}

ALBUQUERQUE JÚNIOR, Roberto Paulino de. O direito de laje não é um novo direito real, mas um direito de superficie, 2017. Disponível em: <http://www.conjur.com.br/2017-jan-02/direito-laje-nao-direito-real-direitosuperficie>. Acesso em: 11 jul. 2017.

ALVIM NETO, José Manuel de Arruda; CLÁPIS, Alexandre Laizo; CAMBLER, Everaldo Augusto (Coord.). Lei de registros públicos comentada. Rio de Janeiro: Forense, 2014.

BRASIL. Conselho da Justiça Federal. I Jornada de Direito Civil: Enunciado 93. Disponível em: < http:/ /www. cjf.jus.br/enunciados/enunciado/725>. Acesso em: 14 jul. 2017.

BRASIL. Conselho da Justiça Federal. I Jornada de Direito Civil: Enunciado 94. Disponível em: < http://www. cjf.jus.br/enunciados/enunciado/726>. Acesso em: 16 jul. 2017.

BRASIL. Conselho da Justiça Federal. III Jornada de Direito Civil: Enunciado 250. Disponível em: <http:// www.cjf.jus.br/enunciados/enunciado/487>. Acesso em: 13 jul. 2017.

BRASIL. Conselho da Justiça Federal. VI Jornada de Direito Civil: Enunciado 568. Disponível em: <http:// www.cjf.jus.br/enunciados/enunciado/639>. Acesso em: 13 jul. 2017.

BRASIL. Exposição de Motivos 00020/2016 MCidades MP CCPR. Brasilia, DF, 21 dez. 2016. Disponível em: <http://www.planalto.gov.br/ccivil_03/_ato2015-2018/2016/Exm/Exm-MP\%20759-16.pdf>. Acesso em: 10 jul. 2017.

BRASIL. Supremo Tribunal Federal. Recurso Extraordinário com Agravo 982.808. Recorrente: REP Participações Ltda. Recorrido: Município de São Paulo. Relator: Gilmar Mendes. Brasília - DF, 15 de agosto de 2016. Diário de Justiça Eletrônico, n. 176, 19 ago. 2016.

CAMARGO, Estela L. Monteiro Soares de. Direito de superfície. In: TUTIKIAN, Cláudia Fonseca; TIMM, Luciano Benetti; PAIVA, João Pedro Lamana (Org.). Novo direito imobiliário e registral. 2. ed. São Paulo: Quartier Latin, 2010.

CAMARgO, Marco Antonio de Oliveira. Direito de laje: explicando para quem quer entender, 2017. Disponível em: <http://www.notariado.org.br/index.php?pG=X19leGliZV9ub3RpY2lhcw==\&in=OTA2 $\mathrm{MQ}==>$. Acesso em: 12 jul. 2017.

CARMONA, Paulo Afonso Cavichioli. Curso de direito urbanístico. Salvador: Jus Podivm; Brasília: Fundação Escola Superior do Ministério Público do Distrito Federal e Territórios, 2015.

CARVALHO, Afrânio de. Registro de imóveis: comentários ao sistema de registro em face da Lei $\mathrm{n}^{\circ}$ 6.015, de 1973, com as alterações da Lei no 6.216, de 1975, Lei no 8.009, de 29.03.1990, e Lei no 8.935, de 18.11.1994.

4. ed. Rio de Janeiro: Forense, 1997. 
CARVALHO, Eusébio. Direito à propriedade. Do discurso à realidade. In: FARIAS, Cristiano Chaves de (Org.). Leituras complementares de direito civil: o direito civil-constitucional em concreto. 2. ed. Salvador: JusPodivm, 2009.

CENEVIVA, Walter. Lei dos registros públicos comentada. 20. ed. São Paulo: Saraiva, 2010.

CONSELHO DE ARQUITETURA E URBANISMO (CAU/BR). Entidades denunciam inconstitucionalidade da MP 759, 2017. Disponível em: <http://www.fna.org.br/entidades-denunciam-inconstitucionalidade-damp-759/>. Acesso em: 12 jul. 2017.

CORRÊA, Cláudia Franco; MENEZES, Juliana Barcellos da Cunha e. A regularização fundiária nas favelas nos casos de "direito de laje": construindo pontes entre o direito inoficial e o direito vigente. In: SALEME, Edson Ricardo; ARAÚJO, Ludmila Albuquerque Douettes; Ó CATÃO, Marcone do (Coord.). Direito urbanistico, cidade e alteridade. Florianópolis: CONPEDI, 2016. Disponível em: <https://www.conpedi.org.br/ publicacoes/y0ii48h0/929a805v/1P20biS8TwWoxxf8.pdf>. Acesso em: 19 jul. 2017.

DI PIETRO, Maria Sylvia Zanella. Direito de superfície. In: DALLARI, Adilson Abreu; FERRAZ, Sérgio (Coord.). Estatuto da Cidade: comentários à Lei Federal 10.257/2001. 4. ed. São Paulo: Malheiros, 2014.

DISTRITO FEDERAL. Provimento Geral da Corregedoria de Justiça, de 7 de janeiro de 2014. Disponível em: <http://www.tjdft.jus.br/publicacoes/ provimento-geral-da-corregedoria-aplicado-aos-servicos-notariaise-de-registro/ProvimentoGeralNotrioseRegistradores.pdf>. Acesso em: 19 jul. 2017.

FARIAS, Cristiano Chaves de. Direito real da laje: novidade de fim de ano no direito civil brasileiro, 2017. Disponível em: <https://www.cers.com.br/noticias-e-blogs/noticia/direito-real-da-laje-novidade-de-fimde-ano-no-direito-civil-brasileiro->. Acesso em: 10 jul. 2017.

FARIAS, Cristiano Chaves de; ROSENVALD, Nelson. Curso de direito civil: reais. 11. ed. São Paulo: Atlas, 2015. v. 5.

FERRAZ JÚNIOR, Tércio Sampaio. Introdução ao estudo do Direito: técnica, decisão, dominação. 46. ed. São Paulo: Atlas, 2003.

INSTITUTO BRASILEIRO DE DIREITO TRIBUTÁRIO (IBDT). Mesa de debates, 1 jun. 2006. Disponível em: <http://www.ibdt.com.br/2006/integra_01062006.htm>. Acesso em: 16 jul. 2017.

INSTITUTO DE REGISTRO IMOBILIÁRIO DO BRASIL (IRIB). Incorporação imobiliária: casas geminadas. Convenção de condomínio, 2016. Disponível em: <http://www.irib.org.br/noticias/detalhes/incorporacao-imobiliaria-casas-geminadas-convencao-de-condominio>. Acesso em: 19 jul. 2017.

LARENZ, Karl. Metodologia da ciência do Direito. Tradução de: José Lamego. 7. ed. Lisboa: Fundação Calouste Gulbenkian, 2014.

LIMA, Frederico Henrique Viegas de. O direito de superfície como instrumento de planificação urbana. Rio de Janeiro: Renovar, 2005.

LIRA, Ricardo Pereira. Liberdade e direito à terra. Revista Direito Administrativo, Rio de Janeiro, n. 143, p. 1-36, jan./mar. 1981.

LIRA, Ricardo Pereira. O Direito de Superfície e o espaço aéreo. Revista Forense, n. , v. , p. 365, 2002.

LOUREIRO, Francisco Eduardo. Direito de superficie e laje, 2017. Disponível em: < http://iregistradores.org. br/direito-de-superficie-e-laje/>. Acesso em: 19 jul. 2017.

MAZZEI, Rodrigo Reis. O direito de superfície no ordenamento jurídico brasileiro. 2007. 406 f. Dissertação (Mestrado) - Direito das Relações Sociais, Pontifícia Universidade Católica de São Paulo, São Paulo, 2007.

MAZZEI, Rodrigo. Direito de superfície: breve comparativo entre o Código Civil e o Estatuto da Cidade. MPMG Jurídico, n. 20, p. 55-61, abr./maio/jun. 2010. Disponível em:<https:/ /aplicacao.mpmg.mp.br/xmlui/ 
bitstream/handle/123456789/458/Direito\%20de\%20superf\%C3\%ADcie_Mazzei.pdf?sequence=3 >. Acesso em: 17 jul. 2017.

NALINI, José Renato. Direitos que a cidade esqueceu. São Paulo: Revista dos Tribunais, 2011.

OLIVEIRA, Carlos Eduardo Elias de. Direito real de laje à luz da Lei n 13.465, de 2017: nova lei, nova hermenêutica, 2017. Disponível em: <https://www12.senado.leg.br/publicacoes/estudos-legislativos/tiposde-estudos/textos-para-discussao/td238>. Acesso em: 12 jul. 2017.

PELAZ, Jesús P. López. Derecho de Vuelo ¿Qué es y qué características tiene?, nov. 2016. Disponível em: <http:// www.abogadoamigo.com/derecho-de-vuelo/>. Acesso em: 23 jul. 2017.

PEREIRA, Caio Mário da Silva. Instituições de direito civil: direitos reais. 22. ed. Rio de Janeiro: Forense, 2014. v. 4.

PONTES DE MIRANDA, Francisco Cavalcanti. Tratado de Direito Privado: Parte Especial - Direito das Coisas: propriedade. São Paulo: Revista dos Tribunais, 2012. v. 9.

PORTUGAL. Código Civil, 1966. Disponível em: <http://www.pgdlisboa.pt/leis/lei_print_articulado. php?tabela=leis\&artigo_id=\&nid=775\&nversao=\&tabela=leis $>$. Acesso em: 13 jul. 2017.

RODRIGUES JUNIOR, Otavio Luiz. Um ano longo demais e seus impactos no Direito Civil Contemporâneo, 2016. Disponível em: < http://www.conjur.com.br/2016-dez-26/retrospectiva-2016-ano-longo-impactos-direitocivil-contemporaneo>. Acesso em: 11 jul. 2017.

SANTOS, Flauzilino Araújo dos. Condominios e incorporações no registro de imóveis: teoria e prática. São Paulo: Mirante, 2012.

STOLZE, Pablo. Direito real de laje: primeiras impressões, 2017. Disponível em: <https://jus.com.br/artigos/54931/direito-real-de-laje-primeiras-impressoes>. Acesso em: 11 jul. 2017.

TARTUCE, Flávio. Direito real de laje à luz da Lei no 13.465/2017: nova lei, nova hermenêutica. Disponível em: <https://flaviotartuce.jusbrasil.com.br/artigos/478460341/ direito-real-de-laje-a-luz-da-lei-n13465-2017-nova-lei-nova-hermeneutica>. Acesso em: 24 jul. 2017.

TEPEDINO, Gustavo José Mendes. Os direitos reais no novo Código Civil: Anais do "EMERJ Debate o Novo Código Civil”, 2002. Disponível em: <http://www.emerj.tjrj.jus.br/revistaemerj_online/edicoes/anais_ onovocodigocivil/anais_especial_2/Anais_Parte_II_revistaemerj_168.pdf>. Acesso em: 17 jul. 2017.

TESHIMA, Márcia; PONA, Everton Willian. Do direito de laje: uma visão mitigada do direito de propriedade ao direito de moradia. Argumentum: Estado, Democracia Econômica e Políticas Públicas, Marília: UNIMAR, v. 12, p. 45-76, 2011.

WEINGARTEN, Marcelo; CYMBALISTA, Renato. Direito de laje: desafios, 2017. Disponível em: <http:// sites.usp.br/outrosurbanismos/direito-de-laje-2/>. Acesso em: 19 jul. 2017. 


\section{REVISTA BRASILEIRA DE POLÍTICAS PÚBLICAS BRAZILIAN JOURNAL OF PUBLIC POLICY}
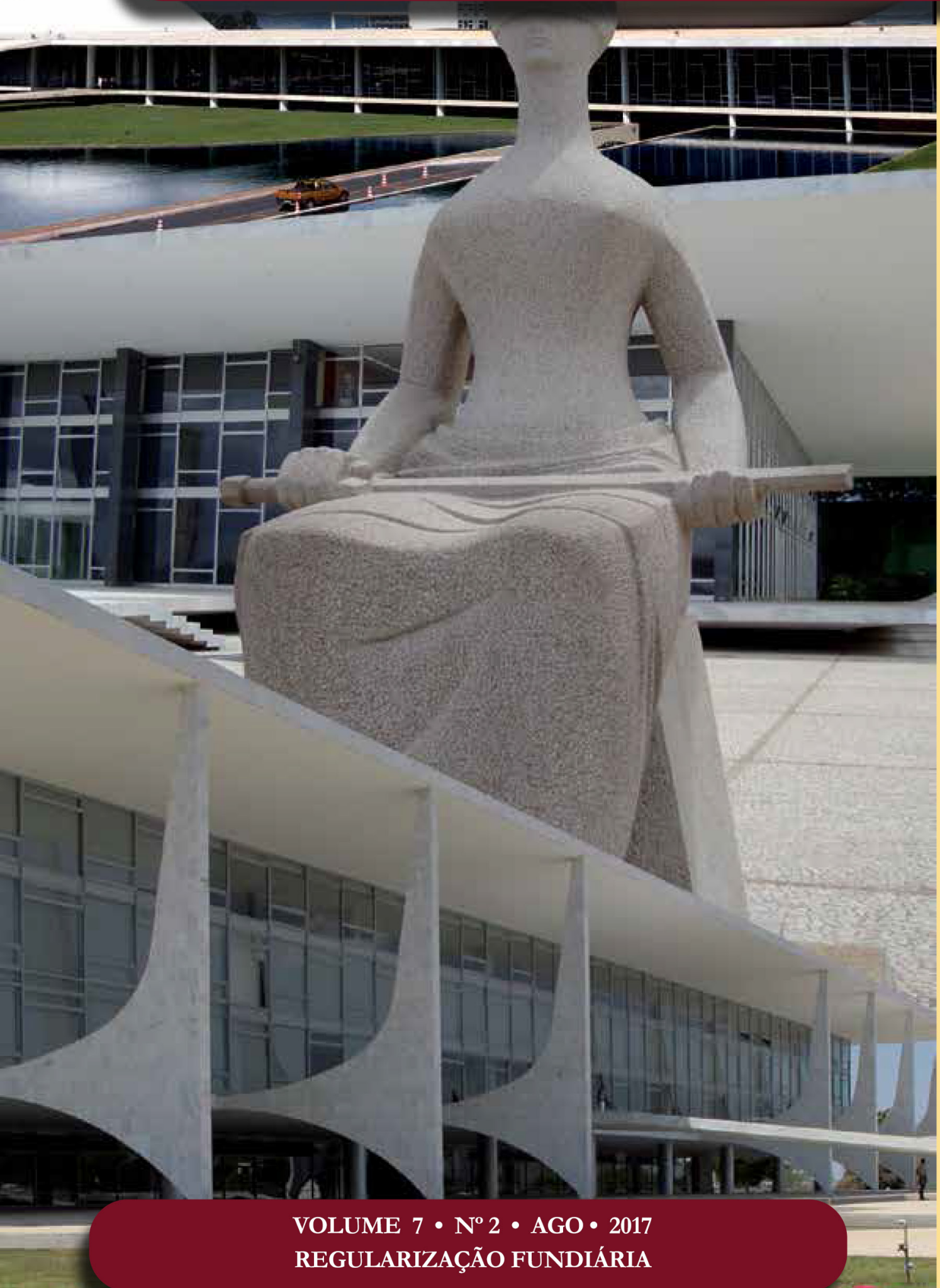

Interação entre a acessibilidade urbanística e o direito à cidade: possibilidade de inclusão social das pessoas com deficiência Interaction between urbanistic accessibility and the right to the city: possibility of social inclusion of persons with disabilities

Daniella Maria dos Santos Dias Domingos do Nascimento Nonato Raimundo Wilson Gama Raiol 


\section{Interação entre a acessibilidade urbanística e 0 direito à cidade: possibilidade de inclusão social das pessoas com deficiência*}

\section{Interaction between urbanistic accessibility and the right to the city: possibility of social inclusion of persons with disabilities}

* Recebido em 03/05/2017

Aprovado em 16/06/2017

** Possui graduação em Bacharel em Direito pela Universidade Federal do Pará (1991), Especialização em Direito Ambiental pela Universidade Federal do Pará (1993), Especialização em Educação Ambiental pela Universidade Federal do Pará (1996), Especialização em Direito Agrário pelo CESUPA (2011) e Doutorado em Direito pela Universidade Federal de Pernambuco (2001) e Investigação Pós-Doutoral na Universidade Carlos III de Madri na Espanha, junto ao Departamento de Direito Público Comparado e ao Instituto Pascual Madoz. Atualmente é Promotora de Justiça do Ministério Público do Estado do Pará e Professora da Universidade Federal do Pará (Graduação e PósGraduação).Email: diasdaniella@gmail.com

*** Licenciado Pleno e Bacharel em História pela Universidade Federal do Pará (UFPA). Bacharel em Direito pela UFPA. Especialista em Metodologia do Ensino de História. Especialista em Direito do Trabalho. Especialista em Educação Inclusiva. Especialista em Saberes Africanos e Afro-brasileiros na Amazônia: implementação da Lei 10.639/2003 (UFPA). Mestre em Direito com ênfase em Direitos Humanos pela UFPA. Doutorando em Direito com ênfase em Direitos Humanos junto à UFPA. Advogado (OAB/PA). Atua como pesquisador junto ao Grupo de Estudos e Pesquisas em Políticas Públicas e Direitos Humanos (GEP3DH), sob certificação do CNPq. Email: dnnonato@yahoo.com.br. Email: rwraiol@ gmail.com

**** Doutor em Direitos Fundamentais e Relações Sociais pela Universidade Federal do Pará. Professor Associado do Curso de Direito (Graduação e Pós-graduação) da mesma instituição. Membro da Academia Paraense de Letras Jurídicas. Advogado. Email: rwraiol@gmail. com
Daniella Maria dos Santos Dias**

Domingos do Nascimento Nonato***

Raimundo Wilson Gama Raiol****

\section{Resumo}

Depreende-se do texto constitucional o propósito de proteger e assegurar o exercício pleno e equitativo de todos os direitos humanos e liberdades fundamentais por todas as pessoas com deficiência. Desse modo, o presente artigo trata da relevância da acessibilidade urbanística, um dos instrumentos materiais determinantes e condicionantes da possibilidade de garantia de inclusão social dessas pessoas e que contribui, também, para a promoção da cidadania desse público e, em razão disso, ao exercício do direito à cidade. Objetiva-se tecer reflexões a respeito das condições para ter a referida acessibilidade, em virtude de sua necessidade para assegurar a efetivação de maior igualdade material ou de oportunidades, pois, dependendo das condições em que as barreiras físicas se apresentem, aliadas às barreiras atitudinais, propiciarão ou inviabilizarão o acesso e utilização de bens e serviços por todas as pessoas. À luz da ideia do direito à cidade e mediante análises de dispositivos constitucionais e infraconstitucionais, parte-se da hipótese de que a ausência das condições de acessibilidade urbanística interfere acintosamente no processo de inclusão social das pessoas com deficiência. Como ressonância dessa questão, o objeto de estudo perfaz-se na discussão bibliográfica e na análise da legislação pertinente sob a âncora da Constituição da República, com algumas ligeiras incursões nas realidades urbanas e rurais dos municípios de Abaetetuba, Igarapé-Miri e Moju/PA quanto à problemática relacionada à falta de acessibilidade urbanística, que representa uma grande ferramenta de igualdade de tratamento e de oportunidades, essencial ao exercício, inclusive, de outros direitos e garantias fundamentais.

Palavras-chave: Acessibilidade urbanística. Acessibilidade arquitetônica. Direito à cidade. Pessoas com deficiência. Inclusão Social.

\section{Abstract}

It appears from the constitutional text that the purpose is to protect and ensure the full and equitable exercise of all human rights and fundamental 
freedoms by all persons with disabilities. In this way, the present article deals with the relevance of urban accessibility, one of the material tools that determine and determine the possibility of guaranteeing the social inclusion of these people and also contributes to the promotion of citizenship of this public and, therefore, to the exercise Of the right to the city. It is intended to reflect on the conditions to have accessibility, due to its necessity to ensure greater equality of material or opportunities, because depending on the conditions in which the physical barriers present, together with the attitudinal barriers, will provide Or prevent access and use of goods and services by all persons. In the light of the idea of the right to the city and through analyzes of constitutional and infraconstitutional devices, it is assumed that the absence of conditions of urban accessibility makes an important difference in the process of social inclusion of people with disabilities. As a resonance of this question, the object of study is made in the bibliographical discussion and analysis of the pertinent legislation under the anchor of the Constitution of the Republic, with some slight incursions into the urban and rural realities of the municipalities of Abaetetuba, Igarapé-Miri and Moju/PA As regards the problem related to the lack of urban accessibility, which represents a great tool for equal treatment and opportunities, essential to the exercise of other fundamental rights and guarantees.

Keywords: Urban accessibility. Architectural accessibility. Right to the city. Disabled people. Social inclusion.

\section{Considerações InICIAIS}

As estatísticas oficiais demonstram que as cidades brasileiras obtiveram acentuado crescimento urbano, nos últimos anos, pois $84,36 \%$ da população brasileira vive nas cidades, segundo o Censo 2010 do Instituto Brasileiro de Geografia e Estatística - IBGE, como consequência de um modelo de urbanização intensivo, porém, extremamente excludente e desigual, causador de profunda segregação socioespacial e de espaços fragmentados. Mais do que expressarem diferenças socioeconômicas, tais desigualdades têm implicações nefastas na organização e no funcionamento socioespacial das cidades, sendo notório que, nestas, determinados segmentos populacionais, por vários fatores, encontram maiores dificuldades de acesso a bens e serviços.

O processo de urbanização acabou por excluir grande contingente populacional do acesso a bens e serviços públicos básicos, dentre estes a garantia de acessibilidade urbanística, que deve existir em termos de as pessoas com deficiência terem acesso, com plenitude e toda segurança, mediante eliminação de barreiras físico-estruturais, às edificações destinadas ao uso público, vias, praças e demais logradouros públicos e aos meios de transportes coletivos terrestres, marítimos e aéreos, como permite interpretar o art. $2^{\circ}$, I e II, a, b e c, da Lei no 10.098, de 19 de dezembro de 2000, o que pode ser compreendido, em última instância, como uma injustiça socioambiental, a despeito de que a cidade é o espaço onde a inclusão social deve ocorrer, o que torna necessário o planejamento e a implementação de ações pelo Poder Público com vistas a assegurarem o que se designa contemporaneamente de direito à cidade, ai inserido, à toda evidência, o direito à acessibilidade urbanística.

Em um universo cada vez mais urbano, identifica-se uma série de problemas de ordem socioambiental, sendo notório o crescimento desordenado das cidades, sem observar, dentre outras necessidades, a questão da acessibilidade. Sob pena de tornar o espaço urbano inviável do ponto de vista socioambiental, são necessárias inúmeras respostas do Poder Público a essa realidade, o que não significa que seja suficiente apenas a edição de normas jurídicas que garantam o direito à cidade sustentável como um direito fundamental e a tipificação do conceito de cidade sustentável, como consta do art. $2^{\circ}$, I, da Lei no 10.257 , de 10 de julho de 2001, denominada Estatuto da Cidade.

Sob o prisma contemporâneo das funções sociais da cidade, previstas no art. 182 da Constituição da Re- 
pública, quando trata do desenvolvimento urbano e, no art. $2^{\circ}$ do Estatuto da Cidade, o desafio é propiciar o acesso amplo e democrático de todas as pessoas ao exercício do direito à cidade, o que remete à constatação de que a garantia das condições de acessibilidade urbanística trata-se de uma questão de urgência, porque, dentre outros fatores, o Censo 2010, realizado pelo Instituto Brasileiro de Geografia e Estatística - IBGE, detectou que cerca de $23,9 \%$ (vinte e três vírgula nove por cento) da população brasileira apresenta, pelo menos, uma das deficiências investigadas. 38.473 .702 (trinta e oito milhões, quatrocentos e setenta e três e setecentas e duas) pessoas se encontravam em áreas urbanas e 7.132 .347 (sete milhões, cento e trinta e duas e trezentos e quarenta e sete), em áreas rurais.

Sabe-se que, para qualquer abordagem a respeito da categoria social e analítica designada pelo vocábulo deficiência, particularmente, por ser um campo de estudo em construção, e diante da necessidade de ressignificar a posição dessa categoria em relação à sociedade em geral, é importante ter a devida compreensão acerca das possíveis limitações, impedimentos e comprometimentos físico-orgânicos que as pessoas com deficiência apresentam, especialmente, quando em confronto com as inadequações das estruturas físicas e ambientais das cidades.

Em que pese a existência de abrangente legislação, é público e notório que as cidades brasileiras têm servido como ambientes que promovem segregações socioespaciais, apresentando conformações físicas inadequadas ou não são dotadas de infraestruturas adequadas, aí incluídas as vias públicas, as edificações coletivas e os sistemas de transportes públicos, representando verdadeira afronta a um direito humano e fundamental constitucionalmente garantido: a liberdade de locomoção.

Sob a égide do Estado Social e Democrático de Direito, mostra-se relevante, portanto, a eliminação de barreiras nas vias públicas, nos edifícios de uso comum e nos sistemas de transportes coletivos ou adaptações destes em atenção ao direito que as pessoas com deficiência têm de aproximação, alcance, locomoção e usufruto de bens, recursos, suportes, serviços e atividades disponíveis em igualdade de condições com as demais pessoas.

Nesse contexto, objetiva-se reconhecer a acessibilidade urbanística como condição necessária e instrumental à garantia da inclusão social da pessoa com deficiência à cidade, em observância aos valores constantes no texto constitucional brasileiro, dentre os quais, a igualdade, a dignidade humana e o próprio dever de inclusão disposto no texto constitucional. À luz da ideia do direito à cidade e mediante análises de dispositivos constitucionais e infraconstitucionais, vislumbra-se que a acessibilidade urbanística integra a concepção de justiça socioambiental. Nesse mirante, deslumbra-se que muitos dispositivos infraconstitucionais foram alterados ou surgiram sob inspiração da Convenção Sobre os Direitos das Pessoas com Deficiência, promulgada, no Brasil, pelo Decreto nº 6.949, de 25 de agosto de 2009, e pela recente Lei Brasileira de Inclusão da Pessoa com Deficiência - Estatuto da Pessoa com Deficiência e, também, da Lei no 12.587, de 03 de janeiro de 2012, Lei da Política Nacional de Mobilidade Urbana.

Parte-se da hipótese de que a ausência das condições de acessibilidade urbanística interfere, acintosamente, no possível processo de inclusão social das pessoas com deficiência. Como ressonância dessa questão, o objeto de estudo perfaz-se na discussão bibliográfica e na análise da legislação pertinente sob à âncora da Constituição da República, com algumas ligeiras incursões nas realidades urbanas e rurais dos municípios de Abaetetuba, Igarapé-Miri e Moju, integrantes da configuração geográfica do Estado do Pará, quanto à problemática relacionada à falta de acessibilidade urbanística.

A fundamentação do direito à acessibilidade urbanística põe em relevo a importância da existência de políticas públicas específicas, as quais podem contribuir para transformar a qualidade socioambiental nas cidades, com efeitos diretos sobre a vida da imensa maioria das pessoas com deficiência, principalmente. A escolha da acessibilidade como cenário de fundo deste estudo decorre do fato de corresponder a uma questão que diz respeito diretamente à afetação da qualidade de vida socioambiental, sabendo-se que é um dos pilares em que deve se apoiar qualquer política pública urbanística, além de ser plataforma ao exercício 
de outros direitos fundamentais sociais.

A pesquisa sobre a ausência ou insuficiência de condições de acessibilidade em espaços urbanos e rurais de cidades objeto de pesquisa empírica, no caso, os municípios de Abaetetuba, Igarapé-Miri e Moju, do território paraense, permitiu avaliar seus impactos no contexto das desconformidades socioambientais vivenciadas por significativa parcela de seus moradores, ressaltando-se os desafios a serem enfrentados pelas políticas públicas que busquem garantir o direito à cidade, de forma gradual, continua, integrada e, sobretudo, inclusiva.

\section{Pessoas com deficiência no Brasil: dados quantitativos e aspectos qualitativos}

O Censo 2010 realizado pelo Instituto Brasileiro de Geografia e Estatística (IBGE) detectou uma população total de 190.755 .799 habitantes, sen 45.606.048, ou seja, 23,9\% desse total possui, pelo menos, uma das deficiências investigadas ${ }^{1}$. Em relação a essas pessoas, 38.473 .702 se encontravam em áreas urbanas e 7.132.347, em áreas rurais. Vale ressaltar que as pessoas incluídas em mais de um tipo de deficiência foram contadas, apenas, uma vez. Além do grau de severidade, registrou-se que a deficiência foi classificada levando-se em consideração a autodeclaração das próprias pessoas com deficiência entrevistas sobre suas funcionalidades ${ }^{2}$. A prevalência da deficiência variou de acordo com a natureza de cada uma. A deficiência visual apresentou a maior ocorrência, afetando 18,8\% (dezoito vírgula oito por cento) da população brasileira. Em segundo lugar, está a deficiência motora, ocorrendo em 7\% (sete por cento) da população, seguida da deficiência auditiva, em 5,1\%, (cinquenta e um por cento) e da deficiência mental ou intelectual, em 1,4\% (quatorze por cento), conforme o gráfico a seguir:

\section{Proporção de pessoas com deficiência no Brasil, Censo IBGE, 2010}

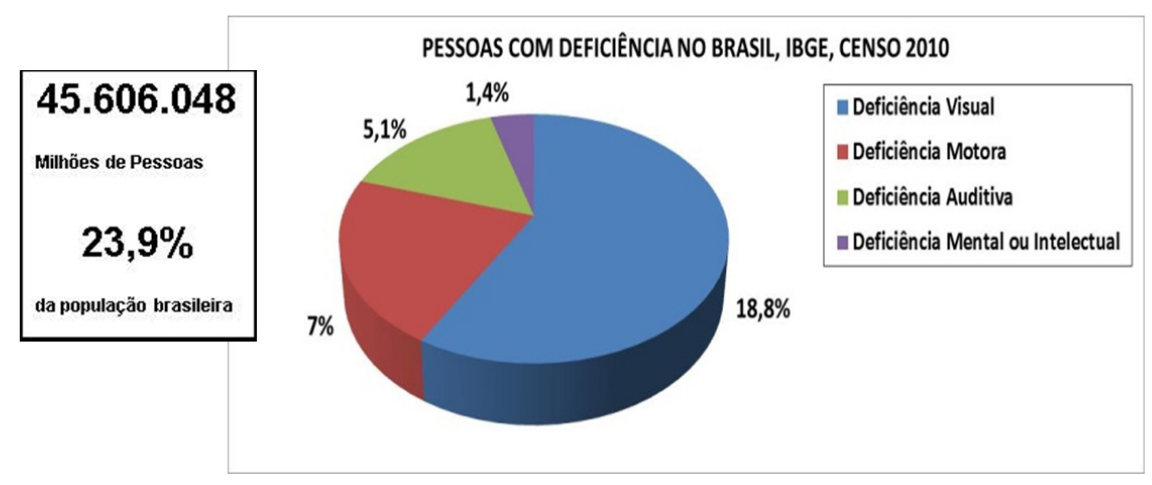

Fonte: IBGE, Censo 2010.

Observa-se que as pessoas com deficiência compõem uma parcela nada desprezível da população brasileira. Com esse expressivo contingente demográfico, aumenta a necessidade de promover ações políticas de inclusão social, como a garantia das condições de acessibilidade arquitetônica, posto que não se reporta neste artigo científico a um número ínfimo de brasileiros que vivem a situação de deficiência. Mais do que refletem as estatísticas, essa categoria social demanda uma melhor compreensão sobre quem são seus in-

1 No Censo de 2010, organizado pelo IBGE, as perguntas feitas aos entrevistados buscaram identificar as deficiências visual, auditiva e motora pelos seguintes graus de dificuldade: (i) tem alguma dificuldade em realizar; (ii) tem grande dificuldade e, (iii) não consegue realizar de modo algum; além da deficiência mental ou intelectual. IBGE. Cartilha do Censo 2010: Pessoas com Deficiência. Brasília: SDH-PR/SNPD, 2012. p. 5. Disponível em: <http://www.pessoacomdeficiencia.gov.br/app/sites/default/files/ publicacoes/cartilha-censo-2010-pessoas-com-deficienciareduzido.pdf>. Acesso em: 10 abr. 2017.

2 Informação extraída da Cartilha do Censo 2010 - Pessoas com Deficiência. Brasília: SDH-PR/SNPD, 2012. p. 5. Disponível em: <http://www.pessoacomdeficiencia.gov.br/app/sites/default/files/publicacoes/cartilha-censo-2010-pessoas-com-deficienciareduzido.pdf>. Acesso em: 10 abr. 2017. 
tegrantes, seus interesses e do que necessitam para a garantia de sua inclusão social. No intento de definir quem são essas pessoas, Raiol, assim, se manifesta:

A noção de quem são as pessoas com necessidades especiais demanda que sejam vistas não apenas pelo ângulo de suas diferenciações orgânicas (físicas, sensoriais ou mentais), em relação a outros seres humanos, mas também sob os prismas das estruturas físico-ambientais que não conseguem superar e das atitudes da sociedade. ${ }^{3}$

Quanto à identificação de quem são as pessoas em situação de deficiência, frisa-se a relevância da definição que prepondera, atualmente, em todo o mundo. Nessa esteira, em 2006, a Organização das Nações Unidas (ONU) aprovou a Convenção sobre Direitos das Pessoas com Deficiência (CDPD). Baseada no modelo social de deficiência, fundado nos direitos humanos como novo paradigma inclusivo, a Convenção desde o preâmbulo reconhece que a deficiência é um conceito em evolução e resultante da interação com as barreiras ambientais e atitudinais. Partindo desse pressuposto, a ONU, em seu art. $1^{\circ}$, positivou uma definição do que deve ser considerada pessoa com deficiência, conforme segue:

Pessoas com deficiência são aquelas que têm impedimentos de longo prazo de natureza física, mental, intelectual ou sensorial, os quais, em interação com diversas barreiras, podem obstruir sua participação plena e efetiva na sociedade em igualdade de condições com as demais pessoas. ${ }^{4}$

Sem dúvida, um dos maiores avanços da CDPD é a mudança no conceito de quem são as pessoas com deficiência, conceito que leva em consideração vários fatores. O Decreto Federal no 6949, de 25 de agosto de 2009, que promulgou a referida Convenção da ONU, manteve o conceito de deficiência estabelecido por esse instrumento internacional. Ressalta-se que, como a CDPD foi incorporada ao ordenamento jurídico brasileiro com status equivalente à emenda constitucional, por força do $\int 3^{\circ}$ do art. $5^{\circ}$ da Constituição da República, a terminologia "pessoa com deficiência" revogou, expressamente, o termo "pessoa portadora de deficiência", como estava grafado originalmente na Carta Magna. Desse modo, a Convenção introduziu uma significativa alteração e atualização na nomenclatura normativa constitucional e na legislação esparsa federal, estadual e municipal mediante a assunção da expressão "pessoa com deficiência", uma terminologia mais inclusiva, "o que, a propósito, ecoa os reclamos dos integrantes desse grupo vulnerável contra denominações que não expressam, com fidelidade, sua real condição", conforme lição de Brito Filho5.

A Lei Brasileira de Inclusão da Pessoa com Deficiência (Estatuto da Pessoa com Deficiência), Lei no 13.146, de 6 de julho de 2015, expressamente, baseia-se na Convenção sobre os Direitos das Pessoas com Deficiência da ONU, nos moldes do seu art. $1^{\circ}$, parágrafo único, e reafirma, no art. $2^{\mathrm{o} 6}$, a definição de pessoas com deficiência, conforme os termos art. $1^{\circ}$ dessa Convenção, por enquanto, único Pacto Internacional aprovado na forma prevista pela abertura permitida pela Emenda Constitucional no 45/2004 - EC 45/2004.

De fato, além de provocar mudanças ${ }^{7}$ na ordem legislativa brasileira, o Estatuto da Pessoa com Deficiên-

3 RAIOL, Raimundo Wilson Gama. Direito das Pessoas com Necessidades Especiais à Acessibilidade: arcabouço, análise crítica e motivação social. Revista Fibra e Ciência. Belém, v. 2, n. 3, p. 35-46, jun. 2010. Disponível em: http://www.fibrapara.edu.br/seer/ ojs/index.php/fibra_e_ciencia/article/view/6. Acesso em: 28 abr. 2017.

4 BRASIL. Presidência da Republica. Decreto no 6949 de 25 de agosto de 2009. Disponível em: <http://www.planalto.gov.br/ccivil_03/_ato2007-2010/2009/decreto/d6949.htm>. Acesso em: 20 mar. 2017.

5 BRITO FILHO, José Cláudio Monteiro de. Assegurando o gozo dos direitos em condições de igualdade: direitos humanos das pessoas com deficiência - contexto geral. In: BELTRÃO, Jane Felipe et al. (Coord.). Direitos Humanos dos Grupos Vulneráveis. Manual. Cidade: Rede Direitos Humanos e Educação Superior, 2014. p. 75-76.

$6 \mathrm{O}$ art. $2^{\circ}$ da Lei n ${ }^{\circ}$ 13.146/2015 assim dispõe: "Art. $2^{\circ}$ Considera-se pessoa com deficiência aquela que tem impedimento de longo prazo de natureza física, mental, intelectual ou sensorial, o qual, em interação com uma ou mais barreiras, pode obstruir sua participação plena e efetiva na sociedade em igualdade de condições com as demais pessoas.”. Disponível em: < http://www.planalto.gov.br/ccivil_03/_ato2015-2018/2015/lei/113146.htm>. Acesso em: 24 maio 2017.

7 Considerando que deficiência não é sinônimo de incapacidade, o Estatuto da Pessoa com Deficiência provocou inúmeras modificações no ordenamento jurídico pátrio, como os novos institutos jurídicos relativos à avaliação biopsicossocial da deficiência, ao direito à participação na vida pública e política e à capacidade legal ou civil (cita-se a nova concepção de curatela/interdição ou o novo instituto da tomada de decisão apoiada), promovendo, ainda, alterações em diversas normas nacionais em suas disposições finais e transitórias, como no Código Civil, Código de Defesa do Consumidor, Lei de Improbidade Administrativa e Consolidação 
cia promoveu uma espécie de guinada ou giro linguístico e conceitual em relação à delimitação dos prováveis fatores que interferem ou contribuem para definição de quem são as pessoas com deficiência. Adota a concepção biopsicossocial ${ }^{8}$ de deficiência, que considera elementos médicos ou biológicos (limitações ou impedimentos físicos, sensoriais, mentais, intelectuais etc.) e, ao mesmo tempo, elementos sociais e ambientais, sendo fundamental, portanto, fomentar estratégias políticas, jurídicas e sociais que excluam ou minimizem tais barreiras/obstáculos e discriminações negativas permitindo a esse segmento social demonstrar suas capacidades e usufruir de autonomia e independência para uma possível inclusão social.

A deficiência é parte constituinte da pessoa, um dos seus atributos, integrante de seu próprio ser e faz parte de sua identidade; não tem como a pessoa se desfazer dela ou abandoná-la. A deficiência não é algo que se carrega; não é um objeto que se porta durante certo tempo e depois dele se desfaz, conforme destaca Araújo'. Com efeito, a pessoa não porta, não conduz, não carrega nem leva consigo a deficiência.

A deficiência é uma das formas de estar no mundo, conforme Diniz; Barbosa e Santos ${ }^{10}$, sendo parte da diversidade humana, que em si, na maioria das vezes, não limita a pessoa. Certamente, o meio no qual a pessoa com deficiência está inserida pode contribuir substancialmente para restringir sua autonomia, independência e inclusão social. Sabe-se que em torno daquilo que se convencionou designar de deficiência existe uma estrutura conceitual ou mental que encerra representações, valores, crenças e concepções que moldam condutas, atitudes e posturas sociais. Tais ingredientes, forjados e profundamente arraigados nas múltiplas relações sociais, padronizam comportamentos e interferem na forma de pensar, agir e perceber a realidade e, portanto, nas interpretações, decisões e interações face às pessoas com deficiência. Essa estrutura conceitual funciona como espécie de "cartilha" ou "gramática natural" para a sociabilidade humana, naturalizando e regulando ideias e relacionamentos intersubjetivos na vida cotidiana, encoberta ou mascarada por uma fina trama de discursos, vocábulos e posturas que legitimam, (re)reproduzem e potencializam desigualdades sociais.

Observa-se, assim, o quadro de vulnerabilização social no qual as pessoas com deficiência estão submetidas, quadro este imensamente difuso, não-linear e complexo, constituído por fatores ou fenômenos interdependentes. Essa situação vai ao encontro às referencias teóricas desafiadoras de Dias e Custódio, quando analisam a influência do discurso midiático nas políticas públicas:

A sociedade contemporânea vive no entorno de uma enorme gama de fatores que tornam complexas não somente as interelações pessoais, mas a totalidade das demandas sociais que se pode buscar sanar. Essa complexidade é um dos elementos principais quando se toca na seara das políticas públicas, haja vista o entendimento de que as questões que estes mecanismos se propõem a dialogar são compostas de natureza densa e de difícil conciliação, assim como são todos os problemas sociais. ${ }^{11}$

Nesse passo, nota-se que é humanitária a aspiração de que as pessoas que não apresentam diferenciações morfológicas ou psíquicas, congênitas ou adquiridas no decorrer da vida passem a aceitar com sentimento de igualdade as pessoas que se ressentem dessas diferenciações, respeitando-as do modo como estão inser-

das Leis Trabalho. Disponível em: <http://www.planalto.gov.br/ccivil_03/_ato2015-2018/2015/lei/113146.htm>. Acesso em: 24 maio 2017.

8 O $\int 1^{\circ}$ do art. $2^{\circ}$ da Lei no 13.146/2015 assim dispõe: "§ $1^{\circ}$ A avaliação da deficiência, quando necessária, será biopsicossocial, realizada por equipe multiprofissional e interdisciplinar e considerará: I - os impedimentos nas funções e nas estruturas do corpo; II - os fatores socioambientais, psicológicos e pessoais; III - a limitação no desempenho de atividades; e IV - a restrição de participação." (Grifamos). Disponível em: <http://www.planalto.gov.br/ccivil_03/_ato2015-2018/2015/lei/113146.htm>. Acesso em: 24 maio 2017.

9 ARAUJO, Luiz Alberto David. A proteção constitucional das pessoas com deficiência. Secretaria de direitos humanos. 4. ed. rev. amp. atual. Brasília: Secretaria Nacional de Promoção dos Direitos da Pessoa com Deficiência, 2011.

10 DINIZ, Débora; BARBOSA, Lívia; SANTOS, Wederson Rufino dos. Deficiência, direitos humanos e justiça. São Paulo. Sur, Revista internacional dos direitos humanos, v. 6, n. 11, p. 65-77, dez. 2009.

11 DIAS, Felipe da Veiga; CUSTÓDIO, André Viana. O discurso expansivo-punitivo dos meios de comunicação e sua influência na formação da agenda das políticas públicas de combate à criminalidade de crianças e de adolescentes no Brasil. Revista Brasileira de Políticas Públicas, Brasília, v. 3, n. 1, jan./dez. p. 92, 2013. Disponível em: <https://www.publicacoesacademicas.uniceub.br/RBPP/ article/view/2162>. Acesso em: 25 maio 2017. 
tas no mundo, sem destacar-lhes as limitações, quer como fator de exclamação humilhante, até mesmo de bullyng, quer como fator de exclusão das rodas, da convivência social ou de participação nos patamares ou searas (educação, trabalho, lazer, esporte, cultura, tratamento de saúde etc.) em que todos buscam se expandir, tenham ou não as referidas singularidades. Afinal de contas, não merecem ser expungidas do concerto social, de vez que não escolheram ser do modo como biologicamente ou psiquicamente estão caracterizadas e, por isso não podem sofrer as intempéries existenciais que, em havendo uma concepção mais humanitária, lhes seriam poupadas.

Nesse prisma, lícito é frisar que às pessoas com deficiência não é dado fazer escolhas, porque colhidas pelo infortúnio, donde as desigualdades materiais não lhes devem ser impingidas, o que somente pode ocorrer em relação às pessoas capazes de fazer suas escolhas, por estas sendo responsáveis, segundo a preconização dworkniana de que "quando é preciso optar com relação ao tipo de vida que a pessoa viva, dentro de qualquer escala de opções que lhes sejam permitidas pelos recursos ou pela cultura, essa pessoa é responsável por suas próprias escolhas", consoante Dworkin ${ }^{12}$. Ora, não tendo as pessoas o ensejo a escolher quanto a nascerem ou adquirirem deficiências, logicamente, não podem optar pelo estilo de vida que levariam de acordo com os recursos materiais ou as atitudes sociais, o que implica algo a lhes ser proporcionado em maior grau, isto é, a eliminação de barreiras, dentre as quais as urbanísticas, mediante a contraposição do viés representado pela acessibilidade urbanística. Ao encalço dessa premissa, "as faculdades físicas e mentais de qualquer pessoa devem ser consideradas parte de seus recursos, de modo que quem nasce deficiente comece com menos recursos do que os outros e deva ter o direito de se igualar por meio de transferências", como entende Dworkin ${ }^{13}$, a hipótese, as garantidoras de suportes econômico-financeiros para a implantação de um urbanismo otimizado pela acessibilidade, que assume feição especial no contexto atual porque, sem reduzir, sensivelmente, as barreiras urbanísticas, desaparecem as condições essenciais de liberdade sociais às pessoas com deficiência, comprometendo, assim, irremediavelmente, o atendimento de suas necessidades e interesses.

\section{A CONCEPÇÃO DE DIREITO À CIDADE: O QUE A ACESSIBILIDADE ARQUITETÔNICA TEM A VER COM ISso?}

Fruto principalmente do progresso econômico-industrial do País, a urbanização brasileira é um processo recente, concentrado, acelerado e produtor de uma distribuição espacial altamente desigual, além de gerar segmentação e diferenciação social, gerando cidades excludentes do ponto de vista socioambiental, marcadas por carências e despojamento material da quase totalidade de seus habitantes.

A taxa de urbanização brasileira, atualmente, é de, aproximadamente, 85\% (oitenta e cinco por cento), segundo dados recentes do Instituto Brasileiro de Geografia e Estatística. Nesse cenário, ganha destaque a preocupação em torno da noção de direito à cidade, sobre o qual, do ponto de vista teórico, emergem algumas ideias essenciais suscitadas por alguns estudiosos da questão urbana brasileira. Assim, para conduzir nossa reflexão sobre o saneamento básico, é forçoso pontuar aspectos mais importantes sobre esse novo direito inserido no ordenamento jurídico brasileiro.

O estudo sobre o direito à cidade não é recente nem se iniciou com a doutrina jurídica, constituindo-se objeto de análise pioneira realizada pelo sociólogo e filósofo marxista francês Henri Lefebvre, crítico da sociedade capitalista, quando do lançamento de sua obra seminal "Le droit à la ville", publicada em 1968, a qual esbouça ideias essenciais e intrigantes sobre o tema, que convergem na compreensão de que esse direito

12 DWORKIN, Ronald. A virtude soberana: a teoria e a prática da igualdade. Tradução: Jussara Simões. Revisão técnica e de tradução: Cícero Araújo, Luiz Moreira. São Paulo: M. Fontes, 2005. p. XVI.

13 DWORKIN, Ronald. A virtude soberana: a teoria e a prática da igualdade. Tradução: Jussara Simões. Revisão técnica e de tradução: Cícero Araújo, Luiz Moreira. São Paulo: M. Fontes, 2005. p. 99. 
corresponde à produção colaborativa e fruição coletiva da cidade, ou seja, com base em uma concepção crítica e inovadora ao urbanismo positivista, Lefebvre postula que todos aqueles que vivem na cidade sejam beneficiários ou tenham acesso aos bens, coletivamente, produzidos.

Denota-se que a concepção de direito à cidade associa-se à própria vivência social, à forma de reprodução qualitativa da vida em sociedade. É o que ensina, nessa linha, Lefebvre, que considera que o direito à cidade deve ser compreendido como um apelo, uma exigência,

uma forma superior dos direitos: direito à liberdade, à individualização na socialização, ao habitat e ao habitar"; onde, segundo o mesmo, se encontram implicados o "direito à obra (à atividade participante) e o direito à apropriação (bem distinto do direito à propriedade). ${ }^{14}$

Sob outro aspecto, como ressalta Harvey ${ }^{15}$, a propósito de Lefebvre, o direito à cidade é, simultaneamente, uma queixa e uma exigência. É queixa enquanto resposta a uma "dor existencial de uma crise devastadora da vida cotidiana na cidade". É uma exigência enquanto ordem impulsionadora "para encarar a crise nos olhos e criar uma vida urbana alternativa que fosse menos alienada, mais significativa e divertida", ao mesmo tempo que "conflitante e dialética, aberta ao futuro, aos embates [...] e à eterna busca de uma novidade incognoscível".

Geógrafo inglês e teórico marxista, Harvey critica o império da lógica capitalista liberal e neoliberal por seu caráter individualista, privatista, mercadológico e utilitarista, e mediante a organização, politização e atuação de classes trabalhadoras, concebe a busca pela efetivação do direito à cidade como objeto de luta de vários movimentos sociais, no mundo todo, consoante Harvey ${ }^{16}$. O direito coletivo à cidade é fruto de uma ambição coletiva, com raiz na seara dos direitos humanos, e que visa se sobrepor à lógica liberal ou neoliberal - em que predominam o direito de propriedade privada e a taxa de lucros acima de todas as outras noções de direitos essenciais para a vida em sociedade, como elucida Harvey ${ }^{17}$.

$\mathrm{O}$ atual padrão de urbanização tem falhado com a maioria dos habitantes das cidades em lhes conferir uma vida urbana digna. As relações socioespaciais são reguladas pelas estruturas capitalistas, de forma a reforçar e reproduzir a riqueza e o poder da classe dominante, por via da acumulação por despossessão, expropriação, desalojamento e expulsão da classe dominada. Em outras palavras: a acumulação capitalista guarda estreita relação com os processos de urbanização, segundo concepção de Harvey ${ }^{18}$. Desse modo, como se depreende de Harvey, o direito à cidade é uma supremacia ao de acesso individual ou grupal aos recursos, tendo o desiderato mais coletivo do que individual de profunda transformação e reinvenção do espaço citadino, na cancha do processo de urbanização:

[...] muito mais do que um direito de acesso individual ou grupal aos recursos que a cidade incorpora: é um direito de mudar e reinventar a cidade mais de acordo com nossos mais profundos desejos. Além disso, é um direito mais coletivo do que individual, uma vez que reinventar a cidade depende inevitavelmente do exercício de um poder coletivo sobre o processo de urbanização. [...]. ${ }^{19}$

Integrada a essa perspectiva teórica está a ideia de que a cidade deve ser vista não como um espaço de fragmentos, mas como um corpo político, produzido, coletivamente, a partir das ideias e ideais dos sujeitos que participam ativamente dessa produção, dentro de uma visão de transformação humanizadora, sendo espaço de materialização da justiça socioambiental. Partindo-se do imperativo social de humanização do urbano, compreende-se, portanto, que a busca pelo direito à cidade se identifica com a luta pelo direito de criação e plena fruição do espaço social, pelo direito à cidade como o direito à vida urbana, transformada e

14 LEFEBVRE, Henri. Espaço e Politica. Belo Horizonte: UFMG, 2008.

15 HARVEY, David. Cidades rebeldes: do direito à cidade à revolução urbana. São Paulo: M. Fontes, 2014. p. 11.

16 HARVEY, David. Cidades rebeldes: do direito à cidade à revolução urbana. São Paulo: M. Fontes, 2014. p. 27.

17 HARVEY, David. Cidades rebeldes: do direito à cidade à revolução urbana. São Paulo: M. Fontes, 2014. p. 27.

18 HARVEY, David. Cidades rebeldes: do direito à cidade à revolução urbana. São Paulo: M. Fontes, 2014. p. 30.

19 HARVEY, David. Cidades rebeldes: do direito à cidade à revolução urbana. São Paulo: M. Fontes, 2014. p. 28. 
renovada, segundo lição de Harvey ${ }^{20}$.

Sob a égide do texto constitucional, o direito à cidade, enquanto direito metaindividual, é, fundamentalmente, o direito que as pessoas têm a uma cidade hígida, com justiça socioambiental que proporcione dignidade aos seus habitantes. Para além de um núcleo essencialmente jurídico, observa-se, assim, que o direito à cidade envolve uma sistemática com aspectos políticos, sociais, econômicos, ambientais e antropológicos. O direito à cidade é um direito eminentemente fundamental coletivo, que, nos dizeres de Lefebvre, seria, portanto, o direito

[...] à vida urbana, à centralidade renovada, aos locais de encontro e de trocas, aos ritmos de vida e empregos do tempo que permitem o uso pleno e inteiro desses momentos e locais etc. [...]. A proclamação e a realização da vida urbana como reino do uso (da troca e do encontro separados do valor de troca) exigem o domínio do econômico (do valor de troca, do mercado e da mercadoria) [...]. ${ }^{21}$

A luta política na década de 1980 no Brasil, em que as forças populares tiveram um árduo trabalho na articulação de suas demandas e ao mesmo tempo fizeram o embate com poderosos lobistas de grupos conservadores, resultou na inclusão na Constituição da República de 1988 de um capítulo intitulado "Da Política Urbana", imbuído do objetivo de redirecionar a política urbana, mediante a inserção dos artigos 182 e 183 no texto constitucional, os quais trazem encaminhamentos no que diz respeito ao desenvolvimento urbano, à função social da cidade e à gestão democrática do espaço urbano. Dessa luta sobreveio, também, o Estatuto da Cidade (Lei n ${ }^{\circ} 10.257 / 2001$ ), que, ao regulamentar os ditos artigos, trata das diretrizes gerais e instrumentos da política urbana, estabeleceu, textualmente, a noção de direito à cidade. De fato, a densificação jurídica do significado do direito à cidade ocorreu com a edição do Estatuto da Cidade, que trouxe diretrizes e instrumentos urbanísticos voltados à construção democrática das cidades, positivando, assim, um novo direito no ordenamento jurídico brasileiro: o direito a cidades sustentáveis, alçado à ordem jurídica pátria na condição de direito difuso.

Em tese, o Estatuto da Cidade veio ao encontro da necessidade de concretizar aqueles preceitos constitucionais, conferindo-lhes corporeidade normativa e disciplinando a execução da política urbana, com normas de ordem pública e interesse social que regulam o uso da propriedade urbana em prol do bem coletivo, da segurança e do bem-estar dos cidadãos, bem como do equilíbrio ambiental (art. $1^{\circ}$, parágrafo único).

Trazendo contornos mais claros ao direito à cidade, o art. $2^{\circ}$ do Estatuto da Cidade enuncia a garantia do direito a cidades sustentáveis, entendido como o direito à terra urbana, à moradia, ao saneamento ambiental, à infraestrutura urbana, ao transporte e aos serviços públicos, ao trabalho e ao lazer, para as presentes e futuras gerações, de onde imediatamente sobressai a noção de que tal direito está intrinsecamente relacionado à implementação de outros direitos de caráter individual e social, dentre os quais os de moradia, saneamento e transporte, que radicam na acessibilidade urbanística, no âmbito da cidade, e se coaduna, inclusive, com a compreensão de justiça socioambiental disposta no artigo 225 da Constituição Federal. Portanto, o desenvolvimento sustentável é componente fundamental da política urbana, o que significa admitir a compatibilidade entre o direito a cidades sustentáveis e o direito das presentes e futuras gerações ao meio ambiente ecologicamente equilibrado. O Estatuto da Cidade, por sua vez, dispensou ao direito à cidade sustentável o status de diretriz geral da política urbana e que se projeta em inúmeros instrumentos de política urbana previstos e regulamentados ao longo do Estatuto.

Não resta dúvidas de que a finalidade precípua desses dispositivos é viabilizar a democratização das funções sociais da cidade e da propriedade em proveito de seus habitantes, em prol do bem-estar e qualidade de vida de todos. Devido à abrangência do direito a cidades sustentáveis, o qual alberga outros tantos direitos referentes à qualidade de vida nas cidades, pode-se dizer que as normas destinadas a implementar, em todos os níveis da Federação, políticas públicas urbanísticas, se constituem, à luz do ordenamento jurídico pátrio,

20 HARVEY, David. Cidades rebeldes: do direito à cidade à revolução urbana. São Paulo: M. Fontes, 2014.

21 LEFEBVRE, Henri. Espaço e Política. Belo Horizonte: UFMG, 2008. 
instrumentos viabilizadores da efetivação daquele direito. Percebe-se que a definição normativa do direito à cidade é, por assim dizer, apenas, a ponta do iceberg, que vai muito além dos artigos 182 e 183 da Constituição da República e do Estatuto da Cidade, que, claro, são hábeis fontes de diretrizes e de previsão instrumental. O estudo do designado direito a cidades sustentáveis faz nascer a percepção de que, na realidade, tal direito se perfaz em um conjunto de direitos que necessitam de efetivação para manter, democraticamente, em termos urbanísticos, a própria cidade. Nesse passo, é válido invocar a posição de Câmara, que ressalta a importância do aludido Estatuto para o atendimento às necessidades das populações que ocupam o espaço citadino informal, como reflexo dos avanços do processo de democratização do espaço urbano:

Com a vigência do Estatuto da Cidade, que constitui um marco histórico para a política urbana uma vez que estabeleceu importantes instrumentos de intervenção na cidade e definiu mecanismos mais adequados ao atendimento das necessidades da parcela da população que ocupa o espaço informal da cidade, pode-se dizer que houve um acentuado índice de modernização na dinâmica de ocupação do solo urbano constituindo um avanço para o processo de democratização das cidades. ${ }^{22}$

Interessante notar, igualmente, a projeção internacional gradativa ${ }^{23}$ do direito à cidade e a forte articulação entre o reconhecimento do direito à cidade no âmbito nacional e as discussões internacionais sobre o assunto, em particular, na pauta dos processos globais voltados a tratar dos assentamentos humanos, conforme Saule Júnior ${ }^{24}$. Conveniente invocar, igualmente, que o direito à cidade tornou-se plataforma política de inúmeros movimentos sociais por reformas urbanas, como ressalta Guimarães: "Originalmente desenvolvido na obra de Lefebvre, o direito à cidade, que logo é incorporado nas demandas de movimentos sociais por reforma urbana, parece ter sido transformado em uma bandeira." 25

Sabe-se que o acesso aos bens e serviços é um importante fator das condições de vida da população, pois daí decorre a estreita relação entre acessibilidade urbanística e direito à cidade, pois a ausência de ambientes que promovam segregações socioespaciais, apresentando conformações físicas inadequadas ou não são dotadas de infraestruturas adequadas, incluídas as vias públicas, as edificações coletivas e os sistemas de transportes públicos, reflete de forma direta no direito de acessar, frequentar e utilizar bens e serviços em condições cômodas, do ponto de vista socioambiental. Isto significa dizer que, numa relação dialógica, a proteção das condições de acessibilidade urbanística está associada ao resguardo dos demais direitos sociais, como saúde, educação, trabalho, lazer, moradia etc. Nota-se que a prestação do direito à acessibilidade está imbricada com os demais direitos, associando aspectos sociais, econômicos, políticos e culturais, que o qualifica como serviço público instrumental à realização dos interesses e das necessidades da população em geral, de modo especial às pessoas com deficiência.

22 CÂMARA, Andreza Aparecida Franco. Políticas públicas de habitação e o programa de aceleração do crescimento: análise das intervenções no estado do Rio de Janeiro. Rev. Bras. Pol. Públicas (Online), Brasília, v. 1, n. 3 - número especial, p. 169 , dez. 2011. Disponível em: <https://www.publicacoesacademicas.uniceub.br/RBPP/article/view/1487> . Acesso em: 24 maio 2017.

23 Nesse processo de internacionalização, o delineamento mais preciso a respeito do entendimento sobre o direito à cidade começou a ser elaborado a partir de 2001, no I Fórum Social Mundial (Porto Alegre/RS/Brasil), quando movimentos sociais e organizações não-governamentais de todo o mundo, articulados com a luta pela reforma urbana, tiveram a iniciativa de elaborar um documento que representasse a positivação desse direito. Os debates tiveram continuidade no II Fórum Social Mundial (Porto Alegre/RS/Brasil, 2002) e no Fórum Social das Américas (Quito, 2004) e no Fórum Mundial Urbano (Barcelona, 2004), sendo que, finalmente, no Fórum Social Mundial realizado em 2005 na cidade de Porto Alegre - RS/BR, obteve-se a redação definitiva e aprovação da Carta Mundial pelo Direito à Cidade, que se traduz em um esforço importante de reunir diversas normas sobre direitos econômicos, sociais, culturais e ambientais.

24 SAULE JÚNIOR, Nelson. Direito Urbanístico: vias jurídicas das políticas urbanas. Porto Alegre. S. A. Fabris Editor: 2007. p. 34.

25 GUIMARÃES, Virgínia Totti. Direito à cidade e direitos na cidade: integrando as perspectivas social, política e jurídica. Revista de Direito da Cidade, v. 9, n. 2, p. 627. Disponível em: <http://www.e-publicacoes.uerj.br/index.php/rdc/article/viewFile/27143/20439>. Acesso em: 26 maio 2017. 


\section{ACESSIBILIDADE URBANÍSTICA COMO DIREITO FUNDAMENTAL}

Comumente, a noção de acessibilidade urbanística é vista de forma reducionista, voltada, apenas, para a construção de rampas ou adaptações de banheiros, por exemplo, não demandando, portanto, avanços substanciais quanto ao atendimento pleno daquelas condições estruturais.

Ao se buscar tal delimitação, subjaz a definição de acessibilidade urbanística ou física como resultante da facilidade e oportunidade com que as pessoas podem aproximar-se, alcançar e usufruir das atividades, serviços, bens, mobiliários e equipamentos e elementos da urbanização relacionada com a capacidade individual, mas com otimização, democratização e qualificação das oportunidades e facilidades de atingir um determinado destino, utilizando-se, para tanto, daquelas condições estruturais dispostas anteriormente. É mister destacar que a qualidade de ser acessível para acolher à diversidade humana deve ser um atributo ou característica do conjunto das atividades, serviços, bens, mobiliários, equipamentos e demais elementos urbanísticos afetados ao público, de modo a haver interações entre estes e os usuários.

Nessa linha de raciocínio, a acessibilidade física representa uma das possibilidades de inclusão social. Parte-se de uma abordagem centrada na pessoa e nas condições acessíveis dos ambientes, bens, equipamentos, mobiliários e serviços. Isso corresponde, também, à qualidade e otimização com que ocorrem os acessos e deslocamentos seguros e autônomos. Essa abordagem conceitual incorpora valências que se traduzem em uma relação entre maior nível de independência, melhor qualidade de vida e igualdade de oportunidade no acesso democrático e pleno às edificações, à arquitetura urbanística, aos bens, serviços, mobiliários, equipamentos e demais adjutórios correlatos disponibilizados à coletividade.

A acessibilidade urbanística ora tratada transmuda-se de caráter sociopolítico e ético, consubstanciado na garantia desses acessos como instrumentos à inclusão social das pessoas com deficiência, a qual se configura como um paradigma que entende que as barreiras físicas e sociais são complexas e vão além das questões individuais. Assim, pode-se compreender que um mecanismo imprescindível e capaz de promover a inclusão social das pessoas com deficiência é a acessibilidade urbanística, que, na qualidade de direito fundamental, deve ter tratamento prioritário, para que outros direitos possam ser efetivados.

Afirmar que a acessibilidade urbanística é um direito fundamental deixa à mostra a obrigatoriedade de pôr no núcleo central das atenções as pessoas com deficiência, quer seja para torná-las, efetivamente, destinatárias desse direito quer seja para perseguir a atuação prestacional do Poder Público, quanto para demarcar, com precisão, a compreensão de que o mais elevado e sublime propósito de se garantir tal direito é a adequada e plena inclusão social daqueles seres humanos. Ao encalço dessa premissa, vale frisar as contribuições de Raiol, a saber:

A acessibilidade é um conceito amplo, que abrange a possibilidade de acesso fácil e seguro ao meio físico e aos meios de transporte. Deve funcionar como antídoto a obstáculos com que se defrontam as pessoas com necessidades especiais [...] A importância da acessibilidade é incomensurável para as pessoas com necessidades especiais. Essa afirmação resulta patente, levando-se em conta que, para uma existência digna, todo ser humano merece ter viabilizada a busca de realizações nos diversos meandros da vida social e econômica, o que lhe exige estar nos mais variados lugares de uso público ou abertos a esse uso [...] Para haver a perspectiva de ingressarem nesses ambientes, devem estes ser dotados de estruturas físicas compatíveis com as singularidades daqueles seres humanos, que, igualmente, para poderem chegar até esses locais, devem ser favorecidos por meios de transporte coletivo dotados de apetrechos acessíveis, em termos de assentos e mecanismos que permitam ingressar e sair de ônibus, embarcações, aviões etc. ${ }^{26}$

26 RAIOL, Raimundo Wilson Gama. Acessibilidade Física, Educação, Saúde e Trabalho: integrantes do mínimo existencial indispensável às pessoas com necessidades especiais, à luz dos direitos humanos e de fundamentos constitucionais, na era da globalização. In: MATTOS NETO, Antonio José de; LAMARÃO NETO, Homero; SANTANA, Raimundo Rodrigues (Org.). Direitos Humanos e Democracia Inclusiva. São Paulo: Saraiva, 2012. p. 311. 
Assegurar, portanto, as condições de acessibilidade às pessoas com deficiência, por via de consequência, funciona como arrimo ao exercício de atividades básicas (educação, saúde, trabalho, lazer etc). Consentâneo a esse postulado, o direito fundamental à acessibilidade arquitetônica mostra-se instrumento primordial e indelével para a inclusão social ora mencionada, dando densidade às disposições internacionais, constitucionais e infraconstitucionais afetas à matéria.

Como condição que cada pessoa tem de chegar, alcançar, obter e utilizar bens, serviços e equipamentos disponíveis, a acessibilidade urbanística passa a abranger novas dimensões e outras esferas do fazer humano. Refere-se a uma gama de variáveis relacionadas às possibilidades de acesso autônomo, seguro, cômodo e independente a um local, discussão que engloba aspectos que vão desde a identificação das trajetórias das pessoas ao se deslocarem em ou para ambientes e às atividades desejadas, serviços, bens, mobiliários e equipamentos que ali acontecem ou estão disponíveis, buscando reconhecer e respeitar a diversidade humana, em que todas as características das pessoas sejam atendidas, independentemente de possuírem ou não uma deficiência.

O Brasil tem abundância legislativa que se ocupa em garantir direitos às pessoas com deficiência, dentre os quais a acessibilidade urbanística, sendo exemplos, no plano constitucional, o art. $5^{\circ}$, XV (direito de ir e vir ou livre locomoção) e os arts. 227, \ $2^{\circ}$ e 244 (acessibilidade aos logradouros, edificações e meios de transportes coletivos), e no âmbito infraconstitucional, a Lei $\mathrm{n}^{\circ} 10.048$, de 08 de novembro de 2000, a Lei $\mathrm{n}^{\circ} 10.098$, de 19 de dezembro de 2000 e o Decreto no 5.296 , de 02 de dezembro de 2004, que regulamentou tais leis.

$\mathrm{Na}$ Convenção sobre os Direitos das Pessoas com Deficiência que ingressa no sistema constitucional brasileiro mediante o Decreto-Legislativo no 186 de 09 de julho de 2008 e do Decreto de Promulgação n ${ }^{\circ}$ 6949, de 25 de agosto de 2009, com status de equivalência de emenda constitucional, por força do $\ 3^{\circ}$ do art. $5^{\circ}$ da Constituição da República, a acessibilidade aparece como princípio e direito fundamental, previstos respectivamente, nos arts. $3^{\circ}$, alínea $f, 4^{\circ}, 1$, alínea $f$; e $9^{\circ}$. Tais dispositivos obrigam o Brasil a envidar esforços apropriados, entre tantas outros, para assegurar às pessoas com deficiência o acesso, em igualdade de condições com as demais pessoas, ao meio físico, ao transporte, à informação e comunicação, bem como a outros serviços e instalações abertos ou propiciados ao público, tanto na zona urbana como na rural. Com isso, o Brasil assumiu, internacional e nacionalmente, o dever de implementar as condições materiais de acessibilidade, harmonizando formal e materialmente seu arcabouço legal, adequando suas políticas públicas, e principalmente, reafirmando direitos já estabelecidos pela legislação pátria.

A Lei $n^{\circ}$ 12.587, de 3 de janeiro de 2012, conhecida como Lei da Mobilidade Urbana, a qual, conforme seu art. 24, IV, e $\mathbb{\int} 3^{\circ}$, prevê que ao Plano Diretor do Município deve estar integrado o Plano de Mobilidade Urbana, por sua vez, deverá contemplar "a acessibilidade para pessoas com deficiência e restrição de mobilidade". Essa Lei instituiu as diretrizes da Política Nacional de Mobilidade Urbana, que, no art. $7^{\circ}$, III, permeia o objetivo de "proporcionar melhoria nas condições urbanas da população no que se refere à acessibilidade e à mobilidade", o que pode contribuir para o acesso universal à cidade.

A Lei Brasileira de Inclusão da Pessoa com Deficiência (Estatuto da Pessoa com Deficiência), Lei ${ }^{\circ}$ 13.146, de 6 de julho de 2015, expressamente, baseia-se na Convenção sobre os Direitos das Pessoas com Deficiência da ONU. O artigo $3^{\circ}$, I, desse Estatuto define acessibilidade. O Título III do Livro I do Estatuto é destinado à acessibilidade, que, nos termos do artigo 53 da Lei, é direito garantido à pessoa com deficiência ou com mobilidade reduzida, garantindo-lhes vida independente e o exercício de seus direitos de cidadania e participação social.

Do ponto de vista das técnicas de engenharia e arquitetura, as condições para assegurar o direito fundamental das pessoas com deficiência à acessibilidade encontram-se descritas em diversas normas da Associação Brasileira de Normas Técnicas (ABNT), tais como: NBR 9.050 - Acessibilidade a Edificações, Mobiliário, Espaços e Equipamentos Urbanos; NBR 13.994 - Elevadores de Passageiros - Elevadores para 
Transportes de Pessoa Portadora de Deficiência; NBR 15.250 - Acessibilidade em caixa de autoatendimento bancário; e NBR 14.022 - Acessibilidade em veículos de características urbanas para o transporte coletivo de passageiros.

A garantia da acessibilidade urbanística representa um grande avanço em termos legais e, ao mesmo tempo, um desafio em termos de cidadania e direitos humanos, pois significa assegurar um direito básico e primordial de toda pessoa humana, que é o direito de ir e vir, com segurança, independência e autonomia. Básico e primordial porque, mediante sua garantia, como uma rede conexa, se obtêm outros direitos, como os direitos econômicos (trabalho, renda etc.), os direitos sociais (educação, saúde, moradia, alimentação etc.), os direitos culturais (lazer, esporte, turismo etc.), os direitos políticos (voto, participação em entidades representativas etc.). Reveste-se de um direito fundamental instrumental, ou seja, constitui condição necessária e mínima para que as pessoas com deficiência possam exercer outros direitos.

A acessibilidade constitui um instrumento de inclusão social aliada à cidadania, uma vez que, não existindo acesso irrestrito às edificações, aos transportes públicos, aos mobiliários e equipamentos urbanos e rurais, as pessoas com deficiência não poderão exercer direitos humanos e garantias fundamentais, condições mínimas à prática cidadã, como preleciona Araújo ${ }^{27}$. Por exemplo, sem transporte adaptado, as pessoas com deficiência terão dificuldade em comparecer ao local de trabalho, à escola e ao lazer. Nesse sentido, a acessibilidade arquitetônica é um direito humano instrumental indispensável ao exercício do direito de ir, vir, ficar e permanecer ou do direito de locomoção, esculpido no art. $5^{\circ}$, inciso XV, da Constituição da República. É uma condição que possibilita ao indivíduo circular ou deslocar-se livremente, conforme o seu desejo.

Nesse cenário, cumpre ressaltar que o respeito ao mínimo existencial, observando-o, de modo efetivo, na perspectiva de uma política pública, é imprescindível para a garantia de acessibilidade urbanística, principalmente quando associado aos meios materiais imprescindíveis à dignidade humana, como bem destaca Souza:

O mínimo existencial pode ser considerado como o conjunto de condições materiais indispensáveis à existência humana, embora seu alcance seja variável no espaço e no tempo. Associado ao princípio da dignidade da pessoa humana, é um importante valor para a concretização dos direitos prestacionais fundamentais. ${ }^{28}$

Apenas o reconhecimento meramente textual da acessibilidade arquitetônica não é suficiente para promover o processo de inclusão social das pessoas com deficiência. É necessário operacionalizar mecanismos e instrumentos que planejem e executem políticas públicas voltadas para esse fim. O direito fundamental à acessibilidade urbanística constitui pressuposto ou plataforma para que tais pessoas ganhem autonomia e independência nos mais diversos escalões no mundo social, político e econômico. Assegura esse direito demanda uma agenda mínima de políticas públicas voltadas a essas pessoas, que, na condição de cidadãs, necessitam de um tratamento diferenciado, ou de recursos facilitadores, imprescindíveis para viverem incluídas socialmente.

Ao comentar a respeito do enfrentamento aos efeitos nefastos do processo de globalização por intermédio de políticas públicas, Custódio e Moreira chamam atenção para a necessária articulação que deve haver entre tais políticas, a participação da comunidade e o interesse em diminuir a exclusão social:

O enfrentamento aos impactos da globalização, por meio de políticas públicas desenvolvidas com a participação efetiva da comunidade, é de grande relevância para o combate a exclusão social e a efetivação da cidadania. A participação comunitária nos assuntos relacionados à própria realidade social, econômica

27 ARAUJO, Luiz Alberto David. A proteção constitucional das pessoas portadoras de deficiência: algumas dificuldades para efetivação dos direitos. In: SARMENTO, Daniel; IKAWA, Daniela; PIOVESAN, Flávia. (Coord.). Igualdade, diferença e direitos bumanos. Rio de Janeiro: Lúmen Júris, 2008. p. 208-209.

28 SOUZA, Pedro Bastos de. Benefícios de renda mínima como um direito fundamental: acesso à justiça e inclusão social. Rev. Bras. Polít. Públicas (Online), Brasília, v. 6, n. 1, p. 158, 2016. Disponível em: <https://www.publicacoesacademicas.uniceub.br/ RBPP/article/view/3802>. Acesso em: 25 maio 2017. 
e política é uma necessidade nas atuais gestões públicas. ${ }^{29}$

Se os espaços públicos e coletivos, os logradouros, as edificações, os elementos de urbanização e os transportes coletivos, em sua grande maioria, não atendem, satisfatoriamente, às pessoas com deficiência, isso representa forte empecilho à circulação livre de pessoas com limitação física, sensorial e intelectual, de modo a constituir-se fator que lhes causa um elevado grau de dependência social, além de provocar situações vexatórias, constrangedoras e de desconforto a que são expostas constantemente. Seja nos ambientes urbanos, seja nos rurais, essas pessoas enfrentam dificuldades cotidianas para transitar frente aos inúmeros ambientes, arquiteturas, edificações, mobiliários, equipamentos, elementos da urbanização e serviços de uso público e coletivo inadequados a esses seres humanos.

Inúmeros diplomas legais reconhecem o direito fundamental à acessibilidade, não obstante, há um descompasso entre o direito posto e a realidade da vida diária dessas pessoas, ou seja, há muita previsão legal, mas sua efetivação é deficitária. Se o fosso entre a idealização das normas e a concretização de seus valores não foi ainda superado, as aludidas leis se tornam retórica vazia, o que, certamente, não contribui para o processo de inclusão social dessas pessoas. Embora os avanços registrados nos últimos anos para garantir os direitos da pessoa com deficiência sejam constantes e visíveis, o Brasil, ainda, não conseguiu alcançar um progresso mais expressivo no sentido de suprimir barreiras que funcionam como empecilho à liberdade de ir e vir, em total descompasso com a preocupação normativa expressa na Constituição da República de reduzir desigualdades sociais com vistas à superação de um grave quadro social em que a população, em sua maioria, ai incluída à toda evidência parte significativa das pessoas com deficiência, não consegue exercer, em plenitude, sua dignidade e sua cidadania.

\section{EvidÊNCIAs EmpíRICAS}

Do ponto de vista da pesquisa empírica, traz-se à baila determinadas realidades relacionadas às precárias condições de acessibilidade arquitetônicas nos municípios de Abaetetuba, Igarapé-Miri e Moju, no Estado do Pará, tanto no meio urbano quanto no meio rural. Sobre tais municípios, o Censo 2010 do IBGE revelou estimativas de pessoas acometidas com, pelo menos, uma das deficiências investigadas ${ }^{30}$. O quantitativo dessas pessoas, nesses locais, está expresso na tabela abaixo, a qual demonstra, ainda, os percentuais no Estado do Pará e no Brasil:

Percentual da população com deficiência, segundo o tipo de deficiência investigada - Brasil e unidades da federação, 2010

\begin{tabular}{|c|c|c|c|c|c|c|}
\hline \multirow[b]{3}{*}{$\begin{array}{c}\text { Brasil e } \\
\text { unidades da } \\
\text { federação }\end{array}$} & \multicolumn{6}{|c|}{ POPULAÇÃO RESIDENTE } \\
\hline & \multirow[b]{2}{*}{ Total } & \multicolumn{5}{|c|}{ Tipo de deficiência } \\
\hline & & $\begin{array}{c}\text { Pelo menos uma } \\
\text { das deficiências } \\
\text { investigadas }\end{array}$ & Visual & Auditiva & Motora & $\begin{array}{c}\text { Mental/ } \\
\text { Intelectual }\end{array}$ \\
\hline Brasil & 190.755 .799 & $23,92 \%$ & $18,8 \%$ & $5,1 \%$ & $7,0 \%$ & $1,4 \%$ \\
\hline
\end{tabular}

29 CUSTÓDIO, André Viana; MOREIRA, Rafael Bueno da Rosa. A garantia do direito à educação de crianças e adolescentes no contexto das políticas públicas brasileiras. Revista Brasileira de Políticas Públicas, Brasília, v. 5, n. 1, p. 240, 2015. Disponível em: <https://www.publicacoesacademicas.uniceub.br/RBPP/article/view/3036>. Acesso em: 25 maio 2017.

30 Frisa-se que no Censo de 2010, organizado pelo IBGE, as perguntas feitas aos entrevistados buscaram identificar as deficiências visual, auditiva e motora pelos seguintes graus de dificuldade: (i) tem alguma dificuldade em realizar; (ii) tem grande dificuldade e, (iii) não consegue realizar de modo algum; além da deficiência mental ou intelectual. IBGE. Cartilha do Censo 2010: Pessoas com Deficiência. Brasília: SDH-PR/SNPD, 2012. p. 5. Disponível em: <http://www.pessoacomdeficiencia.gov.br/app/sites/default/ files/publicacoes/cartilha-censo-2010-pessoas-com-deficienciareduzido.pdf>. Acesso em: 10 abr. 2017. 


\begin{tabular}{|c|c|c|c|c|c|c|}
\hline Pará & 7.581 .051 & $23,63 \%$ & $19,2 \%$ & $4,9 \%$ & $6,5 \%$ & $1,1 \%$ \\
\hline Abaetetuba & 141.100 & $25,4 \%$ & $20,8 \%$ & $5,1 \%$ & $7,7 \%$ & $1,2 \%$ \\
\hline Igarapé-Miri & 58.077 & $25,7 \%$ & $21,1 \%$ & $5,2 \%$ & $8,4 \%$ & $1,6 \%$ \\
\hline Moju & 70.018 & $23,0 \%$ & $18,7 \%$ & $5,4 \%$ & $6,4 \%$ & $0,9 \%$ \\
\hline
\end{tabular}

Fonte: IBGE, Censo Demográfico 2010.

A pesquisa de campo foi realizada tanto no ambiente urbano quanto no meio rural, o que permitiu verificar que tais espaços são locais de acentuada exclusão social das pessoas com deficiência. Percebeu-se claramente a segregação socioespacial, o abandono político quanto às condições físico-estruturais de bens e serviços públicos e coletivos, enfim, o desrespeito quase que completo das normas relativas à acessibilidade, particularmente nos espaços rurais, vindo ao encontro do que Dias assinala:

Toda aglomeração humana que tenha importância como centro de vida e de relações sociais necessita de ordenamentos urbanísticos. Aliás, seria um verdadeiro reducionismo considerar que, somente nos espaços urbanos, o município deva primar pelo pleno desenvolvimento das funções socais da cidade. ${ }^{31}$

Sobressai, assim, a necessária articulação das políticas públicas de desenvolvimento de cidades sustentáveis e inclusivas, de modo a englobar campo e cidade, posto que a vida no município não se limita à vivência em áreas urbanas, mas se estende a todo território municipal.

Ao discorrer a respeito de políticas públicas, Santos ${ }^{32}$ chama atenção para a necessidade imperiosa e permanente de correlacionar as situações de vulnerabilização de determinados grupos populacionais com tais políticas, visando minorar desigualdades sociais manifestas. Nesse horizonte, constata-se facilmente a discrepância entre a ideia elementar levantada por essa autora e as evidências empíricas verificadas nas vias públicas, mobiliários, equipamentos e elementos urbanísticos, edificações e meios de transportes públicos e coletivos existentes nos municípios de Abaetetuba, Igarapé-Miri e Moju, que, via de regra, padecem quanto o atendimento aos critérios técnicos de acessibilidade urbanística.

Poucas rampas de acesso (as que existem estão, em sua grande maioria, deterioradas e em desacordo com as normas técnicas e outras especificações determinadas pela ABNT; rampas sem corrimões; calçadas sem rebaixamentos e sem sinalizações (piso tátil); banheiros de uso público e coletivo sem equipamentos e acessórios adequados e sem dimensões em padrões técnicos; falta de manutenção de calçadas; portas e corredores de locais públicos e coletivos estreitos; ausência de vaga de estacionamento exclusivo para pessoas com deficiência física (no estádio de futebol, nos estabelecimentos bancários, nos supermercados, nas casas lotéricas, nas redes de farmácias, nos hospitais, nos postos de saúde, nas escolas, nas casas de espetáculos, estádios esportivos, restaurantes, bares, lanchonetes, hotéis, cinemas e similares); ausência de plataforma ou elevadores nos ônibus coletivos; afora outras estruturas que não são disponibilizadas em favor das pessoas com deficiência.

Adicionam-se outras dificuldades que essas pessoas enfrentam para transposição e superação de barreiras arquitetônicas nas edificações que apresentam degraus inacessíveis. Tais obstáculos físico-estruturais estão também nos balcões das bilheterias e nas catracas das salas de espetáculos, os quais são confeccionados em desacordo com o previsto nas normas técnicas (por exemplo, têm altura bastante elevada); as portas giratórias e os caixas eletrônicos das respectivas agências bancárias e outros espaços congêneres são intransponíveis pelas pessoas que necessitam utilizar cadeira de roda; elevadores e sanitários construídos em medidas ou dimensões que não acomodam uma cadeira de roda. O cadeirante não pode transitar, livremente, pelas calçadas da cidade, frente à quantidade elevada de lixeiras, comércio ambulante, estacionamentos

31 DIAS, Daniella Maria dos Santos. Planejamento e desenvolvimento urbano no sistema jurídico brasileiro: óbices e desafios. Curitiba: Juruá, 2012. p. 19.

32 SANTOS, Isabelle Dias Carneiro. A educação diferenciada como política pública de inclusão social dos Guarani e Kaiowá no Estado do Mato Grosso do Sul. Rev. Bras. Pol. Públicas (Online), Brasília, v. 6, n. 3, p. 309, dez. 2016. Disponível em: <https://www. publicacoesacademicas.uniceub.br/RBPP/article/view/4389>. Acesso em: 24 maio 2017. 
de ônibus, micro-ônibus, vans e motocicletas em locais proibidos. Há falta muito grande de solidariedade e alteridade, ou seja, quem não se ressente de limitações orgânico-corporais não se coloca no lugar de quem destas padece, nem se predispõe a oferecer-lhes ambientes física e estruturalmente acessíveis.

Incluem-se nessa situação calamitosa outras barreiras, como bueiros sem tampa ou grades de proteção, grelhas quebradas, ruas com estrutura asfáltica quebrada, calçadas estreitas, deterioradas, e rampas demasiadamente inclinadas, além das instalações inadequadas, onde se situam as caixas dos correios, o que obriga as pessoas com deficiência a utilizarem a rua, sem nenhuma proteção; além disso, defrontam-se com rampas com declividade acentuada. Diariamente, elas se deparam com canteiros de obras, tapumes, depósitos de areia, pedra, seixo, tijolo e ferragem, bem como máquinas e outros equipamentos que são utilizados em construções de obras públicas e particulares. Essas barreiras acabam causando uma situação de desconforto àquelas pessoas. Com efeito, esses objetos representam grandes empecilhos à circulação livre de pessoas com limitação física, além de constituírem fatores que causam às pessoas com deficiência um elevado grau de dependência social, além das corriqueiras situações vexatórias e constrangedoras a que são expostas.

Inserem-se no rol dos óbices enfrentados no dia a dia pelas pessoas com deficiência, os que decorrem de algumas barreiras físicas como pavimentos deteriorados, portas demasiadamente estreitas, escadas inacessíveis em edifícios, transportes coletivos urbanos com problemas nos veículos (acesso, circulação interna e acomodação). A estrutura de circulação urbana (ônibus, micro-ônibus, vans, calçadas, ruas, pontos de embarque e desembarque etc.) não é construída pensando nas pessoas com deficiência. Com isso elas enfrentam problemas de mobilidade junto a vários ambientes sociais, pela carência de condições mínimas de acessibilidade.

Nos espaços rurais desses municípios, evidencia-se grande diversidade de tipos de embarcações e portos, ancoradouros, terminais e demais pontos de embarque e desembarque de passageiros, por todo meio rural, refletindo as diferentes realidades socioespaciais do Brasil, particularmente na Amazônia paraense.

Ademais, tanto os locais de embarque e desembarque como as embarcações foram concebidos, em sua grande maioria, sem levar em consideração aspectos atinentes a acessibilidade urbanística. Vários tipos e portes de embarcações existentes não poderão inclusive sofrer adaptações visando à acessibilidade, porém, as embarcações de maior porte podem receber as devidas adaptações. Nem todas as embarcações, sejam elas novas ou adaptadas, permitem plena acessibilidade, tendo em vista existirem condicionantes técnicos e estruturais das embarcações, além do fator financeiro alegado pelos proprietários desses bens.

De outra monta, sabe-se que cerca de 90\% (noventa por cento) da frota de embarcações operantes funcionam na ilegalidade. Há grande informalidade no transporte, muitas construções artesanais e terminais ou portos totalmente improvisados e praticamente inacessíveis a qualquer pessoa. Isso é extremamente preocupante, pois, nos rincões da imensa Amazônia paraense, onde, por força da própria natureza, a situação geográfica é adversa e tais terminais, portos e embarcações são inacessíveis, as pessoas com deficiência, em razão dessa singularidade, certamente, enfrentam, diuturnamente, grandes obstáculos ao livre circulação e acesso a bens e serviços públicos e coletivos disponíveis à coletividade.

Nos meios de transportes coletivos disponíveis ao uso pelas pessoas com deficiência, verificam-se poucas condições de acessibilidades: tais meios de transportes carecem de adaptações físicas, as empresas concessionárias do serviço público respectivo não reservam nem identificam devidamente os assentos nas embarcações; estações, plataformas, portos ou terminais de embarque e desembarque ignoram aquelas condições; as cabines de venda de bilhete de passagem são inadequadas quanto à estrutura (obstáculos à aproximação e acesso, altura do balcão elevada etc.); precariedades das edificações e dos calçamentos dos trapiches, pois em desacordo com as regras de acessibilidade; os transportes coletivos hidroviários não têm as devidas adaptações.

Nos referidos municípios, não se depara com nenhuma embarcação adaptada às peculiaridades das pessoas com deficiência, como determinam as normas pertinentes. Em consequência disso, o direito de ir e vir de um lugar para outro não é garantido plenamente, uma vez que tais embarcações não lhes proporcionam 
as mínimas condições estruturais de acesso e locomoção a qualquer pessoa e, como gravame, às pessoas com deficiência.

\section{Considerações Finais}

Infelizmente, na segunda década do século XXI, as pessoas com deficiência vivenciam, diariamente, uma problemática nevrálgica: a existência de obstáculos físico-estruturais nos espaços, edificações públicas e coletivas, nos transportes públicos, nos equipamentos, mobiliários e nos elementos urbanísticos, e em outros locais onde estão bens e serviços disponíveis, mas que, devido à falta de acessibilidade, não podem ser usufruídos por aquele segmento social.

Salienta-se que não é por falta de legislação que isso acontece, porque, nos planos internacional, constitucional e infraconstitucional, vigora uma profusão de normas jurídicas que proclamam o direito humano e fundamental à acessibilidade, como condição sine quo non à garantia da inclusão social daquelas pessoas, mediante o pleno exercício de direitos civis, políticos, econômicos, sociais e culturais e de garantias fundamentais correlatas.

Frente a essa demanda social, tem-se, verificado, no entanto, que as sucessivas medidas governamentais levadas a efeito, nessa área, particularmente na esfera federal, não têm produzido modificações significativas no quadro existente, subsistindo um quantitativo incomensurável de espaços, edificações, transportes públicos, equipamentos, mobiliários e elementos urbanísticos, que não satisfazem às condições mínimas de acessibilidade, impedindo ou impondo limitações às pessoas, quanto à locomoção e ao acesso a tais bens e serviços, quando os pretendem, legitimamente, usufruir. Torna-se, assim, imperioso ao Poder Público, principalmente o municipal, atuar sistematicamente nessa área.

Sabe-se que a acessibilidade urbanística é condição indispensável, para que toda pessoa possa se desenvolver em sociedade, tendo a possibilidade de alcançar o máximo de suas potencialidades, contribuindo não só para seu próprio desenvolvimento, mas para o desenvolvimento da sociedade como um todo. De inegável relevância, gera resultados sociais positivos e contribui para o desenvolvimento inclusivo e sustentável, sendo essencial sua implementação tanto na cidade quanto no campo.

Prepondera o entendimento no sentido de que há, certamente, uma questão crucial e permanente que atinge mais diretamente às pessoas com deficiência: a precariedade das condições de acessibilidade urbanística nas vias públicas, edificações e meios de transportes de uso público e coletivo, além da barreira atitudinal materializada em critérios avaliativos pautados em estigmas, estereótipos, preconceitos e discriminações com que a sociedade oprime esses sujeitos.

Ponderando tudo o que foi anteriormente exposto com relação aos contornos e vicissitudes das situações dos meios físico-estrutural e social dos municípios de Abaetetuba, Igarapé-Miri e Moju, chega-se à constatação de que a acessibilidade urbanística, lamentavelmente, representa um ideário a ser concretizado, ainda, em um prazo a perder de vista, a despeito da organização e luta política desse segmento social vulnerável, desde o final do século XX, na busca de conquistar espaços de participação, reconhecimento, respeito e efetivação de seus direitos, em todas as esferas da sociedade, tendo sido a sua maior conquista a de assegurar o direito à acessibilidade, no bojo da atual Constituição da República, mas a depender de efetividade.

\section{REFERÊnCIAS BIBLIOGRÁfICAS}

ARAUJO, Luiz Alberto David. A proteção constitucional das pessoas portadoras de deficiência: algumas 
dificuldades para efetivação dos direitos. In: SARMENTO, Daniel; IKAWA, Daniela; PIOVESAN, Flávia. (Coord.). Igualdade, diferença e direitos humanos. Rio de Janeiro: Lúmen Júris, 2008.

ARAUJO, Luiz Alberto David. A proteção constitucional das pessoas com deficiência. Secretaria de direitos humanos. 4. ed. rev. amp. atual. Brasília: Secretaria Nacional de Promoção dos Direitos da Pessoa com Deficiência, 2011.

ARAUJO, Luiz Alberto David. A proteção constitucional das pessoas com deficiência e o cumprimento do princípio da dignidade da pessoa humana. In: MIRANDA, Jorge; SILVA, Marco Antonio Marques da (Coord.). Tratado Luso-Brasileiro da Dignidade Humana. São Paulo: Quartier Latin, 2008. p. 205-211.

ASSOCIAÇÃO BRASILEIRA DE NORMAS TÉCNICAS. NBR 13994: Elevadores de passageiros - elevadores para transporte de pessoa portadora de deficiência. Rio de Janeiro: ABNT, 2000. Disponível em: <http://www.crea-sc.org.br/portal/arquivosSGC/NBR\%2013994.pdf>. Acesso em: 10 mar. 2017.

ASSOCIAÇÃO BRASILEIRA DE NORMAS TÉCNICAS. NBR 14022: Acessibilidade em veículos de características urbanas para transporte coletivo de passageiros. Rio de Janeiro: ABNT, 2006. Disponível em: <http://www.crea-sc.org.br/portal/arquivosSGC/NBR\%2014022.pdf>. Acesso em: 10 mar. 2017.

ASSOCIAÇÃO BRASILEIRA DE NORMAS TÉCNICAS. NBR 15250: Acessibilidade em caixa de autoatendimento bancário. Rio de Janeiro: ABNT, 2005. Disponível em: < http://www.pessoacomdeficiencia. gov.br/app/sites/default/files/arquivos/\%5Bfield_generico_imagens-filefield-description\%5D_16.pdf>. Acesso em: 10 mar. 2017.

ASSOCIAÇÃO BRASILEIRA DE NORMAS TÉCNICAS. NBR 9050: Acessibilidade de pessoas portadoras de deficiência a edificações, espaço, mobiliário e equipamento urbano. Rio de Janeiro: ABNT, 2004. Disponível em: <http://www.pessoacomdeficiencia.gov.br/app/sites/default/files/arquivos/\%5Bfield_ generico_imagens-filefield-description\%5D_24.pdf>. Acesso em: 10 mar. 2017.

BRASIL. Cartilha do Censo 2010: Pessoas com Deficiência. Brasília: SDH-PR/SNPD, 2012. p. 5. Disponível em: $\quad<$ http://www.pessoacomdeficiencia.gov.br/app/sites/default/files/publicacoes/cartilha-censo2010-pessoas-com-deficienciareduzido.pdf>. Acesso em: 10 abr. 2017.

BRASIL. Constituição da República Federativa do Brasil de 1988. Disponível em: <http:/ /www.planalto.gov.br/ ccivil_03/constituicao/constituicaocompilado.htm>. Acesso em: 15 mar. 2017.

BRASIL. Decreto Legislativo n ${ }^{\circ} 186$, de 9 julho de 2008. Aprova o texto da Convenção sobre os Direitos das Pessoas com Deficiência e de seu Protocolo Facultativo, assinados em Nova Iorque, em 30 de março de 2007. Disponível em: <http://www.planalto.gov.br/ccivil_03/constituicao/congresso/DLG/DLG-1862008.htm>. Acesso em: 17 mar. 2017.

BRASIL. Decreto $n^{\circ} 5.296 / 04$, de 2 de dezembro 2004. Regulamenta as Leis $\mathrm{n}^{\text {os }} 10.048$, de 8 de novembro de 2000, que dá prioridade de atendimento às pessoas que especifica, e 10.098, de 19 de dezembro de 2000, que estabelece normas gerais e critérios básicos para a promoção da acessibilidade das pessoas portadoras de deficiência ou com mobilidade reduzida, e dá outras providências. Disponível em: < http://www.planalto. gov.br/ccivil_03/_ato2004-2006/2004/decreto/d5296.htm>. Acesso em: 20 mar. 2017.

BRASIL. Decreto $n^{0}$ 6.949, de 25 de agosto de 2009. Promulga a Convenção Internacional sobre os Direitos das Pessoas com Deficiência e seu Protocolo Facultativo, assinados em Nova York, em 30 de março de 2007. Disponível em: <http://www.planalto.gov.br/ccivil_03/_ato2007-2010/2009/decreto/d6949.htm>. Acesso em: 20 mar. 2017.

BRASIL. Lei no 10.048, de 8 de novembro de 2000. Dá prioridade de atendimento às pessoas que especifica, e dá outras providências. Disponível em: < http://www.planalto.gov.br/ccivil_03/leis/L10048.htm>. Acesso em: 20 mar. 2017.

BRASIL. Lei no 10.098, de 19 de dezembro de 2000. Estabelece normas gerais e critérios básicos para a pro- 
moção da acessibilidade das pessoas portadoras de deficiência ou com mobilidade reduzida, e dá outras providências. Disponível em: <http://www.planalto.gov.br/ccivil_03/leis/L10098.htm>. Acesso em: 17 mar. 2017.

BRASIL. Lei n 10.257, de 10 de julho de 2001. Regulamenta os arts. 182 e 183 da Constituição Federal, estabelece diretrizes gerais da política urbana e dá outras providências. Disponível em: <http://www.planalto. gov.br/ccivil_03/leis/LEIS_2001/L10257.htm>. Acesso em: 18 mar. 2017.

BRASIL. Lei ñ 13.146, de 6 de julho de 2015. Institui a Lei Brasileira de Inclusão da Pessoa com Deficiência (Estatuto da Pessoa com Deficiência). Disponível em: <http://www.planalto.gov.br/ccivil_03/_ato20152018/2015/lei/113146.htm>. Acesso em: 20 abr. 2017.

BRITO FILHO, José Cláudio Monteiro de. Assegurando o gozo dos direitos em condições de igualdade: direitos humanos das pessoas com deficiência - contexto geral. In: BELTRÃO, Jane Felipe et al. (Coord.). Direitos Humanos dos Grupos Vulneráveis. Manual.Rede Direitos Humanos e Educação Superior, 2014.

CÂMARA, Andreza Aparecida Franco. Políticas públicas de habitação e o programa de aceleração do crescimento: análise das intervenções no estado do Rio de Janeiro. Rev. Bras. Pol. Públicas (Online), Brasília, v. 1, n. 3 número especial, p. 169, dez./2011. Disponível em: <https://www.publicacoesacademicas.uniceub. br/RBPP/article/view/1487>. Acesso em: 24 maio 2017.

CUSTÓDIO, André Viana; MOREIRA, Rafael Bueno da Rosa. A garantia do direito à educação de crianças e adolescentes no contexto das políticas públicas brasileiras. Revista Brasileira de Políticas Públicas, Brasília, v. 5, n. 1, p. 240, 2015. Disponível em: <https://www.publicacoesacademicas.uniceub.br/RBPP/article/ view/3036>. Acesso em: 25 maio 2017.

DIAS, Daniella Maria dos Santos. Planejamento e desenvolvimento urbano no sistema jurídico brasileiro: óbices e desafios. Curitiba: Juruá, 2012.

DIAS, Felipe da Veiga; CUSTÓDIO, André Viana. O discurso expansivo-punitivo dos meios de comunicação e sua influência na formação da agenda das políticas públicas de combate à criminalidade de crianças e de adolescentes no Brasil. Revista Brasileira de Políticas Públicas, Brasília, v. 3, n. 1, jan./dez. p. 92, 2013. Disponível em: <https://www.publicacoesacademicas.uniceub.br/RBPP/article/view/2162>. Acesso em: 25 maio 2017.

DINIZ, Débora; BARBOSA, Lívia Barbosa; SANTOS, Wederson Rufino dos. Deficiência, direitos humanos e justiça. São Paulo. Sur, Revista internacional dos direitos humanos, v. 6, n. 11, p. 65-77, dez. 2009.

DWORKIN, Ronald. A virtude soberana: a teoria e a prática da igualdade. Tradução: Jussara Simões. Revisão técnica e de tradução: Cícero Araújo, Luiz Moreira. São Paulo: M. Fontes, 2005.

GUIMARÃES, Virgínia Totti. Direito à cidade e direitos na cidade: integrando as perspectivas social, política e jurídica. Revista de Direito da Cidade, v. 9, n. 2, p. 627. Disponível em: <http://www.e-publicacoes.uerj. br/index.php/rdc/article/viewFile/27143/20439>. Acesso em: 26 maio 2017.

HARVEY, David. Cidades rebeldes: do direito à cidade à revolução urbana. São Paulo: M. Fontes, 2014.

INSTITUTO BRASILEIRO DE GEOGREAFIA E ESTATÍSTICA. Censo Demográfico, Brasil: IBGE 2000. Disponível em: Brasil <http://www.ibge.gov.br/home/estatistica/populacao/censo2000/>. Acesso em: 02 mar. 2017.

LEFEBVRE, Henri. Espaşo e Política. Belo Horizonte: UFMG, 2008.

RAIOL, Raimundo Wilson Gama. Acessibilidade Física, Educação, Saúde e Trabalho: integrantes do mínimo existencial indispensável às pessoas com necessidades especiais, à luz dos direitos humanos e de fundamentos constitucionais, na era da globalização. In: MATTOS NETO, Antonio José de; LAMARÃO NETO, Homero; SANTANA, Raimundo Rodrigues (Org.). Direitos Humanos e Democracia Inclusiva. São Paulo: Saraiva, 2012. 
RAIOL, Raimundo Wilson Gama. Direito das Pessoas com Necessidades Especiais à Acessibilidade: arcabouço, análise crítica e motivação social. Revista Fibra e Ciência. Belém, v. 2, n. 3, p. 35-46, jun. 2010. Disponível em: http://www.fibrapara.edu.br/seer/ojs/index.php/fibra_e_ciencia/article/view/6. Acesso: 28 abr. 2017.

SANTOS, Isabelle Dias Carneiro. A educação diferenciada como política pública de inclusão social dos Guarani e Kaiowá no Estado do Mato Grosso do Sul. Rev. Bras. Pol. Públicas (Online), Brasília, v. 6, n. 3, p. 309, dez. 2016. Disponível em: <https://www.publicacoesacademicas.uniceub.br/RBPP/article/ view/4389>. Acesso em: 24 maio 2017.

SAULE JÚNIOR, Nelson. Direito Urbanístico: vias jurídicas das políticas urbanas. Porto Alegre. S. A. Fabris Editor, 2007.

SOUZA, Pedro Bastos de. Benefícios de renda mínima como um direito fundamental: acesso à justiça e inclusão social. Rev. Bras. Polít. Públicas (Online), Brasília, v. 6, n. 1, p. 158, 2016. Disponível em: <https:// www.publicacoesacademicas.uniceub.br/RBPP/article/view/3802>. Acesso em: 25 maio 2017. 


\section{Longevidade e cidade: do dano urbanístico à garantia do direito à moradia adequada para idosos de baixa renda*}

\section{Longevity and city: from urban damage to the guarantee of the right to adequate housing for low income elderly}

Luzia Cristina Antoniossi Monteiro**

Nayara Mendes Silva***

Vania Aparecida Gurian Varoto****

\section{Resumo}

O rápido crescimento da população idosa contribui para um novo arranjo demográfico nas cidades, resultando em demandas que desafiam o poder público a repensar práticas e meios de suporte a essa população. Este artigo objetiva apontar uma estratégia para obtenção de recursos por meio das atribuições do Ministério Público, instituição nomeada pela lei para agir em defesa dos direitos da pessoa idosa: o uso do Termo de Ajustamento de Conduta - TAC. Trata-se de um estudo qualitativo, documental, exploratório, descritivo e observacional, com o acompanhamento de um caso prático em um condomínio exclusivo para idosos de baixa renda de um município do interior paulista. O devido cumprimento do TAC proporcionou melhores condições de acessibilidade e qualidade de vida aos idosos, revelando-se um mecanismo viável de ser replicado em outros espaços, a fim de proporcionar garantia de direitos, como é o caso da moradia adequada.

* Recebido em 19/05/2017 Aprovado em 30/06/2017

** Advogada, mestre e doutora em Engenharia Urbana pelo Programa de Pós-Graduação em Engenharia Urbana - UFSCar. Chefe e docente do Departamento de Gerontologia. Docente da Pós-Graduação em Gerontologia- UFSCar. E-mail: cristinaantoniossi4@gmail.com

*** Gerontóloga. Mestranda do Programa de Pós-Graduação em Gerontologia-PPGGero, Universidade Federal de São Carlos - UFSCar. E-mail: nayara.mm@live.com

**** Terapeuta Ocupacional, especialista em saúde coletiva e doutora em Engenharia de Produção pelo Programa de Pós-Graduação em Engenharia de Produção-UFSCar (doutorado direto). Docente do Departamento de Gerontologia-DGero, e do Programa de Pós-Graduação em Gerontologia-PPGGero, ambos da UFSCar. E-mail: vania_varoto@yahoo.com.br.
Palavras-chave: Idoso. Ministério Público. Pesquisa Interdisciplinar. Planejamento Urbano. Políticas Públicas.

\section{Abstract}

The rapid growth of the elderly population contributes to a new demographic arrangement in cities, resulting in demands that challenge the government to rethink practices and support means at this population. This article aims to point out a strategy to obtain resources through the powers of the Public Ministry, an institution appointed by law to act in defense of the rights of the elderly: the use of Conduct Adjustment Term - TAC. This is a qualitative, documental, exploratory, descriptive and observational study, with accompaniment of a practical case in an exclusive condominium for low-income seniors in a municipality of São Paulo. Proper compliance with the TAC, provided better conditions of accessibility and quality of life for the elderly, revealing a viable mechanism be replicated in other areas in order to provide better support and hence the guarantee of rights, as in this work. 
Key-words: Elderly. Interdisciplinary Research. Public Attorneys. Public Policies.

\section{INTRODUÇÃo}

A estrutura demográfica brasileira vem apresentando modificações que resultam em um acelerado processo de envelhecimento populacional. Nas últimas décadas, nota-se o crescente número de idosos, ao passo que as taxas de fecundidade e de mortalidade infantil diminuem. Paralelamente, tem-se a migração da área rural para a área urbana. Esses, dentre outros fatores, revelam significativas implicações sociais e contribuem para um novo arranjo demográfico cada vez mais perceptível nas cidades.

Com o aumento da expectativa de vida, consequentemente, há maior concentração de pessoas idosas no espaço urbano. Nesse sentido, é notório o desafio do poder público frente às demandas por serviços e na formulação de políticas públicas urbanas acessíveis de atenção ao idoso. Essa nova configuração demográfica traz a consciência de que o cenário urbano brasileiro necessitará se (re)adequar para abranger esse expressivo segmento etário nas cidades.

Sendo a cidade um direito do ser humano que deve contemplar a todos sem qualquer discriminação, seja por cor, sexo, raça ou idade, em defesa dos direitos da população idosa tem-se documentos internacionais e a legislação brasileira. A princípio, a Constituição Federal de 1988 e, especificamente, a Política Nacional do Idoso ${ }^{1}$ e o Estatuto do Idoso ${ }^{2}$. A própria lei nomeia o Ministério Público como Instituição responsável por agir em defesa dos interesses individuais e coletivos, caracterizando-se, assim, como seu principal aliado.

Considerando-se que as demandas advindas do aumento da expectativa de vida desafiam o poder público a repensar práticas e meios de suporte ao idoso, o presente artigo aponta uma estratégia para obtenção de recursos a partir das atribuições do Ministério Público estampadas em lei.

O presente artigo discorre sobre caso prático, acompanhado em um condomínio exclusivo para idosos de baixa renda na cidade de Araraquara-SP, onde as condições das moradias foram melhoradas a partir da aplicação de um Termo de Ajustamento de Conduta - TAC, firmado pelo Ministério Público com um agente causador de dano urbanístico.

O Termo de Ajustamento de Conduta constitui-se de um procedimento extrajudicial, utilizado com base em análise de irregularidades devidamente apuradas, que resultam em compensação a fim de reparar danos causados à sociedade, efetivando direitos previstos em lei.

Trata-se de um estudo documental, exploratório, descritivo e observacional baseado nos pressupostos do método qualitativo de investigação, com a realização de visitas ao local para a coleta de dados que foram analisados à luz do referencial teórico.

Neste trabalho, o TAC significou uma estratégia viável para captação de recursos para o alcance da moradia adequada, destacando-se o papel do Promotor de Justiça como ator fundamental na efetivação desse direito.

Revelou-se, ainda, que o TAC pode ser utilizado como um recurso do Estado, que, otimizado, acompanhado e implementado corretamente, pode propiciar melhorias nas condições dos espaços de moradia, contribuindo para a efetivação de políticas públicas avançando na rede de amparo à pessoa idosa, no sentido de favorecer o direito à cidade.

1 BRASIL. Lei n. 8842, de 4 de janeiro de 1994. Dispõe sobre a Política Nacional do Idoso e dá outras providências. Disponível em: <http://www.planalto.gov.br/ccivil_03/leis/L8842.htmAcesso em agosto de 2014>.

2 BRASIL. Lei n. 10.741, de 1 de outubro de 2003. Dispõe sobre o Estatuto do Idoso e dá outras providências. Disponível em: <http://www.planalto.gov.br/ccivil_03/leis/2003/110.741.htm>. Acesso em: ago. 2014. 


\section{ENVELHECIMENTO POPULACIONAL NAS CIDADES: ENFOQUE NA MORADIA}

O padrão demográfico brasileiro tem se modificado, profundamente, nos últimos anos de modo que a população idosa, no Brasil, maiores de 60 anos, torna-se cada vez mais evidente, dado o seu tão expressivo crescimento em curto período de tempo.

Dentre as variáveis que estão e continuarão a influenciar o aumento do contingente de pessoas idosas, destacam-se a redução da mortalidade, que diminui ao longo dos anos, assim como a taxa de fecundidade, além de mecanismos e avanços tecnológicos em diferentes áreas que fortalecem as condições de vida das pessoas e, consequentemente, contribuem para o aumento da expectativa de vida ${ }^{3,4}$.

Estimativas revelam que o número de pessoas idosas no Brasil crescerá muito mais do que a média internacional. Enquanto esse contingente, atualmente, totaliza, aproximadamente, 13\% do total da população brasileira, a Organização Mundial de Saúde - OMS divulga que esse número poderá triplicar até a metade do século, evidenciando, assim, o envelhecimento da nação ${ }^{1,5}$.

À medida que tais modificações ocorrem, aceleradamente, na demografia brasileira, também se modifica o perfil das cidades, ao considerar, dentre outros fatores, as desigualdades na distribuição de recursos, falhas na administração pública, falta de rigor na aplicabilidade de leis e altos índices de migração da área rural para a área urbana, que afetam, diretamente, as estruturas físicas de moradias ${ }^{1,6,7}$.

Verifica-se, nesse sentido, que a área urbana ganha novas dimensões e, concomitantemente, conta com um maior número de pessoas idosas. Em face dessas informações, é relevante apontar o mesmo questionamento feito por Prado ${ }^{8}$ : até que ponto as cidades podem acolher um número tão expressivo de pessoas com mais de 60 anos?

O crescimento do número de idosos pode ser visto como uma conquista da humanidade, ao considerar os avanços da ciência e tecnologia ${ }^{9}$. Entretanto, esse feito constitui-se um grande desafio, pois, em igual proporção ao aumento da expectativa de vida, tem-se a necessidade de atenção às demandas quanto ao suporte a esse segmento etário.

Grande parte dos estudos dão enfoque às questões relacionadas à saúde dessa população e os fatores que podem contribuir ou agravar as premissas de envelhecimento saudável e ativo. Nesse contexto, é importante destacar que saúde não se restringe, somente, ao controle e prevenção de agravos de doenças crônicas e não transmissíveis. Esta é composta pela interação de outras dimensões que compõem a vida humana e vão além do âmbito físico ${ }^{10},{ }^{11}$.

O conceito ampliado de saúde, elaborado na $8^{a}$ Conferência Nacional de Saúde de 1986, define que

3 INSTITUTO BRASILEIRO DE GEOGRAFIA E ESTATÍSTICA. Projeção da população por sexo e idade: Brasil 2000-2060. 2013. p. 43 Disponível em: <http://www.ibge.gov.br/home/presidencia/noticias/imprensa/ppts/0000001442560811201356332913764 9.pdf>. Acesso em: ago. 2014.

4 CAMARANO, A. A; KANSO, S. Envelhecimento da população brasileira. 2011. In: FREITAS, E. V. et al. Tratado de geriatria e gerontologia. Rio de Janeiro: Guanabara Koogan, 2011. p. 58-73.

5 ORGANIZAÇÃO MUNDIAL DA SAÚDE. Relatório mundial de envelhecimento e saúde. Brasília: OMS Publicações, 2015.28 p.

6 SANTOS, M. O espaço da cidadania e outras reflexões: o pensamento político brasileiro. 2. ed. Local: Fundação Ulysses Guimarães, 2013.

7 MARICATO, E. As ideias fora do lugar e o lugar fora das ideias: Planejamento urbano no Brasil. In: ARANTES, O; VAINER, C; MARICATO, E. A cidade do pensamento único: desmanchando consensos. Petrópolis, RJ: Vozes, 2000. p. 121-192.

8 PRADO, A. R. A. Cidade livre de barreiras e acessível aos idosos. In: FREITAS, EV et al. Tratado de Geriatria e Gerontologia. Rio de Janeiro: Guanabara Koogan, 2007. p. 645-654.

9 VESCIO, H. et al. Área Temática: Saúde do Idoso. 2013. Disponível em: <http://www.prefeitura.sp.gov.br/cidade/secretarias/ upload/saude/arquivos/pessoaidosa/cd_idoso-ATSaudeIdoso-2003ou2004.pdf>. Acesso em: ago. 2014.

10 MESQUiTA, R. A. V.; COSTA, NE; CARVALHO HBC. Políticas Públicas de Saúde para o Envelhecimento e a Velhice. 2011. In: FREITAS, E. V. et al. Tratado de geriatria e gerontologia. Rio de Janeiro: Guanabara Koogan, 2011. p. 1622-1626.

11 BRASIL. Consolidado dos relatórios das conferências estaduais de saúde. 2006. Disponível em:< http://bvsms.saude.gov.br/bvs/publicacoes/CES_consolidado.pdf >. Acesso em: maio 2017. 
"saúde é a resultante das condições de alimentação, habitação, educação, renda, meio ambiente, trabalho, transporte, emprego, lazer, liberdade, acesso e posse da terra e acesso a serviços de saúde". Esse conceito envolve o reconhecimento do ser humano como ser integral e a saúde como qualidade de vida.

O conceito ampliado de saúde foi estabelecido mais tarde pela Lei Orgânica do Sistema Único de Saú$\mathrm{de}^{12}$, que aponta:

Art. $3^{\circ}$ Os níveis de saúde expressam a organização social e econômica do País, tendo a saúde como determinantes e condicionantes, entre outros, a alimentação, a moradia, o saneamento básico, o meio ambiente, o trabalho, a renda, a educação, a atividade física, o transporte, o lazer e o acesso aos bens e serviços essenciais.

A legislação, ainda, destaca que, também, se referem à saúde, as ações que se destinam a garantir às pessoas e à coletividade condições de bem-estar físico, mental e social. Conforme a $8^{\mathrm{a}}$ Conferência Nacional de Saúde, o direito à saúde significa a garantia de condições dignas de vida e de acesso universal e igualitário às ações e serviços de promoção, proteção e recuperação da saúde, em todos os seus níveis e a todos os cidadãos, o que implica em garantir a toda a sociedade direitos fundamentais, dentre eles, a moradia adequada. Nesse contexto, o conceito de cidadania que a Constituição assegura deve ser traduzido nas condições de vida da população?

Considera-se que, em relação ao atual cenário sociodemográfico brasileiro, alternativas para captação de recursos são imprescindíveis para o direito à cidade, sobretudo para a pessoa idosa. No contexto das cidades, de acordo com Monteiro et al ${ }^{13}$, o principal desafio é a questão da moradia digna. A Organização Mundial da Saúde, preocupada com o arranjo das cidades em face do expressivo aumento de idosos, realizou uma pesquisa, a Estratégia Amiga do Idoso, ouvindo cerca de 1500 idosos, em 35 cidades, de 22 países, que discorreram sobre fatores positivos e negativos que influenciam, diretamente, seus respectivos locais de moradia.

Dentre os eixos identificados essenciais para a melhoria da vida na cidade, tem-se como prioritário a moradia adequada, por ser um direito fundamental do cidadão. Esse eixo deve contemplar fatores como o custo acessível, planejamento de forma a tornar-se adaptada, ser passível de manutenção para atender aos idosos em caso de necessidade, proporcionar integração comunitária e acesso aos serviços disponíveis.

A moradia adequada é direito social estampado no artigo $6^{\circ}$ da Constituição Federal e reconhecido, internacionalmente, pela Declaração Universal dos Direitos Humanos de 1948. Contemplada ainda, no Comentário Geral 4, do Comitê da ONU sobre Direitos Econômicos e Sociais e no Plano de Ação da Assembleia Mundial do Envelhecimento, realizada no ano de 2002 em Madri. Esse Plano recomenda a adoção de medidas como a criação de ambientes propícios e favoráveis, enfatizando o direito de todos a viver em lugar que realce suas capacidades, atribuindo ao poder público a responsabilidade na formulação e aplicação de políticas que promovam um ambiente propício.

A questão da moradia, também, é estampada na legislação específica da pessoa idosa, uma vez que o Estatuto do Idoso afirma esse direito no artigo 37, aprofundando-o no artigo 38 ao referir-se à prioridade da pessoa idosa na aquisição do imóvel para moradia própria, nos programas habitacionais públicos, garantindo a reserva de pelo menos três por cento $(3 \%)$ das unidades.

De acordo com o Estatuto da Cidade ${ }^{14}$, marco jurídico-urbanístico, ao tratar da diretriz sobre cidades sustentáveis afirma a questão da moradia, no artigo $2^{\circ}$, inciso I:

12 BRASIL. Lei n 8.080 de 1990. Dispõe sobre as condições para a promoção, proteção e recuperação da saúde, a organização e o funcionamento dos serviços correspondentes e dá outras providências. Disponível em:<http://www.planalto.gov.br/ccivil_03/ leis/L8080.htm.> Acesso em: jun. 2017.

13 MONTEIRO, L. C. A.; ZAZZETTA, M. S.; ARAÚJO, M. E. J. Sustentabilidade: relação entre o espaço urbano e envelhecimento ativo. Revista novos estudos jurídicos, v. 20, n. 8. p. 118-142, 2015.

14 BRASIL. Estatuto da Cidade. Lei n. 10.257 de 2001. Disponível em: < http://www.planalto.gov.br/ccivil_03/leis/LEIS_2001/ L10257.htm> Acesso em: maio 2017. 
[...] garantia do direito à cidades sustentáveis, entendido como o direito à terra urbana, à moradia, ao saneamento ambiental, à infra-estrutura urbana, ao transporte e aos serviços públicos, ao trabalho e ao lazer, para as presentes e futuras gerações.

Desse modo, verifica-se no que tange à garantia de direitos, que a pessoa idosa está respaldada pela legislação, necessitando, entretanto, de mecanismos para que esta seja cumprida. Para tanto, a pessoa idosa conta com um importante aliado na efetividade de ações que culminem em melhorias e oferta de suporte: o Ministério Público.

\section{O Ministério Público e mecanismos em defesa de direitos da Pessoa idosa}

A Constituição Federal ${ }^{15}$, em seu artigo 225, prevê que todos têm direito ao meio ambiente ecologicamente equilibrado, bem de uso comum do povo e essencial à sadia qualidade de vida, impondo-se ao Poder Público e à coletividade o dever de defendê-lo e preservá-lo para o presente e futura geração.

Milaré ${ }^{16}$ aponta que não existe qualidade de vida sem qualidade ambiental, revelando que a qualidade de vida é intrínseca ao direito do meio ambiente ecologicamente equilibrado. Nesse contexto um ambiente sadio configura-se como extensão do direito à vida. Revela-se, nesse sentido, a necessidade de repensar meios que possam garantir os direitos estampados na legislação, trazendo a consciência de que todos são sujeitos de direitos e, assim, todos têm o dever de se responsabilizar pelo meio ambiente, de forma que este possa caracterizar-se como socialmente equitativo, meio de garantir a proteção da personalidade humana ${ }^{17}$.

Sendo a moradia adequada um direito da pessoa idosa, conforme explícito no Estatuto do Idoso, e o Ministério Público seu aliado nessa conquista, destaca-se a argumentação de Feijó ${ }^{18}$ ao afirmar que o não favorecimento de medidas para efetivação dos seus direitos, como o dever de amparo, proporcionando-lhe tutela específica, requer medidas energéticas por parte do Ministério Público, tais como: instauração de Inquérito Civil, propositura de ações civis públicas, mandados de injunção, dentre outros.

O Ministério Público é uma instituição pública autônoma, incumbida pela Constituição Federal a agir em defesa da ordem jurídica, o regime democrático e os interesses sociais e individuais indisponíveis ${ }^{19}$. Ressalta-se a importância dessa Instituição na fiscalização dos interesses da pessoa idosa, atuando em defesa das garantias asseguradas, de forma a incentivar, mostrar e alertar a família, comunidade e o poder público sobre a necessidade de prevenir o desrespeito e aumentar alternativas de amparo a essa população ${ }^{15}$.

Conforme descreveu Mazzillii ${ }^{20}$ o Ministério Público, no desempenho de suas atribuições, tem, dentre as prioridades, a defesa de minorias, como pessoas com deficiências, indígenas, crianças, adolescentes e idosos. Tendo em vista o crescimento da população idosa e as demandas atinentes a esse aumento, urge caracterizar a parcela hipossuficiente, considerando-se a necessidade de ações por parte do Ministério Público e a utilização de mecanismos para agir em defesa dos direitos dessas pessoas vulneráveis ${ }^{21}$.

15 BRASIL. Constituição da República Federativa do Brasil de 1988. Disponível em: < http://www.planalto.gov.br/ccivil_03/constituicao/constitui\%C3\%A7ao.htm>. Acesso: ago. 2014.

16 MILARÉ, E. O direito do ambiente: a gestão ambiental em foco: doutrina, jurisprudência, glossário. 7. ed. São Paulo: Revista dos Tribunais, 2011.

17 MOLINARO, C. A. Breves reflexões sobre os deveres fundamentais socioambientais. Revista novos estudos jurídicos, v. 20, n. 3, p. 991-1023, 2015.

18 FEIJO, M. C. A aplicabilidade do Estatuto do Idoso junto ao Ministério Público de São Paulo. 2010. Tese (Doutorado). Pontifícia Universidade Católica de São Paulo, São Paulo, 2010.

19 BRASIL. Lei n. 8625 de 1993. Disponível em: <http://www.planalto.gov.br/ccivil_03/leis/18625.htm>. Acesso em: maio 2016.

20 MAZZILLI, N. H. O Ministério Público e a defesa do regime democrático. Brasília, 1998.

21 SILVA, R. S. B. O necessário fortalecimento da atuação do Ministério Público na defesa dos interesses transindividuais. Cadernos de Direito, Piracicaba, v. 12, n. 22, p. 155-166. jan./jun. 2012. 
Além das funções institucionais do Ministério Público, previstas no artigo 129 da Constituição Federal, tem-se, ainda, reiteradas suas funções na Lei Orgânica do Ministério Público ${ }^{18,22}$. Destas, destaca-se a função de promover o Inquérito Civil e Ação Civil Pública para a proteção, prevenção e reparação dos danos causados ao meio ambiente, ao consumidor, aos bens e a outros interesses difusos, coletivos e individuais indisponíveis e homogêneos ${ }^{12,16,23}$.

Segundo Silva et $\mathrm{al}^{24}$, o Inquérito Civil é uma ferramenta utilizada pelo Ministério Público para reunir evidências da prática de atos que de alguma forma violam interesses ou direitos na ordem coletiva social e, quando concluído, pode, dentre outras alternativas, encerrar-se por meio de um ajustamento de conduta.

Já a Ação Civil pública é um instrumento processual que possui como finalidades a regência das ações de responsabilidade por danos morais e patrimoniais causados ao meio ambiente, ao consumidor, à ordem urbanística, ao patrimônio público e social ou a qualquer outro interesse difuso ou coletivo ${ }^{19}$.

Embora a Ação Civil Pública seja um instrumento de tutela civil dos interesses difusos e coletivos, este não é o único mecanismo de defesa do direito ao meio ambiente ecologicamente equilibrado para a presente e futuras gerações. Ao seu lado, de acordo com a Ação Civil Pública ${ }^{25}$, tem-se o Compromisso de Ajustamento de Conduta e o Fundo de Defesa de Direitos Difusos, ambos caracterizam-se como oportunidades indispensáveis para configuração de direitos fundamentais, como é o caso da moradia adequada, cuja efetivação é retratada no presente artigo.

\section{O Termo de Ajustamento de Conduta - taC}

No que se refere à garantia de direitos, considera-se ser de suma importância conhecer mecanismos que possam facilitar sua efetivação. Dentro dessa perspectiva, pode-se considerar o uso do Termo de Ajustamento de Conduta como um facilitador, dado o Ministério Público um dos legitimados para sua utilização e que, no presente artigo, destaca-se como um imprescindível aliado para a efetivação de direitos da pessoa idosa.

Conforme previsto no quinto artigo da Lei da Ação Civil Pública ${ }^{24}$, "os órgãos públicos legitimados poderão tomar dos interessados compromisso de ajustar sua conduta às exigências legais, mediante cominações que terão eficácia de título executivo extrajudicial" ${ }^{24}$. De acordo com Rebouças ${ }^{26}$, o TAC constitui-se de um procedimento extrajudicial, utilizado após a análise de existência de irregularidades, devidamente apuradas por meio de medidas administrativas, por exemplo, o inquérito civil, utilizado antes de uma ação perante o judiciário.

Conforme o artigo $3^{\circ}$ da Lei da Ação Civil Pública ${ }^{24}$, tem-se por objeto três espécies de obrigações: a primeira, "de não fazer", ou seja, cessar toda e qualquer atividade que comprometa a qualidade ambiental; a segunda, "de fazer", relacionada à recuperação do ambiente lesado; e a terceira, "de dar", relacionada à fixação de indenização correspondente ao valor econômico dos danos, sendo, portanto, configurada como

22 SÃO PAULO (Estado). Assembleia Legislativa. Lei Complementar n. 734 de 1993. Institui a Lei Orgânica do Ministério Público e dá outras providências. Disponível em: <http://www.mpsp.mp.br/portal/page/portal/estrutura/734.htm>. Acesso em: jun. 2017.

23 BRASIL. Lei n. 7.347, de 24 de julho de 1985. Disciplina a ação civil pública de responsabilidade por danos causados ao meioambiente, ao consumidor, a bens e direitos de valor artístico, estético, histórico, turístico e paisagístico (VETADO) e dá outras providências. Disponível em: <http://www.planalto.gov.br/ccivil_03/Leis/L7347orig.htm>. Acesso em: 15 abr. 2015.

24 SILVA, F. C.; MEDONÇA, M. L. C. A.; DEOCLECIANO, P. R. M. O instituto do inquérito civil visto como forma e meio importante para pacificar as demandas coletivas e a discussão de seu devido processo constitucional. Revista Expressão Católica, Quixadá, v. 2, n. 2, p. 47-55, jul./dez. 2013.

25 BRASIL. Lei n. 7.347 de 1985. Disciplina a ação civil pública e dá outras providências. Disponível em: < http://www.planalto. gov.br/ccivil_03/leis/L7347orig.htm>. Acesso em: jun. 2017.

26 REBOUÇAS, T. M. O TAC como instrumento de garantia do direito à cidade. In: SEMINÁRIO URBANISMO DA BAHIA, n. 12, 2012, Salvador. Anais... Salvador: UrBa, 2012. 
forma indireta de sanar a lesão ${ }^{27}$.

Destaca-se que o dinheiro oriundo do pagamento indenizatório do TAC é destinado ao Fundo de Defesa dos Direitos Difusos para posterior aplicação de bens lesados ${ }^{23}$. Nesse contexto, alguns Estados criaram seus respectivos fundos estaduais, como é o caso do estado de São Paulo, que, por meio da Lei n 13.555/09, criou o Fundo Especial de Despesa de Reparação de Interesses Difusos Lesados no Ministério Público do Estado, que dispõe:

Art 2. O Fundo Estadual de Defesa dos Interesses Difusos - FID tem por objetivo gerir os recursos destinados à reparação dos danos ao meio ambiente, aos bens de valor artístico, estético, histórico, turístico e paisagístico, ao consumidor, ao contribuinte, às pessoas com deficiência, ao idoso, à saúde pública, à habitação e urbanismo e à cidadania, bem como a qualquer outro interesse difuso ou coletivo no território do Estado ${ }^{28}$.

Tal como a Ação Civil Pública, o objetivo do TAC, como instrumento de uso do Ministério Público, é agir em defesa de interesses difusos, coletivos e individuais homogêneos, caracterizando-se como um meio de reparar danos causados à sociedade. Vale considerar que essa reparação está relacionada à tutela e à preservação de bens e valores fundamentais, ressaltando-se, nesse sentido, a fixação de cominações, que têm a finalidade de compelir o agressor da ordem jurídica a cumprir a lei, e, assim, respeitar o compromisso perante o Ministério Público ${ }^{29}$.

Como destacado por Mazzilli ${ }^{30}$, o ajustamento de conduta é uma medida de tomar do causador de danos a interesses difusos e coletivos o compromisso escrito de que estes adéquem sua conduta às exigências da lei sob pena de cominações. Esse ajustamento não pode ser tomado por qualquer legitimado à ação civil pública ou coletiva, mas, sim, somente, os órgãos públicos legitimados, dentre eles, o Ministério Público.

De acordo com o exposto por Bianchini et a ${ }^{\beta 1}$, o principal objetivo do Termo de Ajustamento de Conduta, além de readequar a conduta do infrator, é solucionar, de maneira rápida e eficiente, os danos causados ao meio ambiente, esquivando todo o lento processo de conhecimento perante o poder judiciário. Para esse fim, possui cláusulas com prazos para o cumprimento das obrigações estabelecidas.

No presente artigo, tem-se a constatação de que o TAC mostrou-se apto a consecução do direito à moradia adequada para idosos de baixa renda, comprovando ser um mecanismo efetivo, pois, em vez de integrar o Fundo de Defesa dos Direitos Difusos, foi aplicado na modalidade obrigação "de fazer", constituindo-se em obra realizada no condomínio para idosos, readequando o local e proporcionando aos moradores qualidade de vida.

27 MilarÉ, E.; SETZER, J.; CASTANHO, R. O Compromisso de Ajustamento de Conduta e o Fundo de Defesa de Direitos Difusos: relação entre os Instrumentos Alternativos de Defesa Ambiental da Lei 7.347/1985, 2005. Disponível em: <http://bdjur.stj.jus.br/ jspui/handle/2011/89933>. Acesso em: mar. 2016.

28 SÃO PAULO (Estado). Assembleia Legislativa. Lei n. 23.555, de 2009. Disponível em: < http://www.al.sp.gov.br/repositorio/ legislacao/lei/2009/lei-13555-09.06.2009.html>. Acesso em: mar. 2016.

29 TELES, ICA. Destinação dos recursos oriundos dos TACs e dos acordos e condenações judiciais. Boletim Científico ESMPU, Brasília, v. 14, n. 44, p. 71-97, 2015.

30 MAZZILLI, N. H. Compromisso de ajustamento de conduta: Evolução e fragilidades- Atuação do Ministério Público. Revista Direito e Liberdade. ESMARN, Mossoró, v. 1, n. 1, p. 225-246. jul./dez. 2005.

31 BIANCHINI, A.; GRAVINA, M. B; TURATTI, L. A (in)eficácia dos termos de ajustamento de conduta na solução de danos ambientais no Vale do Taquari. Estudo \& Debate, Lajeado, v. 12, p. 117-131, 2005. 


\section{Desenvolvimento}

\subsection{Metodologia}

Trata-se de um estudo qualitativo, documental, exploratório, descritivo e observacional. Com a realização de visitas ao Núcleo Habitacional para Idosos em Araraquara/ SP, no período determinado no TAC para a realização do seu cumprimento.

Justifica-se o caráter documental dessa pesquisa embasado no estudo do TAC firmado entre a Promotoria de Justiça do Meio Ambiente e Urbanismo da Comarca de Araraquara com o ente privado causador do dano urbanístico.

Além do estudo do TAC, para a coleta de dados, utilizou-se roteiro de campo pré-elaborado preenchido quinzenalmente (a cada visita) em que foram feitas anotações sobre o andamento da obra.

Ainda, foram realizados registros fotográficos, além do emprego da técnica de observação participante. Desse modo, a pesquisa desenvolveu-se de forma sistemática, com análise do diagnóstico técnico qualitativo à luz do referencial teórico e normativo sobre o tema da pesquisa ${ }^{32},{ }^{33}$.

\subsection{O Condomínio Exclusivo para Idosos de baixa renda e a aplicação do TAC para a efetivação da moradia adequada}

O condomínio para idosos de baixa renda é caracterizado por uma tipologia de moradia exclusiva para idosos, localizada intramuros, com gestão pública realizada pela Secretaria Municipal de Assistência e Desenvolvimento Social, sendo inaugurado em dezembro de 2010. A área física em que foi construído estava abandonada pela antiga Ferrovia Paulista - FEPASA. O projeto arquitetônico, embora destinado a um espaço para uso de pessoas idosas, foi construído sem o devido planejamento, o que culminou na ausência de observância de normas técnicas sobre acessibilidade.

Quanto à sua área interna, conta com um arranjo de 33 (trinta e três) moradias, com $33 \mathrm{~m}^{2}$ (trinta e três metros quadrados) de construção, dispostas em semicírculo. Destas, apenas duas são adaptadas de acordo com os princípios do Desenho Universal. O condomínio dispõe, ainda, de um centro de convivência, destinado ao uso coletivo, sem qualquer indicação de acessibilidade urbana e de edificações, salvo alguns locais com rebaixamento de calçada sem indicação técnica.

O TAC foi firmado em 10 de julho de 2014, entre a Promotoria de Justiça do Meio Ambiente e Urbanismo de Araraquara e um ente privado causador de dano. Nesse documento, a Promotoria constatou a obrigação de reparar o dano urbanístico que consistiu na construção de um prédio comercial, em desacordo com a legislação municipal sobre recuos necessários das divisas do imóvel.

Analisando o documento, verifica-se que houve pedido de demolição da construção, mas a Promotoria em acordo com a municipalidade deixou de ajuizar a ação demolitória, entendendo-se que a irregularidade era passível de compensação, uma vez que não traria prejuízo à sociedade e que a execução da ação fugiria dos princípios de Direito da Razoabilidade e Proporcionalidade, podendo, então, ser resolvida por meio de indenização pecuniária.

Identificou-se no acordo que a indenização poderia ser revertida à sociedade, considerando-se que, na Comarca em que se firmou o TAC, tem-se consciência de entidades sociais extremamente necessitadas de recursos financeiros para concluir obras que proporcionem mais dignidade aos assistidos. Dessa forma, a

32 BARDIN, L. Análise de conteúdo. São Paulo: Edições 70, 2016.

33 MINAYO, M. C. S. O desafio do conbecimento: pesquisa qualitativa em saúde. São Paulo: Hucitec, 2014. 
municipalidade indicou o Núcleo Habitacional do Idoso para ser beneficiado.

Ainda segundo o documento, a escolha desse núcleo habitacional justificou-se considerando-se a realização de estudos e pesquisas científicas do Grupo de Pesquisa fomentado pela FAPESP, cujo presente artigo é fruto, que apontou, preliminarmente, medidas a serem adotadas nesse local, com o propósito de minimizar as dificuldades de locomoção, autonomia, independência, segurança e vida privada.

Em face dessas informações, firmou-se o TAC com relação à reparação compensatória pela inobservância das regras municipais de construção. Assim, como forma de compensação, os responsáveis pagariam, conforme o acordo, indenização pecuniária, correspondente a dois itens: a colocação de forro de PVC em algumas residências, bem como no centro de convivência do condomínio, e a construção de um muro de arrimo com as devidas canaletas para drenagem das águas pluviais. Esse último item é objeto de análise do presente manuscrito, tendo em vista sua importância para o local, pois era evidente que a construção de um muro de arrimo configuraria maior qualidade de vida e segurança, refletindo a saúde dos moradores.

A obrigação de fazer, referente à construção do muro de arrimo, foi firmada considerando a carência de acessibilidade que dificultava o cotidiano dos moradores, já que o local não oferecia condições para usufruir do espaço e contribuía com a vulnerabilidade propiciando a entrada de pessoas desconhecidas.

Conforme a Lei Orgânica do Ministério Público ${ }^{21}$, "a eficácia do compromisso ficará condicionada à homologação da promoção de arquivamento do inquérito civil pelo Conselho Superior do Ministério Público". Nesse sentido, é pertinente revelar que o TAC da presente pesquisa foi, devidamente, homologado nos termos do Conselho, órgão de administração superior e de execução do Ministério Público, que, dentre outras atribuições, delibera sobre a participação de membros da Instituição em organismos estatais de defesa do meio ambiente ${ }^{16}$.

O período estipulado no TAC para a realização da benfeitoria compreendia um prazo de 5 meses. $\mathrm{O}$ descumprimento do acordo firmado, sem a devida justificativa, resultaria em multa diária, no valor de $\mathrm{R} \$$ 1.000,00 (um mil reais), e, ainda, "sem prejuízo da execução específica das obrigações de fazer, respondendo cível e criminalmente em caso de prejuízo ao erário público”.

Consta, ainda, no TAC que o dinheiro oriundo da indenização por descumprimento total ou parcial do acordo, seria destinado ao Fundo Estadual de Defesa dos Interesses Difusos (FID), sem a necessidade de prévia notificação dos responsáveis. Também revela que a indenização é independente para cada item estipulado e que, em casos fortuitos ou força maior que impeçam a obrigação de fazer, os compromissados devem apresentar imediata justificativa, sob pena de aplicação da referida multa.

O local indicado para a construção do muro de arrimo faz divisa com o vizinho confrontante, a linha ferroviária, atualmente operada pela concessionária América Latina Logística - ALL. O muro contaria com, aproximadamente, 80 metros de extensão por 2 metros de altura. A figura abaixo permite visualizar o núcleo habitacional, demarcado em vermelho, em que o pontilhado indica a localização e o comprimento da construção: 
Figura 1 - Demarcação do Núcleo Habitacional e o local para a construção do muro de arrimo

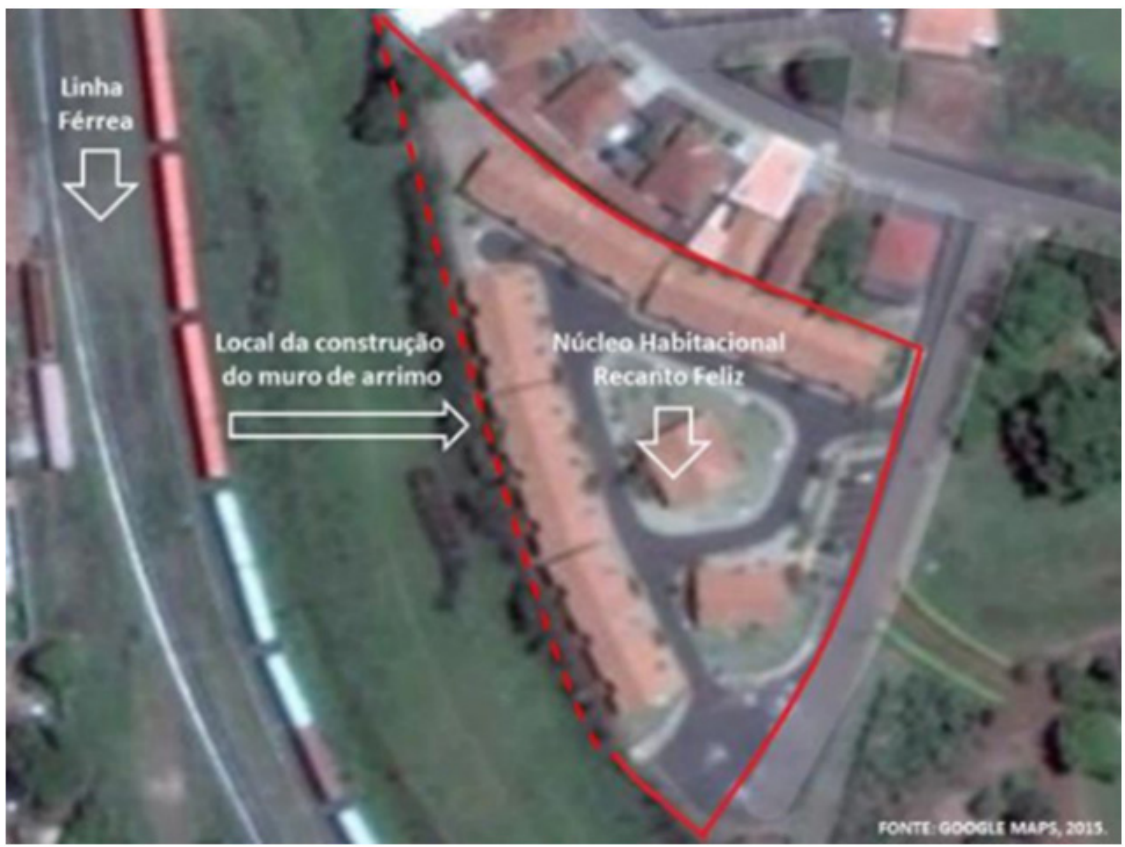

Fonte: Google Maps, 2015.

As observações realizadas, bem como as fotografias relativas às primeiras visitas ao local, mostram a situação do terreno aos fundos do núcleo habitacional, evidenciada nas figuras acima, onde se nota grande erosão próximo às casas dos moradores, com possibilidade de afetar suas estruturas. Nesse contexto, verificou-se que a situação do terreno não possibilitava a circulação dos moradores, expondo-os a fatores de risco, como quedas devido às irregularidades ${ }^{34}$.

Figura 2 - O local indicado para construção do muro de arrimo visto de perto.

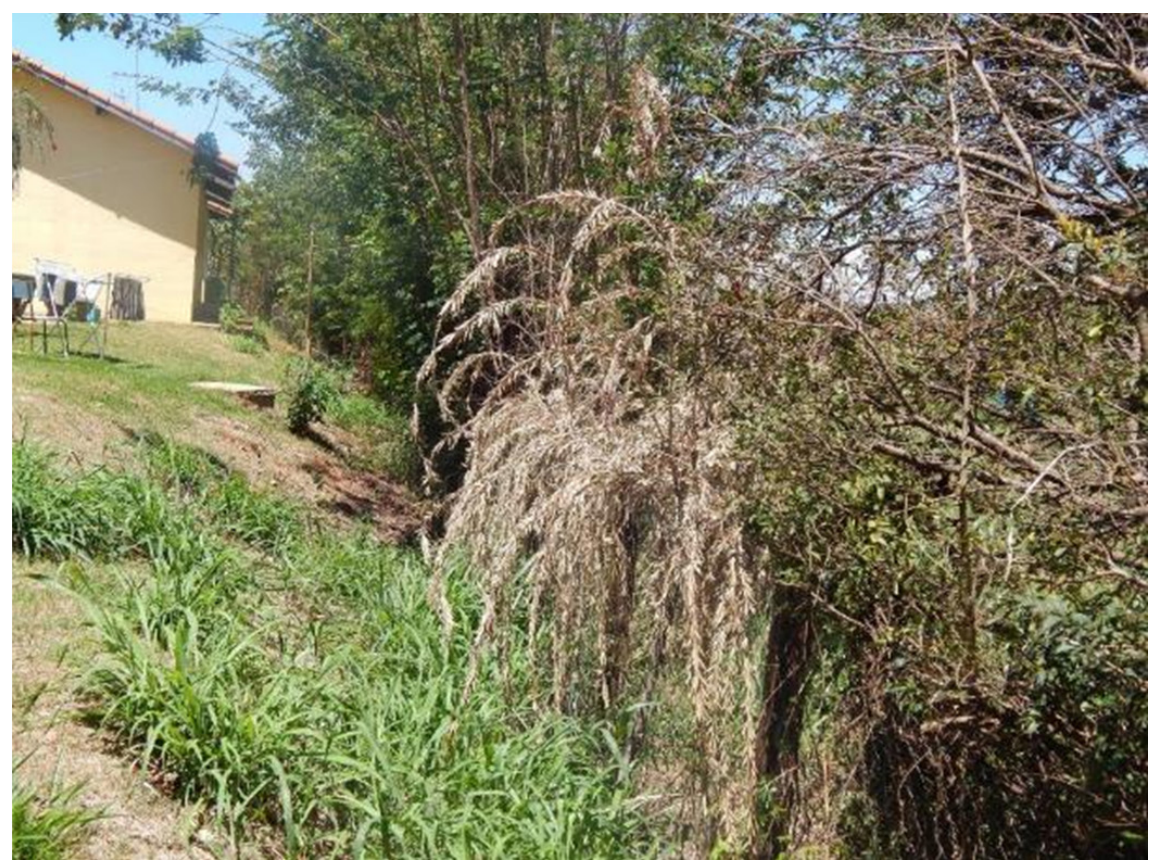

Fonte: Autor, 2014.

34 NOVAES, R. D. et al. Causas e consequências de quedas em idosos como indicadores para implementação de programas de exercício físico. Efdesportes Revista digital, Buenos Aires, abr. 2009. Disponível em: <http://www.efdeportes.com/efd131/causas-econsequencias-de-quedas-em-idosos.htm>. Acesso em: 17 abr. 2015. 
Tal situação configuravam barreiras, que, conforme sua definição, são qualquer entrave ou obstáculo que limite ou impeça o acesso, a liberdade de movimento, a circulação com segurança ${ }^{35}$. Nesse sentido, verificou-se que a ausência do muro de arrimo e o acentuado declive do local impossibilitava o acesso dos moradores a usufruírem do ambiente com segurança.

Essas barreiras limitavam a acessibilidade, entendida atualmente, para além da questão física, alcançando aspectos importantes do dia a dia das pessoas ${ }^{36}$. Diante disso, a construção do muro de arrimo mostrou-se mecanismo factível na complementação de aspectos que compõe a habitabilidade, assegurando o bem-estar e fortalecendo aspectos da saúde integral dos moradores.

\subsection{O muro de arrimo: assegurando a moradia e contendo os riscos}

Muros de arrimo ou de contenção são paredes fortes construídas de alvenaria ou de concreto, com o objetivo de proteger, apoiar ou escorar áreas que apresentam riscos de deslizamento e ou desmoronamento ${ }^{37}$. Nesse sentido, impedem abalos nas estruturas das residências, comumente chamadas de fissuras, caracterizadas como patologias estruturais ${ }^{38}$.

Considerando-se os benefícios da construção do muro de arrimo e, embora evidenciada sua importância no que se refere às melhores condições de moradia no núcleo habitacional, que favoreceram a proteção estrutural das residências, e diminuíram riscos, sua função é, basicamente, estrutural, pois trata-se de um mecanismo de contenção ${ }^{39}$. Nesse sentido, a respeito da proteção do condomínio quanto à ocupação de terceiros, verificou-se a necessidade de um muro ou alambrado que permitisse uma construção em altura, dando continuidade à benfeitoria realizada.

Figura 3 - O muro de arrimo pronto visto de dentro do condomínio

Fonte: Autor

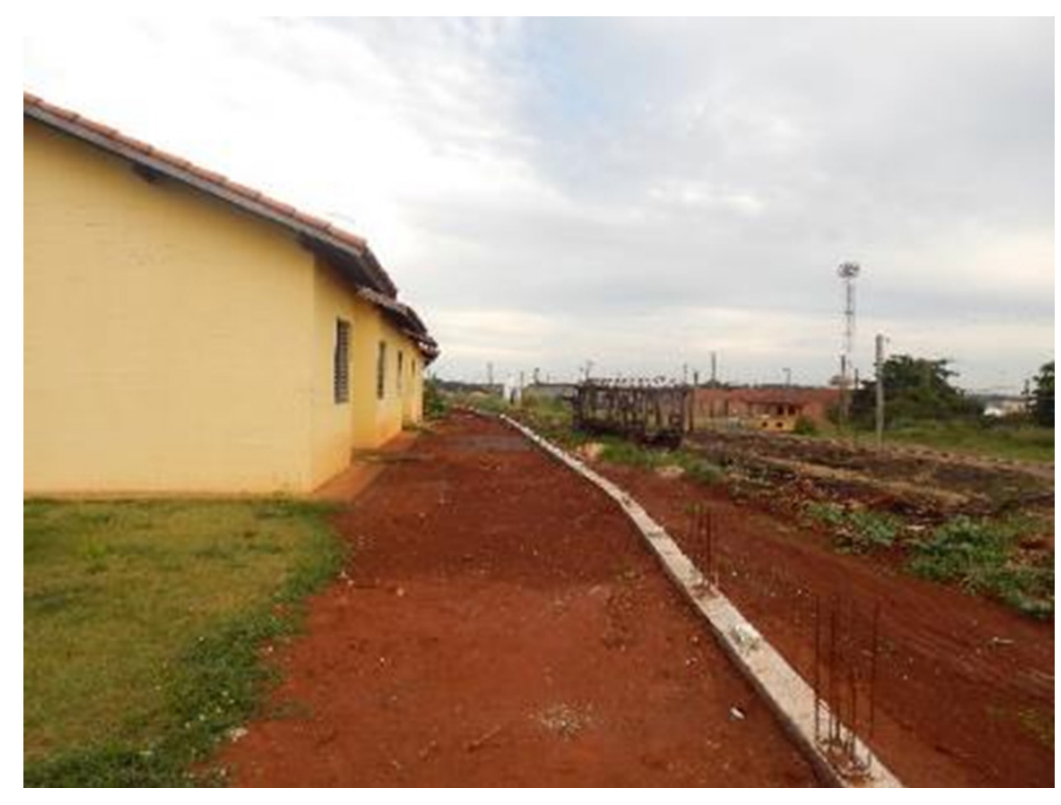

35 SÃO PAUlO (Estado). Ministério Público. Guia Prático de Acessibilidade. 2004. Disponível em: <http://www.mpsp.mp.br/ portal/page/portal/Cartilhas/GuiaPraticoDeAcessibilidade.pdf>. Acesso em: mar. 2016.

36 SÃO PAULO (Estado). Ministério Público. Guia Prático: o direito de todos à educação: diálogo com os Promotores de Justiça do Estado de São Paulo. São Paulo: MP, 2011. 165 p.

37 PINHAL. O que é muro de arrimo. Colégio dos arquitetos. 2009. Disponível em: <http://www.colegiodearquitetos.com.br/ dicionario/2009/02/o-que-e-muro-de-arrimo>. Acesso em: mar. 2016.

38 SANCHES, M. C. S. Estudo de casos de patologias estruturais ocasionados por ação das águas pluviais e aterros na região de Campo Mourão, PR. 2013. 60 f. Trabalho de Conclusão de Curso (Monografia) - Universidade Tecnológica Federal do Paraná, Campo Mourão, 2013. 39 DYMINSKY. Noções de estabilidade e taludes. 2007. Disponível em: <http://www.cesec.ufpr.br/docente/andrea/TC019/Taludes.pdf>. Acesso em: mar. 2016. 
A partir da visualização acima, verifica-se que, quando visto de dentro do condomínio, o muro está rente ao chão, entretanto, quando visto da área externa, especificamente do terreno da linha férrea, o mesmo é, relativamente, alto, verificando os seus aproximadamente dois metros de altura. A ausência da altura em determinada porção do terreno deixava o núcleo habitacional, ainda, vulnerável, mesmo com a construção da contenção.

Embora o prazo estipulado no acordo fosse de 5 meses, o cumprimento da obrigação demorou a iniciar, estendendo o período da construção por, aproximadamente, quarenta e cinco dias, ultrapassando o período máximo determinado para a construção. Em face dessas informações, na época temia-se que o TAC não fosse cumprido, adequadamente, adiando-se essa benfeitoria importante para os residentes.

Após um período de aproximadamente três meses do início da obra, realizou-se um acordo prévio entre a Promotoria e o responsável pela execução do TAC, que justificou o atraso e teve seu prazo prorrogado para a finalização da obra. Assim, cumprindo a obrigação, a obra foi finalizada de acordo com o TAC firmado, corroborando o pensamento de Milarée ${ }^{3}$, ao afirmar a importância de ir além da ressarcibilidade em sequência do dano, em prol de garantir o bem ambiental como direito fundamental, uma vez que este é insubstituível.

A não arrecadação da multa viabilizou a captação do recurso em benefício de melhorias no local de estudo. Considera-se, nesse sentido, que, caso houvesse a aplicação da multa, esta adiaria por mais tempo a adequação do local em prol da conquista do direito à moradia adequada dos idosos, caracterizando-se como ônus no que tange à garantia de direitos.

Revela-se, nesse sentido, que ambas as partes se beneficiaram, uma vez que os idosos obtiveram melhorias no local que habitam e o responsável pelo cumprimento do Termo adequou sua conduta frente a um dano urbanístico previamente realizado, que resultou nessa forma de compensação.

Após a finalização da obra, constatou-se a importância de continuidade do serviço para melhorar as condições de moradia. Nesse contexto, ressalta-se o primeiro desdobramento positivo do TAC no local: o firmamento de um novo TAC. Esse novo acordo tinha como uma de suas cláusulas, além do conserto das fissuras nas residências causadas pela ausência do muro de arrimo, a colocação de alambrado sobre o muro de arrimo, para delimitar a área e proporcionar aos moradores segurança efetiva no que se refere ao isolamento do local, eliminando a sensação de vulnerabilidade.

O novo compromisso firmado reforça a importância do acompanhamento dos desdobramentos do TAC deste estudo, uma vez que a análise dos impactos na sua construção permite visibilidade na importância da continuidade de ações, como a descrita na presente pesquisa, em prol da adequação dos espaços de forma a se tornar mais acessível, repercutindo na saúde individual e coletiva. Também reflete o uso equitativo que possibilita a integração dos moradores e a interação com o ambiente.

\subsection{Um novo TAC reforça as condições de moradia digna}

O novo TAC proporcionou a colocação de um alambrado acima do muro de arrimo. Diante das observações feitas no local, constatou-se que essa nova benfeitoria contribuiu no sentido de oferecer aos moradores maior segurança e satisfação do local em que habitam. A figura abaixo permite visualizar a continuidade da benfeitoria. 
Figura 4 - O alambrado sobre o muro de arrimo

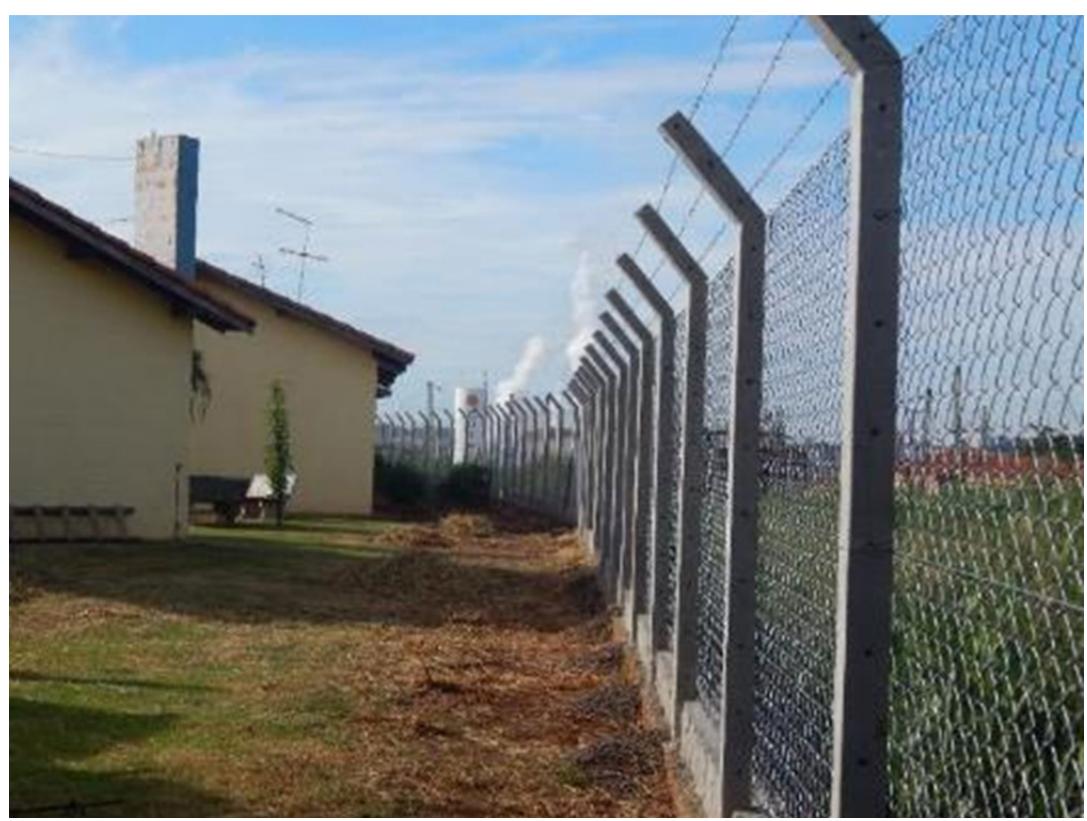

Fonte: Autor, 2016

Verifica-se que o condomínio localiza-se numa região afastada de equipamentos urbanos, como postos de saúde e comércio. Esse fator é um ponto negativo para os moradores, em face da distância, o que atribui um sentimento de abandono. Em contraponto, as obras proporcionaram sensação positiva, uma vez que ações para melhoramentos em suas moradias foram contínuas, cumprindo com o propósito de contribuir, positivamente, para a qualidade de vida deles. Tal fato foi comprovado por meio de uma carta escrita pelos próprios moradores, em agradecimento ao Ministério Público, responsável pelos TACs, à Secretaria de Assistência e Desenvolvimento Social, responsável pelo núcleo, e ao Grupo de Pesquisa, cujo o presente artigo é fruto.

A instalação do alambrado permite identificar seu valor enquanto um desfecho positivo da construção do muro de arrimo, pois a construção viabilizou a continuidade de melhorias nas condições de moradia do local, superando expectativas no que se refere às melhorias previstas no início das ações no condomínio.

\section{Considerações finais}

O expressivo número de pessoas idosas no cenário urbano brasileiro aponta a necessidade de mecanismos que garantam suporte à conquista do direito à cidade em seus mais variados âmbitos, sendo a moradia adequada intrínseca a esse preceito.

Nesse sentido, destaca-se a importância do TAC, firmado entre Ministério Público e o causador de algum dano à cidade ou ao meio ambiente, como um meio de compensar danos e utilizar o recurso, revertendo-o para instituições de assistência à população idosa, proporcionando a garantia dos direitos estampados no Estatuto do Idoso e na Política Nacional do Idoso.

Verifica-se que o caso prático apresentado atribuiu modificações nas características internas e externas do Núcleo Habitacional. Internas no que se refere à percepção dos moradores ao sentirem-se amparados, seguros e ganharem mais autonomia e independência para usufruir do local, e externas no que tange à ação concreta implementada por meio do TAC, já que o muro de arrimo proporcionou melhores condições de moradia. O que justifica que ações externas exercem influência direta na percepção dos indivíduos e con- 
tribuem para a qualidade de vida destes, corroborando o exposto na Estratégia Cidade Amiga do Idoso ${ }^{40}$.

Desse modo, constata-se, com esse estudo, que o devido cumprimento do TAC viabilizou melhorias no que diz respeito à qualidade de vida dos idosos, resultando em desdobramentos que superaram expectativas. Destaca-se a importância em fortalecer a temática, para que outras estratégias como esta possam ser replicadas em outros espaços, não somente para favorecer a população idosa, mas a comunidade em geral.

Revela-se a escassez de estudos acerca do assunto, considerando-se que, os poucos, trabalhos identificados tratam do TAC como mecanismo para solução de conflitos fora do contexto urbano. Em relação ao acompanhamento e à aplicabilidade desse mecanismo, estudos não foram encontrados, tampouco tem-se a consciência deste para captação dos recursos em prol da efetivação de direitos e beneficiação à coletividade. Os achados preocupam-se em quantificar o número de TACs, descrevem alguns casos, porém, não há detalhamento de seus desfechos, nem consideram a interdisciplinaridade, imprescindível no que tange à implementação do acordo em conquista de direitos à sociedade.

É pertinente apontar, diante do conceito ampliado de saúde, que a interdisciplinaridade é fundamental, uma vez que há necessidade de diferentes setores da sociedade para repensar práticas para o alcance da saúde integral. Nesse contexto, esse manuscrito traz, de forma exemplificada, a importância da atuação interdisciplinar, pois descreve o trabalho em parceria com o Ministério Público, órgão executor de medidas que viabilizaram um avanço à conquista de direitos fundamentais.

Soma-se a esse parceiro o apoio técnico da equipe da Gerontologia, expandindo o olhar acerca dos fatores que contribuem para melhor qualidade de vida no processo de envelhecimento e na velhice. A intervenção por meio da articulação de ações, programas e projetos por diferentes setores, atuando em conjunto, favorece a longevidade, por uma cidade consciente da realização do direito à moradia para pessoas idosas de baixa renda.

\section{REFERÊNCIAS BIBLIOGRÁFICAS}

BIANCHINI, A.; GRAVINA, M. B; TURATTTI, L. A (in)eficácia dos termos de ajustamento de conduta na solução de danos ambientais no Vale do Taquari. Estudo \& Debate, Lajeado, v. 12, p. 117-131, 2005.

BRASIL. $8^{a}$ Conferência Nacional de Saúde de 1986. Disponível em: < http://bvsms.saude.gov.br/bvs/publicacoes/8_conferencia_nacional_saude_relatorio_final.pdf>. Acesso em: maio 2016.

BRASIL. Consolidado dos relatórios das conferências estaduais de saúde. 2006. Disponível em: < http://bvsms.saude. gov.br/bvs/publicacoes/CES_consolidado.pdf>. Acesso em: maio 2016.

BRASIL. Constituição da República Federativa do Brasil de 1988. Disponível em:<http://www.planalto.gov.br/ ccivil_03/constituicao/constitui\%C3\%A7ao.htm>. Acesso em: ago. 2014.

BRASIL. Decreto n. 5.296, de 2 de dezembro de 2004. Regulamenta as Leis n. 10.048, de 8 de novembro de 2000, e 10.098, de 19 de dezembro de 2000. 2004b. Disponível em: <http://www.planalto.gov.br/ccivil_03/_ ato2004-2006/2004/decreto/d5296.htm>. Acesso em: 3 jun. 2014.

BRASIL. Lei n. 10.741, de 1 de outubro de 2003. Dispõe sobre o Estatuto do Idoso e dá outras providências. Disponível em: <http://www.planalto.gov.br/ccivil_03/leis/2003/110.741.htm>. Acesso em: ago. 2014.

BRASIL. Lei n. 7.347, de 24 de julho de 1985. Disciplina a ação civil pública de responsabilidade por danos causados ao meio-ambiente, ao consumidor, a bens e direitos de valor artístico, estético, histórico, turístico e

40 ORGANIZAÇÃO MUNDIAL DA SAÚDE - OMS. Guia global das cidades amigas das pessoas idosas. 2008. Versão traduzida para o português. Disponível em: <http://whqlibdoc.who.int/publications/2007/9789899556867por.pdf>. Acesso em: abr. 2016. 
paisagístico (VETADO) e dá outras providências. Disponível em: <http://www.planalto.gov.br/ccivil_03/ Leis/L7347orig.htm>. Acesso em: 15 abr. 2015.

BRASIL. Lei n. 8080, de 19 de novembro de 1990. Dispõe sobre as condições para a promoção, proteção e recuperação da saúde, a organização e o funcionamento dos serviços correspondentes e dá outras providências. Disponível em: <http://www.planalto.gov.br/ccivil_03/leis/L8080.htm>. Acesso em: maio 2016.

BRASIL. Lei n. 8625, de 12 de fevereiro de 1993. Disponível em: <http://www.planalto.gov.br/ccivil_03/leis/ 18625.htm> Acesso em: maio 2016.

BRASIL. Lei n. 8842, de 4 de janeiro de 1994. Dispõe sobre a Política Nacional do Idoso e dá outras providências. Disponível em: <http://www.planalto.gov.br/ccivil_03/leis/L8842.htm>. Acesso em: ago. 2014.

CAMARANO, A. A; KANSO, S. Envelhecimento da população brasileira. 2011. In: FREITAS, E. V. et al. Tratado de geriatria e gerontologia. Rio de Janeiro: Guanabara Koogan, 2011. p.58-73.

DYMINSKY. Noções de estabilidade e taludes. 2007. Disponível em: <http://www.cesec.ufpr.br/docente/andrea/TC019/Taludes.pdf>. Acesso em: mar. 2016.

FEIJO, M. C. A aplicabilidade do Estatuto do Idoso junto ao Ministério Público de São Paulo. 2010. Tese (Doutorado). Pontifícia Universidade Católica de São Paulo, São Paulo, 2010.

INSTITUTO BRASILEIRO DE GEOGRAFIA E ESTATÍSTICA. Projeção da população por sexo e idade: Brasil 2000-2060. Unidades da Federação 2000-2030. p.43. 2013. Disponível em: <http://www.ibge.gov. br/home/presidencia/noticias/imprensa/ppts/00000014425608112013563329137649.pdf>. Acesso em: 31 ago. 2014.

MARICATO, E. As ideias fora do lugar e o lugar fora das ideias: planejamento urbano no Brasil. In: ARANTES, O.; VAINER, C.; MARICATO, E. A cidade do pensamento único: desmanchando consensos. Petrópolis, RJ: Vozes, 2000. p. 121-192.

MAZZILLI, N. H. Compromisso de ajustamento de conduta: Evolução e fragilidades- Atuação do Ministério Público. Revista Direito e Liberdade, ESMARN, Mossoró, v. 1, n. 1, p. 225-246. jul./dez. 2005.

MAZZILLI, N. H. O Ministério Público e a defesa do regime democrático. Brasília, 1998.

MESQUiTA, R. A. V.; COSTA, N. E.; CARVALHO H. B. C. Políticas Públicas de Saúde para o Envelhecimento e a Velhice. 2011. In: FREITAS, E. V. et al. Tratado de geriatria e gerontologia. Rio de Janeiro: Guanabara Koogan, 2011. p. 1622- 1626.

MILARÉ, E. O direito do ambiente: a gestão ambiental em foco: doutrina, jurisprudência, glossário. 7. ed. São Paulo: Revista dos Tribunais, 2011.

MilARÉ, E.; SETZER, J.; CASTANHO, R. O Compromisso de Ajustamento de Conduta e o Fundo de Defesa de Direitos Difusos: relação entre os Instrumentos Alternativos de Defesa Ambiental da Lei 7.347/1985, 2005. Disponível em: <http://bdjur.stj.jus.br/jspui/handle/2011/89933>. Acesso em: mar. 2016.

MOLINARO, C. A. Breves reflexões sobre os deveres fundamentais socioambientais. Revista novos estudos jurídicos. v. 20, n. 3, p. 991-1023, 2015.

MONTEIRO, L. C. A; ZAZZETTTA, M. S.; ARAÚJO, M. E. J. Sustentabilidade: relação entre o espaço urbano e envelhecimento ativo. Revista novos estudos jurídicos, v. 20, n. 8, p. 118-142, 2015.

NOVAES, R. D. et al. Causas e consequências de quedas em idosos como indicadores para implementação de programas de exercício físico. Efdesportes Revista digital. Buenos Aires, abr. 2009. Disponível em: <http://www.efdeportes.com/efd131/causas-e-consequencias-de-quedas-em-idosos.htm>. Acesso em: 17 abr. 2015.

ORGANIZAÇÃO MUNDIAL DA SAÚDE - OMS. Guia global das cidades amigas das pessoas idosas. 2008. 
Versão traduzida para o português. Disponível em: <http://whqlibdoc.who.int/publications/2007/978989 9556867por.pdf>. Acesso em: abr. 2016.

ORGANIZAÇÃO MUNDIAL DA SAÚDE - OMS. Relatório mundial de envelhecimento e saúde. Brasília: OMS Publicações, 2015.

PINHAL. O que é muro de arrimo. Colégio dos arquitetos. 2009. Disponível em: < http://www.colegiodearquitetos.com.br/dicionario/2009/02/o-que-e-muro-de-arrimo>. Acesso em: mar. 2016.

PRADO, A. R. A. Cidade livre de barreiras e acessível aos idosos. In: FREITAS, E. V. et al. Tratado de Geriatria e Gerontologia. Rio de Janeiro: Guanabara Koogan, 2007. p. 645-654.

REBOUÇAS, T. M. O TAC como instrumento de garantia do direito à cidade. In: SEMINÁRIO URBANISMO DA BAHIA, n. 12, 2012, Salvador. Anais... Salvador: UrBa, 2012.

SANCHES, M. C. S. Estudo de casos de patologias estruturais ocasionados por ação das águas pluviais e aterros na região de Campo Mourão, PR. 2013. 60 f. Trabalho de Conclusão de Curso (Monografia) - Universidade Tecnológica Federal do Paraná, Campo Mourão, 2013.

SANTOS, M. O espaço da cidadania e outras reflexões: o pensamento político brasileiro. 2. ed. Fundação Ulysses Guimarães,2013.

SÃO PAULO (Estado). Assembleia Legislativa. Lei Complementar n. 734 de 1993. Institui a Lei Orgânica do Ministério Público e dá outras providências. Disponível em: <http://www.mpsp.mp.br/portal/page/portal/estrutura/734.htm>. Acesso em: jun. 2017.

SÃO PAULO (Estado). Assembleia Legislativa. Lei n. 23.555, de 2009. Disponível em: < http://www.al.sp. gov.br/repositorio/legislacao/lei/2009/lei-13555-09.06.2009.html>. Acesso em: mar. 2016.

SÃO PAULO (Estado). Diretrizes do desenho universal na habitação de interesse social no Estado de São Paulo, agosto de 2010. Disponível em: <http://www.mp.sp.gov.br/portal/page/portal/Cartilhas/manual-desenho-universal.pdf>. Acesso em: abr. 2015.

SÃO PAULO (Estado). Ministério Público. Guia Prático: o direito de todos à educação: diálogo com os Promotores de Justiça do Estado de São Paulo. São Paulo: MP, 2011.

SILVA, F. C.; MEDONÇA, M. L. C. A.; DEOCLECIANO, P. R. M. O instituto do inquérito civil visto como forma e meio importante para pacificar as demandas coletivas e a discussão de seu devido processo constitucional. Revista Expressão Católica, Quixadá, v. 2, n. 2, p. 47-55, jul./dez. 2013.

SILVA, R. S. B. O necessário fortalecimento da atuação do Ministério Público na defesa dos interesses transindividuais. Cadernos de Direito, Piracicaba, v. 12, n. 22, p. 155-166. jan./jun., 2012.

TELES, ICA. Destinação dos recursos oriundos dos TACs e dos acordos e condenações judiciais. Boletim Cientifico ESMPU, Brasilia, v. 14, n. 44, p. 71-97, 2015.

VESCIO, H. et al. Área Temática - Saúde do Idoso. 2013. Disponível em: <http://www.prefeitura.sp.gov. br/cidade/secretarias/upload/saude/arquivos/pessoaidosa/cd_idoso-ATSaudeIdoso-2003ou2004.pdf>. Acesso em: ago. 2014. 


\section{Anexo a}

Figura 1: Demarcação do Núcleo Habitacional e o local para a construção do muro de arrimo

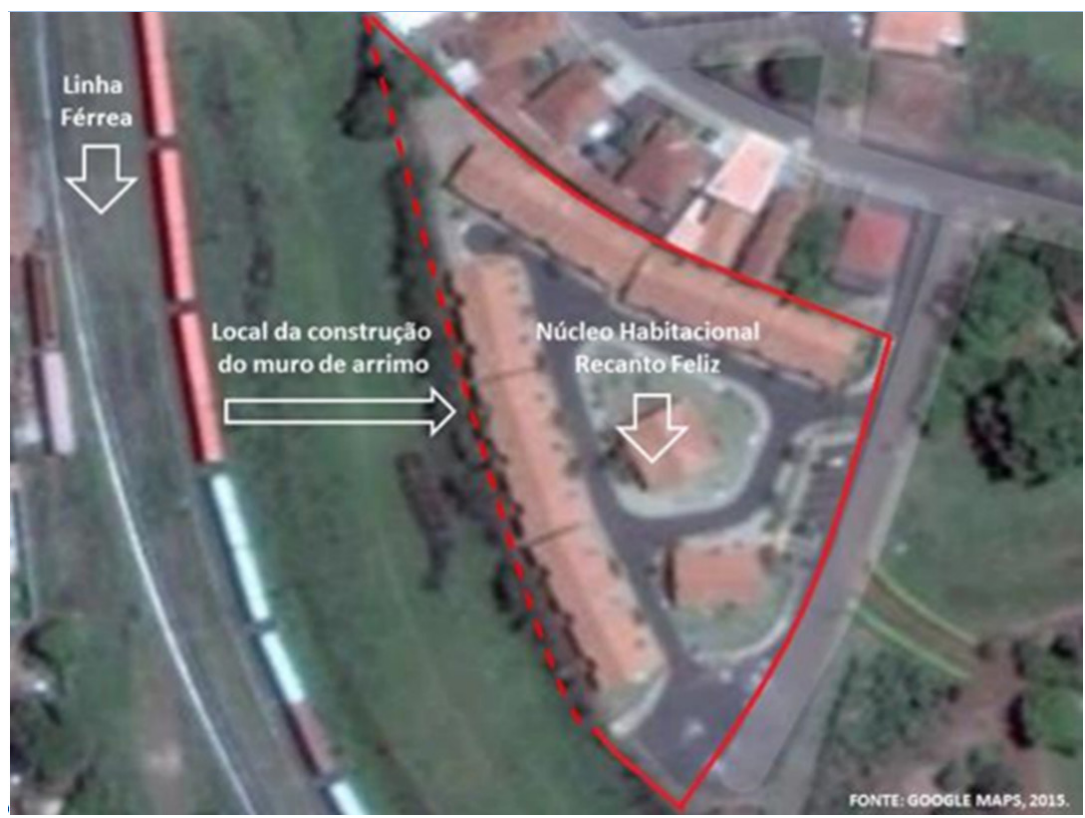

Fonte: Google Maps, 2015.

\section{ApÊNDICE A}

Figura 2 - p. 11. O local indicado para construção do muro de arrimo visto de perto

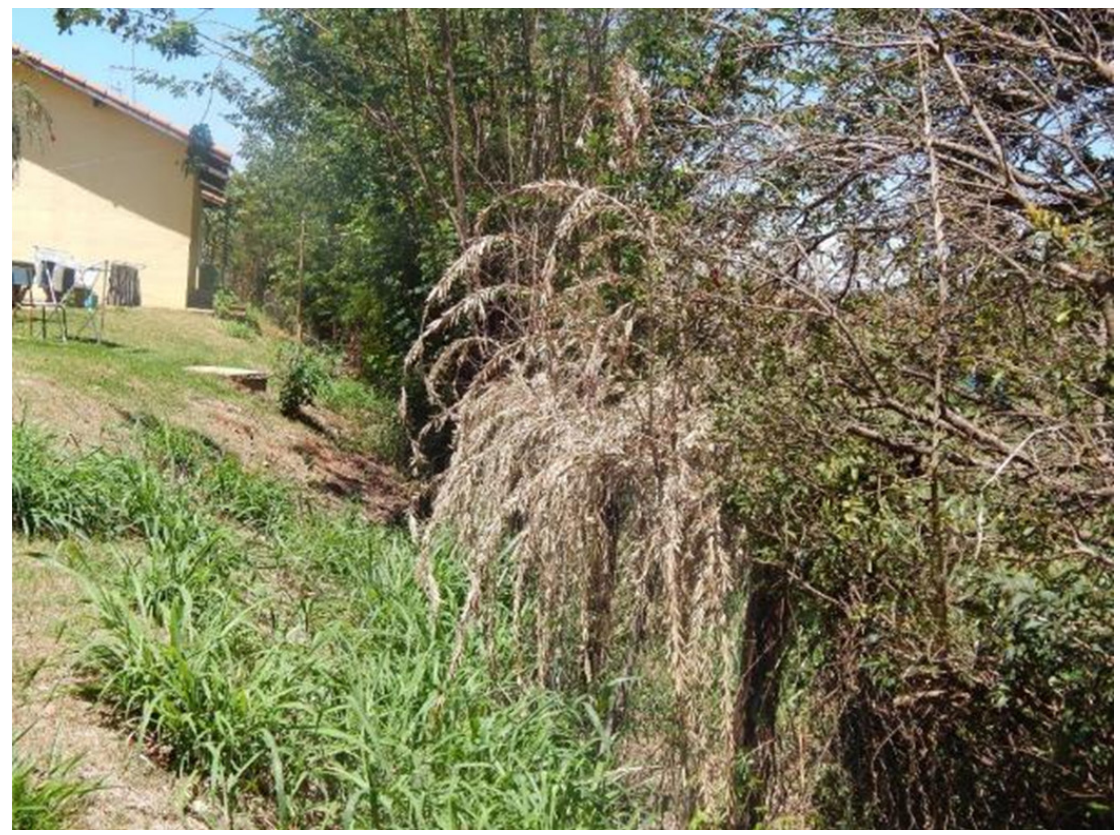

Fonte: Autores, 2014. 


\section{ApÊNDICE B}

Figura 3 - O muro de arrimo pronto, visto de dentro do condomínio. p. 12

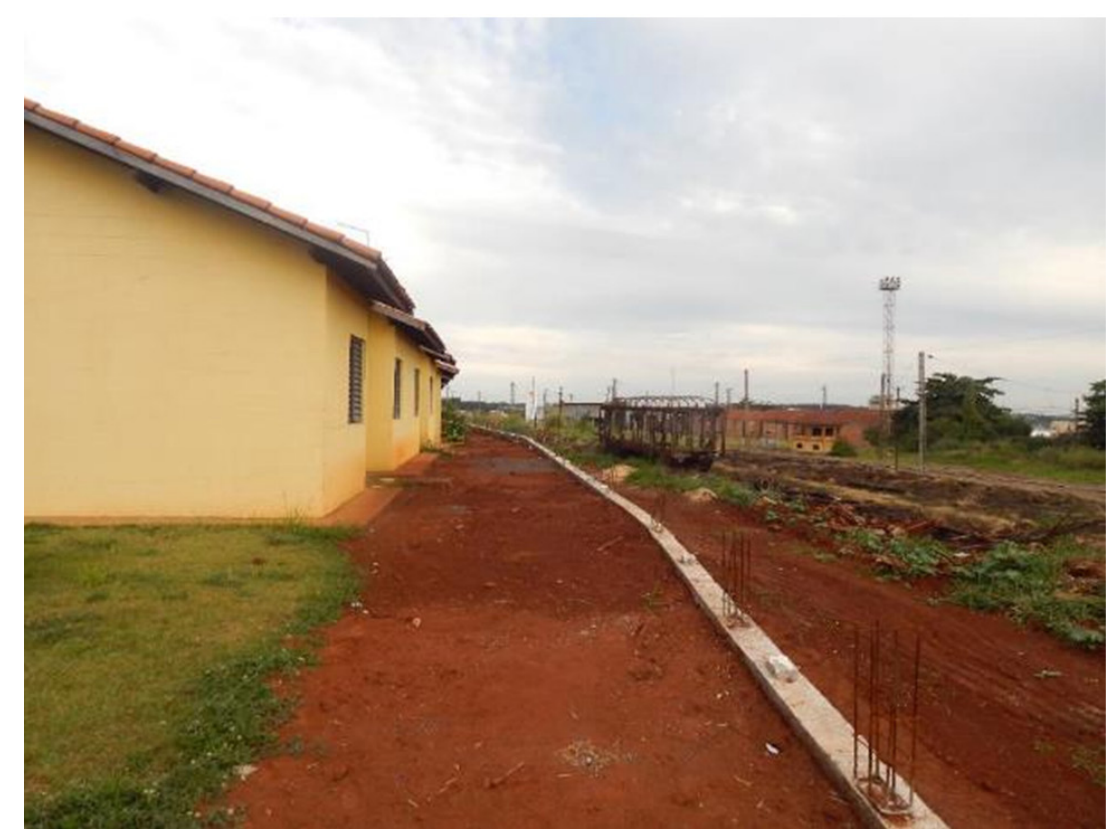

Fonte: Autor, 2015.

\section{ApÊNDICE C}

Figura 4 - O alambrado sobre o muro de arrimo. p. 14

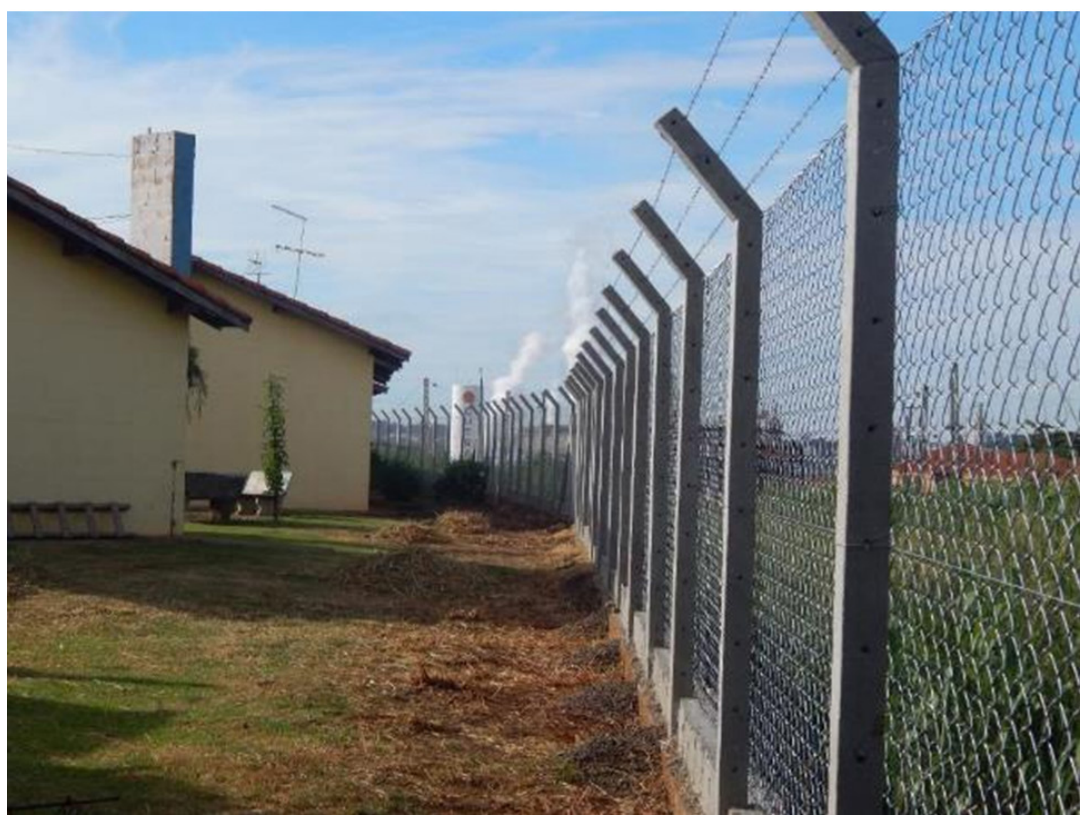

Fonte: Autor, 2016. 


\section{REVISTA BRASILEIRA DE POLÍTICAS PÚBLICAS BRAZILIAN JOURNAL OF PUBLIC POLICY}
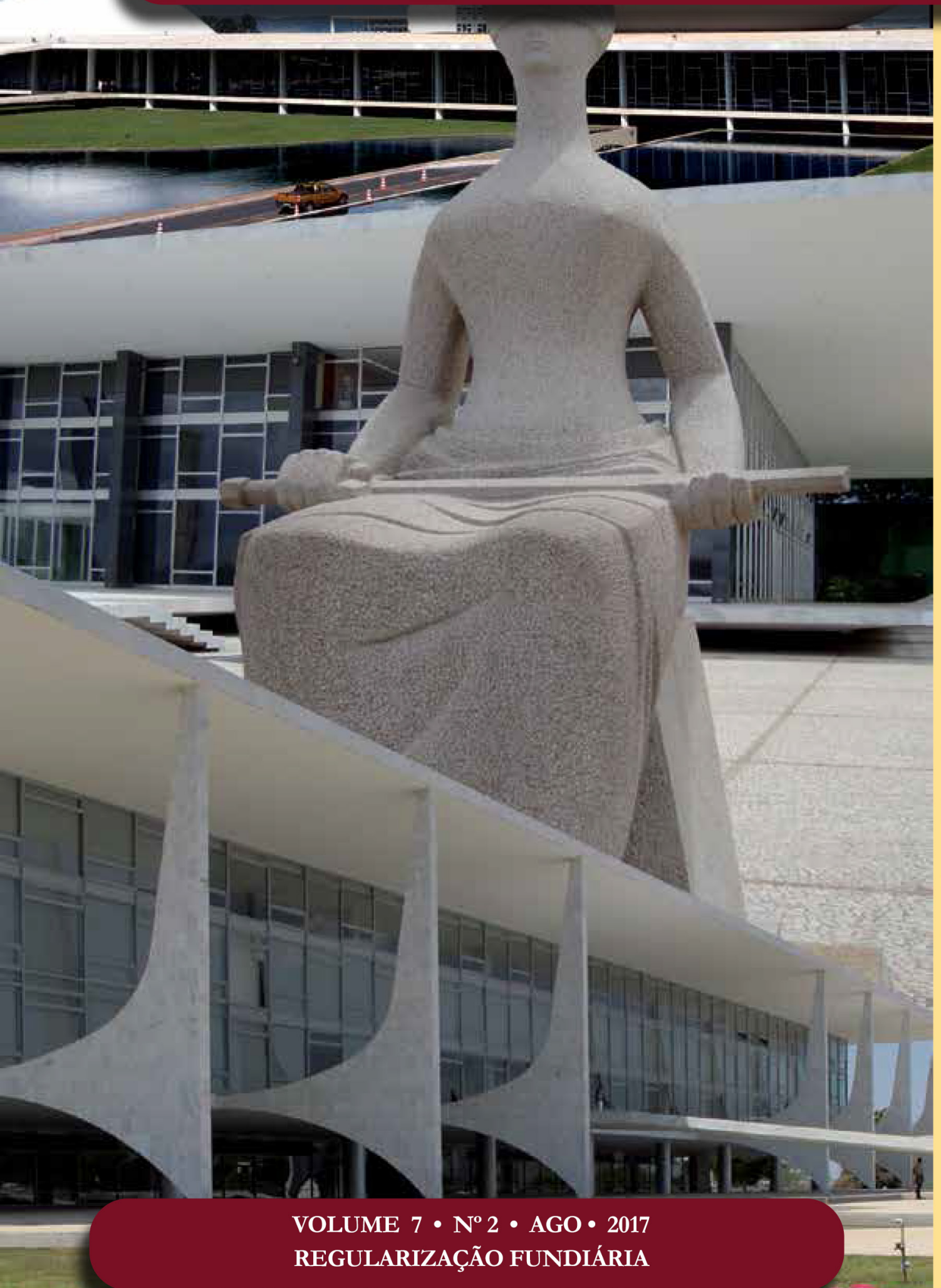

Regularização Fundiária e Política Ambiental: Incongruências do Cadastro Ambiental Rural no Estado do Pará Land Regularization And Environmental Policy: Incongruences Of The Rural Environmental Registry In The State Of Pará 


\section{Regularização Fundiária e Política Ambiental: Incongruências do Cadastro Ambiental Rural no Estado do Pará*}

\author{
Land Regularization And Environmental \\ Policy: Incongruences Of The Rural \\ Environmental Registry In The State Of Pará
}

\author{
Lise Tupiassu** \\ Jean-Raphael Gros-Desormaux*** \\ Gisleno Augusto Costa da Cruz $z^{* * *}$
}

\section{Resumo}

O presente artigo apresenta e analisa as consequências ambientais e fundiárias das várias incongruências que vêm ocorrendo com a implementação no Cadastro Ambiental Rural-CAR no Estado do Pará. Em que pese ter sido criado como um instrumento de auxílio na regularização ambiental, o Cadastro Ambiental Rural vem sendo utilizado, indevidamente, como instrumento de regularização fundiária, com efeitos nefastos tanto na esfera ambiental quanto na esfera fundiária. A partir da análise de diplomas legais, dados primários e secundários e estudos sobre do conteúdo da base de dados do CAR, observa-se o desvio no uso do instrumento, que se constitui em uma nova ferramenta de grilagem e culmina por não atender o objetivo ambiental inicialmente almejado. $\mathrm{O}$ artigo analisa, ainda, os efeitos deletérios das falhas na utilização do CAR para a política de rebate territorial representada pelo ICMS Verde implantado no Estado do Pará, fazendo com que a política fundiário-ambiental implique incongruências na própria repartição de recursos tributários aos municípios. Conclui-se que as incongruências na implementação do CAR no Estado do Pará, além de enfraquecerem o instrumento, ocasionam injustiças fiscais e contribuem para o acirramento do caos fundiário presente na região amazônica.

Palavras-chave: Cadastro Ambiental Rural. Regularização Fundiária. ICMS Ecológico. Meio Ambiente.

\section{Abstract}

This article presents and analyzes the environmental and land consequences of the various inconsistencies that have been occurring in the implementation in the Rural Environmental Registry - CAR in the State of Pará. Although it was created as an instrument to aid in environmental regulation, the CAR being used improperly as an instrument of land regularization, with harmful effects both in the environmental sphere and in the land sphere. From the analysis of legal diplomas, primary and secondary data and 
studies on the content of the CAR database, we observe the deviation in the use of the instrument, which constitutes a new tool of land grabbing and culminates by not meeting the objective environmental impact. The article also analyzes the deleterious effects of the shortcomings in the use of the CAR for the territorial rebate policy represented by the Green Value Added Tax implemented in the State of Pará, causing the land policy to involve inconsistencies in the distribution of tax resources to municipalities. It is concluded that the inconsistencies in the implementation of the CAR in the State of Pará, besides weakening the instrument, cause fiscal injustices and contribute to the aggravation of the present land chaos in the Amazon region.

Keywords: Rural Environmental Registry. Land Regularization. Green Value Added Tax. Environmental.

\section{INTRODUÇão}

A região amazônica brasileira é palco de um caos fundiário que alimenta e se retroalimenta (d)o processo de desmatamento desordenado em crescente aumento nos últimos anos. Esse cenário denota a interrelação existente entre a regularização fundiária e a proteção ambiental, políticas incidentes sobre o mesmo espectro espacial, mas que, na grande maioria das vezes, são tratadas de forma assimétrica, desarticulada, dessincronizada e, até mesmo, contraditória.

O Cadastro Ambiental Rural - CAR é um registro público eletrônico de imóveis rurais que visa identificar a situação ambiental da área, contendo informações a respeito das Áreas de Preservação Permanente, Reserva Legal, remanescentes de vegetação nativa, Áreas de Uso Restrito e consolidadas nas propriedades e posses rurais.

Sua criação traz, a priori, inúmeras vantagens sob o ponto de vista do controle ambiental, uma vez que contribui para a consolidação de uma base de dados voltada para o planejamento e monitoramento das políticas ambientais e de combate ao desmatamento.

Em que pese não ter sido o Cadastro Ambiental Rural - CAR criado com qualquer finalidade voltada à configuração da posse ou propriedade rurais —, sendo estas, apenas, pré-requisitos para a sua inscrição —, a forma como tal instrumento vem sendo utilizado no contexto da estrutura fundiária amazônica vem apresentando disfunções, que culminam em prejudicar as políticas ambientais e incidir negativamente, até mesmo, nas políticas de regularização fundiária, sendo, o CAR, às vezes, considerado como um verdadeiro instrumento de acirramento dos processos de grilagem tão comuns no Estado do Pará.

Nesse sentido, este artigo apresenta algumas das principais incongruências que vêm ocorrendo na implementação no Cadastro Ambiental Rural no Estado do Pará, analisando suas consequências em relação à regularização fundiária e às políticas públicas de rebate territorial, tais como o ICMS Verde implementado no Estado do Pará.

Com tal objetivo, o artigo aborda, em um primeiro momento, os elementos que levam ao desvio de finalidade do CAR no que diz respeito à configuração da posse e propriedade no contexto amazônico. Em seguida são expostos dados de pesquisas referentes às incongruências existentes no Cadastro no Estado do Pará, com efeitos nefastos aos processos de regularização fundiária. Por fim, são apresentados os efeitos negativos da má utilização do sistema nas políticas ambientais de rebate territorial, a exemplo do ICMS Verde paraense. 


\section{O Car Como Indutor De Equívocos Na Regularização Fundiária}

As discussões sobre o CAR surgiram no Pará, no final de 2006, diante de um processo de descentralização da gestão florestal —, antes atribuída ao governo federal —, para os Estados, sendo disciplinado pelo Decreto Estadual no 1.148 de julho de 2008 da Secretaria de Estado de Meio Ambiente do Pará - SEMA/ PA.

Foi pensado como um documento inicial de natureza declaratória e de rápida liberação, a fim de levantar as informações básicas dos imóveis e vinculá-las ao possível responsável pelas irregularidades no uso da terra, especialmente em relação ao desmatamento. ${ }^{1}$

A Resolução no 3.545/2008 do Banco Central - BACEN passou a exigir o CAR para fins de liberação de financiamento agropecuário de execução na Amazônia, sendo que, atualmente, a Resolução no 4.487/2016 alterou o Manual de Crédito Rural e exigirá, a partir de 2018, o recibo de inscrição no CAR como requisito para fins de liberação de financiamentos não apenas para aqueles da Amazônia.

No entanto, foi com o Novo Código Florestal —, Lei n 12.651/2012 —, que o CAR ganhou visibilidade nacional e contornos de um instrumento de fomento e monitoramento da atividade florestal, em âmbito nacional, sendo previsto em seu art. 29 como um "registro público eletrônico de âmbito nacional, obrigatório para todos os imóveis rurais, com a finalidade de integrar as informações ambientais das propriedades e posses rurais, compondo base de dados para controle, monitoramento, planejamento ambiental e econômico e combate ao desmatamento."

O objetivo primordial do CAR é criar uma base de dados capaz de identificar o cumprimento ou não das exigências mínimas do Novo Código Florestal quanto às Áreas de Preservação Permanente - APP e Reserva Legal - RL, conforme exigência para fins de inscrição disposta no seu art. 29, \$1 ${ }^{\circ}$, III.

O CAR se apresenta, portanto, como uma ferramenta de mapeamento georreferenciado dos imóveis rurais, para fins de acompanhamento e imediata detecção do cumprimento ou não das exigências legais mínimas do Novo Código Florestal, especialmente quanto à APP e à RL.

O Cadastro Ambiental Rural, porém, não foi concebido como um instrumento fundiário, pois o cadastramento não é considerado título para fins de reconhecimento do direito de propriedade ou posse —, art. $29, \$ 2^{\circ}$ da Lei $n^{\circ} 12.651 / 2012$ - mas apenas como um mecanismo de controle ambiental.

Nota-se, porém, que o CAR comunga de certos equívocos próprios da política fundiária no Brasil, especialmente aquela dispensada à Amazônia e, principalmente, vem sendo utilizado, indevidamente, como instrumento de regularização fundiária.

Para compreender essa problemática, é necessário resgatar a história fundiária nacional.

A Coroa Portuguesa, por meio da Lei de 26 de junho de 1375, adotou o sistema de sesmarias para o reino de Portugal, que compelia os proprietários a utilizarem, efetivamente, a terra, por meio do seu cultivo, sob pena de decaírem de seu direito, com a transferência compulsória para quem a pudesse lavrar.

No caso do Brasil, a Coroa pretendia ampliar as áreas de exploração extrativa e iniciar o uso agrícola das extensas terras, além de assegurar a conquista portuguesa e incentivar a expansão territorial, considerando a crise financeira do reino ${ }^{2}$.

Esse regime vigorou até 1822, quando foi inaugurado o regime extralegal ou das posses, caracterizado

1 AZEVEDO, A. et al. Cadastro ambiental rural e sua influência na dinâmica do desmatamento na Amazônia Legal. Boletim Amarônia em pauta, Brasília, IPAM, n. 3, maio 2014. p. 6. Disponível em: < http://www.observatorioflorestal.org.br/sites/default/ files/amazonia_em_pauta_3_cadastro_ambiental_r.pdf>. Acesso em: 10 jun. 2017.

2 MATTOS NETO, Antônio José. A questão agrária no Brasil: aspecto sócio-jurídico. Projeto História, São Paulo, n. 33, p. 101103, dez. 2006. 
pelo vazio legislativo decorrente da suspensão do sistema sesmarial, inexistindo lei acerca da problemática fundiária, com o acesso à terra promovido através tão somente da ocupação, findando com a Lei nº 601 de $1850^{3}$. Para Treccani ${ }^{4}$, essa situação gerou uma série de litígios judiciais e extrajudiciais, tornando a situação ainda mais caótica pelo clima de incerteza.

A Lei n ${ }^{\circ} 601$ de 1850 , em seu art. $5^{\circ}$, no afã de regularizar o caos fundiário do país, agravado pelo regime extralegal, legitima as posses mansas e pacíficas, por ocupação primária, ou havida do primeiro ocupante, desde que cultivada ou com princípio de cultura, além de morada, inclusive eventual.

Percebe-se, assim, que o contexto fundiário nacional é marcado pelo descontrole estatal fundiário seguida da tentativa de regularizar situações de fato, sob o contexto não raro de conflitos agrários.

Nesse sentido, a Lei no 13.465/2017, advinda da conversão da Medida Provisória - MP no 750 de 22 de dezembro de 2016, ao dispor sobre a regularização fundiária rural e urbana no país, alterou a Lei $\mathrm{n}^{\circ}$ 11.952/2009, conhecida como Programa Terra Legal, aplicável, apenas, à Amazônia, permitiu a regularização de ocupações anteriores a 22 de julho de 2008, mansas e pacíficas, com exploração direta, abrangendo áreas de até 2.500 hectares, conforme o art. $5^{\circ}$, IV e $6^{\circ}, \$ 1^{\circ}$, sendo o CAR uma exigência para tanto, nos termos do seu art. 15, II.

Essa alteração é altamente criticada por permitir que áreas ocupadas recente e irregularmente ${ }^{5}$, sob grilagem, já que dispensam qualquer análise da cadeia dominial, pudessem ser repassadas a particulares, mesmo que a título oneroso, sendo o CAR um requisito para tanto.

Houve, ainda, a dispensa de licitação para a alienação desses imóveis, consoante os artigos 11 e 12 da mesma lei, com o beneplácito do governo em assegurar a avaliação entre $10 \%$ a 50\% do valor estipulado pelo INCRA ${ }^{6}$ para fins de pauta mínima da terra nua para a reforma agrária. Significa que o Estado alienará suas terras por menos, ou melhor, até muito menos, do que pagará para desapropriar áreas particulares para fins de reforma agrária.

Insta salientar que, no âmbito do Estado do Pará, o Decreto Estadual no 739/2013, conhecido como Programa Municípios Verdes, instituiu um processo especial de regularização fundiária aos Municípios que atingissem metas de caráter ambiental, com a emissão de Certificado de Ocupação de Terra Pública, que ocorrerá com base nos dados georreferenciados do CAR, nos termos do art. $7^{\circ}$ e $8^{\circ}$ do decreto estadual.

Nesse diapasão, apesar de, legalmente, o CAR não ter efeitos fundiários, o Decreto Estadual, no art. $2^{\circ}$, II, define-o como um instrumento de apoio ao processo de regularização fundiária, levando, ao final, na emissão de títulos de propriedade. As semelhanças entre os programas federal e estadual são impressionantes, porque ambos contemplam o CAR como um elemento de aferição para a titulação de terras públicas para particulares.

O CAR compartilha do mesmo equívoco da política fundiária histórica do país, por não ser um instrumento de regularização fundiária, mas de gestão ambiental, que acaba assumindo esse papel, diante da persistência em corrigir falhas e desordens agrárias, inclusive pela grilagem. Não é o direito que cria a ordem, mas a desordem que cria o direito.

A Lei no 6.938/81, acerca da Política Nacional do Meio Ambiente, definiu, dentre os instrumentos de gestão ambiental, o Sistema Nacional de Informações sobre o Meio Ambiente - art. 9 , VII - do qual faz parte o CAR - art. 29 da Lei no 12.651/2012.

3 ARAÚJO, Ionnara Vieira de; TÁRREGA, Maria Cristina Vidotte Blanco. Apropriação de terras no Brasil e o instituto das terras devolutas. RFD-Revista da Faculdade de Direito da UERJ, v.1, n. 19, p. 7, jun./dez 2011.

4 TRECCANI, Girolamo D. Violência e grilagem: instrumentos de aquisição da propriedade da terra no Pará. Belém: UFPA; ITERPA, 2001 p. 70.

5 OBSERVATÓRIO DO CLIMA. Nota de repúdio de 28 de julho de 2017. Disponível em: <http://www.observatoriodoclima.eco. br/60-organizacoes-pedem-janot-acao-contra-lei-da-grilagem/>. Acesso em: 24 ago. 2017.

6 Instituto Nacional de Colonização e Reforma Agrária. 
Os instrumentos de políticas ambientais ou de gestão ambiental podem ocorrer por meio de normas de comando e controle criadas diretamente para resolver questões ambientais ou através de normas indutoras, de mercado ou outras, criadas indiretamente para solucionar problemas ambientais ${ }^{7}$. No caso do CAR, os proprietários e possuidores são obrigados a realizar os registros dos imóveis rurais, caracterizando como norma de comando e controle.

Os instrumentos de regularização fundiária são, extremamente, cambiantes, variando de acordo com a política agrária do país. Prova disso é que o conceito legal de regularização fundiária, dado pelo art. 46 da Lei $n^{\circ} 11.977 / 2009$, foi recentemente revogado pela MP no 759/2016 e pela Lei $n^{\circ} 13.465 / 2017$. Não mais subsiste.

Atualmente, não existe uma definição legal do que seja regularização fundiária de um modo geral, mas apenas de sua modalidade urbana com a criação da denominada Regularização Fundiária Urbana - Reurb, que consiste em "medidas jurídicas, urbanísticas, ambientais e sociais destinadas à incorporação dos núcleos urbanos informais ao ordenamento territorial urbano e à titulação de seus ocupantes", conforme o art. $9^{\circ}$ da Lei no $13.465 / 2017$.

Hodiernamente, conforme visto, a União, por meio do Programa Terra Legal, e o Estado do Pará, por meio do Programa Municípios Verdes, definem alguns instrumentos de regularização, que, em sua essência, advêm da gestão ambiental, especialmente do CAR. O equívoco é permitir que essa ferramenta, baseada em documentos autodeclaratórios e de segurança jurídica duvidosa, possa transformar-se em título de propriedade com implicações jurídicas fundiárias indeléveis.

A relevância do CAR supera, ainda, esse limite. Consoante Azevedo ${ }^{8}$ :

(i) a obtenção de licenças para utilização dos recursos naturais ou uso alternativo do solo, (ii) a suspensão de multas aplicadas pelos órgãos fiscalizatórios por meio da adesão ao PRA, (iii) a emissão de Cotas de Reserva Ambiental (CRA) quando couber, e (iv) a concessão de crédito agrícola a partir de 2017. Além disso, em alguns Estados onde o CAR já existe, a ele já são atreladas algumas exigências de mercado e a oferta de benefícios fiscais.

No caso do Estado do Pará, além das finalidades citadas, o Cadastro Ambiental Rural vem sendo utilizado como critério para a repartição do ICMS Verde (Decreto no 1.696/2017), vincula a Guia de Transporte Animal (Decreto $n^{\circ}$ 1.052/2014), estabelece prioridade da regularização fundiária nos municípios mais avançados no CAR (Decreto n $\left.{ }^{\circ} 739 / 2013\right)$, é exigência para concessão de financiamentos pelo Banco do Estado do Pará, é indispensável para alienação ou concessão das terras públicas estaduais pelo ITERPA e também concessão de incentivos fiscais pelo Governo do Estado (Decreto no 838/2013), além de ser pré-requisito para a emissão da Licença de Atividade Rural - LAR (Decreto $n^{\circ}$ 216/2011).

O Novo Código Florestal, além disso, impõe o CAR aos proprietários, mas também aos possuidores dos imóveis, conforme o seu art. 29, $\$ 1^{\circ}$, o Decreto $n^{\circ} 7.830 / 2012$, que criou o Sistema de Cadastro Ambiental Rural - SICAR, e inova, em seu art. $5^{\circ}$, ao permitir, também, que o CAR contemple o responsável direto pelo imóvel. Não existe explicação legal ou infralegal, porém, sobre o que ou quem se considera como responsável direto pelo imóvel9.

7 BARROS, Dalmo Arantes et al. Breve análise dos instrumentos da política de gestão ambiental brasileira. Política \& Sociedade, Florianópolis, v. 11, n. 22, p. 157, nov. 2012.

8 AZEVEDO, A. et al. Cadastro ambiental rural e sua influência na dinâmica do desmatamento na Amazônia Legal. Boletim Amazônia em pauta, Brasília, IPAM, n. 3, maio 2014. p. 2. Disponível em: < http://www.observatorioflorestal.org.br/sites/default/ files/amazonia_em_pauta_3_cadastro_ambiental_r.pdf>. Acesso em: 10 jun. 2017.

9 O art. $5^{\circ}$ do Decreto 7.830/2012, ao alocar as expressões “proprietário", "possuidor rural" ou "responsável direto" de forma independe, expõe que se tratariam de institutos jurídicos diferentes. Posse consiste no estado de fato de alguns dos poderes inerentes à propriedade, como usar, gozar, dispor e reaver a coisa, enquanto a detenção, não sendo posse, seria o exercício da posse para outro, em uma relação de dependência, conforme o art. 1.196 e 1.998 do Código Civil. Dessa forma, considerando que o CAR não teria, a priori, validade fundiária, pode-se concluir que o próprio mero detentor, enquanto "responsável direto", poderia realizar o registro 
$\mathrm{O}$ art. $6^{\circ}$, caput e $\$ 1^{\circ}$ do Decreto $7.830 / 2012$ aduzem que a inscrição, apesar de obrigatória, tem natureza declaratória e permanente, ficando sob inteira responsabilização do declarante pelas informações prestadas, enquanto não houver manifestação do órgão competente acerca de pendências ou inconsistências, a inscrição do imóvel rural no CAR é considerada ativa para todos os fins legais - art. $7^{\circ}, \$ 2^{\circ}$ do Decreto $7.830 / 2012$.

Dessa forma, desde o protocolo das informações, forma-se um CAR provisório com todos os efeitos legais, mas, somente com a aprovação do órgão ambiental competente, gera-se o CAR definitivo.

Observa-se, pois, que o CAR pode ser realizado, unilateralmente, de forma provisória, pelo eventual possuidor ou, até mesmo, pelo responsável do imóvel.

Mas, além de não se definir de forma clara quem seria o responsável pelo imóvel apto a realizar o cadastro, a documentação exigida para comprovação de posse se afigura bastante frágil, na medida em que a Secretaria de Estado de Meio-Ambiente e Sustentabilidade - SEMAS $/ \mathrm{PA}^{10}$ permite, por exemplo, que qualquer certidão do órgão fundiário ou Sindicato, Associação ou Cooperativa seja aceita para tais fins. Não há, porém, qualquer verificação documental no sentido de assegurar tratar-se de área apropriável, permitindo, inclusive, a inscrição de posses em terras públicas, em total afronta ao ordenamento jurídico ${ }^{11}$.

A fragilidade das inscrições no CAR parece aproximá-lo das antigas modalidades de registro paroquial.

O Decreto no 1.318 de 1854, que regulamentou a Lei de Terras —, Lei no 601/1850 —, permitiu, no art. 91, registros de terras perante os vigários da Igreja Católica, por meio de declarações dos próprios posseiros ou proprietários das glebas, inclusive sem a indicação exata de sua extensão, ficando conhecido como Registros Paroquiais ou Registros do Vigário ${ }^{12}$.

Ocorre que o art. 94 do antigo Decreto aduz, semelhante ao que ocorre com o CAR, não conferirem algum direito aos possuidores, mas apenas para efeitos meramente estatísticos, desprovendo-os de valor jurídico para fins de comprovação da propriedade do imóvel.

No entanto, mesmo assim, foram cadastrados 22.069 imóveis nas diferentes paróquias ${ }^{13}$, e até hoje, são comumente submetidos a registro em Cartórios de Imóveis, legitimando apropriações indevidas de áreas, conforme identificado por Ibrahim Rocha et $\mathrm{al}^{14}$ :

Alguns dos documentos previstos permitiam tão somente o acesso à posse, outros eram translativos de domínio, isto é, garantiam a incorporação do imóvel na propriedade privada. A grande quantidade de títulos outorgados ao longo do tempo contribuiu para criar dificuldades atuais de interpretação sobre seu valor jurídico. Esta indefinição, em alguns casos, favoreceu a apropriação indevida de terras públicas, fenômeno conhecido popularmente como "grilagem", pois documentos não translativos de domínio foram levados a registro cartorial criando uma presunção juris tantum de propriedade em favor de seus detentores ${ }^{15}$.

Nesse sentido, o Relatório Final da Comissão Parlamentar de Inquérito, destinada a investigar a ocupação de terras públicas na região amazônica, identificou que os registros paroquiais serviram de embasamento

do imóvel rural. No entanto, a ausência de trabalhos acerca do tema é uma dificuldade destacada, exigindo maior atenção acadêmica, sem excluir, evidentemente, a necessidade de maiores esclarecimentos regulamentares, senão legal.

10 ESTADO DO PARÁ. Secretaria de Estado do Meio-Ambiente e Sustentabilidade. CAR - documentos. Disponível em: < https:// www.semas.pa.gov.br/2013/06/24/car-documentos/> Acesso em: 8 jun. 2017.

11 MOREIRA, Eliane. O cadastro ambiental rural: a nova face da grilagem na Amazônia? Disponível em: <http://www.abrampa. org.br/site $/$ ?ct $=$ noticia\&id $=230>$. Acesso em: 8 jun. 2017.

12 ROCHA, Ibrahim et al. Manual de direito agrário constitucional: lições de direito agroambiental. 2. ed. Belo Horizonte: Fórum, 2015. p. 71.

13 MUNIZ, João de Palma. Índice geral dos registros de terras. Belém: Imprensa Official, 1907. v. 7.

14 ROCHA, Ibrahim et al. Manual de direito agrário constitucional: lições de direito agroambiental. 2. ed. Belo Horizonte: Fórum, 2015. p. 58.

15 ROCHA, Ibrahim et al. Manual de direito agrário constitucional: lições de direito agroambiental. 2. ed. Belo Horizonte: Fórum, 2015. p. 58. 
para que Carlos Medeiros, uma figura fictícia criada por grileiros, fosse capaz de ser proprietário de 12 milhões de hectares de uma só vez ${ }^{16}$, constituindo-se, pois, em instrumentos privilegiados para legitimar a grilagem na região ${ }^{17}$.

O CAR, hoje vem sendo utilizado, na Amazônia, com efeitos que se assemelham aos dos Registros Paroquiais do século XXI, uma vez que os dados nele constantes são utilizados como ponto de partida para os processos de regularização fundiária, tanto no âmbito do Instituto de Terras do Pará ${ }^{18}$ quanto no âmbito do Programa Terra Legal.

O Instituto de Terras do Pará, inclusive, pretende aprimorar seu processo de regularização fundiária a partir da utilização das "informações do Cadastro Ambiental Rural como base inicial para organização e planejamento de seus trabalhos, além da otimização de procedimentos internos", nos termos do Acordo de Cooperação Técnica no $01 / 2015^{19}$ firmado com o IMAZON.

Dessa forma, é inevitável a replicação das inconsistências de um cenário estritamente ambiental para um agrário, sendo estes um dos principais motivos para o Ministério Público do Estado do Pará ${ }^{20}$ recomendar a suspensão do projeto, com o objetivo de readequar o sistema diante da problemática do CAR.

Essa abordagem deixa o sistema de regularização fundiária vulnerável, especialmente porque os casos de grilagem de terras no Estado do Pará são historicamente recorrentes. Nesse sentido, emblemático o Provimento $\mathrm{n}^{\mathrm{o}} 13$ de junho de 2006 da Corregedoria de Justiça das Comarcas do Interior, que determinou o bloqueio de todas matrículas de imóveis rurais com suspeitas de irregularidades, destacando, em um de seus "considerandos" que:

as medidas pontuais que vêm sendo adotadas por esta Corregedoria e pelo ITERPA no sentido de equacionar o problema têm se mostrado insuficientes, ante a dimensão que a grilagem de terras atingiu em nosso Estado. Para se ter uma ideia, há vários municípios do interior com áreas registradas que superam em uma, duas ou mais vezes a sua superfície territorial, e todos nós conhecemos o tamanho de nossos municípios, alguns deles maiores que vários países;

O CAR, portanto, conferindo tratamento semelhante a proprietário, possuidor e grileiro ${ }^{21}$, contrariando suas intenções iniciais, acirra o desconhecimento e a segurança jurídica acerca das propriedades rurais no Brasil, especialmente na Amazônia, o que é agravado pelas várias inconsistências encontradas no sistema, a exemplo do identificado no Estado do Pará.

16 BRASIL. Câmara dos Deputados. Relatório final da comissão parlamentar de inquérito destinada a investigar a ocupação de terras públicas na região amazônica. p. 132. Disponível em: <http://imagem.camara.gov.br/Imagem/d/pdf/DCD28DEZ2001SUP.pdf\#page=3>. Acesso em: 31 jul. 2017.

17 BRASIL. Instituto de Colonização e Reforma Agrária - INCRA. Livro branco da grilagem de terras. p. 15. Disponível em:< http:// www.incra.gov.br/media/servicos/publicacao/livros_revistas_e_cartilhas/Livro $\% 20$ Branco $\% 20 \mathrm{da} \% 20 \mathrm{Grilagem} \% 20 \mathrm{de} \% 20 \mathrm{Ter}-$ ras.pdf>. Acesso em: 31 jul. 2017. Diante da gravidade do caso, a Corregedoria do Geral e Justiça do Tribunal de Justiça do Estado do Pará determinou, através do Provimento $n^{\circ}$ 001/2001, o bloqueio provisório de todas as matrículas que constem na cadeia dominial Carlos Medeiros. ESTADO DO PARÁ. Tribunal De Justiça Do Estado Do Pará. Provimento No 001/2001-Cgj. Disponível em: < http://www.tjpa.jus.br//CMSPortal/VisualizarArquivo?idArquivo=3062>. Acesso em: 31 jul. 2017.

18 BRITO, Brenda; CARDOSO Junior, Dário. Regularização fundiária no Pará: afinal qual é o problema? Belém: IMAZON, 2015.

19 IMAZON - INSTITUTO DO HOMEM E MEIO AMBIENTE DA AMAZÔNIA. Acordo de Cooperação Técnica n. 1 de 2015. Disponível em: <http://imazon.org.br/PDFimazon/Portugues/transparencia_institucional/Cooperacao\%20Tecnica_01_2015_ ITERPA_SEDAP_SEDEME_SEMAS\%20e\%20IMAZON\%20(1).pdf>. Acesso em: 31 jul. 2017.

20 ESTADO DO PARÁ. Ministério Público Do Estado Do Pará. Recomendação no Inquérito Civil n. 001/2013 - 8ª PJ Agrária. Disponível em: < http://www.mppa.mp.br/upload/recomendacao\%20CARF(1).pdf>. Acesso em: 31 jul. 2017.

21 MOREIRA, Eliane. O cadastro ambiental rural: a nova face da grilagem na Amazônia? Disponível em: <http://www.abrampa. org.br/site/?ct=noticia\&id=230>. Acesso em: 8 jun. 2017. 


\section{As Inconsistências Nos Registros Do Car}

O Estado do Pará adotou o Cadastro Ambiental Rural antes de sua expansão para todo o território nacional, a partir da iniciativa implementada no Estado do Mato Grosso. Desde então, porém, impera o dualismo entre a maior severidade no monitoramento dos dados e o estímulo às adesões ${ }^{22}$.

As análises aqui apresentadas indicam que se priorizou o estímulo às adesões, em detrimento do rigor no controle dos dados e da própria documentação apresentados. Tal fato, somado a ausência de condições técnicas, físicas e financeiras para a ampla validação dos cadastros provisórios efetuados, vem gerando uma série de inconsistências nos bancos de dados do sistema.

Um artigo publicado na revista Land Use Policy, por pesquisadores da Universidade de Wisconsin-Madison, fez a análise do banco de dados do CAR no Estado do Pará, de 2008 a novembro de 2013, compreendendo mais de 100 mil registros que cobrem mais de 30 milhões de hectares da floresta amazônica ${ }^{23}$.

No período estudado, verificou-se que metade das áreas cadastráveis do Estado foram registradas no CAR. Entretanto, o estudo atestou que, em 2013, somente 2\% dos registros eram definitivos e 98\% provisórios, gerados, automaticamente, pelo sistema, a partir da responsabilidade dos dados pelo declarante ${ }^{24}$.

Em pesquisa realizada pela Agência Pública ${ }^{25}$ acerca das falhas e inconsistências do CAR, com dados coletados até junho de 2016, detectou-se um que 20\% dos registros de CAR eram definitivos.

Comparando-as ambas as análises citadas, infere-se que, entre 2013 e 2016, houve um aumento considerável na quantidade de registros definitivos no Estado do Pará, não se podendo afirmar de modo exato, por ausência de dados, que as bases consideradas por ambos os estudos foram as mesmas.

Há indícios, entretanto, que a definitividade dos registros após sua análise e aprovação por parte do poder público não significa a segurança quanto aos dados declarados. Pesquisadores constataram ${ }^{26}$, por exemplo, a existência de, pelo menos, 20 registros de CAR definitivos validados em terras indígenas.

Um dos casos emblemáticos é o da Fazenda Paragominas, que possui uma área de 4 mil hectares. Sabe-se que, por força do disposto no art. $188, \$ 1^{\circ}$ da $\mathrm{CF} / 88$, a alienação ou a concessão de terras públicas em área superior a 2.500 hectares exige prévia aprovação do Congresso Nacional. Na existência de tal autorização, há fortes indícios de falha no destacamento da área do patrimônio público. Além disso a área mencionada encontra-se sobreposta integralmente à Terra Indígena Apyterewa, localizada no Município de São Felix do Xingú e homologada por Decreto Presidencial de 19 de abril de $2007^{27}$.

Outro caso é da empresa Rondobel Indústria e Comércio de Madeira, que tem três cadastros ativos sobrepostos à Terra Indígena Maró, no município de Santarém. A empresa possui diversos Planos de Manejo Florestal Sustentável autorizados pelo Estado do Pará para explorar madeira nessas áreas, sobrepostas, portanto, a terras da União.

22 AZEVEDO, A. et al. Cadastro ambiental rural e sua influência na dinâmica do desmatamento na Amazônia Legal. Boletim Amąônia em pauta, Brasília, IPAM, n. 3, p. 1, maio 2014. Disponível em: < http://www.observatorioflorestal.org.br/sites/default/ files/amazonia_em_pauta_3_cadastro_ambiental_r.pdf>. Acesso em: 10 jun. 2017.

23 L'ROE et al. Mapping properties to monitor forests: Landholder response to a large environmental registration program in the Brazilian Amazon. Land use policy, v. 57, p. 194, nov. 2016.

24 L'ROE et al. Mapping properties to monitor forests: Landholder response to a large environmental registration program in the Brazilian Amazon. Land use policy, v. 57, p. 197, nov. 2016.

25 BARROS, Ciro; BARCELOS, Iuri; GALLO, João Otávio. As falhas e inconsistências do Cadastro Ambiental Rural. Disponível em: <http://apublica.org/2016/08/as-falhas-e-inconsistencias-do-cadastro-ambiental-rural/>. Acesso em: 7 jun. 2017.

26 BARROS, Ciro; BARCELOS, Iuri; GALLO, João Otávio. As falhas e inconsistências do Cadastro Ambiental Rural. Disponível em: <http://apublica.org/2016/08/as-falhas-e-inconsistencias-do-cadastro-ambiental-rural/>. Acesso em: 7 jun. 2017.

27 BRASIL. Presidência da República. Decreto de 19 de abril de 2007. Homologação da terra indígena Apyterewa. Publicado no Diário Oficial da União - DOU. Disponível em: < http://pesquisa.in.gov.br/imprensa/jsp/visualiza/index.jsp?jornal=1\&pagina= 9\&data $=20 / 04 / 2007>$ Acesso em: 8 jun. 2017. 
Estudo sobre os registros do CAR demonstra igualmente que, em 150 mil registros analisados, 108 mil contêm sobreposições, sendo que destes, 48 mil preenchem mais de 100\% do imóvel rural, incidindo completamente entre eles ${ }^{28}$. São, geograficamente, registros dentro de registros.

Na verdade, a própria indicação de área cadastrável no CAR muitas vezes permite a duplicidade. Segundo dados obtidos no sítio eletrônico do Programa Municípios Verdes do Estado do Pará, acerca do Cadastro Ambiental Rural, em março de 2017, foi possível verificar algumas inconsistências:

Tabela 1 - Municípios com áreas cadastráveis no CAR superiores aos seus territórios

\begin{tabular}{|c|c|c|c|c|}
\hline \multirow[b]{2}{*}{ Nome } & \multicolumn{2}{|c|}{ Área Cadastrável } & \multicolumn{2}{|c|}{ Área Cadastrada } \\
\hline & $\mathrm{km}^{2}$ & \% do município & $\mathrm{km}^{2}$ & $\%$ \\
\hline Capanema & 615,04 & 100,23 & 190,84 & 31,03 \\
\hline Concórdia do Pará & 692,27 & 100,2 & 450,46 & 65,07 \\
\hline São Francisco do Pará & 480,29 & 100,14 & 241,20 & 50,22 \\
\hline Castanhal & $1.030,21$ & 100,13 & 500,94 & 48,63 \\
\hline Mãe do Rio & 470,02 & 100,11 & 302,16 & 64,29 \\
\hline Santa Maria do Pará & 458,19 & 100,11 & 149,85 & 32,7 \\
\hline Bonito & 587,22 & 100,09 & 208,66 & 35,53 \\
\hline Irituia & $1.380,64$ & 100,09 & 767,87 & 55,62 \\
\hline Terra Alta & 206,57 & 100,08 & 86,79 & 42,01 \\
\hline Igarapé-açu & 786,45 & 100,06 & 347,18 & 44,14 \\
\hline Ourém & 562,73 & 100,06 & 291,86 & 51,87 \\
\hline Capitão Poço & $2.899,57$ & 100 & $2.095,19$ & 72,26 \\
\hline Eldorado dos Carajás & $2.956,73$ & 100 & $2.794,32$ & 94,51 \\
\hline
\end{tabular}

Fonte: SEMA Março/2017. Nota: Dados trabalhados pelos autores.

Percebe-se, assim, que área igual ou superior a todo o território municipal é passível de registro no CAR. Como ele se aplica aos imóveis rurais tão somente, verifica-se que, segundo esses dados, não existiria área urbana nesses Municípios e, o que é mais grave, é possível cadastrar mais área do que a área efetivamente existente.

Esse fato facilita as ações de grileiros, que buscam, por meio de documentos inverídicos, realizar registros no CAR em nome de laranjas, obter financiamentos públicos e licenças ambientais para esquentar madeira ilegal. O indício de posse, inclusive, poderá facilitar a aquisição de terras públicas diante das recentes alterações impostas pela legislação.

Indícios nefastos sob o ponto de vista fundiário e ambiental foram detectados a partir de operações realizadas pela Polícia Federal e pelo Ministério Público Federal. A Operação Rios Voadores ${ }^{29}$, por exemplo, detectou que grileiros desmatavam áreas de floresta e, após tornarem áreas de pastagens, registravam-nas no CAR em nome de laranjas e arrendavam ou vendiam a terceiros, mesmo sem ser um documento fundiário,

28 BARROS, Ciro; BARCELOS, Iuri; GALLO, João Otávio. As falhas e inconsistências do Cadastro Ambiental Rural. Disponível em: <http://apublica.org/2016/08/as-falhas-e-inconsistencias-do-cadastro-ambiental-rural/>. Acesso em: 7 jun. 2017.

29 BRASIL. Ministério Público Federal. Rios Voadores: novas autuações envolveram mais dois acusados como responsáveis pelo maior desmatamento da Amazônia. Disponível em: < http://www.mpf.mp.br/pa/sala-de-imprensa/noticias-pa/rios-voadoresnovas-autuacoes-envolveram-mais-dois-acusados-como-responsaveis-pelo-maior-desmatamento-da-amazonia>. Acesso em: 31 jul. 2017. 
para exploração pecuária, inclusive com provas da utilização de trabalho análogo ao escravo ${ }^{30}$. A Operação Madeira Limpa ${ }^{31}$, por sua vez, desarticulou uma organização criminosa acusada de usar CAR para conseguir planos de manejo sustentáveis com o intuito de esquentar madeira extraída ilegalmente de assentamentos e unidades de conservação. Em vez de a exploração ocorrer nas áreas do CAR, ocorriam, em verdade, em área proibidas, sendo ele, apenas, um instrumento de obter os Planos de Manejo ${ }^{32}$.

Assim, além dos problemas ligados às sobreposições, as análises demonstram que muitos registros parciais e paralelos são mantidos, principalmente em nome de laranjas, para dificultar a eficácia do monitoramento ambiental, pois as áreas intencionalmente não registradas podem indicar um espaço de exploração florestal ilegal sem a consequente fiscalização e responsabilização dos executores, que ocorreria mais facilmente com o registro do CAR. Há risco, inclusive, de os usuários subverterem o sistema para assegurar um registro que permita ações de limpeza em suas áreas ${ }^{33}$.

Nota-se, assim, que a falta de acuidade e duplicidade dos registros desnatura a finalidade do sistema, que, no lugar de auxiliar no controle remoto dos responsáveis pelo passivo ambiental, culmina por exigir a fiscalização in loco e permitir até mesmo a falta de responsabilização ambiental, ao não permitir identificar-se exatamente quem seria o agente ocasionador de eventual dano ou infração contra o meio ambiente.

Diante desse descolamento entre a realidade da possessão ou propriedade das áreas e os dados registrados no cadastro, este transforma-se em uma "salvaguarda" do produtor para as ações ilegais, sendo necessário, sendo o IPAM, haver uma ligação “entre o 'papel' (CAR) e as ações no chão, sobretudo de adequação ao Novo Código Florestal" 34 .

Essa situação gera o acirramento de tensões entre diversos grupos sociais na região, conforme o primordial alerta de Eliane Moreira ${ }^{35}$ :

Num contexto em que a regra é a ausência de checagem rápida e eficiente dos títulos de propriedade e documentos possessórios, o CAR se estabelece como um sutil instrumento de apropriação de áreas públicas, sob o qual paira uma presunção de propriedade ou posse absolutamente falaciosa, que tem causado ou agravado conflitos na Amazônia

\section{$[\ldots]$}

Pior, ainda, é observar que o detentor do CAR passa aos poucos a ganhar status de proprietário e a ser tratado como tal. Os crédulos dirão: ora, mas CAR não é documento fundiário. E aí precisaremos confrontar esta alegação com a realidade da Amazônia na qual até mesmo protocolos de pedidos de regularização fundiária perante o INCRA se servem, historicamente, para a grilagem de terras e obtenção de financiamento perante instituições financeiras.

Essas incongruências vêm acarretando, além de tudo, injustiças na própria repartição de recursos entre os Municípios, como se observa a partir da utilização do Cadastro Ambiental Rural enquanto critério de repartição do ICMS Verde no Estado do Pará.

30 O processo criminal tramita na Vara Única da Subseção de Altamira, autuado sob o número 0001607-52.2016.4.01.3903. A última movimentação judicial refere-se ao recebimento da denúncia pela justiça.

31 BRASIL. Ministério Público Federal. Caso Madeira Limpa: justiça bloqueia R \$2,8 milhões de madeireiros por danos ambientais. Disponível em: <http://www.mpf.mp.br/pa/sala-de-imprensa/noticias-pa/caso-madeira-limpa-justica-bloqueia-r-2-8-milhoes-demadeireiros-por-danos-ambientais >. Acesso em: 31 jul. 2017.

32 O processo criminal tramita na $2^{\circ}$ Vara Federal da Subseção de Santarém, autuado sob o número 0000716-34.2016.4.01.3902. A última movimentação judicial refere-se ao bloqueio de bens dos envolvidos.

33 L'ROE et al. Mapping properties to monitor forests: Landholder response to a large environmental registration program in the Brazilian Amazon. Land use policy, v. 57, p. 194, nov. 2016.

34 AZEVEDO, A. et al. Cadastro ambiental rural e sua influência na dinâmica do desmatamento na Amazônia Legal. Boletim Amarônia em pauta, Brasília, IPAM, n. 3, p. 1, maio 2014. Disponível em: < http://www.observatorioflorestal.org.br/sites/default/ files/amazonia_em_pauta_3_cadastro_ambiental_r.pdf>. Acesso em: 10 jun. 2017.

35 MOREIRA, Eliane. O cadastro ambiental rural: a nova face da grilagem na Amazônia? Disponível em: <http://www.abrampa. org.br/site/?ct=noticia\&id=230>. Acesso em: 8 jun. 2017. 


\section{Impacto Fundiário Da Utilzação Do Car Na Política Do Icms Verde No Estado Do PARÁ}

A Constituição Federal de 1988 - CF/88, em seu art. 158, IV, determinou que 25\% do produto da arrecadação de ICMS pelos Estados seja repassado aos seus Municípios. O parágrafo único, inciso I, aduz que $75 \%$ desses recursos ocorrem sob a égide do valor adicionado fiscal nas operações realizadas nos territórios locais, o restante, $25 \%$, dar-se-á de acordo com os critérios estabelecidos em lei estadual, conforme o inciso II.

O ICMS Verde é uma política ambiental baseada no permissivo do federalismo fiscal contido no 158, IV da Constituição Federal, a partir do qual os Estados estabelecem critérios ambientais para a repartição da parcela de ICMS a ser repartida aos Municípios ${ }^{36}$. O reequilíbrio federativo, pela destinação dessa receita, busca evitar a crise de sobrecarga e ingovernabilidade aos entes federados ${ }^{37}$, mas especificamente aos Municípios com limitações exploratórias pela ampla preservação ambiental.

Significa a atuação do Estado em áreas, a priori, de desinteresse ao mercado como regulador eficaz da economia, em que prima "pela conservação ambiental, pelo crescimento econômico e pela equidade social" ${ }^{38}$. Incentivam-se os Municipais em espaços que impactarão a realidade socioeconômica locais.

O Estado do Pará, por meio da Lei Estadual n 7.638, de 12 de julho de 2012, introduziu essa política em seu ordenamento prevendo o critério ecológico como fator de aferição e repasse de $8 \%$ da parcela de ICMS cabível aos Municípios ${ }^{39}$.

Após uma primeira regulamentação pelo Decreto Estadual no 775, de 26 de junho de 2013, tal política é hoje regulada pelo Decreto Estadual no 1.696, de 07 de fevereiro de 2017 que fixa, para a repartição dos recursos, a consideração de quatro fatores ambientais.

A regulamentação paraense do ICMS Verde, porém, inovou ao introduzir o percentual de Cadastro Ambiental Rural como critério para a repartição do ICMS Verde ${ }^{40}$. Inicialmente, 50\% (cinquenta por cento) do valor total do repasse correspondente ao ICMS Verde paraense será realizado de forma diretamente proporcional à porcentagem da área cadastrável do Município inserida no Cadastro Ambiental Rural. Atualmente, o Cadastro Ambiental Rural transformou-se em um subfator incluído no critério regularização ambiental, que, em sua totalidade, corresponde a 38,6\% do total do valor do repasse.

A adoção do CAR como critério de repasse de ICMS aos Municípios paraenses contribuiu sobremaneira para o incentivo à adesão a tal cadastro. Vários programas de fomento foram implantados visando o aumento da área cadastrada nos Municípios.

Observa-se, porém, que a repartição da parcela referente a este critério, concentra-se mais fortemente nos Municípios localizados no Sudeste Paraense, onde se localizam cerca de —, dos Municípios que atingem a marca de $80 \%$ de cadastro e, paradoxalmente, trata-se de Municípios com alto grau de desmatamento.

Quatro Municípios paraenses (Paragominas, Santana do Araguaia, Dom Eliseu e Ulianópolis) que saíram

36 SCAFF, F. F.; TUPIASSU, L. V. C. Tributação e Políticas Públicas: O ICMS Ecológico. Verba Juris, João Pessoa, ano 3, n. 3 , p. 154-190. jan./dez. 2004. p. 724-748.

37 FÉ, Raquel Mousinho de Moura. A repartição de rendas entre os entes da federação e sua repercussão na caracterização do federalismo brasileiro: uma investigação acerca do desenvolvimento do federalismo fiscal-financeiro no Brasil. Revista Brasileira de Políticas Públicas, Brasília, v. 5, n. 1, p. 112, 2015.

38 CÂMARA, Andreza Aparecida Franco. O Neodesenvolvimentismo e a questão ambiental: o papel da hidroeletricidade no sistema energético brasileiro. Rev. Bras. Polít. Públicas, Brasília, v. 7, n. 1, p. 229, 2017.

39 Impende destacar que houve um processo gradativo de aumento do percentual do ICMS Ecológico até atingir o patamar de $8 \%$, porque, segundo o art. $9^{\circ}$ da Lei Estadual n ${ }^{\circ} 7.638 / 2012$, o percentual iniciaria com $2 \%$ em 2012, aumentaria para 4\% em 2013 , $6 \%$ em 2014 e $8 \%$ em 2015, quando se estabilizaria.

40 OLIVEIRA, A.; TUPIASSU MERLIN, L. V. C. ICMS Verde para a redução do desmatamento amazônico: estudo sobre uma experiência recente. Veredas do Direito, Belo Horizonte, v. 13, n. 25, p. 277-306, jan./ abr. 2016. 
da lista de Municípios Prioritários do MMA, adequando-se à categoria "Município Verde", figuram dentre os que possuem maiores áreas inseridas no CAR. Contudo, 4 dos maiores desmatadores (Cumaru do Norte, Marabá, São Félix do Xingu e Itupiranga) também possuem grande parcela do território inscrita no CAR ${ }^{41}$.

Incongruências são encontradas, porém, entre a quantidade de área cadastrada e a proporção nos valores recebidos pelos Municípios ${ }^{42}$. Ainda assim, Patrick Oliveira ${ }^{43}$ identificou, através da análise de dados das portarias de índices finais do ICMS Verde, que alguns municípios receberam, em 2014, 2015 e 2016, exclusivamente com base no CAR, conforme relação abaixo:

Tabela 2 - Municípios que receberam ICMS exclusivamente pelo CAR

\begin{tabular}{ccc}
\hline 2014 & 2015 & 2016 \\
\hline Santa Maria do Pará & Santa Maria do Pará & Santa Maria do Pará \\
São Domingos do Capim & São Domingos do Capim & São Domingos do Capim \\
São Francisco do Pará & São Francisco do Pará & São Francisco do Pará \\
São João do Araguaia & São João do Araguaia & São João do Araguaia \\
São Miguel do Guamá & & \\
Sapucaia & Sapucaia & Sapucaia \\
Terra Alta & Tailândia & \\
& & Tomé-Açu \\
Xinguara & Vigia & Xinguara \\
\hline
\end{tabular}

Fonte: Pinheiro, 2017.

Correlacionando as tabelas, infere-se que os municípios de Santa Maria do Pará, São Francisco do Pará e Terra Alta foram os mais impactados por dissonâncias no CAR em relação ao ICMS Verde, considerando que esse incentivo ocorreu em um ou todos os anos, até agora, com registros que ultrapassam o limite do território do município.

Não se descarta, no entanto, a extensão desses impactos aos demais, pois se trata de registros de imóveis sem a veracidade das informações prestadas.

Sendo assim, fica evidente que o incentivo pelas adesões ao CAR deixa de lado a fiscalização efetiva sobre a comprovação das informações prestadas pelos usuários, pois as pesquisas expõem que os registros são meramente declaratórios e baseados em documentação de segurança jurídica mínima.

A introdução do CAR como critério de repasse do ICMS Verde, portanto, em que pese tenha incentivado sobremaneira o aumento na quantidade de cadastros, não é acompanhada da correlação fática, tampouco técnica para a validação das informações obtidas, subvertendo tanto a política ambiental quanto o rebate territorial a ela vinculado.

41 OLIVEIRA, A.; TUPIASSU MERLIN, L. V. C. ICMS Verde para a redução do desmatamento amazônico: estudo sobre uma experiência recente. Veredas do Direito, Belo Horizonte, v. 13, n. 25, p. 277-306, jan./ abr. 2016.

42 BARGAS, N. O cadastro ambiental rural como critério de repasse do ICMS Verde no Estado do Pará. 2017. Monografia (Bacharelado em Direito). Instituto de Ciências Jurídicas. Universidade Federal do Pará - UFPA, Belém. 2017.

43 PINHEIRO, Patrick de Oliveira. A política do ICMS Verde sob o enfoque da análise da teoria sistêmica. 2017. Dissertação (Mestrado profissional em gestão dos recursos naturais e desenvolvimento local na Amazônia). Núcleo de Meio Ambiente - NUMA. Universidade Federal do Pará - UFPA, Belém, 2017. 
O Estado culmina por verter recursos à nova modalidade de grilagem baseada nos seus registros, com implicações não apenas ambientais, mas também sociais de aumento ou acirramento dos conflitos sociais na região.

\section{Considerações Finais}

A estrutura fundiária deficitária existente na região amazônica confere uma de suas maiores fragilidades para a implementação de políticas públicas, inclusive de defesa ao meio ambiente ${ }^{44}$, sendo agravada pela falta de sincronia entre as políticas de rebate territorial e ambiental que incidem sobre o mesmo registro espacial. As dissonâncias identificadas no Cadastro Ambiental Rural expõem tal celeuma.

Conforme amplamente apresentado, o CAR expõe problemas quanto à confiabilidade dos dados registrados e, ainda mais no Estado do Pará, por uma política mais de adesão quantitativa ao programa, sujeitando-se aos riscos de fraudes, já comuns na seara fundiária da região.

Sofre com os reflexos de uma política fundiária tortuosa com instrumentos jurídicos falhos e descontrole imobiliário. Apesar disso, tenta-se utilizar seus dados, premidos de saneamento, como um instrumento base para a regularização fundiária no Estado, repetindo erro do passado, como os registros paroquiais.

As pesquisas discutidas neste trabalho convergem sobre a insegurança dos registros apresentados oficialmente, seja pelas sobreposições, seja pela fraude da posse de imóveis rurais, seja pelas limitações administrativas de controle e monitoramento desses documentos, seja pela prática de grileiros em aproveitar-se das falhas, enfim, situações delicadas.

Agrava-se a questão pela utilização, no Estado do Pará, do CAR como critério para a repartição dos recursos do ICMS entre os Municípios, induzindo o fomento a políticas que não conferem justiça em relação aos esforços ambientais e fundiários por eles realizados.

Com a alteração no regime de regularização fundiária implementadas pela Medida Provisória nº 759/2016, a posse muitas vezes fictícia induzida pelo CAR dará azo para o acirramento dos conflitos fundiários na Amazônia, onde sobreposições de CAR são comuns e possivelmente gerará disputas entre aqueles que auto registraram suas terras

Tais elementos, porém, não buscam desqualificar o CAR como instrumento de controle e monitoramento ambiental, mas alertar que o incentivo à mera quantidade de registros pode desvirtuar sua finalidade e facilitar as ações de grileiros, especialmente pela possibilidade de acesso a linhas de créditos, licenças ambientais e, principalmente, o acesso às terras públicas a partir da flexibilização proposta pela nova legislação.

\section{REFERÊNCIAS BIBLIOGRÁFICAS}

ARAGÃO, Alexandra. O princípio do polvidor pagador: pedra angular da política comunitária do ambiente. São Paulo: Inst. O Direito por um Planeta Verde, 2014.

ARAÚJO, Ionnara Vieira de; TÁRREGA, Maria Cristina Vidotte Blanco. Apropriação de terras no Brasil e o instituto das terras devolutas. RFD-Revista da Faculdade de Direito da UERJ, v.1, n. 19, jun./dez 2011.

AZEVEDO, A. et al. Cadastro ambiental rural e sua influência na dinâmica do desmatamento na Amazônia Legal. Boletim Amazônia em pauta, Brasília, IPAM, n. 3, maio 2014. Disponível em: < http://www.observa-

44 TRENNEPOHL, Curt. Cadastro Ambiental Rural. In: MILARÉ, Edis; MACHADO, Paulo Affonso. Novo Código Florestal. 2. ed. São Paulo: Revista dos Tribunais, 2013. p. 310. 
torioflorestal.org.br/sites/default/files/amazonia_em_pauta_3_cadastro_ambiental_r.pdf>.Acesso em: 10 jun. 2017.

AZEVEDO, Ruy Emmanuel de; OLIVEIRA, Vládia Pinto Vidal de. Reflexos do novo Código Florestal nas Áreas de Preservação Permanente. Desenvolvimento e Meio Ambiente, Curitiba, v. 29, n. 1, p. 71-91, abr. 2014.

BARGAS, N. O cadastro ambiental rural como critério de repasse do ICMS Verde no Estado do Pará. 2017. Monografia (Bacharelado em Direito). Instituto de Ciências Jurídicas. Universidade Federal do Pará - UFPA, Belém, 2017.

BARROS, Ciro; BARCELOS, Iuri; GALLO, João Otávio. As falhas e inconsistências do Cadastro Ambiental Rural. Disponível em: < http://apublica.org/2016/08/as-falhas-e-inconsistencias-do-cadastro-ambiental-rural/>. Acesso em: 7 jun. 2017.

BARROS, Dalmo Arantes et al. Breve análise dos instrumentos da política de gestão ambiental brasileira. Politica \& Sociedade, Florianópolis, v. 11, n. 22, nov. 2012.

BENJAMIN, Antônio Herman. Constitucionalização do ambiente e ecologização da Constituição brasileira. In: CANOTILHO, Joaquim Gomes; LEITE, José Rubens Morato (Org.). Direito constitucional ambiental brasileiro. São Paulo: Saraiva, 2007.

BRASIL. Câmara dos Deputados. Relatório final da comissão parlamentar de inquérito destinada a investigar a ocupação de terras públicas na região amazônica. p. 132. Disponível em: <http://imagem.camara.gov.br/Imagem/d/pdf/ DCD28DEZ2001SUP.pdf\#page=3>. Acesso em: 31 jul. 2017.

BRASIL. Instituto de Colonização e Reforma Agrária - INCRA. Livro branco da grilagem de terras. p. 15. Disponível em:< http://www.incra.gov.br/media/servicos/publicacao/livros_revistas_e_cartilhas/Livro\%20 Branco\%20da\%20Grilagem\%20de\%20Terras.pdf>. Acesso em: 31 jul. 2017.

BRASIL. Ministério Público Federal. Caso Madeira Limpa: justiça bloqueia R \$2,8 milhões de madeireiros por danos ambientais. Disponível em: < http://www.mpf.mp.br/pa/sala-de-imprensa/noticias-pa/caso-madeira-limpa-justica-bloqueia-r-2-8-milhoes-de-madeireiros-por-danos-ambientais>. Acesso em: 31 jul. 2017.

BRASIL. Ministério Público Federal. Rios Voadores: novas autuações envolveram mais dois acusados como responsáveis pelo maior desmatamento da Amazônia. Disponível em: <http://www.mpf.mp.br/pa/salade-imprensa/noticias-pa/rios-voadores-novas-autuacoes-envolveram-mais-dois-acusados-como-responsaveis-pelo-maior-desmatamento-da-amazonia>. Acesso em: 31 jul. 2017.

BRASIL. Presidência da República. Decreto de 19 de abril de 2007. Homologação da terra indígena Apyterewa. Publicado no Diário Oficial da União - DOU. Disponível em: < http://pesquisa.in.gov.br/imprensa/jsp/ visualiza/index.jsp?jornal=1\&pagina $=9 \&$ data $=20 / 04 / 2007>$ Acesso em: 8 jun. 2017.

BRITO, Brenda; CARDOSO Junior, Dário. Regularização fundiária no Pará: afinal qual é o problema? Belém: IMAZON, 2015.

CÂMARA, Andreza Aparecida Franco. O Neodesenvolvimentismo e a questão ambiental: o papel da hidroeletricidade no sistema energético brasileiro. Rev. Bras. Polít. Públicas, Brasília, v. 7, n. 1, p. 220-245, 2017.

ESTADO DO PARÁ. Ministério Público Do Estado Do Pará. Recomendação no Inquérito Civil n. 001/2013 8a PJ Agrária. Disponível em: < http://www.mppa.mp.br/upload/recomendacao\%20CARF(1).pdf>. Acesso em: 31 jul. 2017

ESTADO DO PARÁ. Programa Municípios Verdes: área CAR cadastrada (SEMA - 03/2017). Disponível em: <http://www.municipiosverdes.pa.gov.br/relatorios/rr_area_percentual/30/29>. Acesso em: 8 jun. 2017.

ESTADO DO PARÁ. Secretaria de Estado do Meio-Ambiente e Sustentabilidade. CAR - documentos. Disponível em: <https://www.semas.pa.gov.br/2013/06/24/car-documentos/> Acesso em: 8 jun. 2017. 
ESTADO DO PARÁ. Tribunal De Justiça Do Estado Do Pará. Provimento n. 001/2001-Cgj. Disponível em: < http://www.tjpa.jus.br//CMSPortal/VisualizarArquivo?idArquivo=3062>. Acesso em: 31 jul. 2017.

FÉ, Raquel Mousinho de Moura. A repartição de rendas entre os entes da federação e sua repercussão na caracterização do federalismo brasileiro: uma investigação acerca do desenvolvimento do federalismo fiscalfinanceiro no Brasil. Revista Brasileira de Políticas Públicas, Brasília, v. 5, n. 1, p. 93-114, 2015.

FIORILLO, Celso Antônio Pacheco. Curso de Direito Ambiental Brasileiro. São Paulo: Saraiva, 2009.

FREITAS, Juarez. Sustentabilidade: direito ao futuro. Belo Horizonte: Fórum, 2012.

IMAZON - INSTITUTO DO HOMEM E MEIO AMBIENTE DA AMAZÔNIA. Acordo de Cooperação Técnica n. 1 de 2015. Disponível em: <http://imazon.org.br/PDFimazon/Portugues/transparencia_institucional/Cooperacao\%20Tecnica_01_2015_ITERPA_SEDAP_SEDEME_SEMAS\%20e\%20IMAZON\%20(1).pdf>. Acesso em: 31 jul. 2017.

L'ROE et al. Mapping properties to monitor forests: Landholder response to a large environmental registration program in the Brazilian Amazon. Land use policy, v. 57, p. 193-203, nov. 2016.

MATTOS NETO, Antônio José. A questão agrária no Brasil: aspecto sócio-jurídico. Projeto História, São Paulo, n. 33, p. 97-118, dez. 2006.

MOREIRA, Eliane. O cadastro ambiental rural: a nova face da grilagem na Amazônia? Disponível em: < http:// www.abrampa.org.br/site/?ct=noticia\&id=230>. Acesso em: 8 jun. 2017.

MUNIZ, João de Palma. Índice geral dos registros de terras. Belém: Imprensa Official, 1907. v. 7.

OBSERVATÓRIO DO CLIMA. Nota de repúdio de 28 de julho de 2017. Disponível em: <http://www.observatoriodoclima.eco.br/60-organizacoes-pedem-janot-acao-contra-lei-da-grilagem/>. Acesso em: 24 ago. 2017.

OLIVEIRA, A.; TUPIASSU MERLIN, L. V. C. ICMS Verde para a redução do desmatamento amazônico: estudo sobre uma experiência recente. Veredas do Direito, Belo Horizonte, v. 13, n. 25, p. 277-306, jan./ abr. 2016.

PINHEIRO, Patrick de Oliveira. A política do ICMS Verde sob o enfoque da análise da teoria sistêmica. 2017. Dissertação (Mestrado profissional em gestão dos recursos naturais e desenvolvimento local na Amazônia). Núcleo de Meio Ambiente - NUMA. Universidade Federal do Pará - UFPA, Belém, 2017.

ROCHA, Ibrahim et al. Manual de direito agrário constitucional: lições de direito agroambiental. 2. ed. Belo Horizonte: Fórum, 2015.

SCAFF, F. F.; TUPIASSU, L. V. C. Tributação e Políticas Públicas: O ICMS Ecológico. Verba Juris, João Pessoa, ano 3, n. 3, p. 154-190. jan./dez. 2004.

TRECCANI, Girolamo D. Violência e grilagem: instrumentos de aquisição da propriedade da terra no Pará. Belém: UFPA; ITERPA, 2001.

TRENNEPOHL, Curt. Cadastro Ambiental Rural. In: MILARÉ, Edis; MACHADO, Paulo Affonso. Novo Código Florestal. 2. ed. São Paulo: Revista dos Tribunais, 2013.

TUPIASSU MERLIN, L. V. C; OLIVEIRA, A. ICMS Verde para a redução do desmatamento amazônico: estudo sobre uma experiência recente. Veredas do Direito, Belo Horizonte, v.13, n.25, p.277-306, jan./abr. de 2016.

TUPIASSU, L. Tributação Ambiental: a utilização dos instrumentos econômicos e fiscais na implementação do direito ao meio ambiente saudável. Rio de Janeiro: Renovar, 2006. 


\section{REVISTA BRASILEIRA DE POLÍTICAS PÚBLICAS BRAZILIAN JOURNAL OF PUBLIC POLICY}
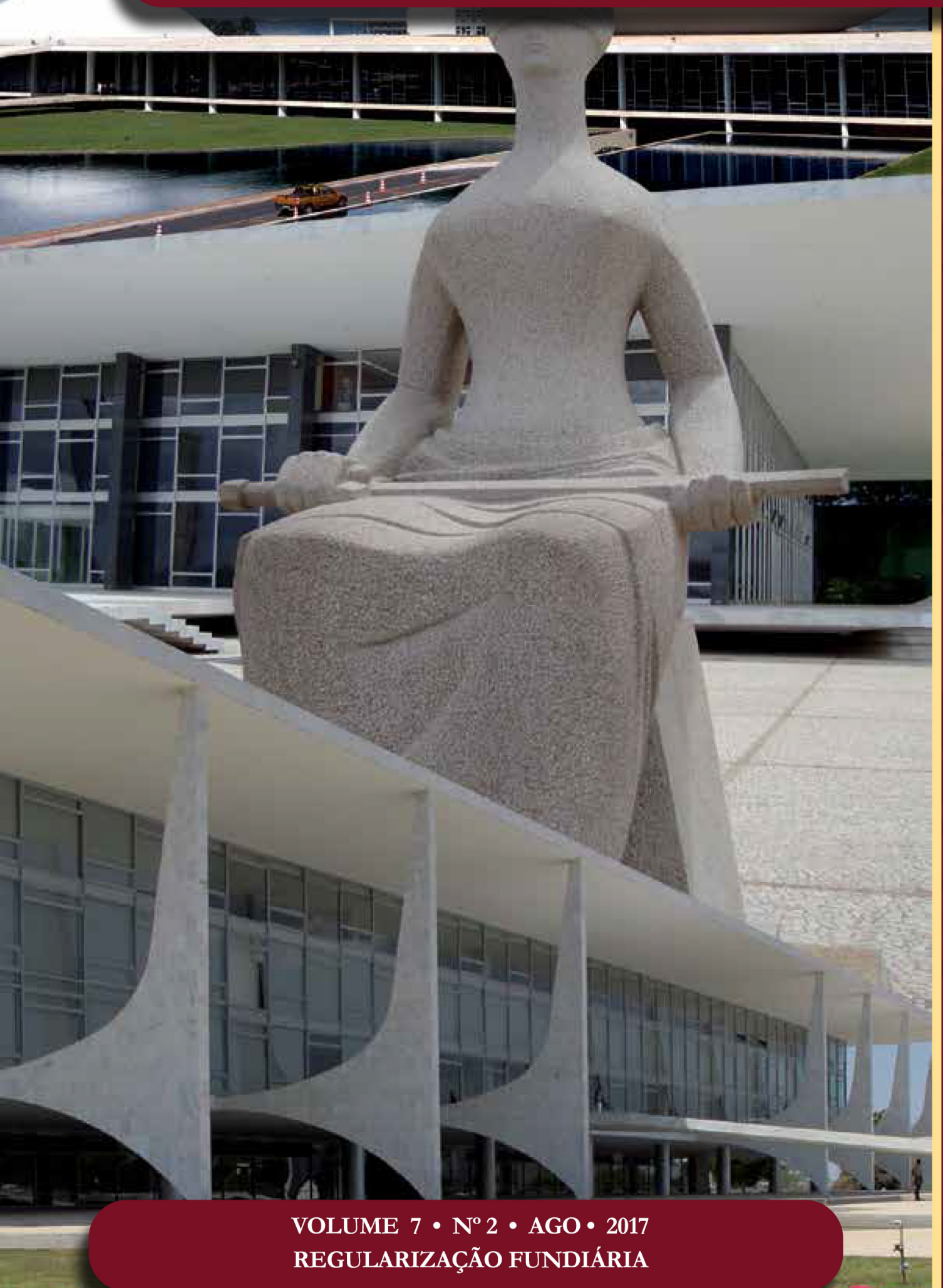

A Regularização do

Parcelamento do Solo de Loteamentos Públicos: Um Estudo Baseado no Projeto do Loteamento de Interesse Social Vila Betinho em Chapecó/Sc

The Regularization Of The Land: A Study Based On The Vila Betinho Project In Chapecó/Sc 


\section{A Regularização do Parcelamento do Solo de Loteamentos Públicos: Um Estudo Baseado no Projeto do Loteamento de Interesse Social Vila Betinho em Chapecó/Sc*}

\author{
The Regularization Of The Land: A Study \\ Based On The Vila Betinho Project In Chapecó/Sc
}

Reginaldo Pereira**

Karen Bissani ${ }^{* * *}$

\section{Resumo}

O artigo tem como objetivo analisar, a partir de um determinado processo de regularização fundiária, aspectos jurídicos que evidenciem, a partir do caso estudado, a importância da adoção de políticas públicas que levem em consideração as diversas matizes do conjunto de direitos que compõem uma das grandes diretrizes da política urbana: a garantia do direito a cidades sustentáveis. Delimitou-se, espacialmente, o estudo ao Loteamento de Interesse Social Vila Betinho, localizado no Município de Chapecó, Estado de Santa Catarina. A originalidade e a pertinência da análise residem na peculiaridade do caso estudado, dado que, mesmo tendo sido criado por iniciativa do Poder Público Municipal, o loteamento objeto de estudo era ilegal, o que configura um caso de irregularidade de loteamento público e impede o pleno exercício dos direitos da cidadania pelos moradores. A metodologia utilizada para a análise e apropriação teórica dos dados é mediada pela perspectiva indutiva. Por meio da técnica de estudo de caso procura-se demonstrar a possibilidade de regularização de loteamentos públicos pela via administrativa com base na Lei de Parcelamento do Solo Urbano. Conclui-se, em relação à análise do caso, que a política pública adotada pelo Município de Chapecó para a regularização fundiária de loteamentos públicos tem a potencialidade de levar em consideração a multidimensionalidade dos direitos relacionados ao direito às cidades que sejam justas, viáveis e equilibradas.

Palavras-chave: Política de desenvolvimento urbano. Função social da cidade. Cidades sustentáveis. Regularização fundiária. Programa de Regularização Bairro Legal.

\section{Abstract}

The objective of this article is to analyze, from a given land regularization process, legal aspects that show, from the case studied, the importance of adopting public policies that take into account the different nuances of the set of rights that make up one of the great guidelines of urban policy: guaranteeing the right to sustainable cities. The study was spatially delimited 
to the Vila Betinho Project, located in the Municipality of Chapecó, State of Santa Catarina. The originality and pertinence of the analysis lie in the peculiarity of the case studied, given that, even though it was created at the initiative of the Municipal Government, the subdivision under study was illegal, which constitutes a case of irregularity of public subdivision and prevents the full rights of citizenship by the residents. The methodology used for the analysis and theoretical appropriation of the data is mediated by the inductive perspective. By means of the case study technique, it is tried to demonstrate the possibility of regularization of public lots by the administrative route based on the Urban Land Installment Law. It is concluded from the analysis of the case that the public policy adopted by the Municipality of Chapecó for the regularization of public land lots has the potential to take into account the multidimensionality of rights related to the right to cities that are fair, viable and balanced.

Keywords: Urban development policy. Social function of the city. Sustainable cities. Land regularization. Legal Neighborhood Regularization Program.

\section{INTRODUÇÃo}

A questão urbana no Brasil recebeu um tratamento orgânico a partir de sua constitucionalização e, principalmente, do surgimento do Estatuto das Cidades, não obstante existirem normas que já tratavam de forma isolada de aspectos ligados ao ordenamento e ao parcelamento do solo, à titularidade dos imóveis, aos limites ao direito de construir, entre outros.

A ausência de políticas públicas que buscassem garantir o direito à cidade sustentável aliada a contínuos processos de gentrificação influenciaram no crescimento da maioria das grandes e médias cidades brasileiras, marcadas ou pela estratificação ou por mosaicos que mesclam a cidade legal com a ilegal. As irregularidades na ocupação do solo urbano se apresentam, pelos mesmos motivos, de diversas ordens e grandezas.

No presente artigo, trata-se da regularização fundiária de uma modalidade específica de irregularidade: a que ocorre em loteamentos públicos. A partir de um estudo de caso - a Vila Betinho —, o texto procura apresentar como o Município de Chapecó, com a finalidade de garantir acesso à moradia a uma parcela da população vulnerável, em um determinado momento criou uma situação irregular e de que forma, quase duas décadas após, pela aplicação de instrumentos de uma política pública municipal, denominada Bairro Legal, o mesmo Poder Público legalizou a situação irregular que houvera criado.

Como a maioria das cidades brasileiras, o Município de Chapecó - SC sofre com a ocupação irregular do seu território e apresenta irregularidades tanto em áreas públicas quanto particulares. Dados levantados pela Secretaria Municipal de Habitação dão conta da existência de vinte áreas de interesse social de propriedade do Município irregulares no ano de $2012^{1}$. O número expressivo de áreas com irregularidades, em uma cidade que conta com pouco mais de duzentos mil habitantes, faz com que a problemática transcenda os campos jurídico e urbanístico e se revele um verdadeiro problema social.

O problema não pode ser atribuído, apenas, a deficiências no exercício do poder de polícia por parte do Município e a falhas nos sistemas de controle e fiscalização que poderiam coibir o parcelamento irregular de solo. Há, sem dúvida, a ausência de mecanismos legais que confiram maior agilidade e eficácia aos processos de regularização das áreas consolidadas, em especial, aos loteamentos públicos.

Desde o ano de 2015, o Município de Chapecó, situado na região oeste do Estado de Santa Catarina, vem implementando políticas públicas com o intuito de regularizar e qualificar suas áreas irregulares. Dentre essas iniciativas, importa, para os fins do presente artigo, o Programa Municipal de Regularização Bairro

1 RELATÓRIO de autoria da secretária de habitação, do ano de 2012. Disponível em: <https://www.chapeco.sc.gov.br/>. Acesso em: jun. 2017. 
Legal. Pretende-se, com tal programa, regularizar áreas públicas de interesse social que se encontram irregulares, há quase duas décadas.

O projeto de regularização do Loteamento Vila Betinho foi escolhido como o piloto desse programa e, nos quase dois anos de processo, agregou muita experiência e trouxe uma forma nova de regularização de loteamentos públicos, pela via administrativa, com fundamento nas disposições da Lei de Parcelamento do Solo (Lei Federal nº 6.766/1979).

A partir do relato do processo de regularização da Vila Betinho, o presente artigo tem como objetivo analisar se tal experiência pode servir de parâmetro para a adoção de propostas semelhantes por outros municípios que possuam loteamentos públicos irregulares.

Os objetivos do artigo não se esgotam com a simples apresentação de uma situação concreta. Ao contrário, em um exercício indutivo, o artigo, a partir do caso estudado, procura demonstrar a importância da adoção de políticas públicas que levem em consideração a multidimensionalidade dos direitos relacionados ao direito às cidades que sejam justas, viáveis e equilibradas sob os aspectos social, ecológico e econômico.

Para tanto, inicia-se o artigo tratando-se do instituto da regularização fundiária enquanto mecanismo de efetivação da política de desenvolvimento urbano preconizada na Constituição Federal de 1988. Posteriormente, serão abordadas as principais nuances do Programa de Regularização Bairro Legal. Por fim, analisar-se-á a regularização fundiária do Loteamento Vila Betinho.

\section{A Regularização Fundiária No Contexto Da Política De Desenvolvimento Urbano}

Ainda que receba tratamento jurídico próprio pela Lei Federal no 13.465/2017, a regularização fundiária urbana não pode ser analisada em apartado das normas de caráter constitucional e infraconstitucional que tratam da Política de Desenvolvimento Urbano no Brasil.

Uma análise sistemática dos dispositivos da Lei Federal no 10.257/2001 indica que a regularização fundiária e a urbanização de áreas ocupadas por população de baixa renda são diretrizes gerais da Política Urbana Brasileira, a qual tem por objetivo ordenar o pleno desenvolvimento das funções sociais da cidade e da propriedade urbana.

Além de ser considerada como um dos instrumentos de concretização das diretrizes e objetivos da Política Urbana Brasileira, o Estatuto das Cidades a utiliza como elemento que enseja a utilização de outros instrumentos urbanísticos, tais como o direito de preempção (artigo 26, I da Lei Federal no 10.257/2001), a transferência do direito de construir (artigo 35, III da Lei Federal no 10.257/2001) e o consórcio imobiliário (artigo 46, $\mathbb{S} 1^{\circ}$ da Lei Federal no $10.257 / 2001$ ).

Ao definir o conteúdo mínimo dos Planos Diretores Municipais, o Estatuto das Cidades determina que eles contenham diretrizes para a regularização fundiária de assentamentos urbanos irregulares (artigo 42, V da Lei Federal no 10.257/2001).

O caráter duplo - instrumental e material — conferido pelo Estatuto das Cidades à regularização fundiária reclama a compreensão de sua constitucionalização, sob pena de se adentrar-se em equívocos quanto à definição correta da natureza jurídica do instituto.

O artigo 182 da Constituição Federal de 1988, ao estabelecer os contornos constitucionais para a Política de Desenvolvimento Urbano, determina que esta deva ser executada pelo Poder Público Municipal, em respeito ao princípio da prevalência dos interesses, em conformidade com as diretrizes gerais fixadas em lei (federal) — que seria aprovada treze anos após a promulgação da Constituição Federal de 1988 e seria batizada como Estatuto das Cidades. 
Além da ressalva do artigo 182, o artigo 24 da Constituição Federal de 1988 insere a atividade legislativa de caráter urbanístico no âmbito da competência concorrente, que confere à União a prerrogativa de editar as normas de caráter geral e aos Estados-Membros a possibilidade de suplementar as regras gerais, adequando-as suas realidades. Nesse regime de competências, os Municípios, por força do artigo 30, I e II da Constituição Federal de 1988, podem suplementar a legislação federal e estadual no que couber.

A concessão de competência à União para definir as regras gerais em matéria de direito urbanístico e de Política de Desenvolvimento Urbano, além de ser uma medida de correção das distorções decorrentes do tamanho continental do País e das diferenças de cunho econômico, social e cultural de cada região, demonstra que o constituinte tinha a noção de que as cidades brasileiras, ao contrário do que ocorre em países desenvolvidos, são periféricas.

As cidades periféricas, ao contrário das centrais, se caracterizam pela ausência de regulação estatal sobre a totalidade do solo urbano. Nessa modalidade de cidade, se observa com frequência que a "[...] maioria da população pode habitar espaços informais que são também segregados em relação à cidade oficial ou legal onde os planos e leis urbanísticas não são aplicados." Se, nas cidades centrais, as irregularidades na ocupação do solo urbano são exceções, nas cidades periféricas: "as exceções são mais regra do que exceções."

Havia, por ocasião da elaboração da Constituição de 1988, um desafio enorme em relação à ordenação do uso e ocupação do solo urbano, no Brasil, que ainda não foi superado e que demandava um tratamento jurídico uniforme, a ser observado em todo o território nacional. Tal deficit ao mesmo tempo que justifica a pertinência de se reservar à União a competência para a definição das regras gerais sobre a Política de Desenvolvimento Urbano, está na raiz do processo de sua constitucionalização.

Era preciso superar uma profunda crise urbana, decorrente de uma diversidade de deficiências da forma e da natureza do processo de urbanização do Brasil, dentre os quais: i) a combinação de segregação socioespacial, deficit habitacional, impactos ambientais e acesso informal à terra urbana e à moradia; ii) a natureza elitista e tecnocrática da limitada intervenção governamental então existente; iii) a baixa qualidade política do sistema de representação democrática em todos os níveis governamentais; iv) a prevalência de uma ordem jurídica obsoleta, de natureza eminentemente civilista, centrada na defesa do direito de propriedade em detrimento da função social da propriedade. ${ }^{3}$

Com a redemocratização brasileira, emerge o Movimento Nacional de Reforma Urbana, o qual, a partir de uma Emenda Popular de Reforma Urbana que tinha sido formulada, discutida, disseminada e assinada por mais de 100 mil organizações sociais e indivíduos, influenciou sobremaneira na redação final dos dispositivos constitucionais dedicados à questão urbana. A citada emenda, propunha, em regras gerais, o reconhecimento constitucional dos seguintes princípios gerais: i) autonomia do governo municipal; ii) gestão democrática das cidades; iii) direito social de moradia; iv) direito à regularização de assentamentos informais consolidados; v) função social da propriedade urbana; e vi) combate à especulação imobiliária nas áreas urbanas. $^{4}$

Os artigos 182 e 183 da Constituição Federal de 1988 acabaram, mesmo que de forma tímida, reconhecendo os princípios acima. Já no Caput do artigo 182, fica clara a intenção de se estruturar no Brasil uma Política de Desenvolvimento Urbano voltada ao pleno cumprimento das funções sociais da cidade e à garantia do bem-estar de seus habitantes. Da mesma forma, os instrumentos enumerados no parágrafo quarto do citado artigo permitem induzir uma certa ruptura com os paradigmas vigentes, até então.

2 MARICATO, Ermínia. O estatuto da cidade periférica. In: CARVALHO, Celso Santos; ROSSBACH, Anaclaudia (Org.). O Estatuto da Cidade Comentado. São Paulo: Ministério das Cidades/Aliança das Cidades, 2010. p. 8.

3 FERNANDES, Edesio. O Estatuto da Cidade e a ordem jurídico-urbanística. In: CARVALHO, Celso Santos; ROSSBACH, Anaclaudia (Org.). O Estatuto da Cidade Comentado. São Paulo: Ministério das Cidades/Aliança das Cidades, 2010. p. 56-57.

4 FERNANDES, Edesio. O Estatuto da Cidade e a ordem jurídico-urbanística. In: CARVALHO, Celso Santos; ROSSBACH, Anaclaudia (Org.). O Estatuto da Cidade Comentado. São Paulo: Ministério das Cidades/Aliança das Cidades, 2010. p. 57-58. 
Os parágrafos primeiro e segundo do artigo 182 da Constituição Federal de 1988 tratam do plano diretor e da função social da propriedade urbana. Na sistemática adotada pelo constituinte, é no Plano Diretor que os Municípios definirão os critérios de cumprimento da função social da propriedade, que deverá atender às exigências fundamentais de ordenação da cidade expressas no plano diretor.

Em relação ao Plano Diretor, este:

[...] deverá explicitar de forma clara qual o objetivo da política urbana. Deve partir de um amplo processo de leitura da realidade local, envolvendo os mais variados setores da sociedade. A partir disso, vai estabelecer o destino específico que se quer dar às diferentes regiões do município, embasando os objetivos e as estratégias. A cartografia dessas diretrizes corresponde a um macrozoneamento, ou seja, a divisão do território em unidades territoriais que expressem o destino que o município pretende dar às diferentes áreas da cidade. ${ }^{5}$

Por fim, o artigo 183 insere no ordenamento jurídico nacional uma nova modalidade de aquisição originária da propriedade urbana, via o exercício de posse ad usucapionem, com prazo muito inferior aos exigidos na época.

Como se percebe, os principais vetores da Política de Desenvolvimento Urbano no Brasil são o cumprimento da função social da cidade e o bem-estar dos seus habitantes.

Há três aspectos a serem explorados quando se trata das funções sociais da cidade: o primeiro está relacionado ao próprio direito à cidade; o segundo, com a ecologização desse direito que remete à função socioambiental da cidade; e o terceiro, com a garantia de uma vida saudável e digna nas cidades ou ao direito às cidades sustentáveis.

Conceitualmente, função social da cidade e função social da propriedade urbana se distanciam. Enquanto a última funcionaliza o direito de propriedade em prol da sociedade, fazendo com que recaiam sobre o proprietário deveres decorrentes dos poderes que tal direito confere, em favor da sociedade ${ }^{6}$, a primeira guarda relação com as funções que a cidade deve cumprir em proveito da população, que podem ser divididas em: i) funções urbanísticas: habitação, trabalho, lazer e mobilidade; ii) funções de cidadania: educação, saúde, segurança e proteção e; iii) funções de gestão: prestação de serviços, planejamento, preservação do patrimônio cultural e natural e sustentabilidade urbana. ${ }^{7}$

O Princípio da função social da cidade está atrelado a interesses e direitos de natureza metaindividual. Nesse sentido, pode ser entendido como um desdobramento do princípio da função social da propriedade. Ele “[...] supera a tradicional visão da urbis. Refere-se ao atendimento das necessidades presentes, futuras e reconhecimento de condições capazes de desenvolver o município e oferecer melhores condições de vida aos seus munícipes. ${ }^{8}$

Nesse sentido, o princípio se coaduna com a materialização do direito à cidade sustentável, diretriz da Política de Desenvolvimento Urbano no Brasil.

Enquanto a proposta de Henri Lefbvre relativa ao direito à cidade parte da constatação da construção de um espaço urbano no qual as relações sociais cotidianas acontecem e que é fruto de dois processos inseparáveis: a industrialização e a urbanização, já que a urbanização representa o sentido, o objetivo, a finalidade da industrialização ${ }^{9}$, o direito à cidade sustentável parte de um processo de ecologização do próprio direito à

5 BRASIL. Estatuto da cidade: guia para implementação pelos municípios e cidadãos. 2. ed. Brasília: Câmara dos Deputados/Coordenação de Publicações, 2002. p. 45.

6 DUGUIT, Leon. Las transformaciones del Derecho Publico y Privado. Buenos Aires: Editorial Heliasta S.R.L., 1975.

7 GARCIAS, Carlos Mello; BERNARDI, Jorge Luiz. As funções sociais da cidade. Direitos Fundamentais \& Democracia, Curitiba, v. 4, jun./dez. 2008. Disponível em: <http://revistaeletronicardfd.unibrasil.com.br/index.php/rdfd/article/viewFile/48/47>. Acesso em: jun. 2017.

8 SALEME, Edson Ricardo. Parâmetros sobre a função social da cidade. Anais do XIV Congresso Nacional do Conpedi. Disponível em: <http://www.publicadireito.com.br/conpedi/manaus/arquivos/anais/XIVCongresso/141.pdf>. Acesso em: maio 2017.

9 LEFEBVRE, Henri. O direito à cidade. Tradução de: Rubens Eduardo Frias. São Paulo: centauro: 2001. p. 114. 
cidade e do reconhecimento de ser a cidade o habitat de grande parte da população detentora de um direito difuso e autônomo à qualidade ambiental, no qual o cotidiano se realiza.

O termo sustentável comporta uma gama de variações cambiáveis, de acordo com o ideário de quem o significa. Dessa forma, seria factível definir cidade sustentável como sendo aquela que é economicamente viável, socialmente justa e ecologicamente equilibrada. Em assim o fazendo, estar-se-ia utilizando um critério fraco de sustentabilidade para determinar o quão sustentável é uma determinada cidade.

Por outro lado, considerando-se o meio ambiente como a base dos outros elementos da sustentabilidade (o social e o econômico), a partir de um critério forte de sustentabilidade, uma cidade somente seria sustentável se fosse ecologicamente equilibrada, para as presentes e futuras gerações, já que os pilares social e econômico dependem do fundamento ecológico para serem erguidos e mantidos de pé. ${ }^{10}$

A adoção do critério forte de sustentabilidade importaria na consideração da cidade como elemento de níveis organizacionais mais complexos que interferem e sofrem interferências das cidades, cujos elementos vão desde o menor nível de organização dos seres vivos, passam pelo rural, incluem os elementos artificiais e culturais do meio ambiente e chegam à ecosfera.

A natureza e as características dos problemas ambientais atuais - aquecimento global, perda da biodiversidade, entre outros — reclama uma abordagem forte da sustentabilidade e, de certa forma, condiciona a noção de cidade sustentável, atrelando-o, primeiramente, ao elemento ecológico, por ser a base dos demais.

Não obstante, o artigo segundo, inciso I do Estatuto das Cidades, define o direito a cidades sustentáveis como o direito à terra urbana, à moradia, ao saneamento ambiental, à infraestrutura urbana, ao transporte e aos serviços públicos, ao trabalho e ao lazer, para as presentes e futuras gerações. Tal definição parece remeter a critérios de sustentabilidade fraca. Todavia, os estudos da ecologia urbana dão conta da interdependência das cidades com fatores, à primeira vista, alheios às cidades, como, por exemplo a questão do clima.

Além disso, a inserção do elemento diacrônico (atuais e futuras gerações) na definição legal do termo (cidade sustentável) remete, necessariamente, à adoção de critérios de governança pautados na preservação e requalificação dos elementos naturais da cidade e em medidas que façam com que estas cumpram funções em benefício dos elementos naturais do meio ambiente. A cidade pode, por exemplo, adotar políticas públicas visando à diminuição do lançamento de gases de efeito estufa, à captação de carbono por meio de sumidouros, à preservação da biodiversidade via construção de corredores ecológicos urbanos que liguem as unidades de conservação ecológica remanescentes etc.

A contribuição das cidades para a manutenção do equilíbrio ecológico é uma das faces daquilo que vem se denominando função socioambiental da cidade. A outra faceta guarda relação com a qualidade de vida e a saúde de seus moradores, dado que ao mais básico dos direitos (direito à vida) foi acrescentado o adjetivo saudável pelo processo de ecologização da Constituição Federal de $1988^{11}$, o que impõe a adoção de medidas de manutenção da qualidade do meio ambiente, pois a vida saudável reclama o equilíbrio ecológico.

Levando-se em consideração a forma de ocupação das cidades periféricas, conclui-se que políticas públicas qualificadas de regularização fundiária são extremamente importantes para que a cidade cumpra com sua função socioambiental e assegure vida saudável e digna a seus habitantes. Da mesma forma, no plano material, verifica-se tanto na Constituição Federal de 1988 quanto na legislação regulamentar a vontade de sanar o deficit habitacional e ambiental das cidades brasileiras, por meio da adoção de instrumentos de indução ao cumprimento da função socioambiental das cidades, dentre os quais, o da regularização fundiária.

Restam, contudo, entraves de cunho procedimental que acabam dificultando e criando objeções para a aplicação dos instrumentos de regularização fundiária.

10 WINTER, Gerd. Desenvolvimento sustentável, OGM e responsabilidade civil na União Europeia. Campinas: Millennium Editora, 2009. 11 BENJAMIN, Antônio Herman. Constitucionalização do ambiente e ecologização da constituição brasileira. In: CANOTILHO, José Joaquim Gomes; LEITE, José Rubens Morato (Org.). Direito constitucional ambiental brasileiro. 2. ed. rev. São Paulo: Saraiva, 2008. p. 57-130. 
É o que acontece, por exemplo, nos casos de intervenção do Poder Público em parcelamento clandestino ou irregular que, muito embora encontrar-se previsto no artigo 40 da Lei de Parcelamento do Solo Urbano há mais de duas décadas, carece de regulamentação de cunho processual que permita aos Município regularizar determinada área por iniciativa própria.

As múltiplas faces e o grau de complexidade dos processos de regularização fundiária reclamam clareza quanto à situação fática e maleabilidade procedimental, que permita a adoção de medidas pontuais visando adequar a situação fática a padrões de qualidade socioambiental compatíveis com as diretrizes, princípios e objetivos da Política de Desenvolvimento Urbano. A articulação entre profissionais de áreas distintas e a adoção de medidas adequadas são imprescindíveis para o sucesso de determinado processo de regularização, sob pena de se criar situações conflituosas entre as diversas dimensões de direitos envolvidas.

A ausência de mecanismos procedimentais adequados à implementação da intervenção do Poder Público faz com que os agentes envolvidos (Poder Público Municipal, Órgãos Ambientais, Ministério Público, Judiciário, Cartório de Registro de Imóveis etc.) criem barreiras e estabeleçam exigências que dificultam e até impedem o andamento e a finalização de processos de regularização fundiária.

O presente artigo analisa a forma encontrada pelo Município de Chapecó para, a partir de uma Política Pública de Regularização Fundiária, materializada pelo Programa de Regularização Bairro Legal, solucionar a ausência de regulamentação adequada para a regularização fundiária de loteamentos públicos, como é o caso da Vila Betinho.

\section{O Programa Municipal De Regularização Bairro Legal}

A Constituição Federal, em seu artigo 182, menciona, expressamente, que a propriedade urbana está inserida no contexto de normas e planos urbanísticos vinculando sua função social ao ordenamento da cidade regrado pelo plano diretor municipal. Assim, a utilização do solo urbano fica sujeita às determinações de leis urbanísticas e em especial pelo plano urbanístico diretor. ${ }^{12}$

O parcelamento de solo para fins urbanos é um procedimento imposto pelas normas urbanísticas, porquanto precisam ser observadas, e não sendo, constituirão loteamentos ilegais, podendo ser clandestinos, quando não são aprovados pela municipalidade, ou, irregulares quando aprovados, mas executados em desconformidade com o plano diretor e os projetos aprovados.

Dessa forma, o parcelador, previamente à comercialização dos lotes, deve apresentar um plano do loteamento firmado por profissional habilitado, aprová-lo na Prefeitura e depois registrá-lo perante o Cartório de Registro de Imóveis. A venda de lotes não registrados é proibida e a conduta criminalizada. ${ }^{13}$

A venda ilegal de lotes constitui um dos grandes problemas urbanísticos do Brasil, pois é comum que os proprietários das áreas parceladas irregularmente não se preocupem com a aprovação da Prefeitura, por ser esta uma providência onerosa e que demanda a transferência de áreas para o sistema viário e equipamentos públicos urbanos e comunitários. Essas áreas na maioria das vezes não recebem a mínima urbanização e criam áreas habitadas sem serem habitáveis por falta de planejamento urbano, transformando-se num problema urbano e social de difícil solução e que se arrasta por décadas até efetivamente ser resolvido ${ }^{14}$.

Os expressivos índices de crescimento populacional e econômicos apresentados nas últimas décadas, ocasionaram o crescimento das periferias em especial das áreas comercializadas informalmente, sem o de-

12 SILVA, José Afonso da. Direito Urbanistico Brasileiro. São Paulo: Malheiros, 2011. p. 73.

13 JUNIOR, Saule Junior. A Proteção Jurídica da Moradia nos Assentamentos Irregulares. Porto Alegre: Sergio Antônio Fabris Editos, 2004. p. 352.

14 SILVA, José Afonso da. Direito Urbanístico Brasileiro. São Paulo: Malheiros, 2011. p. 163. 
vido licenciamento municipal, comprometendo, seriamente, o planejamento urbano e a oferta de áreas públicas que atendam às necessidades da população.

A Lei de Parcelamento do Solo Urbano de 1979 apresenta um conjunto de normas bastante rigorosas com a finalidade de reprimir os loteamentos irregulares e punir seus promotores. Desse modo, notificado o loteador para cumprir com as obrigações de regularizar a área e não atendido, o Município tem a faculdade de assumir a responsabilidade na execução dos trabalhos, oficializando o loteamento e cumprindo as exigências mínimas frente ao Registro de Imóveis permitido pelo seu artigo 40, entretanto, a norma não cria um procedimento claro de como essa regularização se viabilizaria ${ }^{15}$.

Essa dificuldade teria sido resolvida com a aprovação da Lei no 11.977/2009 que delineou um procedimento administrativo para regularização fundiária, criando dois ritos, o primeiro para a regularização de interesse social e o segundo para regularização de interesse específico. O procedimento adotado por esse diploma legal instituiu que o Cartório de Registro de Imóveis seria responsável pelo andamento dos processos, contudo, mostrou-se inviável.

A nova lei de regularização fundiária (Lei no 13.465 aprovada em 11 de julho de 2017) trouxe uma nova formatação para o procedimento administrativo, atribuindo ao Poder Público Municipal a responsabilidade nos atos administrativos e na condução do processo de regularização fundiária urbana, chamado de REURB. O artigo 15 passou a englobar, também, a possibilidade de regularização do parcelamento do solo contido no mencionado artigo 40 Lei de Parcelamento do Solo Urbano, em que se conclui que esse procedimento, também, poderá ser aplicado nos casos em que se pretende apenas a regularização do loteamento sem a necessidade de transferência da propriedade dos lotes.

Na prática, o maior desafio é realizar o trabalho técnico no âmbito municipal que compreende os levantamentos necessários, a execução dos projetos e quando for o caso, a aprovação de lei específica com os índices urbanísticos exclusivos para cada área a ser regularizada.

Quando se trata de loteamentos públicos produzidos pela municipalidade e alienados por meio de contratos habitacionais, a sua regularização perante o Registro de Imóveis se torna, ainda, mais complexa, isso porque a legislação inerente a regularização fundiária se mostrava até então, inaplicável.

Ocorre que o princípio basilar da regularização fundiária é a transformação da posse em propriedade e no caso de loteamentos públicos, em que o Poder Público Municipal subsidia os lotes de interesse social para aqueles que cumpram os requisitos para serem beneficiados por meio de um contrato de financiamento habitacional, essa transferência estaria condicionada ao seu pagamento total, o que torna inviável a aplicação de um instrumento que transfira imediatamente a propriedade mesmo sem a quitação do contrato.

A solução surgiu baseada na permissão legal de que os processos de regularização possam ser implementados em etapas, iniciando-se pela regularização urbanística e ambiental, com a aprovação e registro do parcelamento de solo, na sequência a regularização jurídica e execução de obras de infraestrutura, e, por fim, a regularização da posse com a transferência dos lotes aos beneficiados que cumpriram sua obrigação de pagar, integralmente, o financiamento habitacional, culminando na regularização fundiária plena ou propriamente dita.

Diante dessa nova tese, vislumbrou-se a possibilidade de o próprio Poder Público Municipal regularizar suas áreas, ou seja, os loteamentos públicos implantados, ocupados e sem registro, e, portanto, decidiu-se criar um programa que pudesse delinear a forma com que este trabalho seria executado, tendo surgido então o Programa de Regularização Bairro Legal.

O Programa de Regularização Bairro Legal foi instituído pela lei Municipal no 6.984 de $1^{\circ}$ de março de

15 RIZZARDO, Arnaldo. Promessa de Compra e Venda e Parcelamento do Solo Urbano: Lei n. 6.766/79. 2. ed. São Paulo: Ed. Revistas dos Tribunais, 1983. p. 157. 
2017 com o objetivo de detalhar as ações jurídicas, urbanísticas, ambientais e sociais relacionadas à regularização e urbanização das Áreas de Interesse Social de propriedade do Município de Chapecó. A proposta é realizar um mutirão pela legalidade, pretendendo dar agilidade e prioridade aos projetos de regularização das áreas públicas previamente identificadas.

A regularização dos loteamentos públicos por meio do Bairro Legal anuncia ações voltadas não apenas a regularização jurídica, que visa à entrega dos títulos de propriedade aos moradores, mas, também, quer propiciar a urbanização das áreas com obras de infraestrutura básica, o que beneficiaria não somente os moradores dos loteamentos, mas toda a cidade que ganha uma nova perspectiva urbanística.

O Programa de Regularização Bairro Legal foi aplicado, pela primeira vez, para a regularização de uma área ocupada de forma irregular denominada Vila Betinho.

\section{O Caso Do Loteamento De Interesse Social Vila Betinho}

A Vila Betinho foi ocupada por volta do ano 2000 sobre uma área pública adquirida com o objetivo de oferecer habitação de interesse social para famílias de baixa renda, cadastradas junto à Secretaria Municipal de Habitação e que atendiam aos requisitos para serem beneficiadas.

A área está localizada em um dos bairros mais pobres da cidade, o Bairro São Pedro, acomodando, aproximadamente, cento e quarenta famílias que ocupam os lotes em condomínio. As famílias foram autorizadas a edificar suas residências nos lotes sem ter sido providenciado o devido registro do parcelamento de solo no Cartório de Imóveis.

A maioria dos moradores da Vila Betinho firmaram contrato de financiamento habitacional junto ao Município ${ }^{16}$, que subsidiou a compra dos imóveis e a falta de registro do loteamento impedia que os moradores beneficiados, mesmo estando com seu financiamento pago, pudessem realizar a transferência da titularidade dos lotes. Essa irregularidade, ainda, criou inúmeros problemas, como a falta de endereço oficial, pois as ruas internas do loteamento não sendo oficiais não têm denominação, tampouco as casas possuem numeração predial, o que gera transtornos aos moradores que não têm um endereço para apresentar em cadastros de emprego, comércio, entre outros.

Os moradores, também, se viam impedidos de acessar linhas de crédito para reforma e ampliação das residências, porque na maioria das vezes os bancos financiadores exigem a matrícula imobiliária individualizada como requisito essencial para deferimento de um financiamento.

Diante dessa situação, a área foi escolhida como projeto-piloto do Programa Bairro Legal, tratando-se de uma situação que se repete em, pelo menos, vinte áreas distribuídas pelo município, ocupadas predominantemente por famílias de baixa renda, em que se aplicou a tese da regularização fundiária em etapas e com fundamento no artigo 40 da Lei de Parcelamento de Solo, pois, nos casos dos loteamentos públicos, a municipalidade tem, não só legitimidade, mas o dever de regularizá-los.

Inicialmente, efetuou-se o gravame de Área Especial de Interesse Social (AEIS), abrindo a possibilidade de o parcelamento do solo ser aprovado com índices urbanísticos diferenciados definidos por lei específica. Finalizados os levantamentos necessários aprovou-se a Lei Complementar Municipal no 563 de 17 de dezembro de 2015, autorizando a aprovação do Loteamento de Interesse Social Vila Betinho tornando o projeto apto para o registro.

A questão apresentada neste momento, cerne do presente trabalho, seria qual a forma mais adequada para registrar, somente, a regularização do parcelamento do solo, sem que fosse transferida, imediatamente,

16 Informações fornecidas pela Secretaria Municipal de Habitação, no ano de 2015. 
a propriedade dos lotes àqueles moradores que não tivessem quitado seu financiamento habitacional.

A eleição da via administrativa para o registro do loteamento se deparou com a inexistência de um regramento sobre o procedimento administrativo de regularização de parcelamento do solo, autorizada pelo artigo 40 da Lei de Parcelamento do Solo Urbano.

O fato é que não se tratava de um loteamento novo, bem como não sendo o caso de aplicação da Lei Federal no 11.977/2009 (vigente na época), pois, o objetivo era a regularização do parcelamento de solo e não a regularização fundiária propriamente dita.

Diante da possibilidade de se implementar a regularização fundiária em etapas, optou-se por fazê-lo em duas fases com base artigo 40 da Lei de Parcelamento do Solo: a primeira, com o registro do parcelamento do solo (loteamento) e a consequente a abertura de novas matrículas imobiliárias para cada lote, ainda em nome do Município de Chapecó. A segunda fase, com a titulação dos lotes, dando condições para que os moradores que quitaram seus contratos pudessem transferir seus lotes com a autorização municipal, enquanto aqueles que ainda estivessem pagando o financiamento ou por algum motivo ainda não tivessem firmado o contrato habitacional, também seriam beneficiados posteriormente.

O Loteamento de Interesse Social Vila Betinho teve seu registro efetivado no Cartório de Imóveis em 26 de maio de 2017, e agora os seus moradores receberão assistência jurídica gratuita auxiliando no processo de transferências dos lotes.

A ideia de Regularização Fundiária com foco principal somente na entrega de um título de propriedade se mostrou ultrapassada, pois não se admite mais, apenas, a entrega de uma matrícula imobiliária aos posseiros é preciso melhorar a habitabilidade das áreas ocupadas, e por esse motivo, o investimento em infraestrutura dos loteamentos demonstrou-se absolutamente necessário.

Consolidado o entendimento quanto a sua legitimidade para regularizar parcelamento de solo irregular, o Poder Público Municipal, também, deve garantir à população os requisitos mínimos e indispensáveis à habitação com a infraestrutura e equipamentos urbanos adequados.

O trabalho criado com o Programa de Regularização Bairro Legal, cujo projeto-piloto foi o Loteamento de Interesse Social Vila Betinho, trouxe um sopro de esperança para aos moradores desta área que esperavam por quase duas décadas a regularização do loteamento.

\section{Considerações finais}

O direito às cidades sustentáveis definido pela Constituição Federal e, posteriormente, regulamentado pelo Estatuto da Cidade pretende garantir que todos tenham acesso a um meio urbano dotado de higidez socioambiental, sem a qual não se pode gozar de uma vida saudável e digna. Nesse contexto o papel do Município é fundamental, pois é onde as pessoas mantêm a grande maioria de suas relações.

A demanda de regularização fundiária circula entre questões urbanísticas, sociais, econômicas e ambientais, pretendendo integrar a cidade informal a formal.

Com o caso estudado, verifica-se que a inexistência de mecanismos legais que abarcassem a regularização de loteamentos públicos não foi suficiente para barrar um processo de regularização, que foi levado a cabo com o intuito de garantir aos moradores da área em que se efetuou a intervenção o direito à cidade sustentável.

Com o projeto-piloto do Loteamento de Interesse Social Vila Betinho, criou-se um rito administrativo próprio para regularização de loteamentos públicos mantendo o arcabouço trazido pela Lei de Parcelamento do Solo. 
O estudo de caso apresentou inúmeras contribuições e permitiu avaliar as principais dificuldades encontradas na regularização de loteamentos públicos servindo como fonte para o trabalho em outros municípios que apresentem esse tipo de irregularidade.

Para tanto, devem coexistir ações preventivas efetivadas com a fiscalização ostensiva e aplicação da Lei de Parcelamento do Solo no que concerne às penalidades impostas aos parceladores, que insistem em burlar a lei, e ações curativas como a regularização das áreas passíveis de regularização e a realocação das famílias que ocupam áreas que não passíveis de regularização.

O planejamento urbano e a informação são os instrumentos mais eficazes para que as cidades cumpram sua função socioambiental. É preciso levar a cidade até o cidadão.

\section{REFERÊNCIAS BIBLIOGRÁFICAS}

BENJAMIN, Antônio Herman. Constitucionalização do ambiente e ecologização da constituição brasileira. In: CANOTILHO, José Joaquim Gomes; LEITE, José Rubens Morato (Org.). Direito constitucional ambiental brasileiro. 2. ed. rev. São Paulo: Saraiva, 2008.

BRASIL. Estatuto da cidade: guia para implementação pelos municípios e cidadãos. 2. ed. Brasília: Câmara dos Deputados/Coordenação de Publicações, 2002.

DUGUIT, Leon. Las transformaciones del Derecho Publico y Privado. Buenos Aires: Editorial Heliasta S.R.L., 1975.

FERNANDES, Edesio. O Estatuto da Cidade e a ordem jurídico-urbanística. In: CARVALHO, Celso Santos; ROSSBACH, Anaclaudia (Org.). O Estatuto da Cidade Comentado. São Paulo: Ministério das Cidades/ Aliança das Cidades, 2010.

GARCIAS, Carlos Mello; BERNARDI, Jorge Luiz. As funções sociais da cidade. Direitos Fundamentais \& Democracia, Curitiba, v. 4, jun./dez. 2008. Disponível em: <http://revistaeletronicardfd.unibrasil.com.br/ index.php/rdfd/article/viewFile/48/47>. Acesso em: jun. 2017.

JUNIOR, Saule Junior. A Proteção Jurídica da Moradia nos Assentamentos Irregulares. Porto Alegre: Sergio Antônio Fabris Editos, 2004.

LEFEBVRE, Henri. O direito à cidade. Tradução de: Rubens Eduardo Frias. São Paulo: centauro: 2001.

MARICATO, Ermínia. O estatuto da cidade periférica. In: CARVALHO, Celso Santos; ROSSBACH, Anaclaudia (Org.). O Estatuto da Cidade Comentado. São Paulo: Ministério das Cidades/Aliança das Cidades, 2010.

RIZZARDO, Arnaldo. Promessa de Compra e Venda e Parcelamento do Solo Urbano: Lei n. 6.766/79. 2. ed. São Paulo: Ed. Revistas dos Tribunais, 1983.

SALEME, Edson Ricardo. Parâmetros sobre a função social da cidade. Anais do XIV Congresso Nacional do Conpedi. Disponível em: < http://www.publicadireito.com.br/conpedi/manaus/arquivos/anais/XIVCongresso/141.pdf $>$. Acesso em: maio 2017.

SILVA, José Afonso da. Direito Urbanístico Brasileiro. São Paulo: Malheiros, 2011.

WINTER, Gerd. Desenvolvimento sustentável, OGM e responsabilidade civil na União Europeia. Campinas: Millennium Editora, 2009. 


\section{REVISTA BRASILEIRA DE POLÍTICAS PÚBLICAS BRAZILIAN JOURNAL OF PUBLIC POLICY}

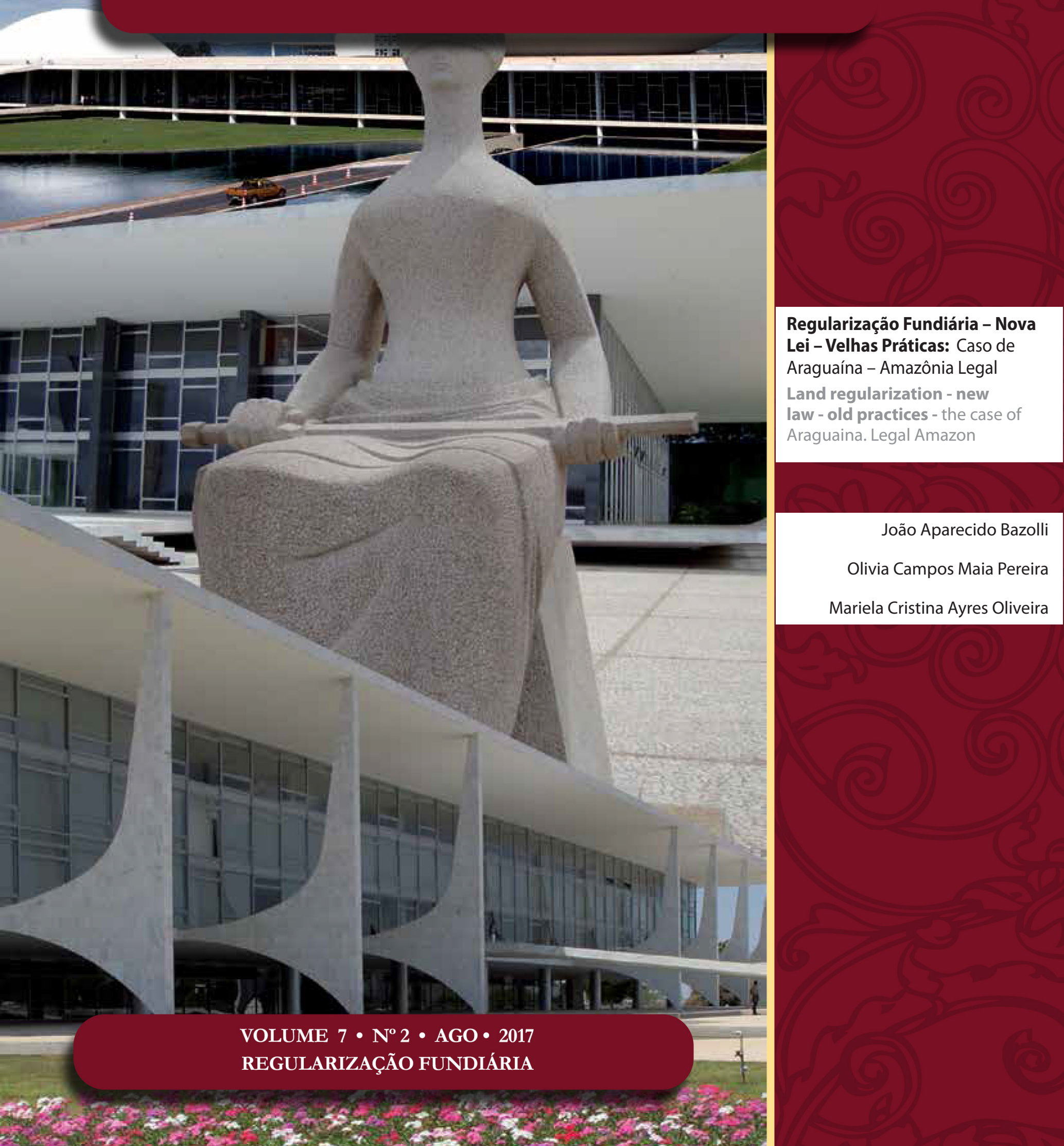




\title{
Regularização Fundiária - Nova Lei - Velhas Práticas: Caso de Araguaína - Amazônia Legal*
}

\author{
Land regularization - new law - old practices - \\ the case of Araguaina. Legal Amazon
}

\author{
João Aparecido Bazolli** \\ Olivia Campos Maia Pereira*** \\ Mariela Cristina Ayres Oliveira****
}

\section{Resumo}

O estudo realizado objetivou, a partir da análise em assentamentos humanos de baixa renda, compreender a segregação periférica e a expansão urbana na cidade de Araguaína-TO. A metodologia de abordagem qualitativa aplicada ao estudo consistiu na análise de documentos sobre os programas habitacionais e os de regularização fundiária, elaborados pelo Poder Público local. Realizou-se pesquisa de campo nos assentamentos humanos de baixa renda definidos pelo estudo. Este trabalho de campo, que consistiu em entrevistas com as lideranças das ocupações estudadas e com os gestores municipais, teve a finalidade de compreender os modos de ocupação irregular na cidade, pela lógica da demanda por moradia e disputa do espaço urbano, entendido como mercadoria pelo setor imobiliário. Concluiu-se haver problema fundiário complexo nesta cidade, o qual vem se dando em razão de a regularização fundiária não ser prioridade para os gestores locais. Identificaram-se, também, ineficiência administrativa da Prefeitura no tratamento desse tema; ausência de medidas concretas para a solução desse problema e a falta de fiscalização para evitar a sua ampliação; descontrole sobre o perímetro urbano da cidade e a constatação da contradição entre a necessidade de regularização fundiária urbana periférica e a urbanização da região central da cidade. Como agravante, destacamos a mudança da legislação federal ocorrida em 11 julho de 2017 (Lei no 13.465), a qual alterou os mecanismos para a regularização fundiária no País, obviamente com reflexos diretos na cidade estudada, tanto pela falta de preparo dos gestores como pela dificuldade de operacionalizar essa nova lei.

Palavras-Chave: Assentamentos Humanos. Regularização Fundiária. Moradia. Amazônia Legal. Município de Araguaína.

*** Prof. ${ }^{a}$ Adjunta do Curso de Arquitetura e Urbanismo da Universidade Federal do Tocantins - UFT - Coordenadora do LabCidades - Laboratório de Cidades/UFT. E-mail: oliviamaia@gmail.com

\section{Abstract}

The objective of this study was, through analysis of low-income human settlements, to understand the peripheral segregation and urban expansion in the city of Araguaína, Tocantins. The qualitative methodology applied to the study was the analysis of documents about the housing programs and land regularization developed by the Local Authorities. Field research 
was undertaken in the low-income settlements defined in the study. This field work, which consisted of interviews with the leaders of the studied occupations and with city managers, aimed to understand the irregular occupation patterns in the city, through the logic of the demand for housing and the dispute for urban space, understood as a commodity by the real estate industry. It is concluded that there is a complex land problem in this city, which has occurred because land regularization is not a priority for local managers. The City Hall's administrative inefficiency in its treatment of this matter was also identified: the absence of concrete measures to solve this problem and the lack of supervision to avoid its growth; the lack of control over the urban perimeter of the city and the contradiction between the need to regularize urban land use and the urbanization of the city. As an aggravating factor, we highlight the change in federal legislation that took place in July 11, 2017 (Law n ${ }^{\circ}$ 13.465), which altered the mechanisms for land regularization in the country - clearly with direct repercussions to the studied city, as much due to the lack of preparation of the managers as to the difficulty of operationalizing the new law.

Keywords: Human Settlements. Land Regularization. Housing. Cool Amazonia. Municipality of Araguaína.

\section{INTRODUÇÃo}

Para entender os problemas atuais que envolvem as questões fundiárias no Brasil, é importante um breve resgate histórico, tendo como ponto de partida a Lei $\mathrm{n}^{\circ}$ 601, de 18 de setembro de 1888, marco legal da normatização da propriedade, promulgada no Império e conhecida como Lei da Terra. Essa Lei garantiu propriedade aos possuidores de título de sesmaria e aos de título de posse mansa e pacífica, fato que fortaleceu e consolidou a propriedade privada no Brasil.

Como resultado da aplicação dessa Lei e de mudanças sociais decorrentes da abolição da escravidão e do movimento migratório e imigratório, chegou às cidades brasileiras, em 1888, um novo perfil populacional constituído por ex-cativos, considerados imenso exército industrial de reserva, descartável e sem força política ; imigrantes europeus e de outras procedências. Esse deslocamento para as cidades provocou aumento da demanda por habitação. Porém, essa população não conseguia arcar com despesas de aluguél. "Aúnica alternativa encontrada eram as moradias coletivas, que recebiam diferentes denominações: cortiço cabeça de porco ou casa de cômodos"1.

Esse crescimento pela demanda de moradias coletivas, criando um ambiente insalubre, levou as autoridades à criminalização, e a destruição dos cortiços. Nesse contexto conturbado, os moradores deslojados do cortiço ‘Cabeça de Porco', no Rio de Janeiro, “se instalaram em 1897 no Morro da Providência, formando uma das primeiras favelas cariocas"”.

Portanto, pode-se constatar que, historicamente, no Brasil há falta de políticas habitacionais e de capacidade do Poder Público, nas três esferas governamentais, para promover o acesso à terra urbanizada "monopolizada conjuntamente pelos proprietários e pelo Estado"’3. Essa condição permite-nos afirmar que a terra urbana vem se tornando mercadoria e instrumento de reserva de valor. Assim, a propriedade não vem cumprindo a sua função social e, dessa maneira, "seguindo os mesmos conceitos da propriedade fundiária do Brasil Colônia"4.

Há, entretanto, de se ressaltar que a tolerância do Poder Público ao avanço das irregularidades urbanas

1 BONDUKI, Nabil Georges. Os pioneiros da habitação social no Brasil. v. 1. São Paulo: Editora Unesp; São Paulo: Edições Sesc, 2014. p. 19.

2 BONDUKI, Nabil Georges. Os pioneiros da habitação social no Brasil. v. 1. São Paulo: Editora Unesp; São Paulo: Edições Sesc, 2014. p. 31.

3 MARTINS, José de Souza. O Cativeiro da Terra. São Paulo: Hurcitec, 1998. p. 147.

4 MORAES, Lúcia Maria. A Segregação Planejada: Goiânia, Brasília e Palmas. Goiânia: Ed. da UCG, 2003. p. 17. 
fomenta as ocupações descontroladas. Para além disso, demonstra que os gestores não têm conseguido exercer competente controle sobre o território, fato que a "flexibilidade com a ocupação ilegal fundiária na prática, mas inflexibilidade formal para a regularização de assentamentos de baixa renda" constantes conflitos de interesses nas cidades brasileiras.

Salienta-se, nesse mesmo viés de análise, que a cidade não é neutra e deve ser vista como força ativa, ferramenta eficaz para gerar emprego e renda e produzir desenvolvimento. O desenvolvimento local é o resultado da mediação dos interesses entre os atores sociais, políticos e econômicos e de suas ações locais ${ }^{6}$.

O papel do território é fundamental para o desenvolvimento local desde que gere identidade e estabeleça as relações de conflitos a serem mediadas ${ }^{7}$. Portanto, o desenvolvimento urbano (crescimento com equidade e sustentabilidade) tem de objetivar o pleno desenvolvimento das funções sociais da propriedade urbana e da cidade. Porém, diante dessa harmonização complexa, não se atinge o equilíbrio desejado, assim a "expansão da cidade se acompanha de uma especulação sobre os terrenos", reafirmando, especialmente, a segregação dos pobres,que são expulsos para a periferia.

O processo de expulsão ocorre a partir de dois momentos, "um primeiro momento do processo especulativo vem com a extensão da cidade". Nesse processo, os trabalhadores contraem dívidas seguindo o raciocínio ditado pelo motivo-especulação; transformam o negócio em aposta financeira, estabelecendo comparativo entre as taxas de juros de mercado e a expectativa do ganho sobre a valorização de sua localização. Noutro momento, são sobressaltados pelo mercado (gentrificação), nos seus círculos periódicos de oscilação, que os empurram para áreas distantes, (re)afirmando a negativa do direito à cidade.

Partindo de análise mais ampla fundada em estudos, tentamos mostrar que os problemas fundiários estão relacionados ao preço da terra e àà especulação imobiliária. Nesse sentido, pode-se afirmar que os "instrumentos de regularização fundiária e de ampliação do acesso à terra urbana podem ser considerados como necessidades comuns a praticamente todos os municípios" ${ }^{\prime 10}$. E, nesse viés, a aplicabilidade dos instrumentos da Lei n ${ }^{\circ}$ 10.257, de 10 de julho de $2001^{11}$, conhecida como Estatuto da Cidade, viabilizaria a utilização mais eficiente do estoque de terras imobilizado pela especulação imobiliária, até mesmo para consolidar uma paisagem construtiva mais satisfatória nas cidades brasileiras.

Salienta-se, então, a importância de observar que o aspecto legal urbanístico está relacionado à segregação informal, pois estudos sobre esse tema revelam que a legalidade urbana provoca a valorização antecipada no mercado de solo, um dos motivos da segregação, razão do lucro e do poder na dinâmica do espaço urbano. Portanto, a gestão de terras pelo Poder Público se torna necessária e essencial para o controle desse mercado.

Encontramos na literatura várias experiências brasileiras e latino-americanas que mostram como alternativa a implementação de programas de desenvolvimento social para assentamentos informais projetados por meio de políticas preventivas. Essas experiências constatam que a urbanização em grande escala poderia ser financiada pela recuperação da mais-valia, resultante dos aumentos nos valores dos imóveis, ocasionada pela valorização da própria urbanização, que seria convertida em impostos ou em contribuição de melhoria.

5 MARICATO, Ermínia. Ministério das Cidades e a politica nacional de desenvolvimento urbano. Políticas sociais: acompanhamento e análise. São Paulo, n. 12, p. 212, fev. 2006. Disponível em: <http://www.ipea.gov.br/sites/000/2/publicacoes/bpsociais/bps_12/ensaio2_ ministerio.pdf>. Acesso em: jul. 2014

6 GUMUCHIAN, H. E.; GRASSET, R.; LAJARGE, Y. E. R. Les acteurs, ces oubliés du territoire. Paris: Anthropos, 2003.

7 AROCENA, J. El desarrollo local: un desafio contemporáneo. Montevideo: Taurus, 2001.

8 SANTOS, Milton. Manual de Geografia Urbana. 3. ed. São Paulo: EDUSP, 2008. p. 206.

9 SANTOS, Milton. Manual de Geografia Urbana. 3. ed. São Paulo: EDUSP, 2008. p. 106.

10 ROLNIK, Raquel; CYMBALISTA, Renato; NAKANO, Kazuo. Solo urbano e habitação de interesse social: a questão fundiária na política habitacional e urbana do país. Revista de Direito da ADVOCEF, Porto Alegre, v. 1, n. 13, p. 143, nov. 2011.

11 BRASIL. Lei 10.257, de 10 de julho de 2001. Disponível em: <http://www.planalto.gov.br/ccivil_03/leis/LEIS_2001/ L10257.htm>. Acesso em: mar. 2017. 
Sabe-se, entretanto, que a regularização fundiária, regra geral, fomenta, também, o mercado imobiliário informal, possibilitando aos beneficiários dos programas implantados usar o capital realizado, resultado da venda do imóvel, para a sua sobrevivência ou para outras finalidades pessoais. Esse fenômeno é constatável em toda a América Latina, pois não há controle do Estado, da situação das localidades pós-regularização. Dessa maneira, caberia à municipalidade criar mecanismos para assegurar a permanência das famílias nos locais regularizados (por exemplo, com a oferta de emprego e renda) e a manutenção de uma fiscalização rígida, para dificultar a transferência dos imóveis, condições não constatadas nas práxis da execução dos programas de regularização fundiária urbana.

Verifica-se, pois, que, nessa linha de raciocínio, haveria a possibilidade de promover o acesso à terra urbanizada a um preço competitivo, se comparado ao preço praticado pelos loteadores clandestinos e irregulares, pois vários estudos mostram que eles oferecem terra sem infraestrutura básica, praticam preços como se ela estivesse implantada, ou seja, regra geral, os loteadores antecipam, com base no preço praticado, futura urbanização a ser realizada pelo Poder Público.

Em síntese, a avaliação da terra deveria, sempre, anteceder os planos locais com previsão de urbanização, condição que possibilitaria obter um preço da terra antes da sua conversão em urbana, recurso utilizado por países europeus ${ }^{12}$.

Portanto, é diante desse quadro que justificamos a realização deste estudo, que aborda a expansão da cidade e as suas relações com as disputas territoriais para o acesso à terra urbanizada, fator que possibilita compreender a dinâmica das ocupações irregulares e segregadas, observando, também, nesse contexto, o fenômeno da valorização imobiliária antecipada pela agregação do valor especulativo da futura urbanização, causada pelos anúncios de programas de regularização fundiária.

Dessarte, o cenário apontado mostra que a irregularidade fundiária é questão estrutural das cidades, caracterizada por desenvolvimento urbano desordenado. Por isso, necessita-se ampliar ainda mais a dimensão desse "problema", pelo fato de chegar a percentuais que variam em torno de 40 a $70 \%$ do parque imobiliário brasileiro existente.

Convém frisar que as relações cidade/sociedade e vice-versa são marcadas, como mencionado anteriormente, pela herança escravista, pelo clientelismo e pela desigualdade social, não obstante pelo monopólio e inexistência de controle sobre o uso e ocupação do solo. Instigados por esse quadro estrutural, e a partir de estudos que constataram a reprodução acentuada de vários problemas fundiários existentes em todo o território nacional nas cidades médias da Região Norte, além dos específicos da região, recorrentes das altas taxas de crescimento ${ }^{13}$, foi possível analisar por este estudo os problemas urbanos da cidade de Araguaína, no estado de Tocantins.

Tratamos dessa cidade de porte médio, localizada na região da Amazônia Legal, que tem apresentado significativo crescimento urbano, por constituir um polo econômico regional. Porém, esse crescimento desordenado da população resultou num número estimado de sessenta assentamentos irregulares urbanos no Município ${ }^{14}$, fator extremamente preocupante e relevante para este trabalho. Objetivou-se, portanto, com este estudo, compreender as ocupações irregulares pela lógica da demanda e da disputa pelos espaços urbanos na cidade de Araguaína, com enfoque jurídico.

A metodologia de abordagem qualitativa aplicada para o desenvolvimento deste trabalho se constituiu

12 ACIOLY JR. Cláudio. Impactos y evaluación de las politicas de suelo: Informalidad, regularización y derecho de propriedade. In: SMOLKA, Martim O.; MULLAHY, Laura (Org.). Temas críticos en politicas de suelo en América Latina. Cambridge: Lincoln Institute of Land Policy, 2010. p. 409.

13 IBGE. Censo Demográfico 2010: primeiros resultados. Rio de Janeiro, Instituto Brasileiro de Geografia e Estatística, 2010. Disponível em: <http://www.censo2010.ibge.gov.br>. Acesso em: fev. 2017.

14 BRASIL. Secretaria Nacional de Acessibilidade e Programas Urbanos. Carta Consulta: relatório sistematizado. Brasília: Ministério das Cidades, 2016. 
numa ampla revisão de literatura especializada acerca do tema, complementada com trabalho de campo realizado por meio de visita técnica aos assentamentos irregulares em Araguaína, com a finalidade de conhecer a problemática e proceder a entrevistas com os presidentes das associações locais, sendo escolhidos como amostra os setores: Presidente Lula, Ana Maria, Setor Sul, Maracanã e Monte Sinai.

Incorporou-se ao estudo a nova Lei de $\mathrm{n}^{\mathrm{o}} 13.465$, de 11 de julho de $2017^{15}$, que instituiu novo marco legal em matéria de regularização fundiária. Importante, nesse contexto, é salientar que a lesgislação, ao criar o termo "Reurb", conceitua, no art. $9^{\circ}$, que a regularização fundiária urbana é um conjunto de "medidas jurídicas, urbanísticas, ambientais e sociais destinadas à incorporação dos núcleos urbanos informais ao ordenamento territorial urbano e à titulação de seus ocupantes", estabelecendo-se novos objetivos em relação à legislação anterior, elencados no seu art. 10.

Entretanto, mesmo tendo sido mantida a base do sistema anterior, ocorreram mudanças significativas para a aplicação dessa nova legislação, especialmente ao interferir e dar novas atribuições aos municípios, muitas vezes despreparados. Isso reforça as fragilidades apontadas por este trabalho no município de Araguaína para a operacionalização da Regularização Fundiária Urbana. O novo marco legal ao ser aplicado invade a competência municipal, obrigando-o a ajustes nas legislações urbanísticas, como Planos-Diretores e Leis de Uso e Ocupação do Solo.

Com este estudo, foi possível mostrar resultados da ineficiência no tratamento da Regularização Fundiária e concluir a existência, na cidade de Araguaína, de um problema fundiário complexo, descrito em nossa análise de resultados e conclusão, ao final deste artigo.

\section{Araguaína: Modelo De Ocupação (Des)Ordenada}

O estado de Tocantins, localizado na Região Norte do País, foi criado em 5 de outubro, pela Constituição Federal, de 1988, fato que levou Araguaína a integrar o conhecido "Bico do Papagaio", mostrado na (Fig. 1), e a se tornar, naquele momento, a cidade mais importante do Estado, chegou até mesmo a receber o título de Capital Econômica ${ }^{16}$, e nesse contexto progressista a "criação do Estado Novo reforça, sem dúvidas, o fluxo migratório que já demandava às terras goianas" 17 .

E foi nesse rumo desenvolvimentista que os problemas de Araguaína se multiplicaram e evidenciaram as dificuldades do acesso à terra urbanizada e a falta de políticas públicas nos variados setores do desenvolvimento urbano e social. Esses fatores fortaleceram a especulação imobiliária local e continuam a ser os responsáveis pelo crescimento das ocupações irregulares na cidade, em razão de a terra urbana centralizada se tornar inacessível à população de baixa renda.

Essa condição demonstrada reforça a desigualdade socioespacial e a exclusão social, haja vista que a "expansão da cidade acompanha-se de uma especulação sobre os terrenos"18, considerando-se que a razão da "valorização exorbitante do solo, fator que é benéfico apenas aos proprietários das áreas, em detrimento aos interesses públicos e da sociedade" 19 faz com que as ocupações irregulares e os loteamentos irregulares e clandestinos se multipliquem exponencialmente.

15 BRASIL. Lei 13.465, de 11 de julho de 2017. Disponível em: <http://legislacao.planalto.gov.br/legisla/legislacao.nsf/Viw_ Identificacao/lei\%2013.465-2017? OpenDocument>. Acesso em: jul. 2017.

16 ARAGUAÍNA - TO. Prefeitura de Araguaina. Disponível em: <http://www.araguaina.to.gov.br/portal/paginas.php? $\mathrm{p}=$ turismo $>$. Acesso em: mar. 2017.

17 CAMPOS, Itami. Questão Agrária: bases sociais da política goiana (1930-1964). Tese (Doutoramento em Ciências Sociais Humanas) - Universidade de São Paulo, São Paulo, 1985. p. 47.

18 SANTOS, Milton. Manual de Geografia Urbana. 3. ed. São Paulo: EDUSP, 2008. p. 206.

1922 BAZOLLI, J. A. A Dialética da Expansão Urbana de Palmas. Vitruvius, Sao Paulo, v. 12, n. 135, p. 3, out. 2011. Disponível em: <http://www.vitruvius.com.br/revistas/read/minhacidade/12.135/4088>. Acesso em: fev. 2017. 
Figura 1 - Localização de Araguaína

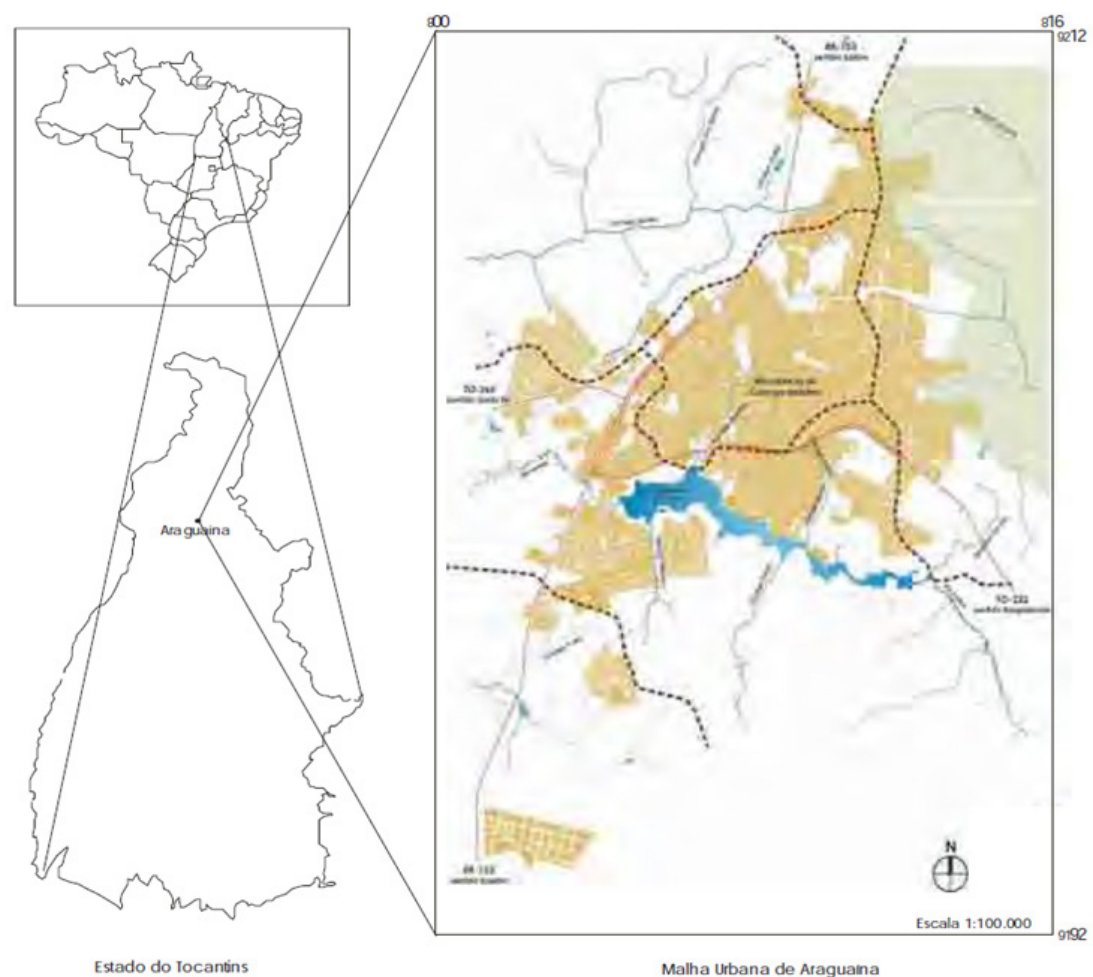

Fonte: Bovolato (2007, p. 19).

Nessa linha de análise, salienta-se que, embora a Região Amazônica seja "uma das fronteiras urbanas que crescem com mais velocidade em todo o mundo", constata-se que " $80 \%$ do crescimento das cidades" dessa Região têm-se dado nas favelas privadas, em sua maior parte de serviços públicos e transporte municipal, tornando-se, assim, sinônimos de 'urbanização' e 'favelização"”20.

Podemos, então, com o estudo, nos certificar de que a cidade de Araguaína se adapta ao contexto regional. Para o estudo, escolhemos e visitamos cinco assentamentos irregulares com a finalidade de conhecer a realidade local no sentido de confrontar os dados coletados com as informações fornecidas pela Prefeitura. As visitas possibilitaram compreender a situação real dos assentamentos, seu contexto histórico, a situação atual do processo de regularização, a forma de ocupação e de urbanização, e a sua situação documental. Os dados foram coletados com os presidentes das associações dos moradores desses assentamentos, os quais nos cederam, para instrumentalizar o estudo, cópias dos documentos existentes.

Cabe salientar que a Prefeitura de Araguaína informou que estaria utilizando os seguintes instrumentos para regularização fundiária: Concessão de Uso Especial para fins de Moradia (CUEM); compra e venda; demarcação urbanística e legitimação de posse; cessão de posse; solução amigável ou litigiosa de conflitos judiciais. Isso para atender, no município, 60 assentamentos irregulares e, aproximadamente, 6 mil famílias carentes.

Desenvolvemos este trabalho caracterizando os assentamentos escolhidos, com a finalidade de destacar seus problemas e de entender as questões legais aplicáveis. Aplicamos a metodologia no sentido de atingir o objetivo proposto pelo estudo, qual seja, o de compreender os problemas fundiários da cidade de Araguaína, conforme estruturado abaixo, por setores, e finalizamos com a análise dos resultados e conclusão.

20 DAVIS, Mike. Planeta Favela. Tradução: Beatriz Medina. São Paulo: Boitempo, 2006. p. 27. 


\section{Os Setores E As Características Das Ocupações Irregulares}

\subsection{Setor Presidente Lula}

Segundo informações oficiais, esse Setor começou a ser ocupado em 2010, com a instalação das primeiras residências ${ }^{21}$. No entanto, constatamos em entrevista realizada com a presidente da associação de moradores, que os primeiros ocupantes chegaram ao local anterior a essa data, a partir de 2008. A entrevistada revelou que a origem fundiária da área ocupada é de propriedade privada (Yoshio Tomihari) e se encontra em demanda judicial em razão de inventário proposto por herdeiros. Portanto, nesse caso, não foram encontradas perspectivas concretas para a resolução do problema, não há garantia da posse, e os moradores se preocupam com a possibilidade de pedido judicial de reintegração desta.

Com a análise dos dados coletados, constatou-se que o processo de ocupação foi conduzido por líderes comunitários que realizaram a abertura de ruas e a divisão dos lotes entre os ocupantes, totalizando 500 lotes, dos quais, 350 foram, imediatamente, ocupados por moradias. Atualmente, vivem nesse local, aproximadamente, 490 famílias.

Esse Setor fica distante do centro da cidade de Araguaína e as principais reclamações dos moradores são: a falta de transporte; iluminação pública; equipamentos e serviços públicos. Os moradores relatam que, após terem reivindicado várias vezes, conseguiram transporte escolar para o local, condição que possibilitou o deslocamento das crianças e jovens com idade escolar para as escolas de ensino fundamental e médio, instaladas nas redondezas.

Interessante salientar que a produção de habitação no local se deu pela prática da autoconstrução, aquela em que "as pessoas constroem suas próprias casas lentamente" ${ }^{22}$. Por essa sistematização, a maioria das casas foi construída em alvenaria; todavia, ainda encontramos casas construídas com materiais improvisados, como tábuas, lonas, palhas e outros.

Embora o assentamento possua água encanada e energia elétrica, identificamos que a coleta de lixo é precária em razão de o veículo coletor não atender a todos os logradouros, ocasionando armazenamento inapropriado, o qual propicia que o lixo não recolhido se espalhe, conforme demonstrado na (Fig. 2), fator que induz a população a queimar ou a enterrar os resíduos produzidos.

21 SILVA, Roberto Antero. Desigualdades socioespaciais em cidades médias: um estudo de Araguaína - TO. Tese. São Paulo: UFU, 2015. p. 23. Disponível em <http://www.cimdepe.com.br/trabalhos-selecionados/>. Acesso em: jan. 2017.

22 ROLNIK, Raquel. Guerra de Lugares: a colonização da terra e da moradia na era das finanças. São Paulo: Boitempo, 2015. p. 144. 
Figura 2 - Falta da coleta de lixo

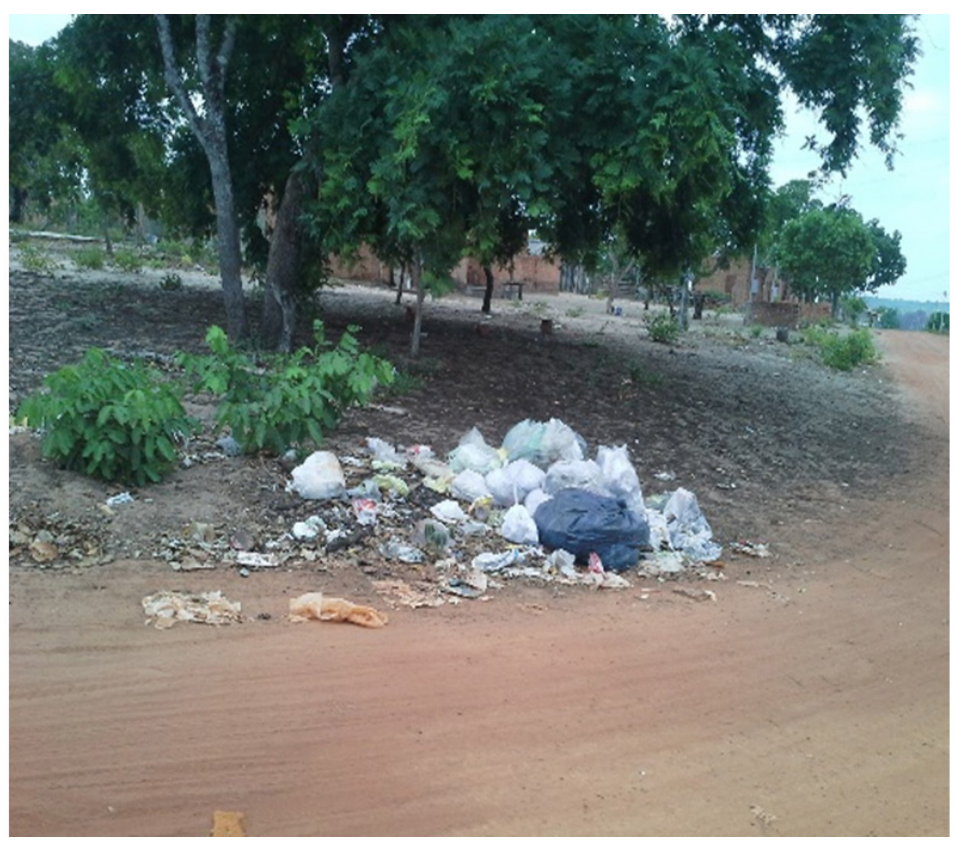

Fonte: Autor, 7 out. 2016.

\subsection{Setor Ana Maria}

Consideramos esse Setor atípico, pois, nos dias atuais, com aproximadamente 110 famílias assentadas, não se encontra totalmente ocupado. Interessante ressaltar que a formação desse assentamento se deu parte em área pública e parte em área privada. O agravante é que a área pública ocupada foi utilizada anteriormente como aterro sanitário, condição que impossibilitaria o uso para a finalidade de moradia, em razão da contaminação do solo e a existência de gases nocivos à saúde.

Diante desse quadro, os moradores contactaram a Prefeitura em inúmeras ocasiões, além de terem promovido protestos, ao longo dos anos da ocupação, com o objetivo de solucionar o problema. Entretanto, não receberam resposta concreta do Poder Púbico, haja vista a impossibilidade de permanência da população nessa área contaminada. Salienta-se que o Poder Público ainda não apresentou alternativas concretas para a resolução do problema, tampouco sinalizou para uma necessária remoção dessa população para outra área disponível, considerando-se ainda o dever de indenizar as pessoas que edificaram suas casas nesse local.

Verificamos que a Secretaria Municipal de Habitação solicitou laudo técnico de avaliação para decidir a situação da ocupação sobre o antigo aterro e constatou que os resíduos depositados no local, sem a proteção técnica (impermeabilização, compactação, drenagem gasosa), oferecem risco aos moradores, tanto pela contaminação do solo como pela existência de bolsões de gases, que poderiam provocar o desabamento de construções, liberando gases que causariam intoxicação, e, no caso do gás metano, a possibilidade de explosão. Portanto, em virtude de essa ocupação estar sobre área de risco, demonstrado na Fig. 3, os ocupantes poderão requisitar providências emergenciais na Prefeitura para resolver esse problema que traz consequências nefastas à saúde e risco de integridade física. 
Figura 3 - Casas construídas sobre antigo lixão

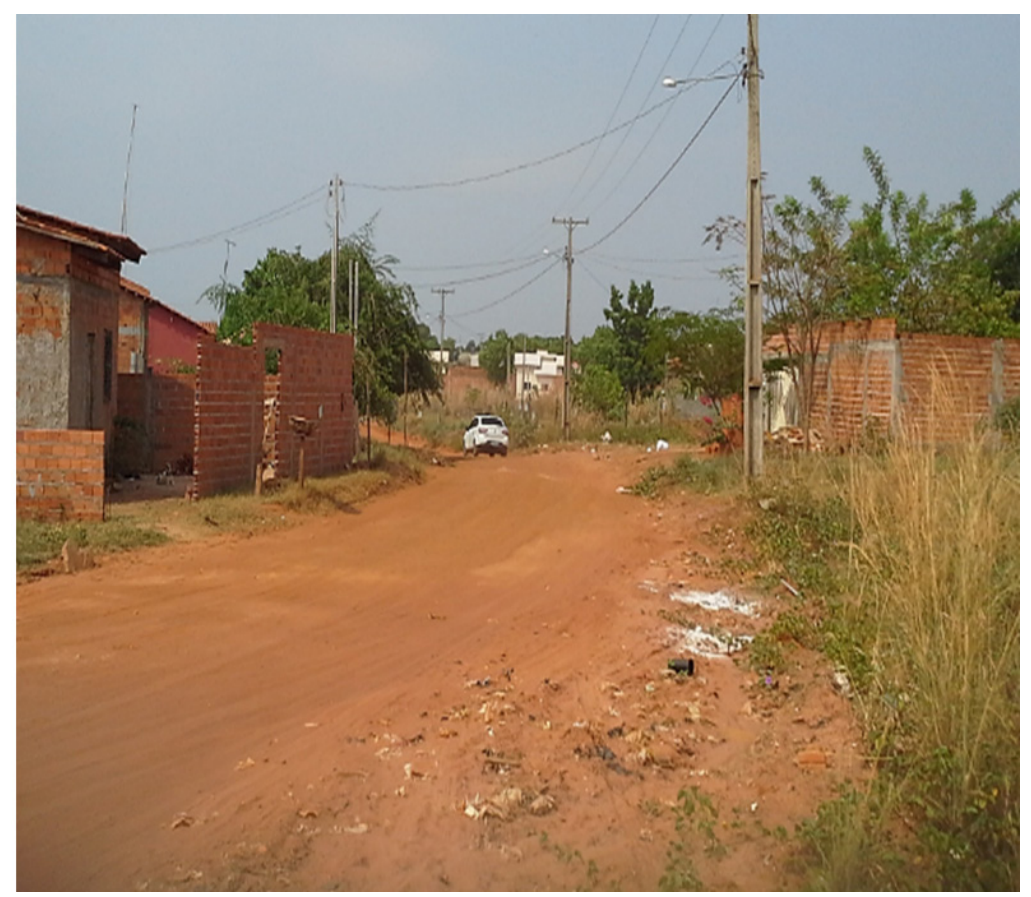

Fonte: Autor, 6 out. 2016.

\subsection{Setor Monte Sinai}

Esse Setor, localizado na Região Sul da cidade, às margens da Rodovia Federal (BR-153), foi resultado da ocupação de moradores em 2006, possui área de 612 mil metros quadrados e abriga, atualmente, aproximadamente 800 famílias. A área é de origem fundiária de propriedade privada. Porém, foi realizada negociação entre o proprietário e a Prefeitura para ser transferida para o Poder Público, como forma de quitar os Impostos Prediais Urbanos (IPTUs) atrasados. Entretanto, isso, ainda, não se efetivou.

Constatamos nesse Setor um histórico de lutas por melhorias e pela regularização do local. Pelas manifestações realizadas na rodovia federal, ao longo da ocupação, os moradores conseguiram a instalação de rede de água, de rede elétrica e a coleta de lixo. A Prefeitura tem manifestado interesse em realizar a regularização fundiária no setor. Em 2009, passou pelo legislativo a Lei Municipal n 2.634, que transformou o assentamento em Zona Especial de Interesse Social (ZEIS).

O crescimento populacional e a valorização imobiliária fizeram com que a ocupação se ampliasse, chamando a atenção dos proprietários das áreas do entorno. Novas áreas estão sendo ocupadas; constata-se, nos últimos dois anos, o acréscimo de 300 lotes. Nesse Setor, também, ocorreu a prática da autoconstrução; encontramos edificações em alvenaria, mas também casas de tábuas, de materiais reciclados da construção civil, além de existirem banheiros externos (latrinas). Observamos que foram edificadas casas sob a rede de alta tensão, mostrada na (Fig. 4), inadequadas em razão de contrariar as normas de segurança. 
Figura 4 - Casa edificada sob rede de alta tensão

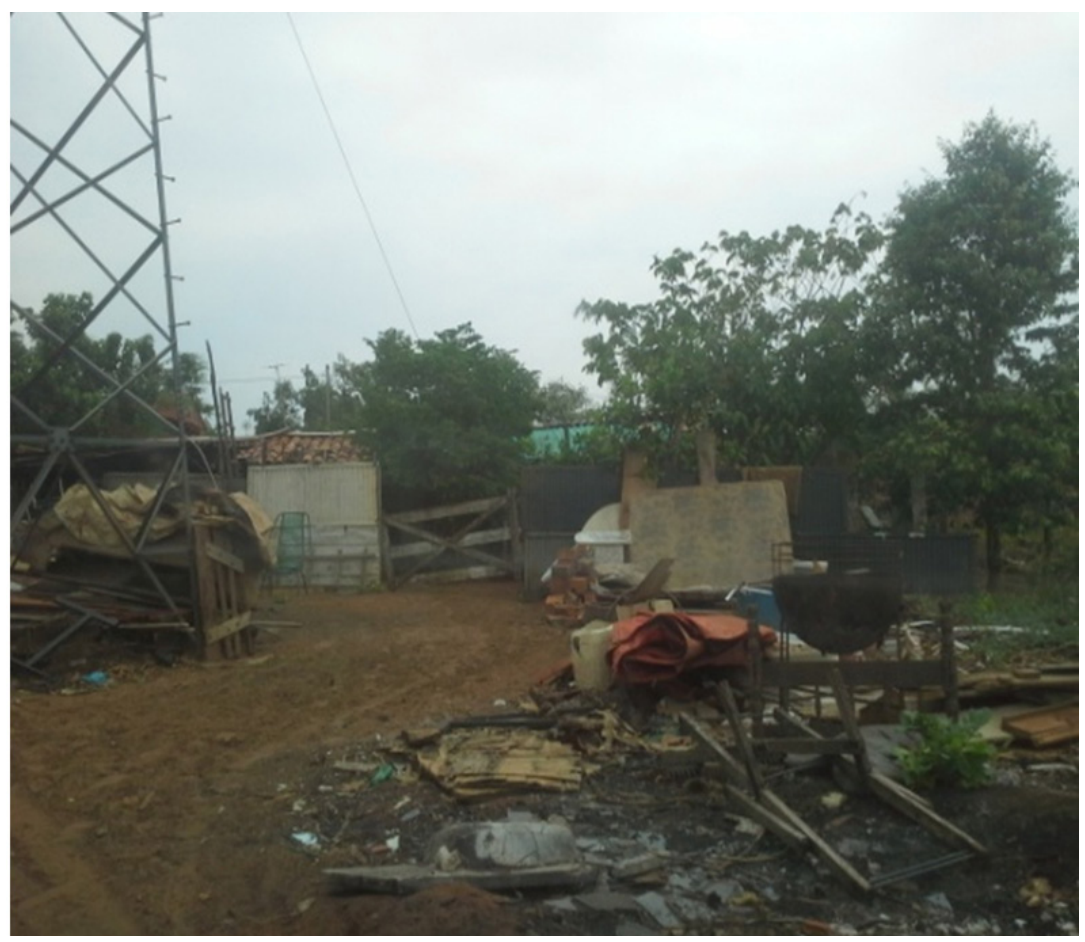

Fonte: Autor, 8 out. 2016.

\subsection{Setor Sul}

Esse Setor foi criado em 2006 por causa da realocação de famílias residentes em outro local, Setor Araguaína Sul II. Nesse mesmo ano, os ocupantes criaram a sua associação representativa, que objetiva, essencialmente, discutir a melhoria urbanística do local e promover a regularização fundiária.

Para dar um caráter igualitário à distribuição dos lotes aos pretendentes cadastrados, a Prefeitura e a associação de moradores realizaram, em 2008, um levantamento dos ocupantes e identificaram 178 famílias que receberam, imediatamente, lotes no local. Todavia, essa quantidade não foi suficiente para atender à demanda, fato que provocou a subdivisão de alguns dos lotes, que foram entregues aos pretendentes remanescentes.

Há de se ressaltar que a organização interna local facilitou à Prefeitura realizar, entre 2009 e 2010, o cadastramento das famílias residentes, que receberam o título de posse dos lotes, aumentando, dessa maneira, a segurança da posse. No entanto, os moradores reclamam da concentração dos documentos legais disponibilizados pela Prefeitura ao presidente da associação de moradores, o qual, de certa maneira, controla a transação de lotes no local.

O Setor passa por alguns problemas estruturais, não possui pavimentação, a iluminação pública é precária, não há coleta de lixo regular, é comum encontrar no local aterros improvisados, mostrado na (Fig. 5). 
Figura 5 - Falta de pavimentação, iluminação pública e coleta de lixo - terreno usado como lixão

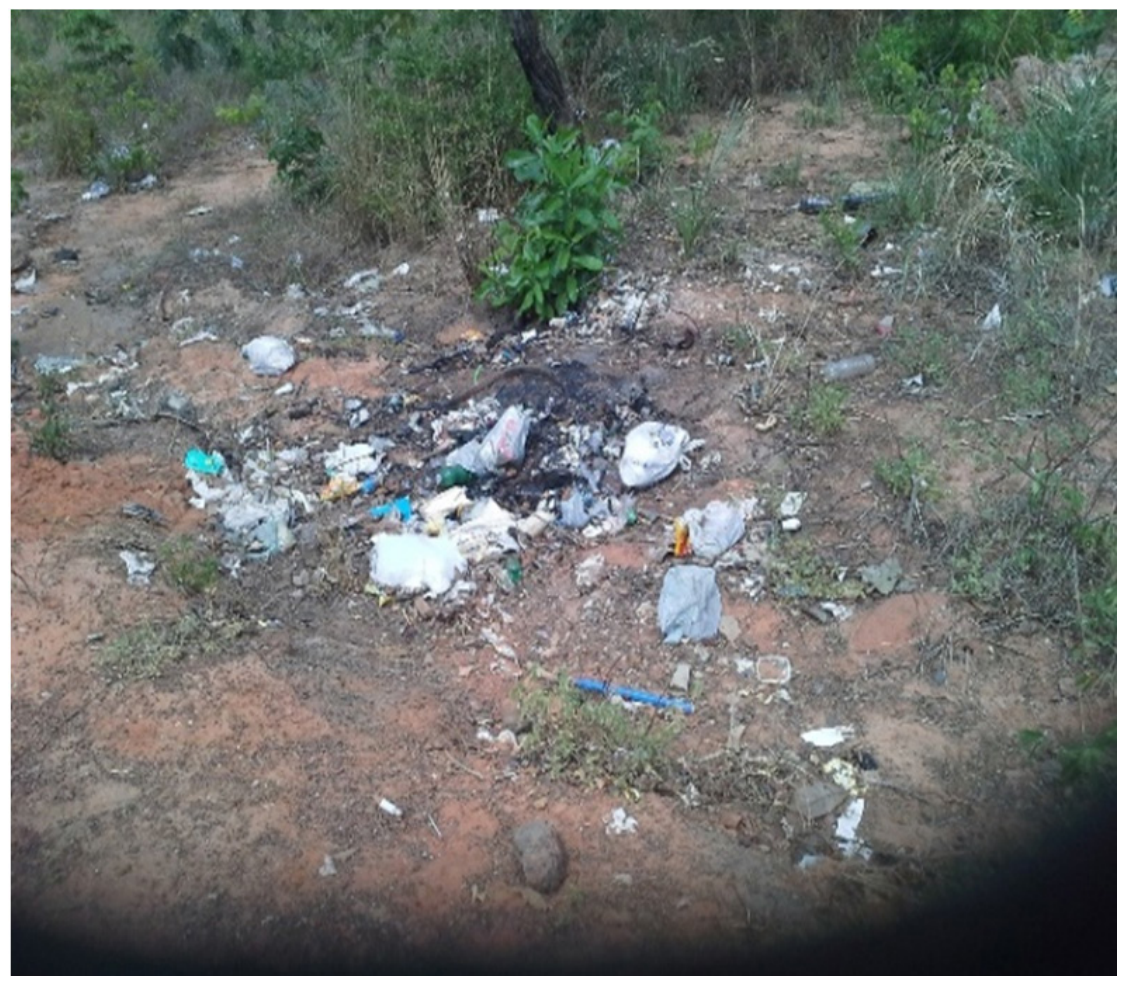

Fonte: Autor, 7 out. 2016.

\subsection{Setor Maracanã}

Esse Setor, situado a nordeste da cidade de Araguaína, próximo aos bairros Vila Couto, Setor Universitário e Setor Barros, faz divisa com o município de Babaçulândia e possui uma área de 150 hectares. Foi implantado, em 1986, a partir da divisão da área em 58 chácaras pela Imobiliária Ferraz. Porém, entre 1999 e 2000, a Imobiliária Maracanã (que originou o nome do Setor) passou a comercializar esses imóveis.

Constata-se a origem clandestina da ocupação, pela transformação, a partir de 2000, em loteamento urbano com a divisão de duas primeiras chácaras próximas às vias de acesso à cidade em lotes menores. Desde então, os lotes foram transacionados com documentos informais de cessão de direitos, sob exigências ao adquirente de edificar e de não negociar o lote vazio, dentro de uma lógica da função social da propriedade e do combate à especulação imobiliária.

Segundo o presidente da associação de moradores, o processo de ocupação local se deu com a emissão de 1.903 cessões de direito. Interessante destacar que estas foram registradas no Cartório de Notas e residem, atualmente, no local cerca de 1.500 famílias.

Destaca-se, entretanto, que as regras contratuais (das cessões de direitos), supostamente impostas, não funcionaram. O Setor possui uma quantidade significativa de terrenos vazios, e vários deles com placas de venda, mostrados na (Fig. 6), convertendo o local "em novas reservas de terras para extração de renda sob a hegemonia do complexo imobiliário-financeiro" ${ }^{23}$. Como os demais, padece de infraestrutura, não tem pavimentação e demais equipamentos públicos.

23 ROLNIK, Raquel. Guerra de Lugares: a colonização da terra e da moradia na era das finanças. São Paulo: Boitempo, 2015 , p. 167. 
Figura 6 - Lote vazio para venda na lógica especulativa

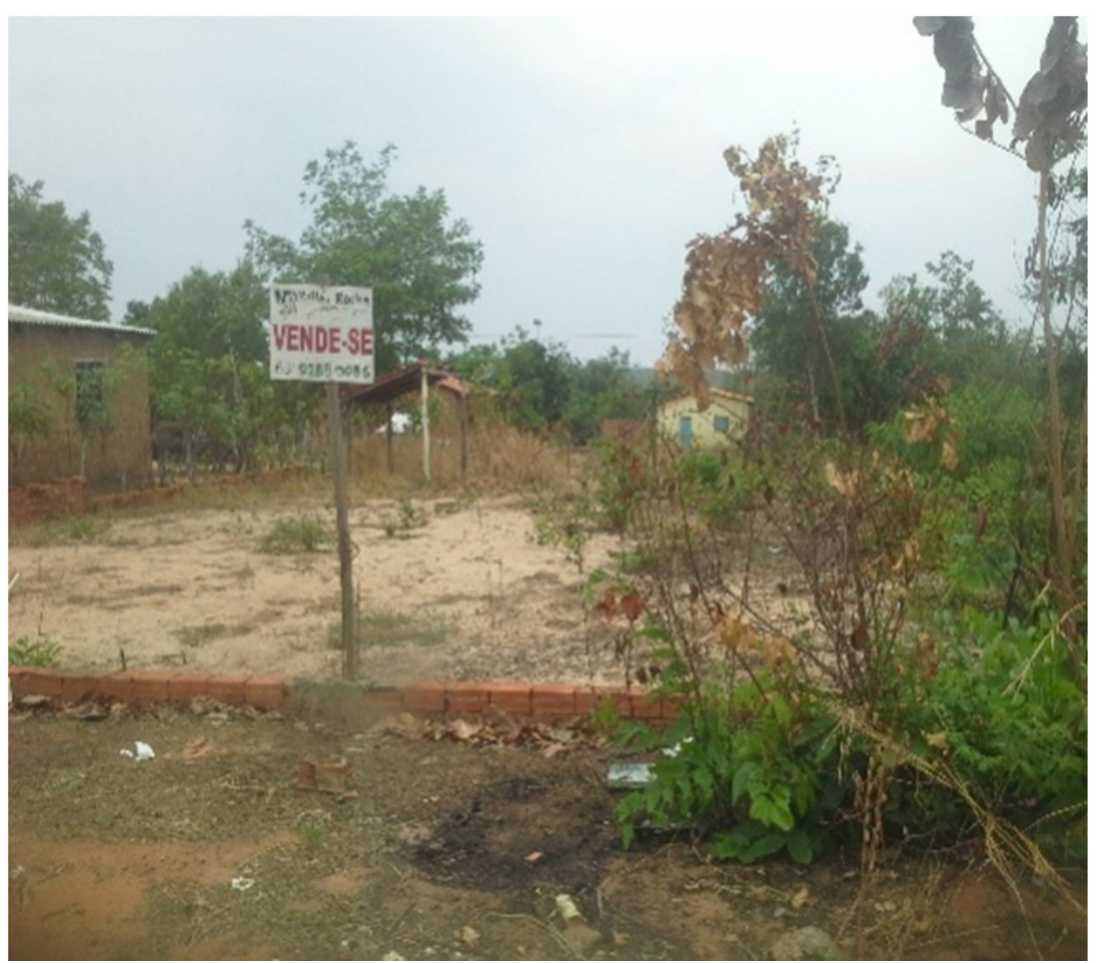

Fonte: Autor, 7 out. 2016.

\section{Análise Dos Resultados}

Os setores estudados apresentaram várias características comuns, como a prática da autoconstrução, os problemas de infraestrutura, a ausência de serviço público, a falta de transporte urbano e outras, cerceando aos moradores o direito à cidade, como se pode perceber nas informações descritas na Tabela 1.

Observa-se que os dados informados na análise dos assentamentos descritos anteriormente foram coletados por trabalho de campo, por meio de entrevistas, visitas técnicas e leitura de documentos entregues pelos moradores.

Tabela 1 - Comparativo entre os setores

\begin{tabular}{|c|c|c|c|c|c|}
\hline $\begin{array}{l}\text { SETORES ANALISADOS } \\
\text { / SERVIÇOS PÚBLICOS }\end{array}$ & $\begin{array}{l}\text { Setor } \\
\text { Presidente Lula }\end{array}$ & $\begin{array}{l}\text { Setor Ana } \\
\text { Maria }\end{array}$ & Setor Sul & $\begin{array}{l}\text { Setor } \\
\text { Maracanã }\end{array}$ & $\begin{array}{l}\text { Setor } \\
\text { Monte Sinai }\end{array}$ \\
\hline Iluminação pública & & & & & \\
\hline Rede de esgoto & & & & & \\
\hline Coleta de lixo & & & & & \\
\hline Transporte público & & & & & \\
\hline Pavimentação asfáltica & & & & & \\
\hline Equipamentos públicos & & & & & \\
\hline
\end{tabular}

\section{Legenda}

Não possui

Possui Parcialmente

Fonte: Elaborado pelo autor. 
Verifica-se que a nova Lei de $n^{\circ}$ 13.465, de 11 de julho de 201724, ao mudar critérios da regularização, do urbanístico para o de propriedade e posse, descontextualiza a integração dos núcleos urbanos à cidade, além de não estabelecer um vínculo imprescindível à Regularização Fundiária, qual seja, a infraestutura básica. Como mostramos na Tabela 1, em Araguaína, os assentamentos estão localizados na periferia da cidade e não dispõem de equipamentos e serviços públicos, tampouco os essenciais. Essa lógica da regularização, voltada para o ponto de vista dominial, sem as melhorias básicas à população das áreas regularizadas, viola os princípios do Direito à Cidade. Esses locais precisam ser urbanizados e passar por um processo de implantação de infraestrutura, pois essa nova sistemática possibilitará aos gestores emitir títulos em escala quantitativa, não priorizando o qualitativo necessário.

Observamos que, na Carta-Consulta, de 2016, o Programa Papel Passado do Ministério das Cidades contemplou o assentamento Araguaína-Sul, com 400 famílias de baixa renda e, aproximadamente, 20 anos de ocupação em loteamento clandestino. Porém, ainda não foram implementadas ações no sentido de regularizar a referida área.

\section{Considerações Finais}

Não se pode excluir deste debate o acesso à terra urbanizada, pois, sem condições de adquirir um imóvel ou pagar aluguel, a única alternativa da população mais pobre é a de ocupar terras ociosas (públicas ou privadas), áreas de risco (encostas de morros, margens de rios), Áreas de Proteção Ambiental (APAs); ou terrenos com restrição absoluta à ocupação (oleodutos e gasodutos; faixa de linhas de alta tensão; faixa de domínio de ferrovias ou rodovia; lixões e áreas contaminadas), dando origem aos aglomerados subnormais, que recebem diferentes denominações; dependendo da região, periferia, favela, barracos, palafitas, invasão, vilas, comunidades etc.

Por esse motivo, a cidade "informal" tem apresentado significativo crescimento, o que exige do Poder Público atenção redobrada. Porém, em razão de não estar preparado para conter o crescimento desordenado, ora por incapacidade técnica, ora por interesse político, omite-se, não realizando a fiscalização necessária ou não enfrentando o problema, criando mecanismos para sua solução.

De maneira geral, atribuímos o problema à falta de legislação que assegure os mecanismos para a resolução dos problemas fundiários. Entretanto, Araguaína possui uma gama de leis que versam sobre o ordenamento da cidade, como: Código de Obras, Lei nº 999, de 1989; Código de Postura, Lei n 1.778, de 1997; Plano-Diretor, Lei n 2.424, de 2005; Lei de Parcelamento do Solo, Lei n 2.494, de 2006; Lei de Uso e Ocupação do Solo, Lei n 2.495, de 2006, entre outras. Porém, apesar de haver legislação, não se notam mudanças significativas, pois "entre a retórica e a prática vai um abismo" 25 .

Durante a realização deste estudo, a cidade de Araguaína se encontrava em processo de Revisão do Plano-Diretor, Lei n ${ }^{\circ}$ 2.424, de 2005, e, na minuta do anteprojeto da Lei Complementar da Revisão, constam a criação de Zonas Especiais de Interesse Social (ZEIS), em parte do Loteamento Maracanã e do Monte Sinai - este último Setor já reconhecido como ZEIS pela Lei n 2.634, de 2009 -, além de que o Poder Público se comprometeu a promover a desocupação e recomposição da área do Setor Ana Maria.

Entende-se, nesse contexto, haver, na Cidade de Araguaína, um problema fundiário complexo em razão do descaso do Poder Público Municipal, pois inexistem mapas atualizados e dados concretos acerca dos assentamentos existentes. Não foram identificadas medidas palpáveis de encaminhamento para a solução desses problemas, além da falta de fiscalização para evitar a sua ampliação, fator provocador da extensão do perímetro urbano na cidade.

24 BRASIL. Lei 13.465, de 11 de julho de 2017. Disponível em: <http://legislacao.planalto.gov.br/legisla/legislacao.nsf/Viw_ Identificacao/lei\%2013.465-2017?OpenDocument>. Acesso em: jul. 2017.

25 MARICATO, Ermínia. O Impasse da política urbana no Brasil. Petrópolis, RJ: Vozes, 2011. p. 189. 
É necessário que o Município elabore estratégias para sanar os problemas administrativos e crie um Plano específico de Regularização Fundiária Sustentável para tentar dar conta dos problemas fundiários existentes.

Como agravante, destacamos a mudança da legislação federal ocorrida em julho de 2017 (Lei no 13.465), a qual alterou os mecanismos para a regularização fundiária no País, obviamente com reflexos diretos em Araguaína, tanto pela falta de preparo dos gestores como pela dificuldade de operacionalizar a regularização fundiária a partir dessa nova lei.

\section{REFERÊNCIAS BIBLIOGRÁFICAS}

ACIOLY JR. Cláudio. Impactos y evaluación de las politicas de suelo: Informalidad, regularización y derecho de propriedade. In: SMOLKA, Martim O.; MULLAHY, Laura (Org.). Temas críticos en políticas de suelo en América Latina. Cambridge: Lincoln Institute of Land Policy, 2010.

ARAGUAÍNA - TO. Prefeitura de Araguaina. Disponível em: < http://www.araguaina.to.gov.br/portal/paginas.php? $\mathrm{p}=$ turismo $>$. Acesso em: mar. 2017.

AROCENA, J. El desarrollo local: un desafio contemporáneo. Montevideo: Taurus, 2001.

BAZOLLI, J. A. A Dialética da Expansão Urbana de Palmas. Vitruvius, Sao Paulo, v. 12, n. 135, out. 2011. Disponível em: <http://www.vitruvius.com.br/revistas/read/minhacidade/12.135/4088>. Acesso em: fev. 2017.

BONDUKI, Nabil Georges. Os pioneiros da habitação social no Brasil. v. 1. São Paulo: Editora Unesp; São Paulo: Edições Sesc, 2014.

BOVOLATO, Luís Eduardo. Uso e gestão de águas subterrâneas em Araguaina/TO. Tese - Universidade Estadual Paulista, Presidente Prudente, 2007.

BRASIL. Lei 10.257, de 10 de julho de 2001. Disponível em: <http://www.planalto.gov.br/ccivil_03/leis/ LEIS_2001/L10257.htm>. Acesso em: mar. 2017.

BRASIL. Lei 13.465, de 11 de julho de 2017. Disponível em: <http://legislacao.planalto.gov.br/legisla/ legislacao.nsf/Viw_Identificacao/lei\%2013.465-2017?OpenDocument>. Acesso em: jul. 2017.

BRASIL. Secretaria Nacional de Acessibilidade e Programas Urbanos. Carta Consulta: relatório sistematizado. Brasília: Ministério das Cidades, 2016.

CAMPOS, Itami. Questão Agrária: bases sociais da política goiana (1930-1964). Tese (Doutoramento em Ciências Sociais Humanas) - Universidade de São Paulo, São Paulo, 1985.

DAVIS, Mike. Planeta Favela. Tradução: Beatriz Medina. São Paulo: Boitempo, 2006.

GUMUCHIAN, H. E.; GRASSET, R.; LAJARGE, Y. E. R. Les acteurs, ces oubliés du territoire. Paris: Anthropos, 2003.

IBGE. Censo Demográfico 2010: primeiros resultados. Rio de Janeiro, Instituto Brasileiro de Geografia e Estatística, 2010. Disponível em: <http://www.censo2010.ibge.gov.br>. Acesso em: fev. 2017.

MARICATO, Ermínia. Ministério das Cidades e a politica nacional de desenvolvimento urbano. Políticas sociais: acompanhamento e análise. São Paulo, n. 12, p. 211-220, fev. 2006. Disponível em: < http://www.ipea.gov.br/ sites/000/2/publicacoes/bpsociais/bps_12/ensaio2_ministerio.pdf>. Acesso em: jul. 2014.

MARICATO, Ermínia. O Impasse da politica urbana no Brasil. Petrópolis, RJ: Vozes, 2011.

MARTINS, José de Souza. O Cativeiro da Terra. São Paulo: Hurcitec, 1998. 
MORAES, Lúcia Maria. A Segregação Planejada: Goiânia, Brasília e Palmas. Goiânia: Ed. da UCG, 2003.

ROLNIK, Raquel. Guerra de Lugares: a colonização da terra e da moradia na era das finanças. São Paulo: Boitempo, 2015.

ROLNIK, Raquel; CYMBALISTA, Renato; NAKANO, Kazuo. Solo urbano e habitação de interesse social: a questão fundiária na política habitacional e urbana do país. Revista de Direito da ADVOCEF, Porto Alegre, v. 1, n. 13, p. 123-158, nov. 2011.

SANTOS, Milton. A Urbanização Brasileira. 5. ed. São Paulo: EDUSP, 2005.

SANTOS, Milton. Manual de Geografia Urbana. 3. ed. São Paulo: EDUSP, 2008.

SILVA, Roberto Antero. Desigualdades socioespaciais em cidades médias: um estudo de Araguaína - TO. Tese. São Paulo: UFU, 2015. Disponível em <http://www.cimdepe.com.br/trabalhos-selecionados/>. Acesso em: jan. 2017. 


\section{REVISTA BRASILEIRA DE POLÍTICAS PÚBLICAS BRAZILIAN JOURNAL OF PUBLIC POLICY}
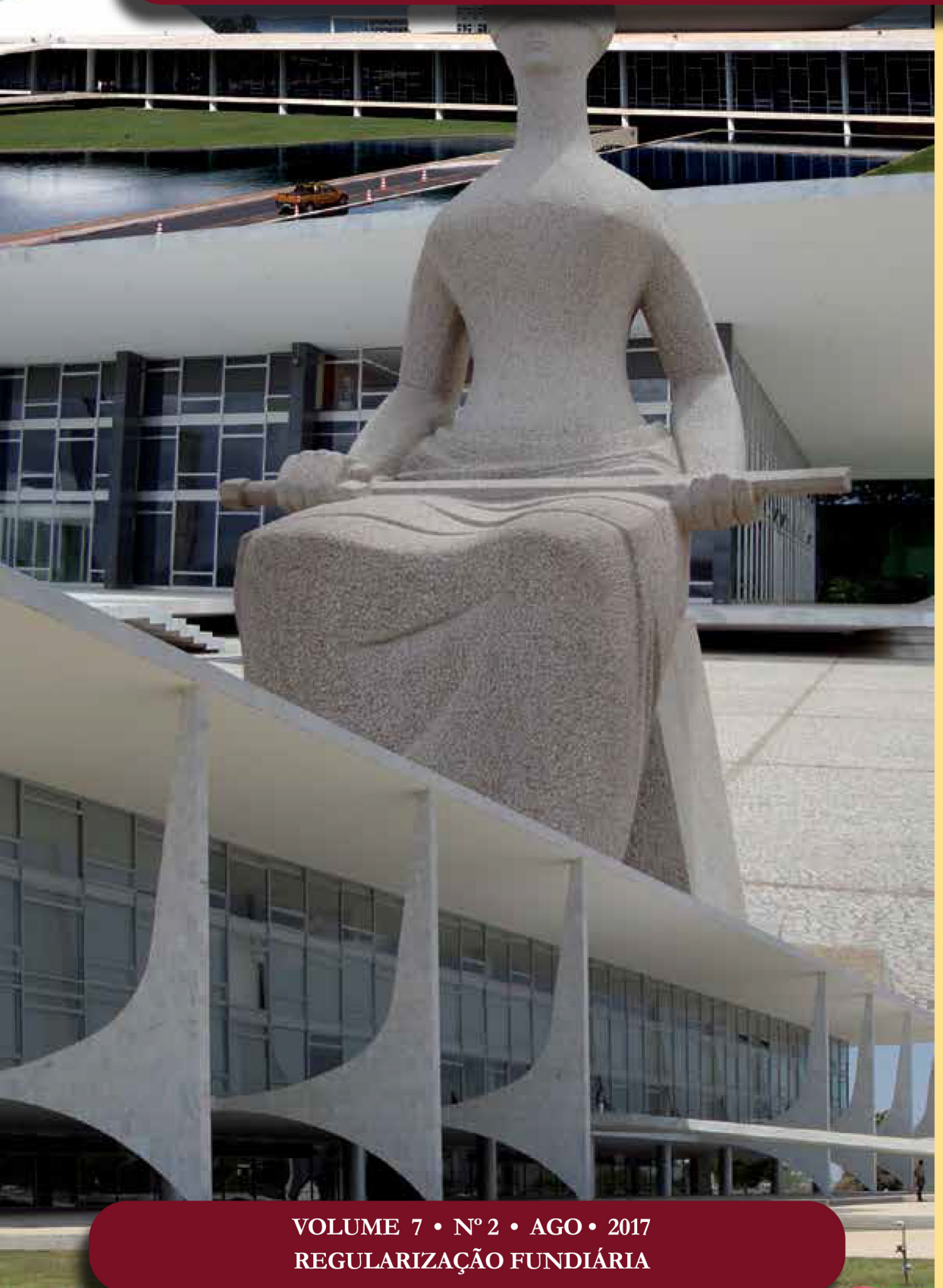

Regularização fundiária de comunidades quilombolas em Mato Grosso do Sul/Brasil

Fundiary regularization of quilombolas communities in Mato Grosso do Sul/Brazil

Antonio Hilario Aguilera Urquiza Lourival dos Santos 


\title{
Regularização fundiária de comunidades quilombolas em Mato Grosso do Sul/Brasil**
}

\section{Fundiary regularization of quilombolas communities in Mato Grosso do Sul/Brazil}

\author{
Antonio Hilario Aguilera Urquiza** \\ Lourival dos Santos***
}

\section{Resumo}

Este texto tem por objetivo apresentar a política de regularização fundiária em algumas comunidades quilombolas, com base nos resultados do projeto de pesquisa "Políticas Públicas em Comunidades Quilombolas de Mato Grosso Sul", realizado com a proposta de fazer diagnóstico acerca da regularização dos territórios tradicionais. Em termos metodológicos, a partir da situação fundiária, foram escolhidas seis comunidades em fase de titulação de seus territórios, com as quais foi realizado trabalho de campo (entrevistas e rodas de conversa com lideranças), além do levantamento bibliográfico e a análise documental, especialmente a partir dos dados dos processos administrativos do INCRA. Analisamos, assim, as políticas públicas incidentes nessas comunidades nos últimos 10 anos e, em particular, a situação atual dos processos de reconhecimento, delimitação, titulação e demarcação das terras ocupadas por remanescente de quilombos. De acordo com os dados, chegamos a alguns resultados: há, na atualidade, aproximadamente, 30 comunidades quilombolas em MS, quase todas identificadas e formalizadas pela Fundação Cultural Palmares e, dentre estas, $18 \mathrm{com}$ procedimento administrativo instaurado no INCRA. Concluímos que garantir o direito à titulação das terras é devolver às comunidades a possibilidade da permanência definitiva em seus territórios, o que acarretará uma maior autonomia e conscientização de seus direitos. As principais limitações da pesquisa foram a ausência de dados oficiais em órgãos municipais e estaduais relacionados a essas comunidades, além da limitação em atualizar todos os dados. Trata-se de trabalho inédito, fruto de pesquisa acadêmica, com vistas a avaliar e subsidiar políticas públicas.

Palavras-chave: Comunidades quilombolas. Território. Políticas públicas. Regularização fundiária.

* Recebido em 30/07/2017 Aprovado em 24/08/2017

** Professor de Antropologia no curso de Ciências Sociais. FACH (Faculdade de Ciências Humanas). Professor da Pós-graduação em Antropologia e da Pós-graduação em Direito da UFMS. E-mail: hilarioaguilera@gmail.com

*** Possui Bacharelado e Licenciatura plena em Historia (1991), Mestrado em História Social (2000) e Doutorado em História Social (2005), todos pela Universidade de São Paulo (USP). E-mail: lourivaldosantos@uol.com.br

\section{Abstract}

This text aims to present the land regularization policy in some quilombola communities, based on the results of the research project "Public Policies in quilombola communities of Mato Grosso do Sul", with the proposal to make a diagnosis about the regularization of the traditional territories. In methodological terms, from the land situation, six communities were chosen in process legalization of their territories, with which fieldwork was carried 
out (interview and discussions with leaders), as well as a bibliographical survey and documentary analysis, especially based on data from INCRA's administrative processes. We analyzed public policies in these communities in the last 10 years and, in particular, the current situation of the processes of recognition, delimitation, titling and demarcation of lands occupied by remaining quilombos. From the data, we have reached some results: there are currently approximately 30 quilombola communities in MS, almost all of them identified and formalized by the Palmares Cultural Foundation, and among these, 18 with an administrative procedure instituted at INCRA. We conclude that guaranteeing the right to land titling is to give the communities the possibility of permanence in their territories, which will lead to them more autonomy and awareness of their rights. The main limitations of the research were the lack of official data in municipal and state bodies related to these communities, besides the limitation in updating all the data. It is an unpublished work, result of academic research, with proposal to evaluate and subside public policies.

Keywords: Quilombolas communities. Territory. Public policy. Land regularization.

\section{INTRODUÇÃo}

O presente texto é fruto da experiência dos autores em atividades e pesquisas desenvolvidas há vários anos com comunidades quilombolas e entre os povos indígenas, assim como orientações (PIBIC, mestrado e doutorado) e perícias antropológicas solicitadas pela Justiça Federal. No entanto, a última pesquisa, que gerou boa parte das informações desse artigo, tem como tema: Políticas Públicas em Comunidades Quilombolas de Mato Grosso Sul: diagnóstico de execução e levantamento das demandas, cuja interdisciplinaridade teve como propósito pesquisar as facetas das políticas públicas que incidiram, e incidem, nas comunidades tradicionais quilombolas do Estado, com enfoque na reivindicação para a regularização de seus territórios tradicionais, assim como pelo reconhecimento de suas estratégias comunitárias, desenvolvidas como meios de sobrevivência frente a um Estado monista calcado na ideologia liberal colonial.

Especialmente nas últimas décadas, os conflitos fundiários, envolvendo povos indígenas e quilombolas no Brasil, têm ocupado as primeiras páginas da imprensa e lugar de destaque nos debates acalorados no Congresso Nacional, particularmente com tentativas da bancada ruralista de retroceder conquistas garantidas no ordenamento jurídico brasileiro, em especial o que se refere à Constituição Federal de 1988 e ao ordenamento jurídico internacional, como a Convenção 169 da OIT ${ }^{1}$ e a Declaração da ONU sobre os povos indígenas ${ }^{2}$. Esses três documentos dizem respeito, em síntese, a um novo olhar sobre a diversidade humana, a qual não pode continuar sendo tratada, em termos de políticas públicas, simplesmente, com políticas homogeneizantes. Assim, cada um, à sua maneira, reconhece a diversidade linguística e cultural dos povos tradicionais (em especial indígenas e quilombolas), assim como os direitos a seus territoriais tradicionais.

Em meio a esse contexto, encontramos a situação das comunidades quilombolas no Estado de Mato Grosso do Sul, historicamente marcadas pela invisibilidade, e expropriadas de boa parte de seus territórios de uso tradicional. Constatamos que são raras as pesquisas envolvendo essas comunidades, muitas vezes, tratando da educação ou saúde (com destaque para a anemia falciforme), as quais denunciam a ausência de políticas públicas específicas nessas áreas, pois estas não conseguem implementar ações específicas, seja no caso da educação (o modelo proposto é o da educação do campo e não com as especificidades culturais da educação quilombola), ou mesmo no caso da saúde.

Há outro aspecto importante a ser analisado, quando falamos em gestão de políticas públicas, que é acerca de sua efetividade, ou histórica deficiência em sua efetivação. Nesse sentido, Amorim³ afirma que

1 ORGANIZAÇÃO INTERNACIONAL DO TRABALHO. Convenção OIT sobre Povos Indígenas e Tribais em países independentes $n^{\circ} 169 ; 1989$.

2 ORGANIZAÇÃO DAS NAÇÕES UNIDAS. Declaração sobre Direitos dos Povos Indígenas, 2007.

3 AMORIM, Ricardo L. Chagas. A construção de novas políticas sociais: o caso de Mato Grosso do Sul. Revista Brasileira de Politicas 
O Brasil, ao longo do século passado, construiu um padrão de políticas públicas marcado pela setorialização e departamentalização da intervenção governamental, especialmente na área social. Seus resultados eram conhecidos em termos da baixa eficácia e, sobretudo, da dificuldade de romper com o ciclo estrutural da pobreza.

Nesse sentido, podemos dizer que, a partir da Constituição Federal de 1988, houve uma importante mudança legal e, em especial a partir do ano 2000, houve, também, uma significativa mudança do poder executivo, quanto à proposição e efetivação de novas políticas públicas, sobretudo, com vistas à erradicação da pobreza no país. Nesse contexto de mudanças sociopolíticas, encontram-se, como veremos a seguir, a implantação de ações para a efetivação dos direitos de comunidades quilombolas: direitos referentes às suas especificidades culturais nas áreas de saúde, educação e, especialmente, na posse de seus territórios tradicionais.

Dessa forma, outra proposta desse texto é comentar e analisar, como diz Abraão, "a viabilidade do Poder Público em promover a efetivação e a afirmação da diversidade sociocultural, enquanto traço histórico marcante da sociedade brasileira, por meio da formulação e implementação de políticas públicas”. Ou seja, a partir desse novo ordenamento jurídico representado pela Constituição Federal, toda política pública deverá ter seu recorte étnico-racial, ou como diz a autora, responder à realidade sociocultural.

Nesse cenário, ainda observamos, de forma mais evidente, a insuficiência do Estado em relação ao reconhecimento e efetivação de direitos de grupos vulnerabilizados, identificados como grupos especiais diferenciados, que precisam de atenção na medida de suas diferenças. Apesar do Estado Democrático de Direito em que vivemos prever expressamente em suas bases o caráter multicultural e plural da sociedade brasileira, as reivindicações de grupos diferenciados no Brasil ainda são um problema ${ }^{5}$.

Constatamos, assim, que boa parte dos gestores de políticas públicas desconhecem a história e a realidade das comunidades quilombolas. Como sabemos, durante séculos, especialmente na região nordeste e sul de Minas Gerais, e durante décadas na região de Mato Grosso do Sul (as primeiras famílias quilombolas chegaram nessa região do país, no final do século XIX, oriundas do sul de Goiás, ou Minas Gerais e, em alguns casos, da Bahia), as comunidades negras constituíram processos próprios que propiciaram a construção de significativa rede de relações socioculturais, econômicas e políticas, conforme explicitado na tese de Carlos Alexandre ${ }^{6}$ - "Fiéis descendentes - Redes-irmandades [...]," acerca das comunidades quilombolas de Mato Grosso do Sul. Esse autor explicita que as relações de parentelas e compadrios foram elementos que produziram especificidades/particularidades e que estão nas origens da própria formação dessas comunidades tradicionais. Essas redes, que o autor chama de irmandades, "estão centradas no movimento e na conexão, interligando territorialidades espacialmente descontínuas, porém intensamente conectadas e articuladas entre si"’

Com a Constituição Federal de 1988, em especial por meio do Artigo 68 do Ato das Disposições Constitucionais Transitórias (ADCT), as comunidades quilombolas foram, oficialmente, reconhecidas pelo Estado brasileiro e tiveram a afirmação de seus direitos sobre os territórios tradicionalmente ocupados, sendo mais tarde o INCRA (Instituto Nacional de Colonização e Reforma Agrária) o órgão federal responsável pela operacionalização dessa nova política pública, qual seja, a regularização fundiária dos territórios quilombolas.

Mato Grosso do Sul possui pouco mais de 30 comunidades quilombolas reconhecidas, oficialmente, pela Fundação Cultural Palmares (órgão ligado à SEPPIR - Secretaria especial de Promoção e Igualdade Racial)

Públicas, Brasília, v. 4, n. 1, p. 114-136, 2014. p. 114-115.

4 ABRAÃO, Pauliane Lisboa. Políticas públicas e diversidade sociocultural. Revista Brasileira de Políticas Públicas, Brasília, v. 1, n. 3 , número especial, p. 1-20, dez. 2011. p. 01.

5 ABRAÃO, Pauliane Lisboa. Políticas públicas e diversidade sociocultural. Revista Brasileira de Políticas Públicas, Brasília, v. 1, n. 3, número especial, p. 1-20, dez. 2011. p. 02.

6 SANTOS, Carlos A. B. Plinio dos. Fiéis descendentes - Redes-irmandades na pós-abolição entre as comunidades negras rurais sul-matogrossenses. Brasília: Universidade de Brasília, 2014.

7 SANTOS, Carlos A. B. Plinio dos. Fiéis descendentes - Redes-irmandades na pós-abolição entre as comunidades negras rurais sul-matogrossenses. Brasília: Universidade de Brasília, 2014. p. 08. 
e responsável por essa certificação, em um universo de cerca de 3.900 comunidades quilombolas, espalhadas por todo o país. Em relação a esse número nacional, apenas, aproximadamente duas mil comunidades são registradas, atualmente, nas políticas públicas, por meio do processo de certificação da Fundação Cultural Palmares.

Em 2014 o INCRA/MS disponibilizou, em seu banco de dados, a informação de 18 comunidades em processo de regularização fundiária em Mato Grosso do Sul. Dessas, apenas duas delas já finalizaram tal processo: comunidade quilombola Chácara Buriti, no Município de Campo Grande e a Comunidade quilombola São Miguel, no Município de Maracaju.

Nos últimos 15 anos, o INCRA tem implementado esse processo de regularização fundiária das comunidades quilombolas de Mato Grosso do Sul. No entanto, no último ano, esse tema da regularização fundiária ganhou novos matizes, com a Medida Provisória 759/2016 (regularização fundiária urbana e rural), editada com a finalidade de modernizar a política agrária, a cargo do INCRA.

\section{COMUNIDADES QUILOMBOLAS A REGULARIZAÇÃo FUNDIÁRIA}

Assim, o presente texto reflete o projeto de pesquisa realizado com o objetivo de realizar um diagnóstico acerca das políticas públicas existentes nas comunidades quilombolas de Mato Grosso do Sul nos últimos dez anos. Tomando como referência a situação fundiária, foram escolhidas seis comunidades em fase de titulação de seus territórios: Comunidade Negra de São Miguel (Maracaju), Furnas de Boa Sorte (Corguinho), Furnas do Dionísio (Jaraguari), Desidério Felipe Oliveira (Dourados), Chácara Buriti e Tia Eva (comunidade urbana em Campo Grande).

A metodologia consistiu em levantamento bibliográfico e a análise documental, especialmente a partir dos dados dos processos administrativos do Instituto Nacional de Colonização e Reforma Agrária - INCRA. Outro elemento da metodologia foi a realização do trabalho de campo, com entrevistas e rodas de conversa com lideranças dessas comunidades. A base teórica para compreensão e discussão dos dados foi da antropologia, especialmente a partir de Arruti $^{8}$, e da história regional. Levantamos, assim, as políticas públicas incidentes nessas comunidades, nos últimos 10 anos, e, em particular, a situação atual dos processos de reconhecimento, delimitação, titulação e demarcação das terras ocupadas por remanescente de quilombos.

A partir dos dados levantados, podemos adiantar que a política pública melhor avaliada pelas comunidades quilombolas em mato Grosso do Sul, foi aquela levada a cabo pelo INCRA, ou seja, justamente a que diz respeito à regularização fundiária, que em nossa avaliação, seria a política mais difícil de ser implementada. Constatamos, outrossim, que garantir o direito à titulação das terras quilombolas significa devolver às comunidades a possibilidade da permanência definitiva em seus territórios tradicionais, o que acarretará em uma maior autonomia e conscientização de seus direitos garantidos por lei e a forma como podem reivindicá-los diante de órgãos competentes, transformando a realidade que se apresenta em forma de lei, mas que, em sua maioria, não se concretizam na vida prática e comunitária.

Quanto ao território, a Constituição Federal de 1988 reconhece às comunidades quilombolas o direito de titulação deste. Trata-se, em nossa História, do primeiro momento em que se dá a essas comunidades voz e vez, e de requererem aquilo que lhes é de direito. Passo inicial que acarretou em direitos legais, mas não necessariamente de fato, uma série de políticas públicas que contemplam essas comunidades. Assim vários outros movimentos e ações legais foram surgindo nos últimos anos, relativos aos direitos de manutenção e reprodução da cultura e dos meios de vida dos afro-brasileiros, um exemplo claro é a Lei 10.639/2003 que

8 ARRUTI, J. M. Mocambo. Antropologia e História do processo de formação quilombola. Bauru: Edusc, 2006. p. 370 ARRUTI, J. M. Quilombos. <http://www.ufgd.edu.br/reitoria/neab/downloads/quilombos-2013-jose-mauricio-arruti. 2008. Acesso em: 21 mar. 2013. 
tornou obrigatório o ensino de História da África e Cultura Afro-brasileira no ensino básico, fato garantido por lei, mas que não se apresenta como realidade na maioria das escolas do estado de Mato Grosso do Sul, principalmente aquelas estabelecidas em comunidades quilombolas como previsto pela resolução número 8 , de 20 de novembro de 2012 que definiu diretrizes curriculares nacionais para educação escolar quilombola na educação básica. Dessa forma, por meio do trabalho de campo e levantamento documental, foi realizado um diagnóstico que pretendeu apresentar, no decorrer deste trabalho, a realidade atual da situação de demarcação, titulação e reconhecimento dos territórios quilombolas.

Dentre os acessos às diversas políticas públicas em que as comunidades dos remanescentes de quilombos de Mato Grosso do Sul estão inseridas, o que se tem apresentado com maior expressividade são os processos de regulamentação fundiária realizada pelo Instituto Nacional de Colonização e Reforma Agrária - INCRA, órgão competente para a delimitação e demarcação dessas terras a partir de 2003 (Decreto Federal número 4.887). Um dos elementos básicos para a pesquisa foi o levantamento documental juntamente ao INCRA da atual situação dos processos administrativos quanto à demarcação e titulação das terras dos remanescentes de quilombos no estado do Mato Grosso do Sul.

No estado, estima-se que o número dessas comunidades chegue ao redor de trinta. Vinte e quatro são identificadas e formalizadas, até o presente momento, pela Fundação Cultural Palmares e dentre elas, 18 comunidades possuem procedimento administrativo de regularização fundiária instaurado no INCRA (dados de 2014). O diagnóstico refere-se a atual situação de regularização e titulação de seis dessas comunidades quilombolas apontadas acima.

\section{MAPA DE SITUAÇÕES DAS COMUNIDADES QUILOMBOLAS EM RELAÇÃO AO ESTADO DO MATO GROSSO DO SUL}
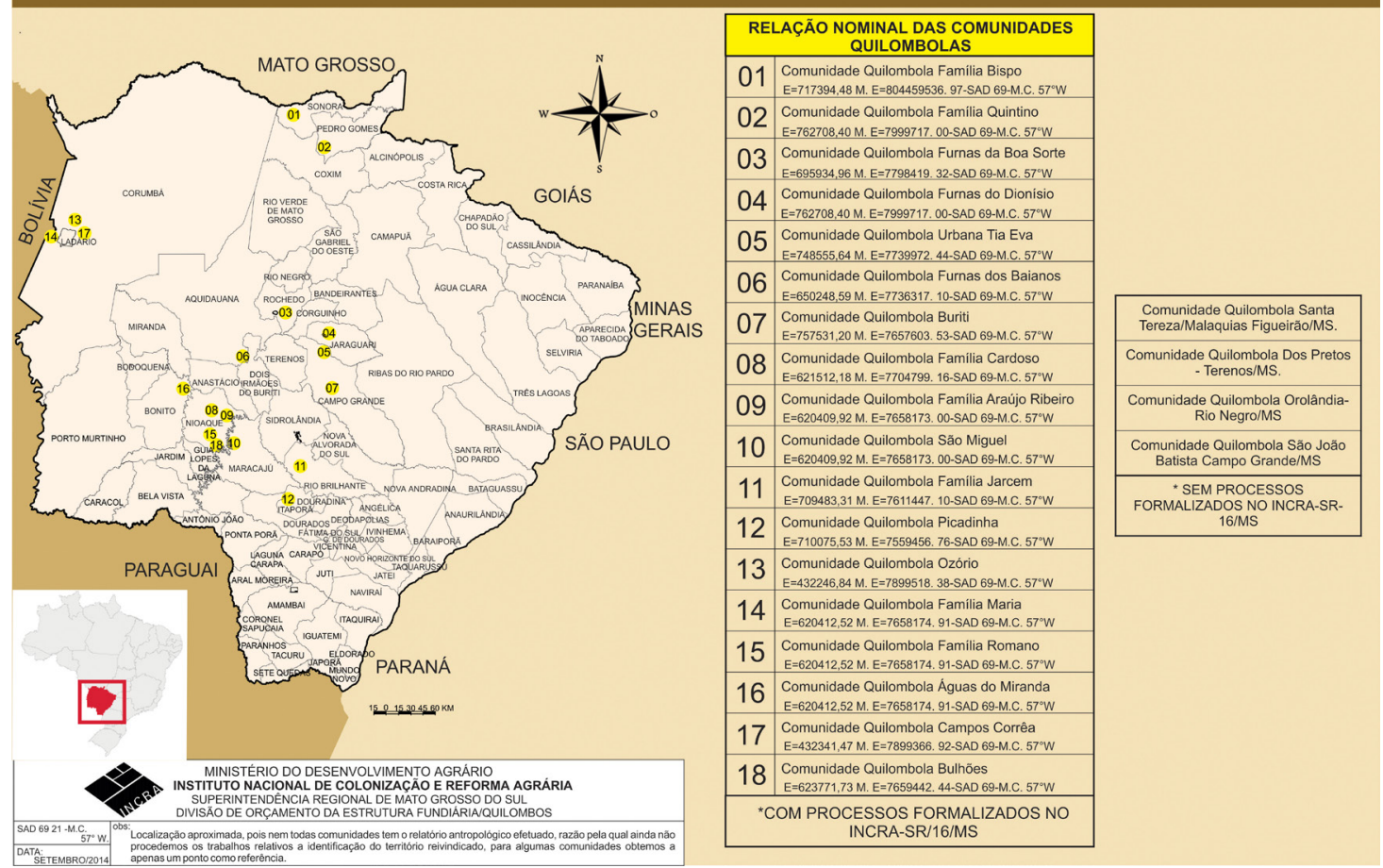

Além do levantamento de dados nos processos administrativos do INCRA, outro fator, de suma importância a ser considerado, foi a realização de trabalho de campo com observação participativa e a produção e aplicação de questionários e entrevistas semiestruturadas com as pessoas da comunidade, bem como aos agentes representantes de órgãos governamentais, trazendo o olhar e os saberes dos quilombolas.

A significância deste trabalho mostra-se no momento em que se entende que a reprodução física e cultural dessas comunidades se dá juntamente à permanência em seus territórios, entendida como garantia legal para as comunidades amparadas por meio do processo de regularização e titulação de seus territórios, sendo 
assim, assegurando tais direitos, possibilitando a continuação e a propagação de suas práticas culturais de forma coletiva.

Outra questão importante deste trabalho é que percebemos que, por meio da conquista da terra, outros direitos vão sendo agregados e conquistados, e esses grupos quilombolas têm se preocupado cada vez mais em cobrá-los: direito à saúde diferenciada e de qualidade; direito à moradia; direito à educação quilombola; dentre outros.

Entendemos que o diálogo entre os pesquisadores e o INCRA se fez fundamental, principalmente quando o órgão se dispôs a discutir e a fornecer informações fundamentais, como levantamento de dados, planilhas, pequeno censo, mapas, contatos e tantos outros elementos que facilitaram o nosso diálogo com as comunidades do estado. Podemos assinalar, também, a presença destes, em algumas idas a campo, o que, de certa maneira, cooperou para o maior diálogo entre as lideranças dessas comunidades e os pesquisadores, servindo como ponte fundamental para o nosso trabalho.

Ainda sobre o trabalho antropológico, os procedimentos metodológicos possuem como elemento básico o que chamamos de trabalho de campo. Nesse sentido, pode-se dizer que a antropologia é privilegiada pelo "estar lá", "ir ver", "conviver", ou seja, é uma ciência social que tem íntima relação com as pessoas e situações sociais.

A partir do que aqui foi dito, podemos sintetizar essas atividades nos seguintes passos: inicialmente foi feito levantamento bibliográfico acerca do tema das comunidades quilombolas no Brasil, nesta região do país; foi de fundamental importância os dados em conjunto com os órgãos federais (INCRA, FUNASA), estaduais (Educação, Moradia e Produção) e municipais (educação), acerca das ações (políticas públicas) implementadas nessas comunidades; finalmente, o mais importante, no trabalho de campo, foram as várias viagens a essas comunidades, por meio das quais se deu a interação, observação participante, entrevistas, rodas de conversa (técnica do grupo focal), dentre outros procedimentos utilizados, com a finalidade de levantar a realidade das políticas públicas nestas comunidades.

Importante destacar a presença de bolsistas de graduação em todos os passos de realização desse projeto de pesquisa, assim como foi fundamental a presença e participação de agentes governamentais, tais como funcionários do INCRA/MS e da Secretaria Estadual de Assistência Social, na época, SETAS. A presença desses profissionais possibilitou a abertura de portas nas comunidades, assim como a discussão constante das próprias políticas efetivadas por esses órgãos governamentais, seus avanços e suas contradições.

\section{COMUNIDADES, TERRITÓRIOS E POLÍTICAS PÚBLICAS}

Como afirmado acima, o objetivo principal deste trabalho foi levantar, entre as seis comunidades quilombolas selecionadas, a situação das políticas públicas existentes no processo de titulação das terras das comunidades quilombolas. Para isso, cabe notar, nas palavras de Arruti', que um dos objetivos dessas comunidades, de forma coletiva, é a conquista de seus territórios. No ensaio "Quilombos", encontramos, segundo o autor, o significado da terra para as comunidades quilombolas. Observe sua descrição:

Eles seriam caracterizados também por alguns traços substantivos, todos relativos à sua territorialidade, como o predomínio do uso comum e a utilização dessas áreas obedecendo à sazonalidade das suas atividades produtivas ou outras, "caracterizando diferentes formas de uso e ocupação do espaço, que tomam por base laços de parentesco e vizinhança, assentados em relações de solidariedade e reciprocidade" ${ }^{\prime 10}$.

9 ARRUTI, J. M. Quilombos. <http://www.ufgd.edu.br/reitoria/neab/downloads/quilombos-2013-jose-mauricio-arruti. 2008. Acesso em: 21 mar. 2013.

10 ARRUTI, J. M. Quilombos. <http://www.ufgd.edu.br/reitoria/neab/downloads/quilombos-2013-jose-mauricio-arruti. 
Dada a importância da terra para as comunidades quilombolas, a situação da titulação territorial é o ponto fundamental desta pesquisa e pretendeu-se, a partir dos dados colhidos nos processos administrativos do INCRA, relatar como está, atualmente, cada caso em particular. Mostrando, se for o caso, motivos da demora de certos processos e conflitos, que por ventura acometem as comunidades e os antigos proprietários das terras.

Cabe apontar, nesse caso, o que o Estado passa a observar de diferente nessas comunidades, conforme o texto de José Mauricio Arruti, sobre políticas públicas para quilombos: terra, saúde e educação. O autor faz uma breve reflexão sobre o ponto de vista do governo, a respeito do trato do Estado com essas comunidades e nos aponta que:

A primeira observação a ser feita, portanto, é relativa à mudança de postura do Estado brasileiro diante da questão quilombola: ela deixa de ser vista como tema exclusivamente cultural, para ser incorporada na larga variedade de políticas de responsabilidade pública ${ }^{11}$.

Fica evidente a mudança de postura do governo sobre essas comunidades tradicionais, e confirma, de certo modo, a importância da terra para esses grupos. Ao estabelecer que a questão quilombola não se limita, apenas, à expressão cultural, o ordenamento jurídico vem reforçar que esses territórios são importantes para a reprodução física e cultural. Nesse aspecto, tomamos o direito de discordar de Assunção ${ }^{12}$, quando, em seu texto "Unidades de conservação, terras indígenas e quilombolas no estado do Amapá: como desenvolver um Estado cujo território está 70\% protegido por leis?", a autora subordina o direito ambiental e, sobretudo, o direito constitucional dos quilombolas e indígenas, por um certo "direito ao desenvolvimento". Assim como preconizado pelo ordenamento jurídico nacional e internacional, essas comunidades tradicionais possuem direitos primevos e inalienáveis, sobre os territórios tradicionais em que vivem (Art. $231 \mathrm{CF}$ e Art. 68 DCT/CF).

Como afirmado anteriormente, somente a partir da Constituição Federal de 1988, os quilombolas começam a superar seu estado de invisibilidade institucional, e por meio dos movimentos negros, passam a ser considerados um grupo distinto e portadores de direitos específicos, com o artigo 68 do ato das Disposições Constitucionais Transitórias da Constituição Federal de 1988. Esse artigo afirma: "aos remanescentes das comunidades dos quilombos que estejam ocupando suas terras é reconhecida a propriedade definitiva, devendo o Estado emitir-lhes os títulos respectivos". Sendo assim, é obrigação do estado garantir a propriedade das terras ocupadas aos "remanescentes de comunidades de quilombos" a partir de sua titulação.

O Decreto no 4887 de 20 de novembro de 2003 apresenta "os procedimentos administrativos para a identificação, o reconhecimento, a delimitação, a titulação e a demarcação da propriedade definitiva das terras ocupadas por remanescentes das comunidades dos quilombos" (Art. $1^{\circ}$ ) e tais funções competem ao Ministério do Desenvolvimento Agrário, por meio do Instituto Nacional de Colonização e Reforma Agrária - INCRA.

Conforme Instrução Normativa n ${ }^{\circ}$ 57, de 20 de outubro de 2009 do INCRA, os passos para todo esse processo de regularização fundiária iniciam-se, primeiramente, com a autodenominação ${ }^{13}$ da comunidade juntamente à Fundação Cultural Palmares, seguido pela elaboração Relatório Técnico de Identificação e Delimitação - RTID, conseguinte da Análise da Situação Fundiária das Áreas Pleiteadas e finalizando com a Demarcação. Importante ressaltar o conceito da autodeterminação, também utilizado pelos últimos censos do IBGE e apoiado, de certo modo, em teorias antropológicas, como a de Fredrik Barth" ${ }^{14}$, na qual, a partir do estudo de "Grupos Étnicos e

2008. Acesso em: 21 mar. 2013. p. 02.

11 ARRUTI, J. M. Quilombos. <http://www.ufgd.edu.br/reitoria/neab/downloads/quilombos-2013-jose-mauricio-arruti. 2008. Acesso em: 21 mar. 2013. p. 79.

12 ASSUNÇÃO, Linara Oeiras. Unidades de conservação, terras indígenas e quilombolas no estado do Amapá: como desenvolver um Estado cujo território está 70\% protegido por leis?. Rev. Bras. Polít. Públicas (Online), Brasília, v. 6, n. 3, p. 289-308, 2016.

13 São considerados quilombolas, segundo Decreto n ${ }^{\circ} 4887$ de 20 de novembro de 2003 , Art. $2^{\circ}$ - $₫ 1^{\circ}$, todos os que se autodefine como sendo quilombola e autodefinição será inscrita no Cadastro Geral juntamente à Fundação Cultural Palmares, que expedirá certidão respectiva na forma do regulamento $\left(\mathbb{\$} 4^{\circ}\right)$.

14 BARTH, Fredrik. O Guru, o Iniciador e Outras Variações Antropológicas. Organização de Tomke Lask. Rio de Janeiro: Contra Capa 
suas fronteiras", afirma que a identidade não está, mas é uma construção social e contextualizada.

Cabe salientar que tal processo de autodenominação obedece a uma forma de proceder para a regulamentação da terra quilombola mediante o INCRA. Poderíamos sintetizar os principais passos de regularização fundiária de comunidades quilombolas levada a cabo pelo INCRA (2014), da seguinte forma: inicialmente, antes da abertura do processo no INCRA, deverá haver a reivindicação da comunidade por sua identidade e consequente reconhecimento (certificação) pela Fundação Cultural Palmares.

Todo o processo de regularização fundiária tem início com a abertura do processo no INCRA, para o reconhecimento do território quilombola, sendo o próximo passo o início dos trabalhos para a elaboração do Relatório Técnico de Identificação e Delimitação (RTID), geralmente, coordenado por um antropólogo com alguma experiência na temática. Após a publicação no Diário Oficial da União (DOU) e do estado, segue a análise dos eventuais recursos impetrados e julgamento de eventuais processos.

O próximo passo no processo na regularização fundiária de uma comunidade quilombola é a Portaria que declara os limites do território tradicional, seguida pelo Decreto Presidencial que autoriza a desapropriação e desintrusão do território. Após a desintrusão, vem a fase da titulação e, finalmente, a posse, pela comunidade, do seu território tradicional.

Segundo a Secretaria de Políticas de Promoção da Igualdade Racial (SEPPIR), há no Brasil 1.948 comunidades reconhecidas oficialmente, sendo 1.834 comunidades certificadas pela Fundação Cultural Palmares (FCP) e 1.167 processos abertos para titulação de terras no INCRA. Destas apenas 193 comunidades são tituladas, somando uma área de 988,6 mil hectares ${ }^{15}$.

Em Mato Grosso do Sul, não falamos em demarcação, pois nesse momento não ocorre a colocação de marcos (postes) demarcando uma área, nesse caso, das comunidades quilombolas. Tal fato ainda não ocorreu em nenhuma dessas comunidades. Para tanto, trataremos com a questão da área reivindicada e a titulada ${ }^{16}$. Também relataremos, em cada uma das seis comunidades pesquisadas, as datas correspondentes à autodefinição ${ }^{17}$ juntamente à Fundação cultural Palmares $(\mathrm{FCP})$ e a emissão do Relatório Técnico de Identificação e Delimitação (RTID). Pelo papel fundamental do INCRA perante a regulamentação fundiária das comunidades quilombolas procuramos e contamos com a ajuda e apoio da Superintendência Regional INCRA/MS, especialmente na pessoa do Sr. Marcelo Souza (Analista em Reforma e Desenvolvimento Agrário - Antropólogo), para a coleta das informações relatadas neste trabalho sobre as seis comunidades quilombolas de Mato Grosso do Sul. Tais informações permeiam o restante deste trabalho.

\section{As COMUNIDADES QUILOMBOLAS E A REGULARIZAÇÃo FUNDIÁRIA}

No que diz respeito às comunidades estudadas podemos apontar que todas as seis comunidades acima citadas obedecem a Instrução Normativa no 57 do INCRA, sendo assim, são reconhecidas como comunidades quilombolas juntamente à Fundação Cultural Palmares (Tabela1) e já tiveram seu Relatório Histórico Antropológico realizado (Tabela 2), inclusive a comunidade Tia Eva recentemente finalizada. Para melhor

Livraria, 2000. p. 243

15 SEPPIR. Programa Brasil Quilombola - Diagnóstico de Açoes Realizadas (07/2012). Disponível em: <http://www.seppir.gov.br/ destaques/diagnostico-pbq-agosto>. Acesso em: 20 mar. 2014.

16 A titulação ocorre quando o processo de regularização do território de uma comunidade quilombola chega ao fim e é emitido um Título indivisível, invendável e inalienável em nome da associação que representa a comunidade.

17 Atualmente, essas comunidades passam por identificação, autodefinição e certificação, passos administrativos de responsabilidade da Fundação Cultural Palmares para que lhes sejam atribuídas à legalidade e a posse inalienável de seus territórios. Decorrente a posse está a garantia do acesso aos direitos fundamentais previstos na Constituição Federal. FUNDAÇÃO CULTURAL PALMARES. Comunidades Quilombolas: conceito, autodefinição e direitos. Acessado em 26 de agosto de 2014. Disponível em http://www. palmares.gov.br/2012/04/comunidades-quilombolas-conceito-autodefinicao-e-direitos/ >. Acesso em: 26 ago. 2014. 
compreensão segue abaixo as duas tabelas:

Tabela 1 - Reconhecimento juntamente à Fundação Cultural Palmares ${ }^{1}$ COMUNIDADES

DATA DE AUTORRECONHECIMENTO

Picadinha

São Miguel

Furnas da Boa Sorte

Furnas do Dionísio

Chácara Buriti

Tia Eva
$19 / 04 / 2005$

$19 / 04 / 2005$

$25 / 05 / 2005$

$25 / 05 / 2005$

$19 / 08 / 2005$

$05 / 03 / 2008$

Tabela 2 - Relatório Técnico de Identificação e Delimitação -- RTID ${ }^{2}$

Comunidades

Picadinha

São Miguel

Furnas da Boa Sorte

Furnas do Dionísio

Chácara Buriti

Data

Setembro de 2007

Dezembro de 2007

Julho de 1998

Trabalho de campo em dezem-

bro de 1997

Setembro de 2007

Tia Eva

Finalizada em 2014
Autoria

INCRA

INCRA

Maria de Lourdes Bandeira

Maria de Lourdes Bandeira e Triana de Veneza

Sodré e Dantas

Carlos Alexandre B. Plínio dos Santos

Carlos Alexandre B. Plínio dos Santos

Como o foco desse texto é a apresentação das percepções das comunidades quilombolas estudadas, acerca das políticas públicas, com foco na regularização fundiária, apresentamos a seguir, a situação desses territórios tradicionais e seus respectivos processos de regularização, enumerando cada uma das comunidades participantes da pesquisa, ressaltando que os dados são referentes até o ano de 2014, sendo, portanto, necessário, futuramente, nova atualização desses dados. A primeira comunidade relatada é a "Chácara Buriti”, distante $27 \mathrm{~km}$ de Campo Grande/MS às margens da rodovia BR 163.

\subsection{Comunidade chácara do buriti}

A comunidade recebe o nome de Chácara "Buriti" por estar localizada próxima à baixada de um córrego repleto de palmeiras de buriti (buritizal), e foi criada, por volta do ano de 1920 a 1930. , conta com 32 Famílias que vivem da agricultura de subsistência e produzem hortaliças que as comercializam utilizando o Programa de Aquisição de Alimentos ${ }^{18}$ - PAA da Conab. Muitos adultos, no entanto, trabalham como empregados, em empresas agrícolas ou mesmo na cidade de Campo Grande.

Recebeu o reconhecimento como comunidade quilombola pela Fundação Cultural Palmares no dia 19 de agosto de 2005 e o seu RTID (Relatório de Identificação) é de autoria de Carlos Alexandre B. Plínio dos Santos (UnB), datado de setembro de 2007. Foi constatado que durante o processo de titulação de suas terras não houve conflitos.

A área reivindicada é de 43,0080 ha. Atualmente, a comunidade tem titulação de, apenas, 12,1812 há. Já foi realizado o processo de desapropriação das terras do proprietário e a comunidade quilombola já conseguiu a titulação. No processo de regulamentar o território de uma comunidade quilombola, o próximo passo é emitir um título indivisível, invendável e inalienável em nome da associação que representa a comunidade, que, para Souza ${ }^{19}$, constitui“"uma proteção para o presente e para as gerações futuras de uma comunidade".

Assim, no processo de titulação, foi feita a avaliação da terra, com os títulos atuais, para a devida indeni-

18 Entrevista realizada com Marcelo Souza (Analista em Reforma e Desenvolvimento Agrário - Antropólogo) no dia 19 de Maço de 2013, por Sônia Rocha Lucas (PIBIC).

19 Entrevista realizada com Marcelo Souza (Analista em Reforma e Desenvolvimento Agrário - Antropólogo/ INCRA) no dia 28 de janeiro de 2013, por Sônia Rocha Lucas (PIBIC). 
zação aos moradores quilombolas da comunidade, os quais possuem título dos imóveis e, posteriormente, passar o título para o nome da associação que representa a comunidade, juntamente ao restante do território reivindicado.

Atualmente, a comunidade quilombola da Chácara Buriti, apesar de pequena em termos populacionais, se compara às demais comunidades estudadas, apresenta-se como uma das mais dinâmicas do estado, tanto em termos de valorização das práticas culturais tradicionais como, em relação à valorização da memória dos mais idosos, assim como em relação ao aspecto de produção de hortaliças para o mercado local. Destaca-se, ainda, pela presença forte das mulheres, como líderes dos processos comunitários, tanto na economia doméstica como na própria associação comunitária.

\subsection{Comunidade Quilombola de São Miguel}

A comunidade quilombola Colônia de São Miguel está situada no município de Maracaju/MS, somando 36 famílias que vivem, basicamente, da agricultura de subsistência, do cultivo de hortaliças, da produção de mel e da pecuária. Teve seu reconhecimento como comunidade quilombola pela Fundação Cultural Palmares em 19 de abril de 2005 e o RTID (Relatório de Identificação) foi realizado pelo INCRA em dezembro de 2007.

Ao contrário da comunidade Buriti, supracitada, a comunidade São Miguel apresentou momentos de conflito, no que se refere à ocupação da área tradicional reivindicada, entre a comunidade quilombola e um dos proprietários, este não quilombola, havendo a intervenção do Ministério Público Federal e Polícia Federal.

A área reivindicada pela comunidade é de 420,682 ha. Destes, 87,68 ha são ocupados, atualmente, pela comunidade e 333,0736 ha foram titulados em 08 de setembro de 2011. O que torna o processo fundiário bem adiantado, mas um problema enfrentado é que muitas famílias que possuem a posse dessas terras precisam fazer o inventário, e por não ter sido emitido, ainda, nenhum normativo, não se tem um procedimento claro para a realização disto, pois as famílias não possuem recurso financeiro para fazê-lo e sem tal procedimento o INCRA não pode dar continuidade ao processo.

Atualmente, a comunidade São Miguel está no processo de desapropriação das terras dos proprietários quilombolas e posterior unificação do título, com o território já titulado em 2011, fruto de desapropriação de uma fazenda lindeira à comunidade.

Atualmente, ainda que predomine praticantes das religiões evangélicas, é notável a revalorização da cultura tradicional, especialmente em relação à constituição de um pequeno museu com peças e memória dos antepassados colonizadores, assim como a valorização das músicas e atabaques tradicionais.

\subsection{Comunidade Quilombola de Furnas da Boa Sorte}

Essa comunidade está situada no município de Corguinho/MS com o território delimitado em 1.413,0834 ha, contendo, aproximadamente, 60 famílias, as quais vivem, basicamente, da agricultura para a sua subsistência, da produção de farinha, derivados da cana-de-açúcar e da renda oriunda do trabalho executado em fazendas vizinhas.

O RTID foi realizado em julho de 1998, pela professora e pesquisadora Maria de Lourdes Bandeira. O reconhecimento pela Fundação Cultural Palmares veio em 25 de maio de 2005. Um fato interessante é que, nos anos 2000, a própria Fundação Cultural Palmares concedeu a titulação das terras, mas não foi feita a desintrusão ${ }^{20}$ dos proprietários não quilombolas, o que não acarretou o final do processo. Atualmente, a comunidade São Miguel enfrenta conflitos, para a regularização e ocupação definitiva da área tradicional,

20 Desintrusão é a etapa em que, após o aceite do valor avaliado e proposto pelo INCRA por parte dos proprietários não quilombolas, a Justiça dá a emissão na posse da propriedade em favor do INCRA. 
conflito que se dá, especialmente, entre a comunidade negra e um dos proprietários não quilombola.

A comunidade São Miguel encontra-se, assim, na fase de desintrusão, processo que não foi realizado no ano 2000. Há incidência de treze imóveis no território tradicional quilombola; em cinco deles já foi dada a imissão do título, aguarda-se a decisão judicial para a imissão dos títulos dos demais territórios. Outro fato de destaque é que há proprietários que não aceitaram o valor proposto e não fizeram o acordo indenizatório com o INCRA, para isso, haverá audiências judiciais de conciliação a fim de resolver cada situação. Somente quando todos os imóveis estiverem em nome do INCRA, o título parcial será emitido em nome da associação que representa a comunidade, sendo depois, unificado com os títulos atuais em posse das famílias quilombolas.

Essa comunidade é a de mais difícil acesso, ainda que não seja a mais distante, dentre as pesquisadas no presente projeto. No entanto, encontra-se encravada em uma morraria, com imponentes formações rochosas, apresentando-se como uma formidável potencialidade para futura exploração do turismo rural. A fonte de renda atual da comunidade centra-se na agricultura familiar, comercialização do excedente, assim como da pecuária e a oferta de mão de obra para as fazendas da região.

\subsection{Comunidade Quilombola Furnas do Dionísio}

Essa comunidade quilombola, a maior em termos populacionais, a mais conhecida e estudada por pesquisadores do estado, situa-se no município de Jaraguari/MS com, aproximadamente, 100 famílias, as quais vivem da agricultura de subsistência, da produção de hortaliças, de derivados da farinha, de derivados da cana-de-açúcar e da pecuária.

Foi reconhecida como comunidade quilombola pela Fundação Cultural Palmares em 25 de maio de 2005 e o RTID foi feito pelas pesquisadoras Maria de Lourdes Bandeira e Triana de Veneza Sodré e Dantas. Cabe salientar que, apesar de alguns desentendimentos iniciais com alguns sitiantes vizinhos (não quilombolas), o processo de regularização fundiária não sofreu consideráveis resistência para a titulação de suas terras.

A área delimitada é de 1.018,2796 ha e, assim como a comunidade Furnas de Boa Sorte, também, foi titulada pela Fundação Cultural Palmares em 2000 e da mesma forma ainda está em curso o lento processo de desintrusão e indenização. Nesse caso, são dezessete imóveis de não quilombolas incidentes no território tradicional reivindicado, dos quais doze o INCRA já havia conseguido emitir o título de posse para a comunidade. Os cinco imóveis restantes dependem de sentença judicial, o que torna outro fato semelhante a Furnas da Boa Sorte, para, então, emitir o título em nome da associação que representa a comunidade.

\subsection{Comunidade Quilombola Desidério Felipe de Oliveira}

Nascido em 1867, Desidério foi escravo e testemunha da abolição da escravatura de 1888. Saiu, então, de Minas Gerais e veio em direção ao que hoje é conhecido como Mato Grosso do Sul. Comunidade, também conhecida como Picadinha está situada em Dourados e Itaporã/MS, com 126 famílias, sendo que apenas 15 estão residindo na área, isto é, o que restou a eles, o que, aproximadamente, chega a 40 ha.

O reconhecimento como comunidade quilombola veio em 19 de abril de 2005 e o RTID da Comunidade Quilombola Desidério Felipe de Oliveira foi elaborado pelo antropólogo Carlos Alexandre Barbosa Plínio Santos (UnB), em setembro de 2007.

A comunidade Picadinha, como também é popularmente conhecida, é marcada pelos conflitos sofridos durante todo o processo de titulação de suas terras. Confinada em 56 hectares, tendo como vizinhos produtores de soja e milho que se mostram bastantes hostis ao trabalho que vem sendo desenvolvido pelo INCRA, a comunidade sofre o recrudescimento dos conflitos, com aumento do preconceito, discriminação e até a negação de empregabilidade na região, sem falar no tratamento hostil dado pela imprensa, que não 
informa sobre o processo histórico de esbulho pelo qual passou a comunidade. É comum, a ocorrência de ameaças aos líderes da comunidade, com a necessidade do auxílio de força policial na realização dos serviços.

A área delimitada é de 3.538,6215 ha e o processo de regularização fundiária no INCRA já passou pelas duas instâncias administrativas, que julgaram improcedentes os recursos impetrados pelos moradores não quilombolas. A primeira instância o foi regional, isto é, na superintendência de MS, e a segunda foi o nacional, com sua Sede em Brasília. Atualmente, o processo de desintrusão e indenização continua parado.

Segundo Marcelo Souza ${ }^{21}$, ainda há a instância judicial. Os processos já passaram da primeira instância (que é a vara federal no estado de MS), foram para segunda instância (vara federal em São Paulo - SP), dos quais julgados em SP, todos foram favoráveis ao INCRA, logo à comunidade. Ainda faltam alguns processos a serem julgados em SP, com a possibilidade de os proprietários recorrerem ao Superior Tribunal Federal, o que, segundo Souza 22 " "é uma op̧̣ão bem onerosa, a cargo das partes".

Quanto à Picadinha tivemos algumas mudanças no quadro da regulamentação de seu território recentemente. Segundo o site do Ministério Público Federal23, o Tribunal Regional Federal da $1^{\text {a }}$ Região (TRF-1) acatou os argumentos do próprio Ministério Público Federal (MPF) e negou mandado de segurança que pretendia anular o processo demarcatório da Comunidade Quilombola Desidério Felipe de Oliveira, distrito de Dourados, sul de Mato Grosso do Sul. A área, conhecida como Distrito de Picadinha, deve receber nova vistoria em agosto de 2014. Essa parte é toda jurídica, portanto, se não aparecer alguma liminar judicial paralisando o processo, haverá o tocante do processo quanto a parte administrativa.

Mais especificamente, quanto ao processo administrativo, a Comunidade Picadinha estaria na fase da Portaria de Reconhecimento de Território Quilombola. Porém, enquanto o INCRA preparava as peças integrantes e necessárias para o Kit Portaria, essencial no processo descobriu-se uma área na qual os proprietários ainda não haviam sido notificados. Essa notificação será realizada e o processo deve atrasar um pouco nesse ponto, para, então, preparar a documentação para publicar a Portaria assinada pela presidência do Incra reconhecendo o território quilombola.

O que constatamos é que o conflito permanece, entre a comunidade quilombola e os possuidores dos títulos e moradores não quilombolas regionais, o que inviabiliza a ampliação da produção de alimentos e da própria agricultura familiar, assim como da prática da pecuária. Tendo em vista o território ser diminuto, a maior parte da comunidade vive de assalariamento na cidade de Dourados/MS.

\subsection{Comunidade Quilombola Tia Eva}

Comunidade quilombola urbana, constituindo-se em um bairro de Campo Grande/MS, também conhecida como comunidade de São Benedito, a qual possui aproximadamente 97 famílias. Muitos são assalariados em empregos urbanos e, por essa especificidade de ser uma comunidade negra urbana, os conflitos e problemas existentes na comunidade a torna diferente das demais comunidades quilombolas do estado.

Nessa comunidade, uma das dificuldades enfrentadas é que grande parte dos moradores está sendo acionada, judicialmente, pela Prefeitura Municipal de Campo Grande por não pagar o Imposto Predial e Territorial Urbano (IPTU), enquanto nas demais comunidades quilombolas o problema principal constitui a luta contra proprietários e afins, no processo de regularização fundiária.

21 Entrevista realizada com Marcelo Souza (Analista em Reforma e Desenvolvimento Agrário - Antropólogo) no dia 19 de Maço de 2013, por Sônia Rocha Lucas (PIBIC).

22 Entrevista realizada com Marcelo Souza (Analista em Reforma e Desenvolvimento Agrário - Antropólogo) no dia 19 de Maço de 2013, por Sônia Rocha Lucas (PIBIC).

23 BRASIL. Ministério Público Federal. Demarcação de área quilombola em Dourados pode se finalizada. Disponível em: <http://www.prms. mpf.mp.br/servicos/sala-de-imprensa/noticias/2013/07-1/demarcacao-de-area-quilombola-em-dourados-pode-ser-finalizada > 
A certificação como comunidade quilombola foi reconhecida pela Fundação Cultural Palmares em 05 de março de 2008 e o processo de titulação de suas terras encontra-se em fase inicial. Foi feito o estudo da área pelo antropólogo Carlos Alexandre Barbosa Plínio Santos (UnB), visando à elaboração do Relatório Técnico de Identificação e Delimitação. Sem este, a comunidade não possui dados para a delimitação do seu território e assim dar continuidade ao processo de regulamentação de suas terras.

O Relatório Antropológico foi concluído em 2014 e apresentado para a comunidade. Sendo assim, este se encontra em fase de conclusão e espera da entrega do RTID pela entidade ganhadora do processo de licitação, para posterior desintrusão e indenização dos proprietários.

Por ser uma comunidade quilombola urbana, a "Tia Eva" recebe muitas visitas de entidades, alunos e pesquisadores, sendo das mais conhecidas e noticiadas no estado. A própria comunidade organiza todos os anos importantes festas tradicionais, abertas para a comunidade local.

Além das demandas por resolver as pendências com os impostos municipais e a regularização fundiária, com consequente ampliação do território tradicional da comunidade, a "Tia Eva" passa ainda por ajustes internos, com disputas políticas entre suas lideranças, assim como a possibilidade em transformar a escola que está localizada no centro do bairro, tenha características e especificidade de uma comunidade quilombola, situação ainda não conquistada.

\section{Considerações finais}

A partir dos dados chegamos a alguns resultados: há, na atualidade, aproximadamente 30 comunidades quilombolas, sendo 21 identificadas e formalizadas pela Fundação Cultural Palmares, e dentre estas, 18 comunidades possuem procedimento administrativo instaurado no INCRA. Garantir o direito à titulação das terras quilombolas é devolver às comunidades a possibilidade da permanência definitiva em seus territórios, o que acarretará em uma maior autonomia e conscientização de seus direitos garantidos por lei e a forma como podem reivindicá-los diante de órgãos competentes, transformando a realidade que se apresenta em forma de lei, mas que, em sua maioria, não se concretizam na vida prática e comunitária.

Por outro lado, levando em consideração a realidade de violência e conflito que o estado de Mato Grosso do Sul tem apresentado na questão territorial, tanto com os quilombolas como com os indígenas, essa temática se faz de suma importância para a discussão quanto às políticas públicas no estado. Outro fato a se levar em conta é que a titulação dos territórios das comunidades quilombolas tem apresentado maiores resultados, mediante as ações do INCRA. Constatamos uma efetiva ação com relação ao processo de reconhecimento e regularização fundiária.

As comunidades visitadas têm relativa clareza do tema, porém ainda se faz necessária uma maior discussão sobre a questão da coletividade da posse das terras, assim como aos órgãos regionais, aqueles ligados a prefeituras, entender e compreender as políticas às quais essas comunidades têm direito. O conhecimento de todas as políticas públicas se faz fundamental, assim como o próprio domínio dessas leis por seus líderes quilombolas.

Compreender que essas comunidades têm ordens e ritmo próprio se faz de fundamental importância para todos aqueles agentes estatais que estão imbuídos e inseridos no processo de melhor aplicabilidade e gestão das políticas públicas.

Outro aspecto que percebemos no decorrer desta pesquisa foi constatar a importância dos negros na formação social e econômica do estado de Mato Grosso do Sul, quebrando velhos paradigmas que negavam a existência desses grupos, não levando em conta o devido valor que os negros tiveram para a formação, não só no que se diz respeito a cultura, mas também no âmbito econômico. Também eles contribuíram para a 
colonização dessas terras.

Sabe-se que há muito para se realizar, principalmente quando se fala em educação e saúde nas comunidades quilombolas. Como afirma Santos ${ }^{24}$, em relação à educação indígena, reforçamos que também a educação quilombola deva ser uma ação diferenciada, como política pública de inclusão. Ações que necessitam ser realizadas, tanto mediante os órgãos governamentais, quanto as comunidades, de maneira a conscientizá-los de seus direitos garantidos por lei e a forma como podem reivindicá-los diante de órgãos competentes, transformando, assim, a realidade que se apresenta em forma de lei, mas que, em sua maioria, não se concretiza na vida prática e comunitária. Essa conscientização dos seus direitos e da vida em comunidade é o caminho fundamental para que tudo que está sendo proposto se estabeleça de forma clara e eficiente para todos que ali estão.

Ao finalizar, retomando os estudos sobre o aspecto territorial, destacamos que duas comunidades, Chácara do Buriti e São Miguel, concluíram a fase de titulação, fase final do processo que regulariza o território da comunidade, e receberam o título em nome da associação que representa a comunidade. Já as comunidades Furnas de Boa Sorte e Furnas do Dionísio estão em processo de desintrusão, quando há negociação entre o INCRA e os proprietários não quilombolas, a respeito do valor referente à venda de suas terras. Ao chegar ao fim dessa avaliação e aceite pelo proprietário, o órgão responsável dá a emissão da posse da propriedade em favor do INCRA, o que posteriormente, seguindo o processo culminará com a titulação em favor da associação da comunidade.

A comunidade Desidério Felipe de Oliveira, também conhecida como Picadinha, acabou de sair da fase de contestação, ou seja, a fase em que foram apresentadas contestações judiciais pelos proprietários não quilombolas e de resultado a favor do INCRA e consequentemente à comunidade Picadinha, seguindo para a fase da Portaria de Reconhecimento de Território Quilombola.

A comunidade Tia Eva, que está no início do processo de titulação das terras, possui seu Relatório Técnico de Identificação e Delimitação, o RTID pronto, para assim dar continuidade ao processo desintrusão e indenização.

Os resultados obtidos nessa pesquisa mostram a diversidade dos processos no estado, os quais são desenvolvidos pelo INCRA junto a essas seis comunidades que lutam para ter a posse de seu direito ao território tradicional. Em suma, esses resultados podem ser demonstrados na tabela 3 que segue abaixo:

Tabela 3 - Áreas reivindicadas e tituladas ${ }^{3}$

$\begin{array}{lccc}\text { COMUNIDADES } & \text { REIVINDICADA } & \text { TITULADA } & \text { FASE ATUAL DO PROCESSO } \\ \text { Chácara do Buriti } & 43,0080 & 12,1812 & \text { Titulação } \\ \text { São Miguel } & 420,6821 & 333,0736 & \text { Titulação } \\ \text { Furnas da Boa Sorte } & 1.413,0834 & & \text { Desintrusão } \\ \text { Furnas do Dionísio } & 1.018,2796 & & \text { Desintrusão } \\ \text { Picadinha } & 3.538,6215 & & \begin{array}{c}\text { Portaria de Reconhecimento de } \\ \text { Território Quilombola. }\end{array} \\ \text { Tia Eva } & \text { Não definido } & & \text { Desintrusão }\end{array}$

Desse modo, podemos observar que a política de regularização dos territórios quilombolas, desde 1988, com a constituição Federal, depois com as leis que organizaram e regulamentaram o processo de reconhecimento, assim como a titulação da terra, avançou consideravelmente.

Por fim, esse projeto pretendeu produzir e acrescentar informações que esclareçam e tirem determinadas dúvidas na situação da aplicação de certas políticas públicas, especificamente a titulação de suas terras, a fim

24 SANTOS, Isabelle Dias Carneiro. A educação diferenciada como política pública de inclusão social dos Guarani e Kaiowá no Estado do Mato Grosso do Sul. Rev. Bras. Polit. Públicas (Online), Brasília, v. 6, n. 3, p. 309-328, 2016. 
de que persistam na reprodução física e cultural e lutem pela conquista de seus direitos e, assim, possam estabelecer novas formas de convívio em um lugar onde os direitos sejam respeitados.

\section{REFERÊNCIAS BIBLIOGRÁFICAS}

ABRAÃO, Pauliane Lisboa. Políticas públicas e diversidade sociocultural. Revista Brasileira de Políticas Públicas, Brasília, v. 1, n. 3, número especial, p. 1-20, dez. 2011.

AMORIM, Ricardo L. Chagas. A construção de novas políticas sociais: o caso de Mato Grosso do Sul. Revista Brasileira de Políticas Públicas, Brasília, v. 4, n. 1, p. 114-136, 2014.

ARRUTI, J. M. Mocambo. Antropologia e História do processo de formação quilombola. Bauru: Edusc, 2006.

ARRUTI, J. M. Políticas Públicas para Quilombos: Terra, Saúde e Educação. In: PAULA, M. HERINGER, R. (Org.) Caminhos Convergentes: Estado e Sociedade na Superação das Desigualdades Raciais no Brasil. <http://www.br.boell.org/downloads/caminhos_convergentes.pdf>. Acesso em: 20 mar. 2014.

ARRUTI, J. M. Quilombos. < http://www.ufgd.edu.br/reitoria/neab/downloads/quilombos-2013-jose-mauricio-arruti. 2008. Acesso em: 21 mar. 2013.

ASSUNÇÃO, Linara Oeiras. Unidades de conservação, terras indígenas e quilombolas no estado do Amapá: como desenvolver um Estado cujo território está 70\% protegido por leis?. Rev. Bras. Polít. Públicas (Online), Brasília, v. 6, n. 3, p. 289-308, 2016.

BARTH, Fredrik. O Guru, o Iniciador e Outras Variações Antropológicas. Organização de Tomke Lask. Rio de Janeiro: Contra Capa Livraria, 2000.

BRASIL. Ministério Público Federal. Demarcação de áreas quilombolas em Dourados pode ser finalizada. Disponível em: <http://www.prms.mpf.mp.br/servicos/sala-de-imprensa/noticias/2013/07-1/demarcacao-de-areaquilombola-em-dourados-pode-ser-finalizada>. Acesso em: 26 ago. 2014.

CACHADO, R. A. O papel de mediação do/ a antropólogo/ a (entre informantes e serviços públicos): um estudo de caso na Quinta da Vitória, Loures. Disponível em: <http://www.raco.cat/index.php/QuadernseICA/article/ view/206112/274649>. Acesso em: 25 mar. 2014.

FUNDAÇÃO CULTURAL PALMARES. Comunidades Quilombolas. Disponível em: < http://www.palmares. gov.br/quilombola/>. Acesso em: 20 mar. 2014.

FUNDAÇÃO CULTURAL PALMARES. Comunidades Quilombolas: conceito, autodefinição e direitos. Acessado em 26 de agosto de 2014. Disponível em http://www.palmares.gov.br/2012/04/comunidades-quilombolas-conceito-autodefinicao-e-direitos/>. Acesso em: 26 ago. 2014.

FUNDAÇÃO CULTURAL PALMARES. Legislação. Disponível em: < http://www.palmares.gov.br/wpcontent/uploads/2010/11/legis12.pdf>. Acesso em: 20 mar. 2014.

INCRA. Etapas da Regulamentação Quilombola. Disponível em: <http://www.incra.gov.br/index.php/estrutura-fundiaria/quilombolas>. Acesso em: 26 ago. 2014.

INCRA. Quadro Atual da Politica de Regulamentação de Territórios Quilombolas no INCRA. Disponível em: $<$ http://www.incra.gov.br/index.php/estrutura-fundiaria/quilombolas/file/109-quadro-atual-da-politicade-regularizacao-de-territorios-quilombolas-no-incra>. Acesso em: 19 ago. 2014.

ORGANIZAÇÃO DAS NAÇÕES UNIDAS. Declaração sobre Direitos dos Povos Indígenas, 2007.

ORGANIZAÇÃO INTERNACIONAL DO TRABALHO. Convenção OIT sobre Povos Indígenas e Tribais em paises independentes $n^{\circ}$ 169; 1989. 
SANTOS, Carlos A. B. Plinio dos. Fiéis descendentes - Redes-irmandades na pós-abolição entre as comunidades negras rurais sul-mato-grossenses. Brasília: Universidade de Brasília, 2014.

SANTOS, Isabelle Dias Carneiro. A educação diferenciada como política pública de inclusão social dos Guarani e Kaiowá no Estado do Mato Grosso do Sul. Rev. Bras. Polít. Públicas (Online), Brasília, v. 6, n. 3, p. 309-328, 2016.

SEPPIR. Programa Brasil Quilombola - Diagnóstico de Ações Realizadas (07/2012). Disponível em: <http://www. seppir.gov.br/destaques/diagnostico-pbq-agosto>. Acesso em: 20 mar. 2014.

SOUZA, D. Comunidades quilombolas: conceito, autodefinição e direitos. Disponível em: <http://www.palmares.gov.br/2012/04/comunidades-quilombolas-conceito-autodefinicao-e-direitos/>. Acesso em: 21 mar. 2014.

(Footnotes)

1 FUNDAÇÃO CULTURAL PALMARES. Comunidades Quilombolas. Disponível em: < http://www.palmares.gov.br/quilombola/>. Acesso em: 20 mar. 2014.

2 INCRA. Quadro Atual da Política de Regulamentação de Territórios Quilombolas no INCRA. Disponível em: $<$ http://www.incra.gov.br/index.php/estrutura-fundiaria/quilombolas/file/109-quadro-atual-da-politicade-regularizacao-de-territorios-quilombolas-no-incra>. Acesso em: 19 ago. 2014.

3 INCRA. Quadro Atual da Política de Regulamentação de Territórios Quilombolas no INCRA. Disponível em: $<$ http://www.incra.gov.br/index.php/estrutura-fundiaria/quilombolas/file/109-quadro-atual-da-politicade-regularizacao-de-territorios-quilombolas-no-incra>. Acesso em: 19 ago. 2014. 


\section{REVISTA BRASILEIRA DE POLÍTICAS PÚBLICAS BRAZILIAN JOURNAL OF PUBLIC POLICY}
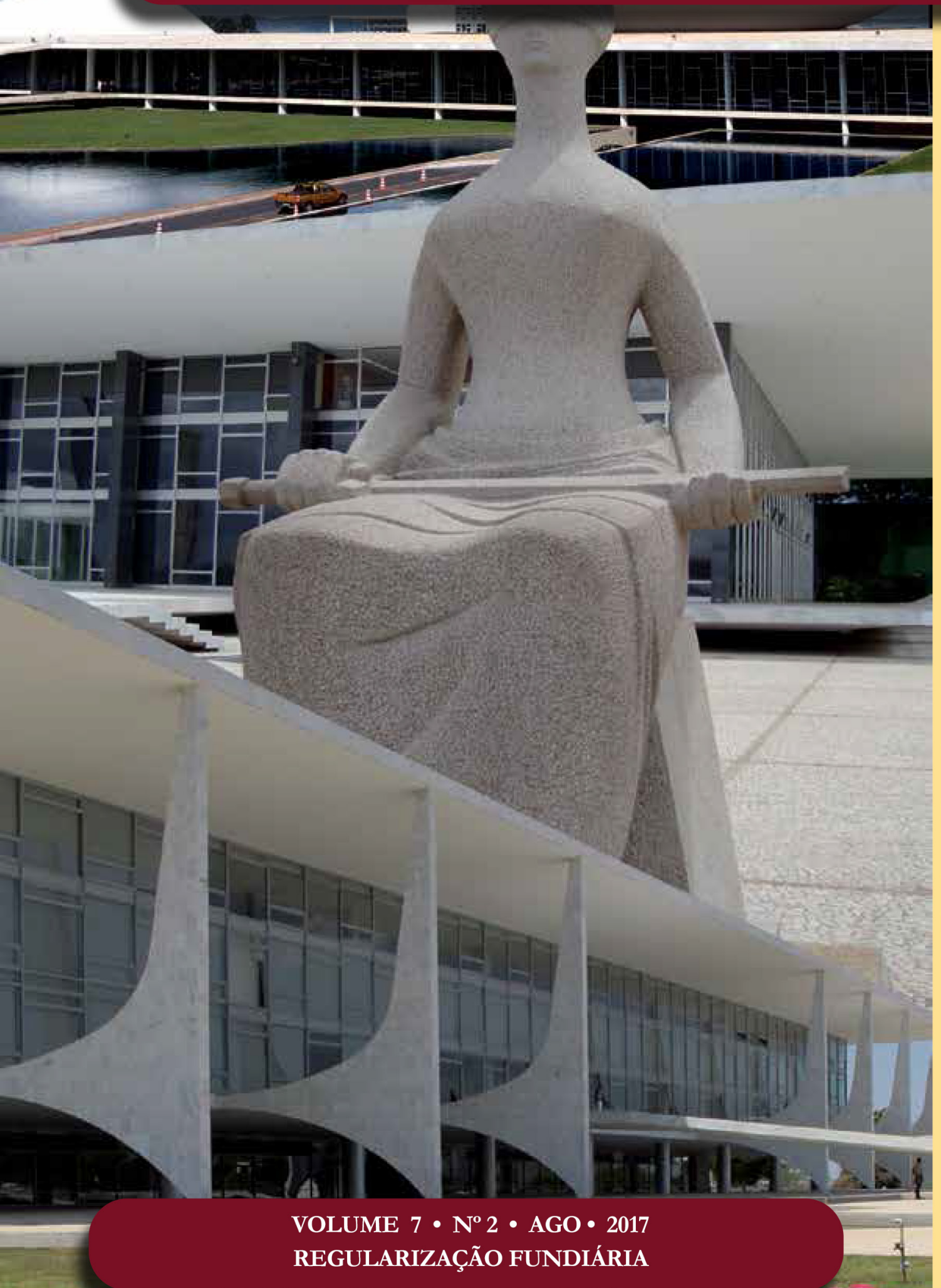

Políticas Públicas e Escolha Racional: O Caso do Centro Urbano de Cultura, Arte, Ciência e Esporte de Fortaleza, Estado do Ceará Public Policies And Rational Choice: The Case of The Urban Center for Culture, Art, Science and Sport of Fortaleza, State of Ceara

Mariana Dionísio de Andrade Rodrigo Ferraz de Castro Remígio 


\section{Políticas públicas e escolha racional: o caso do Centro Urbano de Cultura, Arte, Ciência e Esporte de Fortaleza, Estado do Ceará*}

\author{
Public policies and rational choice: The Case \\ of The Urban Center for Culture, Art, Science \\ and Sport of Fortaleza, State of Ceara
}

Mariana Dionísio de Andrade**

Rodrigo Ferraz de Castro Remígio***

\section{Resumo}

O objetivo do presente artigo consiste em responder a seguinte pergunta: por que determinadas políticas públicas ingressam na agenda política e permanecem na modalidade incremental, apesar das mudanças na gestão governamental? Parte-se da ideia que a construção de determinadas fases do ciclo de políticas públicas ocorre em razão da correspondência ótima entre meios e fins, momento no qual atores políticos utilizam estratégias para a maximização de benefícios. A pesquisa possui abordagem qualitativa e se apoia em revisão de literatura. O método é observacional processual causal, com base no caso do Centro Urbano de Cultura, Arte, Ciência e Esporte de Fortaleza - CUCA, como exemplo de política pública que foi replicada por outra gestão municipal. A seleção dos casos observados foi realizada com base na incidência da política, com periodização compreendida entre 2009 a 2015. Conclui-se que há relação subjacente entre a manutenção da política e a maximização de benefícios, e que a política pública analisada teve continuidade na cidade de Fortaleza não apenas em razão dos resultados, mas também pelos compromissos contratuais assumidos entre a prefeitura municipal e o Banco Interamericano de Desenvolvimento, evidenciando uma inclinação maior às estratégias políticas que à atenção às demandas de ordem social.

Palavras-chave: Políticas públicas. Escolha racional. Neoinstitucionalismo e agenda política. Centro Urbano de Cultura, Arte, Ciência e Esporte de Fortaleza - CUCA.

\section{Abstract}

This research aims to answer the following question: why do certain public policies enter the political agenda and remain in the incremental modality, despite changes in government management? It is based on the idea that the construction of certain phases of the public policy cycle occurs due to the optimal correspondence between means and ends, at which political actors use strategies to maximize benefits. The research has a qualitative approach and is based on literature review. The method is observational causal 
process, based on the case of the Urban Center of Culture, Art, Science and Sport of Fortaleza - CUCA, as an example of public policy that was replicated by other municipal management. The selection of the observed cases was carried out based on the incidence of the policy, with periodization between 2009 and 2015. It was concluded that there is an underlying relationship between the maintenance of the policy and the maximization of benefits, and that the public policy analyzed was continued in the city of Fortaleza not only due to the results but also the contractual commitments assumed between the municipal government and the Bank Inter-American Development Bank, showing a greater inclination to political strategies than to the demands of a social order.

Keywords: Public policy. Rational choice. Neo-institutionalism and political agenda. Urban Center of Culture, Art, Science and Sport of Fortaleza - CUCA.

\section{INTRODUÇÃo}

O objetivo do presente artigo consiste em compreender as razões pelas quais determinadas políticas públicas ingressam na agenda política e permanecem na modalidade incremental, apesar das mudanças na gestão governamental.

A escolha da inclusão de políticas no agenda seeting, a abrangência de seus resultados e a motivação que justifica a incidência destas em determinados contextos constitui razão pela qual se faz necessária a análise do ciclo de políticas públicas sob a ótica neoinstitucional no contexto da escolha racional. Para apresentar e discutir modelos teóricos que sejam hábeis a contribuir para a compreensão do processo de construção de políticas públicas, faz-se necessária a abordagem sobre o processo de formação de agendas políticas, justamente para verificar a relação entre os modelos de políticas públicas a serem formulados e sua dependência com interesses políticos ${ }^{1}$, momento adequado e objetivos estratégicos bem desenhados para que seja possível conjecturar sua implementação.

Há de se considerar que determinados fluxos decisórios devem caminhar paralelamente: o interesse político, a necessidade social, a coincidência entre interesses, demanda, momento político propício e condições políticas de materializar as ideias elaboradas, além da definição da área de especialidade que será tratada pela política pública (educação, saúde, moradia, segurança pública etc.). Ou seja; há de se evoluir a agenda no âmbito decisional, que tenta traduzir preferências governamentais e convergências políticas ${ }^{2}$, consentaneamente à agenda especializada.

Um caso em especial merece atenção para a presente pesquisa; a implementação da Rede de Centros Urbanos de Cultura, Arte, Ciência e Esporte - Rede CUCA no município de Fortaleza. Como será visto ao longo do estudo, trata-se de um caso em que interesses políticos motivaram a formulação e implementação da política, entretanto, mesmo com a mudança de gestão municipal, a política foi mantida e replicada, partindo-se da ideia de que atores políticos e grupos de interesse atuam sob a perspectiva racional.

O estudo possui abordagem qualitativa, pois se destina a interpretar eventos e a verificar sua relevância em contextos específicos. A periodização está compreendida entre 2009 a 2015. O marco inicial se justifica pelo princípio da implementação da política pública analisada, enquanto o marco final foi limitado pela disponibilidade dos dados.

Justifica-se a presente pesquisa pela necessidade de verificar a coincidência de interesses envolvidos na

1 A ideia aqui proposta relaciona a decisão pela formulação e implementação de políticas públicas com base na escolha racional de atores políticos. Tais políticos, no contexto aqui apresentado, seriam os burocratas, que almejam a permanência no cargo; e membros do Executivo, cuja carreira está relacionada à reeleição e previsibilidade de preferências dos eleitores. (Geddes, 1996).

2 "Fazer o governo funcionar melhor para atender as demandas da sociedade a um menor custo tornou-se um desafio central para governos estaduais em contextos de ajuste fiscal e descentralização de políticas públicas”. (Rezende, on line, 2006, p.1). 
formulação, execução e posterior manutenção de políticas públicas apesar da mudança de cenário político, comparando-se casos observáveis para a construção de inferências causais. Parte-se do suposto que a realização de políticas efetivas em um sistema democrático é essencial para a concretização de direitos e alcance da cidadania material dos indivíduos; mas também é ferramenta para a realização de interesses e possível previsão de preferências no âmbito eleitoral.

\section{O LUGAR DAS POLÍTICAS PÚBLICAS NO NEOINSTITUCIONALISMO DE ESCOLHA RACIONAL}

A definição de políticas públicas está relacionada à funcionalidade a qual se propõe, na medida em que se destinam a produzir efeitos específicos. Trata-se da soma das atividades governamentais, realizadas diretamente ou por delegação e que tendem a impactar o contexto social dos cidadãos contemplados pela política (Souza, 2007).

Mas o elemento central da definição, e escopo do presente estudo, é a construção da ideia de políticas públicas sob o enfoque dos interesses envolvidos, partindo-se do pressuposto que indivíduos são racionais em um sistema democrático. Para o presente artigo, importam as decisões que circunscrevem o ciclo das políticas públicas, possibilidades de cooperação entre instituições, entre grupos de interesse ${ }^{3}$ e entre agentes governamentais.

Para Herbert A. Simon (2009, p. 155), "os modelos de escolha racional incorporam, normalmente, um conjunto de simplificações que, na prática, tem como finalidade ajustar o problema de decisão aos limites do modelo escolhido ou aos processos comportamentais que se aproximam das formas reais de decisão".

A partir do momento em que o ator político atua em prol da sociedade, é preciso considerar a hipótese de que sua ação é realizada com base na manutenção do poder, não no altruísmo. O ator político precisa maximizar votos (visto que, em um contexto democrático, sua permanência dependerá da participação dos cidadãos nas eleições), que podem ser reduzidos se a desigualdade social for excessiva ou se as ações políticas anteriores forem inexpressivas para o desenvolvimento social; o que, por conseguinte, leva o ator político a realização de ações pró-sociedade. (Downs, 1999).

Muitas vezes políticas de eficiência mitigam as políticas voltadas ao bem-estar social em razão do contexto econômico vivenciado, motivo pelo qual a análise da escolha racional não se concentra na instituição em si, mas sim no ator político (que age individualmente) que faz parte da instituição. (Stokes, 1999).

Políticas públicas ${ }^{4}$ repercutem nos âmbitos econômico e social, o que justifica a inarredável interação entre ideologia dos partidos, participação das instituições, influência exercida pela economia e preferências dos atores envolvidos. Para a formulação de políticas está ínsita a ideia de planejamento e construção de estratégias, assim como resta evidente que sua manutenção depende de articulações que consigam justificar politicamente a permanência. Há de se considerar a relativa autonomia do Estado (Evans; Rueschmeyer; Skocpol, 1985) na escolha da agenda política e das políticas dela decorrentes que, por sua vez, se relacionam com os

3 "Entre os grupos de interesse, há importantes recursos organizacionais e políticos, entre eles, a informação e as contribuições financeiras para campanhas políticas. Eles também fazem campanha e votam em candidatos que supostamente apoiariam sua causa no governo; entretanto, os impactos políticos dos grupos de interesse na formulação e na implementação de políticas públicas variam de maneira considerável, de acordo com seu acesso aos diferentes níveis de recursos organizacionais e de acordo com sua efetiva representação dos interesses”. (Howlett; Ramesh; Perl, 2013, p. 79).

4 Devem-se distinguir políticas públicas de políticas sociais; "enquanto a primeira classificação se refere ao processo e possui foco em como responder questões como 'por quê' e 'como', os estudos em políticas sociais tomam o processo apenas como 'pano de fundo’ e se concentram nas consequências da política, ou seja, o que a política faz ou fez. Essa aparente simples distinção tem implicações na agenda de pesquisa. Estudos sobre política pública não focalizam necessariamente o conteúdo substantivo da política [...] dado que qualquer produção do governo em qualquer área/setor pode ser tomada como ilustração do processo. Estudos sobre política social, ao contrário, são demarcados pelo objeto da política pública, focalizando, sempre, as questões que a política busca 'resolver' os problemas da área e seus resultados". (Souza, 2007, p. 71). 
interesses e com a extensão da capacidade necessária para desempenhar tarefas e produzir resultados.

Para Bryan D. Jones (2017), as políticas públicas são um conjunto de decisões articuladas às ações governamentais destinadas à resolução de demandas sociais específicas ou mais genéricas.

As políticas públicas obedecem a um ciclo que compreende, pelo menos, quatro fases; a primeira envolve as decisões políticas que se dedicam a solucionar problemas já identificados; a segunda, consiste na implementação das políticas já definidas na tomada de decisão; a terceira comporta a verificação quanto à satisfação das demandas sociais e, finalmente, a quarta etapa envolve a avaliação da política, para que seja possível projetar sua contiuidade, reformulação ou descontinuidade. (Heidemann, 2009).

Produzir políticas públicas voltadas para favorecer uma maior redistribuição social é um eixo que baliza mudanças setoriais e políticas no contexto do Estado Democrático de Direito, mas é necessário lembrar que parte das ações praticadas por indivíduos ou em nome deles ocorre por meio da organização entre grupos e que cada membro do grupo possui interesses.

Para Mancur Olson (1999), nenhum indivíduo atua movido pelo senso coletivo, mas sim por incentivos seletivos que conduzem os atores às suas ações serão prioritariamente individuais, tendo como resultado seu reflexo nas organizações coletivas.

Dessa maneira, as instituições democráticas passam a ser conduzidas pelos interesses individuais de seus agentes, elaborando ações articuladas pela escolha racional, pelo individualismo metodológico e pela realização de estratégias e integração entre atores e discursos políticos para o alcance do resultado subótimo. (Stigler, 1971).

Nesse sentido, importa ao estudo destacar que o principal papel das instituições em uma sociedade é reduzir a incerteza pelo estabelecimento de uma estrutura humana estável. Mas a estabilidade das instituições em nada contradiz o fato de que elas estão mudando, razão pela qual devem ser revisitadas sob a ótica neoinstitucional da escolha racional ${ }^{5}$.

Racionalidade é condição essencial para muitas formas de comportamento político e se baseia na consideração de custos e benefícios, dependendo, ainda, da estabilidade da arena política que o governo propicia. A atuação de eleitores e políticos em geral segue uma trajetória de benefícios calculados, no sentido de majorar vantagens, maximizar votos e reduzir desvantagens para a sociedade com o menor custo possível.

Depois que o governo reconhece a existência de um problema público e a respectiva necessidade de arquitetar ações, espera-se que os policy-makers se organizem para criar alternativas com base nessa análise de custo e benefício. A partir do momento em que um problema é identificado, há a formalização e verificação quanto à viabilidade dessas alternativas, momento no qual ocorre a formulação de políticas públicas como estágio fundamental de um ciclo que envolve apreciação, diálogo e consolidação das decisões. (Howlett; Ramesh; Perl, 2013).

Esse desenho de alternativas que sustenta a formulação de políticas, por sua vez, se relaciona com quatro aspectos essenciais: a) um conjunto determinado de preferências (que justificaria o comportamento utilitário dos atores); b) consideração da vida política como uma sequência de possíveis dilemas de ação coletiva (em que atores optam entre a maximização de votos e as decisões baseadas em escolhas subótimas para a sociedade); c) interação estratégica ${ }^{6}$ na determinação das situações políticas e d) a capacidade de realização das políticas pelas instituições. (Olson, 1999).

5 A unidade básica de análise em relação a essa abordagem envolve a transação entre indivíduos para o desenvolvimento e funcionamento das instituições, tornando-se significativas na medida em que aumentam ou diminuem o custo das transações. Sob essa perspectiva, instituições são produtos finais, outcomes das ações intencionais de indivíduos instrumentalmente orientados. (Howlett; Ramesh; Perl, 2013; Powell; Dimaggio, 1991).

6 Para Thomas R. Dye (2009, p. 119), "a estratégia refere-se à tornada de decisão racional em que um conjunto de movimentos visa a alcançar o melhor prêmio, mesmo depois de considerados todos os possíveis movimentos do adversário". 
Portanto, a relação dialógica existente entre políticas públicas e neoinstitucionalismo com base na escolha racional se sustenta na realidade das circunstâncias, que vão envolver, inevitavelmente, vontades políticas. Há de se definir prioridades em uma agenda governamental, porque essa definição conduzirá as decisões políticas e balizará o planejamento estratégico dos atores.

$\mathrm{O}$ ato de decidir exige interação estratégica e coordenação de interesses políticos, especialmente para a definição de prioridades na agenda governamental. Para Lindblom (2009, p. 169), "comumente, o ato de decidir é formalizado como uma relação entre meios e fins: concebem-se os meios para que sejam avaliados e escolhidos à luz dos fins, que foram, afinal, eleitos, independente e previamente à escolha dos meios. Esta é a relação entre os meios e os fins do método da raiz".

A relação entre políticas públicas e instituições governamentais é extremamente próxima, o que exige uma análise sobre as interações estratégicas dos atores políticos da tomada de decisão sobre qual política pública deve ser realizada. (Dye, 2009).

Porém, nem sempre os formuladores de políticas possuem capacidade preditiva suficiente, especialmente para prever todas as possíveis consequências de cada proposta. Nem sempre é possível calcular a relação entre custos e benefícios de todas as propostas, principalmente se não há total conhecimento. Sobre o tema, Thomas R. Dye (2009, p. 115) destaca que "uma política inteiramente 'racional' talvez se torne 'ineficiente' (apesar da contradição nos termos) se o tempo e os custos necessários para desenvolvê-la forem excessivos".

Assim, pressupondo a racionalidade dos atores, os administradores das políticas devem chegar a um consenso entre os valores e os objetivos das decisões, para tentar conciliar preferências pessoais e atenção às demandas sociais.

\section{Definindo PRIORIDADES NA AGenda GoVernamental}

Embora grande parcela das ações governamentais sejam incrementais, partindo de programas ou projetos já existentes e aprimorando sua atuação, e apesar da enorme extensão da pesquisa quanto à formulação de políticas públicas, faz-se necessária uma análise mais aprofundada da estratégia utilizada pelos programas de governo, que podem manter os programas ou alterá-los, modificando sua estrutura. (Barry; Barry, 2007).

Para apresentar e discutir modelos teóricos que sejam hábeis a contribuir para a compreensão do processo de construção de políticas públicas, faz-se necessária a abordagem sobre o processo de formação de agendas políticas, justamente porque os modelos de políticas públicas a serem formulados dependem de interesses políticos, contratos firmados entre instituições, momento adequado e objetivos estratégicos bem desenhados para que seja possível conjecturar sua implementação.

True, Baumgartner e Jones (2006) argumentam que as mudanças de decisões individuais e coletivas, incluindo reversões de escolha, não surgem da irracionalidade básica (escolher ir contra as próprias preferências); elas nascem de mudanças na atenção e da escolha estratégica de atores racionais.

Para compreender as políticas públicas, é relevante estudar o processo político de tomada de decisões e a legitimidade do processo de elaboração das iniciativas. Para Diogo de Calasans Melo Andrade (2016, p. 142), "os desafios para implementação das políticas públicas são jurídicos, econômicos e, principalmente, políticos".

A tomada de decisão limitadamente racional constitui base forte para grandes e pequenas mudanças. No caso da formulação de políticas públicas, as bases gêmeas de instituições políticas conservadoras e sobrepostas e tomada de decisão limitadamente racional (especialmente o papel das imagens na atenuação ou exacerbação mobilizações contra interesses instalados) se combinam para criar um sistema que é tanto de natureza conservadora como é suscetível de ocasionais mudanças radicais. 
Sobre os requisitos presentes na agenda política governamental de qualquer país, há dois modelos que merecem especial destaque; o modelo de Múltiplos Fluxos (Multiple Streams Model) elaborado e desenvolvido por John Kingdon, na obra "Agenda, Alternatives a Public Policies" (2003) e o modelo de Equilíbrio Pontuado (Punctuated Equilibrium Model), elaborado e desenvolvido por Frank Baumgartner e Brian Jones, apresentado no livro Agendas and Instability in American Politics (1993). Tais modelos tentam explicar as razões pelas quais a formulação de políticas públicas depende do processo político presente no cenário governamental para que venha a ser implementada. (Capella, 2005, on line).

No livro Agendas, Alternatives e Public Policies (2003), John Kingdon ${ }^{7}$ propõe reflexões que envolvem a razão pela qual alguns problemas se tornam materialmente relevantes para o governo, enquanto outros, talvez de semelhante importância, não são caracterizados da mesma forma.

O Modelo de Múltiplos Fluxos, destacado pelo autor, se orienta pela forma como uma iniciativa se insere no rol de preocupações políticas e pela definição de uma agenda de políticas públicas (agenda-setting), que escolherá a alternativa mais adequada entre muitas possibilidades para a realização de uma política pública (policy formulation). Trata-se de um modelo de referência porque pensa nas causas que originam as políticas públicas, o que se apresenta como essencial em um contexto de escolhas políticas racionais, em que a vontade política e a movimentação de grupos de interesse não pode ser desconsiderada.

Para o John Kingdon (2003), o encaminhamento dado à agenda é o resultado da convergência entre três fluxos: problemas ${ }^{8}$ (problems); soluções ou alternativas ${ }^{9}$ (policies); e políticas ${ }^{10}$ (politics). (Capella, 2005).

Assim, é possível perceber que a convergência desses fluxos é essencial para a materialização de políticas públicas. Conforme enuncia John Kingdon (2003), uma possibilidade de mudança na agenda governamental acontece quando um problema concentra a atenção dos atores políticos (evidenciado por indicadores, eventos ou feedback), ou quando há mudanças dentro na arena política, na chefia de órgãos e de empresas públicas, ou modificações contratuais por parte do governo (turnover). Trata-se de uma articulação de interesses que deve ser tecida sob o olhar da estratégia política, porque é isso que, verdadeiramente, definirá a vida e a longevidade de um projeto de políticas públicas eficiente.

Para ilustrar o modelo que segue a dinâmica de Múltiplos Fluxos e fazer referência ao caso estudado no presente artigo, será realizada a análise do Centro Urbano de Cultura, Arte, Ciência e Esporte de Fortaleza - CUCA, como política pública destinada ao fortalecimento do protagonismo juvenil, resultado de parceria institucional e contratual entre Prefeitura de Fortaleza e Banco Interamericano de Desenvolvimento - BID.

\footnotetext{
7 O autor coloca, ainda, o questionamento sobre a forma como uma iniciativa se insere no rol de preocupações políticas a ponto de convergir atenções e se tornar uma política pública. Inicialmente, o autor destaca as políticas públicas como uma reunião coordenada de processos políticos, que consistem na definição da agenda política, identificação de possibilidades de escolhas quanto às ações que serão realizadas, indicação da alternativa dominante entre essas possibilidades de escolha e, por fim, a implementação da escolha.

8 Segundo define John Kingdon (2003), o primeiro fluxo consiste no reconhecimento de um problema como tal e por qual razão ou conjunto de circunstâncias ele passa a ocupar a agenda governamental, concentrando uma atenção política anteriormente inexistente.

9 Consistem na reunião de um conjunto de alternativas e soluções (policy alternatives) disponíveis para resolver os problemas identificados, colocados para análise da agenda governamental. As alternativas devem ser viáveis e, além disso, devem ser vistas como uma opção consensual de uma determinada comunidade política. (Kingdon, 2003).

10 Trata-se da dimensão política (politics stream), que independe da consideração de condições como problemas ou da análise de alternativas e possíveis soluções, porque possui regras políticas próprias. A vontade política possui uma dinâmica diferente, que se relaciona com os grupos de interesses, com as coalizões partidárias formadas pelo processo de barganha eleitoral e negociações políticas. (Kingdon, 2003).
} 


\section{Análise do caso: Centro Urbano de Cultura, Arte, Ciência e Esporte de Fortaleza - Rede CUCA}

A Prefeitura Municipal de Fortaleza, por meio do Programa Integrado de Políticas Públicas da Juventude de Fortaleza (PIPPJ), inaugurou, em 2009, o Centro Urbano de Cultura, Arte, Ciência e Esporte de Fortaleza - CUCA, durante a gestão da então prefeita Luizianne Lins (hoje, presidente estadual do Partido dos Trabalhadores), com a ideia de promover um espaço de expressão e produção cultural para a juventude residente em regiões vulneráveis na zona metropolitana de Fortaleza.

Segundo informação coletada no portal virtual da Prefeitura Municipal de Fortaleza, a unidade municipal, por meio da Coordenadoria de Juventude e da Secretaria Municipal de Saúde, aprovou em 2009 o financiamento para o ProRedes - conjunto de projetos nas áreas de juventude e saúde. O empréstimo foi aprovado na Comissão de Financiamentos Externos (Cofiex), órgão colegiado integrante da estrutura do Ministério do Planejamento, Orçamento e Gestão, com o Banco Interamericano de Desenvolvimento - BID ${ }^{11}$. (2017, on line).

A ideia de formatar uma política pública direcionada ao protagonismo juvenil foi concebida com o intuito de reduzir a criminalidade juvenil na capital alencarina e estimular a inclusão artística de adolescentes que, até então, não possuíam um espaço de expressão cultural mais próximo das periferias. O objetivo da Rede CUCA consiste no fomento da formação, produção, pesquisa e difusão nas áreas de arte, cultura, ciência e esporte.

Para Oliveira, Souza e Devidé Junior (2015, p. 242), a exclusão é um problema que decorre das desigualdades de renda, "cujas origens são históricas e agravaram-se pelo modelo de desenvolvimento econômico concentrador e pelas diferenças regionais perceptíveis num país de magnitude continental".

A primeira unidade, intitulada CUCA Barra do Ceará, foi construída na Secretaria Executiva Regional $\mathrm{I}^{12}$, com infraestrutura composta por salas de aula, biblioteca, piscina olímpica, espaços de arte, laboratórios de informática e de audiovisual, ilhas de edição, laboratórios de fotografia e usina de reciclagem. Conforme determina o Decreto n ${ }^{\circ} 12.587$ de 23 de outubro de 2009:

Art. $1^{\circ}$. É qualificado como Organização Social o Instituto de Cultura, Arte, Ciência e Esporte - Instituto CUCA, com sede na cidade de Fortaleza, Estado do Ceará, portador do CNPJ no 10.514.191/000163, cujo objetivo é apoiar, incentivar, assistir, desenvolver e promover atividades de formação, lazer e entretenimento nas áreas de cultura, arte, ciência e esporte em Fortaleza.

Essa rede conta com três equipamentos financiados pelo Banco Interamericano de Desenvolvimento e Governo Federal e é coordenado, administrativamente, pelo Instituto CUCA, composto por três equipamentos sociais: o CUCA Barra ${ }^{13}$, CUCA Jangurussu ${ }^{14}$ e CUCA Mondubim ${ }^{15}$, todos, estrategicamente, situa-

11 Conforme dados expostos pela página virtual da Prefeitura de Fortaleza, o "ProRedes foi aprovado com valor total de US\$ 261,9 milhões, sendo 50\% do banco e 50\% de contrapartida da Prefeitura. Antes de submeter a Carta Consulta à Cofiex, o Município de Fortaleza certificou-se com o BID sobre seu interesse no financiamento e sobre as condições financeiras da operação do crédito externo. Preparação do projeto, negociação das minutas contratuais (pré-negociação, negociação com o agente financiador), e providências prévias à contratação da operação de empréstimo externo (aprovação pela diretoria do agente financiador, exposição de Motivos à Presidenta da República e envio de Mensagem ao Senado Federal, com posterior deliberação do Senado Federal e contratação de financiamentos externos)". (2017, on line).

12 Também conhecidas como SERs, as Secretarias Executivas Regionais são unidades político-administrativas criadas em 1997 , que exercem funções como subprefeituras para descentralizar a atuação do Poder Executivo municipal.

13 O CUCA Barra (inauguração: 2009) atende a população residente na Regional I, composta pelos bairros Barra do Ceará, Cristo Redentor, Pirambu, Moura Brasil, Carlito Pamplona, Jacarecanga, Álvaro Weyne, Vila Ellery, Monte Castelo, São Gerardo, Farias Brito, Vila Velha, Jardim Guanabara, Floresta e Jardim Iracema. A Regional I possui população estimada em 400 mil habitantes em $24,2 \mathrm{~km}^{2}$. (2017, on line).

14 O CUCA Jangurussu (inauguração: 2014) atende a população residente na Regional VI, composta pelos bairros Jangurussu, Alto da Balança, Aerolândia, Jardim das Oliveiras, Dias Macêdo, Parque Manibura, Cidade dos Funcionários, Água Fria, Edson Queiroz, Sabiaguaba, Sapiranga, Cambeba, Messejana, Curió, Lagoa Redonda, Barroso, Passaré, Parque Dois Irmãos, Boa Vista, Cajazeiras, Guajeru, Coaçu, São Bento, Paupina, Santa Maria, Conjunto Palmeiras, Pedras e Ancuri. A Secretaria-Executiva Regional VI (SER VI) possui população estimada em 600 mil habitantes em 119,98 km². (2017, on line).

15 O CUCA Mondubim (inauguração: 2014) atende a população residente na Regional V, composta pelos bairros Mondubim, 
dos em bairros de reconhecida vulnerabilidade social da região metropolitana de Fortaleza. A coordenação pelo Instituto CUCA foi prevista pelo Diário Oficial de Fortaleza no 15.483 , publicado em março de 2015, conforme segue:

EXTRATO - ESPÉCIE: Contrato de Gestão no 01/2015 - CUCA - SER V - Mondubim, que entre si celebram o Município de Fortaleza, através do Gabinete do Prefeito, sob a supervisão da Coordenadoria Especial de Políticas Públicas de Juventude, e o Instituto de cultura, arte, ciência e esporte - instituto CUCA. CONTRATANTE: Município de Fortaleza, sob a supervisão da Coordenadoria Especial de Políticas Públicas de Juventude. CONTRATADA: Instituto de Cultura, Arte, Ciência e Esporte CUCA. [...] Valor global do contrato: Para o cumprimento deste Contrato de Gestão com a Prefeitura Municipal de Fortaleza, fica acertado o valor global R $7.591 .128,10$ (sete milhões, quinhentos e noventa e um mil, cento e vinte e oito reais e dez centavos), Fonte 100. [...] VIGÊNCIA: O prazo deste Contrato de Gestão é de 12 (doze) meses, iniciando na data de assinatura do contrato, podendo ser renovado e/ou ter o seu prazo dilatado, depois da demonstrada a consecução dos objetivos estratégicos, das metas estabelecidas e avaliações favoráveis da CEPPJ, de acordo com a legislação vigente e presente instrumento. SIGNATÁRIOS: SECRETÁRIO EXECUTIVO DO GABINETE DO PREFEITO Christian Ferreira Melo e SECRETÁRIO MUNICIPAL DE JUVENTUDE - Julio Brizzi Neto - Pelo CONTRATANTE. DIRETORA PRESIDENTE DO INSTITUTO CUCA - Lara Fernandes Vieira - Pelo CONTRATADO. DATA DA ASSINATURA: 10 de março de 2015.

A Rede CUCA atende uma população com faixa etária compreendida entre 15 a 29 anos $^{16}$, em bairros periféricos na cidade de Fortaleza, com altos índices de vulnerabilidade social e cujas oportunidades de crescimento acadêmico e profissional, tradicionalmente, não se projetam.

Conforme Relatório de Avaliação Intermediária dos Programas de Políticas Públicas para a Juventude do Município de Fortaleza, o projeto possui como objetivo a melhora da capacidade do Município de Fortaleza para formular e executar programas voltados para a juventude, "promovendo as potencialidades juvenis e fomentando o desenvolvimento de alternativas econômicas e sociais baseadas em princípios democráticos e solidários".

De acordo com dados do Programa Integrado de Políticas Públicas da Juventude de Fortaleza (PIPP), o contrato de gestão da Rede CUCA é conduzido por metas anuais da Administração Pública Municipal que estabelecem a quantidade de atendimentos e a qualidade das ações realizadas para o exercício de 2016 (em consonância com o art. 222 da Lei Orgânica do Município de Fortaleza e Projeto de Lei no 0091 de 15 de abril de 2015, que dispõe sobre as diretrizes para a elaboração da Lei Orçamentária de 2016 e dá outras providências).

Pelas informações disponibilizadas pelo portal virtual da Prefeitura de Fortaleza, foram previstos os seguintes investimentos em 2014: para o CUCA Barra do Ceará, orçamento de R \$ 7.300.000,00; para o CUCA Mondubim, orçamento de $\mathrm{R} \$ 5.824 .214,00$ e, para o CUCA do Jangurussu, R $\$$ 5.824.214,00, valores estes oriundos do tesouro municipal, Banco Interamericano de Desenvolvimento e Governo Federal.

Importa destacar que, mesmo após a modificação da gestão administrativa da prefeitura, os projetos tiveram continuidade, resistindo a um dos maiores desafios para a manutenção de políticas públicas; qual seja, a alteração na chefia do Executivo municipal. A ideia do projeto de políticas públicas gerada durante a gestão da então prefeita Luizianne Lins (Partido dos Trabalhadores - PT) entre 2004 a 2011, resistiu a um final de mandato extremamente conturbado ${ }^{17}$ e perdurou quando o novo prefeito eleito, Roberto Cláudio (à época

Genibaú, Conjunto Ceará I, Conjunto Ceará II, Granja Portugal, Granja Lisboa, Bom Jardim, Canindezinho, São José, Manoel Sátiro, Siqueira, Conjunto Esperança, Santa Rosa, Presidente Vargas, Jardim Cearense, Prefeito José Walter e Planalto Ayrton Senna. A Secretaria-Executiva Regional V (SER V) possui população estimada em 570 mil habitantes em 56,11 km². (2017, on line).

16 Faixa etária predominante na cidade de Fortaleza, conforme dados do Censo IBGE 2010. Segundo o referido levantamento, a população masculina na faixa etária de 15 a 29 anos corresponde a 344.942 pessoas, enquanto a população feminina corresponde a 373.671 pessoas, perfazendo um total de 718.613 pessoas em uma população de 2.452 .185 indivíduos; ou seja, aproximadamente $30 \%$ do total da população fortalezense corresponde ao público foco da política pública. (IBGE, 2010).

17 Em 2012, foi divulgado que o índice de rejeição ao mandato da prefeita Luizianne Lins era de 63\% (sessenta e três por cento), 
filiado ao Partido Republicano da Ordem Social - PROS e, atualmente, Partido Democrático Trabalhista PDT), assumiu o cargo (ocupa o cargo desde 2012, com recondução por reeleição em 2016).

Durante a execução da presente pesquisa, verificou-se que não apenas questões políticas envolvem a continuidade do projeto, mas também elementos de ordem contratual. Segundo dados do Relatório Intermediário de Avaliação do Projeto Programa Integrado de Políticas Públicas de Juventude de Fortaleza - PIPPJ (Projeto no 2207/OC-BR), disponibilizado pelo BID, foi autorizada pela Lei $n^{\circ}$ 9.349/2008 ${ }^{18}$ a realização de operação de crédito entre Prefeitura de Fortaleza, BID e Governo Federal na importância de US \$ 30.060.000,00 (trinta milhões e sessenta mil dólares americanos) para o projeto, conforme segue:

FAÇO SABER QUE A CÂMARA MUNICIPAL DE FORTALEZA APROVOU E EU SANCIONO A SEGUINTE LEI: Art. $1^{\circ}$ - Fica o chefe do Poder Executivo Municipal autorizado a realizar operação de crédito externo, até o limite de US\$30.060.000,00 (trinta milhões e sessenta mil dólares americanos), junto ao Banco Internacional de Desenvolvimento (BID), com garantia do Governo Federal, destinado à execução do Programa Integrado de Políticas Públicas de Juventude de Fortaleza. Art. $2^{\circ}$ - A execução do Programa Integrado de Políticas Públicas de Juventude de Fortaleza será realizada pela Unidade de Preparação e Gestão (UPG), regida pelos Decretos no 12.225, de 31 de julho de 2007, e o de no 12.252, de 06 de setembro de 2007. Art. $3^{\circ}$ - O Poder Executivo Municipal incluirá nas propostas orçamentárias anuais as dotações necessárias à cobertura dos encargos financeiros decorrentes da execução desta lei. Art. $4^{\circ}$ - Esta lei entra em vigor na data de sua publicação. PAÇO DA PREFEITURA MUNICIPAL DE FORTALEZA, em 27 de março de 2008. Luizianne de Oliveira Lins - PREFEITA MUNICIPAL DE FORTALEZA.

Assim, resta evidente que o estabelecimento contratual de financiamento entre Prefeitura, Governo Federal e BID vincula a execução da política e recomenda avaliações de resultados, o que, naturalmente, condiciona a gestão municipal ao cumprimento do que foi pactuado. Apesar da mudança de gestão municipal, o contrato determinava a avaliação de impacto ${ }^{19}$ em 2014, o que denota a necessidade de continuidade do programa.

De acordo com Khandker, Koolwal e Samad (2010), a ideia central da avaliação de impacto consiste em isolar os inputs dos outcomes, ou seja: isolar as políticas públicas e verificar seus efeitos sobre resultado, retirando elementos que estão relacionados aos resultados.

O efeito do programa depende da comparação de períodos de implementação, fatores econômicos, sociais etc. (confounders). Deve-se comparar áreas tratadas e áreas não tratadas.

Segundo Rossi, Lipsey e Freeman (2004), para ser efetivo no acesso às melhorias nas condições sociais, um programa precisa de mais que um bom plano de ataque, mas principalmente, ter condições de implementar esse plano, executando suas funções de maneira adequada (o que não é tarefa das mais fáceis, visto que muitos programas sociais convivem com influências adversas que podem vir a comprometer sua execução e, consequentemente, seus resultados).

Assim, justifica-se a necessidade de verificar a adequação dos processos, suas rotinas e a linearidade entre os serviços que propõe e as atividades previstas.

Segundo Scheirer (1994), a avaliação de impacto da política pública verifica no que o programa consiste e, se é ou não entregue conforme o esperado para seus destinatários, o que permite verificar, também, se o programa gera efeitos para esses destinatários.

conforme dados do Ibope, em pesquisa contratada pelo Jornal Diário do Nordeste sobre a sucessão municipal. (MOREIRA, 2017, on line).

18 Fonte: Diário Oficial do Município de Fortaleza no 13.788 , de 02 de abril de 2008.

19 Impacto $=[$ I Beneficiário - I Beneficiário $]-[$ I No-Benef - I No-Benef $]$

$$
20142014 \quad 2014 \quad 2012
$$




\section{Políticas públicas e novos diálogos com a CidAde de ReCIFe}

Em maio de 2015, a convite do Secretário de Segurança Urbana do Recife, Murilo Cavalcanti, abriu-se uma porta de diálogo entre a Prefeitura Municipal de Fortaleza e a Prefeitura Municipal do Recife para a implementação de programas similares de políticas públicas voltadas ao resgate da juventude, razão pela qual se torna útil a verificação quanto à probabilidade de incidência do mesmo fenômeno político em Recife, replicando-se a ideia de uma política pública exitosa em cenários políticos distintos.

Com o objetivo de aproximar iniciativas bem-sucedidas oriundas de políticas públicas voltadas para a juventude, o vice-líder do governo na Assembleia Legislativa de Pernambuco, o deputado estadual Lucas Ramos (Partido Socialista Brasileiro - PSB), chegou a realizar visitas em julho de 2015, portanto, após o contato inicial entre a Prefeitura de Recife e de Fortaleza, aos equipamentos da Rede $\mathrm{Cuca}^{20}$.

Além disso, a apresentação das ações realizadas pela Rede CUCA serve como modelo para o Centro Comunitário da Paz - Compaz (com previsão de conclusão das obras para 2015) na qualidade de programa vinculado à Secretaria de Segurança Urbana e Prefeitura Municipal de Recife.

O Centro Comunitário da Paz - Compaz Governador Eduardo Campos teve sua primeira unidade inaugurada em março de 2016, na comunidade Alto Santa Terezinha, na zona norte da cidade de Recife, com funcionamento de terça a domingo, sendo de terça a sexta, das $9 \mathrm{~h}$ às $18 \mathrm{~h}$, e aos sábados e domingos, das $9 \mathrm{~h}$ às 13h. (Recife, 2017, online). Tal como a Rede CUCA, o Compaz oferece serviços voltados ao estímulo às atividades esportivas, culturais e de resgate social, com o objetivo de incentivar o fortalecimento comunitário.

Além do Compaz da comunidade do Alto Santa Terezinha, já em pleno funcionamento, outras quatros unidades serão entregues em bairros estratégicos da periferia do Recife até 2018: o Centro Comunitário da Paz (Compaz) Escritor Ariano Suassuna, no bairro do Cordeiro; Compaz de Joana Bezerra, Compaz do Ibura e Compaz do Totó. (Recife, 2017, on line).

Esse diálogo entre Rede CUCA e Compaz demonstra, inequivocamente, que há interesse na articulação de ações para a implementação de uma política pública incremental ${ }^{21}$, com base no primeiro modelo, evidenciando que os resultados demonstrados pela Rede CUCA fortalecem a constatação de que se trata de uma política efetiva ao que se propôs.

Cumpre destacar que o governo do Estado do Maranhão, por meio da equipe da Secretaria de Estado Extraordinária da Juventude (Seejuv/MA), em março de 2015, realizou visita técnica aos equipamentos da Rede CUCA, também com o objetivo de verificar a atuação e o impacto das ações junto ao público-alvo, conforme informação do portal do Governo do Estado do Maranhão. (2017, on line).

\section{Análise dos dados}

Para que políticas públicas tenham continuidade, faz-se necessário que os valores sejam consensuais, conciliáveis para os modelos políticos posteriores, justamente para que seja possível compor a agenda de ações e suscitar espaço no planejamento estratégico da gestão pública ao longo do tempo.

Escolher pela continuidade de uma política pública consiste em uma decisão incremental, que persiste e se acomoda sob vias conciliáveis mesmo que os atores políticos não concordem integralmente que essa

20 http://blogdofinfa.com.br/2015/07/lucas-ramos-visita-rede-cuca-em-fortaleza.html

21 De acordo com Thomas R. Dye (2009, p. 115 e 116), "O incrementalismo vê a política pública como uma continuação das atividades de governos anteriores com apenas algumas modificações incrementais [...] o incrementalismo é politicamente conveniente. $\mathrm{Na}$ formulação de políticas, os acordos são mais facilmente alcançados quando os itens em discussão consistem apenas de acréscimos ou decréscimos nos orçamentos ou de modificações nos programas existentes". 
decisão seja o meio mais apropriado para o objetivo acordado. (Lindblom, 2009).

Para John Gerring (2008), os estudos de caso devem considerar a utilização de um ou mais casos para gerar inferências causais relativas a uma população mais ampla, justamente para atingir um número mais significativo.

Esses desenhos de pesquisa estão, assim, conectados ao problema metodológico da seleção dos casos $^{22}$.

Trata-se de um desenho de pesquisa com número médio de casos para a produção de inferências causais, visto que a tese pretende abordar as razões pelas quais uma política pública específica se manteve em mandatos governamentais diferentes, utilizando como parâmetro de comparação os resultados da política observada no município de Fortaleza.

Para dar início à análise, é necessário verificar se o caso em tela reflete êxito suficiente para que se torne alvo de estudo e consideração para replicar as ações realizadas. Para tal, será verificado o número de atendimentos registrados nos cursos e iniciativas propostas pela Rede CUCA:

Tabela 1. Número de pessoas atendidas pela Rede Cuca

\begin{tabular}{|l|l|l|}
\hline Gestão Municipal & Período & Número de Beneficiados \\
\hline \multirow{4}{*}{$\begin{array}{l}\text { Luizianne Lins (Partido dos Tra- } \\
\text { balhadores - PT) }\end{array}$} & 2009 & 20.387 \\
\cline { 2 - 3 } & 2010 & 19.589 \\
\cline { 2 - 3 } & 2011 & 59.180 \\
\cline { 2 - 3 } & 2012 & 73.058 \\
\hline \multirow{4}{*}{$\begin{array}{l}\text { Roberto Cláudio Bezerra (Partido } \\
\text { Democrático Trabalhista - PDT) }\end{array}$} & 2013 & 105.295 \\
\cline { 2 - 3 } & 2014 & 197.627 \\
\cline { 2 - 3 } & 2015 & $49.008^{1}$ \\
\hline
\end{tabular}

Fonte: Elaboração própria. Dados fornecidos pelo Relatório de Atividades da Rede Cuca - Coordenadoria da Juventude / Prefeitura Municipal de Fortaleza (2017, on line)

Pela análise da Tabela 1, é possível perceber que o número de pessoas atendidas pela Rede CUCA é crescente, com breve alteração entre os anos de 2009 e 2010, mas com significativo aumento quantitativo a partir de 2011, com continuidade do crescimento na gestão política posterior, liderada por um burocrata oriundo de um partido diferente, com agendas e missões distintas das iniciativas propostas pelo partido da gestão municipal anterior.

Ao final do período analisado, constata-se um total de 524.144 atendimentos, o que identifica grande adesão da população-alvo da iniciativa e tendência à credibilidade do programa e de suas ações, uma vez que, mesmo que tenha havido evasão, os dados demonstram crescimento dos atendimentos, independentemente dos partidos à frente da gestão política.

A seguinte ilustração demonstra que a atual gestão municipal da Prefeitura de Fortaleza conseguiu alavancar o número de atendimentos, especialmente durante o primeiro ano de exercício político, o que traduz a possibilidade de maiores investimentos na política pública e reflete os resultados da replicação da iniciativa em outros dois centros especializados (Rede CUCA Mondubim e Rede CUCA Jangurussu):

22 A escolha do estudo de caso se propõe a gerar informação relativa ao contexto de um modo mais específico, permitindo a construção de teorias e hipóteses relevantes. 
Gráfico 1: Número de pessoas atendidas pela Rede CUCA (período: 2009 a 2015)

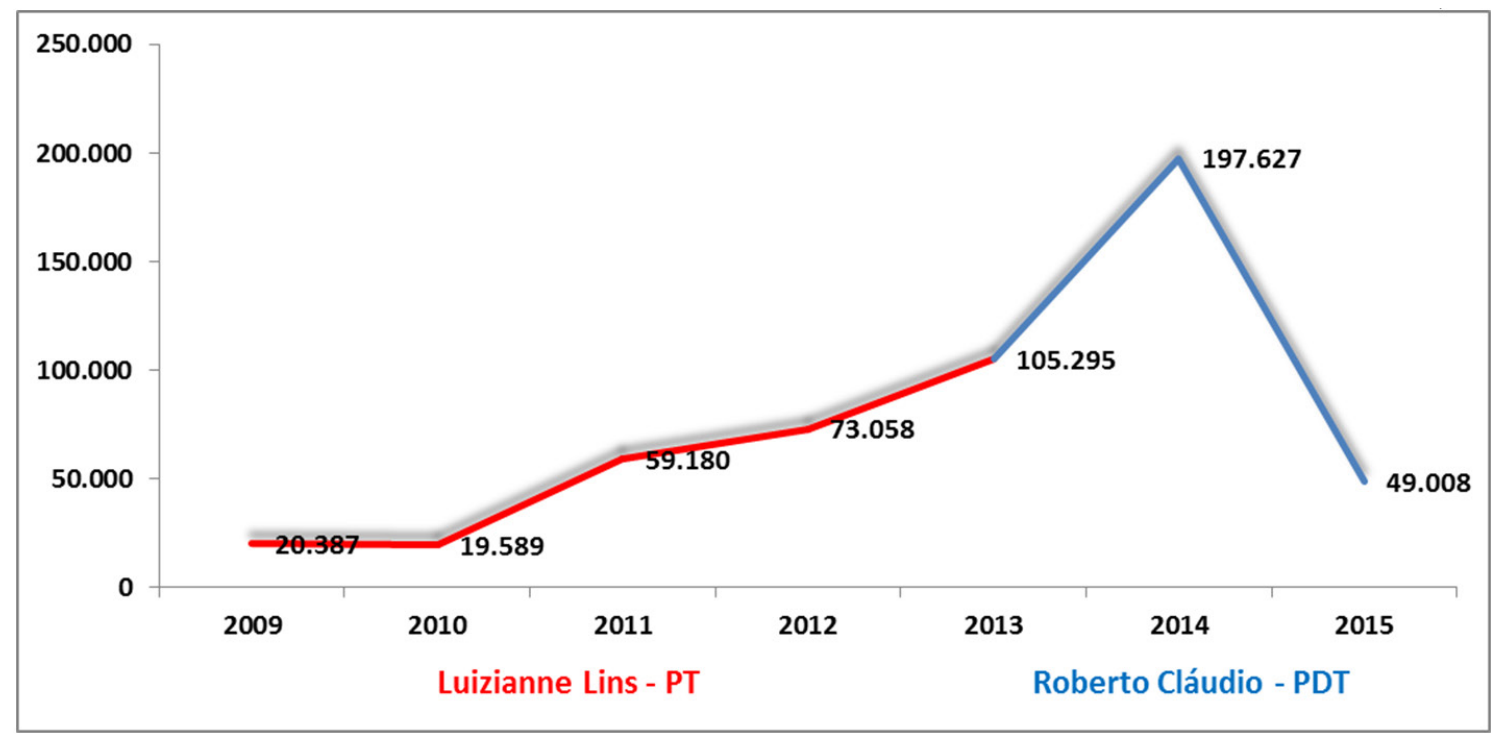

Fonte: Elaboração própria. Dados fornecidos pelo Relatório de Atividades da Rede Cuca - Coordenadoria da Juventude / Prefeitura Municipal de Fortaleza (2017, on line)

A oscilação entre os resultados alcançados, com estimativa de evolução a partir da mudança na gestão municipal (Eleições Prefeitura Municipal em 2012) se relaciona com o crescimento do número de unidades dos equipamentos CUCA e ao aporte de investimentos destinados ao incremento das políticas.

Os períodos destacados representam duas gestões municipais diferentes; de 2009 até o final de 2012, sob a administração da prefeita Luizianne Lins (PT) e, entre 2013 até 2015 (data em que os dados foram compilados), sob a administração do prefeito Roberto Cláudio (PDT).

Gráfico 2: Investimentos Rede CUCA (período: 2009 a 2015)

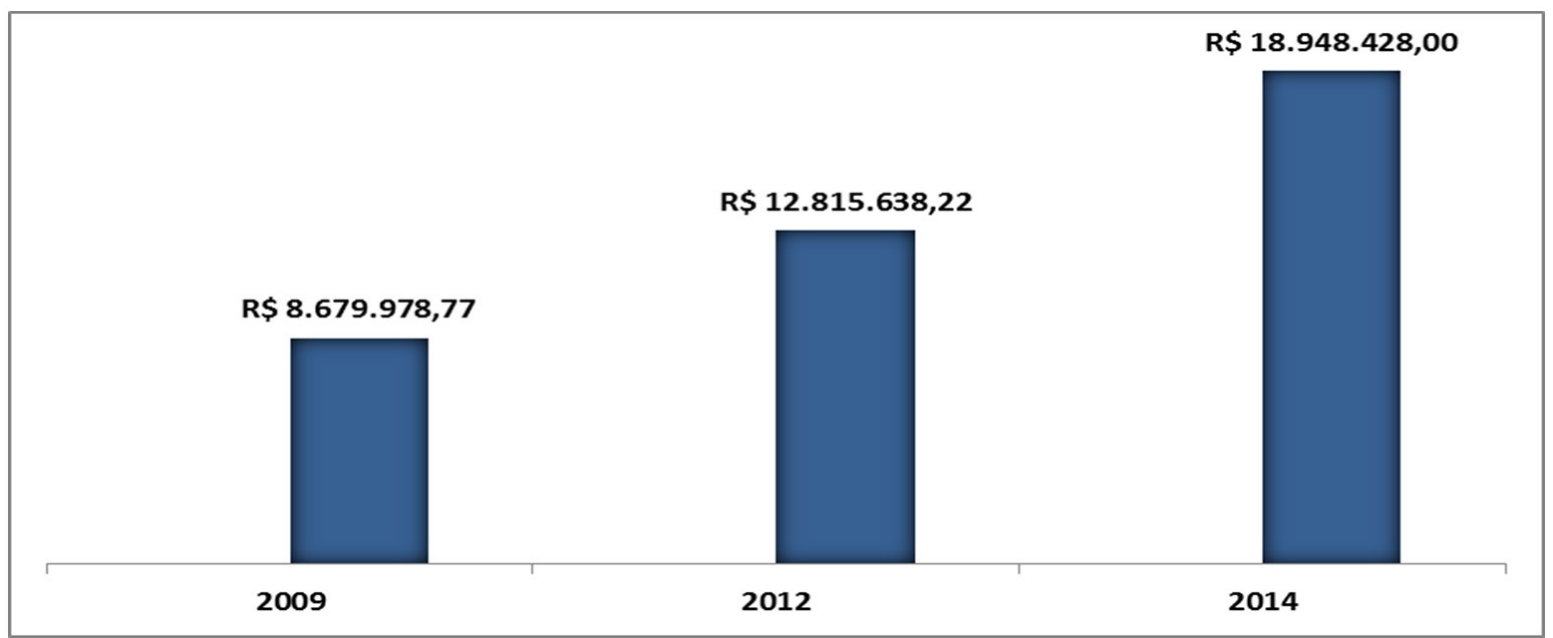

Fonte: Elaboração própria. Dados obtidos com base no Relatório Intermediário de Avaliação do Projeto Programa Integrado de Políticas Públicas de Juventude de Fortaleza- PIPPJ (Projeto nº 2207/OC-BR)

É necessário esclarecer que em 2009, os investimentos eram destinados, apenas, ao CUCA Barra do Ceará; em 2012, às unidades Barra do Ceará e Jangurussu (à época, em construção) e, em 2014, aos CUCAs 
Barra do Ceará, Jangurussu e Mondubim. Proporcionalmente, os investimentos foram reduzidos em 2012 (transição política do PT para o PROS) e, sensivelmente, diminuídos em 2014, conforme segue:

Gráfico 3: Detalhamento de investimentos Rede CUCA por unidade (período: 2009 a 2015)

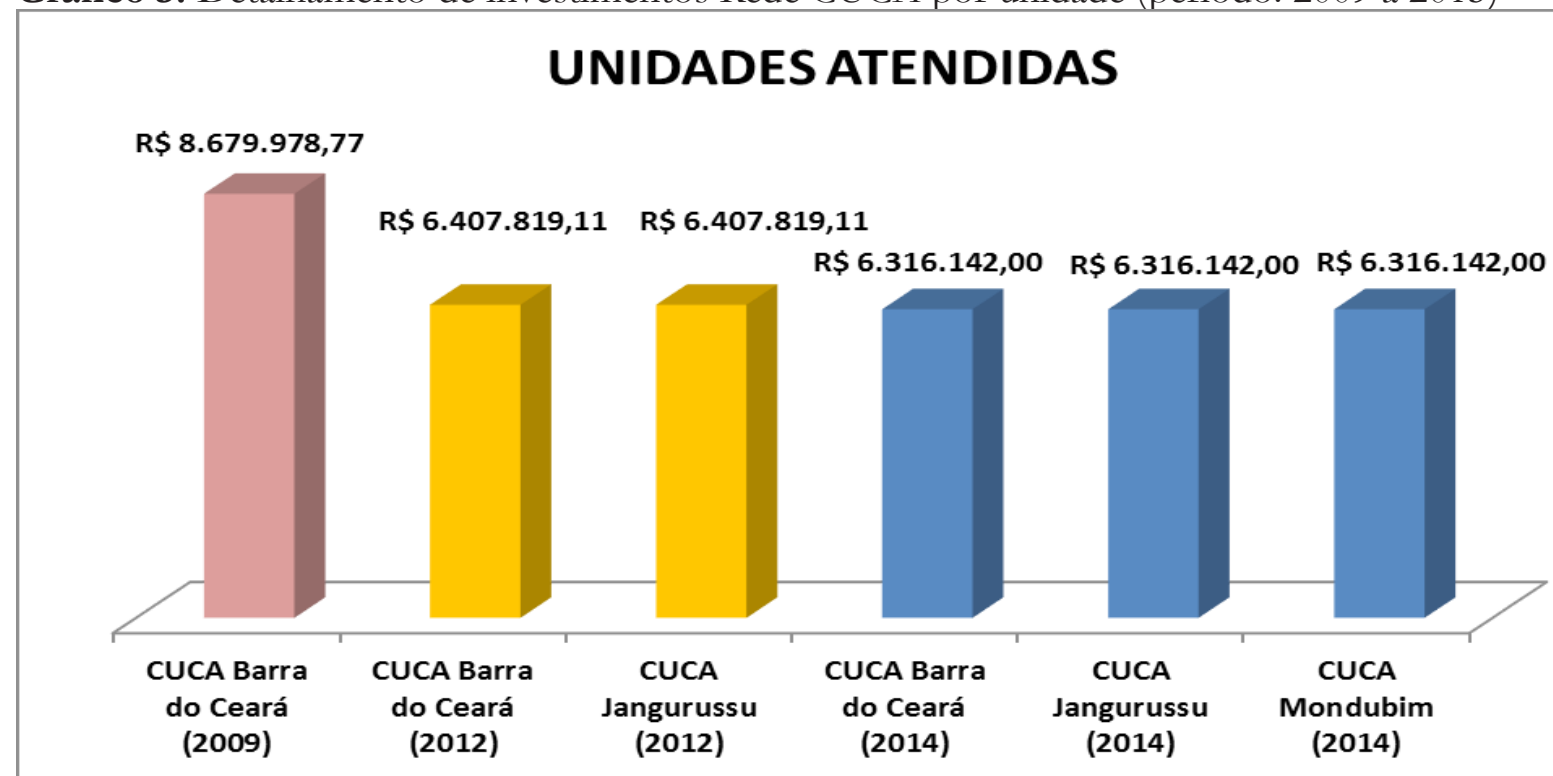

Fonte: elaboração própria. Com base nos dados obtidos pelo Relatório Intermediário de Avaliação do Projeto Programa Integrado de Políticas Públicas de Juventude de Fortaleza- PIPPJ (Projeto nº 2207/OC-BR).

A partir da análise do Gráfico 3, verifica-se redução nos investimentos por unidade da Rede CUCA, o que, em comparação aos gráficos e tabelas anteriores, não impactou a quantidade de atendimentos realizados. Em 2009, o CUCA Barra do Ceará recebeu aportes de R \$ 8.679.978,77, importância reduzida em 2014, quando a mesma unidade recebeu investimentos no valor de $\mathrm{R} \$ 6.316 .142,00$.

Em 2012, o CUCA Jangurussu recebeu a importância de R \$ 6.4007.819,11, enquanto, em 2014, a mesma unidade recebeu valor inferior R \$ 6.316.142,00. Destaque-se que, proporcionalmente, não houve redução no número de atendimentos, portanto, não houve prejuízo quantitativo de atendimento nas ações realizadas pelo programa.

A iniciativa, com altos investimentos, denota não apenas a continuidade com base nos resultados demonstrados, mas também a manutenção de suas ações na agenda política em razão do necessário cumprimento dos contratos firmados entre os entes institucionais.

Conforme enunciado por John Kingdon (2003), a possibilidade de mudança na agenda governamental ocorre na medida em que um fenômeno atrai a atenção dos atores políticos, ou quando o próprio cenário político se modifica. Verifica-se, assim, a existência de articulação de interesses que deve ser observada sob a perspectiva da estratégia política racional, que definirá a duração e replicação de um projeto de políticas públicas eficiente. 


\section{Conclusão}

Cumpre destacar que as tentativas de acesso aos dados referentes às políticas públicas realizadas no Município de Fortaleza foram realizadas com periodização compreendida entre 2009 e 2015, incluindo-se nessa busca o valor orçamentário destinado à execução das políticas. Foram visitados sites atualizados do Tribunal de Contas do Estado do Cearáa ${ }^{23}$, Câmara Municipal de Fortaleza ${ }^{24}$, Portal da Transparência ${ }^{25}$, Prefeitura Municipal de Fortaleza ${ }^{26}$ e site da Coordenadoria da Juventude de Fortaleza ${ }^{27}$.

A partir dos dados coletados, foi possível verificar que os resultados positivos evidenciam a intenção para a continuidade das políticas implementadas, mas não justificam o fato de que a política foi replicada. A força motriz essencial para que a iniciativa fosse replicada se encontra no contrato realizado com o Banco Interamericano de Desenvolvimento e o compromisso institucional firmado pela gestão municipal anterior, devendo ser continuado pela gestão municipal atual. Segundo relatado no portal da Prefeitura de Fortaleza, já existem negociações com o Banco Interamericano de Desenvolvimento quanto ao processo de financiamento de três novas sedes do CUCA. A ideia é que cada regional de Fortaleza possua um equipamento social $^{28}$.

Assim, foi possível concluir, conforme dados levantados, que há relação subjacente entre a manutenção de políticas por uma gestão governamental diferente e os interesses presentes no momento político, e que o Centro Urbano de Cultura, Arte, Ciência e Esporte de Fortaleza - Rede CUCA, na qualidade de política pública analisada pelo presente estudo, teve continuidade na cidade de Fortaleza em razão não apenas dos resultados apresentados, atestando a hipótese de que a manutenção na agenda também se relaciona com os outcomes encontrados, mas também pelo necessário dever contratual firmado pelo compromisso entre a Prefeitura Municipal de Fortaleza e o Banco Interamericano de Desenvolvimento, evidenciando a interação estratégica presente na tomada de decisão dos atores políticos.

\section{REFERÊNCIAS BIBLIOGRÁFICAS}

ANDRADE, Diogo de Calasans Melo. Políticas públicas, mínimo existencial e Poder Judiciário: a questão do direito à moradia. In: Revista Brasileira de Políticas Públicas, vol. 6, n. 1, p. 151-166, jan./ jul. 2016.

BERRY, Frances Stokes; BERRY, William D. Innovation and diffusion models in policy research. In: SABATIER, P. Theories of the policy process. Boulder: Westview Press, 2007.

CAPELLA, Ana Cláudia Niedhardt. Formação da Agenda Governamental: Perspectivas Teóricas. Disponível em: <http://www.anpocs.org/portal/index.php?option=com_docman\&task=doc_ view\&gid=3789\&Itemid=318>. Acesso em: 26 jun. 2017.

DOWNS, Anthony. Uma teoria econômica da democracia. São Paulo: EdUSP, 1999.

DYE, Thomas R. Mapeamento dos modelos de análise de políticas públicas. In: HEIDEMANN, Francisco G.; SALM, José Francisco. Políticas públicas e desenvolvimento: bases epistemológicas e modelos de análise. Brasília: Universidade de Brasília, 2009, p. 99-132.

\footnotetext{
23 http://www.tce.ce.gov.br/

24 http://www.cmfor.ce.gov.br/

25 http://portaldatransparencia.cmfor.ce.gov.br/

26 http://www.fortaleza.ce.gov.br/

27 http://www.fortaleza.ce.gov.br/juventude

28 Os locais escolhidos são a Lagoa do Opaia (Regional IV), o Pici (Regional III), que será construído dentro do campus da Universidade Federal do Ceará - UFC; e na Regional II, ainda sem local definido.
} 
EVANS, Peter B.; RUESCHMEYER, Dietrich; SKOCPOL, Theda. Bringing the state back. Cambridge: Cambridge University Press, 1985.

FORTALEZA. Assembleia Legislativa. Projeto de Lei no 0091 de 15 de abril de 2015. Dispõe sobre as diretrizes para a elaboração da Lei Orçamentária de 2016 e dá outras providências. Diário Oficial de Fortaleza. Disponível em: < http://216.59.16.201:8080/sapl/sapl_documentos/materia/22702_texto_integral>. Acesso em: 20 mar. 2017.

Decreto n 12.587 de 23 de outubro de 2009. Qualifica como Organização Social o Instituto de Cultura, Arte, Ciência e Esporte - Instituto CUCA. Diário Oficial de Fortaleza no 14.179. Disponível em: $<\quad$ http://www.fortaleza.ce.gov.br/sites/default/files/arquivos/diariosoficiais/2009/11/06112009\%20 -14179.pdf>. Acesso em: 20 mar.2017.

Diário Oficial do Município de Fortaleza no 15.483, de 13 de março de 2015. Disponível em: <http://www.fortaleza.ce.gov.br/sites/default/ files/arquivos/diariosoficiais/15/05/suplemento_-_13032015_-_15483.pdf>. Acesso em: 20 mar. 2016.

Diário Oficial do Município de Fortaleza nº 13.788, de 02 de abril de 2008. Disponível em: <http:// www.fortaleza.ce.gov.br/sites/default/files/arquivos/diariosoficiais/2008/04/dom13788.pdf>. Acesso em: 28 jun. 2017.

GEDDES, Barbara. Politician's dilema: building state capacity in Latin América. Los Angeles: University of California Press, 1996.

GERRING, John. Case selection for case-study analysis: qualitative and quantitative techniques. In: Janet M.; BRADY, Henry F. \& COLLIER, David (eds.). The Oxford handbook of political methodology. Oxford: Oxford University Press, 2008.

HEIDEMANN, Francisco G. Do sonho de progresso às políticas de desenvolvimento. In: HEIDEMANN, Francisco G.; SALM, José Francisco. Políticas públicas e desenvolvimento: bases epistemológicas e modelos de análise. Brasília: Universidade de Brasília, 2009, p. 21-39.

HOWLETT', Michael; RAMESH, M.; PERL, Anthony. Politica pública: seus ciclos e subsistemas, uma abordagem integral. 3 ed. Tradução: Francisco G. Heidemann. Rio de Janeiro: Elsevier, 2013.

IBGE. Diretoria de Pesquisas.Coordenação de População e Indicadores Sociais - COPIS. 2015. Disponível em: $\quad<$ http://cidades.ibge.gov.br/xtras/perfil.php?lang $=\&$ codmun $=230440 \&$ search $=$ ceara $\mid$ fortaleza $>$. Acesso em: 02 mar. 2017.

MOREIRA, Roberto. Gestão de Luizianne Lins é desaprovada por 63\% dos eleitores. Disponível em: < http:// blogs.diariodonordeste.com.br/robertomoreira/gestao-de-luizianne-lins-e-desaprovada-por-63-dos-eleitores/>. Acesso em: 28 jun. 2017.

JONES, Bryan D. Behavioral rationality as a foundation for public policy studies. In: Cognitive Systems Research, Texas, v. 43, p. 63-75, June 2017.

KHANDKER, Shahidur R; KOOLWAL, Gayatri B.; SAMAD, Hussain A. Handbook on impact evaluation: quantitative methods and practices. World Bank, 2010.

KINGDON, John. Agendas, Alternatives and Public Policies, 3. ed. New York: Harper Collins. 2003.

LINDBLOM, Charles E. Muddling through. In: Políticas públicas e desenvolvimento: bases epistemológicas e modelos de análise / Francisco G. Heidemann e José Francisco Salm, (Org.). Brasília: Editora Universidade de Brasília, 2009.

OLIVEIRA, Nadja Simone Menezes Nery de; SOUZA, Solange de Cassia Inforzato de; DEVIDÉ JUNIOR, Aricieri. Políticas públicas, mínimo existencial e Poder Judiciário: a questão do direito à moradia. In: Revista Brasileira de Políticas Públicas, vol. 5, n. 3, p. 241-263, jul. / dez. 2015. 
OLSON, Mancur. A lógica da ação coletiva. Tradução: Fabio Fernandez. São Paulo: Editora da Universidade de São Paulo, 1999.

PREFEITURA MUNICIPAL DE FORTALEZA. Secretaria Regional. Disponível em: <http://www.fortaleza.ce.gov.br/regionais/regional-centro>. Acesso em: 22 jun. 2017.

Prefeitura garante financiamento do BID para projetos nas áreas da saúde e juventude. Disponível em: $<$ http://www.fortaleza.ce.gov.br/noticias/destaque/prefeitura-garante-financiamento-do-bid-para-projetos-nas-areas-da-saude-e>. Acesso em: 02 jun. 2017.

PREFEITURA MUNICIPAL DE RECIFE. Notícias Compaz. Disponível em: < http:/ /www2.recife.pe.gov. $\mathrm{br} /$ noticias/recife-ganhara-o-primeiro-compaz-ainda-este-ano>. Acesso em: 19 mar. 2017.

Portal da transparência. Disponível em: <http://transparencia.recife.pe.gov.br/codigos/web/despesas/despesaDetalhadaUnidadeGestora.php\#result>. Acesso em: 19 mar. 2017.

RECIFE. Prefeitura Municipal de Recife Centro Comunitário da Paz - Compaz. Disponível em: < http://www2. recife.pe.gov.br/servico/compaz>. Acesso em: 20 jul. 2017.

REZENDE, Flávio da Cunha. A Nova Gestão Pública e Transformações Recentes na Administração Pública Paulista. 2006. Disponível em: < http://www.bresserpereira.org.br/terceiros/06.9.Rezende,Flavio-NovaGestaoPublica.pdf>. Acesso em: 10 abr. 2017.

ROSSI, Peter H.; LIPSEY, Mark W.; FREEMAN, Howard E. Evaluation: a systematic approach. 7th edition. SAGE Publications, 2004.

SCHEIRER, Mary Ann. Designing and using process evaluation. In: WHOLEY, J. S; HATRY, H. P., NEWCOMER. K., E (Ed.). Handbook of practical evaluation. San Francisco: Jossey-Bass, p. 40-68, 1994.

SIMON, Herbert A. Modelo comportamental de decisão racional. In: HEIDEMANN, Francisco G.; SALM, José Francisco. Políticas públicas e desenvolvimento: bases epistemológicas e modelos de análise. Brasília: Universidade de Brasília, 2009, p. 133-160.

SOUZA, Celina. Estado da arte da pesquisa em políticas públicas. In: HOCHMAN, Gilberto; ARRETCHE, Marta; MARQUES, Eduardo. (Org.). Políticas públicas no Brasil. Rio de Janeiro: Editora Fiocruz, 2007.

STIGLER, George. The theory of economic regulation. Chicago: University of Chicago, 1971.

STOKES, Susan C. What do policy switches tell us about democracy? In: PRZEWORSKI, Adam; STOKES, Susan C.; MANIN, Bernard. (Coord.) Democracy, accountability and representation. New York: Cambridge University Press, 1999.

TRUE, James L.; BAUMGARTNER, Frank R.; JONES, Bryan D. Punctuated-Equilibrium Theory Explaining Stability and Change in Public Policymaking. In: Theories of the policy process. 2006.

TSEBELIS, George. Jogos ocultos: escolha racional no campo da política comparada. Trad: Luiz Paulo Rouanet. São Paulo: Universidade de São Paulo, 1998.

(Footnotes)

1 Dados parciais de janeiro a maio de 2015. 


\section{REVISTA BRASILEIRA DE POLÍTICAS PÚBLICAS BRAZILIAN JOURNAL OF PUBLIC POLICY}
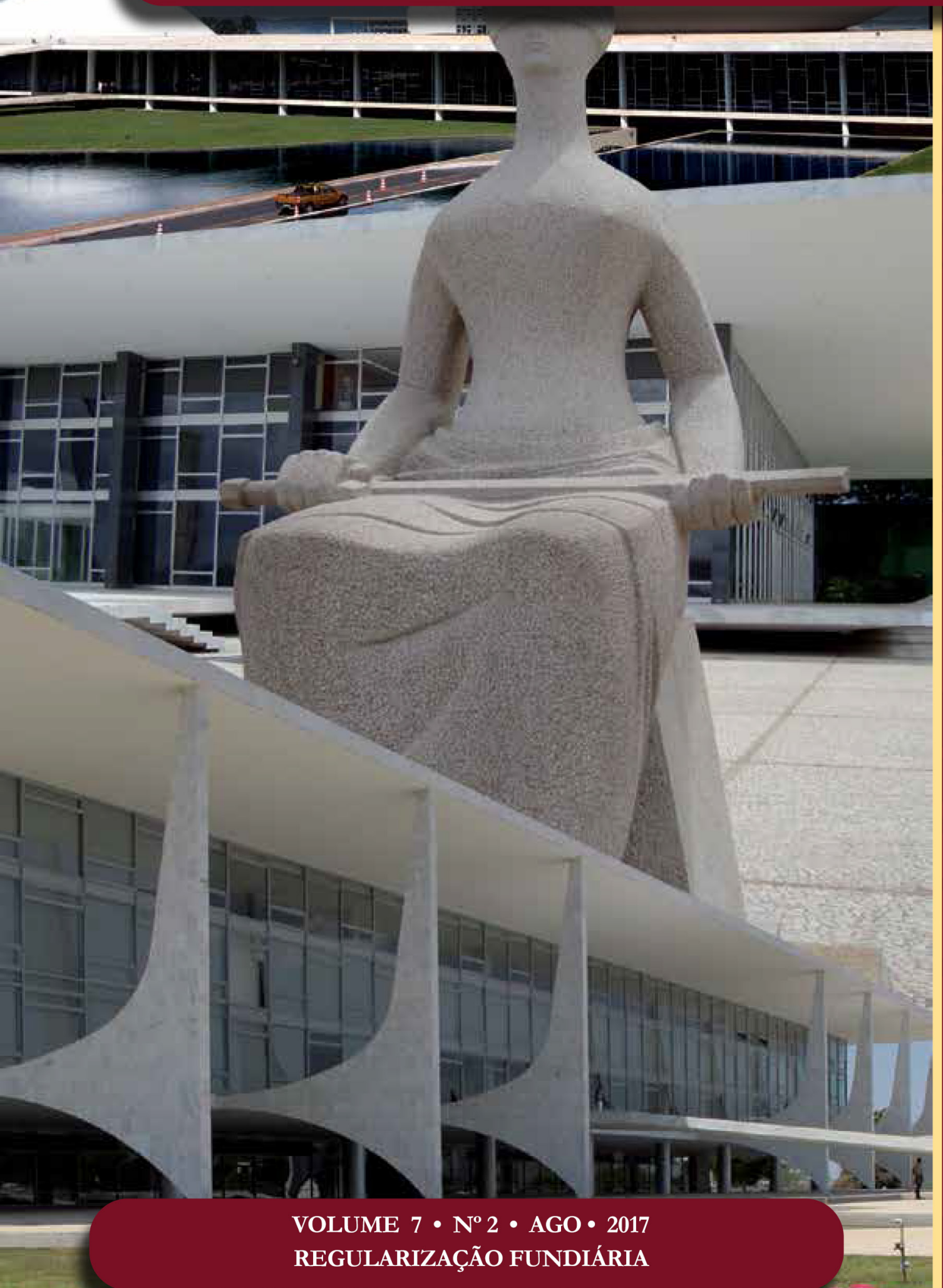

0 acesso à água potável como parcela do mínimo existencial: reflexões sobre a interrupção do serviço público de abastecimento de água por inadimplemento do usuário

Access to potable water as part of the existential minimum: reflections about the interruption of the potable water supply public service by user's default

Augusto César Leite de Resende 


\title{
O acesso à água potável como parcela do mínimo existencial: reflexões sobre a interrupção do serviço público de abastecimento de água por inadimplemento do usuário*
}

\author{
Access to potable water as part of the \\ existential minimum: reflections about the \\ interruption of the potable water supply public \\ service by user's default
}

Augusto César Leite de Resende**

\section{Resumo}

A água é elemento constitutivo da vida, essencial para a composição dos seres vivos e as suas funções biológicas e bioquímicas são indispensáveis para a manutenção da própria vida com dignidade, daí reconhecer-se que o acesso à água é um direito decorrente do direito fundamental ao mínimo existencial, que deverá ser efetivado, dentre outras formas, por meio da prestação do serviço público de abastecimento de água potável, o qual se submete ao princípio da continuidade. Porém, a legislação admite a interrupção da prestação do serviço público por inadimplemento do usuário. Nesse toar, o presente trabalho científico tem como objetivo principal propor, a partir de uma pesquisa dedutiva, doutrinária e legislativa, que a suspensão do serviço de abastecimento de água potável por inadimplemento do usuário doméstico em razão de circunstâncias involuntárias ou insuperáveis não pode ser total, no sentido de que sejam garantidos pelo menos cinquenta litros de água por pessoa ao dia, sob pena de restrição ilegítima ao mínimo existencial.

Palavras-chave: Mínimo existencial. Acesso à água. Serviço de abastecimento de água. Inadimplemento do usuário. Suspensão parcial.

\section{Abstract}

Recebido em 15/07/2017 Aprovado em 06/08/2017

** Doutorando em Direito pela Pontifícia Universidade Católica do Rio Grande do Sul PUCRS. Mestre em Direito pela Pontifícia Universidade Católica do Paraná - PUCPR. Especialista em Direito Público pela Universidade Sul de Santa Catarina - UNISUL. Professor de Direito Constitucional da FANESE. Promotor de Justiça em Sergipe. Email: augusto@mpse.mp.br

Water is a constitutive element of life, essential in the composition of living beings and its biological and biochemical functions are indispensable for the maintenance of life itself, hence it is recognized that access to water is a right deriving from the fundamental right to the existential minimum, which should be carried out, among other forms, through the provision of the water supply public service, which is subject to the principle of continuity. However, the legislation admits the interruption of the provision of the public service due to the user's default. Therefore, this article aims to propose, from a deductive, doctrinal and legislative research, That the suspension of the drinking water supply service due to domestic user default due to 
involuntary or insurmountable circumstances cannot be total, in the sense that they are guaranteed at least fifty liters of water per person per day, under penalty of illegitimate restriction to the existential minimum.

Keywords: Existential minimum. Access to water. Water supply service. User's defaults. Partial suspension.

\section{INTRODUÇÃo}

O Fundo das Nações Unidas para a Infância (UNICEF) e a Organização Mundial da Saúde (OMS) sustentam que, aproximadamente, um bilhão e oitocentas milhões de pessoas não têm acesso seguro à água com condições mínimas para o consumo humano, sendo obrigadas, com isso, a viver em escassez hídrica e com baixa qualidade de vida, notadamente os mais pobres.

A água é elemento constitutivo da vida. Ela é essencial para a composição dos seres vivos e as suas funções biológicas e bioquímicas são indispensáveis para a manutenção da própria vida. Vale dizer, o acesso à água potável é, absolutamente, necessário para a garantia da própria existência humana com dignidade, razão pela qual é compreendido como um específico direito decorrente do direito fundamental ao mínimo existencial.

Assim, as pessoas têm direito à água potável, fisicamente acessível, a preços razoáveis para usos pessoais e domésticos e em quantidade mínima adequada para prevenir a morte por desidratação, reduzir o risco de doenças e satisfazer as necessidades pessoais e domésticas de higiene, competindo ao Estado o dever de promover as medidas administrativas e legislativas necessárias à concretização do direito à água, dentre as quais se destaca a prestação do serviço público de abastecimento de água potável.

O referido serviço público obedece ao princípio da continuidade, de modo que a sua prestação deve ser perene, não podendo ser interrompida ou paralisada. Por outro lado, não caracteriza, em tese, descontinuidade ilícita do serviço a sua suspensão, após prévio aviso, por inadimplemento do usuário, conforme o disposto no art. 40, inciso V, da Lei N. 11.445/2007, mormente porque os serviços de saneamento básico são de alto custo.

Nesse contexto, o presente trabalho científico tem como objetivo principal propor que a suspensão do serviço de abastecimento de água potável por inadimplência do usuário doméstico em razão de circunstâncias involuntárias ou insuperáveis não pode ser total, no sentido de que sejam garantidos pelo menos cinquenta litros de água por pessoa ao dia, sob pena de restrição ilegítima ao mínimo existencial.

Analisar-se-á a abertura material do catálogo de direitos fundamentais ao mínimo existencial. Em seguida, tratar-se-á do acesso à água potável como parcela do mínimo existencial. Por fim, refletir-se-á sobre a possibilidade interrupção do serviço público de abastecimento de água potável e os seus limites à luz dos preceitos constitucionais.

Para tanto, utilizar-se-á o método dedutivo, partindo-se de argumentos gerais, aceitos como verdadeiros, para, em seguida, chegar à proposição objetivada na presente pesquisa científica. A tipologia de pesquisa foi a bibliográfica e a documental, mediante análise da legislação em vigor e de material doutrinário já publicado, especialmente livros, teses e artigos científicos.

\section{Direito fundamental aO MíNIMO EXISTENCIAL}

Os direitos fundamentais podem ser classificados em: direitos formalmente fundamentais e direitos materialmente fundamentais. A fundamentalidade formal dos direitos está, na lição de Ingo Wolfgang Sarlet, diretamente relacionada ao direito constitucional positivo e resulta do regime jurídico especial de proteção 
estabelecido pela Constituição ${ }^{1}$, regime este que os alça à condição de direitos de natureza constitucional, de limites ao poder constituinte derivado reformador e de normas diretamente aplicáveis² ${ }^{2}$.

Os direitos fundamentais meramente formais são aqueles reconhecidos como tais pela Carta Magna ${ }^{3}$, independentemente de seu conteúdo ${ }^{4}$. Nesse sentido, tem-se que são direitos formalmente fundamentais, embora alguns, também, sejam materialmente fundamentais, os positivados no Título II da Constituição Federal de 1988, quais sejam: a) direitos e deveres individuais; b) direitos e deveres coletivos; c) direitos sociais; d) direitos à nacionalidade e e) direitos políticos.

De qualquer forma, o rol do referido Título II da Carta Magna não é taxativo, de modo que existem direitos material e formalmente fundamentais dispersos na Constituição, vale dizer, para além dos artigos $5^{\circ}$ a 17 do Texto Constitucional ${ }^{5}$. Os direitos fundamentais não são, apenas, aqueles consagrados e reconhecidos, formalmente, na Constituição, uma vez que esta admite a existência dos chamados direitos materialmente fundamentais, que poderão ser identificados com base no conceito aberto de direitos fundamentais adotado pelo art. $5^{\circ}, \mathbb{\Omega} 2^{\circ}$, da Constituição Federal.

Tal dispositivo constitucional possibilita o reconhecimento de direitos fundamentais positivados em outras partes do texto constitucional ou em tratados internacionais e até mesmo na identificação de direitos fundamentais não escritos, sejam eles implícitos na Carta Magna ou decorrentes do regime e princípios adotados por ela, Constituição ${ }^{6}$.

A definição de direito fundamental, proposta por Ingo Wolfgang Sarlet ${ }^{7}$, permite ao intérprete a identificação e, consequentemente, a efetivação e a proteção de direitos formal e materialmente fundamentais, direitos apenas formalmente fundamentais e direitos fundamentais exclusivamente materiais.

Porém, a identificação e a caracterização de um direito dotado de fundamentalidade material não são tarefas fáceis para o intérprete e aplicador do direito, pois não decorrem, apenas, da simples leitura do texto constitucional, uma vez que "somente uma análise do seu conteúdo permite a verificação de sua fundamentalidade material"s.

Assim, reconhecem-se direitos que, apesar de não positivados formalmente no rol do Título II da Constituição Federal, por seu conteúdo, importância e significado, podem ser considerados fundamentais e, por isso mesmo, inseridos na Carta Constitucional, produzindo todos os efeitos jurídicos?.

A regra do art. $5^{\circ}, \int 2^{\circ}$, da Constituição da República traduz a ideia de que, além de um conceito formal de Constituição, há um conceito material ${ }^{10}$, no sentido de que a constitucionalização contemporânea do direito, fortemente influenciada pelo pós-positivismo, não se limita ao texto formal e expresso da Cons-

1 SARLET, Ingo Wolfgang. A eficácia dos direitos fundamentais: uma teoria geral dos direitos fundamentais na perspectiva constitucional. 12. ed. Porto Alegre: Livraria do Advogado, 2015. p. 78.

2 SARLET, Ingo Wolfgang. A eficácia dos direitos fundamentais: uma teoria geral dos direitos fundamentais na perspectiva constitucional. 12. ed. Porto Alegre: Livraria do Advogado, 2015. p. 75-76.

3 SARLET, Ingo Wolfgang. A eficácia dos direitos fundamentais: uma teoria geral dos direitos fundamentais na perspectiva constitucional. 12. ed. Porto Alegre: Livraria do Advogado, 2015. p. 76.

4 ALEXY, Robert. Teoria dos direitos fundamentais. Tradução de Virgílio Afonso da Silva. São Paulo: Malheiros, 2008. p. 68.

5 SARLET, Ingo Wolfgang. A eficácia dos direitos fundamentais: uma teoria geral dos direitos fundamentais na perspectiva constitucional. 12. ed. Porto Alegre: Livraria do Advogado, 2015. p. 117.

6 SARLET, Ingo Wolfgang. A eficácia dos direitos fundamentais: uma teoria geral dos direitos fundamentais na perspectiva constitucional. 12. ed. Porto Alegre: Livraria do Advogado, 2015. p. 76.

7 SARLET, Ingo Wolfgang. A eficácia dos direitos fundamentais: uma teoria geral dos direitos fundamentais na perspectiva constitucional. 12. ed. Porto Alegre: Livraria do Advogado, 2015. p. 78.

8 SARLET, Ingo Wolfgang. A eficácia dos direitos fundamentais: uma teoria geral dos direitos fundamentais na perspectiva constitucional. 12. ed. Porto Alegre: Livraria do Advogado, 2015. p. 76.

9 SARLET, Ingo Wolfgang. A eficácia dos direitos fundamentais: uma teoria geral dos direitos fundamentais na perspectiva constitucional. 12. ed. Porto Alegre: Livraria do Advogado, 2015. p. 80.

10 SARLET, Ingo Wolfgang. A eficácia dos direitos fundamentais: uma teoria geral dos direitos fundamentais na perspectiva constitucional. 12. ed. Porto Alegre: Livraria do Advogado, 2015. p. 80. 
tituição, abarcando princípios implícitos e os tratados internacionais de direitos humanos ${ }^{11}$, que passam a ser elementos integrantes da Constituição material, conceituada por José Joaquim Gomes Canotilho como:

[...] o conjunto de fins e valores constitutivos do princípio efectivo da unidade e permanência de um ordenamento jurídico (dimensão objectiva), e o conjunto de forças políticas e sociais (dimensão subjectiva) que exprimem esses fins ou valores, assegurando a estes a respectiva prossecução e concretização, algumas vezes para além da própria constituição escrita. Ao contrário do que muitas vezes se pensa e vê escrito, a constituição material não se reconduz a um simples "poder de facto" ("relações de poder e influência", "facto político puro"), pois a constituição material tem também uma função ordenadora. A chamada força normativa de constituição (K. Hesse) pressupõe, a maior parte das vezes, a vontade de constituição, ou seja, a explicitação na constituição escrita ou formal do complexo de fins e valores agitados pelas constelações políticas e sociais a nível da constituição material ${ }^{12}$.

A Constituição material é composta pelas normas relativas à estrutura do Estado, à organização dos poderes e aos direitos e garantias fundamentais ${ }^{13}$ e permite a abertura da Constituição a outros direitos fundamentais não elencados no Título II da Carta Magna e aos direitos humanos positivados em tratados internacionais.

A Constituição é um sistema aberto de regras e princípios ${ }^{14}$ que vai além da Constituição formal, fruto do poder constituinte. A Carta Magna de 1988 reconhece, expressamente, em seu art. $5^{\circ}, \$ 2^{\circ}$, a existência de outras fontes do direito fora da própria Constituição ${ }^{15}$, o que possibilita a incorporação ao direito brasileiro de normas constitucionais não expressas no texto constitucional. A esse respeito Estefânia Maria de Queiroz Barboza ensina:

No Brasil, é possível identificar a existência de uma Constituição invisível especialmente no que diz respeito aos princípios implícitos, aos princípios gerais do direito e aos direitos humanos e fundamentais, tendo em vista o que estabelece o art. $5^{\circ}, \S 2^{\circ}$, da Carta Constitucional ${ }^{16}$.

A abertura do sistema constitucional impede que a dedução de direitos fundamentais implícitos ou decorrentes possa ser realizada, unicamente, a partir de uma visão cartesiana-reducionista do ordenamento jurídico e da ciência jurídica, uma vez que o Direito, enquanto objeto e conhecimento, é aberto e, por isso, influencia e é influenciado pelos demais campos do conhecimento científico e pelo ambiente em que se insere, razão pela qual deve ser compreendido, indissociavelmente, de seu contexto ${ }^{17}$.

As normas jurídicas, que estão dentro do sistema jurídico, têm o seu conteúdo dependente de interações com o meio e com os outros sistemas sociais ${ }^{18}$. Assim,

[...] o significado de determinadas normas jurídicas pode depender, em maior ou menor medida, de elementos que pertencem ao ambiente do sistema jurídico [...] em casos como esse, a compreensão do sistema depende da compreensão do meio - inclusive, eventualmente, de compreensão cientificamente especializada não jurídica ${ }^{19}$.

11 SCHIER, Paulo Ricardo. Filtragem constitucional e ADPF 138. Gazeta do Povo. Curitiba, 21 de dezembro de 2015. Disponível em: $\quad<$ http://www.gazetadopovo.com.br/vida-publica/justica-e-direito/artigos/filtragem-constitucional-e-adpf-378-1841mh3iwmui5eu9c76tn7ib9>. Acesso em: 05 maio 2017

12 CANOTILHO, José Joaquim Gomes. Direito constitucional e teoria da Constituição. 7. ed. Coimbra: Almedina, 2011. p. 1.139.

13 SARLET, Ingo Wolfgang; MARINONI, Luiz Guilherme; MITIDIERO, Daniel. Curso de direito constitucional. 4. ed. São Paulo: Saraiva, 2015. p. 71.

14 MIRANDA, Jorge. Teoria do Estado e da Constituição. Rio de Janeiro: Forense, 2011. p. 204.

15 BARBOZA, Estefânia Maria de Queiroz. Precedentes judiciais e segurança jurídica: fundamentos e possibilidades para a jurisdição constitucional brasileira. São Paulo: Saraiva, 2014. p. 178.

16 BARBOZA, Estefânia Maria de Queiroz. Precedentes judiciais e segurança jurídica: fundamentos e possibilidades para a jurisdição constitucional brasileira. São Paulo: Saraiva, 2014. p. 179.

17 MORIN, Edgar. Introdução ao pensamento complexo. 4. ed. Porto Alegre: Sulina, 2011. p. 47.

18 FOLLONI, André. Ainda o reducionismo no direito. Disponível em: < http://complexidade.net/2015/02/02/ainda-o-reducionismo-no-direito/>. Acesso em: 20 maio 2017.

19 FOLLONI, André. Ainda o reducionismo no direito. Disponível em: <http://complexidade.net/2015/02/02/ainda-o-reducionismo-no-direito/>. Acesso em: 20 maio 2017. 
O significado dos textos normativos, inclusive os relacionados a direitos fundamentais, emerge das interações existentes no interior do sistema jurídico-normativo e entre o sistema jurídico, o ambiente e os demais sistemas sociais, sendo insuficiente a compreensão dos textos normativos unicamente por meio da análise científica do ordenamento jurídico ${ }^{20}$.

A interpretação dos enunciados normativos não depende, apenas, do texto, mas da sua conversação com outros dispositivos jurídicos, com os demais saberes científicos e com o contexto histórico, social, cultural, econômico e político, de modo que esses fatos não podem ser compreendidos isoladamente ${ }^{21}$.

Não é por outro motivo que os direitos fundamentais são variáveis no tempo e no espaço. Além disso, a cláusula de abertura material do art. $5^{\circ}, \mathbb{} 2^{\circ}$ propicia um processo permanente de identificação de novos direitos $^{22}$ e de transformação de conteúdo dos velhos direitos.

Além do mais, a dignidade da pessoa humana não é, ela mesma, um direito fundamental ${ }^{23}$, mas, enquanto princípio estruturante do Estado brasileiro, é a fonte e o fundamento dos direitos fundamentais ${ }^{24}$ e dos direitos humanos ${ }^{25}$. O jurista gaúcho Ingo Wolfgang Sarlet define a dignidade da pessoa humana como:

[...] a qualidade intrínseca e distintiva reconhecida em cada ser humano que o faz merecedor do mesmo respeito e consideração por parte do Estado e da comunidade, implicando, neste sentido, um complexo de direitos e deveres fundamentais que assegurem a pessoa tanto contra todo e qualquer ato de cunho degradante e desumano, como venham a lhe garantir as condições existenciais mínimas para uma vida saudável, além de propiciar e promover sua participação ativa co-responsável nos destinos da própria existência e da vida em comunhão com os demais seres humanos, mediante o devido respeito aos demais seres que integram a rede da vida ${ }^{26}$.

A partir da conceituação acima exposta, pode-se afirmar que o princípio da dignidade da pessoa humana atua como critério de identificação de direitos materialmente fundamentais eventualmente existentes na ordem jurídica do Brasil, de modo que é verdadeira "fonte jurídico-positiva dos direitos fundamentais, dando-lhes unidade e coerência" ${ }^{\prime 27}$.

Nesse contexto, pode-se afirmar que há, no ordenamento jurídico brasileiro, um verdadeiro direito fundamental implícito ao mínimo existencial, isto é: às condições materiais imprescindíveis a uma vida digna ${ }^{28}$.

20 FOLLONI, André. Ainda o reducionismo no direito. Disponível em: <http://complexidade.net/2015/02/02/ainda-o-reducionismo-no-direito/>. Acesso em: 20 maio 2017.

21 FOLLONI, André. O papel da ciência do direito tributário no desenvolvimento tributário. In: MURTA, Antônio Carlos Diniz; BALTHAZAR, Ubaldo Cesar; FEITOSA, Raymundo Juliano Rego (Coord.). Direito Tributário. Florianópolis: CONPEDI, 2014. p. 206-207.

22 SARLET, Ingo Wolfgang. A eficácia dos direitos fundamentais: uma teoria geral dos direitos fundamentais na perspectiva constitucional. 12. ed. Porto Alegre: Livraria do Advogado, 2015. p. 85.

23 SARLET, Ingo Wolfgang. Dignidade da pessoa bumana e direitos fundamentais na Constituição Federal de 1988. 9. ed. Porto Alegre: Livraria do Advogado, 2012. p. 84.

24 Ressalte-se que nem todos os direitos fundamentais estão diretamente fundados na dignidade humana. SARLET, Ingo Wolfgang. A eficácia dos direitos fundamentais: uma teoria geral dos direitos fundamentais na perspectiva constitucional. 12. ed. Porto Alegre: Livraria do Advogado, 2015. p. 97. Tema que aqui não será desenvolvido porque fugiria dos propósitos do presente artigo científico. 25 SARLET, Ingo Wolfgang. Dignidade da pessoa humana e direitos fundamentais na Constituição Federal de 1988. 9. ed. Porto Alegre: Livraria do Advogado, 2012. p. 95.

26 SARLET, Ingo Wolfgang. Dignidade da pessoa bumana e direitos fundamentais na Constituição Federal de 1988. 9. ed. Porto Alegre: Livraria do Advogado, 2012. p. 73.

27 SARLET, Ingo Wolfgang. A eficácia dos direitos fundamentais: uma teoria geral dos direitos fundamentais na perspectiva constitucional. 12. ed. Porto Alegre: Livraria do Advogado, 2015. p. 110.

28 SARLET, Ingo Wolfgang; FIGUEIREDO, Mariana Filchtiner. Reserva do possível, mínimo existencial e direito à saúde: algumas aproximações. In. SARLET, Ingo Wolfgang; TIMM, Luciano Benetti (Org.). Direitos fundamentais: orçamento e "reserva do possível". 2. ed. Porto Alegre: Livraria do Advogado, 2013. p. 20. 


\section{MíNImo eXISTENCIAL: O ACESSO À ÁGUA POTÁvel}

O mínimo existencial, enquanto garantia e direito fundamental às condições materiais básicas para a vivência com dignidade ${ }^{29}$, tem sua origem no direito alemão ${ }^{30}$. O primeiro jurista a sustentar o reconhecimento de um direito subjetivo a recursos suficientes à existência digna foi Otto Bachof nos primórdios da década de cinquenta do século XX, para quem o princípio da dignidade da pessoa humana reclama não somente a garantia da liberdade, mas também um mínimo de segurança social porque a pessoa despida de meios materiais necessários para viver adequadamente teria sua dignidade violada ${ }^{31}$.

A Corte Constitucional alemã somente veio a reconhecer o direito fundamental à garantia das condições mínimas para uma existência digna nos anos $1970^{32}$. Mais recentemente, o referido Tribunal Federal Constitucional reafirmou, de modo expresso, em dois casos paradigmáticos, denominados de Hartz IV e Asylum Seekers Benefits, julgados em 2010 e 2012, respectivamente, a existência de um verdadeiro direito fundamental individual ao mínimo existencial na Alemanha ${ }^{33}$. No primeiro julgado,

[...] the Court clarified the Fundamental Right to Guarantee a Subsistence Minimum that is in line with Human Dignity, follows from Article I.I GG (Constitution, Grundgesetz) in conjunction with the principle of the social state under Article 20.1 GG. It ensures that every needy person has the right to material conditions that are indispensable for his or her physical existence end for a minimum participation in social, cultural and political life ${ }^{34}$.

O reconhecimento doutrinário e jurisprudencial na Alemanha do direito ao mínimo existencial decorreu da inexistência na Lei Fundamental de um catálogo de direitos fundamentais sociais, entendendo-se que se poderia extrair diretamente da Constituição tedesca, ou seja, sem intermediação legislativa, a partir dos princípios da dignidade da pessoa humana, do Estado Social e do direito à vida, um direito subjetivo a prestações imprescindíveis à consecução da vida com dignidade ${ }^{35}$.

No Brasil, a Constituição Federal de 1988 consagrou, implicitamente, o direito fundamental ao mínimo existencial, que pode ser conceituado como um "direito às condições mínimas de existência humana digna que não pode ser objeto de intervenção do Estado na via dos tributos (= imunidade) e que ainda exige prestações estatais positivas" 36 , na medida em que está diretamente fundado e, por via de consequência, subtendido em diferentes normas constitucionais, especialmente no Princípio da Dignidade da Pessoa Humana, no direito à vida e nos direitos sociais ${ }^{37}$.

29 BARCELLOS, Ana Paula de. A eficácia jurídica dos princípios constitucionais: o princípio da dignidade da pessoa humana. 2. ed. Rio de Janeiro: Renovar, 2008. p. 278.

30 SARLET, Ingo Wolfgang; ROSA, Taís Hemann da. Breves notas sobre a dogmática do mínimo existencial no direito brasileiro. Revista de Direitos e Garantias Fundamentais, Vitória, v. 16, n. 1, p. 217-248, jan./jun. 2015. p. 218.

31 SARLET, Ingo Wolfgang. A eficácia dos direitos fundamentais: uma teoria geral dos direitos fundamentais na perspectiva constitucional. 12. ed. Porto Alegre: Livraria do Advogado, 2015. p. 326.

32 SARLET, Ingo Wolfgang. A eficácia dos direitos fundamentais: uma teoria geral dos direitos fundamentais na perspectiva constitucional. 12. ed. Porto Alegre: Livraria do Advogado, 2015. p. 327.

33 LEIJTEN, Ingrid. The german right to an existenzminimum, human dignity, and the possibility of minimum core socioeconomic rights protection. German Law Journal, Charlottesville, v. 16, n. 1, p. 23-48, 2015. p. 29.

34 [...] o Tribunal clarificou o Direito Fundamental para Garantir um Mínimo de Subsistência que está de acordo com a Dignidade Humana, a partir do Artigo I.I GG (Constituição, Grundgesetz), em conjugação com o princípio do estado social nos termos do Artigo 20.1 GG. Tal direito garante que cada pessoa carente tenha direito a condições materiais indispensáveis para a sua existência física e para uma participação mínima na vida social, cultural e política. LASKOWSKI, Silke Ruth. Time for implementation of the right to water and sanitation: the missing implementation in Germany. Journal for European Environmental \& Planning Law, Kassel, v. 9, n. 2, p. 164-179, 2012. p. 170, tradução nossa.

35 HACHEM, Daniel Wunder. Mínimo existencial e direitos fundamentais econômicos e sociais: distinções e pontos de contato à luz da doutrina e jurisprudência brasileiras. In: BARCELLAR FILHO, Romeu Felipe; HACHEN, Daniel Wunder (Coord.). Direito público no Mercosul: intervenção estatal, direitos fundamentais e sustentabilidade. Belo Horizonte: Fórum, 2013. p. 210.

36 TORRES, Ricardo Lobo. O direito ao mínimo existencial. Rio de Janeiro: Renovar, 2009. p. 35.

37 SARLET, Ingo Wolfgang; FIGUEIREDO, Mariana Filchtiner. Reserva do possível, mínimo existencial e direito à saúde: algumas aproximações. In. SARLET, Ingo Wolfgang; TIMM, Luciano Benetti (Org.). Direitos fundamentais: orçamento e "reserva do possível". 2. ed. Porto Alegre: Livraria do Advogado, 2013. p. 25. 
O mínimo existencial, na qualidade de direito fundamental, vai além do chamado mínimo vital, porque não resume à mera garantia de sobrevivência física do indivíduo, mas sim a uma supervivência consentânea com os padrões mais básicos de dignidade, a abarcar, também, o chamado mínimo sociocultural ${ }^{38}$.

O conteúdo do mínimo existencial não pode ser prévia e abstratamente estabelecido, no sentido de um rol fechado de posições jurídico-subjetivas correspondentes ao mínimo existencial ${ }^{39}$ porque, nesse caso, negar-se-ia a sua contextualização em cada momento histórico ${ }^{40} \mathrm{e}$ as "suas exigências podem variar de acordo com as condições econômicas, culturais e sociais de um povo" "41. Além disso, o direito ao mínimo existencial não se confunde, como quer Ricardo Lobo Torres ${ }^{42}$, com o conteúdo essencial dos direitos fundamentais, embora possa, em alguns casos, coincidir ${ }^{43}$.

A abertura semântica do direito ao mínimo existencial permite sustentar que os "elementos indispensáveis para que se tenham condições mínimas de dignidade, ou, em outras palavras, elementos que concretizam direitos fundamentais [...] devem ser perfilhados como integrantes do mínimo existencial"44. Ademais, a Constituição Federal não garante, como já ressaltado alhures, unicamente a vida biológica, mas a vida com dignidade e qualidade, devendo o Estado criar as condições mínimas necessárias para uma existência digna, cujo primeiro passo deverá ser, por obviedade, não deixar a pessoa morrer de fome ou de sede ${ }^{45}$.

O acesso à água potável é elemento indispensável para a concretização da vida com dignidade porque o homem não vive isolado da natureza. Ao contrário, deve-se reconhecer que "somos filhos da Terra, filhos da Vida, filhos do Cosmo" ${ }^{46}$ e que o "pequeno planeta perdido denominado Terra é o nosso lar - home, Heimat, que ele é nossa mátria, nossa Terra-Pátria" ${ }^{47}$. Enfim:

Precisamos sentir que cada passo nosso é dado não sobre a Terra, mas nela; que caminhamos, falamos e vivemos toda a nossa vida dentro de um grande ser planetário que está continuamente nos alimentando fisicamente com seu prodigioso manto de verde e sua exuberante atmosfera em torvelinho, um ser que acalma nossa psique com sua linguagem sutil de vento e chuva, com a investida de pássaros selvagens e com a majestade de suas montanhas ${ }^{48}$.

A vida, humana e não humana nasce e se desenvolve no planeta Terra, de modo que todos os elementos da biodiversidade constituem uma biosfera eco-organizada e autorregulada em que tudo está interconectado e todos são interdependentes ${ }^{49}$. Tem-se a necessidade de mudanças de paradigmas e de percepção, isto é, da

38 SARLET, Ingo Wolfgang. A eficácia dos direitos fundamentais: uma teoria geral dos direitos fundamentais na perspectiva constitucional. 12. ed. Porto Alegre: Livraria do Advogado, 2015. p. 318.

39 SARLET, Ingo Wolfgang; FIGUEIREDO, Mariana Filchtiner. Reserva do possível, mínimo existencial e direito à saúde: algumas aproximações. In. SARLET, Ingo Wolfgang; TIMM, Luciano Benetti (Org.). Direitos fundamentais: orçamento e "reserva do possivel". 2. ed. Porto Alegre: Livraria do Advogado, 2013. p. 26.

40 ROSA, Taís Hemann da. O acesso à energia elétrica como manifestação do direito ao mínimo existencial: uma análise com ênfase na dimensão defensiva do direito de acesso à energia elétrica. 2016. Dissertação (Mestrado) - Faculdade de Direito, Programa de PósGraduação em Direito. Pontifícia Universidade Católica do Rio Grande do Sul, Porto Alegre, 2016.

41 WEBER, Thadeu. A ideia de um “mínimo existencial” de J. Rawls. Kriterion, Belo Horizonte, n. 127, p. 197-210, jun. 2013. p. 198.

42 TORRES, Ricardo Lobo. O direito ao minimo existencial. Rio de Janeiro: Renovar, 2009. p. 36.

43 SARLET, Ingo Wolfgang. A eficácia dos direitos fundamentais: uma teoria geral dos direitos fundamentais na perspectiva constitucional. 12. ed. Porto Alegre: Livraria do Advogado, 2015. p. 332.

44 ROSA, Taís Hemann da. O acesso à energia elétrica como manifestação do direito ao mínimo existencial: uma análise com ênfase na dimensão defensiva do direito de acesso à energia elétrica. 2016. Dissertação (Mestrado) - Faculdade de Direito, Programa de PósGraduação em Direito. Pontifícia Universidade Católica do Rio Grande do Sul, Porto Alegre, 2016. Disponível em: < http://tede2. pucrs.br/tede2/bitstream/tede/6787/2/DIS_TAIS_HEMANN_DA_ROSA_PARCIAL.pdf>. Acesso em: 24 maio 2017.

45 SARLET, Ingo Wolfgang; FIGUEIREDO, Mariana Filchtiner. Reserva do possível, mínimo existencial e direito à saúde: algumas aproximações. In. SARLET, Ingo Wolfgang; TIMM, Luciano Benetti (Org.). Direitos fundamentais: orçamento e "reserva do possivvel". 2. ed. Porto Alegre: Livraria do Advogado, 2013. p. 23.

46 MORIN, Edgar. A via para o futuro da bumanidade. Rio de Janeiro: Bertrand Brasil, 2013. p. 104.

47 MORIN, Edgar. A via para o futuro da bumanidade. Rio de Janeiro: Bertrand Brasil, 2013. p. 104.

48 HARDING, Stephan. Terra viva: ciência, intuição e a evolução de Gaia: para uma nova compreensão da vida em nosso planeta. São Paulo: Culturix, 2008. p. 280-281.

49 GRUBBA, Leilane Serratine; RODRIGUES, Horácio Wanderlei; WANDERSLEBEN, Myrtha. Caminhos para uma cidadania 
forma de pensar e dos nossos valores, a fim de se reconhecer uma visão holística do mundo, no sentido de que seres humanos e a natureza estão interligados e são interdependentes ${ }^{50}$.

A interdependência e a interconexão entre o ser humano e a natureza são flagrantes porque não há possibilidade de se separar o homem do meio ambiente natural, pelo simples fato de que é a natureza que fornece a vida aos seres humanos, vale dizer, "existe uma solidariedade ecológica e nenhum ser vivente, mesmo o humano, pode se libertar materialmente da biosfera" ${ }^{\prime \prime}$.

Nesse sentido, percebe-se que a água é elemento constitutivo da vida, na medida em que ela é essencial na composição dos seres vivos e as suas funções biológicas e bioquímicas são indispensáveis para a manutenção da própria vida ${ }^{52}$. Enfim, "the link between life and water could not be more apparent and crucial: human life without basic access to water is simply unthinkable. Thus, a human right to water certainly includes essential human rights claims that stem from the right to life" ${ }^{25}$.

Atualmente, aproximadamente um bilhão de pessoas não tem acesso à água potável e cerca de setecentos e sessenta e oito milhões de indivíduos não têm acesso a uma fonte segura de água, em razão da aceleração da urbanização, das alterações climáticas e do aumento da poluição, todos produtos do desenvolvimento econômico empreendido pelos países nos últimos anos ${ }^{54}$. A propósito:

Os hidrólogos preveem que, a continuar esta tendência, a água doce enfrentará uma dupla pressão: por um lado, o crescimento populacional potencializado pelas práticas intensas de consumo que aumentará a demanda por comida e energia e, por outro lado, o impacto das mudanças climáticas. Aproximadamente $80 \%$ da população mundial sofre sérias ameaças quanto à sua segurança hídrica, conforme indicadores do IPCC, como sejam a disponibilidade de água, demanda por água e contaminaçãa ${ }^{55}$.

Segundo o Fundo das Nações Unidas para a Infância (UNICEF) e a Organização Mundial da Saúde (OMS), aproximadamente, um bilhão e oitocentas milhões de pessoas, não têm acesso seguro à água potável, ou seja, com condições mínimas para o consumo humano ${ }^{56}$, sendo obrigadas, com isso, a viver em estresse hídrico e com baixa qualidade de vida, especialmente os mais pobres, uma vez que "quando as pessoas não têm acesso à água potável no lar, ou à água enquanto recurso produtivo, suas escolhas e liberdades são limitadas pela doença, pobreza e vulnerabilidade" 57 .

A água é um recurso natural de extremamente importante para a vida no planeta, mas ela, também, tem um papel econômico relevante porque é usada na produção de energia elétrica, na navegação, na recrea-

planetária e ambiental. Revista de Direito Internacional, Brasília, v. 9, n. 3, p. 1-14, 2012. p. 7.

50 CAPRA, Fritjof. A teia da vida: uma nova compreensão científica dos sistemas vivos. São Paulo: Cultrix, 2006. p. 25-26.

51 GRUBBA, Leilane Serratine; RODRIGUES, Horácio Wanderlei; WANDERSLEBEN, Myrtha. Caminhos para uma cidadania planetária e ambiental. Revista de Direito Internacional, Brasília, v. 9, n. 3, p. 1-14, 2012. p. 8.

52 MILARÉ, Edis. Direito do ambiente. 8. ed. São Paulo: Revista dos Tribunais, 2013. p. 520.

53 A relação entre vida e água não poderia ser mais evidente e crucial: a vida humana sem acesso básico à água é simplesmente impensável. Assim, um direito humano à água certamente inclui reivindicações essenciais de direitos humanos decorrentes do direito à vida. THIELBÖRGER, Pierre. Re-conceptualizing the human right to water: a pledge for a hybrid approach. Human Rights Law Review, Oxford, v. 15, n. 2, p. 225-249, 2015. p. 232, tradução nossa.

54 JACOBI, Pedro Roberto; EMPINOTTI, Vanessa Lucena; SCHMIDT, Luisa. Escassez Hídrica e Direitos Humanos. Revista Ambiente \& Sociedade, São Paulo, v. 19, n. 1, mar. 2016. Disponível em: <http://www.scielo.br/scielo.php?script=sci_ arttext\&pid=S1414-753X2016000100001\&lng=pt\&nrm=iso>. Acesso em: 28 maio 2017. http://dx.doi.org/10.1590/18094422ASOCeditorialV191201.

55 JACOBI, Pedro Roberto; EMPINOTTI, Vanessa Lucena; SCHMIDT, Luisa. Escassez Hídrica e Direitos Humanos. Revista Ambiente \& Sociedade, São Paulo, v. 19, n. 1, mar. 2016. Disponível em: <http://www.scielo.br/scielo.php?script=sci_ arttext\&pid=S1414-753X2016000100001\&lng=pt\&nrm=iso>. Acesso em: 28 maio 2017. http://dx.doi.org/10.1590/18094422ASOCeditorialV191201.

56 UNICEF; ORGANIZAÇÃO MUNDIAL DA SAÚDE. Progress on sanitation and drinking water: 2015 update and MDG Assessment. Genebra: World Health Organization Press, 2015. p. 43.

57 JACOBI, Pedro Roberto; EMPINOTTI, Vanessa Lucena; SCHMIDT, Luisa. Escassez Hídrica e Direitos Humanos. Revista Ambiente \& Sociedade, São Paulo, v. 19, n. 1, mar. 2016. Disponível em: <http://www.scielo.br/scielo.php?script=sci_ arttext\&pid=S1414-753X2016000100001\&lng=pt\&nrm=iso>. Acesso em: 28 maio 2017. http://dx.doi.org/10.1590/18094422ASOCeditorialV191201. 
ção, na indústria e na agricultura e, portanto, para o fornecimento de alimentos para as pessoas no mundo, estimando-se que dezesseis por cento das terras agrícolas do planeta são irrigadas com águas superficiais ou subterrâneas $^{58}$. Por tais razões, a Assembleia Geral das Nações Unidas declarou, por intermédio da Resolução A/RES/64/292, em 28 de julho de 2010, que a água potável é um direito humano essencial para exercer em sua plenitude a vida com dignidade.

Embora o direito de acesso à água potável não esteja expressamente positivado na Constituição Federal de 1988, ele pode ser deduzido a partir de outros direitos fundamentais presentes na Constituição, como os direitos à vida, à saúde, à alimentação e, especialmente, ao mínimo existencial ${ }^{59}$, que reflete a ideia, segundo Thadeu Weber, de "preservação e garantia das condições e exigências mínimas de uma vida digna"

O acesso à água potável está diretamente relacionado ao mínimo existencial e é indispensável para a sua concretização porque não há que se falar em vida com dignidade sem água limpa e segura em quantidade suficiente ao consumo humano. Tal situação afeta, diretamente, a vida, a saúde e o bem-estar do homem ${ }^{61}$. A água potável é, absolutamente, necessária para a concretização do mínimo essencial à vida digna, vale dizer, do mínimo existencial, uma vez que sem ela não se garante sequer a sobrevivência física, quanto ao mais a vida com dignidade.

O Comitê de Direitos Econômicos, Sociais e Culturais das Nações Unidas, em seu Comentário Geral No 15, de 20 de janeiro de 2003, reconheceu que a água é indispensável para viver dignamente. Na oportunidade, o referido organismo internacional consignou que todos os seres humanos devem ter o direito à água suficiente, segura, aceitável, fisicamente acessível e a preços razoáveis para usos pessoais e domésticos e em quantidade adequada para prevenir a morte por desidratação, para reduzir o risco de doenças relacionadas a água e para a satisfação das necessidades pessoais e domésticas de higiene ${ }^{62}$.

Um "direito fundamental completo é um feixe de posições de direitos fundamentais", dizer, de acordo com Ingo Wolfgang Sarlet, que "os direitos fundamentais constituem posições jurídicas complexas, no sentido de poderem conter direitos, liberdades, pretensões e poderes da mais diversa natureza" ${ }^{\prime 4}$. Na lição de Daniel Wunder Hachem e de Alan Bonat, é possível distinguir um direito fundamental "como um todo" e as pretensões jurídicas que decorrem desse direito, que são consideradas, cada qual, um direito fundamental em sentido estrito, uma vez que

[...] se analisada a norma como um todo, a partir do conjunto de pretensões jurídicas por ela asseguradas, trata-se de um direito fundamental em sentido amplo; se tomada apenas uma das pretensões jurídicas dela emanadas, de forma isolada, cuida-se de um direito fundamental em sentido estrito (ou posição de direito fundamental) ${ }^{65}$.

Os direitos fundamentais, na sua perspectiva jurídico-subjetiva, conferem ao seu titular a prerrogativa de exigir judicialmente determinadas prestações a serem realizadas pelo Poder Público, destinatário da norma ${ }^{66}$.

58 TUNDISI, José Galizia. Novas perspectivas para a gestão de recursos hídricos. Revista USP, São Paulo, n. 70, p. 24-35, jun./ ago. 2006. p. 27.

59 ZIGANSHINA, Dinara. Rethinking the concept of the human right to water. Santa Clara Journal of International Law, v. 6, n. 1, p. 113-128, 2008. p. 114. Disponível em: <http://digitalcommons.law.scu.edu/scujil/vol6/iss1/6>. Acesso em: 25 maio 2017.

60 WEBER, Thadeu. A ideia de um "mínimo existencial" de J. Rawls. Kriterion, Belo Horizonte, n. 127, p. 197-210, jun. 2013. p. 198.

61 GREATREX, Helen. The human right to water. Human Rights Research Journal, Wellington, v. 02, p. 10, 2004. Disponível em: <http://www.victoria.ac.nz/law/centres/nzcpl/publications/human-rights-research-journal/publications/vol-2/Greatrex.pdf>. Acesso em: 28 maio 2017.

62 ORGANIZAÇÃO DA NAÇÕES UNIDAS. Comitê de Direitos Econômicos, Sociais e Culturais. Comentário Geral N. 15. 2003, p. 2.

63 ALEXY, Robert. Teoria dos direitos fundamentais. Tradução de Virgílio Afonso da Silva. São Paulo: Malheiros, 2008. p. 249.

64 SARLET, Ingo Wolfgang. A eficácia dos direitos fundamentais: uma teoria geral dos direitos fundamentais na perspectiva constitucional. 12. ed. Porto Alegre: Livraria do Advogado, 2015. p. 159.

65 HACHEM, Daniel Wunder; BONAT, Alan. O ensino médio como parcela do direito ao mínimo existencial. Revista Opinião Jurídica, Fortaleza, ano 14, n. 18, p. 144-176, jan./jun. 2016. p. 149.

66 SARLET, Ingo Wolfgang. A eficácia dos direitos fundamentais: uma teoria geral dos direitos fundamentais na perspectiva constitu- 
Vale dizer, o titular do direito pode exigir da Administração a realização de comportamentos positivos ou negativos, destinados a respeitar, promover ou proteger uma pretensão jurídica correspondente a parcela do conteúdo de um direito fundamental ${ }^{67}$, de modo que ao sujeito ativo "se abre um leque de possibilidades, que se encontram condicionadas à conformação concreta da norma que o consagra" ${ }^{68}$. Nesse contexto, o direito à água, apesar de significar, em linhas gerais, o acesso ao referido recurso hídrico em quantidade e qualidade suficiente para atender as necessidades básicas, engloba uma série de pretensões jurídicas específicas ${ }^{69}$.

O direito à água impõe ao Poder Público o dever de se abster de restringir ou impedir o acesso das pessoas à água limpa e segura em quantidade suficiente ao atendimento das necessidades pessoais e domésticas básicas, de reduzir ou contaminar as fontes de fornecimento de recursos hídricos e de limitar o acesso dos indivíduos ao serviço público de abastecimento de água ${ }^{70}$.

A Administração Pública tem, também, a obrigação constitucional de impedir que terceiros violem o direito à água, adotando-se as medidas administrativas e legislativas necessárias para assegurar que atores privados não deneguem ou dificultem o acesso à água potável em condições de igualdade, não contaminem ou explorem de forma não equitativa os recursos hídricos e não prejudiquem o acesso físico a um custo razoável a recursos de água suficientes, salubres e aceitáveis, sempre que controlarem os serviços de abastecimento de água ${ }^{71}$.

Além disso, o Estado deve adotar todas as medidas legislativas, administrativas, orçamentárias e judiciais necessárias, até o máximo dos recursos disponíveis, para realizar, plenamente, o direito à água. Não há permissão para a postergação da realização prática ou a inexigibilidade do direito à água, de modo que o Estado deve fazer todo o possível para realizá-lo, proporcionando, inclusive, o acesso do ser humano à água limpa e segura, em especial, quando por circunstâncias alheias a seu controle, não pode desfrutar deste ${ }^{72}$.

Enfim, o acesso à água deve ser assegurado de forma igualitária a todas as pessoas, possibilitando-o, especialmente, às populações mais pobres condições dignas de vida ${ }^{73}$. A partir dessa perspectiva, o Estado tem a obrigação jurídica de assegurar a todos os indivíduos o acesso à água potável com qualidade suficiente para garantir a existência humana saudável e com dignidade. Para tanto, deverá fazê-lo, dentre outras formas, por meio da prestação do serviço público de abastecimento de água.

\section{A PRESTAÇÃo do SERVIÇo PÚBlico de ABASTECIMENTO de ÁGUa}

Os direitos fundamentais se apresentam como direitos de defesa e como direitos a prestações. Estes últimos se subdividem em direitos de prestação fática e de prestação jurídica. A diferença entre direitos de defesa e direitos de prestação reside no comando prescritivo das normas jurídicas definidoras de direitos fundamentais, ou seja, nas obrigações ou proibições que recaem sobre os destinatários dos direitos funda-

cional. 12. ed. Porto Alegre: Livraria do Advogado, 2015. p. 158.

67 HACHEM, Daniel Wunder. A discricionariedade administrativa entre as dimensões objetiva e subjetiva dos direitos fundamentais sociais. Direitos Fundamentais \& Justiça, Belo Horizonte, ano 10, n. 35, p. 313-343, jun./dez. 2016. p. 316.

68 SARLET, Ingo Wolfgang. A eficácia dos direitos fundamentais: uma teoria geral dos direitos fundamentais na perspectiva constitucional. 12. ed. Porto Alegre: Livraria do Advogado, 2015. p. 158.

69 SCANLON, John; CASSAR, Angela; NEMES, Noémi. Water as a buman right?. Cambridge: IUCN, 2004. p. 28.

70 PULIDO, Carlos Bernal. O direito fundamental à água e sua intricada satisfação no Direito colombiano. Revista de Investigações Constitucionais, Curitiba, v. 2, n. 1, p. 65-87, jan./abr. 2015. p. 71-72.

71 PULIDO, Carlos Bernal. O direito fundamental à água e sua intricada satisfação no Direito colombiano. Revista de Investigações Constitucionais, Curitiba, v. 2, n. 1, p. 65-87, jan./abr. 2015. p. 72.

72 PULIDO, Carlos Bernal. O direito fundamental à água e sua intricada satisfação no Direito colombiano. Revista de Investigações Constitucionais, Curitiba, v. 2, n. 1, p. 65-87, jan./abr. 2015. p. 72.

73 SANTOS, Ruth; MENEZES, Renata. A necessidade de realização de políticas públicas para a universalização do direito ao saneamento. Revista Brasileira de Políticas Públicas (Online), Brasília, v. 6, n. 2, p. 257-271, 2016. p. 262. 
mentais ${ }^{74}$.

$\mathrm{Na}$ qualidade de direitos de defesa, os direitos fundamentais impõem ao Estado um dever de abstenção, proibindo-o de praticar atos de ingerência ou restrição na autonomia pessoal e na propriedade privada ${ }^{75}$. O papel dos direitos fundamentais, nessa condição, é a de assegurar ao indivíduo a possibilidade de realizar ou não uma ação de acordo com sua vontade, respeitados os limites legais e constitucionais ${ }^{76}$. Cria-se, assim, uma esfera de proteção à liberdade pessoal imune à atividade estatal abusiva, isto é, contrária à Constituição $0^{77}$.

Por outro lado, na condição de direitos prestacionais, os direitos fundamentais obrigam a Administração a implementar os meios e as condições necessárias para que as pessoas possam, efetivamente, exercer suas liberdades fundamentais ${ }^{78}$. São direitos que se realizam por meio do Estado ${ }^{79}$, exigindo-se, portanto, do Poder Público uma postura ativa no sentido de executar prestações fáticas e jurídicas em favor dos indivíduos.

Nessa esteira, o direito fundamental ao mínimo existencial tem, como não poderia deixar de ser, dupla função: negativa e positiva, na medida em que se apresenta, concomitantemente, como direito de defesa e como direito de prestação. No que toca ao aspecto negativo, o mencionado direito fundamental funciona como verdadeiro limite à atividade dos agentes públicos, inclusive, legisladores e magistrados ${ }^{80}$; e, no que se refere à sua dimensão positiva, impõe para o Estado o dever de executar prestações indispensáveis ao mínimo existencial, "de tal sorte que em favor do cidadão há que reconhecer um direito subjetivo, portanto, judicialmente exigível, à satisfação das necessidades vinculadas ao mínimo existencial e, portanto, à dignidade da pessoa humana" $"$.

O Estado tem o dever de fornecer as prestações materiais mínimas necessárias a uma vida com dignidade, sem que isso signifique, por outro lado, que a atuação positiva do Poder Público deva se limitar aos direitos prestacionais inseridos no mínimo existencial. Este deve ser entendido como um piso mínimo dos direitos fundamentais a ser implementado pela Administração ${ }^{82}$, dentre outras formas, através da prestação de serviços públicos, que pode ser conceituado como "toda atividade de oferecimento de utilidade ou comodidade material destinada à satisfação da coletividade em geral, mas fruível singularmente pelos Administrados, que o Estado assume como pertinente a seus deveres" $" 83$.

Não se pode perder de vista, portanto, que "os serviços públicos são meios de desenvolvimento social e instrumentos de materialização da dignidade da pessoa humana e dos direitos fundamentais" ${ }^{84}$, motivo pelo qual a concretização do direito fundamental ao mínimo existencial, em sua relação com o direito à água, dar-se-á, dentre outras formas, primordialmente, por meio da prestação, direta ou indireta, do serviço

74 CARA, Juan Carlos Gavara de. La dimensión objetiva de los derechos sociales. Barcelona: Bosch Editor, 2010. p. 19.

75 PIEROTH, Bodo; SCHLINK, Bernhard. Direitos fundamentais. São Paulo: Saraiva, 2012. p. 62.

76 CARA, Juan Carlos Gavara de. La dimensión objetiva de los derechos sociales. Barcelona: Bosch Editor, 2010. p. 17.

77 SARLET, Ingo Wolfgang. A eficácia dos direitos fundamentais: uma teoria geral dos direitos fundamentais na perspectiva constitucional. 12. ed. Porto Alegre: Livraria do Advogado, 2015. p. 175.

78 SARLET, Ingo Wolfgang. A eficácia dos direitos fundamentais: uma teoria geral dos direitos fundamentais na perspectiva constitucional. 12. ed. Porto Alegre: Livraria do Advogado, 2015. p. 191.

79 PIEROTH, Bodo; SCHLINK, Bernhard. Direitos fundamentais. São Paulo: Saraiva, 2012. p. 63.

80 SARLET, Ingo Wolfgang. A eficácia dos direitos fundamentais: uma teoria geral dos direitos fundamentais na perspectiva constitucional. 12. ed. Porto Alegre: Livraria do Advogado, 2015. p. 333.

81 SARLET, Ingo Wolfgang. A eficácia dos direitos fundamentais: uma teoria geral dos direitos fundamentais na perspectiva constitucional. 12. ed. Porto Alegre: Livraria do Advogado, 2015. p. 334.

82 HACHEM, Daniel Wunder; BONAT, Alan. O ensino médio como parcela do direito ao mínimo existencial. Revista Opinião Jurídica, Fortaleza, ano 14, n. 18, p. 144-176, jan./jun. 2016. p. 150.

83 MÂNICA, Fernando Borges; BRUSTOLIN, Rafaella. Gestão de presídios por parcerias público-privadas: uma análise das atividades passíveis de delegação. Revista Brasileira de Políticas Públicas (Online), Brasília, v. 7, n. 1, p. 304-320, 2017.p. 299.

84 VALLE, Vivian Lima López. Serviço público, desenvolvimento econômico e a nova contratualização da Administração Pública: o desafio na satisfação dos direitos fundamentais. In: BARCELLAR FILHO, Romeu Felipe; GABARDO, Emerson; HACHEN, Daniel Wunder (Coord.). Globalização, direitos fundamentais e direito administrativo: novas perspectivas para o desenvolvimento econômico e socioambiental. Belo Horizonte: Fórum, 2011. p. 283. 
público de abastecimento de água potável, que consiste no conjunto de atividades, infraestruturas e instalações necessárias ao abastecimento público de água, desde a captação até as ligações prediais e respectivos instrumentos de medição ${ }^{85}$.

A questão do "custo" tem especial importância, no caso do direito à água, porque a sua eficácia e efetividade dependem da realização concreta de ações estatais, notadamente a prestação do serviço de abastecimento de água, o que envolve a alocação de recursos públicos ${ }^{86}$. O Estado, porém, tem limitada capacidade financeira para garantir o pleno acesso da população à água limpa e segura, de tal sorte que a limitação dos recursos constitui limite jurídico e fático dos direitos fundamentais ${ }^{87}$. É a chamada reserva do possível, uma das faces ocultas dos direitos fundamentais ${ }^{88}$.

Enfim, a efetividade dos direitos fundamentais, inclusive o mínimo existencial e o direito à água, depende da capacidade econômica do Estado para custear as prestações materiais necessárias para a sua implementação ${ }^{89}$, razão pela qual tal direito não compreende o acesso gratuito à água ${ }^{90}$.

O art. 29, inciso I, da Lei Nacional N. ${ }^{\circ} 11.445 / 2007$ aduz que o serviço público de abastecimento de água potável deverá ter sustentabilidade econômico-financeira assegurada, sempre que possível, mediante remuneração pela cobrança do serviço preferencialmente na forma de tarifa ou preço público.

A fixação do valor da tarifa deve observar dois aspectos: um econômico porque tem de assegurar a sustentabilidade e o equilíbrio econômico-financeiro da prestação do serviço; e outro social, no sentido de levar em consideração a capacidade de pagamento do usuário e, com isso, garantir a universalidade do direito de acesso ao serviço, notadamente em núcleos populacionais de baixa renda ${ }^{91}$.

O direito ao mínimo existencial não é, assim como o direito à água, absoluto. Porém, enquanto direito de hierarquia constitucional, somente pode ser restringido por normas constitucionais ou em virtude delas ${ }^{92}$. Os direitos fundamentais podem ser limitados e restringidos em caráter geral pela própria Constituição ou normas infraconstitucionais, cuja criação é autorizada pela Carta Magna, bem como por outros direitos fundamentais ou por bens constitucionalmente tutelados, independentemente de expressa autorização constitucional para a restrição ${ }^{93}$. As colisões entre direitos fundamentais ou conflitos entre esses direitos e outros bens constitucionais legitimam o estabelecimento de restrições a direitos fundamentais não submetidos a reserva constitucional expressa nesse sentido ${ }^{94}$.

Os serviços públicos de um modo geral devem ser prestados de forma contínua e regular, não podendo sofrer interrupções. Contudo, não caracterizará descontinuidade ilícita do serviço a sua interrupção, mediante prévio aviso, por inadimplemento do usuário ${ }^{95}$, uma vez que a necessidade de manutenção do equilíbrio

85 Art. 3, inciso I, alínea "a", da Lei N. ${ }^{\circ} 11.445$, de 05 de janeiro de 2007.

86 SARLET, Ingo Wolfgang. Direitos fundamentais a prestações sociais e crise: algumas aproximações. Espaço jurídico, v. 16, n. 2 , p. 459-488, jul./dez. 2015. p. 468.

87 SARLET, Ingo Wolfgang. A eficácia dos direitos fundamentais: uma teoria geral dos direitos fundamentais na perspectiva constitucional. 12. ed. Porto Alegre: Livraria do Advogado, 2015. p. 296.

88 NABAIS, José Casalta. A face oculta dos direitos fundamentais: os deveres e os custos dos direitos. Revista de Direito Público da Economia-RDPE, Belo Horizonte, ano 5, n. 20, p. 153-181, out./dez. 2007.

89 SARLET, Ingo Wolfgang. Direitos fundamentais a prestações sociais e crise: algumas aproximações. Espaço jurídico, v. 16, n. 2, p. 459-488, jul./dez. 2015. p. 470.

90 ORGANIZAÇÃO DAS NAÇÕES UNIDAS. The right to water. Fact Sheet N. ${ }^{\circ}$ 35, 2010, p. 11.

91 DI PIETRO, Maria Sylvia Zanella. Cobrança de tarifa independentemente da conclusão do mecanismo de tratamento de esgoto: exame dos aspectos de constitucionalidade e legalidade. A \& C - Revista de Direito Administrativo e Constitucional, Belo Horizonte, ano 13, n. 53, p. 233-263, jul./set. 2013. p. 234.

92 ALEXY, Robert. Teoria dos direitos fundamentais. Tradução de Virgílio Afonso da Silva. São Paulo: Malheiros, 2008. p. 286.

93 SARLET, Ingo Wolfgang. A eficácia dos direitos fundamentais: uma teoria geral dos direitos fundamentais na perspectiva constitucional. 12. ed. Porto Alegre: Livraria do Advogado, 2015. p. 409-410.

94 NOVAIS, Jorge Reis. As restrições aos direitos fundamentais não expressamente autorizadas pela Constituição. 2. ed. Coimbra: Wolters Kluwer; Coimbra Editora, 2010. p. 547.

95 MELLO, Celso Antônio Bandeira de. Curso de direito administrativo. 26. ed. São Paulo: Malheiros, 2009. p. 739. 
econômico-financeiro na prestação do serviço público é incompatível com a possibilidade de inúmeras e sucessivas inadimplências, somente cobráveis em longos processos judiciais ${ }^{96}$. É por isso que o art. 40, inciso V, da Lei N. 11.445/2007 autoriza, expressamente, a interrupção do serviço de abastecimento de água em razão do não pagamento da tarifa pelo usuário, acarretando, por consequência, restrição legítima ao direito de acesso à água.

Por outro lado, deve-se ter em consideração que a restrição a direitos fundamentais somente se dá de modo condicionado a determinados limites, cuja previsão tem como causa primeira a necessidade de proteger a eficácia dos direitos da atividade erosiva do Estado ${ }^{97}$. Em suma, há limites aos limites dos direitos fundamentais.

Como diz José Carlos Vieira de Andrade, “o conteúdo inatacável dos preceitos relativos aos direitos, liberdades e garantias começa onde acaba a possibilidade e a legitimidade de sua restrição" ". Desse modo, as limitações dos direitos fundamentais somente serão válidas se forem formal e materialmente compatíveis com a Constituição, no sentido de que tais restrições devem observar não somente as regras constitucionais de competência, de forma e de procedimento, mas também o núcleo essencial dos direitos fundamentais, o princípio da proporcionalidade e o princípio da proibição do retrocesso ${ }^{99}$.

O princípio da proporcionalidade é, como visto, instrumento necessário para aferir a legitimidade dos atos estatais que restringem direitos fundamentais ${ }^{100}$, que se desdobra em três elementos, quais sejam: a) adequação; b) necessidade; e c) proporcionalidade em sentido estrito ${ }^{101}$.

A adequação impõe que as medidas restritivas a direitos (os meios) sejam aptas a proteger os direitos humanos e os direitos fundamentais de terceiros (os fins), ou seja, o meio deve promover o fim almejado ${ }^{102}$. A necessidade, por sua vez, consiste na escolha, dentre os meios disponíveis e igualmente adequados para promover o fim daquele menos oneroso e lesivo aos direitos fundamentais afetados ${ }^{103}$.

Finalmente, a proporcionalidade em sentido estrito exige que as vantagens da interferência na esfera dos direitos dos cidadãos superem os ônus decorrentes da limitação a direitos fundamentais, ou seja, o benefício alcançado com a adoção da medida restritiva não deve sacrificar direitos fundamentais mais importantes axiologicamente do que os direitos que a medida pretendeu preservar ${ }^{104}$. Nesse momento, valoram-se, sopesam-se e comparam-se os sacrifícios aos direitos fundamentais e os benefícios almejados, as vantagens e as desvantagens da restrição ${ }^{105}$.

Além disso, a restrição de direitos fundamentais deve observar o chamado princípio da proteção do núcleo essencial, que se destina "a evitar o esvaziamento do conteúdo do direito fundamental decorrente de restrições descabidas, desmesuradas ou desproporcionais" ${ }^{\text {106 }}$. O núcleo essencial seria aquele mínimo

96 ARAGÃO, Alexandre Santos de. Direito dos serviços públicos. 3. ed. Rio de Janeiro: Forense, 2013. p. 523.

97 PIEROTH, Bodo; SCHLINK, Bernhard. Direitos fundamentais. São Paulo: Saraiva, 2012. p. 137.

98 ANDRADE, José Carlos Vieira de. Os direitos fundamentais na Constituição portuguesa de 1976. 5. ed. Coimbra: Almedina, 2012. p. 287.

99 SARLET, Ingo Wolfgang. A eficácia dos direitos fundamentais: uma teoria geral dos direitos fundamentais na perspectiva constitucional. 12. ed. Porto Alegre: Livraria do Advogado, 2015. p. 413.

100 PIEROTH, Bodo; SCHLINK, Bernhard. Direitos fundamentais. São Paulo: Saraiva, 2012. p. 138.

101 SARLET, Ingo Wolfgang. A eficácia dos direitos fundamentais: uma teoria geral dos direitos fundamentais na perspectiva constitucional. 12. ed. Porto Alegre: Livraria do Advogado, 2015. p. 415.

102 ÁVILA, Humberto. Teoria dos princípios: da definição à aplicação dos princípios jurídicos. 14. ed. São Paulo: Malheiros, 2013. p. 188.

103 ÁVILA, Humberto. Teoria dos princípios: da definição à aplicação dos princípios jurídicos. 14. ed. São Paulo: Malheiros, 2013. p. 193.

104 MARMELSTEIN, George. Curso de direitos fundamentais. 3. ed. São Paulo: Atlas, 2011. p. 419.

105 NOVAIS, Jorge Reis. As restrições aos direitos fundamentais não expressamente autorizadas pela Constituição. 2. ed. Coimbra: Wolters Kluwer, Coimbra Editora, 2010. p. 753.

106 MENDES, Gilmar Ferreira; BRANCO, Paulo Gustavo Gonet. Curso de direito constitucional. 8. ed. São Paulo: Saraiva, 2013. p. 212. 
insuscetível de limitação, ou seja, a "parcela do conteúdo de um direito sem a qual ele perde a sua mínima eficácia, deixando, com isso, de ser reconhecido como um direito fundamental"107.

A interrupção do serviço de abastecimento de água potável deve observar, portanto, a chamada garantia do núcleo essencial e o princípio da proporcionalidade. Nessa toada, a regra construída a partir do inciso V do art. 40 da Lei de Saneamento Básico, que estabelece a possibilidade de suspensão do serviço de abastecimento de água em caso de inadimplemento do usuário, não é absoluta, devendo, portanto, ser afastada sempre que violar princípios constitucionais.

O acesso à água está, como ressaltado alhures, intrinsecamente relacionado ao direito fundamental ao mínimo existencial e ao direito à vida com dignidade, na medida em que a água é um elemento essencial para a sobrevivência biológica e para a dignidade dos seres humanos, mas isso não significa que tal direito compreenda o acesso gratuito à água ${ }^{108}$, notadamente porque a onerosidade do serviço de água potável é condição indispensável para a sua prestação contínua e eficiente aos usuários e a suspensão do serviço serve de desincentivo ao inadimplemento.

A proteção de patamares mínimos de dignidade não permite a defesa de uma gratuidade absoluta no fornecimento de água potável. Contudo, não se pode perder de vista que a ausência de acesso à água em quantidade mínima suficiente ao atendimento das necessidades básicas de sobrevivência poderá caracterizar violação ao princípio da dignidade humana, ao direito à vida e ao direito fundamental ao mínimo existencial ${ }^{109}$.

As pessoas não podem ter o acesso a uma quantidade mínima de água potável tolhido por razões econômicas incontroláveis ou insuperáveis. Se a falta de pagamento da tarifa decorrer de circunstâncias involuntárias, como desemprego, ou quando se tratar de consumidor de baixa renda per-capita familiar que impossibilite o pagamento da tarifa por comprometer a subsistência digna da unidade familiar, não é possível a suspensão total do serviço de abastecimento de água.

É mister compreender, interpretar e aplicar a regra decorrente do artigo 40, inciso V, da Lei N. 11.445/2007 mediante o diálogo com as outras regras e princípios existentes no ordenamento jurídico, notadamente com o direito fundamental ao mínimo existencial, o direito à vida e o princípio da dignidade da pessoa humana ${ }^{110}$.

Parafraseando Taís Hemann da Rosa, entende-se que, nos casos de inadimplemento involuntário do consumidor, o direito patrimonial das empresas concessionárias, consistente na contraprestação pecuniária pela oferta do serviço público, deverá ser relativizado, sopesado frente à manutenção do mínimo essencial ao direito fundamental à vida digna ${ }^{111}$.

Desse modo, em caso de inadimplência involuntária do usuário doméstico, especialmente o de baixa renda, o Poder Público deverá garantir o fornecimento de, pelo menos, cinquenta litros por pessoa ao dia, não podendo, destarte, interromper, totalmente, o serviço de abastecimento de água portável, sob pena de restrição desproporcional do mínimo existencial, do princípio da dignidade da pessoa humana e do direito à vida, uma vez que, segundo a Organização Mundial de Saúde (OMS), esta é a quantidade mínima necessária

107 SARLET, Ingo Wolfgang. A eficácia dos direitos fundamentais: uma teoria geral dos direitos fundamentais na perspectiva constitucional. 12. ed. Porto Alegre: Livraria do Advogado, 2015. p. 420.

108 ORGANIZAÇÃO DAS NAÇÕES UNIDAS. The right to water. Fact Sheet N. ${ }^{\circ}$ 35, 2010. p. 11.

109 É importante ressaltar que o núcleo essencial dos direitos fundamentais não se confunde com o conteúdo da dignidade humana. SARLET, Ingo Wolfgang. A eficácia dos direitos fundamentais: uma teoria geral dos direitos fundamentais na perspectiva constitucional. 12. ed. Porto Alegre: Livraria do Advogado, 2015. p. 422.

110 BESSA, Leonardo Roscoe; CÉSAR, Gabriela Gomes Acioli. O corte do fornecimento de água em face do inadimplemento do consumidor: análise à luz do Diálogo das Fontes. Revista Brasileira de Políticas Públicas (Online), Brasília, v. 6, n. 2, p. $243-255,2016$. p. 254.

111 ROSA, Taís Hemann da. O acesso à energia elétrica como manifestação do direito ao mínimo existencial: uma análise com ênfase na dimensão defensiva do direito de acesso à energia elétrica. Disponível em: <http://tede2.pucrs.br/tede2/bitstream/ tede/6787/2/DIS_TAIS_HEMANN_DA_ROSA_PARCIAL.pdf>. Acesso em: 07 junho 2017. 
para atender as necessidades básicas pessoais e domésticas ${ }^{112}$, que compreendem água para beber, para lavar roupa, para a preparação de alimentos e higiene pessoal e residencial ${ }^{113}$. Dito de outra forma, cinquenta litros por dia é quantidade mínima indispensável para sustentar, dignamente, a vida do indivíduo.

Enfim, o acesso à água potável, mesmo sendo integrante do mínimo existencial, pode sofrer restrições legítimas, ressalvados aqueles casos de inadimplemento da tarifa pelo usuário comprovadamente sem condições de arcar com ela, hipótese na qual deve-se garantir o fornecimento de, pelo menos, cinquenta litros de água por pessoa ao dia.

Em tais casos, a contrapartida relativa à água potável disponibilizada deverá ser prestada pelo próprio Estado, haja vista que a este cabe o dever de garantir e promover os direitos constitucionais fundamentais, dentre eles o mínimo existencial ${ }^{114}$.

\section{Considerações finais}

O presente artigo científico teve como objetivo principal propor que a suspensão do serviço de abastecimento de água potável por inadimplemento do usuário doméstico por circunstâncias involuntárias ou insuperáveis não pode ser total, no sentido de que sejam garantidos pelo menos cinquenta litros de água por pessoa ao dia, sob pena de limitação desproporcional do direito fundamental ao mínimo existencial, do direito à água e do direito à vida com dignidade.

Partiu-se da premissa de que o acesso à água potável é um direito decorrente do direito fundamental implícito ao mínimo existencial no ordenamento constitucional brasileiro porque a água é elemento constitutivo da vida e o seu acesso é condição necessária para a sobrevivência minimamente digna do ser humano.

O direito à água e o direito ao mínimo existencial não são absolutos, de modo que o serviço público de abastecimento de água potável pode ser legitimamente interrompido por inadimplemento do usuário, conforme expressamente autorizado pelo art. 40, inciso V, da Lei de Saneamento Básico, até porque se trata de um direito cuja concretização é extremamente custosa, fazendo-se mister o seu financiamento por meio das tarifas.

Contudo, a regra jurídica decorrente do supra referido dispositivo legal não pode ser aplicada e interpretada isoladamente, mas em conjunto com as demais regras e princípios existentes no sistema jurídico, uma vez que o Direito deve ser compreendido em sua integridade. Nesse sentido, a solução prevista no art. 40, inciso V, da Lei N. 11.445/2007 pode ser, legitimamente, afastada em determinados casos, sempre que a sua aplicação concreta afetar um bem constitucionalmente tutelado, como são o mínimo existencial, a dignidade da pessoa humana e o acesso à água.

Assim, em caso de inadimplemento de usuário doméstico, por circunstâncias involuntárias ou insuperáveis, especialmente as de natureza econômica-social, o Poder Público, somente, poderá interromper, parcialmente, o serviço público de abastecimento de água potável, desde que garantido o fornecimento diário de, pelo menos, cinquenta litros por pessoa existente na unidade residencial, uma vez que esta é, repita-se, a quantidade mínima necessária de água limpa e segura para garantir a satisfação das necessidades pessoais mais básicas.

112 HOWARD, Guy; BARTRAM, Jamie. Domestic water quantity, service level and health. Genebra: World Health Organization Press, 2003. p. 1.

113 ORGANIZAÇÃO DAS NAÇÕES UNIDAS. The right to water. Fact Sheet N. ${ }^{\circ}$ 35, 2010. p. 8.

114 ROSA, Taís Hemann da. O acesso à energia elétrica como manifestação do direito ao mínimo existencial: uma análise com ênfase na dimensão defensiva do direito de acesso à energia elétrica. Disponível em: <http://tede2.pucrs.br/tede2/bitstream/ tede/6787/2/DIS_TAIS_HEMANN_DA_ROSA_PARCIAL.pdf>. Acesso em: 07 junho 2017. 


\section{ReferênCIAS BIBLIOGRÁFICAS}

ALEXY, Robert. Teoria dos direitos fundamentais. Tradução de Virgílio Afonso da Silva. São Paulo: Malheiros, 2008.

ANDRADE, José Carlos Vieira de. Os direitos fundamentais na Constituição portuguesa de 1976. 5. ed. Coimbra: Almedina, 2012.

ARAGÃO, Alexandre Santos de. Direito dos serviços públicos. 3. ed. Rio de Janeiro: Forense, 2013.

ÁVILA, Humberto. Teoria dos princípios: da definição à aplicação dos princípios jurídicos. 14. ed. São Paulo: Malheiros, 2013.

BARBOZA, Estefânia Maria de Queiroz. Precedentes judiciais e segurança jurídica: fundamentos e possibilidades para a jurisdição constitucional brasileira. São Paulo: Saraiva, 2014.

BARCELLOS, Ana Paula de. A eficácia jurídica dos princípios constitucionais: o princípio da dignidade da pessoa humana. 2. ed. Rio de Janeiro: Renovar, 2008.

BESSA, Leonardo Roscoe; CÉSAR, Gabriela Gomes Acioli. O corte do fornecimento de água em face do inadimplemento do consumidor: análise à luz do Diálogo das Fontes. Revista Brasileira de Políticas Públicas (Online), Brasilia, v. 6, n. 2, p. 250-263, 2016.

CANOTILHO, José Joaquim Gomes. Direito constitucional e teoria da Constituição. 7. ed. Coimbra: Almedina, 2011.

CAPRA, Fritjof. A teia da vida: uma nova compreensão científica dos sistemas vivos. São Paulo: Cultrix, 2006.

CARA, Juan Carlos Gavara de. La dimensión objetiva de los derechos sociales. Barcelona: Bosch Editor, 2010.

DI PIETRO, Maria Sylvia Zanella. Cobrança de tarifa independentemente da conclusão do mecanismo de tratamento de esgoto: exame dos aspectos de constitucionalidade e legalidade. $A \& C$ - Revista de Direito Administrativo e Constitucional, Belo Horizonte, ano 13, n. 53, p. 233-263, jul./set. 2013.

FOLLONI, André. Ainda o reducionismo no direito. Disponível em: <http://complexidade.net/2015/02/02/ ainda-o-reducionismo-no-direito/>.

FOLLONI, André. O papel da ciência do direito tributário no desenvolvimento tributário. In: MURTA, Antônio Carlos Diniz; BALTHAZAR, Ubaldo Cesar; FEITOSA, Raymundo Juliano Rego (Coord.). Direito Tributário. Florianópolis: CONPEDI, p. 194-215, 2014.

GREATREX, Helen. The human right to water. Human Rights Research Journal, Wellington, v. 02, p. 10, 2004. Disponível em: <http://www.victoria.ac.nz/law/centres/nzcpl/publications/human-rights-researchjournal/publications/vol-2/Greatrex.pdf $>$.

GRUBBA, Leilane Serratine; RODRIGUES, Horácio Wanderlei; WANDERSLEBEN, Myrtha. Caminhos para uma cidadania planetária e ambiental. Revista de Direito Internacional, Brasília, v. 9, n. 3, p. 1-14, 2012.

HACHEM, Daniel Wunder. A discricionariedade administrativa entre as dimensões objetiva e subjetiva dos direitos fundamentais sociais. Direitos Fundamentais \& Justiça, Belo Horizonte, ano 10, n. 35, p. 313-343, jun./ dez. 2016.

HACHEM, Daniel Wunder. Mínimo existencial e direitos fundamentais econômicos e sociais: distinções e pontos de contato à luz da doutrina e jurisprudência brasileiras. In: BARCELLAR FILHO, Romeu Felipe; HACHEN, Daniel Wunder (Coord.). Direito público no Mercosul: intervenção estatal, direitos fundamentais e sustentabilidade. Belo Horizonte: Fórum, 2013. p. 205-240. 
HACHEM, Daniel Wunder; BONAT, Alan. O ensino médio como parcela do direito ao mínimo existencial. Revista Opinião Jurídica, Fortaleza, ano 14, n. 18, p. 144-176, jan./jun. 2016.

HARDING, Stephan. Terra viva: ciência, intuição e a evolução de Gaia: para uma nova compreensão da vida em nosso planeta. São Paulo: Culturix, 2008.

HOWARD, Guy; BARTRAM, Jamie. Domestic water quantity, service level and health. Genebra: World Health Organization Press, 2003.

JACOBI, Pedro Roberto; EMPINOTTI, Vanessa Lucena; SCHMIDT, Luisa. Escassez Hídrica e Direitos Humanos. Revista Ambiente \& Sociedade, São Paulo, v. 19, n. 1, mar. 2016. Disponível em: <http:/ /www.scielo.br/scielo.php?script=sci_arttext\&pid=S1414-753X2016000100001\&lng=pt\&nrm=iso $>$. http: $/ /$ dx.doi. org/10.1590/1809-4422ASOCeditorialV191201.

LASKOWSKI, Silke Ruth. Time for implementation of the right to water and sanitation: the missing implementation in Germany. Journal for European Environmental \& Planning Law, Kassel, v. 9, n. 2, p. 164-179, 2012.

LEIJTEN, Ingrid. The german right to an existen₹minimum, human dignity, and the possibility of minimum core socioeconomic rights protection. German Law Journal, Charlottesville, v. 16, n. 1, p. 23-48, 2015.

MÂNICA, Fernando Borges; BRUSTOLIN, Rafaella. Gestão de presídios por parcerias público-privadas: uma análise das atividades passíveis de delegação. Revista Brasileira de Políticas Públicas (Online), Brasília, v. 7, n. 1, p. 304-320, 2017.

MARMELSTEIN, George. Curso de direitos fundamentais. 3. ed. São Paulo: Atlas, 2011.

MELLO, Celso Antônio Bandeira de. Curso de direito administrativo. 26. ed. São Paulo: Malheiros, 2009.

MENDES, Gilmar Ferreira; BRANCO, Paulo Gustavo Gonet. Curso de direito constitucional. 8. ed. São Paulo: Saraiva, 2013.

MILARÉ, Edis. Direito do ambiente. 8. ed. São Paulo: Revista dos Tribunais, 2013.

MIRANDA, Jorge. Teoria do Estado e da Constituição. Rio de Janeiro: Forense, 2011.

MORIN, Edgar. A via para o futuro da bumanidade. Rio de Janeiro: Bertrand Brasil, 2013.

MORIN, Edgar. Introdução ao pensamento complexo. 4. ed. Porto Alegre: Sulina, 2011.

NABAIS, José Casalta. A face oculta dos direitos fundamentais: os deveres e os custos dos direitos. Revista de Direito Público da Economia - RDPE, Belo Horizonte, ano 5, n. 20, p. 153-181, out./dez. 2007.

NOVAIS, Jorge Reis. As restrições aos direitos fundamentais não expressamente autorizadas pela Constituição. 2. ed. Coimbra: Wolters Kluwer, Coimbra Editora, 2010.

ORGANIZAÇÃO DAS NAÇÕES UNIDAS. Comitê de Direitos Econômicos, Sociais e Culturais. Comentário Geral N. 15, 2003.

ORGANIZAÇÃO DAS NAÇÕES UNIDAS. The right to water. Fact Sheet N. ${ }^{\circ}$ 35, 2010.

PIEROTH, Bodo; SCHLINK, Bernhard. Direitos fundamentais. São Paulo: Saraiva, 2012.

PULIDO, Carlos Bernal. O direito fundamental à água e sua intricada satisfação no Direito colombiano. Revista de Investigações Constitucionais, Curitiba, v. 2, n. 1, p. 65-87, jan./abr. 2015.

ROSA, Taís Hemann da. O acesso à energia elétrica como manifestação do direito ao mínimo existencial: uma análise com ênfase na dimensão defensiva do direito de acesso à energia elétrica. 2016. Dissertação (Mestrado) Faculdade de Direito, Programa de Pós-Graduação em Direito. Pontifícia Universidade Católica do Rio Grande do Sul, Porto Alegre, 2016.

SANTOS, Ruth; MENEZES, Renata. A necessidade de realização de políticas públicas para a universali- 
zação do direito ao saneamento. Revista Brasileira de Políticas Públicas (Online), Brasília, v. 6, n. 2, p. 257-271, 2016.

SARLET, Ingo Wolfgang. A eficácia dos direitos fundamentais: uma teoria geral dos direitos fundamentais na perspectiva constitucional. 12. ed. Porto Alegre: Livraria do Advogado, 2015.

SARLET, Ingo Wolfgang. Dignidade da pessoa bumana e direitos fundamentais na Constituição Federal de 1988. 9. ed. Porto Alegre: Livraria do Advogado, 2012.

SARLET, Ingo Wolfgang. Direitos fundamentais a prestações sociais e crise: algumas aproximações. Espaço jurídico, v. 16, n. 2, p. 459-488, jul./dez. 2015.

SARLET, Ingo Wolfgang; FIGUEIREDO, Mariana Filchtiner. Reserva do possível, mínimo existencial e direito à saúde: algumas aproximações. In. SARLET, Ingo Wolfgang; TIMM, Luciano Benetti (Org.). Direitos fundamentais: orçamento e "reserva do possível". 2. ed. Porto Alegre: Livraria do Advogado, 2013. p. 13-50.

SARLET, Ingo Wolfgang; MARINONI, Luiz Guilherme; MITIDIERO, Daniel. Curso de direito constitucional. 4. ed. São Paulo: Saraiva, 2015.

SARLET, Ingo Wolfgang; ROSA, Taís Hemann da. Breves notas sobre a dogmática do mínimo existencial no direito brasileiro. Revista de Direitos e Garantias Fundamentais, Vitória, v. 16, n. 1, p. 217-248, jan./jun. 2015.

SCANLON, John; CASSAR, Angela; NEMES, Noémi. Water as a human right?. Cambridge: IUCN, 2004.

SCHIER, Paulo Ricardo. Filtragem constitucional e ADPF 138. Gazeta do Povo. Curitiba, 21 de dezembro de 2015. Disponível em: <http://www.gazetadopovo.com.br/vida-publica/justica-e-direito/artigos/filtragem-constitucional-e-adpf-378-1841mh3iwmui5eu9c76tn7ib9>.

THIELBÖRGER, Pierre. Re-conceptualizing the human right to water: a pledge for a hybrid approach. Human Rights Law Review, Oxford, v. 15, n. 2, p. 225-249, 2015.

TORRES, Ricardo Lobo. O direito ao mínimo existencial. Rio de Janeiro: Renovar, 2009.

TUNDISI, José Galizia. Novas perspectivas para a gestão de recursos hídricos. Revista USP, São Paulo, n. 70, p. 24-35, jun./ago. 2006.

UNICEF; ORGANIZAÇÃO MUNDIAL DA SAÚDE. Progress on sanitation and drinking water: 2015 update and MDG Assessment. Genebra: World Health Organization Press, 2015.

VALLE, Vivian Lima López. Serviço público, desenvolvimento econômico e a nova contratualização da Administração Pública: o desafio na satisfação dos direitos fundamentais. In: BARCELLAR FILHO, Romeu Felipe; GABARDO, Emerson; HACHEN, Daniel Wunder (Coord.). Globalização, direitos fundamentais e direito administrativo: novas perspectivas para o desenvolvimento econômico e socioambiental. Belo Horizonte: Fórum, 2011. p. 273-284.

WEBER, Thadeu. A ideia de um "mínimo existencial” de J. Rawls. Kriterion, Belo Horizonte, n. 127, p. 197210, jun. 2013.

ZIGANSHINA, Dinara. Rethinking the concept of the human right to water. Santa Clara Journal of International Law, v. 6, n. 1, p. 113-128, 2008. p. 114. Disponível em: < http://digitalcommons.law.scu.edu/scujil/

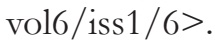




\section{OUTROS TEMAS}




\section{On legal certainty and uniformity decisions in the new civil procedure code in the light of brazilian constitutional process model}

\author{
Lúcio Antônio Chamon Junior***
}

\title{
Resumo
}

O presente estudo pretende analisar os pressupostos teóricos subjacentes à compreensão da nova codificação processual brasileira, a Lei 13.105/15, a partir da reconstrução dos argumentos centrais presentes na sua Exposição de Motivos, objetivando confrontar referidos pressupostos em face das exigências democráticas estabelecidas pela CF/1988, adotando como referencial teórico as Teorias Discursiva do Direito, de Jürgen Habermas, do Modelo Constitucional do Processo, de Andolina e Vignera, e a do Processo de Elio Fazzalari. A pesquisa, do tipo qualitativa, adotou como procedimento a análise documental e a revisão bibliográfica, e como método de inferência, o indutivo. Com relação aos resultados, a reconstrução dos argumentos centrais da Exposição de Motivos possibilitou identificar uma assimilação entre os conceitos de segurança jurídica e uniformidade de decisões, e seu emprego como forma de justificar as alterações introduzidas pela legislação novel. No entanto, tal entendimento apresenta-se destoante dos requisitos democráticos relativos ao exercício da jurisdição, segundo o Modelo Constitucional Processual brasileiro. Segundo este, a jurisdição não deve ser compreendida de forma meramente instrumental, mas como função estatal garantidora de direitos fundamentais, inclusive com relação ao procedimento que viabiliza o seu exercício, devendo ser capaz de assegurar decisões adequadas à singularidade de cada caso, e ao mesmo tempo coerentes com as decisões proferidas pelos demais órgãos do Poder Judiciário. Conclui-se que a pretensão de substituir a lógica da coerência subjacente a uma racionalidade discursiva pela lógica da eficiência-celeridade-segurança importa na desconsideração do caráter democrático-participativo conformador do Modelo Constitucional Processual brasileiro.

Palavras-chave: Novo CPC, Teoria do direito, segurança jurídica

\section{Abstract}

The aim of the present study consists of the analyze of theoretical as- 
sumptions present in the compreehension of the new brazilian procedure code, Federal Law 13.105/15, from the reconstruction of the central arguments presents on its Statement of Purpose, with the intention to confront those assumptions with the democract requirement stablished by brazilian Constitution, adopting, therefore, as theoretical references, Jurgen Habermas's Discursive Theory, Andolina and Vignera's Constitution Model Procedural Theory, and Elio Fazzalari's Procedural Theory. The qualitative research adopted the documentary analysis and bibliographic review methods and, as an inference methodology, the inductive one. Regarding the results, the reconstruction of the main arguments present in the Statement of Purpose of the new brazilian process code allowed the identification of the assimilation between the concepts of legal certainty and uniformity decisions, and its use as a justification for the procedural inovations introduced by the new legislation. However, this comprehension presents itself as incompatible with the democratic requirements settled down by the brazilian Constitution Procedural Model. According to this model, the judicial exercise should not be comprehended in an instrumental way, but as state's power destined to secure fundamental rights, procedural rights included, and should be able to ensure appropriate decisions to the singularity of each case decided, aswell should presents itself coherent with the decisions made by others courts. The study concludes that the intension to replace the logic of coherence presents in a discursive racionality by the logic of eficiency-celerity-certainty matters in disregarding the democratic-participative character that conforms the Brazilian Constitutional Constitutional Model.

Keywords: New Procedural Code; Theory of Law; Brazilian Constitutional Procedural Model

\section{INTRODUÇÃo}

No ano de 2009, o Senado Federal instituiu uma Comissão de Juristas à qual atribuiu a responsabilidade de elaborar o anteprojeto de um novo Código de Processo Civil. Segundo o Ato do Presidente no. 379/09, a elaboração de um novo Código de Processo Civil fazia-se necessária em razão do grande número de alterações legislativas sofrida pelo Código de Processo Civil de 1973, alterações essas que comprometeram sua sistematicidade e ao mesmo tempo foram insuficientes no que tange à sua atualização em face do "desenvolvimento teórico" experimentado pelo Direito Processual brasileiro na contemporaneidade. Também justificou a elaboração de um novo código, a necessidade de se conferir ao processo maior agilidade em face das novas concepções relativas ao acesso à justiça e à razoável duração do processo. ${ }^{1}$

O Anteprojeto foi elaborado então por uma comissão composta por onze processualistas e apresentado pelo Senado Federal em 2010, quando teve início o processo legislativo que culminou com a publicação da Lei 13.105, em 16 de março de 2015. O novo Código de Processo Civil revelou uma fina sintonia com as razões que levaram à constituição da comissão, sobretudo no que tange à estruturação de um processo comprometido com a celeridade processual e a segurança jurídica, como se depreende da análise da Exposição de Motivos que acompanhou a nova lei. Segundo esta, o novo Código objetivou a busca por um processo célere, simplificado, rentável e coeso, convergindo em direção a uma lógica de uniformidade decisória, com fundamento na valorização de precedentes. ${ }^{2}$

Pode-se afirmar que a busca obcecada pela celeridade processual, expressão cunhada por Dinamarco ${ }^{3}$ e que tanto influenciou a elaboração do novo Código, não é fruto de uma preocupação recente quando se discute políticas de acesso à jurisdição. Ela esteve no centro das discussões quando da aprovação da Reforma do Poder Judiciário, realizada pela Emenda Constitucional 45/04, que promoveu, dentre outras relevantes al-

1 SENADO FEDERAL. Ato da Presidência no. 379/2009. Disponível em: https://www.senado.gov.br/senado/novocpc/pdf/ ATO\%20DO\%20PRESIDENTE\%20N\%20379.pdf. Acesso em: 30 de junho de 2017.

2 SENADO FEDERAL. Código de processo civil e normas correlatas. Brasília: Coordenação de Edições Técnicas, 2015. Disponível em: http://www2.senado.leg.br/bdsf/bitstream/handle/id/514048/CPC_8ed_2015.pdf?sequence=1. Acesso em 30 de junho de 2017.

3 DINAMARCO, Cândido Rangel. Instituições de Direito Processual Civil. Vol. I. 8ª ed., São Paulo: Malheiros, 2016 , p. 43. 
terações, a criação do Conselho Nacional de Justiça, a introdução da súmula vinculante e a positivação do princípio da celeridade processual no inciso LXXVIII do artigo $5^{\circ}$. da Constituição Federal.

A aprovação de um novo Código de Processo Civil capaz de garantir a atuação da jurisdição de forma mais eficiente e célere, apresenta-se como o desdobramento natural de uma política pública cujo principal recurso restringiu-se à reformulação dos procedimentos jurisdicionais e à revisão do sentido da jurisdição a partir da lógica da coesão, entendida como uniformidade. Nesse sentido, afirmou o Presidente da Comissão de Juristas, Luiz Fux, que o desafio enfrentado pela referida comissão foi o de "resgatar a crença no judiciário e tornar realidade a promessa constitucional de uma justiça pronta e célere" como forma de responder aos questionamentos postos pelo enorme volume de ações e recursos existentes, caracterizados por solenidades desnecessárias.

Entretanto, a efetivação de direitos processuais requer uma compreensão mais adequada da jurisdição no marco do Estado Democrático de Direito e dos requisitos necessários à sua atuação através do devido processo. $\mathrm{O}$ assegurar o direito fundamental de acesso à jurisdição não se resume a uma lógica de eficiência-celeridade-segurança, mas pressupõe a compatibilidade entre os procedimentos estruturados pelo legislador e o modelo processual constitucionalmente estabelecido. É a partir desse, do Modelo Constitucional do Processo, que o novo Código e seus institutos devem ser compreendidos.

O objetivo do presente artigo é o de reconstruir os pressupostos teóricos subjacentes à elaboração do novo código processual presentes na sua Exposição de Motivos e que servem de guias iniciais para a interpretação do seu conteúdo, e confrontá-los com os pressupostos teóricos constitucionalmente estabelecidos, de modo a possibilitar uma reflexão crítica acerca da função e dos objetivos postos por uma legislação processual no contexto de um Estado Democrático de Direito.

O trabalho é resultado de uma pesquisa qualitativa e adotou como procedimento a análise documental a Exposição de Motivos do Código de Processo Civil de 2015, e o procedimento de revisão bibliográfica. O primeiro tópico do trabalho tem por objeto de análise os pressupostos em torno da Exposição de Motivos no Código de Processo Civil de 2015. Em seguida, tem-se a reconstrução da compreensão procedimental do modelo constitucional processual brasileiro estruturado pela Constituição Federal de 1988, adotando-se como referencial teórico da discussão a Teoria do Processo como Procedimento realizado em Contraditório, de Elio Fazzalari, e a Teoria Discursiva do Direito, de Jürgen Habermas, e os desenvolvimentos por nós realizados em torno de uma Teoria da Argumentação Jurídica e de uma Teoria do Processo Legislativo. No terceiro tópico, as discussões realizadas nos dois primeiros são resgatadas e confrontadas, com a finalidade de se apresentar uma crítica à compreensão jurídico-principiológica subjacente à proposta apresentada pela Comissão, e ao mesmo tempo oferecer um resgate do sentido democrático que a Constituição da República está a exigir da prática jurisdicional.

\section{Pressupostos interpretativos em torno da Exposição de Motivos do Código de Processo CiVIL de 2015}

A demanda por uma nova codificação processual com a finalidade de substituir a anterior, cujos identidade e sentido de unidade restaram comprometidos em função das várias alterações legislativas sofridas ao longo do tempo, intensificou-se com a necessidade de uma atualização capaz de promover a compatibilidade da sistemática processual jurisdicional com o caráter fundamental dos direitos processuais e a efetivação dos demais direitos fundamentais, culminando com a publicação da Lei 13.105, em 2015. A tentativa de

4 SENADO FEDERAL. Comissão de Juristas Responsável pela Elaboração de Anteprojeto de Código de Processo Civil. Brasília: Senado Federal, Presidência, 2010. Disponível em: https://www.senado.gov.br/senado/novocpc/pdf/Anteprojeto.pdf. Acesso em: 30 de junho de 2017. 
conciliar direitos fundamentais com o exercício da jurisdição orientou a motivação da Comissão de Juristas encarregada de elaborar o novo código:

Um sistema processual civil que não proporcione à sociedade o reconhecimento e a realização dos direitos, ameaçados ou violados, que têm cada um dos jurisdicionados, não se harmoniza com as garantias constitucionais de um Estado Democrático de Direito. ${ }^{5}$

Segundo se depreende da Exposição de Motivos que antecede o Código de Processo Civil de 2015, este buscou realizar cinco objetivos supostamente pretendidos com a sua "evidente redução da complexidade inerente ao processo de sua criação", quais sejam: I) estabelecer uma sintonia com a Constituição Federal; II) "criar condições para que o juiz possa proferir decisão de forma mais rente à realidade fática subjacente à causa"; III) "simplificar, resolvendo problemas e reduzindo a complexidade de subsistemas, como, por exemplo, o recursal"; IV) "dar todo o rendimento possível a cada processo em si mesmo considerado" e, finalmente, V) "imprimir maior grau de organicidade ao sistema, conferindo-lhe, assim, mais coesão". ${ }^{6}$

Infere-se da leitura da Exposição de Motivos que a sistematicidade e coesão do "sistema" estão diretamente vinculados ao papel que se atribuiu aos Tribunais Superiores, sobretudo ao Supremo Tribunal Federal, de uniformizar a interpretação do Direito a ser aplicado, a adotar-se, assim, uma padronização decisória de caráter obrigatório para os Tribunais Estaduais, Regionais e juízos de primeira instância. Percebe-se, pois, a pretensa instrumentalização não só do processo em si, mas do exercício da jurisdição, substituindo a exigência de uma coerência discursiva por uma lógica da eficácia/generalização, demonstrando assim a tendência de uma compreensão preponderantemente funcional sobre uma interpretação discursivamente sustentável. ${ }^{7}$

Para ilustrar o que afirmamos, vejamos o trecho abaixo constante da Exposição de Motivos em questão:

O novo Código prestigia o princípio da segurança jurídica, obviamente de índole constitucional, pois que se hospeda nas dobras do Estado Democrático de Direito e visa a proteger e a preservar as justas expectativas das pessoas.

Todas as normas jurídicas devem tender a dar efetividade às garantias constitucionais, tornando "segura" a vida dos jurisdicionados, de modo a que estes sejam poupados de "surpresas", podendo sempre prever, em alto grau, as consequências jurídicas de sua conduta. ${ }^{8}$

A conclusão a que se pode chegar a partir da leitura da Exposição de Motivos é que a pretensão do Código de Processo Civil seria a de "garantir o princípio constitucional da segurança jurídica", "princípio" este que foi pretendido como coerente ao modelo constitucional do processo civil brasileiro. Referida pretensão far-se-ia transversalmente pelos cinco objetivos acima elencados ( $\mathrm{I}$ V), de maneira a permitir um conjunto de mudanças legislativas e de práticas jurisdicionais que fossem capazes de alicerçar pretendido intuito. E tal compreensão de "segurança jurídica" foi assumida, como dito anteriormente, de uma perspectiva funcionalizada, interpretando-a como a ser realizada através da estabilização da jurisprudência dos tribunais e da sua aplicação uniforme.

Tais questões estão presentes de maneira contundente na Exposição de Motivos porque a comissão de especialistas, designada para propor o então Projeto do CPC, partiu do entendimento segundo qual haveria

5 SENADO FEDERAL. Código de processo civil e normas correlatas. Brasília: Coordenação de Edições Técnicas, 2015. Disponível em: http://www2.senado.leg.br/bdsf/bitstream/handle/id/514048/CPC_8ed_2015.pdf?sequence=1. Acesso em 30 de junho de 2017, p. 24.

6 SENADO FEDERAL. Código de processo civil e normas correlatas. Brasília: Coordenação de Edições Técnicas, 2015. Disponível em: http://www2.senado.leg.br/bdsf/bitstream/handle/id/514048/CPC_8ed_2015.pdf?sequence=1. Acesso em 30 de junho de 2017 , p. 26.

7 CHAMON JUNIOR, Lúcio. Teoria da Argumentação: constitucionalismo e democracias em uma reconstrução das fontes no Direito Moderno. Rio de Janeiro: Editora Lumen Juris, 2008.

8 SENADO FEDERAL. Código de processo civil e normas correlatas. Brasília: Coordenação de Edições Técnicas, 2015. Disponível em: http://www2.senado.leg.br/bdsf/bitstream/handle/id/514048/CPC_8ed_2015.pdf?sequence=1. Acesso em 30 de junho de 2017 , p. 28. 
um problema a ser enfrentado pelo novo Código, qual seja, o fato de os juízes, no exercício da jurisdição, "desvirtuando da liberdade de que gozam de decidir com base em seu entendimento sobre o sentido real da norma", extrapolariam o exercício do livre convencimento ao decidirem conforme uma convicção pessoal acerca do que é o Direito, desconsiderando as decisões proferidas pelos Tribunais Superiores. ${ }^{9}$

A partir da proposta deste falso problema, a comissão resolveu apresentar como solução a busca por uma "uniformização do Direito", capaz de gerar não só a "segurança jurídica" como consegui-la através de uma previsibilidade decisória a partir da uniformização das decisões. Para tanto, pretendiam a adoção de decisões jurisdicionais de forma padronizada, assumindo como métrica as decisões proferidas pelos Tribunais Superiores.

Com isto, estar-se-ia restringindo a interpretação do Direito aos Tribunais Superiores assumidos, implicitamente, como mais especializados e, portanto, dotados de um peso argumentativo mais valioso em razão da posição hierárquica e de autoridade sobre os demais. Em última análise, podemos concluir que, em matéria constitucional, estaríamos todos adstritos aos ditames do Supremo Tribunal Federal, sem que tenha havido uma melhor problematização do sistemática de controle de constitucionalidade no Brasil, sobretudo em seu viés difuso.

Por um outro ângulo, equivale a dizer que a preponderância de uma compreensão funcional do exercício da jurisdição leva, invariavelmente, a uma interpretação e prática positivistas do Direito, de maneira a validar argumentos de autoridade em detrimento de uma lógica a respeitar o sentido normativo e principiológico da própria Constituição ${ }^{10}$.

Para operacionalizar essa pretensão de uniformização, o Código de Processo Civil assumiu dois vieses: uma a) uniformização horizontal (no âmbito interno do próprio Tribunal) e uma $b$ ) uniformização vertical (a ser verificada na relação Tribunais Superiores e Tribunais inferiores).

A) Da uniformização horizontal. Estabelece o Código, em seu artigo 926, que "os tribunais devem uniformizar sua jurisprudência e mantê-la estável, íntegra e coerente”. Significa dizer que as decisões proferidas pelos tribunais devem se fazer refletir de maneira vinculante em todos os seus órgãos fracionários, isto é, em suas câmaras ou turmas, de maneira a permitir um posicionamento uníssono daquele tribunal.

Um dos procedimentos previstos no referido Código, e que permitiria a uniformização das decisões dos órgãos fracionários, isto é, a referida uniformização interna corporis, seria o incidente de assunção de competência. Tal procedimento veio a permitir que os processos de competência originária do tribunal, bem como os recursos, necessários ou não, possam ser conhecidos e julgados não pelo órgão fracionário originalmente competente, mas por órgão colegiado "maior", ${ }^{11}$ na hipótese de o procedimento suscitar "relevante questão de direito com grande repercussão social, sem repetição em múltiplos processos”, conforme disposto no artigo 947 do referido Código. O entendimento adotado no que se refere aos fundamentos da decisão proferida pelo órgão colegiado (pleno ou órgão especial) deverá ser observado por todos os órgãos fracionários deste mesmo tribunal em que se deu referido incidente de assunção de competência, gerando assim decisões pretensamente uniformes.

Outro mecanismo que serviria à uniformização horizontal seriam os embargos de divergência, previstos no artigo 1.043 e seguinte do texto codificado, e que segundo a Exposição de Motivos, haveriam que ser interpretados como um "poderoso instrumento, agora tornado ainda mais eficiente, cuja finalidade é [seria]

9 SENADO FEDERAL. Código de processo civil e normas correlatas. Brasília: Coordenação de Edições Técnicas, 2015. Disponível em: http://www2.senado.leg.br/bdsf/bitstream/handle/id/514048/CPC_8ed_2015.pdf?sequence=1. Acesso em 30 de junho de 2017, p. 29.

10 CHAMON JUNIOR, Lúcio. Teoria da Argumentação: constitucionalismo e democracias em uma reconstrução das fontes no Direito Moderno. Rio de Janeiro: Editora Lumen Juris, 2008, p. 145 e ss.

11 THEODORO JÚNIOR, Humberto. Curso de Direito Processual Civil. Volume III. Rio de Janeiro, Forense, 2016 , p. 810. 
a de uniformizar a jurisprudência dos Tribunais superiores, interna corporis". ${ }^{12} \mathrm{E}$ isto porque serviriam os embargos de divergência, portanto, para "uniformizar a jurisprudência interna das Cortes Superiores (...) porque seu cabimento se dá sempre que houver divergência de entendimento entre turmas ou outros órgão (sic) fracionários do Supremo Tribunal Federal ou do Superior Tribunal de Justiça". ${ }^{13}$

B) Uniformização vertical. Por seu turno, a uniformização vertical seria aquela que ocorreria com a uniformização da jurisprudência desde os Tribunais para os órgãos jurisdicionais inferiores a estes, considerando sua estrutura organizacional interpretada, pois, em termos de submissão funcional. E tudo isso de maneira a alinhavar, em termos "materiais", o entendimento do Judiciário acerca de uma determinada questão como forma, agora, não de permitir compreender o que se coloca como posição daquele Tribunal, mas como "a" posição do Poder Judiciário.

Assim, nos termos do artigo 927 do Código de Processo Civil, serviriam de parâmetro decisório para a uniformização das decisões dos tribunais e juízos as decisões proferidas pelo Supremo Tribunal Federal no âmbito do controle concentrado de constitucionalidade, a saber, as decisões proferidas em ação direta de inconstitucionalidade, ação declaratória de constitucionalidade, arguição de descumprimento de preceito fundamental (todas estas com eficácia vinculante), os enunciados de súmulas vinculantes e não vinculantes em matéria constitucional editados pelo Supremo Tribunal Federal, os acórdãos em incidente de assunção de competência ou incidente de resolução de demanda repetitiva julgados pelo Supremo Tribunal Federal e pelo Superior Tribunal de Justiça, as decisões proferidas em recursos especial repetitivo julgado pelo Superior Tribunal de Justiça e recurso extraordinário repetitivo julgado pelo Supremo Tribunal Federal, as súmulas editadas pelo Superior Tribunal de Justiça em matéria não constitucional e, por fim, as orientações do plenário ou do órgão especial aos quais estiverem vinculados. ${ }^{14}$

A partir desses procedimentos, pretender-se-ia alcançar, com o novo Código de Processo, o "objetivo" de uma uniformização jurisprudencial de forma a mantê-la estável, íntegra e coerente conforme disposto no seu artigo 926.

Neste momento, faz-se relevante pontuar que não foi o Código de Processo Civil de 2015 aquele a introduzir no Direito Processual Brasileiro pós 1988, a previsão de que os juízes e tribunais deveriam assumir decisões proferidas por outros órgãos, sobretudo pelos Tribunais Superiores e pelo Supremo Tribunal Federal, de maneira vinculante. Tal previsão foi inaugurada quando da introdução da Ação Declaratória de Constitucionalidade institucionalizada por nosso ordenamento jurídico mediante a Emenda Constitucional 3/93. Referida Emenda veio a prever um novo procedimento de controle concentrado de constitucionalidade de competência originária do STF cujo objetivo era o de eliminar dúvidas ou incertezas acerca da validade de lei ou ato normativo federal em face da Constituição da República. A declaração de constitucionalidade tem, desde então, caráter geral e vinculante com relação a todos os órgãos do Poder Judiciário e do Poder Executivo. ${ }^{15}$ Posteriormente, houve a expansão dessa vinculação aos efeitos decorrentes de provimentos proferidos em sede de Arguição de Descumprimento de Preceito Fundamental ${ }^{16}$ e Ação Direta de Incons-

12 SENADO FEDERAL. Código de processo civil e normas correlatas. Brasília: Coordenação de Edições Técnicas, 2015. Disponível em: http://www2.senado.leg.br/bdsf/bitstream/handle/id/514048/CPC_8ed_2015.pdf?sequence=1. Acesso em 30 de junho de 2017, p. 30.

13 THEODORO JÚNIOR, Humberto. Curso de Direito Processual Civil. Volume III. Rio de Janeiro, Forense, 2016, p. 1.152.

14 SENADO FEDERAL. Código de processo civil e normas correlatas. Brasília: Coordenação de Edições Técnicas, 2015. Disponível em: http://www2.senado.leg.br/bdsf/bitstream/handle/id/514048/CPC_8ed_2015.pdf?sequence=1. Acesso em 30 de junho de 2017.

15 Nos termos do parágrafo $2^{\circ}$ do artigo 102 da Constituição da República, com a redação conferida pela Emenda Constitucional 03/93: "As decisões definitivas de mérito, proferidas pelo Supremo Tribunal Federal, nas ações declaratórias de constitucionalidade de lei ou ato normativo federal, produzirão eficácia contra todos e efeito vinculante, relativamente aos demais órgãos do Poder Judiciário e ao Poder Executivo."

16 Nos termos do $\$ 2^{\circ}$. do art. 102 da Constituição Federal de 1988, com a redação atual conferida pela Emenda Constitucional 45/2004: "As decisões definitivas de mérito, proferidas pelo Supremo Tribunal Federal, nas ações diretas de inconstitucionalidade e nas ações declaratórias de constitucionalidade produzirão eficácia contra todos e efeito vinculante, relativamente aos demais órgãos 
titucionalidade, com a promulgação da Emenda Constitucional 45/04, Emenda esta que também veio a introduzir o instituto da Súmula Vinculante, regulamentada no artigo 103-A da atual Constituição.

O Código de Processo Civil de 2015 inova apenas e tão somente ao criar novos procedimentos produtores de decisões padronizadas. Precedentes podem ser editados tanto a partir do julgamento de uma ação de controle concentrado de constitucionalidade, da edição de uma súmula vinculante, de um incidente de assunção de competência, de um incidente de resolução de demanda repetitiva, quanto também a partir do julgamento de recurso extraordinário repetitivo. Assim sendo, o Código de Processo Civil de 2015 amplia o rol de decisões vinculantes e, portanto, de observância obrigatória.

Entretanto, o que há que ser melhor problematizado é que a ampliação dessas possibilidades de "padronização decisória" para outros e novos procedimentos há que ser acompanhada de um entendimento capaz de permitir-nos compreender que, não obstante a existência de um determinado posicionamento cristalizado em uma súmula, por exemplo, a concretude do caso, o recorte argumentativo apresentado pelas partes, além da consideração da dimensão normativa dos princípios devem, todos, ser considerados como elementos centrais e determinantes das novas decisões, sob pena de se substituir o exercício da jurisdição por uma suposta atividade legislativa dos Tribunais superiores - e de forma absolutamente autoritária a se pretender fazer uma "lei" de aplicabilidade independentemente dos traços concretos de cada caso, como se a jurisdição inferior fosse mera chancelaria das decisões planificadas pelos órgãos superiores.

Essa pretensão de "uniformização de tratamento jurídico" subjacente às referidas inovações acima elencadas, e fortemente visível na Exposição de Motivos do Código de Processo Civil de 2015, quer se fazer conectar, invariavelmente, à forma jurídica moderna, sobretudo no que se refere à positividade do Direito que, ao assumir os textos legislativos convencionados como referência do desdobramento interpretativo do próprio Direito, utiliza de um procedimento a buscar uma abstração e generalidade condizentes com as conquistas funcionais e argumentativas do Direito da Modernidade ${ }^{17} \mathrm{E}$ isto no sentido de que a realização do ideal do Estado de Direito há que pressupor a legislação como norma geral e abstrata, aplicável indistintamente a todos, governantes e governados. Por consequência, tem-se construído um sistema de direitos a um só tempo capaz de garantir iguais direitos e deveres a todos os cidadãos, conquanto, também, sujeitos de direito.

Ou seja, a pretensão de "uniformização de tratamento jurídico", da maneira como pensada e praticada por nossos Tribunais na atualidade, e a partir das inovações legislativas indicadas acima, vale-se, parasitariamente, de características formais do Direito típicas da legislação, mas absolutamente incompatíveis com o exercício de uma jurisdição entendida como locus de aplicação individualizada do Direito.

Por outro lado, mas no mesmo sentido, pode-se compreender que em uma democracia, sempre institucionalizada em um Estado de Direito, o princípio da separação de poderes possibilita maior controle da atuação dos órgãos estatais, vez que entendido como atribuição de funções especializadas a órgãos autônomos, capazes de controlarem-se, reciprocamente, no exercício de suas diferenciadas funções. Assim, as funçoes legislativa e jurisdicional hão que ser assumidas por órgãos diferenciados e competentes, em cada caso, para o exercício de sua respectiva função constitucionalmente atribuída.

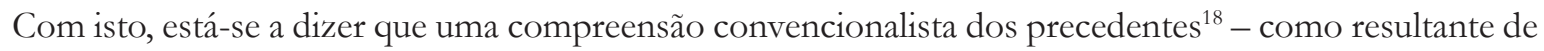

do Poder Judiciário e à administração pública direta e indireta, nas esferas federal, estadual e municipal.” No mesmo sentido dispõe o $\$ 3^{\circ}$ do artigo 10 da Lei 9.882/99, que regulamenta os efeitos da declaração de inconstitucionalidade proferida em arguição de descumprimento de preceito fundamental. Já o parágrafo único do artigo 28 da Lei 9.868/99, complementando o disposto na Constituição Federal de 1988, em seu artigo 102, estabelece que "A declaração de constitucionalidade ou de inconstitucionalidade, inclusive a interpretação conforme a Constituição e a declaração parcial de inconstitucionalidade sem redução de texto, têm eficácia contra todos e efeito vinculante em relação aos órgãos do Poder Judiciário e à Administração Pública federal, estadual e municipal. 17 CHAMON JUNIOR, Lúcio. Teoria da Argumentação: constitucionalismo e democracias em uma reconstrução das fontes no Direito Moderno. Rio de Janeiro: Editora Lumen Juris, 2008 e HABERMAS, Jürgen. Facticidad y validez: 3a ed. Madrid: Editorial Trotta, 2001.

18 Nesse sentido, os precedentes somar-se-iam-se às decisões políticas - provimentos legislativos, na medida em que definiriam o seu sentido de modo vinculante, sujeitando-se a uma aplicação do tipo definitivo. Por outro lado, assumir os precedentes como convenções significa também reconhecer aos juízes um poder decisório discricionário na hipótese de uma omissão convencional. 
uma leitura e prática superficiais do CPC e da própria Constituição - permitir-nos-ia fazer crer que estes não se colocariam como mais uma interpretação da norma, ao lado de tantas outras possíveis a serem tomadas em consideração no caso a caso, diante da concretude argumentativa e probatória de cada processo. Do contrário, estaríamos assumindo os Tribunais Superiores como órgãos legislativo-estabilizadores, ao criar padrões interpretativos de aplicação inquestionável por parte dos órgãos jurisdicionais inferiores, desmoronando-se, assim, a distinção de funções e, portanto, do sentido constitucional do Estado de Direito.

A atuação da jurisdição caracteriza-se, não apenas pela necessária provocação do órgão judiciário através do exercício do direito constitucional de ação, mas sobretudo pela submissão de uma situação concreta conflituosa única, singular, a demandar, nesse sentido, uma decisão jurisdicional capaz de, ao assumir a singularidade do caso, assegurar concretamente direitos pressupostos em uma constelação de princípios, que pode ser desdobrada legislativamente (mediante a criação de normas e procedimentos gerais e abstratos) ou jurisdicionalmente (mediante o reconhecimento coerente de direitos e deveres aos afetados pela decisão, enquanto desdobramento da busca de iguais liberdades no caso concreto).

Entretanto, a prática de uma jurisdição concebida como reprodução de um padrão interpretativo previamente estabelecida por um Tribunal superior veio a substituir, em termos discursivos, a lógica do contraditório e da participação pela lógica da autoridade, assim como substitui a lógica da singularidade do caso concreto, objeto de análise a demandar decisões adequadas a essa singularidade, pela da lógica da generalidade uniformizadora pretensamente garantidora de uma "segurança jurídica", sob o argumento de que esta se "hospeda nas dobras do Estado Democrático de Direito". ${ }^{19}$ Desde uma perspectiva teórica, significa dizer que pretende, com essa proposta subjacente ao Código, perpetuar uma interpretação positivista e convencionalista a explicar a validade da decisão em virtude da autoridade que a prolata, e não em virtude da coerência de argumentos processuais e materiais ao conjunto do sistema de direitos. ${ }^{20}$

A Comissão de Juristas responsável pelo esboço do Novo Código justificou seu posicionamento em torno da busca de uma "uniformização jurisprudencial" e criação de "novas figuras" para este fim, sob o argumento de que "a dispersão excessiva da jurisprudência produz intranquilidade social e descrédito do Poder Judiciário". ${ }^{21}$ Ou seja: não entendem a dimensão interpretativa do Direito, muito menos o fato de que os aspectos funcionais (eficiência do Poder Judiciário) estão invariavelmente atrelados a uma compreensão da Jurisdição a reconhecer no caso a caso, e não no atacado, as iguais liberdades aos afetados. Pretendem nos fazer crer que o problema do Poder Judiciário residir-se-ia na liberdade interpretativa dos juízes motivo pelo qual dever-se-ia restringi-la por meio de mecanismos a concentrar a competência interpretativa nas mãos dos Tribunais superiores.

Ainda de acordo com a Comissão de Juristas, tal expediente resolveria um segundo, mas não menos importante problema: o excessivo número de procedimentos que assoberbam o Poder Judiciário, a comprometer a "qualidade da prestação jurisdicional". ${ }^{22}$

Desta forma, pode-se concluir que a Comissão de Juristas acaba por assumir uma ideia equivocada de segurança jurídica como previsibilidade, repetitividade e controle das decisões jurisdicionais além de, inadvertidamente, assumir tal perspectiva pragmatista do processo em detrimento dos princípios constitucionais

Neste sentido, ver: DWORKIN, Ronald. O império do direito. São Paulo: Martins Fontes, 1999.

19 SENADO FEDERAL. Código de processo civil e normas correlatas. Brasília: Coordenação de Edições Técnicas, 2015. Disponível em: http://www2.senado.leg.br/bdsf/bitstream/handle/id/514048/CPC_8ed_2015.pdf?sequence=1. Acesso em 30 de junho de 2017, p. 28.

20 DWORKIN, Ronald. O império do direito. São Paulo: Martins Fontes, 1999.

21 SENADO FEDERAL. Código de processo civil e normas correlatas. Brasília: Coordenação de Edições Técnicas, 2015. Disponível em: http://www2.senado.leg.br/bdsf/bitstream/handle/id/514048/CPC_8ed_2015.pdf?sequence=1. Acesso em 30 de junho de 2017 , p. 29.

22 SENADO FEDERAL. Código de processo civil e normas correlatas. Brasília: Coordenação de Edições Técnicas, 2015. Disponível em: http://www2.senado.leg.br/bdsf/bitstream/handle/id/514048/CPC_8ed_2015.pdf?sequence=1. Acesso em 30 de junho de 2017, p. 29. 
que regem o modelo constitucional de processo no Brasil.

\section{DA COMPREENSÃo PROCEDIMENTAL DO MODELO CONSTITUCIONAL DO PROCESSO BRASILEIRO}

As relações capazes de serem problematizadas entre Constituição e processo são objeto de análise tanto por parte de constitucionalistas ${ }^{23}$ quanto de processualistas ${ }^{24}$ há algum tempo e essa relação bastante próxima se dá por três fortes razões:

A primeira delas refere-se ao fato de a Constituição estabelece processos para a efetivação e proteção dos direitos fundamentais conhecidos como "garantias constitucionais", como, por exemplo, o mandado de segurança, o habeas corpus, o habeas data, o mandado de injunção, entre outros processos relevantes. ${ }^{25}$

Outra razão refere-se ao fato de as constituições formais, caracterizadas assim por serem escritas e rígidas, estabelecerem, como forma de garantia da sua hierarquia, um sistema de controle de constitucionalidade das leis e atos normativos. Tal sistema é definido constitucionalmente, pela atribuição a um ou a vários órgãos do Poder Judiciário, a garantia da supremacia da Constituição através do exercício do controle de constitucionalidade. A Constituição, destarte, estabelece para o desenvolvimento desta atribuição de controle constitucional procedimentos, legitimados para propor e participar de tais procedimentos, requisitos, condições, dentre outros elementos processualmente relevantes.

Finalmente, a terceira razão encontra-se no fato de que, com o paulatino avanço do constitucionalismo, também as constituições passaram a prever, de modo cada vez mais acentuado, direitos fundamentais processuais, como o contraditório, a ampla defesa, o devido processo legal, o princípio do juiz natural, o do acesso à jurisdição, dentre outros. ${ }^{26}$

Esta última dimensão da relação entre a Constituição e o Direito Processual se torna, neste momento da nossa exposição - e em razão de se conectar profundamente com a dimensão discursivo-processual dos processos de entendimento na Modernidade e se fazer transversalmente indispensável a uma prática constitucional capaz de ser legitimamente assumida como tal -, o centro do interesse, pois nesta dimensão configura-se o modelo constitucional do processo brasileiro. E isto porque as teorias que buscam a compreensão do modelo constitucional do processo têm seu foco orientado à compreensão da dimensão constitucional do processo em detrimento a discussões que se refiram à natureza do processo. Tradicionalmente, a Teoria do Processo buscou explicitar a natureza deste a partir de categorias gerais da Teoria do Direito, o que possibilitou compreensões segundo as quais o processo poderia ser concebido como um "contrato" 27 , "quase contrato" 28 , instituição jurídica, ${ }^{29}$ situação jurídica ${ }^{30}$ e, por fim, uma relação. ${ }^{31}$ Naturalmente, essas concepções, advindas sobretudo da Teoria do Direito Privado, foram "adaptadas" com a finalidade de explicar uma atividade político-estatal, qual seja, a jurisdição, possibilitando, por exemplo, a compreensão do

23 Neste sentido, os trabalhos dos constitucionalistas José Alfredo de Oliveira Baracho (1984), Hector Fix-Zamudio, Mauro Cappelletti, Eduardo Ferrer Mac-Gregor, entre outros.

24 Neste sentido, Eduardo Couture, Fazzalari, Andolina, Vignera, como se verá mais à frente.

25 Tais procedimentos formam o objeto do Direito Processual Constitucional, ao lado dos procedimentos de controle de constitucionalidade e das normas constitucionais concernentes à organização judiciária e tutela constitucional do processo, segundo Baracho, José Alfredo de Oliveira. Processo Constitucional. Rio de Janeiro: Forense, 1984, p. 125 e seguinte.

26 Ainda segundo Baracho, estes princípios formam o objeto do Direito Constitucional Processual. Neste sentido: Baracho, José Alfredo de Oliveira. Processo Constitucional. Rio de Janeiro: Forense, 1984, p. 125.

27 COUTURE, Eduardo Juan. Fundamentos do Direito Processual Civil. São Paulo: Saraiva e Cia., 1946, p. 90.

28 COUTURE, Eduardo Juan. Fundamentos do Direito Processual Civil. São Paulo: Saraiva e Cia., 1946, p. 92.

29 GUASP, Jaime. Derecho Procesal Civil. Madrid, Editorial Civitas, 1998.

30 GOLDSCHMIDT, James. Direito Processual Civil. Campinas: Bookseller, 2003.

31 BÜLLOW, Oskar von. La teoría de las excepciones procesales y los presupuestos procesales. Trad. Miguel Angel Rosas Lichtschein. Buenos Aires: Ediciones Juridicas Europa-America, 1964; CHIOVENDA, José. Principios de Derecho Procesal Civil. Madrid: Editorial REUS, 1.925. 
processo como "relação jurídica de direito público". Por sua vez, as teorias constitucionalistas do processo não buscam explicitar/discorrer/analisar a categoria jurídica à qual o processo pode ser conectado, como forma de melhor compreendê-lo. Buscam, na verdade, contribuir para uma compreensão do processo como forma juridicamente legítima de exercício de uma função estatal garantidora de direitos de participação.

Posto isto, devemos partir da explicitação de que a Teoria Constitucionalista do Processo foi primeiramente estruturada por Eduardo Couture ${ }^{32}$ e despertou interesse da doutrina internacional, encontrando grande aceitação entre os processualistas do mundo inteiro. ${ }^{33}$ No Brasil, seu desenvolvimento decorreu, sobretudo, das pesquisas desenvolvidas pelo Professor José Alfredo de Oliveira Baracho, cuja obra Processo Constitucional tornou-se um marco no estudo do Direito Processual Constitucional brasileiro. ${ }^{34}$

Diferentemente das demais teorias processuais, a teoria constitucionalista do processo não tem por objetivo analisar o processo de sua perspectiva interna, isto é, de sua natureza jurídica, como já explicitado, mas analisar as relações que o processo estabelece com a Constituição.

A relação existente entre Constituição e Processo é apontada por vários publicistas, desde que o texto fundamental traça as linhas essenciais do sistema processual consagrado pelo Estado. A Constituição determina muitos dos institutos básicos do processo, daí as conclusões que acentuam, cada vez mais, as ligações entre a Constituição e o Processo..$^{35}$

Esta colocação de Baracho se alinha ao que Couture prenunciava no sentido de que "a tutela do processo se realiza através do império das previsões constitucionais". ${ }^{36}$ Pois, de uma perspectiva constitucionalista, o processo, como instrumento de aplicação do Direito, está a depender da garantia efetiva dos principios constitucionais processuais. É neste sentido que se deve compreender a afirmação de Baracho, ao citar Eduardo Couture, que a Constituição há que pressupor "a existência do processo como garantia da pessoa humana". ${ }^{37}$

Na mesma linha traçada por Couture, apresentam Ítalo Andolina e Giuseppe Vignera ${ }^{38}$ uma teoria processual centrada na relação do processo com a Constituição. Muito influenciados pelo então paradigma constitucional orientado em termos de um Estado Social, inaugurado em 1948 na Itália, os autores apresentam uma preocupação que se faz ainda extremamente atual: a necessidade de se afirmar um fundamento constitucional para o processo, não apenas desde uma justificativa processual/formal interna ao processo, aos moldes de uma teoria como a da relação jurídico-processual ${ }^{39}$, mas sobretudo “material”, assumindo tal fundamento como consubstanciador de um verdadeiro modelo processual de observância obrigatória, porque constitucionalmente instituído e, pois, conectado à dimensão pragmático-universal da comunicação ${ }^{40}$.

32 O pioneirismo de Couture é reconhecido por Hector Fix-Zamudio, que, como anota Baracho, "considera como obra clássica e iniciadora do Direito Constitucional Processual, o ensaio de Couture intitulado Las Garantias Constitucionales del Proceso Civil. Registrese que a teoria constitucional processual de Couture foi incorporada à sua obra Fundamentos do Direito Processual Civil por ocasião da $3^{a}$ edição, publicada em 1958. Baracho, José Alfredo de Oliveira. Processo Constitucional. Rio: Forense, 1984, p. 127.

33 Acerca do desenvolvimento do Direito Processual Constitucional como ramo do Direito Processual ver: MAG-GREGOR, Eduardo Ferrer. La Ciencia del Derecho Procesal Constitucional. Díkaion. Vol. 22, n. 17, 2008.

34 Baracho, José Alfredo de Oliveira. Processo Constitucional. Rio de Janeiro: Forense, 1984.

35 Baracho, José Alfredo de Oliveira. Processo Constitucional. Rio de Janeiro: Forense, 1984, p. 122.

36 No original: "La tutela del proceso se realiza por imperio delas previsiones constitucionales" In: COUTURE, Eduardo Juan. Fundamentos del Derecho Procesal Civil. Montevideo-Buenos Aires: Editorial B de F, 2007, p. 120.

37 Baracho, José Alfredo de Oliveira. Processo Constitucional. Rio de Janeiro: Forense, 1984, p. 125; COUTURE, Eduardo Juan. Fundamentos del Derecho Procesal Civil. Montevideo-Buenos Aires: Editorial B de F, 2007, p. 122.

38 ANDOLINA, Italo; VIGNERA, Giuseppe. I fondamenti costituఇionali della giustiz̨ia civile: il modello costituzionale del processo civile italiano. Torino: G. Giappichelli Editore, 1997.

39 A teoria do processo como relação jurídica, em linhas gerais, compreende o processo como uma relação jurídica de natureza pública e de caráter complexo, que estabelece entre o órgão jurisdicional e as partes e entre estas posições jurídicas ativas e passivas. Não inferem os teóricos da relação jurídica uma necessária relação de compatibilidade entre as normas constitucionais definidoras de direitos fundamentais processuais e o conjunto de poderes e faculdades, posições jurídicas ativas, sujeição e ônus, posições jurídicas passivas que compõem a complexa estrutura da relação jurídica processual. Neste sentido, ver: LAGES, Cintia Garabini. Direito-Garantia como abolição do vínculo da relação jurídica entre os sujeitos do processo. In: LEAL, Rosemiro Pereira (org.). Estudos Continuados de Teoria do Processo. Vol. II. Porto Alegre: Síntese Editora, 2001.

40 HABERMAS, Jürgen. Facticidad y valider. $3^{\text {a }}$ ed. Madrid: Editorial Trotta, 2001. 
A partir das características próprias da jurisdição como função que se desenvolve através de um procedimento e de sua institucionalização processual a partir da Constituição, duas questões são apresentadas pelos referidos autores. Uma, a possibilidade de identificação, na prática processual, de uma sequência procedimental capaz de ser assumida como "processo jurisdicional". Outra, caso se verifique a primeira dimensão, tratar-se-ia da forma processual de atuação da jurisdição segundo princípios constitucionais. ${ }^{41}$

De acordo com o que os autores denominam de perspectiva "pós-constitucional" 42 , "o problema do processo não pode estar vinculado apenas ao seu ser, ou seja, à sua concreta organização segundo as leis processuais ordinárias vigentes", como também não pode estar atrelado a uma concepção subjetivista da jurisdição, que a identifica a partir da competência do órgão que prolatou o provimento. ${ }^{43} \mathrm{O}$ processo deve ser analisado, segundo os autores, a partir do seu dever ser, isto é, a partir da dimensão normativa do conjunto de princípios constitucionais que regulam a atividade jurisdicional. Ou, de outra perspectiva, podemos afirmar que a dimensão da facticidade há que ser confrontada com a dimensão da validade. ${ }^{44} \mathrm{E}$ tudo isto, porque a jurisdição, ao ser instituída constitucionalmente, há que fundar, pois, sua atuação nos próprios princípios constitucionais instituidores. ${ }^{45}$

Assim, os autores realizam uma distinção necessária de ser reconstruída entre jurisdicionalidade originária e jurisdicionalidade constitucionalmente derivada.

A jurisdicionalidade originária, que seria oriunda da conformação das normas e procedimentos positivados, tem, na visão dos autores, um forte componente fático, qual seja, a concreta forma de organização e funcionamento do Poder Judiciário, sobretudo no que se refere a uma dimensão institucional "pré-constitucional”, em certo sentido, recepcionada ou não pela nova Constituição.

Uma vez ocorrido o giro constitucionalista na Itália, ou a suplantação de qualquer Constituição por outra, devemos passar a interpretar a jurisdicionalidade em seu aspecto institucional-originário, porém de maneira a torná-la compatível com as novas normas constitucionais, razão pela qual se poderia falar em uma jurisdicionalidade derivada da força constitucional imanente à nova ordem jurídico-política.

A jurisdicionalidade, que pode ser melhor compreendida como o qualitativo da função de jurisdizer, quando assumida como derivada da Constituição, isto é, como instituída constitucionalmente, perfazeria o que os autores denominam com muita precisão de "modelo constitucional do processo": conjunto de normas constitucionais referentes ao exercício da função jurisdicional e que se apresenta como um verdadeiro esquema geral de processo, capaz de se fazer entender como "objeto de uma exposição unitária". ${ }^{46}$

O modelo constitucional do processo, assumido pelos autores a partir de uma visão do Processo Civil, caracteriza-se pela sua expansividade, variabilidade e perfectibilidade.

A característica da expansividade importa o reconhecimento, a partir da primazia hierárquica de que gozam as normas constitucionais em face das demais normas do ordenamento jurídico, da potência do modelo constitucional do processo de constituir diretamente a plasticidade dos procedimentos jurisdicionais singulares estabelecidos pelo legislador ordinário, possibilitando a contínua expansão e desenvolvimento dos

41 ANDOLINA, Italo; VIGNERA, Giuseppe. I fondamenti costituzionali della giustizia civile: il modello costituzionale del processo civile italiano. Torino: G. Giappichelli Editore, 1997, p. 05.

42 Por pós-constitucional referem-se os autores a uma nova compreensão do processo que se impõe em razão de uma nova ordem constitucional, inaugurada a partir de 1948 e que, em termos generalistas, poderia referir-se a toda e qualquer ordem constitucional democrática instituidora, pois, do Estado de Direito.

43 ANDOLINA, Italo; VIGNERA, Giuseppe. I fondamenti costituqionali della giustizia civile: il modello costituzionale del processo civile italiano. Torino: G. Giappichelli Editore, 1997, p. 05.

44 No sentido habermasiano, ou seja, entendida aqui como legitimidade (HABERMAS, Jürgen. Facticidady validez. $3^{\mathrm{a}}$ ed. Madrid: Editorial Trotta, 2001, p. 200 e seguintes).

45 ANDOLINA, Italo; VIGNERA, Giuseppe. I fondamenti costituqionali della giustizia civile: il modello costituzionale del processo civile italiano. Torino: G. Giappichelli Editore, 1997, p. 05.

46 ANDOLINA, Italo; VIGNERA, Giuseppe. I fondamenti costituzionali della giustizia civile: il modello costituzionale del processo civile italiano. Torino: G. Giappichelli Editore, 1997, p. 07. 
procedimentos jurídicos.

Por seu turno, o traço característico da variabilidade significa a aptidão que o modelo constitucional apresenta de os procedimentos institucionalizados legislativamente assumirem formas diversas na busca de específicas finalidades previamente pretendidas, demonstrando, assim, não somente o aspecto fático de determinado processo legislativo a decidir por uma e não por outra forma procedimental, como também, e exatamente por isso, demonstra a própria contingência imanente do Direito.

Por fim, a característica da perfectibilidade possibilita que o modelo constitucional processual possa ser aperfeiçoado pela legislação infraconstitucional através da introdução de novas garantias e novos instrumentos não constantes do modelo constitucional original ${ }^{47}$, como maneira de continuamente levar adiante aquilo que Dworkin permite-nos concluir como sendo o processo de autoaprendizagem do Direito, ou, em outro sentido, o processo de autopurificação do Direito $^{48}$.

A essência da teoria do modelo constitucional do processo reside no reconhecimento da Constituição como configuradora de um "modelo único e de uma tipologia plúrima", expressão cunhada por Andolina e Vignera ${ }^{49}$ e que exprime a ideia de que existe um único modelo constitucional do processo a partir do qual surge uma pluralidade de decisões fático-legislativa acerca de procedimentos jurídicos, decisões essas que ao mesmo tempo em que reduzem a complexidade do sistema do Direito, denunciam a contingência de seu próprio funcionamento.

A esta configuração do modelo constitucional como sendo "único", podemos ainda, e agora a partir de uma interpretação devedora à Teoria do Discurso de Habermas, entender também que tal modelo se apresentaria como unitário no que se refere ao seu aspecto de potencialidade de coerência interpretativa. ${ }^{50}$

A teoria do modelo constitucional do processo foi originalmente concebida como uma teoria do processo jurisdicional e civil, o que não impede a sua ampliação para a criação de um verdadeiro modelo geral de processo: não apenas civil, mas também penal e trabalhista, não apenas público, mas também privado, não apenas jurisdicional, mas também legislativo, administrativo e arbitral. E isto porque partimos da perspectiva teórico-processual de Fazzalari, ao compreendermos que procedimento há que ser melhor interpretado como uma concatenação sequencial de atos processuais rumo a um provimento final. ${ }^{51}$

Neste sentido, podemos reconhecer como procedimentos, não somente o procedimento jurisdicional, cujo ato final, via de regra, será a sentença, mas também o procedimento legislativo, que desagua na aprovação de diferentes espécies legislativas ou ainda o procedimento administrativo, que pode tanto se referir a atividades de fiscalização, de regulamentação, de poder de polícia, dentre outras várias formas de atuação da Administração Pública. Processo, por seu turno, há que ser, dentro desta perspectiva, assumido como o procedimento realizado em contraditório, sendo este o reconhecimento recíproco de iguais armas e possibilidades argumentativas no procedimento..$^{52}$

Dessa forma, podemos estabelecer uma mediação entre as perspectivas defendidas, por um lado, por Andolina e Vignera e, por outro, por Fazzalari, ambas mediadas pela Teoria do Discurso de Habermas. Assim, podemos não só, expandir a ideia de que o modelo constitucional do processo há que se referir somente ao Processo Civil, como também compreender que os procedimentos (sejam legislativos, jurisdicionais ou administrativos) devem ser assumidos como interpretativamente derivados da Constituição. Nessa linha, podemos defender mais claramente que a partir de uma compreensão adequada do caráter procedimental

47 ANDOLINA, Italo; VIGNERA, Giuseppe. I fondamenti costiturionali della giustizia civile: il modello costituzionale del processo civile italiano. Torino: G. Giappichelli Editore, 1997, p. 09.

48 Dworkin, Ronald. O império do direito. São Paulo: Martins Fontes, 1999, p. 477.

49 ANDOLINA, Italo; VIGNERA, Giuseppe. I fondamenti costituzionali della giustizia civile: il modello costiturionale del processo civile italiano. Torino: G. Giappichelli Editore, 1997, p. 11.

50 HABERMAS, Jürgen. Facticidad y valider: $3^{\mathrm{a}} \mathrm{ed}$. Madrid: Editorial Trotta, 2001.

51 FAZZALARI, Elio. Istituzioni di Diritto Processuale. $8^{a}$ ed. Padova: CEDAM, 1996.

52 FAZZALARI, Elio. Istituzioni di Diritto Processuale. 8a ed. Padova: CEDAM, 1996. 
da Constituição e da potência legitimadora do Direito conferida ao processo, entende-se que o modelo constitucional processual estabelecido pela Constituição da República de 1988 conforma não apenas a configuração de novos procedimentos jurisdicionais, mas todos os procedimentos adotados pelo Estado para a realização de suas funções e em todos os procedimentos privados juridicamente relevantes. Assim, não há que se falar apenas em modelo constitucional do processo jurisdicional e civil, mas em modelo constitucional do processo e do procedimento, apenas.

\section{Traços reconstrutivos do Modelo Constitucional Processual brasileiro}

Acreditamos não ser mais necessário realizar uma reconstrução sobre o caráter democrático e participativo da Constituição de 1988. Ao longo de quase trinta anos, os estudos jurídicos no Brasil não se colocam em sentido contrário à compreensão de que a um só tempo a Constituição da República instituiu procedimentos democráticos conjuntamente com um rol de direitos fundamentais capazes de reconhecer os sujeitos de direito simultaneamente como cidadãos. A questão central que ora se coloca é como se dá a compreensão entre esses elementos e a indissociabilidade entre os mesmos.

A legitimidade do Direito somente pode ser levada adiante se compreendermos que o Direito retira sua legitimidade de processos discursivo-comunicacionais travados politicamente no âmbito de um processo democrático e se igualmente compreendermos que tal legitimidade, no âmbito de aplicação do Direito (seja jurisdicional, administrativo e legislativo em casos excepcionais) está igualmente atrelada a essa condição comunicacional que se nos faz inexorável e portanto, não-dispensável.

Dessa forma, o caráter democrático da Constituição de 1988 não estará plenamente satisfeito se somente assumido ou compreendido como referente a processos políticos de participação política e de tomada de decisões legislativas. O caráter democrático do Direito exige-nos uma compreensão aprofundada do que significa uma prática jurisdicional sustentável em termos argumentativos e decisórios, portanto, a variabilidade do modelo constitucional do processo brasileiro não se pode dar sem se tomar em consideração as outras duas características indissociáveis, quais sejam, a expansividade ("material", inclusive) e a perfectibilidade - todas essas noções comprometidas com o desenvolvimento e o aprofundamento do caráter constitucional do Direito brasileiro. Decisões legislativas em torno de novos procedimentos, por mais que se coloquem como capazes de permitir um "alívio" ou ganho de eficiência, todos geradores de uma suposta segurança não são capazes de serem enquadrados como coerentes ao modelo constitucional do processo se efetivamente não se verificar a construção capaz de aprofundar o próprio sentido democrático, e portanto, garantidor da condição comunicacional e participativa.

Nesse sentido, prestigiar a uniformidade como forma de garantir-se a segurança jurídica significa substituir, em flagrante ruptura com o modelo constitucional, a participação e argumentação das partes nos mais variados e específicos processos concretos, por mecanismos que introjetam no Direito uma racionalidade instrumental devedora de um raciocínio tipicamente econômico. Todavia a discussão que merece ser feita a partir da Exposição de Motivos do Código de Processo Civil de 2015 é no sentido de problematizar uma tese desde há muito já superada pela Teoria do Direito, qual seja, acerca da variabilidade do sistema e da pretensão da segurança jurídica como previsibilidade de resultado.

Da maneira assumida pela Comissão de Juristas do Código de Processo de 2015, a ideia de segurança jurídica, abertamente entendida como previsibilidade e redundância sistêmicas, é incapaz de compreender que cada caso é único, que os casos a serem decididos pela autoridade competente estão na dependência direta da reconstrução probatória e argumentativa das partes no processo, do sentido adequado dos princípios do contraditório $^{53}$ e da ampla defesa, além da incompreensão da atividade decisória como retroalimentada pelo

53 FAZZALARI, Elio. Istiturioni di Diritto Processuale. 8ª ed. Padova: CEDAM, 1996. 
processo argumentativo concreto a exigir uma coerência e uma fundamentação consistente caso a caso. ${ }^{54}$

Na medida em que a Constituição determina que a lei não pode excluir da apreciação do Poder Judiciário lesão ou ameaça a direito ou a mera infração a deveres ainda que não haja quaisquer direitos subjetivos ameaçados ou lesados, garante-se a todos os sujeitos de direito o exercício do direito de ação, e consequentemente de defesa, para salvaguardar seus interesses enquanto partes argumentativas no processo.

Isso significa dizer que as garantias processuais não estarão satisfeitas com uma mera constatação formal de suas "ocorrências", mas somente quando for assumida a dimensão hermenêutica e pragmático-universal imanentes da condição comunicacional moderna. ${ }^{55}$ Dessa forma, teremos concreta e efetivamente a garantia do contraditório e da ampla argumentação quando os argumentos trazidos pelas partes no bojo do processo, assim como as provas porventura realizadas neste, encontrarem ressonância não somente enquanto atos processuais mas igualmente no sentido material-discursivo dos atos e decisões no exercício da função jurisdicional. E tal ressonância há que se fazer demonstrada e explicitada na argumentação decisória da autoridade quando do seu exercício de fundamentação da decisão.

Assumimos, assim, a ideia central subjacente à obra de Ronald Dworkin ${ }^{56}$, ideia essa acolhida em larga medida por Klaus Günther ${ }^{57}$ e Habermas ${ }^{58}$, no sentido de que os direitos hão de ser levados a sério, isto é, que o processo discursivo comunicacional decisório tem sua legitimidade intimamente relacionada à busca da coerência argumentativa como forma de se respeitar e reconhecer os participantes do processo como sujeitos de direitos e cidadãos com iguais liberdades reconhecidas.

Substituir essa lógica discursiva de busca pela coerência por um privilégio ao aspecto formal-processual de repetição, uniformização e pretensa segurança, não somente contraria a coerência e coesão do sentido constitucional que uma Constituição democrática está a nos exigir, como, a um só tempo, igualmente realiza a não consideração dos cidadãos e sujeitos de direito como realmente livres e iguais.

A instigação e favorecimento de uma lógica a pretender transformar o sentido de uniformidade como uma aquisição desejável de segurança jurídica, não somente demonstra uma não compreensão do sentido hermenêutico do Direito (a buscar um juízo de coerência entre os atos dos falantes que partem de um horizonte de sentido comum e compartilhado) como também apresenta um descaso com o sentido pragmático universal (que está a exigir que todos os participantes do processo discursivo-racional tenham igualmente reconhecidas iguais liberdades e possibilidades de participação e construção no processo comunicacional-decisório).

Isto porque a proposta de compreensão do Código levada adiante pela Comissão neutraliza, achata e abre a possibilidade para aniquilar com as garantias discursivo-processuais dos sujeitos de direito, por inseri-los numa compreensão e prática jurisdicionais extremamente funcionalizadas em que o argumento de uniformização/segurança pretende legitimidade de modo a substituir onipotentemente os argumentos e questionamentos particulares e particularizáveis levados ao juízo por seus afetados.

\section{Conclusão}

A variabilidade, a expansividade e a perfectibilidade não encontram-se asseguradas/garantidas pela reforma legislativa empreendida em 2015, se assumirmos os pressupostos interpretativos oferecidos pela

54 CHAMON JUNIOR, Lúcio. Teoria da Argumentação: constitucionalismo e democracias em uma reconstrução das fontes no Direito Moderno. Rio de Janeiro: Editora Lumen Juris, 2008, p. 154.

55 HABERMAS, Jürgen. Facticidad y validez. $3^{\mathrm{a}}$ ed. Madrid: Editorial Trotta, 2001.

56 DWORKIN, Ronald. O império do direito. São Paulo: Martins Fontes, 1999.

57 GÜNTHER, Klaus. The sense of appropriateness. Application discourses in morality and law. Translated by Jonh Farrell. Albany: State of New York Press, 1993.

58 HABERMAS, Jürgen. Facticidad y validez: $3^{a}$ ed. Madrid: Editorial Trotta, 2001. 
Comissão de Juristas segundo os quais a segurança jurídica realiza-se através da uniformização das decisões judiciais.

O Modelo Constitucional Processual brasileiro impõe o reconhecimento dos direitos fundamentais de participação em simétrica paridade no processo por aqueles que serão afetados pelos efeitos do provimento ${ }^{59}$, o que significa levar a sério a dimensão constitucional e argumentativo-constitutiva dos direitos processuais. E tudo isso há que ser assumido pelo ato decisório cuja linha argumentativa há que se fazer explícita na fundamentação da decisão, visto que referida fundamentação é a um só tempo dever da autoridade jurisdicional e direito das partes.

Pretender substituir a lógica da coerência subjacente a uma racionalidade discursiva pela lógica da eficiência-celeridade-segurança importa em desconhecer a dimensão democrática do processo, e portanto, contrariar o sentido ideal do constitucionalismo moderno ao mesmo tempo em que se coloca como uma flagrante violação ao texto constitucional vigente no Brasil.

\section{REFERÊNCIAS BIBLIOGRÁfICAS}

ANDOLINA, Italo; VIGNERA, Giuseppe. I fondamenti costituzionali della giustizia civile: il modello costituzionale del processo civile italiano. Torino: G. Giappichelli Editore, 1997.

BARACHO, José Alfredo de Oliveira. Processo Constitucional. Rio de Janeiro: Forense, 1984.

BÜLLOW, Oskar von. La teoría de las excepciones procesales y los presupuestos procesales. Trad. Miguel Angel Rosas Lichtschein. Buenos Aires: Ediciones Juridicas Europa-America, 1964.

CHAMON JUNIOR, Lúcio. Teoria da Argumentação: constitucionalismo e democracias em uma reconstrução das fontes no Direito Moderno. Rio de Janeiro: Editora Lumen Juris, 2008.

CHIOVENDA, José. Principios de Derecho Procesal Civil. Madrid: Editorial REUS, 1.925.

COUTURE, Eduardo Juan. Fundamentos do Direito Processual Civil. São Paulo: Saraiva e Cia., 1946.

COUTURE, Eduardo Juan. Fundamentos del Derecho Procesal Civil. Montevideo-Buenos Aires: Editorial B de F, 2007.

DINAMARCO, Cândido Rangel. Instituições de Direito Processual Civil. Vol. I. $8^{a}$ ed., São Paulo: Malheiros, 2016.

DWORKIN, Ronald. O Império do Direito. São Paulo, Martins Fontes, 1999.

FAZZALARI, Elio. Istituzioni di Diritto Processuale. 8ª ed. Padova: CEDAM, 1996.

GOLDSCHMIDT, James. Direito Processual Civil. Campinas: Bookseller, 2003.

GUASP, Jaime. Derecho Procesal Civil. Madrid, Editorial Civitas, 1998.

GÜNTHER, Klaus. The sense of appropriateness. Application discourses in morality and law. Translated by Jonh Farrell. Albany: State of New York Press, 1993.

HABERMAS, Jürgen. Facticidady valider: $3^{\text {a }}$ ed. Madrid: Editorial Trotta, 2001.

LAGES, Cintia Garabini. Direito-Garantia como abolição do vinculo da relação jurídica entre os sujeitos do processo. In: LEAL, Rosemiro Pereira (org.). Estudos Continuados de Teoria do Processo. Vol. II. Porto Alegre: Síntese Editora, 2001.

59 FAZZALARI, Elio. Istiturioni di Diritto Processuale. 8a ed. Padova: CEDAM, 1996. 
MAG-GREGOR, Eduardo Ferrer. La Ciencia del Derecho Procesal Constitucional. Díkaion. Vol. 22, nº 17, 2008.

SENADO FEDERAL. Ato da Presidência no. 379/2009. Disponível em: https://www.senado.gov.br/senado/novocpc/pdf/ATO\%20DO\%20PRESIDENTE\%20N\%20379.pdf. Acesso em: 30 de junho de 2017.

SENADO FEDERAL. Comissão de Juristas Responsável pela Elaboração de Anteprojeto de Código de Processo Civil. Brasília: Senado Federal, Presidência, 2010. Disponível em: https://www.senado.gov.br/senado/novocpc/ pdf/Anteprojeto.pdf. Acesso em: 30 de junho de 2017.

SENADO FEDERAL. Código de processo civil e normas correlatas. Brasília: Coordenação de Edições Técnicas, 2015.Disponível em: http://www2.senado.leg.br/bdsf/bitstream/handle/id/514048/CPC_8ed_2015. pdf?sequence=1. Acesso em 30 de junho de 2017.

THEODORO JÚNIOR, Humberto. Curso de Direito Processual Civil. Volume III. Rio de Janeiro, Forense, 2016. 


\section{REVISTA BRASILEIRA DE POLÍTICAS PÚBLICAS BRAZILIAN JOURNAL OF PUBLIC POLICY}
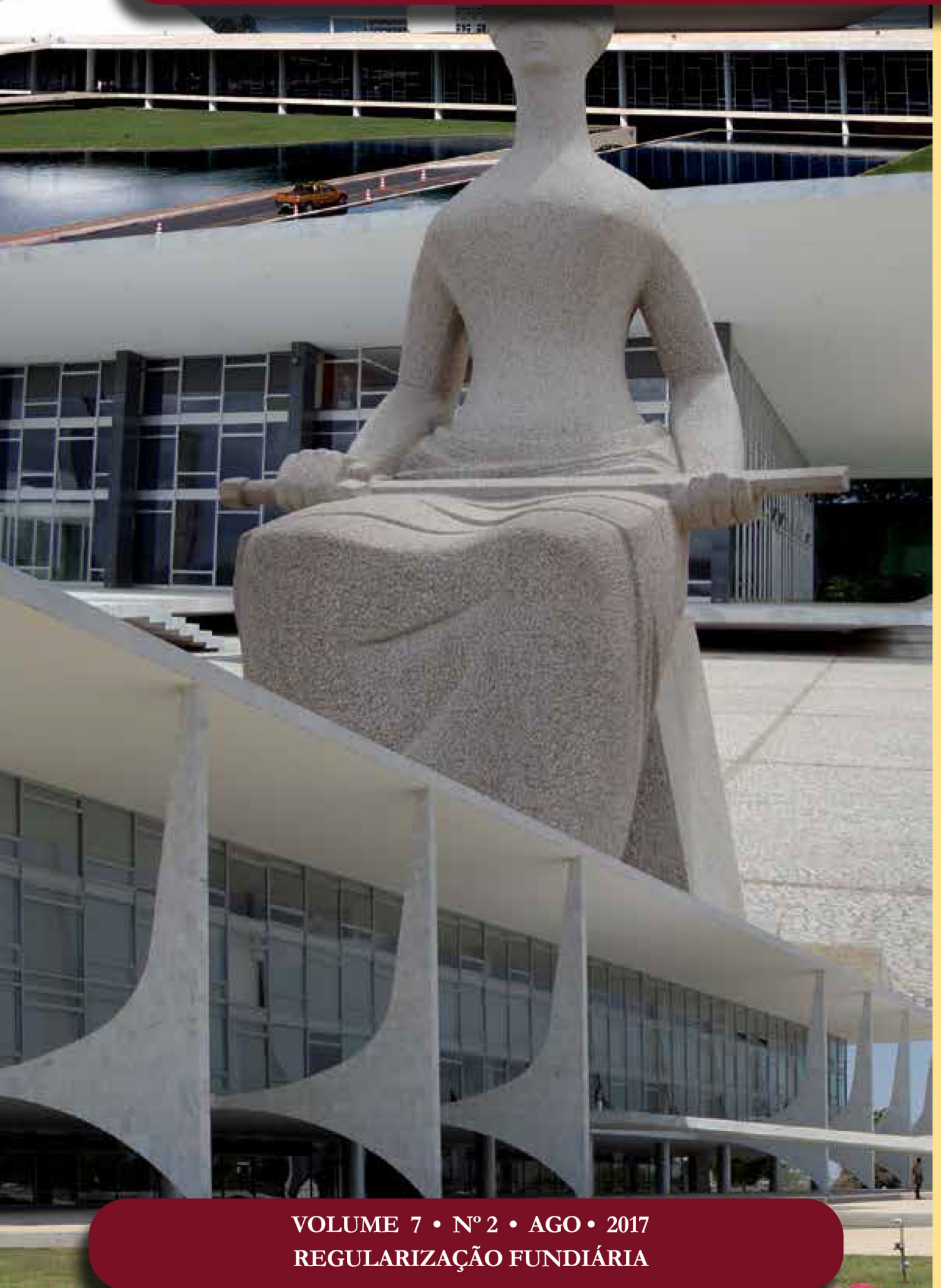

O impacto do federalismo sanitário brasileiro na efetividade do direito à saúde The impact of the Brazilian health federalism on the effectiveness of the right to health

\section{Renato Braz Mehanna Khamis}




\section{O impacto do federalismo sanitário brasileiro na efetividade do direito à saúde*}

\section{The impact of the Brazilian health federalism on the effectiveness of the right to health}

\author{
Renato Braz Mehanna Khamis** \\ Ivan Ricardo Garisio Sartori***
}

\section{Resumo}

Trata-se de trabalho original que busca examinar o sistema federativo brasileiro com base nos dispositivos constitucionais que tratam das competências dos entes federativos, mais precisamente daquelas pertinentes ao direito à saúde, como forma de identificar se existe alguma relação entre o federalismo sanitário brasileiro e a efetividade do direito à saúde. Verificou-se que, enquanto no essencial, a Carta Magna apresenta clara tendência centralizadora, centrípeta, simultaneamente, passa a descentralizar as atribuições dos entes federativos quando trata do direito à saúde, flertando, claramente, com o chamado federalismo centrífugo. Dessa forma, por meio da análise do federalismo brasileiro, pretendeu-se identificar as consequências dessa dicotomia para o sistema de saúde constitucionalmente estabelecido, mormente no tocante à implementação das políticas públicas de saúde, bem como identificar até que ponto essa estruturação normativa impacta a efetividade do direito à saúde. Para tanto, foi utilizado o método hipotético-dedutivo em pesquisa cujo objetivo é explicativo, pois busca identificar os fatores de existência do objeto estudado. Para atingir sua finalidade, a pesquisa que subsidia o trabalho adotou ampla base bibliográfica e documental, já que está amparada por referências normativas e teóricas publicadas em meio escrito e eletrônico. Por fim, concluiu-se que há um descompasso entre o modelo federativo adotado como regra pela Constituição de 1988 e o federalismo sanitário por ela instituído, o que foi reconhecido pelos poderes públicos, e levou a criação das Comissões Intergestores Bipartite (CIB) e Tripartite (CIT). Porém, a notória falta de efetividade do direito à saúde demonstrou ineficiência das medidas adotadas, tornando necessário um rearranjo institucional para solucionar o descompasso apontado.

Palavras-chave: Direito à saúde. Efetividade. Federalismo sanitário.

\section{Abstract}

It is an original work that seeks to examine the Brazilian federal system based on the constitutional provisions that deal with the competencies of federal entities, more precisely those pertinent to the right to health, as a way of identifying if there is any relationship between Brazilian heath federalism and the effectiveness of the right to health. It was found that while the Mag- 
na Carta has a clear centralizing, centripetal tendency, it simultaneously begins to decentralize the powers of the federative entities when it deals with the right to health, clearly flirting with the so-called centrifugal federalism. Thus, through the analysis of Brazilian federalism, it was intended to identify the consequences of this dichotomy for the health system constitutionally established, especially regarding the implementation of public policies in health, as well as to identify the extent to which this normative structuring impacts on the effectiveness of the right to health. For that, the hypothetical-deductive method was used in research whose objective is explanatory, since it seeks to identify the factors of existence of the object studied, and to reach its purpose, the research that subsidizes the work has adopted a wide bibliographic and documentary basis, which is supported by normative and theoretical references published in written and electronic media. Finally, it was concluded that there is a mismatch between the federative model adopted as a rule by the 1988 Constitution and the health federalism established by it, which was recognized by the public authorities, and led to the creation of the Bipartite (CIB) and Tripartite (CIT) Interparts Comissions. However, the notorious lack of effectiveness of the right to health demonstrated the inefficiency of the adopted measures, making necessary an institutional rearrangement to solve the indicated mismatch.

Key-words: Right to health. Effectiveness. Health federalism.

\section{INTRODUÇÃO}

Logo no art. $1^{\circ}$, inciso III, a Constituição de 1988 estabelece como fundamento principal da Federação, dentre outros, a dignidade humana. E nada mais concêntrico com a dignidade do que a saúde. Por isso, a partir do art. 196, a Carta Magna passou a especificar como o Estado deve implementar as políticas públicas pertinentes a essa área, destacando, logo no limiar, que:

Art. 196. A saúde é direito de todos e dever do Estado, garantido mediante políticas sociais e econômicas que visem à redução do risco de doença e de outros agravos e ao acesso universal e igualitário às ações e serviços para sua promoção, proteção e recuperação. ${ }^{1}$

Como se vê, a importância dada pela CF/88 a esse aspecto da dignidade humana é tamanha, ao ponto de prever o acesso universal e igualitário aos serviços de saúde.

Infelizmente, não é o que tem se verificado na realidade. Ao contrário, o direito à saúde não vem sendo efetivado a contento.

No entanto, com o intuito de identificar a causa do problema apresentado partimos das seguintes hipóteses: $1^{\text {a }}$ ) existe um desalinhamento entre a forma federativa adotada oficialmente pelo país e a estrutura do federalismo sanitário estabelecido pela Constituição Federal; $2^{a}$ ) o alinhamento das estruturas federativas geral e sanitária é essencial para a efetividade das políticas públicas de saúde.

Nossa tese, portanto, pode ser sintetizada no enunciado que segue: se há um desalinhamento entre a forma federativa adotada oficialmente pelo Brasil e a estrutura do federalismo sanitário constitucional e se o alinhamento entre ambas é essencial para a efetividade das políticas públicas de saúde, então, o desalinhamento apontado é causa da desfuncionalidade das políticas públicas de saúde no Brasil, impactando a baixa efetividade do direito à saúde no país.

Visando aferir a veracidade da tese formulada neste artigo, utilizaremos o método hipotético-dedutivo em pesquisa cujo objetivo é explicativo, na medida em que almeja identificar os fatores que permitem a existência do objeto estudado. Para atingir essa finalidade, utilizou-se ampla base bibliográfica e documental, amparada por referências normativas e teóricas publicadas em meio escrito e eletrônico.

1 BRASIL. Constituição da República Federativa do Brasil de 1988. Brasília, 1988. Disponível em: <http://www.planalto.gov.br/ccivil_03/constituicao/constituicaocompilado.htm>. Acesso em: 20 mar. 2017. 


\section{Desenvolvimento}

O Estado brasileiro, como sabido, ostenta um federalismo "sui generis". Afinal, é difícil enquadrá-lo dentro das classificações doutrinárias clássicas. De um lado, não pode ser considerado dualista ou competitivo, como ocorre nos Estados Unidos da América, em que os Estados têm autonomia acentuada, graças a uma constituição concisa e, portanto, de interpretação flexível. Lá é a Suprema Corte quem dita a tônica do grau de federalismo, o que, normalmente, é feito com base na chamada "commerce clause" (cláusula de comércio). ${ }^{2}$ Por outro lado, tampouco se aproxima da federação cooperativa que rege a Alemanha, onde há uma vinculação vertical ao poder central, com atribuições descentralizadas e harmônicas. ${ }^{3}$

Todavia, no que tange aos critérios de classificação do federalismo, Rogério Santos Rammê relembra que os principais critérios classificatórios são os seguintes: (a) federalismo simétrico ou assimétrico; (b) federalismo centrípeto ou centrífugo; ${ }^{4}$ (c) federalismo por agregação ou por segregação; (d) federalismo competitivo ou cooperativo. ${ }^{5}$

No que toca ao primeiro critério, qual seja, federalismo simétrico ou assimétrico, o autor supracitado, assim, dispõe:

Por federalismo simétrico, entende-se o modelo no qual a Constituição atribui o mesmo grau de poderes, encargos e competências aos Estados-membros. Federalismo assimétrico, por sua vez, é a tipificação atribuída ao modelo no qual a Constituição atribui poderes, encargos e competências aos Estados-membros em grau diferenciado. ${ }^{6}$

Nesse diapasão, constata-se que a federação brasileira pode ser considerada simétrica, pois não há diferenciação de poderes, encargos e competências entre os Estados.

Por seu turno, essa igualdade formal se deve ao fato de nossa federação ter se originado por segregação (item "c" da classificação supra), haja vista ter surgido sob a forma de Estado unitário, tendo se transformado, posteriormente, porém, em Estado federal.

Nesse ponto, aliás, cumpre frisar que, desde o Governo Geral do Brasil, instalado em 1548, sob a regência de Tomé de Souza, quando as capitanias hereditárias tinham significativa independência, passando pelo Marquês de Pombal, momento em que se criaram as províncias que formaram o Reino Unido (1815), depois pelo Ato Adicional de 18.8.34, por meio do qual se conferia maior poder legiferante às Assembleias Legislativas Provinciais, até as subsequentes Constituições, num total de sete (1891, 1924, 1937, 1946, 1967 e 1988) ${ }^{7}$, o Brasil vem alinhavando uma federação centralizadora, centrípeta (item "b" da classificação mencionada).

Contudo, esse movimento, lamentavelmente, não logrou obter, ainda, a forma de Estado federal adequada às suas necessidades. Nesse sentido, Celina de Souza constata que:

[...] Apesar de a constitucionalização de número significativo de questões limitar o espaço de manobra dos grupos políticos e dos governos, o constitucionalismo brasileiro muitas vezes não foi capaz de

2 HORBACH, Carlos Bastide. Forma de Estado: federalismo e repartição de competências. Revista Brasileira de Politicas Públicas, Brasília, v. 3, n. 2, pp. 2-12, jul./dez., 2013. p. 6.

3 HORBACH, Carlos Bastide. Forma de Estado: federalismo e repartição de competências. Revista Brasileira de Políticas Públicas, Brasília, v. 3, n. 2, pp. 2-12, jul./dez., 2013. p. 8.

4 Na física o movimento centrípeto é aquele que parte da periferia para o centro. O movimento centrífugo, por sua vez, ocorre em sentido oposto, na medida em que "foge" do centro em direção à periferia. No caso do federalismo, será centrípeto quando concentrar o poder no ente central (da periferia para o centro) e centrífugo quando distribuir o poder entre os entes periféricos (do centro para a periferia).

5 Rammê, Rogério Santos. O federalismo em perspectiva comparada: contribuições para uma adequada compreensão do federalismo brasileiro. Revista Eletrônica Direito e Politica, Itajaí, v. 10, n. 4, p. 2302-2323, set./dez. 2015. p. 2307.

6 Rammê, Rogério Santos. O federalismo em perspectiva comparada: contribuições para uma adequada compreensão do federalismo brasileiro. Revista Eletrônica Direito e Política, Itajaí, v. 10, n. 4, p. 2302-2323, set./dez. 2015. p. 2307.

7 Não se olvide a Emenda n.1/69, quase uma nova Constituição, pela forma outorgada. 
sustentar o regime democrático, nem tampouco de encaminhar soluções para um dos problemas cruciais da prática do federalismo no Brasil, que são as desigualdades econômicas entre as regiões. ${ }^{8}$

Referida dificuldade é compreensível por se tratar de um país com dimensões continentais, com diversidades cultural e econômica extremamente acentuadas, o que dificulta o encontro do que seria o ponto ideal do federalismo pátrio.

Porém, a referida centralização salta aos olhos, bastando uma simples leitura da Constituição Federal para constatá-la (v.g. o disposto nos arts. 20 e seguintes).

O problema, portanto, reside em saber qual é o ponto limite a partir do qual o movimento centrípeto faz com que uma nação transforme um verdadeiro Estado federal em um Estado unitário de fato, mas que adota um federalismo formal.

Ora, quando se deixa pouco espaço para os entes subnacionais se movimentarem no quadro governamental, retirando-lhes a possibilidade de implementar políticas públicas essenciais, o Estado passa a ser mais unitário do que federal, ainda que, formalmente, adote um desenho federativo.

Essa mesma preocupação já foi manifestada por Silvio Meira, que pontua:

[...] a centralização levada a extremos poderia confundir-se afinal, com o Estado unitário. Esse é o ponto nevrálgico, sensível, do problema. A poda que se fizer na árvore federativa poderia levá-la a perder os galhos e as ramagens, restando apenas o tronco, vigoroso embora. No equilíbrio entre os Estados e o Centro é que repousaria o ideal federativo. ${ }^{9}$

É verdade que o sucesso na implantação das políticas públicas não depende de ser o Estado federativo ou unitário, mesmo porque muitos são os exemplos de sucesso dentre os Estados unitários. Mas a indefinição entre um e outro modelo - o que pode estar acontecendo no caso brasileiro - dificulta os planos de ação para a implementação de políticas públicas. Basta vislumbrar alguns direitos fundamentais sociais básicos, como saúde, moradia, assistência social e segurança, setores que encontram dificuldades organizacionais que parecem intransponíveis.

É certo que as realidades dos estados unitários mais prósperos, como, v.g., Países Baixos, Itália e Japão, se comparadas à da federação brasileira, são bem distintas. A par do gigantismo e da densidade demográfica superlativos, há, no caso brasileiro, um entrave de ordem cultural ético-comportamental que, mais do que nos países desenvolvidos supracitados, leva o administrador a confundir a coisa pública com os interesses que lhe são afetos. Não existe, ainda, uma ideia precisa do interesse coletivo, haja vista os recentes escândalos aflorados no País. ${ }^{10}$

De todo modo, o centripetismo se faz sentir. A esse respeito, José Angelo Machado e Pedro Lucas de Moura Palotti ressaltam que:

[...] a Constituição de 1988 assegurou à União 'o maior e mais importante leque de competências exclusivas',11 incluindo a defesa nacional, a política macroeconômica - no interior da qual se incluem a emissão de moeda e administração de reservas cambiais -, bem como o controle da exploração dos serviços de telecomunicação e navegação aérea, entre outros. ${ }^{12}$

Compreensiva essa concentração, em linhas gerais, mas não se pode esquecer que os entes subnacionais

8 Souza, Celina. Federalismo, desenho constitucional e instituições federativas no Brasil pós-1988. Revista de Sociologia e Política, Curitiba, v. 24, n. 58, p. 105-121, jun. 2005. p. 118.

9 MEIRA, Silvio. Federalismo e centralização. Revista de Direito Público, São Paulo, v. 32, p. 67-77, nov./dez. 1974 . p. 73.

10 Em que pese não seja este o escopo principal do trabalho, entendemos que esse fato não poderia deixar de ser ao menos mencionado, uma vez que é um dos fatores que, junto com a inconsistência federativa, impacta no insucesso das políticas públicas no Brasil.

11 Souza, Celina. Federalismo, desenho constitucional e instituições federativas no Brasil pós-1988. Revista de Sociologia e Política, Curitiba, v. 24, n. 58, p. 105-121, jun. 2005

12 Machado, José Ângelo; PALOTTI, Pedro Lucas de Moura. Entre cooperação e centralização: federalismo e políticas sociais no Brasil pós-1988. Revista Brasileira de Ciências Sociais, São Paulo, v. 30, n. 88, p. 61-83, jun. 2015. p. 64. 
devem gozar de independência relativa para a consecução de suas finalidades. É preciso que haja divisão racional das receitas e competências tributárias em consonância com essa autonomia.

Note-se que os tributos mais fartos favorecem a União, a teor do art. 153 da Lei Maior, enquanto aos Estados e Municípios cabe uma fatia muito menos favorecida. É certo que há previsão acerca da repartição das receitas tributárias, havendo, ainda, outros mecanismos de repasse, mas isso não chega a ponto de afastar os riscos à autonomia dos entes subnacionais, haja visto que constantemente estão em dívida com a União.

O Estado brasileiro, primeiramente, precisa se definir faticamente - e não apenas formalmente, como fez a Constituição - entre federalismo ou unitarismo, para que possa marchar rumo ao desenvolvimento, uma vez que a forma mista ou indefinida acarreta problemas estruturais intransponíveis. Contudo, para os fins deste trabalho, e em linha com o teor (ao menos formal) da Carta Magna, passamos a tratar o Estado brasileiro como uma federação centrípeta ultracentralizadora.

Outro ponto bastante peculiar na federação brasileira é a circunstância de os Municípios terem status de ente federativo. Essa peculiaridade não tem quase precedentes, ressalvado o Estado Belga.

Raul Machado Horta lembra que a Constituição da Bélgica de 1831 foi reformada em 1993, operando-se a transformação daquele país em Estado Federal com três comunidades (francesa, flamenga e germânica) e três regiões (walônica, flamenga e de Bruxelas). As regiões, por sua vez, passaram a ser divididas em províncias. Foi essa a solução encontrada, segundo lembra o autor, para conciliar "tendências culturais diversificadas". ${ }^{13}$

Por seu turno, Silvio Meira expõe que, no Brasil, muito antes das províncias, desempenharam notável missão histórica as municipalidades, cujas raízes provinham da organização política da península ibérica, remanescente da civilização romana, criadora do "Municipium". ${ }^{14}$

O mesmo autor ressalta que as municipalidades precederam a Província e o Estado na história do nosso país, com eleições para as Câmaras Municipais, depois ratificadas pelo poder central. Lembra, ainda, que, em 1614, a Câmara Municipal do Rio e, em 1681, a do Maranhão, chegaram a ter assento na Corte de Lisboa, por meio de procuradores ou enviados. Assim, essas células representativas, depois evoluídas para Municípios, imbricam-se com a cultura política do país.

Dessa forma, a Constituição de 1988 bem detalhou a forma de organização desses entes subnacionais. Em face dessa estrutura, nossa federação tem sido classificada como tridimensional ou de terceiro grau.

Nos termos do art. 30 da Constituição de 1988, é possível aos Municípios legislar, auferir receita, auto-organizar-se e autoadministrar-se. Nesse tocante Célio Borja anota a prevalência da corrente normativista:

[...] que associa a forma federativa do Estado à existência de três atributos nas unidades federadas: a autonomia - que é o poder de fazer a sua própria ordem jurídica; a autarquia, que é o de se autoadministrar, e a autotutela, ou seja, o poder de, através de órgãos jurisdicionais próprios, aplicar o seu próprio direito. Tudo, por certo, submetido à supremacia da Constituição Federal. ${ }^{15}$

Nesses termos, ao Município brasileiro faltaria, apenas, a autotutela, uma vez que não dispõe do próprio Judiciário. Mesmo assim, goza de autonomia e autarquia (art.18).

Em sentido oposto, Alcino Pinto Falcão contesta essa forma de federação, ponderando que:

[...]por definição e por necessidade lógica, o governo Federal há de ser estruturado bidimensionalmente; para que se pudesse falar em federalismo tridimensional brasileiro, seria necessário demonstrar que os municípios, como a União e os Estados, fossem tidos como unidades políticas, um ao lado dos demais, o que não ocorre quanto àqueles, já que os municípios não estão ao lado da União, mas sim dos

13 HORTA, Raul Machado. Tendências atuais da federação brasileira. Revista da Academia Brasileira de Letras Juridicas, Rio de Janeiro, v. 10, no. 09, pp. 209-225, jan./jun. 1996. p. 212.

14 MEIRA, Silvio. Federalismo e centralização. Revista de Direito Público, São Paulo, v. 32, p. 67-77, nov./dez. 1974 . p. 70.

15 Borja, Célio. Federalismo brasileiro. Revista de Direito Público, São Paulo, v. 73, n. 138, p. 138-144, jan./mar. 1985. p. 138. 
Estados, mais precisamente, dentro dos Estados." E prossegue: "Um federalismo tridimensional seria um terceiro gênero, uma nova modalidade de forma de governo e não mais a federal. ${ }^{16}$

Com a devida vênia ao renomado jurista, não há dúvida da condição de ente federativo do Município, ainda que tal ente não disponha de autotutela, pois a Carta da República lhe confere, como visto, clara possibilidade de obter receita e de autoadministrar-se, dentro das limitações de uma federação acentuadamente centrípeta.

Além disso, esse ente subnacional interage, diretamente, com a União, principalmente no que toca às políticas públicas.

Aliás, o art. 18 da Carta Magna de 1988 é hialino ao classificar o município como ente federativo: “art. 18. A organização político-administrativa da República Federativa do Brasil compreende a União, os Estados, o Distrito Federal e os Municípios, todos autônomos, nos termos desta Constituição." 17

Fernando Rezende ressalta a tradição municipalista brasileira, enfatizando que, advindo a CF/88, "os municípios foram reconhecidos como membros da federação, em pé de igualdade com os estados, no que diz respeito a direitos deveres ditados pelo regime federativo". ${ }^{18}$

Não obstante, cumpre observar a circunstância de a federação brasileira ser, altamente, centralizadora diante do traçado rígido da Constituição de 1988, que enfeixa na União o poder de decidir os rumos da grande maioria das atividades estatais e de governo, sobrando pouco para Estados e, principalmente, para os Municípios.

Mas, na área das políticas públicas, a Carta se altera e passa a conferir aos entes subnacionais grande relevância na sua execução, adotando as características de um federalismo cooperativo (item "d" da classificação).

Enquanto, no essencial, o fenômeno centrípeto se acentua, tem-se que, nas referidas políticas, pelos menos em sede constitucional, ele se atenua. É o que se depreende dos arts. 198 (saúde), 204 (assistência social) e 211 (educação) da Constituição Federal. Esses dispositivos tornam os entes subnacionais mais ativos do que em outras políticas de governo, alçando-os à condição de atores efetivos no tocante àquelas políticas públicas.

Na saúde e na assistência social, há uma conjunção de esforços em cooperação para que se alcance o fim comum, enquanto, na educação, a tônica é a da colaboração, cada ente subnacional atuando em um nível de ensino (infantil, fundamental, médio e superior).

No âmbito da saúde, especialmente, a União é a arquiteta da estrutura infraconstitucional, diretora, gestora e fiscal, enquanto os Estados e, principalmente, os Municípios são os executores.

$\mathrm{Na}$ verdade, ao analisarmos o desenho federativo nacional, vemos que a atividade normalmente exercida pelos entes subnacionais é a de coadjuvantes do sistema, enquanto, na saúde e na assistência social, assumem um certo protagonismo, ainda que norteados pelo poder central.

Segundo José Angelo Machado e Pedro Lucas de Moura Palotti:

[...] há uma divisão vertical de poder bem estabelecida, sendo as competências sobre diferentes políticas públicas distribuídas entre as esferas de governo", enquanto, num segundo, "essas competências são compartilhadas, havendo uma divisão apenas funcional de tarefas entre tais esferas, geralmente cabendo à União a formulação e a coordenação; às unidades subnacionais, a implementação. ${ }^{19}$

16 Falcão, Alcino Pinto. Aspectos da cooperação horizontal no federalismo. Revista de Direito Público, São Paulo, v. 33, n. 23 , p. 23-30, jan./mar. 1975. p. 24.

17 BRASIL. Constituição da República Federativa do Brasil de 1988. Brasília, 1988. Disponível em: <http://www.planalto.gov.br/ ccivil_03/constituicao/constituicaocompilado.htm>. Acesso em: 20 mar. 2017.

18 REZENDE, Fernando. Federalismo fiscal no Brasil. Revista de Economia Política, São Paulo, v. 15, n. 3, p 5-17, jul./set. 1995. p. 7.

19 Machado, José Ângelo; PALOT'TI, Pedro Lucas de Moura. Entre cooperação e centralização: federalismo e políticas sociais no 
Disso decorre que a Constituição de 1988, quando passa a tratar das políticas públicas sociais, notadamente da política de saúde, foge da regra geral adotada pelo sistema constitucional, em que se verifica o federalismo centralizado, centrípeto, passando a atuar como um federalismo centrífugo, ainda que não em sua plenitude, em função do protagonismo da União.

Nesse sentido, a publicação do Ministério da Saúde "Entendendo do SUS” é clara ao afirmar que:

[...] não há hierarquia entre União, estados e municípios, mas há competências para cada um desses três gestores do SUS. No âmbito municipal, as políticas são aprovadas pelo CMS - Conselho Municipal de Saúde; no âmbito estadual, são negociadas e pactuadas pela CIB - Comissão Intergestores Bipartite (composta por representantes das secretarias municipais de saúde e secretaria estadual de saúde) e deliberadas pelo CES - Conselho Estadual de Saúde (composto por vários segmentos da sociedade: gestores, usuários, profissionais, entidades de classe, etc.); e, por fim, no âmbito federal, as políticas do SUS são negociadas e pactuadas na CIT - Comissão Intergestores Tripartite (composta por representantes do Ministério da Saúde, das secretarias municipais de saúde e das secretarias estaduais de saúde). ${ }^{20}$

Na mesma linha aponta a lição de Marlon Alberto Wichert, que ensina:

“[...] a formulação do SUS como uma rede hierarquizada não implica na prevalência de um ente sobre o outro, mas apenas que a rede de instituições de assistência à saúde deverá ser estruturada de modo a compartilhar unidades de atendimento complexo, evitando-se a sobreposição de estruturas e otimizando os recursos disponíveis". ${ }^{21}$

E prossegue: "[...] o Sistema Único de Saúde, portanto, se pauta pela descentralização executiva, acompanhada de uma coordenação centralizada." 22

Contudo, o fato é que a carga maior de execução recai sobre o Municípios, que, não obstante a possibilidade de obterem recursos, acabam sobrecarregados pela demanda crescente de acesso à saúde.

É notório o caos que se instalou na área da saúde, em que o poder público não tem dado conta de suprir a demanda por profissionais e por instalações adequadas à efetiva prestação dos serviços de saúde. Isto provoca um atendimento extremamente deficiente para o cidadão dependente do Sistema Único de Saúde (SUS).

A questão é que, na teoria, o arranjo constitucional - que foi reproduzido e desenvolvido infraconstitucionalmente - não é ruim, mas, na prática, não se mostrou eficiente.

Então, ainda que a Carta Magna procure delinear um quadro cooperativo acentuado, na implementação das políticas públicas de saúde, parece claro que a estruturação estabelecida não é eficiente e impacta, diretamente, a efetivação do direito à saúde.

No entanto, isso se deve ao fato de que (i) o ente federativo que estrutura o sistema de saúde brasileiro está muito distante da sua execução, bem como de que (ii) a estruturação do federalismo sanitário no Brasil (que é descentralizada, centrífuga) está em descompasso com a opção federativa nacional (que é centralizadora, centrípeta). Isso faz com que o ente executor, isto é, o Município, não tenha a estrutura necessária para gerir os serviços de saúde, nem disponha de flexibilidade para fazer as adaptações e os ajustes - financeiros e normativos - que se fizerem necessários no dia a dia da atividade.

Aqui vale relembrar o que pontua Germana de Oliveira Moraes:

A prestação de serviços públicos deveria ser preferencialmente descentralizada — isto é, atribuída aos Estados e Municípios —, seja porque, assim, se contribui para a construção de uma sociedade mais

Brasil pós-1988. Revista Brasileira de Ciências Sociais, São Paulo, v. 30, n. 88, p. 61-83, jun. 2015. p. 62-63.

20 BRASIL. Ministério da Saúde. Entendendo o SUS. Brasília: Ministério da Saúde, 2006. Disponível em: <http:/ / portalarquivos. saude.gov.br/images/pdf/2013/agosto/28/cartilha-entendendo-o-sus-2007.pdf>. Acesso em: 23 mar. 2017.

21 WEICHERT, Marlon Alberto. O sistema único de saúde no federalismo brasileiro. Revista de Direito Constitucional e Internacional, São Paulo, v. 32, p. 154-175, jul./set. 2000. p. 172.

22 WEICHERT, Marlon Alberto. O sistema único de saúde no federalismo brasileiro. Revista de Direito Constitucional e Internacional, São Paulo, v. 32, p. 154-175, jul./set. 2000. p. 172. 
democrática, com a descentralização geográfica do poder, seja porque é nas cidades que os contribuintes, afinal, satisfazem suas necessidades sociais básicas - saúde, educação, transporte coletivo. Sem falar que as demandas sociais são multivariadas, diversificando-se de Município a Município, de Estado a Estado. ${ }^{23}$

Porém, como alerta Fernando Rezende, não basta a descentralização na execução de políticas de saúde que sejam definidas e impostas, verticalmente, pela União. Ao contrário, a descentralização necessária seria mais objetiva, um pouco mais próxima do caráter dualista da federação, na qual cada ente possui a sua esfera de autonomia e responsabilidades bem definidas:

[...] para muitos, a chave para a solução do problema estaria na clara definição de responsabilidades de cada ente federado no contexto constitucional, em substituição ao regime de competências concorrentes em quase todos os campos. Definidas as competências de cada um seria mais fácil estabelecer a repartição de recursos compatível com o respectivo equilíbrio orçamentário. ${ }^{24}$

Ora, reconhecida pela Carta Magna a condição de ente federativo do Município, é preciso lhe conferir o indispensável para gerir seu território, outorgando a verdadeira cidadania aos munícipes, não olvidada a função precípua da federação de mitigar as desigualdades regionais, nos termos, por sinal, dos arts. $3^{\circ}$, inciso III, 21, IX, e 43 da Lei Maior em vigor.

Inclusive, a vasta extensão territorial, as diversidades cultural e econômica, a densidade demográfica e todas as demais peculiaridades brasileiras afastam a funcionalidade do federalismo centrípeto adotado.

Inclusive, é princípio fundamental de gestão e administração delegar, descentralizar, não simplesmente desconcentrar, mantendo o poder central no comando dos cordéis. É justamente isso que vem tornando complexo e pouco funcional o sistema de saúde. Afinal, é contraproducente a adoção de um federalismo sanitário centrífugo quando o país adota um modelo federalista centrípeto tão centralizado que parece quase unitarista.

Essa antítese, naturalmente, gera grande inconsistência na prestação dos serviços de saúde, uma vez que o ente executor tem verba escassa para destinar à saúde e, por isso, depende de repasse dos demais entes. Porém, apesar de possuir pouca verba, ele é o principal executor e, além de deter o dever de execução de políticas formuladas verticalmente, não possui autonomia para fazer as adaptações que se mostrarem necessárias.

Contudo, visando atenuar a discrepância estrutural federativa, foram criadas as Comissões Intergestores Bipartite (CIB) e Tripartite (CIT), as quais atuam como foro de negociação e pactuação dos entes federativos visando operacionalizar o SUS (cf. artigo 14-A da Lei 8.080/90). ${ }^{25}$

Não obstante o protagonismo da União, certo é que não há como instrumentalizar o sistema sem o conhecimento das possibilidades técnicas, financeiras e operacionais dos demais entes federativos integrantes do sistema, os quais, também, são competentes para atuar na implementação das políticas públicas de saúde. Daí, pois, a importância dessas esferas de pactuação.

Essas comissões, segundo o parágrafo único do art. 14-A, têm larga abrangência, a começar pela decisão sobre os aspectos operacionais, financeiros e administrativos da gestão compartilhada do SUS, com possibilidade de traçar diretrizes de âmbito nacional, regional e intermunicipal acerca da operacionalidade do sistema. Esses órgãos, portanto, gozam (em certa medida) de poder regulatório.

Nesse tocante, vale ressaltar as palavras de Thiago Leão e Sueli Dallari, que afirmam:

23 MORAES, Germana de Oliveira. A concepção do federalismo fiscal e seus reflexos no sistema constitucional brasileiro. In: GRAU, Eros Roberto; GUERRA FILHO, Willis Santiago. Direito constitucional: estudos em homenagem a Paulo Bonavides. Malheiros: São Paulo, 2003. p. 308.

24 REZENDE, Fernando. Federalismo fiscal no Brasil. Revista de Economia Politica, São Paulo, v. 15, n. 3, p 5-17, jul./set. 1995. p. 15. 25 Assim dispõe o referido dispositivo: "Art. 14-A. As Comissões Intergestores Bipartite e Tripartite são reconhecidas como foros de negociação e pactuação entre gestores, quanto aos aspectos operacionais do Sistema Único de Saúde (SUS)” BRASIL. Lei 8.080 de 19 de setembro de 1990. Brasília, 1990. Disponível em: <http://www.planalto.gov.br/ccivil_03/leis/L8080.htm>. Acesso em: 21 maio 2017. 
A organização das regiões sanitárias pressupõe o estabelecimento de acordos intragovernamentais entre os entes federados, para que haja gestão regionalizada da saúde. [...]. Dessas negociações, emanam as normas que orientam a atuação administrativas no âmbito do SUS e que devem, necessariamente, ser levadas em consideração pelos Poderes Executivo e Judiciário, em suas respectivas esferas de competência, para garantia do direito à saúde, com respeito à deliberação institucional. ${ }^{26}$

Com a criação das supracitadas comissões, resta claro que os próprios poderes públicos reconhecem o descompasso existente entre a estruturação federativa adotada como regra pela Constituição de 1988 e a estruturação federativa sanitária instituída pelo mesmo documento. Dessa forma, tais podres caminham no sentido da interação e compartilhamento na gestão da saúde, buscando adequar-se à discrepância existente entre o federalismo constitucional em regra centrípeto e o federalismo sanitário centrífugo.

No entanto, em que pese a louvável tentativa efetuada pelos poderes públicos, parece claro que, até o presente momento, as Comissões Intergestores Bipartite (CIB) e Tripartite (CIT) não se mostraram suficientes para solucionar o descompasso federativo existente entre o modelo constitucional geral e a estruturação federativa sanitária. E, por seu turno, o referido descompasso continua a impactar na efetividade do direito à saúde.

\section{Conclusão}

Após a análise efetuada, é possível aferir a veracidade das hipóteses adotadas como premissas no presente trabalho.

De um lado, restou demonstrado que o Brasil de fato adota em sua Constituição, como regra, uma estrutura federativa centralizadora, centrípeta, porém, no tocante à implementação das políticas públicas de saúde adota um federalismo cooperativo, centrífugo. Portanto, existe o desalinhamento federativo apontado.

De outro, demonstrou-se que o alinhamento entre os federalismos geral e sanitário é essencial para a efetividade das políticas públicas de saúde. Tanto é assim que, cientes do descompasso federativo existente, os poderes públicos instituíram as Comissões Intergestores Bipartite (CIB) e Tripartite (CIT), buscando estabelecer arenas de negociação e pactuação entre os entes federativos para fins de implementação de políticas públicas de saúde - ainda que tais instrumentos tenham se mostrado insuficientes para a solução do problema.

Isso posto, uma vez constatada a veracidade das hipóteses formuladas é possível deduzir que a tese proposta e analisada ao longo do presente trabalho é igualmente verdadeira e, então, pode-se concluir que o desalinhamento entre a forma federativa adotada oficialmente pelo Brasil e a estrutura do federalismo sanitário constitucional é causa da desfuncionalidade das políticas públicas de saúde no Brasil, impactando na baixa efetividade do direito a saúde no país.

\section{REFERÊNCIAS BIBLIOGRÁFICAS}

BONAVIDES, Paulo. Federalismo regional num país periférico. In: BONAVIDES, Paulo; LIMA, Franscisco Gérson Marques de; BEDÊ, Fayga Silveira. Constituição e Democracia: estudos em homenagem ao professor J. J. Gomes Canotilho. Malheiros: São Paulo, 2006.

BORJA, Célio. Federalismo brasileiro. Revista de Direito Público, São Paulo, v. 73, n. 138, p. 138-144, jan./mar.

26 LEÃO, Thiago Marques; DALLARI, Sueli Gandolfi. O Poder normativo das comissões intergestores bipartite e a efetividade de de suas normas. Revista de Direito Sanitário, São Paulo, v. 17, n. 1, p. 38-53, mar./jun. 2016. p. 43. 
1985.

BRASIL. Constituição da República Federativa do Brasil de 1988. Brasília, 1988. Disponível em: < http://www. planalto.gov.br/ccivil_03/constituicao/constituicaocompilado.htm>. Acesso em: 20 mar. 2017.

BRASIL. Lei 8.080 de 19 de setembro de 1990. Brasília, 1990. Disponível em: <http://www.planalto.gov.br/ ccivil_03/leis/L8080.htm>. Acesso em: 21 mar. 2017.

BRASIL. Ministério da Saúde. Entendendo o SUS. Brasília: Ministério da Saúde, 2006. Disponível em: <http://portalarquivos.saude.gov.br/images/pdf/2013/agosto/28/cartilha-entendendo-o-sus-2007.pdf>. Acesso em: 23 mar. 2017.

FALCÃO, Alcino Pinto. Aspectos da cooperação horizontal no federalismo. Revista de Direito Público, São Paulo, v. 33, n. 23, p. 23-30, jan./mar. 1975.

HORBACH, Carlos Bastide. Forma de Estado: federalismo e repartição de competências. Revista Brasileira de Políticas Públicas, Brasília, v. 3, n. 2, pp. 2-12, jul./dez., 2013.

HORTA, Raul Machado. Tendências atuais da federação brasileira. Revista da Academia Brasileira de Letras Jurídicas, Rio de Janeiro, v. 10, no. 09, pp. 209-225, jan./jun., 1996.

LEÃO, Thiago Marques; DALLARI, Sueli Gandolfi. O Poder normativo das comissões intergestores bipartite e a efetividade de de suas normas. Revista de Direito Sanitário, São Paulo, v. 17, n. 1, p. 38-53, mar./jun. 2016.

MACHADO, José Ângelo; PALOTTI, Pedro Lucas de Moura. Entre cooperação e centralização: federalismo e políticas sociais no Brasil pós-1988. Revista Brasileira de Ciências Sociais, São Paulo, v. 30, n. 88, p. 61-83, jun. 2015.

MEIRA, Silvio. Federalismo e centralização. Revista de Direito Público, São Paulo, v. 32, p. 67-77, nov./dez. 1974

MORAES, Germana de Oliveira. A concepção do federalismo fiscal e seus reflexos no sistema constitucional brasileiro. In: GRAU, Eros Roberto; GUERRA FILHO, Willis Santiago. Direito constitucional: estudos em homenagem a Paulo Bonavides. Malheiros: São Paulo, 2003.

RAMMÊ, Rogério Santos. O federalismo em perspectiva comparada: contribuições para uma adequada compreensão do federalismo brasileiro. Revista Eletrônica Direito e Política, Itajaí, v. 10, n. 4, p. 2302-2323, set./ dez. 2015.

REZENDE, Fernando. Federalismo fiscal no Brasil. Revista de Economia Política, São Paulo, v. 15, n. 3, p 5-17, jul./set. 1995.

SOUZA, Celina. Federalismo, desenho constitucional e instituições federativas no Brasil pós-1988. Revista de Sociologia e Politica, Curitiba, v. 24, n. 58, p. 105-121, jun. 2005.

WEICHERT, Marlon Alberto. O sistema único de saúde no federalismo brasileiro. Revista de Direito Constitucional e Internacional, São Paulo, v. 32, p. 154-175, jul./set. 2000. 


\section{A Evolução Histórica dos Direitos da Criança e do Adolescente: da insignificância jurídica e social ao reconhecimento de direitos e garantias fundamentais*}

\author{
The Historical Evolution of the Rights of \\ Children and Adolescents: from legal and \\ social insignificance to the recognition of \\ fundamental rights and guarantees
}

* Recebido em 00/00/2016

Aprovado em 00/00/2017

** Possui Graduação em Direito pela Faculdade Milton Campos (2003), Doutorado e Mestrado em Direito pela Pontifícia Universidade Católica de Minas Gerais (2011/2006), tendo realizado pesquisa na Universidade de Pisa/Itália. Professora e Coordenadora do Curso de Direito do Centro Universitário UNA. Tem experiência na área Jurídica, com ênfase em Direito Público. É ainda membro do Jurídico do Grupo Ânima Educação, e vinculada ao Programa de Pós-Graduação da Universidade de Itaúna / MG. Email: remantova@hotmail. com

*** Mestre em Direito pela PUC/MINAS (1999); Doutor em Direito pela UFMG (2006); Professor na UFMG e na PUC Minas; Coordenador do Programa de Pós-Graduação em Direito da PUC/ Minas; Chefe de departamento da Faculdade Mineira de Direito da PUC/Minas; Consultor da Revista Jurídica da Presidência; Advogado. Email: leonardo@policonsultoria.adv.br

**** Mestre em Direito pela PUC/Minas (2014); Doutoranda em Direito Privado pela PUC/MINAS (2015); Membro e Apoiadora do Instituto Brasileiro de Direito de Família (IBDFAM); Membro da Comissão de Bioética e Biodireito e da Comissão de Direitos dos Animais da OAB/MG; Professora universitária; Advogada. Email: fernandasaojose@gmail.com
Renata Mantovani de Lima**

Leonardo Macedo Poli***

Fernanda São José ${ }^{* * * *}$

\section{Resumo}

Ao descrever a evolução histórica dos Direitos da criança e do adolescente no Brasil, o presente artigo objetiva analisar o tratamento a eles conferido pelo Estado em distintas épocas, assim como verificar o processo de desenvolvimento e aperfeiçoamento legal do sistema jurídico, mormente se considerarmos as influências de políticas para a cidadania e direitos humanos. Nesse sentido, primeiramente, apresentamos o histórico do tratamento até o século XIX, período caracterizado pela insignificância das crianças e adolescentes. Em seguida, uma análise do incremento da tutela estatal por considerá-los seres imperfeitos. Finalmente, discutimos as principais mudanças desse sistema ao dotá-los de subjetividade jurídica, detentores de direitos e garantias fundamentais. A intenção, por fim, é demonstrar a responsabilidade da família, sociedade e Estado, articulando-se a discussão entre normas jurídicas e políticas públicas a fim de evidenciar as ações que materializam os direitos preconizados pelo Estatuto da Criança e do Adolescente, tendentes, portanto, à proteção integral desse público.

Palavras chave: Evolução Histórica; Direitos das Crianças e Adolescentes; Políticas Públicas

\section{Abstract}

In describing the historical evolution of the rights of children and adolescents in Brazil, this article aims to analyze the treatment granted to them by the State at different times, as well as to verify the process of development and legal perfectioning of the legal system, especially considering the influences policies for citizenship and human rights. In this sense, we first present the treatment history up to the 19th century, a period characterized by the insignificance of children and adolescents. Next, an analysis of the 
increase of state tutelage by considering them to be imperfect beings. Finally, we discuss the main changes of this system by providing them with legal subjectivity, holders of rights and fundamental guarantees. The intention, finally, is to demonstrate the responsibility of the family, society and State, articulating the discussion between legal norms and public policies in order to highlight the actions that materialize the rights advocated by the Statute of the Child and the Adolescent, tending, therefore, , to the full protection of this public.

Keywords: Historical Evolution; Rights of Children and Adolescents; Public policy

\section{INTRODUÇÃO}

Conforme ressalta Corral (2004), nas antigas sociedades (grega ou romana) a criança e o adolescente sequer eram considerados suscetíveis de proteção jurídica, senão meros objetos de propriedade estatal ou paternal, caracterizados por um estado de imperfeição que se perdia somente com o passar do tempo, e unicamente suavizado por um dever ético-religioso de piedade. Só recentemente é que começaram a olhar para a criança e o adolescente como uma pessoa no sentido pleno do termo, permitindo-lhe atingir direitos e liberdades de que são beneficiários como condição geral, mesmo no período de tempo durante o qual estão em processo de formação. ${ }^{1}$

Igualmente, é cediço que a condição econômico-financeira, a era em que viveu, a criação dada pela família, a cultura na qual está inserida e, para aqueles que acreditam a sorte ou o destino, são algumas das diversas conjunturas probantes que a infância acontece de forma distinta para cada criança, trazendo a cada uma delas experiências diversificadas que contribuirão de forma benéfica, ou não, em todos os estágios de sua evolução, até a conquista da fase adulta.

Concatenando este raciocínio, parece ser possível delimitar o tratamento dado à criança e ao adolescente dentro do ordenamento jurídico brasileiro em três fases: na primeira fase, aproximadamente entre os séculos XVI ao século XIX (1501 a 1900), conforme retrata Ariès (1978), em regra, a criança e o adolescente eram reconhecidos pelos adultos como "bichinhos de estimação"; na segunda fase, aproximadamente a partir da primeira metade do século XX (1901 a 1950), passam a ser tratados como “objetos" de tutela do Estado; e, por fim, na segunda metade do século XX, até os tempos atuais, passam a receber maior proteção tanto da sociedade quanto do Estado, tornando-se alvo de proteção integral e prioritária.

\section{A CRIANÇA E O ADOLESCENTE COMO SERES INSIGNIFICANTES: "AdULtos" em CORPOS INFANTIS}

Na primeira fase, aproximadamente, entre os séculos XVI ao século XIX, as crianças e adolescentes eram tratados, na maioria das vezes, como seres sem relevância. Esta indiferença advinha do alto índice de mortalidade precoce que assombrava aquela época. Assim, o adulto buscando se resguardar do sofrimento advindo da perda precípite de um indivíduo ainda jovem, evitava o apego afetivo ${ }^{2}$ às crianças e adolescentes.

1 Nesse sentido, in verbis: “(..) No es necesario remontarse a sociedades antiguas, como la griega o la romana, en las que el menor ni siquiere era considerado un bien susceptible de protección jurídica, sino un mero objeto de la propriedad estatal o paterna, caracterizado por un estado de imperfección del que sólo se salía con el transcurso del tiempo, y únicamente suavizado por um deber ético- religioso de piedad, para descubrir que solo muy recientemente se le ha comenzado a contemplar como una persona en sentido pleno del término, a la que alcanzan los derechos y libertades de los que ésta es beneficiaria por esa condición general, incluso en el período de tiempo durante el cual se halla en un proceso de formación (...)".(CORRAL, 2004, p.31).

2 Ressalta-se que esta ausência de afeto dos adultos para com as crianças e adolescentes desta época deve ser relativizada. "A falta de maiores referências não significa, entretanto, que a criança tenha sido desvalorizada em si. Há nas entrelinhas, uma outra maneira de mostrar que lhes davam valor, era a continuação da família, gozava do afeto dos seus, participava dos acontecimentos e das festas, 
Ninguém pensava em conservar o retrato de uma criança que tivesse sobrevivido e se tornado adulta ou que tivesse morrido pequena. No primeiro caso, a infância era apenas uma fase sem importância, que não fazia sentido fixar na lembrança; no segundo, o da criança morta, não se considerava que essa coisinha desaparecida tão cedo fosse digna de lembranças: havia tantas crianças, cuja sobrevivência era tão problemática. Ainda no século XVIII, vemos uma vizinha, mulher de um relator, tranquilizar assim uma mulher inquieta, mãe de cinco "pestes", e que acabara de dar à luz: "Antes que eles te possam causar muitos problemas, tu terás perdido a metade, e quem sabe todos". Estranho consolo! As pessoas não se podiam apegar muito a algo que era considerado uma perda eventual. (ARIĖS, 1978, p. 56-57).

\section{Nessa esteira, in verbis:}

De fato, nesse fim do século XVIII, o bebê que vem à luz tem pouco mais que $50 \%$ de chance de ultrapassar o marco dos dois anos. A falta de cuidados e de higiene, a desnutrição e a deficiência da medicina, os abandonos de crianças quando as condições econômicas se tornam duras demais para as classes populares são alguns dos fatores que favorecem essa pavorosa mortalidade (...). O único remédio conhecido é (...) ter muitos filhos e ele é seguido à risca. O estatuto do lactente é pouco invejável ele incomoda a burguesia nas suas atividades mundanas e estorva a operária obrigada a trabalhar do raiar do sol ao anoitecer: "Das vinte e uma mil crianças que nascem a cada ano, menos de mil são alimentadas por suas mães e mil são alimentadas em domicílio por uma ama. Todas as outras, ou seja, dezenove mil, são confiadas a uma criadeira". Esta é a terrível conclusão estatística à qual chega, em 1780, Lenoir, tenentegeral de polícia em Paris (...). Independentemente de seus meios de origem, verdadeiras organizações de aliciamento encaminham as crianças para casas de amas-de-leite mercenárias. Durante o transporte, a mortalidade é grande. Entretanto, essa mortalidade muito elevada, em si, não basta para desculpar a falta de investimento, pelas mães, "na particularidade infantil". (CHALMEL, 2004, p. 62).

Não se pode esquecer que a indiferença com que eram tratados as crianças e adolescentes em terras brasileiras não era muito diferente daquela que lhes era proporcionada em outros países da Europa. Assim, além de adultos, as embarcações marítimas portuguesas traziam consigo para povoar a Terra de Santa Cruz algumas categorias de crianças como: grumetes, pajens, órfãs do Rei ou somente passageiros acompanhados de seus pais ou responsáveis.

Conforme ressalta Ramos (2010), com a comparência feminina escassa, as crianças (ainda que acompanhadas por seus responsáveis) eram violentamente submetidas a abusos sexuais de marujos. Ademais, as órfãs do Rei (virgens destinadas a casar com os membros da Coroa e, consequentemente, contribuir com a proliferação e constituição da família em terras brasileiras) eram diuturnamente guardadas e vigiadas para não serem violentadas e, assim, não perderem o que tinham de mais valioso à época, qual seja, a virgindade.

Sobre isso, Ramos levanta o seguinte questionamento:

Em uma época em que meninas de quinze anos eram consideradas aptas para casar, e, meninos de nove anos plenamente capacitados para o trabalho pesado, o cotidiano infantil a bordo das embarcações portuguesas era extremamente penoso para os pequeninos. Os meninos não eram ainda homens, mas eram tratados como se fossem, e ao mesmo tempo eram considerados como pouco mais que animais cuja mão de obra deveria ser explorada enquanto durasse sua vida útil. As meninas de doze a dezesseis anos não eram ainda mulheres, mas em idade considerada casadoura pela Igreja Católica, eram caçadas e cobiçadas como se o fossem. Em meio ao mundo adulto, o universo infantil não tinha espaço: as crianças eram obrigadas a se adaptar ou perecer. Neste sentido, seriam os grumetes e pajens considerados crianças ou eram vistos como adultos em corpos infantis? (RAMOS, 2010, p.48-49).

Assim como ocorre atualmente, as atividades exercidas pela criança e adolescente naquela época variavam de acordo com sua condição econômico-financeira. Ao contrário do tratamento oferecido aos filhos de artesãos e camponeses advindos de uma infância desafortunada, aqueles advindos de famílias mais abastadas se ocupavam de conhecimentos necessários para a vida em sociedade, como os preceitos de moralidade e etiqueta que deveriam ser aprendidos e respeitados, o ensinamento da leitura, da música, da dança, dentre outros.

enfim, tinha presença na vida do momento. Entretanto, sua morte não era encarada como uma tragédia, outras crianças poderiam nascer substituindo as que se foram. Era aceita como uma fatalidade, tantas nasciam e morriam, sendo substituídas por outras. Não era vista como um ser que fazia falta." (SCARANO, 2010, p. 109-110). 
Em pesquisa dedicada ao trabalho infantil, Teixeira (2007) relata que naquela época as crianças exerciam o trabalho braçal cujos serviços variavam de acordo com as suas capacidades físicas. Assim, para aquelas famílias menos abastadas quanto maior a quantidade de filhos, maior seria o número de trabalhadores braçais e, portanto, maior seria a possibilidade de sobrevivência.

De acordo com a autora, o trabalho infantil faz parte da realidade brasileira desde o seu período colonial. A criança, independente de sua cor de pele (fosse ela branca ou negra), era primordial para o bom funcionamento do lar, em especial, dos domicílios rurais e economicamente mais carentes.

Ademais, várias tarefas exercidas pelas crianças eram consideradas pelos adultos como parte de sua formação educacional, sendo desenvolvidas de acordo com o seu critério etário, por imitação e observação dos adultos.

Sobre o assunto, diz-se, inclusive que:

A pobreza, a escolaridade dos pais, o tamanho e a estrutura da família, o sexo do chefe, idade em que os pais começaram a trabalhar e o local de residência são os determinantes mais analisados e dos mais importantes para explicar a alocação do tempo da criança para o trabalho. As principais consequências socioeconômicas do trabalho de crianças e de adolescentes são sobre a educação, o salário e a saúde dos indivíduos (...). Os primeiros relatos do trabalho infantil no Brasil ocorrem na época da escravidão, que perdurou por quase quatro séculos no País. Os filhos de escravos acompanhavam seus pais nas mais diversas atividades em que se empregava mão-de-obra escrava e exerciam tarefas que exigiam esforços muito superiores às suas possibilidades físicas. O início do processo de industrialização, no final do século XIX, não foi muito diferente de outros países no tocante ao trabalho infantil. Em 1890, do total de empregados em estabelecimentos industriais de São Paulo, 15\% era formado por crianças e adolescentes. Nesse mesmo ano, o Departamento de Estatística e Arquivo do Estado de São Paulo registrava que um quarto da mão-de-obra empregada no setor têxtil da capital paulista era formada por crianças e adolescentes. (KASSOUF, 2007, p. 324).

Independentemente da condição econômico-financeira, parece ser possível afirmar que a forma como as crianças e adolescentes eram tratados perante a sociedade eram propínquas, em muitos aspectos, àquela adotada pelos adultos.

O quadro pintado pelo espanhol Diego Velazques, aproximadamente em 1656 (segunda metade do século XVII), intitulado As Meninas, demonstra a forma com que as crianças daquela época eram cuidadas.

Vê-se que, apesar de a pintura aduzir outros personagens, a obra tem como figura central a princesa Margarida de Áustria, que, à época com cinco anos de idade, aparece na obra vestida, penteada e maquiada igual às mulheres adultas daquela época.

Nesse contexto, merece ressalva o seguinte entendimento:

As pinturas do século XVI ao XIX retratavam as crianças vestidas e enfeitadas como adultos em miniaturas. Os sentimentos expressos na face, a posse, assim como a musculatura, mostravam que não existia distância do mundo das crianças e dos adultos. A criança exercia dentro da organização social as atividades impostas aos mais velhos, variando essas de acordo com a condição social da família. Para as famílias nobres aos 7 anos eram levadas a ter aulas como de escrita, e música. Já para as menos abastadas, restavam as tarefas da economia familiar, e o aprendizado e ajuda nos ofícios dos pais. (BARBOSA; QUEDES, 2008, p. 32).

Scarano (2010), ao narrar sobre o Estado de Minas Gerais no século XVIII, relata que nessa época o individualismo era conduta predominante entre os adultos independentemente de estes serem brancos ou negros escravos e que este comportamento advinha da própria forma de trabalho aventureiro, instável e suscetível à mudança a qualquer tempo no qual estavam inseridos.

Em regra, a criança se diferenciava do adulto apenas em relação ao tamanho e a força para o trabalho. Não havia as etapas da infância, juventude e fase adulta. Assim que adquiria uma independência mínima como, por exemplo, se alimentar, fazer suas necessidades fisiológicas, trocar a vestimenta sozinha, já era 
automaticamente misturada aos adultos. Portanto, não havia um critério a ser seguido como o desenvolvimento biológico, o cronológico de idade e, muito menos, o psicológico para determinar o início e o fim das fases da vida.

A duração da infância era reduzida a seu período mais frágil, enquanto o filhote do homem ainda não conseguia bastar-se; a criança então, mal adquiria algum desembaraço físico, era logo misturada aos adultos, e partilhava de seus trabalhos e jogos. De criancinha pequena ela se transformava imediatamente em homem jovem, sem passar pelas etapas da juventude. (ARIÈS, 1978, p. 10).

É percebido que, nesta primeira fase, a criança e o adolescente eram tratados como seres "engraçadinhos", "bichinhos de estimação" desprovidos de personalidade, cuja serventia era, tão somente, distrair os adultos. Este tratamento advinha, na maioria das vezes, da costumeira e decorrente morte prematura predominante àquela época. Um dos comportamentos sociais que contribuíam com esta morte precoce era o descuido com a saúde física e higiênica.

Necessário se faz ressaltar que, no final do século XIX, a indiferença com que eram tratados as crianças e adolescentes, principalmente por seus pais, passou a ser contestada. Tânia da Silva Pereira (1996) expõe que, influenciado pelos ideais iluministas e pela independência americana, o filósofo francês Jean Jacques Rousseau, com fundamento nos princípios universais de liberdade, igualdade e fraternidade, passou a demonstrar preocupação com as crianças e adolescentes daquela época.

Daí começou a surgir o entendimento de que seria possível a criação de uma sociedade mais livre e igualitária, dando ensejo aos códigos que cuidariam da sistematização material jurídica.

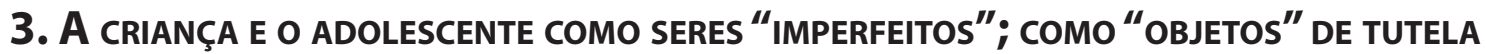 ESTATAL}

$\mathrm{Na}$ segunda fase, aproximadamente na primeira metade do século XX, a criança e o adolescente deixaram de ser tratados como um "animalzinho de estimação" e passaram a ser vistos como um "objeto" de tutela do Estado.

Conforme explica Corral (2004), o motivo principal para considerá-los como "objeto" de proteção paterna ou estatal e não como sujeitos detentores de direitos subjetivos era o fato da menoridade naquela época ser considerada um status do indivíduo (semelhante ao estado civil), prevalecendo o aspecto de "imperfeição" destes indivíduos em fase de desenvolvimento, e, atrelada a esta "imperfeição", a necessidade de proteção e cuidado. Assim, os direitos legais da criança e do adolescente aparecem como autênticos direitos reflexos do interesse paterno ou social, não havendo, portanto, a preocupação em fazer com que estes indivíduos exercessem, ainda que de forma diminuta, a sua autonomia privada.

Com a vigência do Código Beviláqua em 1917, e ao entrar em vigor o Decreto n 17.943-A de 12 de outubro de 1927, conhecido como Código de Menores (apesar de este ainda não proteger integralmente a criança e o adolescente, resguardando tão somente aqueles que se encontravam em situação irregular), o legislador brasileiro passou a refletir sobre a situação da criança e do adolescente no país.

Dornelles constata que:

Os menores em situação irregular seriam aqueles que se encontrassem em condições de privação no que se refere à subsistência, saúde, instrução, etc.; vítimas de maus-tratos impostos pelos pais ou responsável; se encontrassem em ambientes que ferem os bons costumes; que apresentassem condutas desviantes, incluindo-se os autores de infrações penais. A utilização da expressão "menor em situação irregular", pressupunha uma anormalidade que passava a identificar a criança e o adolescente com categorias de indivíduos estranhos, problemáticos ou perigosos. (DORNELLES, 1992, p. 127).

Assim, com as leis de assistência e proteção a menores (Código de Menores), a criança e o adolescente 
passaram a receber, ainda que de forma discriminatória alguma assistência e proteção do Estado. Vê-se:

Art. $1^{\circ}$. O menor, de um ou outro sexo, abandonado ou delinquente, que tiver menos de 18 annos de idade, será submettido pela autoridade competente às medidas de assistencia e protecção contidas neste Codigo.

Art. $2^{\circ}$. Toda creança de menos de dous annos de idade entregue a criar, ou em ablactação ou guarda, fóra da casa dos paes ou responsaveis, mediante salario, torna-se por esse facto objecto da vigilancia da autoridade publica, com o fim de lhe proteger a vida e a saude.

Art. 21 Quem encontrar infante exposto, deve apresental-o, ou dar aviso do seu achado, á autoridade policial no Districto Federal ou, nos Estados, á autoridade publica mais proxima do local onde estiver o infante.

Art. 22. A autoridade, a quem fôr apresentado um infante exposto, deve mandar inscrevel-o no registro civil de nascimento dentro do prazo e segundo as formalidades regulamentares, declarando-se no registro o dia, mez e anno, o logar em que foi exposto, e a idade apparente; sob as penas do art. 388 do Codigo Penal, e os mais de direito. (BRASIL, 1927, grifou-se).

Nesse sentido, é percebido que o Decreto em análise, além de proteger apenas os menores considerados pelo legislador como abandonados ou delinquentes, distinguia-os, discriminadamente, dando-os a alcunha de indivíduos abandonados, vadios, mendigos e libertinos. ${ }^{3}$

Não é apenas na legislação vigente à época que se pode perceber a indiferença com que eram tratados as crianças e adolescentes. Romancistas brasileiros, como José Lins do Rego e Jorge Amado, mostraram em algumas de suas obras o desinteresse tanto do Estado quanto da família com o tratamento a ser dado à infância como fase preponderante para a formação do indivíduo.

Rego (2012), em sua obra Menino de Engenho, lançada em 1932, conta a história de Carlinhos que, com quatro anos de idade perde a mãe violentamente assassinada pelo pai, que acaba sendo internado em um

3 Art. 26. Consideram-se abandonados os menores de 18 annos:

I. que não tenham habitação certa, nem meios de subsistencia, por serem seus paes fallecidos, desapparecidos ou desconhecidos ou por não terem tutor ou pessoa sob cuja, guarda vivam;

II. que se encontrem eventualmente sem habitação certa, nem meios de subsistencia, devido a indigencia, enfermidade, ausencia ou prisão dos paes. tutor ou pessoa encarregada de sua guarda;

III, que tenham pae, mãe ou tutor ou encarregado de sua guarda reconhecidamente impossibilitado ou incapaz de cumprir os seus deveres para, com o filho ou pupillo ou protegido;

IV, que vivam em companhia de pae, mãe, tutor ou pessoa que se entregue á pratica de actos contrarios á moral e aos bons costumes; $\mathrm{V}$, que se encontrem em estado habitual do vadiagem, mendicidade ou libertinagem;

VI, que frequentem logares de jogo ou de moralidade duvidosa, ou andem na companhia de gente viciosa ou de má vida.

VII, que, devido á crueldade, abuso de autoridade, negligencia ou exploração dos paes, tutor ou encarregado de sua guarda, sejam:

a) victimas de máos tratos physicos habituaes ou castigos immoderados;

b) privados habitualmente dos alimentos ou dos cuidados indispensaveis á saude;

c) empregados em occupações prohibidas ou manifestamente contrarias á moral e aos bons costumes, ou que lhes ponham em risco

a vida ou a saude;

d) excitados habitualmente para a gatunice, mendicidade ou libertinagem;

VIII, que tenham pae, mãe ou tutor, ou pessoa encarregada de sua guarda, condemnado por sentença irrecorrivel;

a) a mais de dous annos de prisão por qualquer crime;

b) a qualquer pena como co - autor, cumplice, encobridor ou receptador de crime commettido por filho, pupillo ou menor sob sua guarda, ou por crime contra estes.

Art. 28. São vadios os menores que:

a) vivem em casa dos paes ou tutor ou guarda, porém, se mostram refractarios a receber instruccão ou entregar-se a trabalho sério e util, vagando habitualmente pelas ruas e Iogradouros publicos;

b) tendo deixado sem causa legitima o domicilio do pae, mãe ou tutor ou guarda, ou os Iogares onde se achavam collocados por aquelle a cuja autoridade estavam submettidos ou confiados, ou não tendo domicilio nem alguem por si, são encontrados habitualmente a vagar pelas ruas ou logradouros publicos, sem que tenham meio de vida regular, ou tirando seus recursos de occupação immoral ou prohibida.

Art. 29. São mendigos os menores que habitualmente pedem esmola para si ou para outrem, ainda que este seja seu pae ou sua mãe, ou pedem donativo sob pretexto de venda ou offerecimento de objectos.

Art. 30. São libertinos os menores que habitualmente: (BRASIL, 1927). 
hospício. Órfão, Carlinhos vai morar no engenho Santa Rosa localizado na zona canavieira e às margens do rio Paraíba de propriedade de seu avô materno.

No engenho, Carlinhos vive misturado aos adultos e com apenas doze anos de idade enceta precocemente a sua vida sexual. Nessa iniciação prematura, contrai doença venérea, conhecida como sífilis. Isso faz com que Carlinhos perca imaturamente a inocência da infância e se torne um adulto em corpo de criança.

Por oportuno, transcreve-se excerto da obra em comento:

Tinha uns doze anos quando conheci uma mulher, como homem. Andava atrás dela, beirando a sua tapera de palha, numa ânsia misturada de medo e de vergonha. Zefa Cajá era a grande mundana dos cabras do eito. Mas eu tinha que pagar o meu atributo antecipado do amor. Apanhei doença do mundo. Escondi muitos dias do povo da casa-grande. Ensinaram-me remédios que eu tomava em segredo na beira do rio. Dormia no sereno a goma com açúcar para os meus males. Não melhorava, tinha medo de urinar com as dores medonhas. E por fim souberam na casa-grande. Foi um escândalo. Daquele tamanho e com gálico! (...) Os senhores de engenho tomavam deboche de mim, dando-me confiança nas suas conversas. Perguntaram pela Zefa Cajá, chamavam-na de professora (...). E riam como se fosse uma coisa inocente este libertino de 12 anos. (...) Com um mês mais, já estaria em ponto de ir para o colégio. A doença do mundo me operara uma transformação. Via-me mais alguma coisa que um menino; e mesmo já me olhavam diferente. Já não tinham para mim as condescendências que se reservavam às crianças. As negras faziam-me de homem. Não paravam as conversar quando eu chegava. (...) O sexo vestira calças compridas no Carlinhos; e o coração de um menino depravado só batia ao compasso de suas depravações. (...) Ninguém pode deixar as meninas em casa com o seu Carlinho. João Rouco deume uma carreira por causa do filho pequeno, que eu quis pegar (...). (REGO, 2012, p. 136-137).

Diante desta situação a família de Carlinhos (como a de muitas outras crianças e adolescentes) transfere para a escola o dever de educar, desvencilhando-se de qualquer responsabilidade na sua criação; desamparando-o por completo em uma das fases mais importantes de sua vida e deixando, então, de contribuir para sua formação e de torná-lo competente para que, por si só e de forma consistente, construa seus próprios valores.

Em junho iria para o colégio. Estava marcado o dia de minha partida. Lá ele indireita. Abandonavam-se em desleixos para com os filhos, pensando corrigi-los no castigo dos internatos. E não se importa com a infância, com os anos mais perigosos da vida. (...) Levava para o colégio um corpo sacudido pelas paixões de homem feito e uma alma mais velha do que o meu corpo (REGO, 2012, p.137-141).

Já Amado (2008) em seu romance Capitães da Areia lançado em 1937 relata a história comovente de crianças e adolescentes pobres que moravam em um armazém abandonado e viviam de furtos e golpes na cidade de Salvador.

Apesar de transcorrido aproximadamente mais de setenta anos de seu lançamento, esta obra ainda se mostra atual e faz com que o leitor perceba que o tratamento oferecido às crianças e adolescentes pobres daquela época muito se identifica com o ofertado àquelas que vivem hodiernamente.

Esse bando que vive da rapina se compõe, pelo que se sabe, de um número superior a cem crianças das mais diversas idades, indo desde os oito aos dezesseis anos. (...) Vestidas de farrapos, sujos, semiesfomeados, agressivos, soltando palavrões e fumando pontas de cigarro, eram, em verdade, os donos da cidade, os que a conheciam totalmente, os que totalmente a amavam, os seus poetas. (...) Falavam naturalmente em mulher apesar do mais velho ter apenas dezesseis anos. Cedo conheciam os mistérios do sexo. (AMADO, 2008, p. 11-29).

O líder e corajoso Pedro Bala; o respeitado João Grande; o religioso Pirulito; o admirador de Lampião conhecido como Volta Seca; o prudente João José, conhecido como Professor que, apesar de ter frequentado apenas um ano e meio de escola, ao furtar o primeiro livro, apaixonou-se perdidamente pelo hábito de ler, tornando-se um exímio contador de histórias e um especialista em furtos de livros, (entretanto, o prazer pela leitura não permitiu que ele vendesse sequer uma obra que havia afanado); o sedutor e aprendiz de cafetão Gato; o manco Sem-Pernas; são alguns dos vários personagens retratados pelo autor que buscava 
descrever a personalidade, o conceito de vida e os mais modestos sonhos como um simples passeio em um velho e capenga carrossel que:

De tão desbotado que estava a tinta, tinta que antigamente fora azul e vermelho e agora o azul era um branco sujo e o vermelho um quase cor-de-rosa, e de tantos pedaços que faltavam em certos cavalos e em certos bancos, Nhozinho França resolveu não armá-lo numa das praças centrais da cidade e sim em Itapagipe. (AMADO, 2008, p. 63).

Sempre que um novo integrante passava a fazer parte do "Capitães da Areia" sofria nas mãos de Sem-Pernas que procurava fazer com que todas as atitudes do novato se tornassem motivos de sátira, ridicularizando-o perante os demais. Mas, na verdade, conforme retrata Amado o que Sem-Pernas verdadeiramente queria era:

A felicidade, era a alegria, era fugir de toda aquela miséria, de toda aquela desgraça que os cercava e os estrangulava (...). Queria alegria, uma mão que o acarinhasse, alguém que com muito amor o fizesse esquecer o defeito físico e os muitos anos (talvez tivessem sido apenas meses ou semanas, mas para ele seriam sempre longos anos) que vivera sozinho nas ruas da cidade, hostilizado pelos homens que passavam, empurrado pelos guardas, surrado pelos moleques maiores. Nunca tivera família. Vivera na casa de um padeiro a quem chamava "meu padrinho" e que o surrava. Fugiu logo que pôde compreender que a fuga o libertaria. Sofreu fome, um dia levaram-no preso. Ele quer um carinho, u`a (sic) mão que passe sobre os seus olhos e faça com que ele possa se esquecer daquela noite na cadeia, quando os soldados bêbados o fizeram correr com sua perna coxa em volta de uma saleta. Em cada canto estava um com uma borracha comprida. As marcas que ficaram nas suas costas desapareceram. Mas de dentro dele nunca desapareceu a dor daquela hora. Corria na saleta como um animal perseguido por outros mais fortes. A perna coxa se recusava a ajudá-lo. E a borracha zunia nas suas costas quando o cansaço o fazia parar. A princípio chorou muito, depois, não sabe como, as lágrimas secaram. (AMADO, 2008, p. 38).

Desse breve escorço, é percebido que, tanto a infância de Carlinhos (personagem principal da obra Menino de Engenho) quanto àquela vivenciada pelos vários personagens que deram vida ao romance Capitães da Areia muito se identificam com a de outras crianças e adolescentes da época e também da atualidade.

Em Menino de Engenho, apesar de Carlinhos pertencer a uma família relativamente abastada, ela, ao invés de capacitá-lo, tornando-o apto para o exercício cônscio de determinadas condutas que faziam parte do percurso natural da vida, transfere à escola esta incumbência, abandonando-o em uma das fases mais relevantes para a sua formação pessoal, privando-o de se tornar competente para o exercício consciente de seus direitos e deveres e impedindo-o de construir consistentemente seus próprios valores.

Já em Capitães da Areia, ao descrever o cotidiano das personagens desgraçadamente contempladas com o abandono familiar, com a indiferença do Estado e com uma vida extremamente pobre, Amado (2008) retrata a luta dessas crianças e adolescentes pela sobrevivência e por seus mais singelos sonhos. Conforme diz a voz de Antunes (2013), o que estas crianças e adolescentes realmente desejavam era que: "se alguém de longe me escutar, que venha aqui pra me buscar, me leve para passear, no seu disco voador, como um enorme carrossel, atravessando o azul do céu, até pousar no meu quintal".

Ademais, necessário se faz ressaltar que o trabalho infantil (ainda assente no país) ${ }^{4}$ com a Revolução

4 O trabalho infantil foi assunto recentemente abordado no programa da Rede Globo. Nesse contexto, pertine transcrever excerto da reportagem em questão: "Trabalho infantil: por que ele nunca acaba no nosso país? Lidando com fogo, queimando as mãos para beneficiar castanha de caju, manipulando pólvora para fabricar fogos de artifício, carregando caminhões de pedra no campo, lavando carros no centro das cidades, trabalhando com facas e serras e empurrando carrinhos nas feiras livres e desgastando os olhos e as pontas dos dedos na fabricação de jóias. Até onde o cansaço atrapalha o rendimento escolar destes brasileirinhos? Eles conseguem aprender? O jovem que ficou paraplégico no segundo dia de emprego. Em uma cidade com alarmantes estatísticas de acidentes de trabalho com menores. Em que tipo de emprego adolescentes podem trabalhar legalmente? Ao todo, 40 mil já conseguiram autorização na Justiça" (GLOBO REPÓRTER, 2013). Necessário se faz ressaltar o seguinte entendimento: Desde que não tenham o rendimento escolar prejudicado e não sofram nenhum dano psicológico, evitando, por conseguinte, que sejam submetidos a qualquer forma de exploração, parece ser possível afirmar que seria razoável conceder à criança e ao adolescente autorização legal para o trabalho, desde que sejam periodicamente assistidos por profissionais devidamente preparados (Judiciário, Ministério Público, 
Industrial no Brasil, ocorrida aproximadamente em meados da década de 30, foi muito utilizado pelas indústrias que, com o objetivo de explorar a mão de obra barata executada pelas crianças e adolescentes incentivavam descomedidamente esta modalidade de trabalho, conforme relatado no seguinte excerto:

Era comum as famílias levarem crianças agregadas para "completar a cota e conseguir uma casa melhor na vila. A indústria visava o trabalho das crianças e jovens, que depois de um período de aprendizado, obtinham uma ocupação definitiva. Os pais camponeses eram geralmente empregados em serviços periféricos ao processo industrial, como, por exemplo, o cultivo de roças. Quando membros da família ficavam doentes, procuravam substituí-los por filhos de parentes ou conhecidos (os agregados), para não perderem a casa, já que o seu tamanho dependia do número de pessoas trabalhando na fábrica. Recorrendo a estratégias como pagamento de baixos salários - para forçar as famílias a utilizarem o máximo de seus membros no trabalho - e a prática de induzir/consentir na falsificação da idade das crianças, burlando a legislação da época que permitia o trabalho somente a partir dos 12 anos, a fábrica facilitava a utilização do trabalho infantil. As condições de trabalho não diferiam daquelas observadas no final do século XIX: má alimentação, ambiente insalubre, autoritarismo nas relações do trabalho, longas jornadas (dois turnos de 12 horas cada) e alta incidência de doenças como a tuberculose. (RIZZINI, 2010, p. 377-378).

Não se pode olvidar a debilidade tanto do Estado quanto da sociedade em reconhecer e fazer valer os direitos da criança e do adolescente reconhecendo-os em sua completude como sujeitos detentores de garantias fundamentais. Porém, conforme relatado no capítulo anterior, com a segunda guerra mundial (19391945) tornou-se imprescindível a formalização de determinados princípios e a garantia de sua inviolabilidade para preservação dos direitos do indivíduo. Daí a criança e o adolescente passaram gradativamente a receber, ainda que de forma incompleta, alguma proteção do Estado.

Com a Declaração Universal dos Direitos Humanos (10 de dezembro de 1948), a dignidade passa a ser reconhecida em seu preâmbulo como elemento intrínseco a todos os membros da família humana, assegurando para todos os integrantes desta, direitos iguais e inalienáveis, além de irradiar a liberdade, a justiça e a paz no mundo.

A Declaração resguarda a capacidade indistinta de todos os indivíduos para fruir dos direitos e liberdades nela previstos; a igualdade de tratamento perante a lei, assim como a proteção contra qualquer forma de discriminação; a liberdade de pensamento, consciência e crença religiosa; a liberdade em poder opinar e se expressar; os cuidados necessários à infância e o tratamento igualitário aos filhos concebidos dentro ou fora do casamento; dentre outros direitos e garantias nela previstos. Vale conferir:

Art. II. Toda pessoa tem capacidade para gozar os direitos e as liberdades estabelecidos nesta Declaração, sem distinção de qualquer espécie, seja de raça, cor, sexo, língua, religião, opinião política ou de outra natureza, origem nacional ou social, riqueza, nascimento, ou qualquer outra condição.

Art. VII. Todos são iguais perante a lei e têm direito, sem qualquer distinção, a igual proteção da lei. Todos têm direito a igual proteção contra qualquer discriminação que viole a presente Declaração e contra qualquer incitamento a tal discriminação.

Art. XVIII. Toda pessoa tem direito à liberdade de pensamento, consciência e religião; este direito inclui a liberdade de mudar de religião ou crença e a liberdade de manifestar essa religião ou crença, pelo ensino, pela prática, pelo culto e pela observância, isolada ou coletivamente, em público ou em particular.

Art. XIX. Toda pessoa tem direito à liberdade de opinião e expressão; este direito inclui a liberdade de, sem interferência, ter opiniões e de procurar, receber e transmitir informações e ideias por quaisquer meios e independentemente de fronteiras.

Art. XXV, 2. A maternidade e a infância têm direito a cuidados e assistência especiais. Todas as crianças nascidas dentro ou fora do matrimônio gozarão da mesma proteção social. (BRASIL, 1948).

Conselhos Tutelares, psicólogos, dentre outros...), que acompanharão o desempenho intelectual e psicológico destes. Mais detalhes a este respeito podem ser encontrados em: (GLOBO REPÓRTER, 2013). 
Arnaud evidencia que:

Com efeito, os direitos humanos consagram o subjetivismo, isto é, o triunfo do sujeito enquanto indivíduo absolutamente livre e detentor de todos os direitos que ele não teria aceito limitar, através de um pacto social, em nome do bem comum de toda comunidade. (...) Triunfando o sentimento, os indivíduos que constituem a família exigem que os direitos humanos protejam mais as pessoas do que o grupo: espera-se que o legislador proteja primeiro as pessoas, todas as pessoas, e integralmente. Assim, a mulher será protegida de seu marido; e os filhos, dos pais (ARNAUD, 1999, p. 74-87, grifou-se).

Nesses termos, com a Declaração Universal dos Direitos Humanos o que se buscava (haja vista, na prática, esta não ser verdadeiramente seguida como deveria ser) era fortalecer o respeito e a dignidade do indivíduo nas relações sociais e, principalmente, dentro das relações familiares, passando a tratar todos de forma igualitária sem qualquer discriminação e, por conseguinte, a dar à criança e ao adolescente a importância e proteção que realmente necessitam e merecem.

\section{A CRIANÇA E O ADOLESCENTE COMO SUJeITOS DE DiREITOS, DETENTORES DE DiREITOS E GARANTIAS FUNDAMENTAIS}

Paulatinamente a criança e o adolescente passam a ser considerados pela sociedade e pelo legislador como indivíduos carecedores e detentores de direitos e garantias fundamentais. Deixam de ser tratados como um "fardo" ou um "objeto" e passam, gradativamente, a serem vistos pela sociedade com olhar mais humano e indistinto.

A criança e o adolescente passaram a ser vistos como verdadeiros sujeitos de direitos. Nesse contexto:

Deixam de ser vistos como meros sujeitos passivos, objeto de decisões de outrem (ou seu representante legal), sem qualquer capacidade para influenciarem a condução da sua vida, e passaram a ser vistos como sujeitos de direitos, ou seja, como sujeitos dotados de uma progressiva autonomia no exercício de seus direitos em função da sua idade, maturidade e desenvolvimento das suas capacidades. Pode, por conseguinte, afirmar-se que a criança e o adolescente conquistaram já um estatuto de "cidadania social" incontornável. (MARTINS, 2004, p. 6).

$\mathrm{Na}$ terceira e última fase, aproximadamente na segunda metade do século XX até os tempos atuais, a criança e o adolescente passaram a receber maior proteção, tornando-se alvo de amparo integral e prioritário. Passaram a ser reconhecidos como agentes sociais e, consequentemente, a infância passou a ser considerada uma fase da vida que merece ser debatida, tornando-se objeto de discussão social através de entidades constituídas para este fim.

Nesse sentido, a Declaração Universal dos Direitos da Criança de 20 de novembro de 1959, da qual o Brasil é signatário, prevê que, devido à imaturidade física e mental, haja vista, serem indivíduos em desenvolvimento, a criança e o adolescente necessitam de proteção e de cuidado especial, devendo, ainda, ser amparado por uma legislação apropriada.

O primeiro princípio expõe que todas as crianças farão jus, sem qualquer exceção, distinção ou discriminação, por motivo de raça, cor, sexo, língua, religião, opinião política ou de outra natureza, origem nacional ou social, riqueza, nascimento ou qualquer outra condição, quer sua ou de sua família dos direitos nela previstos.

Em seu sexto princípio ressalta a relevância da família, e na falta desta, da sociedade e do Estado em proporcionar à criança e ao adolescente um ambiente favorável ao desenvolvimento integral e harmônico de sua personalidade. Em seu nono princípio, os protege de qualquer atitude negligente, cruel e de exploração. Por fim, o seu décimo princípio assegura-lhes de qualquer forma de discriminação racial ou religiosa. Vê-se: 
Princípio $6^{\circ}$. Para o desenvolvimento completo e harmonioso de sua personalidade, a criança precisa de amor e compreensão. Criar-se-á, sempre que possível, aos cuidados e sob a responsabilidade dos pais e, em qualquer hipótese, num ambiente de afeto e de segurança moral e material, salvo circunstâncias excepcionais, a criança da tenra idade não será apartada da mãe. À sociedade e às autoridades públicas caberá a obrigação de propiciar cuidados especiais às crianças sem família e aquelas que carecem de meios adequados de subsistência. É desejável a prestação de ajuda oficial e de outra natureza em prol da manutenção dos filhos de famílias numerosas.

Princípio $8^{\circ}$. A criança figurará, em quaisquer circunstâncias, entre os primeiros a receber proteção e socorro.

Princípio $9^{\circ}$. A criança gozará de proteção contra quaisquer formas de negligência, crueldade e exploração. Não será jamais objeto de tráfico, sob qualquer forma.

Não será permitido à criança empregar-se antes da idade mínima conveniente; de nenhuma forma será levada a ou ser-lhe-á permitido empenhar-se em qualquer ocupação ou emprego que lhe prejudique a saúde ou a educação ou que interfira em seu desenvolvimento físico, mental ou moral.

Princípio $10^{\circ}$. A criança gozará de proteção contra atos que possam suscitar discriminação racial, religiosa ou de qualquer outra natureza. Criar-se-á num ambiente de compreensão, de tolerância, de amizade entre os povos, de paz e de fraternidade universal e em plena consciência que seu esforço e aptidão devem ser postos a serviço de seus semelhantes. (BRASIL, 1959).

Nesse sentido, o Pacto de San José da Costa Rica prevê em seu art. 19 que: "Toda criança tem direito às medidas de proteção que a sua condição de menor requer por parte da sua família, da sociedade e do Estado”. (BRASIL, 1992).

Apesar de o antigo Código (Lei no 6.697/79, que se caracteriza por ser uma revisão do Código de Menores de 1927) considerar a criança e o adolescente indivíduos incapazes de responder por suas condutas, seres marginalizados, com grande potencialidade à delinquência, provenientes de famílias carentes e, inclusive, considerados perigosos para a sociedade - daí a definição dada ao Código em questão de "menores em situação irregular" -, com a vigência da Constituição Federal de 1988, esse tratamento passa a sofrer alterações.

Com o advento da Carta Magna de 1988 e, logo em seguida, do Estatuto da Criança e do Adolescente (Lei no 8.069/90), o país passou a aplicar o princípio da proteção integral, afastando por completo o termo "menor" e objetivando proteger a criança e o adolescente, independente da situação em que se encontram.

Mendez (1999) explica que a nova Constituição brasileira incorporou dois itens fundamentais ao longo do desenvolvimento de um novo tipo de política social para as crianças conhecida como política social pública. De acordo com o autor, o artigo 227 da Constituição em comento é uma síntese admirável da futura Convenção, que, na época, circulou em formato de rascunho entre os movimentos que lutavam pelos direitos das crianças. O outro instrumento normativo preponderante foi o artigo 204 (em especial no inciso II), que, legitimando esforços conjuntos entre governo e sociedade civil, prevê explicitamente a reformulação de políticas públicas, passando estas a não serem mais compreendidas como um mero sinônimo de política de governo, mas como o resultado da articulação entre governo e sociedade civil.

Concretizou-se a ideia de que as crianças e adolescentes são sujeitos de direitos e titulares de garantias fundamentais, conferindo-lhes, indistintamente, proteção prioritária, vedando qualquer forma de discriminação.

Corroborando esse entendimento:

A evolução dos direitos de crianças e adolescentes, no Brasil, partiu do denominado "direito do menor", expressão que reduzia a importância da criança como ser humano, para o direito da criança e do adolescente. (...) O Código de Menores, a rigor, "não passava de um Código Penal do Menor", uma vez que suas normas tinham mais um caráter sancionatório do que protetivo ou assistencial. Trouxe consigo a "Doutrina do Menor em Situação Irregular", quando poucas foram as modificações; era o tempo do "menor", do "menor abandonado", do menor delinquente, expressões que estigmatizavam crianças e 
adolescentes e que ainda hoje albergam uma espécie de ranço, quando se houve dizer: "ele é de menor". (FONSECA, 2011, p. 7-8).

A Convenção sobre os Direitos da Criança, Decreto n 99.710 de 21 de novembro de 1990 prevê em seu artigo 2.1, o direito à igualdade das crianças e adolescentes proibida qualquer distinção entre eles. Já o art. 2.2, visa protegê-los de qualquer forma de discriminação ou castigo, assegurando o exercício de atividades, a manifestação de suas opiniões, dentre outros direitos e garantias.

Conforme inserto no art. 3 todas as ações realizadas por instituições públicas ou privadas que, porventura, envolvam crianças ou adolescentes devem levar em conta, primordialmente, os interesses destes. O art. 4 além de agoirar os direitos e deveres dos pais, tutores ou responsáveis, também prevê o direito à proteção e ao cuidado que obrigatoriamente estes deverão ter com a criança ou adolescente que estiverem sob sua responsabilidade.

Nesse sentido, o art. $4^{\circ}$ da Convenção dispõe que: "Os Estados Partes comprometem-se a tomar todas as medidas legislativas, administrativas e outras necessárias à realização dos direitos reconhecidos pela Presente Convenção (...)”.

Ao analisar o art. $4^{\circ}$ acima prescrito, Castro ressalta que:

Cuida-se, portanto, de um dever de máxima aplicação de recursos disponíveis, gerando uma verdadeira inversão no ônus da prova, ao colocar sob a obrigação do Estado comprovar que não pôde fazer mais do que fez em favor da eficácia desses direitos sociais, econômicos e culturais. (...) Embora as políticas públicas em favor de crianças e adolescentes devam ser municipalizadas, visando à proximidade territorial de suas famílias e comunidade, justamente para favorecer o fortalecimento familiar e comunitário, a responsabilidade por esta efetivação de direitos é das três esferas (municipal, estadual e federal). Por isso, todos podem ser cobrados, inclusive judicialmente, pelo cumprimento dos direitos previstos na Constituição, na Convenção e nas leis ordinárias. (CASTRO, p. 449, 2.013).

Ademais, a Convenção sobre os Direitos da Criança em seu art. 12 expressa de forma clara o direito da criança e do adolescente em poder manifestar livremente o seu ponto de vista principalmente em relação a questões que os envolvem, devendo a sua opinião ser considerada de acordo com a sua idade e maturidade.

$\mathrm{O}$ art. 13 assegura-lhes a liberdade de expressão. Já o art. 14 prevê o exercício do direito à liberdade de pensamento, de consciência e de professar a sua crença religiosa; proibindo interferências arbitrárias ou ilegais em sua vida privada (art. 16).

De acordo com Corral (2004), a liberdade ideológica e de consciência da criança e do adolescente dificilmente pode sofrer limitação por parte dos pais ou responsáveis. Esta limitação, entretanto, pode decorrer de determinadas situações específicas como a educação e a representação da criança e do adolescernte. Enquanto estes carecerem de maturidade suficiente para formar a sua ideologia e a sua própria consciência religiosa, tanto as instituições de ensino quanto os pais ou responsáveis devem agir de forma a complementar a garantia que estes indivíduos ainda em fase de desenvolvimento físico e psíquico possuem, dando-lhes a possibilidade de exercer a sua plena liberdade de consciência e ideológica.

Sob essa linha de raciocínio, garantir o direito dos pais ou responsáveis na formação da consciência da criança e do adolescente não quer dizer que aqueles podem tolhir a liberdade destes em fazer as suas escolhas, e, por conseguinte, em decidir por si só qual a crença religiosa ou orientação ideológica resolveu seguir quando demostrada maturidade suficiente para tal escolha. ${ }^{5}$

5 Nesse sentido: "Las libertades ideológica y de conciencia dificilmente pueden resultar afectadas por las potestades de guarda del menor. Sí lo pueden ser, sin embargo, por las potestades educativas y de representación. Por un lado, mientras el menor carezca de madurez suficiente como para poseer una ideología y una consciencia religiosa propias, las potestades educativas y de representación de los padres han de actuar como complemento para garantizarle una libertad de formación de su conciencia e ideología que podría venir amenazada por la incidencia estatal (...) y no tanto garantizar un derecho propio de los padres sobre la formación de las consciencias de sus hijos, que deje sin protección constitucional su liberdad ideológica y de consciencia. Esto no quiere decir que carezca de cobertura constitucional la decisión de los padres de que su hijo estudie em um centro de uno u otro credo religioso o moral, o que asista desde pequeño a los actos de culto de u otra religión. Pero sí implica que dichos actos vulnerarán la libertad de 
$\mathrm{O}$ art. 27 da Convenção em comento assegura à criança e ao adolescente o direito ao pleno desenvolvimento físico, mental, espiritual, moral e social. Já o art. 28 deste mesmo diploma normativo ressalta o direito ao acesso à educação de qualidade. $\mathrm{O}$ art. 31 traz à baila o direito ao descanso, ao lazer e à diversão.

Conforme explica Lara (2011), a Convenção, além de prever os direitos das crianças e adolescentes, obriga os países signatários a proteger estes direitos, impondo aos mesmos o dever de tomar medidas tanto administrativas quanto legislativas necessárias para que estes desfrutem de seus direitos previstos na Convenção. Devendo os países, inclusive, fazer uso da cooperação internacional caso não tenham recursos suficientes, e, por conseguinte, prestarem contas à Organização das Nações Unidas (ONU).

Nesse sentido, é percebida a influência da Convenção sobre os Direitos da Criança na proteção dos direitos humanos de crianças e adolescentes, e a sua influência na aplicação da doutrina da proteção integral contribuindo para que as crianças e adolescentes sejam reconhecidos como indivíduos detentores de direitos e garantias fundamentais.

\section{Considerações finais}

Diante do breve apanhado histórico realizado neste trabalho, constatou-se como a criança ou adolescente era tratada com indiferença até pouco tempo atrás e como a legislação passou a reconhecê-los como sujeitos de direitos e detentores de garantas fundamentais. No entanto, não obstante tais reconhecimentos jurídicos já sejam uma vitória, é preciso colocá-los em prática.

Basta simples acesso às redes de mídia social, jornais, dentre outros mais, para constatar como existem crianças e adolescentes abandonados no país, cujo abandono muitas das vezes não tem a ver com a condição econômico-financeira da família, até porque é cediço que dinheiro não é sinônimo de amparo psicológico, moral dentre outros mais imprescindíveis para o pleno desenvolvimento destes indivíduos ainda em fase de desenvolvimento psico-físico.

O que se pretende neste trabalho é chamar a atenção para o fato de que família e Estado são responsáveis por nossas crianças e adolescentes; a sociedade e o Estado, por meio de seus profissionais devidamente habilitados, tais como: Judiciário, Ministério Público, serviço social, dentre outros mais, devem fazer valer na prática os direitos e garantias fundamentais constitucionalmente previstos às crianças e adolescentes, $\mathrm{o}$ que não quer dizer que sempre os seus desejos serão atendidos, até porque, por estarem ainda em fase de desenvolvimento devem ser a todo o momento assistidos, mas que sempre deverão ser ouvidos e que as suas opiniões devem sempre ser levadas em consideração, principalmente, quando se encontrarem envolvidos em um processo judicial.

Ao se remontar sobre a constituição das políticas sociais no Brasil na área da infância e da juventude destaca-se o código de menores, e o Serviço de Assistência ao Menor de características assistencialista e punitiva, apresentando uma contradição em relação aos objetivos de proteção ás crianças e aos adolescentes. No entanto, com a aprovação Estatuto da Criança e do Adolescente (ECA) em 1990, e as mudanças ocorridas no bojo da organização da políticas sociais a partir da Constituição de 1988, um novo panorama começa a surgir no sentido de incorporar na agenda das políticas públicas sociais os direitos de crianças e adolescentes como sujeitos de direitos.

A promulgação do ECA e a da Lei Orgânica da Assistência Social (LOAS) em 1993 consagram uma

conciencia del menor si no se enmarcan en un contexto educativo en el que se forme al menor con pluralismo, libertad y democracia, o si no van acompanãdas como muy a menudo sucede de una educación que permita al menor decidir por sí mismo, cuando tenga madurez, cuál es su credo religioso o su orientación ideológica”. (CORRAL, 2004, p. 230-231). 
nova abordagem para políticas de proteção integral para infância e juventude. Neste novo marco legal, a criança e o adolescente deixam de ser vistos como portadores de necessidades - e frequentemente um problema a ser enfrentado - e passam a ser considerados sujeitos de direitos, cabendo às gerações adultas o dever de construir um sistema de garantia de direitos. E, para alcançar estes objetivos, as políticas públicas devem ser organizadas segundo os princípios da descentralização, da articulação de ações governamentais e não-governamentais, e da participação da população, por meio de diversos conselhos.

Todo esta arcabouço jurídico, constituído a partir da Constituição de 1988, procura assegurar às crianças e adolescentes o acesso a políticas sociais básicas, como saúde e educação; à política de assistência social, em caso de risco e vulnerabilidade social; e à políticas de garantias de direitos, para as situações de ameaça ou violação de direitos. No entanto, para que os direitos preconizados pelo ECA e demais legislações sejam materializados na prática da proteção da infância e juventude, é preciso que o conjunto de políticas sociais destinadas a inclusão das crianças e adolescentes estejam em pleno funcionamento e suas ações sejam planejadas e pensadas no sentido de garantir a vivência do acesso aos direitos.

A criação ou manutenção de programas de atenção às crianças e aos adolescentes tem sido cada vez mais alimentado pelos objetivos das políticas públicas, no sentido de garantir na vivência os direitos normatizados pelo ECA. As redes de atenção à criança e ao adolescente, que vêm sendo implantadas em nível municipal, oferecem indícios de como é possível caminhar no sentido da construção de políticas públicas, segundo os princípios da LOAS e do ECA. Essas prefeituras vêm enfrentando os desafios de construir uma política para atenção a crianças e jovens em novas bases, a partir do conceito de atuação em rede, com o compromisso de interlocução e fortalecimento de todos os atores envolvidos, modificando-se assim o tratamento conferido às nossas crianças e adolescentes ao longo da história.

\section{REFERÊNCIAS BIBLIOGRÁFICAS}

AMADO, Jorge. Capitães da Areia. Posfácio de Milton Hatoum. 2. ed. São Paulo: Companhia das Letras, 2008.

ARNAUD, André Jean. O direito entre a modernidade e globalização: lições de filosofia do direito e do Estado. Rio de Janeiro: Renovar, 1999.

ARIÈS, Philippe. História social da criança e da família. 2. ed. Rio de Janeiro: Guanabara Koogan S.A, 1978.

BARBOSA, Rita Claudia Aguiar; QUEDES Walkiria. Vestuário e infância: entre a adequação e as determinações sociais. In: III Encuentro Latinoamericano de Diseño. Buenos Aires, 2008, n. 5 p. 31-34.

BEHRING, Elaine R. BOSCHETTI, Ivanete. Política Social: Fundamentos e História. $3^{\text {a }}$ Ed. Vol. 2. São Paulo: Cortez, 2007.

BRASIL. Comissão de Cidadania e Direitos Humanos. Assembleia Legislativa do Rio Grande do Sul. Estatuto da Criança e do Adolescente aprovado pela Lei 8069 em 13 de Julho de 1990. Porto Alegre, 2013.

BRASIL. Constituição da República Federativa do Brasil de 1988. Diário Oficial da União, Brasília, 5 de outubro de 1988. Disponível em: http://www.planalto.gov.br/ccivil_03/constituicao/constituicao.htm Acesso em 10/11/2011.

BRASIL. Declaração Universal dos Direitos da Criança. Adotada pela Assembleia das Nações Unidas de 20 de novembro de 1959 e ratificada pelo Brasil em 24 de setembro de 1990. Disponível em: < http://www.dhnet. org.br/direitos/sip/onu/c_a/lex41htm> Acesso em 10 set. 2012

BRASIL. Decreto no 99.710, de 21 de novembro de 1990. Promulga a Convenção sobre os Direitos da Criança. Convenção sobre os direitos da criança. Diário Oficial da União, Brasília, 22 de novembro de 
1990. Disponível em: <http://www.planalto.gov.br/ccivil_03/decreto/1990-1994/D99710.htm> Acesso em 1/04/2013.

BRASIL. Decreto n 678, de 6 de novembro de 1992. Promulga a Convenção Americana sobre Direitos Humanos (Pacto de São José da Costa Rica), de 22 de novembro de 1969. Diário Oficial da União, Brasília, 9 de novembro de 1992

BRASIL. Decreto n 3.321, de 30 de dezembro de 1999. Promulga o Protocolo Adicional à Convenção Americana sobre Direitos Humanos em Matéria de Direitos Econômicos, Sociais e Culturais "Protocolo de São Salvador", concluído em 17 de novembro de 1988, em São Salvador, El Salvador. Diário Oficial da União, Brasília, 31 de dezembro de 1999.

BRASIL. Decreto Lei no 17.943-A, de 12 de outubro de 1927. Consolida as leis de assistencia e protecção a menores. Código de Menores. Coleção de Leis do Brasil, Rio de Janeiro, 31 de dezembro de 1927. Disponível em: <http://www2.camara.leg.br/legin/fed/decret/1920-1929/decreto-17943-a-12-outubro1927-501820-publicacaooriginal-1-pe.html> Acesso em 11/03/2013.

BRASIL. Lei 8.069, de 13 de julho de 1990. Dispõe sobre o Estatuto da Criança e do Adolescente, e dá outras providências. Diário Oficial da União, Brasília, 16 de julho de 1990.

CASTRO, Myriam Mesquita Pugliese de. Estatuto da Criança e do Adolescente Comentado. Comentários jurídicos e sociais. In: CURY, Munir (coord). 12 ed. São Paulo: Malheiros Editores, 2013, p. 50-52.

CHALMEL, Loic. Imagens de crianças e crianças nas imagens: representações da infância na iconografia pedagógica nos séculos XVII e XVIII. Educação e sociologia. Campinas, v. 2, n. 86, abr. 2004, p. 57-74.

CORRAL, Alaéz Benito. Minoría de edad y derechos fundamentales. Madrid: Tecnos, 2004.

COSTA, Ana Paula Motta. Os adolescentes e seus direitos Fundamentais: da invisibilidade à indiferença. Porto Alegre: Livraria do Advogado, 2012.

DORNELLES, João Ricardo W. Estatuto da Criança e do adolescente: estudos sócio-jurídicos. In: PEREIRA, Tânia da Silva (coord.). Rio de Janeiro: Renovar, 1992, p. 117-131.

FONSECA, Antonio Cezar Lima da. Direitos da Criança e do Adolescente. São Paulo: Atlas, 2011

GONZÁLES, Rodrigo S. O marco jurídico da proteção, promoção e defesa dos direitos da criança e do adolescente no Brasil. In: MACIEL, Ana L. S. FERNANDES, Rosa M. C. (Orgs.) O direito das crianças e dos adolescentes em análise. Porto Alegre: Fundação Irmão José Otão, 2012.

KASSOUF, Ana Lúcia. O que conhecemos sobre o trabalho infantil? Nova Economia. Revista do Departamento de Ciências Econômicas da UFMG, Belo Horizonte, v. 17, n. 2, mai/ago 2007, p. 323-350.

LARA. Rosa María Alvárezde. El concepto de niñez em la convención sobre los derechos del niño y en la legislación mexicana. Instituto de Investigaciones Jurídicas (UNAM), nº 5, 2011, p. 1-11.

MARTINS. Rosa Cândido. Poder paternal vs autonomia da criança e do adolescente? Lex familiae. Revista Portuguesa de direito da família. Portugal, a. 1, n.1, p. 1-8, 2004.

MÉNDEZ, EMILIO GARCÍA. Justicia y derechos del niño. Santiago de Chile. Nuevamerica, 1999, p. 2343.

PEREIRA, Tânia da Silva. Direito da criança e do adolescente: uma proposta interdisciplinar. Rio de Janeiro: Renovar, 1996.

RAMOS, Fábio Pestana. A história trágico-marítima das crianças nas embarcações portuguesas do século XVI. In PRIORE, Mary Del (org.). História das crianças no Brasil. 7 ed. São Paulo: Contexto, 2010, p.19-54.

REGO, José Lins do. Menino de engenho. Apresentação Ivan Cavalcanti Proença. 104. ed. Rio de Janeiro: 
José Olympio, 2012.

RIZZINI, Irma. Pequenos trabalhadores do Brasil. In PRIORE, Mary Del (org.). História das crianças no Brasil. 7. ed. São Paulo: Contexto, 2010, p.376-406.

SCARANO, Julita. Criança esquecida das Minas Gerais. In: PRIORE, Mary Del (org.). História das crianças no Brasil. 7. ed. São Paulo: Contexto, 2010, p. 107-136.

TEIXEIRA, Maria Heloísa. A não-infância: crianças como mão-de-obra em Mariana (1850-1900). Faculdade de Filosofia, Letras e Ciências Humanas - Departamento de História, 2007. 302f. Tese (Doutorado) - Universidade de São Paulo (USP), Programa de Pós-Graduação em História Econômica, São Paulo: 2007. Disponível em: <http://www.teses.usp.br/teses/disponiveis/8/8137/tde-10072008-105745/pt-br.php> Acesso em 23 out. 2013. 


\section{REVISTA BRASILEIRA DE POLÍTICAS PÚBLICAS BRAZILIAN JOURNAL OF PUBLIC POLICY}
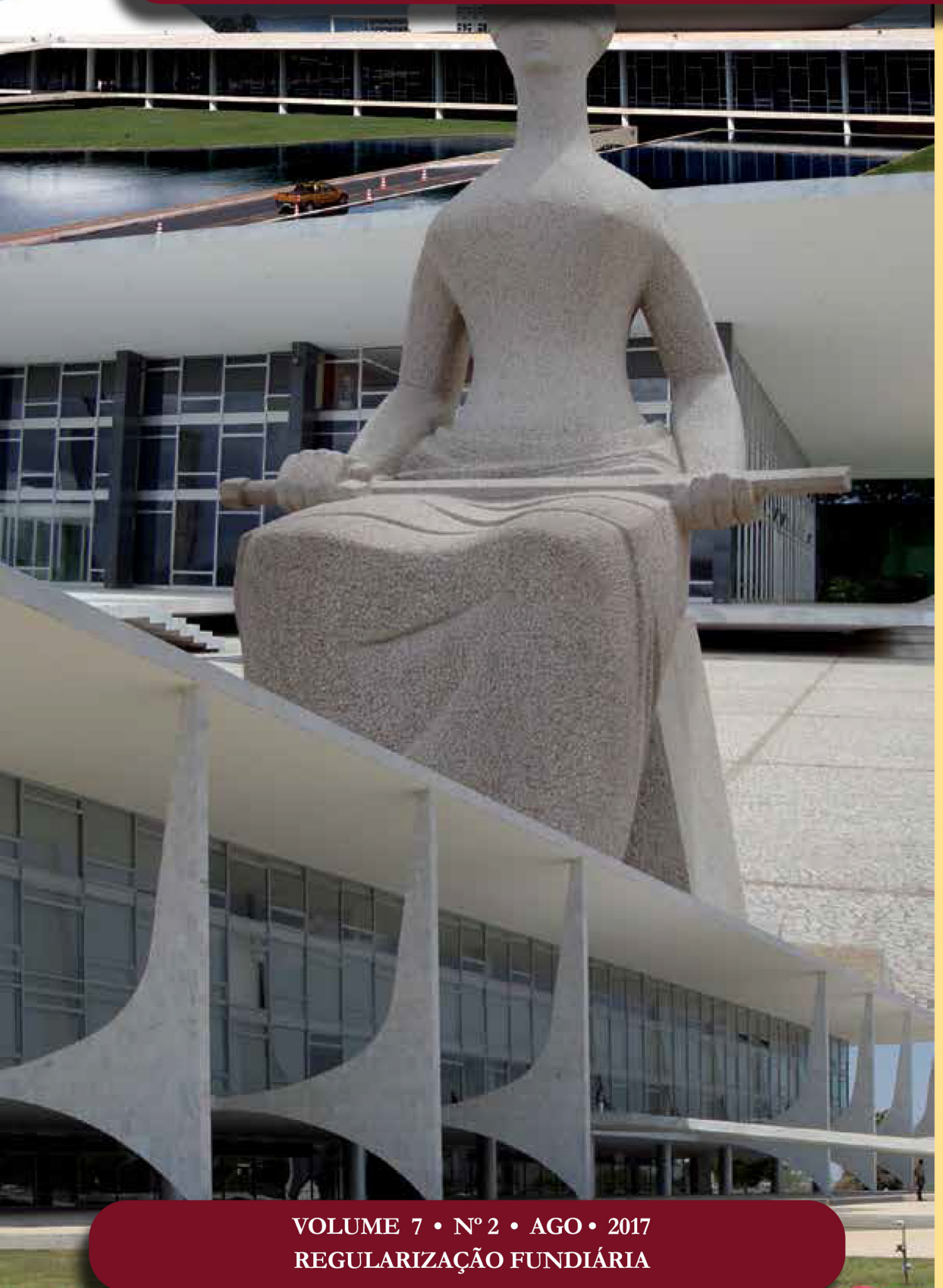

A intervenção direta e indireta na atividade econômica em face da ordem jurídica brasileira

The direct and indirect

intervention in economic

activity in face of Brazilian laws

Antônio Francisco Frota Neves

Hector Valverde Santana 


\section{A intervenção direta e indireta na atividade econômica em face da ordem jurídica brasileira*}

\author{
The direct and indirect intervention in \\ economic activity in face of Brazilian laws
}

\author{
Antônio Francisco Frota Neves** \\ Hector Valverde Santana***
}

\section{Resumo}

Esse artigo tem como principal objetivo a compreensão dos instrumentos de intervenção do Estado na ordem econômica, sopesando as causas e as consequências da utilização desses mecanismos para o atingimento dos objetivos e fundamentos da República, avaliando o comportamento a reação do mercado quanto aos eventuais estímulos, positivos ou negativos, direcionados à iniciativa privada para colocarem em risco seus capitais nas atividades produtivas. Utilizou-se para tanto, de uma análise dogmática e bibliográfica com recorte ao sistema jurídico brasileiro, sob a égide da Constituição Federal de 1988, e por fim, chegou-se às considerações finais de que a medida dessa intervenção requer uma maturação política de toda a sociedade para definir que modelo econômico veste as necessidades institucionais e culturais do povo brasileiro.

Palavras-Chave: Intervenção econômica. Estado regulador. Interesse coletivo. Segurança nacional.

\section{Abstract}

This article aims to understand the state intervention instruments in economic, measuring the causes and consequences of using these mechanisms to achieve the objectives and foundations of the Republic, assessing the behavior the market reaction as to any stimuli, positive or negative, targeted to the private sector to put at risk their capital in productive activities. It using for this purpose, of a dogmatic and literature review to cut the Brazilian legal system, under the aegis of the Federal Constitution of 1988, and finally came to the final remarks that the measure of this intervention requires political maturity of all society to define what economic model wears the institutional and cultural needs of the Brazilian people.

Keywords: Economic intervention. Regulatory state. Collective interest. National security.
*** Doutor e Mestre em Direito pela PUCMestrado e Graduação, nas áreas de Teoria Geral do Direito, Direito do Consumidor e Responsabilidade Civil; Magistrado de 2. Grau TJDFT. Email: hectorvsantana@gmail.com 


\section{INTRODUÇÃO}

O presente artigo tem como objetivo analisar os aspectos proclamados pela ordem econômica estatuída na Constituição Federal, como orientadora de um sistema especial de regulação e intervenção na economia, cujo primado especial é a criação de condições estáveis e indutoras à realização dos fins do Estado. Procurou-se, por meio de uma pesquisa bibliográfica e análise jurídico-dogmática do texto constitucional e da legislação pertinente, extrair os pontos essenciais da intervenção do Estado na ordem econômica.

Sob a ótica do Direito, os instrumentos postos à disposição do Estado para atuar na ordem econômica, seja na qualidade de intervenção direta ou indireta, dirigindo ou induzindo os agentes econômicos para o caminho traçado como objetivo e fundamento da república, tanto podem ser benéficos, na medida em que suas dosagens forem compatíveis com as expectativas dos investidores, como podem produzir resultados indesejáveis quando tais intervenções gerarem desestímulos àqueles que disponham de capitais e sejam desencorajados a assumirem riscos acima do aceitável institucionalmente.

Não se pode olvidar que os grupos de pressão são fortes atores nesse processo de intervenção do Estado. Ocorre, porém, que tais grupos perseguem interesses corporativos, das categorias que representam, portanto, nem sempre saudáveis ao ambiente da regulação geral. Cabendo ao Estado, segundo o modelo político adotado pela Constituição Federal, atuar no sentido de, intervindo na ordem econômica, atingir os objetivos reclamados constitucionalmente, notadamente, os de reduzir as desigualdades sociais e erradicar a miséria pelo desenvolvimento econômico e social.

\section{A INTERVENÇÃo DiRETA NA ECONOMIA}

Diz-se que o Estado está intervindo, diretamente, na economia quando não sendo o titular natural daquela atividade econômica passa a explorá-la, na forma da Constituição Federal, em seu artigo 173, caput - "[...] a exploração direta de atividade econômica pelo Estado só será permitida quando necessária aos imperativos da segurança nacional ou a relevante interesse coletivo, conforme definidos em lei”.

Intervir, diretamente, na economia, para o Estado é medida excepcionalíssima. A atividade econômica é própria dos particulares, não por outro motivo pois estes sabem fazê-lo bem melhor que o Estado, pois são mais ágeis, mais focados, estão mais propícios aos riscos a fim de obterem mais ganhos ao mesmo tempo que submetidos ao insucesso venham a arcar com tais ônus.

O Estado possui uma série de restrições para atendimento ao princípio da legalidade, enquanto o particular, possui um amparo especial na Constituição Federal, em seu art. 5\%, inciso II - "ninguém é obrigado a fazer ou deixar de fazer senão em virtude de lei”. Esse quesito, apenas, traz amarras ao Estado que o deixaria muito a desejar quanto à eficiência, enquanto o particular teria um maior grau de mobilidade em suas ações. ${ }^{1}$

No Estado Democrático de Direito, previsto na Constituição Federal, consignado, desde logo, no artigo $1^{\circ}$, inciso IV, fica evidente que o fundamento da República baseia-se no valor social do trabalho e da livre iniciativa. Trata-se de um direcionamento do modelo econômico adotado - um Estado social democrático, em que, apesar da previsão de livre concorrência, esta encontra-se, largamente, relativizada pela extrema regulação estatal, ainda que a intervenção do Estado aplica-se tão somente de forma subsidiária, ou melhor, quando for imprescindível a atuação do Estado para suprir o desinteresse dos particulares, atendendo-se assim o interesse coletivo ou ainda quando imperiosa tal atuação por questões de segurança nacional. ${ }^{2}$

1 Cf. GRAU, Eros Roberto. Comentários ao artigo 173. In: CANOTILHO, J. J. Gomes et al. (Coord.). Comentários à Constituição do Brasil. São Paulo: Saraiva; Almedina, 2013. p. 1823-1832.

2 Cf. FERRAZ JÚNIOR, Tércio Sampaio. Intervenção do estado no domínio econômico. In: CLÈVE, Clemerson Merlin; BARROSO, Luis Roberto. (Org.). Direito constitucional: constituição financeira, econômica e social. São Paulo: Revista dos Tribunais, 
A simples análise desses dois substratos fáticos, necessários à intervenção do Estado no domínio econômico, tanto os imperativos da segurança nacional quanto o relevante interesse coletivo, têm um grande grau de abstratividade, ou seja, são conceitos bastante indetermináveis, carecendo ao aplicador da lei, uma detida análise do caso concreto. Portanto, ver-se-á adiante, com olhar mais minucioso, os casos mais afetos a tais situações no mundo do ser. ${ }^{3}$

\subsection{Imperativos da segurança nacional}

O primeiro critério autorizador à intervenção do Estado no domínio econômico são os imperativos da segurança nacional. São as hipóteses mais fortemente ligadas à soberania nacional, situações estratégicas em que, nas mãos da iniciativa privada, poderia deixar o País em vulnerabilidade.

A Constituição Federal elaborada sob forte influência da rejeição ao regime militar instalado no País até 15 de março de 1985, quando se iniciou o período de redemocratização marginalizou o termo segurança nacional, como repulsa ao Estado de exceção vivenciado até então.

Em relação à Lei n. 7.170/1983 que define os crimes contra a segurança nacional, a ordem política e social, é possível isolar, apenas, as lesões ou exposição a perigo contra a segurança nacional, extraindo-se do artigo $1^{\circ}$ tão somente os incisos I e III, conquanto o inciso II trataria dos crimes contra a ordem política e social. Assim, é possível formar o conceito de segurança nacional com base em uma proteção à integridade do território e da soberania nacional, bem como a proteção contra lesão ou exposição a perigo contra a pessoa dos chefes dos Poderes da União.

Enquanto a Lei n. 6.620/1978 (revogada pela Lei n. 7.170/1983) trazia um conceito expresso, mas muito abstrato e abrangente de segurança nacional - , em seu artigo $2^{\circ}$ expressava: "é o estado de garantia proporcionado à nação, para a consecução dos seus objetivos nacionais, dentro da ordem jurídica vigente". E, no parágrafo único daquele artigo, definia os objetivos nacionais como sendo —, soberania nacional, integridade territorial, regime representativo e democrático, paz social, prosperidade nacional e harmonia internacional.

Nesse contexto, não resta muita aplicabilidade ao termo segurança nacional inserida na Constituição Federal ao tratar da ordem econômica, necessária à intervenção do Estado, de forma direta, no domínio econômico, exceto se a leitura for conjugada com o disposto no artigo 21, em que lista as atividades de que o próprio Estado disciplina como sendo de sua própria titularidade.

Portanto, em relação a algumas dessas atividades, o constituinte de 1988 reservou exclusividade ao Estado, que as denominou de exercício do monopólio, conforme consignado, expressamente, os termos do artigo 177, em especial as pesquisas e a lavra das jazidas de petróleo e gás natural; o refino do petróleo, tanto o nacional como o estrangeiro e ainda; a importação e exportação dos produtos e derivados básicos resultantes dessas atividades.

Se a intervenção do Estado no domínio econômico já é uma medida excepcional, quando utilizar o fundamento da segurança nacional, deverá restringir-se, fielmente, aos casos já autorizados pela própria Constituição, não tendo o termo segurança nacional a mesma abrangência quando vigorava a Constituição Federal de 1967, com os termos dado pela Emenda Constitucional 01, de 1969.

\subsection{Relevante interesse coletivo}

Não tanto quanto a segurança nacional, a semântica empregada pelo constituinte quanto ao termo relevante interesse coletivo - , é por demais abrangente. Como se trata de ação subsidiária, fora os casos

2011.p. 796-797.

3 MUKAI, Toshio. A administração pública na constituição de 1988. São Paulo: Saraiva, 1989. p. 130. 
previstos na própria Constituição Federal em relação à titularidade das atividades que o Estado as exercerá, ou seja, atividades próprias dos agentes privados, o Estado atuará após o devido sopesamento por parte do Poder Legislativo que definirá, em certa medida, a ocorrência ou não do interesse coletivo, especialmente, nos casos em que não houver interesse do particular ou mesmo havendo esse interesse, não seja o suficiente para o atendimento da demanda coletiva. ${ }^{4}$

A Constituição Federal, tanto em relação à segurança nacional quanto ao interesse coletivo, na parte final do artigo 173, expressa que a atuação do Estado no domínio econômico ocorrerá, naqueles casos, conforme definidos em lei. Não paira dúvida quanto à segurança nacional porque legislar sobre defesa nacional é competência privativa da União, conforme artigo 22, inciso XXVIII, porque interesse coletivo não é de caráter absoluto, nem sempre o interesse coletivo preponderará sobre o interesse individual, não basta uma simples decisão administrativa, é necessário ter processo legislativo para identificar "um relevante interesse coletivo" e autorizar, nesse caso particular, a intervenção do Estado na ordem econômica. ${ }^{5}$

\section{INSTRUMENTOS DE EXPLORAÇÃO DA ATIVIDADE ECONÔMICA}

A atuação direta do Estado na atividade econômica, concorrendo ou não com os agentes privados, dar-se-á por espécies de sociedades empresárias, como (i) por meio de empresa pública, que poderá adotar qualquer das formas societárias, admitidas em direito ${ }^{6}$ ou (ii) por sociedade de economia mista, que, necessariamente, se constituirá na forma de sociedade anônima.

A Emenda Constituição 19/1998 alterou o texto constitucional original do artigo $173, \mathbb{\$} 1^{\circ}$, para estabelecer a criação de um estatuto jurídico para as empresas públicas e sociedades de economia mista, bem como para suas respectivas subsidiárias, especialmente dispondo sobre (i) sua função social e formas de fiscalização; (ii) sujeição ao regime jurídico próprio das empresas privadas; (iii) processo licitatório e contratação obedecendo os princípios da administração pública; (iv) criação e funcionamento dos conselhos de administração e fiscal, reservando participação aos acionistas minoritários e; (v) os mandatos, avaliação de desempenho e a responsabilidade dos administradores.

Há de ressaltar que o Estado, ao decidir imiscuir-se na atividade econômica, renunciará ao seu poder de império para igualar-se ao particular, não possuindo nenhum privilégio quanto aos direitos e obrigações civis, comerciais, trabalhistas e tributárias nem tampouco a eventuais ônus que não sejam próprios da atividade privada. E ratifica o artigo 173, $\int 2^{\circ}$ da Constituição Federal, que as empresas públicas e sociedades de economia mista não poderão gozar de nenhum privilégio que não sejam extensivos às demais empresas privadas. Ou seja, o Estado, nessa condição estará em absoluta igualdade concorrencial aos agentes da iniciativa privada.

Embora, esse direcionamento constitucional, seja no sentido de aproximar o máximo possível, as empresas públicas e sociedades de economia mista, com as empresas próprias da iniciativa privada, ainda assim, não se pode interpretar a Constituição em tiras, pois a observância dos princípios estatuídos no caput do artigo 37, da Constituição Federal, são plenamente válidos e aplicáveis a essas espécies societárias, quanto à legalidade, moralidade, impessoalidade, publicidade e eficiência, o que, aparentemente, deixarão tais empresas em posição de equilíbrio em relação aos particulares. ${ }^{7}$

4 Cf. PETTER, Lafayete Josué. Direito econômico. 7. ed. Porto Alegre: Verbo Jurídico, 2014. p. 124-125.

5 GRAU, Eros Roberto. A ordem econômica na constituição de 1988. 17. ed. São Paulo: Malheiros, 2015. p. 280.

6 Decreto-Lei 200, art. 5‥, [...], considera-se: II - Empresa Pública - a entidade dotada de personalidade jurídica de direito privado, com patrimônio próprio e capital exclusivo da União, criado por lei para a exploração de atividade econômica que o Governo seja levado a exercer por força de contingência ou de conveniência administrativa podendo revestir-se de qualquer das formas admitidas em direito.

7 Cf. GRAU, Eros Roberto. Comentários ao artigo 173. In: CANOTILHO, J. J. Gomes et al. (Coord.). Comentários à Constituição 
Desde 1998, o legislador infraconstitucional permanece inerte na elaboração do referido diploma legal, permanecendo tudo como dantes, aplicando-se os instrumentos próprios da administração pública em geral, trazendo amarras à gestão dessas empresas, inclusive, colocando-as em situação de desigualdade com os agentes privados, quanto à mobilidade de suas decisões e investimentos.

Assim, tanto para a instituição de empresa pública ou sociedade de economia mista a Constituição Federal, no artigo 37, inciso XIX, exige que seja autorizada por lei específica ao Chefe do Poder Executivo que emitirá Decreto dispondo sobre o estatuto constitutivo, após a referida autorização legislativa. A criação de fato e de direito somente ocorrerá após o respectivo registro e arquivamento do Estatuto, na Junta Comercial ou Cartório de Registro de Pessoas Jurídicas, conforme for a espécie societária, pois a efetiva criação de uma pessoa jurídica de direito privado ocorre, somente, após o deferimento do registro e arquivamento dos atos constitutivos (estatuto).

A propósito, a própria Lei n. 11.101/2005, em seu artigo 2o , traz cristalino: "Esta Lei não se aplica a: I - empresa pública e sociedade de economia mista". Se não podem ser submetidas a processos de recuperação judicial ou falimentares, não poderão ser extintas por iniciativas de eventuais credores, pois o interesse público é prevalente e somente o ente federativo que a criou poderá extingui-la.

\subsection{Intervenção mediante empresa pública}

A empresa pública é uma das formas que o Estado poderá atuar na atividade econômica, tanto para executar atividades próprias do Estado, portanto, exclusivas, ou serviços públicos essenciais, como atuar em atividades de titularidade dos particulares. Essa opção, normalmente, levará em consideração a disponibilidade de capital para investimento por parte do próprio Estado, sem auxílio da iniciativa privada, ou porque a esta não interesse, ou porque o Estado avalie como estratégico.

Em relação à análise do Decreto-Lei n. 200/1967 e o conteúdo constitucional previsto no artigo 173, é possível elaborar-se um conceito de empresa pública cujo formato exige uma autorização de lei que servirá como instrumento de ação do Estado, sob as regras de direito privado, contudo submetida a condições e circunstâncias especiais com objetivos e interesse público, podendo tomar a forma de quaisquer espécies de sociedades admitidas em direito, entretanto, o capital, necessariamente, será composto em sua totalidade de recursos públicos, cuja finalidade seja prestar serviços públicos ou explorar atividade econômica. ${ }^{8}$

Eventualmente, poderá a empresa pública tomar a forma de sociedade anônima, considerando que a obrigatoriedade de 100\% (cem por cento) do capital público, não impede que se desdobre em mais de uma pessoa jurídica de direito público. Assim, poderá ser formada uma empresa pública com participações da União, de um ou mais Estados da federação e ainda com um ou mais Municípios, todos unidos em sociedade anônima, não importa. Essa organização societária será traçada pelo legislador que o fará na melhor forma de atender os interesses públicos ou da própria segurança pública. ${ }^{9}$

A atuação da empresa pública para prestação de serviços públicos, inerentes ao Estado quando atua para a geração do bem-estar da coletividade não interessa à presente pesquisa, uma vez que, nesses casos, não gera uma concorrência direta com os agentes da iniciativa privada. Contudo, a empresa pública intervindo no domínio econômico em atividade própria das pessoas jurídicas de direito privado, deverá fazê-lo aproximando-se o máximo possível de todas as variáveis a que são submetidas aquelas empresas privadas.

Um dos fundamentos, pelo menos em tese, para o Estado intervir diretamente na atividade econômica, por meio de empresas públicas é a capacidade de mobilidade gerencial que teriam, considerando-se que a

do Brasil. São Paulo: Saraiva; Almedina, 2013. p. 1827-1828.

8 Cf. MARINELA, Fernanda. Direito administrativo. São Paulo: Saraiva, 2016. p. 245.

9 Cf. JUSTEN FILHO, Marçal. Curso de direito administrativo. 10. ed. São Paulo: Revista dos Tribunais, 2014. p. 453. 
administração direta, por seus órgãos, ou até mesmo a indireta, por suas autarquias ou fundações, seria o regime de emprego, ou relação obrigacional, entre o empregador e o empregado. As relações de trabalho na iniciativa privada são reguladas pela Consolidação das Leis Trabalhistas - CLT, enquanto os da administração pública direta, autárquica ou fundacional é o estatutário. O que a princípio o processo de dispensa no regime celetista seria muito mais rápido, mais célere, enquanto no regime estatutário, o processo administrativo disciplinar é complexo e duradouro, trazendo dispêndio de energia bem além daquele celetista.

São exemplos de empresas públicas federais - , A Caixa Econômica Federal - CEF; a Empresa Brasileira de Comunicações - EBC; a Empresa Brasileira de Serviços Hospitalares - EBSERH; Empresa Brasileira de Correios e Telégrafos - ECT. Essas empresas são vinculadas, hierarquicamente, a algum Ministério, exceto a EBC que é vinculada diretamente à Presidência da República. Tanto os Estados como os Municípios, também, podem criar empresas públicas, o que deverá ser feito mediante lei autorizativa do Poder Legislativo da respectiva unidade federativa.

O Estado pode e tem se valido da instituição de empresas públicas para descentralizar a concreção de políticas públicas (atuando em atividades econômicas ou prestando serviços públicos), ganhando em agilidade e celeridade em questões que, se fossem exercidas diretamente por seus órgãos, autarquias ou fundações públicas, teria um grau maior de obstáculos que são próprios da administração pública direta, o que vai desde a simples criação de um cargo até questões mais complexas de gestão.

\subsection{Intervenção mediante sociedade de economia mista}

A exemplo da empresa pública, a sociedade de economia mista, somente, poderá ser criada por lei que autorize o Poder Executivo a instituí-la. Essa espécie de sociedade empresária, necessariamente, deverá ser constituída sob a forma de sociedade anônima, conforme determina o artigo $5^{\circ}$., inciso III, do Decreto-Lei $200 / 1967^{10}$.

Pode-se extrair da própria lei que, (i) será regida pelos regimes que regram as pessoas jurídicas de direito privado, deverão atuar na exploração de atividade econômica, obedecerá aos ditames da Lei 6.404/1976 (Lei das S.A.), não é preciso ter mais de 50\% do capital social, se este for dividido em ações ordinárias nominativas e ações ordinárias preferenciais, bastando que tenha a maioria das ações com direito a voto, que, eventualmente, poderá representar bem menos do que $50 \%$ do capital total.

O nível de fiscalização pelo mercado sobre as sociedades de economia mista é muito maior, notadamente, se estas operarem em bolsa de valores, pois estarão submetidas às mais rígidas regras da Comissão de Valores Mobiliários - CVM e outras entidades de auditoria independentes.

E é exatamente por conta desse maior controle do mercado sobre as operações de uma empresa submetidas aos preceitos das sociedades anônimas que podem alavancar seus negócios mediante captação de recursos junto aos particulares por meio de IPO's - Initial Public Offering ou também denominados de Oferta Pública de Ações - OPA, em que a empresa Petróleo Brasileiro S.A. - PETROBRÁS e Banco do Brasil S.A. - BB, fizeram, ao final do governo Fernando Henrique Cardozo e durante o governo Luis Inácio Lula da Silva, ocasião em que os trabalhadores puderam usar parte dos recursos do Fundo de Garantia do Tempo de Serviço - FGTS, para aquisição de ações daquelas empresas.

O Estado poderá e deverá fazer uso dessa forma de intervenção na economia, quando os particulares não tiverem interesse ou em função dos elevados custos de investimento inicial, aliados a riscos relevantes do negócio reduzam interesse dos agentes econômicos. Portanto, essa é a forma por excelência de interven-

10 Art. $5^{\circ}$., Para os fins desta lei, considera-se: [...] III - Sociedade de Economia Mista - a entidade dotada de personalidade jurídica de direito privado, criada por lei para a exploração de atividade econômica, sob a forma de sociedade anônima, cujas ações com direito a voto pertençam em sua maioria à União ou a entidade da Administração Indireta. 
ção direta do Estado na ordem econômica, ou seja, quando diretamente produz bens ou produtos, como é o caso da PETROBRÁS ou caso presta serviço econômico de relevante interesse coletivo, em especial, em lugares onde a iniciativa privada não veja como lucrativo, como é o caso do BB.

\section{A INTERVEnÇÃo INDiReta NA ECONOMia}

$\mathrm{Na}$ história da economia, partindo de Adam Smith, ${ }^{11}$ passando por Karl Marx, ${ }^{12}$ por John Keynes, ${ }^{13}$ Von Mises, ${ }^{14}$ Friedrich Hayek, ${ }^{15}$ Milton Friedman, ${ }^{16}$ Celso Furtado, ${ }^{17}$ Douglas North, ${ }^{18}$ nenhum deles consegue ou tenta justificar a ausência absoluta do Estado no domínio econômico. O que de fato se discute é, tão somente, o quantum do Estado pode e deve estar presente na economia. A discussão paira em torno da medida, do tamanho, do quanto Estado. São muitas as variáveis que interferem nessa decisão - , povo, cultura, geografia, história, instituições, moral, ética, recursos naturais, necessidade de poder de intimidação, soberania e outras infindáveis variáveis tangíveis e intangíveis.

Não existem modelos ou figurinos prontos e acabados que possam ser copiados e aplicados com sucesso em nenhum lugar do mundo. Os povos são diferentes, as culturas são diferentes, os medos são diferentes. O mundo do dever-ser opera em dimensão diferente do mundo do ser, do real, do que se vive no dia a dia. Entre determinar —, reduzir as desigualdades sociais —, e fazer no mundo real que essa redução se opere, há uma distância incalculável, são variáveis algorítmicas, desejáveis, mas fora de alcance dos que pensam tratar-se de um caminho curto, fácil e rápido.

Exige-se bases sólidas, de autoestima elevada, sentimento de nação, de desprendimentos egoísticos, espírito de solidariedade, de fraternidade, de tolerância, construção de instituições fortes e éticas, que possam suportar a dinâmica da vida social conturbada no império do consumismo desenfreado, modismo invejoso, da ostentação por ostentação.

Combinar todos esses insumos, na medida de quantidade e qualidade, sopesando, ainda, aspectos externos indomáveis, influxos de todas as espécies, humor dos mais inescrupulosos especuladores internacionais de capitais voláteis, que estão à espreita dos maiores ganhos possíveis para atender todos os tipos de interesses e vaidades. Esse é o mundo real, o mundo do ser. Encontrar e esperar soluções criativas, exclusivamente do mundo do dever-ser é deitar em berço esplêndido esperando o fracasso continuar e permanecer formando fila no subdesenvolvimento, ou no vocábulo menos pejorativo "em desenvolvimento".

Sob o ponto da Constituição Federal, o primeiro mandamento interventivo do Estado na economia encontra-se no art. $1^{\circ}$, observando que a República Federativa do Brasil se constitui num Estado Democrático de Direito e dentre os seus fundamentos se destaca os valores sociais do trabalho e da livre iniciativa. Logo em seguida, no art. $3^{\circ}$, ao traçar os objetivos fundamentais da República, garante o desenvolvimento nacional de forma a erradicar a pobreza e a marginalização para que isso possa reduzir as desigualdades sociais e regionais.

Dos princípios fundamentais traçados no Título da Constituição Federal, levantados anteriormente, como se não bastasse, podendo-se pensar até mesmo em redundância, o legislador constituinte foi mais

11 SMITH, Adams. A riqueza das nações. São Paulo: Nova Cultural, 1995.

12 MARX, Karl. O capital: crítica da economia política. Tradução de Edgard Malagodi. São Paulo: Nova Cultural, 2000.

13 KEYNES, John Maynard. A teoria geral do emprego, do juro e do dinheiro. Trad. de Augusto Sousa. Rio de Janeiro: Fundo Cultural, 1970.

14 MISES, Ludwig von. Liberalismo. Rio de Janeiro: J. Olympio, 1987.

15 HAYEK, Friedrich A. Fundamentos da liberdade. Tradução de Anna Maria Capovilla e José Ítalo Stelle. São Paulo: Visão, 1983.

16 FRIEDMAN, Milton. Capitalismo e liberdade. Tradução de Afonso Celso da Cunha Serra. Rio de Janeiro: LTC, 2014.

17 FURTADO, Celso. Teoria e política do desenvolvimento econômico. 10. ed. São Paulo: Paz e Terra, 2000.

18 NORTH, Douglas. Instituições, mudanças institucionais e desenvolvimento econômico. Cambridge: University Cambridge Press, 1990. 
específico no caput do artigo 174, in verbis: "como agente normativo e regulador da atividade econômica, o Estado exercerá, na forma da lei, as funções de fiscalização, incentivo e planejamento [...]". Quis o constituinte, que o modelo de Estado capitalista brasileiro, será submetido à norma e à regulação. Para isso, deverá esse mesmo Estado fiscalizar, incentivar e planejar as atividades econômicas para cumprir os objetivos da República de garantir o desenvolvimento e erradicar a pobreza e a marginalização. ${ }^{19}$

\subsection{O Estado como agente regulador}

O Estado brasileiro assumiu feições mais contundente de intervenção por regulação na atividade econômica, a partir do processo neoliberalizante ocorrido na segunda metade da década de 1990, em que ocorreram as grandes privatizações. Ocorreu uma drástica redução do tamanho do Estado. Foram privatizadas as empresas de telefonia, as empresas siderúrgicas, sistema bancário estadual, parte de rodovias federais, ferrovias federais, dentre tantas outras.

Com esse relevante fato econômico, gerou-se a necessidade de um sistema de regulação até então inexistente, como a criação de agências nacionais de regulação - Agência Nacional do Petróleo - ANP; Agência Nacional de Águas - ANA; Agência Nacional de Energia Elétrica - ANEEL; Agência Nacional de Telecomunicações - ANATEL; Agência Nacional de Vigilância Sanitária - ANVISA; Agência Nacional de Transportes Terrestres - ANTT'; Agência Nacional de Transportes Aquáticos - ANTAQ; Agência Nacional de Aviação Civil - ANAC; e muitas outras. Tal fenômeno, também, ocorreu no âmbito dos demais entes federativos, notadamente, nos estados.

A intervenção do Estado no domínio econômico como agente normativo e regulador pode ser feita sob duas formas: por (i) direção que por meio de comandos imperativos, denotam compulsoriedade, coações, determinando objetivamente qual caminho deve seguir uma ou outra atividade econômica; ou por (ii) por indução, quando cria estímulos positivos ou negativos para o particular, facultativamente, seguir para um ou outro ponto, segundo suas próprias necessidades ou estratégias negociais. ${ }^{20}$

A intercambialidade de informações é a própria alma da liberdade. A compreensão de ser livre só é perceptível se houver informações suficientes para compor a manifestação da vontade. E o avanço nas telecomunicações gerou um imenso ganho qualitativo de informações, um dos fundamentos previstos no espírito da Lei n. 9.472/1997.

Quanto ao mundo do ser, ocorrência fática nas combinações escusas ou não sobre o objeto das privatizações não é foco da presente pesquisa, portanto, eventuais desvios de conduta dos agentes públicos no trato dos negócios do Estado, por si só, não invalidam os instrumentos adotados para que a intervenção do Estado na ordem econômica se transfira do modelo denominado participação para o de direção. Nesse contexto, Eros Grau foi bastante crítico e cético quanto à política neoliberal do governo Cardozo, alegando que o controle estatal por direção é tão ou mais complexo que o controle fiscalizatório do modelo de intervenção por participação. ${ }^{21}$

Parece exagero, pois uma das variáveis mais complexa em qualquer atividade, passa, necessariamente, pela gestão de pessoas e aquisição de insumos, levando-se em conta o controle de qualidade desses insumos, sendo que pelas próprias características do modelo de Estado adotado pela Constituição Federal, sabe-se que as infindáveis exigências burocráticas legais impedem a eficiência desses processos comparativamente com os mesmos, quando desenvolvidos sob a égide da iniciativa privada.

Ponto de extrema relevância para o sucesso do modelo regulador, ou seja, a efetiva operacionalização

19 Cf. ARAGÃO, Alexandre Santos de. Comentários ao artigo 174. In: CANOTILHO, J. J. Gomes et al. (Coord.). Comentários à Constituição do Brasil. São Paulo: Saraiva; Almedina, 2013. p. 1833-1836.

20 Cf. PIMENTA, Paulo Roberto Lyrio. Contribuições de intervenção no domínio econômico. São Paulo: Dialética, 2002. p. 41.

21 Cf. GRAU, Eros Roberto. A ordem econômica na constituição de 1988. 17. ed. São Paulo: Malheiros Editores, 2015. p. 143. 
das agências reguladoras, é sua autonomia, esta entendida em sua forma mais ampla possível, que sofra o mínimo de influxos gerenciais de políticos, interesses corporativos internos ou externos. Entretanto, um dos grandes problemas da regulação, segundo a Teoria Econômica da Regulação é o fenômeno da captura. ${ }^{22}$

A regulação é exigência constitucional para minimizar os efeitos das falhas de mercado, contudo, grupos de interesses passam a assediar agentes dos órgãos reguladores, cooptando-os aos seus interesses ou ideologias, gerando como consequência inequívoca, as chamadas falhas de governo. No mundo inteiro é fenômeno ocorrente, mas, no Brasil, em função da estrutura política de partição de cargos públicos, a vulnerabilidade a esses fenômenos tem uma grandeza superlativa.

Apesar de receber, veementes, críticas de alguns economistas, é possível com apurada análise econométrica proceder a mensuração de índice de captura de agentes reguladores. A regulação desenvolve, naturalmente, laços mutuamente recíprocos entre agentes de regulação e o próprio grupo de interesses do mercado. Essas relações interativas são naturais, necessárias e saudáveis para o sistema regulatório. Não se pode imaginar que os intercambiadores de complexo sistema de regulação vivam de forma isolados em uma redoma intocável. ${ }^{23}$

\subsection{O Estado como agente regulador por indução}

O Estado em sua função interventiva indutora do equilíbrio econômico ou para o desenvolvimento como finalidade precípua de erradicar a pobreza e eliminar a marginalização utiliza-se de instrumentos jurídicos e econômicos que geram estímulos aos agentes econômicos a tomarem posições mais benéficas aos seus negócios. Nesse caso, estará, também, agindo na regulação da atividade econômica, de maneira diferente em relação quando o faz por direção, impondo sob pressão, os agentes econômicos, enquanto agir por indução criará mecanismos alternativos à escolha do particular para tal.

Os principais mecanismos de indução são denominados de incentivos ou benefícios que, em regra, têm natureza fiscal, ou apresentados sob a forma de benefícios outros, capazes de estimular determinada atividade econômica. São exemplos comuns desses mecanismos indutores de comportamentos empresariais: financiamentos com taxas mais favorecidas, seguro agrícola subsidiado, fornecimento gratuito de determinadas sementes que induzam os pequenos agricultores a cultivarem com o propósito de manter a segurança alimentar equilibrada e tantas outras formas de estímulos que, facultativamente, poderão ser usados ou não por aqueles que foram endereçados.

Outro forte instrumento de intervenção regulatória por indução na economia foi a edição da Lei n. 13.189/2015, criando o Programa de Proteção ao Emprego - PPE, cujos objetivos destacam-se: (i) possibilitar a preservação dos empregos em momentos de retração da atividade econômica; (ii) favorecer a recuperação econômico-financeira das empresas; (iii) sustentar a demanda agregada durante momentos de adversidade, para facilitar a recuperação da economia; que estabeleceu conforme e; (iv) estimular a produtividade do trabalho pela permanência do vínculo laboral. Com a drástica redução da atividade econômica no ano de 2015, o Estado, prontamente, decidiu por medidas que, ao menos, minimizasse os impactos no nível de desemprego crescente.

O mais comum das intervenções dessa espécie de intervenção é a utilização de instrumentos de natureza tributária, propiciando incentivos fiscais, modulando ou alavancando setores da economia geradores de grande mão de obra e simultaneamente manter o mercado de consumo aquecido para gerar um círculo virtuoso na economia. Isso ocorreu com muita ênfase no quadriênio 2010-2014, com a redução do Imposto sobre Produtos Industrializados - IPI, beneficiando um dos maiores setores da economia alocadores de mão de obra —, setor automobilístico.

22 Cf. FIANI, Ronaldo. Teoria da regulação econômica: estado atual e perspectivas futuras. Disponível em: < http://www.ie.ufrj.br/grc/ pdfs/teoria_da_regulacao_economica.pdf>. Acesso em: 20 jul. 2016.

23 Cf. HANCHER, Leigh; MORAN, Michael. Capitalism, culture and economic regulation. Oxford: Oxford University Press, 1989 . p. 52. 
Tem o Estado inúmeros instrumentos para induzir o agente econômico particular a trilhar pelos caminhos, cujo interesse corroborem com a política econômica governamental, seja por incentivos fiscais, reduzindo alíquotas de impostos, de contribuições sociais, seja até mesmo concedendo anistia, de forma que com isso mantenha o nível de atividade econômica a manter empregos e salários, cumprindo a missão importante da ordem econômica que se traduz na busca pelo pleno emprego.

\subsection{A planificação da atividade econômica no marco regulatório}

A previsão constitucional de que o Estado, na qualidade de agente normativo e regulador da atividade econômica, exercerá as funções de planejamento, entretanto, esse planejamento, obrigatoriamente, deverá ser observado pelo setor público e servir de orientação para o setor privado. ${ }^{24}$

Mais uma vez, destaque-se as diferenças entre o Direito e a Economia e outras ciências que, em alguma medida, interessam-se, cientificamente, pelo estudo do comportamento humano na sociedade. No Direito, o mundo do dever-ser é o império da lei, forma a viga central do determinismo científico-jurídico para estimular comportamentos que se adequem ao arcabouço legal. Porém, no mundo do ser, no realismo fático do cotidiano, a realização ou não do prescritivo-normativo esbarra em obstáculos de todas as naturezas, inclusive os traços culturais já decantados ao longo de décadas de repetição.

Nesse escopo, levante-se na cultura do povo brasileiro o imediatismo, o deixar para a última hora, a falta da cultura do planejamento. Um dos grandes males do País é a inadequada formação cultural do planejamento. Vive-se diuturnamente em todos os meios a cultura do "jeitinho" brasileiro, mundialmente conhecido. Assistiram-se dois grandes eventos mundiais realizados no Brasil, em 2014 (Copa Mundial de Futebol) e em 2016 (Jogos Olímpicos Mundiais), portanto, dois eventos que exigem um enorme planejamento de médio prazo (cerca de 8 anos). O resultado concreto confirmou essa triste realidade —, não se sabe planejar, seriamente, no Brasil. Inúmeras obras inacabadas, outras realizadas pela metade, outras sequer iniciadas. Prejuízos de monta elevadíssima.

Em 2016, desde que a Receita Federal do Brasil - RFB disponibilizou a entrega eletrônica da declaração anual de ajuste do Imposto de Renda, tem-se, com clareza, observado a cultura "de última hora" do brasileiro: abre-se um prazo de dois meses para a entrega da declaração e de um total estimado em 28 milhões de declarações, faltando, apenas, cinco dias para o término do prazo, mais da metade dos obrigados a fazê-las não as fizeram. Isso espraia-se por todo o corpo social nas mais diversas atividades humanas que necessitem de um planejamento a possibilitar redução de custos e execução satisfatória no prazo. Esse traço cultural da sistemática ausência de planejamento se reflete no dia-a-dia das organizações públicas e privadas, em toda a sociedade, formado ao longo de décadas.

Feitas essas observações iniciais, é bom que se diga, no âmbito empresarial privado, que o planejamento estratégico tem sido o divisor de águas entre a sobrevivência da atividade empresarial e sua falência. As incertezas e riscos sistêmicos, operacionais, legais, de mercado têm sido determinantes para a continuidade dos negócios privados. As pressões dos ambientes interno e externo têm moldado o processo decisório empresarial, cuja ferramenta essencial para as tomadas de decisões é o planejamento estratégico. ${ }^{25}$

A Refinaria Abreu e Lima, em 2005 quando anunciada sua construção, foi orçada em US\$2,4 bilhões e seria construída em consórcio internacional entre PETROBRÁS e PDVSA (empresa petrolífera estatal

24 Cf. Constituição Federal, art. 174. Como agente normativo e regulador da atividade econômica, o Estado exercerá, na forma da lei, as funções de fiscalização, incentivo e planejamento, sendo este determinante para o setor público e indicativo para o setor privado.

$\int 1^{\circ} \mathrm{A}$ lei estabelecerá as diretrizes e bases do planejamento do desenvolvimento nacional equilibrado, o qual incorporará e compatibilizará os planos nacionais e regionais de desenvolvimento.

$\int 2^{\circ}$ A lei apoiará e estimulará o cooperativismo e outras formas de associativismo.

25 Cf. DRUCKER, Peter F. Administrando em tempos de grandes mudanças. São Paulo: Pioneira, 1998. p. 21. 
venezuelana). Em setembro de 2007, após processo licitatório e conclusão de projetos básicos de execução, estipulou-se como prognóstico de conclusão das obras em 2010. Ocorre, porém, que em 2009, a própria PETROBRÁS verificou erros nos cálculos orçamentários iniciais e reorçou para US\$13,4 bilhões. A Ministra-Chefe da Casa Civil visitou o canteiro de obra e fora anunciada nova data de conclusão das obras (primeiro semestre de 2011). Até junho de 2016, a obra já consumira US\$17,8 bilhões, ainda remanescendo cerca de $20 \%$ de obra inacabada, com previsão de conclusão para 2019, com custo estimado final para US $\$$ 18,9 bilhões. $^{26}$

A evidência da ineficácia do planejamento na construção de tamanha obra espelha com uma magnitude, sem precedentes, a incompetência do sistema estratégico organizacional porque passa a atuação do Estado na atividade econômica. Mesmo retirados ou descontados os desvios criminosos (cuja análise foge a esta pesquisa), propositadamente perpetrados pela desqualificação do planejamento de tamanha obra, ainda assim, observa-se um atraso técnico sem medidas para uma previsão deslocar-se de um valor de US\$2,4 bilhões para US $\$ 18,9$ bilhões, desvio quantitativo de 788\%. E o cumprimento de um cronograma pular de cinco para 15 anos, um desvio de $200 \%$.

Noutro diapasão, apresenta-se uma cultura de planejamento sério, tecnicamente responsável, na construção de uma grande obra, com obstáculos técnicos e científicos muito mais elevados do que o caso brasileiro anteriormente relatado foi a construção do túnel construído sob o canal da Mancha que liga a França à Inglaterra, construído sob condições extremas de riscos, o túnel tem $51 \mathrm{~km}$ de extensão. Custou US\$ 6 bilhões e inaugurado em 1994, à época, foi considerada a obra mais cara do mundo, paga, inteiramente, com recursos privados, sua construção durou, apenas, sete anos, tudo exatamente como planejado, orçamento e cronograma. ${ }^{27}$

A comparação que se fez entre essas duas grandes obras, de um lado a refinaria de petróleo Abreu e Lima e de outro, o gigantesco Eurotúnel, retratam o amadorismo brasileiro em planejamento. Mesmo trazendo o dólar a valor presente (inflação americana estimada em 59\%), o Eurotúnel custaria em torno de US\$ 9,54 bilhões, metade do valor gasto na refinaria Abreu e Lima e ainda não concluída.

A Constituição Federal, em seu art. 174, ao determinar que o planejamento é determinante para o setor público e indicativo para o setor privado, significa dizer que ao setor púbico não caberá outra opção, terá, necessária e obrigatoriamente, que utilizar de todas as técnicas disponíveis para a consecução mais eficiente e eficaz possível de seus negócios, enquanto, para o setor privado, o indicativo redundará num cabedal de instrumentos e mecanismos do Estado para orientar e induzir o setor privado (seja por meio de estímulos, seja por meio de uma matriz curricular do ensino em todos seus níveis) a alocar recursos nessa direção, contribuindo de sua parte, notadamente, com as reduções de incertezas, inclusive jurídicas.

A atuação ou intervenção do Estado no domínio econômico, atendendo os requisitos e fundamentos constitucionais configura-se exercício regular de direito, conforme esposado na decisão exarada pelo Superior Tribunal de Justiça, no REsp 549.873-SC, julgado em 10.08.2004, Rel. Min. Luiz Fux em que explicita que "norma legal indicativa do exercício da intervenção no domínio econômico revela exercício regular de direito, mercê de não se inferir da norma jurídica qualquer atuar omissivo, posto inexistente o dever legal de manutenção da paridade, o qual, se existente, poderia conduzir à culpa in ommittendo".

Nessa decisão o Superior Tribunal de Justiça não vislumbrou a responsabilidade objetiva do Estado por sua intervenção na ordem econômica, conquanto tratar-se do exercício regular de um direito estabelecido constitucionalmente, pois compete sim, à União por meio do Banco Central do Brasil (BACEN), conforme

26 Cf. CARVALHO, Bianca. Refinaria Abreu e lima não está pronta após 8 anos de obras. Disponível em: <http://g1.globo.com/ pernambuco/noticia/2016/04/refinaria-abreu-e-lima-nao-esta-pronta-apos-mais-de-8-anos-de-obras.html>. Acesso em: 20 mar. 2017.

27 Cf. COMO foi construído o túnel sob o canal da mancha. Disponível em: <http://mundoestranho.abril.com.br/materia/ como-foi-contruido-o-tunel-sob-o-canal-da-mancha\#>. Acesso em: 20 mar. 2017. 
a Lei n. 4.595/1964, em seu art. $8^{\circ}$, intervir na política monetária (tarefa atribuída ao COPOM - Comitê de Política Monetária) e cambial, controlando o fluxo monetário, garantindo portanto, a estabilidade da economia nacional.

Porém, há sérias críticas, principalmente de parte dos economistas, quanto às ações do Estado a induzir o planejamento do setor privado, considerando que o Estado não é nenhum exemplo confiável de planejamento, conforme já demonstrado linhas atrás o que, diferentemente, no que se refere ao setor público, a Constituição especificou em seu art. 174, \$1 ${ }^{\circ}$ : "A lei estabelecerá as diretrizes e bases do planejamento do desenvolvimento nacional equilibrado, o qual incorporará e compatibilizará os planos nacionais e regionais de desenvolvimento".

Quanto ao planejamento do Estado, dito orçamentário, por força constitucional são definidos três planos diferentes: (i) Plano Plurianual - PPA; (ii) Lei de Diretrizes Orçamentária - LDO e; (iii) Lei Orçamentária Anual - LOA. Esses três planos estão consignados na CRFB/1988, em seu art. 165, incisos I, II e III. O direito posto atende aos pilares teóricos no sentido de alcançar os objetivos da República, entretanto, os instrumentos de aplicabilidade são deficientes, constatados escancaradamente pela descontinuidade dos governos sucessores daquilo que gestado naqueles que lhes antecederam, o que consagra a ineficácia quanto à exigibilidade e executoriedade da norma e baixíssima possibilidade de efetividade.

\section{A PRESTAÇÃo de SERVIÇOS PÚBLICOS POR TERCEIROS}

A prestação de serviços públicos incumbe ao Poder Público. Este é seu legítimo titular, assim determina a Carta Maior do Estado, em seu artigo 175, caput, ex vi: "Incumbe ao Poder Público [...], a prestação de serviços públicos".

Muito embora a Constituição Federal tenha definido alguns serviços ou atividades de titularidade exclusiva do Estado, ao mesmo tempo abriu oportunidade para que fossem desempenhadas por agentes particulares ou equivalentes, sob o regime de concessão ou permissão, observando-se sempre, que tais transferências se façam por um devido processo licitatório. E nesse particular, o que se discute nesta pesquisa é se a eficácia na prestação desses serviços se concretiza para o cumprimento dos objetivos da República, em especial, a proteção à dignidade da pessoa humana, à erradicação da miséria e da marginalidade, de modo a reduzir as desigualdades sociais e regionais, promovendo assim, o bem de todos.

Necessário se faz conceituar, com mais precisão, o que vem a ser efetivamente um serviço público. No mundo do ser, estampada pela realidade fática, o serviço público seria toda e qualquer prestação efetuada pela administração pública, dentro daquilo que o constituinte diz expressamente - incumbe ao poder público prestá-lo. Sob esse aspecto, todo o universo da administração pública estaria contemplado como serviço público. Nesse diapasão, o fato social em que envolve a prestação, de per si, não o emoldura como fato jurígeno, ou seja, a proposição jurídica tem como função precípua transformar as circunstâncias conforme pautas valorativas e, não simplesmente, reproduzir e perpetuar o já estabelecido no tempo e espaço. ${ }^{28}$

O serviço público estrito seria, somente, aquela atividade prestacional da administração pública, no âmbito do Poder Executivo, em que se "propicia algo necessário à vida coletiva". Portanto, todas aquelas atividades-meio desempenhadas no âmbito da administração pública não se caracterizam, tecnicamente, como serviço público (limpeza, vigilância, serviços de copa, recepção, telefonistas e outros). ${ }^{29}$

Em uma abordagem diferente em que se constrói um conceito bem mais abrangente que o anterior, abarcando mais características, tanto de essencialidade quanto de utilidade pública, ou interesse da coleti-

28 VILANOVA, Lourival. As estruturas lógicas e o sistema de direito positivo. 4. ed. São Paulo: Noeses, 2010. p. 78-79.

29 MEDAUAR, Odete. Direito administrativo moderno. 18. ed. São Paulo: Revista dos Tribunais, 2014. p. 360. 
vidade, em que define serviço público como qualquer atividade em que se oferte utilidade ou comodidade material exercitável por seus administrados diretamente, cujo prestador será o Estado ou por quem lhe represente, fazendo isso no regime de direito público. ${ }^{30}$

Portanto, numa acepção ampliada, serviço público estaria a englobar todas as atividades do Estado, até mesmo a atividade judiciária e administrativa. Nessa acepção dir-se-ia estar diante de funções que o Estado executa proporcionando comodidades e utilidades à comunidade, tanto em seu particular, individualizada ou de forma universalizada, para todos indistintamente. ${ }^{31}$

Com o grande crescimento populacional, a migração do homem do campo para a cidade, com os avanços tecnológicos em todas as áreas e atividades humanas, o Estado não se pode fazer presente na oferta de serviços públicos de todas as ordens. Em decorrência dessa impossibilidade concreta na prestação de serviços públicos, reconhecendo essa necessidade, a Constituição Federal, em seu artigo 175, caput, expressou-se —, "Incumbe ao Poder Público, na forma da lei, diretamente ou sob o regime de concessão ou permissão, sempre através de licitação, a prestação de serviços públicos".

No capítulo que trata da ordem econômica, a previsão de prestação de serviços públicos por terceiros far-se-á tão somente por meio dos regimes de concessão ou de permissão. Entretanto, quando o constituinte tratou da Organização do Estado, no Título III, da Constituição Federal, e em especial, no segundo capítulo, quando dispõe sobre a competência da União, previu uma outra espécie de delegação ao particular de serviços públicos ou fruição de bens públicos —, ex vi - artigo 21: 'Compete à União: [...]; XI - explorar, diretamente, ou mediante autorização, concessão ou permissão, os serviços de telecomunicações, nos termos da lei, que disporá sobre a organização dos serviços [...]". E logo em seguida no inciso XI1, repete a possibilidade de delegação aos particulares de serviços públicos, mediante autorização, in litters: —, "explorar, diretamente ou mediante autoriz̧ação, concessão ou permissão: [...]"

A Lei n. 8.987/1995 regulamenta o artigo 175, da Constituição Federal e a Lei n. 9.074/1995 complementa aquela, acrescentando-lhe a delegação por autorização, trazendo claramente um esclarecimento do porque esta não integrar os regimes de delegação previstos na ordem econômica. Traçam as principais características que se revestem o serviço público. Como ponto de suma importância a destacar é que o serviço público ofertado à coletividade deve ser adequado. O próprio legislador tratou de enumerar os principais requisitos que traduzem um serviço público adequado, como sendo aquele que satisfaz as condições de (i) regularidade; (ii) continuidade; (iii) eficiência; (iv) segurança; (v) atualidade; (vi) generalidade; (vii) cortesia na sua prestação e; (viii) modicidade na cobrança de tarifas.

O legislador infraconstitucional no âmbito da Lei n. 9.897/1995, em seu artigo $6^{\circ}$ traz esclarecimentos adicionais sobre (i) atualidade e (ii) continuidade, sendo que o primeiro compreende a modernidade das técnicas, do equipamento e das instalações e a sua conservação, bem como a melhoria e expansão do serviço; enquanto o segundo traz um conceito negativo informando que situação específica não se caracteriza como descontinuidade dos serviços públicos, quais sejam, sua interrupção em situação de emergência ou após prévio aviso, quando (a) motivada por razões de ordem técnica ou de segurança das instalações; e, (b) por inadimplemento do usuário, considerado o interesse da coletividade.

Adiante, será levantado um referencial bibliográfico acerca desses três regimes de delegação a terceiros para a prestação de serviços públicos.

30 MELLO, Celso Antônio Bandeira de. Curso de direito administrativo. 23. ed. São Paulo: Malheiros, 2006. p. 652.

31 MARQUES NETO, Floriano de Azevedo. Delimitação do conceito de serviço público. In: TRATADO de Direito Administrativo: Funções Administrativas do Estado. São Paulo: Revista dos Tribunais, 2014. p. 73. 


\subsection{A concessão de serviços públicos}

A concessão é a modalidade matriz de delegação dos serviços públicos aos agentes econômicos privados. Tal instituto vem estribado na Lei n. 8.987/1995, tendo sido inovada com o acréscimo do sistema de Parceria Público-Privada - PPP, criada pela Lei n. 11.079/2004.

O Estado deve se fazer presente na prestação dos serviços públicos necessários à boa convivência da sociedade como um todo. Mesmo diante de inúmeros instrumentos criados para o desempenho dessa difícil tarefa, ainda assim, o Estado tem encontrado seriíssimos obstáculos à consecução dos seus objetivos. E, em decorrência disso, mesmo para os serviços públicos de primeira ordem, foram criadas possibilidades de passar tais atividades para os agentes econômicos privados, e para isso, em vez de cobrarem tarifas dos usuários, o Estado lhes pagará por tais serviços.

A primeira definição de concessão toma-se emprestado da própria letra da Lei n. 9.897/1995, pelo que se transcreve: trata-se de uma "delegação de sua prestação, feita pelo poder concedente, mediante licitação, na modalidade de concorrência, à pessoa jurídica ou consórcio de empresas que demonstre capacidade para seu desempenho, por sua conta e risco e por prazo determinado". Decompondo essa conceituação para extrair seus elementos fundantes, tem-se o seguinte: (i) a operação translativa de certo e determinado serviço público deverá ser feito mediante o devido processo licitatório; (ii) não é qualquer processo licitatório, deverá ser o da concorrência; (iii) a referida delegação prestacional deverá ser feita para uma pessoa jurídica ou consórcio de empresas; (iv) as empresas devem demonstrar capacidade técnica/legal/gerencial para assumir tal obrigação; (v) os riscos da atividade correrão por conta do concessionário e; (vii) a delegação será por prazo determinado. ${ }^{32}$

Alguns outros pontos devem ser mencionados; (a) a forma de remuneração está intrínseca à própria natureza da concessão, ou seja, o concessionário haverá de se remunerar pela exploração do serviço público concedido, mediante a cobrança de tarifa; (b) essa remuneração não precisa ser exclusiva, poderá o poder público complementar com subvenções a modicidade no preço das tarifas, é o que ocorre com o serviço de transporte público; (c) a relação jurídica, entre concedente e concessionário, é de natureza contratual; (d) a concessão de serviço público somente é possível para a exploração de uma atividade a ser prestada universalmente à toda a coletividade, em nada se assemelhando ao instituto de concessão de uso de bem público. ${ }^{33}$

O processo licitatório exigido para a concessão de serviço ou obra pública reger-se-á pela Lei n. 8.987/1995, com subsidiariedade da Lei n. 8.666/1993 e demais leis esparsas pertinentes ao caso concreto. Portanto, pelo princípio da especialidade, a Lei 8.987/95 sobrepõe-se à regra do processo licitatório da Lei n. 8.666/1993. Quando se tratar da modalidade de concessão sob o regime de PPP, reger-se-á pela Lei n. 11.079/2004, aplicando-se no que couber, sucessivamente, a Lei n. 8.987/1995 e a 8.666/1993, de forma subsidiária.

Quanto à natureza jurídica do regime de concessão de serviços públicos, sem embargo, possa-se falar de uma relação jurídica de alta complexidade. O concessionário pretende com a prestação de determinado serviço auferir o maior ganho possível, enquanto o poder concedente ao menor custo possível pretende ver um determinado serviço público ser prestado de forma a angariar o máximo de satisfação possível dos administrados. Para o concedente, teria a natureza de ato-condição enquanto que, para o particular concessionário, natureza contratual.

Entretanto, é tema pacificado na doutrina que o contrato de concessão tem natureza do regime de contrato administrativo, submetendo-se ao regime de Direito Público. É verdade, que, no quesito preço da tarifa, em decorrência de o concessionário ter livre vontade de apresentar seu preço, não poderá a norma editalícia estipular preço máximo, embora possa apurar que um preço seja excessivo ou manifestamente

32 Cf. GUIMARÃES, Fernando Vernalha. Concessão de serviço público. 2. ed. São Paulo: Saraiva, 2014. p. 28.

33 MELLO, Celso Antônio Bandeira de. Curso de direito administrativo. 23. ed. São Paulo: Malheiros, 2006. p. 689. 
torne o contrato inexequível. ${ }^{34}$

A previsão contratual deverá abranger o modo, forma e as respectivas condições da prestação do serviço, ou seja, o projeto operacional da concessão deve esclarecer todos esses aspectos da relação jurídica contratual. É bem verdade que é desejável que remanesça alguma margem de lacuna para eventuais ajustes no interesse público, quanto à dimensão, abrangência e até mesmo a objetos adjacentes. ${ }^{35}$

Outro ponto de singular importância é o equilíbrio econômico contratual. Este sim é um dos pontos de maior interesse à presente pesquisa. Considerando-se que a reavaliação econômica a qualquer tempo, de forma a trazer equilíbrio às partes. é inerente ao próprio instituto de natureza civil, conquanto se aplica, também, a Teoria da Imprevisão.

As observações acima traçadas têm o condão tão somente de compreender o alcance do instituto para os fins que se propõe esta pesquisa, ou seja, mostrar caminhos de que dispõe o Estado, na atuação ou intervenção na ordem econômica, o que, se for elaborado uma planificação eficiente e responsável, poderá redundar no alcance dos objetivos da República e na realização dos princípios da própria ordem econômica, em especial naqueles capazes de reduzir as desigualdades sociais e regionais, buscando o pleno emprego, com a mais ampla liberdade de empreender e concretizar a paz social.

\subsection{A permissão de serviços públicos}

Tanto a concessão como a permissão são espécies de delegação. No caso particular da permissão, a Lei n. 8.987/1995 define-a como sendo "a delegação, a título precário, mediante licitação, da prestação de serviços públicos, feita pelo poder concedente à pessoa física ou jurídica que demonstre capacidade para seu desempenho, por sua conta e risco".

Primeiro ponto a observar é que a delegação será a título precário, nascendo dessa assertiva um grande debate doutrinário. O sentido de precariedade parece bastante equivocado e era, exatamente, nessa seara que residia a diferença entre concessão e permissão. Entende-se por ato precário aquele que pode ser desfeito por um dos lados, no caso o lado do Poder Público, sem gerar qualquer direito indenizatório à outra parte, o particular. E daí se extrai a natureza jurídica da permissão, até então, tida como um ato administrativo. $\mathrm{Na}$ própria Constituição Federal, em seu artigo 175, parágrafo único, inciso I, afastada tal precariedade, quando determina que, tanto em relação à concessão quanto à permissão de serviços públicos, o regime de empresas concessionários ou permissionárias terá caráter especial em seus contratos. ${ }^{36}$

A diferença marcante entre o regime de concessão e o de permissão caiu por terra, pois ambas serão submetidas a um contrato especial. Ocorre, porém, que a Lei n. 8.987/1995, em seu art. 40, atribui à permissão a natureza de contrato de adesão. Contrato de adesão é contrato e não ato administrativo puramente. Não bastasse, poder-se-ia dizer que a concessão se formula também por um contrato de adesão, pois o concessionário nada pode fazer para mudar os termos da minuta do contrato estabelecido no edital convocatório. Com certo esforço metodológico argumentativo, poderia se apreciar, apenas, a diferença quanto ao destinatário da avença —, na concessão, abrange-se, apenas, pessoas jurídicas e consórcios de empresas, enquanto na permissão, podem ser permissionárias tanto pessoas físicas como jurídicas, mas não consórcios de empresas. ${ }^{37}$

A própria Lei n. 8.987/1995 é expressa sobre a equiparação do instituto da permissão à concessão, ao dispor que: artigo 40. "A permissão de serviço público será formalizada mediante contrato de adesão, que observará os termos desta Lei, [...]. Parágrafo único. Aplica-se às permissões o disposto nesta Lei.” Portanto,

34 Cf. CARVAlHO FilHO, José dos Santos. Manual de direito administrativo. 21. ed. Rio de Janeiro: Lumen Juris, 2009. p. 279.

35 Cf. GUIMARÃES, Fernando Vernalha. Concessão de serviço público. 2. ed. São Paulo: Saraiva, 2014. p. 299.

36 Cf. CARVALHO FILHO, José dos Santos. Manual de direito administrativo. 21. ed. Rio de Janeiro: Lumen Juris, 2009. p. $396-397$.

37 Cf. GASPARINI, Diogenes. Direito administrativo. 12. ed. São Paulo: Saraiva, 2007. p. 406-407. 
aos que relutam em aceitar a equivalência dos institutos, poderiam encontrar diferenças sem efeito prático, o que não corrobora os objetivos desta pesquisa.

\subsection{A autorização como mecanismo de controle do Estado}

O legislador excluiu a autorização dos instrumentos translativos de serviços públicos da ordem econômica, o que na interpretação puramente econômica faz muito sentido. A autorização não se compreende dentre aqueles elementos substanciais da circulação de riquezas, uma vez que se trata de transferência de um direito ou poder a um particular para uso, tão somente no âmbito do seu patrimônio, sem que haja uma relação prestacional à coletividade. Embora haja pensamento divergente, dizendo tratar-se de ato administrativo e discricionário que serve para "atender interesses coletivos instáveis ou emergência transitória". ${ }^{38}$

O legislador constituinte concebeu a autorização, dentre as competências da União (Constituição Federal, artigo 21, XII) para explorar os serviços de radiodifusão sonora e de sons e imagens; serviços e instalações de energia elétrica; navegação aérea e infraestrutura aeroportuária e; serviços de transporte ferroviário, aquaviário entre portos brasileiros; o que analisando sob o aspecto sistêmico constitucional, tais atividades quando exercidas na prestação de serviços públicos são próprias de acometidas aos particulares por concessão ou permissão, ficando o expediente da autorização como válvula de escape para os casos abstrativamente considerados não suportados pelas vias previstas na ordem econômica. Entretanto, merece ressaltar que autorizações concedidas pela administração pública, em razão do poder de polícia, é instituto de outra natureza, porquanto não se tratar de exploração de serviço público. ${ }^{39}$

\section{Considerações finais}

No Estado Democrático de Direito adotado pelo arcabouço jurídico-constitucional brasileiro não há falar-se em Direito, se seus aplicadores e operadores em geral não se aperceberem de sua máxima finalidade - a pacificação e harmonia social, razão primeira e mais importante da ciência do Direito em amainar os recorrentes conflitos advindos das relações sociais modernas, em todas as suas dimensões.

A intervenção do Estado na ordem econômica é uma clara expressão de reconhecimento que os particulares são incapazes de per si, formularem harmoniosa e pacificamente todos os desideratos que uma economia de mercado plena possa satisfazer as necessidades produzidas a partir do sistema econômico moderno. A história do pensamento econômico tem mostrado que a figura da "mão invisível" do mercado como solução dos seus autorrearranjos, capazes de suplantar todas e quaisquer falhas de mercado já não se sustenta. O que se discute, ideologicamente, é o quanto de Estado, cada sociedade quer e deseja.

Essa medida, do tamanho do Estado não se tem disponível como figurino que possa vestir qualquer sociedade. Cada qual, com sua cultura, seus arranjos sociais, seus recursos naturais terão que descobrir e buscar as soluções em seu próprio seio social. Não se encontrará modelos prontos a substituir o que se tem, devendo ser construído levando-se em consideração os dados concretos de cada grupo social.

Pode-se concluir que os arranjos institucionais, o nível de interesse político da sociedade como um todo, participando, ativamente, das decisões políticas e vigília aos representantes modulam o tamanho do Estado numa ou noutra direção. Para isso exige-se intensa e ativa participação popular.

Para o Estado social de direito, a exata medida de atuação do Poder Público na atividade econômica é uma variável dependente do modelo político-econômico adotado. O quantum de Estado é uma complexa

38 Cf. MEIRELLES, Hely Lopes. Direito administrativo brasileiro. São Paulo: Malheiros, 1993. p. 347.

39 Cf. CARVAlHO FILHO, José dos Santos. Manual de direito administrativo. 21. ed. Rio de Janeiro: Lumen Juris, 2009. p. 425. 
questão a ser decidida pela sociedade por ocasião do processo eleitoral que alçará o pensamento ideológico mais ou menos adepto à presença do Estado na regulação e intervenção da economia.

\section{REFERÊNCIAS BIBLIOGRÁFICAS}

ARAGÃO, Alexandre Santos de. Comentários ao artigo 174. In: CANOTILHO, J. J. Gomes et al. (Coord.). Comentários à Constituição do Brasil. São Paulo: Saraiva;Almedina, 2013.

BRASIL. Comitê de Política Monetária: Circular 2.780, 20 jun. 1996. Disponível em: < http://www.bcb.gov.br/ htms/copom/a-hist.asp>. Acesso em: 20 mar. 2017.

BRASIL. Superior Tribunal de Justiça. REsp 549.873/SC. Ministro Relator Luiz Fux, j. 10.08.2004, $1^{\text {a }}$. Turma. DJE em 25 out. 2004. Disponível em: <https://ww2. stj.jus.br/processo/revista/documento / mediado $/$ ?componente $=$ ATC $\&$ sequencial $=1243551 \&$ num_registro $=200301064725 \&$ data $=20041025$ \&tipo $=5 \&$ formato $=$ PDF $>$. Acesso em: 20 mar. 2017.

CARVALHO FILHO, José dos Santos. Manual de direito administrativo. 21. ed. Rio de Janeiro: Lumen Juris, 2009.

CARVALHO, Bianca. Refinaria Abreu e lima não está pronta após 8 anos de obras. Disponível em: <http:// g1.globo.com/pernambuco/noticia/2016/04/refinaria-abreu-e-lima-nao-esta-pronta-apos-mais-de-8-anos-de-obras.html>. Acesso em: 20 mar. 2017.

COMO foi construído o túnel sob o canal da mancha. Disponível em: <http://mundoestranho.abril.com. br/materia/como-foi-contruido-o-tunel-sob-o-canal-da-mancha\#>. Acesso em: 20 mar. 2017.

DRUCKER, Peter F. Administrando em tempos de grandes mudanças. São Paulo: Pioneira, 1998.

FERRAZ JÚNIOR, Tércio Sampaio. Intervenção do estado no domínio econômico. In: CLÈVE, Clemerson Merlin; BARROSO, Luis Roberto. (Org.). Direito constitucional: constituição financeira, econômica e social. São Paulo: Revista dos Tribunais, 2011.

FIANI, Ronaldo. Teoria da regulação econômica: estado atual e perspectivas futuras. Rio de Janeiro: IE;UFRJ, 1998.

FRIEDMAN, Milton. Capitalismo e liberdade. Tradução de Afonso Celso da Cunha Serra. Rio de Janeiro: LTC, 2014.

FURTADO, Celso. Teoria e política do desenvolvimento econômico. 10. ed. São Paulo: Paz e Terra, 2000.

GASPARINI, Diogenes. Direito administrativo. 12. ed. São Paulo: Saraiva, 2007.

GRAU, Eros Roberto. Comentários ao artigo 173. In: CANOTILHO, J. J. Gomes et al. (Coord.). Comentários à Constituição do Brasil. São Paulo: Saraiva;Almedina, 2013.

GRAU, Eros Roberto. A ordem econômica na constituição de 1988. 17. ed. São Paulo: Malheiros, 2015.

GUIMARÃES, Fernando Vernalha. Concessão de serviço público. 2. ed. São Paulo: Saraiva, 2014.

HANCHER, Leigh; MORAN, Michael. Capitalism, culture and economic regulation. Oxforf University Press, 1989.

HAYEK, Friedrich A. Fundamentos da liberdade. Tradução de Anna Maria Capovilla e José Ítalo Stelle. São Paulo: Visão, 1983.

JUSTEN FILHO, Marçal. Curso de direito administrativo. 10. ed. São Paulo: Revista dos Tribunais, 2014.

KEYNES, John Maynard. A teoria geral do emprego, do juro e do dinheiro. Trad. de Augusto Sousa. Rio de Janeiro: 
Cultural, 1970.

MARINELA, Fernanda. Direito administrativo. São Paulo: Saraiva, 2016.

MARQUES NETO, Floriano de Azevedo. Delimitação do conceito de serviço público. In: TRATADO de Direito Administrativo: Funções Administrativas do Estado. São Paulo: Revista dos Tribunais, 2014.

MARX, Karl. O capital: crítica da economia política. Tradução de Edgard Malagodi. São Paulo: Nova Cultural, 2000.

MEDAUAR, Odete. Direito administrativo moderno. 18. ed. São Paulo: Revista dos Tribunais, 2014.

MEIRELLES, Hely Lopes. Direito administrativo brasileiro. São Paulo: Malheiros, 1993.

MELLO, Celso Antônio Bandeira de. Curso de direito administrativo. 23. ed. São Paulo: Malheiros, 2006.

MISES, Ludwig von. Liberalismo. Rio de Janeiro: J. Olympio, 1987.

MUKAI, Toshio. A administração pública na constituição de 1988. São Paulo: Saraiva, 1989.

NORTH, Douglas. Instituições, mudanças institucionais e desenvolvimento econômico. University Cambridge Press, 1990.

PETTER, Lafayete Josué. Direito econômico. 7. ed. Porto Alegre: Verbo Jurídico, 2014.

PIMENTA, Paulo Roberto Lyrio. Contribuições de intervenção no dominio econômico. São Paulo: Dialética, 2002.

SMITH, Adams. A riqueza das nações. São Paulo: Nova Cultural, 1995.

VILANOVA, Lourival. As estruturas lógicas e o sistema de direito positivo. 4. ed. São Paulo: Noeses, 2010. 


\section{REVISTA BRASILEIRA DE POLÍTICAS PÚBLICAS BRAZILIAN JOURNAL OF PUBLIC POLICY}

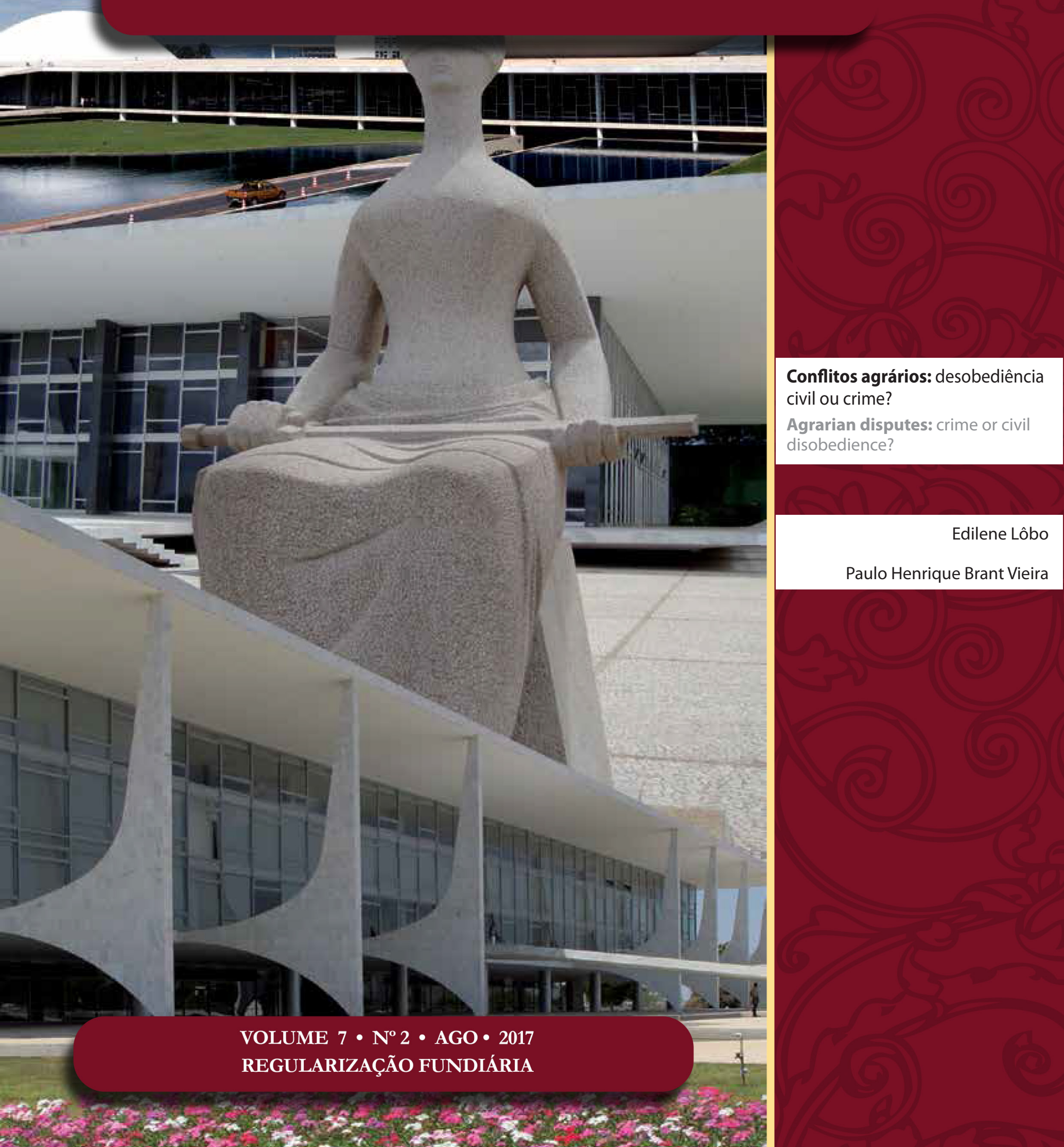




\title{
Conflitos agrários: desobediência civil ou crime?*
}

\section{Agrarian disputes: crime or civil disobedience?}

\author{
Edilene Lôbo** \\ Paulo Henrique Brant Vieira***
}

\section{Resumo}

O presente trabalho objetiva fomentar reflexões acerca da (im)possibilidade de criminalização das ocupações de imóveis rurais, perpetradas por movimentos sociais, desde que buscando oferecer resistência ao statu quo negativador do direito fundamental à terra, provocando o Estado a implementar políticas públicas de reforma agrária. Para se chegar às conclusões oferecidas lançou-se mão do método dedutivo hipotético, realizando retrospectiva histórica acerca da regulação da distribuição de terras no Brasil, exame da legislação mais recente tangendo regularização fundiária agrária e estudo da jurisprudência, chegando aos seguintes produtos: o estado da arte que identifica o processo político-jurídico de criminalização da luta pela terra; esta criminalização violando o paradigma de Estado Democrático de Direito; o descumprimento da promessa constitucional de erradicação da pobreza e redução das desigualdades sociais, num truque perverso de atribuir ao excluído a responsabilidade pela própria exclusão. A primeira conclusão diz que essa ideologização da luta pela terra, configurando-a como crime a fim de reprimir a resistência de grande massa de excluídos, se coloca como combustível a alimentar ainda mais a revolta e o robustecimento da resistência dos envolvidos em tais conflitos, até porque sem outros mecanismos de pressão. Em segundo momento concluiu-se que a ocupação pacífica de propriedades rurais, por si só, sem qualquer outro ato de violência, não se amolda à norma penal vigente no Estado brasileiro, eis que se revela legítimo instrumento de desobediência civil, intencionado mudança comportamental do Estado para efetivação da política pública de acesso à terra, que poderá ser exigida, inclusive, na via judicial.

Palavras-chave: Conflitos agrários. Desobediência civil. Política pública de acesso à terra.

* Artigo convidado

** Doutora em Direito Processual pela PUCMINAS. Mestre em Direito Administrativo pela UFMG. Especialista em Processo Penal pela Universidade Castilla La-Mancha. Professora do Mestrado e da Graduação em Direito da Universidade de Itaúna/MG. Advogada. Email: edileneloboadvogados@yahoo.com.br

*** Universidade de Itaúna. Email: paulobrant@hotmail.com

\section{Abstract}

This work aims to promote reflections over the (im)possibility of criminalizing rural land occupations by grassroots movements, as long as they are searching to put up resistance to the status quo that denies the fundamental right to land-access and in order to provoke the State to implement land reforming public policies. To reach the offered conclusions were used the deductive-hypothetical method; historical retrospective about the regulation 
of land distribution in Brazil; exam of the most recent laws about the subject and analysis of the jurisprudence, reaching the following products: the state of the art that identifies the political-judicial process of criminalization of the struggle for land; the criminalization itself that violates the Democratic-Rule-of-Law State paradigm; the non-fulfillment of the constitutional promise of poverty eradication and reduction of social inequality, in a perverse trick assigning the outcast the responsibility over his own exclusion. The first conclusion says that making the struggle for land as an ideology, establishing it as a crime in order to repress the outcast's mass resistance only fuels the revolt and strengthen the resistance because they lack other means of pressure. In a second moment it is concluded that pacific occupation of agricultural land, by itself, without any other violent act, do not goes against the ruling criminal law in the Brazilian State, because it is a legitimate instrument of civil disobedience, with the intention to change how the State acts to make the land-access public policy effective. This policy can be demanded, also, through the Judiciary.

Keywords: Agrarian disputes. Civil disobedience. Land access and public policy.

\section{INTRODUÇÃo}

A ocorrência de conflitos agrários no Brasil é problema que se faz presente no cenário político administrativo do país desde sua colonização. E desde então, quase sempre, esbarra em atos que são reclamados como crime por um lado e como defesa do direito de acesso à terra para trabalhar, cultivar e promover desenvolvimento regional, dando-lhe a função social desejada pela Constituição, por outro.

De fato, a Constituição brasileira consigna que a reforma agrária é política pública a ser desenvolvida pela União, tendo na desapropriação por interesse social, fulcrando imóvel rural improdutivo, sua principal estratégia.

Dos mandamentos constitucionais sobre o assunto é possível compreender que a reforma agrária objetiva reestruturar a propriedade da terra, distribuindo-a para que atinja sua função, oportunizando trabalho, renda e geração de riquezas. Da lei, recepcionada pela Constituição, o Estatuto da Terra, de 1965, se extraem todos os componentes, vetores e princípios dessa política pública, prometida para realização de justiça social, a cargo do Instituto Nacional de Colonização e Reforma Agrária, criado em 1970 e composto por 30 delegacias distribuídas no País, que tem uma das maiores extensões geográficos do planeta. Mas seu povo é despossuído!

Malgrado isso, os índices de concentração de terras não se modificam, tal qual a disponibilidade de recursos para os médios e grandes produtores, principais contemplados no Plano Agrícola e Pecuário 2017/2018, por exemplo, assinado pelo Governo Federal ${ }^{1}$, sem qualquer atenção aos despossuídos² .

Com isso, vista a determinação constitucional de que o Estado adote postura positiva para implementar o direito fundamental de acesso à terra promovendo a reforma agrária, mas atuando este mesmo Estado em direção oposta à modificação da realidade, certamente que se reproduz o descrédito no âmago dos indivíduos que necessitam da proteção, evidenciando a promessa incumprida e a falência do ideal social. Esse quadro enseja a associação das massas de excluídos e a adoção de postura ativa de luta, com objetivo de chamar a atenção para suas necessidades, lançando mão da ocupação pacífica da terra como hipótese justificadora da desobediência civil, para o fim de ativar a política pública latente.

A desobediência civil, mesmo numa perspectiva liberal de Estado, longe portando do ideal democrático

1 BRASIL. Ministério da Agricultura, Pecuária e Abastecimento. Plano Agrícola e Pecuário 2017/2018. Brasilia. Março de 2017. Disponível em: http://www.agricultura.gov.br/@@busca?b_start:int=10\&SearchableText=quando\%20foi $\% 20$ lan\%C3\%A7ado\%20o\%20Plano\%20Agr\%C3\%ADcola\%202017/2018 . Acesso: ago. 2017

2 O último censo agrário realizado pelo IBGE, em 2009, atestava que quase a metade das terras brasileiras se encontram nas mãos de grandes latifundiários. 
participativo e inclusivo, como já apontava Jonh Rawls³, o filósofo do liberalismo, é instrumento legítimo e eficaz na luta contra a injustiça e faz da democracia locus de discursos legitimadores dos direitos fundamentais.

Entretanto, as ações perpetradas por esses movimentos sociais em luta pela terra têm sofrido censura e uso de violência de toda sorte, encontrando reprimendas penais severas, o que tem causado divergências desde os doutrinadores até a jurisprudência pátria, abrindo ainda mais a chaga social em questão.

Com essa premissa, pretende-se fomentar reflexões acerca da impossibilidade de criminalização dos conflitos agrários quando da ocupação de imóveis rurais perpetradas por movimentos sociais, desde que buscando oferecer resistência ao statu quo negativador do direito fundamental, provocando o Estado a implementar políticas públicas de reforma agrária.

A pesquisa é de natureza qualitativa, exploratória e descritiva, sendo que a operacionalização da investigação se deu por meio da análise da literatura, buscando a evolução histórica do assunto, o avançar da legislação que regulamenta o direito agrário, assim como da jurisprudência. Ainda, fez-se ligeira incursão no direito comparado, para buscar na Constituição portuguesa, em retorno à origem, o direito constitucional à resistência civil como demonstrativo da civilidade de um povo.

Os produtos obtidos permitiram identificar o processo político-jurídico de criminalização da luta pela terra, o que viola o paradigma de Estado Democrático de Direito e reafirma o descumprimento da promessa constitucional de erradicação da pobreza e redução das desigualdades sociais.

Em sede de conclusões chegou-se à convicção que a ideologização da luta pela terra, configurando-a como crime a fim de reprimir a resistência de grande massa de excluídos, se coloca como retrocesso reacionário a alimentar ainda mais a revolta e o robustecimento da resistência, até porque sem outros mecanismos de pressão senão ocupar e resistir. Alfim, concluiu-se que a ocupação pacífica de propriedades rurais, por si só, sem qualquer outro ato de violência, não se amolda à norma penal vigente no Estado brasileiro, eis que se revela legítimo instrumento de desobediência civil, intencionado mudança comportamental do Estado para efetivação da política pública de acesso à terra, que poderá ser exigida, inclusive, na via judicial e sob proteção dos órgãos policiais.

\section{O PROCESSO de COLONIZAÇÃo COMO MARCO FÁtICO dOS CONFLITOS AGRÁRIOS NO BRASIL}

O direito à terra é tema que encontra debates por todo o mundo diante de sua importância como objeto de garantia à propriedade, territorialidade, produtividade, nacionalidade e outros direitos de ordem fundamental. No Brasil, a questão que envolve a posse e propriedade da terra já se construía a partir do desenho de sua história, assinalando um futuro conflituoso desde o processo de colonização, ao ser reconhecido, nas palavras de Pero Vaz de Caminha, quando da carta escrita ao Rei Português Dom Manuel, serem as terras brasileiras terras achadas, mesmo que já habitadas, e de pronto reconhecidas como de propriedade de Portugal, batizadas pelo Capitão Mor como A Terra de Vera Cruz ${ }^{4}$. Esse fato pode ser assinalado como a primeira ação de esbulho em terras brasileiras. E feito por aquele que viria a ser a representação do poder estatal, numa demonstração da tortuosidade que o assunto seguiria até os tempos atuais.

3 RAWLS. John. Uma teoria da justiça. $3^{a}$ ed. São Paulo: Martins Fontes Editores, 2008.

4 "Posto que o Capitão-mor desta vossa frota, e assim os outros capitães escrevam a Vossa Alteza a nova do achamento desta vossa terra nova, que ora nesta navegação se achou, não deixarei também de dar disso minha conta a Vossa Alteza, assim como eu melhor puder, ainda que — para o bem contar e falar — o saiba pior que todos fazer. (...) Neste dia, a horas de véspera, houvemos vista de terra! Primeiramente dum grande monte, mui alto e redondo; e doutras serras mais baixas ao sul dele; e de terra chã, com grandes arvoredos: ao monte alto o capitão pôs nome - o Monte Pascoal e à terra - a Terra da Vera Cruz." BRASIL. Biblioteca Nacional. A carta de Pero Vaz de Caminha. Brasilia. Disponível em: http://objdigital.bn.br/Acervo_Digital/livros_eletronicos/ carta.pdf. .Acesso: 18 jul. 2017. 
Iniciado o processo de colonização e exploração da nova terra achada (Sec. XV e XVI), tendo a colônia portuguesa se preocupado em ocupar e administrar o novo território, utilizou-se de experiência adotada em outras colônias como a ilha de Madeira, Açores e Cabo Verde, com o emprego das Capitanias Hereditárias.

Com a chegada dos Capitães donatários representantes da Coroa Portuguesa, visando não somente a ocupação, mas também o aproveitamento das terras coloniais, tem-se na concessão de sesmarias (grandes glebas de terras) aos colonos, com o respaldo da Lei de Sesmarias, possivelmente editada por volta de 1375, oportunidade de a Coroa obter lucro com sua colônia americana. Daí, aos sesmeiros se concedia a posse, mas não a propriedade das terras, condicionando sua manutenção ao aproveitamento útil com o pagamento de um sexto da produção. Como assevera Newton Rodrigues Miranda:

A transmissão da posse das sesmarias se dava por meio de Cartas de Doação. Uma vez cedida à posse, caso houvesse a subutilização das terras, ocorreria a retomada da sesmaria pela Coroa, com a revogação da Carta de Doação: eis aqui primeira acepção de “terra devoluta”, segundo as Ordenações portuguesas. ${ }^{5}$

A fase inicial do processo de colonização brasileiro, a considerar os interesses da Coroa Portuguesa no comércio de especiarias com as Índias, vendo na administração por meio das Capitanias uma forma de ocupar e vigiar as terras, promove diversas distorções neste sistema, dentre as quais, "a concessão de várias Cartas de Doação a uma mesma pessoa ou familiares, o que na prática concentrava muitas terras em um só colono". ${ }^{6}$

Boris Fausto concluiu, a partir daí, que "a atribuição de doar sesmarias é fator importante a demonstrar a origem da formação de vastos latifúndios". ${ }^{7}$

Outra consequência, também apontada por Newton Rodrigues Miranda, se traduz nos desdobramentos que essa doação indiscriminada de sesmarias provocou, pois, colonos com grandes posses de terras (latifundiários) começaram a revender e ao mesmo tempo monopolizar o recebimento de novas sesmarias, corrompendo assim o instituto que tinha alguma finalidade de tornar a terra proveitosa economicamente. Não satisfeitos, ainda, diante da improdutividade das sesmarias concedidas, saiam tais colonos/sesmeiros a invadir mais terras, destituídos da autorização traduzida nas Cartas de Doação. ${ }^{8}$

Em outro ponto, a tentativa da Coroa Portuguesa em obter lucro com a administração de sua colônia, com cessão de posse de grandes latifúndios, forçava os sesmeiros a grandes sacrifícios, pois recebiam estes terras incultas as quais deveriam ser desbravadas, preparadas e cultivadas, e ainda assim obrigados ao pagamento de um sexto dos frutos obtidos, que deveria ser repassado ao Capitão Donatário.

Além disso, considerando que o Império Português do Ocidente (Brasil), sobretudo "selvagem", era muito menos atrativo do que o Império do Oriente (Índia, Málaga e Costa Africana) - que contava com cidades, portos e especiarias de alto valor econômico na Europa - pontua Boris Fausto, ademais, "que nenhum representante da grande nobreza se incluía na lista dos donatários". Nesse raciocínio, as atividades que se desenvolviam na colônia não eram alvo de fiscalização do poder administrativo de Portugal e, com isso, a possibilidade de retomada ou devolução da posse das terras incultas, nos termos da lei de sesmarias, não ocorria.

5 MIRANDA, Newton Rodrigues. Breve histórico da questão das terras devolutas no Brasil e dos instrumentos legais de posse sobre esses bens. Belo Horizonte: Revista do CAPP, v. XVII, n. 2, 2011, p. 155.

6 MIRANDA, Newton Rodrigues. Breve histórico da questão das terras devolutas no Brasil e dos instrumentos legais de posse sobre esses bens. Belo Horizonte: Revista do CAPP, v. XVII, n. 2, 2011, p. 157.

7 FAUSTO, Boris. História do Brasil. 13ª ed. $1^{a}$ reimp. São Paulo: Editora da Universidade de São Paulo, 2009, p. 44. Como anota esse autor: "A Sesmaria foi conceituada no Brasil como uma extensão de terra virgem cuja propriedade era doada a um sesmeiro, com obrigação raramente cumprida de cultivá-la no prazo de cinco anos e de pagar o tributo devido à Coroa. Houve em toda Colônia imensas sesmarias, de limites mal definidos, como, a de Brás Cubas, que abrangia parte dos atuais municípios de Santos, Cubatão e São Bernardo." (FAUSTO, Boris. História do Brasil. 13ª ed. $1^{\text {a }}$ reimp. São Paulo: Editora da Universidade de São Paulo, 2009, p. 44-45).

8 MIRANDA, Newton Rodrigues. Breve histórico da questão das terras devolutas no Brasil e dos instrumentos legais de posse sobre esses bens. Belo Horizonte: Revista do CAPP, v. XVII, n. 2, 2011, p. 153-176.

9 FAUSTO, Boris. História do Brasil. 13ª ed. 1ª reimp. São Paulo: Editora da Universidade de São Paulo, 2009 , p. 44. 
O processo de colonização não se resumia apenas na busca de povoar e vigiar a colônia, mas também, por meio das sesmarias, integrá-la à economia mercantil europeia. Contudo, é possível afirmar ser o período dessa forma de administração colonial, iniciada por volta do ano de 1530, o marco teórico e fático dos conflitos de posse pela terra em território brasileiro. Nesse tempo, a infelicidade no trato gerencial da ocupação de tais terras conta também com a resistência dos povos indígenas, que lutavam contra aqueles lhes turbavam a propriedade da terra que ocupavam desde tempos imemoriais.

É como narra Boris Fausto:

(...) com exceção das capitanias de São Vicente e Pernambuco, as outras fracassaram em maior ou menor grau, por falta de recursos, desentendimentos internos, inexperiência, ataques de índios. ${ }^{10}$

José Francisco da Rocha Pombo corrobora:

O malogro dos primeiros intentos começou logo a desiludir a muitos. A maior parte das empresas ocupavam-se quase sem descanso, em guerras com os selvagens e algumas não puderam resistir as agressões continuas que sofreram mesmo sem sair da zona marítima. ${ }^{11}$

Além da conflitualidade envolvendo os povos indígenas, os primeiros donos, o processo de colonização contou com mão de obra escrava para ampliar os resultados econômicos para a Coroa, com o cultivo das monoculturas, como a cana de açúcar. E isso também trouxe problemas.

A mão de obra escrava, adquirida por meio da ampliação do comércio com outros Estados e com o sucesso das grandes navegações, se traduziu em atos de resistência e inserção de uma ideologia de organização social contra a opressão. Além dos índios, desapossados, os negros escravizados:

Seria errôneo pensar que, enquanto os índios se opuseram à escravidão, os negros a aceitaram passivamente. Fugas individuais ou em massa, agressões contra senhores, resistência cotidiana fizeram parte das relações entre senhores e escravos, desde os primeiros tempos. Os quilombos, ou seja, estabelecimentos de negros que escapavam à escravidão pela fuga e recompunham no Brasil formas de organização social semelhantes as africanas, existiram as centenas no Brasil colonial. Palmares - uma rede de povoados situada em uma região que corresponde em parte ao Estado de Alagoas, com vários milhares de habitantes - foi um destes quilombos e certamente o mais importante. ${ }^{12}$

Havia conflitos na colônia brasileira envolvendo a resistência de índios e escravos, mas Portugal enfrentava crise ainda maior, de ordem política internacional, com a França de Napoleão Bonaparte. Isso motivou a mudança da Corte para a colônia brasileira, episódio que construiu os primeiros passos da independência e a inauguração do Império local.

Roberto de Paula anota que o modelo sesmeiro foi extinto, no Brasil, em 17 de julho de 1822, passando daí a viger o sistema de posse "cuja regularização definitiva se efetivaria em 18 de setembro de 1850"13, com a Lei de Terras, como se vai comentar adiante.

Com a independência, D. Pedro I determinou a suspensão "de quaisquer concessões por meio de sesmarias até que a Assembleia Geral Constituinte deliberasse sobre o assunto, fato este que acabou não ocorrendo", conforme explica Gilberto Bergovici, secundando as promessas sociais não cumpridas, que se estenderiam no tempo. ${ }^{14}$

Silenciando a Assembleia Nacional Constituinte de 1823, editada a Constituição de 1824 sob o mando do Imperador, somente após 27 anos é que o Brasil conheceu a primeira iniciativa para organizar a propriedade

10 FAUSTO, Boris. História do Brasil. 13a ed. $1^{\text {a }}$ reimp. São Paulo: Editora da Universidade de São Paulo, 2009 , p. 45.

11 ROCHA POMBO, José Francisco da. História do Brasil. 13ª ed. vol. 1. São Paulo: Editora Egéria S/A, 1966 , p. 66.

12 FAUSTO, Boris. História do Brasil. 13ª ed. $1^{a}$ reimp. São Paulo: Editora da Universidade de São Paulo, 2009 , p. 52.

13 DE PAULA, Roberto. Direitos e conflitos agrários: mecanismos de entrave e acesso a justiça e de efetivação de direitos. Artigo hospedado na plataforma Publica Direito. Disponível em: http://www.publicadireito.com.br/ artigos/?cod=46bc56d0ff6bad9d. Acesso em 10 ago. 2017.

14 BERGOVICI, Gilberto. Constituição econômica e desenvolvimento: uma leitura a partir da Constituição de 1988. São Paulo: Malheiros, 2005, p. 127. 
de terras, a lei de $\mathrm{n}^{\circ}$ 601, de 18 de setembro de 1850. Seu objetivo era regular a posse de terras devolutas e legalizar a aquisição das sesmarias.

Todavia, importa dizer que muito daquilo que se ordenou pereceu pelo caminho e permaneceu apenas no papel, motivando os conflitos que objetivavam a posse pela terra. Tais conflitos encontram no termo "terras devolutas", que tem uma nova conceituação na Lei de 1850, em detrimento da Lei de Sesmarias, importante fator no embate quanto à (i)legalidade da luta pelo direito à terra.

Antes da edição da Lei de Terras, porém, em 1835, "um grupo de camponeses sem terra se rebela contra a escravidão e a miséria, no Pará."15 É a revolta da Cabanagem. "Os cabanos eram negros, mulatos, índios. Destaque-se nesse grupo a forte influência dos negros que viviam nos quilombos." 16

Roberto de Paula conta que:

Os cabanos empreenderam uma marcha revolucionária do campo para a cidade. Tomam a capital (Belém).

Ao cabo da terceira tentativa de eliminação da Cabanagem, o Império fortalece suas tropas, recupera o controle governamental e massacra sistematicamente a sublevação popular cabana. Estima-se que $40 \%$ dos habitantes da província foram mortos no enfrentamento com as forças imperiais. ${ }^{17}$

Mesmo depois da Lei de Terras, nenhuma mudança significativa ocorrera, nem mesmo com o advento da República.

Tanto que outro evento sangrento sacudiu a história, sob mando dos militares do Presidente Prudente de Morais, que assassinou cerca de 25.000 sertanejos, na Guerra de Canudos, que durou de 1896 até 1897. Sobre esse conflito, Euclides da Cunha afirmou ter sido "na significação integral da palavra, um crime", um "refluxo para o passado". ${ }^{18}$

Essa guerra, como tantas outras ao longo da história, galvanizou os diversos abusos do próprio processo de colonização das terras brasileiras, que acabaram se desdobrando na República, pautada em fatores como (i) a distribuição indiscriminada e direcionada àqueles que pertenciam a aristocracia; (ii) a falta de fiscalização para fazer cumprir a legislação no tocante a expropriação de terras não produtivas; (iii) a busca de proveito destas terras com a inserção de monoculturas nos latifúndios e, com isso, as tentativas de escravização do índio, a importação da mão de obra escrava do negro, a quem não se reconhecia como sujeito de direitos; (iv) a exploração dos sesmeiros obrigados a pagar tributos sem contrapartidas, e, por que não afirmar, (v) na marginalização do homem brasileiro, fruto da miscigenação de europeus, índios e negros.

Roberto de Paula relembra Canudos:

O discurso pela posse da terra opera uma mobilização grande de ex-escravos, índios, camponeses desamparados, artesãos, migrantes, pequenos proprietários de terra, homens tão cheios de convicção, que preferiram antes a morte do que abandonar a cidade santa e se render.

Ao lado da reivindicação política, instala-se o discurso da efervescência religiosa e do descrédito pela República, com a consequente desobediência civil. A pregação do líder de Canudos fez tremer a terra nos sertões baianos, não somente pelos dons divinatórios (de premonição e cura), que lhe eram atribuídos,

15 DE PAULA, Roberto. Direitos e conflitos agrários: mecanismos de entrave e acesso a justiça e de efetivação de direitos. Artigo hospedado na plataforma Publica Direito. Disponível em: http://www.publicadireito.com.br/ artigos/?cod=46bc56d0ff6bad9d. Acesso em 10 ago. 2017.

16 DE PAULA, Roberto. Direitos e conflitos agrários: mecanismos de entrave e acesso a justiça e de efetivação de direitos. Artigo hospedado na plataforma Publica Direito. Disponível em: http://www.publicadireito.com.br/ artigos/?cod=46bc56d0ff6bad9d. Acesso em 10 ago. 2017.

17 DE PAULA, Roberto. Direitos e conflitos agrários: mecanismos de entrave e acesso a justiça e de efetivação de direitos. Artigo hospedado na plataforma Publica Direito. Disponível em: http://www.publicadireito.com.br/ artigos/?cod=46bc56d0ff6bad9d. Acesso em 10 ago. 2017.

18 CUNHA, Euclides. Os Sertões. São Paulo: Editora Três, 1984 (Biblioteca do Estudante). Disponível em: http:/ /www.dominiopublico.gov.br/download/texto/bv000091.pdf. Acesso em 12 ago. 2017. 
mas, sobretudo, pela capacidade política de articular massas de excluídos, e por sensibilizar o sofrido sertanejo a tomar uma posição de luta e resistência. ${ }^{19}$

Cerca de quarenta anos depois, resistência similar vai ser vista com o protagonismo das Ligas Camponesas, que iniciam seu movimento em torno da década de 1940, num importante movimento campesino, passando à clandestinidade em 1964, com o assassinato e perseguição de seus líderes, coincidentes com a deposição do Presidente Jango pelos militares. ${ }^{20}$

Aliás, antes de ser deposto, o Presidente Jango enviou ao Congresso Nacional proposta de um Estatuto da Terra, que se fez substituir, em 1964, por outra, materializando a Lei 4.504, de 30 de novembro de 1964, o Novo Estatuto da Terra. É desse texto legislativo que se extrai o conceito, a composição, os vetores, princípios e destinatários da política pública em questão. A despeito de sua gênese antidemocrática, o Estatuto da Terra foi recepcionado pela Constituição que lhe sucedeu vinte e dois anos depois, reafirmando seus comandos e realçando seu déficit de aplicação.

Os movimentos democráticos de luta pela terra vão ser retomados, de fato, muito próximo do modelo implementado pelas Ligas Camponesas, somente com a abertura democrática, apoiados pela igreja católica por meio da Comissão Pastoral da Terra (CPT), que "chega até a organizar ocupações de terras"21.

Com a Constituição de 1988 - explicitada a garantia da propriedade como direito fundamental no caput do artigo $5^{\circ}$, da função social da propriedade no inciso XXIII, da desapropriação por interesse social no inciso XXIV, da impenhorabilidade da pequena propriedade rural no inciso XXVI, além da previsão da política agrária e fundiária e da reforma agrária, nos artigos 184 a 191 - chegou-se ao ápice das promessas de garantia do direito social à terra, mas dado o processo autoritário da colonização brasileira, ainda restam ao léu até hoje. Ou seja, a promessa incumprida de justa partilha da terra tomada dos índios pelos portugueses é secular.

O escorço histórico brevemente apresentado demonstra que a organização social voltada à resistência da opressão, tendo por escopo a luta por direitos fundamentais, a exemplo de Canudos, é importante para combater a omissão estatal que nega o reconhecimento dos que clamam pela terra, como vetor de afirmação de sua condição humana.

De mesma sorte, a historicidade carrega consigo a justificativa do Estado, desde a colonização, de defesa da propriedade e do poder instituído, empregando seus aparelhos dotados de instrumentos como o uso da força, a reprimir tais ações de insurreição. O emprego de recursos para reprimir não é proporcional à destinação de esforços para efetivar a oferta dos bens da vida reclamados pelos despossuídos e aí se tem o abismo!

A extensão e abrangência desses conflitos, ainda eclodindo no tempo presente, são suficientes a demonstrar a complexidade dos direitos envolvidos, sem satisfação. Por outro lado põe a nu os timoneiros desse mesmo Estado, que defendiam e ainda defendem seus próprios interesses; o particular, enquanto latifundiário, que detinha e detém o poder econômico de interferência nas decisões do Estado para manutenção de sua propriedade e, finalizando esta tríade, a coletividade marginalizada e miscigenada de homens e mulheres que a cada dia mais são decotados do básico para uma vida boa.

O que se viu, de lá até aqui, do Século XVI ao Século XXI, é a barbárie, se apresentando 2017 como

19 DE PAULA, Roberto. Direitos e conflitos agrários: mecanismos de entrave e acesso a justiça e de efetivação de direitos. Artigo hospedado na plataforma Publica Direito. Disponível em: http://www.publicadireito.com.br/ artigos/?cod=46bc56d0ff6bad9d. Acesso em 10 ago. 2017.

20 DE PAULA, Roberto. Direitos e conflitos agrários: mecanismos de entrave e acesso a justiça e de efetivação de direitos. Artigo hospedado na plataforma Publica Direito. Disponível em: http://www.publicadireito.com.br/ artigos/?cod=46bc56d0ff6bad9d. Acesso em 10 ago. 2017.

21 DE PAULA, Roberto. Direitos e conflitos agrários: mecanismos de entrave e acesso a justiça e de efetivação de direitos. Artigo hospedado na plataforma Publica Direito. Disponível em: http://www.publicadireito.com.br/ artigos/?cod=46bc56d0ff6bad9d. Acesso em 10 ago. 2017. 
"recorde de mortes no campo"22, segundo Carlos Madeiro:

Os cinco primeiros meses de 2017 já registram 37 mortos no campo. É o início de ano mais violento do século, segundo dados da CPT (Comissão Pastoral da Terra). As dez mortes durante a operação policial em Pau D'Arco, no sudeste paraense, na quarta feira (24), se configuram a maior chacina registrada desde 1996, quando houve o famoso Caso de Eldorado dos Carajás, também no Pará. Naquela ocasião, 19 trabalhadores rurais foram mortos, e dois comandantes foram condenados.

O número de mortos superou a violência registrada em 2016, quando 27 pessoas foram assassinadas. ${ }^{23}$

O que ainda surpreende, a despeito da longevidade da violência, é o fato de que "Não nos acostumamos, ainda, com a Democracia" ${ }^{24}$. Ou seja, "o exercício de direitos civis causa absoluto incômodo e truculência por parte dos órgãos estatais" "25. Rubem Siqueira, da coordenação nacional da CPT, em entrevista a Carlos Madeiro, destaca: "parece existir uma licença para matar" ${ }^{26}$. E vai ao ponto nevrálgico: "A gente atribui essa violência brutal, maior que sempre foi, a essa situação do país - em que o Estado ou está ausente, ou está funcionando contra os direitos do cidadão" ${ }^{27}$.

A rejeição violenta aos movimentos sociais é fator já incorporado à realidade, como anota Brenno Tardelli:

Movimentos sociais nunca foram, nem serão visto com bons olhos por quem está no poder - ou dele tirando grande proveito, pelo simples motivo que é do caráter de qualquer movimento sua natureza contestatória, evidenciando alguma injustiça histórica perpetrada no pais. ${ }^{28}$

O que compreende a criminalização desses movimentos, segundo esse autor, é opção ideológica, "não encontrando qualquer respaldo nos princípios regentes do Direito Penal’29.

\section{A CONSTRUÇÃo NORMATIVA DA CRIMINALIZAÇÃo DA LUTA PELA TERRA}

Voltando à Lei no 601, de 1850, denominada Lei de Terras Devolutas do Império, identificam-se pontos importantes para o alinhamento do presente tópico, que merecem ser destacados.

22 MADEIRO, Carlos. Maior massacre desde Eldorado dos Carajás faz 2017 ter recorde de mortes no campo. Maceió: Uol Noticias Cotidiano, 27 de maio de 2017. Disponível em: https://noticias.uol.com.br/cotidiano/ultimas-noticias/2017/05/27/ maior-massacre-desde-eldorado-dos-carajas-faz-2017-ter-recorde-de-mortes-no-campo.htm . Acesso em 18 jul. 2017.

23 MADEIRO, Carlos. Maior massacre desde Eldorado dos Carajás faz 2017 ter recorde de mortes no campo. Maceió: Uol Noticias Cotidiano, 27 de maio de 2017. Disponível em: https://noticias.uol.com.br/cotidiano/ultimas-noticias/2017/05/27/ maior-massacre-desde-eldorado-dos-carajas-faz-2017-ter-recorde-de-mortes-no-campo.htm . Acesso em 18 jul. 2017.

24 TARDELLI, Brenno. Veremos como nunca a criminalização dos movimentos sociais. São Paulo: Revista Eletrônica CONJUR, 24 de dezembro de 2013. Disponível em: http://www.conjur.com.br/2013-dez-24/brenno-tardeli-veremos-nuncacriminalizacao-movimentos-sociais . Acesso em: 18 ago. 2017.

25 TARDELLI, Brenno. Veremos como nunca a criminalização dos movimentos sociais. São Paulo: Revista Eletrônica CONJUR, 24 de dezembro de 2013. Disponível em: http:/ /www.conjur.com.br/2013-dez-24/brenno-tardeli-veremos-nunca-criminalizacao-movimentos-sociais . Acesso em: 18 ago. 2017.

26 MADEIRO, Carlos. Maior massacre desde Eldorado dos Carajás faz 2017 ter recorde de mortes no campo. Maceió: Uol Noticias Cotidiano, 27 de maio de 2017. Disponível em: https://noticias.uol.com.br/cotidiano/ultimas-noticias/2017/05/27/ maior-massacre-desde-eldorado-dos-carajas-faz-2017-ter-recorde-de-mortes-no-campo.htm . Acesso em 18 jul. 2017.

27 MADEIRO, Carlos. Maior massacre desde Eldorado dos Carajás faz 2017 ter recorde de mortes no campo. Maceió: Uol Noticias Cotidiano, 27 de maio de 2017. Disponível em: https://noticias.uol.com.br/cotidiano/ultimas-noticias/2017/05/27/ maior-massacre-desde-eldorado-dos-carajas-faz-2017-ter-recorde-de-mortes-no-campo.htm . Acesso em 18 jul. 2017.

28 TARDELLI, Brenno. Veremos como nunca a criminalização dos movimentos sociais. São Paulo: Revista Eletrônica CONJUR, 24 de dezembro de 2013. Disponível em: http://www.conjur.com.br/2013-dez-24/brenno-tardeli-veremos-nuncacriminalizacao-movimentos-sociais . Acesso em: 18 ago. 2017.

29 TARDELLI, Brenno. Acusar manifestante de quadrilha é opção ideológica. São Paulo: Revista Eletrônica CONJUR, 14 de junho de 2013. Disponível em: http://www.conjur.com.br/2013-jun-14/brenno-tardelli-acusar-manifestante-quadrilha-opcaoideologica . Acesso em: 19 ago. 2017. 
O primeiro ponto envolve o reconhecimento da existência de duas espécies de terras devolutas ${ }^{30}$ : as que eram possuídas por título de sesmarias sem preenchimento das condições legais e aquelas possuídas por simples título de posse mansa e tranquila.

Abstraindo sobre o que diz a história quanto à forma de aquisição das sesmarias por posse mansa e tranquila e sua diferenciação com aquelas havidas sem preenchimento das condições legais, tem-se com a Lei de Terras espécie de anistia para as ocupações irregulares ocorridas durante a colonização, pois, para o artigo $4^{\circ}$ dessa lei, as sesmarias ou concessões, seriam revalidadas, bastando para tanto se acharem cultivadas e utilizadas por morada habitual. De maneira similar, a ocupação primária da terra (quando se apresentasse o título concedido pela Coroa) podia ser legitimada, conforme artigo $5^{\circ}$, anistiando assim a posse irregular exercida no momento da entrada em vigor dessa lei.

Quanto às terras devolutas possuídas sem preenchimento das condições legais, seriam estas demarcadas e cedidas a título oneroso a empresas particulares, assim como para estabelecimentos de colônias de nacionais e de estrangeiros.

Neste contexto, o processo de reavaliação ou legitimação da posse, ou mesmo de anistia quanto à posse irregular, demonstrava na necessidade de utilização dessas terras de forma produtiva, iniciando a compreensão de que a propriedade deveria cumprir determinada função.

O segundo ponto é a criminalização da ocupação de terras devolutas. Com esse propósito, preconizava o artigo $2^{\circ}$ : "Os que se apossarem de terras devolutas ou de alheias, e nellas derribarem mattos ou lhes puzerem fogo, serão obrigados a despejo, com perda de bemfeitorias, e de mais soffrerão a pena de dous a seis mezes de prisão e multa de 100 , além da satisfação do damno causado. Esta pena, porém, não terá logar nos actos possessorios entre heréos confinantes". ${ }^{31}$

Importa destacar que a proteção penal refletia a preocupação do legislador em imunizar as terras públicas devolutas de possíveis apossamentos, não alcançando a propriedade privada. Porém, na ocorrência de tais atos em desfavor do particular era possível reclamar aplicação do Código Criminal do Império, de $1830^{32}$, para proteção da propriedade privada.

Com a edição do Decreto $n^{\circ} 1.318 / 54^{33}$, que regulamentava a Lei de Terras, veio a descrição dos atos administrativos necessários para eficácia da norma vigente, porém, apesar do objetivo de regularização da situação de posse e uso da terra, demonstra Marco Antônio Both da Silva que tal lei não havia pegado, por fatores de ordem intencional e administrativo. ${ }^{34}$

De ordem intencional, esse autor pontua que a lei atendia a um grupo de pessoas que estava diretamente vinculado ao problema da terra e sua ocupação, bem como, que seu objetivo era regularizar a questão da propriedade fundiária e dificultar o acesso à terra, visto a possibilidade de apenas tê-la por compra.

De outra sorte, a considerar os fatores de ordem administrativa, estão aqueles apontados por Francisco

30 A Lei n⿳ 601, em seu artigo $3^{\circ}$, definia que "São terras devolutas: $\int 1^{\circ}$ As que não se acharem applicadas a algum uso publico nacional, provincial, ou municipal. $₫ 2^{\circ}$ As que não se acharem no dominio particular por qualquer titulo legitimo, nem forem havidas por sesmarias e outras concessões do Governo Geral ou Provincial, não incursas em commisso por falta do cumprimento das condições de medição, confirmação e cultura. $\int 3^{\circ}$ As que não se acharem dadas por sesmarias, ou outras concessões do Governo, que, apezar de incursas em commisso, forem revalidadas por esta Lei. $\int 4^{\circ}$ As que não se acharem occupadas por posses, que, apezar de não se fundarem em titulo legal, forem legitimadas por esta Lei."

31 BRASIL. Lei n ${ }^{\circ}$ 601, de 18 de setembro de 1850. Publicada na Carta de Leis Brasileiras - CLBR. Disponível em: http://www. planalto.gov.br/ccivil_03/leis/lim/LIM601.htm. Acesso: 12 jul. 2017.

32 BRASIL. Lei de 16 de dezembro de 1830. Publicada na Carta de Leis Brasileiras - CLBR. Disponível em: http:/ /www.planalto. gov.br/ccivil_03/leis/lim/LIM-16-12-1830.htm . Acesso: 12 jul. 2017.

33 Brasil. Decreto n 1.318, de 30 de Janeiro de 1854. Publicado na Carta de Leis Brasileiras - CLBR. Disponível em: http:/ /www. planalto.gov.br/ccivil_03/decreto/historicos/dim/DIM1318.htm. Acesso em: 12 jul. 2017.

34 SILVA, Marcio Antonio Both da. Lei de Terras de 1850: Lições sobre os efeitos e os resultados de não se condenar “uma quinta parte da atual população agrícola”. Revista Brasileira de Historia. São Paulo, v. 35, n. 70, 2015, p. 90. 
Barros e Accioli de Vasconcelos, em seu relatório produzido em $1889^{35}$, no qual descrevia que a Inspetoria Geral de Terras Públicas (IGTP) "continuava sem elementos para organizar convenientemente o movimento relativo a legitimações e revalidações de posses, assim como a venda das terras devolutas feitas nas províncias", como descreve Marco Antônio Both da Silva ${ }^{36}$.

Toda essa problemática envolvendo as tentativas de regulação das terras devolutas e da regularização de terras cedidas por sesmarias ou quando não, possuídas sem preenchimento dos requisitos necessários, vai se arrastar por um longo período, desde o Brasil Império aos dias atuais, mas encontraria no artigo 64 da Constituição de $1891^{37}$ um ensaio para definir a propriedade pública desses bens.

Diante da ineficiência em estruturar o direito sobre a propriedade de terras devolutas e com isso fazer cumprir a norma vigente, a considerar a Lei de Terras e o Decreto n ${ }^{\circ} 1.138$, de 1954, bem como seu extenso período de vigência, a criminalização de atos de desforço a reclamar o direito à terra foi definitivamente inserido no Código Penal de $1940^{38}$, ainda vigente após vários remendos que buscam o alinhavamento do velho ao novo, do Estado Imperial ao Democrático de Direito. É ali que se diz ser crime ${ }^{39}$, praticado por quem "invade, (...) mediante concurso de mais de duas pessoas, terreno ou edifício alheio, para o fim de esbulho possessório". Nota-se que o tipo dispensa a violência para configuração do ilícito, bastando haver duas ou mais pessoas!

Importante notar que a descrição do tipo penal incriminador traz a ideia de autoria coletiva e finalidade especial de agir, que serve de base para a discussão inaugurada neste trabalho, acerca do seu direcionamento para alcançar as associações ou movimentos organizados, que congregam massas de excluídos buscando implementação da política pública devida pelo Estado.

Essas organizações de colonos, camponeses, trabalhadores ou assalariados rurais, convergem para a descrição de importante categoria que possui objetivo comum: o direito à terra como uma fonte de reconhecimento de sua existência humana. Direito achado na Constituição, bem explicitado no Estatuto da Terra e nas várias leis que o complementam. Ainda assim, descumpridas!

Como já se disse, desde os Cabanos, passando por Canudos, pelo Movimento de Agricultores Sem Terra

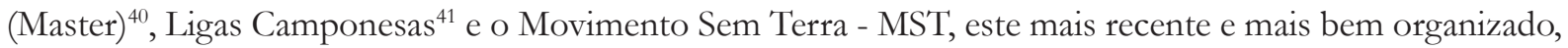
tais associações possuem objetivos que devem ser protegidos e não criminalizados: lutar pela "terra, reforma

35 O relatório produzido pelo Inspetor Geral de Terras Públicas Francisco Bastos e Accioli de Vasconcelos no ano de 1889 serve para demonstrar a informação tardia da ineficiência do órgão estatal em dar efetividade ao que lhe era posto uma vez que a deficiência apontada somente é informada após 45 anos de criação órgão por meio do Decreto de n. 1.138/54, como ressalta SILVA, Marcio Antonio Both da. Lei de Terras de 1850: Lições sobre os efeitos e os resultados de não se condenar "uma quinta parte da atual população agrícola”. Revista Brasileira de Historia. São Paulo, v. 35, n. 70, 2015, p. 90.

36 SILVA, Marcio Antonio Both da. Lei de Terras de 1850: Lições sobre os efeitos e os resultados de não se condenar “uma quinta parte da atual população agrícola”. Revista Brasileira de Historia. São Paulo, v. 35, n. 70, 2015, p. 90.

37 BRASIL. Constituição da República dos Estados Unidos do Brasil, de 24 de fevereiro de 1891. Publicada no Diário Oficial da União em 24 de fevereiro de 1891. Disponível em: http://www.planalto.gov.br/ccivil_03/Constituicao/Constituicao91.htm . Acesso em: 18 jul. 2017

38 BRASIL. Decreto-Lei no 2.848, de 27 de dezembro de 1940. Código Penal. Publicado no Diário Oficial da União em 31 de dezembro de 1940. Disponível em: http://www.planalto.gov.br/CCIVIL_03/Decreto-Lei/Del2848.htm . Acesso em: 18 jul. 2017.

39 Artigo 161, inciso II, do Código Penal brasileiro.

40 Movimento fundado no Rio Grande do Sul, em 1958, sob influência de líderes políticos do PTB, como Leonel Brizola, Paulo Schilling, Jair Calixto e João Sem-Terra. Esse movimento pressionava o governo estadual a realizar assentamentos. Funcionou de 1958 a 1964, quando foi colocado na ilegalidade e perseguido. É o quanto relata FERNANDES, B. M. STEDILE, J. P. Brava Gente: A trajetória do MST e luta pela terra no Brasil. 3 reimp. São Paulo: Editora Fundação Perseu Abramo, 2005, p. 17.

41 Movimento campônes que teve seu início nos idos de 1954, fundado no Engenho Galileia, em Vitoria de Santo Antão, Pernambuco. Teve entre seus fundadores José dos Prazeres e, durante sua trajetória, projetou líderes como Francisco Julião, Clodomir de Moraes, João Pedro Teixeira e Elizabeth Teixeira. As Ligas Camponesas existiram até 1964, quando foram colocadas na ilegalidade e perseguidas. Funcionaram basicamente nos Estados do Nordeste, com maior força em Pernambuco, Paraíba e Alagoas. Também como descreve FERNANDES, B. M. STEDILE, J. P. Brava Gente: A trajetória do MST e luta pela terra no Brasil. 3 reimp. São Paulo: Editora Fundação Perseu Abramo, 2005, p. 18. 
agrária e mudanças na sociedade" - como descreve FERNANDES e STÉDILE ${ }^{42}$.

A rigor, o uso da força pelo Estado contra os campesinos objetiva obnubilar sua ineficiência e o descumprimento do ordenamento jurídico, o que atende bem ao latifúndio e ao retrocesso na concentração de terras produtivas, num processo inverso à caminhada do mundo civilizado, que estimula a produção local, o terroir, a agricultura familiar e as pequenas iniciativas que incluem muitos com poucos recursos. Nessa altura, é de se perguntar: polícia para quem? Quem precisa de polícia? ${ }^{43}$

Além da atual Lei das Organizações Criminosass4, festejadíssima em tempos de operações midiáticas, tem-se na Lei $n^{\circ} 7.170$, de $1983^{45}$, de Segurança Nacional, como ferramentas para criminalizar os integrantes dos inquinados movimentos sociais.

Foi o que se viu com a Ação Penal no 0000454-65.2010.404.7118, que tramitou na Primeira Vara Federal de Carazinho, no Rio Grande do Sul, na qual o Ministério Público Federal ofereceu denúncia em desfavor de integrantes do MST, deduzindo-os como incursos nas sanções dos artigos 16, 17, caput, 20, caput, e 23, I, da Lei n 7.170 e outros, porque ao seu juízo teria sucedido "invasões de terra" ${ }^{46}$. O intento não granjeou sucesso porque houve a absolvição dos acusados, mas serviu para estarrecer: o órgão constitucional criado para defender os direitos sociais e a sociedade agindo na direção contrária aos interesses coletivos.

Vale colacionar trechos da sentença absolutória em outra ação penal similar à anteriormente referida, desta feita a de no 2007.71.18.000178-3, que também tramitou na $1^{\text {a }}$ Vara Federal de Carazinho. De excertos desse julgado, prolatado pelo Juiz Stefan Espirito Santo Hartmann, não se reconhece o direito à resistência civil, mas não se admitiu que atos de ocupação fossem enquadrados como violadores da Segurança Nacional (ao menos isso foi bom):

(...)

No caso em exame, o Ministério Público Federal denunciou os réus por 4 (quatro) fatos, os quais teriam ocorrido nos anos de 2004, 2005 e 2006, no município de Coqueiros do Sul, nos arredores da multicitada Fazenda Coqueiros. Segundo a denúncia, os réus, neste espaço de tempo, (a) integraram grupamentos que tinham por objetivo a mudança do Estado de Direito, por meios violentos e com emprego de grave ameaça, (b) tentaram mudar, com emprego de violência e grave ameaça, a ordem vigente e o Estado de Direito, (c) devastaram, saquearam, roubaram, sequestraram, mantiveram em cárcere privado, incendiaram e depredaram, por inconformismo político, e (d) incitaram os demais acampados do MST à subversão, conclamando-os a resistirem à ação da Brigada Militar e a usarem de violência e grave ameaça contra os policiais, além de incitarem os acampados a cometerem uma série de crimes na região, a fim de forçar o Governo Federal a desapropriar aquela fazenda.

Sucede que, após acurado exame do farto conjunto probatório carreado aos autos, desde o oferecimento da denúncia, em 11 de março de 2008, não vislumbro, em nenhum momento, a motivação e os objetivos perfilados no art. $1^{\circ}$ da LSN. Em outras palavras, entendo que a conduta dos réus não pretendia lesar

42 FERNANDES, B. M. STEDILE, J. P. Brava Gente: A trajetória do MST e luta pela terra no Brasil. 3 reimp. São Paulo: Editora Fundação Perseu Abramo, 2005, p. 31.

43 Não saí da mente a música dos Titãs, importante Banda de Rock surgida na década de 1980, cuja letra dizia: Dižem que ela existe Pra ajudar!/Dizem que ela existe Pra proteger!/ Eu sei que ela pode Te parar!/ Eu sei que ela pode Te prender!/ Polícia! Para quem precisal Polícia! Para quem precisa De polícial Polícia! Para quem precisal Polícia! Para quem precisa De polícial Diæ̌em pra você Obedecer!/ Dižem pra você Responder!/ Dižem pra você Cooperar!/ Dižem pra você Respeitar!/ Polícia! Para quem precisal Polícia! Para quem precisa De policia.

44 BRASIL. Lei no 12.850, de 02 de agosto de 2013. Define organização criminosa e dispõe sobre a investigação criminal. Publicada no Diário Oficial da União de 05 de agosto de 2013. Disponível em: http://www.planalto.gov.br/ccivil_03/_Ato20112014/2013/Lei/L12850.htm . Acesso: 18 jul. 2017.

45 BRASIL. Lei $\mathrm{n}^{\circ}$ 7.170, de 14 de dezembro de 1983. Define os crimes contra a segurança nacional, a ordem política e social. Publicada no Diário Oficial da União de 15 de dezembro de 1983. Disponível em: http://www.planalto.gov.br/ccivil_03/leis/ L7170.htm . Acesso em: 17 jul. 2017.

46 BRASIL. Ação Penal no 0000454-65.2010.404.7118, que tramitou na 1ª Vara Federal de Carazinho, no Rio Grande do Sul. Prolatada pelo Juiz Stefan Espirito Santo Hartmann. Transitada em julgado em 08 de setembro de 2014. Certidão de inteiro teor disponível em: http://www.trf4.jus.br/trf4/processos/visualizar_documento_gedpro.php?local=jfrs\&documento=12379228\&Do cComposto $=\&$ Sequencia $=\&$ hash $=592 \mathrm{f} 762 \mathrm{ea} 5$ aaa805c78441de11202272. Acesso em: 19 jul. 2017. 
ou expor a perigo de lesão a segurança nacional, por meio dos bens jurídicos previstos no art. $1^{\circ}$, mas reivindicar mudanças na condução da política agrária brasileira, ainda que por meios ilícitos.

Inclusive, entendo que é possível chegar a esta conclusão sem adentrar em temas como o (não) alinhamento dos objetivos do Movimento dos Trabalhadores Sem Terra - MST com os ditames da Constituição Federal, bem como a (in)existência do chamado "direito de resistência civil". Na verdade, a não comprovação de ofensa aos bens jurídicos tutelados pela LSN pode ser aferida apenas por critérios jurídico-probatórios, afastando-se de discussões políticas e ideológicas. Ressalto, inclusive, que este Juízo não se constitui o foro adequado para tais debates, os quais devem ser travados nas instâncias competentes - Congresso Nacional, Assembleias Legislativas, audiências públicas, etc. ${ }^{47}$

O ponto alto dessa decisão traz para o debate, que é sim jurídico, não só político, a existência (ou não), na Constituição brasileira, do direito de resistência, como se vê no art. $21^{\circ}$ da Constituição Portuguesa: “Todos têm o direito de resistir a qualquer ordem que ofenda seus direitos, liberdades e garantias e de repelir pela força qualquer agressão, quando não seja possível recorrer à autoridade pública." ${ }^{48}$. Esse assunto será retomado no próximo tópico, para defender que mesmo sem descrição de tipo semelhante ao português, a natureza social do direito que assegura a política pública inquinada, autoriza a ocupação pacífica, sem prática de atos de violência ou depredação ambiental, podendo os movimentos sociais requisitar a força policial para lhes proteger ou facilitar a negociação e não para lhes atacar.

Ainda sobre a regulamentação dos dispositivos que restringem o direito à resistência, a Lei no 8.629 , de 25 de fevereiro de 1993, traz as ações a serem efetivadas para a desapropriação da propriedade rural que não esteja cumprindo a função social, mas conta com o $\int 6^{\circ}$ do artigo $2^{\circ}$, que proíbe vistoria, avaliação ou desapropriação do imóvel rural de domínio público ou particular que for objeto de esbulho possessório ou invasão motivada por conflito agrário ou fundiário de caráter coletivo!

É a célebre manobra de dar com uma mão e tirar com a outra!

Assim, é patente que a legislação se volta, sempre, contra os interesses dos mais pobres, destinatários da política pública sonegada, os mesmos que são criminalizados quando buscam implementá-la com suas próprias mãos. Mas que não veem ação semelhante, quando são brutalizados e chacinados em massacres anuais, numa luta contra titãs!

Esse quadro de horrores fica evidente na pesquisa realizada por NASCIMENTO, SAES e ZYLBERSZTANJ, que demonstram o risco da não implementação da reforma agrária e da expropriação da terra como principais fatores para a eclosão dos conflitos ${ }^{49}$, advertindo:

Se direitos de propriedade forem mal definidos, criam-se condições para disputas de apropriação de benefícios sobre o direito informal, conflitando entre o que é formal e informal (...) Tradicionalmente, as garantias dos direitos de propriedades são executadas pelo poder público, com sua eficiência estando relacionada ao enforcement. Quanto maior for a formalização (definição) do direito de propriedade de terra, mais o Estado pode garantir esses direitos, e os riscos de expropriação tendem a diminuir. retanto, na ausência de garantias públicas, ou do baixo enforcement do Estado, as garantias do direito de propriedade podem advir do esforço privado que, em casos extremos, chegam aos confrontos armados entre os envolvidos nas disputas pela terra..$^{50}$

47 BRASIL. Ação Penal no 0000454-65.2010.404.7118, que tramitou na 1a Vara Federal de Carazinho, no Rio Grande do Sul. Prolatada pelo Juiz Stefan Espirito Santo Hartmann. Publicada em 16 de setembro de 2014. Disponível em: http://www.trf4.jus.br/ trf4/processos/visualizar_documento_gedpro.php?local $=$ ffrs\&documento $=11435723 \&$ DocComposto $=\&$ Sequencia $=\&$ hash $=1 \mathrm{c} 3$ 31242437fa5618c21180acac63aad. Acesso em: 19 jul. 2017.

48 PORTUGAL. Constituição da República Portuguesa. VII Revisão Constitucional [2005]. Assembleia da República. Disponível em: https://www.parlamento.pt/Legislacao/Documents/constpt2005.pdf . Acesso em: 18 jul. 2017.

49 NASCIMENTO, V. E. de S; SAES, M.S.M; ZILBERSTANJ, D. Direito de propriedade, investimento e conflitos de terra no Brasil: uma análise da experiência paranaense. Revista de Economia e Sociologia Rural. São Paulo, v. 48, n. 3, 2010 , p. 17.

50 NASCIMENTO, V. E. de S; SAES, M.S.M; ZILBERSTANJ, D. Direito de propriedade, investimento e conflitos de terra no Brasil: uma análise da experiência paranaense. Revista de Economia e Sociologia Rural. São Paulo, v. 48, n. 3, 2010, p. 17-18. 
Com efeito, a questão a ser enfrentada, no atual estágio de "contrarrevolução jurídica" 51 , é se a exigência da efetivação da política de reforma agrária, por meio de ocupações, pode ser enfrentada pelo direito criminal ou, de outra forma, se o esforço privado estaria protegido pelo ordenamento jurídico, constituindo um direito político de resistência diante da omissão e da ineficiência estatais.

\section{A PROTEÇão CONSTITUCIONAL À PROPRIEDAde E A (IM)POSSIBILIDADE de CRIMINALIZAÇÃo DAS OCUPAÇÕES DE TERRA NOS CONFLTIOS AGRÁRIOS}

Conforme demonstrado, os conflitos agrários estão inseridos na historicidade brasileira desde o processo de colonização. Frente aos desdobramentos e os resultados destes conflitos, o poder público tem tentado enfrentar a temática com o reconhecimento da necessidade de adoção de política agrária que atenda aos anseios da coletividade, contudo, ao revés, vem insistindo na criminalização de atos da coletividade, dirigidos à pressão para que se adotem medidas que garantam as determinações normativas vigentes, de ordem constitucional.

A propósito, a Constituição, ao regular os princípios fundamentais da República, traz em seu artigo $1^{\circ}$, inciso III, a dignidade da pessoa humana como pilar e, em continuidade, elege como objetivos fundamentais da República, no artigo $3^{\circ}$, a construção de uma sociedade livre, justa e solidária, a erradicação da pobreza e da marginalização e a redução das desigualdades sociais e regionais, bem como, a promoção do bem de todos sem preconceitos e quaisquer outras formas de descriminação.

No que diz respeito ao direito à propriedade, o artigo $5^{\circ} \mathrm{o}$ insere no rol das garantias fundamentais individuais e coletivos, cujos desdobramentos estão nos incisos XXII, XXIII, XXIV, XXV e XXVI.

Acrescente-se que a proteção à propriedade, nos termos em que postos, ao pertencer ao rol dos direitos fundamentais individuais, é de aplicação imediata $\left(\operatorname{art.} 5^{\circ}, \S^{\circ}\right.$ ). Daí que, Thiago Penido Martins esclarece que os direitos fundamentais constituem direito subjetivos constitucionais, dotados de dimensão objetiva, que lhes possibilita irradiar efeitos sobre o ordenamento jurídico, sustentando a desnecessidade de mediação legislativa para que produzam efeitos nas relações jurídicas. ${ }^{52}$

Nesse passo, estando a propriedade situada no texto normativo constitucional e classificada como um direito fundamental, consoante lição de Robert Alexy, reclama ações estatais para sua garantia:

De acordo com a interpretação liberal clássica, direitos fundamentais são "destinados, em primeira instância, a proteger a esfera de liberdade do indivíduo contra intervenções dos Poderes Públicos; eles são direitos de defesa do cidadão contra o Estado" (...) direitos a ações negativas. (...) seu contraponto são os direitos a uma ação positiva do Estado, que pertence ao status positivo, mais precisamente ao status positivo em sentido estrito. ${ }^{53}$

Considerando então o direito à propriedade e sua função social, não se pode afastar a complementariedade do artigo 170, da Constituição, em que a propriedade privada e sua função social são princípios da ordem econômica e, dessa forma, de interesse de todos. Melhor dizendo, a conjugação desses comandos constitucionais sintetiza um direito que interessa a toda coletividade. O que, nas palavras de Robert Alexy, exige intervenção positiva do Estado para dar-lhe efetividade. Nessa altura, indiscutível que podem ser, inclusive, exigidos perante o próprio Judiciário, na linha do inciso XXXV do artigo $5^{\circ}$ da Constituição, con-

51 Conforme explica Boaventura de Sousa Santos in Ativismo judicial conservador neutraliza avanços. São Paulo: Revista Eletrônica CONJUR, 04 de dezembro de 2009. Disponível em: http://www.conjur.com.br/2009-dez-04/contrarrevolucao-juridicaativismo-judiciario-conservador?imprimir=1 . Acesso em: 18 jul. 2017.

52 MARTINS, Thiago Penido. Discriminação nas relações contratuais. Belo Horizonte: Editora D’Placido, 2016 , p. 51.

53 ALEXY, Robert. Teoria dos Direitos Fundamentais. 2. ed. 4. tir. Tradução de Virgílio Afonso da Silva. São Paulo: Malheiros Editores LTDA, 2015. p. 433. 
tando com proteção dos órgãos policiais, que assumem atribuições de mediadores para obtenção do bem da vida reivindicado.

Em suma, a questão relativa à possibilidade de ação interventiva de certa coletividade pautada por fins ideológicos, que se reconhece associada em movimentos de luta pela terra, ao provocar conflitos agrários por meio de ocupações de imóveis passíveis de desapropriação, motivada pela omissão ou ineficiência do poder público, é plenamente aceitável não só como direito à resistência contra o injusto, eis que "ninguém será obrigado a fazer ou deixar de fazer alguma coisa senão em virtude de lei” (artigo 5º II, da Constituição), como extensão da própria dignidade da pessoa humana (artigo $1^{\circ}$, III, da Constituição).

Ao enfrentar essa temática, Roberto Sanches Cunha demonstra que há divergência de posicionamentos entre o Superior Tribunal de Justiça e o Supremo Tribunal Federal, pois, para o primeiro, "o movimento popular visando a implantação da reforma agrária não caracteriza crime. Configura direito coletivo, expressão da cidadania, visando implantar programa constante da Constituição Federal de 1988. Acentuando que a pressão popular é própria do Estado Democrático de Direito (RT 747/608)" ${ }^{54}$

Por outro lado, é possível abstrair o posicionamento do STF no sentido de que, não obstante seja legítima a reivindicação para a implantação da reforma agrária, é inaceitável o despojo da propriedade alheia sem que se observem os postulados constitucionais que garantem ao indivíduo a observância do devido processo legal para a privação do bem..$^{55}$

Em sintonia com o posicionamento do Superior Tribunal de Justiça estão Luiz Regis Prado e Celso Delmanto, os quais defendem a inexistência de um delito de esbulho possessório por faltar o elemento constitutivo do tipo uma vez que a conduta da coletividade se direciona a atrair atenção do Estado, para que cumpra com a determinação constitucional de fazer a política de reforma agrária.

\section{Esclarece DELMANTO:}

Quanto a movimentos populares cujos integrantes invadem fazenda, visando exclusiva e unicamente pressionar o governo a desapropria-las, a fim de acelerar a implementação da reforma agrária prevista na CR (arts. 184 a 191), é nossa opinião que essa conduta não configura crime contra o patrimônio. Com efeito, inexiste o elemento subjetivo exigido pelo tipo, ou seja, a intenção de tomar a propriedade alheia, apropriando-se da terra. Neste termos, não há confundir-se a turbação e o esbulho da posse, previsto no CC (art. 1210 e ss.), com o crime de esbulho possessório aqui tratado, que exige o referido elemento subjetivo. ${ }^{56}$

Rogerio Greco também reconhece que as invasões de propriedades rurais ou ocupações (conforme a linguagem dos cidadãos ligados aos movimentos sociais) não se constituem crime. E o faz recorrendo à excludente pautada no estado de necessidade, defendendo existir a necessidade de uma ponderação de bens juridicamente protegidos, pois, se por um lado está o direito à propriedade, de outro está um conjunto de direitos fundamentais que, ao serem englobados, remetem a noção necessária de proteção à dignidade da pessoa humana. Nesse contexto, os indivíduos ligados ao MST possuem a necessidade de subsistência, de manutenção da própria vida no trabalho de cultivar a terra em conflito com o direito de propriedade, ainda mais quando improdutiva. Como afirma:

(...) entre a subsistência dos Sem-Terra e a exploração econômica da terra, aquela deve prevalecer em detrimento desta, podendo-se visualizar, com tranquilidade, a situação característica do estado de necessidade. É claro que não podemos confundir o raciocínio correspondente à ausência de infração penal por parte dos "invasores sem-terra", com a necessidade inafastável, do Estado de indenizar

54 CUNHA, Rogério Sanches. Manual de Direito Penal. 8. ed. rev. ampl. atual. Salvador: JusPODIVM, 2016, p. 306.

55 Conforme dito pelo Ministro Celso de Mello, do Supremo Tribunal Federal, na ADI no 2213 MC, originária do Distrito Federal, decisão publicada no Diário do Judiciário de 23 de abril de 2004. Disponível em: http://www.stf.jus.br/portal/diarioJustica/ verDiarioProcesso.asp? numDj $=77 \&$ dataPublicacaoDj $=23 / 04 / 2004 \&$ incidente $=3700822 \&$ codCapitulo $=5 \&$ numMateria $=11 \&$ cod Materia=1. Acesso em: 19 jul. 2017.

56 DELMANTO, Celso. et al. Código Penal Comentado. 8 ed. rev. atual. e ampl. São Paulo: Editora Saraiva. 2010 , p. 593. 
aqueles que tiveram seus terrenos invadidos em virtude da sua própria incapacidade em administrar a coisa pública, levando a efeito uma distribuição condigna de bens. ${ }^{57}$

Em sede de habeas corpus que alcançou o Supremo Tribunal Federal, tendo por objeto a prisão de integrantes do MST, em conflito agrário no Estado do Rio Grande do Sul, no qual o argumento da necessidade da manutenção da prisão basilava-se na necessidade de manutenção da ordem pública, interessa os seguintes trechos da decisão do Ministro Carlos Brito, ao conceder o contramandado de prisão dos indivíduos:

(...) não me parece que as condutas que embasam a prisão tenham alcance para além do objeto pretendido pelo movimento social. Com isso não quero dizer que a luta social autoriza a prática delitos, mas, tão somente, ponderar que a intranquilidade do meio social, se existente, não ultrapassa a fazenda pleiteada pelo MST. ${ }^{58}$

A afirmativa do voto demonstra a sobriedade para o enfrentamento de um tema que possui desdobramentos tão diversos para se reduzir a tão pouco como se tem visto. No ponto fulcral, Ministro esclarece que quando o objetivo for tão somente a implementação da reforma agrária, não há repercussão na ordem pública a sustentar a prisão. Ao contrário, a repercussão se situa no campo do direito privado, sem elementos a sustentar sequer a ameaça à ordem ou a tranquilidade pública. Diante disso, não há como sustentar a reclamação de normas de direito penal porque não há o uso da violência ou grave ameaça como elementos constitutivos do tipo de esbulho. Mais ainda, não havendo como traduzir a ocupação de imóvel específico em ameaça a toda uma coletividade.

É em nome da defesa da ordem pública, em detrimento dos direitos fundamentais, que seriam criminalizadas as ações implementadas pelos movimentos sociais. Ações que se amoldam a tipos penais variados, segundo Cleber Masson, para quem, diante da ação de uma pluralidade de indivíduos não se estaria frente apenas do crime de esbulho possessório, mas, de um concurso de crimes. ${ }^{59}$

Essa posição antidemocrática assumida por parte da doutrina repercute no Supremo Tribunal Federal, a se considerar a manifestação do Pleno na Ação Direta de Inconstitucionalidade n ${ }^{\circ}$ 2.213-0, sob relatoria do então Min. Celso de Melo, que reconheceu a constitucionalidade da Medida Provisória 2.183-56/01 que incluiu o $\int 6^{\circ}$ no artigo $2^{\circ}$ da Lei 8.629/93, afirmando que constitui crime o ato de ocupações de imóveis rurais por movimentos sociais:

\section{(...)}

O respeito à lei e a autoridade da Constituição da Republica representa condição indispensável e necessária ao exercício da liberdade e à prática responsável da cidadania, nada podendo legitimar a ruptura da ordem jurídica, quer por atuação de movimentos sociais (qualquer que seja o perfil ideológico que ostentem), quer por iniciativa do Estado, ainda que se trate da efetivação da reforma agrária, pois, mesmo esta, depende, para viabilizar-se constitucionalmente, da necessária observância dos princípios e diretrizes que estruturam o ordenamento jurídico nacional.

O esbulho possessório, além de qualificar-se como ilícito civil, também pode configurar-se situação revestida de tipicidade penal, caracterizando-se, desse modo, como ato criminoso (CP, art. 161, $\$ 1^{\circ}$, II; Lei ${ }^{\circ} 4.947 / 66$, art. 20). ${ }^{60}$

Sob a ótica desse posicionamento, há dois pontos que devem ser levados à reflexão uma vez que, se tais atos se constituem em crime, impõe-se ao Estado a possibilidade de reprimenda, e, desta forma, tem-se au-

57 GRECO, Rogério. Curso de Direito Penal: Parte especial. vol. 3. 10. ed. Rio de Janeiro: Impetus, 2013, p. 152.

58 BRASIL. Supremo Tribunal Federal. Habeas Corpus no 91.616-3, originário do Rio Grande do Sul. Relatado pelo Ministro Carlos Brito. Decisão de 30 de outubro de 2007, p. 317. Disponível em: http://redir.stf.jus.br/paginadorpub/paginador. jsp?doc'TP=AC\&docID=499430. Acesso em: 19 jul. 2017.

59 MASSON, Cleber. Direito Penal: Parte Especial. v. 2. 9. ed. rev. atual. Rio de Janeiro: Forense; São Paulo: Metodo, 2016 , p. 523. 60 BRASIL. Supremo Tribunal Federal. Ação Direta de Inconstitucionalidade no 2213/MC, originária do Distrito Federal, relatada pelo Ministro Celso de Mello, decisão publicada no Diário do Judiciário de 23 de abril de 2004. Disponível em: http://www. stf.jus.br/portal/diarioJustica/verDiarioProcesso.asp?numDj=77\&dataPublicacaoDj=23/04/2004\&incidente=3700822\&codCapi tulo=5\&numMateria=11\&codMateria=1. Acesso em: 19 jul. 2017. 
torização para (i) a utilização do poder de polícia, com utilização da força para a prisão de quem se encontre em flagrante delito, tratando-se de crime permanente, em que o estado de flagrância se perpetua no tempo; (ii) o resultado que poderá emergir dessa intervenção de força - e que se traduz em ameaça a direitos de ordem fundamental, quando o fato em si poderia ser conduzido sob a batuta de outras ações previstas - é impossível a previsão de resultados em toda sua extensão, podendo atingir, como tem atingido, o ápice do indesejável, com a morte de pessoas. ${ }^{61}$

\section{É isso mesmo que se quer num Estado Democrático de Direito?}

Aliás, a recorrência de mortes de cidadãos ligados a movimentos de luta pela terra é alvo de acompanhamento por vários organismos, dentre eles a Comissão Pastoral da Terra - CPT, que vem difundindo dados e informações sobre esses conflitos, demonstrando que de 2007 a 2016340 pessoas foram assassinadas. E de 1985 a 2017 houve 45 massacres $^{62}$ somando-se à morte de 214, em nove Estados brasileiros. ${ }^{63}$

Ainda assim, em 2005 foi criada a Comissão Parlamentar Mista de Inquérito - CPMI, no Congresso Nacional, para proceder à análise de casos que repercutiram no cenário nacional diante da violência no campo. Contudo, de se pasmar, em seu relatório final é possível encontrar proposta legislativa para alteração do Código Penal e da Lei de Crimes Hediondos para prever o esbulho possessório com fins políticos e enquadrá-lo no rol de tais ilícitos. Ou seja, permanece a crença de que a resolução do problema deve ser encaminhada com utilização da repressão estatal.

Até quando?

\section{Considerações finais}

Impossível desconsiderar que os problemas afetos à implementação de política de reforma agrária, que atenda os objetivos esculpidos pela Constituição, têm raízes fundas e intrincadas no passado, que traduzem o jogo de interesses de uma minoria que possuía e possui o poder de influenciar o Estado - capacidade esta que, quando não, revela a leniência do Estado de papel, que não consegue sair dos textos legislativos, cultivando ineficiência deliberada e perversa de seus aparelhos administrativos.

A considerar o atual estágio evolutivo da sociedade, na tentativa de construção do Estado Democrático de Direito, é impossível não reconhecer a capacidade desta, de molde a manifestar sua insatisfação, buscando provocar mudanças comportamentais do poder público, para realização da promessa de vida boa que motivou sua instituição.

Nessa nave, a política de criminalização da ocupação de terras, como meio de reprimir a resistência dos excluídos, além de inconstitucional, tem se apresentado como combustível a alimentar ainda mais a revolta. Ou seja, não se revela útil sob qualquer aspecto.

Em contraponto, a ocupação de propriedades rurais, sem qualquer outro ato de violência, além de não se amoldar à tipicidade de qualquer norma penal vigente no Estado brasileiro, se revela direito à resistência

61 No Estado do PARA, no dia 24 de maio de 2017, após intervenção das polícias civil e militar para cumprimento de 14 mandados de prisão contra suspeitos de envolvimento na morte de um segurança da fazenda Santa Lucia, propriedade que é objeto de conflito agrário, resultou na morte de 10 pessoas. O caso está sob investigação da Polícia Federal. Conforme noticiou o Portal Eletrônico G1. Disponível em: http://g1.globo.com/pa/para/noticia/policia-federal-reconstitui-chacina-que-resultou-na-mortede-10-pessoas-em-pau-darco.ghtml. Acesso: 17 jul. 2017.

62 De acordo com a sua metodologia, a CPT reconhece como "massacre" casos em que um número igual ou maior que três pessoas foram mortas na ocasião.

63 Comissão Pastoral da Terra. Conflitos no campo Brasil 2016. Coordenação: Antônio Canuto, Cássia Regina da Silva Luz, Thiago Valentin Pinto Andrade. Goiânia: CPT Nacional. Disponível em: https://www.cptnacional.org.br/component/jdownloads/ send/41-conflitos-no-campo-brasil-publicacao/14061-conflitos-no-campo-brasil-2016. Acesso em: 19 jul. 2017. 
contra o injusto, e se destina à efetivação de política pública importante para o equilíbrio e o progresso do país.

\section{REFERÊNCIAS BIBLIOGRÁFICAS}

ALEXY, Robert. Teoria dos Direitos Fundamentais. 2. ed. 4. tir. Tradução de Virgílio Afonso da Silva. São Paulo: Malheiros Editores LTDA, 2015.

BERGOVICI, Gilberto. Constituição Econômica e desenvolvimento: uma leitura a partir da constituição de 1988. São Paulo: Malheiros, 2005.

BITENCOURT, M.V.L; SCHMITZ, A, P. O estatuto da terra no confronto do pensamento econômico: Roberto Campos versus Celso Furtado. Economia e Sociedade, Campinas, v. 23, n. 3 (52), p. $577-$ 609, dez. 2014.

CAMPOS, Raymundo. História da América. 2. ed. rev. amp. São Paulo: Ática, 1991.

CANOTILHO, J.J. Gomes. Direito constitucional e teoria da constituição. 7. ed. 4. reimp. Portugal: Edições Almedina, 2003.

CPT, Comissão Pastoral da Terra. Conflitos no Campo Brasil 2016. Goiania: CPT Nacional-Brasil, 2016

CUNHA, Rogério Sanches. Manual de Direito Penal. 8. ed. rev. ampl. atual. Salvador: JusPODIVM, 2016.

DE PAULA, Roberto. Direito e conflitos agrários: mecanismos de entrave e acesso a justiça e de efetivação de direitos. Artigo hospedado na plataforma Publica Direito. Disponíveis em: $<$ http://www. publicadireito.com.br/artigos/?cod=46bc56d0ff6bad9d>. Acesso em 10 ago. 2017.

DELMANTO, Celso. et al. Codigo Penal Comentado. 8 ed. rev. atual. e ampl. São Paulo: Editora Saraiva. 2010.

FAUSTO, Boris. Historia do Brasil. 13 ed. 1 reimp. São Paulo: Editora da Universidade de São Paulo, 2009.

FERNANDES, B. M. STEDILE, J. P. Brava Gente: A trajetória do MST e luta pela terra no Brasil. 3 reimp. São Paulo: Editora Fundação Perseu Abramo, 2005.

GORENDER, Jacob. O Escravismo Colonial. Ensaios - 29, 2. ed. São Paulo: Ática, 1978.

GRECO, Rogério. Curso de Direito Penal: Parte especial. vol. 3. 10. ed. Rio de Janeiro: Impetus, 2013

MADEIRO, Carlos. Maior massacre desde Eldorado dos Carajás faz 2017 ter recorde de mortes no campo. Maceió: Uol Noticias Cotidiano, 27 de maio de 2017. Disponível em: https://noticias.uol.com. br/cotidiano/ultimas-noticias/2017/05/27/maior-massacre-desde-eldorado-dos-carajas-faz-2017-ter-recorde-de-mortes-no-campo.htm . Acesso em 18 jul. 2017.

MIRANDA, Newton Rodrigues. Breve histórico da questão das terras devolutas no Brasil e dos instrumentos legais de posse sobre esses bens. Revista do CAPP, Belo Horizonte, v. XVII, n. 2, p. 153 176, 2011.

MARTINS, Thiago Penido. Discriminação nas relações contratuais. Belo Horizonte: Editora D’Placido, 2016

MASSON, Cleber. Direito Penal: Parte Especial. v. 2. 9. ed. rev. atual. Rio de Janeiro: Forense; São Paulo: Metodo, 2016.

NASCIMENTO, V. E. de S; SAES, M.S.M; ZILBERSTANJ, D. Direito de propriedade, investimento e conflitos de terra no Brasil: uma análise da experiência paranaense. Revista de Economia e Sociologia 
Rural. São Paulo, v. 48, n. 3, p. 705-748, 2010

PAUPERIO, A. Machado. O direito político de resistência. 2. ed. rev. atual. Rio de Janeiro: Forense, 1978.

PRADO, Luiz Regis. Comentários ao Código Penal: Doutrina, jurisprudência selecionada, conexões lógicas com o ramo do direito. 4 ed. rev. atual. e ampl. São Paulo: Editora Revista dos Tribunais. 2007.

RAWLS. John. Teoria da Justiça. $3^{\mathrm{a} e}$. São Paulo: Martins Fontes Editores, 2008.

ROCHA POMBO, José Francisco da. História do Brasil. 13 ed. vol. I. São Paulo: Editora Egéria S/A, 1966.

TARDELLI, Brenno. Acusar manifestante de quadrilha é opção ideológica. São Paulo: Revista Eletrônica CONJUR, 14 de junho de 2013. Disponível em: http:/ /www.conjur.com.br/2013-jun-14/brennotardelli-acusar-manifestante-quadrilha-opcao-ideologica . Acesso em: 19 ago. 2017.

SILVA, Marcio Antonio Both da. Lei de Terras de 1850: Lições sobre os efeitos e os resultados de não se condenar "uma quinta parte da atual população agrícola". Revista Brasileira de Historia. São Paulo, v. 35 , n. 70 , p. $87-107,2015$ 


\section{REVISTA BRASILEIRA DE POLÍTICAS PÚBLICAS BRAZILIAN JOURNAL OF PUBLIC POLICY}

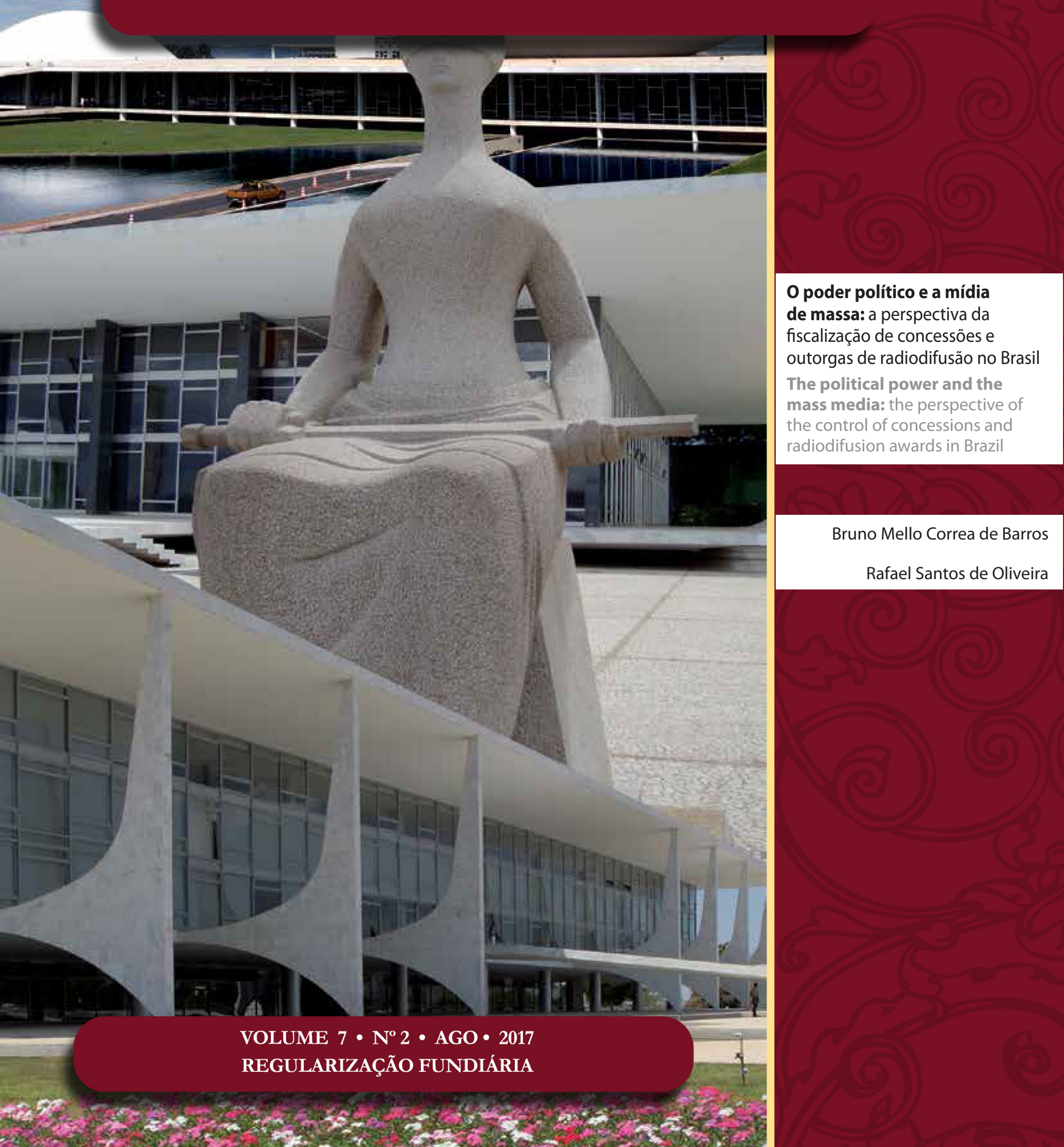




\section{O poder político e a mídia de massa: a perspectiva da fiscalização de concessões e outorgas de radiodifusão no Brasil*}

\author{
The political power and the mass media: the \\ perspective of the control of concessions and \\ radiodifusion awards in Brazil
}

Bruno Mello Correa de Barros**

Rafael Santos de Oliveira***

\section{Resumo}

Este artigo tem o condão de promover uma observância acerca da conjuntura que atravessa os meios de comunicação no Brasil a partir da interferência do poder político nesse meandro. Com base em tal quadro, pretende-se visualizar a atuação fiscalizatória do Ministério Público Federal no que diz respeito a concessões e outorgas do serviço de radiodifusão a parlamentares no exercício de mandato eletivo e a pressão política exercida em tal âmbito. Dessa forma, a partir dessa narrativa determinada, pretende-se analisar os casos em que há descumprimento do preceito constitucional. Para tanto, utilizou-se o método de abordagem indutivo, em virtude da observância dos casos de descumprimento da legislação constitucional gerando a expectativa de uniformização de condutas em um cenário que recai sobre os demais atores. No que diz respeito à técnica de pesquisa, serviu-se da técnica baseada em fonte documental, com pesquisa em doutrina, artigos e escritos sobre a temática ora apresentada, bem como as posições do MPF acerca do assunto tratado.

Palavras-Chave: Comunicação. Fiscalização. Mandato eletivo. Meios de comunicação. Parlamentares.

\section{Abstract}

This article seeks to promote an observance about the conjuncture that the media in Brazil goes through from the interference of the political power. From this framework it is intended to visualize the inspection of the Public Prosecutor's Office (MPF) regarding the concessions and grants of the broadcasting service to parliamentarians in the exercise of elective term and the political pressure exerted in such scope. Thus, from this determined narrative, a representative view of the cases in which there is noncompliance with the constitutional precept is intended. In order to perform the work, the method of inductive approach was used, the analysis of the cases of noncompliance with the constitutional legislation, generates the expectation of standardization of conduct in a scenario that falls on other actors. With 
regard to the research technique, we used the technique based on documentary source, with research in doctrine, articles and writings on the subject presented here, as well as the positions of the MPF on the subject treated.

Keywords: Communication. Elective mandate. Media. Oversight. Parliamentarians.

\section{INTRODUÇÃO}

“Todo o indivíduo tem direito à liberdade de opinião e de expressão, o que implica o direito de não ser inquietado pelas suas opiniões e o de procurar, receber e difundir, sem consideração de fronteiras, informações e ideias por qualquer meio de expressão". Com base no texto extraído da Declaração Universal dos Direitos Humanos, datada de 1948, é possível visualizar o caráter imperioso da informação, de modo que tal configuração implica a observação dos fenômenos e atores sociais que permeiam tal direito de ampla e massificada importância no contexto hodierno.

Nesse sentido, o poder de influência sobre o pensamento das pessoas é exercido por meio da comunicação de forma que se constitui em uma ferramenta de resultado incerto, contudo, fundamental. Imperioso registrar que é por meio da ingerência exercida sobre o pensamento dos povos que os poderes se constituem em sociedade e que as sociedades evoluem e mudam. Os meios de comunicação potencializam a construção de pesos simbólicos que se difundem na esfera pública, dando suporte a diversas pautas da sociedade, nesse seguimento, a esfera pública pode ser descrita como uma rede adequada para a comunicação de conteúdos, tomada de posição e opiniões. Nela os fluxos comunicacionais são filtrados e sintetizados em opiniões públicas enfeixadas em termos específicos.

Destarte, a comunicação é um processo cuja construção se dá mediante espaços em que o diálogo, a pluralidade de vozes e a dissidência são respeitados, uma vez que a informação constitui-se pedra angular no regime democrático, balizando relações e interesses políticos, econômicos e culturais, sobretudo hodiernamente, visto que esta passou a constituir-se como um bem jurídico de alta relevância, seja para a tomada de decisões pessoais, para o conhecimento da realidade ou para se obter consciência plena ao se decidir. Dentro dessa configuração se desenvolve o presente artigo, com fulcro na observância de uma atuação fiscalizatória acerca do processo de concessão de outorgas do serviço de radiodifusão a parlamentares no exercício de mandato eletivo, bem como da pressão política existente no âmbito comunicacional brasileiro.

Sendo assim, o artigo foi estruturado com base em três tópicos, sendo o primeiro direcionado a uma visualização acerca dos pressupostos que condicionaram os meios de comunicação e as mídias à uma concentração hegemônica, bem como a edificação de uma sociedade informacional, baseada nos avanços tecnológicos e digitais da contemporaneidade. O segundo ponto tem o condão de promover uma observância das mídias e o controle da informação na perspectiva brasileira, apontando as nuances das prerrogativas observadas nesse contexto. Por fim, o terceiro e último ponto abarcado no artigo presta-se a tratar sobre o processo fiscalizatório das concessões e outorgas de radiodifusão no Brasil para parlamentares no exercício de mandato eletivo, o qual é atribuição do Ministério Público Federal, no mesmo parâmetro à observância da pressão política existente nesse meandro.

Para a feitura do trabalho, utilizou-se o método de abordagem indutivo, em virtude da observância dos casos de descumprimento da legislação constitucional gerando a expectativa de uniformização de condutas em um cenário que recai sobre os demais atores. Em relação ao procedimento, optou-se pelo monográfico. No que diz respeito à técnica de pesquisa, serviu-se da técnica baseada em fonte documental, com pesquisa em doutrina, artigos e escritos sobre a temática ora apresentada, bem como nas posições do MPF acerca do assunto tratado. 


\section{A COMUNICAÇÃo E A CONCENTRAÇÃo DE MÍDIAS E MEIOS NO PANORAMA DA SOCIEDADE INFORMACIONAL}

Vive-se em uma sociedade marcada pelos constantes fluxos de comunicação, amplamente exercidos pela cidadania, os quais, a partir da televisão, rádio, imprensa escrita, computadores e outras tecnologias recebem uma carga cada vez maior de informação e de conteúdos que carregam notícias. A partir desses constantes fluxos informacionais, recebem-se conteúdos que auxiliam a compreensão de mundo, formando a identidade de um povo, fortalecendo a cultura, determinando os assuntos que serão pauta de conversas entre amigos, família e demais atores da sociedade. Esse quadro propicia a construção da opinião pública e de igual forma condiciona a participação na vida política do país.

Muito embora tenha se ampliado os canais de informação, haja vista a amplitude das Tecnologias da Informação e Comunicação (TIC), especialmente a Internet ${ }^{1}$, os meios de comunicação de massa, traduzidos na Televisão e no rádio, sobretudo, respondem pela grande margem de cobertura em se tratando de acesso - amplo, irrestrito e gratuito, já que atingem quase que a cobertura completa do território nacional. Destarte, com a revolução dos meios técnico-científicos, os quais puderam auxiliar na transformação da sociedade industrial, a informática juntamente às telecomunicações, foram as responsáveis pelo surgimento de uma nova morfologia social, que posiciona a informação como ativo econômico impulsionador, funcionando como centro de desenvolvimento na contemporaneidade.

Assim, com todo esse cenário emergente de comunicações, informação, informática e tecnologias digitais, surge a sociedade da informação, ou sociedade informacional. Essa expressão é utilizada por Castells ${ }^{2}$ para definir a evolução tecnológica e o novo modus vivendi que se desenvolveu a partir dos anos 70, tendo como berço os Estados Unidos. Por sua vez, as grandes empresas dos mais diversos ramos de atividades tiveram de se adequar aos novos ditames da tecnologia, operacionalizando, tecnologicamente, os seus serviços e, no ramo das corporações de comunicação, não foi diferente, visto que tiveram de adaptar-se a um novo meandro de convergência midiática e tecnológica, que modifica e transforma o condicionamento e a busca por informação.

Em que pese à globalização do mundo por meio da inserção de novas tecnologias da informação e comunicação, muitos, ainda, são os desafios que se apresentam quando se trata das mídias tradicionais que são as mais acessíveis a uma parte da população e responsáveis pela geração de informação e entretenimento. Nesse sentido, a respeito do que se pode entender como mídias tradicionais e novas mídias, Colombo ${ }^{3}$ define como mídias tradicionais os meios, de comunicação, de representação e conhecimento.

Já a noção de novas mídias diz respeito à digitalização do sinal e do seu conteúdo, que possuem dimensões de multimídia e interatividade. Silverstone $e^{4}$ igualmente contribui para a procura de uma definição para novas mídias quando ressalva que, olhadas isoladamente, as supostas características distintas das novas mídias (convergência digital ${ }^{5}$, comunicação de muitos para muitos, interatividade, globalização e virtualida-

\footnotetext{
1 A história do desenvolvimento da Internet é abordada por vários autores, que apontam a década de 90 como o marco do surgimento da World Wide Web (WWW) que, através de programas capazes de utilizar a interface gráfica, possibilitaram melhor trânsito de dados na rede. Posteriormente, com o desenvolvimento dos servidores de acesso, este serviço disseminou entre a população. Embora tenha se iniciado a partir de interesse militar, com o fito de proteger as informações do Estado norte-americano no período da Guerra Fria, o desenvolvimento da rede se deu, em grande parte, a partir da colaboração dos estudantes da pós-graduação e pesquisadores norte-americanos, que atuaram na própria rede.

CASTELLS, Manuel. A Galáxia da Internet: reflexões sobre a internet, negócios e a sociedade. Traduzido por Maria Luiza X. de A. Borges. Rio de Janeiro: Jorge Zahar, 2004.

2 CASTELLS, Manuel. A sociedade em rede: A Era da Informação: economia, sociedade e cultura. Tradução de Roneide Venâncio Majer. São Paulo: Paz e Terra, 1999. p. 26.

3 COLOMBO, F. Il videogioco come mezzo di comunicazione. 1995. Disponível em: <http://www.telecomitalia.it/estudi/chieric6. htm>. Acesso em: 21 abr. 2017.

4 SILVERSTONE, R. Television and everyday life. London: Routledge, 1995.

5 Por convergência entende-se o fluxo de conteúdos através de múltiplos suportes midiáticos, à cooperação entre múltiplos mer-
} 
de) são, na maioria dos casos, não diretamente novas. A novidade é a sua conjugação num mesmo suporte tecnológico.

No que diz respeito aos meios de comunicação tradicionais e sua ampla utilização pelos indivíduos sociais, cumpre observar os dados apresentados pela Pesquisa Brasileira de Mídia 2016, realizada pela Secretaria de Comunicação Social da Presidência da República, que demonstra que, segundo as entrevistas realizadas e base de amostragem, a Televisão constitui-se como o meio de comunicação com maior apelo, totalizando $63 \%$ dos dados coletados, como o veículo mais utilizado para informação, seguido pela Internet, com $26 \%{ }^{6}$. Do mesmo modo, a TV apresentou o seu uso quotidiano pela população a partir de dados que contabilizam 77\% da utilização de segunda a sexta-feira. Globo, Record e SBT, respectivamente, apresentam 56, 12 e $11 \%$, das emissoras de TV aberta mais vistas?.

Muito embora, com toda essa evolução técnica e tecnológica, propiciada pelo incremento das tecnologias informacionais, Internet e digitalização, os meios de comunicação de massa ou tradicionais, de acordo com os dados trazidos pela Pesquisa Brasileira de Mídia 2016, ainda se constituem como os potenciais formadores de opinião e que possibilitam o acesso livre e gratuito à informação, haja vista que ainda continuam em processo de concentração privada.

Nesse passo, tal quadro de um sistema organizado em redes de comunicação foi consolidado no Brasil a partir dos anos 70. O projeto de desenvolvimento econômico-político, com viés nacionalista, implementado por meio dos regimes militares iniciados em 1964, foi um dos principais responsáveis por este rápido desenvolvimento $^{8}$. Desse modo, a Ditadura Militar, também, propiciou a hegemonia no setor comunicacional promovendo a confecção de balizas normativas e instituições. A esse respeito, Capparelli, Ramos e Santos ${ }^{9}$ aduzem:

Os militares brasileiros priorizaram alguns setores estratégicos da economia, investindo em infraestrutura para o desenvolvimento industrial acelerado e fortemente controlado. As telecomunicações estavam entre esses setores estratégicos e foram fortemente privilegiadas. Durante os primeiros períodos militares, entre 1965 e 1972, foram criados a Embratel, o Ministério das Comunicações e o Sistema Telebrás, possibilitando a implantação de uma sofisticada infraestrutura de telecomunicações que ligaria os quatro cantos do País, inicialmente por uma rede de microondas, complementada depois por satélites nacionais e, mais tarde, também por extensas ligações físicas por fibras 'ópticas. Esses investimentos do Sistema Telebrás favoreciam, no campo da comunicação de massa, a formação de redes de televisão nacionais.

Reestabelecida a democracia, a partir da Constituinte e da promulgação da Constituição Federal de 1988, que se formalizou como uma carta de direitos progressistas, em estabelecer direitos fundamentais, garantias e demais balizas normativas, no campo da comunicação muito pouco foi realizado, em termos de efetividade das diretrizes ali configuradas. O processo de concentração de mídias e meios continuou caminhando para a consolidação da mídia privada e comercial.

cados midiáticos e ao comportamento migratório dos públicos dos meios de comunicação, que vão a quase qualquer parte em busca de experiências de entretenimento que desejam. Convergência é uma palavra que consegue definir transformações tecnológicas, mercadológicas, culturais e sociais, dependendo de quem está falando e do que imaginam estar falando. JENKINS, Henry. Cultura da Convergência. Tradução de Susana Alexandria. São Paulo: Aleph, 2008. p. 27.

6 RELATÓRIO Final da Pesquisa Brasileira de Mídia 2016. Secretaria da Comunicação da Presidência da República, 29 agosto, 2016. Brasília, DF. Disponível em: < http://www.secom.gov.br/atuacao/pesquisa/lista-de-pesquisas-quantitativas-e-qualitativas-decontratos-atuais/pesquisa-brasileira-de-midia-pbm-2016.pdf/view>. Acesso em: 21 abr. 2017.

7 RELATÓRIO Final da Pesquisa Brasileira de Mídia 2016. Secretaria da Comunicação da Presidência da República, 29 agosto, 2016. Brasília, DF. Disponível em: <http://www.secom.gov.br/atuacao/pesquisa/lista-de-pesquisas-quantitativas-e-qualitativas-decontratos-atuais/pesquisa-brasileira-de-midia-pbm-2016.pdf/view>. Acesso em: 21 abr. 2017.

8 SANTOS, Suzy; CAPPARELLI, Sérgio. Coronelismo, radiodifusão e voto: a nova face de um velho conceito. In: BRITTOS, Valério Cruz; BOLAÑO, César Ricardo Siqueira (Org.). Rede Globo: 40 anos de poder e hegemonia. São Paulo: Paulus, 2005. v. 1, p. 02 .

9 CAPPARELLI, Sérgio; RAMOS, Murilo C; SANTOS, Suzy. A nova televisão no Brasil e na Argentina. In: sós: A nova televisão no Cone Sul. Porto Alegre: LPM, 1999. p. 11. et al. Enfim, 
Ocorre que, desde a implementação do Programa Nacional de Desestatização, em 1991, as privatizações alcançaram níveis altíssimos e, dessa forma, também ocorreu em relação ao campo da privatização da mídia, deixada a cargo da iniciativa privada. Assim, aconteceu com a quebra do monopólio Estatal das telecomunicações, pela emenda constitucional no 8 de 1995, favorecendo a entrada de capital estrangeiro no país e não impedindo a propriedade cruzada ${ }^{10}$.

As políticas de governo, durante a presidência de Fernando Henrique Cardoso, basearam-se em uma teoria da justificação, já que o discurso era de que o aumento da competitividade seria garantidor de um melhor serviço prestado a população, além de importar a inserção do país no processo de globalização. Ocorre que do monopólio estatal passou-se para um oligopólio privado e a "experiência em outros países indica que, enquanto os usuários pessoas físicas pouco ou nada ganham com a privatização, os usuários empresariais são geralmente beneficiados ${ }^{11}$ ".

No atual cenário do Brasil, o sistema de mídias é caracterizado por ser Trusteeship Model, o que diz respeito à opção do Estado brasileiro em privilegiar a atividade midiática como privada e comercial; é, também, No Law, no que se refere à ausência de legislações reguladoras do tema, contando, apenas, com defasado Código Brasileiro de Telecomunicações do ano de 1962 e sem preocupações com a denominada propriedade cruzada $^{12}$; trata-se de Oligarquias políticas e familiares, que controlam não somente a mídia, mas, também, a política de determinadas regiões. Além disso, é pautada pela inserção de Igrejas no controle das programações como forma de disseminação de suas ideologias; e, por fim, é caracterizada pela hegemonia de um único grupo privado, qual seja a rede Globo $^{13}$.

Dentre a conjunção de fatores que geram a concentração de mídias e meios, está a desregulamentação do tema, a concessão irrestrita de licenças e a vinculação delas as estratégias políticas devido ao grande poder das mídias, bem como as espécies de concentração horizontal e vertical, assim entendidas ${ }^{14}$ :

A integração horizontal (fusões dentro do mesmo segmento e ramo de atividade) como a integração vertical (controle por parte de um único indivíduo, empresa ou grupo de elementos-chave dos processos de produção e distribuição, assim como atividades correlatas, como publicidade).

Nesse aspecto, todo o processo histórico e ainda atual de concentração midiática tem grande força no sistema de concessões, centrado em uma espécie de "troca de favores" entre grandes empresas e interesses do Estado. Sobre esse processo, $\mathrm{Lima}^{15}$ refere seis itens dessa realidade: Primeiro: Existem normas legais diferentes para a concessão dos serviços de televisão aberta ou por assinatura; Segundo: as emissoras de TV e rádio são concessões de serviços públicos outorgados pela União - com a participação do Congresso Nacional - com prazos de 15 e 10 anos respectivamente; Terceiro: as regras para renovação e cancelamento das licenças dentro do texto constitucional criam assimetria em relação aos demais contratos de prestação de serviços públicos; Quarto: os critérios que devem pautar as programações das emissoras não são levados em conta na concessão; Quinto: as normas de complementariedade e vedação ao monopólio ou oligopólio não são observadas no processo de concessão; Sexto: coronelismo eletrônico.

Merece destaque esse último item da lista, o coronelismo eletrônico, em que "a moeda de troca continua sendo o voto, como no velho coronelismo. Só que não mais com base na posse da terra, mas no controle

10 LIMA, Venício Artur de. Mídia: teoria e política. 2 ed. São Paulo: Fundação Perseu Abramo, 2004. p. 120.

11 LIMA, Venício Artur de. Mídia: teoria e política. 2 ed. São Paulo: Fundação Perseu Abramo, 2004. p. 135.

12 É quando o mesmo grupo controla diferentes mídias, como TV, rádios e jornais. Na maior parte das democracias consolidadas, há limites a essa prática por se considerar que ela afeta a diversidade informativa.

OBSERVATÓRIO DO DIREITO À COMUNICAÇÃO. [Homepage]. 2015. Disponível em: <http://www.intervozes.org.br/direitoacomunicacao/>. Acesso em: 21 abr. 2017.

13 LIMA, Venício Artur de. Regulação das comunicações. História, poder e direitos. São Paulo: Paulus, 2011. p. 27-30.

14 UNESCO. Indicadores de Desenvolvimento da Mídia: Marco para a avaliação do desenvolvimento dos meios de comunicação. Brasília: UNESCO, 2010. p. 23.

15 LIMA, Venício Artur de. Regulação das comunicações. História, poder e direitos. São Paulo: Paulus, 2011. p. 82-88. 
da informação, vale dizer, na capacidade de influir na formação da opinião pública ${ }^{16 "}$. Por assim dizer, em determinadas regiões e localidades do Brasil, a grande mídia possui tanta influência que as suas agendas pautam o resultado das eleições, propiciando uma troca de favores com políticos que atuam na outorga das suas licenças. Nesse sentido, Delarbe ${ }^{17}$ sustenta que "existem diversas reflexões acerca da relação entre mídia e democracia levando em conta o papel fundamental que os meios de comunicação têm para a consolidação dos regimes políticos mais contemporâneos. "

Ainda, sobre a realidade que enfrenta o Brasil e muitos países da América Latina, Delarbe ${ }^{18}$ refere que:

A concentração dos meios de comunicação é uma tendência corporativa e, portanto, também cultural, política e social em todo o mundo. Mas em alguns países latino-americanos a realidade no cenário da mídia é mais grave porque nem sempre existem restrições legais sobre a propriedade de muitos veículos que significa um pequeno número de mãos.

É evidente que essa realidade precisa ser transformada, pois interfere, diretamente, em questões democráticas, essenciais para a consolidação do Estado de direito e preservação das garantias dos cidadãos. $\mathrm{O}$ direito a uma livre informação e pluralidade de fontes deve se sobressair aos interesses econômicos dos grupos de comunicação e mídia privada, ao passo que se deve investir na regulação da agenda desses veículos e na regularidade das concessões. É essa realidade de controle da informação, questões e assuntos, aliados a interesses políticos, sociais e econômicos que se passará a estudar.

\section{As MÍdIAS E O CONTROLE DA INFORMAÇÃo NA PERSPECTIVA BRASILEIRA}

A globalização modificou o panorama no setor de comunicações, de uma forma nunca antes imaginada, o que provocou a concentração da propriedade e a consolidação e emergência de um reduzido número de megaempresas mundiais. Disso decorre uma ampla redução anual das empresas que controlam jornais, revistas, rádios, televisão, livros e filmes, não sendo possível delinear as empresas dominantes em cada mídia separadamente ${ }^{19}$.

\section{Segundo Observatório do Direito à Comunicação ${ }^{20}$ :}

As famílias da comunicação brasileira, uma vez que não enxergam quaisquer limites para expandir seus negócios, estendem seus tentáculos às principais modalidades de comunicação de massa, e o fazem através das grandes redes de televisão aberta. Como é o caso de Globo, SBT e Bandeirantes. Um importante estudo feito em 2002 pelo Instituto de Estudos e Pesquisas em Comunicação (Epcom), intitulado Os donos da Mídia, sobre os meios de comunicação no Brasil mostra que essas três redes nacionais, além de Record, Rede TV! e CNT, estão aglutinados 668 veículos em todo o país. São 309 canais de televisão, 308 canais de rádio e 50 jornais diários. Os chamados "donos da mídia" no Brasil, então, são as famílias que controlam as redes privadas nacionais de TV aberta e seus 138 grupos regionais afiliados, que são os principais grupos de mídia nacionais.

No entanto, pesquisas ${ }^{21}$ apontam um movimento ascendente de concentração da mídia nacional nos

16 LIMA, Venício Artur de. Regulação das comunicações. História, poder e direitos. São Paulo: Paulus, 2011. p. 106.

17 DELARBE, Raúl Trejo. Muchos médios em pocas manos: concentración televisiva y democracia em América Latina. INTERCOM Revista Brasileira de Ciências da Comunicação, São Paulo, v. 33, n. 1, p. 17-51, jan./jun. 2010. p. 19.

18 DELARBE, Raúl Trejo. Muchos médios em pocas manos: concentración televisiva y democracia em América Latina. INTERCOM Revista Brasileira de Ciências da Comunicação, São Paulo, v. 33, n. 1, p. 17-51, jan./jun. 2010. p. 22.

19 LIMA, Venício Artur de. Mídia: teoria e política. 2 ed. São Paulo: Fundação Perseu Abramo, 2004. p. 91.

20 PORQUE e como se limita a propriedade cruzada, 2011. Disponível em: <http://www.intervozes.org.br/ direitoacomunicacao/?p=25290>. Acesso em 21 abr. 2017.

21 A relação direta entre o poder econômico de uma região e o grau de concentração e pluralidade dos meios de comunicação, leva a uma distribuição extremamente desigual no que se refere ao acesso desses meios a toda a sociedade.

OBSERVATÓRIO DO DIREITO À COMUNICAÇÃO. [Homepage]. 2015. Disponível em: <http://www.intervozes.org.br/direitoacomunicacao/>. Acesso em: 21 abr. 2017. 
últimos anos, por consequência de uma redução drástica de grupos no comando dos principais veículos de comunicação do Brasil. Isso se deve à retirada da lista das famílias Bloch, Levy, Nascimento Brito e Mesquita, que não exercem mais controle direto sobre seus veículos de comunicação. Conforme Bem H. Bagdikian apud Lima 22, "O número de empresas que controla essas mídias tem encolhido":

De 50 grandes empresas [corporations] em 1984, para 26 em 1987, seguidas de 23 em 1990 e, então, na medida em que as fronteiras entre as diferentes mídias começam a explodir, para menos de 20, em 1993. Em 1996 o número de grandes empresas de mídia com poder dominante na sociedade épróximo de de:

Lima $^{23}$ destaca o estudo realizado no início de 2000 pela LAFIS ${ }^{24}$, que aponta que, apenas, quatro ou cinco grupos, não somente nos Estados Unidos, dominarão todas as formas de mídia, desde a imprensa tradicional, internet, cinema, rádio, televisão, videogames. Trata-se de um processo de consolidação vertical e horizontal das diferentes formas de mídia, que apresenta como resultado uma simbiose entre o poder político e econômico.

Tal processo ocorre em função da necessidade de elevados investimentos, conduzindo a integração horizontal, vertical e cruzada da indústria de comunicações, isto é, a ação coordenada de várias empresas no mesmo grupo torna-se inevitável e mais eficiente do que a de empresas isoladas ${ }^{25}$. No Brasil, pouco tempo atrás, a propriedade e o controle das telecomunicações eram monopólio do Estado e foi transferido para alguns poucos oligopólios privados. Nesse sentido, Venício Artur de Lima ${ }^{26}$ afirma que "a indústria de informática, depois de uma frustrada tentativa de reserva de mercado para as indústrias nacionais, consolida-se por meio da presença no mercado dos global players da área."

Percebe-se a ausência de uma legislação uniforme para o setor, pois, mesmo que a Constituição Federal de 1988, no $\ 5^{\circ}$ do art. 220 tenha estabelecido que os meios de comunicação social não podem, direta ou indiretamente, ser objeto de monopólio ou oligopólio, a legislação infraconstitucional não estabelece limites ${ }^{27}$, tampouco controle da concentração da propriedade. Com o mesmo propósito, o referido autor elenca, ainda, mais três fatores que têm contribuído para a concentração da propriedade das comunicações no Brasil ${ }^{28}$ :

(1) a ineficácia da norma legal (Decreto 236/67), que limita a participação societária de 'entidades' de radiodifusão a cinco concessões em VHF, em nível nacional, e a duas em UHF, em nível regional (estadual). Por razões inexplicáveis o Ministério das Comunicações, que deve fiscalizar o cumprimento da lei, interpreta "entidade" como "pessoa física" e considera, portanto, a óbvia situação de propriedade cruzada que predomina em vários grupos de mídia do país como observando as limitações legais. Só a Rede Globo de Televisão tem participação societária em 32 emissoras de televisão, sendo que dez são próprias (LOBATO, 16/09/2000); (2) o período de carência legal para venda das concessões de radiodifusão, isto é, para a troca legal de proprietários, é de apenas cinco anos e, mesmo assim é sabido que existem vendas antecipadas mediante a conhecida prática dos "contratos de gaveta". Isso faz com que os eventuais concessionários independentes se sintam atraídos pela possibilidade de negociar suas concessões com os grandes proprietários e/ou vice-versa; e (3) não há normas ou restrições legais para a "afiliação" de emissoras de radiodifusão, isto é, para a formação de redes nacionais e/ou regionais.

Dessa forma, das palavras do autor pode-se deduzir que a concentração da propriedade das comunicações no Brasil se mantém, hodiernamente, nas mesmas circunstâncias sem que haja uma efetiva fiscalização por parte do Ministério das Comunicações. Constata-se, dentro desse contexto, que a mídia eletrônica, em especial a televisão, é, sem dúvida, a grande vedete dos meios de comunicação. A posição que a TV possui

22 LIMA, Venício Artur de. Mídia: teoria e política. 2 ed. São Paulo: Fundação Perseu Abramo, 2004. p. 91-92.

23 LIMA, Venício Artur de. Mídia: teoria e política. 2 ed. São Paulo: Fundação Perseu Abramo, 2004. p. 92.

24 ANÁLISE de Mercado e Informações do Mercado- com informações padronizadas e atualizadas sobre os setores da economia brasileira e empresas. Disponível em: <https://www.lafis.com.br/lafisinstitucional/default.asp>.

25 LIMA, Venício Artur de. Mídia: teoria e política. 2 ed. São Paulo: Fundação Perseu Abramo, 2004. p. 92.

26 LIMA, Venício Artur de. Mídia: teoria e política. 2 ed. São Paulo: Fundação Perseu Abramo, 2004. p. 95.

27 Exemplos da omissão: A "Lei da TV a Cabo, a Lei Mínima e a Lei Geral de Telecomunicações, que por intenção expressa do legislador, não incluíram dispositivos diretos que limitassem ou controlassem a concentração da propriedade”. LIMA, Venício Artur de. Mídia: teoria e política. 2 ed. São Paulo: Fundação Perseu Abramo, 2004. p. 96.

28 LIMA, Venício Artur de. Mídia: teoria e política. 2 ed. São Paulo: Fundação Perseu Abramo, 2004. p. 96. 
é tão destacada que MIGUEL ${ }^{29}$ assinala que, após a redemocratização, o veículo reconstruiu todo o espaço social, rompendo barreiras entre setores antes incomunicáveis.

Cabe salientar que, no campo político, a TV exige que candidatos e governantes não apenas a levem em consideração, mas que se adaptem a ela, que transforma tudo aquilo que é veiculado em espetáculo, em entretenimento e, apesar de dirigir-se ao todo, à audiência, consegue dirigir-se também a cada um dos telespectadores, o que possibilita controlar o agendamento da campanha e estabelecer quais as questões políticas são relevantes para os envolvidos. Cumpre referir também a respeito da relação de interface dos políticos e meios de comunicação, uma vez que além de utilizarem de tais ferramentas, estes possuem a propriedade dos mesmos, embora a Constituição Federal de 1988 expressamente pró́ba esse tipo de prática. Nesse propósito, de mapear essa relação de interface, o projeto "Os Donos da Mídia” a cargo do Fórum Nacional pela Democratização da Comunicação - FNDC, realiza diversos estudos nesse sentido, conforme se verifica da imagem abaixo:

Figura 1 - Relação de interface entre os meios de comunicação no Brasil e políticos.

\section{Comunicação e políticos}
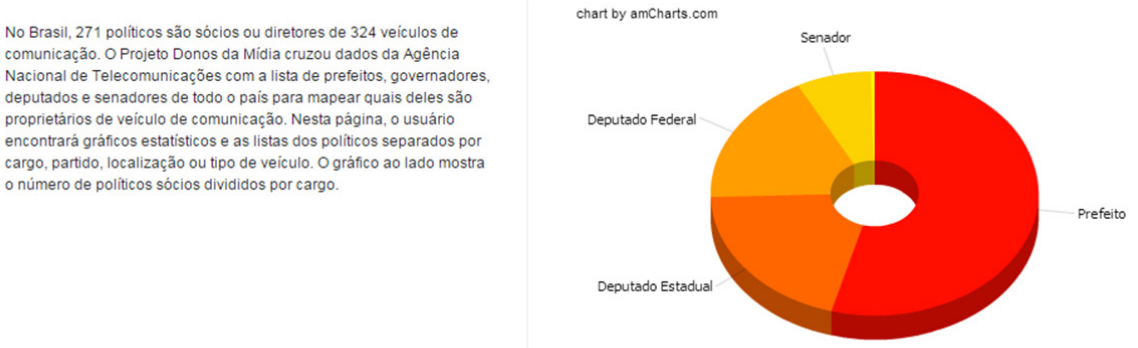

Fonte: Projeto “Os Donos da Mídia”. Disponível em: <http://www.fndc.org.br/>. Acesso em: 21 abr. 2017.

Logo, esse quadro demonstra a grande amplitude de utilização desses meios por políticos, de forma a potencializar seus discursos, preferências, ideologias e interesses. Esse tipo de prática é, essencialmente, perigosa e nociva à democracia, haja vista que pode propiciar que determinadas camadas, nichos sociais, interesses ou campos de atuação sejam, extremamente, beneficiados, em detrimento das camadas mais pobres e aos demais indivíduos e searas que compõe a sociedade, portanto, não deve ocorrer.

Ao lado dessa ingerência de políticos nos meios de comunicação, outras práticas podem ser observadas no cenário brasileiro. Nesse ponto, os meios privados servem-se de determinadas estruturações, como concentração horizontal, vertical, propriedade cruzada, monopólio em cruz ${ }^{30}$, com objetivo precípuo de

29 MIGUEL, Luis Felipe. Mídia e manipulação política no Brasil: a Rede Globo e as eleições presidenciais de 1989 à 1998 . Comunicação \& Política, v. 11, n. 2, p. 119-137, 1998.

30 Afirma Lima que a concentração horizontal se refere à oligopolização ou monopolização dentro de uma mesma área do setor, e no Brasil, temos a televisão, paga ou aberta, como exemplo desse modo de concentração. a concentração vertical é a integração das diferentes etapas da cadeia de produção e distribuição, quando um único grupo controla desde os vários aspectos da produção de programas de televisão até a sua veiculação, comercialização e distribuição. LIMA, Venício Artur de. Mídia: teoria e política. 2 ed. São Paulo: Fundação Perseu Abramo, 2004. p. 99- 100. Já quanto à concentração vertical, na televisão brasileira, já é uma prática consolidada, e aponta como o melhor exemplo, a produção e exibição de telenovelas. Ou seja, a Globo atua na produção e exibição do conteúdo, não havendo uma separação clara, entre estas atividades. Inclusive, porque a Rede Globo possui os estúdios de gravação e mantém, sob contrato permanente, autores, atores e toda a equipe de produção (roteiristas, diretores de programação, cenógrafos, figurinistas, diretores de TV, editores, sonoplastas etc.). Propriedade cruzada é a propriedade, pelo mesmo grupo, de diferentes tipos de mídia do setor de comunicações, e, por fim, o monopólio em cruz conforme LIMA, Venício Artur de. Mídia: 
dominar todo o mercado de comunicação e todas as formas de realizar a dispersão da informação e comunicação na sociedade. E, nesse enfoque, cumpre verificar as formas utilizadas pelas autoridades brasileiras para coibir determinadas práticas, como a concessão e renovação de outorgas para a radiodifusão a políticos no exercício de mandato eletivo, sobre tal assunto que se passa a tratar.

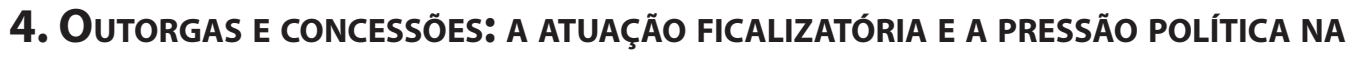 RADIODIFUSÃO DO BRASIL}

A democracia respira pluralidade, assim, vozes, pensamentos e ideias formam os matizes que dão, essencialmente, o tom de uma democracia efetiva, com respeito às diferenciadas nuances que moldam a cultura de um povo. Nessa perspectiva, cumpre uma atenção às agências de poder, àquelas que estabelecem a propositura de um pensamento crítico, equilibrado e com possibilidade de reflexão, diálogo e aprimoramento da consciência da cidadania, tratam-se dos meios de comunicação, os quais perfectibilizam-se como os grandes e promissores vernáculos de distribuição da informação, que realizam a comunicação e empoderam os indivíduos acerca das notícias e conteúdos pertinentes ao escopo social, como informações do executivo, legislativo e judiciário. Logo, os meios de comunicação ou mass media realizam funções, essencialmente, propositivas no cenário de um país, haja vista os grandes fluxos de informação que possibilitam chegar aos lares de todas as pessoas.

Nesse concernente, a informação e a comunicação, sempre, se impuseram como os vetores dos poderes dominantes, dos poderes alternativos, das resistências e das mudanças sociais. O poder de influência sobre o pensamento das pessoas - que é exercido pela comunicação - é uma ferramenta de resultado incerto, porém, fundamental. É, apenas, por meio da influência sobre o pensamento dos povos que os poderes se constituem em sociedades e que estas evoluem e mudam ${ }^{31}$. Por sua vez, esse aspecto revela a preocupação com tais balizas, haja vista o condão de mudança social que podem desempenhar, norteando e compondo o pensamento dos cidadãos e definindo, assim, o destino do povo.

Nesse sentido, ao conceito de povo reporta-se o de cidadania. Cidadãos são os mesmos do Estado, das Civitas, os destinatários da ordem jurídica estatal, os sujeitos e os súbditos do poder. Conforme Miranda, “[...] cidadania é a qualidade do cidadão." “[...] Cidadania significa ainda, mas veementemente, a participação em Estado Democrático 32". Em relação a esse propósito, não se pode perder de vista que "ser cidadão" remete a um sentido mais amplo do que o titular de direitos políticos, pois qualifica os participantes da vida do Estado, os quais devem ser submetidos ao próprio funcionamento do Estado. Isso quer dizer que, para o bom desenvolvimento do Estado, é necessária a manifestação da vontade popular, a qual consiste em um “[...] atributo político decorrente do direito de participar no governo e direito de ser ouvido pela representação política ${ }^{33 "}$.

Assim, a cidadania e, consequentemente, a participação ativa dos cidadãos na vida política e institucional do Estado se faz, primeiramente, com base no conhecimento, que se traduz na informação, por via da comunicação, que estes recebem sobre aqueles, de forma, então, a subsidiar as suas condutas, permissionando-lhes optar por qual caminho seguir. Nesse suporte, os meios de comunicação têm forte atuação, uma vez

teoria e política. 2 ed. São Paulo: Fundação Perseu Abramo, 2004. p.102, é a reprodução, em nível local e regional, dos oligopólios da propriedade cruzada, constituindo o que se chamou monopólio em cruz. Afirma que na grande maioria dos estados da Federação, os sistemas regionais de comunicações são constituídos por dois 'braços’ principais, geralmente ligadas às Organizações Globo. LIMA, Venício Artur de. Mídia: teoria e política. 2 ed. São Paulo: Fundação Perseu Abramo, 2004.

31 CASTELLS, Manuel. A Era da intercomunicação. Le Monde Diplomatique, 01 Agosto 2006. Disponível em: <http://www. diplomatique.org.br/acervo.php?id=1915>. Acesso em: 21 abr. 2017.

32 MIRANDA, Jorge. Teoria do Estado e da Constituição. Rio de Janeiro: Forense, 2011. p. 95-96.

33 SILVA, José Afonso da. Curso de Direito Constitucional Positivo. 32 ed. São Paulo: Malheiros, 2009. p. 346. 
que a sua apropriação por parcelas minoritárias faz esfacelar os princípios que orientam a comunicação social brasileira e, em relação a essa lógica, a formação de oligopólios constitui o eixo preponderante do atual modelo organizacional das corporações de mídia. O paradigma infotelecomunicacional constitui vetor decisivo para a expansão dos impérios midiáticos, tendo por escopo a comercialização, sem limites geográficos, de uma diversidade de produtos e serviços com tecnologias avançadas ${ }^{34}$.

A esfera pública ${ }^{35}$ da comunicação social brasileira, além de sofrer com as dinâmicas já impetradas da concentração hegemônica por parte de alguns grupos familiares e empresariais que gerenciam o setor, também possui uma característica diferenciada e, especialmente determinante, trata-se da composição do cenário a partir da interferência política, haja vista as concessões públicas e outorgas para exploração do serviço público de radiodifusão serem concedidas a políticos e a parlamentares, nos usos e atribuições do exercício de mandados eletivos. Muito embora, o art. 54, inciso I, da Constituição Federal de $1988^{36}$, estipule que:

“Art. 54. Os Deputados e Senadores não poderão:

I - desde a expedição do diploma:

a) firmar ou manter contrato com pessoa jurídica de direito público, autarquia, empresa pública, sociedade de economia mista ou empresa concessionária de serviço público, salvo quando o contrato obedecer a cláusulas uniformes;

II - desde a posse:

a) ser proprietários, controladores ou diretores de empresa que goze de favor decorrente de contrato com pessoa jurídica de direito público, ou nela exercer função remunerada;

Em relação ao artigo referido, existe uma estipulação proibitória, de forma que Deputados e Senadores não podem ter concessões do serviço público de radiodifusão. Contudo, o que se vê, efetivamente, na prática é uma atuação totalmente contrária. Há muitos anos, organizações que defendem a democratização dos meios de comunicação e o respeito à Constituição denunciam essa prática. Não somente porque a lei maior já a proíbe, mas porque seus efeitos para a saúde da democracia são óbvios: favorecimento político, interferência no debate de ideias, violação do direito de acesso à informação, maculação de eleições livres, entre outros. Nesse aspecto, com vistas a efetivar uma reprimenda, atendendo, mormente, aos comandos da Constituição Federal de 1988 que determina tais proibições, que coaduna o Ministério Público Federal, a partir de atuação com manobras efetivas de vigilância e fiscalização.

Assim, o Ministério Público Federal - MPF, com base em seus Procuradores da República, com fundamento no artigo 129, inciso III $^{37}$, da Constituição Federal de 1988, artigo 6 ${ }^{\circ}$, VII, alíneas a, b e d, da Lei

34 MORAES, Dênis de. Comunicação virtual e cidadania: movimentos sociais e políticos na Internet. Revista Brasileira de Ciências da Comunicaşão, v. 23, n. 2, p. 142-155, 2000. p. 01-02.

35 A esfera pública pode ser descrita como uma rede adequada para a comunicação de conteúdos e tomada de posições e opiniões, nela os fluxos comunicacionais são filtrados e sintetizados, a ponto de se condensarem em opiniões públicas enfeixadas em termos específicos. HABERMAS, Jürgen. Direito e Democracia: entre facticidade e validade. Tradução de Flávio Bino Siebeneicher. Rio de Janeiro: Tempo Brasileiro, 1997. p. 92.

36 BRASIL. Constituição da República Federativa do Brasil. Brasília: Senado Federal, 1988. Disponível em: <http://www.planalto.gov. br/ccivil_03/Constituicao/Constituicao.htm>. Acesso em: 21 abr. 2017.

37 Art. 129. São funções institucionais do Ministério Público:

III - promover o inquérito civil e a ação civil pública, para a proteção do patrimônio público e social, do meio ambiente e de outros interesses difusos e coletivos.

BRASIL. Constituição da República Federativa do Brasil. Brasília: Senado Federal, 1988. Disponível em: <http:/ /www.planalto. gov.br/ccivil_03/Constituicao/Constituicao.htm>. Acesso em: 21 abr. 2017. 
Complementar $\mathrm{n}^{\circ} 75 / 93^{38}$ e artigo $1^{\circ}$, inciso IV, da Lei $\mathrm{n}^{\circ} 7.347 / 85^{39}$, com fundamento nos artigos $1^{\circ}$, inciso IV, e $5^{\circ}, \mathrm{V}$ da Lei n $\mathrm{n}^{\circ} 7.347 / 85^{40}$, têm legitimidade para promover Ação Civil Pública, no sentido de investigação de práticas que tenham por objeto a utilização de concessões públicas de radiodifusão por parlamentares em mandatos eletivos.

Cabe referir que o próprio Supremo Tribunal Federal (STF) já se pronunciou a respeito da matéria, haja vista que, na Ação Penal n 530, a ministra Rosa Weber afirmou, em seu voto, que, "a proibição específica de que parlamentares detenham o controle sobre empresas de [...] de radiodifusão" visou evitar o "risco de que o veículo de comunicação, ao invés de servir para o livre debate e informação, fosse utilizado apenas em benefício do parlamentar, deturpando a esfera do discurso público" ${ }^{41}$.

Para a ministra do STF, “democracia não consiste apenas na submissão dos governantes a aprovação em sufrágios periódicos. Sem que haja liberdade de expressão e de crítica às políticas públicas, direito à informação e ampla possibilidade de debate de todos os temas relevantes para a formação da opinião pública, não há verdadeira democracia”. E "para garantir esse espaço livre para o debate público, não é suficiente coibir a censura, mas é necessário igualmente evitar distorções provenientes de indevido uso do poder econômico ou político".

Assim, o Ministério Público Federal, nos usos e atribuições que lhes são pertinentes, têm atuado de forma proativa, uma vez que em 2016 foram ajuizadas pelo menos cinco Ações Civis Públicas para cancelar as concessões de radiodifusão que têm como sócios detentores de mandatos eleitorais no Pará e Amapá, dentre outros estados. Os deputados federais Elcione Barbalho (PMDB/PA) e Cabuçu Borges (PMDB/AP) e o senador Jader Barbalho (PMDB/PA) violam a legislação ao figurarem no quadro societário de rádios e uma emissora de televisão. "O fato de ocupante de cargo eletivo ser sócio de pessoa jurídica que explora radiodifusão constitui afronta à Constituição Federal” diz o MPF nos processos judiciais iniciados em Belém pela Procuradoria Regional dos Direitos do Cidadão ${ }^{42}$.

Segundo o Ministério Público Federal ${ }^{43}$, foi pedido o cancelamento das concessões de radiodifusão ligadas aos políticos, a condenação da União para que faça nova licitação para tais concessões e a proibição de

38 Art. $6^{\circ}$ Compete ao Ministério Público da União:

VII - promover o inquérito civil e a ação civil pública para:

a) a proteção dos direitos constitucionais;

b) a proteção do patrimônio público e social, do meio ambiente, dos bens e direitos de valor artístico, estético, histórico, turístico e paisagístico

BRASIL. Lei Complementar $n^{\circ}$ 75, de 20 de maio de 1993. Dispõe sobre a organização, as atribuições e o estatuto do Ministério Público da União. Disponível em: <https://www.planalto.gov.br/ccivil_03/leis/lcp/lcp75.htm>. Acesso em: 12 dez. 2016.

39 Art. $1^{\circ}$ Regem-se pelas disposições desta Lei, sem prejuízo da ação popular, as ações de responsabilidade por danos morais e patrimoniais causados:

IV - a qualquer outro interesse difuso ou coletivo.

BRASIL. Lei $n^{\circ}$ 7.347, de 24 de julbo de 1985. Disciplina a ação civil pública de responsabilidade por danos causados ao meio-ambiente, ao consumidor, a bens e direitos de valor artístico, estético, histórico, turístico e paisagístico (VETADO) e dá outras providências. Disponível em: <https://www.planalto.gov.br/ccivil_03/LEIS/L7347orig.htm>. Acesso em: 12 dez. 2016.

40 Art. $5^{\circ}$ Têm legitimidade para propor a ação principal e a ação cautelar:

$\mathrm{V}$ - a associação que, concomitantemente.

BRASIL. Lei $n^{\circ}$ 7.347, de 24 de julbo de 1985. Disciplina a ação civil pública de responsabilidade por danos causados ao meio-ambiente, ao consumidor, a bens e direitos de valor artístico, estético, histórico, turístico e paisagístico (VETADO) e dá outras providências. Disponível em: <https://www.planalto.gov.br/ccivil_03/LEIS/L7347orig.htm>. Acesso em: 12 dez. 2016.

41 MPF pede cancelamento das concessões de rádio e TV ligadas à políticos do Pará e Amapá. Procuradoria Federal dos Direitos dos Cidadãos, 26 set. 2016. Disponível em: < http://pfdc.pgr.mpf.mp.br/informativos/edicoes-2016/setembro/mpf-pede-cancelamento-das-concessoes-de-radio-e-tv-ligadas-a-politicos-do-para-e-amapa>. Acesso em: 21 abr. 2017.

$42 \mathrm{MPF}$ pede cancelamento das concessões de rádio e TV ligadas à políticos do Pará e Amapá. Procuradoria Federal dos Direitos dos Cidadãos, 26 set. 2016. Disponível em: <http://pfdc.pgr.mpf.mp.br/informativos/edicoes-2016/setembro/mpf-pede-cancelamento-das-concessoes-de-radio-e-tv-ligadas-a-politicos-do-para-e-amapa>. Acesso em: 21 abr. 2017.

43 MPF pede cancelamento das concessões de rádio e TV ligadas à políticos do Pará e Amapá. Procuradoria Federal dos Direitos dos Cidadãos, 26 set. 2016. Disponível em: <http://pfdc.pgr.mpf.mp.br/informativos/edicoes-2016/setembro/mpf-pede-cancelamento-das-concessoes-de-radio-e-tv-ligadas-a-politicos-do-para-e-amapa>. Acesso em: 21 abr. 2017. 
que eles recebam qualquer outorga futura para explorar serviços de radiodifusão. As emissoras que podem ter a concessão cancelada são a Beija-Flor Radiodifusão, do deputado Cabuçu Borges, a Rede Brasil Amazônia de Televisão, o Sistema Clube do Pará de Comunicação, a Carajás FM, a Belém Radiodifusão e a Rádio Clube do Pará - PRC-5, todas de propriedade de Elcione Barbalho e Jader Barbalho. Todas funcionam no território paraense, já a rádio de Cabuçu Borges transmite na região sudeste do Pará.

A investigação sobre a propriedade de emissoras de rádio e teve por políticos foi iniciada pelo MPF em São Paulo, que fez um levantamento em todo o país das concessões de radiodifusão que tinham políticos como sócios. Assim, várias ações foram iniciadas em vários estados do país ${ }^{44}$. Já existem decisões judiciais em tribunais superiores retirando as concessões das mãos de parlamentares, seguindo o entendimento do Supremo Tribunal Federal, que já se manifestou contrário ao controle de políticos sobre veículos de comunicação ${ }^{45}$.

Cabe ressaltar, ainda, que a situação revela, ainda, um claro conflito de interesses, uma vez que cabe ao Congresso Nacional apreciar os atos de concessão e renovação das licenças de emissoras de rádio e TV, além de fiscalizar o serviço. Dessa forma, parlamentares, inclusive, já participaram de votações para a aprovação de outorgas e renovações de suas próprias empresas. Assim, para o MPF, o cancelamento das concessões visa evitar o tráfico de influência e proteger os meios de comunicação da ingerência do poder político.

Portanto, dentro de sua responsabilidade própria, o Mistério Público Federal tem tido uma conduta que está em perfeita consonância com os direitos dos cidadãos, cumprindo os mandamentos constitucionais, entretanto, a pressão política nesse meandro é algo que deve ser, sempre, considerada, haja vista a determinante influência direta que exerce. Nesse sentido, é possível visualizar o recente intento do Presidente da República Michel Temer, ao requerer que o Supremo Tribunal Federal (STF) uniformize a questão declarando legal esse tipo de concessão.

A AGU, que representa o Presidente na Ação de Descumprimento de Preceito Fundamental - ADPF $\mathrm{n}^{\mathrm{o}} 429$, pede que o Supremo declare inconstitucional todas as decisões que têm impedido a outorga ou a renovação de concessões de rádio e TV a detentores de mandato eletivo. Para o órgão, decisões nesse sentido ofendem preceitos fundamentais como o do valor social do trabalho e da livre iniciativa, da primazia da lei, da livre expressão e da liberdade de associação ${ }^{46}$.

Assim, esse tipo de conduta, como a desempenhada pelo Presidente, revela o caráter de protecionismo exercidos pelos políticos, porquanto a necessidade que possuem de resguardar os seus interesses. Entretanto, outras ações foram propostas com objetivo de desconfigurar essa prática que é vedada pela Constituição Federal, partidos políticos já ingressaram com ações judiciais nesse sentido, como, por exemplo, o PSOL, em 2011 e 2015.

Na manifestação referente à ADPF no 379, apresentada em 2015, o atual procurador-geral, Rodrigo Janot, foi favorável à concessão de medida cautelar. Segundo Janot, a participação de titulares de mandato

44 Com base no artigo 54 da Constituição Federal, que veda a parlamentares serem proprietários, controladores ou diretores de empresas de radiodifusão, o Tribunal Regional Federal da $3^{\text {a }}$ Região determinou o cancelamento das concessões de cinco emissoras de rádio que têm como sócios-proprietários os deputados federais Luiz Felipe Baleia Tenuto Rossi (PMDB) e Paulo Roberto Gomes Mansur (PRB). A medida atende a pedido do Ministério Público Federal que ajuizou ações civis públicas contra os parlamentares em novembro do ano passado. Com as decisões, fica suspensa a execução dos serviços de radiodifusão da Rádio Cultura FM Santos, da Sociedade Rádio Cultura São Vicente e da Empresa de Comunicação PRM LTDA, de Beto Mansur. Também foram suspensos os serviços da Rádio Show de Igarapava e da Rádio AM Show, que contam com a participação de Baleia Rossi em seus quadros societários. TRF-3 cancela concessões de rádios administradas por deputados. Conjur, 15 abr. 2016. Disponível em: <http://www. conjur.com.br/2016-abr-15/trf-cancela-concessoes-radios-administradas-deputados >. Acesso em: 21 abr. 2017.

45 MPF pede cancelamento das concessões de rádio e TV ligadas à políticos do Pará e Amapá. Procuradoria Federal dos Direitos dos Cidadãos, 26 set. 2016. Disponível em: <http://pfdc.pgr.mpf.mp.br/informativos/edicoes-2016/setembro/mpf-pede-cancelamento-das-concessoes-de-radio-e-tv-ligadas-a-politicos-do-para-e-amapa>. Acesso em: 21 abr. 2017.

46 TRF-3 cancela concessões de rádios administradas por deputados. Conjur, 15 abr. 2016. Disponível em: <http://www.conjur. com.br/2016-abr-15/trf-cancela-concessoes-radios-administradas-deputados >. Acesso em: 21 abr. 2017. 
eletivo em pessoas jurídicas concessionárias, permissionárias ou autorizatárias de serviços de radiodifusão confere a políticos poder de influência indevida sobre importantes funções da imprensa, relativas à divulgação de informações ao eleitorado e à fiscalização de atos do poder público. Nesse quadro, "viola, por conseguinte, preceitos fundamentais de democracia e soberania popular (Constituição da República, artigos $1^{\circ}$, parágrafo único, e 14), cidadania (artigo $1^{\circ}$, inciso II), pluralismo político (artigo $1^{\circ}, \mathrm{V}$ ), isonomia (artigo $5^{\circ}$ ), liberdade de expressão (artigos $5^{\circ}$, IX, e 220), direito à informação (artigo $5^{\circ}$, XIV), legitimidade e normalidade dos pleitos eleitorais (artigos 14, $₫ 9^{\circ}$, e $60, \sqrt{\S} 4^{\circ}$, II) e pluripartidarismo (artigo 17)", lista Janot ${ }^{47}$.

Nessa perspectiva, se visualiza, no que tange às outorgas e concessões para operacionalização do serviço público de radiodifusão no Brasil por parte de políticos e parlamentares no exercício de mandato eletivo, que há um efetivo e explícito descompasso, haja vista as proibições oriundas da Constituição Federal de 1988 e que o que é observado na prática, em que muitos políticos têm sob sua égide, propriedade ou atuando como sócios, muitos meios de comunicação como rádios e TVs, subsidiados muitas vezes pela própria classe política. Contudo, visando ao cumprimento dos preceitos constitucionais se coloca o MPF, em uma ação fiscalizatória combativa, tentando desmantelar esse cenário que cada vez mais se consolida no Brasil.

\section{Considerações finais}

A comunicação é parte integrante da existência humana, de forma que todos os seus instrumentos devem ser utilizados em prol da proteção dos direitos humanos, ou seja, em total consonância e conformidade com os ideias de um Estado Democrático de Direito. Contudo, não há que se falar em comunicação livre quando os veículos formadores da consciência pública e que propiciam a exasperação da informação são controlados e têm a ingerência de alguns pequenos e isolados grupos privados, além de igrejas e políticos.

Nesta senda, o presente artigo se preocupou, ou seja, promover a visualização e a reflexão acerca da problemática envolvendo a concentração de mídias no Brasil, especialmente sob o enfoque da fiscalização do processo de concessão de licenças e outorgas de radiodifusão para parlamentares em exercício de mandato eletivo. Nesse sentido, em um primeiro momento destacou-se a comunicação e seu processo histórico de concentração dos meios, alertando para a antiga e contínua prática dos processos de concessão das outorgas para o serviço de radiodifusão no Brasil à parlamentares e os principais atores envolvidos. Do mesmo modo, a atuação proativa do Ministério Público Federal, por meio da propositura de Ações Civis Públicas, tem por objeto pleitear o cancelamento dessas concessões cujos proprietários e sócios são políticos no exercício de mandatos eletivos.

Essa configuração demonstra a preocupação do órgão com os mandamentos constitucionais que proíbem, nesse sentido, atuando desse modo, em conformidade com a lei maior do Estado brasileiro e atendendo, também, aos direitos e às garantias dos cidadãos. Foi possível verificar, assim, que essa atuação do MPF coaduna com diversas posições, inclusive, do STF que acredita ser extremamente prejudicial ao país e à democracia que esse tipo de prática continue se consolidando. A ingerência de políticos nos meios de comunicação e as mídias não podem mais ter espaço em um Estado Democrático de Direito, haja vista as constantes inovações tecnológicas observadas no período e, também, ao rol de direitos e garantias estipulados na Constituição de 1988.

Logo, uma sociedade justa e igualitária pressupõe o livre, amplo e irrestrito acesso ao conteúdo informacional, constituindo baliza indispensável para esse fim que o maior número de informações seja disponibilizado pelo maior número possível de veículos, a visualização de um nicho informativo por diferentes óticas permite ao indivíduo e ao cidadão formar a sua consciência sobre os acontecimentos públicos e privados,

47 TRF-3 cancela concessões de rádios administradas por deputados. Conjur, 15 abr. 2016. Disponível em: <http://www.conjur. com.br/2016-abr-15/trf-cancela-concessoes-radios-administradas-deputados >. Acesso em: 21 abr. 2017. 
construindo o seu próprio ideário, afastado de influências e indulgências políticas, religiosas e econômicas. Todo esse contexto, somente, se viabiliza a partir de meios de comunicação descentralizados, plurais e, essencialmente, democráticos.

\section{REFERÊNCIAS BIBLIOGRÁFICAS}

BARBOSA, Bia. Novo alvo do MPF: os políticos donos da mídia. Carta Capital, 24 nov. 2015. Disponível em: <https://www.cartacapital.com.br/blogs/intervozes/novo-alvo-do-mpf-os-politicos-donos-da-midia-3650.html>. Acesso em: 21 abr. 2017.

BRASIL. Constituição da República Federativa do Brasil. Brasília: Senado Federal, 1988. Disponível em: <http:// www.planalto.gov.br/ccivil_03/Constituicao/Constituicao.htm>. Acesso em: 21 abr. 2017.

BRASIL. Lei Complementar n 75, de 20 de maio de 1993. Dispõe sobre a organização, as atribuições e o estatuto do Ministério Público da União. Disponível em: <https://www.planalto.gov.br/ccivil_03/leis/lcp/lcp75. htm>. Acesso em: 12 dez. 2016.

BRASIL. Lei $n^{\circ}$ 7.347, de 24 de julho de 1985. Disciplina a ação civil pública de responsabilidade por danos causados ao meio-ambiente, ao consumidor, a bens e direitos de valor artístico, estético, histórico, turístico e paisagístico (VETADO) e dá outras providências. Disponível em: < https://www.planalto.gov.br/ccivil_03/ LEIS/L7347orig.htm>. Acesso em: 12 dez. 2016.

BRASIL. Lei no 4.117 de 27 de agosto de 1962. Institui o Código Brasileiro de Telecomunicações. Disponível em: < http://www.planalto.gov.br/ccivil_03/Leis/L4117.htm>Acesso em: 21 abr. 2017.

CAPPARELLI, Sérgio; RAMOS, Murilo C; SANTOS, Suzy. A nova televisão no Brasil e na Argentina. In: et al. Enfim, sós: A nova televisão no Cone Sul. Porto Alegre: LPM, 1999. p. 11.

CASTELLS, Manuel. A Era da intercomunicação. Le Monde Diplomatique, 01 Agosto 2006. Disponível em: <http://www.diplomatique.org.br/acervo.php?id=1915>. Acesso em: 21 abr. 2017.

CASTELLS, Manuel. A Galáxia da Internet: reflexões sobre a internet, negócios e a sociedade. Traduzido por Maria Luiza X. de A. Borges. Rio de Janeiro: J. Zahar, 2004.

CASTELLS, Manuel. A sociedade em rede: A Era da Informação: economia, sociedade e cultura. Tradução de Roneide Venâncio Majer. São Paulo: Paz e Terra, 1999.

COLOMBO, F. Il videogioco come mezzo di comunicazione. 1995. Disponível em: < http://www.telecomitalia.it/ estudi/chieric6.htm>. Acesso em: 21 abr. 2017.

DELARBE, Raúl Trejo. Muchos médios em pocas manos: concentración televisiva y democracia em América Latina. INTERCOM Revista Brasileira de Ciências da Comunicação, São Paulo, v. 33, n. 1, p. 17-51, jan./ jun. 2010.

FÓRUM NACIONAL PELA DEMOCRATIZAÇÃO DA COMUNICAÇÃO. [Homepage]. Disponível em: <http://www.fndc.org.br/>. Acesso em: 08 abr. 2016.

HABERMAS, Jürgen. Direito e Democracia: entre facticidade e validade. Tradução de Flávio Bino Siebeneicher. Rio de Janeiro: Tempo Brasileiro, 1997.

JENKINS, Henry. Cultura da Convergência. Tradução de Susana Alexandria. São Paulo: Aleph, 2008.

LIMA, Venício Artur de. Mídia: teoria e política. 2 ed. São Paulo: Fundação Perseu Abramo, 2004.

LIMA, Venício Artur de. Regulação das comunicações. História, poder e direitos. São Paulo: Paulus, 2011. 
MICHEL Temer vai ao Supremo a favor da concessão de rádio e TV a parlamentares. Conjur, 11 nov. 2016. Disponível em: <http://www.conjur.com.br/2016-nov-11/temer-stf-favor-concessao-radio-tv-politicos>. Acesso em: 21 abr. 2017.

MIGUEL, Luis Felipe. Mídia e manipulação política no Brasil: a Rede Globo e as eleições presidenciais de 1989 à 1998. Comunicação \& Política, v. 11, n. 2, p. 119-137, 1998.

MIRANDA, Jorge. Teoria do Estado e da Constituição. Rio de Janeiro: Forense, 2011.

MORAES, Dênis de. Comunicação virtual e cidadania: movimentos sociais e políticos na Internet. Revista Brasileira de Ciências da Comunicaşão, v. 23, n. 2, p. 142-155, 2000.

MPF pede cancelamento das concessões de rádio e TV ligadas à políticos do Pará e Amapá. Procuradoria Federal dos Direitos dos Cidadãos, 26 set. 2016. Disponível em: <http://pfdc.pgr.mpf.mp.br/informativos/edicoes-2016/setembro/mpf-pede-cancelamento-das-concessoes-de-radio-e-tv-ligadas-a-politicosdo-para-e-amapa>. Acesso em: 21 abr. 2017.

OBSERVATÓRIO DO DIREITO À COMUNICAÇÃO. [Homepage]. 2015. Disponível em: <http://www. intervozes.org.br/direitoacomunicacao/>. Acesso em: 21 abr. 2017.

PORQUE e como se limita a propriedade cruzada, 2011. Disponível em: < http://www.intervozes.org.br/ direitoacomunicacao/?p=25290>. Acesso em 21 abr. 2017.

RELATÓRIO Final da Pesquisa Brasileira de Mídia 2016. Secretaria da Comunicação da Presidência da República, 29 agosto, 2016. Brasília, DF. Disponível em: <http://www.secom.gov.br/atuacao/pesquisa/ lista-de-pesquisas-quantitativas-e-qualitativas-de-contratos-atuais/pesquisa-brasileira-de-midia-pbm-2016. pdf/view>. Acesso em: 21 abr. 2017.

SANTOS, Suzy; CAPPARELLI, Sérgio. Coronelismo, radiodifusão e voto: a nova face de um velho conceito. In: BRITTOS, Valério Cruz; BOLAÑO, César Ricardo Siqueira (Org.). Rede Globo: 40 anos de poder e hegemonia. São Paulo: Paulus, 2005. v. 1, p. 77-101.

SILVA, José Afonso da. Curso de Direito Constitucional Positivo. 32. ed. São Paulo: Malheiros, 2009.

SILVERSTONE, R. Television and everyday life. London: Routledge, 1995.

TRF-3 cancela concessões de rádios administradas por deputados. Conjur, 15 abr. 2016. Disponível em: $<$ http://www.conjur.com.br/2016-abr-15/trf-cancela-concessoes-radios-administradas-deputados $>$. Acesso em: 21 abr. 2017.

UNESCO. Indicadores de Desenvolvimento da Mídia: Marco para a avaliação do desenvolvimento dos meios de comunicação. Brasília: UNESCO, 2010. 


\section{Os imigrantes no Brasil, sua vulnerabilidade e o princípio da igualdade*}

\section{The immigrants in Brazil, its vulnerability and the principle of equality}

Leda Maria Messias da Silva**

Sarah Somensi Lima***

\section{Resumo}

O presente artigo evidencia os direitos da personalidade, explicando em que momento nasceu tais direitos, bem como o que esses direitos asseguram. Em seguida, o estudo aborda a vulnerabilidade dos imigrantes, bem como o princípio da igualdade, ressaltando que independente de estarem legais ou não no País, deve-se garantir a proteção desses estrangeiros. Além disso, o artigo aborda a nova lei dos imigrantes, bem como sua importância para a garantia dos direitos dos estrangeiros. $\mathrm{O}$ estudo avança e traz os motivos que fazem com que os imigrantes decidam sair de seus países de origem em busca de uma nova vida. O trabalho também destaca as condições sociais e econômicas dos imigrantes no Brasil. O método utilizado é o indutivo.

Palavras-chave: Direitos da Personalidade. Igualdade. Imigrantes. Proteção. Vulnerabilidade.

\section{Abstract}

This article highlights the rights of the personality, explaining when the rights were born, as well as what these rights ensure. The study then addresses the vulnerability of immigrants as well as the principle of equality, emphasizing that regardless of whether or not they are legal in the country, the protection of these aliens must be guaranteed. In addition, the article addresses the new law of immigrants, as well as their importance for guaranteeing the rights of foreigners. The study advances and brings the reasons why immigrants decide to leave their countries of origin in search of a new life. The study also highlights the social and economic conditions of immigrants in Brazil. The method used is the inductive one.

Keywords: Equality. Immigrantes. Protection. Rights of the Personality. Vulnerability. 


\section{INTRODUÇÃO}

O presente trabalho tem por objetivo destacar a vulnerabilidade dos imigrantes, bem como levantar as principais e prováveis hipóteses para a imigração no Brasil.

Primeiramente, o estudo aborda os direitos da personalidade, como ocorreu a sua evolução, a partir de quando passaram a ser tutelados, bem como sua importância. Insta evidenciar que não existem controvérsias de que os direitos da personalidade são um conjunto de características intrínsecas ao indivíduo. Ademais, são os primeiros bens do ser humano, quais sejam: a vida, a liberdade e a honra.

Em seguida, discorre-se sobre a importância da proteção ao vulnerável e sobre o princípio da igualdade. Conforme o artigo $5^{\circ}$ da Constituição Federal (CF), todos são iguais perante a lei, desta forma, os imigrantes não podem ter seus direitos preteridos. No entanto, é importante salientar que muitas vezes, é preciso que haja tratamento diferente, para que seja possível alcançar a igualdade e dar a todos as mesmas oportunidades. Ademais, aborda-se a importância do combate à discriminação e a necessidade de proteção especial aos que necessitam dela. Seria igualdade tratar a todos igualmente? Ou para atingir a igualdade e dar as mesmas oportunidades é necessário que haja a discriminação afirmativa?

Posteriormente, o trabalho aborda o tema dos imigrantes no Brasil. Inicialmente ressalta-se que a imigração sempre existiu e sempre foi motivo de preocupação. Entretanto, a imigração atual está bem diferente da imigração de períodos anteriores. Hoje, além de haver um fluxo intenso de imigração, muitos países são simultaneamente regiões de produção de imigrantes e receptores de imigrantes.

O Brasil, por exemplo, possui muitos habitantes que vão para os Estados Unidos e Europa em busca de vida melhor, em contrapartida, há muitos africanos e latino americanos que vêm ao Brasil com esperanças de alcançar uma vida digna para si e para a sua família.

$\mathrm{Na}$ sequência, o estudo versa sobre as condições sociais e econômicas no cenário Brasileiro. Aponta as dificuldades que os imigrantes encontram quando chegam ao Brasil, principalmente com relação ao idioma. Ademais, aborda o Paraná como o segundo estado que mais emprega imigrantes no Brasil.

Para desenvolver a pesquisa proposta neste trabalho, emprega-se, principalmente, o método indutivo, partindo de questões particulares para as conclusões mais amplas acerca do tema.

\section{Os DIREITOS DA PERSONALIDADE}

Quando se fala em direitos da personalidade é importante mencionar a importância do cristianismo, pois foi a partir da noção de pessoa dada ao homem pelos cristãos, que o homem se tornou um ser autônomo e independente na medida em que, na visão cristã, o homem era o único ser querido por Deus em si mesmo ${ }^{1}$.

Os direitos da personalidade nascem no momento do nascimento de um indivíduo, ou seja, são direitos intrínsecos de cada ser humano, não podendo ser renunciado por ninguém. Eles são direitos inerentes, essenciais e inatos a toda pessoa ${ }^{2}$.

Os civilistas sustentam que o ser humano adquire personalidade a partir do nascimento com vida, assegurando, porém, certa proteção aos direitos do nascituro. Essa opinião dos civilistas clássicos vem de origem romana, pois estes consideravam o feto como parte da mulher, não o vislumbrando como um ser

1 GONÇALVES, Diogo Costa. Pessoa e direitos da personalidade: fundamentação ontológica da tutela. Coimbra: Almedina, 2008. p. 28.

2 OLIVEIRA, Alfredo Emanuel Farias de. O fundamento dos direitos da personalidade. Belo Horizonte: Arraes Editores, 2012. p. 41. 
vivo independente ${ }^{3}$.

O Código Civil brasileiro assegura os direitos do nascituro no artigo $2^{\circ}$ : "A personalidade civil da pessoa começa no nascimento com vida, mas a lei põe a salvo, desde a concepção, os direitos do nascituro" ${ }^{4}$

Os direitos da personalidade passaram a ser tutelados após as duas grandes guerras mundiais, devido ao total desrespeito para com a vida humana. Esse desrespeito fez com que o indivíduo passasse a ser tratado como pessoa portadora de proteção à sua personalidade e dignidade ${ }^{5}$.

Assevera-se que a partir do cristianismo, o homem começou a ter a importância que tem hoje. No entanto, foi após as duas grandes guerras mundiais, e depois do total desrespeito para com a vida humana, que passaram a preservar a personalidade do homem. Destaca-se ainda que os direitos da personalidade, assim como quaisquer outros direitos, nasceram e evoluíram pouco a pouco e não se pode deixar de forma alguma que haja um retrocesso desses direitos.

Szaniwaski ${ }^{6}$ define o que vem a ser a personalidade humana, sendo a parte mais intrínseca e deveras importante, tão importante que seus direitos são inatos e irrenunciáveis, ou seja: "a personalidade humana consiste no conjunto de características da pessoa, sua parte mais intrínseca”.

O direito da personalidade trata-se de um bem, no sentido jurídico, pertencente à pessoa. Sendo que não é possível adquirir outros direitos sem que antes sejam protegidos os direitos da personalidade. "Através da personalidade, a pessoa poderá adquirir e defender os demais bens"”.

Roxana Borges evidencia que ${ }^{8}$ :

Os direitos da personalidade são próprios do ser humano, direitos que são próprios da pessoa. Não se trata de direito à personalidade, mas de direitos que decorrem da personalidade humana, da codificação de ser humano.

A Constituição Federal de 88 resultou de anseios do povo brasileiro por um novo paradigma. Isso se deve ao fato de que o Código Civil da época era de 1916 e a Constituição era fruto da ditadura militar que não dava a proteção necessária aos direitos personalíssimos.

Cleide Fermentão elucida que:

Com a evolução da sociedade, os direitos da personalidade tornaram-se de grande importância para o ser humano, levando os textos constitucionais a disporem sobre tais direitos, os quais então, na hierarquia das normas, conseguiram uma posição superior no ordenamento jurídico nacional ${ }^{9}$.

Conforme já explicitado, os direitos da personalidade, assim como outros direitos, foram conquistando espaço, e hoje são parte importante da Constituição Federal (CF).

Segundo Bittar ${ }^{10}$ os direitos da personalidade se constituem: "direitos inatos (originários), absolutos, extrapatrimoniais, intransmissíveis, imprescritíveis, impenhoráveis, vitalícios, necessários e oponíveis erga omnes". Ele quer dizer que os direitos da personalidade nascem com toda pessoa, além disso, não se pode quantificar os direitos da personalidade, também não se pode transferir para outra pessoa, não se prescreve com o tempo.

3 SZANIWASKI, Elimar. Direitos de personalidade e sua tutela. 2.ed. São Paulo: Revistados Tribunais, 2005. p. 63-64.

SZANIWASKI, Elimar. Direitos de personalidade e sua tutela. 2.ed. São Paulo: Revistados Tribunais, 2005. p. 64.

SZANIWASKI, Elimar. Direitos de personalidade e sua tutela. 2.ed. São Paulo: Revistados Tribunais, 2005. p. 57.

SZANIWASKI, Elimar. Direitos de personalidade e sua tutela. 2.ed. São Paulo: Revistados Tribunais, 2005. p. 57.

SZANIWASKI, Elimar. Direitos de personalidade e sua tutela. 2.ed. São Paulo: Revistados Tribunais, 2005. p. 70.

BORGES, Roxana Cardoso Brasileiro. Direitos de personalidade e autonomia privada. São Paulo: Saraiva, 2007. p. 21.

FERMENTÃO, Cleide Aparecida Gomes Rodrigues. Os direitos da personalidade como direitos essenciais e a subjetividade do direito. Revista Jurídica Cesumar, v. 6, n. 1, p. 241-266, 2006. p. 244.

10 BITTAR, Carlos Alberto. Os direitos da Personalidade. 2. ed. Rio de Janeiro: Forense Universitária, 1995. p. 11. 
Para Motta e Cavallini ${ }^{11}$ os direitos da personalidade são "direitos que se destinam a resguardar a eminente dignidade da pessoa humana, preservando-a dos atentados que possa sofrer por parte de outros indivíduos".

Conforme já enfatizado e esclarecido, os direitos da personalidade são inerentes, essenciais e inatos a toda pessoa. A constituição é extremamente cuidadosa quando se refere à tutela da pessoa humana. Para Daniel Sarmento, com os direitos da personalidade e o princípio da dignidade da pessoa humana, o homem se torna mais importante que o Estado, tornando-se o Estado apenas um meio para a garantia e promoção dos direitos fundamentais. O Estado tem a finalidade de buscar sempre a satisfação destes direitos ${ }^{12}$.

Mello ${ }^{13}$ salienta que é deveras importante e juridicamente necessário fundamentar os direitos da personalidade no texto constitucional. Essa importância deve-se ao fato de que inserção destes direitos da personalidade de forma irrestrita é essencial para a própria dignidade da pessoa humana.

Rizzardo $^{14}$ também nos traz esclarecimentos acerca dos direito da personalidade elucidando que:

Trata-se dos direitos decorrentes da personalidade, que vêm do nascimento, sendo intransmissíveis, irrenunciáveis, imprescritíveis e inegociáveis. São essenciais à plena existência da pessoa humana, à sua dignidade, ao respeito, à posição nas relações com o Estado e com os bens, à finalidade última que move todas as instituições, eis que tudo deve ter como meta maior o ser humano.

Pelo exposto, é evidente que os direitos da personalidade estão garantidos constitucionalmente a todas as pessoas, não importando para tanto, se nacionais ou estrangeiras. Assim, os imigrantes devem ser tratados de forma igualitária, devendo primar pelo respeito aos direitos que derivam da personalidade.

\subsection{Proteção dos vulneráveis e o Princípio da Igualdade}

É imprescindível iniciar o presente tópico com a definição de igualdade que predomina na doutrina, na qual assevera que se deve tratar igualmente os iguais e desigualmente os desiguais na medida em que se desigualam. Isso se deve ao fato de que, tratar igualmente os desiguais ou desigualmente os iguais não estaria se atingindo uma igualdade real.

Dessa forma, deve se levar em consideração que os imigrantes são desiguais, mesmo que temporariamente, e por isso, devem ser tratados de forma desigual para que seja preservado os direitos inerentes a toda pessoa.

O entendimento de igualdade não se admite como critério diferenciador da nacionalidade, tendo em vista que existem vários documentos internacionais que não cansam de reforçar o tratamento igualitário entre nacionais e estrangeiros, contudo nem sempre é o que acontece. A adoção de medidas que promovam a igualdade é importante a partir do momento em que se tem o alcance da igualdade como objetivo. São imprescindíveis medidas que abranjam a necessidade de repensar as estruturas sociais, a fim de extinguir divisões que criam obstáculos para as pessoas apresentarem direitos análogos. É evidente a dificuldade de superar as barreiras da desigualdade no Direito, uma vez que este é voltado ao conservadorismo social. Os impedimentos que obstam o igualitarismo do trabalhador imigrante vão além do regime jurídico, abrangendo a questão social, étnica, linguísticas, culturais entre outras formas de segregação ${ }^{15}$.

11 CAVALLINI, Viviane Cristina Rodrigues; DA MOTTA, Ivan Dias. O Conceito de Personalidade no Âmbito dos Direitos da Personalidade. Revista Jurídica Cesumar-Mestrado, v. 9, n. 2, 2009. p. 629.

12 SARMENTO, Daniel. Direitos fundamentais e relações privadas. Rio de Janeiro: Lúmen Juris, 2004. p. 111.

13 MELLO, Cláudio Ari. Contribuição para uma teoria híbrida dos direitos de personalidade. In: SARLET, Ingo Wolfgang. O novo código civil e a constituição. Porto Alegre: Livraria do Advogado, 2003. p. 78.

14 RIZZARDO, Arnaldo. Parte geral do código civil: lei n. 10.406, de 10.01. 2002. 4. ed., rev. e atual. Rio de Janeiro: Forense, 2006. p. 151.

15 JAQUEIRA, Manoela Marli; MARTINS, Fernando José. Os direitos fundamentais e o trabalhador imigrante no Brasil. Derecho y Cambio Social. 19 out. 2015. Disponível em: <http://www.derechoycambiosocial.com/revista042/OS_DIREITOS_ 
O direito à igualdade é um direito que ultrapassa os limites do regime jurídico, pois abrange demandas sociais e culturais em que o imigrante está inserido. Para alcançar a igualdade seria imprescindível uma reestruturação social e econômica, na qual é importante derrubar os obstáculos ideológicos que segregam o estrangeiro do nacional, pois a partir da mudança do pensamento social é que se poderá pensar em mudança normativa.

É importante enfatizar, também, que a Comissão Interamericana dos Direitos Humanos (CIDH) considera os imigrantes como mais vulneráveis quando confrontados com os nacionais ou residentes de um Estado, pois se encontram em condição de desvantagem pela dimensão ideológica mantida por dessemelhanças legalmente estabelecidas e estruturadas. Deste modo, o acesso dos imigrantes aos recursos públicos oferecidos pelos Estados é diferenciado, agravando assim, os preconceitos culturais que ultrajam ainda mais as condições de vulnerabilidade enfrentada por esses indivíduos. Ademais, esta vulnerabilidade é reforçada por preconceitos étnicos, xenofobia e racismo, que dificultam sua integração à sociedade e levam à impunidade por violações de direitos humanos cometidas contra os imigrantes ${ }^{16}$.

O Brasil ratificou a Convenção no 97 da OIT que trata dos trabalhadores imigrantes. Essa convenção prevê, entre outras coisas, assegurar a existência de um serviço gratuito apropriado encarregado de ajudar os trabalhadores migrantes, assegurar a saúde dos trabalhadores imigrantes e de sua família, aplicar aos imigrantes o mesmo tratamento que é dado aos nacionais quanto às seguintes matérias: a remuneração, incluídos os subsídios familiares quando esses subsídios fazem parte da remuneração, a duração do trabalho, as horas extraordinárias, os feriados pagos, as restrições a trabalho feito em casa, a idade de admissão ao trabalho, a aprendizagem e a formação profissional e o trabalho das mulheres e adolescentes, entre outras coisas constantes na convenção ${ }^{17}$.

Salienta-se que até mesmo o imigrante ilegal tem direito a garantias e proteção judicial de acordo com a $\mathrm{CIDH}$, pois os que se encontram nessa condição, indubitavelmente são prejudicados pela precariedade de sua situação devido ao temor perante represálias por parte de particulares e autoridades locais, que podem resultar em deportação, privação de liberdade e outras penalidades, com isso o imigrante tem receio de procurar prestação jurídica. Ao mesmo tempo, as adversidades culturais, o idioma, acrescentadas ao desconhecimento da legislação trabalhista do país onde se encontra, pode impedir a devida prestação jurisdicional ao imigrante. Por isso, a CIDH acredita que a prestação jurisdicional deve ser colocada em prática, deixando de ser apenas formal ${ }^{18}$.

No artigo 2.1 da Convenção Internacional sobre a Proteção dos Direitos de todos os Trabalhadores Migrantes e seus familiares é reiterada a vulnerabilidade dos migrantes em situação irregular, uma vez que são os mais prejudicados por sua condição, nos países receptores, quanto ao gozo e exercício de direitos humanos laborais. O direito do trabalho, regulado no nível nacional ou internacional é um ordenamento tutelar dos trabalhadores, regulamentando obrigações do empregado e do empregador, independente de qualquer consideração de caráter econômico ou social, sem qualquer tipo de discriminação ${ }^{19}$.

O Estado é o responsável por colocar em prática o respeito e as garantias do trabalhador imigrante ilegal em sua relação laboral com os particulares, impedindo assim que os empregadores violem os direitos desses

FUNDAMENTAIS_E_O_TRABALHADOR_IMIGRANTE.pdf>. Acesso em: 18 set. 2016.

16 BATISTA, Vanessa Oliveira; PARREIRA, Carolina Genovez. Trabalho, imigração e o direito internacional dos direitos humanos. Publica Direito. Disponível em: <http://www.publicadireito.com.br/artigos/?cod=47a3893cc405396a> . Acesso em: 18 set. 2016. p. 19.

17 OIT97, 1949.

18 BATISTA, Vanessa Oliveira; PARREIRA, Carolina Genovez. Trabalho, imigração e o direito internacional dos direitos humanos. Publica Direito. Disponível em: <http://www.publicadireito.com.br/artigos/?cod=47a3893cc405396a> . Acesso em: 18 set. 2016. p. 19.

19 BATISTA, Vanessa Oliveira; PARREIRA, Carolina Genovez. Trabalho, imigração e o direito internacional dos direitos humanos. Publica Direito. Disponível em: <http://www.publicadireito.com.br/artigos/?cod=47a3893cc405396a> . Acesso em: 18 set. 2016. p. 19. 
imigrantes ou que os contratos de trabalho não estejam nos padrões internacionais mínimos de proteção aos direitos humanos. Ademais, cabe também ao Estado receptor preservar e proteger a dignidade da pessoa humana e os direitos fundamentais desses trabalhadores, independente de serem ilegais ou não, dando enfoque para assuntos como: "proibição de trabalho forçado; proibição de trabalho infantil; atenção à mulher trabalhadora; associação e liberdade sindical, negociação coletiva; salário justo; seguro social; garantias judiciais e administrativas; duração da jornada de trabalho"20.

Ainda que o Brasil seja um país heterogêneo, há uma realidade cheia de preconceitos, os quais existem de modo camuflado em alguns aspectos, pois, os brasileiros vivem um paradigma colonial, e ainda há desrespeito às minorias ou indivíduos com baixo nível socioeconômico. A convivência com estas diferenças pode deixar de ser uma utopia e caminhar para uma sociedade igualitária e receptiva às diferenças, possibilitando assim que os Direitos Humanos sejam assegurados de modo efetivo a todos os cidadãos. Contudo, não basta somente a garantia Constitucional, é necessário também alterar o paradigma arcaico que muitos indivíduos possuem; dando início a um processo de transição no qual o respeito entre o próximo e a subjetividade do indivíduo seja uma prioridade ${ }^{21}$.

Para John Rawls, os cidadãos são considerados como pessoas iguais, quando se avalia que todos têm, mesmo que em um grau mínimo, as faculdades morais indispensáveis para engajarem-se na cooperação social e integrarem-se na sociedade como cidadãos iguais. Para Rawls, ter essas faculdades, nesse grau mínimo, é o que pode ser considerado como base da igualdade entre os cidadãos ${ }^{22}$.

Deste modo, é preciso garantir ao imigrante um trabalho decente, pois de acordo com o artigo $5^{\circ} \mathrm{da} \mathrm{CF}$, todos são iguais perante a lei. Como argumenta Fermentão ${ }^{23}$ :

$\mathrm{O}$ artigo $5^{\circ}$ da Constituição Federal e seus incisos consagraram os direitos humanos fundamentais, entre eles as garantias e direitos individuais e coletivos. Por meio deste mesmo artigo, a carta magna estabelece que todos são iguais perante a lei, sem distinção de qualquer natureza, garantindo-se aos brasileiros e aos estrangeiros residentes no país a inviolabilidade do direito à vida, à liberdade, à igualdade, à segurança e à propriedade.

Os países que recebem os imigrantes têm a preocupação com as diferenças existentes entre os nacionais e os imigrantes, sobre isso Habermas explica que: "quanto mais profundas forem as diferenças religiosas ou étnicas, ou quanto maiores forem os assincronismos histórico-culturais a serem superados, tanto maior será o desafio, e tanto mais ele será doloroso"24.

De acordo com Marques e Miragem ${ }^{25}$ o direito privado atual possui como fim proteger os mais fracos. É importante perceber que na sociedade nenhuma pessoa é igual. No entanto, algumas diferenças tornam algumas pessoas permanentemente ou temporariamente mais fracas, por conta disso muitas vezes, é preciso dar um tratamento protetivo para esse mais fraco e evitar qualquer discriminação ${ }^{26}$.

No caso em tela, os imigrantes que chegam ao país, podem ser considerados temporariamente mais fracos. Isso porque, estão em um país diferente, no qual, muitas vezes não falam a língua do país, não têm família ou amigos por perto, não conhecem as normas daquele país, dos costumes e cultura, ademais, na

20 BATISTA, Vanessa Oliveira; PARREIRA, Carolina Genovez. Trabalho, imigração e o direito internacional dos direitos humanos. Publica Direito. Disponível em: <http://www.publicadireito.com.br/artigos/?cod=47a3893cc405396a> . Acesso em: 18 set. 2016. p. 20.

21 AGLIA JÚNIOR, 2015.

22 RAWLS, John. Justiça como equidade: uma reformulação. São Paulo: Martins Fontes, 2003.

23 FERMENTÃO, Cleide Aparecida Gomes Rodrigues. Os direitos da personalidade como direitos essenciais e a subjetividade do direito. Revista Jurídica Cesumar, v. 6, n. 1, p. 241-266, 2006. p. 243.

24 HABERMAS, Jurgen. A inclusão do outro: estudos de teoria política. 3. ed. São Paulo: Edições Loyola, 2007. p. 247.

25 MARQUES, Cláudia Lima; MIRAGEM, Bruno. O novo direito privado e a proteção dos vulneráveis. São Paulo: Revista dos Tribunais, 2014. p. 111.

26 MARQUES, Cláudia Lima; MIRAGEM, Bruno. O novo direito privado e a proteção dos vulneráveis. São Paulo: Revista dos Tribunais, 2014. p. 112. 
maioria das vezes chegam sem emprego e precisando de trabalho para poder se sustentar.

Para Dworkin ${ }^{27}$, a igualdade tem duas manifestações, igual respeito e igual consideração. Ter igual respeito é tratar a todos como tendo exatamente o mesmo valor, nem mais e nem menos. Para ele, o tratamento igual, é tratar todas as pessoas da mesma maneira, no entanto, as pessoas não são iguais em todos os aspectos, então para se alcançar a igualdade verdadeira, o tratamento deve ser sensível a essas diferenças.

A igual consideração é dar aos indivíduos tratamentos diferentes de modo que esse tratamento diferente possa dar a cada um as mesmas oportunidades. Dworkin ${ }^{28}$ chama isso de "tratamento como igual", sendo que o tratamento igual é dar a cada um o mesmo tratamento, já o "tratamento como igual” é dar tratamento diferente para que os indivíduos tenham as mesmas oportunidades.

Marques e Miragem ${ }^{29}$ comentam que o direito privado brasileiro possui dois estágios da visão dos vulneráveis e da proteção dos mais fracos. O primeiro se dá com o combate à discriminação dos diferentes, sendo que a igualdade será atingida através de uma proteção especial. E completam que: "muitas vezes para proteger em direito privado é necessário distinguir, assegurar direitos especiais ao vulnerável, tratar de forma especial o mais fraco: diferenciar para proteger" ${ }^{\prime 30}$.

Já o segundo estágio da proteção dos vulneráveis no direito privado é o de proteger respeitando as diferenças sem que haja discriminação. É criar condições de igualdade, garantindo condições de convivência. Marques e Miragem ${ }^{31}$ salientam que: "o direito privado passa a conviver e valorizar as especificidades destes grupos vulneráveis, desenvolvendo instrumentos para compensar (não excluir, vitimizar ou acabar) com as diferenças, pois estas identificam os indivíduos de nossa sociedade".

Por todo o exposto, pode-se verificar a importância de dar igualdade a todos, protegendo-se efetivamente os vulneráveis. Resguardar os vulneráveis é também uma maneira de proteger os direitos da personalidade das pessoas. Tudo está interligado e, sobretudo, não se pode esquecer que é dever de todos lutar pela dignidade do ser humano.

\section{Os imigrantes no Brasil}

As causas que se antepõem ao fenômeno migratório, fazendo com que as pessoas saiam de seus Estados de origem em direção a outros, são diversas, podendo ser econômicas, sociais, políticas, filantrópicas, culturais, religiosas, etc.

Existem dois tipos de estrangeiros, os residentes no país e os não-residentes (aqueles que se encontram em trânsito). Entretanto, não importa o tipo, quaisquer estrangeiros devem possuir uma condição jurídica que respeite a dignidade da pessoa humana, possibilitando-lhes a capacidade de gozar de todos os direitos daí provenientes.

No dia 18 de maio de 2017, o senado aprovou a nova lei da migração, definindo assim, os direitos e deveres do imigrante no Brasil. Tal aprovação representa uma inovação, já que o Brasil, ainda não tinha uma lei que desse segurança e proteção aos imigrantes ${ }^{32}$.

27 DWORKIN, Ronald. Uma questão de princípio. [trad. Luis Carlos Borges]. São Paulo: Martins Fontes, 2000. Capítulo 8.

28 DWORKIN, Ronald. Uma questão de princípio. [trad. Luis Carlos Borges]. São Paulo: Martins Fontes, 2000. Capítulo 8.

29 MARQUES, Cláudia Lima; MIRAGEM, Bruno. O novo direito privado e a proteção dos vulneráveis. São Paulo: Revista dos Tribunais, 2014. p. 112.

30 MARQUES, Cláudia Lima; MIRAGEM, Bruno. O novo direito privado e a proteção dos vulneráveis. São Paulo: Revista dos Tribunais, 2014. p. 114.

31 MARQUES, Cláudia Lima; MIRAGEM, Bruno. O novo direito privado e a proteção dos vulneráveis. São Paulo: Revista dos Tribunais, 2014. p. 116.

32 BAPTISTA, Rodrigo; VILAR, Isabela. Projeto da nova lei de migração segue para sanção presidencial.18 abril 2017. Dis- 
Além disso, como afirma Paulo Illes, coordenador do Centro de Direitos Humanos e Cidadania do Imigrante (Cdhic): "essa nova lei é um grande avanço, principalmente considerando a conjuntura mundial em que há um aumento do conservadorismo e da xenofobia em relação aos imigrantes e refugiados." Paulo Illes ainda afirma, que essa lei veio substituir o estatuto do estrangeiro, que criminalizava o imigrante, e vetava o direito de ter um emprego com visto temporário ${ }^{33}$.

Nessa nova lei, que é resultante de anos de construção e foi proposta pelo senador Aloysio Nunes (PSDB), há o estabelecimento de direitos e deveres dos imigrantes, a abertura para o diálogo social, a igualdade de oportunidade entre brasileiros e imigrantes e a institucionalização do visto humanitário, que deixa de ser provisório e aplicado apenas a haitianos e vítimas da guerra na Síria, e passa a ser concedido a qualquer imigrante em situação de risco ou de vulnerabilidade, mesmo que não se encaixe nas características de refúgio. A lei aborda também o repúdio à xenofobia e ao racismo ${ }^{34}$.

Ressalta-se que a nova lei foi sancionada, com vetos, pelo Presidente Michel Temer, e publicada no Diário Oficial da União no dia 24 de maio de 2017, com no 13.445. A lei entrará em vigor decorridos 180 dias de sua publicação ${ }^{35}$.

$\mathrm{Na}$ esperança de encontrar melhorias na qualidade de vida, centenas de pessoas buscam as fronteiras brasileiras. Muitas acabam tornando-se imigrantes ilegais, seja por falta de informação e documentação ou por condição financeira. Na ilegalidade, esses imigrantes muitas vezes são explorados por empresas clandestinas, que os submete às condições análogas a escravidão, principalmente nos grandes centros do país.

Não é raro encontrar denúncias de abusos de empregadores contra imigrantes que, em busca de maiores lucros, os submetem a condições de trabalhos análogas à escravidão, como por exemplo, obrigam-lhes a trabalharem em ambientes sem ventilação, apreendem seus passaportes e os ameaçam de deportação, coagem-lhes a trabalharem mais de 12 horas diariamente, pagam menos que o salário mínimo, entre outras práticas.

Quando isso acontece, o imigrante acaba se tornando encarcerado a essa situação, pois, sem condições financeiras e na ilegalidade, precisa trabalhar no que lhe é oferecido para poder sustentar a família, que agora vive no Brasil, ou, mandar dinheiro para a família que deixou em sua terra natal.

A DUDH ${ }^{36}$, sustentada pela ONU, destaca como garantias o respeito aos imigrantes indocumentados, assim como o direito à vida, à liberdade ao trato digno, dentre outros. Entretanto a proteção dos direitos humanos aos imigrantes ilegais ainda é um dos grandes desafios do século XXI, pela comunidade internacional. Com efeito, ainda existe uma intimidação constante ante a essas pessoas, como as ameaças de deportação imediata que resultam em vítimas de abusos, como por exemplo: na falta de pagamento de horas extras, salário abaixo do mínimo, trabalho infantil, entre outros, retratando assim, o quadro do trabalho escravo do estrangeiro indocumentado. Deve haver um combate a todo tipo de entendimento de que os imigrantes, legais ou ilegais, são os responsáveis pelas crises de emprego ou causadores de qualquer problema social, pois esses entendimentos resultam em xenofobia e intolerância ${ }^{37}$.

ponível em: <http://www12.senado.leg.br/noticias/materias/2017/04/18/projeto-da-nova-lei-de-migracao-segue-para-sancaopresidencial> . Acesso em: 02 de jun. 2017.

33 VELLEDA, Luciano. Na contramão mundial, Senado aprova inovadora lei para Imigrantes. 02 maio. 2017. Disponível em: <http://www.redebrasilatual.com.br/cidadania/2017/05/na-contramao-mundial-senado-aprova-inovadora-lei-para-entrada-e-estadia-de-imigrantes >.Acesso em: 02 de jun. 2017.

34 VELLEDA, Luciano. Na contramão mundial, Senado aprova inovadora lei para Imigrantes. 02 maio. 2017. Disponível em: <http://www.redebrasilatual.com.br/cidadania/2017/05/na-contramao-mundial-senado-aprova-inovadora-lei-para-entrada-e-estadia-de-imigrantes $>$.Acesso em: 02 de jun. 2017.

35 LEI DE MIGRAÇÃO, 2017.

36 A Declaração Universal dos Direitos Humanos (DUDH) foi aprovada em 1948 na Assembleia Geral da Organização das Nações Unidas (ONU). Este documento luta contra a discriminação, e defende a igualdade e a dignidade da pessoa humana.

37 ALMEIDA, Gyslaine Ferreira; SOUZA, Mônica Teresa Costa. A proteção interna do imigrante ilegal: garantia e efetividade dos direitos humanos no Brasil. Publica Direito, 2008. Disponível em: <http://www.publicadireito.com.br/ artigos/?cod=89dddcba3bee5793.> Acesso em: 16 set. 2016. 
Destaca-se que não importa se o imigrante está ou não legal no país. A ilegalidade não é desculpa para que o empregador abuse do trabalhador, expondo-o a trabalhos degradantes. Além disso, o imigrante nunca tirou os empregos dos nacionais, pois, na maioria dos casos, aqueles acabam ocupando empregos que os nacionais não têm interesse e que exigem pouca escolaridade.

O Brasil possui uma forte tradição histórica de país receptivo à entrada de imigrantes, uma vez que sua formação cultural e social tem seus pilares na imigração de diversas nações, entretanto, o país ainda demonstra uma postura retraída perante o crescente problema internacional que é a imigração ilegal e à situação desses ilegais em território nacional.

Não é de hoje que a entrada de imigrantes preocupa as autoridades no Brasil. Desde a época colonial os estrangeiros continuamente foram motivo de preocupação. O processo de colonização das terras pelos colonizadores portugueses, sempre foi pautado por disputas com outras nações europeias - "a colônia foi conquistada numa luta secular que coibia ou vigiava a presença estrangeira" ${ }^{\prime 3}$.

É incontestável que o Brasil é um país de imigrantes, pois desde sua colonização, aportaram aqui muitos imigrantes de toda parte do mundo, principalmente, italianos, alemães, japoneses, portugueses e espanhóis. Desde aquela época esses imigrantes vinham em busca de crescimento.

As migrações contemporâneas, além de intensas, ocorrem em múltiplas direções, diferentemente do que ocorria no final do século IXX e início do século XX, onde as migrações tinham como epicentro de origem principal a Europa ${ }^{39}$.

Hoje o Brasil recebe muitos imigrantes da América do Sul, como os bolivianos, venezuelanos e paraguaios, muitos haitianos também aportaram aqui nos últimos anos. Chegam também muitas pessoas da África, China e Coréia. Entretanto, há também muitas pessoas que emigram do Brasil em busca de melhores salários. Nesse caso, os destinos mais procurados são os Estados Unidos e a Europa.

Segundo o Relatório Anual de 2015 do Observatório das Migrações Internacionais (OBMigra), os haitianos se consolidaram como a principal nacionalidade no mercado de trabalho brasileiro e os senegaleses ocuparam o segundo coletivo que mais admissões tiveram no ano de 2014 e no primeiro semestre de $2015^{40}$.

Assim, nota-se que os residentes nos países mais vulneráveis e mais subdesenvolvidos que o Brasil, veem este país como uma boa opção para melhorar a qualidade de vida, além disso, o Brasil não é um país tão difícil de conseguir entrar e trabalhar quanto outros, como por exemplo, os Estados Unidos. E o contrário também ocorre, ou seja, os brasileiros acreditam que indo morar em países mais desenvolvidos terão melhores oportunidades.

Indubitavelmente a migração faz parte do processo de desenvolvimento do Brasil desde o seu descobrimento. Nestes mais de 500 anos de história, a migração foi sempre importante pela necessidade de mão de obra nos ciclos de crescimento econômico. "A tríade crescimento, migração e trabalho encontra-se no centro do processo de conformação da sociedade brasileira" ${ }^{41}$.

Observa-se que o imigrante ao chegar ao Brasil, não raras vezes pode se deparar com um ambiente hos-

38 PAIVA, Odair da Cruz. Histórias da (I)migração: imigrantes e migrantes em São Paulo entre o final do século XIX e o início do século XXI. São Paulo: Arquivo Público do Estado, 2013. p. 14.

39 PAIVA, Odair da Cruz. Histórias da (I)migração: imigrantes e migrantes em São Paulo entre o final do século XIX e o início do século XXI. São Paulo: Arquivo Público do Estado, 2013. p. 14.

40 CAVALCANTI, L.; OLIVEIRA, T.; TONHATI, T.; DUTRA. D., A inserção dos imigrantes no mercado de trabalho brasileiro. Relatório Anual 2015. Observatório das Migrações Internacionais; Ministério do Trabalho e Previdência Social/Conselho Nacional de Imigração e Coordenação Geral de Imigração. Brasília, DF: OBMigra, 2015.

41 DEDECCA, Claudio Salvadori. A retomada do crescimento e a migração no início do século. In: BAENINGER, Rosana; DEDECCA, Claudio (Org.). Processos Migratórios no Estado de São Paulo: Estudos Temáticos. Coleção por dentro do estado de São Paulo. Campinas: Núcleo de Estudos de População -Nepo/Unicamp, v. 10, p. 215-228, 2013. Disponível em: <http:// www.academia.edu/4356106/PROCESSOS_MIGRAT\%C3\%93RIOS_NO_ESTADO_DE_S\%C3\%83O_PAULO_estudos_ tem\%C3\%A1ticos_Organizadores_Rosana_Baeninger_and_Claudio_Salvadori_Dedecca >. Acesso em: 07 set. 2016. p. 215. 
til, tanto na forma como chega, às vezes ilegalmente, vindo por caminhos inseguros e perigosos, quanto na forma como são tratados pelos próprios brasileiros.

Além do mais, ao chegarem, quase sempre com poucas economias, acabam vivendo em locais totalmente insalubres e são alvos de propostas para trabalhos degradantes, isso, inclusive, tem sido divulgado de forma notória nos meios de comunicação, apontando até mesmo trabalho escravo, como já foi descrito o caso dos imigrantes peruanos e bolivianos.

Destaca-se que o caminho do imigrante qualificado é diverso do imigrante com baixa escolaridade. Isso porque, aqueles qualificados buscam grandes cidades, que tenham grandes centros financeiros, muitas empresas e indústrias. Já aqueles que possuem baixa escolaridade, buscam cidades que possam absorver mão-de-obra braçal.

Cícero Rufino Pereira ${ }^{42}$ salienta que é possível analisar a imigração sob o enfoque econômico, que ocorre devido à desigualdade entre um país de maiores recursos e outro, menos desenvolvido. Além disso, pode-se analisar sob o enfoque das redes sociais que foram criadas no país que recebeu esses imigrantes, essas redes são atrativos para os novos imigrantes que ao saírem de seus países possuem uma chegada mais fácil, com a adaptação menos dolorosa.

André de Carvalho Ramos ${ }^{43}$ fala da complexidade do assunto, aduzindo que: "o momento atual desafia aquele que trata do tema do direito dos estrangeiros no Brasil. Não há um, mas sim vários "estrangeiros", cada qual a exigir tratamento jurídico e específico, o que gera complexidade na análise".

Ressalta-se ainda, a existência do migrante ambiental, que existe em razão das alterações cada vez mais frequentes do ambiente global, provocada ou acelerada pela ação do homem. Esses migrantes, são motivados por causas ambientais, e em razão de serem cada vez mais frequentes, têm servido de fundamento para a adoção de um sistema internacional de proteção específico às pessoas afetadas nesses $\operatorname{casos}^{44}$.

Pode-se verificar que na antiguidade, a maior parte dos povos via o estrangeiro como um inimigo desprovido de qualquer direito. No entanto, como o passar dos anos, o mundo pôde assistir a várias fases do comportamento estatal, no que concerne ao tratamento dos estrangeiros: "Desde a xenofobia até o estímulo das imigrações" $"$.

Entretanto, no início do século XX, os Estados começaram a criar leis para restringir o fluxo de entrada de estrangeiros. "Em pleno século XXI, a situação não mudou. A Europa é vista como uma fortaleza a espera dos bárbaros" $"$.

Presentemente, o Brasil convive com aproximadamente um milhão e meio de estrangeiros, tendo em vista o enorme número de imigrantes irregulares no território brasileiro ${ }^{47}$.

Frisa-se que a situação em que se vivem hoje no Brasil, qual seja, desemprego com índices elevados, precariedade do serviço público como saúde, educação e segurança, demonstram que a acolhida dos estrangeiros em nosso País está deficitária, mesmo porque, a situação do país ameaça inclusive os nacionais ${ }^{48}$.

42 PEREIRA, Cícero Rufino. Direitos humanos fundamentais: o tráfico de pessoas e a fronteira. São Paulo: LTR, 2015. p. 108.

43 RAMOS, André de Carvalho. Direitos dos estrangeiros no Brasil: a imigração, direito de ingresso e os direitos dos estrangeiros em situação irregular. Igualdade, diferença e direitos humanos. Rio de Janeiro: Lúmen Júris, 2008. p. 721.

44 RAMOS, André de Carvalho. Direitos dos estrangeiros no Brasil: a imigração, direito de ingresso e os direitos dos estrangeiros em situação irregular. Igualdade, diferença e direitos humanos. Rio de Janeiro: Lúmen Júris, 2008. p. 67.

45 RAMOS, André de Carvalho. Direitos dos estrangeiros no Brasil: a imigração, direito de ingresso e os direitos dos estrangeiros em situação irregular. Igualdade, diferença e direitos humanos. Rio de Janeiro: Lúmen Júris, 2008. p. 722-723.

46 RAMOS, André de Carvalho. Direitos dos estrangeiros no Brasil: a imigração, direito de ingresso e os direitos dos estrangeiros em situação irregular. Igualdade, diferença e direitos humanos. Rio de Janeiro: Lúmen Júris, 2008. p. 723-724.

47 RAMOS, André de Carvalho. Direitos dos estrangeiros no Brasil: a imigração, direito de ingresso e os direitos dos estrangeiros em situação irregular. Igualdade, diferença e direitos humanos. Rio de Janeiro: Lúmen Júris, 2008. p. 731.

48 RAMOS, André de Carvalho. Direitos dos estrangeiros no Brasil: a imigração, direito de ingresso e os direitos dos estrangeiros em situação irregular. Igualdade, diferença e direitos humanos. Rio de Janeiro: Lúmen Júris, 2008. p. 732. 
Por outro aspecto, é importante salientar que a cultura de um determinado lugar é derivada de anos, e até séculos de vivência naquele local. Assim, quando ocorre esse grande movimento de entrada de imigrantes em um país, é fato que a cultura daquele país, aos poucos, vai se alterando.

Nesse sentido, cada pessoa tem um nível de consciência diferente sobre a forma como pretendem compreender-se como cidadãos de determinada república, sobre que tradições pretendem perpetuar ou interromper, sobre a maneira como pretendem lidar com seu destino histórico, com a natureza, etc e isso depende muito do contexto no qual ela está inserida, depende muito da cultura da região. É por isso que há atualmente uma grande preocupação na Europa, pois é fato que alterando o conjunto básico dos cidadãos, o modo de vida também se altera, desenvolvem-se novos discursos sobre os mesmos temas e se almejam outros fins ${ }^{49}$.

Dessa maneira, é possível afirmar que a identidade coletiva de certa região, em longo prazo, não fica imune às mudanças devido a essas ondas imigratórias, simplesmente porque é impossível fazer com que os imigrantes abandonem suas próprias tradições ${ }^{50}$.

Além dos imigrantes que saem de seus países por vontade de crescer financeiramente, ou ter melhor qualidade de vida, há também os Refugiados, que são os imigrantes que buscam refúgio em outro país devido às perseguições políticas e guerras, e ainda os migrantes ambientais, que são forçados a deixar sua terra em razão de desastres naturais, muitas vezes provocado pela ação do próprio homem.

Pode-se evidenciar neste enlace, que os Refugiados possuem condições especiais desde a Convenção de Genebra do Estatuto dos Refugiados, aprovada em 1951, e que de acordo com a lei do Brasil, 9.474/97, o refugiado é "todo aquele que devido a grave e generalizada violação de direito humanos, é obrigado a deixar seu país de nacionalidade para buscar refúgio em outro País”. A partir desse dispositivo, o Brasil já recebeu refugiados do Afeganistão, Serra Leoa, Angola, entre outros ${ }^{51}$.

Nesse caso, segundo a Convenção de 51, não cabe a discricionariedade dos Estados, pois aquele que alega ser refugiado tem o direito subjetivo de ingressar no país e receber proteção da vida e da liberdade, sendo que seu pedido de refúgio será devidamente analisado e, caso não for considerado refugiado, será devolvido ao País de origem ou a outro País que o aceitar ${ }^{52}$.

De acordo com um relatório divulgado pelo Centro de Monitoramento de Deslocamento Interno (IDMC), que possui base em Genebra, o número de pessoas que tiveram que se deslocar por causa dos conflitos, aumentou para 40,8 milhões no ano passado ${ }^{53}$.

A maior parte dessas pessoas que precisam se deslocar para fugir da guerra são dos países do Oriente Médio, como Iêmen, Síria, Iraque, Afeganistão, República Central Africana, República Democrática do Congo, Nigéria, Sudão do Sul e Ucrânia. O estudo aponta que os maiores responsáveis por esse crescente aumento são a primavera árabe e a ascensão do grupo Estado Islâmico $(\mathrm{EI})^{54}$.

Além disso, os desastres naturais também deram causas a vários deslocamentos, principalmente na China, Índia e Nepal. No Brasil, o relatório estima que 59 mil pessoas tiveram que deixar suas casas em 2015 por causa de desastres naturais. A violência também é considerada fator preponderante que faz muitas pessoas abandonarem seus países, como é o caso de El Salvador, Honduras, Guatemala e México ${ }^{55}$.

49 HABERMAS, Jurgen. A inclusão do outro: estudos de teoria política. 3. ed. São Paulo: Edições Loyola, 2007. p. 255.

50 HABERMAS, Jurgen. A inclusão do outro: estudos de teoria política. 3. ed. São Paulo: Edições Loyola, 2007.

51 RAMOS, André de Carvalho. Direitos dos estrangeiros no Brasil: a imigração, direito de ingresso e os direitos dos estrangeiros em situação irregular. Igualdade, diferença e direitos humanos. Rio de Janeiro: Lúmen Júris, 2008. p. 738.

52 RAMOS, André de Carvalho. Direitos dos estrangeiros no Brasil: a imigração, direito de ingresso e os direitos dos estrangeiros em situação irregular. Igualdade, diferença e direitos humanos. Rio de Janeiro: Lúmen Júris, 2008. p. 739.

53 DW, 2016

54 DW, 2016.

55 DW, 2016. 
Por todo o exposto, percebe-se que são inúmeras as causas da imigração. Ocorre que, não importa qual seja o motivo do deslocamento, os imigrantes devem ter seus direitos da personalidade e dignidade respeitados.

\subsection{A situação econômica e social dos imigrantes}

É muito difícil sair do país de origem e começar uma nova vida em outro país. Na maioria dos casos as pessoas saem de seu país, pois a situação ali não é favorável, seja pelo desemprego, seja por questões políticas ou violência. Ocorre que enfrentar o começo de uma nova vida em um novo país também não é nada fácil. Isso se torna ainda mais difícil quando a língua falada no país de origem é diversa da língua do país a que se destina.

Quando pessoas abandonam sua terra natal com certeza é porque enfrentam grandes dificuldades, de modo que basta o fato de terem fugido para documentar sua necessidade de auxílio.

O Brasil sempre foi visto como um país acolhedor. Tanto que a identidade do Brasil, desde o século XIX, é pensada como resultado da fusão de três raças, qual seja, o branco, o índio e o negro. Assevera-se que no século XIX a miscigenação era vista como um $\mathrm{mal}^{56}$.

Já no século XX, via-se a vinda dos imigrantes brancos como um bem, pois em três ou quatro gerações surgiria uma nação branca. Assim, além de contribuir com o trabalho, ainda contribuíram com o branqueamento da população. Desde então, tem-se que a civilização ocidental possui uma ideia de fronteira aberta ${ }^{57}$. Esse componente já aponta para a exclusão, o que deve ser rechaçado.

Ultimamente, como já exposto, houve uma onda de imigração haitiana, que passaram a vir ao Brasil depois da catástrofe natural que assolou o Haiti. No entanto, desde o momento em que chegam já encontram dificuldades, pois eles não falam português. A língua oficial no Haiti é o crioulo africano, uma mistura de francês com outra língua falada entre eles, que possui algumas regras próprias. Essa diferença na língua acaba dificultando a comunicação, gerando um isolamento e mais dificuldade na hora de conseguir emprego. Ocorre que, apesar do problema existente ainda não há políticas públicas eficazes para que a língua portuguesa seja ensinada aos haitianos ${ }^{58}$.

Em contrapartida, algumas paróquias, principalmente na região Norte, que é por onde os haitianos entram no país, possuem projetos que oferecem aulas de português para os haitianos. Em Rondônia, há um projeto entre a Universidade Federal de Rondônia e a Paróquia São João Bosco para ensinar a língua portuguesa. A turma inicialmente com cinquenta alunos, cresceu com a chegada de novos imigrantes, sendo necessário dividir a turma em iniciantes e intermediários. O grupo que frequenta as aulas é muito heterogêneo, contendo aqueles que possuem ensino superior e também aqueles que cursaram apenas as primeiras séries do ensino fundamental ${ }^{59}$.

Nesse sentido, percebe-se que apesar de existirem poucas ações do Estado em prol dos imigrantes, o próprio povo brasileiro começou a agir criando iniciativas para minimizar o sofrimento da chegada em outro país.

56 OLIVEIRA, Alfredo Emanuel Farias de. O fundamento dos direitos da personalidade. Belo Horizonte: Arraes Editores, 2012. p. 10.

57 OLIVEIRA, Alfredo Emanuel Farias de. O fundamento dos direitos da personalidade. Belo Horizonte: Arraes Editores, 2012. p. 10.

58 DUTRA, Cristiane Feldmann; GAYER, Suely Marisco. A inclusão social dos imigrantes haitianos, senegaleses e ganeses no Brasil. 2015. Disponível em: <http://online.unisc.br/acadnet/anais/index.php/sidspp/article/viewFile/13067/2282>. Acesso em: 11 ago. 2015.

59 COTINGUIBA, Geraldo Castro; PIMENTEL, Marília Lima. Elementos etnográficos sobre imigração na Amazônia Brasileira: Inserção social de haitianos em Porto Velho. Revista Temas de Antropología y Migración, n. 7, dez. 2014, p. 31-55, ISSN: 1853354X. Disponível em: <http://www.migrantropologia.com.ar/images/stories/PDF/Revista7/revista07.pdf>. Acesso em: 11 ago. 2015. p. 42-43. 
O Ministério do Trabalho divulgou o relatório anual sobre a situação dos imigrantes no mercado de trabalho brasileiro. Verifica-se que o número de imigrantes no mercado de trabalho formal do país cresceu 126\% nos últimos quatro anos, passando de 69 mil, em 2010, para 156 mil em 2014 ${ }^{60}$.

De acordo com uma pesquisa realizada em 2013, 68,8\% dos imigrantes vivem no Brasil em residências compartilhadas com outros imigrantes e, na absoluta maioria, essas residências são alugadas. Ainda de acordo com a pesquisa, grande parte dos haitianos conseguiu o primeiro emprego logo após a chegada ao Brasil. A maior parte atuou na construção civil, seguida por serviços gerais, indústria e serviços ligados ao setor de alimentação ${ }^{61}$.

A maioria dos haitianos consegue o primeiro emprego com a ajuda de amigos e parentes, alguns por conta própria, outros conseguem por contato direto com a empresa e alguns com a ajuda de uma agência ${ }^{62}$.

$\mathrm{Na}$ entrevista, $71 \%$ dos haitianos trabalhavam de carteira assinada e 25\% trabalhavam no mercado informal. Para a maioria, o relacionamento com o patrão e com os colegas de trabalho eram amigáveis. Apesar do salário pago no Brasil ser insuficiente para sobreviverem, mesmo assim, cerca de $40 \%$ afirmaram que conseguem fazer alguma economia. Para quase todos os entrevistados, os recursos economizados são enviados às famílias no Haiti ${ }^{63}$.

Quanto aos serviços de saúde utilizados no Brasil, 81\% já utilizaram o SUS para algum tratamento de saúde e a maioria deles avaliou o serviço como bom e muito bom ${ }^{64}$.

De acordo com essa pesquisa, a maior de todas as dificuldades encontrada pelos imigrantes é realmente o idioma, em seguida vem o emprego, depois a habitação, a formação, a regularização imigratória, saúde, discriminação e a segurança social. Além disso, o imigrante atual encontra no Brasil um cenário econômico que não favorece nem aos nacionais, quanto mais aos imigrantes. Ocorre que a situação do país de origem é ainda pior, mas isso não é motivo para que eles não possam depositar a sua esperança de sobrevivência digna no Brasil. Então é necessário dar-lhes condições para isso, num esforço geral e conjunto.

$\mathrm{Na}$ maioria das vezes os imigrantes entram no Brasil pelo Norte, sendo este apenas um lugar de passagem. Em seguida, esses Estados disponibilizam ônibus para transportá-los até São Paulo, evitando assim a superlotação no abrigo. Esse transporte é gratuito, mas só embarca quem estiver com a documentação em ordem, essa é uma estratégia adotada para que os recém-chegados tenham seus direitos preservados ${ }^{65}$.

Muitos dos imigrantes já sabem para onde vão, pois já possuem parentes ou amigos no Brasil, outros estão abertos às possibilidades. Dessa forma, a maioria deles, que nem ao menos fala português tornam-se vulneráveis e atraem os aliciadores que se valem de falsas promessas, estabelecendo rede de tráfico de pessoas para a exploração do trabalho escravo ou sexual ${ }^{66}$.

Uma reportagem da Gazeta do Povo apontou o Paraná como sendo o $2^{\circ}$ estado que mais emprega estrangeiros do País, em $1^{\circ}$ lugar está o estado de São Paulo. A maioria desses imigrantes é de haitianos, que vieram para o Brasil depois da catástrofe que ocorreu em Porto Príncipe em 2010, em seguida estão os

60 CRISTHINE, Geórgia. Inclusão pelo trabalho. O estrangeiro.24 out. 2015. Disponível em: <https://oestrangeiro. org/2015/10/27/inclusao-pelo-trabalho/>. Acesso em: 18 ago. 2016.

61 FERNANDES, Durval; MILESI, Rosita; PIMENTA, Bruna; DO CARMO, Vanessa. Migração dos Haitianos para o Brasil: a RN no 97/2012: uma avaliação preliminar. Refúgio, Migrações e Cidadania, v. 8, n. 8, p. 55-71, 2013. p. 61.

62 FERNANDES, Durval; MILESI, Rosita; PIMENTA, Bruna; DO CARMO, Vanessa. Migração dos Haitianos para o Brasil: a RN no 97/2012: uma avaliação preliminar. Refúgio, Migrações e Cidadania, v. 8, n. 8, p. 55-71, 2013. p. 62.

63 FERNANDES, Durval; MILESI, Rosita; PIMENTA, Bruna; DO CARMO, Vanessa. Migração dos Haitianos para o Brasil: a RN no 97/2012: uma avaliação preliminar. Refúgio, Migrações e Cidadania, v. 8, n. 8, p. 55-71, 2013. p. 62.

64 FERNANDES, Durval; MILESI, Rosita; PIMENTA, Bruna; DO CARMO, Vanessa. Migração dos Haitianos para o Brasil: a RN no 97/2012: uma avaliação preliminar. Refúgio, Migrações e Cidadania, v. 8, n. 8, p. 55-71, 2013. p. 64.

65 SANTINI, Daniel. Sistema Nacional de Empregos não funciona e refugiados ficam sujeitos a aliciadores. Imigrantes. 15 dez. 2014. Disponível em: <http://imigrantes.webflow.io/>. Acesso em: 18 set. 2016.

66 SANTINI, Daniel. Sistema Nacional de Empregos não funciona e refugiados ficam sujeitos a aliciadores. Imigrantes. 15 dez. 2014. Disponível em: <http://imigrantes.webflow.io/>. Acesso em: 18 set. 2016. 
paraguaios e argentinos ${ }^{67}$.

De acordo com a ativista cubana, historiadora e antropóloga Maria Ileana Faguaga, de 52 anos, que há dois anos aguarda resposta do governo brasileiro para seu pedido de refúgio, mais difícil do que ser refugiado, é ser refugiada. Ela diz que existe um estereótipo de que a pessoa que solicita refúgio é criminosa. E para a mulher, há o preconceito de que além de ser criminosa, é bem provável que seja prostituta ${ }^{68}$.

A advogada Silvye Mutiene, de 33 anos, veio da República Democrática do Congo e foi reconhecida como refugiada pelo Brasil desde 2014. Ela chegou ao Brasil com dois filhos pequenos e deixou para trás o marido e a filha. Ela diz que foi muito difícil chegar a um país com duas crianças pequenas e sem falar o idioma. Complementa que para o homem é mais fácil entrar no mercado de trabalho ${ }^{69}$.

Salienta-se que o número de refugiados e solicitantes de refúgio não para de crescer no Brasil e as mulheres são a menor parte ${ }^{70}$.

De acordo com o secretário Nacional de Justiça e presidente do CONARE ${ }^{71}$, Beto Vasconcelos, as mulheres são mais vulneráveis no país onde serão acolhidas. Isso se deve ao fato de que na maioria das vezes estão acompanhadas de filhos, não possuem qualquer renda de seu país de origem e, muitas vezes, nunca tinham trabalhado antes ${ }^{72}$.

A maioria dos haitianos chega ao Brasil ilegalmente e fazem a rota Equador, Peru e Brasileia no Acre. Então, Brasileia é a primeira cidade aonde os imigrantes haitianos chegam ao Brasil e nos dias de maiores movimentos, o governo do Acre estima que chegam 50 haitianos pela fronteira. Muitas vezes, eles ainda estão em situação ilegal e aguardam a regularização pela Polícia Federal. Enquanto aguardam a regularização, eles vivem uma situação precária ${ }^{73}$.

João Paulo Charleaux, coordenador de Comunicação da Conectas $^{74}$ relata que: "É insalubre, desumano até. Os haitianos passam a noite empilhados uns sobre os outros, sob um calor escaldante, acomodados em pedaços de espuma que algum dia foram pequenos colchonetes" ${ }^{\text {s. }}$.

67 JASPER, Fernando. Paraná é o 2. ${ }^{\circ}$ maior empregador de estrangeiros do país; veja de onde eles vêm. Gazeta do povo. Caderno Economia, 01 abr. 2016. Disponível em: <http://www.gazetadopovo.com.br/economia/parana-e-o-2-maior-empregadorde-estrangeiros-do-pais-veja-de-onde-eles-vem-5bzbolmiv9wzmmooshddokfev?utm_source=facebook\&utm_medium=midiasocial\&utm_campaign=midia-social>. Acesso em: 03 ago. 2016.

68 JUNQUEIRA, Diego. Pior que ser refugiado é ser refugiada. Mulheres contam suas dificuldades de viver no Brasil. Notícias R7. 06 mar. 2016. Disponível em: <http://noticias.r7.com/internacional/pior-que-ser-refugiado-e-ser-refugiada-mulheres-contamsuas-dificuldades-de-viver-no-brasil-10032016>. Acesso em: 03 ago. 2016.

69 JUNQUEIRA, Diego. Pior que ser refugiado é ser refugiada. Mulheres contam suas dificuldades de viver no Brasil. Notícias R7. 06 mar. 2016. Disponível em: <http://noticias.r7.com/internacional/pior-que-ser-refugiado-e-ser-refugiada-mulheres-contamsuas-dificuldades-de-viver-no-brasil-10032016>. Acesso em: 03 ago. 2016.

70 JUNQUEIRA, Diego. Pior que ser refugiado é ser refugiada. Mulheres contam suas dificuldades de viver no Brasil. Notícias R7. 06 mar. 2016. Disponível em: <http://noticias.r7.com/internacional/pior-que-ser-refugiado-e-ser-refugiada-mulheres-contamsuas-dificuldades-de-viver-no-brasil-10032016>. Acesso em: 03 ago. 2016.

71 Comitê Nacional para os Refugiados, se trata do órgão responsável por analisar os pedidos e declarar o reconhecimento, em primeira instância, da condição de refugiado, além disso é responsável por coordenar as ações necessárias para dar proteção, assistência e apoio jurídico aos refugiados

72 JUNQUEIRA, Diego. Pior que ser refugiado é ser refugiada. Mulheres contam suas dificuldades de viver no Brasil. Notícias R7. 06 mar. 2016. Disponível em: <http://noticias.r7.com/internacional/pior-que-ser-refugiado-e-ser-refugiada-mulheres-contamsuas-dificuldades-de-viver-no-brasil-10032016>. Acesso em: 03 ago. 2016.

73 MORAES, Maurício. ONG leva caso de imigrantes haitianos no Acre à OEA. BBC Brasil em São Paulo, 23 ago. 2013. Disponível em: <http://www.bbc.com/portuguese/noticias/2013/08/130819_acre_haitianos_conectas_oea_mm.>. Acesso em: 22 de julho de 2015 .

74 Conectas Direitos Humanos é uma organização não governamental internacional, sem fins lucrativos, fundada em setembro de 2001 em São Paulo, e promove a efetivação dos direitos humanos e do Estado Democrático de Direito, no Sul Global - África, América Latina e Ásia

75 MORAES, Maurício. ONG leva caso de imigrantes haitianos no Acre à OEA. BBC Brasil em São Paulo, 23 ago. 2013. Disponível em: <http://www.bbc.com/portuguese/noticias/2013/08/130819_acre_haitianos_conectas_oea_mm.>. Acesso em: 22 de julho de 2015. 
O secretário de Direitos Humanos do Acre, Nilson Mourão, diz que o estado do Acre está exaurido. O Governo Estadual do Acre alugou um Centro de Convenções e Lazer Chácara Aliança, para abrigar os imigrantes que não paravam de chegar, desses imigrantes a maioria são haitianos e senegalenses. A estimativa é de que de dezembro de 2010 até dezembro de 2014 já passaram pelo Acre mais de 40 mil imigrantes ${ }^{76}$.

O Governo do Acre providencia ônibus para levar os imigrantes que estejam com a documentação em ordem, para São Paulo. Rio Branco é apenas um lugar de passagem. O Acre oferece o transporte gratuito, mas para garantir que os imigrantes tenham seus direitos garantidos, embarca somente quem estiver com passaporte com protocolo de ingresso no país, carteira de trabalho e $\mathrm{CPF}^{77}$.

Muitos imigrantes acabam ficando em situação de vulnerabilidade devido ao pouco conhecimento da língua e do país. Por conta disso, muitos aliciadores se aproveitam da situação, valendo-se de falsas promessas, constroem uma rede de tráfico de pessoas para exploração de trabalho escravo ou exploração sexual ${ }^{78}$.

O Ministério Público do Trabalho (MPT) tem acompanhado com atenção o caso dos imigrantes. De acordo com Marcos Cutrim, procurador-chefe da 14 Região: "recebemos denúncias de que empresas queriam contratar haitianos pela grossura da canela, pelo tamanho da genitália. Quem foi à Brasiléia viu uma situação que a gente tinha há 300 anos, um mercado negreiro funcionando como nos séculos anteriores"77.

O Secretário Estadual de Justiça e Direitos Humanos, Nilson Mourão, explica que muitas empresas aproveitam a situação vulnerável dos imigrantes: “O cara que está edificando obra no Paraná não quer pagar para o brasileiro o valor que os brasileiros querem. E os haitianos sabem fazer, são bons na construção civil”»0.

Santini ${ }^{81}$ afirma que os setores que mais empregam são os frigoríficos e a construção civil, sendo o sul do país a região mais procurada.

Indiscutivelmente, o Brasil vem enfrentando uma situação desfavorável, tanto no cenário político, como no econômico. Por essa razão, sofrem os brasileiros, no qual muitos estão desempregados, e sofrem também os imigrantes, que vem pra cá com esperanças, mas se deparam com situações muito precárias. Possivelmente, tal situação é ainda melhor do que a deixada no país de origem. No entanto, o ser humano não pode viver com menos do mínimo que ele precisa para uma vida digna, por isso, é preciso que o Estado crie políticas públicas eficazes para proteger os vulneráveis. Evidencia-se que estas políticas podem garantir os direitos da personalidade daqueles que se encontram, ainda que temporariamente, em uma situação de vulnerabilidade.

\section{Considerações finais}

Prefacialmente tem-se o cristianismo como precursor dos direitos da personalidade, pois a partir da ideia de que o homem era a imagem e semelhança de Deus, deveria então, ter os direitos mais intrínsecos respeitados.

Após as duas guerras mundiais, a necessidade de acentuar os direitos da personalidade tornou-se latente,

76 SANTINI, Daniel. Sistema Nacional de Empregos não funciona e refugiados ficam sujeitos a aliciadores. Imigrantes. 15 dez. 2014. Disponível em: <http://imigrantes.webflow.io/>. Acesso em: 18 set. 2016.

77 SANTINI, Daniel. Sistema Nacional de Empregos não funciona e refugiados ficam sujeitos a aliciadores. Imigrantes. 15 dez. 2014. Disponível em: <http://imigrantes.webflow.io/>. Acesso em: 18 set. 2016.

78 SANTINI, Daniel. Sistema Nacional de Empregos não funciona e refugiados ficam sujeitos a aliciadores. Imigrantes. 15 dez. 2014. Disponível em: <http://imigrantes.webflow.io/>. Acesso em: 18 set. 2016.

79 SANTINI, Daniel. Sistema Nacional de Empregos não funciona e refugiados ficam sujeitos a aliciadores. Imigrantes. 15 dez. 2014. Disponível em: <http://imigrantes.webflow.io/>. Acesso em: 18 set. 2016.

80 SANTINI, Daniel. Sistema Nacional de Empregos não funciona e refugiados ficam sujeitos a aliciadores. Imigrantes. 15 dez. 2014. Disponível em: <http://imigrantes.webflow.io/>. Acesso em: 18 set. 2016.

81 SANTINI, Daniel. Sistema Nacional de Empregos não funciona e refugiados ficam sujeitos a aliciadores. Imigrantes. 15 dez. 2014. Disponível em: <http://imigrantes.webflow.io/>. Acesso em: 18 set. 2016. 
visto o total desrespeito que o ser humano enfrentou. A partir de então, o ser humano passou a ser tratado como portador de proteção à personalidade e dignidade.

Dessa forma, não importa onde ou em que posição esteja o ser humano, se no trabalho ou em outro lugar, é necessário que se preserve os direitos da personalidade. Da mesma forma, também não importa a nacionalidade, se brasileiro ou estrangeiro, a Constituição prevê que todos são iguais perante a lei e a todos é garantido a inviolabilidade do direito à vida, à liberdade, à igualdade, à segurança e à propriedade.

Cabe salientar, que o imigrante é considerado vulnerável, ainda que temporariamente, e por isso, para que se atinja a igualdade daqueles que são diferentes, muitas vezes é preciso oferecer-lhes uma proteção especial, para assim, assegurar alguns direitos, criando condições de igualdade.

Apesar de estar expresso na Constituição que todos são iguais perante a lei, há grande preocupação com o tema dos imigrantes no Brasil. Sabe-se que o processo de colonização do Brasil, pelos estrangeiros, existe há muito tempo, tanto que há no país muitos descendentes de italianos, portugueses, espanhóis, japoneses, alemães etc.

Não se pode olvidar que houve muita contribuição desses estrangeiros, desde quando colonizaram o Brasil, no século passado. No entanto, a imigração atual vem ocorrendo com características diferenciadas da imigração de antigamente.

Os brasileiros também se beneficiaram e ainda se beneficiam muito com a imigração, nota-se que o Brasil é um país que recebe imigrantes, principalmente da África, Haiti e de países latino americanos, como também é um país que envia pessoas para os Estados Unidos, Inglaterra e outros países da Europa.

Sendo assim, o mundo todo é marcado pelas imigrações, tendo se beneficiado por elas de alguma forma. Ultimamente, esse assunto está de novo no centro das atenções devido ao grande número de imigrantes, principalmente de pessoas que fogem de guerra e de países que sofreram desastres naturais.

Observa-se atualmente que o Brasil está enfrentando uma situação difícil, tanto pelo desemprego que assola as famílias, como pelos sistemas precários que são oferecidos para a população, como saúde, educação e segurança. Dessa forma, devido a falta de emprego, muitas vezes os brasileiros consideram os estrangeiros como concorrentes na busca por trabalho. No entanto, de forma inovadora e diante de tantas atitudes xenofóbicas pelo mundo, foi sancionada a lei de Migração no Brasil, sendo considerada um enorme avanço e um primeiro passo para uma sociedade mais igualitária e justa, na qual não tratamos pessoas como nacionais e estrangeiros, imigrantes e não imigrantes, mas em primeiro lugar, como seres humanos que vulneráveis estão, necessitam de acolhimento.

Por fim, não se pode permitir que os direitos da personalidade sejam aniquilados, uma vez que tais direitos nascem com todas as pessoas e são irrenunciáveis, devendo ser garantidos e protegidos pelo Estado.

\section{REFERÊCIAS BIBLIOGRÁfICAS}

ALMEIDA, Gyslaine Ferreira; SOUZA, Mônica Teresa Costa. A proteção interna do imigrante ilegal: garantia e efetividade dos direitos humanos no Brasil. Publica Direito, 2008. Disponível em: <http://www. publicadireito.com.br/artigos/?cod=89dddcba3bee5793.> Acesso em: 16 set. 2016.

BAENINGER, Rosana. Migrações internas no Brasil no século 21: entre o local e o global. In: BAENINGER, Rosana; DEDECCA, Claudio (Org.). Processos Migratórios no Estado de São Paulo: Estudos Temáticos. Coleção por dentro do estado de São Paulo. Campinas: Núcleo de Estudos de População - NEPO/ Unicamp, v. 10, p. 193-214, 2013. Disponível em: <http://www.academia.edu/4356106/PROCESSOS_ MIGRAT\%C3\%93RIOS_NO_ESTADO_DE_S\%C3\%83O_PAULO_estudos_tem\%C3\%A1ticos_Or- 
ganizadores_Rosana_Baeninger_and_Claudio_Salvadori_Dedecca>. Acesso em: 07 set. 2016.

BAPTISTA, Rodrigo; VILAR, Isabela. Projeto da nova lei de migração segue para sanção presidencial.18 abril 2017. Disponível em: <http://www12.senado.leg.br/noticias/materias/2017/04/18/projeto-da-nova-lei-de-migracao-segue-para-sancao-presidencial> . Acesso em: 02 de jun. 2017.

BATISTA, Vanessa Oliveira; PARREIRA, Carolina Genovez. Trabalho, imigração e o direito internacional dos direitos humanos. Publica Direito. Disponível em: <http://www.publicadireito.com.br/ artigos/?cod=47a3893cc405396a > . Acesso em: 18 set. 2016.

BITTAR, Carlos Alberto. Os direitos da Personalidade. 2. ed. Rio de Janeiro: Forense Universitária, 1995.

BORGES, Roxana Cardoso Brasileiro. Direitos de personalidade e autonomia privada. São Paulo: Saraiva, 2007.

CAVALCANTI, L.; OLIVEIRA, T.; TONHATI, T.; DUTRA. D., A inserção dos imigrantes no mercado de trabalho brasileiro. Relatório Anual 2015. Observatório das Migrações Internacionais; Ministério do Trabalho e Previdência Social/Conselho Nacional de Imigração e Coordenação Geral de Imigração. Brasília, DF: OBMigra, 2015.

CAVALLINI, Viviane Cristina Rodrigues; DA MOTTA, Ivan Dias. O Conceito de Personalidade no Âmbito dos Direitos da Personalidade. Revista Jurídica Cesumar-Mestrado, v. 9, n. 2, 2009.

COSTA, Gelmino A. Haitianos em Manaus: Dois anos de imigração - e agora! In: Travessia: Revista do Migrante, n. 70, jan./jun. 2012, p. 91. Disponível em: <http://haitiaqui.com/files/Travessia\%20-\%20Revista\%20 do\%20Migrante\%20-\%20n\%C2\%BA70\%20-\%20Jan-Junho\%202012.pdf>. Acesso em: 20 jul. 2015.

COTINGUIBA, Geraldo Castro; PIMENTEL, Marília Lima. Elementos etnográficos sobre imigração na Amazônia Brasileira: Inserção social de haitianos em Porto Velho. Revista Temas de Antropología y Migración, n. 7, dez. 2014, p. 31-55, ISSN: 1853354X. Disponível em: <http://www.migrantropologia.com.ar/images/ stories/PDF/Revista7/revista07.pdf>. Acesso em: 11 ago. 2015.

CRISTHINE, Geórgia. Inclusão pelo trabalho. O estrangeiro.24 out. 2015. Disponível em: < https:/ / oestrangeiro.org/2015/10/27/inclusao-pelo-trabalho/>. Acesso em: 18 ago. 2016.

DEDECCA, Claudio Salvadori. A retomada do crescimento e a migração no início do século. In: BAENINGER, Rosana; DEDECCA, Claudio (Org.). Processos Migratórios no Estado de São Paulo: Estudos Temáticos. Coleção por dentro do estado de São Paulo. Campinas: Núcleo de Estudos de População -Nepo/ Unicamp, v. 10, p. 215-228, 2013. Disponível em: <http://www.academia.edu/4356106/PROCESSOS_ MIGRAT\%C3\%93RIOS_NO_ESTADO_DE_S\%C3\%83O_PAULO_estudos_tem\%C3\%A1ticos_Organizadores_Rosana_Baeninger_and_Claudio_Salvadori_Dedecca>. Acesso em: 07 set. 2016.

DIOME, Fatou. Vamos enriquecer juntos ou vamos afundarjuntos. Vídeo exibido no canal France $2 \mathrm{em}$ 24/04/2015. Disponível em: <https://www.youtube.com/watch?v=H_yVUIHAjSA>. Acesso em: 02 dez. 2015.

DUTRA, Cristiane Feldmann; GAYER, Suely Marisco. A inclusão social dos imigrantes haitianos, senegaleses e ganeses no Brasil. 2015. Disponível em: <http://online.unisc.br/acadnet/anais/index.php/sidspp/article/ viewFile/13067/2282>. Acesso em: 11 ago. 2015.

DWORKIN, Ronald. Uma questão de princípio. [trad. Luis Carlos Borges]. São Paulo: Martins Fontes, 2000. Capítulo 8.

FERNANDES, Durval; MILESI, Rosita; PIMENTA, Bruna; DO CARMO, Vanessa. Migração dos Haitianos para o Brasil: a RN no 97/2012: uma avaliação preliminar. Refúgio, Migrações e Cidadania, v. 8, n. 8, p. $55-71,2013$.

FERMENTÃO, Cleide Aparecida Gomes Rodrigues. Os direitos da personalidade como direitos essenciais e a subjetividade do direito. Revista Jurídica Cesumar, v. 6, n. 1, p. 241-266, 2006. 
GOMES, Orlando. Introdução ao direito civil. 11. ed. Rio de Janeiro: Forene, 1996.

Tendências modernas na teoria da responsabilidade civil. Estudos em homenagem ao Professor Silvio Rodrigues. São Paulo: Saraiva, 1989.

GONÇALVES, Diogo Costa. Pessoa e direitos da personalidade: fundamentaşão ontológica da tutela. Coimbra: Almedina, 2008.

HABERMAS, Jurgen. A inclusão do outro: estudos de teoria política. 3. ed. São Paulo: Edições Loyola, 2007.

JAQUEIRA, Manoela Marli; MARTINS, Fernando José. Os direitos fundamentais e o trabalhador imigrante no Brasil. Derecho y Cambio Social. 19 out. 2015. Disponível em: <http://www.derechoycambiosocial.com/ revista042/OS_DIREITOS_FUNDAMENTAIS_E_O_TRABALHADOR_IMIGRANTE.pdf $>$. Acesso em: 18 set. 2016.

JASPER, Fernando. Paraná é o 2. maior empregador de estrangeiros do país; veja de onde eles vêm. Gazeta do povo. Caderno Economia, 01 abr. 2016. Disponível em: <http://www.gazetadopovo.com.br/economia/parana-e-o-2-maior-empregador-de-estrangeiros-do-pais-veja-de-onde-eles-vem-5bzbolmiv9wzmmooshddokfev?utm_ source $=$ facebook\&utm_medium $=$ midia-social\&utm_campaign $=$ midia-social $>$. Acesso em: 03 ago. 2016.

JUNQUEIRA, Diego. Pior que ser refugiado é ser refugiada. Mulheres contam suas dificuldades de viver no Brasil. Notícias R7. 06 mar. 2016. Disponível em: <http://noticias.r7.com/internacional/pior-que-serrefugiado-e-ser-refugiada-mulheres-contam-suas-dificuldades-de-viver-no-brasil-10032016>. Acesso em: 03 ago. 2016.

LEI da Migração. Disponível em: <http://www.planalto.gov.br/ccivil_03/_ato2015-2018/2017/lei/ L13445.htm>. Acesso em: 02 jun. 2017.

MARQUES, Cláudia Lima; MIRAGEM, Bruno. O novo direito privado e a proteção dos vulneráveis. São Paulo: Revista dos Tribunais, 2014.

MAZZUOLI, Valério de Oliveira. Curso de direito internacional público. 5.ed. rev., atual. e ampl. São Paulo: Editora Revista dos Tribunais, 2011.

MELLO, Cláudio Ari. Contribuição para uma teoria híbrida dos direitos de personalidade. In: SARLET, Ingo Wolfgang. O novo código civil e a constituição. Porto Alegre: Livraria do Advogado, 2003.

MILESI, Rosita. Brasil e os desafios da lei de migracõoes. Entrevistas, 18 jan. 2012. Disponível em: < http://www. ihu.unisinos.br/entrevistas/505828-entrevista-especial-com-rosita-milesi>. Acesso em: 15 jul. 2015.

MINISTÉRIO do Trabalho e Emprego (MTE). Norma Regulamentadora, 2010.

MORAES, Maurício. ONG leva caso de imigrantes haitianos no Acre à OEA. BBC Brasil em São Paulo, 23 ago. 2013. Disponível em: <http://www.bbc.com/portuguese/noticias/2013/08/130819_acre_haitianos_conectas_oea_mm.>. Acesso em: 22 de julho de 2015.

OBMIGRA. Autorizações concedidas a estrangeiros, Relatório II trimestre de 2016.Observatório das Migrações Internacionais; Ministério do Trabalho/ Conselho Nacional de Imigração. Brasília, DF: OBMigra, 2016. Disponível em: <http://trabalho.gov.br/dados-abertos/trabalho-estrangeiro/estatisticas-imigracao/conselho-nacional-de-imigracao-cnig >. Acesso em: 16 set. 2016.

OLIVEIRA, Alfredo Emanuel Farias de. O fundamento dos direitos da personalidade. Belo Horizonte: Arraes Editores, 2012.

PAIVA, Odair da Cruz. Histórias da (I)migração: imigrantes e migrantes em São Paulo entre o final do século XIX e o início do século XXI. São Paulo: Arquivo Público do Estado, 2013.

PEREIRA, Cícero Rufino. Direitos humanos fundamentais: o tráfico de pessoas e a fronteira. São Paulo: LTR, 2015. 
RAMOS, André de Carvalho. Direitos dos estrangeiros no Brasil: a imigraşão, direito de ingresso e os direitos dos estrangeiros em situação irregular. Igualdade, diferença e direitos humanos. Rio de Janeiro: Lúmen Júris, 2008.

RAWLS, John. Justiça como equidade: uma reformulação. São Paulo: Martins Fontes, 2003.

RIZZARDO, Arnaldo. Parte geral do código civil: lei n. 10.406, de 10.01. 2002. 4. ed., rev. e atual. Rio de Janeiro: Forense, 2006.

SANTINI, Daniel. Sistema Nacional de Empregos não funciona e refugiados ficam sujeitos a aliciadores. Imigrantes. 15 dez. 2014. Disponível em: <http://imigrantes.webflow.io/>. Acesso em: 18 set. 2016.

SARMENTO, Daniel. Direitos fundamentais e relações privadas. Rio de Janeiro: Lúmen Juris, 2004.

SZANIWASKI, Elimar. Direitos de personalidade e sua tutela. 2.ed. São Paulo: Revistados Tribunais, 2005.

VELLEDA, Luciano. Na contramão mundial, Senado aprova inovadora lei para Imigrantes. 02 maio. 2017. Disponível em: <http://www.redebrasilatual.com.br/cidadania/2017/05/na-contramao-mundial-senadoaprova-inovadora-lei-para-entrada-e-estadia-de-imigrantes $>$.Acesso em: 02 de jun. 2017. 


\section{Normas Editoriais}

1. Serão aceitas colaborações inéditas e a publicação de um artigo está condicionada à sua adequação às normas editoriais, e seu simples recebimento desobriga a sua publicação. A revista Prismas: Direito, Políticas Públicas e Mundialização classificará as colaborações de acordo com as seguintes seções:

1.1 Artigos: compreende textos que contenham relatos completos de estudos ou pesquisas concluídas, matérias de caráter opinativo, revisões da literatura e colaborações assemelhadas.

1.2 Resenhas: compreende análises críticas de livros, de periódicos recentemente publicados, dissertações e teses.

2. Excepcionalmente, a equipe editorial poderá aceitar a submissão de trabalhos que já tenham sido publicados e caso isso ocorra, serão submetidos ao mesmo processo de avaliação pelos pares que aqueles inéditos. $\mathrm{O}$ autor deverá apresentar autorização por escrito do editor da revista na qual seu trabalho tenha sido originalmente publicado, acompanhado de cópia do mesmo.

3. O processo de avaliação dos artigos e resenhas compreende duas fases: a primeira destinada à análise da adequação do trabalho à linha editorial da revista (Equipe Editorial) e a segunda referente à avaliação do conteúdo e qualidade dos trabalhos. Esta segunda fase é realizada mediante o processo de avaliação pelos pares, ou seja, os artigos serão submetidos à aprovação de no mínimo 2 pareceristas adhoc.

4. Os trabalhos serão enviados para a avaliação sem a identificação de autoria

5. Os trabalhos devem ser enviados no seguinte padrão:

$1^{a}$ Página: Começar com o título do título do trabalho, seguido do texto. Não inseriro nome dos autores ou outros elementos queidentifiquem a autoria. A autoria do artigo e a qualificação dos autores são inseridas nos campos específicos do formulário eletrônico. O objetivo aqui é garantir uma avaliação cega por pares. Os textos deverão ser digitados em Arial 12, espaço 1,5 margem de 2,5 $\mathrm{cm}$, numeração arábica das páginas no ângulo superior direito, em programa compatível com o Word para Windows.

Título do trabalho: o título deve ser breve e suficientemente específico e descritivo para representar o conteúdo do texto e deverá ter a sua tradução para o inglês.

Resumo: em todos os artigos submetidos deve ser incluído um resumo informativo com o máximo de 250 palavras e espaço entre linhas simples. O resumo deve ser estruturado com as seguintes informações:

Objetivo do artigo (obrigatório);

Metodologia (obrigatório);

Conclusões (obrigatório);

Limitações da pesquisa e suas implicações (se aplicável);

Limitações práticas (se aplicável)

Originalidade ou valor (obrigatório); 
A evolução da comunicação científica e da transmissão de conhecimentos possibilitou ao UniCEUB a criação de meios para o intercâmbio de idéias entre pares e a disseminação de informações.

As novas tecnologias da informação produzem sensíveis alterações nos processos de comunicação científica. Atualmente, a editoração das publicações acadêmicas do UniCEUB é informatizada em todas as suas etapas, com a utilização da plataforma SEER, Sistema de Editoração Eletrônico de Revistas. A aplicação do SEER permitiu acrescentar, no processo editorial, a avaliação dos pareceristas ad hoc e deu aos membros dos comitês editoriais e aos editores condições para consolidar a produção científica no UniCEUB e difundi-la por meio dos periódicos acadêmicos em mídia impressa e eletrônica.

Todas as edições das publicações científicas do UniCEUB estão disponíveis no site www.publicacoesacademicas.uniceub.br, com infraestrutura para acesso livre.

O UniCEUB publica as seguintes revistas:

- Revista Brasileira de Políticas Públicas

- Revista de Direito Internacional

- Universitas Arquitetura e Comunicação Social

- Universitas Ciências da Saúde

- Universitas Gestão e TI

- Universitas Humanas

- Universitas JUS

- Universitas Relações Internacionais

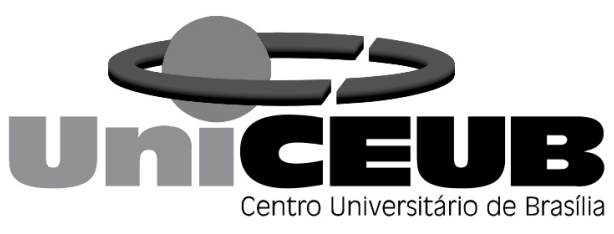


Destacar no mínimo três e no máximo seis palavraschave que representem o conteúdo do texto. O resumo e as palavras-chave deverão ter a sua tradução para o inglês.

Agradecimentos: agradecimentos a auxílios recebidos para a elaboração do trabalho deverão ser mencionados no final do artigo.

Notas: notas referentes ao corpo do artigo deverão vir no rodapé do texto.

Apêndices: apêndices podem ser empregados no caso de listagens extensivas, estatísticas e outros elementos de suporte.

Materiais gráficos: fotografias nítidas e gráficos (estritamente indispensáveis à clareza do texto) poderão ser aceitos e cada fotografia ou gráfico deverá vir no texto e além disso cada um deverá ser enviado em arquivo separado. Se as ilustrações enviadas já tiverem sido publicadas, mencionar a fonte e a permissão para reprodução.

Quadros: os quadros deverão ser acompanhados de cabeçalho que permita compreender o significado dos dados reunidos, sem necessidade de referência ao texto. Assinalar, no texto, pelo seu número de ordem, os locais onde os quadros devem ser intercalados.

Referências: as referências redigidas segundo a norma NBR 6023/2002 da Associação Brasileira de Normas Técnicas (ABNT), deverão ser apresentadas por ordem alfabética e constituir uma lista única no final do artigo. A exatidão e adequação das referências a trabalhos que tenham sido consultados e mencionados no texto do artigo são da responsabilidade do autor. Informações procedentes de comunicação pessoal, de trabalhos em andamento ou não publicados não devem ser incluídas na lista de referências, mas indicada em nota de rodapé. Não utilizar o sistema Autor data para citações. O formato utilizado pela revista é o sistema numérico, onde a citação é indicada por número sobrescrito e a referência mencionada em nota de rodapé.

Recomendações: recomenda-se que se observem as normas da ABNT referentes à apresentação de artigos em publicações periódicas (NBR 6022/2002), apresentação de citações em documentos (NBR 10520/2002), apresentação de originais (NBR 12256), norma para datar (NBR 892), numeração progressiva das seções de um documento (NBR 6024/2003) e resumos (NBR $6028 / 2003)$.

A revista se reserva o direito de efetuar nos originais alterações de ordem normativa, ortográfica e gramatical, com vistas a manter o padrão culto da língua, respeitando, porém, o estilo dos autores.

A partir de 2009, consideramos útil formular algumas sugestões (não obrigatórias) aos autores, com base nos principais motivos por recusa de artigos nos anos anteriores.

8. Responsabilidades e conflitos de interesse: A responsabilidade pelas informações e opiniões indicadas nos artigos é exclusiva dos autores. Eventuais conflitos de interesse serão de responsabilidade dos próprios autores e não do periódico.

\section{Envio dos trabalhos:}

1. Os trabalhos deverão ser enviados para a equipe editorial da revista no endereço eletrônico www.rdi.uniceub.br

2. Cada autor deve enviar declaração de responsabilidade nos termos abaixo:

“Eu XXXX certifico que participei da concepção do trabalho tornar pública minha responsabilidade pelo seu conteúdo, que não omiti quaisquer ligações ou acordos de financiamento entre os autores e companhias que possam ter interesse na publicação deste artigo."

3. Para as colaborações inéditas, cada autor deve enviar a transferência de direitos autorais nos termos abaixo:

"Eu XXXX declaro que em caso de aceitação do artigo inédito, a revista Revista Brasileira de Políticas Públicas passa a ter os direitos autorais a ele referentes. 
V. $7, n \circ 2$ 